UNIVERSIDADE DE SÃO PAULO

FACULDADE DE DIREITO

PROGRAMA DE PÓS-GRADUAÇÃO

\title{
O PRINCÍPIO DE \\ NÃO-DISCRIMINAÇÃO TRIBUTÁRIA \\ NO COMÉRCIO INTERNACIONAL \\ DE BENS
}

Tese apresentada ao Programa de PósGraduação em Direito da USP como requisito parcial à aprovação no DOUTORADO em DIREITO ECONÔMICO E FINANCEIRO.

Aluno: Washington Juarez de Brito Filho Orientador: Professor Associado Livre-docente Heleno Taveira Tôrres 
Brito Filho, Washington Juarez de

O princípio de não-discriminação tributária no comércio internacional de bens / Washington Juarez de Brito Filho. - São Paulo : W. J. de Brito Filho, 2011.

$621 \mathrm{p}$.

Tese (Doutorado) - Faculdade de Direito da USP, 2011.

Orientador: Professor Associado Livre-docente Heleno Taveira Tôrres

Notas de rodapé.

Inclui bibliografia.

1. Não-discriminação 2. Tributação indireta 3. Livre Circulação de mercadoria 4. Ajustes fiscais de fronteira 5. Protecionismo I. Título. 


\section{O PRINCÍPIO DE NÃO-DISCRIMINAÇÃO TRIBUTÁRIA NO COMÉRCIO INTERNACIONAL DE BENS}

São Paulo, de de 2011.

Banca Examinadora:

Professor Associado Livre-docente Heleno Taveira Tôrres Orientador 


\section{AGRADECIMENTOS}

Meus sinceros e profundos agradecimentos ao Professor Heleno Taveira Tôrres, mais do que meu orientador e professor, um exemplo de ética acadêmica e pessoal, que me permitiu retornar aos bancos da quase bicentenária Faculdade de Direito da Universidade de São Paulo e que viabilizou a elaboração deste trabalho, compreendendo, com humanidade, todas as dificuldades ultrapassadas por mim nesse período. 
A Virgínia, Victor, Anita e Enrico, cujos amores são o combustível que me move. 


\section{SUMÁRIO}

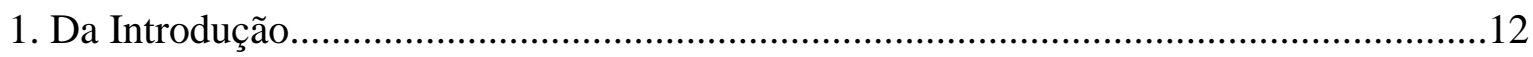

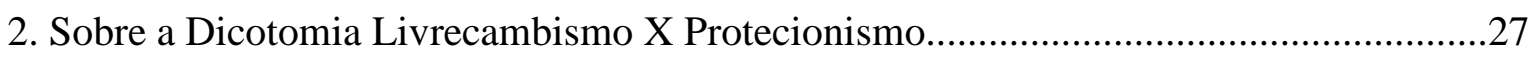

3. Do Princípio de Não-Discriminação no Sistema Multilateral de Regulação do Comércio

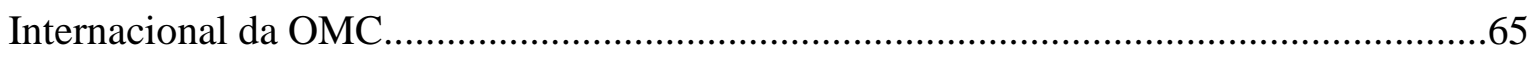

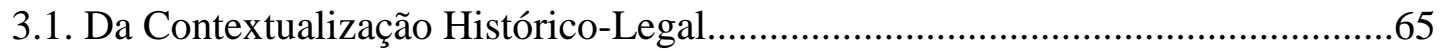

3.2. Da Não-Discriminação entre produtos estrangeiros - O Tratamento Geral de Nação Mais Favorecida (Art. I) 101

3.3. Da Não-Discriminação entre produto nacional e estrangeiro - O Tratamento

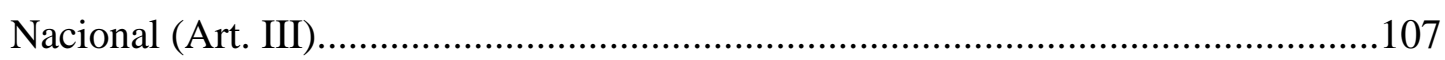

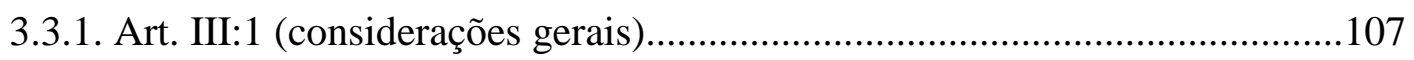

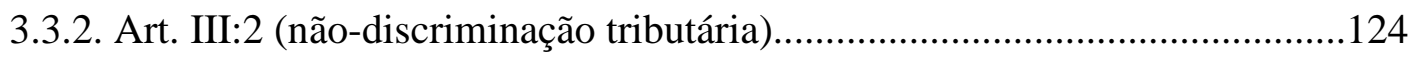

3.3.3. Art. III:2, $1^{\mathrm{a}}$ frase (discriminação explícita)...............................................127

3.3.4. Art. III:2, $2^{\mathrm{a}}$ frase (discriminação implícita)..............................................133

3.3.5. Art. III:4 (não-discriminação regulatória)...................................................139

3.4. Dos Julgados do Órgão de Solução de Controvérsias sobre o Artigo III............141

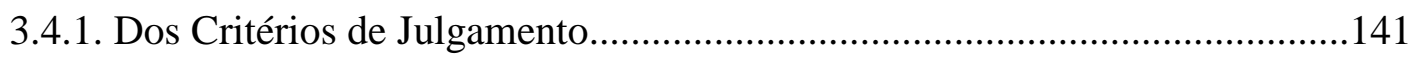

3.4.2. Testes objetivos - teste diagonal e teste de impacto assimétrico..................143

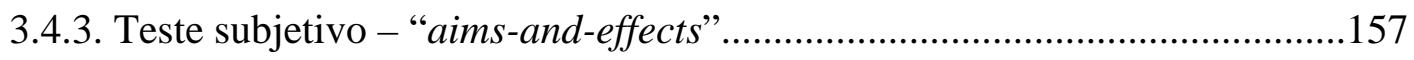

3.5. Das Críticas Doutrinárias à Jurisprudência......................................................173

3.6. Das Exceções ao Princípio de Não-Discriminação.............................................186

4. Do Princípio de Não-Discriminação no Sistema da União Europeia.............................195

4.1. Da Livre Circulação Comunitária de Mercadorias..............................................195

4.2. Da Evolução Histórico-Legal.......................................................................215

4.3. Da Não-Discriminação Tributária no comércio de bens - Art. $90^{\circ}$ do Tratado que

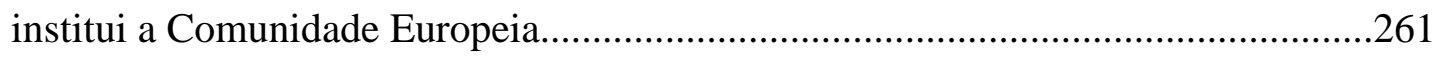

4.3.1. Art. $90^{\circ}, 1^{\mathrm{a}}$ frase (discriminação explícita)..................................................262

4.3.2. Art. $90^{\circ}, 2^{\mathrm{a}}$ frase (discriminação implícita).............................................282

4.4. Das Exceções ao Princípio de Não-Discriminação Tributária.............................316

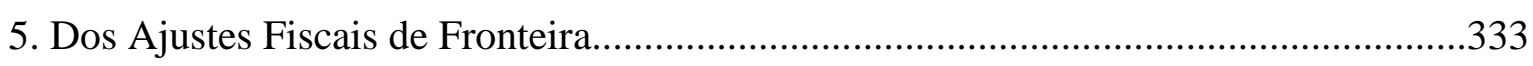

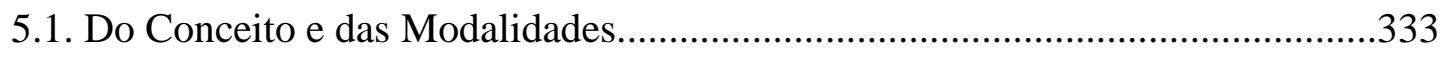

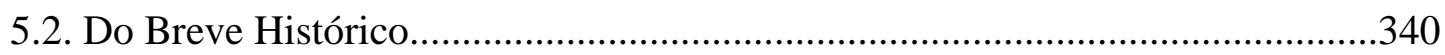


5.3. Do Tratamento no Sistema Multilateral de Regulação do Comércio Internacional. .355

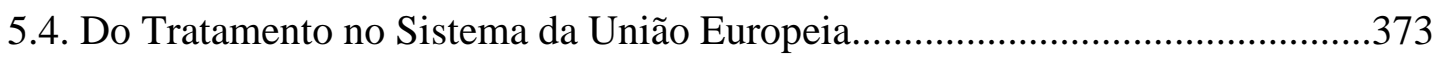

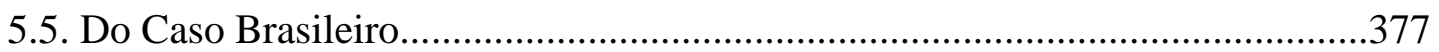

6. Do Princípio de Não-Discriminação na experiência dos Estados Unidos da América..396

6.1. Do Federalismo Constitucional norteamericano................................................396

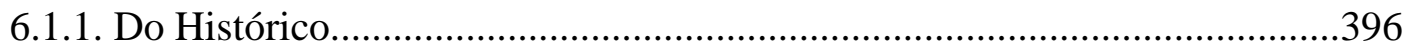

6.1.2. Da doutrina dos poderes enumerados e da sua superação...........................402

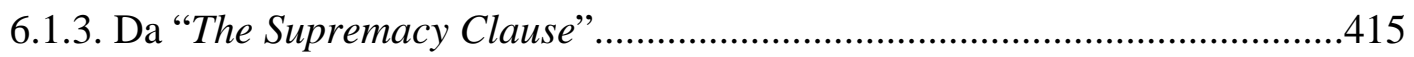

6.1.4. Do Poder de Tributar e de Despender.........................................................418

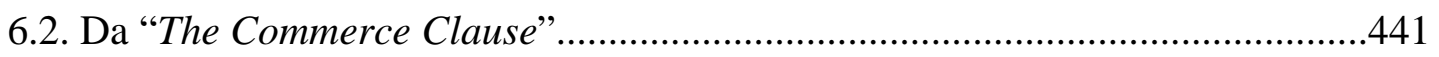

6.3. Da “The Dormant Commerce Clause" ............................................................448

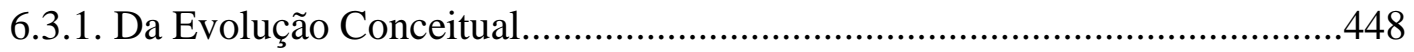

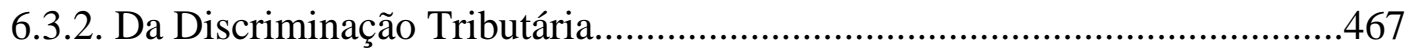

6.3.2.1. Da Discriminação Tributária Explícita........................................475

6.3.2.2. Da Discriminação Tributária Implícita........................................484

7. Do Princípio de Não-Discriminação Tributária na experiência do MERCOSUL e do Brasil. 495

7.1. Do Princípio de Não-Discriminação Tributária na experiência do

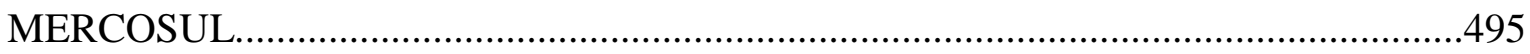

7.2. Do Princípio de Não-Discriminação Tributária na experiência brasileira..........508

8. Para uma Densificação Semântica do Princípio de Não-Discriminação Tributária........520

8.1. Dos Conceitos Jurídicos Indeterminados e a Jurisprudência...............................520

8.2. Da Não-discriminação Tributária como Neutralidade Fiscal..............................532

8.2.1. Da (impossível) Neutralidade Fiscal Absoluta...........................................532

8.2.2. Do (inexistente) Princípio Geral de Neutralidade Fiscal..............................547

8.2.3. Das (possíveis) Neutralidades Fiscais (Relativas e Parciais)......................555

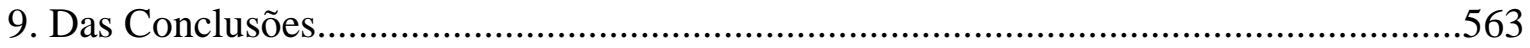

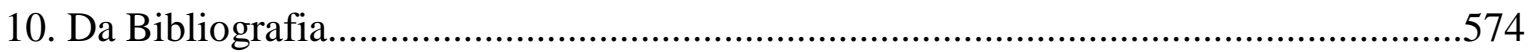




\section{LISTA DE ABREVIATURAS}

ADI - Ação Direta de Inconstitucionalidade.

BISD - Basic Instruments and Selected Documents.

CIDE - Contribuição de Intervenção no Domínio Econômico.

COFINS - Contribuição para o Financiamento da Seguridade Social.

FMI - Fundo Monetário Internacional.

GATS - General Agreement on Trade in Services (Acordo Geral sobre o Comércio de Serviços).

GATT - General Agreement on Tariffs and Trade (Acordo Geral sobre Tarifas Aduaneiras e Comércio).

ICM - Imposto sobre operações relativas à circulação de mercadorias.

ICMS - Imposto sobre operações relativas à circulação de mercadorias e sobre prestações de serviços de transporte interestadual e intermunicipal e de comunicação.

IPI - Imposto sobre Produtos Industrializados.

IVA - Imposto sobre o Valor Agregado.

MERCOSUL - Mercado Comum do Sul.

NAFTA - North America Free-Trade Agreement.

OCDE - Organização para a Cooperação e Desenvolvimento Econômico.

OECD - Organisation of Economic Cooperation and Development.

OIC - Organização Internacional do Comércio.

OMC - Organização Mundial do Comércio.

OSC - Órgão de Solução de Controvérsias. 
PIS/PASEP - Programa de Integração Social/ Programa de Formação do Patrimônio do Servidor Público.

RE - Recurso Extraordinário.

REsp - Recurso Especial.

SATAP - “... so as to afford protection..." - “... de modo a proteger...”.

SPS - Agreement on Sanitary and Phytosanitary Measures (Acordo sobre a Aplicação de Medidas Sanitárias e Fitossanitárias).

STF - Supremo Tribunal Federal.

STJ - Superior Tribunal de Justiça.

TBT - Agreement on Technical Barriers to Trade (Acordo sobre Barreiras Técnicas ao Comércio).

TCE - Tratado que institui a Comunidade Europeia.

TCEE - Tratado que institui a Comunidade Econômica Europeia.

TJCE - Tribunal de Justiça das Comunidades Europeias.

TJUE - Tribunal de Justiça da União Europeia.

TPR - Tribunal Permanente de Revisão do MERCOSUL.

TUE - Tratado sobre o Funcionamento da União Europeia. 


\section{RESUMO}

Hoje em dia, muito se fala sobre a globalização e o aprimoramento das relações comerciais no plano internacional, tanto do ponto de vista econômico quanto do político. No entanto, tais fenômenos carecem de estudos mais aprofundados quanto a alguns dos seus aspectos eminentemente jurídicos.

No que se refere à disciplina multilateral de regulação do comércio, o objetivo do sistema GATT/OMC é o de, mediante um contínuo processo de reforma e liberalização das políticas comerciais nacionais, proporcionar melhores condições de competitividade entre os países, especialmente por meio da proibição da edição de normas nacionais discriminatórias que afetem a livre circulação de mercadorias.

Todavia, tal proposta não tem alcançado a efetividade que deveria, não só em função da proposital limitação do seu escopo como também por conta da fluidez conceitual que, ainda hoje, ronda alguns de seus institutos basilares. O mesmo pode-se falar a respeito de outros sistemas, tanto regionais, como o da União Europeia, quanto nacionais, em países de forma de estado federalista, como os Estados Unidos.

O objetivo da tese é, portanto, após fornecer um levantamento sistemático dos instrumentos mais evoluídos atualmente à disposição dos juristas, apresentar uma proposta de solução para essa fluidez conceitual que, ao mesmo tempo em que faça uso de referencial teórico objetivamente construído, permita que se possa vislumbrar a perspectiva de que o mundo globalizado, no futuro, torne-se mais justo e igual.

\section{Palavras-chave}

Não-discriminação - Tributação indireta - Livre Circulação de Mercadorias Ajustes Fiscais de Fronteira - Protecionismo. 


\section{ABSTRACT}

Nowadays, globalization and international economic relations improvement are very common subjects, both in the economic and political point of view. Nevertheless, such phenomena need deeper studies related to their law aspects.

In what concerns to the multilateral trade regime, the GATT/WTO system purpose is to, by means of a continuum process of reform and liberalization of national trade policies, provide better competitive conditions to the states, specially through prohibition of internal discriminatory laws that affect the free movement of goods. However, this purpose hasn't been well succeeded, due not only to its deliberatedly restrict scope but also to a conceptual fluidity of some fundamental institutes of the system. That's also the reality of some other situations - regional systems, like the European Union, or national ones, in the case of federalist states, like the United States of America.

So, the thesis purpose is to provide a sistematic survey of the more advanced legal instruments today available and to present an objective and theoretically-built solution to solve this conceptual fluidity which permits that we all might foresee a fair and more equal globalized world in the future.

\section{Key-words}

Non-discrimination - Indirect Taxation - Free Movement of Goods - Border Tax Adjustments - Protectionism. 


\section{RESUMÉ}

Aujourd'hui, on parle beaucoup sur la mondialisation et l'amélioration des relations commerciales internationales, sur les points de vue économique et politique. Malgré cela, ces phenomènes ont besoin d'études plus aprofondis sur ces aspects émminement juridiques.

En ce que s’agit du régime commercial multilatéral, l'objectif du système GATT/OMC est, par un processus de réforme et de libéralisation des politiques commerciales, pourvoir meilleurs conditions de concurrence entre les pays, surtout par la proibition d'edition des lèges discriminatoires. Néanmoins, cette intention ne reste pas bien heureux, non seulement à cause d'une delibérée limitation de sa extension, comme aussi par compte de la fluidité conceptuelle de quelques de ses institutes fondamentaux. Ça est vrai aussi pour les systèmes regionaux, comme l'Union Européenne, comme pour les systèmes federalistes, comme cet des États Unis de l'Amerique.

Alors, la proposition de cette thèse est celle de fournir une enquête systématique des plus evolués instruments juridiques presentement disponibles et de presenter une solution pour cette fluidité conceptuelle qui, tandis que s'utilise d'une theorie objective, permette aussi qu'on peut entrevoir une mondialisation qui soit vraiment juste et égalitaire.

\section{Mots-clées}

Non-discrimination - Fiscalité Indirecte - Libre Circulation des Marchandises Ajustements Fiscaux à la Frontière - Protecionisme. 


\section{DA INTRODUÇÃO.}

Hoje em dia, muito se fala sobre a globalização e o aprimoramento das relações comerciais no plano internacional, tanto do ponto de vista econômico quanto do político. No entanto, tais fenômenos carecem de estudos mais aprofundados quanto a alguns dos seus aspectos eminentemente jurídicos.

Talvez não exista objeto de controvérsia de cunho ideológico mais aguerrida, hoje em dia, no debate internacional, do que a aferição da justiça e da equidade na distribuição dos ganhos e perdas com o advento do sistema multilateral de regulação do comércio entre os Estados independentes (KAPSTEIN, 1999), hoje administrado pela Organização Mundial do Comércio (OMC).

Trata-se da instituição internacional reconhecida como o mais evidente símbolo da globalização econômica (WOLF, 2001, p. 183), fenômeno sobre o qual, nos nossos dias, tanto se fala, mas que pouco realmente se compreende ${ }^{1}$.

Por um lado, há vozes que identificam diversos pontos positivos na existência de um arcabouço institucional regulatório estável no plano internacional.

Assim os defensores do atual sistema multilateral de regulação do comércio internacional argumentam, por um lado, em função de considerações teórico-econômicas (TANZI, 2002), entendendo a função do arcabouço institucional como meio de assegurar a segurança e a previsibilidade necessárias à maximização dos lucros entre as partes, característica intrínseca do estudo das trocas nas teorias modernas sobre o comércio exterior (CARVALHO; SILVA, 2004), superando o jogo de soma zero denunciado por Adam Smith em 1776 (KRUGMAN; OBSTFELD, 2004).

Para esses entusiásticos defensores, a implementação, ainda que não total, de dogmas como o da redução de tributos aduaneiros, da eliminação de barreiras regulatórias e do livre acesso a mercados ${ }^{2}$ guardam estreita correlação com a prosperidade econômica que caracterizou a segunda metade do Século XX (SHORT, 2001).

Assim, a própria existência permanente de um sistema internacional de regulação do comércio deve ser entendida como um bem público ${ }^{3}$ internacional (WOLF,

\footnotetext{
1 Trata-se, a globalização econômica, de conceito equívoco, cujas diferentes acepções implicam sempre pesada carga ideológica. A propósito, quanto aos vários sentidos e ideologias, ver Gonçalves (2003).

2 Tríade que se costuma associar ao conceito de "livre comércio", embora a doutrina internacional mais abalizada discuta acidamente tal definição. Nesse aspecto, ver a obra de David Driesen, professor de Direito Internacional do Comércio (International Trade Law) em Syracuse, NY, Estados Unidos (2001).

${ }^{3}$ Bem (puramente) público, na teoria econômica, é algo de cujo consumo, uma vez produzido, ninguém pode ser privado (entendido consumo como o usufruto do benefício de sua disponibilidade, já que ele não se
} 
2001, p. 194), pelo acréscimo geral de bem-estar que gera (JORDAN, 2001, p. 244). Terse-iam alcançados, portanto, os objetivos presentes na primeira parte do preâmbulo do Acordo Constitutivo da OMC, internalizado no Direito brasileiro pelo Decreto $\mathrm{n}^{\mathrm{o}} 1.355 / 94^{4}$ - por sinal, também presentes, embora apenas parcialmente, no texto originário do preâmbulo do GATT, de $1947^{5}$.

Mas há também respeitáveis posições discordantes, especialmente entre representantes de países ditos em desenvolvimento. Não negam os dados estatísticos sobre o incremento do comércio internacional desde a vigência do GATT, mas ponderam que tal realidade foi alcançada mediante desproporcionais esforços entre países desenvolvidos e sub-desenvolvidos (RICUPERO, 2001, p. 49 - 54), pelo que o seu atendimento, de tão oneroso à aplicação pelos países menos favorecidos, pode ter acabado por gerar desemprego e pobreza nesses locais do mundo, em função da perda de parcelas de mercado para os seus produtos (SHORT, 2001, p. 60 - 61).

Como consequência, não se veem realizados, ao menos até o presente momento, os objetivos arrolados no preâmbulo do Acordo Constitutivo da OMC, no que toca aos países em desenvolvimento ${ }^{6}$ (KAPSTEIN, 1999), sendo cada vez mais pessimistas as expectativas quanto à efetiva implementação dos objetivos relacionados ao desenvolvimento previstos na Declaração Ministerial de Doha (WT/MIN(01)/DEC/1), de 20 de novembro de 2001, de que o comércio internacional efetivamente exerça um papel fundamental na promoção do desenvolvimento econômico e na redução da pobreza no planeta ${ }^{7}$.

exaure - é "non-rival”) e cujo custo social marginal de produção para um consumidor adicional é zero, não sendo portanto vedado a ninguém dele usufruir - é non-excludable (NICHOLSON, 2002; WOLF, 2001, p. 207).

4 “As Partes do presente Acordo,

Reconhecendo que as suas relações na esfera da atividade comercial e econômica devem objetivar a elevação dos níveis de vida, o pleno emprego e um volume considerável e em constante elevação de receitas reais e demanda efetiva, o aumento da produção e do comércio de bens e de serviços, permitindo ao mesmo tempo a utilização ótima dos recursos mundiais em conformidade com o objetivo de um desenvolvimento sustentável e buscando proteger e preservar o meio ambiente e incrementar os meios para fazê-lo, de maneira compatível com suas respectivas necessidades e interesses segundo os diferentes níveis de desenvolvimento econômico, $(\ldots) "$

5 "Recognizing that their relations in the field of trade and economic endeavour should be conducted with a view to raising standards of living, ensuring full employment and a large and steadily growing volume of real income and effective demand, developing the full use of the resources of the world and expanding the production and exchange of goods,"

6 "Reconhecendo ademais que é necessário realizar esforços positivos para que os países em desenvolvimento, especialmente os de menor desenvolvimento relativo, obtenham uma parte do incremento do comércio internacional que corresponda às necessidades de seu desenvolvimento econômico, (...)"

7 "2. International trade can play a major role in the promotion of economic development and the alleviation of poverty. We recognize the need for all our peoples to benefit from the increased opportunities and welfare gains that the multilateral trading system generates. The majority of WTO members are developing 
Dado o seu cunho fortemente ideológico, pretende-se aqui permanecer à margem da discussão centrada principalmente na já tradicional dicotomia liberalismo $\mathrm{X}$ intervencionismo (SUTHERLAND; SEWELL; WEINER, 2001), livrecambismo X protecionismo (DORDI, 2002, p. 44) ou entre Davos e Porto Alegre, mais modernamente (GUTMANN, 2004), cidades que acabaram por simbolizar tal embate, embora o Fórum Social Mundial, a partir de 2006, não mais tenha se realizado necessariamente na capital gaúcha.

A presente análise, de cunho eminentemente jurídico, não pretende penetrar na discussão de políticas públicas, mas não se pode negar que há a realidade insofismável da existência de um conjunto de regras acordadas entre as nações a afetar profundamente suas orientações políticas (SAMPSON, 2001), chegando mesmo a afetar o poder soberano dos Estados (LEHNER, 2002), criando um historicamente inigualável grau de interdependência entre as nações (VAN GINKEL, 2001).

Em verdade, o que se tem presenciado, e a disciplina multilateral do comércio internacional é a melhor vitrine dessa realidade (PAHUJA, 2006), é uma cada vez maior interpenetração, em outras áreas do conhecimento e da política, de um discurso econômico predominante nas esferas de domínio global, que impõe um conjunto de princípios a serem adotados pelos ordenamentos nacionais (DAUVERGNE, 2006), sempre formulados em elevado nível de abstração (TWINING, 2006), e empregados pragmaticamente algumas vezes sem maiores cuidados pelas instituições nacionais.

Nas palavras de Teubner (2006b), essa mistura entre concepções e princípios econômicos e institutos jurídicos é parte de um processo global de acoplamentos estruturais entre as instituições legais e os ramos de atividade de natureza especializada e técnica, entendidos esses acoplamentos estruturais como formas de influência do ambiente externo no sistema jurídico (LUHMANN, 2004).

Tal realidade de interpenetração já tem sido enfrentada em domínios como o dos direitos humanos, em que se pode apontar hoje a existência de uma doutrina internacional (BIANCHI, 2006); ou mesmo do Direito Ambiental (TEUBNER, 2006b). Lamentavelmente, não se pode dizer o mesmo do Direito do Trabalho ou da disciplina internacional da nacionalidade e da naturalização (DAUVERGNE, 2006).

countries. We seek to place their needs and interests at the heart of the Work Programme adopted in this Declaration. Recalling the Preamble to the Marrakesh Agreement, we shall continue to make positive efforts designed to ensure that developing countries, and especially the least-developed among them, secure a share in the growth of world trade commensurate with the needs of their economic development. In this context, enhanced market access, balanced rules, and well targeted, sustainably financed technical assistance and capacity-building programmes have important roles to play". 
No caso do Direito Tributário, ramo do Direito em que a análise, no presente trabalho, das consequências de tal multiplicidade de fontes normativas vai concentrar suas atenções, hoje se fala em um Regime Tributário Internacional - "International Tax Regime" (AVI-YONAH, 2007), pelo que os países, no campo da tributação direta, repositório das preocupações com a segurança jurídica por parte dos detentores do capital, não poderiam, no exercício de suas soberanias fiscais, fugir de uma série de princípios de coerência do sistema, como a prevenção à bitributação econômica e jurídica, a tributação do investimento passivo na residência e da renda negocial ativa no país da fonte dos rendimentos (p. 1).

O problema é saber quais são os limites desses regimes, se é que existem, e se realmente é do interesse do bem-estar geral do planeta que eles se consolidem da forma como hoje são prevalescentes.

Embora haja quem defenda que a OMC e o discurso econômico globalizado não implicam redução do poder soberano dos Estados, mas apenas dos grupos de interesse protecionistas (McGINNIS; MOVSESIAN, 2001), não há dúvida que a globalização econômica é um fenômeno multifacetado (VAN DEN BOSSCHE, 2005), sendo a própria emergência de um necessário requestionamento da doutrina tradicional das fontes do Direito (TEUBNER, 2006a) uma manifesta consequência dessa realidade.

No entanto, pode-se contestar em que aspectos a globalização é realmente um fenômeno novo, mesmo no aspecto legal (GOLDMAN, 2006), mormente sabendo-se que a história dos acordos comerciais entre nações independentes, no hoje já arcaico sentido westphaliano (ZACHER, 1992), monta ao Século XII (MATSUSHITA; SCHOENBAUM; MAVROIDIS, 2005). Mas a existência de uma desterritorialização do poder de decisão das instituições democráticas, com a formação de redes policêntricas de produção normativa (LADEUR, 2003), é aspecto ainda em aberto no pensamento jurídico internacional.

Nessa perspectiva, a proposta do presente trabalho deve ser, dentro dessas realidades cada vez mais insofismáveis de interpenetração, tanto dos conceitos e disciplinas internacionais nos ordenamentos nacionais quanto dos conceitos econômicos na ciência jurídica, tentar buscar um novo entendimento em relação àquele que é o princípio basilar (BALASSA, 1962; COTTIER; MAVROIDIS, 2000; UCKMAR, A, 2002) do sistema multilateral de regulação do comércio internacional - o Princípio de NãoDiscriminação, em uma das duas principais vertentes de aplicação prática, a que se direciona a produtos nacionais em relação aos estrangeiros, representada no plano multilateral, pela obrigação aos Estados-Membros de obediência à cláusula de tratamento 
nacional (Art. III do GATT 1947) - sem entrar mais profundamente no outro pilar básico do GATT, a disciplina que projeta seus efeitos entre dois ou mais produtos estrangeiros: a cláusula de nação mais favorecida (Art. I do GATT 1947) (HUDEC, 2000). Paralelamente, estudar-se-á como tal obrigação é concebida e implementada em outros sistemas jurídicos, regionais e locais, em se tratando de países federais.

É de tal relevância a vedação ao tratamento discriminatório nas relações comerciais internacionais que é declarada como sendo o objetivo expresso da celebração dos acordos internacionais multilaterais iniciados com o GATT e sucedidos pelo atual Acordo Constitutivo da OMC, ao lado do instrumento concreto para a sua obtenção, construído na base da reciprocidade e das vantagens mútuas, que é a redução substancial das tarifas aduaneiras e dos demais obstáculos ao comércio, como relacionado nos preâmbulos dos textos de $1947^{8}$ e de $1994^{9}$.

Mais do que simplesmente reconhecer sua relevância, será a partir da comparação com o sentido com o qual o Princípio de Não-Discriminação é compreendido em outros sistemas jurídicos, caracterizados pela multiplicidade de fontes normativas, que se pretende concluir por um sentido teórico mais consistente para o princípio.

Não se deve esquecer que, como muito bem lembrado por Thomas Cottier e Petros Mavroidis (2000), o sistema westphaliano de nações Estado foi construído sobre determinações e esforços discriminatórios. A ideia de nação tem sido, portanto, ancestralmente ligada e consolidada à custa do prejuízo e do preconceito em relação ao que se origina do exterior, sejam produtos, sejam pessoas, manifestações culturais ou pensamentos.

Uma questão preliminar que avulta é, portanto, saber, empregando as modalidades de soberania delimitadas por Krasner (2001), até que ponto o exercício da soberania legal internacional - na medida em que os Estados soberanos acordaram entre si

\footnotetext{
8 "Being desirous of contributing to these objectives by entering into reciprocal and mutually advantageous arrangements directed to the substantial reduction of tariffs and other barriers to trade and to the elimination of discriminatory treatment in international commerce,

Have through their Representatives agreed as follows:"

9 "Desejosas de contribuir para a consecução desses objetivos mediante a celebração de acordos destinados a obter, na base da reciprocidade e de vantagens mútuas, a redução substancial das tarifas aduaneiras e dos demais obstáculos ao comércio, assim como a eliminação do tratamento discriminatório nas relações comerciais internacionais;

Resolvidas, por conseguinte, a desenvolver um sistema multilateral de comércio integrado, mais viável e duradouro que compreenda o Acordo Geral sobre Tarifas Aduaneiras e Comércio, os resultados de esforços anteriores de liberalização do comércio e os resultados integrais das Negociações Comerciais Multilaterais da Rodada Uruguai;

Decididas a preservar os princípios fundamentais e a favorecer a consecução dos objetivos que informam este sistema multilateral de comércio, acordam o seguinte:"
} 
pela submissão ao sistema multilateral que aí está diante de todos nós - restringe ou atenua o exercício da soberania westphaliana, a capacidade dos Estados de se gerirem sozinhos, nas suas decisões no plano interno que afetem as fontes externas de autoridade (os demais Estados soberanos). Porém, trata-se de ponto apenas a ser indicado, sobre o qual não se pretende evoluir, por transbordante à análise a ser empreendida.

Tal indagação é ainda mais relevante se admitirmos como válida a preocupação de Maduro (2003, p. 257) quanto à percepção comum de que a liberalização comercial seria mesmo uma inexorabilidade.

Não se pretende chegar a uma definição teórica do que seja livre comércio, algo que aguçou a pesquisa de investigadores nos últimos quatrocentos anos (DRIESEN, 2001). Por outro lado, conceituar livre comércio como trocas ocorrendo em ambiente com normatividade não-discriminatória, como Driesen faz, acaba gerando um novo problema, o de definir o que seja a normatividade não-disciminatória. O presente objetivo, ao menos no plano das incidências tributárias, pois, é discutir esse novo problema.

O tema aqui proposto será abordado dentro de uma perspectiva interdisciplinar, que procurará demonstrar como as realidades do Direito Internacional, do Direito Tributário e da Economia demandam a elaboração de um modelo teórico que dê fundamento mais consistente ao processo de solução de conflitos comerciais que se refiram aos eventuais efeitos protetivos das incidências tributárias.

Considerando todas essas tendências até então expostas, o tema objeto de reflexão não se limitará a examinar, portanto, apenas o conteúdo da obrigação do Tratamento Nacional, na disciplina positiva da OMC, ou da Livre Circulação de Bens, na União Europeia $^{10}$, mas sim, dentro de toda essa perspectiva teórica e consoante a casuística daí advinda, tentar chegar a um conceito material do princípio que seja abrangente e ultrapasse a ideia formal de tratamento diferenciado em função da origem ou destino.

Tencionando alcançar o objetivo de conduzir espontaneamente a esse tipo de reflexões, e a propor respostas a algumas delas, inicia-se o estudo com uma resumida contextualização histórica da disciplina do comércio internacional de bens e serviços, na qual se fará um cotejo dos fatos históricos, com ênfase na normatização jurídica que os

\footnotetext{
${ }^{10}$ Deve ser relembrado que, a partir de $1^{\circ}$ de dezembro de 2009, com a entrada em vigor do Tratado de Lisboa, a União Europeia passou a ter existência jurídica como tal, inclusive passando a ser Membro da OMC com essa denominação. A propósito, ver o sítio na organização internacional em http://www.wto.org/english/thewto_e/countries_e/european_communities_e.htm. Acesso em 27/03/2011. Não obstante, os relatos dos julgados arbitrais pelos Grupos Especiais do OSC da OMC, que serão empreendidos no decorrer do desenvolvimento do texto, empregarão o termo histórico, "Comunidades Europeias". Também as referências aos órgãos e diplomas da atual União Europeia, quando do estudo da não-discriminação em seu âmbito, respeitarão as denominações de cada época.
} 
provocou, pari passu a exposição resumida do pensamento jurídico e econômico que banhava a atuação legislativa naqueles momentos, ou que, eventualmente, a ela se opunha.

A partir desse Capítulo 2, de caráter introdutório, o leitor deverá contextualizar o advento histórico do sistema multilateral de regulação do comércio internacional dentro da teia de interesses que era o motor da atuação dos seus grandes idealizadores à época. Pois, como afirma Sainz de Bujanda (1986, p. 254 - 256), a formulação dos sistemas fiscais sempre compreende, ponderadamente, os aspectos de racionalidade e de historicidade. Assim se inicia o Capítulo 3.

De posse da informação assim introduzida, deve-se tentar entender quais os vetores que estão por trás do imbricamento do sistema de tratados, multi, pluri e bilaterais, se a principiologia econômica ou o jogo de interesses nacionais.

Evoluindo na análise, temos que, para a compreensão do principal pilar do sistema, o Princípio de Não-Discriminação, e para o minucioso entendimento do conteúdo da obrigação do Tratamento Nacional, é imperioso que se compreenda com detalhes a disciplina normativa do sistema multilateral, assim como entender como se consolidaram os conceitos convencionais na experiência arbitral desde a época do antigo GATT. É como se desenvolverá o Capítulo 3.

Deve-se ressaltar que é aqui entendido o Princípio de Não-Discriminação, no campo eminentemente tributário, como um plexo conceitual de limitações às pretensões impositivas soberanas à tributação discriminatória, à tributação protetiva e aos subsídios fiscais, na tricotomia apontada por Antonio Uckmar (2002, p. 1118).

De posse desse conceito, o próximo passo repousa em entender a relevância de questionar se os mecanismos nacionais listados anteriormente e empregados no exercício da política comercial e fiscal soberana são ou não são discriminatórios ou, mesmo se o forem, se são ou não são considerados ilícitos diante dessa ordem multilateral. Com isso, tenciona-se avaliar a eficiência dos critérios hoje empregados na aferição do conceito de efeito discriminatório da norma tributária. Com isso, superar o entendimento meramente formal do que seja uma norma tributária nacional de cunho discriminatório ou protetivo.

De se ressaltar, a propósito, que o foco do presente estudo, sobre a intelecção do Artigo III do GATT, será aplicado, como se verá, na dicção de Antonio Uckmar, tanto à tributação discriminatória (ou explícita ou "de jure", conceitos adiante minudenciados) e à tributação protetiva (ou implícita ou "de facto", idem), dependendo das frases tomadas do 
seu parágrafo 2, com ênfase na segunda, ou seja, aquela baseada em regras aparentemente neutras em relação à origem ${ }^{11}$, pois é a que permite maiores reflexões ontológicas.

Deve-se ressaltar que não se pretende examinar o Princípio de NãoDiscriminação em seus dois aspectos, tanto o tributário quanto o regulatório ${ }^{12}$, mas apenas no fiscal. Estabelecida essa limitação, o próximo passo é estudar com minúcias que tipo de incidências tributárias o Artigo III do GATT se destina a limitar. De toda essa análise poder-se-á verificar que é no campo tributário que as soluções jurisprudenciais têm sido mais decepcionantes, embora potencialmente mais simples do que as referentes à matéria regulatória. De se ressaltar que a dicotomia tributária-regulatória não só é a empregada pela doutrina que adota a mesma opção de espectro de análise que o presente trabalho (por exemplo, Ehring, 2002 e Zdouc, 2004), como também é a do direito positivo, já que presente na rubrica do artigo III do GATT $^{13}$, abrangendo, de forma sistemática, todo o campo de análise do poder normativo soberano estatal: tributário e de polícia administrativa.

O presente trabalho visa, portanto, a investigar como as limitações ao poder impositivo tributário (e não o regulatório) estatal devem ser entendidas, apenas com relação ao comércio de bens, sem entrar no mérito, por exemplo, de como os acordos

11 “Origin-neutral”, no original em inglês.

12 Deve-se perceber que os adjetivos aqui empregados, tributário e regulatório, correspondem aproximadamente ao conceito que alguns doutrinadores do Direito Internacional (de formação não advinda do Direito Tributário) e todos os estudiosos de matiz econômica atribuem aos vocábulos tarifário e nãotarifário. Esse emprego dos termos tarifário e não-tarifário, muito comum também nos escritos jurídicos em inglês, não obstante, não pode ser utilizado em um estudo de Direito Tributário, mesmo que fundado no Direito Internacional do Comércio, como o presente, por dois motivos. Primeiro porque o Direito Tributário brasileiro, predominantemente, adotou um conceito autônomo e diferenciado para o que seja tarifa - como preço público; distante, portanto, de entender no mesmo sentido de Imposto de Importação (no Direito Brasileiro), ou direitos aduaneiros, como empregado pelo GATT, inclusive na sua versão em português. Em segundo lugar, porque, como se verá adiante, há normas do GATT que são direcionadas ao tratamento de tributos que não o imposto de importação, direitos aduaneiros ou encargos de efeito equivalente. Ou seja, o GATT trata especificamente, em mais de um ponto e, como veremos, em uma disciplina relevante e minuciosa, de tributos que não a chamada tarifa aduaneira. Assim, no rigor científico, não existe, na disciplina que estamos estudando, a mencionada dicotomia tarifário ou não-tarifário, motivo pelo qual empregar-se-ão unicamente os termos do direito positivo, tributário e regulatório. Assim, a indicação do termo tarifa para o Imposto de Importação, nos moldes do brasileiro, como incidência diferenciada dos tributos internos, preferencialmente não será empregada, preferindo-se o emprego dos termos imposto de importação ou tributo ou imposto ou encargo aduaneiro. Por vezes, no entanto, ao mencionar textos de autores econômicos, o termo tarifa poderá ser empregado, com o fim de não desnaturar a fundamentação original. Mesmo nesses casos, é importante se estar assegurado a que tecnicamente se está referindo, no rigor da ciência tributária. Semelhante abordagem pode ser empreendida em relação ao termo paratarifa para se referir aos ajustes fiscais de fronteira, como se verá oportunamente.

${ }^{13}$ Segundo a Lei $\mathrm{n}^{\circ}$ 313, de 30 de julho de 1948, que autoriza o Poder Executivo a aplicar, provisoriamente, o Acordo Geral sobre Tarifas Aduaneiras e Comércio; (na sua versão original) reajusta a Tarifa das Alfândegas, e dá outras providências:

"ARTIGO III

TRATAMENTO NACIONAL EM MATÉRIA DE IMPOSTOS E DE REGULAMENTAÇÃO INTERNOS". 
complementares do GATT tratam da questão dos subsídios, nem das próprias normas, com efeitos tributários, presentes no General Agreement on Trade in Services - GATS, relativamente ao comércio de serviços. Ou seja, referindo-se às quatro liberdades básicas ${ }^{14}$ ao comércio internacional referidas no sistema comunitário europeu, apenas a livre circulação de mercadorias será examinada aqui, até porque é aquela em que já se chegou a alguma definição conceitual teórica na experiência jurisprudencial internacional, como se tentará captar ao final.

O tema dos subsídios fiscais será aqui abordado apenas tangencialmente. Fundamentalmente apenas no que seja necessário para entender sua distinção em relação aos ajustes fiscais de fronteira, no caso das exportações. A necessidade de tocar no assunto deve-se ao fato de que, como veremos, a disciplina dos ajustes fiscais de fronteira, nas exportações, na experiência multilateral, vem trazida em conjunto com a dos subsídios fiscais de outra ordem e os não-fiscais.

Em resumo, o trabalho aqui apresentado cingir-se-á à tentativa de compreensão sistematizada do Princípio de Não-Discriminação no comércio internacional de bens, tanto na importação quanto na exportação, no seu caráter eminentemente tributário - portanto, referente à tributação indireta ${ }^{15}$, em todas as suas modalidades - e sem fazer menção senão indireta ao complexo problema do interrelacionamento entre os diferentes sistemas jurídicos.

Fala-se hoje da existência de uma "defasagem de legitimação", ora vislumbrada no sistema da Organização Mundial do Comércio. Não há dúvida que há ausência de transparência (RICUPERO, 2001) no processo de tomada de decisões da OMC, ao mesmo tempo em que se sabe que o próprio aparato normativo pode ser visto como algo se prestando a reproduzir as relações fáticas de poder Norte-Sul (SHORT, 2001).

Não obstante, pode-se entender que a busca eficaz da pacificação dos conflitos comerciais entre as nações pode vir a ser pari passu alcançada na medida em que o Órgão de Solução de Controvérsias (OSC) da OMC aprofunde o debate científico sobre a sua forma de julgamento. Essa evolução mereceria ser vista, então, como, sem negar a existência de críticas gratuitas oriundas de um debate puramente ideologizado, um meio de conferir legitimidade ao sistema, ao mesmo tempo em que ele recupera a eficiência e a

\footnotetext{
${ }^{14}$ De circulação de mercadorias, de serviços, de pessoas e de capitais (GORJÃO-HENRIQUES, 2005).

${ }^{15}$ Deve-se ressaltar que não se abordará aqui a controvérsia entre os autores brasileiros e internacionais sobre o correto elemento diferenciador da classificação dos impostos em diretos ou indiretos - segundo meramente o critério da repercussão econômica, da repercussão jurídica ou no lançamento, entre outros. Adotar-se-á a simplificação de que tributos indiretos são aqueles que incidem sobre bens. Para uma abordegam aprofundada da distinção, consultar a minha dissertação de mestrado (BRITO FILHO, 2003).
} 
coercitividade de suas decisões, vencendo o problema identificado por Maria Livanos Cattaui (2001).

Não há meio mais direto de alcançar o respeito da sociedade civil organizada do que produzindo decisões mais justas e bem fundamentadas. Mais do que isso, também a investigação científica pode fazer com que o próprio arcabouço normativo venha a se desenvolver. Como bem afirma Driesen (2001), apenas a intelecção pacificada e cientificamente fundamentada do conceito de não-discriminação vai conferir maior legitimidade aos conceitos empregados nas arenas internacionais de solução de conflitos comerciais. Há quem diga, como Cattaui (2001), que a OMC tem sido vítima do seu próprio sucesso, mas não há dúvida que essa situação pode e deve ser atenuada com a melhoria de suas decisões técnicas. Também é inconteste que tal aprimoramente científico deve, idealmente, ser reproduzido em outras experiências internacionais, regionais ou nacionais.

Diante dessa realidade é imensamente relevante entender a fundo o entendimento do OSC. Ciente dessa necessidade, do meio para o final do Capítulo 3 manifesta-se a preocupação com que se chegue à compreensão, com detalhes, não só da disciplina normativa do sistema multilateral, como também de como se consolidaram os conceitos convencionais na experiência arbitral desde a época do antigo GATT. Para isso, o exame do Princípio de Não-Discriminação Tributária, um dos pilares do sistema multilateral, corresponde à compreensão do conteúdo da obrigação do Tratamento Nacional como manifestada pelo OSC da OMC, mormente os conceitos jurídicos indeterminados de produtos "similares" ou "diretamente competidores ou substitutos", não só nos seus clássicos critérios de aferição (pelas características físicas, pela classificação fiscal, pela possibilidade de substituição ou pelo mercado de consumo), para evoluir para os casos em que tais critérios não mais satisfazem, como também os de "superiores a" e “de modo a proteger a produção nacional”. O Capítulo 3, portanto, terminará com o exame de como o Órgão de Solução de Controvérsias da OMC tem estabelecido a ocorrência ou não de incidências tributárias nacionais protetivas no comércio internacional de bens, por meio da análise dos testes subjetivos e objetivos que o órgão arbitral tem empregado na sua jurisprudência.

Avançando nesse passar de olhos nos exames teóricos a serem empreendidos adiante, deve-se entrar então na concepção positiva e doutrinária europeia, mas, principalmente, no exame dos julgados do Tribunal de Justiça das Comunidades Europeias. Essa é a função do Capítulo 4. 
Como se sabe, a doutrina europeia entende que a primeira das liberdades, a liberdade base (ALMEIDA, 1985, p. 265), a liberdade de circulação de mercadorias, pressupõe basicamente dois princípios: o princípio de acesso ao mercado, que diz com o direito de atravessar as fronteiras físicas, e o princípio de igualdade no mercado, que consiste justamente na vedação à discriminação por nacionalidade ou origem (TERRA; WATTEL, 2008, p. 44).

Inicialmente, há que serem identificados os campos de análise, dentro de um princípio de independência de disciplinas: de um lado, o art. $12^{\circ}$ do Tratado que institui a Comunidade Econômica Europeia (TCEE), de Roma; após, o art. $25^{\circ}$ do Tratado que institui a Comunidade Europeia (TCE), lavrado em Maastricht, com a renumeração efetivada pelo Tratado de Amsterdam; atual art. $30^{\circ}$ do Tratado sobre o funcionamento da União Europeia (TUE), após o Tratado de Lisboa, de 2007, que pode ser resumido na proibição de "medidas de efeito equivalente" aos direitos aduaneiros; de outro, a eliminação das restrições quantitativas, do art. $30^{\circ}$ originário, após art. $28^{\circ}$, atual art. $34^{\circ}$, cujo entendimento vem sendo profundamente discutido desde os casos Dassonville ${ }^{16}$ e Cassis Dijon ${ }^{17}$.

Tais regras, ambas, se diferenciam das que foram mais desenvolvidas no exame das questões concernentes às imposições internas, consoante o art. 95 $5^{\circ}$ do TCEE; após, art. $90^{\circ}$ do TCE; atual art. $110^{\circ}$ do TUE. Foi larga a atuação jurisprudencial, especialmente nos anos oitenta, com vistas a dar efetividade a essa disposição comunitária, aclarando o significado de termos como "imposição interna", "imposição discriminatória", "produtos similares", "produtos em relação de concorrência", "tratamento diferenciado" e "efeito protetivo", o que alcançou, em última análise, a realização concreta da harmonização tributária europeia, no seu aspecto negativo.

$\mathrm{Na}$ verdade, do exame dessa jurisprudência comunitária pode-se identificar realmente o grande cimento que consolidou a integração europeia, ainda na fase de união aduaneira ou mesmo com o advento do mercado comum. A partir da construção jurisprudencial europeia, pode-se entender a relevância da definição, tendo em vista os fundamentos integracionistas aqui abordados, do chamado Princípio de NãoDiscriminação.

\footnotetext{
${ }^{16}$ Caso 8/74 - Procureur du Roi v. Dassonville. ECR 1974, 837.

${ }^{17}$ Caso 120/78 - Rewe-Zentrale AG v. Bundesmonopolverwaltung für Branntwein. ECR 1979, 649.
} 
Tal princípio, cuja definição genericamente considerada é a hoje presente no art. $7^{\mathrm{o}^{18}}$ do TCEE; após, art. $12^{\mathrm{o}^{19}}$, do TCE, atualmente art. $18^{\mathrm{o}^{20}}$ do TUE, agora expressamente destinado, nessa localização, às questões de cidadania, é parte, conjuntamente com os princípios da solidariedade e da liberdade econômica, para a doutrina comunitária - entre outros, Laureano (1997, p. 18) -, da trilogia de princípios que constitui a espinha dorsal do esforço integracionista europeu.

Mais do que isso, defende Laureano (1997, p. 19) ser a não-discriminação, nessa abordagem não só no plano físcal, o aspecto realmente estruturante da União Europeia, chegando mesmo a apontar fundamentos históricos a comprovarem que o tratado constitutivo nada mais é que a concretização desse princípio em termos de normas jurídicas.

No sistema multilateral de regulação do comércio internacional disciplinado pela OMC, encontra-se o sistema de direito positivo que mais bem aborda e trata o importante conceito jurídico-tributário de ajuste fiscal de fronteira, de capital importância para o entendimento de um conceito mais amplo, menos meramente formalista, de nãodiscriminação, que aqui se quer propor. Em complemento, a experiência europeia na matéria e até a forma com que o sistema brasileiro implementa o conceito, embora sem mencioná-lo, serão examinados com profundidade. O Capítulo 5 dedica-se a esse tema.

Importante também, retomando a análise dos casos examinados na jurisprudência internacional a respeito, é examinar a realidade de países de forma de estado federal, como, tipicamente, os Estados Unidos da América. Ao conhecimento dessa experiência dedicar-se-á o Capítulo 6. Nesse ponto, inafastável é a lição da Suprema Corte dos Estados Unidos na formulação da doutrina da "The Dormant Commerce Clause".

18 "Article 7.

Dans le domaine d'application du présent traité, et sans préjudice des dispositions particulières qu'il prévoit, est interdite toute discrimination exercée en raison de la nationalité.

Le Conseil, sur proposition de la Commission et après consultation de l'Assemblée, peut prendre, à la majorité qualifiée, toute réglementation en vue de l'interdiction de ces discriminations".

19 "ARTIGO $12^{\circ}\left(\right.$ ex-artigo $\left.6^{\circ}\right)$

No âmbito de aplicação do presente Tratado, e sem prejuízo das suas disposições especiais, é proibida toda e qualquer discriminação em razão da nacionalidade.

O Conselho, deliberando nos termos do art. $251^{\circ}$, pode adoptar normas destinadas a coibir essa discriminação".

20 "PARTE II

NÃO DISCRIMINAÇÃO E CIDADANIA DA UNIÃO

Artigo $18^{\circ}$

(ex-artigo $\left.12^{\circ} \mathrm{TCE}\right)$

No âmbito de aplicação dos Tratados, e sem prejuízo das suas disposições especiais, é proibida toda e qualquer discriminação em razão da nacionalidade.

O Parlamento Europeu e o Conselho, deliberando de acordo com o processo legislativo ordinário, podem adoptar normas destinadas a proibir essa discriminação". 
Trata-se exatamente da limitação ao poder dos estados-membros da federação americana em legislarem, na inexistência de norma federal a respeito, quanto a relações comerciais interestaduais, restrição retirada da interpretação pretoriana do art. $1, \S 8$ da Constituição Americana, que autoriza o Congresso Nacional a regular o comércio entre estados.

Também se pretende estudar o pouco que existe do Princípio de NãoDiscriminação na nossa experiência de integração regional, o MERCOSUL, a partir do estudo dos conflitos concretos ocorridos na nossa iniciativa de integração e da norma do tratado institutivo que o veicula. Ao lado disso, será abordada tanto a forma com que a jurisprudência brasileira tem tratado assuntos que poderiam se relacionar com a experiência internacional apresentada, como também como as regras constitucionais referentes à vedação de diferenças tributárias em função de origem ou destino são abordadas na melhor doutrina brasileira. Assim se encaminhará o Capítulo 7.

Pode-se ressaltar a absoluta ausência de estudos sistematizados sobre o tema diante do arcabouço constitucional brasileiro, ou mesmo por detrás da reduzida jurisprudência superior nacional a respeito, ao menos as que considerem nas suas razões de decidir as diretrizes consolidadas internacionalmente. Para piorar, a doutrina brasileira, como sempre de costas para o MERCOSUL, não só não discute a não-discriminação em matéria de tributação indireta e no comércio de bens, como pula etapas e prefere discutir temas de tributação direta, relacionados às liberdades de estabelecimento de pessoas físicas e jurídicas e de capitais (TÔRRES, 2002; OKUMA, 2003). Como resultado, o Princípio de Não-discriminação acaba sendo, no Brasil, diminuído em sua carga semântica, como quer Xavier (1997), em oposição à gradual importância que o seu estudo vem ganhando no resto do mundo. Paradoxal, em se tratando de um país com um sistema jurídico constitucional tributário tão rico.

Busca-se, portanto, erigir uma construção teórica que dê supedâneo à correta valoração do princípio e a uma justa aplicação de seus critérios de aferição quando do potencial e futuro aparecimento de conflitos concretos internamente, na medida em que se conhecem as problemáticas já enfrentadas pela União Europeia e pela Organização Mundial do Comércio. Afinal, trata-se de tema com o qual teremos de nos defrontar mais cedo ou mais tarde, sob pena de não podermos dizer existente um entendimento nacional ou regional sul-americano, jurisprudencial ou doutrinário, acerca da concepção teórica do que seja o Princípio de Não-Discriminação no comércio internacional de bens. Tal se configuraria desastroso, já que inexorável e próximo o enfrentamento concreto de tais questões na evolução da integração econômica do Cone Sul. 
Trata-se de realidade insofismável não apenas porque urge que se progrida no aprofundamento da integração no Cone Sul (AMARAL, 1995), até mesmo no rumo do cumprimento dos objetivos previstos no art. $1^{\circ}$ do Tratado de Assunção ${ }^{21}$, saindo de sua atual condição de uma união aduaneira imperfeita (SANTA-BÁRBARA RUPÉREZ, 2001, p. 203), sua natureza jurídica atual, dentro da classificação tradicional dos níveis de integração econômica (PORTO, 2001), mas também porque a recuperação econômica da tétrade sul-americana nos últimos anos tem de tal maneira incrementado ${ }^{22}$ o comércio regional local, que já se estão verificando amiúde controvérsias, embora ainda em estado incipiente, como se verá.

Mais do que isso, a inexistência, no Brasil, não só de uma concepção, senão pacificada, mas nem sequer ao menos discutida sobre o assunto, como nem mesmo de um mínimo de atenção concertada e organizada para o problema, a menos de vozes isoladas (por exemplo, Heleno Torres, 2002), faz com que proliferem, no direito brasileiro, especialmente no Direito Tributário nacional, normas que vêm potencialmente de encontro ao Princípio da Não-discriminação, na forma como entendido no plano internacional.

No Brasil, apenas nesse momento começa-se a despertar para a importância da compreensão do alcance e conceituação do Princípio de Não-discriminação. Alguns artigos doutrinários já começam a mencioná-lo, como os da lavra de Heleno Tôrres (2002) ou de Alessandra Okuma (2003). São, não obstante, trabalhos dedicados a aplicar o Princípio de Não-discriminação ao exame de alguma específica pretensa infringência detectada no regime jurídico brasileiro, sem aprofundar na conceituação do princípio em si.

Ao final, no capítulo 9, procurar-se-á sistematizar o conceito de nãodiscriminação, não apenas de uma maneira formal. Pelo contrário, a partir dos conceitos explorados pelas diversas experiências normativas internacionais, construir um conceito do Princípio de Não-discriminação que seja materialmente consentâneo com a necessidade, muito bem apontada por Fritz Neumark (1974, p. 273 - 336), de que a política fiscal respeite o ordenamento econômico, vedando-se tributos que sejam economicamente

21 "Os Estados-Partes decidem constituir um Mercado Comum, que deverá estar estabelecido a $31 \mathrm{DE}$ DEZEMBRO DE 1994, E QUE SE DENOMINARÁ “Mercado Comum do Sul” (MERCOSUL).

Este Mercado Comum implica:

A livre circulação de bens, serviços e fatores produtivos entre os países, através, entre outros, da eliminação dos direitos alfandegários e restrições não-tarifárias à circulação de mercadorias e de qualquer outra medida de efeito equivalente; (...)"

${ }^{22}$ Corrente de comércio Brasil - Mercosul de US\$ (FOB) 8.930.395.501 em 2002, US\$ (FOB) 11.369.638.701 em 2003, US\$ (FOB) 15.335.394.972 em 2004, US\$ (FOB) 18.799.710.686 em 2005, US\$ (FOB) 22.952.215.052 em 2006, US\$ (FOB) 28.978.328.821 em 2007 e US\$ (FOB) 35.770.935.245 em 2008 (BRASIL, SECEX, 2010). 
dirigistas, com o fim de que o sistema fiscal não interfira na esfera econômica e na espera privada dos indivíduos. Mais do que isso, as incidências tributárias não só devem ser neutras quanto à origem (não discriminatórias no sentido empregado pela OMC), como também é necessário que não acarretarem em seu bojo qualquer grau de protecionismo. Assim, para implementar o que Neumark denomina de caráter positivo da neutralidade tributária (1974, p. 317) quantos aos aspectos do comércio internacional decorrentes da existência de fronteiras fiscais, o emprego dos ajustes fiscais de fronteira é imprescindível. Pretende-se explorar, embora em outro contexto, a ideia trazida por Heleno Torres (2003, p. 11), de "fechamento operacional" entre o sistema de direito positivo, o poder de tributar, e a autonomia privada constitucionalmente atribuída aos particulares, para então aduzir uma conceituação mais densa do que seja o Princípio de Não-Discriminação tributária. 


\section{SOBRE A DICOTOMIA LIVRECAMBISMO X PROTECIONISMO.}

Inicialmente, antes de se analisar especificamente as circunstâncias históricas que cercaram a criação do GATT e, posteriormente, da OMC, é importante previamente conhecer algo acerca da evolução do pensamento econômico e político ocidental sobre o comércio internacional, a compreensão de seus mecanismos, assim como as vantagens e as desvantagens em regulá-lo.

A intenção é a de primeiramente discutir as ideias favoráveis e contrárias ao comércio internacional em geral dentro de uma perspectiva histórica, introduzindo assim a dicotomia entre o que atualmente Douglas Irwin (1998, p. 4), mencionando John Stuart Mill, denomina de doutrina protecionista, e as doutrinas do livre comércio a que se refere Joseph Schumpeter (1954, p. 370).

A partir dessa visão histórica, tenciona-se ressaltar a importância capital das contribuições de Adam Smith, por meio da concepção das vantagens absolutas, e de David Ricardo, acerca da Teoria das Vantagens Comparativas, como ponto de inflexão na avaliação negativa anterior, mesmo anteriormente à era mercantilista, da maioria do pensamento econômico, de maneira a alcançar a situação atual, quando, malgrado a diversidade de argumentos contrários que a essas teorias sobrevieram, nos últimos dois séculos, poder-se dizer, como afirma Harry G. Johnson (1971, p. 187), que a concepção, de que a liberdade no comércio internacional é mais benéfica do que a proteção, é uma das mais fundamentais proposições que a teoria econômica pode oferecer para guiar as políticas econômicas nos dias de hoje.

Mais ainda do que expor concepções econômicas, prevalentes ou não, para o nosso estudo importa conhecer a evolução das doutrinas sobre o livre comércio porque, como nos ensina Andreas Lowenfeld (2008, p. 3), o GATT é claramente baseado na percepção de que o comércio internacional é benéfico, que os ganhos para a sociedade decorrentes do comércio ultrapassam as perdas impostas àqueles que são solapados pela concorrência internacional e que há criação de valor por meio da especialização e das trocas em mercados abertos.

Em verdade, a razão de ser da realidade da preponderância do pensamento livre-cambista é o fato de que as ideias econômicas do pensamento clássico, independentemente das considerações pontuais que justificariam ainda hoje o esgrimir de argumentos protecionistas específicos, trouxeram de forma definitiva à dicotomia 
apresentada a questão da eficiência econômica - a indagação acerca de como uma particular política comercial pode afetar a capacidade de um país em empregar os seus recursos escassos, em termos de fatores de produção, como terras, capital e trabalho, de forma a gerar a maior renda possível, como a consequência de poder adquirir o maior conjunto possível de bens em troca (IRWIN, 1998, p. 4).

Como afirma Douglas Irwin (1998, p. 3), anteriormente ao pensamento clássico havia uma visão largamente difundida de que o uso apropriado de encargos na importação e outras restrições governamentais constituíam políticas comerciais mais efetivas, no que tange ao bem-estar da população, do que o livre comércio, entendimento que chegou ao ápice na literatura dita mercantilista, especialmente na Espanha e na França.

Diz-se literatura "dita mercantilista" porque, como bem ressalta José António Avelãs Nunes (2007, p. 291), não é correto se afirmar que tenha havido um conjunto de ideias ou um corpo coerente e sistemático do pensamento econômico mercantilista. Nenhum dos seus autores assim se proclamava, sendo que esse termo adveio da sistematização didática realizada, na segunda metade do Século XIX, pelos estudiosos da Escola Histórica Alemã. Nem sequer identifica-se uma terminologia comum, um vocabulário técnico minimanente rigoroso ou um caráter analítico desses escritos, motivo pelo qual Schumpeter $(1954$, p. 187 - 188) referiu-se ao "sistema mercantilista" como uma entidade imaginária. Não existiu, portanto, nem uma escola nem uma doutrina mercantilista (AVELÃS NUNES, 2007, p. 291).

Não obstante, é a partir da leitura dos autores dessa época que, embora muito menos interessados em construir um pensamento econômico teoricamente consistente, já que visavam mesmo a justificar um sistema de poder e a uma política de unificação nacional, podemos retirar o corpo mais diversificado de ideias relacionadas com as políticas de comércio internacional de toda a História, em regra de fulcro protecionista.

Da mesma forma, pode-se dizer que foi em reação a todos esses escritos ditos mercantilistas que se criou o pensamento analítico econômico clássico e, com ele, a ideia de livre comércio, como, na definição de Douglas Irwin (1998, p. 5), a inexistência de impedimentos artificiais para a troca de bens através de fronteiras nacionais, pelo que os preços dos mercados diante dos produtores e consumidores domésticos são os mesmos determinados pelos mercados internacionais, à exceção dos custos de transporte e de seguro e de outros custos de transação relacionados.

Assim, os preços, tanto os locais quanto os internacionais, viriam a refletir, com fidelidade, a escassez relativa das mercadorias por todo o mundo, de modo a que possam 
se converter, mediante uma análise inversa, em custos de oportunidade, tanto para os produtores, as firmas nacionais, quanto para os consumidores internos, as famílias.

Essa possibilidade decorre da presunção que, em tese, o mercado mundial estará sempre disposto a negociar a esses preços. E essa ideia de custo de oportunidade no comércio internacional, trazida com a Teoria das Vantagens Comparativas, não logra enfrentar contraposição relevante mesmo no pensamento econômico moderno.

Antes disso, durante a Antiguidade clássica, embora o Império Romano deva parcela significativa de sua opulência econômica às suas redes rodoviárias e de navegação, pelo que a cidade de Roma caracterizou-se por ter se tornado um centro de afluência de povos de todo o mundo conhecido à época (SOARES, 2004), assim como a riqueza de Atenas também se deveu à sua localização geográfica propícia à navegação mediterrânea, tornando-se "pólo de atração dos comerciantes que trafegavam as zonas que constituíam o Mundo Antigo" (STRENGER, 1996, p. 55), prevaleceu no pensamento antigo a visão de profunda desconfiança em relação ao comércio internacional e de relevo ao seu potencial deletério aos costumes locais.

O motivo para isso é o fato de que o comércio, mesmo o local, no seu início, se constituía, no dizer de Max Weber (2006, p. 191), em um fenômeno que implicava necessariamente um choque cultural, como resultado de uma "especialização interétnica da produção”. Era a época do comerciante forasteiro (WEBER, 2006, 197), aquele que, para reduzir o risco do transporte marítimo ou mesmo terrestre, viajava juntamente com a mercadoria (WEBER, 2006, p. 200 e 203).

Por isso, como nos mostra Douglas Irwin (1998, p. 12), Platão, na sua “A República”, sugere que as cidades bem governadas assegurassem que os postos de comerciantes e trabalhadores braçais fossem reservados às pessoas inferiores, aquelas que não teriam sido úteis em outras atividades. Aristóteles, na "Política", no mesmo sentido, condenava as trocas comerciais com o estrangeiro porque não era de acordo com a natureza humana, já que pressupunha que os homens tirassem coisas de outros homens.

À época, na Grécia, segundo Irwin (1998, p. 12), era difundido o pensamento de que os cidadãos não deveriam participar do comércio, que deveria ficar restrito inteiramente aos estrangeiros residentes, que, privados dos seus direitos, já estavam mesmo segregados da vida civil grega. Em regra, os pensadores gregos viam no comércio um perigo moral e cívico.

Não obstante, já na Grécia Antiga se verificava o que será o padrão do comportamento das sociedades em relação ao comércio ao longo da História: a incoerência 
entre a formulação teórica e a sua aplicação prática. Do ponto de vista teórico, na própria “A República”, Platão reconhece, naquilo que Douglas Irwin (1998, p. 13) se refere como a primeira discussão, datada de 380 A. C., acerca das vantagens da divisão de trabalho na república, que dessa repartição de tarefas resulta que mais bens são produzidos, com mais qualidade e mais facilmente do que um único homem poderia desempenhar de acordo com sua natureza, no mesmo momento e em detrimento de suas outras atividades. Prossegue afirmando que seria praticamente impossível a uma pólis produzir tudo e não precisar comerciar, pelo que os mercadores são necessários e que a produção doméstica de certos produtos deveria ser excedentária, para que se pudesse trocá-las com as cidades interessadas.

Análoga, também negativa, era a avaliação da atividade comercial em Roma: Cícero, no "De Officiis", afirma que o comércio deve ser considerado vulgar, embora reconhecesse a sua importância econômica.

Jacob Viner (1976, p. 27 - 54) menciona uma exceção a esse pensamento, no que ele denominou de "Doutrina da Economia Universal". Desenvolvida por filósofos e teólogos dos primeiros séculos depois de Cristo, como Sêneca, Filo de Alexandria e Libânio, apregoava, com base na irmandade universal dos homens, que as trocas de mercadorias viriam a gerar benefícios para a humanidade, uma vez que os recursos naturais estavam assimetricamente dispersos pela face da Terra, sendo que cabia à intervenção divina agir com a deliberada intenção de promover o comércio e a cooperação pacífica entre os homens.

Malgrado essa visão de natureza teológica, ainda assim os primeiros pensadores de índole católica viram, como os gregos e os romanos, o comércio, nas palavras de Jacob Viner (1978, p. 34 - 38), como instigador de fraudes, promotor da avareza e estimulador de ganhos injustificados, com base no trecho bíblico no qual Jesus expulsa os vendilhões do templo.

Santo Agostinho, por exemplo, defendia que o comércio não estava nas graças de Deus, porque consistia em risco às almas pelas tentações aos pecados da cobiça, da mentira, da trapaça e da fraude. Assim, exortava os cristãos a se afastarem dessa atividade perniciosa.

Interessante é observar, como faz Irwin (1998, p. 18) que, diferentemente dos gregos e romanos, que propugnavam a autarquia de suas culturas, os cristãos empenhavamse em difundir seus ideais por todo o mundo. Malgrado isso, ambos viam no comércio o 
indutor de práticas potencialmente nocivas, sendo que os cristãos ainda percebiam nas atividades comerciais o defeito de desviar a atenção dos fieis das questões transcendentais.

Na Idade Média, a filosofia escolástica continuou a destilar seus preconceitos contra a atividade comercial. No entanto, pode-se perceber, paulatinamente, especialmente diante do crescimento populacional das cidades, e mormente com o revigoramento comercial decorrente das vitórias nas Cruzadas, iniciadas no Século XI, que reabriram a navegação no Mar Mediterrâneo, principal via de distribuição de mercadorias na Europa, que as resistências às práticas comerciais foram se atenuando ao longo da Baixa Idade Média e no início da Idade Moderna.

São Tomás de Aquino, por exemplo, na "Summa Theologica", do Século XIII, mostrava-se mais tolerante com as atividades comerciais. Reconhecia que os alimentos poderiam ser produzidos tanto localmente quanto em localidades distantes, mas acreditava que a produção própria seria melhor, uma vez que a auto-suficiência seria mais dignificante. Mas também, como Aristóteles, alertava contra o contato com estrangeiros e a degenerescência moral daí advinda, assim como recomendava aos cidadãos que não dedicassem suas vidas ao comércio, já que, dessa forma, estariam se abrindo à tentação de diversos vícios. No entanto, entendia a necessidade das trocas comerciais, pois seria muito difícil que qualquer cidade produzisse tudo do que necessitasse.

Não obstante, permanecia o preconceito contra a atividade que não agregava valor, que não se consubstanciaria em atividade economicamente produtiva. Assim também entendeu Tomás de Aquino, mas no próprio Século XIII já se viam teólogos, especialmente na Inglaterra, como Thomas de Cobham, posteriormente eleito Arcebispo de Canterbury, e Richard de Middletown, que viam utilidade na atividade de transportar as mercadorias do produtor ao consumidor, da fartura para a escassez.

Mas mesmo a filosofia escolástica nos locais mais apegados à tradição cristã aos poucos foi atenuando tal visão negativa. Carletti de Clavasio, veneziano, em sua "Summa Angelica", do final do Século XV, mencionado por Douglas Irwin (1998, p. 20), afirmava que o comércio não é em si uma atividade perniciosa, mas pode sê-lo dependendo das circunstâncias e o motivo pelo qual é realizado.

Evoluindo mais no tempo, em 1557, nas suas "Relectiones Theologicae", Francisco de Vitória, teorizando acerca do relacionamento entre os espanhóis e os nativos no novo mundo, defendeu que o comércio é um direito das nações, e que o jus gentium autorizava o comércio, desde que não houvesse danos físicos aos indígenas, pelo que nem 
os príncipes nativos poderiam se escusar a comerciar seus produtos nem os soberanos espanhóis deveriam evitar tal atividade (1964, p. 151 - 153).

Era o ínicio de uma nova visão, que se consagrou com os filósofos da chamada Escola do Direito Natural, os primeiros a trazerem a ideia de liberdade de comerciar como uma projeção das liberdades naturais do ser humano. Francisco Suárez, em seu "Tractatus de Legibus ac deo Legislatore", de 1612, propalava que todo o comércio deveria ser livre, como decorrência da lei dos povos, o jus gentium, assim como qualquer violação ao livre intercurso comercial deveria ser entendida como infração a esse direito (1934, p. 2:347).

Alberico Gentili, por sua vez, no seu "De Iure Belli Libri Tres", de um pouco antes, de 1598, chegava mesmo a entender justificável a guerra contra os países que se recusassem a comerciar (1933, p. 86).

Para outro dos grandes teóricos da época, Huig de Groot (Hugo Grócio), no "De Jure Praedae", de 1604, a regra da liberdade de negociar foi fortemente defendida quando da sua condenação (1950, p. 218) à exclusão da República das Sete Terras Baixas Unidas, seu país, independente desde 1581, do comércio com as Índias Ocidentais, por parte do Rei de Portugal, na tentativa de preservar o seu monopólio.

Tal monopólio só veio a ser quebrado com a expedição do navegador holandês Jacob van Neck, que retornou à Europa nos fins do ano de 1600, literalmente abrindo o caminho para a criação da Vereenigde Oost-Indische Compagnie, a Companhia das Índias Ocidentais, em 1602, diante dos extraordinários lucros obtidos. Conta William Bernstein (2008, p. 219) que essa expedição havia partido de Amsterdam, em $1^{\circ}$ de março de 1598, com vinte e dois navios, tendo chegado, com honras de herói, apenas com catorze deles e sem metade da tripulação original. Na ocasião, o capitão afirmou, segundo Bernstein, que a sua intenção "não é roubar ninguém em sua propriedade, mas comerciar com justiça com todas as nações estrangeiras".

O entendimento de Hugo Grócio foi reforçado na sua maior obra, "De Jure Belli ac Pacis Libri Tres", de 1625, embora, ao mesmo tempo em que defendia que o comércio de qualquer Estado não poderia ser restringido, pois a oportunidade de comerciar era um direito das nações, admitia a incidência de pequenos encargos aduaneiros que compensassem as despesas associadas com o comércio exterior, como aquelas com a manutenção dos faróis, ao mesmo tempo em que rejeitava incidências que não se relacionassem com a mercadoria negociada (1925, p. 199).

Do exame do pensamento de Hugo Grócio, mormente em comparação com os pensadores de matiz cristã da Alta Idade Média, pode-se inferir o início de uma tendência 
que se consolidou na era mercantilista: a consideração de aspectos econômicos em relevo, em detrimento de indagações éticas ou relativas à moral (IRWIN, 1998, p. 25). Com isso, não só se pode entender a aparição dos escritos dos ditos mercantilistas, assim como, embora ainda embrionariamente, a emergência de um relativo pensamento analítico de raiz econômica - o que vai surgir realmente apenas, segundo Douglas Irwin (1998, p. 56 - 57), com a obra de Henry Martyn, "Considerations upon the East India Trade", de 1701, na qual retoma, com inacreditável rigor científico, o exame do problema do comércio com as Índias Ocidentais, sobre o qual já havia discorrido Hugo Grócio.

Desde o fim do feudalismo, a terra deixava de ser a única fonte de riqueza. Assim, os burgueses, comerciantes e banqueiros, mediante a acumulação de capitais derivados do ressurgimento do comércio, dadas as condições de segurança e tecnologia da época, passaram a não mais terem uma preocupação com a satisfação autárquica de necessidades, no ideal medieval de desprendimento e de moderação, para pensar a riqueza como símbolo de poder. Assim, o financiamento dos exércitos reais, em fase de consolidação dos regimes absolutistas, como de resto a necessidade de sustentação de toda a estrutura monárquica, fez o comércio passar a ser estimulado e financiado pelos Estados nacionais. Os problemas econômicos passaram a ser examinados sob a ótica de Estado (AVELÃS NUNES, 2007, p. 290).

Nesse mesmo sentido, cabe relembrar que, nas palavras de Douglas Irwin (1998, p. 28), duas características do ambiente econômico internacional de então passaram a esculpir o pensamento mercantilista: a vasta expansão do comércio internacional e a exploração ultramarina, assim como a ascensão dos Estados-nações como entidades políticas. Em função da conjugação desses dois fatores, os comerciantes passaram a ser vistos como uma classe bem posicionada, apta a explorar o lucro em proveito próprio e dos respectivos países. Com isso, deixaram de ser párias sociais, vistos com suspeição, como ocupados em uma atividade econômica de má reputação, mas sim como bem-sucedidos cidadãos com grande potencial de colaboração para a riqueza nacional.

Portanto, os pensadores acerca do comércio internacional deixaram de ser os filósofos ou os teóricos e passaram a ser homens de negócios, comerciantes, ou administradores públicos, que "discorrem sobre os problemas concretos que se levantam no mundo dos negócios ou no domínio da administração estadual”. Seus trabalhos não podem ser entendidos como construções teóricas ou especulativas, mas sim programas de ação inspirados pela diferente realidade de cada país (AVELÃS NUNES, 2007, p. 292 293). 
Como se viu, o que se tem de comum na literatura mercantilista, mais do que um conjunto de ideias, foi um determinado arsenal de temas - fundamentalmente, a necessidade da regulação estatal do comércio exterior, com algum ou alguns dos seguintes objetivos em mente: a acumulação de tesouros ou de metais preciosos, a promoção da riqueza ou do bem-estar nacionais, o atingimento de uma balança comercial favorável, a maximização do emprego, a proteção da indústria nacional ou o acréscimo do poder estatal (IRWIN, 1998, p. 26).

Jacob Viner (1937, p. 59), a propósito, assinala que o que caracteriza a literatura mercantilista é o fato de que são tratados que, parcial ou inteiramente, aberta ou disfarçadamente, consistem em pedidos com o fim de satisfazer interesses econômicos específicos. Nesse sentido, não raramente os tratadistas exageram na importância do comércio internacional na formação da riqueza nacional (IRWIN, 1998, p. 29).

Assim é que, embora na Idade Moderna, dos Séculos XV ao XVIII, o mercantilismo fosse a política econômica prevalente na Europa, as ideias externadas pelos seus defensores variavam substancialmente conforme o país de origem do autor.

$\mathrm{Na}$ Espanha predominou o que António Avelãs Nunes denominou de “bulionismo" (2007, p. 293): a preocupação com o entesouramento e a acumulação contínua de ouro e prata proveniente das colônias da América e com sua conservação no país, na convicção de que conseguiriam assim preservar a riqueza e o poderio do estado espanhol. Para tanto, Luiz Ortiz, em 1558, em suas obras “Memorial al Rey para prohibir las salidas de oro" e "Memorial al Rey para que no salga dinero de estos reinos de España", apresentados a Felipe II, e Damián de Olivares, no "Memorial para prohibir la entrada de los géneros extranjeros", apresentado, em 1621, a Felipe III, defendem políticas públicas intervencionistas com o fim de proibir a saída do país do ouro e da prata e de evitar a entrada de gêneros estrangeiros, fortalecendo a balança comercial.

Essa política alcançou resultados desastrosos, no mesmo compasso em que se deu a derrocada da economia espanhola, tendo sido mesmo tempestivamente combatida pelo jesuíta Juan de Mariana, reputado como o maior dos mercantilistas espanhóis por Armando Herrerías (2005, p. 58). Em obra de 1609, "De Monetae Mutacione Disputatio", Mariana propõe restrições aos gastos suntuários da coroa espanhola, pleiteia a moralização dos servidores públicos, e advoga que o melhor caminho para o país obter ouro e prata seria o desenvolvimento da agricultura e da indústria, traçando a distinção entre valor intrínseco e extrínseco da moeda. Explica assim, o fenômeno inflacionário que assolara a Espanha do Século XVI. 
Para se ter uma pálida noção do impacto das remessas de metais preciosos na economia da Europa dos Séculos XVI e XVII, basta perceber que, segundo Francisco de Magalhães Filho (1970, p. 235 - 236), calcula-se que, até 1500, o valor total dos metais preciosos em circulação ou entesourados na Europa alcançava cerca de cinquenta milhões de libras esterlinas, valor correspondente a toda a prata e todo o ouro até essa data produzidos na Europa desde o Império Romano. A produção da Europa de então, anual, era de apenas cem mil libras, às quais se somavam, desde o final do Século XV, igual produção vinda do litoral da Guiné, onde hoje fica a República de Gana. A partir da descoberta da América, a estimativa anual da produção americana de metais preciosos chegava a um milhão e trezentas mil libras esterlinas, situação que perdurou, embora com decréscimo na produção, durante todo o período colonial, até o início do Século XIX. Especialmente as grandes jazidas de prata no México e do Alto Potosí, em território hoje boliviano, mas escoado pelo Rio Paraguai, até o Rio da Prata, na atual República Argentina, produziram, por todo esse período, aproximadamente duzentos e vinte e seis milhões de libras esterlinas - ou seja, em três séculos, viu-se sextuplicada a quantidade de riqueza na Europa em relação a toda a anterior história da humanidade.

Com isso, diante do aumento da quantidade de moeda em circulação, ainda lastreada em metais preciosos, e sem o correspondente aumento da produção, gerou-se inflação, o aumento generalizados dos preços, principalmente na Espanha, local onde os preços multiplicaram por quatro durante o Século XVI.

Muito posterior aos trabalhos de Mariana, em 1726, outra obra relevante do mercantilismo espanhol, "Teoría y Práctica del Comercio", de Jeronimo de Uztariz, voltase a defender a restrição à fuga do ouro, mediante uma balança comercial favorável, dada a importância desse metal para a economia espanhola. No entanto, considera ilusórias e ineficazes as regulamentações bulionistas e a proibição das espécies monetárias, sugerindo como política fundamental a industrialização. Para tanto, sugere a imposição de encargos aduaneiros elevados para as importações de manufaturados e para as exportações de matérias-primas e de baixas alíquotas para as exportações de manufaturados e para as importações de matérias-primas.

Diferentemente do caso espanhol, como a França não dispunha de metais preciosos à mão, o problema a ser enfrentado, sempre dentro da perspectiva pragmática das análises dos autores mercantilistas, referia-se não à sua conservação, mas à sua obtenção.

O primeiro dos considerados mercantilistas franceses foi Jean Bodin, mas não por conta de suas obras dedicadas à Ciência Política e à Teoria Geral do Estado, 
especialmente os célebres "Les Six Livres de la République", de 1576, pelas quais passou à imortalidade como pensador. Tal se deve à obra de 1568, chamada "Réponse au paradoxe de Monsieur Malestroit", obra que tinha como subtítulo a preocupação com a carestia geral e uma maneira de a evitar ("Touchant le fait des monnaies et l'enrichissement de toutes choses"), na qual trata de matérias de economia política, em particular da moeda e da subida dos preços. Tencionava responder ao livro de Malestroit, que, embora reconhecesse o aumento dos preços na França, defendia que tal carestia era apenas nominal, uma vez que o metal contido em cada moeda havia se reduzido. Jean Bodin refutou tal ideia, entendendo que a inflação devia-se ao aumento da quantidade do metal precioso vindo da América, aos monopólios estatais, e aos gastos do Rei e de sua corte, pelo que o empobrecimento era real, não efetivo (HERRERÍAS, 2005, p. 64 - 65). Defendeu efusivamente, em suma, as regras de formação de preços pelas forças de mercado e o livre comércio, com ênfase na importância das exportações.

Outro autor francês com relevo no pensamento da época foi Antoine de Montchrestien, que publicou, em 1615, a sua obra "Traité d'Economie Politique", na qual pela primeira vez se menciona esse ramo do conhecimento econômico. Nela, um oferecimento endereçado ao Rei Luís XIII e à sua mãe de um relatório sobre as finanças do reino e dos modos de enriquecê-lo, embora considere favorável a abundância de metais preciosos no país, defende a necessidade para a França de uma economia completa e autosuficiente. Assim, advoga o que foi o entendimento prevalente dos mercantilistas franceses, a preferência pela intervenção do Estado no sentido de regulamentar a produção, fortalecer as manufaturas nacionais e de exigir um sistema eficaz de proteção alfandegária, conquistando assim os mercados externos (AVELÃS NUNES, 2007, p. 294 - 295).

Mas o grande realizador das determinações mercantilistas na França foi JeanBaptiste Colbert, na medida em que foi o Controlador Geral das Finanças de Luís XIV, a partir de 1665. Colbert quis tornar a França a nação mais rica da Europa, e para isso implantou o que se denominou mercantilismo industrial, apostando na alta qualidade dos produtos franceses, incentivando a produção de manufaturas de luxo, visando à exportação. Concedeu privilégios especiais às manufaturas, reais ou privadas, mas delas exigiu rigorosos padrões de fabricação. Promoveu a criação das grandes companhias de comércio e de colonização. Empreendeu uma política fortemente protecionista, proibindo a exportação de matérias-primas nacionais, impedindo ou estabelecendo pesada tributação às entradas de manufaturados estrangeiros, ao mesmo tempo que eliminou os encargos à exportação de manufaturados e à importação de matérias-primas alienígenas (AVELÃS 
NUNES, 2007, p. 294 - 295). Vale dizer, investiu pesadamente no fomento industrial, como forma de fazer com que os produtos franceses prevalecessem nos mercados externos, gerando assim superavits comerciais.

Por outro lado, foi severamente criticado por ter descuidado da atividade agrícola, até como forma de proporcionar baixos preços aos insumos industriais, assegurando a sua competitividade externa (HERRERÍAS, 2005, p. 68 - 69). Daí adveio a reação posterior dos fisiocratas.

Diferentemente do que foi pensado na Espanha e na França, o mercantilismo inglês não se baseou nem no entesouramento em metais preciosos nem na regulação da atividade industrial. A prioridade da nação deveria ser o atingimento de uma balança comercial favorável o que, para teóricos como Thomas Mun, em sua obra de 1628, mas publicada apenas em 1664, "England's Treasure by Forraign Trade" poderia levar, indiretamente, à entrada líquida de metais preciosos e outros tesouros no país.

Tal realidade teria vantagens tanto políticas, como a formação de riqueza para preparar a nação contra contingências de segurança nacional, como as guerras, fome ou epidemias, como também econômicas, para aumentar a liquidez e o crédito no país (IRWIN, 1998, p. 35).

Porém, para tanto, embora até mencione perifericamente a utilidade dos encargos aduaneiros para alcançar tais objetivos, Thomas Mun preferiu se concentrar nos determinantes monetários da balança comercial. Mais do que políticas protecionistas, mediante barreiras tributárias, a política que sugeria baseava-se no fomento da atividade produtiva voltada à exportação, inclusive no que tange à qualidade dos produtos, e no aprimoramento da cunhagem de moedas. Não deu relevância às restrições à importação (IRWIN, 1998, p. 36).

De se notar que Thomas Mun foi um diretor da Companhia das Índias Orientais britânicas (AVELÃS NUNES, 2007, p. 297), a "English East India Company", fundada em 1600, assim como o foi, posteriormente, outro tratadista de linha mercantilista bastante proeminente, embora algo mais moderado, Josiah Child. Em suas principais obras, "Brief Observations concerning Trade and the Interest of Money" (1668) e "A New Discourse of Trade" (1690), já se vislumbra alguma menção a noções de livre comércio, especialmente na segunda obra, até por ter sido escrita em época mais tardia.

Com o mesmo fim, de assegurar a balança comercial superavitária, Avelãs Nunes (2007, p. 296) aponta a necessidade de assegurar a supremacia naval e controlar as rotas de navegação. Na consecução dessa política estratégica de domínio dos mares, podem 
ser relacionados os "Atos de Navegação" ("Navigation Acts"), promulgados por Oliver Cromwell e o seu Parlamento, em 1651, como resposta à deterioração do comércio inglês, especialmente na Península Ibérica, no Mar Mediterrâneo e no Oriente Médio, pela concorrência com os comerciantes holandeses, com o fim da Guerra dos Oitenta Anos (1568 - 1648), entre Espanha e Holanda.

O fim dessa guerra, com a celebração do Tratado de Münster, e o consequente levantamento do embargo espanhol aos navios de bandeira das Sete Terras Baixas Unidas, a república tornada independente com a paz, também foi a ocasião para que se verificasse a importância econômica das sólidas instituições financeiras e legais e da tolerância à usura e às diferentes religiões que caracterizavam a confederação flamenga de então (BERNSTEIN, 2008, p. 222).

As mencionadas normas britânicas determinaram que as mercadorias europeias só poderiam ser descarregadas na Inglaterra se transportadas por meio de embarcações inglesas ou do país de origem da mercadoria. Simultaneamente, o mercado de navegação entre a metrópole e as colônias inglesas ficavam restritos aos navios de bandeira da então Commonwealth of England (a república parlamentarista que governou a Inglaterra e o País de Gales, de 1649 a 1653, e toda a Grã-Bretanha, de 1653 até 1660, quando se reinstaurou a monarquia no reino unificado $)^{23}$.

Em 1660, houve um adendo na norma para estabelecer que as tripulações dos navios deveriam ter três quartos de nacionais ingleses, ao mesmo tempo que enumerava produtos das colônias, como tabaco, algodão e açúcar, que só poderiam ser comercializados com a Inglaterra ou suas outras colônias. Logo em seguida, o "Staple Act", também denominado de "Act for the Encouragement of Trade", já no reinado de Charles II, em 1663, determinava que todas as mercadorias europeias vindas da América e de outras colônias deveriam passar pela Inglaterra ou por Gales, onde seriam descarregadas, inspecionadas, e recarregadas apenas após o pagamento de encargos aduaneiros, sempre por meio de embarcações inglesas.

Tais Atos só foram revogados em 1849, em época de pleno apogeu do pensamento liberal no comércio internacional.

\footnotetext{
${ }^{23}$ Não se deve confundir com a Commonwealth of Nations, anteriormente (até 1949) denominada British Commonwealth, ou simplesmente Commonwealth, organização internacional formada por Estados independentes outrora integrantes do Império Britânico, com base no "The Statute of Westminster", de 1931, uma lei do Parlamento do Reino Unido que estabeleceu um status de equiparação legal entre tais Estados e a anterior metrópole.
} 
Outra grande preocupação dos mercantilistas ingleses deu-se com a composição da balança comercial. John Pollexfen, ele próprio um bem-sucedido importador de vinhos portugueses, defendia, em sua obra de 1697, "England and East India Inconsistent in their Manufactures", que a exportação de manufaturados e a importação de matérias-primas eram positivas e vice-versa prejudiciais. Em essência, seu pensamento, assim como o de congêneres, como o de John Cary, em "An Essay, on the Coyn and Credit of England: as they stand with respect to its trade", de 1695, defendia que as atividades econômicas que gerassem alto valor agregado ou que fossem extensivas em mão-de-obra deveriam ser produzidas domesticamente, até como forma de gerar mais empregos (IRWIN, 1998, p. 38).

Aquele que se considera o último dos mercantilistas ingleses é James Steuart, cuja obra de 1767, "Inquiry into the Principles of Political Oeconomy", de apenas nove anos antes de Adam Smith, é considerada a obra mais abrangente e representativa do conjunto do pensamento inglês do gênero, e pode ser vista, para Douglas Irwin (1998, p. 43), como o apogeu da sistematização das doutrinas mercantilistas sobre o comércio exterior. Não obstante, mesmo antes da publicação da obra de Adam Smith, a obra sofreu maciça rejeição por parte dos seus contemporâneos, especialmente porque defendia fortemente a intervenção estatal no comércio internacional.

Não obstante Joseph Schumpeter afirmar (1954, p. 348) que falta à doutrina mercantilista um trabalho genuinamente analítico, também não se pode afirmar que a tônica dos mercantilistas, especialmente os ingleses, tenha sido a necessidade do emprego de políticas protecionistas para proteger a manufatura doméstica e desencorajar as exportações das matérias-primas nacionais, até por que nem todos assim defendiam. Como ressalta Douglas Irwin (1997, p. 44), o principal traço do pensamento da época, na Inglaterra, até como consequência da origem dos seus defensores, foi a ideia de que deveria haver harmonia entre os interesses estatais e os privados, sem o que a mais correta alocação de recursos não seria possível, o que, no mais, das vezes, pressupunha a intervenção estatal.

Foi exatamente contra essa visão que se formou, fundamentalmente na Inglaterra agora, apenas, o pensamento liberal. Assim se verifica que, embora ainda houvesse prevalência das práticas mercantilistas e dos seus defensores até o fim do Século XVIII, desde meados do século anterior, já se podem detectar manifestações na Inglaterra contrárias ao entendimento mercantilista dominante. 
Tal se deveu não só ao absurdo do ambiente normativo de então, diante da instituição dos monopólios nacionais oriundos dos Atos de Navegação, bem como pela percepção de que países que mantiveram sempre políticas liberais, como os Países Baixos, principalmente, permaneciam em vantagem na concorrência com as embarcações inglesas, também por conta de uma indústria naval mais eficiente e tecnológicamente mais avançada (HOEKMAN; KOSTECKI, 2001, p. 19).

Foi nessas circunstâncias, assinala Douglas Irwin (1998, p. 46), que as primeiras manifestações que empregaram a expressão "livre comércio", ainda no fim do Século XVII, deram-se em debates no Parlamento Britânico contrários aos monopólios garantidos nas operações de comércio exterior, especialmente por se aplicarem mediante autorizações reais (royal grants) a específicos comerciantes, no que se refere ao direito de comerciar, sem concorrência, com determinadas regiões do globo terrestre. Definitivamente, um sentido de livre comércio ainda bem mais restrito, e limitado a interesses pré-determinados, do que o conceito que temos nos dias de hoje.

Simultaneamente, em uma perspectiva analiticamente mais consistente, discordava-se das formulações mercantilistas da balança comercial favorável e da sua composição em relação às commodities. Roger Coke, em seu "A Discourse of Trade", de 1670, já apontava a contradição nessa doutrina, mencionando que os holandeses importavam tudo e ainda assim prosperavam com o comércio, ao passo que os irlandeses exportavam oito vezes mais do que importavam, mas continuavam pobres. William Petty, em 1662, por sua vez, no "A Treatise of Taxes and Contributions", também contestava a pretensão de se conseguir uma balança de pagamentos permanentemente excedentária e uma acumulação indefinida de metais preciosos.

Mas a crítica mais consistente a essas ideias, nessa época ainda de forma minoritária, veio de David Hume, no seu famosíssimo ensaio, "Of the Balance of Trade", no tardio ano de 1752, por meio da formulação de que as barreiras à exportação de commodities, assim como a tentativa de limitar as importações de manufaturados, viriam a ser contrárias às suas intenções originárias. Segundo seu raciocínio, abrindo-se a possibilidade de importar produtos manufaturados de um país qualquer, o preço dessas mercadorias aumentará e o das nacionais diminuirá, de modo a que, em algum tempo, as mercadorias inglesas possam vir a competir com as importadas. Trata-se da primeira formulação acerca do equilíbrio dinâmico dos mercados, embora, por óbvio, sem usar essa expressão. 
David Hume entendia que a teoria mercantilista de acumulação cíclica e infinita de ouro e prata não se sustentava, pois se os produtos domésticos ficassem cada vez mais caros com a acumulação de ouro e prata, não se conseguiria vender a mesma quantidade de mercadorias de antes do aumento dos preços. E, para reforçar isto, dizia que o outro país, cujos preços ficavam cada vez mais baixos, teria cada vez menos dinheiro para comprar os produtos domésticos. Em suma, ele demonstrou que ter mais ouro e prata não levava a uma acumulação cíclica. Nem a perda levaria ao exaurimento das reservas. Portanto, importar não era necessariamente ruim para a economia do país.

David Hume provava que, se houvesse déficit, a perda de ouro era corrigida automaticamente, fazendo as reservas se recuperarem. Isso porque, com a perda de ouro, os preços domésticos se reduziriam. Haveria então um aumento no volume de exportações. E os preços mais altos dos importados gerariam uma diminuição de importações. Em conseqüência, haveria um aumento de reservas de metal precioso, desfazendo o déficit inicial.

Outro pensador importante dessa fase de transição foi Charles Davenant, cuja obra, "Essay on the East India Trade", de 1696, tratava da controvérsia acerca se a importação de calicoes (produtos têxteis de algodão) das Índias iria interferir na produção doméstica de derivados da lã e da seda, com o propalado empobrecimento dos produtores domésticos. Nela criticou severamente a política comercial voltada a determinados produtos, trazendo a ideia da interdependência de todos os setores industriais. Aduziu a constatação de que o acréscimo das importações iria aumentar o número de pessoas envolvidas no comércio, como marinheiros e armadores, com aumento geral da riqueza da nação. Para ele, a melhor maneira de promover a indústria lanifícia nacional seria mediante a criação de incentivos para a redução dos preços dos seus produtos, de modo a que possam competir com aqueles vindos das Índias. Trouxe também a formulação de que a artificial proteção à indústria doméstica da seda seria prejudicial ao público e que deveria ser naturalmente deslocada para outros países, sendo que a mão-de-obra inglesa deveria se voltar a outras atividades - um pensamento ancestral à concepção da especialização internacional do trabalho.

No entanto, Charles Davenant, como afirma Douglas Irwin (1998, p. 55), nunca chegou a propriamente defender a liberdade absoluta em comerciar, recomendando em seu lugar que a política comercial se fizesse com vistas a evitar a importação de produtos inúteis e talvez perigosos ao público. 
O que gerou a elaboração da obra de Charles Davenant foi o fim previsto da vigência, em 1690, de um adicional de imposto de importação que onerava as importações de tecidos estrangeiros pelo Reino em mais dez por cento ad valorem, além do encargo anterior de cinco por cento, incidência essa criada pelo Rei James II, em 1685, a pretexto de fazer frente às despesas com a campanha contra o Duque de Monmouth, filho bastardo primogênito de Charles II, que tentava usurpar o trono de seu tio, diante da recente morte do seu pai, já que a esposa do monarca conduzido ao trono pela Restauração, em 1660, a princesa portuguesa Catarina de Bragança, não teve filhos. Diante das pressões protecionistas, o encargo adicional, que a priori deveria ser revogado, até pelo sufocamento do levante que pretensamente o motivou, acabou sendo confirmado e, mais do que isso, dobrado (THOMAS, 1963, p. 66).

Era muito influente a indústria inglesa de lã na época, quando esse tipo de tecidos representavam cerca de $75 \%$ de todos os tecidos utilizados então na Europa, sendo o principal artigo manufaturado utilizado no comércio internacional (MAGALHÃES FILHO, 1970, p. 237). Assim é que, em 1681, o governo português, atendendo aos interesses de uma incipiente indústria lanifícia local, criou encargos alfandegários protetivos em 1681, para, ao final, a partir de 1690, proibir tais importações em Portugal.

Como se tratava do principal produto de exportação inglês para a terra lusitana, em troca do que adquiria vinhos, que concorriam no mercado inglês em melhores condições de competitividade do que os franceses, a Inglaterra condicionou o seu apoio militar a Portugal, àquela altura receoso das investidas espanholas tendentes à sua anexação novamente, à revogação dessas barreiras impostas pelo soberano luso. Com isso, em 1703, assinou-se o Tratado de Methuen, nome do embaixador inglês em Lisboa à época de sua assinatura, por meio do qual, em troca do levantamento das medidas restritivas portuguesas, a Inglaterra concedia redução do imposto de importação incidente sobre as entradas de vinho português a um nível correspondente a um terço da alíquota vigente para as demais procedências. Com isso, a ainda incipiente indústria portuguesa foi aniquilada, tornando-se a sua economia completamente dependente da importação de manufaturados da Inglaterra, com permanente déficit da balança comercial entre os dois países.

Nessa mesma esteira de condicionantes normativas adveio a importantíssima obra de Henry Martyn, de 1701, "Considerations upon the East India Trade”, que deu, nas palavras de Douglas Irwin (1998, p. 56 -57), o primeiro tratamento sistemático, profundo e analítico ao tema do protecionismo comercial e das vantagens do livre comércio. Opôs-se veementemente contra tanto as restrições monopolistas no comércio inglês com suas 
colônias quanto aos gravames impostos às importações de manufaturados da Índia, propondo abrir radicalmente essas vias comerciais, não só pela abolição dos tributos incidentes como também pela eliminação da licença real.

Assim, defendia que não se deveria beneficiar alguns em detrimento de outros, já que o livre comércio era a única forma de proporcionar trabalho para todas as pessoas, mesmo que eventualmente em outros setores nos quais as empresas do Reino fossem competitivas. Trouxe a concepção da relevância do comércio internacional para o acréscimo de competitividade como busca da alocação mais eficiente dos recursos nacionais. Estabeleceu a ideia pioneira de que o comércio é uma forma indireta de adquirir bens por meio das exportações e não pelas aquisições internas, de maneira a possibilitar que um país adquira mais bens com o mesmo trabalho, assim aumentando a produtividade de sua economia como um todo.

Em obra datada de 1720, denominada "The System or Theory of the Trade of the World", Isaac Gervaise também inova, trazendo pela primeira vez a formulação da noção de custos de oportunidade, como valoração do sacrifício de alternativas, algo retomado depois por David Ricardo, aspecto fundamental no entendimento da Teoria das Vantagens Comparativas.

Assim, embora ainda prevalecessem, na prática, as concepções mercantilistas, havia um nascituro sentimento de desconforto com aquela situação por parte de alguns autores, de matiz econômica, na Inglaterra do início do Século XVIII.

Embora muitas das formulações posteriormente empregadas por Adam Smith possam ser encontradas nesses tratadistas, dos quais apenas os mais importantes foram aqui mencionados, Jacob Viner (1937, p. 91) afirma que o que realmente influenciou a obra fundamental de 1776 foi principalmente a literatura filosófica, mormente dos fisiocratas franceses e dos adeptos da Filosofia Moral na Inglaterra, até porque as obras dos economistas ingleses não traziam uma visão ampla das vantagens do livre comércio, só apontando aspectos pontuais, em passagens isoladas, naquilo que vislumbravam como defeitos das políticas comerciais mercantilistas de então (VINER, 1937, p. 108).

A concepção teórica da liberdade em comerciar veio inicialmente das obras, ainda não propriamente fisiocratas, de Pierre le Pesant, o Senhor de Boisguillebert. Do ponto de vista econômico, especialmente em sua principal obra, de 1695, "Le détail de la France - la cause de la diminution de ses biens et la facilité du remède”, entendia que a má situação financeira da França na transição entre os Séculos XVII e XVIII devia-se às políticas do mercantilismo industrial colbertiano que teria reduzido o consumo das famílias 
francesas. Defendia que, mais importante do que o mercado externo, a política que viesse a intentar o aumento da renda do país deveria focar no mercado interno. Valorizava a agricultura e discordava dos exagerados incentivos à indústria francesa. Na sua visão filosófica, entendia que os indivíduos, motivados pelos seus autointeresses, não intencionalmente prestam um serviço público ao direcionar seus esforços para as atividades que os remuneram melhor. Nessa formulação ancestral do conceito de eficiência econômica, advogou que, para preservar esse sistema eficiente, praticamente nada além da preservação da justiça e da segurança jurídica deveria ser requerido do Estado.

Conjugando as duas visões, Boisguillebert foi o responsável pela emergência da ideia de liberdade econômica, como liberdade de produzir e de comerciar, mais tarde sumarizada na expressão "laissez faire - laissez passer" (IRWIN, 1998, p. 65). Mais do que isso, introduziu o princípio de que haveria uma lei natural que rege a livre formação dos preços.

Em verdade, é em Thomas Hobbes, no "Leviathan", de 1651, que se viu pela primeira vez a defesa da liberdade de comerciar como uma lei da natureza, o que depois foi confirmado por William Petty (em "A Treatise of Taxes and Contributions", de 1662) e John Locke (no segundo dos "Dois Tratados sobre o Governo", ou "Two Treatises of Government: In the Former, The False Principles and Foundation of Sir Robert Filmer, And His Followers, are Detected and Overthrown. The Latter is an Essay concerning The True Original, Extent, and End of Civil-Government", de 1689), que defenderam a existência de leis naturais a governarem a vida econômica.

A visão de Thomas Hobbes, como resumida por Ernst-Ulrich Petersmann (1998, p. 175), consistia na imagem inicial de um estado de natureza, a luta de cada homem com todos os outros, pelo que haveria a necessidade de um contrato social entre os indivíduos para formar monarquias com poderes ilimitados, como meio de superar a anarquia do estado anterior e para assegurar uma ordem pacífica. No plano internacional, no entanto, Hobbes não previa a saída do estado de anarquia entre os Estados nacionais, já que imaginava um governo internacional como mais perigoso do que o "bellum omnium contra omnes" no plano interestatal.

Mas foi Boisguillebert que trouxe tais concepções filosóficas libertárias inicialmente para o plano econômico, relacionando-as aos preços, aos impostos, ao consumo e à demanda dos produtos de sua época, e aos conceitos de renda e circulação de riqueza. 
Porém, só se pode dizer que surgiu uma escola da Ciência Econômica com a Fisiocracia elaborada por François Quesnay, a quem Schumpeter (1937, p. 167) se refere como uma das maiores figuras da Economia. Defendeu fortemente, no seu "Tableau Économique - avec son explication", de 1758, a produção agrícola, para ele a atividade produtiva por excelência, e não as estéreis ocupações comerciais ou de serviços. Entendia que a renda da agricultura seria a fonte precípua da riqueza de um país, invertendo completamente a prioridade conferida pelos mercantilistas.

No entanto, as contribuições de Quesnay mais importantes ao pensamento liberal e, por conseguinte, às formulações de Adam Smith, foram suas concepções de ordem natural, o ambiente social no qual se processa a divisão do trabalho e do qual resulta a multiplicação dos meios de subsistência e a abundância, a partir das relações de troca (o individualismo social), a crença na harmonia universal dos interesses, as suas ideias acerca das funções do Estado, especialmente no que concerne às relações entre o Direito e a Economia, além da sua concepção metodológica acerca da relevância para a Economia dos conceitos filosóficos de propriedade, de liberdade e de igualdade (AVELÃS NUNES, 2007, p. $330-331)$.

No que se refere à Filosofia moral inglesa, a grande influência sobre Adam Smith veio de seu professor, Francis Hutcheson, quem o introduziu na tradição do direito natural de Hugo Grócio e Samuel von Pufendorf. Além disso, em sua obra de 1755, “ $A$ System of Moral Philosophy", defende a ideia de que existe um direito natural do homem a exercer seus poderes, de acordo com o seus próprios julgamentos e inclinações, com o propósito de alcançar a sua própria felicidade, em todas as suas atividades econômicas, sem a interferência de nenhum interesse público que o direcione as suas ações para os interesses de outros, o que denominou "liberdade natural".

Outra obra que muito influenciou Adam Smith foi, da autoria de David Hume, seu amigo pessoal, "Of The Jealousy of Trade", de 1758. Nela Hume critica fortemente a maligna opinião que vê o sucesso dos vizinhos com ciúmes, de que a riqueza de um país só existe mediante a perda daqueles com que ele comercia. Para ele, se a indústria de um país não consegue ser competitiva, deve atribuir isso às suas próprias deficiências, não aos vizinhos, restando oportunidades em outros setores, aproveitando as vantagens naturais e peculiares de cada exportador. Entendeu que nenhum país poderia ser fechado ao mercado internacional, uma vez que a natureza, por conferir diversidade de climas e solos às diferentes nações, assegurou o intercâmbio das riquezas sem que haja perda para nenhuma delas. 
Como afirmou Jacob Viner (1937, p. 92), certos elementos doutrinários favoravelmente tendentes ao livre comércio eram fortemente prevalentes, tanto no pensamento econômico quanto no filosófico, antes da publicação da principal obra de Adam Smith. Havia sim um forte sentimento, tanto na França quanto na Inglaterra e na Escócia, sob a forma de um clamor por mais liberdade econômica e menor intervenção estatal, em prol da ideia de livre comércio. Isso, não obstante, segundo Douglas Irwin (1998, p. 74), não retira os méritos do seu extraordinário esforço em conferir uma lógica econômica mais sólida, que desse consistência científica àqueles fundamentos filosóficos, de forma a que se relacionassem os interesses privados e os benefícios públicos decorrentes do livre comércio. Smith, portanto, transformou o que era antes um vago cosmopolitanismo filosófico em uma teoria econômica com forte conteúdo conceitual. Portanto, dificilmente contestável, de forma que remanesce até hoje em muitas de suas formulações, tendo por isso se tornado um ponto de inflexão no pensamento econômico e político acerca das políticas comerciais, tanto do ponto de vista conceitual quanto do histórico.

Joseph Schumpeter (1954, p. 184), a propósito, afirma que a obra “An Inquiry into the Nature and Causes of the Wealth of Nations" (abreviadamente "Riqueza das Nações”), publicada em 9 de março de 1776, não continha uma única ideia analítica ou método que fosse inteiramente novo na época em que publicado. Sem discordar dessa ponderação, Andrew Skinner (1990, p. 157), por seu lado, afirma que se pode encontrar na obra mencionada pela primeira vez a concepção da Economia como um sistema, e que Adam Smith em 1776 deu à Economia Política a base analítica em cima da qual todos os avanços posteriores puderam se fundar.

A "Riqueza das Nações” é uma obra que trouxe à Economia Política diversas formulações teóricas originais, ao menos do ponto de vista sistemático, como a Teoria do Valor, a Teoria da Distribuição do Rendimento (do salário e da renda), e a concepção da Acumulação do Capital como causa da riqueza das nações, muito além apenas de ser um tratado de Economia Internacional.

No que presentemente interessa, o maior objeto de ataque por parte de Adam Smith, na sua obra "Riqueza das Nações", especificamente no seu Livro IV, "Of Systems of Political Oeconomy", que trata das políticas comerciais, foram, segundo Dominick Salvatore (1998, p. 18), os ideais mercantilistas como os formulados por Thomas Mun, na concepção inglesa, notadamente a busca incessante da balança comercial favorável, ou que a boa política comercial deveria diminuir o quanto possível a importação de produtos 
estrangeiros para consumo doméstico e aumentar ao máximo as exportações dos produtos nacionais. E que as duas formas básicas para o enriquecimento de um país seriam o estabelecimento de restrições às importações e o fomento às exportações.

Então, um dos principais objetivos do Livro IV é estabelecer um específico critério para aferir os efeitos das diversas políticas comerciais em termos de riqueza (produção bruta de bens) e renda nacionais como um todo. Com isso, visava a combater mecanismos específicos de proteção de determinados setores sob o pretexto da preservação dos empregos e da produção de uma indústria em particular. Nessa esteira, defendeu que a imposição de altos encargos aduaneiros na entrada ou, o que é pior, o banimento das importações, diminuiriam a concorrência e confeririam ao produtor nacional um monopólio, possibilitando que aumentassem seus preços e levando à perda de eficiência produtiva, pelo desestímulo à redução dos seus custos.

Sustentou que a liberdade natural dos indivíduos interagindo no ambiente econômico, cada um deles focando na maximização de seu bem-estar pelo fornecimento de bens e serviços aos demais, iria levar a uma alocação eficiente de recursos do ponto de vista da sociedade como um agregado, com acréscimo da renda nacional ao valor mais alto possível.

Nesse raciocínio, defendeu que o ambiente econômico não deveria ser totalmente imune à atuação estatal, para a qual via a importante função de transformar os mecanismos de mercado em uma instituição social, por meio do fornecimento de bens públicos e a prestação de serviços como o de justiça, com o que o sistema iria operar mais eficientemente. Como afirma Douglas Irwin (1998, p. 78), diferentemente do que muito se fala, o sistema proposto por Adam Smith não repousava unicamente e exclusivamente na ideia de "laissez-faire".

Para Smith, o conceito chave para a formulação de uma política comercial é a noção de custos de oportunidade, ou as escolhas e trocas entre atividades alternativas em circunstância de restrição de recursos. O comércio internacional livre possibilitava a melhor alocação de tais recursos, sendo que os encargos aduaneitos protetivos interfeririam nessa distribuição ótima.

Só admitiu duas exceções a esse princípio: a proteção de determinado tipo de indústria que fosse necessária à defesa do país, já que a segurança é mais importante que a opulência, assim como no caso em que os produtos nacionais fossem sujeitos a tributos não incidentes sobre os produtos estrangeiros. Trata-se de uma formulação antecedente da dos ajustes fiscais de fronteira, tema fundamental no exame da presente tese, ainda como 
encargos aduaneiros, mas que tivessem a função de equalizar a carga fiscal dos produtos domésticos em relação aos alienígenas.

Também aduzia dois pontos a serem considerados, acerca da eliminação dos encargos aduaneiros transfronteiriços. $O$ primeiro referia-se à necessidade de reciprocidade, ou à possibilidade de retaliação, sempre temporária, na situação em que o país estrangeiro impusesse análogo gravame aos bens do país. No entanto, ressalva, tratase de uma questão política, não econômica. A outra consideração referia-se à velocidade com que os existentes gravames na importação deveriam ser extintos - advogava que deveria ser realizada tal eliminação mediante suaves gradações, com reserva e circunspecção.

Em suma, não trazia novas ideias sobre o comércio, mas antes revolucionou o conceito sobre a organização econômica da sociedade e sobrelevou o papel na liberdade natural na promoção da riqueza nacional (IRWIN, 1998, p. 79).

Sua visão, no resumo empreendido por Adílson Rodrigues Pires (2001, p. 3), concluiu pelas "vantagens do comércio sem barreiras", por meio dos seus estudos, "nos quais sustenta que ao Estado compete assegurar a liberdade nas trocas, a manutenção da ordem interna, o exercício do comércio individual e a possibilidade de melhorar a utilização dos recursos disponíveis, promovendo, consequentemente, o desenvolvimento econômico do Estado". Conclui afirmando que o "mestre do pensamento liberal do século XVIII" entendeu que "qualquer regulamentação imposta ao livre comércio entre as nações fatalmente anulará o resultado positivo das trocas internacionais".

Finalmente, apresentando a sua concepção mais relevante para a disciplina do comércio internacional, Adam Smith trouxe, embora sem usar tal expressão, a formulação de que cada país, se por algum motivo, tem a capacidade de produzir uma commodity mais barata do que os seus concorrentes, deveria se dedicar a produzi-la, e assim as outras nações em relação a outras mercadorias, com o que, com as trocas com as demais, a partir dos seus excedentes comerciais, cada país terá o potencial de aumentar a sua renda e produção internas - a Teoria das Vantagens Absolutas. Pela formulação teórica, como a resume Dominick Salvatore (1998, p. 19), o crescimento da produção de ambas as commodities corresponde aos ganhos da especialização na produção disponíveis para serem divididos entre as duas nações por meio do comércio.

Como nos noticia Douglas Irwin (1998, p. 87), embora a "Riqueza das Nações" tenha sido uma obra de razoável impacto logo após sua publicação, decorreu ainda aproximadamente um quarto de século para que se possa dizer que há evidências de que as 
suas ideias tenham sido afinal consolidadas e integralmente absorvidas no pensamento econômico de então.

Assim, o que se convencionou denominar período clássico do pensamento econômico foi um pouco retardado diante das conturbações políticas do quadro ocidental na virada entre os Séculos XVIII e XIX, como a Revolução Francesa, a independência americana e as guerras napoleônicas.

Nessa época, o evento de maior importância do ponto de vista normativo foi a formação do "Sistema Continental", a política externa de Napoleão Bonaparte, àquela altura o Imperador Napoleon I de França e Rei da Itália, em sua luta contra o seu grande adversário das guerras napoleônicas, o Reino Unido, contra quem havia desistido da sua intenção de invasão, diante da derrota na Batalha Naval de Trafalgar, na Espanha, de 21 de outubro de 1805. Com isso, pensando em lograr êxito indiretamente, mediante o empobrecimento do adversário, determinou a imposição, por meio do Decreto de Berlim, de 21 de novembro de 1806, logo após a vitória napoleônica contra a Prússia na Batalha (terrestre) de Jena, de um embargo de ampla extensão, por parte tanto da França quanto dos seus aliados ou dependentes, contra o comércio inglês.

A partir de então, era proibido qualquer comércio ou correspondência com as ilhas britâncias, endereçados ao país, a algum nacional britânico ou em linguagem inglesa. Consideravam-se confiscadas quaisquer mercadorias pertencentes a cidadãos ingleses ou vindas de suas indústrias ou das sua colônias, com a possibilidade de indenização do responsável pela imposição do perdimento por suas despesas. Os portos das regiões aliadas à França, assim como decerto os franceses, estavam também proibidos de receber ou deixar partir qualquer embarcação vinda da Inglaterra ou de suas colônias, ou que a elas se destinasse.

Posteriormente, Napoleon I editou o Decreto de Milão, de 17 de dezembro de 1807, reforçando o Decreto de Berlim, estabelecendo que nenhum país europeu poderia comerciar com o Reino Unido. O Decreto também autorizava os navios, tanto de guerra quanto os piratas, de bandeira francesa, a capturar qualquer embarcação, mesmo de bandeira neutra, que tivesse origem ou destino em algum porto britânico ou localizado em região ocupada pelas forças britânicas.

O que aconteceu foi que o embargo europeu continental ao comércio inglês, de 1806, produziu uma controvérsia teórica que fez surgirem as primeiras obras que se podem dizer como realmente caudatárias das lições smithianas. 
Um economista inglês simpático ao pensamento fisiocrático, William Spencer, fez publicar, em 1807, uma obra, chamada "Britain Independent of Commerce", na qual afirmava não ver desvantagens na situação por que passava o seu país, uma vez que, para ele, a agricultura e o mercado interno seriam as bases da riqueza. Contra essa postura prontamente se insurgiram James Mill e Robert Torrens, escrevendo obras em 1808, respectivamente "Commerce Defended" e "The Economists Refuted", que defendiam a existência de ganhos de produtividade e eficiência econômica no comércio internacional, repetindo a concepção de que é melhor usar o capital próprio e o trabalho do país naquilo que a produção própria é mais eficiente.

Assim, é recomendável, para eles, trocar a commodity essencial, por exemplo, o milho, com um país, por exemplo, a Polônia, que o produza a mais baixo custo, graças às suas férteis planícies, do que tentar produzir tudo domesticamente. Ambos defendiam que a melhor forma de determinar qual a quantidade de recursos necessária para gerar a maior quantidade de milho para consumo local deveria ser por meio das forças de mercado. Tais formulações foram mais bem desenvolvidas no artigo denominado "Corn Laws", de 1814, de James Mill, e no ensaio "Essay on the External Corn Trade", de Robert Torrens, de 1815, ambas obras francamente pertencentes à Escola Clássica.

Mas o mais ilustre membro da Escola Clássica foi, sem sombra de dúvidas, David Ricardo, aquele quem recebe virtualmente todo o crédito pela exposição da Teoria das Vantagens Comparativas, no capítulo 7 (“On Foreign Trade") de sua obra de 1817, "On the Principles of Political Economy and Taxation". Segundo Avelãs Nunes (2007, p. 462), a obra que inaugura o objeto da Economia Política, não por acaso tendo para ela sido adotada a denominação reduzida de "Princípios", dada a extensão e profundidade de seus propósitos.

David Ricardo toma o modelo de dois países e de dois produtos para explicar a teoria que formulara. Digamos que os países possuam a seguinte matriz de custos de produção dos bens analisados:

\begin{tabular}{|l|c|c|}
\hline & Custos de produção & (Homens X Ano de Trabalho) \\
\hline & Vinho (n unidades) & Tecido (n unidades) \\
\hline PORTUGAL & 80 & 90 \\
\hline INGLATERRA & 120 & 100 \\
\hline
\end{tabular}


Comparando-se os custos de produção dos dois produtos nos dois países, verifica-se que Portugal possui vantagens absolutas tanto na produção de vinho (80 contra 120) quanto na produção de tecido (90 contra 100), em relação à Inglaterra. No entanto, no que tange ao conceito de vantagem comparativa no sentido ricardiano, como diferença relativa de custos, Portugal possui vantagem relativa na produção de vinho (pois 80/90 < 120/100), mas a vantagem relativa na produção de tecidos é da Inglaterra (já que 100/120 < 90/80).

Como explicado por David Ricardo, em apenas três parágrafos, a Inglaterra ficará estimulada a produzir o tecido, que requer o trabalho de 100 homens durante um ano de trabalho, uma vez que, se tencionasse produzir vinho, teria que despender 120 homens $\mathrm{X}$ ano. Melhor então, para os interesses ingleses, trocar a sua unidade de tecido por uma unidade de vinho produzido em Portugal, do que produzi-lo localmente.

Analogamente, Portugal terá interesse em produzir apenas vinho, pois com uma unidade de vinho de sua produção, que lhe consumirá o trabalho de 80 homens em um ano, poderá adquirir uma unidade de tecido inglês, ao passo que, se quisesse produzir localmente os tecidos, teria que alocar para tanto o trabalho de 90 homens em um ano. Haverá interesse, pois, na transação internacional, exportar vinho e receber tecido em troca.

Tal equação é favorável a ambos os países independentemente do fato de que a commodity, no caso o tecido, pudesse, por hipótese, ser produzida em Portugal, com menor carga laboral (90 homens por ano), do que na Inglaterra (100 homens por ano), ou seja, que haja vantagens absolutas de Portugal, porque é mais benéfico a Portugal produzir vinho, que lhe exige ainda menor dispêndio de recursos. Seu capital, portanto, não deve ser desviado para a produção de tecidos, mas concentrado na produção de vinhos. A razão para isso, explica Ricardo, no parágrafo 7.17, repousa no fato de que as fontes de forças de trabalho humano não possuem a mesma mobilidade que as mercadorias, já que não se trata de indivíduos de um mesmo país.

Douglas Irwin (1998, p. 91), a propósito desses meros três parágrafos, reputa-os pobremente explicados, deslocados do contexto do capítulo e falhos em evidenciar a essência da teoria. Mencionando historiadores da Economia como John Chipman e William Thweatt, chega a especular se o autor realmente havia entendido o fundamental de sua teoria, sugerindo que o real responsável por ela tenha sido James Mill, até por ele ser interlocutor frequente de David Ricardo em seus estudos. Com efeito, a formulação teórica vem mais bem desenvolvida na obra de Mill de 1821, "Elements of Political Economy". 
Nela Mill explica que o benefício oriundo da troca entre as mercadorias advém daquela que foi recebida, não da que foi dada. Trata-se do ganho diante do custo de adquirir produtos importados em comparação com o custo de produzir localmente.

Na visão de Adílson Rodrigues Pires (2001, p. 4), a teoria das vantagens comparativas, introduzida por David Ricardo, trouxe o "critério mais adequado para a especialização da produção de cada país, com vistas ao atendimento do mercado interno e da produção destinada à exportação".

Porém, a consolidação da Teoria das Vantagens Comparativas só veio a se dar com o advento da obra do filho de James Mill, John Stuart Mill, de 1848, "Principles of Political Economy", na qual se expõem com mais clareza as vantagens para todos os Estados no comércio internacional e os custos da atividade protetiva, em termos de perda de eficiência produtiva. No livro em questão ilustra-se claramente como se dão os aumentos agregados de renda, de produção e de consumo advindos da especialização internacional, espancando completamente qualquer resquício do ideal mercantilista do comércio internacional como ambiente de disputas pelas riquezas entre os países.

Segundo Andreas Lowenfeld (2008, p. 6), a ilustração ricardiana é uma vasta simplificação, uma vez que supõe apenas um fator de produção (as horas de trabalho); admite a plena mobilidade desses fatores entre os produtos; prevê apenas dois produtos e dois países; presume preços constantes e custos invariáveis; e não pressupõe diferenciações entre os produtos, não considera o papel das firmas, despreza o fato de que os objetos comerciados são o produto de outros bens que podem ter origens diversas, e considera uma taxa de câmbio fixa.

Posteriormente, a Teoria das Vantagens Comparativas logrou ser aprimorada basicamente em duas ocasiões. A primeira, publicada em obra de 1933, pelos economistas suecos Eli Hecksher e Bertil Ohlin, introduziu no problema a circunstância de que o uso proporcional dos fatores de produção não necessariamente deveria ser idêntico entre as diversas alternativas alocativas, uma vez que o modelo ricardiano só prevê a comparação por meio de um fator, a mão-de-obra. A segunda, em 1936, por Gottfried Haberler, com a "Theory of International Trade", veio a explicar a Teoria das Vantagens Comparativas por meio da teoria do custo de oportunidade.

A constatação do aperfeiçoamento posterior de sua teoria não vem, de forma alguma, retirar méritos da inicial formulação de David Ricardo, mas, ao contrário, infirmar a posição de que a sua relevância científica vai além meramente da sua criação da Teoria das Vantagens Comparativas. Por exemplo, do ponto de vista político, é fundamental a 
influência não só da obra de David Ricardo, àquela altura já amplamente reconhecida na Inglaterra, como também da sua atividade panfletária em discursos na House of Commons, na revogação em definitivo das "Corn Laws", em 1846 - embora houvesse falecido, ainda frustrado, em 1823 (BERNSTEIN, 2008, p. 306 - 307).

Ensina William Bernstein (2008, p. 300 - 301) que, pelo menos desde o Século $\mathrm{XV}$, a coroa inglesa administrava o comércio de grãos com a ilha britânica mediante uma série de leis chamadas "Corn Laws". No sentido vulgar, o termo em inglês corn denota qualquer tipo de cereal, tal como cevada, centeio e principalmente, trigo, e não apenas o milho, que possui origem americana e, ao que tudo indica, ainda não era muito cultivado na ilha àquela época. Registros mais detalhados dessas normas existem desde $1660 \mathrm{e}$, até 1846, cerca de cento e vinte e sete dessas leis haviam sido promulgadas, dispondo de diversos aspectos do comércio de grãos com o Reino, como operações a varejo e no atacado, armazenamento, importação, exportação e, no que foram mais críticas, no imposto de importação.

As "Corn Laws" mais traumáticas foram as leis determinando radicais aumentos de impostos de importação, introduzidas pelo Importation Act, de 1815, com o fim de evitar a concorrência do milho inglês com aquele oriundo dos países da Europa Continental. Foram aprovadas depois da maciça pressão dos proprietários rurais ingleses assustados com a invasão dos cereais decorrente do fim do embargo napoleônico, em março de 1814, após a primeira abdicação de Napoleon I.

A propósito, tanto as "Corn Laws" quanto o embargo napoleônico foram circunstâncias que geraram um fantástico campo de prova empírico para as doutrinas sobre Economia Política de então (IRWIN, 1998, p. 93). Não se deve esquecer que o embargo econômico ao Reino Unido foi profundamente deletério para alguns países aliados à França, como a Rússia, que, em 1812, acabou, empobrecida e faminta, tendo que reabrir o comércio com os britânicos, situação que foi um dos principais incentivos à decisão de Napoleon I em invadir o território russo, em 23 de junho de 1812 - o que terminou por causar a reviravolta histórica conhecida.

Por outro lado, o despencar dos preços dos cereais e do pão na Inglaterra com o fim do embargo e a carestia originada com o advento das "Corn Laws" provocaram profunda cisão no seio político britânico, com a criação de uma "The Anti-Corn Law League", em 1837, com o que, em contraposição, o Duque de Richmond fundou a "Central Agricultural Protection Society", em 1844. 
Com isso, abriu-se uma profílica controvérsia, a gerar estudos de diversas teorias econômicas, não só dos tratadistas clássicos, mas também daqueles ligados à Escola Histórica Alemã e à Teoria Socialista.

Além dos já mencionados "Corn Laws", de 1814, de James Mill, e "Essay on the External Corn Trade", de Robert Torrens, de 1815, também David Ricardo dedicou-se a escrever especificamente sobre o problema, na sua obra, especialmente nos ensaios " $A n$ Essay on the Influence of a Low Price of Corn on the Profits of Stock", de 1815, e "On Protection to Agriculture", de 1822. Sem falar na sua notória controvérsia a respeito com o Reverendo Thomas Malthus, em cujas obras de 1815 ("Essay on the Principle of Population") e de 1820 ("Principles of Political Economy"), defende abertamente os direitos dos landlords britânicos e a proteção da atividade agrícola.

Foi um dos fundadores da sucursal da "The Anti-Corn Law League" na cidade de Manchester, Richard Cobden, em 1838, reestruturando-a nacionalmente no ano seguinte, quem se tornou um dos responsáveis pela revogação parlamentar das "Corn Laws", em 1846, muito em função da depressão inglesa de 1840 - 1842 e da quebra da safra de batatas na Irlanda, em 1845, com a consequente fome em massa da população.

Enfraquecido com a sua derrota política, Sir Robert Peel, primeiro ministro conservador da época, renunciou, subindo ao cargo Lord John Russell, que ofereceu a Cobden o posto de Secretary of State for Foreign Affairs de seu governo. Cobden, ele próprio um próspero comerciante que havia perdido sua fortuna por conta de sua defesa política do livre comércio, recusou e passou a combater a política externa de Lord Palmerston, o indicado em seu lugar.

Richard Cobden foi eleito nas Eleições Gerais Parlamentares de 1859. Lord Palmerston então ofereceu a Cobden a oportunidade de se tornar Presidente do Board of Trade. Cobden também recusou, por discordar da política belicosa vigente e por entender que a melhor maneira de combater o potencial conflito com a França de Napoleon III seria pela abertura comercial e não pela dispendiosa compra de armamentos. Então, William Gladstone, o Chancellor of the Exchequer (o equivalente britânico ao Ministro da Fazenda brasileiro ou ao Secretary of the Treasury dos Estados Unidos da América), concordou com suas posições e recrutou Richard Cobden para negociar um novo acordo comercial com a França.

Havendo tomado conhecimento dos escritos de Cobden externando tais ideias, um deputado da Assemblée Nationale francesa e professor de Economia Política, Michel Chevalier, buscou e angariou o apoio de Eugène Rouher, o poderoso Ministre de 
l'Agriculture, du Commerce et des Travaux Publics, assim como logrou convencer o Imperador Napoleon III das vantagens do livre comércio e da necessidade de reformar o sistema tarifário francês.

Em 23 de janeiro de 1860, o Reino Unido e a França assinaram um tratado comercial, conhecido como Tratado Cobden-Chevalier, que reduzia os encargos aduaneiros franceses em relação a uma série de bens manufaturados ingleses a não mais que $25 \%$ em cinco anos, ao mesmo tempo em que reduzia os encargos britânicos sobre os vinhos e licores franceses e os eliminava em relação a todos os demais produtos. Em consequência, apenas na década seguinte, a corrente de comércio entre os dois países quadruplicou.

Mais do que isso, a inclusão no tratado de uma cláusula prevendo o tratamento de nação mais favorecida, aliada ao fato de, no período entre 1862 e 1867, a França ter assinado uma série de tratados comerciais bilaterais com países como a Bélgica, a Prússia e o Zollverein, a Suécia, a Itália, a Suíça, a Noruega, os Estados Hanseáticos, a Espanha, os Países Baixos, a Áustria e Portugal - com todo o mundo ocidental relevante da época, à exceção da Rússia e dos Estados Unidos - fez com que, no fim da década de 60 do Século XIX, a França houvesse se tornado o centro de uma rede de tratados internacionais por toda a Europa (CURZON, 1965, p. 15 - 16), inaugurando o período de maior liberdade comercial de toda a história da humanidade - talvez o único.

Como resume Jagdish Bhagwati (1993, p. 25 - 32), somente durante todo esse período pode-se dizer que a política comercial britânica baseou-se na abertura unilateral do mercado - aquela preferida dos economistas, mas raramente, senão notadamente durante apenas esse meio século, empregada na prática (HOEKMAN; KOSTECKI, 2001, p. 19).

Mais mordaz, Ha-Joon Chang (2003, p. 34) avalia que não seria insensato dizer que o regime da época foi o mais próximo do livre-comércio que o mundo já teve "ou (provavelmente) terá”. Por esse motivo, Gerard Curzon (1965, p. 20) nos informa que o período entre 1860 e 1914 é conhecido como a "época de ouro" da política comercial do mundo ocidental.

E não apenas do mundo ocidental. Fora da Europa, a maior parte do resto do mundo, como defende Ha-Joon Chang (2003, p. 34), ou foi obrigada a praticar livrecomércio pela submissão colonial ou, no caso daqueles países que denomina como "nominalmente 'independentes"”, como os latino-americanos, a China, o Sião (atual Tailândia), a Pérsia (hoje o Irã) e o Império Otomano (atual Turquia), os respectivos governos foram forçados a celebrar tratados desiguais. 
Tais tratados desiguais normalmente envolviam o estabelecimento de "tetos tarifários", quase sempre em torno de $5 \%$, assim como a perda da "autonomia tarifária", como se refere Ha-Joon Chang (2003, p. 97)

Um exemplo desses tratados, na verdade o primeiro deles, é o "Tratado de Comércio e Navegação", de 19 de fevereiro de 1810, assinado no Rio de Janeiro pelo plenipotenciário do governo britânico, Lord Strangford, enviado pelo Secretary of State for Foreign Affairs britânico, George Canning, e o governo português, àquela altura sediado aqui e chefiado por Dom João. Em verdade, as duas coroas já haviam assinado um acordo secreto, em outubro de 1807, por meio do qual o Reino Unido se comprometia a dar proteção, por meio da esquadra britânica, à corte portuguesa, na eventualidade de haver uma fuga naval pelo Atlântico Sul, desde que o mercado brasileiro fosse posteriormente aberto, estendendo-se à nova sede do reino os privilégios comerciais portugueses ao Reino Unido (BETHELL, 1970, p. 7 - 8).

Nas é por outro motivo que a primeira Carta Régia promulgada pelo Príncipe Regente Dom João no Brasil, o que se deu apenas quatro dias após sua chegada, com a Família Real, em 24 de Janeiro de 1808, foi o "Decreto de Abertura dos Portos às Nações Amigas", em 28 de Janeiro, em Salvador, na Capitania da Baía de Todos os Santos, ainda antes de chegar ao seu destino final.

A intenção inglesa tinha sua razão de ser, já que o Brasil consistia em um grande mercado por si só e uma porta de entrada alternativa à América Espanhola, em época em que o comércio na Europa sofria o embargo napoleônico mencionado e o da América do Norte se via constantemente ameaçado.

Não se deve esquecer que o Presidente Thomas Jefferson havia proposto um embargo aos britânicos por conta de um incidente naval, o "Chesapeake-Leopard Affair", o que foi aceito pelo United States Congress e se tornou o "Embargo Act", de 1807, revogado no ano seguinte, por falta de apoio popular e por ter sido considerado inexequível. Posteriormente foram ainda intentadas duas outras normas com a mesma pretensão, o "Non-Intercourse Act" de 1 de março de 1809 e o "Macon's Bill Number 2", de $1^{\circ}$ de maio de 1810 .

O tratado de 1810 com Portugal limitava a $15 \%$ ad valorem, no máximo, as alíquotas do imposto de importação incidente sobre os produtos ingleses e autorizava a autoridade britânica a indicar juízes que seriam os responsáveis em julgar as causas dos cidadãos britânicos no país (BETHELL, 1970, p. 8). Para avaliar o significado dessa 
medida, basta lembrar que a alíquota do imposto de importação de produtos portugueses era de $16 \%$ e, a de produtos de outras nações, de $24 \%$.

No final do século XVIII, por seu lado, os Estados Unidos foram o primeiro país a adotar o protecionismo como política de Estado, utilizando a justificativa das indústrias nascentes, com base na doutrina de Alexander Hamilton, seu primeiro Secretary of the Treasury. Em sua obra de 1791, "Report on Manufactures", embora Hamilton reconhecesse que a imposição de encargos aduaneiros na importação elevasse os preços das mercadorias, defendia que a situação contrária daria o efeito de impor obstáculos ao nascimento de novas indústrias e até inviabilizar as ainda em processo de consolidação. Propunha quatro tipos de políticas comerciais: encargos protetivos, proibições à importação, tributos sobre a exportação de matérias-primas e subsídios, sendo essa a preferível, por ser a mais imediata e porque não produziria escassez interna, assim como geraria mercados externos.

Um grande historiador aduaneiro americano, Frank Taussig, autor de obra clássica, de 1907, "The Tariff History of the United States", afirmou que a primeira norma americana sobre o comércio exterior, o Tariff Act de 1789 (ou "Hamilton Tariff", apenas a segunda lei promulgada pelo novo governo federal dos Estados Unidos da América), já era protetivo em intenção e no espírito, segundo Charles McFarland e Nevin Neal (1969, p. 22). A afirmação é controvertida, mas é certo que, com o "Dallas Tariff”, de 1816, no governo James Madison, estabeleceu-se definitivamente a proteção comercial americana, que perdurou até quase a Primeira Guerra Mundial - por cerca de cem anos, portanto.

$\mathrm{Na}$ verdade, embora se possa identificar historicamente a prevalência das formulações de Economia Internacional baseadas no livrecambismo, como todas as teorias apresentadas até agora, ao mesmo tempo em que, nas práticas comerciais dos países desenvolvidos, como também foi exaustivamente apresentado até agora, a realidade seja outra, é importante assinalar que, já no Século XIX, em seu início, duas foram as formulações teóricas que justificaram o protecionismo econômico.

A primeira, no dizer de Douglas Irwin (1996, p. 101), consiste no argumento de mais difícil reputação, sob o ponto de vista teórico, e permanece, a seu ver, como a mais importante e durável exceção ao livre comércio jamais formulada, embora, como afirma Manuel Porto (2001, p. 38), seja bem menos popular do que a construção do argumento da indústria nascente. Trata-se da defesa intransigente que Robert Torrens elaborou, em suas obras de 1824, "An Essay on the Production of Wealth", da reciprocidade na redução das alíquotas aduaneiras, em lugar da unilateralidade própria das visões livrecambistas, como 
política comercial para o Reino Unido, baseada na teoria dos termos de troca ou termos de comércio.

Robert Torrens é também conhecido por ter sido, segundo alguns, o pioneiro, dois anos antes de David Ricardo, a expor a Teoria das Vantagens Comparativas, em sua obra de 1815, "Essay on the External Corn Trade" - trazendo argumentos depois aprimorados por Ricardo em "On the Principles of Political Economy and Taxation", de 1817.

Termos de troca seria a razão entre o equivalente ao poder de compra das exportações de um país em relação aos produtos importados que poderiam ser adquiridos com esse mesmo valor. Segundo Torrens, as restrições ao livre comércio, em se tratando de países com possibilidade de influenciar os seus parceiros comerciais ${ }^{24}$, poderiam ser válidas se empregadas com o fim de melhorar os termos de troca de um país.

Se fizermos a avaliação dos termos de troca entre produtos primários e produtos industrializados, como nos alerta Fábio Nusdeo (2010, p. 331), sendo os preços internacionais muito mais valorizadas para os segundos, a tendência é a de que tenhamos uma degeneração dos termos de troca deletéria ao exportador primário. Em casos como tais, Robert Torrens via a necessidade de alterar o perfil da balança comercial por meio da reciprocidade e não da unilateralidade. $\mathrm{O}$ argumento foi em muito aprimorado por Charles Frederick Bickerdike, em seu artigo, publicado no Economic Journal, "The Theory of Incipient Taxes", vol XVI, de dezembro de 1906, em que cria o conceito de Tarifa Ótima, como sendo aquela que maximiza os termos de troca de um país.

A segunda visão teórica justificadora do protecionismo é a mais conhecida. Veio com a obra do filho de James Mill, John Stuart Mill, de 1848, "Principles of Political Economy", embora, como já visto, seu norte principal seja o de expor com mais clareza as vantagens para todos os Estados no comércio internacional e os custos da atividade protetiva, em termos de perda de eficiência produtiva. No entanto, em uma breve passagem, vislumbrou uma exceção no argumento da indústria nascente, como único a justificar as políticas comerciais protecionistas, desde que houvesse a garantia. Defendia então que uma proteção temporária para as indústrias nascentes, aquelas que ainda não eram capazes de sobreviver em face da concorrência com produtos importados, mas que, com tempo e experiência, poderiam, no futuro, competir no mercado internacional.

\footnotetext{
${ }^{24} \mathrm{O}$ argumento de Robert Torrens não se aplica aos países pequenos, aqueles de tal maneira menores em volume de demanda em relação à oferta dos seus parceiros comerciais, e viceversa, que enxergam as funções oferta de importações e demanda de exportações como funções inelásticas, pois não as podem influenciar em seus pontos de equilíbrio.
} 
Segundo esse argumento, para Nusdeo (2010, p. 330), os benefícios da especialização nem sempre são frutos de uma vantagem específica apresentada por um país, seja ela por que motivo for, qualificação dos recursos humanos, desenvolvimento tecnológico, condições físicas ou climáticas, mas podem simplesmente resultar de economias de escala das quais puderam se aproveitar os países que puderam se antecipar aos demais no desenvolvimento de seus parques industriais. Tal realidade não significaria que tais países, retardatários, não poderiam alcançar o mesmo estágio de desenvolvimento, ultrapassado a fase adolescente das suas indústrias, aquela em que elas ainda estivessesm operando abaixo do pleno proveito das suas economias de escala.

Tal visão, aliás, como já visto, havia sido inicialmente apresentada, embora sob diversos pressupostos, por Alexander Hamilton, em 1791, no seu afamado "Report on Manufactures", e, de forma muito mais fundamentada, por Friedrich List, no seu "Das Nationale System der Politischen Ökonomie" (Sistema Nacional de Economia Política), de 1841.

Friedrich List, preocupado com a situação da Alemanha em meados do Século $\mathrm{XIX}$, tendo contato com as transformações que estavam ocorrendo nos Estados Unidos e haviam ocorrido no Reino Unido, inspirado nas ideias de Alexander Hamilton, desenvolveu a teoria de que, para um país se desenvolver, era necessário promover a unidade nacional, abolir as tarifas internas e proteger sua economia da concorrência externa, principalmente para a instalação de manufaturas, consideradas uma atividade superior à atividade agrícola e imprescindível para seu próprio desenvolvimento.

Das suas observações de então e da análise histórica que empreendeu, percebeu o autor que o desenvolvimento das nações se dava em função de um protecionismo, como fora o caso da Inglaterra, ainda que, alicerçada nas teorias vigentes, a Inglaterra alegava fundar o verdadeiro motivo de seu desenvolvimento no livre-cambismo.

De acordo com o seu pensamento econômico, as empresas nacionais não se desenvolveriam se o mercado já estivesse ocupado por empresas de países estrangeiros economicamente mais avançados. Nessas circunstâncias, justificava-se um protecionismo educador, tendo por objetivo proteger temporariamente o mercado nacional para assegurar a consolidação das indústrias nacionais para que a médio prazo pudessem concorrer com sucesso num ambiente de livre concorrência que não se transformasse rapidamente num sistema de sentido único pelo esmagamento das indústrias do território economicamente menos desenvolvido. 
List, portanto, contrapõs-se às teorias liberais então vigentes e demonstrou como os países, de fato, se desenvolveram. Identificou relevância econômica fundamental no mercado interno, considerando-o muito mais importante que o comércio com o exterior, pois o primeiro é garantido e permite um melhor planejamento sobre a produção; em contrapartida, o comércio exterior pode ser interrompido a qualquer momento, ao sabor das intempéries externas, deixando algumas nações que ainda não desenvolveram seu mercado interno e não implementaram a manufatura numa situação em que não podem exportar suas matérias-primas e também não podem importar os produtos manufaturados dos quais carecem, por falta de divisas para isso (RODRIGUES, 2005, p. 3 - 4).

O autor alemão, na sua obra, contrariava frontalmente a visão, alicerçada na teoria das vantagens comparativas, de que o livre comércio e a não participação do Estado em assuntos econômicos, a não ser em situações bastante específicas, seriam a melhor forma das nações alcançarem o seu desenvolvimento, respeitando suas condições naturais de competitividade.

Enquanto isso, nos Estados Unidos, como já vimos, havia um intenso debate sobre a viabilidade de se adotar uma política protecionista, o que contrapunha o norte, protecionista, ao sul, livrecambista, o que veio a fazer eclodir, anos depois, uma guerra civil naquele país. Friedrich List, fez-se presente nessa discussão, militando contra o livrecomércio, escrevendo nos Estados Unidos alguns trabalhos defendendo o protecionismo antes de, em 1832, retornar à Europa (RODRIGUES, 2005, p. 54).

Para ele, o desenvolvimento do mercado interno apenas se dá a partir do momento da instalação da manufatura, por meio de uma política coerente e protetora por parte do Estado, o qual deve, inclusive, orientar os investimentos privados para os setores mais importantes para o país.

Sempre preocupado com a situação de sua terra natal, foi deputado na câmara de Württemberg, e um dos inspiradores da criação da União Aduaneira dos Estados Alemães de 1834 (Zollverein), que abrangeu a maior parte das entidades políticas que formaram a posterior Alemanha unificada, em 1871.

Para List, os norteamericanos haviam aprendido da experiência que a agricultura não pode atingir um estado elevado de prosperidade se não assegurar para o futuro a troca de produtos agrícolas por artigos manufaturados; que, ao contrário, quando o agricultor vive na América e o manufator vive na Inglaterra, tal intercâmbio não raro é interrompido por guerras, crises comerciais ou por tarifas alfandegárias estrangeiras, e, por 
conseguinte, se se quiser que o bem-estar nacional repouse sobre fundamentos seguros, o manufator deve vir a estabelecer-se bem próximo do agricultor.

Posterior à obra de List, já no século XX, em 1929, é lançada em Paris, a primeira versão da obra fundamental de Mihaïl Manoïlescu, "Théorie du protectionnisme et de l'échange international" pelas Éditions Giard, na coleção Bibliothèque Économique Internationale ${ }^{25}$. Segundo o autor, trata-se de uma teoria científica do protecionismo já que Manoïlescu, economista nascido na Moldávia, de nacionalidade da Romênia, propõe-se a discutir com os livre-cambistas no terreno estritamente econômico, diferentemente do que, a seu ver, havia feito de List, que considera ter discutido também na esfera política.

Manoïlescu critica duramente os autores que defendiam o livre comércio, dentre eles Adam Smith e David Ricardo, estendendo suas críticas a Georg Friedrich List, por ter considerado argumentos livrecambistas, principalmente para defender um período limitado de proteção, o período de infância da indústria, caracterizando assim o protecionismo como uma situação de exceção (MANOILESCO, 1931, p. 24).

Segundo Manoïlescu, a reserva de List à aplicação do protecionismo às nações muito pobres ou muito atrasadas, e para as quais seria prematura a educação industrial, não se justificaria, pois, para o político romeno, mesmo nos graus mais incipientes de civilização, existem indústrias elementares que podem nascer e cuja produtividade - por mais fraca que seja - é maior do que a produtividade média muito reduzida, para um país tão pouco adiantado (MANOILESCO, 1931, p. 324 - 325).

Além de defender sempre o protecionismo para as indústrias, o autor também defenderá uma proteção para as atividades agrícolas que representarem uma produtividade que seja maior que a das atividades já instaladas em determinado país, embora reconhecendo que a atividade industrial apresenta uma produtividade muito maior em relação à agricultura. Segundo sua visão, haveria, o que deveria ser estimulado, uma migração da força de trabalho da agricultura, decorrente das suas baixas remunerações, consequência da sua baixa produtividade, para a indústria, em função de seu maior potencial gerador de renda - por esse motivo, Douglas Irwin identifica a sua defesa protecionista como fundada no argumento do diferencial de salários (IRWIN, 1996, p. 153).

A análise do autor romeno do Tratado de Methuen, celebrado entre Portugal e Inglaterra em 1703, foi o laboratório da crítica mais candente de Manoïlescu à teoria das

\footnotetext{
${ }^{25}$ No Brasil, Mihail MANOILESCO. Theoria do Protecionismo e da Permuta Internacional. São Paulo: Centro das Indústrias do Estado de São Paulo, 1931.
} 
vantagens comparativas de Ricardo (MANOILESCO, 1931, p. 116 - 124). Pelo acordo internacional, Portugal deveria produzir vinhos e exportá-los à Inglaterra que, em contrapartida, produziria tecidos e os exportaria para Portugal. David Ricardo, como já visto, defendia que cada país estava se beneficiando com essa relação comercial.

Manoïlescu discordou das conclusões às quais chega David Ricardo, pois defende que não seria por meio da da superioridade comparativa da produção de vinhos e tecidos que se deve chegar às definições de produção e troca entre cada nação, e sim pelo grau de produtividade das mercadorias, principalmente comparadas à média de produtividade de cada país.

Ricardo asseverava, erroneamente, para o romeno, que, na produção de uma mercadoria, cada vez que um país tem relativa superioridade sobre outro (uma vantagem relativa) isto é, uma superioridade maior do que a superioridade (vantagem) que ele tem na produção de outra mercadoria, deve limitar-se a produzir exclusivamente a primeira mercadoria. No entender de Ricardo, seria a comparação na produção de uma mesma mercadoria em dois países diferentes o fator decisivo e não a comparação de duas mercadorias diferentes no mesmo país, como preferia Manoïlescu.

Com isso, segundo Manoïlescu, acreditou Ricardo erroneamente que era preciso concentrar-se nas atividades que conferem uma superioridade comparativa em face do estrangeiro, quando é necessário concentrar-se nas atividades que representam maiores produtividades absolutas em relação às demais do próprio país. Se um país (como Portugal) produzir duas mercadorias diferentes, tendo dois graus de produtividade muito diferentes, é para ele proveitoso renunciar a produzir a mercadoria suscetível de pequena produtividade, ainda mesmo que a primeira mercadoria fosse produzida em condições comparativamente superiores às do estrangeiro.

Em seus estudos sobre produtividade, chega Manoïlescu à constatação de que os produtos industriais comportam uma produtividade considerável, em média duas vezes maior, e mesmo mais, do que a produtividade dos produtos agrícolas. Assim sendo, a superioridade intrínseca (qualitativa) da indústria é da ordem de duas vezes ou mais. Portanto, a mensuração da produtividade é que vai definir se é ou não vantajoso para um país produzir determinada mercadoria ou importá-la do estrangeiro, principalmente a produtividade média desse país.

Se uma determinada indústria tiver potencial de alcançar produtividade acima da produtividade média da nação ou entre as de maiores produtividades, essa indústria teria totais condições de se tornar economicamente viável no país e, para tanto, mereceria gozar 
de um protecionismo promovido pelo Estado. A partir do momento em que um país renunciar a produzir uma determinada mercadoria e adquiri-la no exterior, torna-se necessário encontrar nesse país uma mercadoria de permuta que comporte uma produtividade maior que a mercadoria que seria produzida.

As ideias de List e Manoïlescu foram muito importantes no que tange à influência que gerou, no Brasil, em economistas como Celso Furtado e Roberto Simonsen, e, na América Latina, no pensamento da Comissão Econômica para a América Latina das Nações Unidas (CEPAL), cujo secretário executivo, Raúl Prebisch, formulou, com fundo em toda essa influência, a "Teoria da Substituição de Importações”, sistemática concretamente implementada no Brasil por muitos anos, cujo marco inicial foi a elaboração da Reforma Aduaneira (em que as entidades de classe empresarial paulistas tiveram participação destacada) promulgada em 14 de agosto de 1957 como Lei $\mathrm{n}^{\circ} 3.244$ (COLISTETE, 2006, p. 136) e que perdurou, embora de forma atenuada, até o início da Década de 90 do Século XX.

Comentando essas argumentações, assim como o que se denomina "novo protecionismo", movimento direcionado aos setores em crise permanente, como têxtil e confecções, calçados, siderurgia e construção e reparo naval, principalmente, entre outros, e instrumentalizado por mecanismos regulatórios e não tributários, Manuel Porto, ao final afirma que "não parece, todavia, que todas as referidas justificações restricionistas, com o intuito de justificar políticas seguidas, tenham sido suficientes para que a sua defesa se sobrepusesse ao pensamento livre-cambista" (2001, p. 40).

Em verdade, se há alguma controvérsia restante no plano das ideias, verificarse-á que, no plano do direito positivo internacional, pouco há a contestar em relação à constatação de que a visão livrecambista seria a que teria inspirado os responsáveis pelos fenômenos de integração comercial de bens mais bem sucedidos da história, a OMC e a União Europeia (DORDI, 2002, p. 3). Não obstante, como se verificará, deve-se ressaltar que as nações poderosas tenham sempre inserido, ou omitido, subreptíciamente, disposições tendentes a promover realmente as aberturas comerciais pontuais e localizadas.

Porém, como nos põe a refletir Miguel Poiares Maduro (2002, p. 58 - 60), tratando da complexa interpretação que se deve dar ao poder comunitário de tolher as faculdades regulatórias dos Estados-membros da agora União Europeia quando acarretarem restrições quantitativas às importações, tendo em vista o fato de que tais fenômenos internacionais ou supranacionais implicam sempre perda considerável dos poderes soberanos nacionais, há sempre que se indagar sobre as escolhas concernentes à 
divisão de competência entre os Estados-membros e, mais importante ainda, sobre aquelas que tocam aos limites constitucionais ao Estado, especialmente uma estrutura estatal não diretamente eleita, e a sua intervenção no mercado. Em termos mais didáticos, como questiona o Advogado-Geral do então Tribunal de Justiça das Comunidades Europeias, Giuseppe Tesauro, no processo C-292/92, Ruth Hünermund e outros contra Landesapothekerkammer Baden-Württemberg, o "artigo 30 do Tratado" (TCEE) "é uma norma de liberalização das trocas intracomunitárias ou uma norma destinada, mais genericamente, a promover o livre exercício da actividade comercial em cada Estadomembro?" Nos termos em que posicionados por Maduro, o intuito da norma supranacional europeia é o liberalismo econômico ou apenas o antiprotecionismo? 


\section{DO PRINCÍPIO DE NÃO-DISCRIMINAÇÃO NO SISTEMA MULTILATERAL DE REGULAÇÃO DO COMÉRCIO INTERNACIONAL.}

\subsection{Da Contextualização Histórica.}

Conforme visto logo antes, se os Founding Fathers norteamericanos, especialmente Hamilton, primavam pelas posições protecionistas em tese, efetivamente, apenas com a "Dallas Tariff", de 1816, no governo James Madison, estabeleceu-se definitivamente a proteção comercial americana, que perdurou até quase a Primeira Guerra Mundial.

Àquela altura, nos ensinam Charles McFarland e Nevin Neal (1969, p. 22 - 23), já florescia nos Estados Unidos uma indústria próspera, especialmente as de roupas de algodão e de lã e as fundições, muitas das quais estabelecidas no Novo Mundo por líderes industriais britânicos afugentados pelo clima de beligerância e embargo comercial no Velho Continente ditados pelas guerras napoleônicas, nos primeiros anos do Século XIX. Essa indústria era ávida de proteção para poder manter a sua existência e viabilidade econômicas com o advento da estabilização política da Europa.

A norma de 1816, vale esclarecer, assim conhecida por ter sido apresentada por meio de um relatório do Secretary of the Treasury chamado Alexander J. Dallas, estabelecia uma alíquota ad valorem de $25 \%$ para as importações de artigos de algodão e lã, assim como estabelecia um valor aduaneiro mínimo de 25 cents por jarda quadrada, para mercadorias que, anteriormente, eram vendidas a 6 cents por jarda quadrada. Fazia também uma classificação dos bens manufaturados em três modalidades: na primeira estavam os artigos que eram produzidos domesticamente em quantidades suficientes a satisfazer o mercado interno, para os quais a alíquota era alta; na segunda, as mercadorias cuja produção local era limitada e que provavelmente poderia ser aumentada com apropriado fomento, para as quais o encargo ainda era alto, mas nem tanto quanto nas anteriores; e, por último, para as mercadorias cuja produção nacional era insuficiente para o consumo interno, a incidência visava apenas ao seu aspecto fiscal (McFARLAND; NEAL, 1969, p. 24). 
Inicialmente os Estados do Sul apoiaram a norma, que só foi refutada pelos empresários ligados ao transporte naval, concentrados na região de Boston. Posteriormente, diante do fim das importações de algodão bruto por parte da Inglaterra e com o seu mercado interno reduzido por conta da escravidão, os Estados do Sul passaram a também rejeitar a norma que, no seu entender, só prestigiava os Estados do Norte e do Nordeste do país (McFARLAND; NEAL, 1969, p. 23 - 24).

Além do mais, como explicam Bernard Hoekman e Michel Kostecki (2001, p. 23), o que sucedia é que o setor agrícola, concentrado no Sul, era obrigado a transferir sua renda para os estados do Norte, na medida em que tinha que pagar mais caro por maquinário e bens de consumo duráveis. Nessa tensão repousou boa parte das controvérsias que geraram, mais de cinquenta anos depois, a Guerra Civil americana.

Tais discordâncias regionais foram ainda mais agravadas também pela duplicação da alíquota média geral com o Tariff Act de 1861, também conhecida como "Morril Tariff", em homenagem ao deputado que a apresentou, Justin Morril, de Vermont, e que foi elaborada pelo economista Henry Carey e assinada pelo Presidente James Buchanan, ambos da Pennsylvania, estado americano que concentrava a indústria mais beneficiada internamente, a de ferro e de aço.

Mas que não se pense que o furor protecionista americano houvesse ficado congelado durante esse período. Ha-Joon Chang (2003, p. 52) informa que os armadores da Nova Inglaterra conseguiram evitar leis protecionistas nos anos de 1820, 1821 e 1823, mas tais esforços foram em vão, pois entraram em vigor tarifas majorativas do imposto de importação em 1824, a "Sectional Tariff'; em 1828, a "Tariff of Abominations"; em 1832; e em 1842, a “Black Tariff'. Em contraposição, apenas a lei tarifária de 1833, promulgada diante da ameaça de secessão da Carolina do Sul, e a de 1846, a “Walker Tariff', durante o governo de um presidente democrata e sulista, do Tennessee, James Knox Polk, algo raro de acontecer, posteriormente emendada em 1857.

Por outro lado, a Prússia e o Zollverein haviam sido, desde aproximadamente 1818, extremamente liberais nas suas políticas comerciais e, a despeito da Guerra Francoprussiana de 1870, mesmo assim o Tratado Cobden-Chevalier permaneceu em vigor até 1882.

Após a unificação da Alemanha, Otto von Bismarck manteve a tradição liberal do Zollverein até 1879, quando, baseado também na pregação de Friedrich List ("Das Nationale System der Politischen Ökonomie”, de 1841), calcada na proteção à indústria nascente, visando principalmente a proteger a sua indústria de ferro e aço, inicialmente, 
passou a também implementar políticas protetivas. Em 1885 e 1888 houve novos aumentos dos encargos aduaneiros alemães, especialmente direcionados aos produtos agrícolas americanos.

Gerard Curzon, a propósito, afirma que, da mesma forma que a França, com o Tratado Cobden-Chevalier, tornou-se por uma década o motor do livre comércio no continente europeu, a Alemanha, sob Bismarck, após 1879, passou a ser o ponto nodal de um sistema protecionista que vigorou até a Primeira Guerra Mundial (1965, p. 17).

Em 1892, na França, já exauridos os efeitos do Tratado Cobden-Chevalier, houve um grande aumento da tributação sobre o comércio exterior com a chamada "Tarif Méline”, por conta de Felix-Jules Méline, Presidente do Conselho de Ministros, chefe de Estado francês à época, visando a proteger a agricultura francesa também contra a concorrência americana, o que marcou o fim do período de abertura comercial francesa.

Em meados do Século XIX, o Japão era ainda uma economia semifeudal e, em função da Revolução Meiji e pela aplicação do protecionismo, tornou-se uma potência industrial média já ao final do Século XIX, com especial projeção diante dos seus vizinhos do Extremo Oriente.

No Reino Unido, embora mantida a tradição do livre comércio unilateral, havia indícios, como a aprovação da Convenção do Açúcar (que proibia a importação de açúcar vinda da Alemanha, da Dinamarca, da Espanha e da Argentina), de 1902, e a campanha de 1903, de Joseph Chamberlain e da "Tariff Reform League", pelo incremento da proteção, inclusive pela criação de um sistema imperial de preferências aos países da Commonwealth of Nations, daquilo que Jagdish Bhagwati (1993, p. 33) menciona como "síndrome do gigante diminuído", especialmente pelo crescimento do poder econômico e concorrencial dos novos industrializados protecionistas, como Alemanha e Estados Unidos (BHAGWATI, 1993, p. 27). Em ocasiões que tais, palavras como reciprocidade e comércio justo começam a ser a tônica dos discursos políticos, e não foi diferente no panorama britânico do início do Século XX.

Como afirma Gerard Curzon (1965, p. 20), se olharmos para as principais nações às vésperas da Primeira Guerra Mundial, veremos que todas, Reino Unido, Alemanha e França, tinham, em maior ou menor grau, manifestado uma tendência a adotarem políticas mais fortemente protecionistas. De tal forma esse era o panorama prevalente à época, que Gottfried Haberler denominou o período de desintegração (PORTO, 2001, p. 210). 
Contrariamente a essa maré, o único país com tendência a liberalizar a sua política comercial foram os Estados Unidos uma vez que, em 3 de outubro de 1913, por meio do "Underwood-Simmons Act", assinado pelo Presidente Woodrow Wilson, reduziuse a alíquota média do Imposto de Importação americano de $40 \%$ para $25 \%$. Mais do que isso, foi a lei de tributação aduaneira, o Tariff Act, como denominam os americanos, mais liberal da História: quase todas as posições da tabela passaram a ser tributadas em alíquotas ad valorem; os encargos sobre tecidos de lã passaram de $56 \%$ a 18,5 \%; e sobre bens como trilhos de aço, lã crua, minério de ferro e implementos agrícolas, passaram a ter suas respectivas alíquotas zeradas. Foi também eliminada qualquer exigência de reciprocidade.

Para compensar tal brutal perda de receita, foi reinstituído o Imposto de Renda federal americano, consoante a autorização que havia sido recentemente conferida pela Décima-Sexta Emenda à Constituição, de 3 de fevereiro de 1913, na incidência que havia sido declarada inconstitucional pela Suprema Corte no julgamento do caso Pollock $v$. Farmers' Loan \& Trust Co., de 1895, à instituição pela União sem distribuição da receita pelos Estados.

Deve ser esclarecido o fato de que a primeira incidência do imposto de renda federal nos Estados Unidos em tempos de paz, por meio do Wilson-Gorman Tariff Act de 1894, visou unicamente a compensar a redução de receita tributária com o imposto de importação decorrente da redução das suas alíquotas aos patamares do McKinley Tariff Act de 1890. Não obstante, tais reduções de alíquotas do imposto de importação, que haviam sido a principal plataforma eleitoral do presidente eleito Grover Cleveland em 1892, especialmente no que tange às alíquotas zero para o minério de ferro, o carvão mineral, madeiras e lã, foram derrubadas pelos esforços protecionistas no Senado.

Não se pode esquecer que, embora os Estados Unidos, à época, até então, ainda incentivassem fortemente a sua industrialização dentro de uma política de cunho eminentemente protecionista, revelando a sua função extrafiscal, o imposto de importação, como nos ensina Adílson Pires (2001, p. 10), ainda representava importante parcela da receita tributária federal.

A declaração de guerra, logo após, em 1914, desestruturou completamente a já então intrincada rede de tratados de comércio internacional existente. Além disso, o comércio entre os países passou a ser controlado, com o fim de que não se transferisse renda para os inimigos, sem falar na redução natural diante do esforço de guerra. Gerard Curzon (1965, p. 20) informa que, em 1917, os aliados resolveram instituir um sistema supranacional de compras das principais commodities. 
Ao final da Primeira Guerra Mundial, em 1918, percebeu-se a necessidade de implantar um sistema completamente renovado de tratados de comércio internacional, muito por conta do fracionamento dos dois grandes impérios ocidentais, o alemão e o austro-húngaro. Com isso, os novos pequenos países recém-criados, como esclarece Gerard Curzon (1965, p. 21), passaram a ser muito zelosos de sua identidade cultural, com o que vieram a valorizar as suas indústrias locais e a buscar maior autonomia comercial. Sem falar na necessidade, dos países centrais, em soerguer os seus parques industriais e, porque não dizer, as suas economias como um todo, devastadas pelo longo conflito. $\mathrm{O}$ ambiente, portanto, não se verificava propício a ideias liberais em termos de comércio exterior.

Exemplo disso é a lei britânica de 1921, o “The Safeguarding of Industries $A c t$ ", que impunha um encargo de 33,3\%, ad valorem, em nove categorias de produtos fundamentais à vitória bélica, assim como criava mecanismos antidumping, em função dos baixos preços dos países de origem, cujas moedas haviam tido seu valor cambial depreciado com a crise pós-guerra, como era o caso da Alemanha da República de Weimar.

Nos Estados Unidos, por conta da pressão dos fazendeiros americanos, ainda descontentes como a "Underwood-Simmons Tariff', no mesmo ano de 1921 foi promulgada a "The Emergency Tariff', como uma medida temporária para aumentar as alíquotas de importação do trigo, do açúcar, da carne, da lã e de outros produtos agrícolas, como meio de aumentar a renda do setor diante da queda da demanda internacional.

Foi substituída, no ano seguinte, em 1922, pela "Fordney-McCumber Tariff", norma que, segundo Curzon (1965, p. 23), introduziu tão extremo grau de proteção que eliminou qualquer esperança dos países devedores das reparações de guerra em adimpli-las por meio das receitas de exportação. A norma criou dois mecanismos peculiares: a tarifa científica, que visava a equalizar os custos de produção entre os diversos países exportadores, e o preço de venda americano, que permitia ao Poder Executivo calcular o imposto com base em valor aduaneiro retirado do preço de venda do produto no mercado americano, não pelo preço da transação. Com isso, o grau de proteção efetiva do mercado americano havia voltado a níveis superiores aos de 1913.

A instabilidade política e econômica da época contribuía para as restrições dos mercados. Até 1925, informa Curzon (1965, p. 24), os tratados eram poucos e de limitada duração e a cláusula de nação mais favorecida incondicional que, antes da guerra, havia sido amplamente difundida, agora não mais era efetivamente utilizada. As diversas 
tentativas de estabilizar a ordem econômica de então, como, por exemplo, a Conferência Econômica Mundial, de 1927, no seio da Liga das Nações, em Genebra, foram infrutíferas. Essa conferência, a propósito, veio a ser convocada especificamente para recomendar aos países pertencentes à organização internacional (da qual o Brasil já havia se desfiliado) uma redução coletiva de encargos aduaneiros. Na ocasião, foi elaborada a "International Convention on the Abolition of Import and Export Prohibitions", assinada por vinte e nove Estados, mas jamais propriamente colocada em prática.

Na campanha eleitoral de 1928, Herbert Hoover, o candidato republicano, partido então tradicionalmente protecionista e que tinha sido veementemente contrário à “Underwood-Simmons Tariff', de 1913, foi enfático em manifestar seu apoio aos agricultores. Porém, uma vez iniciado o respectivo processo legislativo, ficou difícil conter o furor revisionista da pauta aduaneira no Congresso americano.

Com a derrocada generalizada de Wall Street, em 1929, a situação piorou. O setor agrícola americano foi o primeiro a sofrer com a depressão econômica, especialmente agora com a concorrência cada vez maior dos países não europeus. E, com isso, o seu poder de pressão política entrou em cena mais uma vez.

Aos agricultores se juntaram, a partir de então, os industriais, afundados em dívidas, e os trabalhadores, diante do desemprego que grassava. O produto dessa circunstância foi promulgado em junho de 1930, a "Smoot-Hawley Tariff', que elevou de $38,2 \%$ para 55,3\% o nível médio dos impostos aduaneiros cobrados pelas autoridades norte-americanas. A alíquota efetiva de mais de 3.200 produtos passou a ser maior do que $60 \%$, o quádruplo do valor anterior.

A circunstância de a "Smoot-Hawley Tariff' não se poder justificar segundo os argumentos protecionistas clássicos, procurando apenas reduzir as importações, ao lado do fato de o balanço de pagamentos norte-americano não ser, nessa época, deficitário, acentuaram em definitivo a irritação dos países terceiros, especialmente na Europa, pela instauração da nova tarifa aduaneira, manifestação de um egoísmo indigno a uma nação próspera (BHAGWATI, 2000). O aumento de $1000 \%$ dos encargos aduaneiros sobre a castanha de caju, mencionado por Pedro Mota (2005, p. 17), é plenamente elucidativo, dado que se tratava de um bem não produzido nos EUA.

Pedro Mota (2005, p. 17) também menciona comentários no sentido de que "o espetáculo de ver a principal nação credora com um excedente comercial a adotar uma pauta altamente protecionista era absurdo" (cf. Richard POMFRET, The Economics af Regional Trading Arrangements, Clarendon Press, Oxford, 1997, p. 38, apud). 
Tendo sido uma iniciativa do Senador Reed Smoot, de Utah, e do Deputado Willis C. Hawley, do Oregon, ambos republicanos, a "Smoot-Hawley Tariff' contou com a severa oposição dos democratas e foi objeto, ainda em maio de 1930, de um abaixoassinado subscrito por 1.029 economistas, entre os quais se contavam Frank Taussig, Paul Howard Douglas, Frank Graham e Irving Fisher, clamando ao Presidente para que vetasse o projeto de lei.

O resultado da sanção dessa lei foi um agravamento da depressão econômica ocorrida no ano anterior e uma autêntica corrida ao protecionismo, entendido como tal o fato de os encargos aduaneiros sofrerem aumentos em vários países, ao mesmo tempo em que muitos países passaram a recorrer a controles cambiais e a restrições quantitativas.

Para se ter uma ideia, antes mesmo de a "Smoot-Hawley Tariff' entrar em vigor, mas já em função dos debates em torno dela, o grande parceiro comercial americano, o Canadá, em maio de 1930, impôs encargos aduaneiros a 16 produtos que correspondiam a cerca de $30 \%$ das exportações dos EUA ao seu vizinho do norte.

Tal chegou ao ponto de que, em 1932, durante um mês, entre julho e agosto, representantes do Reino Unido, até então, como se viu, o grande baluarte do livre comércio, assim como dos seus domínios autônomos (principalmente Austrália, Canadá, Nova Zelândia e África do Sul) e suas colônias, terem participado de uma conferência, a Commonwealth Conference on Economic Consultation and Co-operation (ou "British Empire Economic Conference"), em Ottawa, no Canadá, criada com a finalidade de discutir os efeitos da depressão econômica nos seus países membros, ao final do qual foi celebrado um tratado que estabelecia um sistema de preferências no seio da Commonwealth of Nations (a "Imperial Preference"), criando uma Zona de Livre Comércio (a "Imperial Free-Trade Zone").

Noticia-se que houve então uma cisão no governo britânico em função do resultado da conferência, em que muitos dos seus componentes, de postura liberal, rejeitavam a iniciativa. Essa conferência entrou particularmente para a História por conta da adoção de práticas keynesianas, como a diminuição de taxas de juros, o incremento do suprimento de moeda e a expansão dos gastos públicos.

Alguns meses antes, em fevereiro de 1932, o Reino Unido havia estabelecido a sua primeira pauta aduaneira geral desde meados do século XIX (quando da revogação das “Corn Laws"), o "Import Duties Act”. Introduziu a alíquota geral de $10 \%$ para todas as importações, à exceção de gêneros alimentícios e matérias-primas. As regiões sob o domínio britânico, assim como a Índia e a Rodésia do Sul, foram isentos desse imposto até 
15 de novembro de 1932, no aguardo da implementação do sistema de preferências imperiais.

Assim também aumentaram as suas incidências na importação países como Cuba, França, Austrália, China, Índia, e Itália, apenas para citar alguns (CURZON, 1965, p. 25).

Sob a liderança do Presidente do Reichsbank, Hjalmar Schacht, a Alemanha nazista também concluiu uma série de acordos bilaterais reducionistas com países da Europa Central que, efetivamente, criaram um novo bloco regional, de modo a orientar as suas políticas comerciais em torno da Alemanha.

Na Ásia, o Império do Japão criou a "Dai-tō-a Kyōeiken", traduzida para o inglês como "Greater East Asia Co-Prosperity Sphere", estendendo a sua influência política para a China, a Mandchúria e o Sudeste Asiático, também orientando os respectivos fluxos comerciais em seu proveito.

O caráter deletério da onda protecionista que varria o mundo ocidental no período entre-guerras pode ser aferido do estudo das conseqüências nefastas desses acontecimentos que, segundo os historiadores, agravaram ainda mais a depressão econômica e concorreram para o eclodir da Segunda Guerra Mundial.

Com a redução acentuada do comércio internacional e da atividade econômica, o que se produziu foi o prejuízo à posição dos moderados em relação aos nacionalistas no Japão e a facilitação do caminho para a vitória eleitoral dos nazistas na Alemanha em 1932, já que, no período de 1929 - 1932, o valor das trocas comerciais mundiais diminuiu cerca de $50 \%$ e, entre 1929 e 1933, o PNB real dos principais países industrializados caiu $17,7 \%$, o volume de exportações $35,3 \%$ e o volume de importações 23,5 \% (MOTA, 2005).

Embora Jagdish Bhagwati (2000) entenda que a questão comercial teria sido apenas mais uma causa para a instabilidade política da época, alguns como Richard Cooper (1988, p 291 - 292) defendem que as sementes do segundo conflito mundial, no Extremo Oriente e na Europa, foram plantadas pela assinatura da "Smoot-Hawley Tariff' pelo presidente Herbert Clark Hoover, o que teria sido "o erro mais desastroso alguma vez cometido por um presidente dos Estados Unidos no âmbito das relações internacionais", o que decerto contribui para a sua fama de ter sido um dos piores presidentes da história dos Estados Unidos da América. Nas palavras de Marcelo de Paiva Abreu (2008, p. 1), alguém que concorre com George W. Bush ao título de "lame duck" mais oneroso da história. 
A 'Smoot-Hawley Tariff', hoje um símbolo dos perigos do protecionismo exacerbado, marcou o fim da linha desse tipo de políticas nos Estados Unidos, ao menos até o "Omnibus Trade and Competitiveness Act", de 1988, no governo Ronald Reagan, novamente um republicano conservador. Sua importância, não obstante, para o nosso estudo, é fundamental, pois do seu fracasso adveio uma nova postura dos Estados Unidos em procurar a liberalização comercial por meio de acordos bilaterais e, principalmente, pela construção de um sistema regulatório multilateral.

A primeira manifestação dessa nova postura foi o "Reciprocal Trade Agreements Act", de 12 de junho de 1934. Por seu intermédio, o Presidente Franklin D. Roosevelt estava autorizado, por um prazo fixo de tempo, a negociar, em bases bilaterais, concessões tarifárias com outros países em até $50 \%$, desde que houvesse reciprocidade. Incluía a autorização para aduzir a cláusula de nação mais favorecida nos tratados.

Foi uma resposta inteligente à 'Smoot-Hawley Tariff', e consistiu em uma delegação do Poder Legislativo ao Executivo americano, diante de sua incompetência em criar uma política comercial coerente e eficaz. Cabia ao Congresso Nacional apenas referendar, ou não, o ato celebrado pelo plenipotenciário do Poder Executivo.

Também trazia implicitamente em seu bojo a assunção, por parte do governo americano, da verdade de que uma liberalização comercial multi, ou ao menos plurilateral, em plena época de depressão, seria dificilmente acompanhada de apoio popular.

Por meio desse instrumento, foram negociadas concessões tarifárias com mais de vinte países, até o eclodir da Segunda Guerra Mundial, predominantemente com países da América Latina, cujos produtos não eram competitivos com os americanos, mas também com o Canadá e o Reino Unido. Com isso, já em 1938, os Estados Unidos haviam obtido concessões ou consolidações em mais da metade dos produtos que exportavam para os países, o que correspondia a mais de $30 \%$ das suas exportações totais, em valores de 1937, ao mesmo tempo em que haviam garantido aos concelebrantes redução de algo em torno de $45 \%$ dos seus encargos aduaneiros e determinado a inexistência de quaisquer restrições a $65 \%$ das importações oriundas dos países relacionadas nas listas com as quais tais tratados foram celebrados (CURZON, 1965, p. 27).

Tais acordos bilaterais alcançam também grande relevância porque foram os embriões, inclusive no que se refere à redação convencional, das cláusulas principais do GATT.

Não obstante, mesmo tendo sido realizados sob a condução da nação mais importante do mundo já à época, tais iniciativas não conseguiram reverter a tendência 
protecionista mundial que havia se consolidado após a eclosão da Primeira Guerra Mundial. Não se pode esquecer, contudo, que, mesmo mediante concessões recíprocas, as alíquotas efetivas americanas ainda continuavam muito altas.

Por trás dessa inflexão na postura americana, mais do que a subida ao poder, em 1932, de Franklin Delano Roosevelt, mais até do que a implementação de sua política com traços keynesianos, a "New Deal", alcança proeminência em realidade a assunção do cargo de Secretary of State por parte de Cordell Hull, em 1933. Como explica Gerard Curzon (1965, p. 26), nascida unicamente da concepção de Hull, a política comercial externa americana visava a recuperar o setor exportador americano por meio da política de barganhas. Mas, contrariamente ao New Deal, segundo Curzon, tencionava na verdade reduzir a intervenção estatal no comércio exterior, desfazendo o equívoco de 1930, quatro anos antes.

Embora Cordell Hull tenha recebido o Prêmio Nobel da Paz, em 1945, por seu papel na criação da Organização das Nações Unidas, a ponto de o Presidente Franklin Delano Roosevelt qualificá-lo de "Pai das Nações Unidas", deve-se concordar com a afirmação de Douglas Irwin, Petros Mavroidis e Alan Sykes (2008, p. 12) de que o seu grande objetivo de vida sempre foi o de assegurar a liberalização do comércio em nível mundial. Como um democrata e sulista (do Tennessee), tinha ancestralmente uma posição contrária ao protecionismo do norte, e foi o responsável, quase solitário, pelo reposicionamento da política comercial dos Estados Unidos, a partir de 1933. Além disso, embora tenha saído da Secretaria de Estado em novembro de 1944, por motivos de saúde, um pouco antes da morte do presidente a quem era fiel, foi a inspiração para os esforços do pós-guerra que redundaram no Acordo de Bretton Woods e, sem qualquer sombra de dúvidas, foi o mais importante responsável individual pelo que posteriormente veio a ser o GATT (IRWIN; MAVROIDIS; SYKES, 2008, p. 12).

A grande fonte de insatisfação de Cordell Hull, no entender de Douglas Irwin, Petros Mavroidis e Alan Sykes (2008, p. 10), e que foi um dos motores para as negociações que redundaram no GATT, foram as preferências imperiais, que causavam fortes impactos negativos nos negócios americanos, porque reduziam a competitividade dos produtos americanos no Reino Unido e no Canadá, os dois mais importantes mercados americanos.

Um acordo reciproco de comércio, assinado em 1938, de resultados limitados (IRWIN; MAVROIDIS, SYKES, 2008, p. 10 - 11), chegou a ser efetivado apenas por poucos meses, no ano de 1939, antes do Reino Unido entrar em guerra. 
Esses mesmos autores apresentam o seguinte gráfico (p. 182), ilustrativo dos valores relativos das exportações dos chamados "GATT Founders", Estados Unidos, Canadá e Reino Unido, entre os anos de 1919 e 1938, sendo o valor de referência (100) o correspondente ao volume exportado em 1929, data do início da crise econômica do entreguerras.

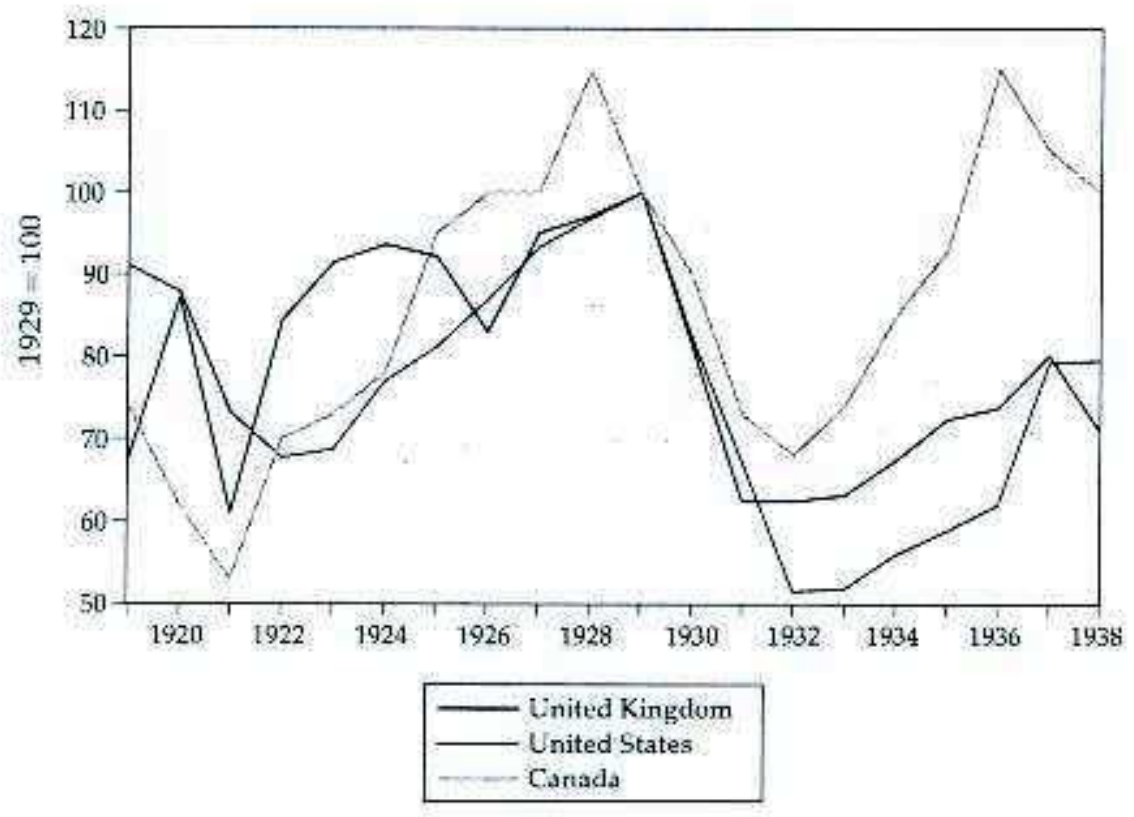

Como se percebe pelo exame das informações dele extraídas, enquanto o Canadá, já no ano de 1936, havia conseguido recompor plenamente o seu volume de exportações de antes da crise econômica, embora logo depois tenha sofrido uma queda oriunda da eclosão da Segunda Guerra Mundial, tanto os Estados Unidos quanto o Reino Unido conseguiram recuperar, no melhor dos anos seguintes, 1936, apenas algo um pouco menor do que $75 \%$ das suas vendas mundiais anteriores à depressão. Para Douglas Irwin, Petros Mavroidis e Alan Sykes (2008, p. 181), então, o fracasso dessas nações líderes em retomar o lugar de proeminência econômica, ao menos em termos de comércio internacional de bens, que possuíam antes de 1929, teria sido uma importante motivação para que fossem envidados esforços conjuntos para celebrar um acordo multilateral no comércio internacional de bens.

Embora não tenha participado diretamente das negociações do GATT propriamente, pode-se dizer que, durante os onze anos em que esteve à sua frente, Cordell Hull conferiu uma marca ao Departamento de Estado americano como ele nunca havia tido 
em sua história. Afinal de contas, foi o Secretary of State que mais tempo permaneceu à frente do Departamento, sempre com a sua forte convicção ideológica pela paz e pela liberdade de comerciar (IRWIN; MAVROIDIS, SYKES, 2008, p. 10 - 11). Além disso, a redação das disposições convencionais celebradas pelos Estados Unidos durante a sua gestão foi se aprimorando, sendo partes relevantes das cláusulas do GATT já perceptíveis nos acordos do fim da década de 30 do Século XX (IRWIN; MAVROIDIS, SYKES, 2008, p. 12).

Além disso, outra contribuição relevante para o texto do GATT, do lado britânico, foi o "Proposal for an International Commercial Union", escrito em 1942, da lavra do economista inglês James Meade, então na Seção Econômica do War Cabinet Secretariat, que foi submetido ao Board of Trade de então. Posteriormente, com o fim da guerra, Meade veio a prestar diretamente serviços ao Board of Trade, na gestão do Primeiro Ministro Clement Richard Attlee. No final de sua vida, em 1977, Meade foi agraciado com o Prêmio Nobel de Economia, por seus trabalhos na área da política comercial.

A relação direta entre tarifas aduaneiras elevadas, radicalização de posicionamentos políticos e conflitos militares levou a que, ainda durante o conflito mundial, a Carta do Atlântico, discutida entre o Primeiro Ministro britânico Winston Churchill e o Presidente norte-americano Franklin D. Roosevelt, e destinada a definir os grandes princípios em que devia assentar a organização econômica e política do Mundo depois da Guerra incluísse, no seu ponto quarto ${ }^{26}$, a intenção dos seus governos de garantir o acesso, em igualdade de condições, de todos os Estados, grandes ou pequenos, vencedores ou vencidos, ao comércio e às matérias-primas do mundo necessárias à sua prosperidade econômica.

Não se deve esquecer que um dos fatores que o conduziu à guerra foi o fato de que tanto a Alemanha como o Japão colocavam, como uma das reivindicações das suas políticas, o livre acesso às matérias-primas que os aliados lhes negaram, como resquício do período colonial do qual não se beneficiaram, em que as colônias, fornecedoras de matérias-primas, tinham o seu comércio monopolizado pela metrópole.

Também se pôde então perceber que as nações aliadas viram o equívoco dos Tratados de Versalhes de 1919, que haviam imposto a obrigação de os países vencidos

\footnotetext{
26 "Fourth, they will endeavor, with due respect for their existing obligations, to further the enjoyment by all States, great or small, victor or vanquished, of access, on equal terms, to the trade and to the raw materials of the world which are needed for their economic prosperity;"
} 
concederem, apenas unilateralmente, aos países vencedores, o tratamento de nação mais favorecida.

Os propósitos da Carta do Atlântico foram, posteriormente, ratificados pelos representantes dos 26 Estados signatários da Declaração das Nações Unidas, no dia $1^{\circ}$ de janeiro de 1942.

Foi também durante o conflito, mais precisamente em 23 de fevereiro de 1942, que se deu o segundo passo importante na definição dos objetivos econômicos a serem observados depois do final da guerra, por meio da celebração do acordo anglo-americano de auxílio mútuo (“Anglo-American Mutual Aid Agreement”), cujo art. VII previa "a eliminação de todas as formas de tratamento discriminatório no comércio internacional, a redução das tarifas aduaneiras e demais barreiras comerciais" ${ }^{27}$.

Esse preceito, repetido em todos os acordos de auxílio mútuo celebrados posteriormente pelos EUA (assim como no art. $1^{\circ}, \mathrm{n}^{\circ} .4$, da Carta de Havana e no preâmbulo do GATT de 1947), tornou-se, então, o embrião do princípio de nãodiscriminação, no entender de Gerard Curzon (1965, p. 57), “o mais importante conceito isolado a informar o GATT" e o pilar básico a caracterizar as relações econômicas mundiais no período pós-guerra.

Passou a ser um princípio multilateral e não apenas restrito aos dois países anglo-saxões, uma vez que o ponto quinto ${ }^{28}$ da Carta do Atlântico dispunha que os EUA e o Reino Unido desejavam promover, no âmbito econômico, a mais ampla colaboração entre todas as nações, a fim de se conseguir, para todos, melhores condições de trabalho, prosperidade econômica e segurança social.

27 "ARTICLE VII

In the final determination of the benefits to be provided to the United States of America by the Government of the United Kingdom in return for aid furnished under the Act of Congress of March 11, 1941, the terms and conditions thereof shall be such as not to burden commerce between the two countries, but to promote mutually advantageous economic relations between them and the betterment of world-wide economic relations. To that end, they shall include provision for agreed action by the United States of America and the United Kingdom, open to participation by all other countries of like mind, directed to the expansion, by appropriate international and domestic measures, of production, employment, and the exchange and consumption of goods, which are the material foundations of the liberty and welfare of all peoples; to the elimination of all forms of discriminatory treatment in international commerce, and to the reduction of tariffs and other trade barriers; and in general, to the attainment of all the economic objectives set forth in the Joint Declaration made on Aug. 12, 1941, by the President of the United States of America and the Prime Minister of the United Kingdom

At an early convenient date, conversations shall be begun between the two governments with a view to determining, in the light of governing economic conditions, the best means of attaining the above-stated objectives by their own agreed action and of seeking the agreed action of other like-minded governments.".

28 "Fifth, they desire to bring about the fullest collaboration between all nations in the economic field with the object of securing, for all, improved labor standards, economic advancement and social security;" 
Como afirma Robert Hudec (1975, p. 7 - 8), as discussões no período de guerra, que foram a base dos trabalhos que geraram as negociações sobre o sistema da futura Organização Internacional do Comércio e do GATT, consistiram predominantemente em questões restritas aos Estados Unidos e ao Reino Unido, com base no Artigo VII acima referido. Nelas, sempre os americanos tentando repetir as experiências com base no "Reciprocal Trade Agreements Act"; os britânicos, querendo impor o modelo convencional multilateral concebido por James Meade.

Tais propostas, segundo Robert Hudec, no mesmo trecho, mostraram-se, com as negociações posteriores, claramente complementares. John Howard Jackson e William Davey (1986, p. 294) afirmam, por seu lado, que as fraquezas da perspectiva bilateral cada vez mais se tornavam evidentes, sendo que o seu único remédio seria a extensão da avença a outros países de participação relevante no comércio internacional.

No que se refere às preocupações com a paz mundial, mesmo com a entrada dos Estados Unidos na Segunda Guerra Mundial, em 8 de dezembro de 1941, Hull, já antecipando a vitória dos aliados, iniciou planos para a criação de instrumentos multilaterais para a manutenção da segurança. Na Terceira Conferência de Ministros das Relações Exteriores, de 18 de outubro a 11 de novembro de 1943, junto com o britânico Anthony Eden e o soviético Vyacheslav Molotov, a despeito de sua já frágil saúde, assinou a "Declaration of the Four Nations on General Security", que, em sequência à "Declaration by United Nations", de $1^{\circ}$ de janeiro de 1942, foram os nascedouros da organização internacional, na medida em que tais declarações solidificaram as bases de segurança e paz sobre as quais o mundo do pós-guerra se edificaria.

Como afirma Robert Hudec (1975, p. 4), logo após a Segunda Guerra Mundial, havia um sentimento unânime de que as diversas políticas comerciais nacionais nos anos 20 e 30 do Século XX foram desastrosos erros e que se deveria evitar que tais situações novamente se repetissem, sob pena de se verem renascidas tensões potencialmente belicosas. Para Bernard Hoekman e Michel Kostecki (2001, p. 24), logo após a Segunda Guerra Mundial ainda eram muito vívidas as lembranças negativas dos efeitos das políticas to tipo "beggar-thy-neighbor",29 do período entre guerras, especialmente da década de 30.

Mas o problema, para Hudec, como também afirmava Douglas Irwin, não repousa no que tange ao entendimento teórico do problema, na medida em que sempre os

\footnotetext{
${ }^{29} \mathrm{Na}$ tradução em português, "empobrecer o vizinho" (ABREU, 2008, p. 2). Consiste na política comercial predatória de resolver os seus deficits comerciais mediante comportamentos protecionistas, em detrimento da balança comercial dos países com quem costuma comercializar.
} 
discursos políticos são férteis em proclamar as benesses do livre comércio. A questão era a da implementação prática, motivo pelo qual o período entreguerras assistiu à instalação de diversas conferências internacionais, dentro ou fora do âmbito da Liga das Nações, com o fim de dar cabo à deterioração nas relações comerciais que se via claramente aumentando no período. Como se viu acima, ainda que brevemente, o resultado prático foi nenhum, só levando ainda a um maior descrédito das organizações internacionais de então.

Prossegue Robert Hudec (1975, p. 5 - 6), nos ensinando que a primeira lição, para ele evidente, tirada da experiência histórica, foi a de que políticas comerciais baseadas nas restrições ao livre comércio e na discriminação sempre conduziriam a resultados negativos. Assim, no seu entender, as experimentações governamentais, tomadas em âmbito geral e não apenas no norteamericano, provaram que não deveriam jamais ser prevalentes às formulações teóricas da doutrina econômica.

Foi no intuito de cumprir essa missão de paz pelo comércio que, depois de várias conferências convocadas sob os auspícios do Conselho Econômico e Social das Nações Unidas, as propostas dos Estados Unidos tomaram a forma de um projeto de carta constitutiva de uma Organização Internacional do Comércio (a chamada Carta de Havana). Tal Organização, que deveria funcionar como uma instituição especializada das Nações Unidas, tinha como ambição principal organizar as relações comerciais internacionais em moldes verdadeiramente novos. Participaram da discussão sobre os seus termos um total de cinquenta e seis países.

Nesse sentido, a Carta de Havana estabelecia um verdadeiro código de conduta para o comércio internacional e abordava, pela primeira vez numa perspectiva mundial, as questões do desenvolvimento econômico (arts. $8^{\circ}$ a $15^{\circ}$ ) e das práticas comerciais restritivas (arts. $46^{\circ}$ a $54^{\circ}$ ), tencionando realizar o duplo objetivo de expansão do comércio mundial e do emprego. Para tanto, a referida organização internacional pretendia empregar o desenvolvimento da produção, do consumo e das trocas; o auxílio e estímulo ao desenvolvimento industrial, assim como ao desenvolvimento econômico em geral, especialmente em relação aos países cujo desenvolvimento industrial estava ainda no seu começo; o encorajamento do movimento internacional de capitais destinados aos investimentos produtivos; o acesso de todos os países, em condições de igualdade, aos mercados, às fontes de aprovisionamento e aos meios de produção necessários à sua prosperidade e ao seu desenvolvimento econômico; a redução dos direitos aduaneiros e outros entraves ao comércio internacional, assim como a eliminação das discriminações em matéria de comércio internacional; e a cooperação no seio da Organização Internacional do 
Comércio, com vista à solução dos problemas que interessavam ao comércio internacional nos domínios do desemprego, do desenvolvimento econômico, da política comercial, das práticas comerciais restritivas e da política dos produtos de base.

Robert Hudec (1975, p. 14) pontua que a sugerida carta claramente refletia os interesses do governo que a apresentou, o americano. Assim, as regras mais rigorosas eram justamente aquelas que a prática comercial americana não costumava contrariar. É o caso evidente da cláusula do Tratamento Nacional, que veremos mais profundamente adiante, até por conta da preocupação dos americanos com as preferências britânicas à Commonwealth. Ademais, outras normas, como a proibição das restrições quantitativas, possuíam exceções mais restritas do que tratados anteriores, como no caso, por exemplo, dos problemas com a balança de pagamentos. Por outro lado, as determinações que teriam o potencial de atingir políticas comerciais habitualmente empregadas pelos Estados Unidos, como a eliminação de subsídios à exportação e o tratamento diferenciado à agricultura, eram consideravelmente mais relaxadas.

Assim é que a sugestão de carta proibia qualquer subsídio à exportação que tornasse os preços dos produtos exportados menores que os preços praticados no mercado interno, a menos dos produtos em crônica superoferta, situação em que estaria a maioria dos produtos agrícolas americanos. Além disso, a norma proposta atribuía ao país de exportação a determinação das condições de mercado tomadas para a verificação da implementação dessas exceções.

Como informa Robert Hudec (1975, p. 15), houve forte oposição a essa disposição. Assim, o texto final da Carta de Havana acabou solucionando o caso basicamente adotando a redação sugerida pelos americanos, mas introduzindo a listagem de um conjunto de medidas consideradas subsídios a produtos primários. Os Estados Unidos, na reunião, informa, haviam feito esforços para persuadir os demais participantes que o Congresso Nacional dos EUA não aceitaria jamais outra fórmula.

O que se pode depreender desses relatos factuais é que, enquanto os governos britânico e americano concordavam com os mais básicos princípios a serem fundamentos do acordo comercial, discordavam em aspectos substantivos que afetavam a forma final do tratado, como os subsídios à exportação, acima mencionados. Por seu lado, os Estados Unidos eram francamente contrários a qualquer discriminação comercial, exigindo que o sistema de preferências imperial fosse desmantelado, ao passo que o Reino Unido tencionava principalmente a redução dos encargos americanos, ainda muito altos em função da “Smoot-Hawley Tariff', de 1930. 
Deve-se recordar, como bem aponta Andreas Lowenfeld (2008, p. 7, nota de rodapé $\mathrm{n}^{\circ}$ 6), que as preferências do Império Britânico à Commonwealth of Nations foram preservadas, embora congeladas, pelos Artigos I:2(a), I:4, XIV:5(b) e pelo Anexo A.

Enquanto não havia consenso sobre um tratado multilateral sobre comércio internacional, esses dois países concordaram com um documento que serviria como base para uma negociação posterior, e que conformaria por então apenas um arcabouço legal para a política comercial multilateral. Por outro lado, foram negociados diversos acordos bilaterais acerca de concessões tarifárias, cujos benefícios deveriam ser estendidos aos demais países por conta do tratamento geral de nação mais favorecida.

Alcançado esse consenso, enquanto o projeto de criação de uma Organização Internacional do Comércio ainda se encontrava em discussão, com poucas perspectivas de sucesso, dada as discordâncias entre os dois principais, foram convidados, inicialmente quinze e posteriormente vinte e um outros países, além daqueles dois, que na época representavam em conjunto mais de $80 \%$ do comércio mundial (IRWIN, 1995), entre eles o Brasil, na sessão de encerramento da Conferência de Londres, de setembro de 1946 (CURZON, 1965, p. 32), a participar das negociações para redução das fortes barreiras ao comércio então existentes e a dar opiniões no esboço de regramento, nas conferências seguintes.

Assim é que foram realizadas ainda discussões sobre ambos os tratados na Conferência de Nova York, de fevereiro de 1947, até se encerrarem, em 30 de outubro, durante a terceira conferência, realizada em Genebra, no Palais des Nations. Assim, como afirma Gerard Curzon, a experiência bilateral de cooperação, no período da Segunda Guerra Mundial, entre Estados Unidos e Reino Unido, havia se transformado em um sistema multilateral, embora provisório (1965, p. 33).

Com esse intuito, francamente menos pretensioso que o da Carta de Havana, destacaram do projeto de carta constitutiva o capítulo IV, referente à política comercial, que foi revisto e melhorado, tornando-se o Acordo Geral sobre Tarifas Aduaneiras e Comércio, mais conhecido pela sigla GATT, da sua sigla em inglês. Esse acordo, que tinha como objetivo essencial servir de guia ao comércio internacional até a entrada em funcionamento da Organização Internacional de Comércio, começou a vigorar provisoriamente no dia $1^{\circ}$ de janeiro de 1948.

Para viabilizar a entrada rápida em vigor desse tratado provisório, especialmente no que tange às concessões tarifárias (IRWIN; MAVROIDIS, SYKES, 2008, p. 105), Robert Hudec (1975, p. 45 - 46) pondera que o GATT (um "provisional" 
que acabou vigendo solitariamente por quase cinquenta anos e, atualizado, até hoje, mais de sessenta anos depois), tinha que eliminar problemas de ratificação por parte dos países signatários. Assim, teria que ser entendido como meramente um acordo comercial, para ser dessa forma submetido ao Congresso Nacional americano, provavelmente o local onde o tratado teria maiores problema em ser internalizado, mediante tramitação legislativa mais célere.

Fora isso, aponta Robert Hudec, dois grandes problemas tiveram de ser resolvidos para enfrentar os problemas quanto à sua viabilidade nos legislativos nacionais. O primeiro, a possibilidade de haver colisões com os ordenamentos internos, foi mitigada pela qualificação do GATT como norma transitória, o que era garantido pela vinda em anexo de um protocolo de aplicação provisória que, à exceção dos compromissos tarifários e do tratamento geral de nação mais favorecida, permitia a imposição de reservas.

O segundo tratava-se de evitar a qualificação do GATT como uma organização internacional no sentido formal, até para que não fosse vista como uma substituta disfarçada da natimorta OIC, sem falar do fato que não deveria gerar muitos gastos aos países que o assinaram. Não obstante, seria necessário um mínimo de estrutura organizacional, até para garantir minimamente a sua eficácia. Para esse problema, a solução foi conferir o poder decisório a um virtual grupo coletivo de partes contratantes, cujas decisões equivaleriam, na prática, a de um ente com personalidade jurídica de Direito Internacional. No exercício dessas funções, esse grupo se denominaria PARTES CONTRATANTES, sendo que a referência em letras maiúsculas indicaria o seu caráter de entidade coletiva.

Enquanto isso, para entrar em vigor, a adesão à Carta de Havana deveria ser ratificada, no mínimo, por 20 dos governos que assinaram a Ata Final da Conferência das Nações Unidas sobre Comércio e Emprego (art. $103^{\circ}, \mathrm{n}^{\circ} 2$, da Carta), o que nunca se verificou.

A razão disso foi que, dada a admissão, pela Carta de Havana, de práticas protecionistas, ainda que excepcionais, o que lhe dava um certo caráter contraditório (KRUEGER, 1999), o Congresso Nacional dos EUA, seus grandes mentores, recusaram a sua ratificação ${ }^{30}$. Segundo Pedro Mota, a isso se somou a limitação excessiva da sua

\footnotetext{
${ }^{30}$ São conhecidos, na história do Direito Internacional do Comércio, os episódios que caracterizaram a oposição doméstica, nos Estados Unidos, à ratificação do tratado internacional que instituía a OIC, que vieram a tornar inúteis os esforços do presidente Harry Truman em conseguir sua aprovação do Congresso Nacional americano. Havia inúmeros opositores da OIC na comunidade de negócios americana, que entendiam que a Carta de Havana ("Havana Charter for an International Trade Organization") falhava em
} 
margem de manobra em termos comerciais prevista na Carta, a imensa satisfação dos EUA com o funcionamento do GATT no início e a situação de guerra-fria que se tinha instalado, e que levou os EUA a dar primazia ao comércio com os seus aliados da Europa Ocidental.

Com a recusa dos EUA, os países mais importantes abandonaram o projeto, definitivamente posto de lado em 1951, com o que perdurou o GATT, durante 47 anos, como instrumento principal de enquadramento, de liberalização e de multilateralização do comércio internacional, o que se pode verificar do crescimento do número de suas partes contratantes, das 23 iniciais para 128 em finais de 1994.

Desde então realizaram-se oito rodadas completas de negociações comerciais multilaterais: Genebra (1947); Annecy, na França (1949); Torquay, no Reino Unido (1950 - 1951); Genebra (1956); Genebra, também conhecido por Rodada Dillon (1960 - 1961); Rodada Kennedy (1964 - 1967); Rodada Tóquio (1973 - 1979) e Rodada Uruguai (1986 1994).

A primeira rodada, realizada em Genebra e que produziu, como vimos, a assinatura do GATT, envolveu aproximadamente quarenta e cinco mil concessões tarifárias trocadas, cobrindo cerca de metade do comércio internacional na época. As duas rodadas posteriores, Annecy e Torquay, consistiram fundamentalmente em negociações quanto a acessões (na primeira, nove países aderiram ao GATT; na segunda, mais outros quatro). No entanto, no início da década de 50 do Século XX, quatro países já haviam denunciado o tratado, dos quais três haviam sido Partes Contratantes originárias (China, Líbano e Síria).

Embora a rodada de Genebra também não tenha sido tão efetiva em produzir cortes tarifários, ainda assim em meados da década de 50 a alíquota na importação média ponderada dos principais países industrializados havia alcançado a marca de redução a 15 $\%$ (HOEKMAN; KOSTECKI, 2001, p. 103).

A Rodada Dillon, assim nomeada em homenagem ao Secretário de Estado americano que a convocou, chegou a resultados modestos, embora dela tenham participado trinta e quatro países, já contando com a participação do Japão, que teve seu acesso ao sistema autorizado em 1955. Apenas quatro mil e quatrocentas concessões tarifárias foram então efetivamente trocadas.

proteger adequadamente os investimentos internacionais do país assim como não reconhecia suficientemente os interesses americanos no processo de votação da OIC. Tal foi a pressão sobre os congressistas que o presidente Truman decidiu, em 1951, não submeter a Carta da OIC, de Havana, ao Congresso para ratificação, com receio do desgaste político que poderia ser gerado de sua derrota. Como o sucesso da OIC dependia da participação dos Estados Unidos, o projeto não foi à frente. 
Na verdade, a rodada, a primeira após o Tratado de Roma e a formação da então Comunidade Econômica Europeia, pretendia evitar o protecionismo europeu e tratar da convivência do sistema multilateral com esse primeiro grande sistema regional, inclusive prevendo mecanismos compensatórios bilaterais. Porém, o resultado foi o de que, especialmente em áreas como a agrícola, a rodada não garantiu concessão tarifária alguma.

Importante é ressaltar que, até a Rodada Dillon, a técnica de negociação empregada foi a predominantemente a que a literatura (HOEKMAN; KOSTECKI, 2001, p. 125) denomina "item-a-item", que consiste em negociações bilaterais baseadas em requerimentos e ofertas.

Embora à época o sistema GATT já possuísse setenta e quatro membros, apenas quarenta e seis participaram da Rodada Kennedy, que teve como aspecto relevante a alteração da técnica de negociação, pelo emprego do corte linear de tarifas. Implica uma percentagem de redução idêntica para todos os setores econômicos, mediante um cálculo como $\mathrm{T}_{2}=\mathrm{rT}_{1}$, sendo $\mathrm{T}_{1}$ a alíquota inicial e $\mathrm{T}_{2}$ a alíquota final; $\mathrm{r}$ um coeficiente de redução entre 0 e 1 - no caso da Rodada Kennedy, de $35 \%$. Outra inovação foi o início das discussões sobre assuntos não-tarifários, acabando pela elaboração de um Código Antidumping e um acordo sobre valoração aduaneira.

Na Rodada Tóquio, já com a participação de noventa e três países, representando mais de noventa por cento do comércio mundial (HOEKMAN; KOSTECKI, 2001, p. 104), foram incluídos mais cerca de trinta e três mil itens tarifários, com o estabelecimento das respectivas consolidações, com o que a alíquota na importação média ponderada dos principais países industrializados havia sido reduzida a $6 \%$. Foi também mais efetiva na harmonização dos sistemas tarifários, pelo emprego de uma fórmula, que visava a cortar os picos tarifários de forma mais incisiva do que os vales, chamada fórmula suíça: $T_{2}=R T_{1} / R+T_{1}$, sendo $R$ um coeficiente entre 14 e 16. Na Rodada Tóquio foi também patente a ampliação do escopo do Direito Internacional do Comércio, passando a abranger áreas completamente diferenciadas dos aspectos meramente tributários, pela introdução e adoção dos acordos complementares.

Como o GATT, não obstante o êxito alcançado, apenas possuía normas fundadas precipuamente no princípio de não-discriminação, em breve começou a revelar sinais de esgotamento e de falta de capacidade para gerir as cada vez mais, complexas relações comerciais internacionais (SALVATORE, 1993). Na sessão ministerial realizada em novembro de 1982, chegou-se à constatação do fato de que estava havendo uma acentuação das tensões comerciais, especialmente em decorrência das lacunas existentes 
no sistema de então, já que importantes domínios do comércio internacional não se encontravam regulamentados, como os serviços e os ativos intangíveis, ou se encontravam à margem das regras comerciais multilaterais, como a agricultura e os têxteis, o que punha em evidência a necessidade de uma reforma profunda do sistema comercial multilateral.

Visando dar resposta a estes problemas, iniciou-se oficialmente em 20 de setembro de 1986, em Punta del Este, no Uruguai, o ciclo de negociações comerciais multilaterais mais ambicioso e complexo de todos - a Rodada do Uruguai.

Tal ciclo que ficou marcado por dois compromissos fundamentais: por um lado, cada participante nas negociações comerciais multilaterais concordou em não tomar qualquer medida no sentido de restringir ou falsear as trocas comerciais que se revelasse incompatível com as disposições do GATT ou dos instrumentos negociados no âmbito do GATT ou sob os seus auspícios, no sentido de melhorar a sua posição de negociador (a chamada cláusula standstill); por outro lado, todas as medidas que limitassem ou falseassem as trocas incompatíveis com as disposições do GATT ou dos instrumentos negociados no âmbito do GATT ou sob os seus auspícios deveriam ser progressivamente eliminadas ou tomadas conformes às ditas disposições, o mais tardar até a conclusão oficial das negociações (a chamada cláusula roll-back).

O Tratado de Marraqueche, de 15 de abril de 1994, que criou a Organização Mundial do Comércio (OMC), contém apenas 16 artigos, sem regras de direito substantivo, mas incorpora como anexos os acordos complementares resultantes da Rodada do Uruguai e incorpora o acquis do GATT, pelo que o tratado então vigente passa a ser designado de GATT de 1947, parte integrante do GATT de 1994, embora se mantenha como ato distinto. Não há sucessão, não obstante, no sentido da Convenção de Viena sobre Sucessão de Estados em Matéria de Tratados, de 23 de agosto de 1978.

Com a entrada em funcionamento, em $1^{\circ}$ de janeiro de 1995, da Organização Mundial do Comércio, o GATT de 1994 e seus acordos complementares passaram a constituir o fundamento institucional e jurídico do sistema comercial multilateral, consagrando não só os princípios que devem nortear a atividade dos governos em matéria de comércio internacional, de cunho evidentemente liberal, mas também o quadro institucional ao abrigo do qual as relações comerciais entre os países devem evoluir.

A Rodada do Uruguai representou uma mudança significativa na natureza e na estrutura do sistema comercial multilateral. Por comparação com o GATT de 1947, o qual não abarcava todos os setores do comércio internacional nem todas as restrições passíveis de dificultar as trocas entre os países, o alcance material do sistema comercial multilateral 
passa a ser, com a entrada em funcionamento da OMC, consideravelmente mais amplo, trazendo de volta ao sistema setores antes marginalizados, como a agricultura, os têxteis e o vestuário, incluindo regulamentações obrigatórias para todos os membros em domínios como os obstáculos técnicos ao comércio, as medidas antidumping, as subvenções e as medidas de compensação, as medidas de salvaguarda, as regras de origem, etc., e estendendo as regras e disciplinas do sistema comercial multilateral aos serviços e direitos de propriedade intelectual relacionados com o comércio, matérias nunca antes sujeitas às regras do GATT de 1947.

Malgrado todo o arcabouço multilateral, material e institucional, para harmonização do sistema internacional de comércio, os países permanecem com sua soberania para conceberem o que se costuma mencionar como a sua política comercial, embora consideravelmente reduzidos, especialmente desde a Rodada Uruguai (BARRAL, 2002, p. 26).

Política Comercial pode ser entendida como o conjunto de intervenções governamentais, a alterar o fluxo internacional de mercadorias, que um Estado soberano pode lançar mão na medida em que em entenda que seja necessário para alcançar algum objetivo doméstico (SALVATORE, 1993, p. 4).

O problema é identificar realmente qual objetivo doméstico seja esse. Para Paul Krugman e Maurice Obstfeld (2004, p. 6), a política comercial ótima é aquela que maximize o bem-estar de sua população, área de estudo complexa e autônoma na Economia Internacional moderna. Por outro lado, há duas maneiras de tratar a política comercial, assim como qualquer outra política governamental: buscando-se a política comercial ótima ou, dados determinados objetivos, avaliar o que o governo deveria fazer para alcançá-los. Assim, os efeitos do comércio sobre a distribuição de renda são cruciais no primeiro caso e apenas importantes na segunda forma de tratar o tema.

É, pois, o que diferencia uma teoria normativa, baseada no bem-estar, da teoria positiva da política comercial, (GANDOLFO, 1998, p. 147), a segunda unicamente preocupada em examinar os vários efeitos, nos padrões de consumo e na alocação de recursos, decorrentes da incidência dos tributos e encargos na importação e das outras medidas de intervenção no comércio.

Assim é que, na maioria dos casos, a política comercial acaba se convertendo no conjunto de diversos instrumentos de intervenção pública sobre o comércio exterior, com o objetivo de favorecer o produtor nacional frente aos concorrentes estrangeiros. Esse processo é denominado proteção e, embora predominantemente vise a reduzir importações, 
pode incluir também mecanismos de promoção às exportações (CARVALHO; SILVA, 2004). Nessa mesma esteira, podemos afinal definir protecionismo por empréstimo das palavras de Welber Barral (2002, p. 14), como sendo "a utilização de medidas visando à modificação de um fluxo comercial, geralmente buscando favorecer produtores nacionais".

O principal instrumento de política comercial são as, como denominadas pelos economistas, barreiras tarifárias; ou melhor, encargos aduaneiros. Consiste, fundamentalmente, no imposto de importação incidente sobre uma mercadoria, cujo fato gerador será a transposição das fronteiras de um país e cujas alíquotas podem ser ad valorem, como uma percentagem do valor tributável definido em lei ou em tratado internacional; específicas, como um valor fixo por unidade de medida; ou mistas, aquelas que são a combinação das duas. Assim também reza a disciplina brasileira, no artigo 24 do Código Tributário Nacional.

Bernard Hoekman e Michel Kostecki (2001, p. 147), ao comentarem as modalidades de alíquotas do imposto de importação, afirmam que o GATT não dá preferência a nenhum dos tipos, sendo que os membros da OMC podem passar de uma para outra, como desejarem, desde que isso não implique infringência aos compromissos tarifários.

Relacionando as vantagens de cada uma delas, esclarecem que as ad valorem são mais transparentes e, por serem indexadas, são variáveis com a inflação e com a alteração da taxa de câmbio, não demandando ajustes legislativos para isso. As específicas possuem a vantagem de não demandarem às autoridades alfandegárias a determinação do valor tributável da operação, no caso de alguma desconfiança em relação ao declarado. Também não variam com eventuais flutuações pontuais nos preços (2001, p. 147).

Mas no conceito de encargos aduaneiros não se inclui apenas o imposto de importação, já que também assim se consideram outros gravames a onerarem as importações, como taxas e preços públicos, e até preços privados, que podem ser exigidos para a conclusão do despacho aduaneiro de exportação. Tal assunto será abordado com maior atenção posteriormente, quando se estudar o espectro de aplicação do Princípio de Não-discriminação, particularmente o Tratamento Nacional, em contraste com o Princípio da Proteção Aduaneira Exclusiva: mais especificamente, a quais tributos internos (não se estará abordando, por óbvio, o Imposto de Importação) aplicam-se os Artigos II e III do GATT, de forma mutuamente exclusiva.

A propósito, dessa discussão se estabelece a distinção entre o que sejam, no linguajar dos economistas, as tarifas, as paratarifas e os tributos indiretos (HOEKMAN; 
KOSTECKI, 2001, p. 147). Em resumo, como veremos extensamente adiante, sob a denominação de "Tarifas" podem ser relacionados o imposto de importação e os encargos aduaneiros em geral, aos quais se aplica o Princípio da Proteção Aduaneira Exclusiva.

"Paratarifas" são os ajustes fiscais de fronteira, as incidências compensatórias dos tributos indiretos internos, tanto dos gerais e universais - ou melhor, das sintéticas - do tipo imposto geral sobre o consumo, cujo melhor exemplo é Imposto sobre o Valor Agregado (IVA) europeu, quanto dos seletivos, do tipo excise tax - impostos indiretos seletivos ou analíticos ${ }^{31}$, objeto do Princípio de Não-discriminação. "Tributos indiretos" é, por exclusão, a denominação genérica para as demais incidências que oneram apenas as operações internas.

A tarifa, ou melhor, o imposto de importação, é uma das formas mais antigas de tributação e, no passado, era utilizada como importante fonte de receita de governos. Ainda hoje, em muitos países menos desenvolvidos, representa parcela expressiva da receita pública - como é o caso, por exemplo, de Belize, Guiné ou Lesoto, nações nas quais cerca de metade das receitas do governo corresponde a tributos sobre o comércio (CARVALHO; SILVA, 2004).

Essa participação elevada se deve, em grande parte, à maior facilidade de arrecadação relativamente a outras formas de tributação, pois, para arrecadar esse imposto, basta controlar os ingressos de mercadoria nos portos e fronteiras, em regra em poucas localidades do país, enquanto a tributação da renda ou a do consumo, por exemplo, exigem um aparato burocrático expressivo, inclusive mediante recursos tecnológicos.

O imposto de importação, no entender de Bernard Hoekman e Michel Kostecki (2001, p. 147) e de Giancarlo Gandolfo (1998, p. 147), é o principal objeto de proteção autorizado pelo GATT. Nisso que, fundamentalmente, consiste o Princípio da Proteção Aduaneira Exclusiva.

Para os países com participação expressiva no comércio, o principal objetivo dos encargos aduaneiros é o de, na teoria, realizar um controle sobre o comércio exterior e, subsidiariamente, embora indevidamente, na prática oferecer alguma vantagem ao produtor doméstico frente à concorrência estrangeira. Tem sido essa a lição que a História nos ensina, como ilustrados pelos exemplos históricos do capítulo anterior e que Ha-Joon

\footnotetext{
${ }^{31}$ A propósito, como fim de se entender no que consiste a modalidade tributária excise taxation, ou tributo indireto analítico, e quais seus pressupostos econômicos e tributários, especialmente distinguindo-a da tributação sintética, do tipo imposto geral sobre o consumo, como o IVA, conferir a minha dissertação de mestrado, "Tributação Indireta Analítica na União Européia e nos Países do MERCOSUL - Harmonização Positiva e Negativa”, Rio de Janeiro: Universidade do Estado do Rio de Janeiro, 2003.
} 
Chang, no seu livro "Chutando a Escada" (2003), explica perfeitamente, por meio da menção a diversos outros fenômenos históricos que detidamente examina.

Relata, por exemplo, a evolução que se deu com a indústria indiana de algodão, que tantos problemas criou à então prevalente indústria de lã na Inglaterra do final do Século XVII, e de como foi completamente dizimada em 1813, com o fim do monopólio comercial da Companhia das Índias Ocidentais, quando a Grã-Bretanha passou a ser uma produtora industrial de algodão mais eficiente do que a Índia. Ilustra a situação de que, duas gerações depois, em 1873, já se estimava que $40 \%$ a $50 \%$ da exportação têxtil de algodão britânica se destinava à gigantesca nação asiática (2003, p. 45).

$\mathrm{Na}$ verdade, qualquer que seja o objetivo da política tarifária, sua adoção provoca várias alterações na economia. Sob a perspectiva de um país pequeno, ou seja, aquele que não possui participação relevante no comércio internacional a ponto de influir nos preços internacionais, a Microeconomia demonstra que haverá perda de bem-estar para o conjunto da sociedade, pois o excesso de despesas do consumidor supera a soma das receitas adicionais do governo e do produtor (KRUGMAN; OBSTFELD, 2004).

Além disso, há também as barreiras que são fiscais, mas não relacionadas aos impostos de importação do produto em exame propriamente dito - as conhecidas medidas paratarifárias, já mencionadas. Segundo Giancarlo Gandolfo (1998, p. 174), caracterizamse por meio de manipulação dos ajustes fiscais de fronteira, os tributos indiretos que visam à equalização da carga tributária consolidada entre o produto nacional e o importado, de modo a que, em lugar de limitar-se aos estritos montantes rigorosamente aptos a proceder a essa compensação, sobrepujá-los de modo a consistirem em encargo aduaneiro disfarçado. É exatamente em direção a essas incidências que o GATT reserva a disciplina do Tratamento Nacional, como se verá.

A modalidade positiva, ativa, de protecionismo é a concessão de subsídios, conhecidos como tais, de acordo com o art. XVI do GATT/47, toda forma de manutenção de preço pelo Governo com o objetivo de estimular exportações ou reduzir importações. Podem ser condições de crédito mais favoráveis, cobertura de seguro de certos riscos pagas pelo governo, atividades promocionais organizadas por agências públicas, entre outras formas.

Entre todas essas possibilidades, o Acordo Geral só disciplina quatro métodos de restrições às importações: os encargos aduaneiros, as quotas, os subsídios e os monopólios estatais. Segundo John Howard Jackson e William Davey (1986, p. 366), tal se deve ao fato de que essas eram as técnicas conhecidas à época em que o GATT foi 
concebido. Com a Rodada Uruguai, outras modalidades foram previstas, tais como as compras governamentais, mas ainda não se disciplina todo o vasto cabedal protecionista à disposição dos países soberanos.

De tudo isso, o que importa é perceber que o sistema multilateral, sob os auspícios do Acordo Geral sobre Tarifas e Comércio (GATT) e aprimorado pela Rodada Uruguai, como mencionado, retirou indubitavelmente graus de liberdade da política comercial das partes contratantes. No entanto, por diversos motivos, alguns de elaboração jurídica superior aos objetivos desse texto, outros mais evidentes, como o fato de alguns compromissos terem sido determinados apenas em caráter plurilateral e não multilateral, o fato é que um número bastante significativo desses mecanismos descritos nesse capítulo não é coibido ou nem sequer restringido pelo GATT/47 ou pelo GATT/94, ainda que sejam claramente discriminatórios. É dessas lacunas de normatização que os governos nacionais se utilizam para defender os interesses protecionistas de setores específicos de suas economias, sujeitos que são democraticamente a toda sorte de pressões, legítimas ou ilegítimas.

Como se vê, nos dias de hoje, principalmente após a Rodada Uruguai do GATT (1986 - 1993), o liberalismo tem mostrado a sua força, com reduções e eliminações das barreiras ao comércio internacional. No entanto, o protecionismo tem retornado, especialmente após a década de 70 do século passado.

Como vimos anteriormente, sempre existiram justificativas técnicas para a definição de políticas protecionistas, algumas das quais reconhecidamente válidas pelo sistema multilateral de comércio internacional, como a proteção à indústria nascente (criação de salvaguardas), a promoção da segurança nacional, a preservação ambiental e a coibição da deslealdade comercial (imposição de medidas anti-dumping e compensatórias de subsídios).

Outros motivos tradicionalmente invocados pelos países ao adotarem o protecionismo, como o déficit no Balanço de Pagamentos, altas taxas de desemprego, o estímulo à substituição de importações e o diferencial de salários (dito dumping social), por sua vez, não são considerados argumentos juridicamente válidos para assegurar a consecução de políticas discriminatórias.

Por isso que autores modernos como Giancarlo Gandolfo (1998), Jagdish Bhagwati (2000), Dominick Salvatore (1993) e W. Max Corden (1993) hoje falam em novo protecionismo, situação em que as barreiras protecionistas são preponderantemente não-tarifárias ou paratarifárias. 
Segundo Reinaldo Gonçalves (2003, p. 101), "há uma distância significativa entre a retórica de livre comércio e a realidade do protecionismo praticado pelos países desenvolvidos". Sem deixar de reconhecer a extraordinária redução média das tarifas nos países desenvolvidos, afirma que tais Estados se utilizam de uma bateria expressiva de medidas comerciais restritivas - trata-se de uma correlação inversa, já que, na medida em que decrescem as barreiras tarifárias, aumentam as não-tarifárias (BARRAL, 2002, p. 16).

O que se refere Reinaldo Gonçalves é a distância entre o "discurso liberal do sistema multilateral de comércio" e sua "consubstanciação jurídica", a que refere Welber Barral (2002, p. 15) como o exercício de "uma grande dose de hipocrisia (o que já se denominou Keynes at home and Smith abroad)".

Sem querer entrar em pormenores acerca de que mecanismos consistem o chamado novo protecionismo, é de se dar relevância à menção de Reinaldo Gonçalves (2005, p. 102) aos chamados picos tarifários, um conjunto selecionado de produtos sobre os quais, deliberada e estrategicamente, incidem tarifas muito elevadas, sem, no entanto, infringirem as concessões tarifárias nos parâmetros médios.

Também ilustra com as tarifas específicas, as que não incidem sobre o valor do produto e sim sobre a quantidade importada, o que permite um mascaramento maior da carga tarifária. Ao final, menciona "uma gama extraordinária de medidas não-tarifárias” (p. 102), acompanhando o grau de institucionalidade do comércio exterior dos países desenvolvidos, como, por exemplo, "medidas para-tarifárias ou de natureza fiscal (tarifas associadas a cotas ou cotas tarifárias, tarifas sazonais, direitos compensatórios e direitos antidumping); autorizações (automáticas e não-automáticas), controle de preços (preço mínimo, preço de referência, investigações antidumping e anti-subsídios), restrições quantitativas (cotas, proibição total, acordos voluntários de controle das exportações) e outras medidas (medidas fitossanitárias, normas técnicas, compras governamentais, normas trabalhistas, medidas ambientais)".

Adicione-se a isso aquela que é a questão que constitui o cerne de um presente mal-estar diante do arcabouço normativo e jurisprudencial do sistema multilateral de regulação do comércio internacional - a avaliação efetiva e não nominal do grau de proteção tarifária -, que já foi alvo de insurgência específica dos países em desenvolvimento quando das negociações da Rodada Tóquio (GATT, 1979, p. 164 - 165), com vistas a criticar o método linear de redução tarifária empregado na Rodada Kennedy.

Trata-se de questão que, como veremos, acarreta efeitos deletérios na verticalização da produção, mas, no entanto, tem sido também esquecida pelos 
especialistas na matéria, à exceção da obra de John Howard Jackson (2000, p. 321) e de Michael J. Trebilcock e Robert Howse (2005, p. 481).

Nessa obra, Michael J. Trebilcock e Robert Howse (2005, p. 481) expressamente afirmam que todo esse arcabouço do sistema GATT/OMC não parece responder adequadamente à justa preocupação dos países em desenvolvimento com o fenômeno do escalonamento tarifário, que produz como efeito perverso a inviabilização da produção e exportação, em condições competitivas mundialmente, por parte dos países não desenvolvidos, de produtos com substantivo valor agregado, desestimulando ou dificultando qualquer esforço na elaboração de políticas públicas na área comercial no sentido de distribuir renda pelo comércio, seja por parte dos países em desenvolvimento, seja por iniciativa de órgãos internacionais ou multilaterais.

Na doutrina brasileira, Welber Barral (2002, p. 37) é autor isolado em apontar o escalonamento tarifário como meio do que entende ser um protecionismo seletivo, aquele que, mais bem elaborado pelos países desenvolvidos, visa a "selecionar o impacto das medidas adotadas sobre mercados específicos”. É tratado o escalonamento tarifário, embora sem empregar essa denominação, como "as regras de política comercial que dificultam a importação de produtos elaborados", buscando a "forçar os parceiros comerciais a exportar apenas produtos primários, a fim de que as atividades de transformação, de maior valor agregado, possam ser realizadas no território do Estado importador". Apenas em texto de 2006 esse autor emprega o termo "escalada tarifária" (p. 32).

Como muito bem elabora Welber Barral nesse trecho (2002, p. 37), o que se tem visto é que o mero conhecimento das normas multilaterais de regulação do comércio internacional tem se consistido em um "mecanismo de poder", não só, como é tradicional, na negociação em defesa dos interesses nacionais, como também, e cada vez mais, por meio da "utilização ótima" do conhecimento sobre tais normas, a explicar o aparecimento dessas formas disfarçadas (e impunes) de infringência dos princípios do sistema.

Falando em conhecimento técnico elaborado a respeito de meios evoluídos de prover protecionismo tributário, há que se apontar a obra do economista canadense Harry Johnson no esforço de reescrever a história do comércio internacional sem o viés dos países preponderantes.

Nela, Harry Johnson formula pela primeira vez, em artigo denominado "The Theory of Tariff Structure with Special Reference to World Trade and Development", a ideia que consistiu na gênese da Teoria da Estrutura Tarifária. 
Adveio do reconhecimento de que uma sociedade industrial é um complexo de atividades ou processos econômicos cada um dos quais empregando como insumos produtos de outros processos e produzindo saídas que, por sua vez, em parte também servem como entradas de outros processos. Assim, a partir da constatação que as tarifas (impostos de importação) presentes em uma determinada estrutura tributária possuem o condão de influenciar na alocação, nacional e internacional, de atividades produtivas, verificou-se a necessidade de estabelecer qualitativa e quantitativamente o valor e a natureza dos subsídios e dos ônus implícitos, na estrutura tributária, a imporem efeitos nas diversas atividades econômicas - ou melhor, no valor agregado por elas (JOHNSON, 1969, p. 120). Trata-se de uma desconstrução da pressuposição da teoria formal das tarifas, assim como de toda a base da teoria do comércio internacional de então, de que os produtos sendo comerciados internacionalmente são todos produtos finais (JOHNSON, 1965, p. 9).

Assim, superou-se a limitação inicial, de que todos os estágios de produção dos bens estivessem sido realizados domesticamente, restringindo a competição entre produtos nacionais e estrangeiros ao produto final. Pressupondo o comércio internacional de produtos intermediários, passa a ser relevante a determinação não da proteção nominal representada pela alíquota tarifária, ad valorem ou específica, aplicada ao produto final, mas a extensão da efetiva proteção representada pelo aumento percentual do valor adicionado unitário em determinada atividade econômica, resultante da estrutura tarifária vigente (CORDEN, 1966, p. 222). Tal relevância é de tal magnitude, que, segundo Bela Balassa (1971, p. 247), quatro quintos do comércio internacional de então se referiam a maquinarias, formação bruta de capital fixo, fluxo comercial que estaria à margem dos cálculos nominais, meramente voltados ao consumidor final.

A essa visão mais amplificada, consubstanciada em uma abordagem mais moderna e rigorosa do problema do impacto de uma política comercial e tributária no comércio internacional, tanto do ponto de vista teórico quanto das ferramentas quantitativas, convencionou-se conceituar como proteção efetiva, proteção implícita ou proteção do valor adicionado (JOHNSON, 1965, p. 10 e 1969, p. 119) - o que implica a visão do efeito protetivo da estrutura tributária como um todo sobre o processo de produção e não sobre o produto (JOHNSON, 1965, p. 10).

A Teoria da Estrutura Tarifária leva em conta, portanto, a consideração que as tabelas de incidência do imposto de importação (e dos ajustes fiscais de fronteira, por extensão) nos diversos países diferenciam os produtos entre si não só em função de suas 
classificações fiscais, mas também de acordo com sua natureza (se produtos primários, semi-acabados ou manufaturados; bens de capital, de consumo ou produtos intermediários; combustíveis, entre outros, assim como se possuem similar ou bem substituto nacional ou não) e com o estágio dentro do processo produtivo em que inserem ao entrar no país tributante.

O problema analítico na formulação inicial de Harry Johnson podia ser equacionado da seguinte forma: dado um sistema de entrada e saída de mercadorias e uma estrutura tarifária $\mathrm{t}_{\mathrm{j}}$, consistindo de alíquotas incidentes sobre a importação de cada mercadoria $\mathrm{j}$, para achar $\tau_{\mathrm{j}}$, o conjunto de coeficientes de proteção do valor adicionado na produção da mercadoria $\mathrm{j}$ determinado pela estrutura tarifária $t_{j}$, os $\tau_{j}, j=1 \ldots n$, serão definidos como as máximas proporções para as quais a estrutura tarifária em questão permite que os valores domésticos dos fatores usados no j-ésimo processo de produção excedam os seus respectivos valores a preços internacionais de mercado.

Com isso, haveria uma divergência entre os coeficientes nominais e efetivos de proteção de cada mercadoria da tabela de incidência, que seria consequência do fato de que uma estrutura tarifária nacional (uma tabela de incidência do imposto de importação) simultaneamente representa um favorecimento à produção doméstica dos bens sobre os quais ela incide e uma oneração da produção doméstica dos outros bens que empregam aqueles bens protegidos como seus insumos.

Esse duplo papel da incidência do imposto de importação é modernamente reconhecido, para o fim de alcançar a desoneração como objetivo do ajuste fiscal, pelo regime de destino, por institutos como o drawback ou os regimes de crédito presumido de impostos sobre os produtos destinados à exportação, em se tratando de impostos que não se submetem à técnica da não-cumulatividade, ou pelo próprio direito ao crédito do imposto de importação pago quando do desembaraço aduaneiro, no caso dos ajustes fiscais de fronteira de natureza não cumulativa. São procedimentos previstos nos Anexos Específicos da "International Convention on the simplification and harmonization of Customs procedures" (chamada Convenção de Kioto, entrada em vigor em 1974, revisada em 2000 e não assinada pelo Brasil, no âmbito do Conselho de Cooperação Aduaneira, a partir de 1986 denominado Organização Mundial das Alfândegas - OMA, ou WCO, de World Customs Organization).

Nesse ponto, Harry Johnson introduz o que é o ponto principal a ser avaliado em qualquer análise a respeito do efeito protetivo da incidência tributária (não apenas do imposto de importação, embora ainda, nessa fase, estivesse se referindo apenas à estrutura 
tarifária): a incidência na importação (e, por extensão, o ajuste fiscal de fronteira como um todo) pode e deve ser "compensatória", mas jamais "protetiva", no sentido que deve se propor a compensar a desvantagem competitiva decorrente de sua própria incidência sobre os insumos empregados, sem, no entanto, proporcionar o surgimento de uma nova vantagem competitiva ao produto final nacional (JOHNSON, 1965, p. 14).

Assim é que uma típica estrutura tarifária de um país desenvolvido, do capitalismo industrial avançado, como produto, ensina Johnson, dos mecanismos de negociação e barganha próprios da era GATT, comumente reconhecida como moderna ou racional, estabelece um escalonamento ou cascateamento ${ }^{32}$ das alíquotas do imposto de importação desde zero ou muito baixas, para matérias-primas e combustíveis; intermediárias para semi-manufaturados; e altas para produtos finais, exibindo exemplos concretos dessa realidade em tabela (JOHNSON, 1965, p. 17).

Apontando quem discorde e veja argumentos que justificam licitamente tal tendência, como é o caso de Clarence Barber ${ }^{33}$, Harry Johnson sugere que o objetivo da adoção de tal estrutura tarifária é apenas, basicamente, o de burlar o sistema multilateral de comércio e proporcionar proteção à indústria doméstica dos países dominantes, gerando importantes e deletérias implicações nos padrões de comércio internacional e desenvolvimento, na medida em que traz ao comércio internacional um viés a facilitar a troca de matérias-primas e combustíveis; de bens de capital e não de consumo, entre outros, realidade ainda mais evidente se associada a mecanismos presentes nos países desenvolvidos de proteção da agricultura e da produção primária doméstica com o fim de evitar a redução da renda desses produtores nacionais (1965, p. 18 - 21).

Assim é que Harry Johnson aponta que a própria então Comunidade Econômica Europeia revelou, em 1963, que o objetivo da Rodada Kennedy de discussões, no seio do GATT, era o de harmonizar os sistemas tarifários (as tabelas de incidência do imposto de importação) dos países industrializados de modo a todos contemplarem esse mecanismo de escalonamento (1965, p. 17 - 18).

Com a adoção dessa sistemática nas estruturas tarifárias dos países mais ricos, criam-se sérias barreiras ao desenvolvimento dos países mais pobres, que poderiam se beneficiar das vantagens comparativas decorrentes dos custos relativos menores no que se refere à mão-de-obra; Com isso, acabam por confinarem-se às vantagens comparativas

\footnotetext{
${ }^{32}$ Escalation or "cascading", no original em inglês.

${ }^{33}$ Em "Canadian Tariff Policy". Canadian Journal of Economics and Political Science. Montreal: WileyBlackwell. Vol. XXI, nº 4, novembro 1955, p. 513 - 530.
} 
oriundas da exploração dos seus recursos naturais. Harry Johnson chega a manifestar o seu espanto como os países subdesenvolvidos deixam-se levar por um mecanismo de barganha reiteradamente explorado pelos países desenvolvidos, e que se caracteriza pela negociação de reduções de alíquotas do imposto de importação incidente sobre matérias-primas e produtos semi-elaborados, meio pelo qual se está, na verdade, aumentando o grau de proteção de sua estrutura tarifária ao passo que se dá a falsa impressão de estar reduzindo as suas barreiras tarifárias (1965, p. 15).

Tal realidade, o que é pior, fica escamoteada pela ingênua forma, nominalista, de calcular o grau de proteção médio de uma estrutura tarifária, como empregada nas negociações internacionais, por meio de uma média ponderada das alíquotas considerando ou os volumes importados ou os valores faturados das importações.

Ao invés de prestarem atenção a esses mecanismos protecionistas ocultos, Johnson levanta o paradoxo de que os países subdesenvolvidos ficam, nas negociações internacionais, sempre se restringindo a preocupações quanto ao nível e à variabilidade dos preços dos seus produtos primários e à pesquisa de mecanismos para estabilizá-los ou elevá-los (1965, p. 21). Não foi outra a realidade que moveu os países não-alinhados na construção do movimento que veio a culminar com a criação da UNCTAD.

Como consequência, acaba-se não podendo usufruir das vantagens comparativas decorrentes, por exemplo, dos custos de mão-de-obra reduzidos, o que, em uma situação de concorrência perfeita, dado o aumento do mercado em potencial, levaria a um aumento da renda nos países em desenvolvimento e, em consequência, a uma situação de estabilidade futura decorrente dos incrementos da massa salarial naqueles países.

Embora Harry Johnson, em seus trabalhos, tenha se preocupado fundamentalmente com a análise qualitativa dessa realidade, deixando, tanto a formulação matemática mais rigorosa quanto a posterior simulação quantitativa em casos concretos, para teóricos como Bela Balassa e William Max Corden, é salutar trazer o exemplo numérico básico que traz como ilustrador dessa realidade (1965, p. 21 - 22).

Suponhamos que países industrializados permitam a livre entrada de uma certa matéria-prima, mas imponham ao produto que a empregue como insumo uma alíquota de 10 por cento na sua importação. Para poder competir com esse produto no mercado do país industrializado, o país não-industrializado que a exporta deve poder produzi-lo a um custo, após o cômputo das despesas de transporte para o mercado do país industrializado, de $90,90 \%$ do preço naquele mercado $(1,0 / 1,1)$. 
Pressupondo que o custo dessa matéria-prima seja o equivalente a 75 por cento do valor agregado total do produto que a emprega em seu processo produtivo, tanto nas industrializações efetivadas nos países industrializados quando nas nos nãoindustrializados, assim, o custo de sua industrialização, que pode ser de $25 \%$ (100 - 75) nos países industrializados, passa a poder ser, no máximo, de aproximadamente $16 \%$ (90,90 - 75), nos países não-industrializados, para ainda assim assegurar o seu preço competitivo. Em outras palavras, o custo do valor adicionado (decorrente do processo produtivo) pode ser mais de $50 \%$ maior no país industrializado (de $16 \%$ para $25 \%$ ), ou, de outra forma, o custo do valor adicionado deve ser pelo menos um terço menor (de $25 \%$ para $16 \%$ ) no país não-industrializado, para sobrepujar essa incidência de $10 \%$ no preço final do produto manufaturado.

Estendendo esse raciocínio, se decompusermos esse custo do valor adicionado em custos de mão-de-obra e encargos de capital, diante da constatação de que o capital possui presumivelmente mobilidade infinita, resta apenas ao país não-industrializado concentrar as suas vantagens comparativas, em se tratando de processos industriais, nos menores custos laborais. Se estabelecermos entre mão-de-obra e capital a proporção de metade para cada um dos custos de industrialização, do valor adicionado no processo produtivo do país industrializado, portanto, país de origem do capital, teremos custos de capital de 12,5 \% do preço final. Assim, para justificar a produção no país nãoindustrializado, os custos da mão-de-obra deverão ser no máximo de 3,5 \% (16 \% - 12,5 $\%)$ do preço final no mercado do país industrializado. Dessa forma, prova-se que uma alíquota de imposto de importação de $10 \%$ no país industrial acarreta um necessário achatamento da renda salarial no país exportador, não-industrializado, que monta a, no mínimo, $70 \%(100 \%-(3,5 \% / 12,5 \%))$ dos custos laborais no país de recebimento do produto manufaturado. Vale dizer, necessariamente os custos laborais dos países nãoindustrializados têm que ser $70 \%$ menores do que os dos países industrializados, para que possam concorrem em igualdade de condições!

Assim, em conclusão do seu estudo, as estruturas tarifárias escalonadas, como as define Harry Johnson, possuem um inequívoco potencial inibidor do desenvolvimento econômico e da transferência de renda para os países subdesenvolvidos, realidade que se torna ainda mais evidente no caso de produtos industrializados que necessitam de mercados globalizados para alcançarem economias de escala (1965, p. 23).

A questão do escalonamento tarifário veio apenas pontualmente sendo retomado nos estudos econômicos desde então, e ainda mais raramente nas obras jurídicas 
sobre o Direito Internacional do Comércio. Os autores modernos que mais bem tocam no assunto são Bernard Hoekman e Michel Kostecki (2001, p. 152 - 154), em obra que toca especificamente na análise do sistema multilateral de regulação do comércio exterior do ponto de vista da Economia Política.

Afirmam, apoiando a formulação de Harry Johnson, que o escalonamento tarifário tem se consistido tradicionalmente em um problema para os países que pretendem se desenvolver, por meio da tentativa de processar suas commodities antes de exportá-las, gerando valor adicionado no próprio local, situação que afirma ser mais grave no que se refere a produtos baseados em recursos naturais, como metais e minerais não-ferrosos, produtos florestais e pescados e seus derivados (2001, p. 152). Nessa perspectiva, embora reconheçam que o fenômeno tem se reduzido atualmente, asseveram que os esforços específicos nesse sentido, como o estabelecimento de um grupo de negociação a respeito na Rodada Uruguai, acabaram sendo sobrepujados pelo resultado decorrente da redução generalizada dos níveis tarifários nos diferentes estágios produtivos, o que reduziu as diferenças relativas $(2001$, p. 151 - 152). Não obstante, afirmam ser prática presente na maioria das estruturas tarifárias atuais, à exceção de países que se caracterizam pela ausência da imposição de encargos aduaneiros, como Hong-Kong e Estônia, e outros que implementaram tarifação uniforme (como a Bolívia de então, o Chile e a República do Quirguistão).

Defendem, em consequência, que há diversos argumentos econômicos favoráveis à aplicação de uma tarifa uniforme e baixa, como a igualdade de tratamento entre os setores produtivos; desestímulo a pressões por favorecimentos específicos, evitando lobbies, corrupção, gastos sociais e dispersão por meio de programas isentivos setoriais; redução dos custos de cumprimento pela desnecessidade, ao menos do ponto de vista eminentemente tributário, de rigor quanto à classificação fiscal das mercadorias; sem falar nas facilidades nas negociações internacionais - em resumo, todos aspectos que implicam redução generalizada de custos de transação (2001, p. 153 - 154).

$\mathrm{Na}$ outra obra que veio a ser o ícone dessa pioneira insubordinação ao sistema então (e até agora) estabelecido, Harry Johnson elabora extenso estudo, agora ocupando um livro inteiro, denominado "Economic Policies Toward Less Developed Countries", publicado pela primeira vez em 1967, visando a relacionar as principais questões que confrontariam os Estados Unidos e os países menos desenvolvidos e a explorar as alternativas entre as quais as escolhas de políticas públicas podem ser feitas (CALKINS, 1967, p. vii). 
No que aqui nos interessa, o Capítulo III da obra examina os impedimentos para o desenvolvimento eficiente da economia mundial imposto pelas políticas comerciais, entre outras, analisando-as tanto na sua conformação nos países desenvolvidos quanto nos menos desenvolvidos. A partir desses estudos, examina, uma a uma, três específicas alternativas de política comercial: a ação de acordo com o arcabouço institucional existente então - basicamente o fomento ao investimento internacional, público e privado, nos países menos desenvolvidos, e à assistência técnica e o alargamento das oportunidades de exportação no sistema GATT; os mecanismos de estabilização e incremento dos fluxos de renda por meio dos mercados de commodities; e as propostas da UNCTAD I - o estabelecimento de um sistema geral de preferências para a exportação de produtos manufaturados por países menos desenvolvidos.

Sem querer neste trabalho examinar as propostas de lege ferenda, o que não é o nosso escopo, o destaque a essa obra é merecido na medida em que foi o primeiro capítulo científico de peso (já que a obra anterior mencionada tinha por base apenas uma exposição realizada em Genebra, em 3 de junho de 1964, como dito) a apontar de que forma o sistema GATT, na forma como projetado, permitia ainda a implementação, por parte dos países desenvolvidos, de políticas públicas de índole comercial que, ainda que formalmente válidas diante dos cânones do Tratamento Nacional e do Tratamento Geral de Nação mais Favorecida (o Príncipio de Não-discriminação no comércio internacional de bens e serviços), consubstanciariam obstáculos ao desenvolvimento e a transferência de renda aos países menos desenvolvidos.

Visto de outra forma, deve a obra de Harry Johnson de 1967 ser vista como a primeira denúncia que o princípio de não-discriminação no comércio internacional de bens e serviços era apenas um princípio formal de equiparação entre as nações, não possuindo eficácia em alcançar materialmente os seus reais objetivos, presentes no preâmbulo do GATT $47^{34}$, de elevar os padrões de vida, de assegurar o pleno emprego "e um alto e

\footnotetext{
${ }^{34}$ Segundo a Lei $\mathrm{n}^{\mathrm{o}}$ 313, de 30 de julho de 1948, que autoriza o Poder Executivo a aplicar, provisoriamente, o Acordo Geral sobre Tarifas Aduaneiras e Comércio; (na sua versão original) reajusta a Tarifa das Alfândegas, e dá outras providências:

"ACÔRDO GERAL SÔBRE TARIFAS ADUANEIRAS E COMÉRCIO

Os Governos da Comunidade da Austrália, do Reino da Bélgica, dos Estados Unidos do Brasil, da Birmânia, do Canadá, do Ceilão, da República do Chile, da República da China, da República Cuba, dos Estados Unidos da América, da República Francesa, da Índia, do Líbano, do Grão Ducado de Luxemburgo, do Reino da Noruega, da Nova Zelândia, do Pakistan, do Reino dos Paises-Baixos, da Rodésia do Sul, do Reino-Unido da Grã-Bretanha e da Irlanda do Norte, da Síria, da República Tchecoslovaca e da União Sul-Africana;

Reconhecendo que suas relações no domínio comercial e econômico devem ser orientadas no sentido de elevar os padrões de vida, de assegurar o emprêgo pleno e um alto e sempre crescente nível de rendimento
} 
sempre crescente nível de rendimento real e de procura efetiva, para a mais ampla exploração dos recursos mundiais e a expansão da produção e das trocas de mercadorias".

De todo o raciocínio desenvolvido, o que se pode concluir, sucintamente, é que ainda há um vastíssimo campo de manobra dos Estados nacionais em adotar políticas protecionistas, completamente à margem do sistema multilateral. Há, portanto, um protecionismo proscrito, porém não evidente, mas dissimulado, cujos contornos de caracterização costumam ser por vezes irreconhecíveis (BARRAL, 2002, p. 15).

Embora proscritos, por dissimulados, não oferecem aos países que os praticam qualquer risco de se submeterem a uma sanção internacional. E, o que é pior, os mecanismos estão cada vez mais se sofisticando, o que acabará por alijar ainda mais as nações menos desenvolvidas e menos preparadas para a corrida para o desenvolvimento, da qual já estão agora participando como meras retardatárias. A questão é grave e não devemos nos iludir com as maravilhas da globalização e da institucionalização do comércio internacional. Ainda que não mais tenhamos no plano internacional o completo estado de natureza hobbesiano, o Leviatã permanece à solta, apenas agora um pouco mais disfarçado. Em verdade, o Princípio de Não-discriminação ainda possui baixa efetividade do panorama econômico internacional.

real e de procura efetiva, para a mais ampla exploração dos recursos mundiais e a expansão da produção e das trocas de mercadorias;

Almejando contribuir para a consecução dêsses objetivos, mediante a conclusão de acôrdos recíprocos e mútuamente vantajosos, visando à redução substancial das tarifas aduaneiras e de outras barreiras às permutas comerciais e à eliminação do tratamento discriminatório, em matéria de comércio internacional; Por intermédio de seus representantes, convieram no seguinte:" 


\subsection{Da Não-Discriminação entre produtos estrangeiros - O Tratamento Geral de Nação Mais Favorecida (Art. I).}

Hoje em dia já é assente, entre os doutrinadores de Direito Internacional do Comércio, a concordância com a clássica formulação de John Jackson (1969) acerca do papel preponderante da proibição da discriminação em função na nacionalidade na concretização da liberalização do comércio internacional e, portanto, em todo o estudo teórico da disciplina. Não é por outro motivo que muitos estudiosos atuais, como Federico Ortino (2004, p. 217), entre outros, chegam a afirmar que o princípio decorrente dessa proibição, o Princípio de Não-discriminação, seja, talvez, o pilar fundamental na normatização advinda da Organização Mundial do Comércio (OMC).

Sem querer entrar a fundo nesse momento no correto entendimento quanto à exata extensão do conteúdo jurídico do princípio da não-discriminação, consideração de grande complexidade, é importante ressaltar que a proibição de discriminação em função da nacionalidade, na disciplina oriunda do GATT e das suas alterações posteriores e dos seus acordos complementares, possui dois instrumentos de efetivação: a cláusula de Nação Mais Favorecida (artigo I do Acordo Geral) e a cláusula do Tratamento Nacional (artigo III do Acordo Geral).

A doutrina internacional costuma afirmar que diferença básica entre essas duas cláusulas repousa em que a primeira é aplicável a produtos não-nacionais entre si, e a segunda ao nacional em contraste com o não-nacional (VAN DEN BOSSCHE, 2005, p. 308). Na verdade, tal diferenciação, se é correta do ponto de vista formal, não contempla toda a diferenciação que um estudo mais aprofundado de ambas faz ressaltar.

Em comum entre ambas, no que tange ao aspecto formal, está a proibição do critério da nacionalidade do produto (ou do serviço, em se tratando de equivalente cláusula no GATS) como exclusivo fator de discrímen no seu tratamento tributário ou regulatório (ORTINO, 2004, p. 217).

No entanto, a cláusula de tratamento nacional é, fundamentalmente, a aplicação do princípio de não-discriminação no plano interno, doméstico, dos Estados-contratantes do GATT. Já a cláusula de tratamento da nação mais favorecida é a aplicação do mesmo princípio no plano internacional. Daí, e dado o seu caráter instrumental à eficácia do próprio sistema multilateral como um todo, pode-se concluir facilmente por que motivo o 
tratamento geral da nação mais favorecida está relacionada no artigo I do GATT, antes mesmo das concessões tarifárias.

Não obstante ser o pilar fundamental do Sistema Multilateral de Regulação do Comércio Internacional, o Princípio de Não-discriminação possui sua eficácia condicionada ao Princípio da Proteção Aduaneira Exclusiva, cujo caráter é nitidamente instrumental, de forma a possibilitar que as concessões tarifárias funcionem de acordo com as intenções das Partes que as contrataram.

O Princípio da Proteção Aduaneira Exclusiva, para os doutrinadores que, corretamente, o admitem assim sistematizado, como Pedro Mota (2005, p. 223), significa dizer que o único instrumento de caráter protecionista que resta ao poder soberano dos Estados-contratantes do GATT é o de impor direitos aduaneiros às suas importações. $\mathrm{O}$ motivo é que tais imposições possuem duas características bastante apreciadas pelo sistema multilateral de proteção ao comércio internacional instaurado pelo GATT: transparência (MOTA, 2005, p. 223) e previsibilidade (FAUCHALD, 2003, p. 446).

Trata-se de incidência tributária transparente porque as suas alíquotas, mesmo que sejam específicas ${ }^{35}$, são facilmente identificáveis e o respectivo ônus econômico aferível. Sua previsibilidade advém do fato de que uma das características do sistema GATT é a liberalização paulatina do comércio internacional por meio do emprego da técnica da consolidação tarifária, a qual consiste em que, consoante o primeiro parágrafo do artigo II do GATT, os países concedentes se comprometem a não elevar a alíquotas dos direitos aduaneiros em proporções maiores que as que foram objeto de concessão ${ }^{36}$, com relação às mercadorias listadas em anexo ao acordo ${ }^{37}$ e dentro do prazo eventualmente

\footnotetext{
${ }^{35}$ Alíquota específica é aquela que é estabelecida em função de alguma unidade de medida aplicada ao produto (art. 20, I, do Código Tributário Nacional). A ad valorem, por sua vez, é proporcional ao preço normal de venda que a mercadoria alcançaria em condições de livre concorrência (art. 20, II, do Código Tributário Nacional), ou, consoante as determinações internacionais a respeito da matéria, proporcional ao valor aduaneiro apurado segundo as normas do Artigo VII do Acordo Geral sobre Tarifas e Comércio GATT 1994 (Regulamento Aduaneiro - Decreto $\mathrm{n}^{\circ}$ 6.759, de 5 de fevereiro de 2009, art. 75, I e II, com fundamento legal no Decreto-lei ${ }^{\circ} 37$, de 1966 , art. $2^{\circ}$, com a redação dada pelo Decreto-lei ${ }^{\circ} 2.472$, de $1^{\circ}$ de setembro de 1988, art. $1^{\circ}$, e Acordo sobre a Implementação do Artigo VII do Acordo Geral sobre Tarifas e Comércio - GATT 1994 - Acordo de Valoração Aduaneira, Artigo 1, aprovado pelo Decreto Legislativo n ${ }^{\circ}$ 30, de 15 de dezembro de 1994, e promulgado pelo Decreto $\mathrm{n}^{\circ} 1.355$, de 30 de dezembro de 1994).

${ }^{36}$ Na redação da Lei no $313 / 48$ :

"ARTIGO II LISTAS DE CONCESSÕES
}

1. (a) Cada parte contratante concederá às outras partes contratantes, em matéria comercial, tratamento não menos favorável do que o previsto na parte apropriada da lista correspondente, anexa ao presente Acordo".

${ }^{37}$ Idem "(b) Os produtos das partes contratantes, ao entrarem no território de outra parte contratante, ficarão isentos dos direitos aduaneiros ordinários que ultrapassarem os direitos fixados na Parte I da lista das concessões feitas por esta parte contratante, observados os termos, condições ou requisitos constantes da mesma lista. Esses produtos também ficarão isentos dos direitos ou encargos de qualquer natureza, exigidos 
convencionado. Como consequência, os gravames que forem exigidos em montante superior à chamada tarifa consolidada não poderão ser cobrados sem caracterizar infringência à disciplina convencional ${ }^{38}$. Como forma de preservar a efetividade dos compromissos representados pelas as concessões tarifárias consolidadas, os Estados-partes afirmam que preservarão os métodos de apuração do valor aduaneiro e não realizarão alterações nas fórmulas de cálculo da taxa de câmbio ${ }^{39}$.

Embora o conceito de tratamento geral de nação mais favorecida advenha de uma cláusula presente em tratados internacionais de comércio internacional desde $1055^{40}$, malgrado o termo tenha sido empregado pela primeira vez apenas no Século XVII (JACKSON, 2000), a semântica principiológica por trás dela é muito mais ampla que o de uma simples norma de extensão de efeitos. Não é por outro motivo que o título do artigo I do GATT é “Tratamento Geral de Nação mais Favorecida”, pois representa um conceito que perpassa toda a filosofia e sistemática de multilateralização da disciplina do comércio internacional. Como ensina o Consultative Board da $\mathrm{OMC}^{41}$, o tratamento geral de nação mais favorecida é a norma geral de organização do GATT, na condição de acordo geral que é, assim como de todo o arcabouço institucional de normas dele decorrentes.

É, pois, um tratamento que se propõe ser geral. Tal expressão, no que tange ao tratamento de nação mais favorecida, diferentemente do tratamento nacional, deve ser entendida no seu elastério o mais amplo possível. Significa que é incondicional, multilateral, automática e ilimitada e que se aplica tanto às importações quanto às

por ocasião da importação ou que com a mesma se relacionem, e que ultrapassem os direitos ou encargos em vigor na data do presente Acordo ou os que, como consequiência direta e obrigatória da legislação vigente no país importador, na referida data, tenham de ser aplicados ulteriormente".

38 Ibidem "(c) Os produtos enumerados na Parte II da lista relativa a qualquer das partes contratantes, originários de território que, em virtude do art. I, goze do direito de tratamento preferencial no tocante à importação, ao serem importados, estarão isentos no território correspondente a essa lista, da parte que exceder dos direitos aduaneiros ordinários fixados na Parte II dessa Lista. observados os termos, as condições ou requisitos constantes da mesma. Esses produtos também ficarão isentos dos direitos ou encargos de qualquer natureza, exigidos por ocasião da importação ou que com a mesma se relacionem, e que ultrapassem os direitos ou encargos em vigor na data do presente Acordo ou os que, como conseqüência direta e obrigatória da legislação vigente na referida data, no país importador, tenham de ser aplicados ulteriormente. Nenhuma disposição do presente artigo impedirá que qualquer parte contratante mantenha exigências existentes na data do presente Acordo, quanto às condições de entrada dos produtos sujeitos às taxas dos direitos preferenciais".

${ }^{39}$ Ibidem "3. Nenhuma parte contratante modificará seu método de avaliação, para fins aduaneiros, ou de conversão de moedas, de maneira a diminuir o valor das concessões constantes da lista correspondente, anexa ao presente Acordo".

${ }^{40}$ Para conhecer todo o percurso histórico da cláusula de nação mais favorecida, incluindo os sete diferentes estágios por que o respectivo princípio passou, examinar Trebilcock e Howse (2005, p. 49 - 51).

${ }^{41}$ Ver nota de rodapé $\mathrm{n}^{\circ} 388$, p. 19. 
exportações (MOTA, 2005, p. 110) ${ }^{42}$. É, mais do que a cláusula do artigo I, um tratamento que perpassa todo o Acordo, como, por exemplo, os artigos III:7 (regulamentações quantitativas internas), IV (b) (filmes cinematográficos), V:2, V:5 e V:6 (trânsito de mercadorias), IX:1 (marcas de origem), XIII:1 (restrições quantitativas), XVII:1 (empresas comerciais do Estado), XVIII:20 (assistência governamental) e XX (j) (medidas relativas ao suprimento de curto prazo de mercadorias, sem falar das normas análogas do GATS e do Acordo sobre Aspectos dos Direitos de Propriedade Industrial Relacionados ao Comércio (TRIPS, de Agreement on Trade-Related Aspects of Intellectual Property Rights) (MATSUSHITA, SCHOENBAUM, MAVROIDIS, 2003, p. 147).

E não podia ser de outra forma, pois a cláusula do artigo $I^{43}$ é a pedra angular do sistema multilateral de regramento do comércio internacional (TREBILCOCK; HOWSE, 2005, p. 49) porque é, antes de tudo o seu mecanismo de viabilização. Imaginese quantos acordos bilateriais, ou mesmo plurilaterais, referentes às mesmas concessões tarifárias consolidadas no seio do GATT, em qualquer de suas rodadas, haveriam de ser celebrados com o fim de produzir o mesmo efeito que as mesmas tarifas consolidadas alcançam em conjunto com o artigo I?

E não é só isso, já que a existência em si do tratamento extensivo benéfico é responsável por uma economia inimaginável de custos de transação, bastando para isso vislumbrar o que seria a necessidade quase que contínua de complicadas renegociações na ausência da cláusula, ao mesmo tempo em que, a partir do que a Teoria dos Jogos afirma sobre o dilema do prisioneiro $^{44}$, poderíamos imaginar essa realidade aplicada às

\footnotetext{
${ }^{42}$ Para uma abordagem completa dos prós e dos contras dessa amplitude do tratamento da nação mais favorecida, ver Davey e Pauwelyn (2000, p. 13).

${ }^{43}$ Na redação da Lei $n^{\circ}$ 313/48:

"ARTIGO I

TRATAMENTO GERAL DE NAÇÃO MAIS FAVORECIDA

1. Qualquer vantagem, favor, imunidade ou privilégio concedido por uma parte contratante em relação a um produto originário de ou destinado a qualquer outro país, será imediata e incondicionalmente estendido ao produtor similar, originário do território de cada uma das outras partes contratantes ou ao mesmo destinado. Este dispositivo se refere aos direitos aduaneiros e encargos de toda a natureza que gravem a importação ou a exportação, ou a elas se relacionem, aos que recaiam sobre as transferências internacionais de fundos para pagamento de importações e exportações, digam respeito ao método de arrecadação desses direitos e encargos ou ao conjunto de regulamentos ou formalidades estabelecidos em conexão com a importação e exportação bem como aos assuntos incluídos nos $\S \S 1$ e 2 do art. III".

${ }^{44} \mathrm{O}$ jogo do dilema do prisioneiro é um jogo paradigmático do que pode acontecer em situações de informação completa, porém imperfeita. Consiste em jogo de dois jogadores, com duas estratégias, em que os interesses reunidos de ambos não são alcançados, pelo uso de uma mesma estratégia, de ficar em silêncio, porque cada um dos jogadores supõe que essa estratégia é dominada pela estratégia do outro jogador, em confessar. É, portanto, um exemplo emblemático dos problemas advindos da ação coletiva no Direito, em que o interesse individual leva a ações que não são do interesse do grupo como um todo (BAIRD; GERTNER; PICKER, 2003, p. 312 - 313).
} 
negociações comerciais, a concluir pela sua completa inviabilização na hipótese de inexistência do tratamento geral de nação mais favorecida.

O emprego do tratamento geral de nação mais favorecida inibe, portanto, qualquer tentativa de trapacear, como essa mencionada pelos teóricos dos jogos, já que a nação trapaceira é desestimulada a agir em seu único proveito em função do fato de que qualquer benefício que vier a auferir ter de ser estendido a todos os envolvidos no sistema (MATSUSHITA, SCHOENBAUM, MAVROIDIS, 2003, p. 145).

Matsushita, Schoenbaum e Mavroidis (2003, p. 144) e Jackson (2000, p. 158 159) também aduzem oito benefícios econômicos e políticos no emprego do tratamento geral de nação mais favorecida, no plano do Direito Internacional do Comércio, mas que podem ser vistos de forma extensiva a todos os planos do Direito Internacional, inclusive o tributário:

- assegura a remoção de distorções que poderiam de outra maneira ocultar a manifestação das vantagens comparativas;

- proporciona concorrência justa e livre;

- protege as concessões tarifárias contra a corrosão gradual originada por favores concedidos a alguns, mas não a todos, os Estados;

- é um corolário do princípio da igualdade soberana dos Estados, independentemente do seu tamanho ou importância;

- protege contra a corrupção e a possibilidade de compra de favores;

- proporciona simplicidade administrativa, pois todas as nações são tratadas de forma equânime;

- previne ciclos retaliatórios de discriminação e conseqüente animosidade entre as nações;

- possui um efeito multiplicador, já que, em função de sua operação, as negociações tarifárias concedidas bilateralmente podem se espalhar por todo o sistema multilateral.

Por conseguinte, no que tange aos seus efeitos tributários, deve-se entender, ao menos no plano do Direito Internacional do Comércio, que o tratamento geral da nação mais favorecida é aplicável a todos os tributos, sem exceção e em qualquer hipótese.

Segundo Celso Lafer (1977, p. 14 - 15), a fórmula da "cláusula de nação mais favorecida" parte de dois pressupostos teóricos básicos: “(i) o de que a liberação dos entraves ao comércio internacional, num contexto de livre concorrência, traz reais vantagens econômicas para os países envolvidos num esquema que a consagra", o que 
justificaria a conveniência de sua extensão aos demais, assim como "(ii) o de que a organização do comércio internacional, através de um esquema descentralizado de decisões resultante do funcionamento do mercado, é de mais fácil e eficiente manejo do que um esquema centralizado - produto de algum esforço de planejamento".

No entanto, o emprego do tratamento geral de nação mais favorecida possui a grande desvantagem de proporcionar o fenômeno do oportunismo ("free riding") 45 . Tratase de problema muito comum em situações em que estamos tratando de bens públicos, como o é uma disposição legal aplicável a todos, também estudada pela Teoria dos Jogos, em que um jogador, sem qualquer esforço próprio, está apto a usufruir dos benefícios decorrentes dos compromissos e da ação de um outro (BAIRD; GERTNER; PICKER, 2003, p. 308). No caso do sistema multilateral de comércio, os oportunistas ("free riders") poderiam ser encorajados a tomar partido do sistema, utilizando-se dos benefícios da liberalização comercial sem precisar abrir o seu próprio mercado ou, genericamente falando, sem se submeterem às obrigações do sistema (JACKSON, 2000, p. 162).

Esse problema, intrínseco ao tratamento geral de nação mais favorecida, propiciou, especialmente nos Estados unidos, desde o Século XIX, o emprego do tratamento condicional - ou seja, desde que o outro Estado garantisse concessões em troca. No entanto, o tratamento condicional de nação mais favorecida está hoje em desuso, entendido que foi, como bem explicam Matsushita, Schoenbaum e Mavroidis (2003, p. 145), como impraticável e contra-producente, em se tratando de avenças multi ou plurilaterais.

John Jackson (2000, p. 161 - 162) admite também um terceiro gênero, que é o tratamento de nação mais favorecida condicional ao código ("code conditional"), que condiciona a sua utilização ao fato de o Estado estar submetido a algum código ou tratamento especificado na norma internacional - por exemplo, pertencer a algum fenômeno específico de integração econômica.

Não obstante, o tratamento incondicional é hoje largamente empregado, já que é o mais útil e prático em sistemas multi e plurilaterais. Assim é que o North American Free Trade Agreement (NAFTA), em diversos pontos, equipara em todos os aspectos os

45 Também conhecido como o problema de "pegar carona", nas traduções em português de textos de Microeconomia, como Hal Varian (2006), pode ser ilustrado pela situação dos dois colegas de quarto que desejam comprar uma TV, supondo que não é possível que um dos colegas, o que adquiriu a televisão, possa impedir que o outro a assista. Cada um dos colegas estará incentivado a esperar que o outro a compre, se pensarmos apenas no que tange ao custo-benefício na ótica de cada um deles, o que gerará um equilíbrio estratégico dominante que consiste em um dilema (semelhante ao dilema do prisioneiro), pois nenhum dos dois terá motivação para comprar a TV e assim não haverá acréscimo de bem-estar (VARIAN, 2006, p. 725 726). 
tratamentos nacional e da nação mais favorecida, aplicando-os a matérias como investimentos (artigos 1102 e 1103), serviços transfronteiriços (artigos 1202 e 1203) e serviços financeiros (artigos 1405 e 1406).

Não se deve deixar de perceber, por outro lado, que o tratamento unilateral possui o grave inconveniente, apontado por J. H. Jackson (2000, p. 159), de inibir o desenvolvimento de economias mais frágeis, em que o peso da indústria nascente é mais relevante, obrigadas que estão a obedecer ao tratamento mais favorável e aberto que as nações mais ricas celebraram entre si.

O que ocorre é que as negociações das concessões tarifárias são restritas aos seus maiores produtores e consumidores, sendo depois estendidas aos demais, por meio do tratamento geral de nação mais favorecida. Não é por outro motivo que Celso Lafer (1977, p. 15 - 16) afirma que os países subdenvolvidos, sem peso específico relevante nos mercados das mercadorias objeto de redução de gravames, com isso, acabaram por situarse na "periferia institucional" nas negociações, por falta de "locus standi" nelas, com o que conclui que a "cláusula", referindo-se à experiência do GATT de até então, "não atendeu às conveniências dos países subdesenvolvidos", mas sim apenas às "necessidades de liberação do comércio entre as economias desenvolvidas de mercado".

Embora se percebam diversos esforços para impor o tratamento geral de nação mais favorecida como uma regra aplicável a outros ramos do Direito, como a sua presença na Carta de Direitos Econômicos e de Obrigações dos Estados, lavrada pela AssembleiaGeral da ONU em 1974, o que nem sempre tem sido adotado nos tratados bilaterais nas diversas matérias, não há dúvidas de sua caracterização, pelo menos, como uma regra costumeira de Direito Internacional Público (JACKSON, 2000).

\subsection{Da Não-Discriminação entre produto nacional e estrangeiro - O Tratamento Nacional (Art. III).}

\subsubsection{Art. III:1 (considerações gerais).}

O primeiro parágrafo do artigo III do GATT enuncia os termos da avença fundamental, entre as partes contratantes, consistente nos compromissos relacionados ao 
tratamento nacional "no tocante à tributação e regulamentação internas", como literalmente vazado no direito positivo nacional ${ }^{46}$. Mas não é apenas isso, uma vez que dessa norma ${ }^{47}$ podem ser extraídos os objetivos e fundamentos hermenêuticos para a aplicação concreta dos demais parágrafos, esses sim consistentes concretamente em normas de conduta diretamente endereçadas aos estados-partes.

Por esse motivo, tanto o Grupo Especial ${ }^{48}$ quanto o Órgão de Apelação ${ }^{49}$ do OSC da OMC, no caso "Japan - Taxes on Alcoholic Beverages", fundamental para o entendimento do tratamento nacional em matéria tributária, comentam que o referido primeiro parágrafo conteria "princípios gerais" acerca da matéria ${ }^{51}$. Ou, conforme ensinam Matsushita, Schoenbaum e Mavroidis (2003, p. 157), o primeiro parágrafo informaria e proveria o contexto de interpretação dos demais parágrafos do artigo III.

Algumas ilações importantes podem ser retiradas na exegese do parágrafo 1 , todas fundamentais na aplicação dos respectivos parágrafos posteriores.

Primeiramente, trata-se de norma voltada ao regramento dos impostos e outros tributos internos. Não se refere, portanto, aos direitos aduaneiros, imposto de importação, ou encargos de efeito equivalente (MATSUSHITA; SCHOENBAUM; MAVROIDIS, 2003, p. 168), até porque não faria sentido que o fosse, uma vez que tais incidências são intrinsecamente discriminatórias (MOTA, 2005, p. 125), dado que só oneram o produto

\footnotetext{
${ }^{46}$ Ocorre que, logo após a sua lavratura, em 30 de outubro de 1947, o GATT sofreu, durante a Segunda Reunião das Partes Contratantes, realizada em Havana, Cuba (a chamada Conferência de Havana, durante a qual também se elaborou a carta da natimorta Organização Internacional do Comércio), em agosto e setembro de 1948, uma emenda, que alterou completamente a redação no artigo III do GATT (ZARRILLI, 2003, p. 376), ao mesmo tempo em que lhe inseria, em anexo específico, quatro importantes notas interpretativas, uma ao artigo como um todo, as três seguintes referentes aos parágrafos 1, 2 e 5, respectivamente. Tal alteração veio internalizada ao direito brasileiro por meio do Decreto Legislativo $\mathrm{n}^{\circ} 43$, de 20 de junho de 1950, desde já estabelecendo que a rubrica do artigo III seria "Tratamento nacional no tocante à tributação e regulamentação internas", derrogando a denominação dada pela lei de 1948. Trata-se de diploma legal que veicula diversas imperfeições de tradução, mas que será utilizado nesse trabalho, já que constitui a norma brasileira positiva no assunto. Não vamos entrar aqui em considerações sobre a eficácia da revogação de lei por meio de decreto legislativo, até porque demandaria análise no regime constitucional aplicável consoante a carta constitucional de 1946. Independentemente disso, pelo que se vê, tanto pelo emprego dos veículos normativos da lei ordinária, como também do decreto legislativo, para promulgar e dar publicidade ao texto de acordo internacional assinado, aprovado e ratificado pelo Brasil, pode-se perceber que, à época, ainda não se encontrava consolidada a prática administrativa de fazê-lo por meio de decreto do chefe do Poder Executivo Federal, como sói acontecer nos dias atuais (MELLO, 2000, p. 228).

47 Segundo a redação do mencionado Decreto Legislativo no 43/50: "1. As partes contratantes reconhecem que os impostos e outros tributos internos, assim como leis, regulamentos, e exigências relacionadas com a venda, oferta para venda, compra, transporte, distribuição ou utilização de produtos no mercado interno e as regulamentações sobre medidas quantitativas internas que exijam a mistura, a transformação ou a utilização de produtos, em quantidade e proporções especificadas, não devem ser aplicados a produtos importados ou nacionais, de modo a proteger a produção nacional".

${ }^{48}$ Documento WT/DS8/R, WT/DS10/R, WT/DS11/R, de 11 de julho de 1996.

${ }^{49}$ Documento WT/DS8/AB/R, WT/DS10/AB/R, WT/DS11/AB/R, de 4 de outubro de 1996.

${ }^{50}$ Doravante denominado caso "Japão - Bebidas Alcóolicas II".

${ }^{51}$ Parágrafo 6.12 e item $\mathrm{G}$, respectivamente.
} 
importado. No mesmo sentido se manifestou o Diretor-Geral do GATT, em $1980^{52}$, assim como o OSC, ainda no seio do GATT ${ }^{53}$.

Isso não quer dizer, não obstante, que o imposto, dito interno, não possa ser exigido no decorrer do procedimento administrativo de importação ${ }^{54}$, ou quando de seu derradeiro ato administrativo, o desembaraço aduaneiro, ocasião na qual é encerrada a conferência aduaneira, geralmente em zona primária ${ }^{55}$. Assim reza a nota interpretativa ao artigo III do GATT ${ }^{56}$. Durante as discussões em Havana, na Décima Primeira Reunião, em 15 de dezembro de 1947, ao final das quais se decidiu pela introdução dessa nota, informou-se que o seu propósito foi o de também abranger os tributos internos que são, por

\footnotetext{
52 "I wish to point out in this connexion that such "other duties or charges" are in principle only those that discriminate against imports. As can be seen frm Article II:2 of the General Agreement, such "other duties or charges;' concern neither charges equivalent to internal taxes, nor anti-dumping or counterailing duties, nor fees or other charges commensurate with the cost of services rendered" $(\mathrm{C} / 107 / \mathrm{REV} .1$. Introduction of a loose-leaf system for the schedules of Tariff concessions: Proposal by the Director-General. Revision).

53 " 5.4 Categorization as customs duties (Article II:1(b)) or internal taxes (Article III:2). The Panel noted that Japan argued that the anticircumvention duties could be considered to be either duties imposed on or in connection with importation within the meaning of Article II:l(b) or internal taxes within the meaning of Article III:2. The EEC considered that the duties do not fall under Article III:2. The Panel recalled that the distinction between import duties and internal charges is of fundamental importance because the General Agreement regulates ordinary customs duties, other import charges and internal taxes differently: the imposition of "ordinary customs duties" for the purpose of protection is allowed unless they exceed tariff bindings; all other duties or charges of any kind imposed on or in connection with importation are in principle prohibited in respect of bound items (Article II:1(b)). By contrast, internal taxes that discriminate against imported products are prohibited, whether or not the items concerned are bound (Article III:2). The Panel therefore first examined whether the duties constitute customs or other duties imposed on or in connection with importation falling under Article II:1(b) or internal taxes falling under Article III:2" - "EEC - Regulation on Imports of Parts and Components": Relatório do Grupo Especial. L/6657, de 22 de março de 1990.

${ }^{54}$ No caso do direito positivo brasileiro, do despacho aduaneiro de importação, disciplinado pelos artigos 542 ("Despacho de importação é o procedimento mediante o qual é verificada a exatidão dos dados declarados pelo importador em relação à mercadoria importada, aos documentos apresentados e à legislação específica") e seguintes do Decreto $\mathrm{n}^{\circ}$ 6.759/09, que "regulamenta a administração das atividades aduaneiras, e a fiscalização, o controle e a tributação das operações de comércio exterior" (Regulamento Aduaneiro).

${ }^{55}$ Art. 571 do Regulamento Aduaneiro ("Desembaraço aduaneiro na importação é o ato pelo qual é registrada a conclusão da conferência aduaneira (Decreto-Lei $n^{\circ}$ 37, de 1966, art. 51, caput, com a redação dada pelo Decreto-Lei n ${ }^{\circ} 2.472$, de 1988, art. $2^{\circ}$ )").

${ }^{56}$ Segundo a redação do mencionado Decreto Legislativo no $43 / 50$ :

“i) o texto seguinte será inscrito no Anexo I, imediatamente após as notas interpretativas referentes ao artigo II.

Ao Artigo II (sic)

Qualquer imposto ou outros tributos internos, bem como qualquer lei, regulamento ou prescrição mencionados no $\S 1^{\circ}$ que se apliquem não só ao produto importado como também ao produto nacional similar e que sejam cobrados ou exigidos no caso do produto importado no momento e no local da importação, serão não obstante considerados como taxa interna ou um outro tributo interno ou como uma lei, regulamentação ou exigências regidas no $\S 1^{\circ} \mathrm{e}$ estão consequentemente sujeitas às disposições do art. III". Curioso é perceber o erro de impressão, por meio do qual as notas interpretativas ao art. III estão referidas ao artigo anterior.
} 
motivos meramente administrativos, exigidos no momento da importação ou da entrada formal no território nacional, sem falar nas normas regulatórias na mesma situação ${ }^{57}$.

Deve-se ressaltar que a mencionada nota interpretativa (ao artigo III como um todo, embora a versão brasileira encerre um erro de impressão), ao estabelecer a possibilidade que "impostos ou outros tributos internos" sejam "cobrados ou exigidos" no "momento e no local da importação", de forma alguma quis confundir os espectros de aplicação do artigo III com o do artigo XI, embora autores como Matsushita, Schoenbaum e Mavroidis (2003, p. 166) vejam alguma dificuldade na questão.

$\mathrm{O}$ artigo XI refere-se a restrições quantitativas, exigidas, sim, quando da entrada da mercadoria no país de destino e justificadas apenas nos casos relacionados no parágrafo 2, e que podem, até, serem, eventualmente, implementadas por meio de incidências tributárias progressivas em função do volume importado, como quotas tarifárias, mas sempre exclusivamente ao produto importado. Aplica-se à importação propriamente dita, enquanto o tratamento nacional aos produtos importados, assim como aos nacionais necessariamente (MATSUSHITA, SCHOEMBAUM, MAVROIDIS; 2003, p. 124). Como já vimos, portanto, não se aplica o Artigo XI no caso em que as restrições quantitativas são aplicadas igualmente aos produtos nacionais assim como aos importados.

A intenção da nota interpretativa, portanto, foi a de esclarecer que a caracterização de tributo interno do Artigo III, que, como veremos, refere-se aos ajustes fiscais de fronteira, não se altera se, eventualmente, o dito tributo interno for cobrado em zona primária. É o caso das nossas incidências, como veremos, que, embora internas, também são exigidas pela autoridade alfandegária quando do procedimento administrativo do despacho aduaneiro de importação, como requisito ao desembaraço final.

Não se pode, portanto, vislumbrar qualquer possibilidade de sobreposição nesses conceitos, embora se reconheça que, na prática, podem se encontrar zonas cinzentas de aplicação, especialmente no que se refira às práticas regulatórias previstas no Artigo III:4.

A matéria, decerto, no que tange à distinção entre tributo interno e tributo aduaneiro, já foi analisada pelo OSC da OMC. No julgamento do caso "EEC - Measures on Animal Feed Proteins", o Grupo Especial, mencionando entendimento oriundo da

\footnotetext{
57 "In regard to the United States amendment (item 74), the proposed additional paragraph was intended to cover cases where internal excise duties were, for, administrative reasons, collected at the time of importation, as well as mixing regulations also enforced at that stage" (E/CONF.2/C.3/SR.11. Summary Record Of The Eleventh Meeting (III a): Held at the Capitol, Havana, Cuba, on Monday, 15 December 1947, at 4.00 p.m).
} 
Conferência de Havana, estabeleceu que os direitos aduaneiros distinguem-se das imposições fiscais internas por dois motivos: i) por serem exigidos e cobrados no momento da entrada do bem no território nacional do país de importação, e como sua condição de internalização; ii) por se aplicarem unicamente a produtos importados, sem possuírem qualquer relação com as incidências semelhantes impostas a mercadorias nacionais similares $^{58}$.

Como se viu, ao examinarmos o Princípio da Proteção Aduaneira Exclusiva, apenas os ditos direitos aduaneiros são limitados pelas negociações entabuladas nos termos dos artigos I e II do GATT. Os tributos aqui previstos, diferentemente, não sofrem qualquer limitação quantitativa, podendo ter suas alíquotas definidas dentro do poder soberano de imposição tributária dos Estados Contratantes (MATSUSHITA; SCHOENBAUM; MAVROIDIS; 2003, p. 167).

Podemos concluir, então, que tributo interno, para os termos do artigo III do GATT, é qualquer incidência que onere tanto o produto nacional quanto o importado similar, não importa onde seja feita a sua exigência, e que possua, no núcleo do aspecto material de sua hipótese de incidência, as operações de "venda, oferta para venda, compra, transporte, distribuição ou utilização".

Portanto, o artigo III do GATT também está limitado em seu escopo a tributos, independentemente das denominações que lhe forem atribuídas, incidentes sobre modalidades de materialidades relacionadas intrinsecamente à circulação das mercadorias. Não se aplica a tributos (no Brasil seriam taxas) cujos fatos geradores sejam a prestação de serviços públicos (ou o exercício do poder de polícia) por parte da administração aduaneira, os quais sujeitam-se ao artigo VIII.

Podemos afirmar, consoante entendimentos do OSC, que o mais correto é entender que o que se intentou focar no referido artigo III prioritariamente foram os ajustes fiscais de fronteira ${ }^{59}$, modalidade tributária sobre a qual discorreremos exaustivamente em capítulo específico.

\footnotetext{
58 "The Sub-Committee at the Havana Conference considered (Havana Reports pp. 62-63, paragraphs 42-43, E/CONF.2/C.3/A/W.30 page 2) that "certain charges ... were import duties and not internal taxes because ... (a) they are collected at the time of, and as a condition to, the entry of the goods into the importing country, and $(b)$ they apply exclusively to imported products without being related in any way to similar charges collected internally on like domestic products"', - BISD/25S/49, parágrafo 4.16.

${ }^{59}$ Não se adotará, no presente trabalho, o termo "ajustes fiscais na fronteira", mesmo sendo o presente na primeira aparição da questão no direito positivo brasileiro; qual seja, na nota de rodapé $\mathrm{n}^{\circ} 58$ ao Anexo I (Lista Ilustrativa de Subsídios à Exportação) do Acordo sobre Subsídios e Medidas Compensatórias, apensa por cópia ao Decreto $\mathrm{n}^{\circ} 1.355$, de 30 de dezembro de 1994, que promulgou a Ata Final que Incorpora os Resultados da Rodada Uruguai de Negociações Comerciais Multilaterais do GATT - ver a nota de rodapé 118, abaixo. Tal se deve ao fato de que o termo presente em primeira aparição no direito positivo brasileiro
} 
Tal posição, não obstante, não é consensual. Robert Floyd (1973, p. 497) entende que a norma do artigo III do GATT refere-se aos efeitos alocativos de tributos seletivos do tipo excise tax, impostos indiretos seletivos ou analíticos, uma vez que entende aplicável à espécie a análise econômica apenas em equilíbrio parcial, com fundamento neoclássico, pela qual se conclui que o ajuste fiscal de fronteira não possui qualquer influência sobre o ponto de equilíbrio, como veremos. Para ele, corretissimamente nesse ponto, o grau de proteção a ser aferido no parágrafo 1 do artigo III do GATT confundiriase com o conceito de "efeito protetivo" da Teoria Econômica do Comércio Internacional, como se verá. Por esse motivo, a norma convencional não poderia se referir aos ajustes fiscais de fronteira e sim a excise taxes, dada a fundamentação econômica que teria motivado a redação do GATT. No entanto, engana-se ao desconsiderar a análise vertical, mais complexa e que realmente considera o grau de proteção efetiva, para o qual, como também veremos, os ajustes fiscais de fronteira alcançam relevância na eficiência alocativa. A visão de Robert Floyd já foi contestada na doutrina por mais de uma vez, como no caso de Paul Demaret e Raoul Stewardson (1994, p. 11, nota de rodapé 24).

Como bem nos ensinam Matsushita, Schoenbaum e Mavroidis (2003, p. 168), o OSC da OMC ainda não se pronunciou expressamente sobre o que é o conceito de tributo interno para o fim de aplicar o artigo III do GATT. Por outro lado, o GATT, em sua fase anterior à OMC, sinalizou um caminho com a edição do Relatório do Grupo de Trabalho sobre Ajustes Fiscais de Fronteira ${ }^{60}$, que, como veremos, foi mais importante para prever soluções com fulcro microeconômico para a valoração dos conceitos jurídicos indeterminados de produtos similares (da primeira frase do parágrafo 2, na discriminação explícita) e produtos diretamente substitutos ou competidores (da segunda frase do parágrafo 2, consoante sua nota interpretativa, para o caso de discriminação implícita). Tal importância se verifica pela diversidade de julgados do OSC, tanto da época do GATT quanto da $\mathrm{OMC}$, que o mencionam, sempre em relação à questão da similaridade ou da substitutabilidade ${ }^{61}$.

induz ao conceito errôneo de que os ajustes tenham necessariamente que ser produzidos no momento da entrada em território nacional, o que, como se verá, não corresponde ao rigor do conceito, bastando que sejam destinados à internalização ou à venda no mercado externo. Melhor seria que o tradutor brasileiro do acordo internacional houvesse empregado desde logo a expressão "ajuste fiscal DE fronteira", que se viu aparecer, logo após, na nota de rodapé 60 ao Anexo I, e que será a empregada neste texto.

${ }^{60}$ Border Tax Adjustments. Report of the Working Party, adotado em 2 de dezembro de 1970 - L/3464. BISD 18S/100-101.

${ }^{61}$ A nota de rodapé no 46 do Relatório do Órgão de Apelação do caso Japão - Bebidas Alcóolicas II, menciona, a propósito, os casos "The Australian Subsidy on Ammonium Sulphate", BISD II/188; "EEC Measures on Animal Feed Proteins", BISD 25S/49; "Spain - Tariff Treatment of Unroasted Coffee", BISD 28S/102; "Japan - Customs Duties, Taxes and Labelling Practices on Imported Wines and Alcoholic 
Não se pode confundir a aplicabilidade das disposições do GATT precipuamente aos ajustes fiscais de fronteira, que aqui se está discutindo, com a listagem, empreendida pelo parágrafo 14 do Relatório, de quais tributos são elegíveis para serem ajustados na fronteira - tanto excise taxes quanto outros tributos indiretos, monofásicos sobre vendas (sales taxes), plurifásicos cumulativos (cascade taxes), ou plurifásicos nãocumulativos (tax on value added), excluindo contribuições sociais, incidentes sobre empregados ou empregadores, ou tributos sobre a folha de pagamentos ${ }^{62}$.

$\mathrm{Na}$ apreciação do caso "United States - Taxes on Petroleum and Certain Imported Substances (Superfund) ${ }^{, 63}$, mencionando também o Relatório ali denominado “Working Party on Border Tax Adjustements", ponderou-se que os impostos diretamente incidentes sobre produtos são os elegíveis para ajustes fiscais, sendo exemplos precípuos dessa hipótese tributos tais como impostos sobre vendas (sales taxes), exigências específicas (excise taxes) e impostos em cascata, ou mesmo o imposto sobre o valor adicionado, mas que tal não seria possível em se tratando de encargos para a Seguridade Social, cujo ônus é atribuído ao empregado, ou ao empregador, se proporcional à folha de pagamento - em exata transcrição, portanto ${ }^{64}$. Vale dizer, apenas aplicável a impostos sobre produtos, nos termos em que estabelecido no artigo II, parágrafo 2 , item a, do $\mathrm{GATT}^{65}$, não constituindo infração ao Princípio da Proteção Aduaneira Exclusiva.

Beverages", BISD 34S/83; "United States - Taxes on Petroleum and Certain Imported Substances", BISD 34S/136, todos da época ainda do GATT. Posteriores ao Tratado de Marraqueche temos "United States Standards for Reformulated and Conventional Gasoline", WT/DS2/9, de 20 de maio de 1996; "Korea Taxes on Alcoholic Beverages", WT/DS75/AB/R e WT/DS84/AB/R, de 18 de janeiro de 1999 e "ArgentinaMeasures Affecting the Export of Bovine Hides and the Import of Finished Leather", WT/DS155/R, de 19 de dezembro de 2000, como exemplos.

62 "14. On the question of eligibility of taxes for tax adjustment under the present rules, the discussion took into

account the term "... directly or indirectly ..." (inter alia Article III:2). The Working Party concluded that there was convergence of views to the effect that taxes directly levied on products were eligible for tax adjustment. Examples of such taxes comprised specific excise duties, sales taxes and cascade taxes and the tax on value added. It was agreed that the TVA, regardless of its technical construction (fractioned collection), was equivalent in this respect to a tax levied directly - a retail or sales tax. Furthermore, the Working Party concluded that there was convergence of views to the effect that certain taxes that were not directly levied on products were not eligible for tax adjustment. Examples of such taxes comprised social security charges whether on employers or employees and payroll taxes".

${ }^{63} \mathrm{~L} / 6175$, adotado em 17 de junho de 1987, BISD 34S/136.

${ }^{64}$ "There was convergence of views to the effect that taxes directly levied on products were eligible for tax adjustment. Examples of such taxes comprised specific excise duties, sales taxes and cascade taxes and the tax on value added ... Furthermore, the Working Party concluded that there was convergence of views to the effect that certain taxes that were not directly levied on products were not eligible for tax adjustment. Examples of such taxes comprised social security charges whether on employers or employees and payroll taxes" - parágrafo 5.2.4.

${ }^{65} \mathrm{Na}$ redação da Lei $\mathrm{n}^{\circ}$ 313/48:

"2. Nenhuma disposição do presente artigo impedirá que, uma parte contratante, a qualquer tempo, aplique no tocante à importação de qualquer produto: 
Por outro lado, refletindo as circunstâncias com que foi suscitada a instalação desse grupo de trabalho, o Relatório, em seu característico tom conciliatório e tendente à ubiquidade programática ${ }^{66}$, procurou em outro contexto mencionar especificamente os impostos seletivos, afirmando-os como possuindo potencial de afetar deleteriamente o comércio internacional, de forma a ferir o Acordo Geral, mesmo se submetidos a ajustes de fronteira, dada a sua ausência de generalidade ${ }^{67}$, o que teóricos da Economia Internacional como Melvyn Krauss (1969, p. 554 - 555) e Melvyn Krauss e Harry Johnson (1970, p. 598) já haviam afirmado.

Os tributos seletivos também foram lembrados pelo Relatório diante de reclamações dos países em desenvolvimento contra a imposição desse tipo de tributo pelos países desenvolvidos em relação a produtos não produzidos por eles internamente, o que, além de, segundo os menos desenvolvidos, ser contrário aos princípios de neutralidade fiscal que norteiam o GATT, seriam também colidentes com o compromisso de promover o desenvolvimento pelo comércio do Artigo XXXVII. A questão, nesse ponto, passa por outra circunstância, também apontada por Harry Johnson, como veremos, acerca da reiterada prática dos países desenvolvidos em fazerem surgir incidências tributárias seletivas sobre produtos que não são fabricados pela indústria doméstica ou gerados pela agropecuária nacional, embora formalmente incidentes sobre tanto o nacional como o estrangeiro, como forma de aumentar a receita tributária sem influir no mercado nacional nem tampouco violar as obrigacões convencionais.

Diante da alegação quanto à relevância desses tributos para a receita dos países que os impõem, o Relatório estabeleceu uma importante determinação, talvez a única peremptória de todo o seu texto, de que considerações sobre a receita tributária não podem ser impeditivas à remoção de tributos que afetem negativamente o consumo ${ }^{68}$.

A propósito, quanto ao dano que a medida em violação à cláusula de tratamento nacional acarreta, não há a necessidade de que ele seja demonstrado, mas apenas

(a) encargo equivalente a um imposto interno exigido, de conformidade como o disposto no parágrafo primeiro do art. III, sobre um produto nacional similar ou uma mercadoria com a qual o produto importado tenha sido fabricado ou produzido no todo ou em parte;(...)"

${ }^{66}$ No sentido que se propõe a comentar todos os assuntos, ainda que paralelos ao tema dos ajustes fiscais de fronteira, sem entrar em análises concretas e avaliações de mérito quanto a eles. Tal é irônico reconhecer-se hoje, dada a sua subsistência e relevância, atestada pela reiterada menção pelo OSC, primordialmente em ponto periférico ao tema que deveria ter sido abordado consoante o seu mandato.

67 “27. (...) Furthermore, the adjustments in relation to selective excise taxes could be applied on certain products but not other related products in order to affect international trade. It was recognized that this could be inconsistent with the General Agreement".

68 "31. (...) Revenue considerations should not therefore stand in the way of removal of such taxes, particularly as these adversely affected consumption". 
presumido, vislumbrado em potencial, uma vez que o objetivo do tratamento nacional não é apenas restaurativo, mas principalmente preventivo ${ }^{69}$. Assim ficou decidido em um dos primeiros casos submetidos ao antigo GATT, em 1949, o caso "Brazilian Internal Taxes" $^{, 70}$.

Portanto, os impostos seletivos não são os precipuamente submissíveis às disposições do GATT, senão principalmente os ajustes fiscais de fronteira, gerais e universais, até porque, como se provará, as excise taxes tendem a produzir efeito protetivo negativo, em se tomando a proteção efetiva em agregado, tanto na economia como um todo quanto em relação ao seu segmento industrial, a menos que haja reduzida ou nenhuma produção local do bem.

Em verdade, independentemente do seu efeito protetivo negativo tomado em agregado, as excise taxes deveriam, no exercício rigoroso de uma preocupação presente em todo o Acordo Geral, de assegurar condições parelhas de competitividade entre os países, ser extintas, por serem prejudiciais à eficiência no comércio internacional, reduzindo o bem-estar geral dos consumidores e produtores do país que os instituiu.

$\mathrm{Ou}$, pelo menos, terem seu campo de incidência o mais possível ampliado, aproximando-se dos impostos sintéticos, o que acarretaria redução dos seus efeitos distorcivos internos, embora aumentando o seu caráter protetivo potencial. Contrariamente, os ajustes fiscais de fronteiras são benéficos, na exata medida em que se propõem justamente a preservar proativamente tal igualdade competitiva, deixando as nações concorrerem apenas em função de suas vantagens comparativas.

\footnotetext{
69 "15. The Brazilian delegate supported by two other delegates, advanced the view that unless damage to other contracting parties could be demonstrated, a breach of Article III could not be alleged. Three other members of the working party took the view that, whether or not damage was shown, taxes on imported products in excess of those on like domestic products were prohibited by Article III, and that the provisions of Article III were intended to prevent damage and not merely to provide a means of rectifying such damage. The Cuban delegate supported the interpretation of the Brazilian delegate in cases where there was no domestic production of the like imported product".

${ }^{70}$ Primeiro Relatório, adotado pelas PARTES CONTRATANTES em 30 de junho de 1949 - GATT/CP.3/42, BISD II/181.
} 
A UNCTAD, ao definir os termos de seu banco de dados TRAINS ${ }^{71}$, no "UNCTAD Coding System of Trade Control Measures" (o seu glossário), relaciona tanto os ajustes fiscais de fronteira quanto os excise taxes como medidas paratarifárias, em contraposição às tarifárias e às não-tarifárias. Seriam paratarifárias as medidas que acrescem o custo das importações de uma maneira análoga às medidas tarifárias, calculadas por alíquotas ad valorem ou específicas por unidade de medida ou mediante base de cálculo fixa (pauta fiscal).

Poderiam ser divididas, segundo a UNCTAD, em quatro tipos de incidências tributárias: os adicionais de impostos aduaneiros ("surtaxes douanières"), de caráter claramente protecionista ou arrecadatório, caracterizando evidente intuito de burla ao sistema GATT/OMC; os encargos adicionais ("impositions additionnelles"), que também não possuem equivalentes internos e que corresponderiam às incidências previstas no Artigo VIII do GATT e que poderiam ser os ODC; os tributos e encargos interiores sobre as importações ("taxes et impositions intérieures sur les importations"), que seriam aqueles aos quais se aplica o Artigo III e, por último, a "évaluation en douane sur la base d'une valeur fixe". No entanto, embora na mesma categoria, como a de tributos interiores, que poderiam ser subdivididos em impostos sobre vendas (como o Retail Sales Tax norteamericano), em impostos sobre o valor agregado (como o IVA comunitário europeu) ou em impostos sobre o faturamento (como as nossas atuais contribuições para o PIS/PASEP e COFINS, na modalidade cumulativa), os tributos interiores típicos possuem código diferenciado (2300) em relação aos impostos seletivos (2310), segundo a $\mathrm{UNCTAD}^{72}$.

${ }^{71}$ O TRAINS (TRade Analysis and INformation System) é um banco de dados, mantido e alimentado pela
UNCTAD, que proporciona acesso online a indicadores de medidas de política comercial nacionais (como
mencionado no sítio, tarifas, paratarifas e medidas não tarifárias, ou, juridicamente falando, encargos
aduaneiros, ajustes fiscais de fronteira e impostos seletivos, e medidas regulatórias), assim como dados sobre
importações por fornecedor, discriminados por classificação de seis dígitos no Sistema Harmonizado, para
cento e cinquenta países do mundo. Também provê notas explicativas por país, discorrendo sobre regimes
comerciais de aproximadamente quarenta países em desenvolvimento, descrevendo condições de acesso a
mercado, de acordo com a classificação do "UNCTAD Coding System of Trade Control Measures". Não deve
ser confundido com o WITS (World Integrated Trade Solution), elaborado em conjunto com o Banco
Mundial, que compreende também séries temporais. Ver em http://www.unctad.org/Templates/WebFlyer.asp?intItemID=2177\&lang=1, acesso em 01/06/2009. 72 " 2300

Taxes et impositions intérieures sur les importations

L'Article III de l'Accord général autorise l'application de taxes intérieures aux produits importés; toutefois, ces taxes ne doivent pas être appliquées de manière à protéger la production nationale. L'impôt général sur les ventes prélevé sur les importations équivaut aux taxes intérieures appliquées à la totalité ou à la plupart des produits. On peut distinguer trois types de taxes intérieures. En premier lieu, l'impôt généralement dénommé impôt sur les ventes, qui est une imposition ad valorem sur le produit brut des ventes de marchandises, prélevée à intervalles réguliers auprès des commerçants. En deuxième lieu, l'impôt sur le chiffre d'affaires ou taxe en cascade sur les ventes, qui est imposé à plusieurs niveaux de la production et de 
A comprovar que não só os ajustes fiscais de fronteira são capituláveis no Artigo III, como também o são os impostos seletivos ou específicos (excise taxes), recentemente, o Secretariado do OSC da OMC deferiu, em 30 de agosto e $1^{\circ}$ de outubro de 2002, os requerimentos para instalação de Grupos Especiais, formulados pelo Brasil em 26 de março e 19 de agosto de 2002, no caso WT/DS250 - "United States - Equalizing Excise Tax imposed by Florida on processed orange and grapefruit products". Tratava-se de reclamação do Brasil, com base nos Artigos II:1(a), III.1 e III:2 do GATT/1994, contra tributo do tipo excise tax, criado pelo Estado da Flórida nos Estados Unidos (Section 601.155, Florida Statutes), denominado Equalizing Excise Tax, incidente sobre produtos processados derivados da laranja ou da toranja (grapefruit) a partir de frutas cultivadas fora dos Estados Unidos. Embora o simples deferimento para a instalação dos Grupos Especiais já denote um juízo de viabilidade, não chegou a haver julgamento da matéria, já que, em 2 de junho de 2004 os países envolvidos, Brasil e Estados Unidos notificaram o OSC da OMC, nos termos do Artigo 3.6 do Entendimento relativo às Normas e Procedimentos sobre Solução de Controvérsias, que a Assembleia Legislativa da Flórida (Florida Legislature), em 30 de abril de 2004, havia emendado a referida norma, o que havia sido sancionado pelo governador daquele estado em 12 de maio de 2004 (WT/DS250/3, $\mathrm{G} / \mathrm{L} / 680)$.

Certo é também, como se verá, que no exame do caso "United States Measures Affecting Alcoholic and Malt Beverages", avaliou-se o caráter discriminatório de diversos benefícios fiscais referentes a excise taxes estaduais sobre bebidas nos Estados Unidos. No entanto, não foi detectada a presença de tratamentos discriminatórios no que se

la distribution, et qui est basé sur les recettes brutes, ce qui entraîne une accumulation des prélèvements. En troisième lieu, la taxe sur la valeur ajoutée, qui est un impôt sur le chiffre d'affaires modifié basé sur la valeur ajoutée nette et non plus sur les recettes brutes, ce qui évite l'accumulation des prélèvements et qui ne modifie ni la structure des prix, ni la répartition des ressources.

Les droits d'accises (contributions indirectes) à l'importation équivalent au droit d'accise appliqué à la production intérieure, qui est une taxe intérieure prélevée sur certaines catégories de produits, en général de luxe ou autres que de première nécessité, les boissons alcoolisées et les tabacs, par exemple. Il s'agit de droits ad valorem ou spécifiques, distincts de l'impôt général sur les ventes et qui viennent s'y ajouter. Les taxes somptuaires, les taxes sur les produits de luxe, les taxes sur les produits ou à la consommation sont toutes de même nature que les droits d'accises. C'est pourquoi, dans la Base de données, toutes ces taxes sont codées comme droits d'accises. Dans certains pays, la taxe à la consommation est similaire à l'impôt sur les ventes, car elle s'applique à tous les produits, alors que, dans d'autres, les taxes d'application générale sont parfois appelées droits d'accises; dans les deux cas, le code 2310 leur est affecté. Les impositions pour les catégories de produits sensibles comprennent des impositions pour émissions, des taxes de produits et des charges administratives. Ces dernières charges sont utilisées pour récupérer les frais des systèmes de contrôle administratif. Ces taxes ont normalement un équivalent interne. Certaines taxes équivalent à des impositions internes qu'il est difficile d'assimiler à des impôts sur les ventes, par exemple les taxes de péréquation sur les apports industriels, la patente fondée sur une proposition arbitraire de bénéfices, etc., sont classées pour des raisons pratiques avec les impôts et charges sur les ventes prélevés à l'importation, n.d.a." 
referia às incidências em si. Também no caso "Chile - Bebidas Alcoólicas", "73, que examinar-se-á com vagar, a incidência contestada era restrita às bebidas destiladas.

Indagação que se pode fazer, especialmente diante de uma realidade como a brasileira, em que predominam operadoras de recintos alfandegados de controle estatal, quer sejam empresas públicas (como a Empresa Brasileira de Infra-estrutura Aeroportuária - INFRAERO) ou sociedades de economia mista (como a Companhia Docas do Estado de São Paulo - CODESP), é se valores cobrados por tais empresas, por serviços prestados, como armazenagem, capatazia, arrumação e congêneres, denominadas taxas ou tarifas (como, por exemplo, as previstas na Lei ${ }^{\circ}$ 6.009, de 26 de dezembro de 1973), estariam dentro do escopo do art. III - por hipótese, se poderia ou não haver discriminação entre os valores cobrados sobre tais operações aplicadas a produtos importados em proveito daqueles cobrados em relação aos produtos nacionais destinados à exportação.

A princípio, não estariam subsumidas à vedação ao Princípio de Nãodiscriminação, até porque a norma do artigo XVII do GATT, que faz expressa referência ao "princípio geral de não discriminação adotado pelo presente Acordo", direciona-se apenas às compras ou vendas por parte de "empresas comerciais do Estado",74. Também por tais "tarifas" ou "taxas" consistirem obrigações de direito privado, ainda que, muitas vezes, previstas em lei, tal aplicabilidade deve se considerar descartada, pois prevalece o entendimento doutrinário de que empresas privadas não estariam obrigadas a tratar

\footnotetext{
73 “Chile - Taxes on Alcoholic Beverages”, WT/DS87/R, WT/DS110/R, 15 de junho de 1999.

${ }^{74}$ Na redação da Lei no 313/48:

“ARTIGO XVII - TRATAMENTO NÃO DISCRIMINATÓRIO POR PARTE DAS EMPRESAS COMERCIAIS DO ESTADO
}

1. a) Cada Parte Contratante que funde ou mantenha uma empresa de Estado, seja onde for, ou que conceda de direito ou de fato, a qualquer empresa privilégios exclusivos ou especiais compromete-se a que essa empresa, em suas compras ou vendas que tenham por origem ou por conseqüência importações ou exportações, se conforme ao princípio geral de não discriminação adotado pelo presente Acordo para as medidas de natureza legislativa ou administrativa relativas às importações ou exportações efetuadas pelos comerciantes particulares.

b) As disposições da alínea (a) do presente parágrafo deverão ser interpretadas como impondo a essas empresas a obrigação, levadas devidamente em conta as outras disposições do presente Acordo, de proceder às compras e vendas dessa natureza inspirando-se unicamente em considerações de ordem comercial, inclusive no que diz respeito ao preço, à qualidade, às quantidades disponíveis, às possibilidades de venda, aos transportes e outras indicações de compra ou venda, e como impondo a obrigação de oferecer às empresas de outras Partes Contratantes todas as facilidades de livre concorrência nas vendas ou compras dessa natureza, de acôrdo com as práticas comerciais usuais,

c) Nenhuma Parte Contratante impedirá qualquer emprêsa quer se trate ou não de uma emprêsa mencionada na alínea (a) do presente parágrafo sujeita à sua jurisdição, de agir de acôrdo com os princípios enunciados nas alíneas (a) e (b) do presente parágrafo.

2) As disposições do parágrafo primeiro do presente artigo não se aplicarão às importações de produtos destinados a serem imediata ou finalmente consumidos pelos poderes públicos ou por sua conta e não a serem revendidos ou a servirem à produção de mercadorias destinadas à venda. No que diz respeito a tais importações, cada parte contratante concederá ao comércio das outras Partes Contratantes um tratamento leal e eqüitativo". 
igualmente o produto nacional em relação ao importado (MOTA, 2005, p. 125 e JACKSON, 1969, p. 289 - 290).

Mas nem sempre temos comunhão de entendimentos doutrinários. A propósito, deve-se ressaltar poder ser encontrada controvérsia na doutrina internacional quanto ao objeto do tratamento nacional, pois há aqueles que entendem serem unicamente visados por tal princípio os chamados impostos indiretos, assim entendidos aqueles relacionados na nota de rodapé $\mathrm{n}^{\circ} 58$ ao Anexo I (Lista Ilustrativa de Subsídios à Exportação) do Acordo sobre Subsídios e Medidas Compensatórias ${ }^{75}$ (ZARRILLI, 2003), entendimento que é quase unânime na doutrina especializada (BOURGEOIS, 2005, p. 127 - 128).

No entanto, Jacques Bourgeois (2005, p. 128) também informa que algumas partes contratantes do GATT já alegaram no passado que os tributos diretos que possuíssem efeitos discriminatórios na venda de seus produtos poderiam ser entendidos como contrários ao Artigo III.

Pedro Infante Mota e Ricardo H. da Palma Borges (2005), por sua vez, entendem que não só o art. III do GATT, como também o art. XVII do Acordo Geral sobre o Comércio de Serviços (GATS) e o art. $3^{\circ}$ do Acordo sobre Aspectos dos Direitos de Propriedade Intelectual Relacionados ao Comércio (TRIPS), todos celebrados por ocasião do encerramento da Rodada Uruguai de negociações, em função do emprego do termo "utilização de produtos", podem se referir a impostos diretos ${ }^{76}$, malgrado toda a imprecisão terminológica intrínseca ao conceito $^{77}$. Seria o caso, por exemplo, de alíquotas diferenciadas para veículos automotores nacionais e importados, em se tratando de imposto sobre o patrimônio, ou, para impostos sobre a renda, por meio de taxas diferenciadas de depreciação para itens do ativo permanente imobilizados, caso nacionais ou importados, ou diferenciados critérios de avaliação do ativo, por exemplo.

Matsushita, Schoenbaum e Mavroidis (2003, p. 168), diferentemente, negam expressamente tal hipótese, na medida em que o que qualificam de impostos diretos, por serem incidentes sobre a renda ou produtores, não sobre os produtos, não teriam sido objeto da norma do artigo III, já que o seu ônus tributário não poderia ser transferido para o

\footnotetext{
75 "O termo "impostos indiretos" significa tributos sobre vendas, consumo, volume de negócio, valor acrescido, franquias, selo, transmissões, estoques e equipamentos, ajustes fiscais na fronteira e todos os impostos além dos que se denominam impostos diretos e direitos de importação".

${ }^{76}$ Segundo a mesma nota de rodapé, o termo "impostos diretos" significa "impostos sobre salários, lucros, juros, rendas, direitos de autor e todas as outras formas de ganho, além de impostos sobre a propriedade de bens imóveis".

${ }^{77}$ Os acordos internacionais sobre comércio, ao regrar matéria tributária, empregam conceito equivocado dos termos impostos diretos e indiretos, mais próximo à classificação doutrinária, no Brasil, em reais e pessoais. A esse respeito, ver minha dissertação de mestrado (BRITO FILHO, 2003).
} 
seu adquirente, o contribuinte de fato, embora eles mesmos reconheçam que a questão da repercussão econômica dos tributos não possa ser tratada com tanta simplicidade ${ }^{78}$. Como corretamente afirma John H. Jackson (2000, p. 220), tanto os tributos diretos quanto os indiretos oneram parcialmente tanto os consumidores quanto os detentores do capital, dependendo das características particulares da estrutura de mercado e do bem sendo comercializado, apenas havendo variações nos respectivos percentuais, dependendo da situação.

A questão de aplicar ou não as disposições do GATT também gerou muita discussão quando do advento do Imposto sobre o Valor Adicionado (IVA) na então Comunidade Econômica Europeia, o que suscitou, como veremos, no fim da década de 60 e início da de 70 do Século XX, vigoroso debate acerca do tema dos ajustes fiscais de fronteira e sua aplicabilidade aos tributos ditos diretos, assim como os efeitos concorrenciais decorrentes dessa opção por parte do sistema.

Por outro lado, não há dúvida que a incidência sobre a renda propriamente dita não se presta ao controle da não-discriminação, ao menos a partir do exame das normas do GATT. Tal se comprova pela natureza diferenciada da tributação da renda dos residentes em relação a dos não-residentes, o que é da própria essência da incidência pessoal (TORRES, 2001, p. 133, entre outras).

A par disso, não há dúvida que, especialmente no que tange à apuração (não propriamente à incidência) do imposto de renda das pessoas jurídicas, é possível se vislumbrar o emprego discriminatório de normas relacionadas à formação de sua base imponível.

Em verdade, o emprego do termo "utilização de produtos" pelo artigo III do GATT sugere a aplicabilidade a algo mais do que simplesmente os impostos sobre a circulação econômica. Mas isso não quer dizer que a irrefutável afirmação de Heleno Torres não deva ser considerada. Então, a solução é entender que a tributação direta pode ser sim objeto de disputas com base no GATT, desde que não seja relacionada com a própria incidência em si, mas com algum mecanismo de apuração que possa ser discriminatório autonomamente. A título de ilustração, hipotético, se o benefício da depreciação acelerada incentivada, no Imposto de Renda brasileiro autorizado a ser instituído pelo art. $57, \S 5^{\circ}$, da Lei $\mathrm{n}^{\mathrm{o}} 4.506 / 64$, for aplicável apenas aos valores de

\footnotetext{
${ }^{78}$ Para um estudo definitivo sobre a questão da translação dos impostos, ver o trabalho definitivo de Maffeo Pantaleoni, "Teoria della Translazione dei Tributti”.
} 
aquisição dos bens, máquinas e equipamentos, destinados ao Ativo Não-circulante ${ }^{79}$ Imobilizado, que sejam de produção nacional, teríamos em tese um caso de discriminação explícita, salvo se justificado nos termos das exceções dos Artigos XX e XXI. É o caso, por exemplo, do benefício fiscal previsto no art. 320 do Regulamento do Imposto de Renda (Decreto $n^{\circ} 3.000 / 99$ ), com base legal no Decreto-Lei $n^{\circ} 2.433$, de 1988, art. $6^{\circ}$, inciso III, e na Lei $\mathrm{n}^{\mathrm{o}}$ 8.661, de 1993, arts. $8^{\circ}$ e 13, destinados ao fomento dos Programas de Desenvolvimento Tecnológico Industrial - PDTI, aprovados até 3 de junho de $1993^{80}$.

Outro aspecto relevante a ser considerado, e já esclarecido em julgamentos anteriores do OSC, refere-se a que mercadorias seria aplicável o artigo III. O próprio Órgão de Apelação, no caso “Japão - Bebidas Alcoólicas II”, afirmou que, embora o artigo terceiro venha topologicamente em sequência à lista de concessões tarifárias do artigo II, isso não quer dizer que apenas os produtos relacionados nas chamadas "tarifas consolidadas" estejam protegidos pela não-discriminação trazida pela cláusula do tratamento nacional. Embora a proteção das concessões tarifárias negociadas seja um dos objetivos do artigo III, o que já foi declarado no caso “Japan - Customs Duties, Taxes and Labelling Practices on Imported Wines and Alcoholic Beverages " ${ }^{\text {, }}$, ainda no regime do GATT anterior a 1995, já que de nada adiantaria que os direitos de importação reduzidos viessem a ser anulados em seus efeitos por impostos internos discriminatórios, o tratamento nacional aplica-se a todos os produtos comercializados no país de importação ${ }^{82}$.

Em verdade, a interpretação teleológica que se deve dar a esse que é o cerne do entendimento quanto ao espírito que norteia o acordo, concernente à intelecção conjunta dos seus três primeiros artigos, é o de que, ao lado das concessões tarifárias negociadas em primeiro lugar, e que consistiam a própria gênese do Direito Internacional do Comércio, em uma perspectiva histórica, assim como sua extensão a todos os demais países com os quais o acordante comercie ou venha a comerciar (intenção da cláusula de nação mais favorecida, como se verá adiante), haveria que se atentar para a possibilidade de tais

\footnotetext{
${ }^{79} \mathrm{Na}$ nova denominação determinada pela alteração do art. 178 da Lei $\mathrm{n}^{\circ} 6.404 / 76$ consoante o art. 36 da Medida Provisória $n^{\circ} 449$, de 3 de dezembro de 2008, convertido no art. 37 da Lei n 11.941 , de 27 de maio de 2009.

80 "Art. 320. As empresas que executarem, direta ou indiretamente, Programas de Desenvolvimento Tecnológico Industrial no País, sob sua direção e responsabilidade diretas, aprovados até 3 de junho de 1993, poderão usufruir do benefício da depreciação acelerada das máquinas, equipamentos, aparelhos e instrumentos, novos, de produção nacional, nas condições fixadas em regulamento".

${ }^{81}$ BISD 34S/83, parágrafo. 5.5, doravante denominado "Japão - Bebidas Alcóolicas I".

82 "Although the protection of negotiated tariff concessions is certainly one purpose of Article III, the statement in Paragraph 6.13 of the Panel Report that "one of the main purposes of Article III is to guarantee that WTO Members will not undermine through internal measures their commitments under Article II" should not be overemphasized. The sheltering scope of Article III is not limited to products that are the subject of tariff concessions under Article II" - WT/DS8/AB/R, WT/DS10/AB/R, WT/DS11/AB/R, item F.
} 
renúncias de soberania, no comércio internacional propriamente dito, viessem acompanhadas de plena igualdade de concorrência entre produto nacional e importado no mercado interno do país renunciante.

É, pois, como ressaltam Trebilcock e Howse (2005, p. 83), uma norma a disciplinar as políticas públicas internas dos Estados-Membros de um regime de liberalização do comércio e a sua justificativa principal é o acanhado alcance que a disciplina do comércio multilateral se propôs a possuir, até como requisito à sua viabilização. Na Comunidade Europeia, contrariamente, fenômeno de integração econômica em que se assegura, desde o Tratado de Roma, plena liberdade no comércio de bens, surgem muito menos questionamentos acerca do entendimento de cláusula análoga. Não é por outro motivo que os mesmos autores $(2005$, p. 84) afirmam que a cláusula do tratamento nacional é uma questão de jurisprudência, demandando acentuado labor hermenêutico na ponderação entre a necessidade de evitar o protecionismo discriminatório e, ao mesmo tempo, preservar a autonomia regulatória, ínsita ao regime democrático, dos países contratantes.

No dizer de Matsushita, Schoenbaum e Mavroidis (2003, p. 3 e 153), a cláusula de tratamento nacional visa preponderantemente ao acesso a mercados, com o fim de assegurar que as concessões tarifárias funcionem em sua plenitude e não venham a ser boicotadas por outras medidas soberanas dos contratantes. $\mathrm{Na}$ verdade, tal visão está plenamente adequada á uma sistematização do sistema GATT como a aqui empreendida a regra que consagra o princípio como instrumento de efetivação do objetivo de proporcionar pleno acesso a mercados.

Como se verá, tal característica está contemplada em diversos termos do artigo III, e mais especificamente na parte final de seu parágrafo 1, no seu objetivo (e de todo o acordo geral, de resto) de que os tributos (assim como as regulamentações) internos não devem ser aplicados "a produtos importados ou nacionais, de modo a proteger a produção nacional" ${ }^{\prime 3}$, sendo uma - talvez a principal - das chaves históricas e hermenêuticas para entender o princípio da não-discriminação ${ }^{84}$.

\footnotetext{
83 "The Article III national treatment obligation is a general prohibition on the use of internal taxes and other internal regulatory measures so as to afford protection to domestic production. This obligation clearly extends also to products not bound under Article II. This is confirmed by the negotiating history of Article III' - WT/DS8/AB/R, WT/DS10/AB/R, WT/DS11/AB/R, item F.

${ }_{84}$ "At the Second Session of the Preparatory Committee of the United Nations Conference on Trade and Employment, held in 1947, delegates in the Tariff Agreement Committee addressed the issue of whether to include the national treatment clause from the draft Charter for an International Trade Organization ("ITO Charter") in the GATT 1947. One delegate noted:
} 
O fato é que o próprio OSC ainda não se definiu quanto ao real alcance desse conceito (que se denominará efeito protetivo) à produção nacional e de como o princípio da não-discriminação deve ter seu conteúdo jurídico perfeitamente construído, a ponto de estudiosos como Donald H. Regan (2002, p. 443) afirmarem que o OSC está andando em círculos ${ }^{85}$ no entendimento desse aspecto.

A doutrina (ZARRILLI, 2003, p. 370; TREBILCOCK; HOWSE, 2005, p. 83 84 e REGAN, 2002, p. 447, entre outros) e o OSC da OMC, desde o caso "United States Section 337 of the Tariff Act of 1930", de 7 de novembro de $1989^{86}$ têm se manifestado no sentido de que o objetivo amplo e fundamental do artigo III do GATT é evitar o protecionismo no mercado interno, tanto no aspecto tributário quanto no regulatório, obrigando as partes contratantes a assegurar igualdades competitivas entre o produto nacional e o importado ${ }^{87}$.

Assim, diferentemente da Comunidade Europeia, que preferiu assegurar a igualdade de competição interna em matéria de tributação de mercadorias e serviços pela via da harmonização positiva e negativa do imposto sobre o valor acrescido, ao mesmo tempo em que impunha limites e regramentos aos impostos especiais de consumo,

This Article in the Charter had two purposes, as I understand it. The first purpose was to protect the items in the Schedule or any other Schedule concluded as a result of any subsequent negotiations and agreements that is, to ensure that a country offering a tariff concession could not nullify that tariff concession by imposing an internal tax on the commodity, which had an equivalent effect. If that were the sole purpose and content of this Article, there could really be no objection to its inclusion in the General Agreement. But the Article in the Charter had an additional purpose. That purpose was to prevent the use of internal taxes as a system of protection. It was part of a series of Articles designed to concentrate national protective measures into the forms permitted under the Charter, i.e. subsidies and tariffs, and since we have taken over this Article from the Charter, we are, by including the Article, doing two things: so far as the countries become parties to the Agreement, we are, first of all, ensuring that the tariff concessions they grant one another cannot be nullified by the imposition of corresponding internal taxes; but we are also ensuring that those countries which become parties to the Agreement undertake not to use internal taxes as a system of protection.

This view is reinforced by the following statement of another delegate:

... [Article III] is necessary to protect not only scheduled items in the Agreement, but, indeed, all items for all our exports and the exports of any country. If that is not done, then every item which does not appear in the Schedule would have to be reconsidered and possibly tariff negotiations re-opened if Article III were changed to permit any action on these non-scheduled items" - WT/DS8/AB/R, WT/DS10/AB/R, WT/DS11/AB/R, nota de rodapé 39.

85 “(C)ome full circle", no original em inglês.

${ }^{86}$ BISD 36S/345, parágrafo 5.10.

87 "The broad and fundamental purpose of Article III is to avoid protectionism in the application of internal tax and regulatory measures. More specifically, the purpose of Article III "is to ensure that internal measures 'not be applied to imported or domestic products so as to afford protection to domestic production'". Toward this end, Article III obliges Members of the WTO to provide equality of competitive conditions for imported products in relation to domestic products. "[T] he intention of the drafters of the Agreement was clearly to treat the imported products in the same way as the like domestic products once they had been cleared through customs. Otherwise indirect protection could be given" - WT/DS8/AB/R, WT/DS10/AB/R, $\mathrm{WT} / \mathrm{DS} 11 / \mathrm{AB} / \mathrm{R}$, item F. 
especialmente empregando a harmonização negativa ou de segundo grau ${ }^{88}$, os países signatários do GATT preferiram manter intactas as suas soberanias fiscais ${ }^{89}$, a menos da obediência aos ditames, principalmente, do artigo III $^{90}$.

Como visto, apresentadas as formulações gerais relacionadas à cláusula do tratamento nacional por meio do parágrafo primeiro do artigo III, há que serem examinadas aquelas que o Órgão de Apelação, no caso "Japão - Bebidas Alcoólicas II", caso paradigmático na sua inteleção jurisprudencial, denominou de "obrigações específicas", previstas no parágrafo segundo ${ }^{91}$.

\subsubsection{Art. III:2 (não-discriminação tributária).}

O parágrafo 2 do artigo III do GATT disciplina o tratamento nacional em relação a tributos e outras exigências internas. Ocorre que sua redação se dá por meio de duas frases, razão pela qual o OSC da OMC, pelo Órgão de Apelação, no mencionado caso “Japão - Bebidas Alcoólicas II", entendeu que a sua intelecção deveria ser diferenciada para cada um deles autonomamente ${ }^{92}$.

O elemento de diferenciação entre as duas frases do parágrafo segundo é o seu objeto de aplicação, para o OSC da OMC, o que desencadeia toda uma disciplina diferenciada, como veremos a seguir: se a norma jurídica nacional cuja adequação à cláusula do tratamento nacional está sendo submetida à análise encerra dentro de si uma expressa diferenciação de tratamento quanto à origem do produto $^{93}$, situação em que

\footnotetext{
${ }^{88}$ Para entender como se operou essa evolução, ver minha dissertação de mestrado (BRITO FILHO, 2003).

89 "The purpose of Article III is not to harmonize the internal taxes and regulations of contracting parties, which differ from country to country” - BISD/39S/206, parágrafo 5.71.

90 "Members of the WTO are free to pursue their own domestic goals through internal taxation or regulation so long as they do not do so in a way that violates Article III or any of the other commitments they have made in the WTO Agreement" - WT/DS8/AB/R, WT/DS10/AB/R, WT/DS11/AB/R, item F.

91 "The purpose of Article III:1 is to establish this general principle as a guide to understanding and interpreting the specific obligations contained in Article III:2 and in the other paragraphs of Article III, while respecting, and not diminishing in any way, the meaning of the words actually used in the texts of those other paragraphs. In short, Article III:1 constitutes part of the context of Article III:2, in the same way that it constitutes part of the context of each of the other paragraphs in Article III" - WT/DS8/AB/R, WT/DS10/AB/R, WT/DS11/AB/R, item G.

92 "Any other reading of Article III would have the effect of rendering the words of Article III: 1 meaningless, thereby violating the fundamental principle of effectiveness in treaty interpretation. Consistent with this principle of effectiveness, and with the textual differences in the two sentences, we believe that Article III:I informs the first sentence and the second sentence of Article III:2 in different ways" - WT/DS8/AB/R, WT/DS10/AB/R, WT/DS11/AB/R, item G.

93 "Origin specific measures", na versão original empregada pela doutrina, em inglês (FAUCHALD, 2003, p. 443).
} 
teremos o que a doutrina denomina "discriminação de jure" (TREBILCOCK; HOWSE, 2005, p. 72) ou explícita (FAUCHALD, 2003, p. 444) ou tributação discriminatória (UCKMAR, 2002, p. 1118); ou se, do exame formal da norma não é possível, a priori, identificar qualquer traço discriminatório - normas neutras em relação à origem do produto $^{94}$-, o que se alcança apenas com o exame (mediante critérios diferenciados) da efetividade da medida. Nesse caso, teremos uma "discriminação de facto" (TREBILCOCK; HOWSE, 2005, p. 72) ou implícita (FAUCHALD, 2003, p. 444) ${ }^{95}$ ou tributação protetiva (UCKMAR, 2002, p. 1118).

Ilustrando um caso do que seria a tributação protetiva ou discriminação implícita ou de facto, John H. Jackson (1989, p. 212 - 213), em exemplo que se tornou clássico na doutrina, menciona uma situação que efetivamente foi realidade, e que ocorreu, como é comum, na tributação de bebidas, nos Estados Unidos, por sinal o país do qual grande parte das normas do GATT proveio. Uma lei americana previa uma alíquota específica de US\$ 10,50 para cada galão de prova ou galão de vinho ${ }^{96}$, seja de bebida produzida nos Estados Unidos, seja de bebida importada. Um galão de vinho consistia simplesmente em uma galão da bebida, independentemente do quão estava concentrada. Um galão de prova consistia em um galão de bebida, qualquer uma, à concentração de 50 $\%$ de álcool. Ora, o comerciante varejista da mercadoria nacional poderia, depois de a bebida ser tributada, diluí-la e engarrafá-la para a venda no local. Em se tratando de bebida estrangeira, tal artifício não poderia ser feito, uma vez que o engarrafamento já havia sido realizado, pelo que não haveria como proceder à operação de planejamento fiscal sem perder a característica da mercadoria de ser produzida no exterior, o que é relevante na diferenciação do produto, no caso de vinhos e uísques, por exemplo. Assim, supondo-se uma bebida com teor de pureza de $43 \%$, o tributo incidente sobre o galão produzido domesticamente cairia para US\$9,03, configurando nítida vantagem competitiva para o produto nacional.

\footnotetext{
94 "Origin neutral measures", na versão original empregada pela doutrina, em inglês (FAUCHALD, 2003, p. 443).

${ }^{95}$ Embora seja francamente predominante na doutrina internacional o uso da díade discriminação "de jure" "de facto", deve ser acatado o argumento de Ole K. Fauchald de que tais termos encerram possibilidade de equívoco, uma vez que, no caso "Canada - Certain Measures Affecting the Automotive Industry" (WT/DS139/AB/R, parágrafo 78), o Órgão de Apelação usou tal dicotomia para diferenciar tratamentos discriminatórios com fulcro em normas administrativas baseadas em leis vinculantes daqueles fundados em meras práticas administrativas sem fundamento legal. O emprego dos termos implícita e explícita, por sua vez, não acarreta tal risco de ambiguidade, sem falar que é mais corriqueiro no direito brasileiro, razão pela qual será adiante efetivado.

96 “(...) each proof gallon or wine gallon when below proof”, no original em inglês.
} 
Mais ainda apropriada explicação do que seria a discriminação implícita ou de facto ou a tributação protetiva foi dada no dia 5 de junho de 1947, no Nono Encontro da Segunda Sessão do Comitê Preparatório da UNCTAD que elaborava o que viria a se constituir no GATT. Discutindo o que viria a ser a segunda frase do Artigo III:2, o representante do Reino Unido, Mr. R. J. Shackle, ilustrou com o caso de um país que fizesse uma concessão tarifária para a importação de laranjas, mas não as produzisse internamente. Poderia, à luz da primeira frase, a única que existia então, tributar pesadamente por meio de um imposto interno a importação de laranjas, de modo a que os consumidores passassem a consumir maçãs, que são produzidas no país, de tão caras que se tornaram as laranjas ${ }^{97}$.

No exame do caso "Japão - Bebidas Alcoólicas II", o Órgão de Apelação estabeleceu consideração que se tornou clássica acerca da intelecção das duas frases do parágrafo 2 do artigo III. A partir de considerações acerca de normas sobre interpretação de tratados, a partir do exame dos artigos 31 e 32 da Convenção de Viena sobre o Direito dos Tratados, entendeu-se que a única interpretação que conseguiria contemplar maior carga semântica possível aos termos das duas frases do parágrafo 2 do artigo III, especialmente na forma como elas se relacionam com o parágrafo primeiro, seria atribuindo a cada uma delas sentido diferenciado, como veremos a seguir ${ }^{98}$.

Em verdade, no exame do caso "Japão - Bebidas Alcoólicas I", a segregação dos sentidos entre as duas frases já havia sido esclarecida, a partir de considerações acerca da história da concepção do GATT, consentâneas com as ideias já aqui mencionadas, de preservar a neutralidade das políticas tributárias do ponto de vista do comércio internacional, de forma a prover igualdade de condições no mercado nacional dos Estados

\footnotetext{
97 "Mr. R.J. SHACKLE (United Kingdom): Mr. Chairman, I would say this: that I would agree, I think, that paragraph 1 of this Article, as it is drawn, is too widely worded. At the same time, I think there is quite a definite case for the addition which the United States suggests to make to the end of the present paragraph 2. I might illustrate by an example. Let us suppose that some country in its negotiations has secured the binding of the duty on oranges. Country A gots a duty on the binding of oranges from Country B. Now, Country B after that can proceed to put on an internal duty of any height at all on oranges, seeing that it grows no oranges itself. But by putting on that very high duty on oranges, it protects the apples which it grows itself. The consequence is that the binding duty which Country A has secured from Country B on its oranges is made of no effect, because in fact the price of oranges is pushed so high by this internal duty that no one can buy them. The consequence is that the object of that binding is defeated. It seems to me that that is a point that has got to be taken care of, and I think that the United States amendment is well-conceived to take care of $i t^{\prime \prime}$. E/PC/T/A/PV/9, p. 7.

98 "In short, Article III:1 constitutes part of the context of Article III:2, in the same way that it constitutes part of the context of each of the other paragraphs in Article III. Any other reading of Article III would have the effect of rendering the words of Article III:1 meaningless, thereby violating the fundamental principle of effectiveness in treaty interpretation. Consistent with this principle of effectiveness, and with the textual differences in the two sentences, we believe that Article III:1 informs the first sentence and the second sentence of Article III:2 in different ways" - WT/DS8/AB/R, WT/DS10/AB/R, WT/DS11/AB/R, item G.
} 
Partes $^{99}$, embora não ainda da forma aprimorada como a desenvolvida posteriormente e que veremos a seguir ${ }^{100}$.

\subsubsection{Art. III:2, $1^{\text {a }}$ frase (discriminação explícita).}

Como se disse anteriormente, no exame do caso "Japão - Bebidas Alcoólicas II", o Órgão de Apelação entendeu que a sua primeira frase ${ }^{101}$ aplica-se unicamente aos casos em que a própria norma combatida estabelece a discriminação entre o produto nacional e o importado, expressamente - são os casos de discriminação implícita.

Tal consideração será mais bem entendida na próxima seção, quando for examinada a segunda frase, mas prende-se, basicamente, ao fato de que a nota interpretativa ao parágrafo segundo (também examinada adiante) não faz referência à expressão, prevista no parágrafo primeiro, ao final, como visto, "de modo a proteger a produção nacional", a identificar a tendência de repressão ao protecionismo que seria a intenção da disciplina da cláusula do tratamento nacional.

Para o Órgão de Apelação, a omissão à referência a tão importante cláusula deveria ter algum significado. Não obstante, esse significado não poderia ser o de que a preocupação com o protecionismo fosse dispensada no caso das hipóteses previstas na primeira frase. Ao contrário, teria como escopo apenas não exigir que se empreendesse um

\footnotetext{
99 “c) The drafting history confirms that Article III:2 was designed with "the intention that internal taxes on goods should not be used as a means of protection" (see: UN Conference on Trade and Employment, Reports of Committees, 1948, page 61). As stated in the 1970 Working Party Report on Border Tax Adjustments in respect of the various GATT provisions on taxation, "the philosophy behind these provisions was the ensuring of a certain trade neutrality" (BISD 18S/99). This accords with the broader objective of Article III "to provide equal conditions of competition once goods had been cleared through customs" (BISD 7S/64), and to protect thereby the benefits accruing from tariff concessions. This object and purpose of Article III: 2 of promoting non-discriminatory competition among imported and like domestic products could not be achieved if Article III:2 were construed in a manner allowing discriminatory and protective internal taxation of imported products in excess of like domestic products" - L/6216, BISD 34S/83, de 13 de outubro de 1987, parágrafo 5.5 .

100 "The Panel concluded that the ordinary meaning of Article III:2 in its context and in the light of its object and purpose supported the past GATT practice of examining the conformity of internal taxes with Article III:2 by determining, firstly, whether the taxed imported and domestic products are "like" or "directly competitive or substitutable" and, secondly, whether the taxation is discriminatory (first sentence) or protective (second sentence of Article III:2)" - parágrafo 5.5, in fine.

${ }^{101} \mathrm{Na}$ redação do Decreto Legislativo $n^{\circ} 43 / 50$ :

“2. Os produtos do território de qualquer parte contratante, importados por outra parte contratante, não estão sujeitos, direta ou indiretamente, a impostos ou outros tributos internos de qualquer espécie superiores aos que incidem, direta ou indiretamente, sobre produtos nacionais".
} 
teste separado para aferir esse intento ${ }^{102}$. Seria como que houvesse, nesses casos, uma presunção juris et de jure de intenção protecionista (MELLONI, 2005, p. 160), a não demandar e não permitir qualquer indagação a respeito. Haveria, portanto, uma medida, em função do descumprimento de obrigações contraídas no acordo, que autorizaria a se caracterizar o fato de pleno direito como de anulação ou redução ${ }^{103}$ de benefícios, nos termos do artigo 3.8 do Acordo sobre Solução de Controvérsias ${ }^{104}$, baseado na previsão do artigo XXIII do Acordo Geral ${ }^{105}$, com presunção de efeitos desfavoráveis ao país

102 "Article III:1 informs Article III:2, first sentence, by establishing that if imported products are taxed in excess of like domestic products, then that tax measure is inconsistent with Article III. Article III:2, first sentence does not refer specifically to Article III:1. There is no specific invocation in this first sentence of the general principle in Article III:1 that admonishes Members of the WTO not to apply measures "so as to afford protection". This omission must have some meaning. We believe the meaning is simply that the presence of a protective application need not be established separately from the specific requirements that are included in the first sentence in order to show that a tax measure is inconsistent with the general principle set out in the first sentence. However, this does not mean that the general principle of Article III:1 does not apply to this sentence. To the contrary, we believe the first sentence of Article III:2 is, in effect, an application of this general principle. The ordinary meaning of the words of Article III:2, first sentence leads inevitably to this conclusion" - WT/DS8/AB/R, WT/DS10/AB/R, WT/DS11/AB/R, item H.1.

${ }^{103}$ Embora o texto da norma que internalizou a disposição no Brasil, o Decreto ${ }^{\circ} 1.355 / 94$, como se vê abaixo, tenha empregado o termo "Restrição". Trata-se de desacordo em relação à tradução do termo em inglês "Impairment". Aqui se adotará o termo "Redução", que é o previsto no Artigo XXIII:1 do GATT, também transcrito um pouco mais abaixo, além de ser o que mais claramente traduz o alcance do instituto. Regina Maria de Souza Pereira, em O Conceito de Anulação ou Prejuízo de Benefícios no Contexto da Evolução do GATT à OMC. Rio de Janeiro: Renovar, 2003, prefere o termo "Prejuízo". Significa, em termos gerais, que o sistema GATT/OMC presume relativamente que toda violação, total ou parcial, a qualquer norma convencional, produz efeitos desfavoráveis para outros Membros que sejam partes do acordo abrangido, que de outra maneira dele se beneficiariam.

${ }^{104}$ Nos termos do Anexo 2 ao Decreto $\mathrm{n}^{\circ}$ 1.355/94: "8. Nos casos de não cumprimento de obrigações contraídas em virtude de um acordo abrangido, presume-se que a medida constitua um caso de anulação ou de restrição. Isso significa que normalmente exista a presunção de que toda transgressão das normas produz efeitos desfavoráveis para outros Membros que sejam partes do acordo abrangido, e em tais casos a prova caberá ao Membro contra o qual foi apresentada a reclamação”.

105 “ARTIGO XXIII

PROTEÇÃO DE CONCESSÕES E VANTAGENS

1. No caso de uma Parte Contratante considerar que uma vantagem qualquer resultante para ela, direta ou indiretamente, do presente Acordo, está sendo anulada ou reduzida, ou que um dos objetivos do Acordo está sendo dificultado, em conseqüência:

(a) do não cumprimento por outra das Partes Contratantes dos compromissos pela mesma assumidos em virtude do presente Acordo;

(b) da aplicação por outra das Partes Contratantes de uma medida, contrária ou não às disposições do presente Acordo; ou

(c) da existência de qualquer outra situação,

dita Parte Contratante, a fim de obter solução satisfatória para a questão, poderá dirigir representações ou propostas por escrito à outra ou outras Partes Contratantes que lhe parecerem interessadas. Qualquer Parte Contratante, por essa forma interpelada, examinará, com boa vontade, as representações ou propostas que lhe tenham sido dirigidas.

2. Se as Partes Contratantes interessadas não chegarem a um Acordo satisfatório dentro de um prazo razoável, ou se a dificuldade for uma das previstas no $§ 1$ (c) deste artigo, a questão poderá ser submetida às Partes Contratantes. As Partes Contratantes iniciarão, sem demora, uma investigação sobre qualquer assunto que lhes seja submetido e, se julgarem conveniente, dirigirão recomendações especiais e apropriadas às partes Contratantes que julguem interessadas, ou baixarão normas sobre a questão. As Partes Contratantes, quando acharem necessário, poderão efetuar consultas com as outras Partes Contratantes, com o Conselho Econômico e Social das Nações Unidas e com qualquer outra organização intergovernamental competente. Se elas consideram que as circunstâncias são suficientemente graves para justificar uma tal medida, poderão 
exportador, dispensando maiores esforços probatórios. É o que ocorre, pois, no caso de discriminação explícita.

Tal interpretação vem ao encontro da formulação de Horn e Mavroidis (2004, p. 39 - 40), para quem a única concepção do escopo do Artigo III apta a conciliar tanto a visão de cunho econômico, favorável ao sistema multilateral de proteção ao comércio exterior, como meio de proporcionar a eficiência econômica, quanto a abordagem desfavorável, de índole político-institucional, que abomina a restrição à soberania ínsita à imposição de soluções econômicas importadas de modelos teóricos neoclássicos, impondo custos aos países, especialmente os de menos desenvolvimento, é entender que o compromisso primordial do GATT e, em consequência, de toda a disciplina multilateral, não são as concessões tarifárias, senão o de não usar o poder soberano estatal, tanto de imposição tributária quanto do exercício do poder de polícia administrativo, de forma a proteger o produto originado no próprio país, evitando, portanto, a criação de condições artificiais de competitividade. Tal obrigação, entendem, é de tal maneira fundamental, que provisões sobre tratamento nacional perpassam toda a disciplina, tanto do Acordo Geral, quanto dos complementares.

Restaria, assim, ao OSC da OMC, quando deparado com algum caso de discriminação explícita, em que se estivesse aplicando a subsunção do fato à norma da primeira frase do segundo parágrafo do artigo III do GATT, que apenas examinasse dois aspectos: i) se o produto importado e o produto nacional seriam similares e ii) se os impostos ou outros tributos internos aplicados ao produto importado seriam "superiores" aos incidentes sobre o nacional ${ }^{106}$.

Entrando rapidamente no entendimento do OSC da OMC quanto a esses dois aspectos, já que nossa preocupação repousa principalmente sobre o entendimento da segunda frase, é exatamente porque a primeira frase não emprega o termo similar, ou

autorizar uma ou várias Partes Contratantes a suspender, com respeito a tal outra ou tais outras Partes Contratantes, a aplicação de qualquer concessão ou outra obrigação resultantes do Acordo geral cuja suspensão justificada elas examinarão, levando em conta as circunstâncias. Se uma tal concessão ou outra obrigação, for efetivamente suspensa com respeito a uma Parte Contratante, será permitido à referida Parte Contratante, no prazo de 60 dias, a contar da data da aplicação desta suspensão, notificar por escrito ao Secretário Executivo4 das Partes Contratantes, sua intenção de denunciar o Acordo geral; esta denúncia se efetuará ao término do prazo de 60 dias, contados a partir da data em que o Secretário executivo das Partes Contratantes tiver recebido a aludida notificação".

106 "Read in their context and in the light of the overall object and purpose of the WTO Agreement, the words of the first sentence require an examination of the conformity of an internal tax measure with Article III by determining, first, whether the taxed imported and domestic products are "like" and, second, whether the taxes applied to the imported products are "in excess of" those applied to the like domestic products. If the imported and domestic products are "like products", and if the taxes applied to the imported products are "in excess of" those applied to the like domestic products, then the measure is inconsistent with Article III:2, first sentence" - WT/DS8/AB/R, WT/DS10/AB/R, WT/DS11/AB/R, item H.1. 
similares, que se deve entender que o espectro de similaridade aplicável à possibilidade de discriminação explícita deve ser o mais estreito possível, análise a ser empreendida de forma casuística ${ }^{107}$, fundamentalmente baseada nas características físicas do produto ou a sua classificação fiscal, sem maiores considerações sobre condições de competitividade.

Quanto ao sentido do termo "superiores", o OSC da OMC também adotou interpretação restritiva, admitindo que apenas um pequeno excesso seria suficiente à caracterização da infringência a essa primeira frase. Não seria necessária uma análise do efeito genérico da norma no comércio entre os países contendores, em uma defesa que a doutrina qualifica de "de minimis" - baseada no dano irrisório (ORTINO, 2004, p. 238) ${ }^{108}$.

Ponto relevante que se relaciona com o amplo entendimento que se deve dar à primeira frase do Artigo III:2 é o alcance da locução "outros tributos internos de qualquer espécie". De se notar que, ao que parece, tem-se aqui mais uma impropriedade na tradução empreendida em português, ja que o texto em inglês ${ }^{109}$ contrapõe impostos ("taxes") a outros encargos de qualquer natureza (“charges of any kind") e não impostos a tributos, norma com alcance evidentemente muito mais limitado. Interessante é observar que a segunda frase em inglês também emprega os mesmos termos, ao passo que a tradução do

107 "Because the second sentence of Article III:2 provides for a separate and distinctive consideration of the protective aspect of a measure in examining its application to a broader category of products that are not "like products" as contemplated by the first sentence, we agree with the Panel that the first sentence of Article III:2 must be construed narrowly so as not to condemn measures that its strict terms are not meant to condemn. Consequently, we agree with the Panel also that the definition of "like products" in Article III:2, first sentence, should be construed narrowly.

How narrowly is a matter that should be determined separately for each tax measure in each case. We agree with the practice under the GATT 1947 of determining whether imported and domestic products are "like" on a case-by-case basis" - WT/DS8/AB/R, WT/DS10/AB/R, WT/DS11/AB/R, item H.1.a.

108 "The only remaining issue under Article III:2, first sentence, is whether the taxes on imported products are "in excess of" those on like domestic products. If so, then the Member that has imposed the tax is not in compliance with Article III. Even the smallest amount of "excess" is too much. "The prohibition of discriminatory taxes in Article III:2, first sentence, is not conditional on a 'trade effects test' nor is it qualified by a de minimis standard." We agree with the Panel's legal reasoning and with its conclusions on this aspect of the interpretation and application of Article III:2, first sentence" - WT/DS8/AB/R, WT/DS10/AB/R, WT/DS11/AB/R, item H.1.b.

109 "1. The contracting parties recognize that internal taxes and other internal charges, and laws, regulations and requirements affecting the internal sale, offering for sale, purchase, transportation, distribution or use of products, and internal quantitative regulations requiring the mixture, processing or use of products in specified amounts or proportions, should not be applied to imported or domestic products so as to afford protection to domestic production.

2. The products of the territory of any contracting party imported into the territory of any other contracting party shall not be subject, directly or indirectly, to internal taxes or other internal charges of any kind in excess of those applied, directly or indirectly, to like domestic products. Moreover, no contracting party shall otherwise apply internal taxes or other internal charges to imported or domestic products in a manner contrary to the principles set forth in paragraph 1."

E a Nota Interpretativa ao Artigo III:2:

"A tax conforming to the requirements of the first sentence of paragraph 2 would be considered to be inconsistent with the provisions of the second sentence only in cases where competition was involved between, on the one hand, the taxed product and, on the other hand, a directly competitive or substitutable product which was not similarly taxed." 
direito positivo brasileiro acerta apenas na segunda tentativa. Não obstante, não há qualquer diferença do ponto de vista do alcance material das normas entre as duas frases nesse aspecto.

Portanto, trata-se de indagar em que sentido as disposições do GATT abrangem apenas as incidências tributárias do ponto de vista eminentemente material ou também outras sistemáticas de tributação.

Tal questão foi dirimida no exame do caso "Argentina - Measures Affecting the Export of Bovine Hides and the Import of Finished Leather". Entre outras reclamações referentes aos procedimentos administrativos de exportação de partes de bovinos que, a propósito, dão nome ao caso, também foi arguído, pelas Comunidades Europeias, em relação a todas as importações realizadas pela República Argentina, de todos os bens, que o "Impuesto al Valor Agregado" (IVA), incidente não só sobre as vendas de bens dentro do território argentino, mas também no caso de importações definitivas de bens no território do país platino, à alíquota geral de $21 \%$, mas aplicável à carne bovina a 10,5\%, encerrava uma sistemática de tributação desigual em relação ao produto importado.

A Resolución General n 3.431, de 19 de novembro de 1991, da Administración Federal de Ingresos Públicos - Dirección General Impositiva (“AFIP-DGI”), no exercício da autorização dada pelo art. 27 da lei do IVA, de regulamentar a tributação na fonte desse imposto, conferiu à Administración Nacional de Aduanas o poder de ser seu agente coletor e determinou que as autoridades aduaneiras estavam autorizadas a exigir ("percibir"), além do IVA ordinário, incidente sobre a importação definitiva do bem, um montante adicional, qque poderia ser creditado pelo importador quando da revenda do bem, no caso de importação por contribuinte do IVA. Se a importação fosse realizada por não-contribuinte, não haveria direito ao crédito, obviamente, mas permaneceria a cobrança do adicional, porém em montante menor. Esse adicional seria de $5 \%$ para partes de bovinos e $10 \%$ para outros bens, no caso de importador não-contribuinte, e 5,8 \% para partes de bovinos e 12,7 $\%$ para outros bens, se o importador fosse contribuinte. Assim, como as bases de cálculo são as mesmas, o montante total exigido na importação era de $15,5 \%$ para partes de bovinos e $31 \%$ para outros bens, do importador não-contribuinte; no caso de importador contribuinte, de $16,3 \%$ para partes de bovinos e $33,7 \%$ para outros bens.

Por outro lado, a Resolución General no 3.337, de 7 de março de 1991, também da AFIP-DGI, determinou que houvesse também essa retenção na fonte do IVA nas operações internas, desde que se tratasse de venda a contribuinte do IVA, que poderia se apropriar do respectivo crédito. O montante adicional corresponderia a $5 \%$ do imposto 
calculado na operação principal. Assim, o montante total exigido nas operações em território argentino deveria ser de 15,5\% para partes de bovinos e $26 \%$ para outros bens.

Além disso, a Resolución General n ${ }^{\circ}$ 3.543, de 7 de julho de 1992, também da AFIP-DGI, determinou às autoridades aduaneiras que exigissem, no ato do despacho aduaneiro de importação, a título de adiantamento de "Impuesto de Ganancias" (IG, o imposto direto sobre a renda federal), compensável no mesmo exercício fiscal, à alíquota de $3 \%$ da base de cálculo do IVA, se importação de bem destinado à revenda; ou $11 \%$, se para consumo próprio.

Diante dessas normas, as Comunidades Europeias requereram ao Grupo Especial que declarassem o adicional do IVA e o adiantamento do IG nas importações como inconsistentes com o Artigo III:2, primeira frase. O Grupo Especial foi claro em entender que as normas em análise implicavam maior carga pecuniária e, portanto, plenamente aplicável no caso o Artigo III: $2^{110}$, uma vez que se constituíam em encargos de qualquer natureza.

Mais importante ainda do que essa afirmação foi a constatação, logo após, pelo mesmo Grupo Especial, quando da verificação do conceito de impostos "superiores", de que o que está em jogo no exame da aplicabilidade do Artigo III:2, em ambas as frases, não é meramente o exame nominal da alíquota do tributo incidente, mas o montante real, material, do ônus tributário que recai sobre os produtos, nacional ou importado, sejam eles similares ou diretamente competidores ou substitutos ${ }^{111}$. Assim, as obrigações do Artigo III têm de ser vistas do ponto de vista econômico, relacionado à carga tributária amplamente considerada, e não apenas jurídico, inclusive em termos de custos financeiros e de oportunidade $^{112}$. De se ressaltar apenas que o caso "Argentina-Measures Affecting the

\footnotetext{
110 "11.143 We consider that RG 3431 and RG 3543 are properly viewed not as taxes in their own right, but as mechanisms for the collection of the IVA and IG. What is special, however, about RG 3431 and RG 3543 as mechanisms for the collection of the IVA and IG is that they provide for the imposition of charges. We recall that Article III:2 covers "charges of any kind" (emphasis added). The term "charge" denotes, inter alia, a "pecuniary burden" and a "liability to pay money laid on a person..." ${ }^{430}$. There can be no doubt, in our view, that both $R G 3431$ and $R G 3543$ impose a pecuniary burden and create a liability to pay money. ${ }^{431}$ Moreover, the charges provided for in $R G 3431$ and $R G 3543$ represent advance payments of the IVA and IG. $R G 3431$ and $R G 3543$ in effect impose on importers part of their definitive IVA and IG liability. ${ }^{432}$ It is clear to us, therefore, that the charges in question qualify as tax measures. As such, they fall to be assessed under Article III:2".

111 "11.183 We consider that Article III:2, first sentence, requires a comparison of actual tax burdens rather than merely of nominal tax burdens. Were it otherwise, Members could easily evade its disciplines. Thus, even where imported and like domestic products are subject to identical tax rates, the actual tax burden can still be heavier on imported products. This could be the case, for instance, where different methods of computing tax bases lead to a greater actual tax burden for imported products".

112 "11.184 It may thus be stated, in more general terms, that a determination of whether an infringement of Article III:2, first sentence, exists must be made on the basis of an overall assessment of the actual tax burdens imposed on imported products, on the one hand, and like domestic products, on the other hand.
} 
Export of Bovine Hides and the Import of Finished Leather", encerrou-se com a decisão do Grupo Especial, não tendo sido ela objeto de apelação.

Essa formulação econômica do conceito de ônus tributário previsto no Artigo III:2 não é algo reiteradamente mencionado das decisões do sistema GATT/OMC. Apenas em uma outra situação, no exame do caso "Japão - Bebidas Alcoólicas I", cujo relatório do Grupo Especial foi adotado em 10 de novembro de 1987, L/6216, BISD 34S/83, pode-se perceber a sua adoção ${ }^{113}$. Não obstante sua extemporaneidade, devida muito mais à natureza das demandas até agora submetidas às análises da adequação ao Artigo III, uma formulação ampla, material, do Artigo III:2 do GATT, como as aqui mencionadas deve ser vista como um bom exemplo de como se deve interpretar a norma convencional de forma a densificar sua carga normativa.

\subsubsection{Art. III:2, $2^{\mathrm{a}}$ frase (discriminação implícita).}

Quanto à segunda frase do segundo parágrafo do artigo III ${ }^{114}$, a situação tornase diferenciada por dois motivos. O primeiro, pela expressa referência, malgrado o erro de impressão na versão brasileira, aos princípios estabelecidos no parágrafo 1. Ademais, a existência de uma nota interpretativa, de função precipuamente aclaradora, a esse parágrafo segundo ${ }^{115}$ em que expressamente se estão submetendo as "taxas" (rectius, impostos ou tributos) que foram aprovadas no teste da primeira frase a uma nova análise,

(...)

11.188 It is clear to us that both of these situations give rise to a financial burden, an opportunity "cost" in one case and a debt financing "cost" in the other. ${ }^{474}$ Likewise, it is readily apparent that that financial burden is incidental to and directly caused by $R G 3431$ and $R G 3543 .{ }^{475}$ For these reasons, it is properly regarded as an integral part of the actual tax burden imposed by $R G 3431$ and $R G 3543 .{ }^{476}$ As such, it falls squarely within the scope of Article III:2, first sentence".

113 "The Panel further found that the wording "directly or indirectly" and "internal taxes... of any kind" implied that, in assessing whether there is tax discrimination, account is to be taken not only of the rate of the applicable internal tax but also of the taxation methods (e.g. different kinds of internal taxes, direct taxation of the finished product or indirect taxation by taxing the raw materials used in the product during the various stages of its production) and of the rules for the tax collection (e.g. basis of assessment)" - parágrafo 5.8, in fine.

${ }^{114}$ Na redação do Decreto Legislativo $n^{\circ} 43 / 50$ :

"2 Além disso, nenhuma parte contratante aplicará, de outro modo, impostos ou outros encargos internos a produtos importados nacionais, contrariamente as (sic) principais (sic) estabelecidas no parágrafo 1."

${ }^{115} \mathrm{Na}$ redação do Decreto Legislativo no 43/50:

"Parágrafo 2. Uma taxa que satisfaça às prescrições da primeira frase do parágrafo 2 somente deve ser considerada como incompatível com as prescrições da segunda frase nos casos em que haja concorrência entre de um lado, o produto taxado e de outro, um produto diretamente competidor ou que possa ser substituto direto e que não seja taxado igualmente". 
são motivos para entender-se que a segunda frase aduz requisitos mais amplos a serem preenchidos para o tributo em exame na análise de seu caráter discriminatório ou não.

Então, segundo o Órgão de Apelação, haveria três questões a ser enfrentadas no exame da adequação de um tributo à segunda frase do parágrafo segundo do artigo III: i) se os produtos importados e os produtos nacionais são diretamente competidores ou possam ser substitutos diretos; ii) se o produto importado diretamente competidor ou substituível pelo nacional não é tributado igualmente ao local e iii) se a tributação desigual não está sendo aplicada a produtos importados ou nacionais diretamente competidores ou substituíveis "de modo a proteger a produção nacional"116.

Quanto ao primeiro item, acerca da condição de competitividade entre os produtos e da sua condição de substitutos, o Órgão de Apelação entendeu que o mais importante seria a pesquisa à situação de mercado dos produtos, o que poderia ser aferido mediante a verificação, entre outros critérios, da elasticidade-preço cruzada da demanda ${ }^{117}$ entre os produtos ${ }^{118}$.

\footnotetext{
116 "Unlike that of Article III:2, first sentence, the language of Article III:2, second sentence, specifically invokes Article III:1. The significance of this distinction lies in the fact that whereas Article III:1 acts implicitly in addressing the two issues that must be considered in applying the first sentence, it acts explicitly as an entirely separate issue that must be addressed along with two other issues that are raised in applying the second sentence. Giving full meaning to the text and to its context, three separate issues must be addressed to determine whether an internal tax measure is inconsistent with Article III:2, second sentence. These three issues are whether:

(1)the imported products and the domestic products are "directly competitive or substitutable products" which are in competition with each other;

(2)the directly competitive or substitutable imported and domestic products are "not similarly taxed"; and

(3)the dissimilar taxation of the directly competitive or substitutable imported domestic products is "applied ... so as to afford protection to domestic production".

Again, these are three separate issues. Each must be established separately by the complainant for a panel to find that a tax measure imposed by a Member of the WTO is inconsistent with Article III:2, second sentence". WT/DS8/AB/R, WT/DS10/AB/R, WT/DS11/AB/R, item H.2.

${ }^{117}$ Elasticidade-preço cruzada da demanda, ou simplesmente elasticidade cruzada da demanda, mede quão sensíveis são os consumidores de um determinado bem em relação a variações de preço de um outro bem. Se for positiva, os bens são substitutos - há uma potencial concorrência no gosto dos consumidores quando da opção por um ou pelo outro. Se for negativa, os bens são complementares - a preferência dos consumidores é consumir ambos em conjunto. Se for nula ou próxima de zero, isso significa que os bens não competem entre si (WONNACOTT, P; WONNACOTT, R., 2004, p. 479 - 501).

118 "In this case, the Panel emphasized the need to look not only at such matters as physical characteristics, common end-uses, and tariff classifications, but also at the "market place". This seems appropriate. The GATT 1994 is a commercial agreement, and the WTO is concerned, after all, with markets. It does not seem inappropriate to look at competition in the relevant markets as one among a number of means of identifying the broader category of products that might be described as "directly competitive or substitutable".

Nor does it seem inappropriate to examine elasticity of substitution as one means of examining those relevant markets. The Panel did not say that cross-price elasticity of demand is "the decisive criterion" for determining whether products are "directly competitive or substitutable". The Panel stated the following: In the Panel's view, the decisive criterion in order to determine whether two products are directly competitive or substitutable is whether they have common end-uses, inter alia, as shown by elasticity of substitution" - WT/DS8/AB/R, WT/DS10/AB/R, WT/DS11/AB/R, item H.2.a.
} 
Portanto, abandonar-se-ia a confrontação meramente a partir de características intrínsecas ao produto (físicas ou jurídicas), como se deveria empreender em se tratando da primeira frase, para se alcançar uma visão de natureza concorrencial e econômica quanto à convivência entre o produto nacional e o importado, não necessariamente idênticos do ponto de vista físico.

Tal realidade veio a se solidificar com a edição do Relatório do Grupo de Trabalho sobre Ajustes Fiscais de Fronteira, que, em seu parágrafo 18, sugere, a identificar o que seriam produtos diretamente competidores ou substitutos diretos, a partir de critérios microeconômicos relacionados com a inserção dos produtos no mercado, tais como seus usos finais, os hábitos e gostos dos consumidores, assim como as propriedades dos produtos, sua natureza e qualidade ${ }^{119}$. A análise seria, portanto, de natureza microecômica e, é fundamental ser ressaltado, precipuamente voltada para o exame das condições de concorrência sob o enfoque do consumidor.

Essa visão do Grupo de Trabalho sobre Ajustes Fiscais de Fronteira tem sido consolidada doutrinariamente, como em artigo de Marco Bronckers e Natalie McNelis (2000, p. 345 - 348), como sendo uma acepção econômica das condições de competitividade dos produtos analisados, a partir de critérios de mercado, dentro de uma perspectiva do consumidor, denominada "Market Based Approach".

No que tange à verificação de estar se caracterizando tributação desigual entre o produto nacional e o estrangeiro, o Órgão de Apelação novamente fez questão de estabelecer distinção bastante clara entre os tratamentos jurídicos a serem adotados para cada uma das frases que compõem o parágrafo segundo, novamente diante da necessidade e conferir interpretação que não esvaziasse a letra do tratado, conferindo a iniciativa de construção de significado autônomo à nota interpretativa ao parágrafo 2 do artigo III.

A conclusão a que o Órgão de Apelação chegou é a de que o conceito de tributação desigual da segunda frase encerraria dentro de si uma relevância distintiva maior que a de tributo superior da primeira frase. Haveria, portanto, uma quantidade de tributação

\footnotetext{
119 "18. With regard to the interpretation of the term "... like or similar products ...", which occurs some sixteen times throughout the General Agreement, it was recalled that considerable discussion had taken place in the past, both in GATT and in other bodies, but that no further improvement of the term had been achieved. The Working Party concluded that problems arising from the interpretation of the term should be examined on a case-by-case basis. This would allow a fair assessment in each case of the different elements that constitute a "similar" product. Some criteria were suggested for determining, on a case-by-case basis, whether a product is "similar": the product's end-uses in a given market; consumers' tastes and habits, which change from country to country; the product's properties, nature and quality. It was observed, however, that the term "... like or similar products ..." caused some uncertainty and that it would be desirable to improve on it; however, no improved term was arrived at".
} 
diferenciada que poderia se caracterizar como superior no sentido da frase primeira, mas não chagar a constituir tributação desigual para o efeito de gerar a desaprovação no teste previsto na segunda frase. Valeria, portanto, o chamado argumento de minimis, a, eventualmente, tornar escusável o tributo distintivo à luz da segunda frase ${ }^{120}$.

A doutrina entende que a razão para esse entendimento também se insere em uma perpectiva da preferência dos consumidores. Se os produtos não são assim tão similares de modo que são apenas substitutos ou competidores, uma pequena diferença no ônus tributário não iria afetar o comportamento dos consumidores senão marginalmente, de forma que as condições de competitividade entre o produto nacional e o importado necessitariam de uma defasagem tributária maior para que houvesse efeito nas respectivas curvas de demanda que justificasse se vislumbrar no caso a existência de proteção ao nacional (HORN; WEILER, 2003, p. 10).

Exatamente em função dessas distinções hermenêuticas formuladas pelo OSC, especialmente no caso "Japão - Bebidas Alcoólicas II", que Trebilcock e Howse (2005, p. 86) qualificam a primeira frase como proibidora da tributação discriminatória; a segunda, da tributação protetiva - na mesma linha de sistematização formulada por Antonio Uckmar (2002, p. 1118).

Até esse ponto, as conclusões do OSC no caso "Japão - Bebidas Alcoólicas II", por esse ser o primeiro caso envolvendo uma norma tributária formalmente neutra em relação à origem após o advento da OMC e a criação do seu Órgão de Apelação, consistiram e consistem em formulações clássicas e irrefutáveis acerca da correta intelecção das referidas normas, especialmente o artigo III, primeiro e segundo parágrafos, e, nesse, suas duas frases componentes. Assim, trata-se de entendimentos que foram

\footnotetext{
120 "To interpret "in excess of" and "not similarly taxed" identically would deny any distinction between the first and second sentences of Article III:2. Thus, in any given case, there may be some amount of taxation on imported products that may well be "in excess of" the tax on domestic "like products" but may not be so much as to compel a conclusion that "directly competitive or substitutable" imported and domestic products are "not similarly taxed" for the purposes of the Ad Article to Article III:2, second sentence. In other words, there may be an amount of excess taxation that may well be more of a burden on imported products than on domestic "directly competitive or substitutable products" but may nevertheless not be enough to justify a conclusion that such products are "not similarly taxed" for the purposes of Article III:2, second sentence. We agree with the Panel that this amount of differential taxation must be more than de minimis to be deemed "not similarly taxed" in any given case.57 And, like the Panel, we believe that whether any particular differential amount of taxation is de minimis or is not de minimis must, here too, be determined on a case-bycase basis. Thus, to be "not similarly taxed", the tax burden on imported products must be heavier than on "directly competitive or substitutable" domestic products, and that burden must be more than de minimis in any given case". - WT/DS8/AB/R, WT/DS10/AB/R, WT/DS11/AB/R, item H.2.b.
} 
seguidos nos outros casos similares apresentados à $\mathrm{OMC}$, também referentes à tributação: os casos "Coreia - Bebidas Alcoólicas"121 e "Chile - Bebidas Alcoólicas".

Por outro lado, o mesmo não se pode dizer do terceiro ponto de verificação quanto à subsunção à vedação prevista na segunda frase do parágrafo segundo: se a tributação desigual não está sendo aplicada a produtos importados ou nacionais diretamente competidores ou substituíveis "de modo a proteger a produção nacional", empregando a expressão do final do parágrafo primeiro. Nesse ponto, não só no entendimento à luz da discriminação tributária, mas também em confrontação com a utilização do requisito por meio do parágrafo quarto (discriminação regulatória), o OSC tem andado em círculos, como afirma Regan (2002, p. 443), e, o que é pior, a própria doutrina tem sido instável em aplaudir ou criticar as diferentes razões de decidir em que são fundamentadas tais decisões díspares (REGAN, 2002, p. 444).

A situação de indefinição acerca de como avaliar a existência ou não de cunho protetivo em uma medida legal ou regulamentar nacional é de tal forma evidente que Mattia Melloni (2005, p. 160) menciona que, à luz da jurisprudência do OSC da OMC, proteção é um conceito fluido e diversionista.

Como melhor ilustração dessa realidade, podemos nos ater à investigação sobre a relevância da pesquisa quanto à intenção do legislador na verificação do caráter protecionista da norma examinada. Segundo Melloni (2005, p. 168), o uso da expressão "de modo a proteger a produção nacional" "122 aparentemente induz a que preste atenção na intenção da norma. Porém, as formulações sobre tal indagação são radicalmente díspares na jurisprudência do OSC: por vezes a nega absolutamente ${ }^{123}$, por vezes a adota apenas no sentido objetivo, a partir da própria estrutura da norma tributária ${ }^{124}$, por vezes a verifica

\footnotetext{
121 "Korea - Taxes on Alcoholic Beverages", WT/DS75/AB/R, WT/DS84/AB/R, 17 de fevereiro de 1999.

122 "So as to afford protection to domestic production", ou, mais resumidamente, como adota a doutrina internacional em peso, SATAP - por exemplo, Mattia Melloni (2005, p. 2).

123 "This third inquiry under Article III:2, second sentence, must determine whether "directly competitive or substitutable products" are "not similarly taxed" in a way that affords protection. This is not an issue of intent. It is not necessary for a panel to sort through the many reasons legislators and regulators often have for what they do and weigh the relative significance of those reasons to establish legislative or regulatory intent. If the measure is applied to imported or domestic products so as to afford protection to domestic production, then it does not matter that there may not have been any desire to engage in protectionism in the minds of the legislators or the regulators who imposed the measure. It is irrelevant that protectionism was not an intended objective if the particular tax measure in question is nevertheless, to echo Article III:1, "applied to imported or domestic products so as to afford protection to domestic production". This is an issue of how the measure in question is applied". WT/DS8/AB/R, WT/DS10/AB/R, WT/DS11/AB/R, "Japan Taxes on Alcoholic Beverages", de 4 de outubro de 1996, item H.2.c.

124 "14.115. In light of the foregoing finding under Article III:2, first sentence, we consider that it would not be necessary to examine the same programmes under Article III:2, second sentence. We note, however, that any imported motor vehicle that would be directly competitive or substitutable to a domestic product at issue, would not be taxed similarly to a National Car or to a finished motor vehicle that meets a certain local
} 
quanto ao aspecto subjetivo, como intenção originária do legislador ${ }^{125}$. Diante dessa

content value. Indeed the large tax differential (for instance under the 1996 car programmes, National Cars are completely exempted from sales tax and under the 1993 car programme - as modified by Regulation No. 36/1996 - domestic sedans below 1600cc and with greater than 60\% local content are exempted from sales tax while imported sedans or domestic sedans with $60 \%$ or less local content are subject to a sales tax of $35 \%)$ is clear evidence that the relevant products are not similarly taxed. Finally, the nature of the discrimination, which is to promote a national industry by giving it advantages vis-à-vis imported products, is clearly designed so as to afford protection to domestic production, contrary to the second sentence of Article III:2 of GATT.

14.116 We find therefore that the various measures adopted pursuant to the Indonesian car programmes under examination, are inconsistent with Article III:2 first and second sentences, in that the structure of the tax scheme is such that imported products are taxed in excess of domestic like products and imported products which are directly competitive or substitutable to domestic products are also necessarily not similarly taxed so as to afford protection to the domestic production of such products" - WT/DS54/R, WT/DS55/R, WT/DS59/R, WT/DS64/R, "Indonesia - Certain Measures Affecting the Automobile Industry", de 2 de julho de 1998.

125 "Although it is true that the aim of a measure may not be easily ascertained, nevertheless its protective application can most often be discerned from the design, the architecture, and the revealing structure of a measure. The very magnitude of the dissimilar taxation in a particular case may be evidence of such a protective application, ... Most often, there will be other factors to be considered as well. In conducting this inquiry, panels should give full consideration to all the relevant facts and all the relevant circumstances in any given case.

With respect to Part V.1 of the Excise Tax Act, we note that the magnitude of the dissimilar taxation between imported split-run periodicals and domestic non-split-run periodicals is beyond excessive, indeed, it is prohibitive. There is also ample evidence that the very design and structure of the measure is such as to afford protection to domestic periodicals.

The Canadian policy which led to the enactment of Part V.1 of the Excise Tax Act had its origins in the Task Force Report. It is clear from reading the Task Force Report that the design and structure of Part V.1 of the Excise Tax Act are to prevent the establishment of split-run periodicals in Canada, thereby ensuring that Canadian advertising revenues flow to Canadian magazines. Madame Monique Landry, Minister Designate of Canadian Heritage at the time the Task Force Report was released, issued the following statement summarizing the Government of Canada's policy objectives for the Canadian periodical industry:

The Government reaffirms its commitment to protect the economic foundations of the Canadian periodical industry, which is a vital element of Canadian cultural expression. To achieve this objective, the Government will continue to use policy instruments that encourage the flow of advertising revenues to Canadian magazines and discourage the establishment of split-run or 'Canadian' regional editions with advertising aimed at the Canadian market. We are committed to ensuring that Canadians have access to Canadian ideas and information through genuinely Canadian magazines, while not restricting the sale of foreign magazines in Canada.

Furthermore, the Government of Canada issued the following response to the Task Force Report:

The Government reaffirms its commitment to the long-standing policy of protecting the economic foundations of the Canadian periodical industry. To achieve this objective, the Government uses policy instruments that encourage the flow of advertising revenues to Canadian periodicals, since a viable Canadian periodical industry must have a secure financial base.

During the debate of Bill C-103, An Act to Amend the Excise Tax Act and the Income Tax Act, the Minister of Canadian Heritage, the Honourable Michel Dupuy, stated the following: ... the reality of the situation is that we must protect ourselves against split-runs coming from foreign countries and, in particular, from the United States.

Canada also admitted that the objective and structure of the tax is to insulate Canadian magazines from competition in the advertising sector, thus leaving significant Canadian advertising revenues for the production of editorial material created for the Canadian market. With respect to the actual application of the tax to date, it has resulted in one split-run magazine, Sports Illustrated, to move its production for the Canadian market out of Canada and back to the United States. Also, Harrowsmith Country Life, a Canadianowned split-run periodical, has ceased production of its United States' edition as a consequence of the imposition of the tax.

We therefore conclude on the basis of the above reasons, including the magnitude of the differential taxation, the several statements of the Government of Canada's explicit policy objectives in introducing the measure and the demonstrated actual protective effect of the measure, that the design and structure of Part V.1 of the 
realidade, avulta necessária a pesquisa a alguma ferramenta, inclusive de natureza quantitativa, que torne a verificação do efeito protetivo da norma tributária algo mais estável e confiável. Tal necessidade já foi detectada no Relatório sobre Ajustes Fiscais de Fronteira, em $1970^{126}$, mas o que se vê é que um conceito fundamental à própria concepção do sistema multilateral, como o de proteção, não foi de forma alguma aclarado, como defendem Horn e Mavroidis (2004, p. 39), mesmo após tantos anos de decisões a respeito nas controvérsias internacionais mencionadas no decorrer desse texto.

Não se pode duvidar que tal realidade advém da falta de atenção que a apropriada medida da proteção vem recebendo pelos painelistas ao longo desse tempo todo, mormente se observarmos que a análise do ponto de vista do consumidor, levada a cabo a partir do conceito de produtos "diretamente competidores" ou "substitutos diretos", tem sido reiteradamente empregada, como visto.

Ao que parece, é válida a conclusão de Damien Neven (2000, p. 421), de que o lado dos produtores, ao qual o conceito de proteção é referente (ETHIER, 1971, p. 17), tem sido negligenciado porque os grupos especiais tendem a presumir que uma significativa possibilidade de substituição entre os produtos doméstico e estrangeiro por si só teria o condão de propiciar alto grau de proteção à indústria doméstica, o que nem sempre é verdadeiro. Além disso, outros fatores, como a carga de imposto de importação sobre os insumos e o efeito conjunto com os demais impostos incidentes sobre o produto, podem, potencialmente, acarretar significativas mudanças nos entendimentos exarados no histórico do OSC da OMC.

\subsubsection{Art. III:4 (não-discriminação regulatória).}

Excise Tax Act is clearly to afford protection to the production of Canadian periodicals". "Canada - Certain Measures Concerning Periodicals" - WT/DS31/AB/R, de 30 de junho de 1997, item VI, B, 3.

126 "16. The Working Party noted that there were some taxes which, while generally considered elegible for adjustment, presented a problem because of the difficulty in some cases of calculating exactly the amount of compensation. Examples of such difficulties were encountered in cascade tazes. For adjustment, countries operating cascade systems usually resorted to calculating average rates of rebate for categories of products rather than calculating the actual tax levied on a particular product. It was noted, however, that most cascade tax systems were to be replaced by TVA systems, and that therefore the area in which such problems occured was diminishing. Other examples included composite goods which, on export, contained ingredients for which the Working Party agreed in principle it was administratively sensible and sufficiently accurate to rebate by average rates for a given class of goods". 
A não-discriminação regulatória é a prevista no parágrafo 4 do Acordo Principal do GATT ${ }^{127}$ (TREBILCOCK; HOWSE, 2005, p. 86), nela sendo veiculado o relevante conceito de "tratamento não menos favorável". No entanto, os critérios de identificação desse tratamento não menos favorável têm sido empregados pelo OSC da OMC de forma análoga aos relativos à não-discriminação tributária ${ }^{128}$. Não obstante, não é objeto de análise no presente trabalho, que, como já afirmado, pretende cingir-se apenas à análise dos aspectos tributários da questão.

Ademais, pela diversidade de possibilidades que abrange, um estudo mais aprofundado do uso de medidas regulatórias de cunho protecionista - o que os economistas denominam de "barreiras não-tarifárias" - iria dilargar por demais o exame aqui focado no caráter de proteção efetiva ao processo produtivo dos Estados Contratantes e da forma como tal pode e deve ser aferido pelo OSC da OMC.

O restante do Artigo III $^{129}$, por se referir a disciplinas transitórias ou técnicas, constituem parágrafos que não possuem relevância para serem examinados.

${ }^{127}$ Na redação do Decreto Legislativo $n^{\circ} 43 / 50$ :

“4. Os produtos do território de uma parte contratante que entrem no território de outra parte contratante não usufruirão tratamento menos favorável que o concedido a produtos similares de origem nacional, no que diz respeito às leis, regulamento (sic) e exigências relacionadas com a venda, compra, transporte, distribuição e utilização no mercado interno. Os dispositivos deste parágrafo não impedirão a aplicação de tarifas de transporte internas diferenciais, desde que se baseiem exclusivamente na operação econômica dos meios de transporte e não na nacionalidade do produto".

128 "We recognize that, by interpreting the term "like products" in Article III:4 in this way, we give that provision a relatively broad product scope - although no broader than the product scope of Article III:2. In so doing, we observe that there is a second element that must be established before a measure can be held to be inconsistent with Article III:4. Thus, even if two products are "like", that does not mean that a measure is inconsistent with Article III:4. A complaining Member must still establish that the measure accords to the group of "like" imported products "less favourable treatment" than it accords to the group of "like" domestic products. The term "less favourable treatment" expresses the general principle, in Article III:1, that internal regulations "should not be applied ... so as to afford protection to domestic production". If there is "less favourable treatment" of the group of "like" imported products, there is, conversely, "protection" of the group of "like" domestic products. However, a Member may draw distinctions between products which have been found to be "like", without, for this reason alone, according to the group of "like" imported products "less favourable treatment" than that accorded to the group of "like" domestic products." "European Communities - Measures Affecting Asbestos and Asbestos-Containing Products", WT/DS135/AB/R, 12 de março de 2001, parágrafo 100.

${ }^{129} \mathrm{Na}$ redação do Decreto Legislativo no 43/50:

“3. Relativamente a qualquer imposto interno existente, incompatível com o que dispõe o parágrafo 2 , mas expressamente autorizado por um acordo comercial, em vigor a 10 de abril de 1947, no qual se estabelece o congelamento do direito de importação que recai sobre um produto à parte contratante que aplica o imposto será lícito protelar a aplicação dos dispositivos do parágrafo 2 a tal imposto, até que possa obter dispensadas obrigações desse acordo comercial, de modo a lhe ser permitido aumentar tal direito na medida necessária compensar a supressão da proteção assegurada pelo imposto.

(...)

5. Nenhuma parte contratante estabelecerá ou manterá qualquer regulamentação quantitativa interna que se relacione com a mistura, transformação ou utilização de produtos em quantidades ou proporções determinadas e que exija, direta ou indiretamente o fornecimento pelas fontes produtoras nacionais, de quantidade ou proporção determinada de um produto enquadrado na regulamentação. Além disso, nenhuma 


\subsection{Dos julgados do Órgão de Solução de Controvérsias sobre o} Artigo III.

\subsubsection{Dos Critérios de Julgamento.}

Já vimos que, em se tratando da questão da proteção, do SATAP, o "de modo a proteger", ou melhor, do efeito protetivo da tributação interna, ainda temos, na doutrina e na jurisprudência, exaustivas discussões doutrinárias, mormente diante da obscuridade dos critérios adotados até agora pelo OSC da OMC.

Diferente é a situação no que tange ao outro conceito jurídico indeterminado envolvido, o de similaridade ou substitutabilidade. Se por um lado tem sido reiteradamente entendido como devendo ser examinado caso-a-caso, como já visto, o que, a um primeiro exame, implica ausência de critério, por outro, tem sempre sido objeto da sinalização de que o seu norte principal de apreciação deve ser a inserção dos produtos em análise no mercado. Tal análise deve ser sempre empregada na ótica dos consumidores, aspecto que deve ser entendido de forma preponderante às características físicas ou de classificação

parte contratante aplicará de outro modo, regulamentações quantitativas internas, de forma a contrariar os princípios estabelecidos no parágrafo $1^{\circ}$.

6. Os dispositivos do parágrafo $5^{\circ}$ não se aplicarão a qualquer regulamentação quantitativa interna em vigor, no território de qualquer parte contratante, a 1 de julho de 1939, a 10 de abril de 1947, ou a 24 de março de 1948, à escolha da parte contratante, contanto que qualquer regulamentação dessa natureza, contrária ao que dispõe o parágrafo $5^{\circ}$, não seja modificada em detrimento de importações e seja tratada como se fosse um direito aduaneiro, para efeito de negociação.

7. Nenhuma regulamentação quantitativa interna que se relacione com a mistura, transformação ou utilização de produtos em quantidades ou proporções determinadas será aplicada, de modo a repartir qualquer quantidade, ou proporção dessa natureza entre fontes estrangeiras de suprimento.

8. (a) As disposições desse Artigo não se aplicarão às leis, regulamentos ou exigências que se refiram a aquisições, por órgão governamentais de produtos comprados para atender às necessidades dos poderes públicos e não se destinam à revenda, no comércio, ou à produção de bens para venda no comércio.

b) As disposições deste artigo não impedirão o pagamento de subsídios exclusivamente a produtores nacionais compreendidos os pagamentos a produtores nacionais com recursos provenientes da arrecadação dos impostos ou tributos internos aplicados de conformidade com os dispositivos deste Artigo e de subsídios concedidos sob a forma de compra de produtos nacionais pelos poderes públicos.

9. As partes contratantes reconhecem que as medidas internas para controle de preços máximos embora guardem conformidade com outros dispositivos deste Artigo, podem ocasionar prejuízos aos interesses das partes contratantes que fornecem os produtos importados. As partes contratantes que tomarem tais medidas levarão em conta os interesses das partes contratantes exportadoras, com o fim de evitar o mais possível, esses efeitos perniciosos".

10. Os dispositivos deste Artigo não impedirão qualquer parte contratante de estabelecer ou manter regulamentações quantitativas internas relativas à exibição de filmes cinematográficos e de atender às exigências do Artigo IV". 
fiscal, entre outras que possam ser empregadas e que já o foram em julgados mais pretéritos.

O GATT, desde a sua fase anterior à OMC, com a edição do Relatório do Grupo de Trabalho sobre Ajustes Fiscais de Fronteira, o que foi corroborado pelos julgamentos posteriores a $1^{\circ}$ de janeiro de 1995, dadas as seguidas referências a esse trabalho nas fundamentações de diversos casos, tanto nos Grupos Especiais quanto pelo Órgão de Apelação, apontou que o critério preponderante se baseia em conceitos microeconômicos, com base na preferência dos consumidores.

No caso absolutamente paradigmático, já na fase da OMC, “Japão - Bebidas Alcoólicas II", determinou-se que o julgador arbitral tem que olhar não para características físicas ou a classificação fiscal das mercadorias, mas para o mercado, pois, afinal de contas, o GATT 1994 é um acordo comercial e a OMC está preocupada com os mercados, já que busca, como já mencionado, assegurar pleno acesso a mercados em condições de igualdade de competitividade a todas as Partes Contratantes ${ }^{130}$.

Malgrado tal realidade, de parcial estabilidade, há que se tentar dar alguma sistematização aos critérios que têm sido até agora empregados pelos entes julgadores, com o fim de não só entender (ou não) a razoabilidade dos julgados, como também para tentar inserir a aplicabilidade do conceito econômico de efeito protetivo dentro desses critérios, ao menos no que tange ao exame das normas tributárias. Adotar-se-á tal caminho científico, em detrimento a uma análise detalhada dos casos concernentes, não só por conta

130 “(a) "Directly Competitive or Substitutable Products"

If imported and domestic products are not "like products" for the narrow purposes of Article III:2, first sentence, then they are not subject to the strictures of that sentence and there is no inconsistency with the requirements of that sentence. However, depending on their nature, and depending on the competitive conditions in the relevant market, those same products may well be among the broader category of "directly competitive or substitutable products" that fall within the domain of Article III:2, second sentence. How much broader that category of "directly competitive or substitutable products" may be in any given case is a matter for the panel to determine based on all the relevant facts in that case. As with "like products" under the first sentence, the determination of the appropriate range of "directly competitive or substitutable products" under the second sentence must be made on a case-by-case basis.

In this case, the Panel emphasized the need to look not only at such matters as physical characteristics, common end-uses, and tariff classifications, but also at the "market place". ${ }^{3}$ This seems appropriate. The GATT 1994 is a commercial agreement, and the WTO is concerned, after all, with markets. It does not seem inappropriate to look at competition in the relevant markets as one among a number of means of identifying the broader category of products that might be described as "directly competitive or substitutable".

Nor does it seem inappropriate to examine elasticity of substitution as one means of examining those relevant markets. The Panel did not say that cross-price elasticity of demand is "the decisive criterion" ${ }^{\prime 54}$ for determining whether products are "directly competitive or substitutable". The Panel stated the following: In the Panel's view, the decisive criterion in order to determine whether two products are directly competitive or substitutable is whether they have common end-uses, inter alia, as shown by elasticity of substitution. ${ }^{55}$

We agree. And, we find the Panel's legal analysis of whether the products are "directly competitive or substitutable products" in paragraphs 6.28-6.32 of the Panel Report to be correct" - WT/DS8/AB/R, WT/DS10/AB/R, WT/DS11/AB/R, item H.2.(a). 
da absoluta falta de sistematização dos julgadores na matéria, o que tornaria o relato casoa-caso exaustivo e muito dependente da subjetividade da linha que se fosse adotar para se elaborar os resumos dos casos, mas também por comodidade didática.

Dentro das diversas classificações de critérios encontráveis na doutrina, é o mais didático o adotado por Henrik Horn e Joseph Weiler (2003, p. 4), separando as metodologias entre objetivas e subjetivas.

\subsubsection{Testes objetivos - Teste Diagonal e Teste de Impacto Assimétrico.}

Dentro dessa proposta de conferir alguma sistematização de critérios, adotandose o de Henrik Horn e Joseph Weiler (2003, p. 4), entre métodos objetivos e subjetivos, há que se fazer a prévia ressalva de que todas as metodologias compartilham a premissa de que as Partes Contratantes do GATT e, agora, os Membros da OMC, preservam suas soberanias, mesmo após terem voluntariamente se submetido às respectivas disciplinas convencionais, de modo que podem exercer as suas competências fiscais e regulatórias de modo amplo, desde que não infrinjam as normas do Acordo Geral globalmente considerado e o Artigo III, parágrafos 2 e 4, respectivamente, em particular.

A infrigência à Cláusula do Tratamento Nacional, à qual tais normas se subsumem, tende a verificar, segundo a modalidade objetiva, meramente os efeitos que se produzem nos mercados, de forma a, como se viu, distorcer as suas condições de competitividade, objetivo fundamental de preservação do GATT, como tem entendido a doutrina e a jurisprudência.

Para Henrik Horn e Joseph Weiler (2003, p. 6), a locução SATAP é indicativa de uma proibição objetiva geral, de forma a que a tributação e a regulação não possam ser aplicadas de modo que resulte em proteção sendo concedida à produção doméstica (há um grifo no texto original). Trata-se de proibição, como vimos, e com o que concordam Horn e Weiler, aplicada à norma tributária ou regulatória que seja neutra quanto à origem ou, como tem se preferido no presente texto, que encerre uma discriminação meramente implícita. Como vimos, o efeito protetivo da norma explicitamente discriminatória é entendido como presumido absolutamente. Assim, o que esse critério tenciona ver é o efeito da norma tributária ou regulatória no mercado, do ponto de vista das relações de competitividade entre o produto nacional e o importado, não os seus objetivos ou propósitos (HORN; WEILER, 2003, p. 6). 
Segundo esse critério, ensinam (p. 7), se uma norma é explicitamente redigida com a intenção de ser protecionista, mas, por incompetência do regulador ou da administração fiscal, não alcança esse intento, não haverá infração ao Artigo III. Caso contrário, se uma norma tributária ou regulatória é elaborada com a melhor das boas intenções, mas se o seu efeito inadvertidamente é o de distorcer as condições de competitividade, será considerada discriminatória.

O que se verifica é que, após o advento do caso "Japão - Bebidas Alcoólicas I", de 1987, que Lothar Ehring (2002, p. 935) considera como o primeiro caso, ainda na era GATT, de tributo neutro na origem submetido ao exame de sua adequação ao Artigo III, a atividade do julgador arbitral tornou-se muito mais difícil (EHRING, 2002, p. 922), pois passou a ter que examinar tal situação de distorção de competitividade, no plano normativo ou no plano positivo (ou em ambos), por meio da verificação da aplicação protetiva da norma tributária, representada pela partícula SATAP. Isso sem falar das intermináveis discussões, cujo teor nesta presente tese apenas é tangenciado, já que fora do seu escopo senão para o seu uso em uma visão comparativa, acerca do conceito de produtos similares ou diretamente competitivos ou substitutos.

Uma dessas dificuldades é o receio de se estar por demais restringindo o poder impositivo soberano dos Estados em perseguir objetivos extrafiscais e não ligados à política comercial propriamente dita (EHRING, 2002, p. 922). É o caso, por exemplo da intenção, por motivos fiscais e extrafiscais, de tributar mais onerosamente bebidas alcoólicas e ainda mais pesadamente quanto maior o seu teor alcoólico. Trata-se de intenção que poderia ser legitimamente vislumbrada, mas que seria no mais das vezes rechaçada, diante da violação ao Artigo III:2, na medida em que produzisse consequências protetivas - basta ver as suas características factuais e como têm sido julgados os casos práticos da jurisprudência arbitral.

Sem querer entrar nessa outra tormentosa questão, acerca da soberania limitada que o sistema multilateral implica, é fato que há que serem estabelecidos critérios (dentro do possível) acerca do que seja exatamente o que o sistema visa a combater, de modo a conferir-lhe a previsibilidade a qual se refere Ole Fauchald (2003, p. 446).

A previsibilidade é característica que, junto com a segurança, tem a sua consecução como objetivo do sistema de solução de controvérsias da OMC, com o fim de permitir o funcionamento eficaz do sistema multilateral do comércio, consoante o Artigo 3.2 e 3.4 do Entendimento Relativo às Normas e Procedimentos sobre Solução de 
Controvérsias $^{131}$, na busca pelo OSC de solução satisfatória para o direito em litígio, de forma a respeitar os direitos e obrigações convencionados. Muito embora tão bela proposta programática, o que se verá é que, ao menos no que se refere à tributação protetiva, o OSC e, porque não se dizer, também a doutrina especializada, não conseguiram ainda satisfazer nem mesmo às críticas trazidas a partir meramente da lógica presente no entendimento das duas frases do Artigo III:2.

A maneira de aferir essa realidade distorciva ou essa aplicação protetiva ou o SATAP é, no dizer de Federico Ortino (2009, p. 140), o “impacto adverso desproporcional" que a norma impõe aos produtos alienígenas em relação ao tratamento aos produtos substitutos ou competidores nacionais.

Se esse minus deve ser tomado de forma agregada, em relação a todos os produtos domésticos e importados, ou de forma isolada, em prejuízo a pelo menos um produto estrangeiro é, fundamentalmente o que diferencia os critérios - assim, verificar se poderá ou não haver violação à obrigação do tratamento nacional sem que haja um efeito protetivo generalizado sobre a indústria doméstica do país importador (EHRING, 2002, p. 922).

Lothar Ehring (2002, p. 924 - 927), portanto, a partir de sua intelecção do modo de decidir do OSC do GATT e da OMC, embora se baseando em considerações anteriores (DAVEY; PAUWELYN, 2000), formula a mais clara explicação e sistematização didática na doutrina da diferença entre dois critérios objetivos.

A primeira forma de aferir objetivamente o caráter protetivo da norma, seja tributária ou regulatória, é denominado por Lothar Ehring (2002, p. 924) como "Teste Diagonal" e por William Davey e Joost Pauwelyn (2000, p. 41) como "Interpretação Tradicional". Verifica apenas se há algum (e basta um) produto importado que receba

\footnotetext{
131 "Artigo 3

Disposições Gerais

1 - Os Membros afirmam sua adesão aos princípios de solução de controvérsias aplicados até o momento com base nos Artigos 22 e 23 do GATT 1947 e ao procedimento elaborado e modificado pelo presente instrumento.

2 - O sistema de solução de controvérsia da OMC é elemento essencial para trazer segurança e previsibilidade ao sistema multilateral de comércio. Os Membros reconhecem que esse sistema é útil para preservar direitos e obrigações dos Membros dentro dos parâmetros dos acordos abrangidos e para esclarecer as disposições vigentes dos referidos acordos em conformidade com as normas correntes de interpretação do direito internacional público. As recomendações e decisões do OSC não poderão promover o aumento ou a diminuição dos direitos e obrigações definidos nos acordos abrangidos. (...)

4 - As recomendações ou decisões formuladas pelo OSC terão por objetivo encontrar solução satisfatória para a matéria em questão, de acordo com os direitos e obrigações emanados pelo presente Entendimento e pelos acordos abrangidos. (...)"
} 
tratamento menos favorável que qualquer dos produtos domésticos, para que se entenda que estamos diante de infração ao tratamento nacional.

Assim, se existir incidência tributária que submeta mais gravosamente, ainda que potencialmente, o produto importado, e tivermos um produto menos onerado de origem domestica, configurar-se-á a violação ao tratamento nacional em matéria tributária.

O motivo de sua denominação é facilmente visível de forma gráfica. Pode-se dividir o universo de produtos, nacionais ou estrangeiros, que são competidores ou substitutos diretos, quando sobre eles é incidente uma norma neutra quanto à origem, em uma matriz 2 X 2, com quatro possíveis situações: produtos nacionais submetidos ao tratamento não menos favorável do que o produto estrangeiro; produtos nacionais submetidos ao tratamento menos favorável do que o produto estrangeiro; produtos estrangeiros submetidos ao tratamento não menos favorável do que o produto nacional e produtos estrangeiros submetidos ao tratamento menos favorável do que o produto nacional (se estamos tratando da discriminação regulatória); ou produtos nacionais não tributados internamente igualmente ao produto estrangeiro; produtos nacionais tributados internamente igualmente ao produto estrangeiro; produtos estrangeiros não tributados internamente igualmente ao produto nacional e produtos estrangeiros tributados internamente igualmente ao produto nacional (se estamos tratando da discriminação tributária, nos termos da Nota Adicional ao parágrafo 2 do Artigo III).

Importante é ressaltar que, para a elaboração da tabela de incidência, preferiu-se adotar os termos em inglês aplicáveis à segunda frase: "domestic product", "imported product" e, principalmente, "not similarly taxed" e não "taxado igualmente". Isso se deve ao fato de que o termo taxado igualmente, quando submetido à sua negação lógica, leva à taxado desigualmente, o que pode induzir à conclusão errônea de que inclui a tributação menos onerosa ao importado. Tal problema também existe com o termo em inglês, é verdade, mas em menor escala. Ademais, o termo "taxed" não deve ser traduzido para taxado, mas sim tributado.

Assim, teremos, em uma situação típica de clara violação, segundo o critério diagonal:

\begin{tabular}{l|l|l|} 
& Produto Doméstico & Produto Importado \\
\hline Tributação não similar (maior) & $4 \%$ & $98 \%$ \\
\hline Tributação similar (não maior) & $96 \%$ & $2 \%$ \\
\hline
\end{tabular}


É o caso mais evidente de tributação protetiva, em que o resultado acarreta um peso muito maior na diagonal "produto doméstico beneficiado e produto importado prejudicado" do que na diagonal oposta, concernente à situação de "produto importado beneficiado e produto doméstico prejudicado".

No entanto, ainda que tenhamos a seguinte situação, mesmo assim a norma tributária será considerada protetiva, segundo o Teste Diagonal:

\begin{tabular}{l|l|l|} 
& Produto Doméstico & Produto Importado \\
\hline Tributação não similar (maior) & $4 \%$ & $2 \%$ \\
\hline Tributação similar (não maior) & $96 \%$ & $98 \%$ \\
\hline
\end{tabular}

Ainda nesse caso, como há mesmo apenas $2 \%$ de produtos importados em situação prejudicada em relação ao produto doméstico, a norma em questão não passaria no teste diagonal. Haveria que não possuir quaisquer produtos importados nessa condição.

Assim, apenas em casos como tais a norma tributária seria considerada como não protetiva segundo o Teste Diagonal:

\begin{tabular}{l|l|l|} 
& Produto Doméstico & Produto Importado \\
\hline Tributação não similar (maior) & $4 \%$ & $0 \%$ \\
\hline Tributação similar (não maior) & $96 \%$ & $100 \%$ \\
\hline
\end{tabular}

A propósito, na primeira tabela, em que se verifica a situação típica de violação de assimetria, no dizer de Ehring (2002, p. 926), temos que a maioria dos produtos domésticos é beneficiada e a maioria dos produtos importados é prejudicada. Daí se vê o porquê da denominação "diagonal" - pois a situação mais comum de violação implica a formação de uma diagonal mais lotada de produtos e a outra esvaziada.

$\mathrm{Na}$ verdade, o que ocorre é que existe uma diagonal permitida, a que contempla produtos nacionais não tributados internamente igualmente ao produto estrangeiro (nacionais desfavorecidos) e produtos estrangeiros tributados internamente igualmente ao o produto nacional (estrangeiros favorecidos); e uma diagonal proibida, a que contém produtos nacionais tributados internamente igualmente ao produto estrangeiro (nacionais favorecidos) e produtos estrangeiros não tributados internamente igualmente ao produto nacional (estrangeiros desfavorecidos).

Por sua vez, o "Teste de Impacto Assimétrico", para Ehring (2002, p. 924) ou "Requisito de Efeito Discriminatório", para William Davey e Joost Pauwelyn (2000, p. 38 - 41), exige apenas que, na comparação dos agregados entre os subgrupos, produtos 
importados ou domésticos, verifique-se se os encargos que incidem sobre os importados sejam substancialmente maiores em quantidade. Afere-se, na verdade, se há a existência de uma distribuição assimétrica do ônus tributário entre os subgrupos. Não se afere, assim como não se via também no Teste Diagonal, se alguns produtos domésticos também são mais onerados, alegação muito comum entre os reclamados na casuística. Tampouco não se quer saber se apenas um produto importado estará na situação mais prejudicada, como era decisivo no caso do Teste Diagonal. O que se verifica é a situação dos grupos no agregado, cada um como um todo.

A sua aferição pode ser representada pela fórmula (EHRING, 2002, p. 965):

Sejam,

$$
\begin{aligned}
& A=\text { Produtos Domésticos Favorecidos } \\
& B=\text { Produtos Domésticos Desfavorecidos } \\
& \text { C }=\text { Produtos Importados Favorecidos } \\
& D=\text { Produtos Importados Desfavorecidos }
\end{aligned}
$$

Teremos então:

$$
\frac{A}{B} \approx \frac{C}{D}
$$

Como já vimos, para o caso de discriminação implícita, como esses para os quais é necessário o emprego de tais critérios, objetivos ou subjetivos, vale a alegação da ocorrência da violação irrisória ou de minimis, pelo que não se exige que os quocientes sejam iguais, apenas que sejam aproximadamente iguais.

Interessante é verificar que a segunda situação apresentada em tabela acima, se foi considerada reprovada diante do emprego do Teste Diagonal, será aprovada se o órgão julgador entender aplicável o Teste de Impacto Assimétrico.

Vejamos uma situação de simetria, que não acarretaria violação ao GATT se adotado tal critério pelo Órgão Julgador:

\begin{tabular}{l|l|l|} 
& Produto Doméstico & Produto Importado \\
\hline Tributação não similar (maior) & $24 \%$ & $28 \%$ \\
\hline Tributação similar (não maior) & $76 \%$ & $72 \%$ \\
\hline
\end{tabular}


Como se viu, mesmo que a situação dos produtos importados, no agregado, seja algo pior do que a dos domésticos, a distribuição do encargo tributário torna-se aproximadamente equitativa. A norma tributária que produzisse tais efeitos no mercado seria considerada válida diante do GATT, uma vez empregado o Teste de Impacto Assimétrico.

Comentando tais formulações,a partir do exame por ele empreendido dos julgados, Lothar Ehring (2002) afirma que o emprego do Teste Diagonal tem sido raro na casuística (p. 948), até porque, de tão rigoroso, não afere a existência de não-discriminação na norma, mas sim exige que haja tratamento igual entre os produtos (p. 954), o que decerto não seria o escopo da disciplina convencional. Na verdade, discorda de que seja o mesmo critério que a interpretação tradicional (p. 948).

Não obstante, defende que haja uma prevalência de casos em que o OSC adota claramente avaliações de assimetria do impacto das normas, tanto tributárias quanto regulatórias, apontando apenas dois casos em que se adotou o critério subjetivo propriamente dito, segundo ele (p. 953), ambos ainda na fase GATT, os casos "United States - Measures Affecting Alcoholic and Malt Beverages", de 19 de junho de 1992, DS23/R, BISD 39S/206 e "United States - Taxes on Automobiles", de 11 de outubro de 1994, DS31/R, antes de esse critério ser rechaçado no caso "Japão - Bebidas Alcoólicas II'.

No seu entender (p. 937), o caso "Chile - Bebidas Alcoólicas” é um clássico exemplo de como o impacto assimétrico da medida sob exame exerceu um importante papel no raciocínio tanto do Grupo Especial quanto do Órgão de Apelação.

Diferentemente do que afirma Lothar Ehring, não é assim tão fácil vislumbrar critérios objetivos na atuação histórica dos tribunais arbitrais, tanto do GATT quanto da OMC, nem tampouco se pode falar com segurança que um determinado critério foi o determinante no raciocínio que levou à decisão final, mesmo se tomado como referência um julgado que siga um raciocínio mais linear em particular. Para tanto, examine-se esse caso pretensamente prototípico com mais profundidade, para que se veja que os caminhos da racionalidade dos árbitros são mais tortuosos do que otimistamente quer sistematizar o autor alemão.

A medida tributária em exame no caso "Chile - Bebidas Alcoólicas" é o “Impuesto Adicional a las bebidas Alcohólicas", doravante ILA, previsto na Lei no 19.534, de 13 de novembro de 1997, alterando a redação do Decreto-lei nº 825, de 25 de dezembro de 1974. O ILA é um imposto seletivo (excise tax) incidente na venda e na importação de 
bebidas alcoólicas, cujos contribuintes são o vendedor ou, no caso da importação, o importador. É cobrado mediante alíquota ad valorem, sob a mesma base de cálculo do IVA chileno.

A Lei $\mathrm{n}^{\circ}$ 19.534/97 foi promulgada em 18 de novembro de 1997, com vigência a partir de $1^{\circ}$ de dezembro de 1997 , revogando o decreto-lei anterior, cuja disciplina no julgado é tratada como "Antigo Sistema”. Tinha por escopo criar um novo regime tributário, o "Novo Sistema", vigente a partir de $1^{\circ}$ de dezembro de 2000 , e um regime transitório nesse intervalo temporal, o "Sistema Transitório".

O "Antigo Sistema" diferenciava três tipos de bebidas destiladas ("pisco", "whisky" e "los demás licores", essa última uma categoria residual que compreendia todas as outras bebidas destiladas, aos quais se aplicavam alíquotas ad valorem. Tal sistemática era seguida pelo "Sistema Transitório", porém reduzindo as alíquotas incidentes sobre o "whisky", permanecendo estanques no tempo as alíquotas incidentes sobre as demais bebidas destiladas.

Assim eram as alíquotas ad valorem aplicáveis ao ILA incidente sobre bebidas destiladas no "Antigo Sistema" e no "Sistema Transitório":

\begin{tabular}{|l|l|l|l|}
\hline & "Whisky" & "Pisco" & "Los demás licores" \\
\hline Até 30/11/1997* & $70 \%$ & $25 \%$ & $30 \%$ \\
\hline Até 30/11/1998 & $65 \%$ & $25 \%$ & $30 \%$ \\
\hline Até 30/11/1999 & $59 \%$ & $25 \%$ & $30 \%$ \\
\hline Até 30/11/2000 & $53 \%$ & $25 \%$ & $30 \%$ \\
\hline * “Antigo Sistema" & & \\
\hline
\end{tabular}

O "Novo Sistema" abolia a distinção entre os tipos de bebidas e, em seu lugar, trazia uma tabela progressiva de incidência de acordo com o teor alcoólico da bebida:

\begin{tabular}{|l|l|}
\hline Teor Alcoólico & Alíquota Ad Valorem \\
\hline Menor ou igual a $35^{\circ}$ & $27 \%$ \\
\hline Menor ou igual a $36^{\circ}$ & $31 \%$ \\
\hline Menor ou igual a $37^{\circ}$ & $35 \%$ \\
\hline Menor ou igual a $38^{\circ}$ & $39 \%$ \\
\hline Menor ou igual a $39^{\circ}$ & $43 \%$ \\
\hline
\end{tabular}


O termo "pisco" é uma indicação geográfica protegida pela lei chilena desde 1931, com o uso reservado exclusivamente para vinhos destilados produzidos e engarrafados em certas regiões do Chile, a partir de certas variedades de uvas moscatel que crescem nessas regiões. Segundo informado pelo Chile, o pisco deve conter, por lei, um teor de álcool de no mínimo $30^{\circ}$. Eram os seguintes os tipos de pisco determinados pela lei chilena e o teor alcoólico do pisco então em produção e venda no mercado chileno.

\begin{tabular}{|l|l|l|}
\hline Denominação & Teor Alcoólico Permitido & Teor Alcoólico no Mercado \\
\hline Pisco corriente ou tradicional & Entre $30^{\circ}$ e $35^{\circ}$ & $30^{\circ}, 32^{\circ}$ e $33^{\circ}$ \\
\hline Pisco especial & Entre $35^{\circ}$ e $40^{\circ}$ & $35^{\circ}$ \\
\hline Pisco reservado & Entre $40^{\circ}$ e $43^{\circ}$ & $40^{\circ}$ \\
\hline Gran pisco & Mais de $43^{\circ}$ & $43^{\circ}, 46^{\circ}$ e $50^{\circ}$ \\
\hline
\end{tabular}

Segundo as normas regulamentares chilenas, as quatro espécies de pisco se distinguem unicamente em função do seu teor alcoólico. Como a própria designação enseja, o pisco corriente ou tradicional é o de maior aceitação no mercado tradicionalmente, embora nos últimos cinco anos anteriores ao relatório tenha sido ultrapassado em consumo pelo pisco especial. Os demais, pisco reservado e gran pisco, respondem por apenas $9 \%$ do mercado.

O Grupo Especial também noticiou que os dois maiores produtores de pisco, Control e Capel, foram autorizados em 30 de outubro de 1998 pelo órgão de controle da concorrência chileno a realizarem uma fusão, de forma a compartilharem uma faixa de mercado de $90 \%$. A indicação por detrás dessa autorização foi a de que a autoridade concorrencial entendia que o mercado consumidor de pisco era submetida a uma forte concorrência com outras bebidas alcoólicas, como vinho, cerveja e uísque, dada a prática de consumi-lo misturado com bebidas não-alcoólicas, pelo que haveria produtos alternativos que o consumidores de bebidas alcoólicas poderiam preferir em seu lugar.

Outra norma chilena, o Decreto $\mathrm{n}^{\circ} 78 / 86$, determinava o teor alcoólico mínimo para os diversos tipos de bebidas destiladas vendidas no mercado local: 


\begin{tabular}{|l|l|}
\hline Brandy, cognac, armagnac & $38^{\circ}$ \\
\hline Aguardente e aguardente de frutas & $30^{\circ}$ \\
\hline Licores de frutas & De $25^{\circ}$ a $34^{\circ}$ \\
\hline Bebidas à base de aniz & De $25^{\circ}$ a $40^{\circ}$ \\
\hline Bitters & De $25^{\circ}$ a $30^{\circ}$ \\
\hline Coqueteis & De $12^{\circ}$ a $16^{\circ}$ \\
\hline Outros licores & De $25^{\circ}$ a $28^{\circ}$ \\
\hline
\end{tabular}

A Reclamação das Comunidades Europeias deu-se tanto contra o "Sistema Transitório" quanto o "Novo Sistema", arguindo suas inconsistências diante do Artigo III:2, segunda frase. No que tange ao "Sistema Transitório", porque ele estabelece a imposição de tributos menores ao pisco do que a outras bebidas destiladas importadas, que lhe sejam diretamente competidoras ou substitutas, que recaiam na classificação de "whisky" ou "los demás licores", de modo a proteger a indústria doméstica chilena. No que tange ao "Novo Sistema", porque ele estabelece a imposição de tributos menores ao pisco com teor alcoólico menor do que $35^{\circ}$ do que a outras bebidas destiladas importadas, que lhe sejam diretamente competidoras ou substitutas, que possuam maior teor alcoólico, de modo a proteger a indústria doméstica chilena.

Interessante observar que, embora as Comunidades Europeias pudessem ter reclamado contra o "Sistema Transitório" em violação ao Artigo III:2, primeira frase, já que se tratava de evidente discriminação explícita contra algumas bebidas exportadas por países europeus, como alguns tipos de brandy, que poderiam ser consideradas similares ao pisco, foi decidido não entrar no espinhoso campo de discussão quanto à similaridade, preferindo-se arguir apenas a condição de competidores ou substitutos diretos, de mais fácil comprovação diante do Grupo Especial.

Passando ao exame do primeiro passo de análise, o Grupo Especial verificou se as bebidas exportadas pelos países das Comunidades Europeias seriam diretamente competidores ou substitutos do pisco chileno. Após um exaustivo exame dos usos finais dos produtos, suas características físicas, os canais de distribuição, as relações de preço e as elasticidades-preço cruzadas dos produtos, concluiu-se que os produtos importados e os domésticos sob exame eram competidores ou substitutos diretos. 
O segundo passo seria verificar se os produtos eram não "tributados igualmente" ("not similarly taxed"). Quanto ao "Sistema Transitório", preliminarmente, concluiu-se que era óbvio que as diferenças de tributação eram maiores que o de minimis.

Ocorre que, no que tange à tributação diferenciada, foi empreendido um exame mediante algo assemelhado ao Teste Diagonal, já que se entendeu que, para que se verificasse a discrepância, seria suficiente identificar que certas importações eram tributadas diferentemente de certos produtos substitutos domésticos, não sendo necessário, segundo o Grupo Especial, mostrar que todas as importações são tributadas de forma diferenciada em relação aos produtos domésticos. Por isso, a alegação do reclamado, de que alguns dos seus produtos nacionais, como o uísque, era tributado igualmente, não fazia sentido $^{132}$, como já explicamos ao mostrar as tabelas de efeitos acima descritas. O Grupo Especial, nesse ponto, faz referência, por meio de nota de rodapé, a entendimentos anteriores no caso "Canadá - Periódicos"133 e no caso "Coreia - Bebidas Alcoólicas"134, com expressa menção à análise caso-a-caso.

132 "7.97. We are of the view that under the Transitional System imported and domestic distilled alcoholic beverages are not similarly taxed. The fact that some of the domestic production (e.g., products such as Chilean whisky) is similarly taxed is irrelevant to this step of the analysis. That is, it is sufficient to find that certain of the imports are taxed dissimilarly compared to certain of the domestic substitutable products. It is not necessary to show that all of the imports are taxed dissimilarly to all of the domestic products".

133 "2. Not Similarly Taxed

Having found that imported split-run and domestic non-split-run periodicals of the same type are directly competitive or substitutable, we must examine whether the imported products and the directly competitive or substitutable domestic products are not similarly taxed. Part V.1 of the Excise Tax Act taxes split-run editions of periodicals in an amount equivalent to 80 per cent of the value of all advertisements in a split-run edition. In contrast, domestic non-split-run periodicals are not subject to Part V.1 of the Excise Tax Act. Following the reasoning of the Appellate Body in Japan - Alcoholic Beverages58, dissimilar taxation of even some imported products as compared to directly competitive or substitutable domestic products is inconsistent with the provisions of the second sentence of Article III:2. In United States - Section 337, the panel found:

... that the "no less favourable" treatment requirement of Article III:4 has to be understood as applicable to each individual case of imported products. The Panel rejected any notion of balancing more favourable treatment of some imported products against less favourable treatment of other imported products. ${ }^{59}$

With respect to Part V.1 of the Excise Tax Act, we find that the amount of the taxation is far above the de minimis threshold required by the Appellate Body Report in Japan - Alcoholic Beverages. ${ }^{60}$ The magnitude of this tax is sufficient to prevent the production and sale of split-run periodicals in Canada. ${ }^{61,}$

134 "10.99.The Appellate Body in Japan - Taxes on Alcoholic Beverages II summed up its findings with respect to this element of the decision as follows:

Thus, to be "not similarly taxed", the tax burden on imported products must be heavier than on "directly competitive or substitutable" domestic products, and that burden must be more than de minimis in any given case. $^{411}$

10.100.In the present case, the Liquor Taxes on diluted soju are 35 percent and 50 percent on distilled soju. The Education Tax is surtax of 10 percent levied on soju. With respect to imported alcoholic beverages, the Liquor Tax ranges from 50 percent for liqueurs to 100 percent for whisky and brandy. The Education Tax is 30 percent for all imported alcoholic beverages except liqueurs which have a 10 percent rate. Thus the total tax on diluted soju is 38.5 percent; on distilled soju and liqueurs it is 55 percent; on vodka, gin, rum, tequila and ad-mixtures it is 104 percent; on whisky, brandy and cognac it is 130 percent. Thus the tax rate on imported whisky, for example, is more than three times the ad valorem rate on diluted soju. These differentials are clearly in excess of de minimis levels. ${ }^{412,}$ 
No que tange ao "Novo Sistema", embora a defesa chilena tenha alegado que o sistema era baseado em fatores objetivos e neutros, sendo que o critério baseado no teor alcoólico já havia sido declarado válido no caso "Japão - Bebidas Alcoólicas I", o Grupo Especial manteve o mesmo entendimento ${ }^{135}$, não sem antes asseverar que a avaliação do impacto assimétrico dos efeitos entre os produtos não estava sendo levado em conta àquela altura $^{136}$.

Passou-se então ao próximo passo, agora o ponto nodal, a aplicação protetiva ou SATAP. Após afastar considerações sob a pressão da indústria chilena no congresso nacional do país, alegação de pronto afastada, o Grupo Especial pôs-se a fazer importantíssima afirmação de que, nessa altura da análise, o que é importante é verificar quem recebe o benefício da tributação desigual, tanto no exame do "Sistema Transitório" 137 quanto no do "Novo Sistema" 138 , independentemente se o critério é objetivo ou não, formalmente neutro ou não. Nessa perspectiva, tanto no exame do "Sistema Transitório"139 quanto no do "Novo Sistema"140 foram tidas como definitivas

135 "7.113. As with our finding above with respect to the Transitional System, the fact that some imported and domestic distilled alcoholic beverages could in particular factual circumstances be assessed identical taxes, or different taxes at less than de minimis levels, does not change our conclusion. It is sufficient for this step of the analysis to find that some of the imports are being taxed dissimilarly from some of the domestic production and the difference is more than de minimis".

136 "7.103. In our view the question of dissimilar taxation is relatively straightforward. It does not involve judgements about the objectivity of the laws or regulations involved. It does not involve an assessment of who benefits from the tax system. It does not involve an examination of the design, structure or architecture of the law in question. Such inquiries are relevant only to the next step of our analysis; namely, whether any system of dissimilar taxation has been applied so as to afford protection to domestic production. All we are doing at this point is determining whether there is dissimilar taxation of directly competitive or substitutable imported and domestic products. Even if it were to turn out that the large majority of imported products benefited from a particular tax, that would be irrelevant to this stage of the analysis. Our only issue here is to identify whether there is dissimilar taxation".

137 "7.123. In our view, an important question is who receives the benefit of the dissimilar taxation. (...) For example, the magnitude of the differentials would not be particularly relevant if the products realizing the resulting benefits were imports. (...) This is only logical given the language of Article III itself'.

138 "7.142. Thus, the panel rested its conclusion in part on the factual finding that the primary beneficiaries of the particular structure in that case were the domestic producers. At no point did the panel in that case or the panels and Appellate Body in the cases of Japan - Taxes on Alcoholic Beverages I and II state or imply that any system based on so-called "objective" factors would necessarily survive scrutiny under Article III:2."

139 "7.129. The largest category of imports by far at the present time is whisky and that is presently taxed at a rate of 53\% (at its least discriminatory level beginning 1 December 1999) compared to pisco's 25\% and pisco accounts for almost $75 \%$ of domestic production of distilled spirits. It is clear that the beneficiary of this structure is the domestic industry".

140 "7.158. It is important at this juncture to recall that Article III is meant to protect competitive opportunities. There is no question that the structure of the New Chilean System will distort competition between directly competitive domestic products and products which are now imported and ones that might reasonably be considered potential imports. First of all, it does not save a measure from running afoul of Article III:2, second sentence, merely because there are domestic products taxed at the same level as the imported products, as we noted in the previous section. Second, as Chile itself has noted, there is considerable world-wide supply capacity of potential imports, the majority of which would be taxed at the highest level. The potential imports have the right to equal competitive opportunities to the Chilean market 
considerações sobre a assimetria do impacto das medidas em relação aos produtos domésticos em detrimento dos importados.

Vale dizer, o Teste de Impacto Assimétrico foi empregado pelo Grupo Especial para a aferição do termo SATAP, apenas na medida em que o Artigo III:1, referido pela Nota Adicional ao Artigo III:2, menciona a indústria nacional como um todo. Importante ressaltar que isso se deu sem prejuízo do emprego do Teste Diagonal para a verificação da questão da tributação não igual, em relação a ambos os regimes tributários aplicados no Chile. Também se verifica, no relatório do Grupo Especial, mesmo no exame do SATAP, considerações referentes ao Teste Diagonal ${ }^{141}$.

Em verdade, diferentemente do que defende Lothar Ehring, o Grupo Especial levou em consideração, ao tomar sua decisão, uma série de fatores, e não apenas a assimetria no impacto das medidas tributárias ${ }^{142}$.

Passemos então a examinar a fundamentação do Órgão de Apelação nesse mesmo caso, uma vez que foi objeto de recurso se o Grupo Especial cometeu um erro de direito tanto no exame da tributação não igual e quanto na do SATAP ${ }^{143}$.

which they cannot receive under the New Chilean System. Were all distilled alcoholic beverages taxed at the same level, or at a level reflecting no more than de minimis differences, then it is entirely possible that the percentages of domestic versus imports at $40^{\circ}$ alcohol content or above would change dramatically. That is, lower value, high alcohol content imports could become more viable in the marketplace, particularly as consumers become more familiar with the products. In effect, Chile offers the result of its discrimination over a long period of time as a justification for perpetuating it. On balance, we find the most persuasive evidence to be that roughly $75 \%$ of domestic production will enjoy the lowest tax rate and that over $95 \%$ of current (and potential) imports will be taxed at the highest rate unless the imported products change their alcohol content and abandon their generic, familiar product names".

141 "7.128 The Transitional System assesses tax rates by type of spirits. The lowest tax rate is on pisco which under Chilean law is exclusively a domestic product. There could be an import physically identical to pisco and it would be assessed a tax rate five percentage points higher. This illustrates the protective nature of the structure of the tax system."

142 "7.159 Im sum, considering: (1) the structure of the New Chilean System (with its lowest rate at the level of alcohol content of the large majority of domestic production and its highest rate at the level of the overwhelming majority of imports); (2) the large magnitude of the differentials over a short range of physical difference (35 versus $39^{\circ}$ of alcohol content); (3) the interaction of the New Chilean System with the Chilean regulation which requires most of the imports to remain at the highest tax level without losing their generic name and changing their physical characteristics; (4) the lack of any connection between the stated objectives and the results of such measures (recognizing that "good" objectives cannot rescue an otherwise inconsistent measure); and, (5) the way this new measure fits in a logical connection with existing and previous systems of de jure discrimination against imports, we find that the dissimilar taxation assessed on directly competitive or substitutable imports and domestic products is applied in a way that affords protection to domestic production."

143 "43.The following issues are raised in this appeal:

(a) whether the Panel erred in its interpretation and application of the term "not similarly taxed", which appears in the Ad Article to Article III:2, second sentence, of the GATT 1994;

(b) whether the Panel erred in its interpretation and application of the term "so as to afford protection", which is incorporated into Article III:2, second sentence, of the GATT 1994, by specific reference to the "principles set forth in paragraph 1" of Article III of that Agreement;

(c) whether the Panel failed to set out the basic rationale for its findings and recommendations regarding the interpretation and application of the term "not similarly taxed", as required by Article 12.7 of the DSU; and 
No que tange ao exame da tributação desigual, o Órgão de Apelação, muito mais laconicamente, manteve a decisão do Grupo Especial integralmente do que tange à tributação não igual, usando agora argumento relacionado à assimetria do impacto exclusivamente tributário como um todo da norma ${ }^{144}$. No que tange à conclusão do Órgão de Apelação, apenas houve expressa referência ao erro do Grupo Especial quanto a mencionar a regulamentação administrativa do teor alcoólico mínimo das diferentes bebidas destiladas e a apontar a relação do caráter discriminatório da nova sistematização em relação ao histórico protetivo desse tipo de tributação no país ${ }^{145}$. Ao final, mantém a decisão do Grupo Especial, uma vez que a exclusão daqueles fundamentos fáticos não alteraria a conclusão de direito ${ }^{146}$

$\mathrm{O}$ que se pode concluir do exame minucioso do que seria o ícone, na jurisprudência do OSC da OMC, da avaliação da proteção sob o ponto de vista do impacto assimétrico das normas tributárias, em exame, na indústria doméstica em relação ao efeito aos produtos importados, é que, para dizer o mínimo, é altamente temerário elaborar uma

(d) whether the Panel acted inconsistently with Articles 3.2 and 19.2 of the DSU by adding to the rights and obligations of WTO Members in its interpretation and application of the terms "not similarly taxed" and "so as to afford protection", under Article III:2, second sentence, of the GATT 1994".

144 "53.A comprehensive examination of this nature, which looks at all of the directly competitive or substitutable domestic and imported products, shows that the tax burden on imported products, most of which will be subject to a tax rate of 47 per cent, will be heavier than the tax burden on domestic products, most of which will be subject to a tax rate of 27 per cent. We agree with the Panel that the difference in the level of the tax burden is clearly more than de minimis and, in any event, Chile has not appealed the Panel's finding that the difference between these tax rates is more than de minimis".

145 "73.In reaching its conclusion on the issue of "so as to afford protection", the Panel also relied on the fact that Chilean law imposes minimum alcohol content requirements on a range of distilled alcoholic beverages, including most of the beverages imported into Chile. ${ }^{68}$ The Panel invoked the "interaction of the New Chilean System with the Chilean regulation which requires most of the imports to remain at the highest tax level without losing their generic name and changing their physical characteristics". ${ }^{69}$ We believe this reliance by the Panel to be unjustified. Chilean law does not prohibit the importation of any distilled alcoholic beverages, whatever their alcohol content. Under Chilean law, a regulation imposes minimum quality standards, in respect of various kinds of distilled alcoholic beverages, relating to, inter alia, alcohol content, maximum sugar content and maximum volatile (e.g., aldehydes, furfural) impurities content. ${ }^{70}$ This $^{\circ}$ regulation appears to be broadly reflective of similar standards enforced in many markets. The "interaction" the Panel sees between the New Chilean System and the Chilean regulation does not contribute to the cogency of the Panel's conclusion on the "so as to afford protection" issue and, in our view, should not have been taken into account by the Panel.

74.The final factor that the Panel relied upon in reaching the conclusion under the issue of "so as to afford protection" was "the way this new measure fits in a logical connection with existing and previous systems of de jure discrimination against imports". ${ }^{71}$ In our view, the Panel has relied on the fact that previous Chilean measures, which are no longer applicable, involved some protection of domestic alcoholic beverages to show that the new tax system will also be applied "so as to afford protection". The Panel's reliance on this factor is wrong. Members of the WTO should not be assumed, in any way, to have continued previous protection or discrimination through the adoption of a new measure. ${ }^{72}$ This would come close to a presumption of bad faith. Accordingly, we hold that the Panel committed legal error in taking this factor into account in examining the issue of "so as to afford protection"."

146 "75. However, in view of the other factors properly relied upon by the Panel, we believe that the Panel's conclusion that the dissimilar taxation is applied "so as to afford protection" is unaffected by the exclusion of these last two factors." 
sistematização quanto a critérios empregados. No caso agora examinado, não só foram empregados os dois testes, em ocasiões diversas, como também na aferição de conceitos diferentes.

Ademais, embora o Órgão de Apelação tenha sido muito técnico na sua decisão nesse caso "Chile - Bebidas Alcoólicas", o que se verifica é que o que tem sido relevante nas decisões é um conjunto de fatores, muitas vezes avaliados e dispostos sem muita organização lógica, indiscriminadamente entre as análises dos conceito de produtos competidores diretos ou substitutos, tributação não igual ou SATAP, os três passos necessários na aferição da violação ao Artigo III:2, segunda frase, como já se viu. Os casos problemáticos, aos quais se refere Lothar Ehring (2002, p. 940 - 947), ao que se verifica, são mais numerosos do que o autor reconhece.

\subsubsection{Teste subjetivo - "aims-and-effects".}

O critério radicalmente contrário aos objetivos acima referidos é aquele que visa a perquirir quais teriam sido os motivos que fizeram com que a norma, tributária ou regulatória, fosse elaborada. Foi denominado pela doutrina de critério "aims-and-effects" (HUDEC, 1998, p. 620), ou teste dos "fins e efeitos" na doutrina em língua portuguesa (MOTA, 2005, p. 167).

Prepondera na doutrina (MOTA, 2005, p. 167) o entendimento de que a primeira utilização do critério se deu no exame do caso "United States - Measures Affecting Alcoholic and Malt Beverages", de 19 de junho de 1992, embora haja quem discorde e o veja já presente no caso "EEC - Measures on Animal Feed Proteins"147, de 14 de março de 1978 (CHOI, 2003, p. 82).

De acordo com a opinião francamente majoritária, devemos examinar o caso no qual os Estados Unidos são os demandados. Com o advento da Vigésima-Primeira Emenda à Constituição dos Estados Unidos da América, de 1933, foi revogado o sistema da Décima-Oitava Emenda, que proibia a fabricação, transporte e importação de bebidas alcoólicas. Com isso, o governo federal estabeleceu o "Federal Alcohol Administration Act", que criou um imposto seletivo (excise tax) sobre a comercialização e a importação dessas mercadorias. Não obstante, cada Estado, com o advento da Emenda, obteve a

${ }^{147} \mathrm{~L} / 4599-$ BISD $25 \mathrm{~S} / 49$. 
autonomia regulatória e impositiva, não só para estabelecer as condições de venda e distribuição das bebidas como também para impor seus próprios tributos sobre elas incidentes.

Assim, diversos estados norte-americanos instituíram excise taxes adicionais calculadas com base da produção anual de bebidas pelas indústrias. Porém, os benefícios fiscais concedidos pelos diversos estados eram muito diferenciados.

A título ilustrativo, confiram-se os mencionados no relatório do Grupo Especial. Os estados de New York, Rhode Island e Porto Rico isentaram ou reduziram alíquotas para pequenos produtores de cerveja locais. No Oregon, instituiu-se a isenção para pequenas vendas de vinho de produtores de até 100.000 galões por ano; em Kentucky, Minnesota, Ohio e Wisconsin, criou-se um crédito do imposto baseado na produção anual em proveito de vendas de quantidades pre-determinadas de cerveja aos cervejeiros cuja produção não excedesse determinado nível, sendo que tal benefício no Kentucky e no Ohio era restrito aos produtores locais. Em Alabama, Georgia, Nebraska e New Mexico, a alíquota da excise tax era fixada de acordo com a origem do produto, havendo isenção ou alíquotas muito baixas para os produtores locais de vinho. Iowa aplicou o imposto apenas nas vendas no atacado, mas autorizou que as vendas unicamente de "vinhos nativos" fosse realizada diretamente no varejo ao consumidor final, beneficiando-os da não-incidência. Michigan, Ohio e Rhode Island diferenciaram o tratamento do imposto conforme o uso de ingredientes locais. O estado do Mississippi estabeleceu a aplicação de alíquotas mais baixas se $51 \%$ ou mais do vinho produzido houvesse sido obtido da fermentação da uma certa variedade de uvas, a vitus rotundifolia. A Pennsylvania criou um crédito do imposto calculado a partir das compras de equipamentos para a produção de bebidas, limitados a um certo valor, para as cervejarias locais.

Como se vê, tem-se um lauto banquete de incidências tributárias e benefícios fiscais discriminatórios ou protetivos, contra os quais o Canadá se rebelou. Delas, a maioria consiste em evidente violação direta, ou explícita, às normas do Princípio de Nãodiscriminação em matéria tributária. Mas, entre elas, o exame da incidência do Mississippi, até por ser a de caráter discriminatório mais velado, foi o que trouxe à baila o novo enfoque subjetivo na apreciação, que a doutrina logrou em peso denominar de "aims and effects test".

Os Estados Unidos, é claro, alegaram em sua defesa que a norma em análise era neutra quanto a origem, já que a isenção parcial seria aplicável a qualquer vinho, de qualquer origem, que fosse fabricado a partir daquela modalidade de uva. 
O ponto interessante é notar que a alegação do Canadá não se baseou na incidência ao caso do SATAP em uma análise da configuração da ocorrência de uma discriminação implícita, como se consolidou com o caso "Japão - Bebidas Alcoólicas II", mas sim que os vinhos de sua produção eram produtos similares e que, assim, haveria uma discriminação explícita, combatida pelo Artigo III:2, primeira frase. Ainda assim, o Grupo Especial entendeu que os princípios gerais do primeiro parágrafo teriam que ser aplicados ao caso, de modo que a similaridade entre os produtos, o vinho canadense e o vinho do Mississippi (ou dos estados vizinhos) haveria de ser examinada tendo em vista os objetivos do tratamento nacional ${ }^{148}$.

Ocorre que o Grupo Especial percebeu que aquela particular variedade de uvas só florescia em climas temperados amenos, como o dos países do Mediterrâneo ou do sudeste dos Estados Unidos e que a distinção tributária com base nesse fator seria excepcional. Com base no decidido no caso "Japão - Bebidas Alcoólicas I", o Grupo Especial entendeu que as leis tributárias, inclusive a federal e as de outros estados, e a classificação fiscal de mercadorias, não empregam a distinção de acordo com a matériaprima consumida no processo produtivo. Com isso, o Grupo Especial entendeu que haveria violação na espécie ao Artigo III:2, primeira frase, por se tratarem de produtos similares, mas, mesmo que assim não fossem considerados, o seriam como produtos diretamente competidores ou substitutos, a caracterizar infrigência à segunda frase, uma vez que haveria sido caracterizada a tributação não igual e protetiva.

Importante é ressaltar que o que a doutrina logrou denominar como o teste subjetivo foi apenas a consideração, quando da avaliação do porquê de haver a distinção das bebidas em função da variedade de uvas de sua fabricação, que os Estados Unidos não teriam logrado apresentar justificativa razoável baseada em políticas públicas válidas, pelo

\footnotetext{
148 “5.25 (...) The purpose of Article III is thus not to prevent contracting parties from using their fiscal and regulatory powers for purposes other than to afford protection to domestic production. Specifically, the purpose of Article III is not to prevent contracting parties from differentiating between different product categories for policy purposes unrelated to the protection of domestic production. The Panel considered that the limited purpose of Article III has to be taken into account in interpreting the term "like products" in this Article. Consequently, in determining whether two products subject to different treatment are like products, it is necessary to consider whether such product differentiation is being made "so as to afford protection to domestic production". While the analysis of "like products" in terms of Article III:2 must take into consideration this objective of Article III, the Panel wished to emphasize that such an analysis would be without prejudice to the "like product" concepts in other provisions of the General Agreement, which might have different objectives and which might therefore also require different interpretations".
} 
que se presume que fossem fundadas em intenção não outra que o ânimo protetivo aos pequenos produtores locais ${ }^{149}$.

Robert Hudec (1998, p. 627) entendeu a partir daí que o Grupo Especial avaliou conceitualmente o SATAP de forma a que a legitimidade de tributos e regulamentações internos deveria ser determinada primariamente com base nos fins presentes no bojo das suas normas institutivas e nos seus efeitos no mercado. Ou seja, que deveria haver simultaneamente não só uma motivação regulatória de boa-fé assim como que o seu efeito nas condições de competitividade não deveria ser o de criar vantagens protetivas em proveito dos produtos domésticos. Conclui, portanto, de forma algo exagerada, ao menos a partir da dicção do Relatório, que o critério dos fins e efeitos então adotado exigiria a concorrência tanto da existência do objetivo não protetivo quanto de que não houvesse a produção de efeitos deletérios ao produto estrangeiro.

Um outro ponto controvertido no mesmo caso, que Robert Hudec (1998, p. 627) aponta como exemplo ilustrativo da nova visão quanto às normas do Acordo Geral, agora em se tratando de normas regulatórias, mas examinadas no mesmo caso, refere-se às cervejas em função de seu teor alcoólico.

Os estados do Colorado, Florida, Kansas, Minnesota, Missouri, Oklahoma e Utah promulgaram leis que estabeleciam restrições aos pontos de venda, distribuição e rotulagem de cervejas nos casos de produtos com mais de $3,2^{\circ}$ de teor alcoólico. Semelhante restrição era determinada pelo Alabama, acima de $5^{\circ}$, e pelo Oregon, a $4^{\circ}$. O Canadá alegou que as cervejas de alto e de baixo teor alcoólicos seriam produtos similares

\footnotetext{
149 "5.26 Applying the above considerations to the Mississippi wine tax, the Panel noted that the special tax treatment accorded in the Mississippi law to wine produced from a particular type of grape, which grows only in the southeastern United States and the Mediterranean region, is a rather exceptional basis for a tax distinction. Given the limited growing range of the specific variety of grape, at least in North America, the Panel was of the view that this particular tax treatment implies a geographical distinction which affords protection to local production of wine to the disadvantage of wine produced where this type of grape cannot be grown. The Panel noted that a previous panel concerning Article III treatment of wines and alcoholic beverages found imported and Japanese unsweetened still wines to be like products. ${ }^{7}$ The Panel agreed with the reasoning of this previous panel and was of the view that tariff nomenclatures and tax laws, including those at the United States federal and state level, do not generally make such a distinction between still wines on the basis of the variety of grape used in their production. The Panel noted that the United States did not claim any public policy purpose for this Mississippi tax provision other than to subsidize small local producers. The Panel concluded that unsweetened still wines are like products and that the particular distinction in the Mississippi law in favour of still wine of a local variety must be presumed, on the basis of the evidence submitted to the Panel, to afford protection to Mississippi vintners. Accordingly, the Panel found that the lower rate of excise tax applied by Mississippi to wine produced from the specified variety of grape, which lower rate is not available to the imported like product from Canada, is inconsistent with Article III:2, first sentence. The Panel wished to point out that even if the wine produced from the special variety of grape were considered unlike other wine, the two kinds of wine would nevertheless have to be regarded as "directly competitive" products in terms of the Interpretive Note to Article III:2, second sentence, and the imposition of a higher tax on directly competing imported wine so as to afford protection to domestic production would be inconsistent with that provision".
} 
e que os patamares de distinção das leis locais eram inteiramente arbitrários. Os Estados Unidos, obviamente, alegaram em sua defesa que a norma em análise não estabelecia distinções contra bebidas importadas do Canadá. Além disso, a cerveja com baixo teor alcoólico não poderia ser considerada produto similar em relação à de alto teor e que, alternativamente, tais medidas seriam justificáveis diante dos Artigos XX(a) e (b), uma vez que necessárias à proteção da vida humana e da moralidade pública.

O Grupo Especial iniciou sua análise examinando se as cervejas de baixo e de alto teor alcoólicos poderiam ser vistas como produtos similares. Mantendo a posição que a avaliação da similaridade deveria ser realizada não apenas a partir das características físicas, mas também com fundo no SATAP, concluiu, primeiramente, em um parágrafo, com base nas características físicas de ambos, que os produtos seriam similares. Nesse mesmo parágrafo, passou a examinar o SATAP, concluindo que, como tanto os Estados Unidos quanto o Canadá produzem cervejas com as duas classificações, e a lei vale para as bebidas independentemente de sua origem, não teria havido ônus maior para qualquer dos países. Um argumento de impacto assimétrico, portanto. Ao final do parágrafo, afirma a existência de certo grau de diferenciação e especialização dos mercados, tanto do ponto de vista da preferência dos consumidores quanto das estratégias de marketing e propaganda dos fabricantes ${ }^{150}$.

Não obstante, no parágrafo seguinte, o Grupo Especial, aí sim, adotou claramente um argumento de natureza subjetiva. Passou a examinar os objetivos de política pública e o histórico legislativo daquelas medidas. Concluiu que não só os objetivos trazidos pela defesa, que buscariam a proteção da saúde e da vida humana e a moralidade pública, como também os mencionados pelo reclamante, de meramente aumentar a receita pública, nenhum deles teria o condão de poderem ser entendidos como medidas

\footnotetext{
150 "5.73 The Panel recognized that on the basis of their physical characteristics, low alcohol beer and high alcohol beer are similar. It then proceeded to examine whether, in the context of Article III, this differentiation in treatment of low alcohol beer and high alcohol beer is such "as to afford protection to domestic production". The Panel first noted that both Canadian and United States beer manufacturers produce both high and low alcohol content beer. It then noted that the laws and regulations in question in the various states do not differentiate between imported and domestic beer as such, so that where a state law limits the points of sale of high alcohol content beer or maintains different labeling requirements for such beer, that law applies to all high alcohol content beer, regardless of its origin. The burdens resulting from these regulations thus do not fall more heavily on Canadian than on United States producers. The Panel also noted that although the market for the two types of beer overlaps, there is at the same time evidence of a certain degree of market differentiation and specialization: consumers who purchase low alcohol content beer may be unlikely to purchase beer with a higher alcohol content and vice-versa, and manufacturers target these different market segments in their advertising and marketing".
} 
protecionistas, nem houve qualquer fato levantado durante as discussões que levasse a tal raciocínio $^{151}$.

Malgrado a correção da formulação do argumento decisório, a decisão se deu no sentido que as cervejas de alto e de baixo teor alcoólico não são produtos similares nos termos do Artigo III: $4^{152}$. Como se vê, uma fundamentação repleta de razoabilidade, pressupondo-se a correção no emprego do critério objetivo, mas que leva a um julgamento equivocado.

Ao final, passando-se à análise do SATAP, o Grupo Especial retornou às formulações apresentadas quando do exame das questões subjetivas, na perquirição quanto à motivação legislativa, que haviam sido empreendidas anteriormente ${ }^{153}$.

Examinando esses dois trechos da fundamentação do caso "United States Measures Affecting Alcoholic and Malt Beverages", Robert Hudec (1998, p. 628) afirma que a abordagem subjetiva adotada nesse julgado oferece dois melhoramentos principais em relação à análise tradicional. O primeiro é diminuir a relevância da "metafísica" da

151 "5.74 The Panel then turned to a consideration of the policy goals and legislative background of the laws regulating the alcohol content of beer. In this regard, the Panel recalled the United States argument that states encouraged the consumption of low alcohol beer over beer with a higher alcohol content specifically for the purposes of protecting human life and health and upholding public morals. The Panel also recalled the Canadian position that the legislative background of laws regulating the alcohol content of beer showed that the federal and state legislatures were more concerned with raising tax revenue than with protecting human health and public morals. On the basis of the evidence submitted, the Panel noted that the relevant laws were passed against the background of the Temperance movement in the United States. It noted further that prior to the repeal of the Eighteenth Amendment of the United States Constitution authorizing Prohibition, amendments to the federal Volstead Act -- the Act which implemented the Eighteenth Amendment -- authorized the sale of low alcohol beer, and that the primary focus of the drafters of these amendments may have been the establishment of a brewing industry which could serve as a new source of tax revenue. However, irrespective of whether the policy background to the laws distinguishing alcohol content of beer was the protection of human health and public morals or the promotion of a new source of government revenue, both the statements of the parties and the legislative history suggest that the alcohol content of beer has not been singled out as a means of favouring domestic producers over foreign producers. The Panel recognized that the level at which the state measures distinguished between low and high alcohol content could arguably have been other than 3.2 per cent by weight. Indeed, as the Panel previously noted, Alabama and Oregon make the distinction at slightly different levels. However, there was no evidence submitted to the Panel that the choice of the particular level has the purpose or effect of affording protection to domestic production".

152 "5.75 Thus, for the purposes of its examination under Article III, and in the context of the state legislation at issue in Alabama, Colorado, Florida, Kansas, Minnesota, Missouri, Oklahoma, Oregon and Utah, the Panel considered that low alcohol content beer and high alcohol content beer need not be considered as like products in terms of Article III:4. The Panel again emphasized that this determination is limited to this particular case and is not to be extended to other Articles or other legislative contexts".

153 "5.76 The Panel then proceeded to examine whether the laws and regulations in the above-mentioned states affecting the alcohol content of beer are applied to imported or domestic beer so as to afford protection to domestic production in terms of Article III:1. In this context, the Panel recalled its finding in paragraph 5.74 regarding the alcohol content of beer and concluded that the evidence submitted to it does not indicate that the distinctions made in the various states with respect to the alcohol content of beer are applied so as to favour domestic producers over foreign producers. Accordingly, the Panel found that the restrictions on points of sale, distribution and labelling based on the alcohol content of beer maintained by the states of Alabama, Colorado, Florida, Kansas, Minnesota, Missouri, Oklahoma, Oregon and Utah are not inconsistent with Article III: 1 ". 
similaridade, colocando em seu lugar os dois pontos principais que, segundo ele, distinguem a boa-fé da intenção protecionista: os efeitos comerciais da medida e a existência de um objetivo regulatório ou tributário válido. Em segundo lugar, o que pode parecer uma confusão de conceitos, para ele é uma vantagem que permite que a verificação da justificativa legislativa ao mesmo tempo do exame dos critérios referentes à violação viabiliza que não sejam de pronto desprezadas alegações válidas apenas por conta da ausência de similaridade, sem falar no fato de o seu emprego atenua o rigor das justificativas válidas segundo a cláusula das Exceções Gerais (Artigo XX), nos casos em que os produtos são entendidos como similares. Robert Hudec qualifica, ao esgrimir esse raciocínio, como vantagem do critério subjetivo o que é, na verdade, o seu grande defeito, o de tornar demasiadamente aberta a possibilidade de defesa do país reclamado na justificação da sua medida tributária, livrando-o das amarras restritas das justificativas válidas pelo próprio Acordo Geral - que, não obstante, como afirmam Aaditya Mattoo e Arvind Subramanian (1998, p. 307), constituem decerto um conjunto bastante limitado de objetivos regulatórios autorizados. Essa realidade incontestável não permite, no entanto, que se conceda um elastério interpretativo demasiado amplo às restrições convencionais, mesmo que seja empregado um critério de extrema razoabilidade, como o da eficiência econômica da medida, como proposto (MATTOO; SUBRAMANIAN, p. 318), sob pena de estarmos ainda mais infringindo a previsibilidade do sistema.

A segunda e última vez em que o teste dos "fins e efeitos" foi empregado deuse no caso "United States - Taxes on Automobiles" ${ }^{154}$, certamente um dos exemplares mais interessantes da casuística do OSC, ainda na fase GATT, não só pelas características das incidências tributárias analisadas como também pelos erros de direito na sua decisão, o que fez com que não tenha sido adotada pelos Estados Contratantes.

O primeiro tributo arguido pela Comunidade Europeia como discriminatório nesse caso foi o "Luxury Tax" (ou imposto sobre o luxo), um imposto seletivo instituído nos Estados Unidos pelo Omnibus Budget Reconciliation Act de $1990^{155}$. Incidia na primeira venda a varejo de veículos de passageiros cujo valor de venda fosse superior a US\$ 30.000,00; assim como de US\$ 100.000,00 para embarcações; US\$ 250.000,00 para aeronaves e US\$10.000,00 para peles e joias. O tributo correspondia a $10 \%$ da diferença entre o preço de venda do automóvel, da embarcação, da aeronave, da peça em pele de animais ou da joia, em relação ao que fosse superior ao limite de preço estabelecido e

\footnotetext{
${ }^{154}$ DS31/R, de 11 de outubro de 1994.

155127 U.S.C. 4001 e seguintes.
} 
deveria ser recolhido pelo varejista juntamente com o preço, lançado na nota fiscal de venda e declarado pelo varejista à US Internal Revenue Service.

Em 1993, o Congresso Nacional Americano exarou outro Omnibus Budget Reconciliation Act, que não previa mais o luxury excise tax incidente sobre embarcações, aeronaves, joias e peles. Também atualizou o valor limite para os automóveis para US\$ $32.000,00$, em $1^{\circ}$ de janeiro de 1994 , em função da inflação correspondente ao tempo transcorrido desde 1990.

Importante é ressaltar que o "Luxury Tax on Automobiles" incidia sobre veículos domésticos e importados indistintamente. Para a norma, veículo de passageiros é aquele de quatro rodas que é fabricado precipuamente para o emprego em ruas, estradas e autoestradas e que pesasse no máximo 6.000 libras, sem carga. As limousines eram tributadas independentemente do seu peso. Caminhões e camionetes eram tributados de acordo com o seu peso apenas, independentemente do seu preço. O imposto não incidia sobre vendas de veículos adquiridos para comércio ou para o serviço de transporte de passageiros ou locação, assim como também para entes governamentais de todos os níveis para o uso na repressão legal, atividades de segurança pública ou nos serviços de emergência médica.

O segundo imposto previsto era o "Gas Guzzler Tax on Automobiles" (imposto sobre os automóveis beberrões de gasolina), previsto no Energy Tax Act de 1978, com alterações posteriores e respectivas regulamentações ${ }^{156}$. Era também um excise tax incidente sobre a produção de automóveis (o contribuinte era o fabricante) cujo modelo básico não atingia determinados objetivos de economia de combustível, consoante uma tabela de valores mínimos e máximos, como a seguinte, vigente a partir de 1990, com a alteração do Omnibus Budget Reconciliation Act de 1990157.

\begin{tabular}{|l|l|}
\hline Economia de combustível (milhas por galão) & Imposto (US\$) \\
\hline Maior que 22,5 & 1.000 \\
\hline Maior que 21,5 e menor que 22,5 & 1.300 \\
\hline Maior que 20,5 e menor que 21,5 & 1.700 \\
\hline Maior que 19,5 e menor que 20,5 & 2.100 \\
\hline Maior que 18,5 e menor que 19,5 & \\
\hline
\end{tabular}

15626 U.S.C. 4064 e seguintes. Regulamentação em 40 C.F.R. Part 600.

15726 U.S.C., $\$ 4064$ (a). 


\begin{tabular}{|l|r|}
\hline Maior que 17,5 e menor que 18,5 & 2.600 \\
\hline Maior que 16,5 e menor que 17,5 & 3.000 \\
\hline Maior que 15,5 e menor que 16,5 & 3.700 \\
\hline Maior que 14,5 e menor que 15,5 & 4.500 \\
\hline Maior que 13,5 e menor que 14,5 & 5.400 \\
\hline Maior que 12,5 e menor que 13,5 & 6.400 \\
\hline Menor que 12,5 & 7.700 \\
\hline
\end{tabular}

A norma definia os automóveis submetidos ao campo de incidência do "Gas Guzzler Tax on Automobiles" de forma semelhante ao "Luxury Tax on Automobiles", como acima descrito. Também o regime das isenções era deveras análogo.

De diferenciado em relação à incidência anterior eram as determinações acerca da forma de apuração do consumo de combustível dos automóveis. A norma legal, o Energy Tax Act, determinava que o consumo de gasolina deveria ser obtido a partir de um tipo modelo para cada particular classe de veículo comercializada a cada ano, o que seria aferido pelo órgão ambiental americano, a US Environmental Protection Agency (EPA), segundo metodologia a ser discriminada em regulamento. Em resumo, a metodologia era baseada no projeto de fabricação do modelo do automóvel, de acordo com a sua marca, segmentado por categorias segundo características (como número de cilindros do motor, torque, tipo de transmissão e número de marchas) que poderiam influenciar significativamente no consumo de combustível.

As Comunidades Europeias solicitaram a instalação de Grupo Especial entendendo que tanto o Luxury Tax quanto o Gas Guzzler Tax eram inconsistentes com o Artigo III:2 do GATT, e que o Gas Guzzler Tax não poderia ser justificado diante das exceções dos Artigos XX(g) ou do Artigo XX(d).

A fundamentação fática por trás da insurgência europeia era o fato de que a maioria dos automóveis importados da Europa pagava uma média de imposto a título de Luxury Tax muito maior do que a maior parte dos automóveis de luxo americanos. Como exemplos, têm-se: Mercedes (US\$ 2.685), BMW (US\$ 1.003), Porsche (US\$ 3.023), Ferrari (US\$ 12.842), Rolls-Royce (US\$ 13.300), Bentley (US\$ 14.940), Maserati (US\$ 1.370), Lotus (US\$ 1.493), Lamborghini (US\$ 18.385) e Aston Martin (US\$ 17.294), de fabricação europeia, em contraposição com Buick (US\$ 150), Cadillac (US\$ 373), Chevrolet (US\$ 307) e Lincoln (US\$ 150), norteamericanos (dados de 1992). 
No que tange ao Gas Guzzler Tax, segundo a Comunidade Europeia, em 1990, quarenta e cinco dos quarenta e sete modelos sujeitos ao imposto eram importados e, desses, quarenta e quatro eram europeus (o outro japonês). Apenas dois modelos americanos, o Cadillac Fleetwood Brougham e o Cadillac Allanté, estavam dentro do campo de incidência do Gas Guzzler Tax, sendo que o Cadillac Allanté era também fabricado na Europa, na Carrozzeria Pininfarina, na Itália, sob encomenda de montadora de capital norteamericano, também sendo considerado um produto importado. Assim, dos 6.563.527 automóveis de passageiros fabricados e vendidos nos Estados Unidos em 1990, 34.244 ou 0,5 \% estavam sujeitos ao Gas Guzzler Tax. Em contraste, dos 395.958 carros europeus vendidos nos Estados Unidos em 1990, 71.449 ou 18 \% sofriam essa incidência.

A mera apresentação desses dados fáticos relativos às duas modalidades tributárias poderia fazer-nos prever uma análise, por parte do julgador arbitral, com base no critério objetivo do impacto assimétrico, como classifica Lothar Ehring. No entanto, diante da alegação da Comunidade Europeia quanto ao precedente de "Japão - Bebidas Alcoólicas I", referente ao fato de que a existência de pelo menos um produto nacional na categoria desfavorecida não eximia a norma tributária do seu potencial caráter protetivo ${ }^{158}$, inicialmente apenas no exame do Luxury Tax, os Estados Unidos retrucaram afirmando que o que importa em casos semelhantes é a natureza do fator de discrimen, a existência de objetivo de política pública legítimo, que justifique a medida tributária em análise ${ }^{159}$. Na defesa americana, pleiteou-se expresso afastamento do critério do impacto desproporcional, na medida em que a igualdade de condições de competitividade não pressupõe necessariamente igualdade nos fluxos comerciais, afirmando que aquele critério em relação aos efeitos concretos no comércio não fazia sentido ${ }^{160}$.

158 "3.25 Furthermore, the fact that a few American cars were also taxed was not a defense under Article III:2. In the Panel on Japan - Alcoholic beverages, Japan argued that its liquor tax system was nondiscriminatory because "there was no category where only imported products were subject to taxation". ${ }^{16}$ However, the Panel concluded that the existence of certain domestic products in a tax category was insufficient per se to establish non-discrimination under Article III. Instead, the Panel examined whether imported whiskies/brandies had been singled out for a disproportionate tax burden. It concluded that the Japanese system violated Article III because most imported whiskies/brandies were in product categories subject to the highest tax rates. ${ }^{17 "}$

159 "3.26 The United States considered the EC's citation of the Japan - Alcoholic beverages panel inapposite, since that case involved the creation of categories based on no discernible objective criteria and no defensible policy purpose. The United States did not agree that a trade neutral tax, based on legitimate policy purpose, which did not afford protection to domestic production, could be inconsistent with Article III on the basis that it had a "disproportionate impact" on exports from a few manufacturers of a particular contracting party".

160 "3.27 GATT panel findings over the years had confirmed that the first sentence of Article III:2 required that imports be provided equivalent competitive opportunities, it did not guarantee trade flows. The second sentence, and the Note Ad Article III, addressed the situation where the targeting of imports was more subtle, for example, a country's levying of a high tax on peaches, in which it had no substantial domestic production, 
Diante desses argumentos, o Grupo Especial, equivocadamente, por tratar da matéria no bojo da análise da primeira frase do Artigo III:2, na questão da similaridade, novamente mencionando o Grupo de Trabalho sobre Ajustes Fiscais de Fronteira e seus critérios baseados nas preferências dos consumidores, ressaltou que o objetivo do Acordo Geral é o de reduzir as barreiras ao comércio internacional e não harmonizar o tratamento regulatório das Partes Contratantes, pelo que políticas governamentais que visem a objetivo diverso do protecionista seriam válidas ${ }^{161}$.

Em seguimento, adotou expressamente a doutrina dos "fins e efeitos", analisando detidamente o que ela significava. Foi afastada a alegação dos efeitos pelos volumes de vendas no mercado, o que pretensamente corresponderia a um critério de impacto assimétrico. Como havia sido defendido pelos Estados Unidos no curso dos trabalhos do Grupo Especial, os julgadores acabaram afirmando-os, tais volumes, como dependentes de diversos fatores alheios à norma tributária ${ }^{162}$.

in order to protect domestic pears, which were directly competitive products. In cases where GATT panels had found that applying separate tax rates for similar imports and domestic products was inconsistent with the first sentence of Article III:2, it had been observed that Article III's central concern was the targeting of imports as such for differential treatment. No panel, including those cited by the EC in this case, had found a trade-neutral tax law inconsistent with Article III based solely on the incidence of the tax on imports by manufacturers of one particular contracting party, or that happened to have a "disproportionate impact" on certain imports. Rarely, if ever, were all manufacturers and their production equally situated. Accordingly it would be rare for all goods to be equally affected by a government's measure. Yet under the EC's approach, whenever a measure affected some manufacturer's products in another country more than domestic products, the measure would be inconsistent with the General Agreement. This approach did not make sense, nor was it consistent with the drafting history or practice of the General Agreement".

161 "5.8 The Panel noted that earlier practice of the CONTRACTING PARTIES had been to determine the permissibility of regulatory distinctions under Article III on a case-by-case basis, examining likeness in terms of factors such as "the product's end-uses in a given market, consumers' tastes and habits, which change from country to country; the product's properties, nature and quality."129 The Panel noted that regulatory distinctions based on such factors were often, but not always, the means of implementing government policies other than the protection of domestic industry. Non-protectionist government policies might, however, require regulatory distinctions that were not based on the product's end use, its physical characteristics, or the other factors mentioned. Noting that a primary purpose of the General Agreement was to lower barriers to trade between markets, and not to harmonize the regulatory treatment of products within them, the Panel considered that Article III could not be interpreted as prohibiting government policy options, based on products, that were not taken so as to afford protection to domestic production".

162 "5.10 The Panel then proceeded to examine more closely the meaning of the phrase "so as to afford protection." The Panel noted that the term "so as to" suggested both aim and effect. ${ }^{131}$ Thus the phrase "so as to afford protection" called for an analysis of elements including the aim of the measure and the resulting effects. A measure could be said to have the aim of affording protection if an analysis of the circumstances in which it was adopted, in particular an analysis of the instruments available to the contracting party to achieve the declared domestic policy goal, demonstrated that a change in competitive opportunities in favour of domestic products was a desired outcome and not merely an incidental consequence of the pursuit of a legitimate policy goal. A measure could be said to have the effect of affording protection to domestic production if it accorded greater competitive opportunities to domestic products than to imported products. The effect of a measure in terms of trade flows was not relevant for the purposes of Article III, since a change in the volume or proportion of imports could be due to many factors other than government measures. A previous panel had stated: 
Diante disso, o Grupo Especial entendeu que a norma instituidora do Luxury Tax em relação aos automóveis comercializados no mercado dos Estados Unidos não possuía nem a finalidade ${ }^{163}$ nem tampouco o efeito ${ }^{164}$ de proporcionar proteção à indústria doméstica.

Quanto ao Gas Guzzler Tax, o Grupo Especial foi mais direto, e, aproveitando a linha de raciocínio já alinhavada para o outro imposto, analisou diretamente os fins e efeitos da sua lei instituidora, novamente entendendo que a incidência tributária não tinha por escopo atingir precipuamente os automóveis europeus ou japoneses ${ }^{165}$, nem tampouco

"Article III:2, first sentence, obliges contracting parties to establish certain competitive conditions for
imported products in relation to domestic products. Unlike some other provisions in the General Agreement,
it does not refer to trade effects."132
The Panel observed that the central objective of the analysis remained the determination of whether the
egulatory distinction was made "so as to afford protection to domestic production." The analysis of aims and
effects of the measure were elements that contributed to that determination".
163 "5.12 The Panel first considered whether the aim of establishing the threshold within the luxury tax was to
afford protection to domestic production. It noted that the EC had argued that evidence of statements by
legislators suggested that the threshold was intentionally targeted on foreign automobiles. The Panel
considered however that an assessment of the aim of the legislation could not be based solely on such
statements or on other preparatory work. The aim of the legislation had also to be determined through the
interpretation of the wording of the legislation as a whole. In the view of the Panel, the policy objective
apparent in the legislation, to raise revenue from sales of perceived "luxury" products, was consistent with
setting a price threshold, and setting it at a level at which only a small proportion of automobiles sold within
the United States market were taxed. The fact that a large proportion of EC imports (but not necessarily a
large proportion of imports from other countries) was affected by the measure did not demonstrate that the
legislation was aimed at affording protection to domestic automobiles selling for less than $\$ 30,000$. The
Panel further noted that the conditions of competition accorded to products just above the $\$ 30,000$ threshold
did not differ markedly from those just below the threshold, and that there was considerable uncertainty as to
the proportion of foreign and domestic automobiles selling above and below the threshold. This also
suggested that the principal aim of the legislation was not to target closely a distinct product category of
imported automobile". 164 "5.13 The Panel then considered whether the threshold distinction in the luxury tax had the effect, in terms of conditions of competition, of affording protection to domestic production. The Panel noted that the parties submitted extensive data on sales of automobiles above and below the $\$ 30,0000$ threshold. The data did not accord, due mainly to different assumptions regarding the actual transaction price at which the automobiles were sold. Just below the threshold, EC figures suggested that some 85 percent of automobiles sold in 1991 in the United States were domestic; the United States estimate was 42 percent. Just above the threshold, in the \$30,000 to \$33,000 range, the EC claimed that some 40 percent of automobiles sold in the United States in 1991 were domestic; the United States put the figure at 90 percent. The Panel noted that large numbers of cars of non-EC (mainly Japanese) origin were also sold at prices just below and just above the threshold level. The Panel did not find that the sales data provided conclusive evidence of a change in the conditions of competition favouring United States automobiles. Under either set of figures, the greater or lesser percentages could have been due to marketing and production decisions by EC manufacturers, by their United States or other foreign competitors, or by decisions of consumers in the market".

165 "5.24 The Panel noted that the gas guzzler tax was triggered by a fuel economy threshold of $22.5 \mathrm{mpg}$. Automobiles with a fuel economy above that figure did not pay any gas guzzler tax. The Panel first examined whether this threshold distinction was aimed at affording protection to domestic production. The EC argued that the United States measure targeted EC automobiles, and was therefore aimed at protecting domestic production. The United States argued that the threshold distinction in the gas guzzler tax was aimed at a policy goal other than the protection of domestic production. The United States stated that the overall purpose of the gas guzzler tax was to conserve fossil fuels, and that the threshold ensured that only the most uneconomical automobiles were subject to the tax. It had been designed to cover only some automobiles because it was complementary to the CAFE regulation. The EC replied that the overall aim of the measure could not be fulfilled, since the few cars affected by the measure could have only a very small effect on the 
que houvesse o efeito protetivo da norma tributária, até porque a tecnologia para a fabricação de automóveis de baixo consumo de gasolina não era de propriedade exclusiva dos fabricantes nortemericanos ${ }^{166}$.

Como o Grupo Especial entendeu que nenhuma das duas incidências havia sido instituída "de modo a proteger a indústria nacional", no exame da primeira frase do Artigo III:2 (devemos lembrar que se trata de julgado anterior à formulação que prevalece hoje, trazida apenas no caso "Japão - Bebidas Alcoólicas II") e como a segunda frase previa a mesma condicionante, dispensou-se automaticamente sua análise em relação à segunda frase. Como não se vislumbrou violação ao Artigo III, restou prejudicada a análise da norma diante do Artigo XX.

É importante se ressaltar que, no julgado de 11 de outubro de 1994, o Grupo Especial analisou os dois aspectos do teste, tanto a não-existência de objetivo normativo legítimo quanto o efeito desproporcional, dando a entender que apenas no caso em que a norma tributária falhasse no atendimento aos dois requisitos simultaneamente seria considerada violadora das obrigações do Tratamento Nacional. Assim também vê Pedro Infante Mota (2005, p. 170), muito embora o autor português se equivoque ao defender que a abordagem havia sido diferenciada daquela do caso do Relatório de 16 de março de 1992, ocasião em que, segundo ele, havia sido estipulado que apenas um dos requisitos deveria ser verificado como atendido. Naquele, no exame do tratamento das cervejas de diferentes teores alcoólicos, nem se fez propriamente o exame dos efeitos da norma, afastado que foi

overall consumption of fossil fuels in the United States. The Panel observed that the threshold in the gas guzzler tax created an incentive in the United States market to purchase more fuel-efficient automobiles, and that this incentive would normally lead to increased conservation of fossil fuels. Although the overall economic efficiency of the measure with respect to the reduction of fuel consumption might be questioned when compared to, for example, a fuel tax, the Panel did not consider that this factor was by itself relevant in determining obligations under Article III. The Panel also noted that when the gas guzzler tax was introduced in 1978, most domestic automobiles could not achieve the final threshold figure set out in the legislation. This was a further indication to the Panel that the gas guzzler threshold figure did not target foreign automobiles".

166 "5.25 The Panel then examined whether the effect of the threshold, in terms of conditions of competition, was to afford protection to domestic production. The Panel noted that the parties had submitted extensive sales and trade-flow data on automobiles subject to the gas guzzler tax. However, the Panel did not consider that these figures in themselves could provide evidence of a change in conditions of competition favouring domestic automobiles. The Panel further noted that the nature and level of the regulatory distinction made at the threshold of the gas guzzler measure were consistent with the overall purpose of the measure and did not appear to create categories of automobiles of inherently foreign or domestic origin. The technology to manufacture high fuel economy automobiles - above the $22.5 \mathrm{mpg}$ threshold - was not inherent to the United States, nor were low fuel economy automobiles inherently of foreign origin, as the Panel noted from fuel economy figures submitted by the parties. Thus the fact that EC automobiles bore most of the burden of the tax did not mean that the measure had the effect of affording protection to United States production. The Panel also noted that the amount of the tax payable at the threshold did not seem excessive, given the range and progression of the tax. The Panel found therefore that the threshold distinction created under the gas guzzler law did not have the effect of affording protection to domestic production". 
prima facie o seu caráter violador pelo entendimento de que as cervejas de baixo e de alto teor alcoólicos não seriam produtos similares ${ }^{167}$.

Esse julgado, por ser um dos últimos no antigo GATT, possui relevância política capital na história do sistema multilateral. Gaëtan Verhoosel (2002, p. 53) afirma que o seu resultado foi muito influenciado pelo debate instalado no Congresso Nacional dos Estados Unidos acerca da sua participação na OMC, sugerindo que o seu veredicto se deu favoravelmente à potência hegemônica predominantemente como forma de viabilizar a continuidade e aprimoramento do sistema.

A comprovar o estado de discordância que gerou, o seu Relatório Final, de 11 de outubro de 1994, apenas foi posto à circulação, não logrando ter sido aprovado pelas Comunidades Europeias. Na Quinquagésima Sessão do GATT, em 8 de fevereiro de 1995, a questão foi discutida pela última vez. Nela, o representante europeu, Mr. Leng reiterou a insatisfação do bloco com o Relatório ${ }^{168}$, especialmente no que trazia uma nova interpretação que entendeu contrária aos precedentes anteriores, especialmente no que tange ao fato de que o objetivo subjacente ao Artigo III, parágrafos 2 (quanto à tributação) e 4 (referente à disciplina regulatória) seria o de prevenir a redução de benefícios obtidos por meio das concessões tarifárias dos Artigos I e II, assegurando igualdade de tratamento

\footnotetext{
${ }^{167}$ Ver nota de rodapé $\mathrm{n}^{\circ} 180$.

168 "Mr. Leng (European Communities) said that the Community was not prepared to adopt the panel report. In the Community's opinion, the report introduced a totally new interpretation of the first sentence of Article III:2. This interpretation was contrary to the well-established precedents of earlier panels, in particular the panel report on Japan - Customs duties, taxes and labelling practices on imported wines and alcoholic beverages. 2 According to these established precedents, the first of which dates back to the 1950s concerning Italian tractors, the underlying objective of Article III, paragraphs 2 and 4, was to prevent any impairment of tariff obligations under Articles I and Il and to ensure equality of treatment for imported products once they had undergone customs clearance. This was an overriding objective for all contracting parties. In the present case, this had not been mentioned at all, being replaced by emphasis on prohibition on imposing taxes "so as to afford protection to production".

In accordance with the text of Article III:2, this prohibition applied only to competitive and substitutable products, mentioned in the second sentence. By introducing this prohibition as a decisive criterion also in the first sentence of Article III:2 concerning like products, the panel had gone against the text of that provision. Without giving any grounds for doing so, the panel had blurred the fundamental distinction between the first and second sentences of Article III:2. This interpretation, which was contrary to the actual terms of Article III, was unacceptable, since panels were not the lawmaking bodies of the GATT. The European Union was well aware that some flexibility must be given to "regulatory taxes" of the contracting parties. But to achieve this flexibility by an interpretation that was contrary to the very wording of Article III:2, created a danger of calling into question the wellestablished precedents on tax discrimination. It could not be denied that the new interpretation, owing to the variety ofregulatory distinctions it authorized, allowed "tariff specialization" in an indirect manner and hindered full protection against any impairment of tariff concessions. Furthermore, the panel had set a very high standard with respect to proving the purpose and effect of protection of domestic production, even quite explicit statements by members of the American legislature had not been considered reliable proof. In doing so, the panel had exposed the legislators of contracting parties to the constant temptation - at a time when all governments were constantly looking for fresh revenues - to tax first and foremost imports, which often occupied "specialized market niches"'" - SR.50/1, de 8 de fevereiro de 1995, Subponto $17(\mathrm{~d})(\mathrm{v})$, p. 10.
} 
entre os produtos no mercado do país importador. Em lugar disso, defendeu que o Grupo Especial optou por dar um entendimento diferenciado ao SATAP, quando da análise da primeira sentença do Artigo III, o que não se coadunaria, no entendimento europeu, com o texto convencional, caracterizando ter havido um exercício legislativo desautorizado por parte do Grupo Especial. Assim, tal proceder seria muito perigoso, uma vez que daria azo a tentações protecionistas e arrecadatórias dos legisladores locais.

A Suécia, àquela altura ainda fora do então mercado comum europeu, que havia intervindo no Grupo Especial na qualidade de terceira interessada, também expressou seu descontentamento com o fato de que o Relatório não teria dado a devida atenção aos aspectos e efeitos discriminatórios das incidências tributárias americanas, nem tampouco entrado no exame de suas motivações ambientais ${ }^{169}$.

Talvez por todas essas injunções políticas de momento, o teste dos "fins e efeitos" foi expressamente afastado logo depois da instituição da $\mathrm{OMC}$, no exame do caso "Japão - Bebidas Alcoólicas II", ainda no exame de primeira instância, no Grupo Especial. Assim se deu depois de o Grupo Especial examinar os testes sugeridos por todas as partes envolvidas, tanto por parte das Comunidades Europeias, a parte reclamante inicial, quanto do Canadá e dos Estados Unidos, que a elas se juntaram no pólo ativo, quanto do Japão, a parte demandada, que, expressamente, solicitou que fosse empregado o teste dos "fins e efeitos", já que alegava, entre outras, razões de saúde pública para tributar mais pesadamente as bebidas destiladas de maior teor alcoólico. Diante da insistência dos representantes japoneses em empregar o teste subjetivo e concluindo que a sustentação dos Estados Unidos ia, no fundo, na mesma direção ${ }^{170}$, o Grupo Especial pôs-se desde logo a

\footnotetext{
169 "Mr. Mahhusen (Sweden) said that in his delegation 's view, the panel had not given due attention to all the discriminatory aspects and effects of the American car tax system. Its analysis of Article XX $(g)$ and the issue of the least trade restrictiveness lacked in comprehension and provided no support for future discussion on taxes for environmental purposes" - SR.50/1, de 8 de fevereiro de 1995, Subponto 17(d)(v), p. 11.

170 "6.15 The Panel further took note of the statements by Japan that essentially argued that the Panel should examine the contested legislation in the light of its aim and effect in order to determine whether or not it is consistent with Article III:2. According to this view, in case the aim and effect of the contested legislation do not operate so as to afford protection to domestic production, no inconsistency with Article III:2 can be established. The Panel further took note of the statement by the United States that essentially argued that, in determining whether two products that were taxed differently under a Member's origin-neutral tax measure were nonetheless "like products" for the purposes of Article III:2, the Panel should examine not only the similarity in physical characteristics and end-uses, consumer tastes and preferences, and tariff classifications for each product, but also whether the tax distinction in question was "applied ... so as to afford protection to domestic production": that is, whether the aim and effect of that distinction, considered as a whole, was to afford protection to domestic production. According to this view, if the tax distinction in question is not being applied so as to afford protection to domestic production, the products between which the distinction is drawn are not to be deemed "like products" for the purpose of Article III:2. The Panel noted that the United States and Japan reached opposite results by applying essentially the same test. Japan concluded that its legislation did not have the aim or effect of affording protection, while the United States concluded that the categorization made in that legislation did have such an aim and effect. Lastly in this context, the Panel
} 
examinar o cabimento de tal critério subjetivo, afastando-o especialmente diante da dificuldade de se examinar o objetivo de uma norma jurídica de natureza tributária, exercício que acabaria dificultando por demais o acesso a uma prova segura ${ }^{171}$.

Ao final, comentando acerca de como o caráter subjetivo da norma deveria ser avaliado, remete esse tipo de teste ao Artigo XX, afirmando que de outra forma as Exceções Gerais, com a sua específica sistemática de ônus da prova, tornar-se-iam normas inúteis, de modo a que se desviasse completamente do exame da necessidade da medida, aspecto relevante na disciplina do Acordo Geral ${ }^{172}$.

Para concluir de forma peremptória o enterro definitivo do teste subjetivo, o Grupo Especial afastou a aplicabilidade ao seu caso do Relatório do Grupo Especial no caso "United States - Taxes on Automobiles", por ele não ter sido adotado pelas Partes

noted that the United States also argued that independently of the legal test chosen and applied, the Panel should find that Japan in this case is in violation of its obligations under Article III:2. It was also the view of Japan that independently of the legal test chosen and applied, the Panel should find that Japan is not in violation of its obligations under Article III:2".

171 "6.16 The Panel first turned to the test proposed by Japan and the United States. The Panel noted, in this respect, that the proposed aim-and-effect test is not consistent with the wording of Article III:2, first sentence. The Panel recalled that the basis of the aim-and-effect test is found in the words "so as to afford protection" contained in Article III: $1 .^{86}$ The Panel further recalled that Article III:2, first sentence, contains no reference to those words. Moreover, the adoption of the aim-and-effect test would have important repercussions on the burden of proof imposed on the complainant. The Panel noted in this respect that the complainants, according to the aim-and-effect test, have the burden of showing not only the effect of a particular measure, which is in principle discernible, but also its aim, which sometimes can be indiscernible. The Panel also noted that very often there is a multiplicity of aims that are sought through enactment of legislation and it would be a difficult exercise to determine which aim or aims should be determinative for applying the aim-and-effect test. ${ }^{87}$ Moreover, access to the complete legislative history, which according to the arguments of the parties defending the aim-and-effect test, is relevant to detect protective aims, could be difficult or even impossible for a complaining party to obtain. Even if the complete legislative history is available, it would be difficult to assess which kinds of legislative history (statements in legislation, in official legislative reports, by individual legislators, or in hearings by interested parties) should be primarily determinative of the aims of the legislation. ${ }^{88}$ The Panel recalled in this respect the argument by the United States that the aim-and-effect test should be applicable only with respect to origin-neutral measures. The Panel noted that neither the wording of Article III:2, nor that of Article III:1 support a distinction between origin-neutral and origin-specific measures".

172 "6.17 The Panel further noted that the list of exceptions contained in Article XX of GATT 1994 could become redundant or useless because the aim-and-effect test does not contain a definitive list of grounds justifying departure from the obligations that are otherwise incorporated in Article III. ${ }^{89}$ The purpose of Article XX is to provide a list of exceptions, subject to the conditions that they "are not applied in a manner which would constitute a means of arbitrary or unjustifiable discrimination between countries where the same conditions prevail, or a disguised restriction of international trade", that could justify deviations from the obligations imposed under GATT. Consequently, in principle, a WTO Member could, for example, invoke protection of health in the context of invoking the aim-and-effect test. The Panel noted that if this were the case, then the standard of proof established in Article XX would effectively be circumvented. WTO Members would not have to prove that a health measure is "necessary" to achieve its health objective. ${ }^{90}$ Moreover, proponents of the aim-and-effect test even shift the burden of proof, arguing that it would be up to the complainant to produce a prima facie case that a measure has both the aim and effect of affording protection to domestic production and, once the complainant has demonstrated that this is the case, only then would the defending party have to present evidence to rebut the claim. ${ }^{91}$ In sum, the Panel concluded that for reasons relating to the wording of Article III as well as its context, the aim-and-effect test proposed by Japan and the United States should be rejected". 
Contratantes, assim como, em relação ao caso "United States - Measures Affecting Alcoholic and Malt Beverages", foi feita crítica ao exame da similaridade dos produtos em conjunto com o SATAP, o que seria inconsistente com a melhor intelecção da primeira frase do Artigo III:2, motivo pelo qual não foi acompanhado ${ }^{173}$.

\subsection{Das Críticas Doutrinárias à Jurisprudência.}

A doutrina especializada no Direito Internacional do Comércio é majoritária no sentido de criticar a forma como a casuística tem sido abordada e julgada nos laudos arbitrais. Michael Treblicock e Shiva Giri (2004, p. 55), por exemplo, afirmam peremptoriamente que os diversos Grupos Especiais e o Órgão de Apelação jamais estabeleceram uma interpretação consistente para os conceitos-chave do Artigo III, especialmente o SATAP, chegando a sugerir que se adote algo mais definitivo do que um "teste de cheiro" "174, uma vez que não há como vislumbrar no conceito de proteção um evidente sentido comum (no sentido de ordinário, como na versão em inglês) que possa ser extraído de uma interpretação literal, havendo que se recorrer à sua interpretação segundo o contexto do GATT e à luz de seu objetivo e finalidade, consoante o artigo 31 da Convenção de Viena Sobre o Direito dos Tratados, de 26 de maio de 1969, que estabelece a "Regra Geral de Interpretação dos Tratados"175.

\footnotetext{
173 " 6.18 The Panel turned at this point to the relevance of the two GATT panel reports that, according to the arguments of Japan and the United States, have espoused the aim-and-effect test. With respect to the panel report on "United States - Taxes on Automobiles" (US Auto Taxes) ${ }^{92}$, the Panel noted that the report remains unadopted and that, for the reasons stated in paragraph 6.10, it did not have to take it into account since it does not constitute subsequent practice. At any rate, for the reasons mentioned in paragraphs 6.16 and 6.17 , the Panel was not persuaded by the reasoning contained in the panel report on US Auto Taxes. With respect to the 1992 Malt Beverages report, the Panel first noted that it interpreted the term "like product" as it appears in Article III:2 in a manner largely consistent with the interpretation of the 1987 Panel Report that had previously interpreted the same term. The Panel noted that the 1992 Malt Beverages report, when interpreting the term "like product", took into account the product's end-uses, consumer tastes and habits, and the product's properties, nature and quality. However, the 1992 Malt Beverages report also considered whether product differentiation is being made "so as to afford protection to domestic production". ${ }^{93}$ The Panel was not in a position to detect how the 1992 Malt Beverages panel weighed the different criteria that it took into account in order to determine whether the products in dispute were like. In the Panel's view, however, an interpretation of the term "like product" as it appears in Article III:2, first sentence, that conditions likeness on the criterion whether a domestic legislation operates so as to afford protection to domestic production, is inconsistent with the wording of Article III:2, first sentence. The Panel recalled its conclusions reached in this respect in paragraphs 6.16 and 6.17. For this reason, the Panel decided not to follow the interpretation of the term "like product" as it appears in Article III:2, first sentence, advanced by the 1992 Malt Beverages report in so far as it incorporates the aim-and-effect test".

174 "Smell test", no original em inglês.

175 “S E C A A O 3

Interpretação de Tratados
} 
Esse objetivo e finalidade, por sua vez, tem sido unissonamente assinalado pela doutrina, por exemplo, Trebilcock e Giri (2004, p. 5 e 61) - como sendo a preservação do "equilíbrio competitivo", da "efetiva igualdade de oportunidades competitivas", ou, em outros termos, a não criação de vantagens competitivas artificiais por meio da disciplina tributária ou regulatória interna, entendimento que tem sido reiteradamente repetido, até exaustivamente, pelos julgadores arbitrais desde o caso "United States - Section 337 of the Tariff Act of 1930”.

Não se deve esquecer que a doutrina do Direito Internacional Público em geral, e do Direito Internacional do Comércio em particular, segundo Francesco Galgano e Fabrizio Marrella (2004, p. 162), tem reconhecido a aplicação da Teoria dos Poderes Implícitos na interpretação dos tratados internacionais, especialmente os institutivos de organizações internacionais. Trata-se da contraposição à visão conservadora que apregoa a restrição na sua interpretação, como forma de contenção dos poderes dos Estados. Por essa teoria, de viés constitucionalista, uma organização internacional pode se utilizar de todos os meios ao seu alcance e disposição para atingir o escopo previsto no seu tratado institutivo, mesmo quando eles não são rigorosamente previstos. Autoriza-se, pois, uma interpretação teleológica ampliativa no plano do Direito Internacional Público.

Assim, como examinar os conceitos de similaridade, substitutabilidade e, principalmente, de proteção, à luz desse conceito e dessa finalidade?

Talvez por sua extrema subjetividade, e por assim poder dar margem a muita abertura no exame pelo OSC, comprometendo a segurança e previsibilidade previstas no Artigo 3.2 do Entendimento Relativo às Normas e Procedimentos sobre Solução de Controvérsias, assim como por todas essas injunções políticas já mencionadas em episódios do passado, dado o potencial impacto que uma abordagem mais rigorosa da

Artigo 31

Regra Geral de Interpretação

1. Um tratado deve ser interpretado de boa fé segundo o sentido comum atribuível aos termos do tratado em seu contexto e à luz de seu objetivo e finalidade.

2. Para os fins de interpretação de um tratado, o contexto compreenderá, além do texto, seu preâmbulo e anexos:

a) qualquer acordo relativo ao tratado e feito entre todas as partes em conexão com a conclusão do tratado;

b) qualquer instrumento estabelecido por uma ou várias partes em conexão com a conclusão do tratado e aceito pelas outras partes como instrumento relativo ao tratado.

3. Serão levados em consideração, juntamente com o contexto:

a) qualquer acordo posterior entre as partes relativo à interpretação do tratado ou à aplicação de suas disposições;

b) qualquer prática seguida posteriormente na aplicação do tratado, pela qual se estabeleça o acordo das partes relativo à sua interpretação;

c) quaisquer regras pertinentes de Direito Internacional aplicáveis às relações entre as partes.

4. Um termo será entendido em sentido especial se estiver estabelecido que essa era a intenção das partes." 
Cláusula do Tratamento Nacional poderá impor sobre a soberania fiscal e regulatória dos Estados-Membros da OMC, tem-se que o maior dos estudiosos do assunto, John Howard Jackson, afirma que o exame da tributação e da regulação protetivas, aquelas que implicam discriminação implícita ou de facto, são um dos mais tormentosos problemas conceituais no exame das normas do GATT (1989, p. 212).

O assim denominado pela doutrina teste dos "fins-e-efeitos" foi expressamente afastado logo depois da instituição da OMC com a conclusão da Rodada Uruguai, quando do caso "Japão - Bebidas Alcoólicas II", ainda no julgamento de primeira instância, no Grupo Especial, como se viu acima. O problema é que não se tem uma noção perfeita do que ficou em seu lugar.

Predominantemente, a doutrina especializada entende que teria sido a formulação empregada no caso "Coreia - Bebidas Alcoólicas"176, em seguida à determinação do Órgão de Apelação no caso "Japão - Bebidas Alcoólicas II"177 e que os

176 "B. "So As To Afford Protection"

146. We now address whether the Panel erred in its application of the term "so as to afford protection", which is incorporated into Article III:2, second sentence, by specific reference to paragraph 1 of Article III.

147. With regard to this third element of Article III:2, second sentence, the Panel stated:

The Appellate Body in the Japan Alcoholic Beverages case stated that the focus of this portion of the inquiry should be on the objective factors underlying the tax measure in question including its design, architecture and the revealing structure. In that case, the Panel and the Appellate Body found that the very magnitude of the dissimilar taxation supported a finding that it was applied so as to afford protection. In the present case, the Korean tax law also has very large differences in levels of taxation, large enough, in our view, also to support such a finding.

(...)

149. In our Report in Japan - Alcoholic Beverages, we said that examination of whether a tax regime affords protection to domestic production "is an issue of how the measure in question is applied", and that such an examination "requires a comprehensive and objective analysis" ${ }^{\prime 134}$ : it is possible to examine objectively the underlying criteria used in a particular tax measure, its structure, and its overall application to ascertain whether it is applied in a way that affords protection to domestic products.

Although it is true that the aim of a measure may not be easily ascertained, nevertheless its protective application can most often be discerned from the design, the architecture, and the revealing structure of a measure. The very magnitude of the dissimilar taxation in a particular case may be evidence of such protective application. Most often, there will be other factors to be considered as well. ${ }^{135, "}$ (WT/DS75/AB/R e WT/DS84/AB/R, de 18 de janeiro de 1999).

177 "(c) "So As To Afford Protection"

This third inquiry under Article III:2, second sentence, must determine whether "directly competitive or substitutable products" are "not similarly taxed" in a way that affords protection. This is not an issue of intent. It is not necessary for a panel to sort through the many reasons legislators and regulators often have for what they do and weigh the relative significance of those reasons to establish legislative or regulatory intent. If the measure is applied to imported or domestic products so as to afford protection to domestic production, then it does not matter that there may not have been any desire to engage in protectionism in the minds of the legislators or the regulators who imposed the measure. It is irrelevant that protectionism was not an intended objective if the particular tax measure in question is nevertheless, to echo Article III:1, "applied to imported or domestic products so as to afford protection to domestic production". ${ }^{58}$ This is an issue of how the measure in question is applied.

(...)

As in that case, we believe that an examination in any case of whether dissimilar taxation has been applied so as to afford protection requires a comprehensive and objective analysis of the structure and application of the measure in question on domestic as compared to imported products. We believe it is possible to examine 
próprios árbitros denominaram "aplicação protetiva" no entendimento do que seria o SATAP, na busca de então por um critério que fosse objetivo e abrangente, afastando por completo a pesquisa pela intenção. Em resumo, a aplicação protetiva de uma norma tributária se revelaria por meio de uma análise "de sua arquitetura, de seu design e de sua estrutura reveladora".

Não obstante, como afirmam Henrik Horn e Petros Mavroidis (2004, p. 57 58), não há uma definição concertada do termo "proteção" ou do que seja "aplicação protetiva", assemelhando-se a posição do Órgão de Apelação a uma postura semelhante a: "nós não podemos definir o que seja proteção, mas nós (usualmente) reconhecemos quando nos defrontamos com isso" ${ }^{178}$. Como bem afirmam $(2004$, p. 58), não dá para entender o que o Órgão de Apelação tinha em mente quando estabeleceu esse parâmetro. Não há qualquer indício minimamente seguro a ser trilhado pelos futuros árbitros acerca do que seria a arquitetura ou a estrutura de uma norma tributária que se manifeste reveladora do seu caráter protetivo.

Não é por outro motivo que Michael Trebilcock e Robert Howse (2005, p. 108) afirmam com todas as letras que o que o Órgão de Apelação fez com esse entendimento foi sacrificar demasiadamente a transparência, a previsibilidade e a coerência de princípios do sistema multilateral de comércio internacional.

Por seu lado, Henrik Horn e Petros Mavroidis (2004, p. 43) afirmam, corretamente, que o OSC jamais ofereceu uma metodologia clara para a interpretação da Cláusula do Tratamento Nacional, o que, em se tratando de um aspecto central do Acordo Geral (p. 40), é preocupante. A concepção por detrás do Artigo III, portanto, é apenas a de uma noção abstrata de falta de neutralidade regulatória (p. 50).

Embora seja reiterada, por parte do OSC, em diversos casos, a remissão ao Art. 31 da Convenção de Viena sobre Direito dos Tratados, a sua "Regra Geral de Interpretação", o fato é que os conceitos de "proteção" e de "produtos similares" ou “produtos diretamente complementares ou substitutos" não só não possuem um "sentido

objectively the underlying criteria used in a particular tax measure, its structure, and its overall application to ascertain whether it is applied in a way that affords protection to domestic products.

Although it is true that the aim of a measure may not be easily ascertained, nevertheless its protective application can most often be discerned from the design, the architecture, and the revealing structure of a measure. The very magnitude of the dissimilar taxation in a particular case may be evidence of such a protective application, as the Panel rightly concluded in this case. Most often, there will be other factors to be considered as well. In conducting this inquiry, panels should give full consideration to all the relevant facts and all the relevant circumstances in any given case". (WT/DS10/AB/R e WT/DS11/AB/R, de 4 de outubro de 1996).

178 "In essence, the approach of the $A B$ has been to say: 'we can't define protection, but we (usually) recognize it when we see it"” no original em inglês, grifado (HORN; MAVROIDIS, 2004, p. 58). 
comum" segundo os termos do GATT, seu preâmbulo e anexos, nem tampouco se pode afirmar que o emprego de soluções, objetivas ou subjetivas, possa ser univocamente depreensível "à luz de seu objeto e finalidade”, consoante os seus parágrafos 1 e 2, Da mesma forma, o Acordo não estabelece qualquer "sentido especial" para esses termos, nos termos do parágrafo 4, de modo que, ao que parece, a intenção dos negociadores de 1947 foi realmente a de deixar as suas interpretações para o exame casuístico, quiçá permeado de injunções políticas e acertos diplomáticos.

Abstraindo-se dessa indefinição, o que fez com que Henrik Horn e Petros Mavroidis afirmassem no próprio título do artigo em questão que a interpretação do Tratamento Nacional no que tange à discriminação tributária está ainda nebulosa após tantos anos ("Still Hazy after All These Years: The Interpretation of National Treatment in the GATT/WTO Case-law on Tax Discrimination"), importante é asseverar que os últimos laudos do OSC (especialmente "Japão - Bebidas Alcoólicas II", "Coreia - Bebidas Alcoólicas" e "Chile - Bebidas Alcoólicas") procuraram dar uma solução predominantemente objetiva ao que seja o SATAP.

Em oposição a essa visão hoje prevalente, embora não muito consistente, podemos ver duas grandes vertentes de críticas na doutrina especializada. A propósito, essas duas correntes de pensamento acompanham a própria formação dos doutrinadores que as defendem, na verdade.

Podemos detectar na doutrina especializada no Direito Internacional do Comércio, especialmente na de língua inglesa, americana ou europeia, fundamentalmente as duas perspectivas vislumbradas por Henrik Horn e Petros Mavroidis (2004, p. 39 - 40), cujas discrepâncias de ponto de vista perpassam todo o debate acerca das vantagens e desvantagens do sistema multilateral de regulação do comércio internacional.

De um lado, a visão tradicional, de base econômica, mas também capitaneada pelos especialistas em Relações Internacionais e Ciência Política, além dos economistas, mormente os de linha liberal, que vê no sistema multilateral de regulação do comércio internacional um meio de abolir o mais possível os obstáculos às livres trocas de mercadorias, talvez na concretização da quimera visualizada por Adam Smith. Com isso, como já vimos, se consagraria a visão econômica prevalente, de que a melhor forma de auferir ganhos com o comércio internacional, para todos os países, que se daria com a plena liberalização dos fluxos de bens e serviços.

Por outro lado, como apontam Henrik Horn e Petros Mavroidis, colocam-se os doutrinadores de viés jurídico, muitas vezes não especializados no Direito Internacional do 
Comércio, mas sim no Direito Tributário ou no Direito Administrativo, mas principalmente vindos dos países dominantes, que percebem no sistema multilateral de regulação do comércio internacional uma forma de restrição ao poder soberano dos Estados-Membros, limitação da competência tributária ou regulatória que poderia vir a ser de tal maneira deletéria que viria a compensar negativamente os ganhos que a liberalização comercial proporcionaria.

Esse é o que Aaditya Mattoo e Arvind Subramanian (1998, p. 303) apontam como o dilema fundamental do sistema multilateral de comércio internacional e o seu maior desafio, na medida em que exige que se elaborem normas que permitam que os julgadores arbitrais tenham a sensibilidade de distinguir a situação de um governo nãoprotecionista, que não consiga eventualmente prevenir os efeitos incidentalmente protetivos de uma política pública ou incidência tributária a onerar os competidores estrangeiros, em relação a governos protecionistas que se valham de um legítimo objetivo público como pretexto para elaborar políticas domésticas que visem a inibir a competição de produtos estrangeiros.

O sistema multilateral regulatório ideal deveria, por consequência, autorizar a primeira e coibir a segunda hipótese. A par disso, comentam, há uma variedade de matizes que também demandam ser detectadas pelo sistema contencioso, como, por exemplo, as regulações domésticas desordenadamente zelosas ao extremo em relação àquelas que restringem apenas no que é necessário e legítimo ao alcance do objetivo pretendido.

Sem prejuízo da existência desse dilema, Henrik Horn e Petros Mavroidis (2004, p. 40) discordam de ambas as posições por eles apresentadas, que, por trás de si, enfatizam um ou outro extremo nas visões da questão, posições polarizadas que, não obstante, o OSC não pode adotar, uma vez que necessariamente deve achar o ponto exato de avaliação do que seja legítimo ou não. Trazem em lugar das posições antagônicas uma visão convergente, na medida em que afirmam que, em verdade, o GATT e, agora, a OMC, são mais do que acordos que visam a reduzir barreiras tarifárias transfronteiriças, mas sim um compromisso básico entre países soberanos, ou as Partes-Contratantes do GATT ou os Estados-Membros da OMC, no sentido de evitar que qualquer deles empregue medidas de políticas públicas de forma protecionista.

Embora com esse raciocínio Henrik Horn e Petros Mavroidis queiram na verdade introduzir a sua posição de que a racionalidade básica do Tratamento Nacional pressupõe necessariamente a verificação da intenção do formulador da política pública, é importante trazer essa concepção para que entendamos as origens em termos de formação 
acadêmica das duas grandes correntes de crítica às formulações até hoje construídas pelo OSC no que tange ao Tratamento Nacional em matéria tributária.

Para a primeira dessas correntes, denominada por Michael Trebilcock e Robert Howse (2005, p. 108) como a da pesquisa do "objetivo regulatório" "179, na qual se alinham Henrik Horn e Petros Mavroidis (2004), tende-se a entender que a essência do Acordo Geral pressupõe uma pesquisa subjetiva, embora não necessariamente a intenção subjetiva do legislador, como o "teste dos fins-e-efeitos" pressupunha.

Qual seria essa pesquisa à intenção subjetiva é aspecto sobre o qual não há coincidência também. Por exemplo, Gaëtan Verhoosel (2002) propõe um teste integrado de necessidade, juntando os exames subjetivos do Artigo III e do Artigo XX de forma a verificar se a disciplina tributária ou regulatória é necessária a alcançar o objetivo a que se propôs ou, se, alternativamente, outros meios menos onerosos estavam disponíveis, sempre de forma a assegurar a eficiência econômica regulatória (p. 51 - 74). Emprega o conceito de causalidade de John Mackie, em sua obra "Causation in the Law", de 1959 (p. 74 - 78) e um instrumento de Análise Econômica do Direito, a regra de negligência, mediante o emprego à obrigação do Tratamento Nacional da "Hand formula" - aplicada pela primeira vez pelo Judge Learned Hand, da Corte Federal do Segundo Circuito, no seu voto no caso U. S. v. Carrol Towing Co., em 1947, às análises da Teoria dos Jogos, com o fim de investigar as estratégias dos países membros nos diversos casos analisados pelo OSC referentes ao Artigo III do GATT.

Henrik Horn e Petros Mavroidis (2004, p. 39 e 53 - 54) entendem que o GATT é um contrato obrigacionalmente incompleto, decorrente do enorme volume de informações necessárias a que se prevejam todas as contingências oriundas da sua aplicação, o que não permite que se restrinjam adequadamente os comportamentos dos contraentes, dada a sua multiplicidade de implicações, já que virtualmente toda política pública interna possui potencial de afetar o comércio exterior. A Cláusula do Tratamento Nacional se voltaria a, portanto, desfavorecer comportamentos do tipo "beggar-thyneighbour" decorrentes desse deficit informacional e assim deve ser interpretada pelos órgãos arbitrais, tentando detectar o intento protecionista da norma interna (p. 56).

A segunda corrente, que Michael Trebilcock e Robert Howse (2005, p. 108) identificam como a da "abordagem econômica" ${ }^{180}$, defende que se empreguem métodos

\footnotetext{
179 “Regulatory purpose”, no original em inglês (2005, p. 109).
}

180 "Economic approach", no original em inglês (2005, p. 108). 
quantitativos mais objetivos, de origem nos modelos matemáticos da Ciência Econômica, na verificação do efeito protetivo da norma tributária ou regulatória.

Como exemplos mais claros dessa visão, temos dois textos de Damien Neven (2000 e 2001).

O primeiro, apresentado em um fórum jurídico e multidisciplinar, o segundo World Trade Forum, patrocinado pela Universidade de Neuchâtel, Suíça, sob a organização de Petros Mavroidis, já traz a visão mais fundamental do autor, professor de Economia Internacional na Universidade de Lausanne: a de que a pesquisa aos casos submetidos ao GATT, particularmente à obrigação do Tratamento Nacional, devem se valer da vasta formulação de pesquisa empírica decorrente das investigações antitruste a cargo das agências especializadas dos países desenvolvidos.

O motivo para tanto, assegura, é que tais investigações sempre são muito rigorosas em empregar um conjunto estruturado de ferramentais de análise econômica plenamente consentâneos com os princípios teóricos envolvidos, situação que não é acompanhada, ao seu ver, corretamente aliás, nos casos que envolvem o comércio internacional (2000, p. 331).

Parte da formulação que o ramo concorrencial do Direito Empresarial faz do conceito de mercado relevante, tentando trazê-lo para a realidade do Artigo III do GATT. Em acanhado resumo, pretende que a qualificação de protetiva seja atribuível a uma norma na situação em que confere a possibilidade aos produtores domésticos de aumentar seus preços acima de um valor "calibrado", no sentido de previamente estipulado, que pode ser, por exemplo, de $5 \%$ do preço em livre concorrência sem imposto de importação (2000, p. 332).

No segundo, exclusivamente com fulcro econômico, busca avaliar a proteção das disputas comerciais pelo emprego de um método quantitativo inspirado na definição de mercado relevante do Direito Antitruste, baseada no acréscimo no custo marginal imposto às firmas estrangeiras pela norma protetiva, mediante o apoio de um modelo de simulação de condições de competitividade de uso nos estudos de Economia Internacional, chamado "Modelo de Cournot".

Trazendo uma abordagem também de fulcro econômico, porém mais completa no plano jurídico, tem-se o artigo de Michael Trebilcock e Shiva Giri (2004), apresentado no encontro anual da American Law \& Economics Association.

Consoante a visão de Michael Trebilcock e Shiva Giri (2004, p. 60), a qualificação do que seja produto similar ou diretamente competidor ou substituto deve 
fazer uso também da consolidada jurisprudência americana e canadense no exame do conceito de mercado relevante do Direito Concorrencial, especialmente o " $U$. $S$. and Canadian Merger Enforcement Guidelines" e o seu teste do monopolista hipotético.

No que tange à densificação conceitual do SATAP, propõem (2004, p. 61 - 62) que, na esteira do proclamado pelo Grupo Especial do caso “United States - Section 337 of the Tariff Act of 1930" ${ }^{\prime 181}$, assim como diversas decisões posteriores, sempre focadas na preservação da efetiva igualdade de oportunidades competitivas, também com base na literatura antitruste acerca do acréscimo dos custos dos rivais ${ }^{182}$, o exame arbitral deveria condenar as medidas domésticas que aumentassem os custos marginais (incluindo os custos de oportunidade) dos rivais estrangeiros relativamente aos custos marginais (incluindo os custos de oportunidade) dos competidores domésticos de forma a substancialmente reduzir a competição no mercado doméstico. Essa discrepância deve se dar a tal ponto que os produtores domésticos possam aumentar seus preços significativamente por um período de tempo não transitório, de modo a manter suas margens de lucro, sem, no entanto, atrair suficientemente a entrada de concorrentes estrangeiros.

Malgrado a abordagem econômica de Trebilcock e Giri seja pouco clara em esclarecer de que modo a ferramenta matemática seria efetivamente aplicável, por outro lado acerta em fazer uma importantíssima distinção metodológica para o mais correto entendimento sistemático do Acordo Geral. Embora a presente tese também vise precipuamente a trazer uma resposta de fulcro econômico à indagação de qual o mais apropriado critério para investigar a proteção a que se refere o Artigo III do GATT, o desacerto na eleição da metodologia econômica em relação àquela que este trabalho propõe é problema muito menor do que a correção na formulação jurídica que está por trás da posição dos autores mencionados. Trata-se, fundamentalmente da consideração que a análise do Artigo III deve implicar apenas a verificação dos efeitos protetivos das normas tributárias ou regulatórias, nada mais.

A mera consideração de caráter literal que se pode empreender à primeira vista, uma vez que a dicção em português do Artigo III:1 reporta-se aos termos "de modo a proteger a produção nacional", claramente referentes à mera pesquisa aos efeitos da norma,

\footnotetext{
${ }^{181}$ Ver nota de rodapé $\mathrm{n}^{\mathrm{o}} 106$

${ }^{182}$ Como SALOP, Steven C.; SCHEFFMAN, David T. Raising Rivals' Costs, The American Economic Review, vol. 73, $\mathrm{n}^{\mathrm{o}}$ 2, Papers and Proceedings of the Ninety-Fifth Annual Meeting of the American Economic Association, maio de 1983, p. 267 - 271; e KRATTENMAKER, Thomas G.; SALOP, Steven C. Anticompetitive Exclusion: Raising Rivals' Costs to Achieve Power Over Price, Yale Law Journal, vol. 96, p. 209, 1986 .
} 
independentemente de qualquer indagação sobre a intenção protecionista do legislador, já favorece aqueles que defendem a visão objetiva. Como afirmam Henrik Horn e Joseph Weiler (2003, p. 6), o termo em inglês "so as" é indicativo de uma proibição objetiva geral.

Por sua vez, Trebilcock e Giri (2004, p. 64) defendem a completa segregação entre os espectros de aplicação do Artigo III, eminentemente objetivo, em relação ao Artigo XX, esse sim o local no qual os redatores convencionais quiseram focar a pesquisa do elemento subjetivo ao legislador interno.

Fora a já propalada - e reconhecida até pelos defensores do "objetivo regulatório" como de difícil identificação - metafísica da racionalidade do legislador ou regulador, Trebilcok e Giri (2004, p. 58) indagam, muito apropriadamente, quais seriam os objetivos regulatórios ou fiscais que seriam classificados como legítimos e quais não o seriam? Será que o OSC teria recebido um mandato por parte do Artigo III para estabelecer ao seu talante qual o conjunto de objetivos normativos justificáveis do ponto de vista da regulação internacional do comércio?

Tanto para os que se filiam ao entendimento pelo "objetivo regulatório", como, além de Henrik Horn e Petros Mavroidis (2004), também Robert Howse e Donald Regan (2000), Henrik Horn e Joseph Weiler (2003), Gaëtan Verhoosel (2002) e Mattia Melloni (2005), quanto para os de linha econômica, o ponto nodal de divergência não é, portanto, como afirmam Trebilcock e Howse (2005, p. 109), o emprego ou não de métodos quantitativos, o que, deve-se entender, é por todos admitido, embora por nenhum deles apontado com correção qual, mesmo que, eventualmente, apenas como mera metodologia de apoio à decisão.

Ocorre que os de linha econômica cingem-se à análise objetiva e de maior rigor conceitual do que simplesmente a dita "aplicação protetiva" pelo OSC, enquanto que os da linha do "objetivo regulatório", ao aspecto meramente objetivo sobrepõem também a consideração de natureza subjetiva.

Exemplo disso é a posição de William Davey e de Joost Pauwelyn (2000, p. 36 - 41) que, entendendo que a norma do Artigo III:2 preocupa-se apenas com o que entendem ser um "efeito discriminatório" da norma tributária, acabam por condenar quaisquer critérios que envolvam a subjetividade do legislador. No entanto, falham em não esmiuçar como aferir o que seria esse "efeito discriminatório".

Fundamentalmente, para os subjetivistas, diga-se assim, a redação do Artigo XX do GATT não esgota o rol dos propósitos legítimos a excepcionarem a regra objetiva do Tratamento Nacional, até por sua reduzida pormenorização, na medida em que a própria 
finalidade do Acordo Geral como um todo, nos termos do artigo 31.1 da Convenção de Viena sobre Direito dos Tratados, como já repisado exaustivamente, contempla o propósito de evitar o protecionismo, sendo que a Cláusula do Tratamento Nacional é um dos pilares básicos na consecução desse objetivo.

Para esses defensores, a ilustrar tal concepção, é fundamental perceber a ausência na listagem do Artigo XX de propósitos como a proteção do consumidor ou a imposição de padrões mínimos de condições de trabalho, dentro de uma visão moderna dos direitos fundamentais, exigências hoje de aceitação universal e que não poderiam estar afastadas da excepcionalidade conferida pelo Artigo XX. Isso sem falar, diante da experiência brasileira, do vasto campo da extrafiscalidade interventiva no domínio econômico.

Para estudiosos como Trebilcock e Giri - repita-se, de índole objetivista embora seja reconhecida a obsolescência da listagem de Exceções Gerais ao Acordo Geral do Artigo XX, não há como se inserir outras possibilidades excepcionais na hermenêutica do Artigo II, por mais que sejam universalmente consideradas justificáveis, na medida em que, por essa maneira, estar-se-ia conferindo um mandato aos Grupos Especiais e ao Órgão de Apelação para eleger quais seriam tais justificativas (2004, p. 57 - 58). Com isso, o produto seria uma tensão entre a legitimidade interna do Sistema de Solução de Controvérsias, como conferida pelo Acordo específico que o regula, e as instituições políticas que fundamentaram a criação da OMC.

Não há dúvida que ainda não há entendimento consolidado sobre alguns conceitos do Artigo XX, como já se viu. É o caso da "moralidade pública", da alínea "a", jamais objeto de exame pelo OSC, e que pode ser vista como potencial claúsula de escape genérica ou residual, nos termos do conceito de "ordem pública" do Direito Internacional Público e do Privado (TREBILCOCK; HOWSE, 2005, p. 109). Resta saber se essa solução não se configuraria também em apropriação por parte de um pretenso órgão técnico de uma função claramente política, de estabelecer o que é entendido como moralmente justificável do ponto de vista do Acordo Geral. Como afirmam Trebilcock e Giri (2004, p. 58 - 59), configurar-se-ia uma radical usurpação da autoridade política da condição de membro da OMC, o que, para além do fator de legitimidade, também implicaria desigualdade no tratamento em relação a outros artigos, como o Artigo XI, o que poderia gerar ainda maior inconsistência na interpretação do Acordo Geral. No mundo ideal, afirmam, teríamos uma lista de Exceções Gerais do Artigo XX revisada e expandida (p. 64). A ausência dessa realidade, portanto, deve ter uma razão de ser. 
Trebilcock e Giri (2004, p. 64 - 65) também veem um outro fator importante e favorável na segregação das disciplinas dos Artigos III e XX, para além da preservação do limitado rol das Exceções Gerais como convencionado. Trata-se no fato de que tal entendimento implicaria uma adequada distribuição do ônus da prova. Caberia ao reclamante apenas a prova dos elementos subjetivos previstos no Artigo III. As alegações referentes à subjetividade, quanto ao justificável propósito tributário ou regulatório, ficariam a cargo do reclamado. Assim, caberia àquele que possui as informações alegá-las em seu proveito, e não ao reclamante suscitar abstratamente a inexistência de intuito não protecionista na norma tributária ou regulatória, o que, do ponto de vista processual, afirmam, corretamente, seria muito mais técnico e conveniente. Trebilcock e Howse (2005, p. 109 -110), por sua vez, dada a estreiteza com que o OSC interpreta as justificativas do Artigo XX, especialmente quanto ao conceito de medida necessária como a menos restritiva ao comércio, vê nisso um ônus inconveniente ao país regulador que age inocentemente, embora, ponderem, o OSC tem admitido uma ponderação proporcional de impactos no teste de necessidade, no que tange à matéria ambiental, como foi decidido no caso "Korea - Measures Affecting Imports of Fresh, Chilled and Frozen Beef"183.

Como bem apontam Robert Howse e Donald Regan (2000, p. 265), mesmo por detrás do termo "aplicação protetiva" hoje aplicado, esconde-se na verdade um intento de pesquisar o propósito aparente da norma analisada, muito embora mediante emprego de comprovações meramente objetivas. Ou seja, nem bem se consegue identificar com clareza qual das duas visões hoje é a prevalente.

Em resumo, tal discussão encerra dentro de si uma questão nodal no exame da disciplina convencional, relacionada ao fato de se aplicar maior peso específico ao efeito protetivo da norma tributária ou regulatória, independente de suas eventuais boas intenções, ou a imputar prevalência ao exame das motivações legislativas primárias que a ocasionaram, ainda que eventualmente o legislador investido de tal legitimidade não tenha sido feliz da aplicação de sua disposição legal.

Assim é que Henrik Horn e Joseph Weiler (2003, p. 20) identificam na questão, mais do que aspectos meramente jurídicos ou processuais, um simbolismo de identidade política. A visão objetivista implicaria a concepção de que a liberalização comercial é a base de sustentação do sistema, autêntica norma lógica de encerramento, a que se pressupõe na ausência de qualquer outra circunstância excepcional. A eventual prevalência

\footnotetext{
${ }^{183}$ WT/DS161/AB/R e WT/DS169/AB/R, de 11 de dezembro de 2000.
} 
de norma regulatória ou tributária não neutra só poderia surgir se convenientemente justificada. Por outro lado, a visão subjetivista tenderia a privilegiar a autonomia soberana da identidade nacional política e moral, que requereria justificação apenas no caso de suspeitas de seu emprego abusivo. Como afirmam Michael Trebilcock e Robert Howse (2005, p. 111), trata-se do tratamento da relevante e complexa transição entre o plano dos mercados globais competitivos e o âmbito das políticas nacionais visando no mais das vezes a objetivos não econômicos.

Outro importante doutrinador do Direito Internacional do Comércio, Federico Ortino, em recentíssima obra de amplas pretensões, sendo responsável pelo capitulo sobre o GATT, ao selecionar pontos chave da análise do tratado que entende como um "contrato incompleto", justamente aqueles que revelariam de maneira mais evidente essa incompletude (2009, p. 130), relaciona como um dos mais importantes aspectos a ser ainda completado exatamente a análise da obrigação do Tratamento Nacional no Artigo III do GATT, que afirma ser a sua disposição mais invocada e que, a despeito de ser indubitavelmente um pilar do sistema, permanece sendo sujeita a extensivo debate (p. 138).

Didaticamente, resume as visões em relação à questão do que consiste a garantia do tratamento nacional, em quatro características centrais, as quais, dependendo do posicionamento do estudioso, devem receber maior relevo para identificar a medida discriminatória ("language, effect, inherence, and intent").

A primeira é a linguagem. Presta-se, basicamente, a ressaltar os casos de discriminação de jure, ou explícita, aquela que é evidenciada nos próprios termos da norma, tributária ou regulatória, que assim estabelece a discriminação. A segunda visão centra o seu foco no efeito adverso ou no impacto deletério da medida discriminatória na demanda do produto estrangeiro no mercado nacional. A terceira se prende ao inerente caráter discriminatório da medida nacional em análise. A última, quarta, atenta para a intenção discriminatória do legislador nacional.

Não importa como são classificadas as diferentes abordagens, mas, de toda essa análise, o que sobressalta é a constatação de que, muito embora se percebam esforços da doutrina especializada em divisar critérios empregados pelos julgadores arbitrais, assim como alguma lógica neles, o que se conclui da fluidez no emprego em concreto de cada uma das formas de examinar tais questões é que, na verdade, tais critérios são muito mais apenas tipologias de argumentos a serem esgrimidos conforme sejam mais úteis e convincentes a embasarem a decisão do OSC na situação específica, resolvendo seu 
problema pontual, do que propriamente vetores a definirem uma metodologia de análise. Exemplo disso é o fato de que, como apropriadamente assinalam Robert Howse e Donald Regan (2000, p. 266), mesmo no caso "Japão - Bebidas Alcoólicas II”, em que expressamente se afastou o "teste dos fins-e-efeitos", não se deixou-se de considerar, porém, aspectos de natureza subjetiva - os fins da norma analisada.

Com isso, falta ao OSC, claramente, definir uma sistemática de análise que confira a segurança e a previsibilidade que o sistema multilateral de regulação do comércio internacional tanto almeja construir, como já mencionado.

\subsection{Das Exceções ao Princípio de Não-Discriminação.}

Como vimos, os Princípios de Não-Discriminação e da Proteção Aduaneira Exclusiva funcionam em conjunto, estruturando entre si os pilares do sistema multilateral de regulação do comércio internacional. Enquanto o segundo reserva para si o terreno básico de negociações no âmbito do Acordo Geral, no seu escopo precipuamente destinado à redução dos encargos aduaneiros, o primeiro visa a que tais iniciativas não gerem benefícios ao sistema que sejam eventualmente anulados ou reduzidos por meio de mecanismos unilaterais de política comercial. Serão efetivos, portanto, apenas na medida em que sejam mutuamente tomados como dependentes um do outro. Assim, as concessões tarifárias só fazem sentido se os Estados-Membros não discriminarem os produtos estrangeiros em proveito dos domésticos, de forma a não criarem encargos de efeito equivalente aos direitos aduaneiros, por meio dos gravames paratarifários; semelhantemente, a imposição da necessidade de igualdade de tratamento na tributação e na regulação internas, entre o produto doméstico e o estrangeiro e entre estrangeiros de diversas procedências, não acarretará realmente igualdade material, no sentido, que sempre repetir-se-á aqui, de iguais oportunidades competitivas no mercado do importador, de não produção de vantagens competitivas artificiais, se o sistema tarifário - rectius, dos encargos na importação - for por demais oneroso ao produto estrangeiro.

São, como todos os princípios, normas de baixa carga vinculante, enunciados deônticos razoavelmente abertos, necessitando serem densificados mediante a conjugação com uma pletora de normas específicas, mencionadas com algum vagar nos itens anteriores desse capítulo. 
No entanto, também como todos os princípios, comportam exceções, previsões normativas de situações objetivas ou motivos subjetivos de política comercial que justificam, a critério da determinação convencional, a derrogação daqueles pilares básicos estruturantes do sistema.

Tais exceções perpassam todo o Acordo Geral, pelo que há discordância entre os autores quanto à melhor forma de sistematizá-las didaticamente (BLIACHERIENE, 2007, p. 44). Como exemplos de diferentes formas de classificação, temos a de John H. Jackson (1997, p. 180) e a de Bernard Hoekman e Michel Kostecki (2001, p. 303 - 304).

Welber Barral (2002, p. 27 - 33), por exemplo, após criticar a doutrina que as reúne em uma categoria genérica de "salvaguardas", por se tratar de identificação que confunde tais exceções com as salvaguardas propriamente ditas, aquelas medidas de emergência para a importação de produtos especiais, do Artigo XIX, prefere estabelecer a denominação de "exceções ao livre comércio", uma vez que defende que os princípios que entende básicos, da nação mais favorecida e do tratamento nacional, consagram, no plano normativo, o "ideário do livre comércio" (p. 27).

No entanto, é corrente na doutrina definições para o termo "salvaguardas" que abrangem um conceito genérico de medidas excepcionais, como a de John Jackson (1997, p. 175), como sendo "ações governamentais em resposta às importações tidas como lesivas à economia do país importador ou à competição da indústria doméstica", na tradução de Ana Carla Bliacheriene (2007, p. 306 - 307).

Prosseguindo no seu raciocínio, Welber Barral (2002, p. 27 - 33) agrupa as exceções em três classes: as medidas de defesa comercial; as exceções contingenciais e as exceções permanentes. Como medidas de defesa comercial, arrola as salvaguardas em sentido estrito, as medidas compensatórias e os direitos antidumping. Como exceções contingenciais, lista as restrições, do Artigo XII, destinadas a proteger o equilíbrio da balança de pagamentos (o que identifica como "exceção da balança de pagamentos") e a possibilidade, do Artigo XVIII:4:(a), das Ajudas de Estado em favor do desenvolvimento econômico no caso de Estados-Membros cuja economia não pode assegurar à população senão um baixo nível de vida e que se encontra nos primeiros estágios de seu desenvolvimento (o que denomina "exceção da indústria nascente"). Por fim, como exceções permanentes, assim classifica as Exceções Gerais, do Artigo XX; o waiver, que é a possibilidade, prevista no Artigo XXV: $5^{184}$, de os Estados-Membros, mediante ação

\footnotetext{
${ }^{184}$ Na redação da Lei no 313/48:
}

"ARTIGO XXV 
coletiva, dispensarem um ou mais de um Estado específico do cumprimento de uma obrigação prevista no Acordo Geral; as "razões de segurança nacional”, do Artigo XXI; e a renegociação de concessões, do Artigo XXVIII, que se refere à modificação ou à retirada de uma concessão mencionada na respectiva lista, nas condições previstas no Acordo Geral.

Tal classificação, malgrado muito didática, é falha, até porque não consegue segregar as diferentes circunstâncias autorizadoras de uma modalidade e de outra entre as exceções. Por exemplo, o conceito de "medida de defesa comercial" não é inequívoco, até porque as salvaguardas, em sentido estrito, também são exceções contingenciais.

Ana Carla Bliacheriene (2007, p. 306) também, além das acima mencionadas, lista como salvaguardas, genericamente consideradas, a possibilidade de aderir a acordos regionais de comércio, prevista no Artigo XXIV, a sanção prevista no Artigo XXIII:2 e as medidas antidumping e compensatórias do Artigo VI, assim como as medidas de emergência para a importação de produtos especiais, do Artigo XIX, qualificando-as, essas últimas, como "cláusula de escape" ou "provisão de salvaguarda" (p. 207), no sentido estrito.

A par dessas divergências conceituais e terminológicas, afirmando que não é a preocupação de momento entrar no tormentoso campo da classificação e sistematização das exceções ao Regime Geral presentes no Acordo, o que nos importa é estudar com maior afinco a relevantíssima disciplina das Exceções Gerais, do Artigo XX do GATT, cujo percuciente conhecimento é necessário a que se perceba o alcance das implicações do entendimento do OSC da OMC quanto ao conceito de tributação protetiva.

AÇÃO COLETIVA DAS PARTES CONTRATANTES

1. Os representantes das Partes Contratantes se reunirão, periòdicamente, a fim de garantir a execução das disposições do presente Acôrdo que comportem uma ação coletiva, e, em geral, para facilitar a aplicação do presente Acôrdo e contribuir para a consecução dos seus objetivos. Tôdas as vezes em que no presente Acôrdo haja referência às Partes Contratantes agindo coletivamente, serão os mesmos designados com o nome de Partes Contratantes.

2. Cabe ao Secretário Geral das Nações Unidas convocar a primeira reunião das Partes Contratantes, que deverá efetuar-se, o mais tardar, em primeiro de março de 1948.

3. Cada Parte Contratante terá direito a um voto em tôdas as reuniões das Partes Contratantes.

4. Salvo disposições em contrário do presente Acôrdo, as decisões das Partes Contratantes serão adotadas por maioria de votos.

5. Em circunstâncias excepcionais, não previstas nos demais artigos do presente Acôrdo, as Partes Contratantes poderão relevar a uma Parte Contratante o não cumprimento de uma obrigação imposta pelo presente Acôrdo com a condição de que tal decisão seja aprovada por maioria de dois terços dos votos emitidos e de que tal maioria compreenda mais da metade das Partes Contratantes. Por meio de um voto semelhante, as Partes Contratantes poderão:

a) Determinar certas categorias de circunstâncias excepcionais ás quais deverão aplicar-se outras condições de votação para relevar uma Parte Contratante de uma ou mais de suas obrigações; e

b) estabelecer os critérios que deverão ser observados na aplicação do presente parágrafo". 
São as exceções do Artigo $\mathrm{XX}^{185}$ gerais porque valem para qualquer dos princípios fundamentais do GATT, característica que também se aplica às do Artigo XXI. Dessa maneira, como consistem em uma ampla derrogação das normas gerais do Acordo como um todo, suas disposições, que visam a preservar a soberania nacional dos Estados membros na proteção de aspectos como a saúde pública, a proteção do patrimônio histórico, artístico ou arqueológico, os recursos naturais não renováveis, o meio ambiente, a moralidade pública e o respeito às leis, entre outras, as regras aplicáveis à sua interpretação deverão ser de capital importância na aplicação do Acordo Geral como um todo.

Tais regras foram determinadas logo no primeiro caso julgado já na era OMC, em que houve pioneiramente deu-se o emprego do recurso de apelação ao Órgão de Apelação. Trata-se do caso "United States - Standards for Reformulated and Conventional

185 “ARTIGO XX

\section{EXCEÇÕES GERAIS}

Desde que essas medidas não sejam aplicadas de forma a constituir quer um meio de discriminação arbitrária, ou injustificada, entre os países onde existem as mesmas condições, quer uma restrição disfarçada ao comércio internacional, disposição alguma do presente capítulo será interpretada como impedindo a adoção ou aplicação, por qualquer Parte Contratante, das medidas:

(a) necessárias à proteção da moralidade pública;

(b) necessárias à proteção da saúde e da vida das pessoas e dos animais e à preservação

dos vegetais;

(c) que se relacionem à exportação e a importação do ouro e da prata;

(d) necessárias a assegurar a aplicação das leis e regulamentos que não sejam incompatíveis com as disposições do presente acordo, tais como, por exemplo, as leis e regulamentos que dizem respeito à aplicação de medidas alfandegárias, à manutenção em vigor dos monopólios administrados na conformidade do $\S 4^{\circ}$ do art. II e do art. XVII à proteção das patentes, marcas de fábrica e direitos de autoria e de reprodução, e a medidas próprias a impedir as práticas de natureza a induzir em erro;

(e) relativas aos artigos fabricados nas prisões:

(f) impostas para a proteção de tesouros nacionais de valor artístico, histórico ou arqueológico;

(g) relativas à conservação dos recursos naturais esgotáveis, se tais medidas forem aplicadas conjuntamente com restrições à produção ou ao consumo nacionais;

(h) tomadas em execução de compromisso contraídos em virtude de um Acordo intergovernamental sobre um produto de base, em conformidade com os critérios submetidos às Partes Contratantes e não desaprovados por elas e que é ele próprio submetido às Partes Contratantes e não é desaprovado por elas.

(i) que impliquem em restrições à exportação de matérias primas produzidas no interior do país e necessárias para assegurar a uma indústria nacional de transformação as quantidades essenciais das referidas matériasprimas durante os períodos nos quais o preço nacional seja mantido abaixo do preço mundial, em execução de um plano governamental de estabilização; sob reserva de que essas restrições não tenham por efeito reforçar a exportação ou a proteção concedida à referida indústria nacional e não sejam contrárias às disposições do presente Acordo relativas à não discriminação.

(j) essenciais à aquisição ou a distribuição de produtos dos quais se faz sentir uma penúria geral ou local; todavia, as referidas medidas deverão ser compatíveis com o princípio segundo o qual todas as Partes Contratantes têm direito a uma parte eqüitativa do abastecimento internacional desses produtos e as medidas que são incompatíveis com as outras disposições do presente Acordo serão suprimidas desde que as circunstâncias que as motivaram tenham deixado de existir. As Partes Contratantes examinarão, em 30 de junho de 1960, no máximo, se é necessário manter a disposição da presente alínea”. 
Gasoline 186 , em que a Venezuela e o Brasil se insurgem contra uma norma ambiental americana que estabelecia tratamento diferenciado, aos importadores e formuladores americanos que revendiam gasolina importada, em proveito dos refinadores domésticos, sob o pretexto de redução dos graus de poluição estival nas nove zonas metropolitanas mais prejudicadas nesse aspecto ambiental. Alegaram que a regulamentação administrativa, por parte da EPA (“United States Environmental Protection Agency”), agência americana de proteção ambiental, seria contrária aos Artigos I e II do GATT, não contemplada ppor nehuma das exceções previstas no Artigo XX, assim como também contrárias ao Artigo $2^{\circ}$ do Acordo sobre Barreiras Técnicas ao Comércio.

Os Estados Unidos, por sua vez, defenderam-se alegando que a norma, denominada pelos árbitros como "Gasoline Rule", era compatível com os Artigos I e III do GATT, também incidente dentro do campo de aplicação do Artigo XX (b), (d) e (g) do GATT 1994 e compatível com o Acordo sobre Barreiras Técnicas ao Comércio.

Inicialmente, o Órgão de Apelação afirmou que as disposições do Artigo XX não podem ser interpretadas em um sentido tão amplo que levasse a por em risco o fim e o objeto de outras disposições do Acordo Geral, mas tampouco não deveriam comportar intelecção tão estrita que pudesse retirar dos Estados membros a possibilidade de regular as políticas de interesse público listadas nas alíneas do Artigo XX, desde que sejam aplicadas razoavelmente.

Assim foi a correta exegese do caput do Artigo XX enunciada no caso acima mencionado ${ }^{187}$, de uma forma que se pode entender como ainda tomada de uma certa

\footnotetext{
${ }^{186}$ Para uma análise profunda e definitiva sobre tão relevante caso, ver o nosso "Estados Unidos - Padrões para Gasolina Reformulada e Convencional (Restrições Não-Tarifárias ao Comércio Internacional)" (BRITO FILHO, 2003, p. $79-128)$.

187 "IV. The Introductory Provisions of Article XX of the General Agreement: Applying the Chapeau of the General Exceptions

Having concluded, in the preceding section, that the baseline establishment rules of the Gasoline Rule fall within the terms of Article $X X(\mathrm{~g})$, we come to the question of whether those rules also meet the requirements of the chapeau of Article XX. In order that the justifying protection of Article XX may be extended to it, the measure at issue must not only come under one or another of the particular exceptions - paragraphs $(a)$ to $(j)$ - listed under Article XX; it must also satisfy the requirements imposed by the opening clauses of Article XX. The analysis is, in other words, two-tiered: first, provisional justification by reason of characterization of the measure under $X X(\mathrm{~g})$; second, further appraisal of the same measure under the introductory clauses of Article $X X$.

The chapeau by its express terms addresses, not so much the questioned measure or its specific contents as such, but rather the manner in which that measure is applied. ${ }^{43}$ It is, accordingly, important to underscore that the purpose and object of the introductory clauses of Article XX is generally the prevention of "abuse of the exceptions of [what was later to become] Article [XX]." ${ }^{\prime 4}$ This insight drawn from the drafting history of Article XX is a valuable one. The chapeau is animated by the principle that while the exceptions of Article XX may be invoked as a matter of legal right, they should not be so applied as to frustrate or defeat the legal obligations of the holder of the right under the substantive rules of the General Agreement. If those exceptions are not to be abused or misused, in other words, the measures falling within the particular
} 
superficialidade. Como o presente autor já teve a oportunidade de se manifestar (2003, p. 127), embora o exame do caso em exame tenha sido das mais felizes e relevantes na história do OSC da OMC, perdeu-se uma boa oportunidade de traçar contornos mais definidos aos termos "discriminação arbitrária", "discriminação injustificada" e "restrição disfarçada ao comércio internacional", presentes no caput do Artigo XX, limitando-se a enunciar uma genérica regra interpretativa de ponderação de princípios, com o fim de não comprometer os objetivos do Acordo Geral.

O Órgão de Apelação do OSC da OMC também estabeleceu, no exame do caso "United States - Import Prohibition of Certain Shrimp and Shrimp Products", explicando melhor determinação já promanada no caso acima referido, que o procedimento apropriado, com vistas a respeitar a lógica e a estrutura da disposição, de modo a verificar se uma determinada medida nacional é uma exceção válida, nos termos do Artigo XX do Acordo Geral, abrange dois passos: no primeiro, verifica-se se a medida pode ser adequada a algumas das alíenas "a" a “j” do artigo, atentando para os requisitos específicos de cada uma delas; no segundo, verifica-se a sua subsunção aos ditames do caput respectivo ${ }^{188}$.

Não obstante, o Órgão de Apelação do OSC da OMC, no exame do caso "United States - Standards for Reformulated and Conventional Gasoline", estabeleceu entendimento, desde então sempre mantido, no sentido de aplicar, ao conceito de medida "necessária", nos termos das alíneas "b" e "d" do Artigo XX, in initio, o princípio da

exceptions must be applied reasonably, with due regard both to the legal duties of the party claiming the exception and the legal rights of the other parties concerned".

188 "118. In United States - Gasoline, we enunciated the appropriate method for applying Article XX of the GATT 1994: 'In order that the justifying protection of Article XX may be extended to it, the measure at issue must not only come under one or another of the particular exceptions -- paragraphs (a) to (j) -- listed under Article XX; it must also satisfy the requirements imposed by the opening clauses of Article XX. The analysis is, in other words, two-tiered: first, provisional justification by reason of characterization of the measure under XX $(\mathrm{g})$; second, further appraisal of the same measure under the introductory clauses of Article XX ${ }^{92}$ 119. The sequence of steps indicated above in the analysis of a claim of justification under Article XX reflects, not inadvertence or random choice, but rather the fundamental structure and logic of Article XX. The Panel appears to suggest, albeit indirectly, that following the indicated sequence of steps, or the inverse thereof, does not make any difference. To the Panel, reversing the sequence set out in United States Gasoline "seems equally appropriate. ${ }^{193}$ We do not agree.

120. The task of interpreting the chapeau so as to prevent the abuse or misuse of the specific exemptions provided for in Article XX is rendered very difficult, if indeed it remains possible at all, where the interpreter (like the Panel in this case) has not first identified and examined the specific exception threatened with abuse. The standards established in the chapeau are, moreover, necessarily broad in scope and reach: the prohibition of the application of a measure "in a manner which would constitute a means of arbitrary or unjustifiable discrimination between countries where the same conditions prevail" or "a disguised restriction on international trade."(emphasis added) When applied in a particular case, the actual contours and contents of these standards will vary as the kind of measure under examination varies. What is appropriately characterizable as "arbitrary discrimination" or "unjustifiable discrimination", or as a "disguised restriction on international trade" in respect of one category of measures, need not be so with respect to another group or type of measures. The standard of "arbitrary discrimination", for example, under the chapeau may be different for a measure that purports to be necessary to protect public morals than for one relating to the products of prison labour". 
medida menos inconsistente ("least inconsistent measure principle"). Vale dizer, a medida, com efeito protetivo, violadora do Artigo III, para não ser considerada como contrária às disposições do Acordo Geral como um todo, não só deve ser considerada como visando a uma finalidade pública contemplada pelo Artigo XX, como também deve ser o menos onerosa possível ao Estado-membro prejudicado.

Entendeu-se, no caso, que a medida tomada pelos Estados Unidos, por meio de sua agência de regulação ambiental, tendente a estabelecer requisitos de controle da qualidade da gasolina produzida no território nacional menos rigorosos que os aplicáveis à gasolina importada ou formulada no país, era uma medida "relativa" à "proteção da saúde e da vida das pessoas e dos animais e à preservação dos vegetais", no termos da alínea "b", porém não "necessária". Assim se concluiu porque as investigações levadas a cabo puderam fazer ver que os Estados Unidos não fizeram qualquer esforço em procurar celebrar acordos de cooperação técnica que pudessem resolver as dificuldades administrativas em fazer valer extraterritorialmente as normas de controle e coerção da EPA (BRITO FILHO, 2003a, p. 127).

Interessante é observar as regras aplicáveis ao ônus da prova, no que tange especificamente às Exceções Gerais. Como são, decerto, exceções, há que primeiro se verificar a infringência a algum dos parágrafos, o segundo ou o quarto, do Artigo III, para depois se verificar se o Artigo XX especificamente a escusa (MATSUSHITA; SCHOENBAUM; MAVROIDIS, p. 176). Por isso, cabe ao demandante inicialmente arguir o caráter discriminatório ou protetivo da norma tributária ou regulatória sob análise.

Assim foi estabelecido no caso "United States - Section 337 of the Tariff Act of 1930 ”, de 7 de novembro de $1989^{189}$.

Em passo posterior, no que se costuma denominar de defesa afirmativa (BRITO FILHO, 2003a, p. 80), agora então é ao demandado que compete provar que alguma das alíneas do Artigo XX é aplicável à norma objeto de reclamação, primeiramente, e, posteriormente, ao caput do mesmo Artigo, nos moldes acima descritos.

\footnotetext{
189 "5.9 The Panel noted that Article XX is entitled "General Exceptions" and that the central phrase in the introductory clause reads: "nothing in this Agreement shall be construed to prevent the adoption or enforcement ... of measures ...". Article XX(d) thus provides for a limited and conditional exception from obligations under other provisions. The Panel therefore concluded that Article $X X(d)$ applies only to measures inconsistent with another provision of the General Agreement, and that, consequently, the application of Section 337 has to be examined first in the light of Article III:4. If any inconsistencies with Article III:4 were found, the Panel would then examine whether they could be justified under Article XX $(d)$ ".
} 
Deve-se notar que a prova da subsunção tanto ao Artigo III quanto a uma das alíneas do Artigo XX é uma prova positiva, ao passo que a prova da aplicabilidade ao caso do caput do Artigo XX é uma prova negativa (BRITO FILHO, 2003a, p. 127).

Quanto a essa regra de inversão do ônus da prova, a respectiva definição deu-se no exame do próprio caso "United States - Standards for Reformulated and Conventional Gasoline", ainda no Grupo Especial ${ }^{190}$.

Interessante é apontar o ocorrido em um dos mais recentes casos em que o OSC da OMC tocou no aspecto da tributação de bebidas. Trata-se do caso "Mexico - Tax Measures on Soft Drinks and other Beverages" ${ }^{191}$. Nele, os Estados Unidos alegam que o México, por meio de uma alteração da Ley del Impuesto Especial sobre Producción y Servicios, a viger a partir de $1^{\circ}$ de janeiro de 2002, assim como duas outras, 30 de dezembro de 2002 e de 31 de dezembro de 2003, ao estabelecer que os refrigerantes e outras bebidas que empregassem adoçantes outros que não o açúcar de origem na cana-deaçúcar (o "soft drink tax"), assim como os serviços de comissionamento, mediação, agenciamento, representação, corretagem, consignação e distribuição dessas bebidas (o “distribution tax"), seriam sujeitos, tanto nas operações internas quanto nas importações, a uma alíquota de $20 \%$ ad valorem a título de imposto especial, teria infringido as obrigações do Artigo III:2, primeira e segunda frase e do Artigo III:4 do GATT.

Sem querer discutir muito o caso, o importante é que o México, em uma defesa impressionantemente fraca, não se defendeu da alegação de violação ao Artigo III. Apenas aduziu preliminarmente que a matéria deveria ser submetida ao OSC do NAFTA, pelo que o Órgão Especial deveria declinar de examinar a matéria. No mérito, pleiteou a subsunção

190 “D. Article $X X(b)$

6.20 The Panel proceeded to examine whether the aspect of the baseline establishment methods found inconsistent with Article III:4 could, as argued by the United States, be justified under paragraph (b) of Article XX. The relevant parts of Article XX were as follows:

Subject to the requirement that such measures are not applied in a manner which would constitute a means of arbitrary or unjustifiable discrimination between countries where the same conditions prevail, or a disguised restriction on international trade, nothing in this Agreement shall be construed to prevent the adoption or enforcement by any contracting party of measures:

(b)necessary to protect human, animal or plant life or health;

The Panel noted that as the party invoking an exception the United States bore the burden of proof in demonstrating that the inconsistent measures came within its scope. The Panel observed that the United States therefore had to establish the following elements:

(1)that the policy in respect of the measures for which the provision was invoked fell within the range of policies designed to protect human, animal or plant life or health;

(2)that the inconsistent measures for which the exception was being invoked were necessary to fulfil the policy objective; and

(3)that the measures were applied in conformity with the requirements of the introductory clause of Article $X X$.

In order to justify the application of Article $X X(b)$, all the above elements had to be satisfied".

${ }^{191}$ WT/DS308/R, de 7 de outubro de 2005. 
da norma tributária ao Artigo XX do GATT, sem especificar inicialmente qual a alínea. Posteriormente, aduziu que a exceção alegada estaria prevista na alínea (d) do Artigo XX. Ainda assim, o Grupo Especial teve que examinar as alegações dos Estados Unidos referentes ao Artigo III, como se defesa mexicana houvera ${ }^{192}$.

192 "IX - Conclusions and Recommendation

9.1 For the reasons indicated in this report, the Panel has determined that, under the DSU, it has no discretion to decline to exercise its jurisdiction in the case that has been brought before it.

9.2 With respect to the United States' claims, the Panel concludes as follows:

(a) With respect to Mexico's soft drink tax and distribution tax:

(i) As imposed on sweeteners, imported beet sugar is subject to internal taxes in excess of those applied to like domestic sweeteners, in a manner inconsistent with Article III:2, first sentence, of the GATT 1994;

(ii) As imposed on sweeteners, imported HFCS is being taxed dissimilarly compared with the directly competitive or substitutable products, so as to afford protection to the Mexican domestic production of cane sugar, in a manner inconsistent with Article III:2, second sentence, of the GATT 1994;

(iii) As imposed on sweeteners, imported beet sugar and HFCS are accorded less favourable treatment than that accorded to like products of national origin, in a manner inconsistent with Article III:4 of the GATT 1994;

(iv) As imposed on soft drinks and syrups, imported soft drinks and syrups sweetened with non-cane sugar sweeteners (including HFCS and beet sugar) are subject to internal taxes in excess of those applied to like domestic products, in a manner inconsistent with Article III:2, first sentence, of the GATT 1994.

(b) With respect to Mexico's bookkeeping requirements: As imposed on sweeteners, imported beet sugar and HFCS are accorded less favourable treatment than that accorded to like products of national origin, in a manner inconsistent with Article III:4 of the GATT 1994.

9.3 With respect to Mexico's invocation of Article XX(d) of the GATT 1994, the Panel concludes that the challenged tax measures are not justified as measures that are necessary to secure compliance by the United States with laws or regulations which are not inconsistent with the provisions of the GATT 1994". 


\section{DO PRINCÍPIO DE NÃO-DISCRIMINAÇÃO NO SISTEMA DAS COMUNIDADES EUROPEIAS.}

\subsection{Da Livre Circulação Comunitária de Mercadorias.}

As três Comunidades Europeias nasceram de um projeto internacional com um caráter eminentemente econômico (MONIZ, 2002, p. 237). Ilustrativo desse viés marcadamente voltado a propiciar melhores oportunidades econômicas é o fato de que, em 9 de maio de 1950, Robert Schuman, um dos conhecidos "Pais da Europa", então Ministro Francês dos Negócios Estrangeiros, apresentou uma proposta de criação de uma Europa organizada, conhecida como "Declaração Schuman"193. Esse documento, que é

${ }^{193}$ Texto integral, obtenível em http://europa.eu/abc/symbols/9-may/decl_fr.htm, acesso em 10 de março de 2011.

"La paix mondiale ne saurait être sauvegardée sans des efforts créateurs à la mesure des dangers qui la menacent.

La contribution qu'une Europe organisée et vivante peut apporter à la civilisation est indispensable au maintien des relations pacifiques. En se faisant depuis plus de vingt ans le champion d'une Europe unie, la France a toujours eu pour objet essentiel de servir la paix. L'Europe n'a pas été faite, nous avons eu la guerre. L'Europe ne se fera pas d'un coup, ni dans une construction d'ensemble : elle se fera par des réalisations concrètes créant d'abord une solidarité de fait. Le rassemblement des nations européennes exige que l'opposition séculaire de la France et de l'Allemagne soit éliminée. L'action entreprise doit toucher au premier chef la France et l'Allemagne.

Dans ce but, le gouvernement français propose immédiatement l'action sur un point limité mais décisif.

Le gouvernement français propose de placer l'ensemble de la production franco-allemande de charbon et d'acier sous une Haute Autorité commune, dans une organisation ouverte à la participation des autres pays d'Europe.

La mise en commun des productions de charbon et d'acier assurera immédiatement l'établissement de bases communes de développement économique, première étape de la Fédération européenne, et changera le destin de ces régions longtemps vouées à la fabrication des armes de guerre dont elles ont été les plus constantes victimes.

La solidarité de production qui sera ainsi nouée manifestera que toute guerre entre la France et l'Allemagne devient non seulement impensable, mais matériellement impossible. L'établissement de cette unité puissante de production ouverte à tous les pays qui voudront y participer, aboutissant à fournir à tous les pays qu'elle rassemblera les éléments fondamentaux de la production industrielle aux mêmes conditions, jettera les fondements réels de leur unification économique.

Cette production sera offerte à l'ensemble du monde sans distinction ni exclusion, pour contribuer au relèvement du niveau de vie et au développement des oeuvres de paix. L'Europe pourra, avec des moyens accrus, poursuivre la réalisation de l'une de ses tâches essentielles: le développement du continent africain. Ainsi sera réalisée simplement et rapidement la fusion d'intérêts indispensable à l'établissement d'une communauté économique qui introduit le ferment d'une communauté plus large et plus profonde entre des pays longtemps opposés par des divisions sanglantes.

Par la mise en commun de productions de base et l'institution d'une Haute Autorité nouvelle, dont les décisions lieront la France, l'Allemagne et les pays qui y adhéreront, cette proposition réalisera les premières assises concrètes d'une Fédération européenne indispensable à la préservation de la paix.

Pour poursuivre la réalisation des objectifs ainsi définis, le gouvernement français est prêt à ouvrir des négociations sur les bases suivantes. 
considerado o embrião do que é hoje a União Europeia, iniciativa que se entendeu então como indispensável para a manutenção de relações pacíficas entre todos os estados Europeus, acabados de sair cinco anos antes de mais uma Guerra que a dilacerou (II Guerra Mundial), visa, primacialmente, a apresentar uma proposta concreta, a sua intenção de, imediatamente, num plano limitado mas decisivo, subordinar o conjunto da produção franco-alemã de carvão e de aço a uma Alta Autoridade, numa organização aberta à participação dos outros países da Europa. Para justificar tal construção, identifica, como corolário dessa providência, o fato de que a comunitarização das produções de carvão e de aço asseguraria imediatamente o estabelecimento de bases comuns de desenvolvimento econômico, como primeira etapa da federação europeia, e mudaria o destino das regiões durante muito tempo condenadas ao fabrico de armas de guerra, das quais os próprios cidadãos dos países que as construíram vieram a ser as suas mais constantes vítimas.

Em verdade, Robert Schuman nada mais fez do que verter em papel as ideias do real pai da iniciativa comunitária europeia, Jean Monnet, cuja formulação ideal sempre foi a de ver construído um espaço europeu de liberdade, prosperidade e de paz. Porém, por

La mission impartie à la Haute Autorité commune sera d'assurer dans les délais les plus rapides : la modernisation de la production et l'amélioration de sa qualité, la fourniture à des conditions identiques du charbon et de l'acier sur le marché français et sur le marché allemand, ainsi que sur ceux des pays adhérents, le développement de l'exportation commune vers les autres pays, l'égalisation dans le progrès des conditions de vie de la main-d'oeuvre de ces industries.

Pour atteindre ces objectifs à partir des conditions très disparates dans lesquelles sont placées actuellement les productions des pays adhérents, à titre transitoire, certaines dispositions devront être mises en oeuvre, comportant l'application d'un plan de production et d'investissements, l'institution de mécanismes de péréquation des prix, la création d'un fonds de reconversion facilitant la rationalisation de la production. La circulation du charbon et de l'acier entre les pays adhérents sera immédiatement affranchie de tout droit de douane et ne pourra être affectée par des tarifs de transport différentiels. Progressivement se dégageront les conditions assurant spontanément la répartition la plus rationnelle de la production au niveau de productivité le plus élevé.

A l'opposé d'un cartel international tendant à la répartition et à l'exploitation des marchés nationaux par des pratiques restrictives et le maintien de profits élevés, l'organisation projetée assurera la fusion des marchés et l'expansion de la production.

Les principes et les engagements essentiels ci-dessus définis feront l'objet d'un traité signé entre les Etats et soumis à la ratification des parlements. Les négociations indispensables pour préciser les mesures d'application seront poursuivies avec l'assistance d'un arbitre désigné d'un commun accord; celui-ci aura charge de veiller à ce que les accords soient conformes aux principes et, en cas d'opposition irréductible, fixera la solution qui sera adoptée.

La Haute Autorité commune chargée du fonctionnement de tout le régime sera composée de personnalités indépendantes désignées sur une base paritaire par les gouvernements; un président sera choisi d'un commun accord par les gouvernements; ses décisions seront exécutoires en France, en Allemagne et dans les autres pays adhérents. Des dispositions appropriées assureront les voies de recours nécessaires contre les décisions de la Haute Autorité.

Un représentant des Nations Unies auprès de cette autorité sera chargé de faire deux fois par an un rapport public à l'ONU, rendant compte du fonctionnement de l'organisme nouveau, notamment en ce qui concerne la sauvegarde de ses fins pacifiques.

L'institution de la Haute Autorité ne préjuge en rien du régime de propriété des entreprises. Dans l'exercice de sa mission, la Haute Autorité commune tiendra compte des pouvoirs conférés à l'Autorité internationale de la Ruhr et des obligations de toute nature imposées à l'Allemagne, tant que celles-ci subsisteront". 
jamais haver exercido cargos públicos, o internacionalista francês não teria o poder de propor semelhantes iniciativas.

Por detrás dessa proposta do documento, inicialmente modesta e concentrada, estava, no fundo, a visão de que a fusão destes interesses econômicos contribuiria, por meio da união dos mercados e da expansão da produção, para a melhoria do nível de vida das populações e tenderia a evoluir para a criação de uma comunidade econômica, o que reproduziria, com vantagem, tal objetivo de geração de bem-estar coletivo.

Juntados os esforços no plano econômico, entendia Robert Schuman que a solidariedade de produção alcançada tornaria qualquer guerra entre a França e a Alemanha não apenas impensável como também materialmente impossível.

Para os que conceberam tal iniciativa, o estabelecimento de uma poderosa unidade de produção aberta a todos os países que nela queiram participar, inicialmente voltada para a produção do carvão e do aço, permitiria fornecer a todos os países que a compõem os elementos fundamentais da produção industrial em condições idênticas, assim lançando os fundamentos reais da sua unificação econômica. Tal produção, na visão do então Ministro Francês dos Negócios Estrangeiros deveria ser oferecida a todos os países do mundo sem distinção nem exclusão, a fim de que todos pudessem participar no aumento do nível de vida e no desenvolvimento de obras de paz.

Tais palavras contaram com a adesão do seu correpondente alemão, o Ministro dos Negócios Estrangeiros da República Federal da Alemanha, Konrad Adenauer, pelo que transcritas também no Tratado de Paris, de 18 de abril de 1951, instituidor da Comunidade Europeia do Carvão e do Aço (CECA), organismo internacional que foi extinto com o fim da vigência temporária, por cinquenta anos, do tratado que o instituiu, segundo seu art. 97.

Os seis países signatários (Reino da Bélgica, República Federal da Alemanha, República Francesa, República Italiana, Grão-Ducado de Luxemburgo e Reino dos Países Baixos) puderam então celebrar uma forma de cooperação internacional inteiramente nova e pioneira, pela via da construção de uma união aduaneira referente ao carvão e ao aço. Vale dizer, mediante a supressão dos direitos de aduana e das restrições quantitativas à livre circulação dos produtos que disciplinava; a proibição de medidas discriminatórias e de subvenções ou ajudas conferidas pelos Estados.

O mercado unificado passou a se submeter à livre concorrência, não obstante a preservada existência de mecanismos de controle de abastecimento e fixação dos preços pela Comunidade. A entrada em vigor do tratado demandaria, primeiramente, um período preparatório para a criação e organização das instituições, seguido de um período de 
transição para que as indústrias nacionais se adaptassem às novas condições de mercado. Segundo o Tratado de Paris de 1951, a união aduaneira inicou-se em 10 de fevereiro de 1953 para o carvão e o ferro, e em $1^{\circ}$ de maio do mesmo ano para o aço.

Essa supraestrutura político-institucional se revestiu de revolucionária originalidade, e revelou o esboço e o embrião da futura e não então distante experiência de implantação de um verdadeiro mercado comum, estágio mais avançado no processo de integração europeu que culminou em 1957 com a assinatura de dois outros tratados (FONSECA, 1997, p. 3). Como vemos, sempre a partir de motivações econômicas, no caso da Comunidade Econômica Europeia as iniciativas integracionistas se verificavam ainda mais ambiciosas que a mera liberalização econômica presente como objetivo do GATT, em seu preâmbulo, como já visto.

Nessa esteira, a celebração, em 25 de março de 1957, do Tratado que instituiu a Comunidade Econômica Europeia, lavrado em Roma, contemplava, em seu preâmbulo, diversos objetivos econômicos, como o de assegurar por uma ação comum o progresso econômico e social de seus países pela eliminação das barreiras que dividem a Europa; o de fixar como objetivo essencial dos seus esforços a melhoria constante das condições de vida de trabalho dos povos; reconhecer que a eliminação dos obstáculos existentes demanda uma ação organizada com vistas a garantir a estabilidade na expansão, o equilíbrio nas trocas e a lealdade na concorrência; atentos em reforçar a unidade de suas economias e a assegurar o desenvolvimento harmonioso, reduzindo as desigualdades entre as diferentes regiões e o atraso das menos favorecidas; desejando contribuir, graças a uma política comercial comum, com a supressão progressiva das restrições às trocas internacionais. Com isso, com a contribuição desse conjunto de recursos, declararam-se resolvidos a salvaguardar a paz e a liberdade, apelando aos outros povos da Europa para que compartilhassem de seus ideais e que se associem a seus esforços e decidiram criar uma Comunidade Econômica Europeia ${ }^{194}$.

194 "No original:

Déterminés à établir les fondements d'une union sans cesse plus étroite entre les peuples européens,

Décidés à assurer par une action commune le progrès économique et social de leur pays en éliminant les barrières qui divisent l'Europe,

Assignant pour but essentiel à leurs efforts l'amélioration constante des conditions de vie et d'emploi de leurs peuples,

Reconnaissant que l'élimination des obstacles existants appelle une action concertée en vue de garantir la stabilité dans l'expansion, l'équilibre dans les échanges et la loyauté dans la concurrence,

Soucieux de renforcer l'unité de leurs économies et d'en assurer le développement harmonieux en réduisant l'écart entre les différentes régions et le retard des moins favorisés.

Désireux de contribuer, grâce à une politique commerciale commune, à la suppression progressive des restrictions aux échanges internationaux, 
Não se deve deixar de lado que o Tratado de Roma foi radicalmente alterado pelo Tratado de Maastricht, de 7 de fevereiro de 1992, passando a se chamar Tratado que institui a Comunidade Europeia. Porém, o Tratado de Maastricht, por sua vez, também sofreu alterações e, no que tange à matéria fiscal, uma consolidação normativa que gerou renumeração dos artigos pertinentes, pelo Tratado de Amsterdam, de 2 de outubro de 1997. Recentemente, como a assinatura do Tratado de Lisboa, a União Europeia ganhou, com essa denominação, a condição de pessoa jurídica de direito internacional, inclusive passando a ser, sob essa alcunha, membro da OMC, o que também acarretou nova consolidação de tratados e da respectiva numeração, com a criação do Tratado sobre o funcionamento da União Europeia (TUE), a par da existência agora do Tratado da União Europeia propriamente dito.

Como se sabe, o Tratado de Lisboa (inicialmente conhecido como o Tratado Reformador), assinado pelos Estados-membros da União Europeia em 13 de dezembro de 2007, visou a reformar o funcionamento do bloco, e entrou em vigor em $1^{\circ}$ de dezembro de 2009, primeiro dia do mês seguinte ao depósito, em 13 de novembro, pela República Tcheca, do vigésimo-quinto e último instrumento de ratificação. Ele emenda o Tratado que institui a Comunidade Europeia tendo em vista a instituição da Comunidade Europeia (TCE, de Maastricht, 1992; alterado por Amsterdam, 1997), no seu art. 8º renomeando-o para Tratado sobre o Funcionamento da União Europeia (TUE). Porém, ele mesmo passou a se chamar Tratado da União Europeia, norma de direito originário comunitário que não abordaremos aqui por não conter disposições tributárias materiais.

A construção da CEE alargou o campo de cooperação supranacional e relançou, assim, a ideia de um espaço único europeu. O domínio econômico, menos sujeito que outros a resistências nacionais, avultava, com efeito, como um campo propício para uma iniciativa dessa magnitude (SILVA, 2003, p. 78).

A modalidade de integração econômica denominada união aduaneira, como se pretendeu, exige, entre os Estados-membros, o estabelecimento de uma política comercial, ou seja, a negociação conjunta de acordos comerciais com países terceiros, e de uma tarifa aduaneira comum em relação aos Estados não participantes, sem falar na abolição das fronteiras fiscais entre eles. Assim, além da livre circulação de mercadorias, a união

Entendant confirmer la solidarité qui lie l'Europe et les pays d'outre-mer, et désirant assurer le développement de leur prospérité, conformément aux principes de la Charte des Nations Unies, Résolus à affermir, par la contribution de cet ensemble de ressources, les sauvegardes de la paix et de la liberté, et appelant les autres peuples de l'Europe qui partagent leur idéal à s'associer à leur effort,

Ont décidé de créer une Communauté économique européenne et ont désigné à cet effet comme plénipotentiaires:" (...) 
aduaneira previu para o futuro igualmente a abolição, entre os Estados membros, de obstáculos à livre circulação de pessoas, serviços e de capital, no rumo da criação de um mercado comum (BARNARD, 2007, p. 9). Difere, pois, da Associação Europeia de Comércio Livre (EFTA, do termo em inglês, European Free Trade Area), da qual Portugal foi fundador, estágio mais rudimentar de integração, na qual, por se constituir em zona de livre comércio, manteve-se a soberania comercial dos países membros intacta, no que tange a terceiros países (PORTO, 2001, p. 213).

Para a construção da união aduaneira, a liberdade base, no dizer de José Carlos Moitinho de Almeida (1985, p. 265), é a livre circulação de mercadorias, na medida em que entende que as demais liberdades comunitárias são dessa um instrumento.

Assim é de tal maneira relevante a construção da união aduaneira dentro dos objetivos da então Comunidade Econômica Europeia, que, na redação original do Tratado de Roma (TCEE), de 1957, que a sua previsão vem logo no art. $9^{\circ}$, exatamente após uma Primeira Parte que trata de "Os Princípios", no qual avulta com especial relevância o art. $2^{\text {o195}}$, que dispõe que a Comunidade tem como missão, por meio da da criação de um mercado comum e da aproximação progressiva das políticas dos Estados-Membros, a de promover, em toda a Comunidade, um desenvolvimento harmonioso das atividades econômicas, uma expansão contínua e equilibrada, uma maior estabilidade, um rápido aumento do nível de vida e relações mais estreitas entre os Estados que a integram.

Na Segunda Parte, que trata "Dos Fundamentos da Comunidade", seu Título Primeiro, sobre “A Livre Circulação de Mercadorias”, inicia-se, portanto, com o art. 90196, que determinava que a Comunidade se fundava em uma união aduaneira que abrangia a totalidade do comércio de mercadorias e implica a proibição, entre os Estados-membros, de direitos aduaneiros de importação e de exportação e de quaisquer encargos de efeito equivalente, bem como a adoção de uma Tarifa Aduaneira Comum nas suas relações com países terceiros. A própria posição topológica do artigo, assim como sua própria redação,

\footnotetext{
195 "Article 2.

La Communauté a pour mission, par l'établissement d'un marché commun et par le rapprochement progressif des politiques économiques des États membres, de promouvoir un développement harmonieux des activités économiques dans l'ensemble de la Communauté, une expansion continue et équilibrée, une stabilité accrue, un relèvement accéléré du niveau de vie et des relations plus étroites entre les États qu'elle réunit".

196 "Article 9.

1. La Communauté est fondée sur une union douanière qui s'étend à l'ensemble des échanges de marchandises, et qui comporte l'interdiction, entre les États membres, des droits de douane à l'importation et à l'exportation de toutes taxes d'effet équivalent, ainsi que l'adoption d'un tarif douanier commun dans leurs relations avec les pays tiers.

2. Les dispositions du chapitre 1, section première, et du chapitre 2 du présent titre s'appliquent aux produits qui sont originaires des États membres, ainsi qu'aux produits en provenance de pays tiers qui se trouvent en libre pratique dans les États membres".
} 
demonstram a relevância da construção da união aduaneira na concretização da entã Comunidade Econômica Europeia. No dizer de Peter Wattel (2008, p. 9), ideia básica da Comunidade Europeia é uma ideia fiscal.

Antes dele, o artigo $8^{\circ}$ do Tratado CEE previa a realização do mercado comum ao longo de um período de transição de 12 anos, dividido em três fases de quatro anos cada. A cada fase, correspondia um conjunto de ações que deveriam ser iniciadas e prosseguidas. Sem prejuízo das exceções e derrogações previstas no Tratado, o termo do período de transição constituía a data-limite para a entrada em vigor de todas as regras relativas ao estabelecimento do mercado comum.

A construção do mercado comum só se tornou possível, como afirma Ana Raquel Moniz (2002, p. 239), graças à aliança entre a livre circulação de mercadorias e as liberdades circulatórias dos restantes fatores produtivos, pessoas, serviços e capitais. Dessa forma, ainda se fala nas quatro liberdades básicas como pilares da unidade europeia, mesmo após a introdução do direito de residência, em 1993, pois, como ensina Peter Wattel (TERRA; WATTEL, 2008, p. 44), a nova provisão trata-se de uma extensão do direito de livre circulação de pessoas.

Restringindo a nossa análise ao que importa ressaltar, na livre circulação de mercadorias, da redação do art. $9^{\circ}$ do TCEE, pode-se perceber, nas palavras de Catherine Barnard (2007, p. 27), a existência de duas dimensões dos direitos por ele conferidos: uma interna, referente às mercadorias originárias dos demais Estados-membros, e uma externa, quando oriundas de terceiros países. Para a primeira dimensão, o compromisso é o de abolição dos ônus alfandegários; para a segunda, a adoção uniformizada de um imposto de importação, único portanto.

Importante asseverar que, no caso $7 / 68^{197}$, Comissão das Comunidades Europeias contra República Italiana, mercadorias, na acepção do art. $9^{\circ}$, foram definidas como produtos avaliáveis em dinheiro e que suscetíveis, como tal, de ser objeto de transações comerciais. Nessa definição, não apenas bens tangíveis são classificáveis, como também a energia elétrica, por exemplo, como estabelecido no processo C-393/92, assim como obras de arte (C-97/98), animais (C-67/97), resíduos sólidos (C-2/90) ou moedas sem curso legal, de mero valor histórico, artístico ou arqueológico (no próprio caso 7/78).

Nessa esteira, ainda no exame do tratado institutivo original, o TCEE, ainda em seu Título Primeiro, da Segunda Parte, sobre "A Livre Circulação de Mercadorias”, passa,

\footnotetext{
${ }^{197}$ ECR $1968,889$.
} 
após o art. $9^{\circ}$, a dividir no que consiste, do ponto de vista dos conjuntos das disposições legais pertinentes, as determinações tendentes à construção da liberdade circulatória de mercadorias: a criação de uma União aduaneira, no seu Capítulo 1, dividida nas suas duas dimensões, como visto, em suas duas seções - a eliminação dos direitos alfandegários entre Estados-membros e o estabelecimento da Tarifa Aduaneira Comum; e a eliminação das restrições quantitativas entre os Estados-membros, pelo Capítulo 2.

Como não se poderia eliminar, de um dia para o outro, todas as imposições aduaneiras então existentes, mesmo entre Estados-membros, a Primeira Seção do Capítulo $1^{\circ}$ do Título Primeiro do Tratado de Roma consistia em uma cláusula de standstill, de compromisso de abstenção de majorações, no seu art. $12^{\mathrm{o}^{198}}$, assim como um detalhado cronograma de desonerações tanto às importações quanto às exportações, nos $\operatorname{art.} 13^{\circ} \mathrm{a}$ $17^{\mathbf{o}^{199}}$.

198 “Chapitre $1:$ L'Union douanière

Section première : L'élimination des droits de douane entre les États membres

Article 12.

Les États membres s'abstiennent d'introduire entre eux de nouveaux droits de douane à l'importation et à l'exportation ou taxes d'effet équivalent, et d'augmenter ceux qu'ils appliquent dans leurs relations commerciales mutuelles".

199 "Article 13.

1. Les droits de douane à l'importation, en vigueur entre les États membres, sont progressivement supprimés par eux, au cours de la période de transition, dans les conditions prévues aux articles 14 et 15.

2. Les taxes d'effet équivalant à des droits de douane à l'importation, en vigueur entre les États membres, sont progressivement supprimées par eux au cours de la période de transition. La Commission fixe, par voie de directives, le rythme de cette suppression. Elle s'inspire des règles prévues à l'article 14, paragraphes 2 et 3, ainsi que des directives arrêtées par le Conseil en application de ce paragraphe 2.

Article 14.

1. Pour chaque produit, le droit de base sur lequel les réductions successives doivent être opérées est constitué par le droit appliqué au ler janvier 1957.

2. Le rythme des réductions est déterminé comme suit:

a) au cours de la première étape, la première réduction est effectuée un an après l'entrée en vigueur du présent traité; la deuxième, dix-huit mois plus tard; la troisième, à la fin de la quatrième année à compter de l'entrée en vigueur de ce traité;

b) au cours de la deuxième étape, une réduction est opérée dix-huit mois après le début de cette étape; une deuxième réduction, dix-huit mois après la précédente; une troisième réduction est opérée un an plus tard;

c) les réductions restant à réaliser sont appliquées au cours de la troisième étape; le Conseil, statuant à la majorité qualifiée sur proposition de la Commission, en fixe le rythme par voie de directives.

3. Lors de la première réduction, les États membres mettent en vigueur entre eux, sur chaque produit, un droit égal au droit de base diminué de $10 \%$.

Lors de chaque réduction ultérieure, chaque État membre doit abaisser l'ensemble de ses droits, de sorte que la perception douanière totale, telle qu'elle est définie au paragraphe 4 , soit diminuée de $10 \%$, étant entendu que la réduction sur chaque produit doit être au moins égale à $5 \%$ du droit de base.

Toutefois, pour les produits sur lesquels subsiste un droit qui serait encore supérieur à $30 \%$, chaque réduction doit être au moins égale à $10 \%$ du droit de base.

4. Pour chaque État membre la perception douanière totale visée au paragraphe 3 se calcule en multipliant par les droits de base la valeur des importations effectuées en provenance des autres États membres au cours de l'année 1956.

5. Les problèmes particuliers que soulève l'application des paragraphes précédents sont réglés par directives du Conseil, statuant à la majorité qualifiée sur proposition de la Commission. 
Em seguida, a Segunda Seção do Capítulo $1^{\circ}$ do Título Primeiro do Tratado de Roma trazia as estipulações referentes a terceiros países, notadamente a elaboração de uma Tarifa Aduaneira Comum entre eles. Determinava, assim, nos seus artigos $18^{\circ}$ a $29^{\circ}$, o compromisso, no que tange ao comércio internacional, de reduzir, até o fim de um período de transição, os entraves aduaneiros e de sempre acordarem em valores menores do que os prevalentes na união aduaneira (art. $18^{\circ 200}$ ), a estabelecerem a Tarifa Adunaneira Comum em valores correspondentes à média aritmética das alíquotas então vigentes nos quatro territórios aduaneiros então reunidos (Benelux, República Francesa, República Federal da Alemanha e República Italiana), pelo art. $19^{\circ 201}$, obedecidos os limites lá minuciosamente

6. Les États membres rendent compte à la Commission de la manière selon laquelle les règles ci-dessus pour la réduction des droits sont appliquées. Ils s'efforcent d'aboutir à ce que la réduction appliquée aux droits sur chaque produit atteigne:

- à la fin de la première étape, au moins $25 \%$ du droit de base;

- à la fin de la deuxième étape, au moins $50 \%$ du droit de base.

La Commission leur fait toutes recommandations utiles si elle constate qu'il existe un danger que les objectifs définis à l'article 13 et les pourcentages fixés au présent paragraphe ne puissent être atteints.

7. Les dispositions du présent article peuvent être modifiées par le Conseil, statuant à l'unanimité sur proposition de la Commission et après consultation de l'Assemblée.

Article 15.

1. Indépendamment des dispositions de l'article 14, tout État membre peut, au cours de la période de transition, suspendre totalement ou partiellement la perception des droits appliqués aux produits importés des autres États membres. Il en informe les autres États membres et la Commission.

2. Les États membres se déclarent disposés à réduire leurs droits de douane à l'égard des autres États membres selon un rythme plus rapide que celui prévu à l'article 14, si leur situation économique générale et la situation du secteur intéressé le leur permettent.

La Commission adresse aux États membres intéressés des recommandations à cette fin.

Article 16.

Les États membres suppriment entre eux, au plus tard à la fin de la première étape, les droits de douane à l'exportation et les taxes d'effet équivalent.

Article 17.

1. Les dispositions des articles 9 à 15, paragraphe 1, sont applicables aux droits de douane à caractère fiscal. Toutefois, ces droits ne sont pas pris en considération pour le calcul de la perception douanière totale ni pour celui de l'abaissement de l'ensemble des droits visés à l'article 14, paragraphes 3 et 4.

Ces droits sont abaissés d'au moins $10 \%$ du droit de base à chaque palier de réduction. Les États membres peuvent les réduire selon un rythme plus rapide que celui prévu à l'article 14.

2. Les États membres font connaître à la Commission, avant la fin de la première année à compter de l'entrée en vigueur du présent traité, leurs droits de douane à caractère fiscal.

3. Les États membres conservent la faculté de remplacer ces droits par une taxe intérieure conforme aux dispositions de l'article 95.

4. Lorsque la Commission constate que le remplacement d'un droit de douane à caractère fiscal se heurte dans un État membre à des difficultés sérieuses, elle autorise cet État à maintenir ce droit, à la condition qu'il le supprime au plus tard six ans après l'entrée en vigueur du présent traité. L'autorisation doit être demandée avant la fin de la première année à compter de l'entrée en vigueur de ce traitê".

200 "Section deuxième: L'établissement du tarif douanier commun

Article 18.

Les États membres se déclarent disposés à contribuer au développement du commerce international et à la réduction des entraves aux échanges, en concluant des accords visant, sur une base de réciprocité et d'avantages mutuels, à la réduction des droits de douane au-dessous du niveau général dont ils pourraient se prévaloir du fait de l'établissement d'une union douanière entre eux."

201 "Article 19. 
descritos, segundo o cronograma definido no art. $23^{\text {o202 }}$, ou mais rapidamente, se possível,

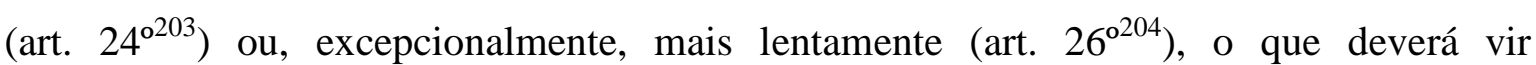

1. Dans les conditions et limites prévues ci-après, les droits du tarif douanier commun s'établissent au niveau de la moyenne arithmétique des droits appliquées dans les quatre territoires douaniers que comprend la Communauté.

2. Les droits retenus pour le calcul de cette moyenne sont ceux appliqués par les États membres au ler janvier 1957.

Toutefois, en ce qui concerne le tarif italien, le droit appliqué s'entend compte non tenu de la réduction temporaire de $10 \%$. En outre, sur les postes où ce tarif comporte un droit conventionnel, celui-ci est substitué au droit appliqué ainsi défini, à condition de ne pas lui être supérieur de plus de $10 \%$. Lorsque le droit conventionnel dépasse le droit appliqué ainsi défini de plus de $10 \%$, ce droit appliqué majoré de $10 \%$ est retenu pour le calcul de la moyenne arithmétique.

En ce qui concerne les positions énumérées à la liste A, les droits figurant sur cette liste sont substitués aux droits appliqués pour le calcul de la moyenne arithmétique.

3. Les droits du tarif douanier commun ne peuvent dépasser:

a) $3 \%$ pour les produits relevant des positions tarifaires énumérées à la liste $B$,

b) $10 \%$ pour les produits relevant des positions tarifaires énumérées à la liste $C$,

c) $15 \%$ pour les produits relevant des positions tarifaires énumérées à la liste D,

d) $25 \%$ pour les produits relevant des positions tarifaires énumérées à la liste E; lorsque, pour ces produits, le tarif des pays du Bénélux comporte un droit n'excédant pas $3 \%$, ce droit est porté à $12 \%$ pour le calcul de la moyenne arithmétique.

4. La liste F fixe les droits applicables aux produits qui y sont énumérés.

5. Les listes de positions tarifaires visées au présent article et à l'article 20 font l'objet de l'annexe I du présent traité".

202 "Article 23.

1. Aux fins de la mise en place progressive du tarif douanier commun, les États membres modifient leurs tarifs applicables aux pays tiers selon les modalités qui suivent:

a) pour les positions tarifaires où les droits effectivement appliqués au ler janvier 1957 ne s'écartent pas de plus de $15 \%$ en plus ou en moins des droits du tarif douanier commun, ces derniers droits sont appliqués à la fin de la quatrième année à compter de l'entrée en vigueur du présent traité;

b) dans les autres cas, chaque État membre applique, à la même date, un droit réduisant de $30 \%$ l'écart entre le taux effectivement appliqué au ler janvier 1957 et celui du tarif douanier commun ;

c) cet écart est réduit de nouveau de $30 \%$ à la fin de la deuxième étape;

d) en ce qui concerne les positions tarifaires pour lesquelles les droits du tarit douanier commun ne seraient pas connus à la fin de la première étape, chaque État membre applique, dans les six mois après que le Conseil a statué conformément à l'article 20, les droits qui résulteraient de l'application des règles du présent paragraphe.

2. L'État membre qui a obtenu l'autorisation prévue à l'article 17, paragraphe 4, est dispensé d'appliquer les dispositions qui précèdent, pendant la durée de validité de cette autorisation, en ce qui concerne les positions tarifaires qui en font l'objet. À l'expiration de l'autorisation, il applique le droit qui serait résulté de l'application des règles du paragraphe précédent.

3. Le tarif douanier commun est appliqué intégralement au plus tard à l'expiration de la période de transition".

203 "Article 24.

Pour s'aligner sur le tarif douanier commun, les États membres restent libres de modifier leurs droits de douane selon un rythme plus rapide que celui prévu à l'article 23 ”.

204 "Article 26.

La Commission peut autoriser un État membre, qui doit faire face à des difficultés particulières, à différer l'abaissement ou le relèvement, à effectuer en vertu de l'article 23, des droits de certaines positions de son tarif.

L'autorisation ne pourra être donnée que pour une durée limitée, et seulement pour un ensemble de positions tarifaires ne représentant pas pour l'État en cause plus de $5 \%$ de la valeur de ses importations effectuées en provenance de pays tiers au cours de la dernière année pour laquelle les données statistiques sont disponibles". 
acompanhado da harmonização, ainda nessa fase preliminar, das disposições legislativas, regulamentares e administrativas (art. $27^{\mathrm{o} 205}$ ).

Tal estrutura normativa era repetida no Capítulo $2^{\circ}$ do Título Primeiro do Tratado de Roma, que se referia a normas não tributárias, as eliminações das restrições quantitativas entre Estados-membros, como, por exemplo, as quotas de importação ou exportação, assim como as medidas de efeito equivalente, exemplarmente, as chamadas barreiras regulatórias (ou não-tarifárias, como preferem os economistas; por exemplo, barreiras técnicas sobre embalagem ou rotulagem). Primeiramente a vedação à instituição

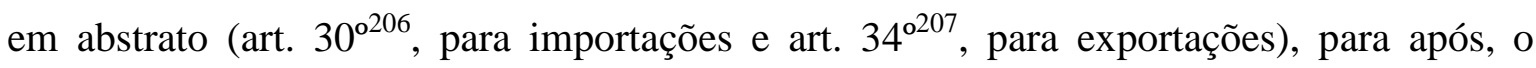
compromisso de não criação de novos entraves e de não aprofundamento das restrições existentes (art. $31^{\circ}$ e $32^{\circ 208}$ ), a transformação de contingentes bilaterais em globais (art. $33^{\text {o209}}$ ) e a possibilidade de aceleração do cronograma (art. $34^{\text {o210 }}$ ).

205 "Article 27.

Avant la fin de la première étape, les États membres procèdent, dans la mesure nécessaire, au rapprochement de leurs dispositions législatives, réglementaires et administratives en matière douanière. La Commission adresse aux États membres toutes recommandations à cette fin".

206 “Chapitre $2:$ L'élimination des restrictions quantitatives entre les États membres Article 30.

Les restrictions quantitatives à l'importation, ainsi que toutes mesures d'effet équivalent sont interdites entre les États membres, sans préjudice des dispositions ci-après".

207 "Article 34.

1. Les restrictions quantitatives à l'exportation, ainsi que toutes mesures d'effet équivalent, sont interdites entre les États membres.

2. Les États membres suppriment, au plus tard à la fin de la première étape, les restrictions quantitatives à l'exportation et toutes mesures d'effet équivalent existant à l'entrée en vigueur du présent traité".

208 "Article 31.

Les États membres s'abstiennent d'introduire entre eux de nouvelles restrictions quantitatives et mesures d'effet équivalent.

Toutefois, cette obligation ne s'applique qu'au niveau de libération réalisé en application des décisions du Conseil de l'Organisation européenne de coopération économique en date du 14 janvier 1955. Les États membres notifient à la Commission, au plus tard six mois après l'entrée en vigueur du présent traité, leurs listes des produits libérés en application de ces décisions. Les listes ainsi notifiées sont consolidées entre les États membres.

Article 32.

Les États membres s'abstiennent, dans leurs échanges mutuels, de rendre plus restrictifs les contingents et les mesures d'effet équivalent existant à la date d'entrée en vigueur du présent traité.

Ces contingents doivent être supprimés au plus tard à l'expiration de la période de transition. Ils sont progressivement éliminés au cours de cette période dans les conditions déterminées ci-après.".

209 "Article 33.

1. Un an après l'entrée en vigueur du présent traité, chacun des États membres transforme les contingents bilatéraux ouverts aux autres États membres en contingents globaux accessibles sans discrimination à tous les autres États membres.

A la même date, les États membres augmentent l'ensemble des contingents globaux ainsi établis de manière à réaliser, par rapport à l'année précédente, un accroissement d'au moins $20 \%$ de leur valeur totale. Toutefois, chacun des contingents globaux par produit est augmenté d'au moins $10 \%$.

Chaque année, les contingents sont élargis, suivant les mêmes règles et dans les mêmes proportions, par rapport à l'année qui précède.

Le quatrième élargissement a lieu à la fin de la quatrième année à compter de l'entrée en vigueur du présent traité ; le cinquième, un an après le début de la deuxième étape. 
A única assimetria entre as disposições tributárias, refererentes aos artigos $12^{\circ} \mathrm{a}$ $17^{\circ}$, e as regulatórias, não tributárias, previstas nos artigos $30^{\circ}$ a $35^{\circ}$, consiste na previsão de uma cláusula derrogatória, no seu art. $36^{0^{211}}$, das obrigações referentes à eliminação das restrições quantitativas e aos encargos de efeito equivalente no caso de razões de ordem pública, segurança pública, proteção da saúde e da vida das pessoas e dos animais, preservação dos vegetais, e proteção do patrimônio artístico, histórico e arqueológico, assim como da propriedade industrial e comercial, desde que não constituam um meio de dsicriminação arbitrária nem tampouco restrições disfarçadas ao comércio entre os Estados-membros.

2. Lorsque, pour un produit non libéré, le contingent global n'atteint pas $3 \%$ de la production nationale de l'État en cause, un contingent égal à $3 \%$ au moins de cette production est établi au plus tard un an après l'entrée en vigueur du présent traité. Ce contingent est porté à $4 \%$ après la deuxième année, à $5 \%$ après la troisième année. Ensuite, l'État membre intéressé augmente annuellement le contingent d'au moins $15 \%$.

Au cas où il n'existe aucune production nationale, la Commission détermine par voie de décision un contingent approprié.

3. A la fin de la dixième année, tout contingent doit être au moins égal à $20 \%$ de la production nationale.

4. Lorsque la Commission constate par une décision que les importations d'un produit, au cours de deux années consécutives, ont été inférieures au contingent ouvert, ce contingent global ne peut être pris en considération dans le calcul de la valeur totale des contingents globaux. Dans ce cas, l'État membre supprime le contingentement de ce produit.

5. Pour les contingents qui représentent plus de $20 \%$ de la production nationale du produit en cause, le Conseil, statuant à la majorité qualifiée sur proposition de la Commission, peut abaisser le pourcentage minimum de $10 \%$ prescrit au paragraphe 1 . Cette modification ne peut toutefois porter atteinte à l'obligation d'accroissement annuel de $20 \%$ de la valeur totale des contingents globaux.

6. Les États membres ayant dépassé leurs obligations en ce qui concerne le niveau de libération réalisé en application des décisions du Conseil de l'Organisation européenne de coopération économique en date du 14 janvier 1955 sont habilités à tenir compte du montant des importations libérées par voie autonome. dans le calcul de l'augmentation totale annuelle de $20 \%$ prévue au paragraphe 1. Ce calcul est soumis à l'approbation préalable de la Commission.

7. Des directives de la Commission déterminent la procédure et le rythme de suppression entre les États membres des mesures d'effet équivalant à des contingents, existant à la date de l'entrée en vigueur du présent traité.

8. Si la Commission constate que l'application des dispositions du présent article, et en particulier de celles concernant les pourcentages, ne permet pas d'assurer le caractère progressif de l'élimination prévue à l'article 32, alinéa 2, le Conseil, statuant sur proposition de la Commission, à l'unanimité au cours de la première étape et à la majorité qualifiée par la suite, peut modifier la procédure visée dans le présent article et procéder en particulier au relèvement des pourcentages fixes".

210 "Article 35.

Les États membres se déclarent disposés à éliminer, à l'égard des autres États membres, leurs restrictions quantitatives à l'importation et à l'exportation selon un rythme plus rapide que celui prévu aux articles précédents, si leur situation économique générale et la situation du secteur intéressé le leur permettent.

La Commission adresse aux États intéressés des recommandations à cet effet".

211 "Article 36.

Les dispositions des articles 30 à 34 inclus ne font pas obstacle aux interdictions ou restrictions d'importation, d'exportation ou de transit, justifiées par des raisons de moralité publique, d'ordre public, de sécurité publique, de protection de la santé et de la vie des personnes et des animaux ou de préservation des végétaux, de protection des trésors nationaux ayant une valeur artistique, historique ou archéologique ou de protection de la propriété industrielle et commerciale. Toutefois, ces interdictions ou restrictions ne doivent constituer ni un moyen de discrimination arbitraire, ni une restriction déguisée dans le commerce entre les États membres". 
O Tratado de Roma (TCEE), após uma Primeira Parte que trata de "Os Princípios”, no qual, como já visto, avulta com especial relevância o art. $2^{\circ}$, que dispõe sobre a missão comunitária de criação de um mercado comum e da aproximação progressiva das políticas dos Estados-Membros, traz, também como visto, uma Segunda Parte, que trata "Dos Fundamentos da Comunidade", cujo Título Primeiro, apresenta "A Livre Circulação de Mercadorias”, iniciado com o art. $9^{\circ}$. Em diante, a Segunda Parte trata da agricultura; da livre circulação de pessoas, de serviços e de capitais; e dos transportes.

A partir daí, o TCEE entra na regulação das políticas internas dos Estadosmembros, iniciando a sua Terceira Parte, denominada "A Política da Comunidade", com um Título Primeiro, sobre “As Regras Comuns”, cujo Capítulo $1^{\circ}$ discorre sobre "As Regras de Concorrência", sendo seguido pelo Capítulo 20 "Disposições Fiscais", cujo principal dispositivo é o art. $95^{\circ}$, norma veiculadora do princípio de não-discriminação comunitário, assim, nos artigos seguintes, referentes à disciplina da chamada integração econômica positiva ${ }^{212}$, como lembra Federico Ortino (2004, p. 17 - 18), cujo exame detalhado será empreendido nos itens posteriores.

Essa configuração do Tratado de Roma, dividindo entre as normas referentes à união aduaneira, incluindo os então necessários compromissos de paulatinos desgravamentos dos direitos de importação e exportação e dos encargos de efeito equivalente, e as normas referentes às políticas comunitárias, de direito interno, que Tom O’Shea (2005, p. 108) qualifica como "regras de integração negativa", ainda no regime do TCEE, embora já tivesse sido anteriormente declarada, veio claramente esclarecida no julgamento do processo C-17/91 213 , Georges Lornoy en Zonen NV e outros contra o Reino da Bélgica, uma decisão a título prejudicial sobre a interpretação dos artigos $12^{\circ}, 13^{\circ}, 30^{\circ}$, $92^{\circ}$ e $95^{\circ}$ do Tratado CEE.

Controvérsia a respeito da qualificação da espécie tributária segundo a estrutura da fonte de direito comunitário originário foi suscitada no âmbito de litígios entre empresas

\footnotetext{
${ }^{212}$ Segundo o mencionado autor, a partir das lições de J. Tinbergen e J. Pinder, a integração (genericamente considerada ou a harmonização, aplicando-se o conceito à experiência europeia) positiva é a criação de novas instituições e seus instrumentos ou a modificação dos existentes. Vale dizer, a elaboração e aplicação de políticas comuns e coordenadas com o fim de preencher um objetivo econômico de atingimento de bemestar. Corresponde, na experiência comunitária, à atuação da Comissão Europeia. Por outro lado, a integração ou a harmonização negativa consiste na remoção das normas internas discriminatórias. Esse é o fundamento da necessidade da atuação negativa do Poder Judiciário Comunitário, não só em relação a impostos não harmonizados, notadamente os diretos, mas também, em se tratando dos impostos indiretos seletivos, com o fim de evitar que nascessem accises que viessem a substituir gravames aduaneiros, no exercício da liberdade legislativa residual que restou aos Estados-membros quanto a essa modalidade de tributos, ou que implicassem superposição com o IVA, pela via de uma nova incidência disfarçada sobre o volume de negócios.

${ }^{213}$ ECR 1992, I - 6523.
} 
que comercializam bovinos ao Estado belga, a propósito da legalidade de uma cotização obrigatória cobrada na Bélgica pelo abate ou pela exportação de bovinos e de suínos e que revertia a favor de um "Fonds de la santé et de la production des animaux".

A lei belga de 24 de março de 1987, relativa à proteção da saúde dos animais (Moniteur belge de 17.4.1987), tem como objetivo, segundo o seu artigo $2^{\circ}$, lutar contra as epizootias, de modo a promover a saúde pública e a prosperidade econômica dos criadores de animais. $\mathrm{O}$ artigo 32, $\mathrm{n}^{\circ}$ 2, da lei em questão, criou, no Ministério da Agricultura, um "Fonds de la santé et de la production des animaux" (Fundo para a proteção da saúde e a criação de animais), tendo como objetivo participar no financiamento das indenizações, dos subsídios e de outras prestações no âmbito da luta contra as epizootias e do melhoramento da higiene, da saúde e da qualidade dos animais e dos produtos animais.

O Fundo seria financiado, entre outras receitas, pelas cotizações obrigatórias a cargo das pessoas físicas ou jurídicas que produzissem, transformassem, transportassem, tratassem, vendessem ou comercializassem animais.

Para a fiel execução desta lei, adveio o decreto real de 11 de dezembro de 1987 (Moniteur belge de 23.12.1987), que entrou em vigor em $1^{\circ}$ de janeiro de 1988 , e fixou o montante da cotização obrigatória a pagar, em benefício do Fundo, por bovino ou suíno abatido ou exportado, pelos matadouros ou pelos exportadores.

Nos termos do artigo 4, primeiro parágrafo, desse decreto, as cotizações obrigatórias a pagar pelos matadouros e pelos exportadores seriam repercutidas por estes no fornecedor dos animais, que, se for caso disso, as repercutiria no vendedor, até ao estágio do criador. $\mathrm{O}$ segundo parágrafo deste artigo determina que, na fatura do matadouro ou do exportador, a cotização em causa seja mencionada separadamente. O decreto real em questão prevê ainda que, em caso de não pagamento das cotizações, após dois avisos, o matadouro ou o exportador em causa teriam de pagar o dobro do montante devido.

As recorrentes no processo principal, em litisconsórcio, são empresas belgas que importam vitelos de outros Estados-membros, para abate na Bélgica. Tendo sido obrigadas a pagar as ditas cotizações, interpuseram contra o Estado belga, no Rechtbank van eerste aanleg te Turnhout, um recurso destinado a obter a restituição das somas pagas. Como fundamento do pedido, alegavam que essas cotizações infringem os artigos $12^{\circ}, 13^{\circ}$ e $95^{\circ}$ do Tratado, pelo fato de também serem cobradas sobre os vitelos importados para a Bélgica, apesar de os rendimentos do Fundo serem exclusivamente utilizados em benefício da produção belga. 
Segundo o TJCE, era jurisprudência assente (v., nomeadamente, acórdãos de 22 de março de 1977, Iannelli, 74/76, Recueil, p. 557, e de 11 de março de 1992, Compagnie Commerciale de l' Ouest e outros, C-78/90 a C-83/90, Colect., p. I - 1847) que não estão abrangidos pela esfera de aplicação do artigo $30^{\circ}$ do Tratado os entraves a que se referem outras disposições específicas do mesmo Tratado e que os entraves de natureza fiscal ou com efeito equivalente a direitos aduaneiros a que se referem os artigos $9^{\circ}$ a $16^{\circ}$ e $95^{\circ}$ do Tratado não estão abrangidos pela proibição do artigo $30^{\circ}$.

Tendo em consideração essa jurisprudência, o Tribunal teve de começar por analisar se uma medida, como a descrita nas questões submetidas pelo órgão jurisdicional nacional, recairia na esfera de aplicação dos artigos $12^{\circ}$ e $13^{\circ}$, ou do artigo $95^{\circ}$ do Tratado, e só no caso de a resposta ser negativa teria o Tribunal de analisar se a medida considerada fica abrangida pelo disposto no artigo $30^{\circ}$ do Tratado.

Dado que as disposições do Tratado relativas aos encargos de efeito equivalente e as relativas às imposições internas discriminatórias não podem ser aplicadas cumulativamente (v. acórdãos de 18 de junho de 1975, IGAV, 94/74, Recueil, p. 699, e de 11 de junho de 1992, Sanders, C-149/91 e C-150/91, Colect., p. I - 3899), o TJCE julgou necessário delimitar o campo de aplicação de cada uma destas disposições.

O TJCE asseverou que os artigos $12^{\circ}$ e $13^{\circ}$ do Tratado contém a proibição de direitos aduaneiros de importação e de exportação, bem como de encargos de efeito equivalente, nas relações comerciais entre Estados-membros. Relativamente aos direitos aduaneiros e aos encargos de efeito equivalente na importação, o Tribunal de Justiça frisou (acórdãos de 19 de junho de 1973, Capolongo, 77/72, Recueil, p. 611; Compagnie Commerciale de l' Ouest e outros e Sanders, já referidos) que, em princípio, a proibição em causa abrange qualquer imposição exigida por ocasião ou em virtude da importação, que incida especificamente sobre um produto importado, com exclusão do produto nacional similar. Afirmou igualmente que os encargos pecuniários destinados a financiar a atividade de um organismo de direito público podiam constituir encargos de efeito equivalente.

O Tribunal de Justiça esclareceu, nesses mesmos acórdãos, que, na interpretação da noção de "encargo de efeito equivalente a um direito aduaneiro de importação", pode ter de atender-se ao destino dos encargos pecuniários cobrados. Com efeito, quando esse encargo pecuniário ou contribuição se destine exclusivamente a financiar atividades que beneficiem especificamente os produtos nacionais tributados, pode daí decorrer que a contribuição geral cobrada, com base nos mesmos critérios, tanto sobre o produto importado como sobre o produto nacional, constitua para um, no entanto, um 
encargo pecuniário suplementar sem compensação, enquanto para o outro representa efetivamente a contrapartida de benefícios ou auxílios recebidos. Em consequência, uma contribuição que faça parte de um regime geral de imposições internas que tenham sistematicamente por objeto, de acordo com os mesmos critérios, tanto os produtos nacionais como os importados, pode, contudo, constituir um encargo de efeito equivalente a um direito aduaneiro de importação, quando essa contribuição se destine exclusivamente a financiar atividades que beneficiem especificamente os produtos nacionais abrangidos.

$\mathrm{O}$ artigo $95^{\circ}$ proíbe que os Estados-membros façam incidir, direta ou indiretamente, sobre os produtos dos outros Estados-membros imposições internas superiores às que incidem sobre os produtos nacionais similares ou que sejam susceptíveis de proteger outras produções nacionais. O critério de aplicação desta disposição reside, em consequência, na natureza discriminatória ou protetora de uma medida de imposição interna (acórdão Compagnie Commerciale de l' Ouest e outros, já referido, $\left.\mathrm{n}^{\circ} 25\right)$.

Vale dizer, em resumo, que os artigos $12^{\circ}$ e $13^{\circ}$ estão voltados a qualquer imposição, exigida por ocasião ou em virtude da importação, que incida especificamente sobre um produto importado, com exclusão do produto nacional similar. $\mathrm{O}$ artigo $95^{\circ}$, por sua vez, está tratando de tributos que incidam tanto sobre produtos nacionais quanto sobre os importados, porém de maneira discriminatória ou protetiva, nos termos dos respectivos parágrafos.

Em relação a uma imposição que incide sobre os produtos nacionais e importados com base em critérios idênticos, pode ter de atender-se, de acordo com uma jurisprudência constante, ao destino da receita da imposição. Assim, quando a receita de tal imposição se destinar a financiar atividades que beneficiem especialmente os produtos nacionais tributados, pode daí resultar que a contribuição cobrada de acordo com critérios idênticos constitua, apesar disso, uma imposição discriminatória, na medida em que o encargo fiscal sobre os produtos nacionais é neutralizado pelos benefícios para cujo financiamento serve, enquanto que o que incide sobre os produtos importados representa um encargo sem compensação (acórdãos de 21 de maio de 1980, Comissão/Itália, no 15 , 73/79, Recueil, p. 1533, e Compagnie Commerciale de l'Ouest e outros, já referido, nº 26).

Assim, resulta das considerações precedentes que, se as vantagens que resultam da afetação da receita da cotização na causa compensam integralmente o encargo suportado pelo produto nacional quando da sua comercialização, essa cotização constitui um encargo de efeito equivalente a um direito aduaneiro, contrário aos artigos $12^{\circ} \mathrm{e}$ seguintes do Tratado. Se esses benefícios apenas compensam uma parte do encargo que 
incide sobre o produto nacional, a imposição em questão rege-se pelo artigo $95^{\circ}$ do Tratado. Nesta última hipótese, a imposição é incompatível com o artigo $95^{\circ}$ do Tratado e, portanto, proibida, desde que seja discriminatória em prejuízo do produto importado, quer dizer, desde que compense parcialmente o encargo suportado pelo produto nacional tributado (v., em último lugar, acórdão Sanders, já referido).

Competirá, portanto, ao órgão jurisdicional nacional verificar se o encargo que incide sobre o produto nacional é integral ou parcialmente compensado pela utilização das receitas da imposição em causa (acórdão Compagnie Commerciale de l' Ouest e outros, já referido, $\left.n^{\circ} 28\right)$.

Em resumo, uma cotização obrigatória, que constitui uma imposição parafiscal, aplicada nas mesmas condições de cobrança aos produtos nacionais e aos produtos importados, cujas receitas apenas beneficiam os produtos nacionais, de tal modo que as vantagens daí decorrentes compensam integralmente o encargo que onera esses produtos, constitui um encargo de efeito equivalente a um direito aduaneiro, proibido pelo artigo $12^{\circ}$ do Tratado. Se essas vantagens apenas compensarem uma parte do encargo suportado pelos produtos nacionais, esse encargo constitui uma imposição discriminatória proibida pelo artigo $95^{\circ}$ do Tratado.

Ao final, o Tribunal de Justiça sublinhou, por último, que, de acordo com a sua jurisprudência constante, as disposições dos artigos $12^{\circ}, 13^{\circ}$ e $95^{\circ}$ do Tratado tem efeito direto e atribuem direitos aos particulares que os órgãos jurisdicionais nacionais devem tutelar (acórdãos de 5 de Fevereiro de 1963, Gend \& Loos, 26/62, Recueil, p. 1; Capolongo e Iannelli, já referidos).

O Tribunal de Justiça também, desde há muito tempo, tem sublinhado a segregação das disciplinas das disposições dos artigos $12^{\circ}, 13^{\circ}$ e $95^{\circ}$ do TCEE em relação às restrições quantitativas do então artigo $30^{\circ}$ - essas de natureza não tributária, regulatória; aquelas consistentes em imposições tributárias. É o que Jesús de Santa-Bárbara Rupérez denomina de princípio da independência (2001, p. 281).

Assim foi declarado no processo 8/74 214 , Procureur du Roi contra Benoît e Gustave Dassonville, tendo por objeto um pedido apresentado ao então TJCE pelo Tribunal de Première Instance de Bruxelles, destinado a obter uma decisão, a título prejudicial, sobre a interpretação dos artigos $30^{\circ}$ a $33^{\circ}, 36^{\circ}$ e $85^{\circ}$ do Tratado CEE.

\footnotetext{
${ }^{214}$ ECR 1974, 426.
} 
Trata-se de litígio que entre um comerciante atacadista de bebidas alcoólicas, situado na França, Gustave Dassonville, que havia comprado uísque escocês, das marcas Johnnie Walker e Vat 69, dos distribuidores franceses dos respectivos fabricantes, para serem posteriormente importados por Benoît Dassonville, seu filho, responsável pela filial situada na Bélgica, com documentos franceses, já que a mercadoria se encontrava em território francês. Como se sabe, tais bebidas alcoólicas possuem origem no Reino Unido, país que ainda não havia aderido à então Comunidade Econômica Europeia.

No entanto, os documentos apresentados no ato da nova importação, da França para a Bélgica, foram repelidos pelo governo da Bélgica, uma vez que não preenchiam os requisitos básicos dos documentos a serem apresentados, consoante legislação belga, a Decisão Real no 57, de 02 de dezembro de 1934, por não incluírem um certificado de origem da alfândega britânica. Dassonville defendeu-se argumentando que as disposições da Decisão Real seriam incompatíveis com os artigos $30^{\circ}$ e seguintes do Tratado da CEE.

Em sede de reenvio prejudicial, na primeira questão ponderada ao TJCE indaga-se se constitui uma medida de efeito equivalente a uma restrição quantitativa no sentido do artigo $30^{\circ}$ do TCEE uma disposição regulamentar nacional que proíba a importação de uma mercadoria que não tenha uma declaração de origem, uma vez que não esteja acompanhada um documento oficial, expedido pelo Estado exportador, atestando a regularidade da sua situação ${ }^{215}$.

O TJCE então decidiu que toda regulamentação comercial dos Estadosmembros que seja suscetível de impor obstáculos, direta ou indiretamente, efetiva ou potencialmente, ao comércio intracomunitário, deve ser considerada uma medida de efeito equivalente às restrições quantitativas ${ }^{216}$.

Assim, o TJCE decidiu que a exigência por um Estado-membro de um certificado de autenticidade cuja obtenção é mais difícil para os importadores de um produto autêntico regularmente em livre prática noutro Estado-membro do que para os importadores do mesmo produto em proveniência direta do país de origem constitui uma medida de efeito equivalente a uma restrição quantitativa incompatível com o Tratado.

\footnotetext{
215 "2 que, par la première question, il est demandé si constitue une mesure d'effet équivalant à une restriction quantitative au sens de l'article 30 du traité une disposition réglementaire nationale interdisant l'importation d'une marchandise portant une appellation d'origine lorsque cette marchandise n'est pas accompagnée d'une pièce officielle délivrée par l'État exportateur et attestant son droit à cette appellation"; 216 "5 attendu que toute réglementation commerciale des États membres susceptible d'entraver directement ou indirectement, actuellement ou potentiellement le commerce intracommunautaire est à considérer comme mesure d'effet équivalant à des restrictions quantitatives";
} 
Não obstante, nesse mesmo acórdão, o Tribunal admitiu a possibilidade de haver algumas restrições parciais, o que é observado por Miguel Gorjão-Henriques (2005, p. 441), na medida em que foi declarado que os Estados-membros podiam manter certos obstáculos à circulação intracomunitária, no caso de inexistência de uma regulamentação comum acerca da produção e comercialização do produto em causa que viesse a garantir dos direitos dos seus consumidores, condicionado a que a regulamentação seja razoável e que os meios de prova exigidos não possuam o efeito de opor obstáculos ao comércio entre os Estados-membros ${ }^{217}$.

O entendimento do que seriam esses critérios de razoabilidade e de proporcionalidade (esse extraído da interpretação em conjunto com as exceções do artigo $36^{\circ}$, após $30^{\circ}$, atual $36^{\circ}$, dos respectivos tratados) no contexto do poder regulatório dos Estados-membros abriu oportunidade à formulação jurisprudencial e doutrinária da regra da razão ${ }^{218}$. Não obstante, é assunto demasiadamente complexo e que foge ao presente tema, por se tratar de controle comunitário negativo quanto ao caráter discriminatório das normas nacionais unicamente de cunho regulatório.

Porém, de forma resumida e didática, pode-se tomar a lição fornecida pelo TJCE em outro processo referente ao mesmo tema, igualmente pioneiro, o chamado caso Cassis Dijon, processo 120/78, Rewe-Zentrale AG contra Bundesmonopolverwaltung für Branntwein (Administração Federal de Monopólio de Álcool) ${ }^{219}$. Nele, o Tribunal de Justiça das Comunidades Europeias construiu entendimento acerca do que consistiria a proibição de "medidas de efeito equivalente" aos direitos aduaneiros, do art. $12^{\circ}$ do Tratado de Roma, após art. $25^{\circ}$ do Tratado que institui a Comunidade Europeia, com a renumeração efetivada pelo Tratado de Amsterdam, atual art. $30^{\circ}$ do Tratado sobre o Funcionamento da União Europeia.

Assim, a interpretação do TJCE é a de que um Estado-membro não poderá, em princípio, proibir a venda no seu território de um produto legalmente produzido noutro Estado-membro, ainda que o referido produto seja produzido de acordo com requisitos técnicos ou de qualidade diferentes dos que são impostos aos produtos domésticos. Nas situações em que um produto adequada e satisfatoriamente cumpra os objetivos legítimos,

\footnotetext{
217 " 6 que, tant que n'est pas institué un régime communautaire garantissant aux consommateurs l'authenticité de l'appellation d'origine d'un produit, si un État membre prend des mesures pour prévenir des pratiques déloyales à cet égard, c'est cependant à la condition que ces mesures soient raisonnables et que les moyens de preuve exigés n'aient pas pour effet d'entraver le commerce entre les États membres et soient, par conséquent, accessibles à tous leurs ressortissants";

${ }^{218}$ Sobre a regra da razão, aplicada à análise do artigo $30^{\circ}$, após artigo $28^{\circ}$, atual $34^{\circ}$, confira-se ORTINO (2004, p. 389 - 434); TERRA; WATTEL (2008, p. 44 - 52); BARNARD (2007, p. 64 - 90).

${ }^{219}$ ECR 1979, 649.
} 
nos termos do atual art. $36^{\circ}$ (saúde pública, proteção dos consumidores ou do ambiente) presentes nas regras que um Estado-membro aplique aos produtos domésticos, o Estadomembro importador não poderá justificar a proibição da sua venda com base no fato de ser diferente a sua forma de salvaguardar os referidos objetivos. Trata-se do princípio do reconhecimento mútuo das legislações nacionais, em virtude do qual se deverão admitir à circulação e comercialização num Estado-membro os produtos regularmente produzidos e comercializados no Estado-membro de origem.

Com a consolidação do fenômeno integracionista europeu, a redação de tais dispositivos do direito comunitário originário, aquele que é diretamente oriundo dos tratados constitutivos, teve que ser alterada, refletindo a situação de estabilidade alcançada. Porém, a estrutura triparticionada da liberdade de circulação de mercadorias manteve-se incólume, embora a disposição do respectivo tratado institutivo, em relação a essa estrutura, tenha se alterado.

Hoje, o TUE inicia-se com uma Primeira Parte que trata de "Os Princípios", nela não mais se verificando a presença de normas que tratam da criação do mercado comum ou da aproximação progressiva das políticas dos Estados-Membros. Em lugar disso, há um Título I, denominado "As Categorias e os Domínios de Competência da União", que estabelece fundamentalmente a divisão de competências, exclusivas ou partilhadas, entre os Estados-membros e a União.

A Segunda Parte agora trata da "Não-Discriminação e Cidadania da União", normas que consistem na carta de direitos humanos da União, em suma. Apenas na Terceira, "Políticas e Acções Internas da União", após um Título I que trata de "O Mercado Interno”, passa-se, no título seguinte, para “A Livre Circulação de Mercadorias”, que se inicia com o art. $28^{\circ}$, anteriormente art. $23^{\circ}$, originariamente art. $9^{\circ}$. Assim, a liberdade de circulação de mercadorias passou de fundamentos da comunidade para see tornar uma simples política interna. Agora, a própria posição topológica do artigo demonstra a consolidação da união aduaneira e a proposta de avançar no campo da cidadania, dado o sucesso econômico. Assim a preocupação com o mercado interno é apenas mais uma das políticas internas da União, no mesmo patamar que os títulos seguintes, respectivamente "A Agricultura e as Pescas"; "A Livre Circulação de Pessoas, de Serviços e de Capitais"; "O Espaço de Liberdade, Segurança e Justiça"; "Os Transportes" e "As Regras Comuns Relativas à Concorrência, à Fiscalidade e à Aproximação das Legislações", na qual se insere a tributação interna, o art. $110^{\circ} \mathrm{e}$ seguintes, não mais em título isolado. 


\subsection{Da Evolução Histórico-legal.}

Como primeiro passo para o exame minudente da evolução do tratamento dos impostos indiretos comunitários europeus é mister estudarem-se os diplomas comunitários constitutivos de seu embasamento legal assim como as alterações neles empreendidas ao longo do tempo. O enfoque deverá ser dado a todos os tributos concernentes à livre circulação de mercadorias, tanto ao Imposto sobre o Valor Agregado, como é mais comum, por conta de sua relevância, quanto aos impostos especiais de consumo e ao código aduaneiro comunitário.

Preliminarmente, no entanto, devem ser estabelecidas algumas conceituações interessantes à correta compreensão do processo de harmonização positiva.

O primeiro aspecto a ser abordado é o próprio conceito de harmonização - a positiva - e sua distinção em relação a outros fenômenos de integração legislativa correlatos. E a ordem de apresentação dessas modalidades de processos de aproximação legislativa deve dar-se em grau crescente de uniformidade legislativa.

Aquele que é caracterizado como o conceito mais incipiente em termos de aproximação entre legislações é o de coordenação legislativa. Implica haver mero estabelecimento de estratégias comuns, tomadas, de comum acordo, por dois ou mais Estados interessados em integrar os respectivos mercados, com vistas a alcançarem determinados objetivos pactuados (FERNANDES, 2000, p. 200).

Nessa modalidade, as legislações ainda se encontram muito pouco aproximadas, mormente se examinadas diante de outros processos de integração. Importante ressaltar que o traço mais identificador da coordenação legislativa é o fato de que cada Estado, mais do que se comprometer a alterar suas legislações, propõe-se a adotar as medidas avençadas no esforço coordenado.

A harmonização legislativa, por sua vez, encerra em seu conceito a circunstância de que, como conteúdo de acordo entre os Estados-Membros, esteja a definição de princípios legislativos comuns (FERNANDES, 2000, p. 200).

Agora, evoluindo na aproximação das disciplinas legais entre dois Estados, não se está tratando mais apenas da adoção de medidas isoladas, embora decididas em coletividade, pelos Estados envolvidos. Trata-se sim de se fixarem princípios a serem 
obedecidos e mandatoriamente adotados pelas legislações de cada país. Não obstante, a aproximação legislativa existe calcada apenas nas bases de cada normatização legal tomada singularmente.

O ápice da integração legislativa entre Estados encontra-se na uniformização. $\mathrm{O}$ que está pressuposto aqui é mais que uma aproximação das legislações, ou de confluência de princípios, mas sim uma identidade de texto legal (FERNANDES, 2000, p. 200). As normas jurídicas são concretamente redigidas pelos representantes dos diversos Estados acordantes e deverão ser adotados, na forma de internalização do Direito Positivo que exige o respectivo diploma constitucional.

Não há, pois, adaptação da lei comunitária às normas nacionais existentes, mas sim a recepção do seu texto integral. Dependendo da estrutura institucional do espaço de integração econômica, pode ter até efeito direto e imediato (REIS, 2001, p. 90 - 91) sobre o ordenamento interno - a possibilidade de revogar, de pleno direito, disposições internas incompatíveis com a disciplina comunitária, independentemente de procedimento de recepção interna.

Fernandes (2000, p. 200) ensina que, "no processo de formação de um mercado comum, a sua evolução demonstra claramente a adoção de cada uma dessas modalidades de aproximação legislativas". Vale dizer, à medida em que os Estados-partes acordam em evoluir na aproximação dos mercados, aprofundando a integração econômica, tal realidade é desde logo transferida para o plano da produção legislativa, até como forma de viabilizar a concretização do acordado internacionalmente.

Não obstante, esclarece que "a correspondência entre as etapas de construção do bloco regional e os métodos de aproximação legislativas não é absoluta ou estática", podendo haver situações em que há descompasso entre os dois processos até mesmo com relação a dois segmentos econômicos ou jurídicos distintos.

Outro aspecto preliminar importante é o de se verificar que elemento de conexão atrai, no caso concreto, a tributação indireta. $\mathrm{O}$ legislador tributário, interno ou comunitário, deve escolher qual o critério que rege a aplicação territorial dos impostos indiretos (GEST e TIXIER, 1990, p. 430). Em outras palavras, se, na eleição da territorialidade aplicável aos impostos indiretos, há o emprego do princípio de tributação na origem ou no destino, uma vez que outros elementos de conexão, como o lugar de assinatura dos contratos, o lugar onde o pagamento é efetuado, a natureza da moeda utilizada no pagamento do avençado ou a nacionalidade ou o domicílio das partes têm sido, 
na prática internacional, absolutamente irrelevantes em se tratando de impostos indiretos (XAVIER, 1997, p. 208).

São aqueles princípios que limitam a soberania fiscal de cada país (VAN HOORN Jr., 1988, p. 420), que merecem especial atenção em ambientes integrados com vistas a evitar a bi-tributação ou a não-tributação internacional (CHRISTIAANSE, 1988, p. 431 e WILLIAMS, 1998, p. 171), potenciais fontes de desvios do curso normal do comércio internacional (XAVIER DE BASTO, 1991, p. 77). A importância da adoção de um dos dois princípios é, portanto, saber como se vai reger a divisão da soberania fiscal entre os Estados em matéria de tributação indireta (XAVIER DE BASTO, 1991, p. 77).

Cabe esclarecer que soberania fiscal, para Louis Cartou (1986, p. 13), pode ser definida como o poder de editar, pela via legislativa ou regulamentar, um sistema de impostos com autonomia técnica em relação aos outros sistemas fiscais suscetíveis de com ele concorrerem.

Empregando-se o princípio chamado da tributação no país de origem abreviadamente "princípio da origem" - a competência para tributar as transações internacionais é atribuída ao país da origem das mercadorias, abstendo-se o país do destino de gravá-las. Vale dizer, adotado o princípio da origem, são tributadas as exportações - o exportador vende com incidência do imposto na saída do país - mas são isentas as importações - o país importador não tributa a entrada de mercadorias estrangeiras ou desnacionalizadas (AMARAL, 1994b, p. 93).

O chamado princípio da tributação no país do destino - abreviadamente, "princípio do destino" - consiste na atribuição de competência impositiva indireta unicamente ao país de destino das mercadorias. Ao mesmo tempo, o país de origem acorda com que as suas exportações estarão livres de qualquer conteúdo fiscal. Utilizado o princípio do destino, passam a ser tributáveis as importações - ao Estado importador incumbe-se onerar as mercadorias importadas em montante não superior ao que incide internamente sobre mercadorias similares. Simultaneamente são exoneradas de gravame tributário as exportações - o Estado exportador deverá imputar aos bens exportados algum fenômeno de desoneração tributária, como imunidade, isenção ou não-incidência, livrandoos de todo o conteúdo econômico de origem fiscal. Eventualmente tal se pode dar por meio de algum mecanismo de ressarcimento ou restituição do montante incluído em fases anteriores do processo produtivo (AMARAL, 1994b, p. 93).

Em matéria de divisão da receita entre os Estados, a utilização da tributação na origem ou da tributação no destino acarretará consequiências diferentes (XAVIER DE 
BASTO, 1991, p. 78). Vigente o princípio da origem, os Estados obterão receita unicamente de suas exportações; inversamente, se vigorar o princípio do destino, os Estados não tributarão as exportações, renunciando à receita que a elas respeitaria, mas tributarão as importações, delas auferindo sua receita tributária.

Daí resulta que o princípio da origem dispensa controles nas fronteiras, ao contrário do princípio do destino, que os exige (XAVIER DE BASTO, 1991, p. 79 e XAVIER, 1997, p. 210).

Adotado o princípio da origem, as exportações são tratadas de idêntica maneira de como o são as transações internas. O exportador lança imposto na saída da mercadoria destinada ao seu cliente alienígena, tal como qualquer vendedor o faria em se tratando de comprador no mesmo estado da federação. Não há diferença, pois, entre o tratamento fiscal das transações internas e externas. Os sistemas fiscais dos vários países, ou jurisdições, nessa hipótese, tornam-se contínuos e comunicantes (XAVIER DE BASTO, 1991, p. 79). Por essa razão é que doutrinadores como Arlindo Correia (1998, p. 223) entendem que o princípio da origem é o único que permite realmente abolir as fronteiras fiscais entre os países, sendo aquele que só pode viger em um espaço econômico integrado.

Havendo o emprego do princípio do destino, pelo contrário, é mister a manutenção de "fronteiras fiscais". Vale dizer, há que proceder a "ajustes fiscais de fronteira" (border tax adjustments), a serem mais bem estudados posteriormente, tanto por parte do país exportador como do país importador.

A partir dessas considerações, conclui-se que o princípio da origem, já que só poderá ser efetivo em um ambiente economicamente integrado, apenas em teoria poderia ser concebido como solução universal. Na prática, sendo as relações desse espaço com o resto do mundo reguladas pelo princípio do destino, o que se adota é o princípio da origem restrito (restrained origin principle), como foi designado por Hirofumi Shibata ${ }^{220}$, em que a tributação na origem vigora no espaço integrado e a tributação no destino é a regra de tratamento das transações com o resto do mundo.

No sistema europeu, a aproximação das legislações tributárias tem merecido capítulo próprio desde o Tratado de Roma, de 25 de março de 1957, que instituiu a então Comunidade Econômica Europeia. Lá estava prevista no então art. $100^{\circ 21}$ - após o Tratado

\footnotetext{
${ }^{220}$ Apud Xavier de Basto (1991, p. 78).

221 “Chapitre 3 : Le rapprochement des législations. Article 100.
} 
de Amsterdam, art. $94^{\text {o222 }}$ do Tratado que instituiu a Comunidade Europeia; hoje, o art. $115^{\circ 223}$ do Tratado que institui a União Europeia, prevendo um processo legislativo especial. É norma que possui aplicação genérica, em relação àquelas matérias que não são contempladas com disciplina específica no Tratado. É o caso da tributação direta, por exemplo.

A tributação indireta, como aspecto básico na consecução da liberdade de tráfego de bens, sempre tem merecido capítulo próprio, sob a rubrica "Disposições Fiscais", como já se viu. Ao seu final encontra-se o art. $93^{0224}$ do Tratado de Maastricht com a numeração do Tratado de Amsterdam (antigo artigo 99 ${ }^{\circ 25}$ ), atual art. $113^{\circ}$, que determina expressamente que, em se tratando da "harmonização das legislações relativas aos impostos sobre o volume de negócios, aos impostos especiais de consumo e a outros impostos indiretos", o "Conselho, deliberando por unanimidade, de acordo com um processo legislativo especial, e após consulta do Parlamento Europeu e do Comité Económico e Social," procederá à harmonização das disposições e eles relacionadas, "na medida em que essa harmonização seja necessária para assegurar o estabelecimento e o funcionamento do mercado interno e para evitar distorções de concorrência".

Le Conseil, statuant à l'unanimité sur proposition de la Commission, arrête des directives pour le rapprochement des dispositions législatives. réglementaires et administratives des États membres qui ont une incidence directe sur l'établissement ou le fonctionnement du marché commun.

L'Assemblée et le Comité économique et social sont consultés sur les directives dont l'exécution comporterait, dans un ou plusieurs États membres, une modification de dispositions législatives".

222 "Artigo $94^{\circ}$ (ex-artigo $\left.100^{\circ}\right)$

O Conselho, deliberando por unanimidade, sob proposta da Comissão, e após consulta do Parlamento Europeu e do Comité Económico e Social, adopta diretivas para a aproximação das disposições legislativas, regulamentares e administrativas dos Estados-Membros que tenham incidência directa no estabelecimento e no funcionamento do mercado interno comum".

223 “Artigo $115^{\circ}$ (ex-artigo $\left.94^{\circ} \mathrm{TCE}\right)$

Sem prejuízo do disposto no artigo $114^{\circ}$, o Conselho, deliberando por unanimidade, de acordo com um processo legislativo especial, e após consulta do Parlamento Europeu e do Comité Económico e Social, adopta directivas para a aproximação das disposições legislativas, regulamentares e administrativas dos Estados-Membros que tenham incidência directa no estabelecimento ou no funcionamento do mercado interno".

224 “Artigo $93^{\circ}$ (ex-artigo 99)

O Conselho, deliberando por unanimidade, sob proposta da Comissão, e após consulta do Parlamento Europeu e do Comité Económico e Social, adopta as disposições relacionadas com a harmonização das legislações relativas aos impostos sobre o volume de negócios, aos impostos especiais de consumo e a outros impostos indirectos, na medida em que essa harmonização seja necessária para assegurar o estabelecimento e o funcionamento do mercado interno no prazo previsto no artigo $14^{\mathbf{o}}$ ',

${ }^{225}$ Redação original, do Tratado de Roma (TCEE):

"Article 99.

La Commission examine de quelle façon les législations des différents États membres relatives aux taxes sur le chiffre d'affaires, aux droits d'accise et autres impôts indirects, y compris les mesures de compensation applicables aux échanges entre les États membres, peuvent être harmonisées dans l'intérêt du marché commun.

La Commission soumet des propositions au Conseil qui statue à l'unanimité, sans préjudice des dispositions des articles 100 et 101". 
O correto alcance desse importantíssimo artigo será examinado mais tarde. Nesse momento, introdutoriamente, é importante acentuar-se que os diplomas constitutivos comunitários sempre colocaram a tributação dos bens em patamar diverso das demais matérias, para as quais estipula-se unicamente a coordenação legislativa, determinando a plena harmonização das legislações fiscais indiretas como alicerce fundamental para a construção do mercado comum.

Essa diferença de ênfase é hoje claramente visível na própria topologia do tanto do TCE quanto do TUE, até como reflexo da evolução histórica em matéria fiscal. Assim é que o Capítulo 2 - "Disposições Fiscais" e o Capítulo 3 - "A Aproximação das Legislações", contidos que estão no Título VI desse diploma constitutivo - "As Regras Comuns relativas à Concorrência, à Fiscalidade e à Aproximação das Legislações" -, tratam de matéria concernente à convergência legislativa, seja sob a forma de harmonização - Capítulo 2 - seja sob a forma de coordenação - Capítulo 3. Não obstante, apenas um artigo referente às disposições fiscais, na redação conferida pelo Ato Único Europeu, de 17 de fevereiro de 1986, fazia remissão a artigo da Parte I - "Os princípios", no que se refere à constituição, então, do mercado comum - o art. $14^{\circ}$ do TCE, mas que, atualmente, como art. 260226, vem veiculado na Parte III sobre "As Políticas e Acções Internas da União”, no Título I, “O Mercado Interno”, não mais na Parte I.

Verifica-se daí um caráter cada vez mais expressamente instrumental da harmonização da tributação do comércio de bens, já que hoje, assim como se dava no TCE, diferentemente de como se dava anteriormente no TCEE, todos os títulos diretamente referentes à matéria tributária encontrarem-se incluídos na Parte III, referente antes "As Políticas da Comunidade"; hoje, "As Políticas e Acções Internas da União", ao lado, no mesmo plano, das quatro liberdades básicas da etapa união aduaneira ${ }^{227}$ - de circulação de

\section{6 "PARTE III \\ AS POLÍTICAS E ACÇÕES INTERNAS DA UNIÃO \\ TÍTULO I \\ O MERCADO INTERNO}

Artigo $26^{\circ}$

(ex-artigo $\left.14^{\circ} \mathrm{TCE}\right)$

1. A União adopta as medidas destinadas a estabelecer o mercado interno ou a assegurar o seu funcionamento, em conformidade com as disposições pertinentes dos Tratados.

2. O mercado interno compreende um espaço sem fronteiras internas no qual a livre circulação das mercadorias, das pessoas, dos serviços e dos capitais é assegurada de acordo com as disposições dos Tratados.

3. O Conselho, sob proposta da Comissão, definirá as orientações e condições necessárias para assegurar um progresso equilibrado no conjunto dos sectores abrangidos".

${ }^{227}$ Para a etapa de evolução da integração econômica referente ao mercado comum, entende-se serem cinco as liberdades básicas: livre circulação de mercadorias, liberdade de estabelecimento, livre circulação de 
bens, pessoas, serviços e de capitais, na lição de, entre outros, Ben Terra e Peter Wattel (2008, p. 44), a partir do artigo 3 (1) (c) do Tratado de Roma ${ }^{228}$ - (Título I - "A Livre Circulação de Mercadorias"; Título III - "A Livre Circulação de Pessoas, de Serviços e de Capitais" e Título IV - "Vistos, Asilo, Imigração e outras Políticas relativas à Livre Circulação de Pessoas") e de aspectos sensíveis da integração econômica (Título II - "A Agricultura"; Título V - "Os Transportes"; Título VII - "A Política Econômica e Monetária" e assim por diante).

Percebe-se, portanto, que a harmonização fiscal ganhou supervenientemente contornos de política autônoma da comunidade. Mas não foi sempre assim. Daí especialistas, como Xavier de Basto (1991, p. 107), afirmarem não ser a harmonização fiscal indireta, no Tratado de Roma, um "fim em si mesmo", mas apenas um meio apto a atingir os objetivos de realização da então união aduaneira. Entende que não havia propriamente uma política fiscal comunitária, no mesmo "sentido em que há uma política comercial exterior comum, uma política agrícola comum, ou uma política comum de transportes", as que, posteriormente, foram dispostas na Parte III do Tratado de Amsterdam.

A harmonização das legislações referentes à tributação do comércio de bens, como se verá concretamente, tem sido efetivada por meio de diretivas ${ }^{229}$, embora os tratados constitutivos da União Europeia, historicamente, no mencionado artigo $93^{\circ}$ do TCE (antigo artigo 99 ${ }^{\circ}$; art. $113^{\circ}$ do TUE), deixem entrever que o Poder Executivo comunitário poderia se utilizar de instrumentos legislativos de efeito direto ${ }^{230}$.

De se ressaltar que o Poder Executivo comunitário é exercido por meio da Comissão Europeia, anterior Comissão das Comunidades Europeias, que possui a iniciativa legislativa em matéria fiscal - a quem cabe, no dizer de Villemot (1995, p. 9 - 10), o importante poder de "concepção e de iniciativa", por ser quem estabelece os projetos de

trabalhadores ou de pessoas, livre circulação de capitais e liberdade de concorrência (NAKAYAMA, 2003, p. 47).

228 “Artigo $3^{\circ}$.

1. Para alcançar os fins enunciados no artigo $2^{\circ}$, a acção da Comunidade implica, nos termos do disposto e segundo o calendário previsto no presente Tratado:

(...).

c) Um mercado interno caracterizado pela abolição, entre os Estados-membros, dos obstáculos à livre circulação de mercadorias, de pessoas, de serviços e de capitais".

${ }^{229}$ Diplomas comunitários que, nos termos do art. $249^{\circ}$ do TCE e $288^{\circ}$ do TUE, vinculam "o Estado-membro destinatário quanto ao resultado a alcançar, deixando, no entanto, às instâncias nacionais a competência quanto à forma e aos meios".

${ }^{230}$ Os regulamentos que, pelo mesmo art. $249^{\circ}$ do TCE e $288^{\circ}$ do TUE, são o diploma comunitário que possui "carácter geral" e é "obrigatório em todos os seus elementos e directamente aplicável em todos os Estadosmembros". 
diretivas e de regulamentos, por isso por ele denominada (1995, p. 40) "motor de Bruxelas" ("moteur bruxellois"). A proposta legislativa tributária, no regime do TCE, era então submetida ao Conselho da União Europeia - mais conhecido como o Conselho - que, na disciplina tributária, deliberava por unanimidade. O Parlamento europeu manifestavase, após, sobre a deliberação unânime do Conselho, ouvido anteriormente o Comitê Econômico e Social, em uma tramitação que caracteriza o exercício do Poder Legislativo comunitário europeu.

Com a alteração do Art. $251^{\circ}$ do TCE, hoje art. $294^{\circ}$, esse passou a ser o processo legislativo ordinário. A matéria relativa à harmonização tributária, como já visto, obedece hoje a um procedimento legislativo especial que, mesmo após as recentes modificações comunitárias tendentes a alargar as matérias as quais podem ser decididas por maioria qualificada, ainda permanece sendo decidida apenas por unanimidade.

Essa atividade trata-se de um processo de evolução e aproximação legislativas que exige uma intervenção proativa do Poder Executivo comunitário, por intermédio da Comissão Europeia, pelo que a doutrina (VASQUES, 2001, p. 135) o denomina harmonização positiva.

A origem cronológica de tal processo evolutivo, como já mencionado, encontrase no Tratado de Roma. A norma pioneira do esforço de convergência legislativa é aquela que preconizava, ainda em 1957, no seu já mencionado art. 99º a harmonização dos impostos indiretos sobre o volume de negócios (no modelo do ainda recente TVA francês Taxe sur la Valeur Ajoutée), assim como os impostos especiais de consumo específicos e outros impostos indiretos.

Importante frisar que, à época, como hoje, era evidente o caráter instrumental da disciplina fiscal. O que estava em causa realmente era a realização de um objetivo fundamental da Comunidade, a concretização da própria União Aduaneira - o que pressupõe a plena eliminação dos obstáculos à livre circulação das mercadorias no espaço integrado. A ideia era a de se alcançar a neutralidade fiscal em relação ao comércio internacional, em que ocorresse situação tal que os sistemas tributários não afetassem as condições de concorrência do livre mercado comunitário. Esse foi o caráter do mencionado artigo, na sua versão original.

Também os outros artigos versando matéria tributária presentes no Tratado de Roma refletiam tal preocupação.

No que tange à construção da União Aduaneira, em cumprimento ao compromisso previsto no art. $16^{\circ}$, de eliminação de encargos aduaneiros e equivalentes na 
exportação, tais tributos foram completamente extintos ao fim do primeiro estágio do cronograma, em 31 de dezembro de 1961. Em função da Decisão do Conselho 66/532/EEC ${ }^{231}$, de 26 de julho de 1966, a chamada decisão de aceleração, relacionada ao cumprimento do art. $15^{\circ}$ do TCEE, direito alfandegários e encagos equivalentes na importação, que deveriam inicialmente ser abolidos apenas ao fim do período transitório, em 31 de dezembro de 1969, foram de fato eliminados em julho de 1968. Como afirma Federico Ortino (2004, p. 42), desde então a normativa do Tratado de Roma definindo o desgravamento gradual dos tributos na fronteira (e encargos de efeito equivalente) deixou de ser uma questão problemática.

Desde então, e ainda na vigência do TCEE, o esforço uniformizatório (por meio de regulamentos, portanto) em matéria do imposto de importação e da regulamentação administrativa das alfândegas no território comunitário recebeu um número grande de normas a efetivá-lo, tais como, entre os mais importantes: Regulamento (CEE) nº 802/68 do Conselho, de 27 de junho de 1968, relativo à definição comum da noção de origem, com a última redação dada pelo Regulamento (CEE) $n^{\circ} 456 / 91$; Regulamento (CEE) $n^{\circ}$ 754/76 do Conselho, de 25 de março de 1976, relativo ao tratamento pautal aplicável às mercadorias de retorno ao território aduaneiro da Comunidade, com a última redação dada pelo Regulamento (CEE) no 1147/86; Regulamento (CEE) n 2779/78 do Conselho, de 23 de novembro de 1978, relativo à aplicação da unidade de conta europeia nos atos adotados no domínio aduaneiro, com a última redação dada pelo Regulamento (CEE) no 289/84; Regulamento (CEE) no 1430/79 do Conselho, de 2 de julho de 1979, relativo ao reembolso ou à dispensa do pagamento dos direitos de importação ou de exportação, com a última redação dada pelo Regulamento (CEE) n 1854/89; Regulamento (CEE) no 1697/79 do Conselho, de 24 de julho de 1979, relativo à cobrança a posteriori dos direitos de importação ou dos direitos de exportação que não tenham sido exigidos ao devedor por mercadorias declaradas para um regime aduaneiro que implica a obrigação de pagamento dos referidos direitos, com a última redação dada pelo Regulamento (CEE) $n^{\circ}$ 1854/89; Directiva 79/695/CEE do Conselho, de 24 de julho de 1979, relativa à harmonização dos procedimentos de introdução em livre prática das mercadorias, com a última redação dada pela Directiva 90/504/CEE; Regulamento (CEE) n ${ }^{\text {o }}$ 1224/80 do Conselho, de 28 de maio de 1980, relativo ao valor aduaneiro das mercadorias, com a última redação dada pelo Regulamento (CEE) no 4046/89; Directiva 81/177/CEE do Conselho, de 24 de fevereiro de

\footnotetext{
${ }^{231}$ EUROPA. Jornal Oficial no ${ }^{\circ}$ 165, de 21 de setembro de 1966, p. 2971.
} 
1981, relativa à harmonização dos procedimentos de exportação das mercadorias comunitárias, com a última redação dada pelo Regulamento (CEE) n n 1854/89; Regulamento (CEE) n 3599/82 do Conselho, de 21 de dezembro de 1982, relativo ao regime de importação temporária, com a última redação dada pelo Regulamento (CEE) $\mathrm{n}^{\circ}$ 1620/85; Regulamento (CEE) no 2763/83 do Conselho, de 26 de setembro de 1983, relativo ao "regime que permite a transformação sob controlo aduaneiro de mercadorias antes da sua introdução em livre prática", com a última redação dada pelo Regulamento (CEE) n ${ }^{\circ}$ 720/91; Regulamento (CEE) no 2151/84 do Conselho, de 23 de julho de 1984, relativo ao território aduaneiro da Comunidade, com a última redação dada pelo Acto de Adesão de Espanha e Portugal; Regulamento (CEE) no 1999/85 do Conselho, de 16 de julho de 1985, relativo "ao regime do aperfeiçoamento activo"; Regulamento (CEE) n 3632/85 do Conselho, de 12 de dezembro de 1985, que define as condições segundo as quais uma pessoa é admitida a fazer uma declaração aduaneira; Regulamento (CEE) no 2473/86 do Conselho, de 24 de Julho de 1986, relativo ao regime do aperfeiçoamento passivo e ao regime de trocas comerciais padrão; Regulamento (CEE) no 2144/87 do Conselho, de 13 de julho de 1987, relativo à dívida aduaneira, com a última redação dada pelo Regulamento (CEE) no 4108/88; Regulamento (CEE) no 1031/88 do Conselho, de 18 de abril de 1988, relativo à determinação das pessoas obrigadas ao pagamento de uma dívida aduaneira, com a última redação dada pelo Regulamento (CEE) $n^{\circ}$ 1716/90; Regulamento (CEE) $n^{\circ}$ 1970/88 do Conselho, de 30 de junho de 1988, relativo ao tráfego triangular no âmbito do regime de aperfeiçoamento passivo e do regime de trocas comerciais padrão; Regulamento

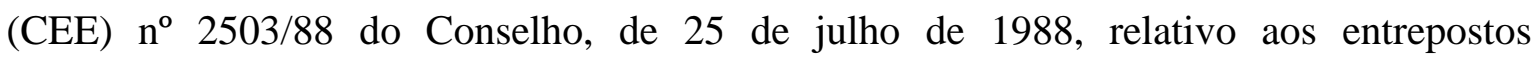
aduaneiros, alterado pelo Regulamento (CEE) no 2561/90; Regulamento (CEE) 2504/88 do Conselho, de 25 de julho de 1988, relativo às zonas francas e aos entrepostos francos, alterado pelo Regulamento (CEE) no 1604/92; Regulamento (CEE) $n^{\circ}$ 4151/88 do Conselho, de 21 de dezembro de 1988, que estabelece as disposições aplicáveis às mercadorias introduzidas no território aduaneiro da Comunidade; Regulamento (CEE) $\mathrm{n}^{\circ}$ 1854/89 do Conselho, de 14 de junho de 1989, relativo ao registo de liquidação e às condições de pagamento dos montantes dos direitos de importação ou dos direitos de exportação resultantes de uma dívida aduaneira; Regulamento (CEE) nº 1855/89 do Conselho, de 14 de junho de 1989, relativo ao regime de admissão temporária de meios de transporte; Regulamento (CEE) no 3312/89 do Conselho, de 30 de outubro de 1989, relativo ao regime de importação temporária dos contentores; Regulamento (CEE) $\mathrm{n}^{\circ}$ 4046/89 do Conselho, de 21 de dezembro de 1989, relativo às garantias a apresentar para 
assegurar o pagamento de uma dívida aduaneira; Regulamento (CEE) n ${ }^{\circ}$ 1715/90 do Conselho, de 20 de junho de 1990, relativo às informações pelas autoridades aduaneiras dos Estados-membros em matéria de classificação das mercadorias na nomenclatura aduaneira; Regulamento (CEE) no 2726/90 do Conselho, de 17 de setembro de 1990, relativo ao trânsito comunitário; Regulamento (CEE) n $n^{\circ}$ 717/91 do Conselho, de 21 de março de 1991, relativo ao documento administrativo único; e Regulamento (CEE) $\mathrm{n}^{\circ}$ 719/91 do Conselho, de 21 de março de 1991, relativo à "utilização na Comunidade de cadernetas TIR e dos livretes ATA, enquanto documentos de trânsito".

Quanto às demais disposições do TCEE acerca da tributação indireta interna, os seus artigos $96^{\circ}$ e $98^{\circ 232}$ também estabelecem normas para a coordenação fiscal dos Estados-Membros. Por meio de tais artigos, depois renumerados para $\operatorname{artigos} 91^{\circ}$ e $92^{\circ}$ do $\mathrm{TCE}^{233}$, respectivamente, enunciam-se limitações quantitativas e temporais, respectivamente, aos ajustes fiscais de fronteiras no que tange às exportações e às importações, no caso de incidências diretas, na ordem. Tais normas vêm hoje veiculadas nos artigos $111^{\circ}$ e $112^{\circ 234}$ do TUE. Embora, especialmente a segunda norma, visasse a ser

232 "Article 96.

Les produits exportés vers le territoire d'un des États membres ne peuvent bénéficier d'aucune ristourne d'impositions intérieures supérieure aux impositions dont ils ont été frappés directement ou indirectement. (...) Article 98.

En ce qui concerne les impositions autres que les taxes sur le chiffre d'affaires, les droits d'accise et les autres impôts indirects, des exonérations et des remboursements à l'exportation vers les autres États membres ne peuvent être opérés, et des taxes de compensation à l'importation en provenance des États membres ne peuvent être établies, que pour autant que les mesures envisagées ont été préalablement approuvées pour une période limitée par le Conseil, statuant à la majorité qualifiée sur proposition de la Commission".

".

233 “Artigo $91^{\circ}$ (ex-artigo 96 $)$

Os produtos exportados para o território de um dos Estados-membros não podem beneficiar de qualquer reembolso de imposições internas, superior às imposições que sobre eles tenham incidido, directa ou indirectamente.

Artigo $92^{\circ}$ (ex-artigo 98 $)$

Relativamente às imposições que não sejam os impostos sobre o volume de negócios, sobre consumos específicos e outros impostos indirectos, só podem ser concedidas exonerações e reembolsos à exportação para outros Estados-membros, ou lançados direitos de compensação às importações provenientes de Estadosmembros, desde que as medidas projetadas tenham sido previamente aprovadas pelo Conselho, deliberando por maioria qualificada, sob proposta da Comissão, para vigorarem por um período de tempo limitado".

234 "Artigo $111^{\circ}$

(ex-artigo $\left.91^{\circ} \mathrm{TCE}\right)$

Os produtos exportados para o território de um dos Estados-Membros não podem beneficiar de qualquer reembolso de imposições internas, superior às imposições que sobre eles tenham incidido, directa ou indirectamente.

Artigo $112^{\circ}$

(ex-artigo $\left.92^{\circ} \mathrm{TCE}\right)$

Relativamente às imposições que não sejam os impostos sobre o volume de negócios, sobre consumos específicos e outros impostos indirectos, só podem ser concedidas exonerações e reembolsos à exportação para outros Estados-Membros, ou lançados direitos de compensação às importações provenientes de Estados- 
aplicada especialmente enquanto ainda estivesse em processo de consolidação o mercado comum, permanecem exatamente com a mesma redação desde a assinatura em 1957, caso raro em matéria tributária.

Esses artigos vêm ao encontro da formulação, já referida, de Harry Johnson, de que a incidência na importação (e, por extensão, o ajuste fiscal de fronteira como um todo, incluindo os na exportação) pode e deve ser "compensatória", mas jamais "protetiva", no sentido que deve se propor a compensar a desvantagem competitiva decorrente de sua própria incidência sobre os insumos empregados, sem, no entanto, proporcionar o surgimento de uma nova vantagem competitiva ao produto final nacional (JOHNSON, 1965, p. 14). Trata-se, como já dito, de um dos pontos centrais a serem avaliados em qualquer análise a respeito do efeito protetivo da incidência tributária sobre os bens como um todo.

Alberto Xavier (1997, p. 210) ensina que o método de restituição ou reembolso do montante de impostos indiretos incidentes nas operações anteriores à de exportação presta-se a ser utilizado nos casos de impostos plurifásicos não-cumulativos, ao passo que, alternativamente, o método da isenção costuma ser aplicável, na exportação, aos impostos monofásicos seletivos.

À guisa de comparação com o sistema da OMC, em que há a expressa menção à modalidade na normatização dos subsídios, a disciplina dos ajustes fiscais de fronteira sob a forma de reembolsos, tanto na exportação, como é mais comum, como na importação, não é tratada juntamente com a disciplina das ajudas de Estado no sistema comunitário (arts. $92^{\circ}$ a $94^{\circ}$ do TCEE; arts. $87^{\circ}$ a $89^{\circ}$ do TCE; arts. $107^{\circ}$ a $109^{\circ}$ do TCE).

O princípio da não-discriminação propriamente dito veio contemplado no artigo $110^{\circ}$ do TUE; $90^{\circ}$, do TCE; e $95^{\circ}$ do TCEE, sobre o qual haverá extensa análise posteriormente.

As três normas referem-se, respectivamente, aos dois ajustes fiscais impostos pela tributação do destino, ensina Xavier de Basto (1991, p. 108), com vistas a assegurar a neutralidade fiscal: a proibição da tributação discriminatória e a vedação dos subsídios, na forma de reembolsos excessivos aos exportadores, ambos inspirados no Artigo III do GATT.

Membros, desde que as medidas projectadas tenham sido previamente aprovadas pelo Conselho, sob proposta da Comissão, para vigorarem por um período de tempo limitado". 
Não obstante, mesmo a regra da tributação no país de destino à altura inicial da construção do esforço unionista, não garantia fazer funcionar equitativamente a união aduaneira.

Isso porque, à exceção da França, país sabidamente pioneiro, desde 1954 (VILLEMOT, 1995, p. 15), na adoção da tributação sobre o valor agregado, todos os demais Estados-Membros possuíam, sob formas diversas, modalidades cumulativas de tributação indireta. E, como já visto, os impostos em cascata inviabilizam uma precisa atuação dos ajustes fiscais fronteiriços, uma vez que a carga tributária incidente em cada bem isoladamente considerado não mais poderá ser calculada com rigor.

Para que se consiga obter um resultado de não-discriminação entre o produto interno e o importado, é necessário que a incidência tributária tenha uma sistemática tal que permita a segregação, no seu preço final, da parcela nela embutida que advenha dos tributos internos nele incidentes. A informação precisa da parcela de tributo no preço do bem é, para os doutrinadores como Mazz (1999, p. 16 - 17), verdadeiro imperativo da harmonização tributária em processos de integração econômica, na consecução do objetivo da livre circulação de bens e serviços.

Apenas os impostos sobre bens possuem a capacidade e a aptidão de atender aos requisitos para a realização destes ajustes (TERRA, 1998, p. 249) até porque neles eventuais discrepâncias nos ordenamentos internos causariam mais profundas distorções econômicas (XAVIER DE BASTO, 1991, p. 77).

Em se tratando de impostos que recaiam sobre bens e que sejam revestidos do atributo da não-cumulatividade, é facilmente identificável a carga impositiva na mercadoria ao final da cadeia produtiva em território nacional. Se estamos falando de imposições cumulativas, tal apuração torna-se demasiadamente complicada.

Efeito dessa realidade veio pelo reconhecimento, no próprio Tratado de Roma, da possibilidade, como referência aos impostos sobre as importações e aos reembolsos às exportações, de os países cujos impostos indiretos incidirem em cascata poderem se valer de alíquotas médias por produtos ou por grupos de produtos, com o fim de alcançar os objetivos dos artigos $95^{\circ}$ e $96^{\circ}$, calculadas, tais alíquotas, de maneira algo presumida, a partir da carga tributária média. Uma forma de preservar, aproximadamente, pela via das compensações, a neutralidade fiscal internacional.

Por certo que essa solução revestia-se de caráter meramente paliativo. Xavier de Basto (1991, p. 109) afirma que poder-se-ia imaginar que aquelas alíquotas médias prestarse-iam sempre a traduzir, o que freqüentemente acontecia, discriminações contra os 
produtos importados provenientes de outros países mesmo da Europa dos Seis, ou favorecimentos às exportações nacionais por meio de subsídios disfarçados pela prática de reembolsos em montante maior que a carga tributária incidente internamente.

Como conseqüência, na década de 1960 percebeu-se grande preocupação da Comissão das Comunidades Europeias, com fulcro na autorização do art. $97^{0235}$ do Tratado de Roma, em regulamentar os métodos de cálculo dessas alíquotas médias, até mesmo mediante a elaboração de diretivas dirigidas aos Estados transgressores ao princípio da não-discriminação.

Esse art. $97^{\circ}$ não se encontra mais presente no ordenamento jurídico comunitário. No entanto, sua existência então, o que veio a ser reforçado pelo fato de ter sido concretamente necessário o seu emprego - em 12 de dezembro de 1968, contra Luxemburgo; e em 11 de fevereiro de 1969, contra a Itália - fez despertarem os órgãos técnicos e políticos comunitários para a inviabilidade da supressão dos obstáculos à livre circulação de mercadorias em um espaço integrado em que predominassem impostos indiretos cumulativos e para a imprescindibilidade da adoção harmonizada de um imposto sobre transações que se revestisse da característica da neutralidade econômica.

Verificou-se então a necessidade de se estudarem mais profundamente os aspectos fiscais envolvidos com o esforço de integração econômica em um mercado comum, especialmente examinar em que medida as disparidades então existentes entre os sistemas tributários dos seis Estados-membros o impediam, total ou parcialmente, ao lado de propor maneiras de serem suplantadas essas dificuldades.

Nessa perspectiva, por decisão da Comissão das Comunidades Europeias, a 5 de Abril de 1960, foi constituído um Comitê Fiscal e Financeiro, com mandato determinando a realização dos mencionados estudos, presidido pelo economista alemão Fritz Neumark - comumente designado Comitê Neumark - e composto por reconhecido corpo de especialistas acadêmicos e administrativos dos Estados-membros, além do americano, Carl Shoup ${ }^{236}$.

235 “Article 97.

Les États membres qui perçoivent la taxe sur le chiffre d'affaires d'après le système de la taxe cumulative à cascade peuvent, pour les impositions intérieures dont ils frappent les produits importés ou pour les ristournes qu'ils accordent aux produits exportés, procéder à la fixation de taux moyens par produit ou groupe de produits sans toutefois porter atteinte aux principes qui sont énoncés aux articles 95 et 96.

Au cas où les taux moyens fixés par un État membre ne sont pas conformes aux principes précités, la Commission adresse à cet État les directives ou décisions appropriées".

${ }^{236}$ O Comitê, presidido por Fritz Neumark, possuía a seguinte composição: Willy Albers, de Kiel; Alain Barrière, de Paris; Cesare Cosciani, de Roma; Joseph Kauffman, de Luxemburgo; Maurice Masoin, de Bruxelas; Benard Schendstok, da Haia; Carl Shoup, de Nova York; Gaetano Stammati, de Roma e Georges Vedel, de Paris. 
Em fevereiro de 1963 foi divulgado seu relatório final, o denominado "Relatório Neumark". Após proceder ao exame global dos problemas fiscais e financeiros oriundos da construção do mercado comum, preliminarmente expressa a opinião de que não há necessidade, dentro dos objetivos de integração europeia, que o processo de harmonização elimine todas as disparidades entre os sistemas fiscais. Defende que algumas desarmonias nos sistemas tributários podem ser preservadas, principalmente quando sua origem tem fulcro na história e na tradição, no desnível do potencial econômico dos países membros, ou em peculiaridades culturais e ideológicas. Apenas as sujeita ao requisito que não distorçam as condições de competição.

No que interessa no momento, quanto à tributação das transações, o Relatório primeiramente examina o imposto geral sobre o movimento econômico. Conclui que o sistema de tributação multifásico em cascata, pelos seus efeitos distorsivos, deve ser abolido dos Estados-membros, recomendando, entre as demais opções de tributação indireta estudadas ${ }^{237}$, a introdução da tributação sobre o valor acrescido por todos os países membros.

Propõe também que o imposto sobre o valor acrescido adotado deveria abranger todos os estágios da produção e comercialização, à exceção da venda ao consumidor final. Para essas operações, recomenda a instituição de um imposto autônomo. Fundamenta essa proposta na consideração de que, tendo em vista a provável sensível redução de receita nos países com alíquota mais elevada dos impostos sobre o movimento econômico, em função de sua uniformização, o "imposto sobre varejo" poderia se prestar, mediante o emprego de alíquotas mais elevadas, a atender às necessidades orçamentárias prementes de cada país. Ressalte-se que deve ser preservada a impossibilidade de discriminação em detrimento de mercadorias originárias dos outros países membros, mediante incidência do "imposto sobre varejo" em relação a todas as mercadorias igualmente, ainda que na vigência do princípio do país de origem e na hipótese da abolição completa das fronteiras tributárias.

A propósito, reconhece o Relatório que a harmonização do imposto sobre o valor acrescentado deveria realizar-se por etapas.

Inicialmente, vigorando o princípio do país de destino, a ocorrência de discriminações poderia ser evitada pela utilização de ajustes dos impostos internos, que,

${ }^{237}$ Segundo Alcides J. Costa (1978, p. 5 - 6), os impostos sobre vendas, ou, como preferem os franceses, os impostos sobre o volume de negócios, podem comportar basicamente três modalidades: o imposto multifásico cumulativo; o monofásico e o imposto de valor acrescido. A OCDE (1988, p. 25), por sua vez, como já visto acima, estabelece classificação diversa. 
como comentado anteriormente, pela técnica da não-cumulatividade, podem ser projetados mediante exata aferição das cargas tributárias incidentes.

$\mathrm{Na}$ fase final do processo de harmonização alcançar-se-ia a introdução do princípio do país originário como meio de definitiva abolição das fronteiras fiscais. Para tanto, o Relatório entende necessária ou a unificação das alíquotas ou a sua convergência muito próxima à igualdade. Também seria imperativo que a política de isenções do imposto sintético dos países membros fosse coordenada, assim como que a classificação fiscal das mercadorias nos diversos países fosse idêntica.

O Relatório Neumark recomenda a introdução do princípio do país de origem apenas no que se refere às transações internas entre os Estados-membros da união aduaneira ou do mercado comum, mantendo-se o princípio do país destinatário no comércio extra-regional. Corresponderia à adoção do "princípio do país de origem restrito", como já comentado, em uma implementação concreta e realista de um regime meramente hipotético, que corresponderia à aplicação indiscriminada do princípio do país de origem.

No que tange aos impostos especiais sobre o consumo, o Relatório não recomendou, nem como perspectiva ideal, em passo posterior, a introdução do princípio do país de origem com a abolição das fronteiras tributárias. Ao contrário, em função do peso orçamentário relevante desses impostos, aliado à impossibilidade, por motivos políticos, de se introduzir modificações nos monopólios estatais existentes (como o monopólio de fumo na França e na Itália), opta pela manutenção do princípio do país destinatário. Vislumbra dificuldades no estabelecimento de quais categorias de bens estariam sujeitas aos impostos seletivos. Recomenda que as mercadorias que podem ser utilizadas como matérias-primas na indústria, como açúcar e álcool, sofressem apenas a incidência da tributação geral sobre vendas. Sugere a abolição total desses impostos especiais sobre alguns produtos cuja incidência houvesse sido criada em alguns desses países, mas não em todos, tais como sal, fósforos, baralhos de cartas, adoçantes artificiais etc.

Em resumo, o Relatório Neumark, de 1962, delineou as características fundamentais apenas do imposto geral sobre o movimento econômico no espaço da Europa dos Seis, identificando os critérios básicos de harmonização fiscal que até hoje permanecem, baseados que foram na técnica do Imposto sobre o Valor Adicionado ou Agregado - IVA - imaginada, em 1918, pelo alemão W. von Siemens, introduzida concretamente primeiro na experiência francesa pré-comunitária da TVA - Taxe sur la 
Valeur Ajoutée - instaurada em 1954, assim como nos fundamentos teóricos sistematizados principalmente por Maurice Lauré (COSTA, 1978, p. 13 - 18).

São tais critérios básicos: imposto geral sobre consumo de bens e serviços (transações em geral); multifásico; não cumulativo; tipo consumo; o preço final como base de cálculo; alíquota ad valorem e a prevalência do princípio do país de destino como opção inicial.

No que tange aos tributos indiretos seletivos, diferentemente, havia a mera sugestão de harmonização, desde que incidissem sobre os mesmos bens em todos os países comunitários, bens esses que deveriam necessariamente ser produtos finais; caso contrário, se incidentes sobre produtos intermediários, deveriam ser extintas e agregadas ao IVA.

À época, pouco se falava sobre a harmonização dos impostos sobre o consumo, até pelo medo dos países de perder essa importante fonte de receita própria. Em função disso, a harmonização dos impostos especiais de consumo consistia então preocupação menor do Conselho Econômico e Financeiro e da Comissão das Comunidades Europeias como um todo.

Produto da atenção então canalizada para os impostos sobre o volume de negócios, mais ainda significativa a partir do impacto político e científico alcançado pelo Relatório Neumark, viu-se o sistema fiscal europeu ganhar seus primeiros diplomas positivos. Em 1967 adveio a publicação simultânea, em 11 de Abril, de duas diretivas do Conselho, geralmente conhecidas por $1^{\mathrm{a}}$ e $2^{\mathrm{a}}$ Diretivas IVA, que instituíram o que se convencionou denominar "O Primeiro Sistema Comum do IVA".

O primeiro desses atos comunitários, a Diretiva 67/227/CEE, vem sob a rubrica "Primeira Directiva do Conselho de 11 de Abril de 1967 em matéria de harmonização das legislações dos Estados-membros respeitantes aos impostos sobre o volume de negócios", enquanto o segundo, Diretiva 67/228/CEE, possui o título "Segunda Directiva do Conselho de 11 de Abril de 1967 em matéria de harmonização das legislações dos Estados membros relativas aos impostos sobre o volume de negócios - Estrutura e modalidades de aplicação do sistema comum de imposto sobre o valor acrescentado",238. Ambas invocam expressamente, como suporte jurídico para sua prolação, os artigos $99^{\circ}$ e $100^{\circ}$ do Tratado de Roma.

\footnotetext{
${ }^{238}$ Essas duas primeiras diretivas foram resultantes de propostas da Comissão apresentadas respectivamente em julho de 1964 e abril de 1965, depois de ouvidos o Parlamento Europeu e o Comitê Econômico e Social, tendo sido publicadas no J.O.C.E. de 14 de Abril de 1967.
} 
A $1^{\text {a }}$ Diretiva, a rigor, não cria um sistema comum do IVA, verdadeiramente. Sua função, não obstante, é ainda mais importante, motivo pelo qual ainda está em vigor, ao passo que a $2^{\text {a }}$ Diretiva, que traz em seu bojo propriamente o já ultrapassado sistema comum do IVA, já foi revogada pelo art. $37^{\circ}$ da $6^{a}$ Diretiva. Ao invés disso, traça, em breves seis artigos, as linhas gerais de aplicação do IVA na então Comunidade Econômica Europeia, a partir das conclusões do Relatório Neumark.

Em seu art. $1^{\text {o239 }}$, a $1^{\text {a }}$ Diretiva limita-se a determinar aos seis Estadosmembros, seus destinatários, que substituam os sistemas então existentes de impostos sobre o volume de negócios por um sistema comum de imposto sobre o valor acrescentado (IVA), na forma como estabelecido no art. $2^{\circ}$, o mais tardar até $1^{\circ}$ de Janeiro de 1970.

Enuncia também que o princípio da não-discriminação aplica-se a partir da sua entrada em vigor, pela via da proibição ao Estado-membro da instituição ou manutenção de qualquer medida de compensação fixa, em relação às trocas comerciais entre os Estadosmembros, na importação e na exportação, a título de imposto sobre o volume de negócios. Vale ressaltar, como aponta Xavier de Basto (1991, p. 114 - 115), que o termo “compensação fixa”, presente na versão oficial portuguesa do diploma comunitário, consiste em tradução infeliz da expressão francesa forfaitaire - aquela calculada por meios indiciários, com recurso a alíquotas médias, a forfait. Assim, o que se visou a coibir era a prática, àquela altura já abusiva, da compensação da carga tributária incidente em bens sujeitos a tributos indiretos cumulativos, como autorizado no art. $97^{\circ}$ do Tratado de Roma, que, segundo o financista de Coimbra, havia criado pesados empecilhos à plena realização da União Aduaneira, na etapa inicial de harmonização tributária.

\footnotetext{
239 “Artigo $1^{\circ}$ Os Estados-membros substituirão o seu sistema actual de impostos sobre o volume de negócios pelo sistema comum de imposto sobre o valor acrescentado, definido no artigo 2 o; Em cada Estadomembro, a lei que determine tal substituição será promulgada no mais curto prazo, de forma a poder entrar em vigor em data que será fixada por cada Estado-membro, tendo em conta a situação conjuntural, mas, o mais tardar, em 1 de Janeiro de 1970. A partir da entrada em vigor dessa lei, o Estado-membro não pode manter nem instituir qualquer medida de compensação fixa na importação e na exportação a título de imposto sobre o volume de negócios, em relação às trocas comerciais entre os Estados-membros”.
} 
No artigo seguinte ${ }^{240}$, a Primeira Diretiva passa descrever as linhas gerais do IVA europeu, nos exatos termos em que sugeridas pelo Relatório Neumark, com ênfase no emprego da técnica da não-cumulatividade e no seu caráter sintético - banhado nos princípios da generalidade (aplicável a todos os bens) e da universalidade (todas as etapas do processo de produção e distribuição sendo tributadas, em incidência plurifásica, qualquer que seja o número de operações intermediárias ocorridas; a menos, excepcionalmente, das vendas a varejo ou ao estágio a elas anterior, em que se possibilita a criação de imposto autônomo, mediante autorização da Comissão, consoante as considerações trazidas pelo Relatório Neumark).

Fora essas linhas mestras, a Primeira Diretiva, no que tange à definição da estrutura e das modalidades de aplicação do sistema comum, delega tal função a uma segunda diretiva, cuja iniciativa de proposta impõe à Comissão, para posterior aprovação pelo Conselho - no art. $3^{\mathrm{o}^{241}}$ - assim como de outras propostas tendentes à realização, no plano fiscal, de um mercado comum europeu (art. $4^{0^{242}}$ ), tendo-se em conta os objetivos da diretiva e o seu impacto sobre a política fiscal e orçamentária dos Estados-membros.

Embora a análise dos artigos da Primeira Diretiva alcance significativa importância no exame dos princípios adotados pela Comissão das Comunidades Europeias no desenho da tributação indireta como um todo e do tributo sobre o volume de negócios

\footnotetext{
240 “Artigo $2^{\circ} \mathrm{O}$ princípio do sistema comum de imposto sobre o valor acrescentado consiste em aplicar aos bens e aos serviços um imposto geral sobre o consumo exactamente proporcional ao preço dos bens e dos serviços, qualquer que seja o número de transacções ocorridas no processo de produção e de distribuição anterior à fase de tributação. Em cada transacção, o imposto sobre o valor acrescentado, calculado sobre o preço do bem ou do serviço à taxa aplicável ao referido bem ou serviço, é exigível, com prévia dedução do montante do imposto sobre o valor acrescentado que tenha incidido directamente sobre o custo dos diversos elementos constitutivos do preço. O sistema comum de imposto sobre o valor acrescentado é aplicável até ao estádio do comércio a retalho, inclusive. Todavia, até ao momento da supressão da tributação na importação e do desagravamento na exportação em relação às trocas comerciais entre os Estados-membros, estes últimos têm a faculdade, sem prejuízo da consulta prevista no artigo $5^{\circ}$, de aplicar tal sistema só até ao estádio do comércio por grosso, inclusive, e de aplicar, se for caso disso, ao estádio do comércio a retalho ou ao estádio anterior a este, um imposto complementar autônomo".

241 "Artigo $3^{\circ}$

Sob proposta da Comissão, o Conselho adoptará uma segunda directiva relativa à estrutura e às modalidades de aplicação do sistema comum de imposto sobre o valor acrescentado".

242 "Artigo $4{ }^{\circ} \mathrm{A}$ fim de permitir ao Conselho discuti-las e, se possível, tomar decisões antes do termo do período de transição , a Comissão apresentará ao Conselho , antes do final do ano de 1968 , propostas que indiquem de que modo e em que prazo a harmonização dos impostos sobre o volume de negócios pode atingir o objectivo da supressão da tributação na importação e do desagravemento na exportação em relação às trocas comerciais entre os Estados-membros, garantindo a neutralidade de tais impostos no que se refere à origem dos bens e das prestações de serviços . Para o efeito, ter-se-á em conta, designadamente, a relação entre os impostos directos e os indirectos, que difere nos vários Estados-membros, os efeitos de uma modificação dos sistemas fiscais sobre a política fiscal e orçamental dos Estados-membros e , também , a influência exercida pelos sistemas fiscais nas condições de concorrência e na situação social na Comunidade".
} 
(sintética) em particular, a ideia mais completa de seus pressupostos advém de uma análise dos aspectos considerados na sua elaboração e que vêm dispostos na sua introdução.

Ressaltando que "o objectivo essencial do Tratado é instituir, no âmbito de uma união económica, um mercado comum, que permita uma concorrência sã e apresente características análogas às de um mercado interno", por meio da "aplicação prévia, nos Estados-membros, de legislações respeitantes aos impostos sobre o volume de negócios que não falseiem as condições de concorrência e não impeçam a livre circulação das mercadorias e dos serviços no mercado comum", o que exige a realização de "uma harmonização das legislações respeitantes aos impostos sobre o volume de negócios a fim de eliminar, tanto quanto possível, os factores que possam falsear as condições de concorrência , tanto no plano nacional como no plano comunitário", "de modo a permitir que se atinja em seguida o objectivo da supressão da tributação na importação e do desagravamento na exportação em relação às trocas comerciais entre os Estadosmembros", constata que "dos estudos efectuados resultou que a harmonização deve conduzir à eliminação dos sistemas de impostos cumulativos em cascata e à adopção, por parte de todos os Estados-membros, de um sistema comum de imposto sobre o valor acrescentado".

Prossegue aduzindo como fundamento basilar da sua opção técnica de imposição o próprio conceito de tributação indireta sintética, quando afirma que "um sistema de imposto sobre o valor acrescentado consegue a maior simplicidade e a maior neutralidade se o imposto for cobrado da forma mais geral possível e se o seu âmbito de aplicação abranger todas as fases da produção e da distribuição, bem como o sector das prestações de serviços", o que conduziria "a uma neutralidade concorrencial, no sentido de que, em cada país, mercadorias de um mesmo tipo estejam sujeitas à mesma carga físcal, independentemente da extensão do circuito de produção e de distribuição, e de que, nas trocas comerciais internacionais, seja conhecido o montante da carga fiscal que incide sobre as mercadorias, a fim de se poder efectuar uma exacta compensação dessa carga fiscal".

Ao final, tendo em vista a complexidade do processo de harmonização das legislações, termina o Conselho, em mais uma de suas considerações preliminares à edição das normas comunitárias previstas na Primeira Diretiva, afirmando "que é necessário proceder por fases, pois que a harmonização dos impostos sobre o volume de negócios implicará, nos Estados-membros, relevantes modificações nas suas estruturas fiscais e terá sensíveis conseqüências nos domínios orçamental, económico e social”, sendo que a 
primeira dessas fases deve levar à “adopção, por parte de todos os Estados-membros, do sistema comum de imposto sobre o valor acrescentado, sem a harmonização simultânea das taxas e das isenções", ressalva "que não é possível prever, neste momento, de que modo e em que prazo a harmonização dos impostos sobre o volume de negócios pode atingir o objectivo da supressão da tributação na importação e do desagravamento na exportação em relação às trocas comerciais entre os Estados-membros", motivo pelo qual entende "preferível que o início da segunda fase e as medidas a adoptar para tal fase sejam fixados mais tarde, com base em propostas apresentadas pela Comissão ao Conselho".

Depreende-se, portanto, de todas essas considerações preliminares, que o objetivo da abolição das fronteiras fiscais esteve sempre subjacente aos esforços da harmonização da tributação indireta na então CEE.

A $2^{\text {a }}$ Diretiva CEE, proposta em 1965 e também aprovada em 1967, estipulou concretamente o delineamento estrutural e os métodos de aplicação do sistema comum do IVA, estabelecendo a definição de suas operações tributáveis (entrega de bens, prestações de serviços e importações) e de seus sujeitos passivos, ao mesmo tempo em que minudencia sua base de cálculo.

Por ser sistema revogado posteriormente, não merece ser examinado com atenção, senão pelas suas singularidades relevantes dentro de uma visão histórico-evolutiva do processo de aproximação das legislações. Nessa perspectiva, a característica mais importante desse primeiro sistema comum a ser ressaltada é a de ser um sistema de base de incidência restrita, embora as preliminares da Primeira Diretiva apontem para a adoção dos princípios da generalidade e da universalidade. Trata-se, em verdade de um primeiro passo na efetivação de uma real tributação indireta sintética.

O motivo principal para essa pequena ambição inicial é de cunho político, a partir da opção pela conservação, na soberania dos Estados-membros, de considerável discricionariedade legislativa.

Conseqüentemente, a Segunda Diretiva não logra uniformizar completamente as isenções, nem estipula alíquotas do imposto, deixando ambas à livre fixação dos legisladores nacionais.

No que se refere às isenções, a Segunda Diretiva não só autoriza aos Estadosmembros, em seu art. $10^{\circ}$, o estabelecimento de "outras isenções que considerem necessárias", totais ou parciais, como também consente que sejam praticadas com "reembolso dos impostos suportados nas operações anteriores" ou sem "perda do direito à 
dedução do IVA a montante", desde que estabelecidas "por razões de interesse social bem definidas e a favor dos consumidores finais".

Outro aspecto em que o primeiro sistema comum do IVA falha na harmonização legislativa refere-se à tributação da prestação de serviços. Embora a estipulação do fato gerador fosse genérica, a Segunda Diretiva consentia em que os Estados-membros tributassem obrigatoriamente apenas os dez grupos de prestações de serviços enumeradas no seu Anexo B, tais como licença de uso de patente de invenção ou registro de marca, publicidade, transporte e assemelhados. Em regra consistiam prestações de serviços intermediárias, tomadas por contribuintes do IVA, que eram tributáveis por permitirem a dedução do IVA nelas pago no incidente nas operações posteriores. A ideia era não tributar as prestações de serviço a usuário final, por poder originar efeitos cumulativos na incidência.

Quanto ao aspecto subjetivo, o primeiro sistema comum do IVA também não assegurava larga base de abrangência, uma vez que ressalvava a possibilidade de não incidência em relação a pequenas empresas e aos produtores agrícolas, consoante entendesse o Estado-membro.

As três diretivas seguintes cuidaram apenas da entrada em vigor do primeiro sistema comum do IVA. A Terceira (Diretiva 69/463/CEE, de 9 de dezembro de 1969), dirigida a todos os Estados-membros, substituía a data de $1^{\circ}$ de janeiro de 1970, estipulada na Primeira Diretiva como prazo fatal de sua vigência, pela data de $1^{\circ}$ de janeiro de 1972 , a partir de comunicações, feitas à Comissão das Comunidades Europeias em julho e setembro de 1969, respectivamente pela República Italiana e pelo Reino da Bélgica, de que não estariam em condições de respeitar a data limite então fixada. A Quarta Diretiva (71/401/CEE, de 24 de dezembro de 1972), essa dirigida apenas à Itália, autorizava esse Estado-membro a aplicar o sistema comum em data não posterior a $1^{\circ}$ de julho de 1972 , tendo em vista o conturbado processo de internação das duas primeiras diretivas, mormente em função de crises governamentais por que passou o país peninsular. Finalmente, após nova dissolução de gabinete parlamentar na Itália, foi necessária a edição da Quinta Diretiva (72/250/CEE, de 18 de julho de 1972), igualmente só dirigida à República Italiana, a permitir uma última dilação de prazo por seis meses, até $1^{\circ}$ de Janeiro de 1973. Tal foi o dilargamento de prazo concedido à Itália que, quando da introdução do IVA na península italiana, dois dos novos países admitidos na Comunidade naquela mesma data, Dinamarca e Irlanda, adotaram o IVA europeu simultaneamente à Itália, embora o Tratado de Adesão facultasse a introdução do sistema comum até 1975. Em $1^{\circ}$ de abril de 
1973, o terceiro aderente, o Reino Unido, também introduziu o sistema comum, que passa a ser vigente plenamente na Europa dos Nove desde então.

Já se viu que os documentos da Comissão das Comunidades Europeias na década de 60 não tratavam da matéria concernente aos impostos especiais de consumo. Muito menos as diretivas prolatadas pelo Conselho. Nem sequer se viam esforços no sentido de se estipularem quais os bens submetidos à tributação seletiva, tendo em vista a diversidade de tratamento da matérias nos diversos Estados-membros.

O Doc. 4998/XIV/70-D da Comissão, de 1970, menciona que apenas em 1966 e 1967 - ao mesmo tempo em que foram publicadas as primeiras diretivas referentes ao sistema comum do IVA - pôde-se ver traçado um cronograma de trabalho, proposto pela Comissão das Comunidades Europeias, envolvendo a harmonização unicamente dos impostos sobre o álcool, o tabaco, o açúcar e os óleos minerais.

$\mathrm{Na}$ verdade, a tributação do tabaco foi o espaço no qual mais se progrediu na harmonização comunitária dos Impostos Especiais de Consumo nessa fase inicial. A primeira proposta de regulamento sobre impostos sobre o tabaco veio publicada ainda em 17 de agosto de $1967^{243}$. Não obstante tal fato, o que se verificou foi que a harmonização dos impostos especiais sobre o tabaco sempre acarretou acaloradas discussões, notadamente quanto à delimitação dos produtos tributáveis e à adoção de alíquotas específicas ou ad valorem.

A mencionada proposta de regulamento veio a ser logo substituída por uma proposta de diretiva, de 20 de novembro de 1970, a partir da qual se prolatou a Primeira Diretiva relativa à tributação do tabaco, a Diretiva n $n^{\circ}$ 72/464/CEE, do Conselho, de 19 de dezembro de $1972^{244}$. Nela, a solução para o impasse quanto à alíquota do imposto veio a ser dada pela adoção de uma sistemática de alíquota mista, que ainda hoje sobrevive no quer tange aos cigarros: o crédito tributário consistiria de uma parcela proporcional, calculada sobre o preço máximo de venda a varejo, e uma parcela específica, calculada sobre a unidade de medida do produto.

A Primeira Diretiva relativa à tributação do tabaco estabelecia como universo tributável do imposto harmonizado os tabacos manufaturados: cigarros, charutos e cigarrilhas, tabaco para fumar, rapé e tabaco para mascar. Previa também um processo de harmonização estipulado em fases, admitindo-se que a passagem à fase seguinte fosse adiada caso trouxesse, a algum Estado-membro, perda de receita considerada inadequada.

\footnotetext{
${ }^{243}$ EUROPA. Jornal Oficial no . C 92.

${ }^{244}$ EUROPA. Jornal Oficial no. L 303, de 31 de dezembro de 1972.
} 
Em função disso, e por motivos políticos, a vigência da Primeira Diretiva veio a ser sucessivamente adiada, de tal forma que não chegou a ter eficácia cogente.

No que tange à tributação dos produtos petrolíferos, surge, logo após a primeira proposta de diretiva relativa ao tabaco, em dezembro de 1970, uma primeira proposta de diretiva que visava a harmonizar, de início, apenas as alíquotas específicas incidentes sobre os combustíveis ${ }^{245}$ identificados pela sua classificação fiscal na Tarifa Aduaneira Comum.

Quanto aos demais produtos, em 6 de março de 1970, a Comissão, por meio do mencionado documento 4998/XIV/70-D, havia apenas fixado, como critério básico de seleção dos impostos a serem harmonizados, o seu caráter estritamente fiscal - a capacidade de produzir uma receita significativa. Haveriam de incidir sobre bens de consumo massificado, sem onerar a cadeia produtiva. Não poderiam ser selecionados, então, gêneros de primeira necessidade ou matérias-primas utilizadas no processo de transformação, pelo que se excluiu da possibilidade de incidência o açúcar, o café e o chá.

Logo depois, em outubro de 1970, por meio dos Docs. 18.274/XIV/70, 18.238/XIV/70, 18.328/XIV/70 e 18.200/XIV/70, a Comissão das Comunidades Europeias apresentou as primeiras propostas de diretivas dirigidas à harmonização dos impostos especiais de consumo, em uma disciplina sistematizada.

Tais propostas, após revistas e ampliadas, deram origem ao chamado "pacote de 1972”, que consistia em cinco propostas de diretiva e uma proposta de decisão do Conselho $^{246}$ que, invocando, nos moldes daquelas relativas ao IVA, a livre concorrência e a eliminação das fronteiras internas, tiveram por objetivo selecionar os bens em relação aos quais se harmonizariam os impostos especiais de consumo e traçar os contornos gerais de sua estrutura. A partir das conclusões já mencionadas, referiam-se à tributação do álcool, do vinho, da cerveja e das bebidas misturadas.

Eram apenas propostas de um sistema comum, a serem aprovadas pelo Conselho, não tendo a pretensão de serem definitivas. Não tratavam, portanto, da fixação das respectivas alíquotas.

Nenhuma das propostas do pacote de 1972 foi aprovada pelo Conselho, mas a sua concepção pode ser considerada o primeiro passo à frente da Comunidade Europeia no sentido da harmonização dos impostos gerais de consumo como um todo. Além disso, mais do que pela sua importância histórica, a análise ainda que superficial de suas linhas gerais antecipa os fundamentos do regime comunitário ora em vigor.

\footnotetext{
${ }^{245}$ EUROPA. Jornal Oficial $\mathrm{n}^{\mathrm{o}}$. C 14, de 11 de fevereiro de 1971.
}

${ }^{246}$ EUROPA. Jornal Oficial $n^{\circ}$. C 43, de 29/04/72, p. $23-46$. 
A própria estruturação legislativa é prenúncio do sistema que seria posto em vigor após. Partia-se de uma proposta de Diretiva-Quadro sobre a harmonização dos impostos especiais de consumo, na qual se delimitavam os impostos a harmonizar e os que se relegavam à soberania dos Estados-membros, remetendo-se a estruturação da harmonização para diretivas posteriores do Conselho, sob proposta da Comissão.

Com base no artigo $99^{\circ}$ do Tratado de Roma, a Diretiva-Quadro proposta pela Comissão obrigava os Estados-membros à adoção, até janeiro de 1974, de um regime harmonizado de impostos especiais de consumo sobre o álcool, a cerveja, o vinho, o tabaco e os óleos minerais. Ademais, fixava a regra de que os Estados-membros poderiam instituir novos impostos especiais de consumo, desde que não implicassem tributação na importação, reembolso na exportação ou instituição de controles aduaneiros.

Ao seu lado vinham as diretivas de estruturação dos impostos especiais de consumo tomados individualmente. Nelas vinham definidos os fatos geradores, bases de cálculo e isenções, além de extensa disciplina quanto à fiscalização e administração dos impostos. No que se refere às alíquotas, não eram fixadas, mas algumas regras a elas concernentes eram estabelecidas, como a unicidade de alíquota dos impostos sobre o álcool, a alíquota mínima sobre o vinho ou a progressividade do imposto sobre a cerveja em função do seu teor alcoólico.

Por fim, compunha o pacote uma proposta de decisão sobre a instituição de um Comitê das Accises. Composto por representantes dos Estados-membros e presidido por um representante da Comissão, tinha por função coordenar o esforço de harmonização dos impostos especiais de consumo por meio da tomada de decisões e medidas instrumentais necessárias à correta aplicação das diretivas comunitárias.

A crise do petróleo de 1973, com a conseqüente conturbação política e econômica, fez com que o sensível tema tributário ficasse ainda mais delicado, especialmente no que tange a impostos com elevada influência fiscal. Mas não foi só por isso que o Pacote de 1972 veio a ser integralmente reprovado pelo Conselho. Como comenta Vasques (2001, p. 139), tratava-se de "textos com deficiências técnicas graves: a delimitação da incidência objectiva não é feita com rigor nem pelo mesmo método em todas as accises harmonizadas; o respectivo facto gerador varia de imposto para imposto, nem sempre se autonomizando o conceito da exigibilidade; a renúncia à fixação das taxas torna os textos largamente irrelevantes na construção do mercado interno". Hoje é considerado importante apenas por ter representado uma primeira iniciativa de elaboração 
de um sistema comum de impostos especiais de consumo, como antepassado ao que veio a ser afinal vigente no início da década de 90.

Da publicação do meramente teórico Pacote de 1972 até 1985, seguiu-se fase em que a harmonização dos impostos especiais de consumo só avançou, ainda que palidamente, no domínio da incidência sobre o tabaco.

Corresponde à época anterior à ascensão do francês Jacques Delors à presidência da Comissão das Comunidades Europeias, em fins do ano de 1984. Foi o líder que teve por grande mérito fazer renascer o sonho da construção comunitária, algo que tinha, nos fins dos anos setenta, sofrido grave turbulência pelo ressurgimento de nacionalismos, o que se acirraria com a crise econômica do início dos anos oitenta (VILLEMOT, p. 35).

Como visto, a Primeira Diretiva relativa à tributação do tabaco - 72/464/CEE não logrou alcançar vigência. Antes que isso acontecesse, surgiu no mundo jurídico a Segunda Diretiva sobre a harmonização dos impostos sobre o tabaco, a Diretiva $\mathrm{n}^{\circ}$ 79/32/CEE, do Conselho, de 18 de dezembro de $1978^{247}$.

A função mais relevante da Segunda Diretiva repousa na definição dos vários tipos de tabaco manufaturados, diferenciando-os entre eles pelas suas características e pelas utilizações a que destinam. Para esse efeito, considera como tabacos manufaturados os charutos e as cigarrilhas, os cigarros, o tabaco para fumar, o rapé e o tabaco para mascar. Embora as espécies não se distinguissem das anteriormente arroladas, suas definições vinham a ser mais minudentes. Também estabelece o termo final da segunda fase de harmonização das estruturas do imposto específico sobre o consumo de tabacos manufaturados.

Enquanto a harmonização dos impostos especiais de consumo, nessa fase intermediária, permaneceu congelada, procedeu-se, no campo dos impostos sobre o volume de negócios, a relevante alteração.

A origem dessa reestruturação vem da aplicação da Decisão de 21 de abril de 1970, que determinou a substituição das contribuições financeiras dos Estados-membros por recursos próprios das Comunidades. Para o Conselho, então, o orçamento das Comunidades, sem prejuízo das outras eventuais receitas, deveria passar a ser financiado integralmente por recursos próprios das Comunidades, entre os quais os provenientes do Imposto sobre o Valor Acrescentado. Por questão de equidade no custeio das

${ }^{247}$ EUROPA, Jornal Oficial nº. L 10, de 16 de janeiro de 1979. 
Comunidades, tais recursos, provenientes do Imposto sobre o Valor Acrescentado, deveriam ser auferidos mediante a aplicação de uma alíquota comum a uma matéria tributável determinada de modo uniforme, e de acordo com as normas comunitárias.

Ora, a participação eqüitativa na formação de um orçamento baseado em receita tributária, e não mais em contribuições dos Estados-membros, não se coadunava mais com a flexibilidade de definição de institutos e na falta de uniformidade na fixação de sujeitos passivos e bases de cálculo que caracterizava o primeiro sistema comum do IVA.

Daí adveio a Sexta Diretiva do Conselho, 77/388/CEE, de 17 de maio de 1977 "relativa à harmonização das legislações dos Estados-Membros respeitantes aos impostos sobre o volume de negócios - sistema comum do imposto sobre o valor acrescentado: matéria colectável uniforme" ${ }^{248}$.

Embora o texto de diretiva finalmente aprovado pelo Conselho venha a avançar menos do que a proposta da Comissão apresentada em 12 de agosto de 1974 (BERLIN, 1988, p. 250), a Sexta Diretiva possui o mérito de definir regras comuns a todos os Estados-membros quanto a fatos geradores, sujeitos passivos, isenções, base de cálculo e valor tributável - aspectos da incidência tributária insertos dentro do conceito de "matéria colectável uniforme", de modo a prover as condições para fazer funcionar o sistema de recursos próprios IVA.

Xavier de Basto (1991, p. 126) explica que o fracasso em corresponder às ambições da Comissão justifica-se pelas dificuldades de toda a harmonização das legislações fiscais, por tocar "um ponto crucial da soberania dos Estados". É realidade que se complica em vista da sistemática de aprovação de diretivas em matéria fiscal que, nos termos do artigo $99^{\circ}$ do Tratado de Roma, exige a unanimidade dos Estados-membros, algo de difícil compatibilização "com sistemas de regras comuns que restrinjam, para além de determinados limites, as margens de manobra na fixação dos elementos essenciais dos impostos, a qual constitui prerrogativa histórica dos Parlamentos nacionais".

O segundo sistema comum, o estabelecido pela Sexta Diretiva, confere ao Imposto sobre o Valor Acrescentado assim características de um imposto de base de incidência alargada - um "broad based tax" (XAVIER DE BASTO, 1991, p. 126) - em relação ao sistema anterior, ganhando contornos próximos de uma modalidade de tributação indireta efetivamente sintética, geral e universal, com o fim de assegurar plenamente a neutralidade fiscal.

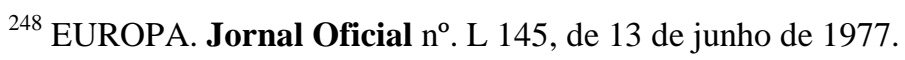


Alguns aspectos são mais relevantes nesse caminhar:

- o imposto expande sua incidência ao último estágio produtivo, uma vez que não se permite mais a possibilidade de os Estados-membros excluírem do campo de aplicação do imposto a venda a consumidor final;

- torna-se obrigatória a tributação geral das prestações de serviço, retirando-se dos Estados-membros a faculdade de restringir a incidência a prestações de serviços relacionadas exaustivamente;

- é fixada uma lista comum de isenções, ressalvados os regimes transitórios estabelecidos pela própria Comissão;

- o conceito de sujeito passivo passa a abranger as pessoas que realizam operações ocasionais;

A par da expansão da base tributável, alguns outros passos típicos de um esforço cada vez mais consistente de harmonização foram tomados, como o regime das deduções, o sistema de cobrança e as garantias a eles necessárias e as obrigações de declarar o montante global das respectivas operações. Fora isso, questões relativas a conflitos de competência, notadamente no que se refere à entrega de bens para montagem e às prestações de serviço, foram também dirimidas no segundo sistema comum do IVA.

O processo de harmonização positiva dos impostos especiais de consumo comunitários teve como seu efetivo estopim, no plano do direito positivo, o compromisso, entre os Estados-membros, de concretizar o mercado interno até ao final de 1992, advindo da aprovação do Ato Único Europeu, assinado em 17 de fevereiro de 1986.

Por suas diretrizes, especialmente a nova redação dada ao artigo $99^{\circ 249}$ do Tratado de Roma, a harmonização fiscal deixa de ser meramente acessória à realização, sucessivamente, da união aduaneira e, após, do estabelecimento do sistema de recursos próprios, nas duas primeiras fases, para que a "abolição de fronteiras fiscais" seja, na construção do mercado comum, um dos principais objetivos aos quais se associa a data de $1^{\text {o }}$ de janeiro de 1993, sinônimo de "supressão da tributação na importação e do desagravamento na exportação em relação às trocas comerciais entre os Estados membros", para usar as expressões do artigo $40^{\circ}$ da $1^{\text {a }}$ Diretiva.

\footnotetext{
${ }^{249}$ Redação após o Acto Único Europeu: "Article 99.

Le Conseil, statuant à l'unanimité sur proposition de la Commission et après consultation du Parlement européen, arrête les dispositions touchant à l'harmonisation des législations relatives aux taxes sur le chiffre d'affaires, aux droits d'accises et autres impôts indirects dans la mesure où cette harmonisation est nécessaire pour assurer l'établissement et le fonctionnement du marché intérieur dans le délai prévu à l'article 8 A".
} 
Daí se explica a pouca ênfase anterior na harmonização dos impostos especiais de consumo. Tal esforço só encontra justificação plena dentro de uma perspectiva de abolição das fronteiras fiscais, uma vez que, em princípio, tais impostos não constituem obstáculo à livre circulação de mercadorias - pressuposto de construção da união aduaneira - como era o caso dos impostos em cascata antecessores do IVA na maioria dos países europeus (XAVIER DE BASTO, 1991, p. 268).

Importante ressaltar - a título de ilustração das dificuldades que, àquela altura da evolução integracionista europeia, já se divisavam em termos de harmonização fiscal - o fato de que uma das mais importantes inovações do Ato Único Europeu no que se refere à harmonização legislativa genericamente considerada, o advento de um artigo $100^{\circ}$ - $\mathrm{A}^{250}$ (artigo $95^{\circ}$ do TCE), que, em derrogação ao artigo $100^{\circ 251}$ de então (artigo $94^{\circ}$ do TCE), determinava que a aproximação das disposições legislativas deveria obedecer ao procedimento do anterior artigo $189^{\circ}$-B (artigo $251^{\circ}$ do TCE), pelo qual o Conselho poderia deliberar por maioria qualificada, após parecer do Parlamento Europeu, não mais se exigindo a unanimidade. Tal requisito, não obstante, só se manteve quanto às

250 "Article $100 \mathrm{~A}$.

1. Par dérogation à l'article 100 et sauf si le présent traité en dispose autrement, les dispositions suivantes s'appliquent pour la réalisation des objectifs énoncés à l'article $8 \mathrm{~A}$. Le Conseil, statuant à la majorité qualifiée sur proposition de la Commission en coopération avec le Parlement européen et après consultation du Comité économique et social, arrête les mesures relatives au rapprochement des dispositions législatives, réglementaires et administratives des États membres qui ont pour objet l'établissement et le fonctionnement du marché intérieur.

2. Le paragraphe 1 ne s'applique pas aux dispositions fiscales, aux dispositions relatives à la libre circulation des personnes et à celles relatives aux droits et intérêts des travailleurs salariés.

3. La Commission, dans ses propositions prévues au paragraphe 1 en matière de santé, de sécurité, de protection de l'environnement et de protection des consommateurs, prend pour base un niveau de protection élevé.

4. Lorsque, après l'adoption d'une mesure d'harmonisation par le Conseil, statuant à la majorité qualifiée, un État membre estime nécessaire d'appliquer des dispositions nationales justifiées par des exigences importantes visées à l'article 36 ou relatives à la protection du milieu de travail ou de l'environnement, il les notifie à la Commission.

La Commission confirme les dispositions en cause après avoir vérifié qu'elles ne sont pas un moyen de discrimination arbitraire ou une restriction déguisée dans le commerce entre États membres.

Par dérogation à la procédure prévue aux articles 169 et 170, la Commission ou tout État membre peut saisir directement de la Cour de justice s'il estime qu'un autre État membre fait un usage abusif des pouvoirs prévus au présent article.

5. Les mesures d'harmonisation mentionnées ci-dessus comportent, dans les cas appropriés, une clause de sauvegarde autorisant les États membres à prendre, pour une ou plusieurs des raisons non économiques mentionnées à l'article 36 , des mesures provisoires soumises à une procédure communautaire de contrôle."

251 “Chapitre 3 : Le rapprochement des législations

Article 100.

Le Conseil, statuant à l'unanimité sur proposition de la Commission, arrête des directives pour le rapprochement des dispositions législatives. réglementaires et administratives des États membres qui ont une incidence directe sur l'établissement ou le fonctionnement du marché commun.

L'Assemblée et le Comité économique et social sont consultés sur les directives dont l'exécution comporterait, dans un ou plusieurs États membres, une modification de dispositions législatives". 
disposições fiscais, às relativas à livre circulação das pessoas e às relativas aos direitos e interesses dos trabalhadores assalariados ${ }^{252}$.

$\mathrm{Na}$ verdade, o Ato Único Europeu representa relevante reorganização institucional da Comunidade Econômica Europeia. O empenho na construção do mercado único não passou a ser o efeito apenas de se ter uma data estabelecida para sua realização, mas sim o produto de uma alteração de competências nos órgãos comunitários, em função da qual os poderes da Comissão, como detentor do dever de iniciativa e de mediação do processo legislativo comunitário, e do Conselho, na qualidade de centro de impulso político, foram assegurados (FORTE, 1994, p. 147 - 148).

No plano pré-positivo, tais iniciativas - de efetivação de um mercado interno pela abolição das fronteiras fiscais, superando a ideia de mercado comum do Tratado CEE (FORTE, 1994, p. 142) - já haviam sido externadas pela Comissão com a divulgação, em 28 de junho de 1985, de um relatório conhecido como o "Livro Branco sobre o mercado interno", apresentando, a partir das metas a serem alcançadas pela integração econômica europeia já referidas, um conjunto de propostas sobre a harmonização da tributação indireta.

Baseava-se em novo princípio jurídico balizador do processo de integração europeia, segundo Umberto Forte (1994, p. 143), com a passagem de uma mera criação de um sistema normativo homogêneo dos vários Estados-membros para o "reconhecimento recíproco dos respectivos ordenamentos”, pelo qual cada Estado reconhece como válidas em seu próprio território normas do ordenamento jurídico de outro país comunitário, assumindo a responsabilidade de não invocar eventual desconformidade legislativa como motivo de restrição, ao livre acesso do próprio mercado, de bens e serviços oriundos desse outro membro.

Na concepção trazida pelo "Livro Branco", a abolição das fronteiras fiscais objetivo primordial dos esforços de então, conjuntamente com a supressão das barreiras físicas e a eliminação das barreiras técnicas - implicava, em relação aos impostos sobre o volume de negócios, superar o princípio da tributação no país de destino pela adoção do

\footnotetext{
${ }^{252}$ Artigo $95^{\circ}$ (ex-artigo $100^{\circ}$-A)

1. Em derrogação do artigo $94^{\circ}$ e salvo disposição em contrário do presente Tratado, aplicam-se as disposições seguintes à realização dos objectivos enunciados no artigo $14^{\circ}$. O Conselho, deliberando de acordo com o procedimento previsto no artigo $251^{\circ}$, e após consulta do Comitê Econômico e Social, adopta as medidas relativas à aproximação das disposições legislativas, regulamentares e administrativas dos Estados-membros, que tenham por objecto o estabelecimento e o funcionamento do mercado interno.

2. $\mathrm{O} \mathrm{n}^{\mathrm{o}} 1$ não se aplica às disposições fiscais, às relativas à livre circulação das pessoas e às relativas aos direitos e interesses dos trabalhadores assalariados. $(\ldots) "$
} 
princípio da tributação no país de origem, uma vez que tal opção, como já examinado, tornaria dispensáveis os ajustamentos fiscais que caracterizariam as chamadas fronteiras fiscais. Seria a única solução de coordenação fiscal que asseguraria um verdadeiro e próprio mercado único interno europeu.

No domínio dos impostos especiais de consumo, o "Livro Branco", em uma primeira fase, propunha a harmonização das estruturas dos impostos sobre as bebidas alcoólicas, o tabaco e os óleos minerais, para, após, uniformizar as respectivas alíquotas e criar um sistema comum de depósitos fiscais. Mediante o emprego desse sistema, o pagamento do imposto teria lugar no momento da saída do produto, para consumo final, dos respectivos depósitos.

Paralelamente à primeira fase, com relação às incidências não-harmonizadas, impunha um congelamento à extensão ao alargamento dos impostos especiais de consumo que representassem entraves à circulação intracomunitária. Após, em uma segunda fase, proceder-se-ia à sua eliminação.

Em seguida ao "Livro Branco", a Comissão propõe aos Estados-membros, logo em dezembro de $1985^{253}$, um compromisso de standstill quanto à introdução de novos impostos especiais de consumo - abstenção de criação de novas modalidades tributárias a partir da data de adoção da medida - e ao aumento das alíquotas dos impostos nãoharmonizados, proposta que não veio a ter acolhimento entre os seus destinatários, por ser considerada restritiva em demasia.

$\mathrm{Na}$ esteira do compromisso do Ato Único Europeu, surge, em 21 de agosto de 1987, a elaboração do chamado "Plano Cockfield", por meio da comunicação da Comissão COM (87) 320, em homenagem ao comissário britânico então responsável pela matéria fiscal.

No que tange ao Imposto sobre o Valor Agregado, a Comissão no "Plano Cockfield" propõe a abolição das fronteiras fiscais pela adoção integral do princípio da tributação no país de origem. O exportador passaria a destacar o IVA na fatura, à alíquota do país de origem, que seria dedutível pelo importador. As transações internas e intracomunitárias passariam a se submeter ao mesmo regime jurídico, enquanto as importações oriundas de países da Comunidade deixariam de ser fato gerador do imposto. Os sistemas tributários indiretos dos países membros, no que se refere ao IVA interno e ao IVA intracomunitário, passariam a consistir em um único sistema contínuo.

${ }^{253}$ EUROPA. Jornal Oficial no ${ }^{\circ}$ C 313 , de 4 de dezembro de 1985. 
Duas são as principais inconveniências da adoção dessa sistemática, para as quais o "Plano Cockfield" traz as suas respectivas soluções, com o fim de assegurar a exeqüibilidade da proposta.

A primeira repousa na possibilidade de a adoção da regra da origem alterar as opções alocativas dos agentes econômicos no interior da Comunidade, especialmente em se tratando das operações finais, aquelas realizadas com não sujeitos passivos de IVA que, portanto, não guardam o direito ao aproveitamento dos créditos das operações anteriores.

Essas distorções econômicas, por óbvio, são mais relevantes quanto mais diferenciadas forem as alíquotas de IVA nos países da Comunidade. Em função disso, a Comissão estipulou como necessária a aproximação das alíquotas de IVA dos Estadosmembros.

A convergência de taxas dar-se-ia, então, na proposta da Comissão, pela autorização a que os Estados-membros adotassem apenas duas alíquotas. A primeira, a normal, deveria ser fixada em uma escala entre $14 \%$ a $20 \%$; a outra, reduzida, incidente sobre bens previstos em uma lista comum - gêneros ditos de primeira necessidade -, limitar-se-ia pelas percentagens de $4 \%$ a $9 \%$.

O outro problema detectado teria como causa a redistribuição de receitas do IVA no interior da Comunidade, a favor dos países exportadores líquidos, em detrimento dos importadores líquidos. A ideia por detrás dessa preocupação é o dever das instituições da Comunidade de procurar não pôr em perigo a estabilidade financeira (interna e externa) dos Estados membros.

Para tanto, seria necessária a criação de um sistema de compensação de receitas - clearing system - que evitasse a queda de receita, para os países importadores líquidos, resultante da cobrança do IVA na origem, com os evidentes inconvenientes fiscais e políticos daí advindos.

Por esse sistema, os países exportadores líquidos pagariam aos países importadores líquidos o excesso de receita em relação ao que obtinham com a sistemática de tributação no destino, mediante a utilização de clearing houses (câmaras de compensação), nas quais se restituiriam os saldos calculados a partir de dados estatísticos levantados junto aos órgãos de controle do comércio exterior dos Estados-membros sistema dito "Intrastat", mencionado por Villemot (1995, p. 47). Funcionaria como uma conta central, gerida pelos serviços da Comissão, no dizer de Umberto Forte (1994, p. 151). 
Xavier de Basto (1991, p. 274) opina que, sem a concretização de um sistema de compensação, qualquer tentativa de abolição das fronteiras fiscais "seria de todo irrealizável". Entende dessa forma mesmo ponderando que não "necessariamente o modo de distribuição da receita próprio da tributação no destino - a distribuição conforme o nível do consumo - seja essencialmente mais justo do que o modo de distribuição próprio da tributação na origem - a distribuição conforme o nível da produção" -, mas sim pelas dificuldades políticas em se atingir a unanimidade de aceitação de qualquer proposta que significasse importantes perdas financeiras a alguns dos Estados-membros, seja qual fosse o fundamento teórico invocado.

No que toca aos impostos especiais de consumos, as propostas da Comissão ainda são mais limitadoras da soberania fiscal dos Estados-membros, chegando a consistir não mais em harmonização, senão em uniformização das legislações.

No bojo de um pacote de propostas dirigidas à harmonização de tributos indiretos, vêm cinco propostas de diretivas ${ }^{254}$ destinadas aos impostos especiais de consumo.

A ideia nelas veiculada repousa em três providências principais:

. a incidência comunitária estaria restrita aos impostos sobre o consumo de óleos minerais, bebidas alcoólicas e álcool, cigarros e outros tabacos manufaturados;

. as alíquotas incidentes sobre os bens acima descritos seriam absolutamente idênticas em todos os Estados-membros, à exceção dos cigarros e de outros tabacos manufaturados, para os quais se toleraria uma variação na alíquota ad valorem de até $2 \%$, mantida a igualdade na parcela específica;

. no que se refere às outras incidências nacionais sobre consumos específicos, referentes a outros bens comercializados internacionalmente, Lord Cockfield impunha a obrigação de standstill até o momento da queda das fronteiras fiscais; vale dizer, seria proibida a instituição de novas incidências e o aumento de alíquotas das já existentes.

\footnotetext{
${ }^{254}$ Proposta de Directiva do Conselho que institui um processo de convergência das taxas do Imposto sobre o Valor Acrescentado e dos impostos sobre consumos específicos (COM (87) 324 final, in JOCE C 250, de 18 de setembro de 1987); Proposta de Directiva do Conselho relativa à aproximação dos impostos sobre cigarros (COM (87) 325 final, in JOCE C 251, de 19 de setembro de 1987); Proposta de Directiva do Conselho relativa à aproximação dos impostos sobre tabacos manufacturados diferentes dos cigarros (COM (87) 326 final, in JOCE C 251, de 19 de setembro de 1987); Proposta de Directiva do Conselho relativa à aproximação das taxas do imposto sobre o consumo específico dos óleos minerais (COM (87) 327 final, in JOCE C 262, de $1^{\circ}$ de outubro de 1987) e Proposta de Directiva do Conselho relativa à aproximação das taxas sobre o consumo específico de bebidas alcoólicas e de álcool contido noutros produtos (COM (87) 328 final, in JOCE C 250, de 18 de setembro de 1987).
} 
A intenção do plano era justamente evitar que nascessem accises que impusessem gravames aduaneiros ou que implicassem superposição com o IVA, pela via de uma nova incidência sobre o volume de negócios. Esse é mais um fundamento da necessidade da atuação negativa do Poder Judiciário Comunitário.

Ademais, embora tais impostos continuassem a ser cobrados no destino, o plano estipulava que fossem eliminados os controles fronteiriços por meio da interconexão (informatizada) dos entrepostos alfandegários dos Estados membros. Dispensa-se, portanto, o emprego de qualquer mecanismo de compensação financeira.

É fácil justificar a rigidez da posição da Comissão em matéria de impostos especiais de consumo, especialmente se analisada em confronto com a tolerância manifestada em relação ao IVA.

Por se tratar de impostos de tipo monofásico, sem recurso à técnica da nãocumulatividade, a abolição das fronteiras fiscais teria quanto a eles potencial de gerar mais profundas distorções econômicas, mesmo nas transações entre sujeitos passivos, especialmente em função das relevantes discrepâncias entre os regimes jurídicos internos pretéritos ou presentes concernentes aos impostos especiais de consumo. Daí se justifica a extinção ou congelamento de todos os outros impostos sobre bens que sejam objeto de comércio no interior da Comunidade.

A uniformidade quase absoluta das alíquotas advém de decisão da Comissão no sentido de que, como regra geral, toda a margem de flexibilidade na aproximação das alíquotas deveria ser reservada para as alíquotas do IVA. A opção foi necessária porque, sendo os impostos especiais de consumo componentes da base de cálculo do IVA, eventual flexibilidade nas alíquotas dos impostos especiais de consumo teria um efeito nas diferenças de preços finais muito maior do que ocorreria em situação análoga no IVA.

Diante da rigidez do regime proposto, o "Pacote Cockfield" foi prontamente rejeitado pelos Estados-membros. Xavier de Basto (1991, p. 290), comentando as circunstâncias nas quais se apresentou o plano à Comunidade, afirma que "muitas vezes o rigor tem de ceder ao pragmatismo", já que "as propostas Cockfield, pese o seu mérito técnico, mostraram não serem um modo pragmático de abordar a harmonização fiscal, se atentarmos nas resistências que suscitaram". Nenhuma das características fundamentais a serem efetivadas no "horizonte 93", comenta, - aproximação de alíquotas e sistema de compensação para o IVA; uniformização dos impostos especiais de consumo -, esteve ao menos "perto de ser aprovada". 
As resistências não se limitavam abstratamente à restrição das soberanias nacionais, no domínio fiscal, mas sim em críticas concretas às opções de política fiscal que a adoção das propostas acarretaria aos Estados comunitários.

A primeira crítica repousava na aproximação das alíquotas do IVA. Como exemplo das resistências, ilustre-se com o fato de que, para países de alíquota normal elevada, mais alta que a máxima permitida, como Dinamarca e Irlanda, havia o receio de uma acentuada perda de receita. De outro modo, nos em que a alíquota normal estivesse abaixo do limite mínimo proposto pela Comissão, como Luxemburgo e Espanha, temia-se a possibilidade de pressão inflacionária. Arlindo Correia (1999, p. 229) noticia que se chegou ao extremo, por parte de Estados-membros como o Reino Unido e Luxemburgo, de se propor a harmonização ditada pelo mercado - market oriented approach - com mera liberação das fronteiras físicas, para que as soberanias fiscais se ajustassem meramente pela força dos mecanismos concorrenciais.

Reação significativa também proveio, afirma Pitta e Cunha (1996, p. 46), de países como Portugal e Irlanda, que utilizavam exaustivamente o chamado, em Portugal, "regime de taxa zero" - a concessão de isenção com crédito ficto de imposto na operação posterior. Era prática muito empregada como forma de alcançar alguma progressividade no sistema tributário indireto, sendo aplicado ao consumo de bens reputados como essenciais. Tratava-se de possibilidade vedada pela proposta de Cockfield.

Não teve melhor acolhida a proposta de um sistema de compensação de receitas. Ela fez aflorar a desconfiança dos países importadores líquidos em um sistema que pressuporia um grau de cooperação entre as administrações fiscais até então inexistente, especialmente porque parcela relevante de suas receitas fiscais dependeria do sucesso e eficiência de um imbricado sistema, cujos controles não haviam sido testados. Mais uma circunstância derrogadora da soberania fiscal dos Estados - nações, no que possuem de mais precioso, a possibilidade de auferir receitas para traçar seus destinos políticos, estariam na hipótese na dependência da administração de um sistema cujo centro de decisões ficaria nas mãos da Comissão das Comunidades Europeias.

Quanto aos impostos especiais de consumo, por si só a fixação das alíquotas e dos produtos tributados é motivo de dificuldade de aprovação unânime. Agrava tal realidade o fato de que nem mesmo a definição dos produtos era igual em todos os países da Comunidade, especialmente no plano das bebidas alcoólicas e dos cigarros. Sem falar nas preferências regionais, a exigirem diferentes políticas locais de tributação. Basta verificar o patamar de tributação do vinho, por exemplo, nos países mediterrâneos em 
relação aos escandinavos. De forma radicalmente contrária, deve-se examinar a tributação da cerveja nos demais países em confronto com a da Alemanha. No domínio dos óleos minerais verificavam-se também diversidades, especialmente calcadas nas diferenças de importância do transporte automotor e da relevância política dos interesses da indústria automobilística nos diferentes Estados.

Ademais, Umberto Forte (1994, p.167) afirma ter-se entendido que a unificação das alíquotas entre os Estados-membros não fosse condição essencial a possibilitar a queda das fronteiras fiscais, já que os impostos especiais de consumo deveriam ser efetivamente pagos ao Estado de seu consumo, mediante o sistema de depósitos fiscais. Bastaria, portanto, que fosse estabelecido um adequado sistema de controle físico sobre a circulação intracomunitária dos produtos.

O impasse daí surgido só veio a ser suplantado com a posse, na "DirecçãoGeral da Fiscalidade e da União Aduaneira”, DG XXI da Comissão das Comunidades Europeias, em janeiro de 1989, da Comissária Christiane Scrivener, de nacionalidade francesa, trazendo uma filosofia pragmática de flexibilização do rigor técnico que imperou na gestão anterior.

Já em 17 de maio de 1989, a Comissão enviou Comunicação ao Conselho e ao Parlamento Europeu com o fim de fazer um balanço sobre o programa de abolição das fronteiras fiscais, a partir do qual o relançaria em novas bases, mais consensuais.

Ressalvando a tecnicalidade dos objetivos gerais subjacentes às propostas do "pacote Cockfield", a Comissão, em face dos "importantes desacordos" ocorridos na sua discussão, entendeu estabelecer novas orientações, que pudessem atingir o consenso entre os Estados-membros, preservando os princípios gerais de abolição das fronteiras fiscais já conhecidos.

Xavier de Basto (1991, p. 294) sintetiza tais novas orientações, no que se refere ao IVA:

- criação, o mais cedo possível e até ao fim de 1992, de "fase transitória de aproximação dos impostos indiretos" - durante um período transitório seriam feitas as adaptações necessárias para uma transição menos brusca, de forma a favorecer a entrada em vigor da reforma na data prevista, desde que "acompanhada de uma concretização do compromisso dos Estados-membros a favor da realização do mercado interno no domínio da fiscalidade indireta"; - menores exigências no processo de aproximação das alíquotas - fixação de apenas um limite mínimo de $15 \%$ para a alíquota normal, sem fixação de limite 
máximo, com possibilidade de instituição de alíquota reduzida e tolerância temporária com a manutenção de isenções ou alíquotas zero nos Estadosmembros;

- admissibilidade de tratamentos especiais de certas operações - possibilidade de serem dadas soluções específicas para distorções pontuais, como, por exemplo, nas vendas por correspondência ou de veículos de turismo ou para autarquias ou instituições exoneradas, como bancos e seguradoras, para as quais manter-se-ia o sistema de incidência no destino;

- nova concepção do sistema de compensação das receitas - os dados em que seriam baseados os reembolsos não mais seriam disponibilizados pelas administrações tributárias dos Estados-membros, mas sim oriundos de estatísticas macro-econômicas, produzidas pelos órgãos da própria Comunidade;

Quanto aos impostos especiais de consumo, a formulação inicial da Era Scrivener de plano anunciava a disponibilidade para soluções que rompessem a rigidez da uniformidade de alíquotas e de regimes jurídicos, desde que a flexibilidade tolerada não infringisse o objetivo de abolição das fronteiras fiscais. A ideia primordial consistia em que as alíquotas fixadas nas cinco propostas de 1987 passassem a ser valores de referência, a serem tomados como alíquotas mínimas ou valor médio de uma faixa de alíquotas possível, dependendo do produto tributado.

O que era simplesmente uma mudança na estratégia de integração veio a se concretizar como efetivamente uma inflexão nos rumos da harmonização da tributação indireta europeia com o Conselho ECO-FIN ${ }^{255}$ de 13 de novembro de 1989.

Decidiu-se então que, por um período transitório - posterior a 1993, data final de convergência proposto por Scrivener - o princípio da tributação no destino seria mantido, no que tange a todas as operações efetuadas entre sujeitos passivos de imposto. Reconheceu-se que, no estado de então de evolução do processo integracionista, não havia como adotar-se o princípio da origem. Assim, deixou também de existir necessidade para a introdução do mecanismo de compensação de receitas, reconhecidamente de pouca confiabilidade.

${ }^{255}$ Conselho ECO-FIN é o Conselho da União Europeia - conhecido simplesmente com o Conselho, distinto do Conselho Europeu - reunido na formação especializada destinada a solucionar questões econômicas e financeiras. 
A conciliação dessa solução com a determinação do Ato Único Europeu, de abolição das fronteiras fiscais, necessária para que se possa falar de mercado interno europeu, vem, segundo Xavier de Basto (1991, p. 303) de uma interpretação mais elástica - para Pitta e Cunha (1996, p. 47), eufemística - do que do que sejam fronteiras fiscais e sua abolição. Passou-se a entender a abolição das fronteiras fiscais como mera atenuação dos controles fronteiriços típicos das transações entre os diferentes Estados membros, que passaram a ser exigidos, indispensáveis que são à prevenção da sonegação e da fraude, periodicamente e a posteriori. Foi a forma encontrada, diz, de se conseguir "a aparência de um mundo sem fronteiras fiscais".

Quanto à aproximação de alíquotas, o Conselho autorizou o diferimento de uma solução definitiva para 31 de dezembro de 1991, especialmente no que toca ao nível e ao campo de aplicação da alíquota reduzida incidente sobre bens e serviços essenciais, tendo em conta objetivos de política social e cultural.

A partir dessa engenhosa saída, tornou-se possível encontrar consenso entre os Estados, especialmente na reunião do Conselho ECO-FIN de 3 de dezembro de 1990. A ideia fundamental a ser desenvolvida era, sem adotar o sistema de tributação na origem para o IVA, eliminar a principal vulnerabilidade do princípio do destino: a existência de dois circuitos de bens, uns circulando com imposto (os transacionados no interior do país); outros circulando sem imposto (os exportados).

A partir desses novos conceitos, não se podia manter como antes as definições de exportação e de importação no comércio intracomunitário. Passou-se a não considerar as importações provenientes de outros Estados membros - "a entrada de bens no território do país”, como previa a Sexta Diretiva - como fato gerador do IVA, que passou a ser a “aquisição intra-comunitária de bens realizada no país de destino". Esse novo fato gerador, ensina Umberto Forte (1994, p. 157 - 158), corresponderia à “obtenção do poder de dispor", como proprietário, de um bem material, expedido ou transportado ao destino do adquirente, pelo vendedor ou pelo próprio comprador, ou de terceiros por sua conta, em Estado-membro diverso daquele onde ocorreu o negócio.

Por outro lado, as exportações - agora "transmissões intra-comunitárias de bens realizadas no país de origem" - permaneciam tributadas à alíquota zero, sem, no entanto, serem controladas por documentos alfandegários, apenas por documentos fiscais comuns. A operação, para ser favorecida com a exoneração, deveria obedecer a dois requisitos básicos: os bens deveriam ser efetivamente objeto de transporte ou de expedição para fora do Estado-membro de origem; e a venda dos bens deveria ser efetuada a um sujeito passivo 
do IVA, registrado como tal em um Estado-membro diverso daquele de origem, expedição ou transporte do bem.

Do ponto de vista do adquirente das mercadorias, sendo sujeito passivo, não haveria prejuízo, pois remanesceria o direito ao crédito do imposto incidente na aquisição.

Porém, desapareceram os ajustamentos fiscais de fronteira, tanto nas importações quanto nas exportações. Haveria algo como uma suspensão do imposto nas importações, mas sem documentos aduaneiros e controles físicos das mercadorias importadas. Como conseqüência, tornou-se mais estratégica a eficiência na troca de informações entre as administrações tributárias dos diferentes países.

Não haveria, todavia, igualdade de tratamento entre as transações intracomunitárias, mesmo entre sujeitos passivos de IVA, e as transações internas, como previsto no "Plano Cockfield", já que a isenção na saída dependia de a mercadoria se destinar a contribuinte registrado em outro Estado-membro.

No que tange aos impostos especiais de consumo, o que foi feito em 1989 e 1990 foi simplesmente uma flexibilização do regime, possibilitando diferenciações de alíquotas entre os Estados-membros, desde que respeitado o patamar mínimo comunitário. Para os impostos sobre o consumo não-comunitários, convolou-se a necessidade de sua supressão em uma possibilidade de sua manutenção, desde que não impedissem a abolição das fronteiras fiscais, por meio da criação de distorções ou obstáculos à livre circulação de mercadorias no espaço intra-comunitário. Fora isso, mantiveram-se as bases da proposta da Comissária Scrivener, inclusive no que tange à previsão de que os produtos poderiam viajar com suspensão de impostos entre depositantes autorizados pelas Administrações Tributárias nacionais, incidindo o imposto no momento de saída do depósito para a entrada no consumo.

No Conselho ECOFIN de 3 de dezembro de 1990, a Comissão apresenta o novo pacote de propostas que deu origem àquele que é hoje o sistema comunitário dos impostos especiais de consumo, a ser proximamente estudado.

A única alteração de relevo em relação às orientações de 1989 foi a autorização, ao lado do regime geral de circulação de produtos entre depósitos fiscais autorizados, para que operadores não autorizados - não titulares de ditos armazéns de depósitos - pudessem receber, em determinadas condições, produtos com suspensão de impostos especiais de consumo.

Posteriormente, sob a presidência luxemburguesa, o Conselho ECO-FIN elaborou as orientações que serviriam, de forma definitiva, tendo em vista o avanço das 
negociações políticas, como cumpridores da função de prover os balizamentos da harmonização fiscal europeia em termos de impostos especiais de consumo, na sistematização de Umberto Forte (1994, p. 171):

- a partir de $1^{\text {o }}$ de janeiro de 1993, os óleos minerais, as bebidas alcóolicas e os tabacos beneficiados passariam a ser submetidos a um regime de controle e circulação comunitários relativo aos impostos especiais de consumo;

- tais produtos poderiam ser objeto de outros tributos indiretos com finalidades específicas, desde que as incidências nacionais respeitassem as regras de tributação aplicáveis ao IVA e aos impostos especiais de consumo, no que tange a base de cálculo, exigibilidade e controle dos impostos - na prática, a regra implica apenas a possibilidade de majoração das alíquotas comunitárias nas operações internas;

- os Estados-membros conservam a faculdade de introduzir ou manter impostos que incidam sobre produtos diversos dos sujeitos aos impostos especiais de consumo no regime comunitário de circulação e controle, mesmo nas transações intracomunitárias, desde que tais impostos não exijam formalidades na passagem de fronteira entre os Estados-membros;

- os Estados-membros conservam a faculdade de instituir impostos sobre as prestações de serviços, compreendidas também aquelas prestadas em conjunto com a alienação de produtos sujeitos a impostos especiais de consumo;

- não haveria possibilidade da instituição de regimes especiais; qualquer venda ou consignação de produtos sujeitos aos impostos especiais de consumo, mesmo vendas à distância ou a organismos de direito público, ocasionará pagamento de impostos especiais de consumo no Estado-membro onde os produtos forem consumidos.

Trata-se de um sistema que tem funcionado sem grandes ajustes desde então, com relevante sucesso, especialmente tendo em vista as dificuldades naturais de um processo de integração econômica, ilustrado por todas as difíceis negociações aqui relatadas por que passou a integração fiscal, e tomando como referência o impasse que se verifica na harmonização do IVA europeu. A única previsão de revisão do regime dos impostos especiais de consumo refere-se à determinação do Conselho para que se proceda a um reexame, inicialmente a cada dois anos, das alíquotas mínimas, em consideração especificamente "ao bom funcionamento do mercado interno". 
A propósito do IVA, as propostas de 1990 vieram a ser positivadas em 1991, após a aprovação definitiva pelo Conselho ECO-FIN de 16 de dezembro de 1991 e o advento da Diretiva $n^{\circ}$ 91/680/CEE, estabelecendo um regime transitório do IVA, de janeiro/93 a dezembro/96, mediante as mencionadas alterações na $6^{\text {a }}$ Diretiva (77/388). Posteriormente, advieram duas diretivas simplificadoras, 92/111/CEE, de 14 de dezembro de $1992^{256}$, e 95/7/CE, de 10 de abril de $1995^{257}$.

O regime determinado pela Diretiva $n^{\circ}$ 91/680/CEE, o chamado regime transitório para 1993, mas que foi posteriormente prorrogado até o fim de 1996, e permanece em vigor até hoje, é considerado o Terceiro Regime Comum do IVA (PITTA E CUNHA, 2003a, p. 122).

Suas normas contemplam basicamente as decisões do Conselho ECO-FIN de 1991, especialmente a manutenção do que Xavier de Basto (1996, p. 70) denomina "fronteiras fiscais virtuais", com o desaparecimento das fronteiras fiscais ostensivas. Vale dizer, a substituição, como já esclarecido, dos controles alfandegários por controles fiscais documentais e contabilísticos.

Nesse campo, dos ditos deveres instrumentais, vêem-se inovações importantes na Diretiva $n^{\circ}$ 91/680/CEE, como implementações concretas das decisões anteriores do Conselho, essas em plano mais estratégico.

Parte-se do princípio de que, adotada uma sistemática de fronteiras virtuais, o correto funcionamento do sistema não prescindiria de mecanismos de controle que oferecessem garantias semelhantes às dos sistemas de controle alfandegário, sem que isso onerasse por demais os contribuintes ou as Administrações Fiscais dos Estados-membros.

O sistema de controle apóia-se, portanto, em uma declaração específica das vendas de bens efetuadas em outros países da comunidade - como um listing de exportação, esclarece Umberto Forte (1994, p. 159) - cuja apresentação é obrigatória a cada três meses, com a identificação do contribuinte de destino, por meio de seu código IVA, e a discriminação detalhada do objeto da transação, com a respectiva classificação fiscal na Pauta Aduaneira Comum. Tais dados compõem bancos de dados de responsabilidade da Administração Tributária de cada Estado-membro que procedeu à entrega intracomunitária dos bens, disponíveis à pesquisa pelos demais.

\footnotetext{
${ }^{256}$ EUROPA. Jornal Oficial no. L 384 de 30/12/1992.
}

${ }^{257}$ EUROPA. Jornal Oficial no. L 102 de 05/05/1995. 
Faculta-se também aos Estados-membros a exigência de semelhante declaração às empresas importadoras, com o fim de possibilitar o exame cruzado das respectivas informações.

Se, por um lado, no que refere à materialidade da incidência do IVA, o regime dito transitório permanece em vigor até hoje, pelas dificuldades políticas e operacionais em se implementar o regime de tributação na origem, é no campo da administração do IVA que se têm visto os maiores avanços na sua disciplina desde então.

Inovações como o "Programa FISCALIS", pela Decisão 98/888/CEE ${ }^{258}$, e o VIES (VAT Information Exchange System - criado pelo Regulamento 92/218/CEE ${ }^{259}$ ) têm se verificado nesse campo, o que é inegável. Fora isso, são dignos de menção alguns esforços da Comissão referentes à aproximação de alíquotas, especialmente tendentes a simplificar o sistema, como a Diretiva 92/111/CEE, que fixou a alíquota normal mínima em $15 \%$ e uniformizou os bens e serviços essenciais que estariam submetidos à alíquota reduzida.

$\mathrm{Na}$ verdade, a própria Comissão reconhece os defeitos do sistema atual. Em documento de 10 de julho de 1996 - alguns meses, portanto, antes do fim previsto para o período transitório -, a Comissão publicou estudo denominado “A Common System of VAT. A Programme for the Single Market" (COM 328(96) final), no qual aponta as limitações do presente sistema, chegando a responsabilizá-lo pela falta de competitividade europeia, especialmente pelo ônus administrativo que impõe aos contribuintes e pela oportunidade que propicia à evasão fiscal (TERRA; WATTEL, 2008, p. 139 - 146).

Por outro lado, houve, na mesma época, um significativo avanço na tributação aduaneira, pelo que não se pode dizer que nada na então Comunidade Europeia estivesse dando certo àquela altura. Durante os anos de 1992 a 1993, a Comissão Europeia completou o que Ben Terra (TERRA; WATTEL, 2008, p. 217) classifica de o mais ambicioso projeto de consolidação legislativa jamais empreendido, em se tratando de matéria submetida ao direito comunitário, por meio da elaboração do Regulamento (CEE) $\mathrm{n}^{\mathrm{o}}$ 2913/92 ${ }^{260}$ do Conselho, de 12 de outubro de 1992, que estabelece o Código Aduaneiro Comunitário, e o respectivo regulamento (no sentido que se dá ao termo no direito

\footnotetext{
${ }^{258}$ EUROPA. Jornal Oficial no ${ }^{\circ}$ L 126 de 28/04/1998, p. 1 - 5. Trata-se de um programa de intercâmbio de autoridades (servidores) e informações fiscais e treinamento conjunto ou patrocinado pela Comissão, por meio do seu "Comité de Cooperação Administrativa no campo da Tributação Indirecta".

${ }^{259}$ EUROPA. Jornal Oficial $n^{\circ}$. L 24 de 01/02/1992, p. 1. Consiste em uma rede informática, ligando os computadores das diferentes Administrações Fiscais nacionais, com o fim de possibilitar um controle em linha da correta aplicação do IVA.

${ }^{260}$ EUROPA. Jornal Oficial nº. L 302 de 19/10/1992, p. 1 - 50.
} 
brasileiro), pelo Regulamento (CEE) $\mathrm{n}^{\circ} 2454 / 93^{261}$ da Comissão, de 2 de julho de 1993, que "fixa determinadas disposições de aplicação do Código Aduaneiro Comunitário". Assim, segundo o autor holandês, mais de cento e seis regulamentos e diretivas foram substituídas por uma só disciplina normativa consolidada em 1168 artigos e 113 anexos.

Fora o Código Aduaneiro Comunitário, remanescem isolados apenas o Regulamento (CEE) no 2658/87262 do Conselho de 23 de julho de 1987 relativo à "nomenclatura pautal e estatística e à pauta aduaneira comum", com suas inúmeras diversas alterações, sempre por regulamento; a última, em março de 2011, sendo o Regulamento (UE) n $n^{\mathrm{o}} 1238 / 2010^{263}$ do Parlamento Europeu e do Conselho, de 15 de dezembro de 2010 , que altera o anexo I do Regulamento (CEE) no 2658/87 do Conselho no que se refere "à isenção de direitos para determinados princípios ativos farmacêuticos com uma "denominação comum internacional” (DCI) da Organização Mundial de Saúde e para determinados produtos utilizados no fabrico de produtos farmacêuticos acabados", e o Regulamento (CE) no $1186 / 2009^{264}$ do Conselho, de 16 de novembro de 2009, relativo ao estabelecimento "do regime comunitário das franquias aduaneiras" (as isenções dos impostos de importação e de exportação, na expressão empregada no Brasil).

Em 30 de novembro de 2005, por meio da $\operatorname{COM(2005)} 608$ final, com o fim de “executar o programa comunitário de Lisboa”, a Comissão Europeia apresentou a Proposta de Regulamento (CE) do Parlamento Europeu e do Conselho, que estabelece o Código Aduaneiro Comunitário (Código Aduaneiro Modernizado), ainda em processo de discussão.

Em função de todas as dificuldades apontadas no campo da harmonização do IVA, especialmente o medo de os Estados-membros em perderem receita com eventuais novas alterações na sistemática tributária, malgrado seus reconhecidos inconvenientes, a própria Comissão propôs, em junho de 2000, por meio do documento COM 348 (2000), uma nova estratégia, baseada no melhoramento geral da operação do sistema IVA atual, reconhecendo a sistemática de tributação na origem apenas como um objetivo de longo prazo. Tais melhorias consistiriam apenas na simplificação, modernização e aprimoramento da harmonização no sistema atual (TERRA; WATTEL, 2008, p. 146 157).

\footnotetext{
${ }^{261}$ EUROPA. Jornal Oficial no ${ }^{\circ}$ L 253 de 11/10/1993, p. 1 - 766.

${ }^{262}$ EUROPA. Jornal Oficial $n^{\circ}$. L 256 de 07/09/1987, p. 1 - 675.

${ }^{263}$ EUROPA. Jornal Oficial no ${ }^{\circ}$ L 348 de 31/12/2010, p. $36-73$.

${ }^{264}$ EUROPA. Jornal Oficial $n^{\circ}$. L 324 de 10/12/2009, p. $23-57$.
} 
No início do século foram promulgadas pelo Conselho as duas últimas diretivas relevantes sobre o sistema IVA. Uma, 2000/65/CE, de 17 de outubro de 2000, alterando a disciplina da responsabilidade tributária pelo pagamento do imposto; outra, 2001/41/CE, de 19 de janeiro de 2001, estendendo o tempo de aplicação da alíquota mínima.

Como consequiência de toda essa realidade, prepondera na doutrina especializada um sentimento de decepção com os recentes rumos da harmonização fiscal indireta comunitária. Embora Pitta e Cunha (2003a, p. 123), por exemplo, reconheça que a harmonização fiscal é um processo delicado, uma vez que os países relutam em aceitar a perda de suas soberanias fiscais, não deixa de se assumir como frustrado com suas expectativas de avanço na coordenação fiscal comunitária (2003a, p. 129).

Essa decepção ganha contornos ainda mais dramáticos quando confrontada com os avanços no domínio da política monetária, o que consistiria, para Xavier de Basto (1996, p. 65), em autêntica "esquizofrenia" dos decisores comunitários. Manifestando seu desapontamento com a renúncia às propostas do "Plano Cockfield", que entende necessárias (1996, p. 76), remetendo à expressão proposta por Pitta e Cunha em texto que menciona (1996, p. 63), afirma que o progresso "por revoadas" que tem caracterizado a integração europeia seria conseqüência de uma sensibilidade maior que a matéria fiscal possuiria em termos de derrogação de soberanias, ideia também presente nas análises de Dominique Villemot (1995, p. 3) e de Arlindo Correia (1999, p. 221). Entende Xavier de Basto (1996, p. 64 - 65) que o que estaria acontecendo é que, tendo esbarrado a integração europeia no maior empecilho a uma verificação da vontade real por parte de seus Estadosmembros em se aglutinarem, a atenção das autoridades comunitárias voltou-se para outros aspectos em que não houvesse obstáculos tão intransponíveis. Teria acontecido, no dizer de Dominique Villemot, de a harmonização fiscal ter passado para um "segundo plano" nas preocupações da Comissão das Comunidades Europeias. Assim, o assunto harmonização fiscal indireta passou a ser matéria pouco discutida no contexto da construção europeia nos dias mais próximos.

Em verdade, o que se pode concluir é que, desde os passos mais incipientes do processo de integração, trava-se um embate, em se tratando da harmonização dos impostos indiretos europeus, entre a tecnicalidade e o pragmatismo. Ao que parece, a obediência às exigências técnicas alcançou o seu limite máximo de avanço no que tange ao IVA, o que explicaria a estagnação, na situação atual, das iniciativas da Comissão e a insatisfação da doutrina técnica europeia. 
Por outro lado, o sistema dos impostos especiais de consumo parece ter chegado a um ponto ideal de conciliação entre esses dois vetores. Alguma discussão, especialmente nas hostes científicas, ainda remanesce, mas sempre com o claro intento de alcançar o aprimoramento de uma realidade de harmonização fiscal já satisfatória. Como exemplo, pode ser citado estudo de Sijbren Cnossen e Michael Smart (2002, p. 1 - 20), em que se propõe sistemática diversa de apuração do elemento quantitativo do imposto especial de consumo comunitário europeu sobre os cigarros, em abandono à complexa metodologia atual, em que utiliza alíquota mista, comparando com incidências similares nos diversos estados dos Estados Unidos da América e em outros países da OCDE. Outra fonte de inquietação na situação atual dos impostos especiais de consumo comunitários europeus refere-se ao tributo sobre as bebidas alcoólicas, em que o grau de harmonização tem sido insignificante, especialmente em se tratando daqueles bens para os quais a alíquota mínima comunitária foi estabelecida em nível muito baixo. Stephen Smith (2002, p. 2 - 5) apresenta dados empíricos, referentes a 2001, comprovando que a discrepância de valores de crédito tributário específicos, notadamente entre os elevados tributos escandinavos e os irrisórios mediterrâneos, para bebidas como o vinho, acarreta problemas de eficiência econômica no mercado integrado.

Como comprovação dessa realidade de pacificação das discussões relativas aos impostos especiais de consumo comunitários europeus, pode-se verificar o teor de documentos emitidos pela Comissão das Comunidades Europeias, como aquele entitulado "Tax policy in the European Union - Priorities for the years ahead" - COM(2001) 260 final.

Tratando do Imposto sobre o Valor Agregado, é nítida a preocupação da Comissão em deixar claros os seus esforços no sentido de implementar efetivamente os objetivos de 1987 e os empecilhos que vêm enfrentando por parte dos Estados-membros, temerosos em arriscar suas receitas tributárias com o ousado sistema de tributação na origem, que, reconhece, permanece como um objetivo de longo prazo. Diante de uma realidade que, nas entrelinhas, lamenta estar acontecendo, deixando, não obstante, transparecer ser de natureza política e não técnica - portanto, fora do alcance da Comissão -, acaba por se conformar em ter que apresentar soluções paliativas de aprimoramento do sistema ora existente.

O tom do referido documento ao tratar das "Excise Duties" é totalmente diverso. Nada se coloca como problema nas incidências harmonizadas. Pelo contrário, os problemas detectados repousam justamente nas imposições instituídas pelos Estados- 
membros quando em valores muito superiores aos mínimos harmonizados, em montantes muito diferenciados entre os países, gerando obstáculos ao comércio transfronteiriço. A solução proposta pela Comissão tem sido a de simplesmente aumentar o tributo mínimo harmonizado, especialmente no que se refere aos cigarros e ao álcool.

A Comprovar essa realidade de pacificação na aceitação dessa modalidade tributária, a Comissão tem empreendido estudos bastante reiterados, a significar avanço no exame da matéria, acerca da extensão dos impostos especiais de consumo comunitários com finalidades extrafiscais, seguindo a tendência científica atual na evolução dessa modalidade de tributação indireta.

Tais esforços viraram realidade em 27 de outubro de 2003, quando foi promulgada, no âmbito da Comunidade Europeia, a Directiva 2003/96/EC, do Conselho da Comunidade Europeia, com o fim de reestruturar "o quadro comunitário de tributação dos produtos energéticos e da electricidade", ampliando em muito o escopo da Directiva 92/12/EEC, que regula a tributação pela via dos impostos especiais de consumo (a Diretiva-Geral), revogando, a partir de $1^{\circ}$ de janeiro de 2004, as diretivas quanto aos óleos minerais, a "Directiva 92/81/CEE do Conselho, de 19 de Outubro de 1992, relativa à harmonização das estruturas do imposto especial sobre o consumo de óleos minerais" ${ }^{265}$, a Diretiva-Estrutura, e a "Directiva 92/82/CEE do Conselho, de 19 de Outubro de 1992, relativa à aproximação das taxas do imposto especial sobre o consumo de óleos minerais"266, a Diretiva-Alíquota, estendendo-os às incidências sobre eletricidade, gás natural e carvão, com expresso intuito ambiental.

A Directiva 2003/96/EC possui como principais objetivos reduzir distorções competitivas então existentes entre Estados-Membros em função de diferenças de incidências e alíquotas sobre produtos de energia; reduzir distorções competitivas especialmente quanto aos produtos de energia ainda não submetidos à legislação fiscal comunitária até então; incrementar os incentivos ao uso mais eficiente da energia, com o fim de reduzir a dependência energética da Europa em relação aos países estrangeiros e cortar emissões de dióxido de carbono e, por fim, permitir aos Estados-Membros da Comunidade Europeia que ofereçam incentivos fiscais como recompensa por iniciativas que reduzam tais emissões ${ }^{267}$.

\footnotetext{
${ }^{265}$ EUROPA. Jornal Oficial $n^{\circ}$ L 316 de 31/10/1992, p. $12-15$.

${ }^{266}$ EUROPA. Jornal Oficial no L 316 de 31/10/1992, p. 19 - 20.

267 Pesquisa, em 15 de maio de 2009, ao sítio da Comissão Europeia, com endereço virtual como sendo: http://ec.europa.eu/taxation_customs/taxation/excise_duties/energy_products/legislation/index_en.htm\#.
} 
Trata-se de imposição nos mesmos moldes do "Green Tax" a que se refere a OCDE (2001b, p. 33), inspirado no "Stromsteuer" alemão (PETERS, BONGARTZ e SCHRÖER-SCHALLENBERG, 2000, p. 415 - 418), baseados no princípio do poluidorpagador, visando também a, pela uniformização da tributação mínima, reduzir as opções do consumidor entre fontes diversas de energia.

Também com finalidades extrafiscais, ligadas às emissões de gás carbônico, aliadas à necessidade de evitar problemas de bi-tributação nos Estados-membros, têm sido elaboradas, recentemente, estratégias preliminares para a criação de um imposto comunitário europeu sobre veículos automotores.

Nessa perspectiva, adveio a Proposta de Diretiva do Conselho, de 5 de julho de 2005, sobre os impostos aplicáveis aos automóveis de turismo, COM (2005) 261 final, não publicada no Diário Oficial, com o objetivo de melhorar o funcionamento do mercado interior e reduzir as emissões de $\mathrm{CO}_{2}$ dos automóveis de turismo.

Ao exigir a reestruturação dos sistemas impositivos dos países da União Europeia aplicáveis a tais veículos, o projeto de Diretiva pretende suprimir os obstáculos fiscais aos traslados de automóveis de turismo de um país europeu a outro, algo que, como se poderá ver da jurisprudência que se colaciona, tem sido fonte de muito trabalho para o Tribunal de Justiça.

O projeto de Diretiva propõe o desaparecimento gradual do imposto de matrícula dentro de um período transitório de cinco a dez anos; a implantação de um sistema de reembolso do imposto de matrícula aplicável aos automóveis de turismo, matriculados em um país europeu, que sejam exportados ou trasladados posteriormente, em caráter permanente, a outro país da UE; e a introdução na base de cálculo dos impostos anuais de circulação e nos impostos de matrícula de um componente baseado nas emissões de $\mathrm{CO}_{2}$.

\subsection{Da Não-discriminação Tributária no comércio de bens - Art. 90 $^{\circ 268}$ do Tratado que institui a Comunidade Europeia.}

\footnotetext{
${ }^{268}$ Malgrado a alteração recente da numeração do artigo, preferiu-se manter a numeração antiga, com vistas a compatibilizá-la com os textos dos acórdãos mencionados, todos anteriores ao Tratado de Lisboa - portanto, sempre empregando a numeração antiga.
} 


\subsubsection{Art. $90^{\circ}, 1^{\text {a }}$ frase (discriminação explícita).}

A disciplina relativa à não-discriminação tributária explícita, no âmbito comunitário, vem trazida pela primeira frase do art. $90^{\circ}$ do Tratado que institui a Comunidade Europeia (Tratado de Maastricht, na numeração conferida pelo Tratado de Amsterdam), que corresponde, atualmente, a partir de $1^{\circ}$ de dezembro de 2009 , com o advento do Tratado de Lisboa, ao art. $110^{\circ}$ do Tratado sobre o Funcionamento da União Europeia $^{269}$.

Mesmo à primeira vista, até pela organização da norma em duas frases justapostas, pode-se identificar a similitude entre a disciplina comunitária e a do GATT, antes estudada. Não é por outro motivo que, entre outros, Pieter Kuyper, da Universidade de Leiden, especula (1996, p. 130) que os pais da então Comunidade Econômica Europeia, uma vez que o texto hoje vigente é o mesmo desde o Tratado de Roma, em 25 de março de 1957, devem ter se inspirado na redação do Art. II:2 do GATT quando da elaboração do seu então art. 95.

Merece observação o fato de que o texto comunitário contempla o termo "similares", ao se referir aos produtos cuja carga tributária se quer comparar, o que, como indaga Federico Ortino (2004, p. 135), parece ser mais amplo do que o termo em inglês presente no texto do GATT - como visto com profundidade anteriormente, o termo em inglês "like". Na verdade, e a jurisprudência do atual Tribunal de Justiça da União Europeia corrobora tal entendimento, como se verá, provavelmente o fato motivador dessa discrepância seja porque, entre os países constitutivos da Europa dos Seis não havia nenhum cuja língua-mãe fosse o inglês, motivo pelo qual o texto no qual os fundadores devem ter se embasado deveria ser a versão francesa do GATT, que também emprega o termo "similaires" 270 , em francês.

\footnotetext{
269 "CAPÍTULO 2

DISPOSIÇÕES FISCAIS

Artigo $110^{\circ}$

(ex-artigo $\left.90 .^{\circ} \mathrm{TCE}\right)$

Nenhum Estado-Membro fará incidir, directa ou indirectamente, sobre os produtos dos outros EstadosMembros imposições internas, qualquer que seja a sua natureza, superiores às que incidam, directa ou indirectamente, sobre produtos nacionais similares" (...).

270 "PARTIE II

Article III

Traitement national en matière d'impositions et de réglementation intérieures

1. Les parties contractantes reconnaissent que les taxes et autres impositions intérieures, ainsi que les lois, règlements et prescriptions affectant la vente, la mise en vente, l'achat, le transport, la distribution ou l'utilisation de produits sur le marché intérieur et les réglementations quantitatives intérieures prescrivant le
} 
Fora esse pormenor, as redações são praticamente idênticas. Assim, embora algo diferenciado, o entendimento jurisprudencial construído em âmbito comunitário em muito se assemelha àquele estabelecido em sede multilateral.

Foi larga a atuação jurisprudencial, especialmente nos anos oitenta, com vistas a dar efetividade a essa disposição comunitária, tanto da primeira quanto da segunda frase, aclarando o significado de conceitos jurídicos indeterminados como imposição interna, imposição discriminatória, produtos similares, produtos concorrentes e efeito protetivo, com vistas a, em última análise, realizar concretamente a harmonização tributária europeia, em sentido amplo.

Nos primeiros anos, como vimos anteriormente, por falta de efetivação da harmonização positiva comunitária em impostos especiais de consumo, à exceção da tributação dos tabacos manufaturados, pode-se entender a jurisprudência comunitária sobre os impostos especiais de consumo como sendo a única fonte de intervenção comunitária sobre a soberania dos Estados-membros.

Ao largo disso, quanto ao imposto sobre o volume de negócios, não havia muita controvérsia jurisprudencial em relação às normas dos tratados constitutivos, porque, como afirma Sérgio Vasques (2001, p. 152), o advento da harmonização positiva teria roubado o objeto da harmonização negativa.

Isso também pode ser compreendido, hoje em dia, como verdadeiro em relação às grandes incidências seletivas comunitárias, após a harmonização. Porém, em relação a outros produtos não gravados comunitariamente, e mesmo nas atuais incidências seletivas comunitárias, porém em fases anteriores aos respectivos processos de harmonização, a importância da integração e do controle legislativos empreendidos pela jurisprudência comunitária sempre se mostrou e ainda tem se mostrado de grande magnitude.

$\mathrm{O}$ caso pioneiro, ainda preliminar, relacionado ao antigo artigo $95^{\circ}$, foi o processo 57/65 271 , pedido de decisão a título prejudicial, de Alfons Lütticke GmbH, KölnDeutz, contra Hauptzollamt von (Gabinete Principal das Alfândegas do) Saarland. Tratava da exigência, em uma importação para a então Alemanha Federal, de leite inteiro em pó

mélange, la transformation ou l'utilisation en quantités ou en proportions déterminées de certains produits ne devront pas être appliqués aux produits importés ou nationaux de manière à protéger la production nationale.

2. Les produits du territoire de toute partie contractante importés sur le territoire de toute autre partie contractante ne seront pas frappés, directement ou indirectement, de taxes ou autres impositions intérieures, de quelque nature qu'elles soient, supérieures à celles qui frappent, directement ou indirectement, les produits nationaux similaires. En outre, aucune partie contractante n'appliquera, d'autre façon, de taxes ou autres impositions intérieures aux produits importés ou nationaux d'une manière contraire aux principes énoncés au paragraphe premier".

${ }^{271}$ ECR 1966, 363. 
proveniente do Grão-Ducado de Luxemburgo, ao importador, autor da ação, do pagamento, para além dos direitos aduaneiros, de imposto compensatório sobre o volume de negócios (Umsatzausgleichsteuer). A partir de 1 de fevereiro de 1956, por força do $§ 4$, $\mathrm{n}^{\circ}$ 20, Buchstabe f, da lei alemã relativa ao imposto sobre o volume de negócios (Umsatzsteuergesetz), o leite inteiro em pó de produção interna estava isento desse imposto.

De tão evidente a discriminação explícita, e dada a ainda pequena evolução jurisprudencial acerca da matéria, o acórdão pouco toca nos requisitos para a verificação do caráter discriminatório de norma tributária, sendo hoje muito mais importante como precedente no que se refere a questões preliminares, posteriormente completamente superadas, como se o primeiro parágrafo do artigo $95^{\circ}$ do TCEE teria efeito direto, atribuindo, portanto, aos particulares direitos individuais que os órgãos jurisdicionais nacionais devam salvaguardar, e quanto a se os então artigos $12^{\circ}$ e $13^{\circ}$, por um lado, e o artigo $95^{\circ}$, por outro, podem ou não ser aplicados conjuntamente a uma única e mesma situação - vale dizer, se os encargos de efeito equivalente a direitos aduaneiros, por um lado, e as imposições internas, por outro, estão sujeitos a regimes diferentes, e se um imposto destinado a compensar o efeito de uma imposição interna, como o Umsatzausgleichsteuer, compartilha, por esse fato, da natureza interna da imposição cujo efeito se destina a compensar, o Umsatzsteuer.

Outro caso preliminar que merece referência é o processo $45 / 75$, Rewe-Zentrale des Lebensmittel-Großhandels GmbH, Köln contra Hauptzollamt Landau-Pfalz ${ }^{272}$. Trata-se de litígio que opõe um importador de vermute italiano a uma administração aduaneira regional da então República Federal da Alemanha, pondo em causa a compatibilidade com o então art. $95^{\circ}$ de um imposto sobre o consumo aplicado, na República Federal da Alemanha, ao álcool importado e denominado Monopolausgleich.

De acordo com a lei federal relativa ao monopólio do álcool (Gesetz über das Branntweinmonopol), o álcool etílico de origem agrícola ou não agrícola devia ser entregue à administração do monopólio a um preço fixado pela autoridade e, após tratamento, por ela vendido a preços diferentes, consoante a utilização para a qual é revendido, mas também segundo determinação pelos poderes públicos.

Nos termos do $\mathrm{n}^{\circ} 76$ da referida lei, alguns álcoois de produção local, designadamente o álcool de cereais e os álcoois provenientes de certos frutos, encontram-

${ }^{272}$ ECR 1976, 92. 
se isentos da entrega ao monopólio. O álcool isento da obrigação de entrega no monopólio é objeto de um encargo denominado Branntweinaufschlag, igual à diferença entre o preço de base do álcool de monopólio e o seu preço de venda normal, que, por este fato, compreendia, para além do imposto sobre o álcool (Branntweinsteuer), de um montante igual ao que era aplicado ao álcool do monopólio, uma contribuição para as despesas do monopólio.

Ao álcool e às bebidas espirituosas importados — estas últimas de acordo com o seu teor em álcool - era aplicado um encargo designado Monopolausgleich, que compreendia, além do imposto que atinge o álcool de monopólio (Branntweinsteuer), um encargo suplementar, que é suposto corresponder ao montante que, no preço de venda do álcool do monopólio, se destina a cobrir as despesas do monopólio. A cobrança deste encargo suplementar, chamado Monopolausgleichspitze, não estava afetada ao financiamento do monopólio, mas sim, tal como o Monopolausgleich de que é um componente, ao orçamento geral do Estado. Destinava-se, de acordo com as afirmações do Governo da República Federal da Alemanha, a restabelecer a igualdade das condições de concorrência, entre as aguardentes e as bebidas espirituosas importadas e as aguardentes e as bebidas espirituosas nacionais, fabricadas a partir de álcool isento da obrigação de entrega.

Examinado o caso, o TJCE declarou, primeiramente, que o primeiro parágrafo do artigo $95^{\circ}$ deve ser interpretado no sentido de que ele proíbe a imposição do produto importado, de acordo com um modo de cálculo ou modalidades diferentes, como um montante uniforme num caso e progressivo no outro, dos utilizados para o encargo que atinge o produto nacional similar e que conduz a montantes superiores para o produto importado, ainda que esta disparidade se verifique apenas numa minoria de casos.

O TJCE também entendeu que o primeiro parágrafo do artigo $95^{\circ}$ não proíbe aplicar um mesmo imposto a um produto importado e a um produto nacional similar, mesmo que uma parte do encargo que onera o produto nacional seja afetada ao financiamento de um monopólio de Estado, enquanto que a parte do encargo que onera o produto importado reverta para o orçamento geral do Estado.

Os primeiros casos levados a julgamento do Tribunal de Justiça das Comunidades realmente relevantes na consolidação da jurisprudência, hoje solidificada, referente ao antigo artigo $95^{\circ}$, foram apreciados em 1978, contra a França, Itália, a Dinamarca e o Reino Unido. Referiam-se todos à tributação, anterior à harmonização 
positiva de fins do ano de 1992, do consumo das bebidas alcoólicas e os termos em que a Comissão a entendia discriminatória ao bem estrangeiro e protetora do produto nacional.

São exemplos emblemáticos da importância da jurisprudência no entendimento do alcance do antigo art. $95^{\circ}$ no que se refere à harmonização dos impostos especiais de consumo. E trata-se de circunstância ainda mais evidente se for considerado que o domínio das bebidas alcoólicas é refúgio tradicional do nacionalismo europeu, o que se estende, por óbvio, ao campo tributário dos Estados-Membros.

No processo 168/78, Comissão das Comunidades Europeias v. República Francesa, acórdão de 27 de fevereiro de $1980^{273}$, questionava-se a tributação de aguardentes de cereal, predominantemente importadas, do tipo uísque, com impostos de consumo no montante de 6.380 francos por hectolitro de álcool. O mesmo imposto incidia, para as aguardentes do vinho e de frutas, majoritariamente de fabricação francesa, com denominação de origem, como cognac, armagnac ou calvados, à alíquota de 4.270 francos, e, para as aguardentes de cereal, produzidas no norte da França, do tipo genièvre, ou fabricadas nos departamentos ultramarinos franceses, do tipo rum, de 4.980 francos, sempre pela mesma unidade de medida.

No processo contra a Itália, 169/78, Comissão v. República Italiana, acórdão de 27 de fevereiro de $1980^{274}$, a lide versava a tributação das aguardentes do vinho com um imposto de 105 liras por cada dois litros, quando o mesmo imposto sobre as aguardentes de cana e cereais era de 640 liras, ao mesmo volume.

Contra a Dinamarca, processo 171/78, Comissão v. Reino da Dinamarca, acórdão de 27 de fevereiro de $1980^{275}$, perquiria-se a legalidade da tributação da akvavit ou snaps ou aquavit, aguardente de produção local, com uma carga tributária mais amena que a aplicável às demais aguardentes, de produção essencialmente estrangeira.

O caso Comissão v. Reino Unido da Grã-Bretanha e Irlanda do Norte, 170/78 276 , é algo mais complexo. A Comissão das Comunidades Europeias acusava de protecionista a tributação do vinho com um imposto de consumo no valor de 2,955 libras, e da cerveja a 0,557 libras, por galão. Trata-se, portanto, de um caso de discriminação implícita, o que será visto posteriormente.

\footnotetext{
${ }^{273}$ ECR, 1980, 347.

${ }^{274}$ ECR, 1980, 385.

275 ECR, 1980, 447.

${ }^{276}$ ECR, 1983, 2265.
} 
No julgamento desses casos, os respectivos acórdãos, todos lavrados de forma assemelhada, trouxeram os delineamentos básicos acerca do entendimento do então art. $95^{\circ}$.

Para o Tribunal, conforme esclareceu nas próprias ementas dos casos, o art. 95 constituía um complemento das disposições relativas à supressão dos direitos alfandegários e dos encargos de efeito equivalente, do então art. $12^{\circ}$, com o fim de assegurar a livre circulação de mercadorias entre os Estados membros em condições normais de concorrência, pela eliminação de qualquer forma de proteção eventualmente resultante da imposição de gravames interiores discriminatórios aos produtos originários de outros Estados membros ${ }^{277}$. Referindo-se à posição da Comissão a respeito, o Tribunal afirmava que o então art. $95^{\circ}$ deveria garantir a perfeita neutralidade das imposições interiores, tendo em vista a concorrência entre produtos nacionais e importados ${ }^{278}$.

Tal caráter subsidiário do art. $95^{\circ}$ em relação à eficácia das liberdades econômicas trazidas pela norma supressiva das fronteiras fiscais, como providência normativa que evitasse que a determinação do então art. $12^{\circ}$ fosse burlada ${ }^{279}$, também veio

277 “ 1 . DANS LE SYSTEME DU TRAITE CEE, LES DISPOSITIONS DE L ' ARTICLE 95, ALINEAS 1 ET 2 CONSTITUENT UN COMPLEMENT DES DISPOSITIONS RELATIVES A LA SUPPRESSION DES DROITS DE DOUANE ET DES TAXES D ' EFFET EQUIVALENT . ELLES ONT POUR BUT D ' ASSURER LA LIBRE CIRCULATION DES MARCHANDISES ENTRE LES ETATS MEMBRES , DANS DES CONDITIONS NORMALES DE CONCURRENCE, PAR L ' ELIMINATION DE TOUTE FORME DE PROTECTION POUVANT RESULTER DE L ' APPLICATION D ' IMPOSITIONS INTERIEURES DISCRIMINATOIRES A L ' EGARD DES PRODUITS ORIGINAIRES D ' AUTRES ETATS MEMBRES . L ' ARTICLE 95 DOIT GARANTIR LA PARFAITE NEUTRALITE DES IMPOSITIONS INTERIEURES AU REGARD DE LA CONCURRENCE ENTRE PRODUITS NATIONAUX ET PRODUITS IMPORTES" ECR, 1980, 347 - Aff. 168/78.

278 "Sur l'interprétation de l'article 95

Aux termes de l'article 95, alinéa 1, «aucun État membre ne frappe directement ou indirectement les produits des autres États membres d'impositions intérieures, de quelque nature qu'elles soient, supérieures à celles qui frappent directement ou indirectement les produits nationaux similaires.»Il est ajouté, à l'alinéa 2, qu'«en outre, aucun État membre ne frappe les produits des autres États membres d'impositions intérieures de nature à protéger indirectement d'autres productions».

Dans le système du traité, les dispositions citées constituent un complément des dispositions relatives à la suppression des droits de douane et des taxes d'effet équivalent. Elles ont pour but d'assurer la libre circulation des marchandises entre les États membres dans des conditions normales de concurrence, par l'élimination de toute forme de protection pouvant résulter de l'application d'impositions intérieures discriminatoires à l'égard de produits originaires d'autres États membres. Ainsi que la Commission l'a exposé avec raison, l'article 95 doit garantir la parfaite neutralité des impositions intérieures au regard de la concurrence entre produits nationaux et produits importés" ECR, 1980, 399 - Aff. 168/78.

279 "Par contre, l'article 95, alinéa 1, exige que les avantages fiscaux en cause soient étendus sans discrimination aux produits en provenance des autres États membres qui répondent aux mêmes conditions que les produits nationaux bénéficiant des exonérations ou réductions consenties par la legislation nationale. L'article 95, alinéa 1-qui a pour objet d'éviter que par l'instauration d'impositions intérieures frappant de façon discriminatoire les produits importés par rapport aux produits nationaux, les prescriptions du traité relatives à l'abolition des droits de douane et des taxes d'effet équivalent ne puissant être tournées ou neutralisées - met en oeuvre un principe fundamental du marché commun. Il en résulte que les inégalités qu'il interdit doivent être éliminées malgré les problèmes délicats de comparaison qui peuvent se poser en ce 
externada pelo Tribunal no julgamento do caso Comissão v. Itália - Produtos Petrolíferos Regenerados, 21/79 280 . Em verdade, tal sistemática, de emprego do então art. 95 como meio para que não se mine, na expressão de Paul Craig e Gráinne de Búrca (2003, p. 593), o escopo da união aduaneira, é reconhecida desde os primórdios do Tribunal de Justiça, como, por exemplo, nos casos 2/62 e 3/62, Comissão v. Bélgica e Luxemburgo ${ }^{281}$.

Quanto à interpretação do artigo, afirmam os acórdãos de 1980, referentes aos casos de 1978, que deveria ser feita a diferenciação entre as frases. No que se refere à primeira, estaríamos no campo da discriminação aberta e dois seriam os nortes hermenêuticos a serem perseguidos em relação aos conceitos jurídicos indeterminados presentes no texto legal.

Primeiramente, em relação ao conceito de imposições internas "superiores", deveria se empreender a comparação entre as cargas fiscais incidentes sobre cada um dos produtos sendo comparados. Dentro do conceito de carga tributária, não é apenas relevante o valor da alíquota, como também a forma com que se processa a exigência e se aplica a norma tributária. Mais geral ainda é o critério a ser empregado no caso da segunda frase (como veremos, o conceito jurídico indeterminado de "efeito protetivo") ${ }^{282}$.

Já vimos, a respeito de como se consideram as "imposições internas, qualquer que seja a sua natureza, superiores às que incidam, directa ou indirectamente, sobre produtos nacionais similares", no julgamento do processo C-17/91, Georges Lornoy en Zonen $N V$ e outros contra o Reino da Bélgica, que a destinação da receita também é relevante - no caso de uma contribuição parafiscal, a afetação da receita a um fundo que se destina a financiar atividades que beneficiem especialmente os produtos nacionais tributados, situação que pode resultar que a contribuição cobrada de acordo com critérios idênticos constitua, apesar disso, uma imposição discriminatória, na medida em que o encargo fiscal sobre os produtos nacionais seja neutralizado pelos benefícios para cujo financiamento serve, enquanto que o que incide sobre os produtos importados representa um encargo sem compensação.

qui concerne l'assimilation entre le produit importé et les divers produits nationaux - différemment imposés - avec lesquels il peut se trouver dans un rapport de similarité" ECR, 1980, 12 - 13 - Aff. 21/79.

${ }^{280} \mathrm{ECR}, 1980,2$.

${ }^{281}$ ECR 1962, 425.

282 "Alors que le critère d'appréciation indiqué par l'alinéa 1 consiste dans la comparaison des charges fiscales, que ce soit en fonction du taux, des modalités d'assiette ou d'autres modalités d'application, l'alinéa 2, compte tenu de la difficulté d'établir des comparaisons suffisamment précises entre les produits en cause, s'attache à un critère plus global, à savoir le caractère protecteur d'un système d'impositions intérieures" ECR, 1980, 360 - Aff. 168/78. 
Um exemplo típico do caráter amplo do conceito de carga tributária nos foi apresentado no processo 55/79, Comissão v. República da Irlanda ${ }^{283}$. No caso em concreto, um imposto seletivo sobre bebidas alcoólicas era exigido, das bebidas estrangeiras, na data da importação ou quando de sua entrega vinda da repartição aduaneira, ao passo que, no caso das bebidas nacionais, havia um diferimento do pagamento do imposto para entre quatro a seis semanas após, dependendo do produto tributado.

O julgamento trouxe a formulação de que o critério decisivo para a comparação para aplicação do art. $95^{\circ}$ é o efeito concreto de cada tributo na produção nacional em relação ao incidente sobre as vendas de produtos importados, mesmo que as alíquotas sejam idênticas, uma vez que outros pormenores quanto à constituição e à exigência do crédito tributário podem ser relevantes ${ }^{284}$. Nesse julgamento, no mesmo ponto, também fícou estabelecido que o critério do "de minimis" não é aplicável à primeira frase do então art. $95^{\circ}$, atual art. $110^{\circ}$ - vale dizer, mesmo que o impacto financeiro desse diferimento não seja relevante, ainda assim a situação se caracteriza como discriminatória ao produto importado.

Interessante observar que, no acórdão relativo ao processo 55/79, Comissão v. República da Irlanda, o Tribunal de Justiça tocou em ponto importante já referido. Como se tratava de indagação quanto ao caráter discriminatório de imposto indireto analítico, seletivo, sobre bebidas alcoólicas, que, como vimos, ainda estava sendo submetido a um processo de elaboração de normatização comunitária harmonizada, houve a preocupação de se deixar bem claro que a disciplina do então art. $95^{\circ}$ possui eficácia de forma

\footnotetext{
${ }^{283}$ ECR 1980, 481.

284 "These defences put forward by the Government of Ireland cannot be accepted. In fact, as the Court of Justice has stated in an established line of cases (see judgments of 5 May 1970, Commission of the European Communities v Kingdom of Belgium, Case 77/69 [1970] ECR 237, 20 February 1973 Fonderie Officine Riunite FOR v Vereinigte Kammgarn-Spinnereien VKS, Case 54/72 [1973] ECR 193, 17 January 1976, REWE - Zentrale des Lebensmittel-Großhandels GmbH v Hauptzollamt Landau-Pfalz, Case 45/75 [1976]ECR 181, 22 June 1976 Bobie Getränkevertrieb GmbH v Hauptzollamt Aachen-Nord, Case 127/75 [1976] ECR 1079, 16 February 1977 Schöttle \& Söhne GmbH w Finanzamt Freudenstadt, Case 20/76 [1977] ECR 247, 22 March 1977, Ianelli \& Volpi S.pA. v Ditta Paolo Meroni, Case 74/76 [1977] ECR 557 and 22 March 1977, Firma Steinike \& Weinling v Federal Republic of Germany, Case 78/76 [1977] ECR 595), it is necessary, for the purposes of the application of the prohibition on discrimination laid down in Article 95, to take into consideration the provisions relating ot the basis of assessment and the detailed rules for levying the various duties in addition to the rate of tax. In fact the decisive criterion of comparison for the purposes of the application of Article 95 is the actual effect of each tax on national production on the one hand and on imported products on the other, since even where the rate of tax is equal the effect of that tax may vary according to the detailed rules for the basis of assessment and levying thereof applied to national production and imported products respectively.

Such is the case with the difference in treatment applied to the alcoholic beverages referred to in the application according to whether those beverages are produced in Ireland or imported from other Member States. Although the benefit reserved to national production in the form of facilities for deferred payment is small, the discrimination against products imported from other Member States is none the less obvious" ECR $1980,490-491$.
} 
independente dos esforços harmonizatórios dos então artigos $99^{\circ}$ e $100^{\circ}$ - normas do Tratado de Roma (Tratado que instituiu a Comunidade Econômica Europeia, de 1957) que, respectivamente, determinavam à Comissão as missões de estudar a possibilidade de harmonizar os impostos indiretos sobre o volume de negócios e demais impostos analíticos, e estabeleciam o seu instrumento de implementação, as diretivas ${ }^{285}$. Embora, disse o Tribunal, o processo de harmonização seja fundamental para a consecução do objetivo de prover a liberdade básica de circulação de mercadorias, enquanto essa realidade não se concretizava, não se poderia impô-la como condição de aplicabilidade às demais disposições do Tratado - os Estados membros não poderiam, de toda maneira, impor exações discriminatórias desde então ${ }^{286}$.

Outro elemento constitutivo da obrigação tributária principal inserido no conceito de carga fiscal é a base de cálculo. Exemplo significativo dessa realidade é o processo C-375/95 287 , Comissão das Comunidades Europeias contra República Helênica, sobre, em primeira acusação, medidas que, em matéria de tributação de veículos usados, para determinação da base de tributação para efeitos do imposto especial sobre o consumo, apenas permitiam deduzir ao preço de venda dos veículos novos correspondentes uma percentagem de $5 \%$ por cada ano de utilização, percentagem que não pode exceder $20 \%$ do valor dos veículos novos correspondentes; em segundo lugar, regulamentavam a cobrança

\footnotetext{
285 “Chapitre 2 : Dispositions fiscales.

Article 95.

(...)

Article 99.

La Commission examine de quelle façon les législations des différents États membres relatives aux taxes sur le chiffre d'affaires, aux droits d'accise et autres impôts indirects, y compris les mesures de compensation applicables aux échanges entre les États membres, peuvent être harmonisées dans l'intérêt du marché commun.

La Commission soumet des propositions au Conseil qui statue à l'unanimité, sans préjudice des dispositions des articles 100 et 101.

Chapitre 3 : Le rapprochement des legislations.

Article 100.

Le Conseil, statuant à l'unanimité sur proposition de la Commission, arrête des directives pour le rapprochement des dispositions législatives. réglementaires et administratives des États membres qui ont une incidence directe sur l'établissement ou le fonctionnement du marché commun.

L'Assemblée et le Comité économique et social sont consultés sur les directives dont l'exécution comporterait, dans un ou plusieurs États membres, une modification de dispositions legislatives".

286 "Finally, it is necessary to reject the argument that discrimination such as that which forms the subjectmatter of the application must be eliminated by the procedure for the harmonization of tax legislation under Articles 99 and 100 of the Treaty, rather than by means of Article 95. There is no doubt that obstacles to the free movement of goods may be eliminated by applying the procedure for the harmonization of tax legislation, but the implementation of the provisions of the Treaty relating thereto and in particular of Article 99 cannot be posed as a condition for the application of Article 95, which imposes on Member States with immediate effect the duty to apply their tax legislation without discrimination even before there is any harmonization" ECR 1980, 492.

${ }^{287}$ ECR 1997, I - 5990.
} 
da imposição especial adicional única sem preverem nenhuma redução para os veículos usados; e, em terceiro lugar, previam benefícios fiscais (redução do imposto especial sobre o consumo) apenas a favor dos veículos novos com tecnologia antipoluição e não para os veículos usados importados com tecnologia antipoluição; pelo que o estado grego não haveria cumprido as obrigações que lhe incumbem por força do então artigo $95^{\circ}$ do já então vigente Tratado CE (o Tratado de Maastricht, antes da renumeração empreendida pelo Tratado de Amsterdam - que, como já visto, transformou a norma no art. $90^{\circ}$ ).

Neste momento, apenas nos interessa a primeira questão colocada ao Tribunal.

A Lei helênica $n^{\circ} 363 / 1976$, alterada pela Lei $n^{\circ} 1.676 / 1986$, instituiu, para os veículos ligeiros de passageiros importados ou montados na Grécia, um imposto especial sobre o consumo e uma imposição especial adicional única. O imposto especial sobre o consumo era pago no momento da primeira compra ou da importação do veículo. A alíquota variava em função da cilindrada do motor. O montante do tributo era, portanto, igual a uma determinada percentagem do preço de venda sem impostos do veículo. Relativamente aos automóveis usados importados, a base de cálculo era determinada deduzindo $5 \%$ ao preço dos veículos novos correspondentes por cada ano de antiguidade dos veículos considerados, sendo a diminuição máxima possível, em princípio, de $20 \%$ (25\% se o veículo estivesse danificado ou apresentasse uma depreciação superior à devida em uma utilização normal).

O Tribunal iniciou sua análise salientando que o imposto especial sobre o consumo não se aplica às transações internas que tenham por objeto veículos usados porque este imposto é cobrado apenas uma vez, quando da primeira compra do veículo em território nacional grego, e uma parte desse imposto mantém-se incorporada no valor dos veículos em causa (v., em relação a um imposto semelhante, o acórdão de 9 de Março de 1995, Nunes Tadeu, C-345/93, Colect., p. I - 479, $\left.\mathrm{n}^{\circ} 10\right)$.

Preliminarmente, recordou que os veículos usados importados e os que são comprados no país constituem produtos similares ou concorrentes e que o disposto no artigo $95^{\circ}$ do Tratado CE é aplicável, por conseguinte, ao imposto especial sobre o consumo, quando este é cobrado no momento da importação dos veículos usados (v., neste sentido, o acórdão de 11 de Dezembro de 1990, Comissão/Dinamarca, C-47/88, Colect., p. $\left.\mathrm{I}-4509, \mathrm{n}^{\circ} 17\right)$.

Assim, entendeu o Tribunal que, para verificar o respeito ao artigo $95^{\circ}$ do Tratado CE, há que se comparar o montante do imposto especial sobre o consumo incidente sobre os veículos usados importados e a parte residual do imposto que permanece 
incorporada nos veículos que foram lançados em circulação na Grécia no estado de novos antes de aí serem revendidos.

Nesse ponto, o acórdão recordou que, ao aplicar o artigo $95^{\circ}$ do Tratado CE, há que tomar em consideração não apenas a alíquota da imposição interna que incide direta ou indiretamente sobre os produtos nacionais e importados, mas também a base de cálculo e as modalidades do imposto em causa (acórdão de 11 de Dezembro de 1990, Comissão/Dinamarca, já referido, n 18; v. igualmente o acórdão de 12 de Maio de 1992, Comissão/Grécia, C-327/90, Colect., p. I - 3033, n 11).

Por outro lado, lembrou que foi decidido, em diversas ocasiões, que haveria violação do artigo $95^{\circ}$, primeiro parágrafo, sempre que a imposição que incide sobre o produto importado e a que incide sobre o produto nacional similar sejam calculadas de forma diferente e segundo modalidades diferentes, que conduzam, ainda que apenas em certos casos, a uma imposição superior do produto importado (v., designadamente, os acórdãos de 17 de Fevereiro de 1976, Rewe-Zentrale, 45/75, Colect., p. 104, n 15, e de 12 de Maio de 1992, Comissão/Grécia, já referido, nº 12).

Em concreto, o Tribunal concluiu que não há dúvida que as modalidades de determinação da base de cálculo do imposto especial de consumo, o valor dos veículos usados importados, implicam, para estes veículos, qualquer que seja o seu estado de utilização, uma diminuição de apenas $5 \%$ por cada ano de antiguidade do total do imposto cobrado sobre um veículo novo, não podendo esta redução, por via de regra, exceder $20 \%$ do total do imposto, qualquer que seja a idade do veículo em causa. Ao invés, a parte residual do imposto especial sobre o consumo incorporada no valor de um veículo usado comprado no território nacional diminui proporcionalmente à depreciação do veículo. Nesse ponto, o acórdão concordou com a Comissão, quando a autora afirmou que a diminuição anual do valor dos automóveis é, em regra, significativamente superior a 5\%; que esta depreciação não é linear, nomeadamente nos primeiros anos, em que é muito mais acentuada do que posteriormente; e, finalmente, que este fenômeno continua para além do quarto ano de lançamento em circulação dos veículos.

Daí o Tribunal entendeu que o imposto especial sobre o consumo que atinge os veículos usados importados é geralmente superior à parte residual do imposto que permanece incorporada no valor dos veículos usados previamente matriculados e adquiridos no mercado grego (v., no mesmo sentido, o acórdão Nunes Tadeu, já referido, $\mathrm{n}^{\circ} 14$ ), sendo, portanto, superior a carga tributária incidente sobre o produto importado em relação à aplicável ao nacional. 
Outro aspecto relevante é a existência de tabelas de incidência progressivas diferenciadas. Comforme já vimos, no processo 45/75, Rewe-Zentrale des LebensmittelGroßhandels GmbH, Köln contra Hauptzollamt Landau-Pfalz, o TJCE manifestou-se que haveria cargas fiscais diferentes, no sentido do primeiro parágrafo do artigo $95^{\circ}$, em havendo modos de cálculo ou modalidades diferentes, como um montante uniforme para o produto nacional e o emprego de uma tabela progressiva para os importados similares, conduzindo a créditos tributários superiores para o produto importado, ainda que esta disparidade se verifique apenas numa minoria de casos. No mesmo sentido, processo 127/75 288 , Bobie Getränkevertrieb GmbH contra Hauptzollamt Aachen-Nord, de 22 de junho de 1976, também sobre o imposto incidente sobre cervejas na então República Federal da Alemanha.

Quanto ao conceito jurídico de produtos "similares", o entendimento jurisprudencial determina que não se poderia ficar preso às características físicas, mas sim aos produtos que, aos olhos dos consumidores, possuíssem propriedades análogas ou que satisfizessem às suas mesmas necessidades, de acordo com sua utilização no mercado ${ }^{289}$.

Defende Federico Ortino (2004, p. 136) que, a partir dos estabelecidos critérios de similitude, que podem ser tanto examinados sob o aspecto físico quanto o legal, no caso de regra não neutra quanto à origem, apenas o conceito legal é relevante. Por outro lado, Catherine Barnard (2007, p. 49 - 50) afirma que o TJCE evoluiu cronologicamente de uma fase formal, baseada nas características físicas, para uma fase de entendimento mais amplo, mediante a análise econômica do uso dos produtos em situação de concorrência.

Não parece que essas afirmações sejam corretas. Embora não se possa deixar de reconhecer que não mais seja o norte prevalecente, a pesquisa das características físicas dos produtos em comparação será sempre de relevância, ainda que meramente prejudicial examine-se, a seguir, o recente processo 243/84, John Walker \& Sons Ltd. contra Ministeriet for Skatter og Afgifter.

\footnotetext{
${ }^{288}$ ECR 1976, 1079.

289 "La règle de base en la matière est constituée par l'alinéa 1 de l'article 95, qui est fondé sur une comparaison des charges fiscales incombant aux produits nationaux et aux produits importés pouvant être qualifiés de «similaires». Cette disposition, ainsi que la Cour a eu l'occasion de la souligner dans son arrêt Hansen \& Balle, du 10 octobre 1978 (affaire 148/77, Recueil 1978 p. 1787), doit recevoir une interprétation large, de manière à permettre d'appréhender tous les procédés fiscaux qui porteraient atteinte à l'égalité de traitement entre les produits nationaux et les produits importés. Il convient donc d'interpréter de manière suffisamment souple la notion de "produits similaires». La Cour a précisé dans l'arrêt Rewe, du 17 février 1976 (affaire 45/75, Recueil 1976 p. 181), qu'il y a lieu de considérer comme similaires des produits qui "présentent au regard des consommateurs des propriétés analogues ou répondent aux mêmes besoins». C'est, dès lors, en fonction d'un critère non d'identité rigoureuse, mais d'analogie et de comparabilité dans l'utilisation qu'il convient de déterminer le champ d'application du premier alinéa de l'article 95" idem.
} 
É verdade que, nos casos mais antigos, como é o processo 27/67, Fink-Frucht GmbH. v. Hauptzollamt München-Landsbergerstraße ${ }^{290}$, o Tribunal de Justiça já afirmou que a relação de similitude que refere o primeiro parágrafo do artigo $95^{\circ}$ existe quando os produtos em causa devam ser normalmente considerados como fazendo parte da mesma classificação fiscal, aduaneira ou estatística, conforme o caso.

Mas, posteriormente, o Tribunal de Justiça, então das Comunidades Europeias, no processo 106/84, Comissão v. Reino da Dinamarca ${ }^{291}$, também considerou no seu julgamento a relevância das características objetivas das bebidas alcoólicas.

Lei dinamarquesa, criadora do imposto indireto analítico sobre os vinhos e os vinhos de frutas, de 1984, previa uma alíquota específica, para os vinhos de uva, de 10,725 DKR para os vinhos de mesa e de 19,93 DKR para os vinhos licorosos cujo teor alcoólico é superior aos dos vinhos de mesa, sem superar $23^{\circ}$ vol., acima do qual se entende a bebida como aguardente, a ser tributada pelo excise tax respectivo. Para os vinhos de fruta, a alíquota específica estipulada era de 6,92 DKR para os vinhos de mesa com teor alcoólico não maior de $14^{\circ}$ vol. e de 11,02 DKR para os demais vinhos de fruta; vale dizer, aqueles licorosos entre 14 e $20^{\circ}$ vol., acima do qual também se caracterizavam como aguardentes.

A legislação dinamarquesa não definia o que fossem vinhos de frutas, mas nos dados fáticos do processo chegou-se à conclusão de que os vinhos de uva consumidos no Reino da Dinamarca, consoante as especificações da norma tributária, eram todos de procedência importada e, quanto aos vinhos de fruta, os de tipo licoroso eram, na quase totalidade, produtos de fabricação nacional e, entre os do tipo vinho de mesa, aproximadamente um terço seriam importados e dois terços produtos típicos e tradicionais da produção de bebidas alcoólicas do reino, representando um mercado essencial para os produtores dinamarqueses de frutas.

Como se pode verificar claramente dos fatos narrados acerca da questão deduzida em juízo, trata-se de um caso de aplicação da vedação à discriminação implícita, aquela veiculada por normas aparentemente neutras conforme a origem. Porém, o Tribunal de Justiça, então das Comunidades Europeias, em fase em que tais conceitos ainda não eram completamente solidificados, julgou o caso como se tratasse de discriminação explícita, particularmente avaliando a similitude dos produtos a partir das suas características físicas, sem prejuízo daquelas referentes às preferências e hábitos dos consumidores. Houve menção expressa à primeira frase do então art. $95^{\circ}$, motivo pelo qual,

\footnotetext{
${ }^{290}$ ECR 1968, 327.

${ }^{291}$ ECR 1986, 867.
} 
embora os fatos levem à conclusão de se tratar de discriminação indireta ou implícita, podemos tomar a sua decisão como precedente relevante para a interpretação aplicável no caso de discriminação explícita.

Comentando os casos dessa fase, Paul Craig e Gráinne de Búrca (2003, p. 600 602) confirmam que, na época dos chamados "early 'spirit cases", especialmente aqueles iniciados mediante a iniciativa da Comissão das Comunidades Europeias (assim então denominada), no exercício do seu direito de ação previsto no então art. $226^{\circ}$ do TCE, anteriormente art. $169^{\circ}$ do TCCE, e atual art. $258^{\circ}$ do TUE ${ }^{292}$, era comum que o Tribunal de Justiça condenasse a exação nacional sem uma análise detalhada se a norma infringida seria a primeira ou a segunda frase do então art. $90^{\circ}$.

Ao final de sua análise, condenam o que chamam de "globalização" do artigo (p. 601), uma vez que tal proceder obscureceria a resposta apropriada ao estado infrator: se a equalização das cargas tributárias, como é o necessário no caso da primeira frase; ou a remoção do efeito protetivo, remédio correspondente às infrações às segunda frase. Catherine Barnard (2007, p. 57 - 58), por sua vez, também comenta a possibilidade de o TJCE efetivar essa globalização das duas frases do art. $90^{\circ}$, sem, no entanto, deixar de reconhecer que, em algumas situações, a análise englobadora faz sentido, nos casos em que há alguma forma de sobreposição entre as situações de discriminação implícita e explícita.

Retornando ao processo 106/84, o Tribunal, inicialmente, recordou-se ${ }^{293}$ de seus acórdãos de 27 de Fevereiro de 1980 (Comissão/França, 168/78, Recueil 1980, p. 347; Comissão/Itália, 169/78, Recueil 1980, p. 385; Comissão/Dinamarca, 171/78, Recueil 1980, p. 447), afirmando que o então artigo $95^{\circ}$, no seu conjunto, tem por fim assegurar a livre circulação das mercadorias entre os Estados-membros em condições normais de concorrência, por meio da eliminação de todas as formas de protecionismo que possam resultar da aplicação de impostos internos discriminatórios em relação aos produtos originários de outros Estados-membros, e garantir a perfeita neutralidade dos impostos internos em face da concorrência entre produtos nacionais e produtos importados.

No que diz respeito aos produtos similares, reiterou que o primeiro parágrafo deste artigo proíbe, mais especificamente, toda a disposição fiscal cujo efeito seja tributar

292 "Artigo 258. ${ }^{\circ}$

(ex-artigo 226. o TCE)

Se a Comissão considerar que um Estado-Membro não cumpriu qualquer das obrigações que lhe incumbem por força dos Tratados, formulará um parecer fundamentado sobre o assunto, após ter dado a esse Estado oportunidade de apresentar as suas observações.

Se o Estado em causa não proceder em conformidade com este parecer no prazo fixado pela Comissão, esta pode recorrer ao Tribunal de Justiça da União Europeia".

${ }^{293}$ ECR 1986, 870. 
mais fortemente os produtos importados que os produtos nacionais, por qualquer mecanismo que seja.

Afirma que, para apreciar o caráter de similitude, no qual se funda a proibição do primeiro parágrafo do então artigo $95^{\circ}$, há que examinar, como o Tribunal indicou no seu acórdão de 17 de Fevereiro de 1976 (Rewe, 45/75, Recueil 1976, p. 181), se os produtos apresentam propriedades análogas e satisfazem as mesmas necessidades dos consumidores.

Consagrando uma interpretação lata da noção de similitude, nos seus acórdãos de 27 de Fevereiro de 1980 (Comissão/França, 168/78, Recueil 1980, p. 347) e de 15 de Julho de 1982 (COGIS, 216/81, Recueil 1982, p. 2701), o Tribunal apreciou a similitude em função de um critério, não de identidade rigorosa, mas de analogia e de comparabilidade na utilização. Para a apreciação do caráter de similitude importa, por isso, tomar em consideração, por um lado, um conjunto de características objetivas das duas categorias de bebidas, tais como a sua origem (fruta ou cereal), os seus processos de fabrico (destilação ou fermentação), as suas qualidades organolépticas, nomeadamente, o seu gosto e o seu teor em álcool e, por outro lado, o fato de as duas categorias de bebidas serem susceptíveis ou não de satisfazer as mesmas necessidades dos consumidores.

Posteriormente, no processo 243/84, John Walker \& Sons Ltd. v. Ministeriet for Skatter og Afgifter (Ministério das Finanças dinamarquês) ${ }^{294}$, tal critério voltou a ser empregado. Trata-se de um caso semelhante em termos de fatos, embora se trate de matéria submetida ao Tribunal de Justiça sob a forma de reenvio prejudicial, nos termos do art. $177^{\circ}$ do TCEE, $234^{\circ}$ do TCE e $267^{\circ}$ do atual TUE 295 .

\footnotetext{
${ }^{294}$ ECR 1986, 877.

295 "Artigo $267^{\circ}$

(ex-artigo $\left.234^{\circ} \mathrm{TCE}\right)$

O Tribunal de Justiça da União Europeia é competente para decidir, a título prejudicial:

a) Sobre a interpretação dos Tratados;

b) Sobre a validade e a interpretação dos actos adoptados pelas instituições, órgãos ou organismos da União. Sempre que uma questão desta natureza seja suscitada perante qualquer órgão jurisdicional de um dos Estados-Membros, esse órgão pode, se considerar que uma decisão sobre essa questão é necessária ao julgamento da causa, pedir ao Tribunal que sobre ela se pronuncie.

Sempre que uma questão desta natureza seja suscitada em processo pendente perante um órgão jurisdicional nacional cujas decisões não sejam susceptíveis de recurso judicial previsto no direito interno, esse órgão é obrigado a submeter a questão ao Tribunal.

Se uma questão desta natureza for suscitada em processo pendente perante um órgão jurisdicional nacional relativamente a uma pessoa que se encontre detida, o Tribunal pronunciar-se-á com a maior brevidade possível”.
} 
Interessante é observar que a versão em inglês ${ }^{296}$ do julgado no processo 243/84 traz uma pretensa ordem entre os critérios, motivo pelo qual Federico Ortino (2004, p. 279) identificou uma prioridade expressa na decisão judicial para as características objetivas em detrimento dos gostos e preferências dos consumidores, o que não se pode de maneira nenhuma inferir da versão francesa ${ }^{297}$. Assim também eram diferenciadas e rigorosamente iguais as redações das duas versões do acórdão 106/84.

Por outro lado, Philippe Derouin e Philippe Martin (2008, p. 147) defendem que as características objetivas e as preferências dos consumidores são condições cumulativas, de forma a que produtos, mesmo com modos de consumo comuns, não poderão ser considerados similares uma vez que suas características intrínsecas sejam fundamentalmente diferentes. No entender deles, seria essa justamente a diferença básica entre as duas frases do art. $95^{\circ}$, posteriormente art. $90^{\circ}$ e atual art. $110^{\circ}$, no tocante ao caráter de similaridade, da primeira, em contraste com a relação de concorrência, do segundo - ao menos do que se pode se depreender de suas palavras, nessa relação de competição, as características objetivas não teriam relevância.

Embora não se possa concordar em tese com a hieraquização dos critérios proposta por Ortino em função da equívoca redação na língua de Shakespeare, não se pode negar que, no processo John Walker \& Sons Ltd. v. Ministeriet for Skatter og Afgifter, o Tribunal de Justiça, mesmo concordando que o uísque escocês pode prestar-se às mesmas formas de consumo que os vinhos de frutos do tipo vinho licoroso, sendo utilizados como aperitivos misturados com água, ou de sumo de frutos, entendeu que isso não bastou para tornar o uísque escocês similar aos vinhos de frutos do tipo vinho licoroso, produtos, como oferecidos no mercado dinamarquês, predominamente de fabricação nacional, mas com forte participação de bebidas de origem italiana.

A propósito, a controvérsia instaurada pela fabricante escocesa de uísque contra o fisco dinamarquês foi também a base jurisprudencial para a afirmação de Philippe Derouin e Philippe Martin antes referida.

\footnotetext{
296 "Consequently, in order to determine whether products are similar it is necessary first to consider certain objective characteristics of both categories of beverages, such as their origin, the method of manufacture and their organoleptic properties, in particular taste and alcohol content, and secondly to consider whether or not both categories of beverages are capable of meeting the same needs from the point of view of consumers" ECR 1986, 870.

297 "Pour l'appréciation du caractère de similitude, il importe donc de prendre en considération, d'une part, un ensemble de caractéristiques objectives des deux catégories de boissons, telles que leur origine, leurs procédés de fabrication, leurs qualités organoleptiques, notamment leur goût et leur teneur en alcool, et, d'autre part, le fait que les deux catégories de boissons sont susceptibles ou non de répondre aux mêmes besoins des consommateurs" idem.
} 
O principal fundamento para a conclusão do Tribunal de Justiça, então das Comunidades Europeias, no processo John Walker \& Sons Ltd. v. Ministeriet for Skatter og Afgifter, foi o fato de ter sido avaliado que as respectivas características intrínsecas são fundamentalmente diferentes. Avaliou-se que os vinhos de frutos do tipo vinho licoroso são produtos à base de frutos, obtidos por fermentação natural, enquanto os uísques escoceses são produzidos à base de cereais obtidos por destilação. Do mesmo modo, as qualidades organolépticas dos dois produtos foram entendidas como diferentes. Como foi precisado no acórdão 45/75, não é suficiente, para que se aplique a proibição do primeiro parágrafo do artigo $95 .^{\circ}$, que uma mesma substância, tal como o álcool, se encontre em ambos os produtos. É necessário, ainda, para que haja similitude, que esta substância se encontre em proporções mais ou menos iguais. Neste aspecto há que ter presente que, no caso em exame no processo, o uísque escocês tem $40^{\circ}$ por unidade de volume de álcool, enquanto os vinhos de frutos do tipo vinho licoroso, visados pela legislação dinamarquesa, contém no máximo $20^{\circ}$ de álcool por unidade de volume.

Com efeito, o julgamento do processo 243/84 parece mesmo reconhecer haver uma predominância das características objetivas sobre as econômicas. Assim é que no processo 106/84, em que tais características eram mais próximas, entre vinhos de frutas e vinhos de uva, os produtos foram considerados similares.

Outro lapidar exemplo de discriminação explícita em que preponderou, no exame da primeira frase, as características físicas, vem vazado no caso Comissão das Comunidades Europeias contra República Italiana, processo 184/85. Trata-se de iniciativa do Poder Executivo Comunitário contra a manutenção, pela Itália, de um Imposto de consumo sobre bananas. Trata-se de um imposto específico sobre o consumo no país de bananas frescas ou secas, assim como sobre a sua farinha.

Ocorre que a produção italiana de bananas, limitada à Sicília, foi, em 1985, de 120 toneladas. Por outro lado, no mesmo ano, foram importadas, pela Itália, 357.500 toneladas de bananas, especialmente provenientes dos departamentos ultramarinos franceses.

O regime fiscal caracteriza-se pelo fato de o imposto sobre o consumo em causa não se aplicar às mais típicas frutas de mesa de produção nacional italiana, como as maçãs, as peras, os pêssegos, as ameixas, os damascos, as cerejas, as laranjas e as tangerinas, só incidindo sobre o consumo de bananas in natura ou de seus derivados. A natureza protecionista desta imposição era sugerida pelo fato de a sua alíquota específica ser de 525 LIT por kg - ou seja, praticamente metade do preço de importação da banana em 1985. 
A Comissão baseou a sua ação fundamentalmente no primeiro parágrafo do artigo $95^{\circ}$, em relação ao qual a jurisprudência do Tribunal declarou que, no conjunto com o segundo, visa a garantir a livre circulação de mercadorias entre os Estados-membros em condições normais de concorrência, por meio da eliminação de todas as formas de proteção que possam resultar da aplicação de imposições internas discriminatórias relativamente a produtos originários de outros Estados-membros, e assegurar a neutralidade total das imposições internas no que respeita à concorrência entre produtos nacionais e produtos importados.

Quanto aos produtos similares, o Tribunal afirmou que primeiro parágrafo deste artigo proíbe, mais concretamente, qualquer disposição fiscal que tenha por efeito a aplicação aos produtos importados de imposições mais gravosas, qualquer que seja a sua natureza, do que as que incidam sobre os produtos nacionais. Em se lembrando que a produção de bananas na Itália é, como já foi referido, de todo insignificante, devendo, pois, ser negligenciada, a similitude em que se baseia a proibição do primeiro parágrafo do $\operatorname{artigo~} 95^{\circ}$ foi analisada por referência às frutas de mesa de produção tipicamente nacional.

Nessa esteira, as duas categorias de frutas em causa, isto é, as bananas e as frutas de mesa de produção tipicamente italiana, atrás referidas, foram entendidas como apresentando características diferentes. As qualidades organolépticas, bem como o teor em água das duas categorias de produtos foram concluídas como diversos, como a própria Comissão admitiu. Além disso, aceitou-se a observação do Governo italiano, não contestada pela Comissão, de que a banana é considerada, pelo menos no mercado italiano, um alimento particularmente nutritivo, energético e bem adaptado à primeira infância. Assim concluiu-se que as duas categorias de produtos não são similares, na acepção do primeiro parágrafo do artigo $95^{\circ}$, o que exigiu que o Tribunal partisse para o exame à luz da segunda frase.

Importante é perceber que, diferentemente do sistema multilateral, o artigo $90^{\circ}$ também pode ser aplicado às exportações. $\mathrm{O}$ caso pioneiro nesse aspecto são os processos 27/74 ${ }^{298}$, Demag AG contra Finanzamt Duisburg-Süd e 51/74 ${ }^{299}$, Sociedade em comandita P. J. Van der Hulst's Zonen, contra Produktschap voor Siergewassen (Serviço de Produção de Plantas Ornamentais).

\footnotetext{
${ }^{298}$ ECR 1974, 462.

${ }^{299}$ ECR 1975, 35.
} 
Apenas como melhor ilustração, veja-se o processo, mais recente, 142/77 $7^{300}$, entre Statens Kontrol med adle Metaller (serviço nacional de garantia de metais preciosos) e Preben Larsen, ourives, estabelecido em Jyllinge, e entre Flemming Kjerulff, ourives, estabelecido em Copenhagen, e Statens Kontrol med aedle Metaller, uma decisão a título prejudicial sobre a interpretação das noções de encargo de efeito equivalente a um direito aduaneiro de exportação, na acepção do artigo $16^{\circ}$, e de imposição interna, na acepção do artigo $95^{\circ}$, primeiro parágrafo, do Tratado $\mathrm{CEE}$, relativamente ao regime legal dinamarquês em matéria de controle dos artefatos de metais preciosos.

As questões foram suscitadas no âmbito de um litígio entre o serviço nacional de garantia dos metais preciosos do Reino da Dinamarca e dois ourives, a propósito do pagamento da imposição instituída com vista a cobrir as despesas relacionadas com o controle das empresas que produzissem, importassem ou negociassem artefatos de metais preciosos.

O serviço nacional de garantia é o órgão do governo dinamarquês que exerce um controle geral, no território nacional, no que diz respeito à produção de artefatos de metais preciosos, isto é, de ouro, prata e platina. Os custos relativos a esse controle são cobertos, nomeadamente, por contribuições pagas pelas empresas sob a forma de uma imposição calculada em função da quantidade de metais preciosos utilizada por cada uma.

Quanto aos artefatos comercializados no território nacional danês, a base de cálculo desta imposição é constituída pelos metais utilizados por cada empresa. O regime de contribuições em litígio, como se provou, tinha por fim abranger todos os metais preciosos utilizados por empresas dinamarquesas, sendo, por este motivo, incluídas na base de cálculo destas, segundo os mesmos critérios, todas as quantidades de metal importadas, quer sejam negociadas no próprio território dinamarquês quer sejam exportadas, independentemente da sua origem ou destino.

O Tribunal de Justiça, por conta disso, entendeu tratar-se de um regime de imposições internas, na acepção em que esta expressão é utilizada pelo artigo $95^{\circ} \mathrm{e}$ seguintes do Tratado. No caso de produtos destinados à exportação serem incluídos no campo de incidência do exportador, os tributos assim cobrados não podem ser qualificados como encargos de efeito equivalente a um direito aduaneiro de exportação, já que é característica destes direitos o incidirem especificamente sobre o produto exportado, com

\footnotetext{
${ }^{300}$ ECR 1978, 551.
} 
exclusão do mesmo produto comercializado no território nacional, o que não sucedeu no caso em juízo.

Assim, a análise do problema passou a ser a de saber se a regra da não discriminação formulada no artigo $95^{\circ}$ do Tratado é igualmente aplicável ao caso da incidência de uma imposição interna sobre um produto destinado à exportação e, na afirmativa, se um regime de imposições tal como o vigente na Dinamarca em matéria de controle dos artefatos de metais preciosos é compatível com esta regra da não discriminação.

Segundo o TJCE, nos termos do artigo $95^{\circ}$ do TCEE, a priori só é visada a aplicação discriminatória de regimes de imposições internas aos produtos importados de outros Estados-membros. A aplicação dos mesmos regimes de imposições às exportações é referida nos artigos $96^{\circ}$ a $98^{\circ}$ do TCEE, na perspectiva dos reembolsos de imposições excessivas, susceptíveis de falsear as condições das trocas comerciais no interior do mercado comum.

Entendeu então resultar do cotejo destas disposições que a intenção do Tratado é a de garantir, de modo geral, neste domínio, a neutralidade dos regimes de imposições internas relativamente às trocas comerciais intracomunitárias, sempre que uma transação econômica que ultrapasse as fronteiras de um Estado-membro constituir ao mesmo tempo o fato gerador de uma cobrança fiscal no âmbito de tais regimes.

Tornou-se, por conseguinte, segundo o TJCE, necessário interpretar o artigo $95^{\circ}$ de forma a que a regra da não discriminação, que está subjacente a este preceito, se aplique igualmente aos casos em que seja a exportação de um produto que constitua, no âmbito de um sistema de imposições internas, o fato gerador de uma cobrança fiscal. No seu entender, seria, com efeito, incompatível com o sistema das disposições fiscais do Tratado admitir que os Estados-membros, na falta de proibição expressa constante do Tratado, tivessem a liberdade de aplicar de maneira discriminatória um regime de imposições internas relativamente a produtos destinados à exportação para outros Estadosmembros.

Ponderou que, se é verdade que, por via de regra, os Estados-membros não têm qualquer interesse em dificultar as suas exportações por meio deste tipo de medidas, não pode, no entanto, excluir-se a hipótese de tais discriminações, em casos como o da exportação de produtos raros, particularmente preciosos ou especialmente procurados.

Segundo o TJCE, convinha portanto ter presente - como o Tribunal já havia indicado no seu acórdão de 23 de janeiro de 1975, Van der Hulst (51/74, Colect., p. 33, n. ${ }^{\circ}$ 
34) - que o artigo $95^{\circ}$, visto em conexão com as demais disposições fiscais do Tratado, deve ser interpretado de forma a proibir igualmente qualquer discriminação fiscal relativamente a produtos destinados à exportação para outros Estados-membros.

Dito isso, o TJCE passou a apreciar, à luz de quanto ficou dito, a questão da compatibilidade com as exigências do Tratado de um sistema de imposições internas tal como o que está em causa no litígio. Tendo em conta as indicações fornecidas pelo órgão jurisdicional nacional, não se entendeu poder considerar-se discriminatório um regime de tributos organizado de tal maneira que fiquem sujeitas a pagar a sua contribuição todas as empresas utilizadoras de metais preciosos, de modo a abranger, nos mesmos termos, quer as transações puramente nacionais, quer as que se relacionem com a importação ou a exportação desses metais.

Por fim, importante mencionar que a discriminação reversa é permitida pelo sistema. Discriminação reversa, como explica Abel Laureano (1997), ocorre nas situações em que os produtos domésticos são tratados de forma menos favorável do que seus similares importados. Assim foi decidido no processo 86/78 301 , SA des grandes distilleries Peureux contra Directeur des services fiscaux de la Haute-Sâ̂ne et du territoire de Belfort $^{302}$.

\subsubsection{Art. $90^{\circ}, 2^{\mathrm{a}}$ frase (discriminação implícita).}

A disciplina relativa à não-discriminação tributária explícita, aquela que é vazada em normas aparentemente neutras consoante a origem, no âmbito comunitário, vem trazida pela segunda frase do art. $90^{\circ}$ do Tratado que institui a Comunidade Europeia (Tratado de Maastricht, na numeração conferida pelo Tratado de Amsterdam), que corresponde, atualmente, a partir de $1^{\circ}$ de dezembro de 2009, com o advento do Tratado de Lisboa, ao art. $110^{\circ}$ do Tratado sobre o Funcionamento da União Europeia ${ }^{303}$.

\footnotetext{
${ }^{301}$ ECR 1979, 897.

302 "attendu que, si l'article 95 interdit à chaque État membre d'imposer plus lourdement les produits importés des autres États membres que les produits nationaux, il n'interdit pas d'imposer plus lourdement les produits nationaux que les produits importés"; ECR 1979, 913.

303 “CAPÍTULO 2

DISPOSIÇÕES FISCAIS

Artigo $110^{\circ}$

(ex-artigo $\left.90 .^{\circ} \mathrm{TCE}\right)$

(...)
} 
Para a hipótese que ora examinamos, vale o que foi antes comentado a respeito da não-discriminação explícita. Identifica-se claramente a similitude entre a disciplina comunitária e a da GATT, estudada em tópico anterior.

No caso da segunda frase em especial, em contraponto com a respectiva no segundo parágrafo do Art. III do GATT, pode-se dizer que a redação do diploma comunitário é muito mais feliz, porque elaborada de forma consolidada, de maneira a evitar a remissão ao parágrafo anterior, no caso do Art. III do GATT, que traz o princípio basilar do artigo como sendo o de impedir que toda espécie de imposição interna seja criada de modo protecionista. Interessante é observar que o texto comunitário não se restringe à produção nacional, de modo que o efeito protetivo combatido pode ser efetivado em proveito de produções de terceiros países também, desde que em detrimento da produção de Estados-Membros.

No entanto, não se tem notícia de casuística judicial em que essa diferença tenha se manifestado de forma concreta. Assim, embora também algo diferenciado, o entendimento jurisprudencial construído em âmbito comunitário ao longo dos anos em matéria de não-discriminação implícita analogamente em muito se assemelha àquele estabelecido em sede multilateral.

Dessa forma, da mesma forma como no caso dos julgados do OSC da OMC, como didaticamente classificam Paul Craig e Gráinne de Búrca (2003, p. 598 - 607), há dois passos a serem percorridos pelo julgador: a determinação da similaridade e a determinação do efeito protetivo. No mesmo sentido, mas empregando denominações diferentes, Federico Ortino (2004, p. 278) identifica os dois problemas como a relação entre os produtos sob exame e os efeitos da medida em si na produção doméstica e no consumo dos produtos importados.

Quanto ao primeiro passo, ao mesmo tempo em que, como já se viu, aplica-se a primeira frase a produtos domésticos similares ao produto estrangeiro importado, a segunda frase, como dito no processo 168/78, tem por função reprimir toda forma de protecionismo fiscal no caso de produtos que, sem serem similares no sentido da primeira frase, se achem ao menos, em relação a produtos do país de importação, em relação de concorrência ao menos parcial, indireta ou potencial ${ }^{304}$. Basta haver algum efeito de

Além disso, nenhum Estado-Membro fará incidir sobre os produtos dos outros Estados-Membros imposições internas de modo a proteger indirectamente outras produções."

304 “L'alinéa 2 de l'article 95 a pour fonction d'appréhender en outre toute forme de protectionnisme fiscal indirect dans le cas de produits qui, sans être similaires au sens de l'alinéa 1, se trouvent néanmoins, avec certaines productions du pays d'importation, dans un rapport de concurrence même partielle, indirecte ou 
substituição entre os produtos, aferido pela elasticidade-preço cruzada da demanda (CRAIG; DE BÚRCA, 2003, p. 599). Em verdade, como afirma Catherine Barnard (2007, p. 55), o que denomina de teste econômico, aquele baseado na grandeza microeconômica acima mencionada, não é o único. Controles relacionados com o processo produtivo e a composição física do produto também podem ser tomados em consideração.

Assim, desde o remoto processo 27/67, Fink-Frucht GmbH. v. Hauptzollamt München-Landsbergerstraße, o Tribunal de Justiça tem afirmado que o teste de concorrência a que se refere a segunda frase do artigo $95^{\circ}$ deve ser empregado nos casos em que a relação de similitude do primeiro parágrafo do artigo $95^{\circ}$ não foi preenchida, na medida em que o Tribunal ressaltou o seu caráter "complementar ao primeiro parágrafo, 305 .

Em verdade, a mais correta interpretação é a de que as condições para a segunda frase são mais abrangentes do que as para a primeira. Vale dizer, os requisitos para a capitulação no primeiro parágrafo são mais rigorosos do que os necessários ao segundo, no que tange às características dos produtos. Ou seja, todos os produtos que obedeçam à relação de similaridade possuem potencial relação de concorrência entre si, mas a relação de concorrência pode se verificar entre produtos não similares.

Também desde esse julgado afirma-se que o segundo parágrafo do artigo $95^{\circ}$ proíbe a cobrança de qualquer imposição interna que incida de forma mais gravosa sobre um produto importado que sobre um produto nacional, que, sem ser similar, na acepção do primeiro parágrafo do artigo $95^{\circ}$, é seu concorrente, ou, não existindo uma concorrência direta, a imposição interna onera o produto importado com uma carga fiscal especial, de forma a proteger certas atividades distintas daquelas desenvolvidas para a industrialização do produto importado.

A mensagem de tal concepção é clara. Para que haja possibilidade de se produzir um efeito protetivo para a produção nacional, conceito que estudaremos adiante, é necessário, como condição prejudicial, que os bens, nacional e estrangeiro, de alguma forma, mesmo parcial, indireta ou potencial, possam concorrer no mercado do país importador. Se não há a relação competitiva entre eles, por menor que seja, torna-se inexequível a produção de efeitos protetivos pela norma tributária.

potentielle. La Cour a déjà mis en évidence certains aspects de cette disposition dans son arrêt Fink-Frucht, du 4 avril 1968 (affaire 27/67, Recueil 1968 p. 327), où il est indiqué qu'il suffit, pour l'application du deuxième alinéa de l'article 95, que le produit importé se trouve en concurrence avec la production nationale protégée en raison d'une ou de plusieurs utilisations économiques, même à défaut de remplir pleinement la condition de similitude exigée par l'article 95, alinéa l" ECR 1980, 360.

${ }^{305}$ ECR $1968,829$. 
No processo 170/78, Comissão das Comunidades Europeias contra Reino Unido da Grã-Bretanha e Irlanda do Norte $^{306}$, controvérsia relativa à relação de competição, no mercado inglês, entre os vinhos de uva leves, especialmente os produzidos na Itália, e a cerveja britânica, dada a discrepância das alíquotas específicas do tributo seletivo incidente (UKL 2,955 por galão para os vinhos de uva e UKL 0,557 por galão para a cerveja), explicou-se o que seria a dita relação competitiva potencial.

Decidiu-se que, para a determinação da relação de concorrência no sentido do segundo parágrafo do então art. 95 , é necessário considerar não apenas o presente estado do mercado como também possíveis desenvolvimentos diante da liberdade de circulação de mercadorias dentro da Comunidade e o potencial futuro de substituição de produtos entre si, decorrente da intensificação das trocas entre os Estados-membros, na consecução dos objetivos de desenvolvimento das características econômicas complementares, previstos no art. $2^{\circ}$ do Tratado de Roma ${ }^{307}$.

O motivo para tal abordagem por parte do Tribunal é o fato de que, no caso em concreto, ponderou-se que o sistema fiscal também deve ser considerado discriminatório, mesmo se, eventualmente, a preferência dos consumidores, como a dos ingleses pontualmente, não recaia naquele momento examinado sobre o vinho, se houver a possibilidade de que tais hábitos houvessem sido historicamente consequência de desigual carga tributária entre o produto importado e o nacional. Tal concepção justificaria a qualificação de tais produtos, cerveja e vinho, como relacionados concorrencialmente, mesmo se o grau de substituição entre ambos, aferido em determinado momento, não fosse assim tão relevante ${ }^{308}$.

\footnotetext{
${ }^{306}$ ECR 1983, 2265.

307 "In its judgment of 17 February 1980, the Court emphasized that the second paragraph of Article 95 applied to the treatment for, tax purposes of products which, without fulfilling the criterion of similarity laid down in the first paragraph of that article, were nevertheless in competition, either partially or potentially, with certain products of the importing country. It added that, in order to determine the existence of a competitive relationship within the meaning of the second paragraph of Article 95, it was necessary to consider not only the present state of the market but also possible developments regarding the free movement of goods within the Community and the further potential for the substitution of products for one another which might be revealed by intensification of trade, so as fully to develop the complementary features of the economies of the Member States in accordance with the objectives laid down by Article 2 of the Treaty" ECR 1983, 2286.

308 "As regards the question of competition between wine and beer, the Court considered that, to a certain extent at least, the two beverages in question were capable of meeting identical needs, so that it had to be acknowledged that there was a degree of substitution for one another. It pointed out that, for the purpose of measuring the possible degree of substitution, attention should not be confined to consumer habits in a Member State or in a given region. Those habits, which were essentially variable in time and space, could not be considered to be immutable; the tax policy of a Member State must not therefore crystallize given consumer habits so as to consolidate an advantage acquired by national industries concerned to respond to them" ECR 1983, 2286 - 2287.
} 
Comentando tal entendimento jurisprudencial, Catherine Barnard (2007, p. 56) afirma que o que releva considerar, nessa perspectiva futura, é a existência de potenciais substituições tanto de produtos quanto de produtores com o acréscimo de mercado decorrente da liberalização comercial.

Tal amplitude da análise correspondente não significa que as características objetivas, físicas ou legais, não sejam relevantes no caso da segunda frase do antigo art. $95^{\circ}$, depois art. $90^{\circ}$, atual art. $110^{\circ}$. Pelo menos no caso do processo $168 / 78$, foi ponderado pelo Tribunal que, primeiramente, não haveria como negar que, entre o conhaque e o uísque haveria certos traços comuns como o fato de serem bebidas destiladas e com relativamente alto teor alcoólico. Por outro lado, entre tantas modalidades de bebidas abrangidas pela controvérsia, haveria também que se ponderar o fato de que, tanto do ponto de vista objetivo, acerca de suas características, como do subjetivo, quanto aos hábitos e preferências dos consumidores, há a possibilidade de distinguir entre todas elas algumas utilizações específicas para algumas determinadas ${ }^{309}$. Com isso, chegou à dupla conclusão: por um lado, a de que, entre a miríade de bebidas abrangidas pela controvérsia deduzida em juízo, poder-se-ia divisar aquelas que são qualificadas como produtos similares, no sentido da alínea 1 do então art. 95; ao mesmo tempo, mesmo entre as bebidas cujas características objetivas fossem diferenciadas, sempre haveria alguma

309 "Ces thèses appellent de la part de la Cour la prise de position suivante. L'application des dispositions de l'article 95 aux situations nationales particulières qui font l'objet des recours introduits par la Commission doit être envisagée dans la perspective de l'état général du marché des boissons alcooliques dans la Communauté. A ce sujet, il convient de tenir compte de trois ordres de considérations:

a) on ne saurait, tout d'abord, perdre de vue le fait que tous les produits en cause, quelles que soient par ailleurs leurs caractéristiques particulières, présentent des traits génériques communs. Tous sont issus du procédé de la distillation; tous comportent, comme élément caractéristique principal, la présence d'alcool apte à la consommation humaine à un degré relativement élevé de concentration. Il en résulte qu'à l'intérieur du groupe plus large des boissons alcooliques, les eaux-de-vie forment un ensemble identifiable, uni par des caractéristiques communes;

b) nonobstant ces traits communs, il est possible de distinguer, à l'intérieur de cet ensemble, des produits qui présentent des caractéristiques propres plus ou moins prononcées. Celles-ci dérivent soit des matières premières utilisées (sous ce rapport on peut distinguer notamment les alcools de vin, de fruits, de céréales et de canne), soit des procédés de fabrication, soit encore des substances aromatiques surajoutées. Ces caractéristiques propres permettent effectivement de définir des variétés typiques d'eaux-de-vie, au point que certaines d'entre elles sont même protégées par des appellations d'origine;

c) en même temps, on ne peut cependant pas perdre de vue la présence, parmi les eaux-de-vie, à côté de produits bien définis et servant à des usages relativement précis, d'autres produits aux caractéristiques moins profilées et aux usages plus diffus. Il s'agit, d'une part, des nombreux produits dérivés d'alcools dits «neutres», c'est-à-dire d'alcools de toutes origines, y compris les alcools de mélasse et de pommes de terre; ces produits ne doivent leur individualité qu'à des additifs aromatiques au gô̂t plus ou moins prononcé. D'autre part, il convient d'attirer l'attention sur la présence, parmi les eaux-de-vie, de produits susceptibles d'être consommés sous des formes très diverses, soit à l'état pur, soit allongés, soit encore sous forme de mélanges. Ces produits peuvent dès lors entrer en compétition avec une gamme plus ou moins large d'autres produits alcooliques à usage plus limité. Or, les trois procédures dont la Cour se trouve saisie sont caractérisées par le fait que, dans chacune, interviennent, à côté d'eaux-de-vie bien caractérisées, un ou plusieurs produits à large éventail d'utilisation" ECR 1980, 361 - 362. 
relação de concorrência de mercado entre elas, de modo que a todos seria aplicável o então art. $95^{\mathrm{o} 310}$.

No já mencionado caso Comissão das Comunidades Europeias contra República Italiana, processo 184/85, como visto, o Tribunal entendeu não haver relação de similaridade entre as duas categorias de frutas em causa, as bananas e as frutas de mesa de produção tipicamente italiana, por apresentarem características diferentes, especialmente as qualidades organolépticas e o teor em água das duas categorias de produtos.

Não se verificando o requisito de similitude exigido pelo primeiro parágrafo do artigo $95^{\circ}$, o Tribunal passou a ver se o segundo parágrafo deste artigo é aplicável. Como foi referido pelo Tribunal no acórdão de 27 de Fevereiro de 1980 (Comissão/Itália, 169/78, Recueil, p. 385), lembrou que a disposição visa a todas as formas de protecionismo fiscal indireto no caso de produtos que, não sendo similares na acepção do primeiro parágrafo, se encontram contudo numa relação de concorrência, ainda que parcial, indireta ou potencial.

Uma vez que as bananas e as frutas de mesa de produção tipicamente italiana não são produtos similares para efeitos do primeiro parágrafo do artigo $95^{\circ}$, entendeu o Tribunal de Justiça que as bananas constituem uma alternativa para os consumidores de frutas. Assim, considerou que as bananas se encontram numa relação de concorrência parcial com essas frutas.

Está visto, portanto, em que a condição de "similares" entre os produtos, necessária à caracterização da primeira frase, diferencia-se da relação de concorrência instrinsecamente prevista na segunda.

Adentrando agora no exame do segundo aspecto relevante na avaliação do caráter discriminatório da norma tributária neutra conforme a origem, há que se analisar, nesse momento, o que Federico Ortino (2004, p. 278) identifica como os efeitos da medida em si na produção doméstica e no consumo dos produtos importados.

O que importa ressaltar, nesse aspecto, é que os critérios de comparação agora não são tão facilmente identificáveis.

\footnotetext{
310 "Une double conclusion résulte de cette analyse du marché des eaux-de-vie. Premièrement, il existe, parmi les eaux-de-vie, considérées comme um ensemble global, un nombre indéterminé de boissons qui doivent être qualifiées de «produits similaires» au sens de l'article 95, alinéa 1, bien qu'il puisse être difficile d'en décider dans des cas particuliers, compte tenu de la nature des facteurs impliqués par des critères de distinction tels que le goût et les habitudes de consommation. Deuxièmement, même là où il ne serait pas possible de reconnaître un degré suffisant de similitude entre les produits concernés, il existe néanmoins entre toutes les eaux-de-vie des traits communs suffisamment accusés pour admettre l'existence, dans tous les cas, d'un rapport de concurrence à tout le moins partiel ou potentiel. Il en résulte que l'application de l'article 95, alinéa 2, peut entrer en ligne de compte dans les cas où le rapport de similitude entre des variétés spécifiques d'eaux-de-vie resterait douteux ou conteste" (idem).
} 
Tal realidade foi didaticamente exposta quando do julgamento do processo 168/78, então Comissão das Comunidades Europeias contra República Francesa, no qual se afirmou em seu respectivo acórdão que, enquanto a primeira frase visa a comparar as cargas tributárias, do ponto de vista da obrigação tributária, tanto em função do seu elemento quantitativo, alíquota ou base de cálculo, quanto das condições de pagamento ou outras modalidades de aplicação da norma tributária, o critério aplicável à segunda frase deve ser mais global, uma vez que fica dificultada a comparação precisa acerca dos efeitos da imposição tributária no mercado consumidor dos produtos em concorrência - esse critério é o efeito protetivo do sistema de imposições interiores ${ }^{311}$.

Traduzindo em minúcias a dicção do Tribunal de Justiça, ainda das Comunidades Europeias, em 1980, há que serem identificados, como bem nos ensina Federico Ortino (2004, p. 284), mais dois passos de verificação para a caracterização da aplicabilidade da segunda frase do atual art. $110^{\circ}$. O primeiro, decorrente do fato que, diferentemente da primeira frase, não temos o emprego do termo "superiores", de mais rápida intelecção, pelo que há, preliminarmente, que verificarmos a existência de um tratamento diferenciado determinado pela norma tributária submetida à análise de seu caráter discriminatório. Posteriormente, como externado pelo acórdão de 1980, fundamental é divisar-se na norma tributária a presença de uma natureza protetiva.

Então, como se identificar a presença do tratamento diferenciado? Diferentemente da primeira frase, também ampla, mas que abrange apenas a incidência do tributo em questão, no exame da segunda frase entende-se aplicável à análise todos os tributos incidentes, direta ou indiretamente, sobre um produto, assim como a todos aqueles que, embora aparentemente onerosos apenas à pessoa do produtor, podem representar, em realidade, mediante um exame mais aprofundado, incidências indiretas sobre o produto final. Da mesma forma, fora do escopo da segunda frase do atual art. $110^{\circ}$ estarão as imposições efetivamente e verdadeiramente incidentes sobre o produtor - o critério distintivo, para Ortino (2004, p. 285), será a relação entre a carga tributária e o produto.

No processo $20 / 76^{312}$, tendo por objeto um pedido apresentado ao Tribunal de Justiça, nos termos do artigo $177^{\circ}$ do Tratado CEE, pelo Finanzgericht BadenWürttemberg, Außensenate Stuttgart, destinado a obter uma decisão a título prejudicial

311 "Alors que le critère d'apprécitation indiqué par l'alinéa 1 consiste dans la comparaison des charges fiscales, que ce soit en fonction du taux, des conditions d'assiette ou d'autres modalités d'application, l'alinéa 2, compte tenu de la difficulté d'établir des comparaisons suffisamment précises entre les produits en cause, s'attache à un critère plus global, à savoir le caractère protecteur d'un système d'impositions intérieures" ECR 1980, 360.

${ }^{312}$ ECR 1977, 247. 
sobre a interpretação do então artigo $95^{\circ}$ do Tratado CEE, no litígio pendente no mencionado órgão jurisdicional entre Schöttle \& Söhne OHG, Oberkollwangen contra Finanzamt Freudenstadt, abordou -se essa questão. Embora não trate a priori de comércio de bens, mas sim do serviço de transporte, sua análise é muito ilustrativa desses conceitos relacionados à concretude dos efeitos da norma tributária.

Trata-se do conflito entre um importador alemão de saibro do território francês e o Fisco alemão, pondo em causa a compatibilidade da imposição alemã sobre o transporte rodoviário de mercadorias com o artigo $95^{\circ}$, primeiro parágrafo, do Tratado, na medida em que o importador, relativamente a transportes comparáveis ponto por ponto, teve que pagar o encargo no que diz respeito à mercadoria francesa, mas pôde efectuar o transporte sem o pagar relativamente à mercadoria nacional.

Segundo o fisco alemão, o encargo em causa fazia parte de um conjunto de medidas adotadas em 1968 para garantir a coordenação dos diferentes meios de transporte. Neste âmbito, o encargo sobre o transporte rodoviário de mercadorias destinava-se a orientar o transporte de longa distância para as estradas-de-ferro e para a navegação interna.

Por conseguinte, o transporte de mercadorias de curta distância, que não poderia razoavelmente ser desviado das estradas, foi isento do encargo.

Pela norma tributária alemã, o transporte de curta distância é definido como qualquer transporte de mercadorias por veículo automóvel, por conta de outrem, nos limites de um setor comunal ou da zona "imediata", essa sendo o território compreendido num raio de 50 quilômetros calculado em linha reta a partir do centro da comuna em que o da localização do caminhão e abrange o território de qualquer comuna cujo centro se encontre no interior do perímetro.

A primeira questão posta ao Tribunal de Justiça foi se "um encargo cobrado sobre os transportes rodoviários de mercadorias, em função da distância percorrida no território nacional e do peso das mercadorias em causa, constitui uma imposição que incide sobre produtos, na acepção do artigo $95^{\circ}$ do Tratado CEE?"

O Tribunal entendeu que o então artigo $95^{\circ}$ tem por objeto afastar as restrições dissimuladas à livre circulação de mercadorias que possam resultar das disposições fiscais de um Estado-membro. Tendo em conta a economia geral e os objetivos da referida disposição, a noção de imposição que incide sobre um produto deve ser interpretada em sentido lato. Tais restrições podem resultar de um encargo que, na realidade, compense a imposição que incide sobre a atividade da empresa e não sobre os produtos enquanto tais. 
Este problema não se coloca quando se trata de tributar o produto nacional e o produto importado na mesma fase, em função de uma atividade determinada, por exemplo, a utilização das estradas nacionais. No entanto, esse encargo, ao repercutir-se imediatamente no custo dos produtos nacional e importado, deve, por força do artigo $95^{\circ}$, ser aplicado de modo não discriminatório aos produtos importados, de modo que a resposta foi positiva.

Nas segunda e terceira questões, o Tribunal se pronunciou quanto à interpretação da proibição de fazer incidir sobre produtos estrangeiros uma imposição superior à que incide sobre a produção nacional, tendo em conta o fato de que: a hipótese de um tratamento diferente do produto importado só poder verificar-se, em todo o caso, se esse produto for entregue no interior de uma zona territorial de, aproximadamente, 50 quilômetros de largura, que se estenda paralelamente à fronteira, a uma distância de 50 quilômetros desta; e o encargo em questão incidir do mesmo modo não só sobre o transporte de produtos estrangeiros para o território nacional, mas também sobre o transporte de produtos nacionais para o estrangeiro.

Quanto à terceira questão, o Tribunal afirmou que o artigo $95^{\circ}$ deve garantir que, da aplicação de imposições internas, não resulta, num Estado-membro, a incidência sobre produtos provenientes de outros Estados-membros de imposições superiores às que oneram produtos nacionais similares no mercado nacional. Por conseguinte, entendeu irrelevante que o encargo seja igualmente cobrado nas mesmas condições sobre produtos nacionais exportados e sobre produtos importados.

Quanto à segunda, respondeu que se verifica uma imposição superior sobre o produto importado quando as condições em que o transportador fica sujeito ao encargo forem diferentes para os transportes internacionais e os transportes puramente nacionais, de modo que, em situações comparáveis, o produto que circula no interior do Estado não fica sujeito ao encargo, enquanto o produto importado fica. Assim, a fim de comparar, para efeitos da aplicação do artigo $95^{\circ}$, o encargo que incide sobre o produto que circula no interior com o que incide sobre o produto importado, deve ter-se em conta não só a matéria tributável da imposição, mas também as vantagens ou as isenções de que um e outro beneficiam.

Para que se verifique uma imposição superior sobre o produto importado, basta que, em determinadas circunstâncias, o produto nacional possa, em relação ao mesmo percurso no Estado-membro, ser transportado sem ficar sujeito ao encargo, enquanto o produto importado fica sujeito ao encargo pela simples razão de ter havido passagem da 
fronteira. Para esse efeito, competirá ao juiz nacional comparar, em casos determinados, as situações que podem ocorrer.

No caso em concreto, os dados fornecidos pelo juiz nacional alemão demonstraram que, por vezes, um obstáculo real à livre circulação de mercadorias pode resultar da aplicação de condições diferentes de imposição do encargo aos transportes internacionais e aos transportes nacionais. A natureza menor e incidental do obstáculo criado por um encargo nacional e o fato de, na prática, este só ter podido ser evitado pela supressão do encargo, não são suficientes, no entender do Tribunal, para afastar a aplicação do artigo $95^{\circ}$ do Tratado.

No já referido processo 170/78, Comissão das Comunidades Europeias contra Reino Unido da Grã-Bretanha e Irlanda do Norte, a questão também foi colocada. A aferição quanto à carga tributária ficaria prejudicada, uma vez que, no que se refere à base de volume, o montante do tributo seletivo, para a cerveja padrão, seria de 0,6084 UKL por galão contra 3,250 UKL por galão para os vinhos; se baseado também no teor alcoólico, de 0,2028 UKL por galão e por grau, para a cerveja e 0,2955 UKL ou 0,2708 UKL para os vinhos leves de 11 ou $12 \%$ respectivamente. Porém, em função do preço de venda ao consumidor, teríamos a alíquota efetiva em média de $23 \%$ para a cerveja e de $24 \%$ para os vinhos leves, no mínimo (para os vinhos mais caros), chegando a até 38\%, para os mais baratos.

Assim, a priori, dependendo do meio de aferição, poderia nem se estar falando em tratamento diferenciado.

Porém, o Tribunal afirmou que, tanto do ponto de vista absoluto, quanto do relativo em termos de volume ou teor alcoólico, o tratamento diferenciado era patente. Quanto à consideração em preço de venda, considerou-se que precisamente os vinhos que, em função de seu preço, estavam mais evidentemente em concorrência com a cerveja doméstica, por serem mais baratos, eram os que estavam mais onerados em relação ao produto nacional ${ }^{313}$, pelo que se entendeu haver, na espécie, sob qualquer critério, tratamento diferenciado, em função do que não foi necessário optar por um entre eles ${ }^{314}$.

\footnotetext{
313 "After considering the information provided by the parties, the Court has come to the conclusion that, if a comparison is made on the basis of those wines which are cheaper than the types of wine selected by the United Kingdom and of which several varieties are sold in significant quantities on the United Kingdom market, it becomes apparent that precisely those wines which, in view of their price, are most directly in competition with domestic beer production are subject to a considerably higher tax burden" ECR 1985, 2291 $-2292$.

314 "It is clear, therefore, following the detailed inquiry conducted by the Court - whatever criterion for comparison is used, there being no need to express a preference for one or the other - that the United Kingdom's tax system has the effect of subjecting wine imported from other Member States to an additional
} 
Com isso, a imposição analítica britância foi declarada colidente com as obrigações do então art. $90^{\circ}$, segundo parágrafo ${ }^{315}$.

Independentemente de suas particularidades circunstanciais, esses dois exemplos ilustram como a verificação do tratamento diferenciado por vezes pode tomar contornos de complexidade a desafiar a consistência dos julgamentos do Tribunal de Justiça. Dessa forma, deve ser visto como um passo intermediário, após a conclusão pela existência de uma relação de concorrência entre os produtos e antes de passar à desafiadora fase de analisar a sua natureza protetiva.

Importante assinalar-se que a inexistência de tratamento diferenciado ao produto estrangeiro, segundo o entendimento do TJCE, não só deverá ser verificada na incidência do tributo, como também na sua destinação, se a hipótese tratar de tributos com destinações determinadas, como as contribuições parafiscais. Essa conclusão é a que chega da análise do processo C-266/91 ${ }^{316}$, Celulose Beira Industrial (CELBI), SA contra Fazenda Pública, decisão em reenvio prejudicial, acórdão de 2 de agosto de 1993. Trata-se de impugnação a imposto português, incidente sobre a venda de pastas químicas, de produção lusa ou importada, destinada ao Instituto de Produtos Florestais, órgão público voltado à regulação e fomento, inclusive mediante concessão de créditos e outros apoios de natureza financeira, ao setor de extrativismo vegetal explorado por empresas portuguesas.

O TJCE entendeu que o tributo, mesmo indistintamente aplicável, sendo, portanto, considerado uma imposição interna, constitui, não obstante, uma violação da proibição de discriminação estabelecida no artigo $95^{\circ}$ do Tratado, se os benefícios que a afetação da receita da imposição comporta beneficiarem especialmente os produtos nacionais tributados, compensando parcialmente o encargo suportado por estes e desfavorecendo, desta forma, os produtos importados.

Tal formulação tem sido repetida, como no processo C-347/95 $5^{317}$, Fazenda Pública contra União das Cooperativas Abastecedoras de Leite de Lisboa, UCRL (UCAL), de 17 de setembro de 1997, concernente às taxas de comercialização de laticínios, e o

\footnotetext{
tax burden so as to afford protection to domestic beer production, inasmuch as beer production constitutes the most relevant reference criterion from the point of view of competition. Since such protection is most marked in the case of the most popular wines, the effect of the United Kingdom tax system is to stamp wine with the hallmarks of a luxury product which, in view of the tax burden which it bears, can scarcely constitute in the eyes of the consumer a genuine alternative to the typical domestically produced beverage" ECR 1985, 2292.

315 "It follows from the foregoing considerations that, by levying excise duty on still light wines made from fresh grapes at a higher rate, in relative terms, than on beer, the United Kingdom has failed to fulfil its obligations under the second paragraph of Article 95 of the EEC Treaty" idem.

${ }^{316}$ ECR 1993, I - 4357.

${ }^{317}$ ECR 1997, I - 4923.
} 
processo C-28/96 $6^{318}$, Fazenda Pública contra Fricarnes SA, de 17 de setembro de 1997, , relativo às taxas de comercialização de carnes e miudezas bem como sobre os ruminantes e da taxa contra a peste suína. Ambos os processos consistem em decisões em reenvio prejudicial contra exações destinadas aos respectivos órgãos de vigilância sanitária portugueses.

Nesses casos, o TJCE generalizou a sua formulação anterior, afirmando que tributos com tais mecanismos de benefício, não apenas destinadas ao custeio do exercício do poder de polícia ("regularização do comércio", na dicção dos acórdãos), constituem um encargo de efeito equivalente a um direito aduaneiro ou uma imposição interna discriminatória, conforme o benefício obtido pelos produtos nacionais onerados compense integralmente ou apenas em parte o encargo suportado por eles.

Recentemente, tal entendimento do TJCE foi reiterado, nos processos C234/99 ${ }^{319}$, Niels Nygård contra Svineafgiftsfonden (Fundo de tributação dos suínos), e Ministeriet for Fødevarer, Landbrug og Fiskeri, como interveniente, referente à imposição nacional sobre o abate de suínos do Reino da Dinamarca e C-517/04 ${ }^{320}$, Visserijbedrijf D. J. Koornstra \& Zn. vof contra Productschap Vis, acerca do tributo, instituído pelo Reino dos Países Baixos, sobre o desembarque e a venda de camarão, de qualquer procedência, no território holandês, desde que o crustáceo seja transportado a bordo de barcos de pesca matriculados nos Países Baixos, destinado ao financiamento das instalações de crivagem e descasque de camarão no país.

Quanto à aferição do caráter protetivo da norma tributária, terceiro e último passo na análise conforme a segunda frase do art. $90^{\circ}$ do TCE, atual $110^{\circ}$ do TUE, o critério definitivo é o efeito da norma sobre, de um lado, a quantidade de produção da mercadoria nacional e, de outro, a quantidade importada da mercadoria alienígena no mercado em questão. Temos, portanto, um critério completamente positivo, quantitativo, concreto, não jurídico, embora a verificação de sua caracterização ou não, ao final, esteja confinada ao campo do direito.

Um caso jurisprudencial típico dessa consideração pode ser apontado no processo 196/85, Comissão das Comunidades Europeias contra República Francesa ${ }^{321}$.

Os vinhos licorosos e equiparados são tributados por um imposto francês sobre o consumo de álcool, em regra geral com a alíquota específica de 6.795 FF por hectolitro

\footnotetext{
${ }^{318}$ ECR 1997, I - 4943.

${ }^{319}$ ECR 2002, I - 3657.

${ }^{320}$ ECR 2006, I - 5015.

${ }^{321}$ ECR 1987, 1597.
} 
de álcool puro (artigo $403^{\circ}$-I-3. ${ }^{\circ}$ do Code Général des Impôts). Todavia, alguns desses vinhos estão submetidos a regime mais favorável que consiste em tributar as quantidades de álcool acrescentadas à sua preparação com a alíquota de $2.545 \mathrm{FF}$ por hectolitro de álcool puro, a título de imposto sobre o consumo (artigo $403^{\circ}$-I-1. ${ }^{\circ}$ do Code Général des Impôts), ao qual se acrescenta um imposto de circulação à alíquota de 54,80 FF por hectolitro (artigo $438^{\circ}-1$ do Code Général des Impôts). O regime privilegiado é aplicado, no que respeita aos produtos franceses, aos "vinhos doces naturais", denominação reservada aos "vinhos cuja produção é tradicional e usual", consoante descrição técnica de fabricação referida em lei, no artigo $416^{\circ}$ do Code Général des Impôts.

O regime privilegiado era inicialmente aplicável apenas aos produtos franceses, razão pela qual a Comissão instaurou, em 1978, um processo por infração contra a República Francesa. Este processo foi, no entanto, arquivado, depois que a lei de finanças para 1982 modificou o regime de tributação por meio da introdução do artigo $417^{\circ}$ A no Code Général des Impôts, disposição que alargava o regime em causa aos produtos importados provenientes de outros Estados-membros, equiparando-os, do ponto de vista fiscal, aos vinhos doces naturais referidos no artigo $416^{\circ}$, sob reserva de serem submetidos a um dispositivo de controle que ofereça garantias equivalentes às exigidas para os vinhos doces naturais no que respeita às condições da sua produção e comercialização.

Quanto à condição da "produção tradicional e usual", a Comissão censurou na legislação francesa o fato de ter introduzido um critério não objetivo de definição que é insusceptível de uma aplicação não discriminatória, porque só se realizaria, em concreto, em benefício exclusivo ou quase exclusivo da produção nacional. Quanto à exigência de um dispositivo de controle, a Comissão considerou que tem por efeito excluir dos benefícios as produções dos Estados-membros cuja legislação não preveja um dispositivo análogo.

Não obstante, os argumentos da Comissão foram todos afastados pelo Tribunal de Justiça, que concluiu pela regularidade do benefício fiscal.

Inicialmente recordou que, por força de uma jurisprudência constante, (ver, para uma aplicação então recente, o acórdão de 4 de Março de 1986, Comissão/Dinamarca, 106/84, Colect. p. 833), o direito comunitário não limita, no então estado da sua evolução, a liberdade de cada Estado-membro estabelecer um sistema de tributação diferenciado para certos produtos, ainda que similares no sentido do artigo $95^{\circ}$, primeiro parágrafo, do Tratado, em função de critérios objetivos, como sejam a natureza das matérias-primas utilizadas ou os processos de produção aplicados. 
Tais diferenciações são entendidas compatíveis com o direito comunitário se prosseguirem objetivos de política econômica, eles próprios, compatíveis com as exigências do Tratado e do direito derivado e se as suas modalidades forem de natureza a evitar qualquer forma de discriminação, direta ou indireta, de importações provenientes de outros Estados-membros, ou de proteção em favor de produções nacionais concorrentes.

Mais especificamente, o Tribunal lembrou que havia reconhecido, por diversas vezes, que no estado de então do direito comunitário o artigo $95^{\circ}$ do Tratado não impede que os Estados-membros concedam vantagens fiscais a objetivos econômicos ou sociais legítimos, sob a forma de isenções ou de reduções de direitos a certos tipos de álcool ou a certas categorias de produtores, na condição de tais regimes mais favorecidos serem alargados, sem discriminação, aos produtos importados que tenham as mesmas condições que as produções nacionais favorecidas. Entendeu, sem maiores considerações, que tais critérios estariam reunidos no caso em apreço.

No que respeita aos objetivos prosseguidos pelo sistema de tributação impugnado, o Governo francês explicou no decurso do processo que os vinhos doces naturais são fabricados em regiões caracterizadas por uma fraca pluviometria e por terrenos relativamente áridos, nas quais, devido à dificuldade em cultivar outros produtos agrícolas, a economia local é fortemente dependente da sua produção. O benefício fiscal reservado a esses vinhos tende portanto a compensar as condições de produção mais rigorosas que pesam sobre eles, a fim de permitir a manutenção de produções de qualidade que apresentam para certas regiões da Comunidade um interesse econômico particular. Tais objetivos de política econômica foram considerados como compatíveis com as exigências do direito comunitário.

No que respeita à extensão do regime de favor aos produtos importados, foi constatado pelo Tribunal que o caráter de "produção tradicional e usual" se refere indistintamente aos produtos nacionais e aos produtos importados. Nenhum elemento do processo indicou, segundo o acórdão, que da sua aplicação resulte o favorecer dos vinhos de origem francesa em detrimento dos vinhos originários de outros Estados-membros e que apresentem as mesmas características. Nomeadamente, não se demonstrou que, devido a condições naturais ou a estruturas de produção, a vantagem fiscal em causa beneficie exclusivamente ou, pelo menos, essencialmente, as produções nacionais. Além disso, acrescentou que se não pode considerar contrária ao direito comunitário uma regulamentação nacional que cobre indistintamente os produtos nacionais e os produtos 
importados, apenas com base no fato de poder ser susceptível de uma aplicação discriminatória, enquanto não for provado que é efetivamente aplicada dessa forma.

Como se vê, a análise do efeito protetivo é, basicamente, matéria que depende de correta instrução processual probatória. Caso raro, no Direito Tributário, de matéria de fato a ser aferida para verificar a caracterização da presença de um elemento normativo, no caso, o efeito protetivo necessário à conclusão pelo caráter discriminatório da norma.

Sobre a exigência de um dispositivo de controle no Estado-membro exportador, o Tribunal recordou a jurisprudência estabelecida (acórdão de 7 de Maio de 1981, Hansen, 153/80, Recueil, p. 1165) no sentido de que um Estado-membro não pode recusar aos produtos provenientes de um outro Estado-membro um benefício fiscal com base em condições impostas pela sua legislação e que os produtos importados não tenham possibilidade de preencher devido à sua situação geográfica ou à legislação do Estado em que são produzidos. Ressaltou-se que o Estado-membro importador é livre de exigir elementos de prova que permitam verificar se os produtos importados satisfazem efetivamente os critérios estabelecidos pela sua legislação nacional, por meio, por exemplo, de certificados emanados das autoridades ou outras instâncias competentes do Estado-membro de origem dos produtos. Todavia, tal regulamentação, para ser compatível com o princípio da proporcionalidade, deve deixar ao Estado-membro de origem dos produtos a escolha dos métodos e da autoridade encarregada da aplicação dos controles e não deve subordinar o reconhecimento da equivalência à condição prévia de um acordo negociado entre as administrações nacionais interessadas.

Veja-se o processo $140 / 79^{322}$, Chemial Farmaceutice SpA. contra DAF SpA, duas sociedades anônimas particulares com sede na República Italiana. A primeira, sociedade que se dedica à indústria de transformação química, adquiriu da segunda, sociedade produtora e importadora de álcool e produtos químicos, um lote de álcool etílico anidro desnaturado, sintético, derivado do petróleo, de origem externa à Itália. Não quis pagar, em conjunto com o valor da mercadoria, o crédito tributário de imposto específico incidente, à alíquota de 6.000 liras por hectolitro, alegando que deveria, no caso, ser aplicada a alíquota aplicável ao álcool produto de fermentação de produtos naturais, que montava a 1.000 liras por hectolitro, alegando que a imposição era discriminatória. Os dois líquidos são perfeitamente fungíveis, destinados ambos à industrialização química e impróprios ao consumo humano. Também são capituláveis na mesma posição na

\footnotetext{
${ }^{322}$ ECR 1981, 2.
} 
classificação fiscal do sistema harmonizado (22.08 - Álcool etílico desnaturado de qualquer tipo).

Ocorre que o álcool sintético é produto basicamente de importação, sem, à época, fabricação relevante em território italiano.

A requerente alegava que os produtos não apenas seriam similares mas idênticos e que o tratamento diferenciado era patente. Para ela, a intenção da norma tributária italiana não haveria sido outra senão a implementação de uma política protecionista.

Como sempre, o Tribunal de Justiça afirmou a possibilidade de os Estadosmembros, no exercício de suas soberanias fiscais, diferenciar produtos tributáveis por critérios objetivos, com o que o sistema italiano seria compatível ${ }^{323}$.

Após, entrou na consideração mais importante do acórdão, a de que o caráter discriminatório da norma tributária não é verificado se a tributação mais onerosa tem por efeito o de frear a importação do produto originário de outros Estados-membros, mas também com um efeito equivalente no estado nacional de importação de não permitir a produção rentável do mesmo produto ${ }^{324}$. Assim, não se entende haver o efeito protetivo em causa se, por meio da aplicação do sistema de tributação sendo analisado, uma produção rentável do produto beneficiado pela imposição menos gravosa não pode se desenvolver no estado da importação ${ }^{325}$. O Tribunal de Justiça terminou por concluir, embora tal consideração não houvesse sido relevante para o deslinde da controvérsia, que, aparentemente, o regime tributário diferenciado italiano tinha por fim um objetivo público

\footnotetext{
323 “Ainsi que la Cour l'a itérativement affirmé, notamment dans les arrêts cités par le gouvernement italien, le droit communautaire ne restreint pas, en l'état actuel de son évolution, la liberté de chaque État membre d'établir un système de taxation différenciée pour certains produits, en fonction de critères objectifs, tels que la nature des matières premières utilisées ou les procédés de production appliqués. De telles différenciations sont compatibles avec le droit communautaire si elles poursuivent des objectifs de politique économique compatibles, eux aussi, avec les exigences du traité et du droit dérivé et si leurs modalités sont de nature à éviter toute forme de discrimination, directe ou indirecte, à l'égard des importations en provenance des autres États membres, ou de protection en faveur de productions nationales concurrentes.

Une taxation différentielle telle qu'elle existe en Italie pour l'alcool dénaturé de synthèse, d'une part, et l'alcool de fermentation dénaturé, d'autre part, répond à ces exigences" ECR 1981, 15.

324 "Les modalités de la législation mise en cause devant la juridiction nationale ne sauraient être considérées comme discriminatoires, alors que, d'une part, il n'est pas contesté que les importations d'alcool de fermentation en provenance des autres États membres jouissent du même traitement fiscal que l'alcool de fermentation italien et que, d'autre part, si le taux d'imposition prévu pour l'alcool de synthèse a pour effet de freiner l'importation de ce produit originaire des autres États membres, il a un effet économique équivalent sur le territoire national en ce qu'il freine aussi la création d'une production rentable du même produit par l'industrie italienne" idem.

325 "L'application d'un tel système de taxation ne saurait être considérée comme constituant une protection indirecte de la production nationale d'alcool de fermentation, au sens de l'article 95, alinéa 2, du seul fait qu'elle a pour conséquence que le produit le plus lourdement taxé est, en fait, un produit exclusivement importé des autres États membres de la Communauté si, en raison de la taxation de l'alcool de synthèse, une production rentable de ce type d'alcool n'a pas pu se développer sur le territoire national" ECR 1981, 16.
} 
legítimo, o de favorecer o uso de matérias-primas renováveis, com o fim de evitar a transformação do etileno do petróleo em álcool etílico, reservando o derivado de produto fóssil para usos econômicos prioritários, como alegado pelo respondente ${ }^{326}$.

Resumidamente, podemos concluir que a existência de efeito protetivo de uma norma tributária pode ser detectada sempre nos casos em que houver alteração nas partilhas de um mercado importador, entre produtos nacionais e importados, em função não das preferências e gostos dos consumidores pura e simplesmente, mas sim também e consideravelmente de fatores decorrentes de decisões dos consumidores visando à economia de impostos.

Como exemplos desse raciocínio, mencionam-se os casos Michel Humblot contra Directeur des Services Fiscaux, de 1984, processo C-112/84 ${ }^{327}$, e Jacques Feldain contra Directeur des Services Fiscaux du département du Haut-Rhin, de 1985, processo C$433 / 85^{328}$, nos quais se combatia lei francesa que tributava os automóveis por meio de imposto progressivo em função da cilindrada. Os casos se referem ao regime anterior e posterior, respectivamente, à alteração do artigo $18^{\circ}$ da Lei n. ${ }^{\circ} 85-695$, em 11 de julho de 1985, da República Francesa. Em ambos os processos, o Tribunal acatou as alegações da Comissão das Comunidades Europeias.

O primeiro processo, anterior à alteração legislativa, refere-se ao regime fiscal em que existiam na França dois tipos de tributos anuais sobre os veículos automóveis: por um lado, um tributo diferencial que incidia sobre os veículos com uma potência físcal inferior ou igual a $16 \mathrm{CV}$, aumentando de forma contínua e progressiva em função da potência do motor do veículo; e, por outro, um tributo especial, de montante fixo e substancialmente mais elevado, que se aplicava aos veículos com potência fiscal superior a $16 \mathrm{CV}$.

A tributação dos motores mais potentes, especialmente punitiva, se aplicava de fato apenas a veículos importados, notadamente de outros Estados-membros, uma vez que não havia, à época, nenhum automóvel de fabricação francesa com potência maior do que $16 \mathrm{CV}$.

O Tribunal, após as considerações de praxe, no sentido de que os Estadosmembros estão livres para submeter seus produtos, como automóveis, a um sistema

\footnotetext{
326 "Il apparaît, en effet, que ce régime de taxation poursuit un but de politique industrielle légitime, en ce sens qu'il est de nature à favoriser la distillation de produits agricoles par rapport à la fabrication d'alcool à base de dérivés du pétrole. Cette option ne se trouve pas en conflit avec les règles du droit communautaire ou les exigences d'une politique arrêtée dans le cadre de la Communauté" ECR 1981, 15.

${ }^{327}$ ECR, 1985, 1367.

${ }^{328}$ ECR, 1987, 3521.
} 
tributário indireto cujo montante aumente progressivamente em função de um critério objetivo, como a potência fiscal, a ser calculado de diversas formas, desde que não seja o caso de possuir efeitos discriminatórios ou protetivos ${ }^{329}$, entrou, no parágrafo 15 do acórdão a tratar do critério fundamental.

Para o Tribunal de Justiça, importante é perceber que, se não existisse a tributação nos moldes descritos, os consumidores escolheriam seus automóveis de acordo com o seu tamanho, conforto, potência real, custo de manutenção, longevidade ou consumo, e seriam naturalmente direcionados a escolher entre automóveis de mesma faixa de potência fiscal. Diferentemente, com a incidência do tributo especial, o aumento do custo para a aquisição de veículos de potência fiscal maior que $16 \mathrm{CV}$ é de tal forma relevante, no preço final, que o consumidor pode entender que as vantagens decorrentes das características proprias dos automóveis ficariam como que neutralizadas pelo preço majorado, assim vindo a optar pelo produto menos tributado, majoritariamente nacional. Com isso, o tributo especial reduziria a concorrência com os produtos nacionais, o que é contrário ao princípio de neutralidade ao qual devem obedecer as imposições internas ${ }^{330}$.

O segundo processo trata do regime fiscal posterior à alteração legislativa que se procedeu em obediência à decisão no feito anterior.

O cálculo da potência fiscal, a partir do novo regime, base de cálculo para o tributo, passou a ser estabelecido, consoante a circular administrativa de 23 de Dezembro de 1977 (JORF de 8.2.1978, p. 1052) pela seguinte fórmula:

$$
\mathrm{P}=\mathrm{m}(0,0458 \cdot \mathrm{C} / \mathrm{K})^{1,48}
$$

\footnotetext{
329 "II convient d'abord de souligner qu'en l'état actuel du droit communautaire, les États membres restent libres de soumettre des produits comme les voitures à um système de taxe de circulation dont le montant augmente progressivement en fonction d'un critère objectif, tel que la puissance fiscale, qui peut être déterminée selon différentes modalités.

Un tel système d'imposition intérieure n'est toutefois légitime au regard de l'article 95 que pour autant qu'il soit exempt de tout effet discriminatoire ou protecteur" ECR, 1985, 1378.

330 "Si des considérations tenant au montant de la taxe spéciale n'intervenaient pas, les consommateurs à la recherche de voitures comparables sur le plan, notamment, de a taille, du confort, de la puissance réelle, du coût d'entretien, de la longévité de la consommation et du prix seraient naturellement amenés à choisir entre des voitures qui se situent en dessous et des voitures qui se situent au-dessus du seuil critique de puissance fiscale fixé par la loi française. Toutefois, l'assujettissement à la taxe speciale entraîne une augmentation de la taxation qui est beaucoup plus importante que celle qui résulterait du passage d'une catégorie à l'autre de voitures dans un système de taxation progressive comportant des écarts équilibrés comme celui auquel correspond la taxe différentielle. Cette charge supplémentaire est de nature a neutraliser les avantages que pourraient avoir aux yeux des consommateurs certaines voitures importées d'autres États membres par rapport aux voitures de fabrication nationale comparables, d'autant plus qu'elle se répète pendant plusieurs années. Dans cette mesure, la taxe spéciale réduit la concurrence à laquelle sont soumises ces dernières voitures et est par là contraire au principe de neutralite auquel doivent obéir les impositions intérieures" ECR, 1985, 1379.
} 
Nesta fórmula, $\mathrm{P}$ designa a potência administrativa, $\mathrm{m}$ é igual a 1 para a gasolina e 0,7 para o gasóleo, C corresponde à cilindrada do motor expressa em centímetros cúbicos. K é um parâmetro que exprime a transmissão do movimento e que se obtém calculando "a média aritmética ponderada das velocidades expressas em quilômetros por hora, teoricamente alcançadas pelo veículo num regime de motor de mil rotações por minuto, nas várias relações da caixa de velocidades em marcha à frente".

Todavia, para os veículos com uma potência real superior a $100 \mathrm{~kW}$, o fator $\mathrm{K}$ está limitado a um máximo de 21 . Relativamente aos veículos com caixa de velocidades automática, o fator $\mathrm{K}$ era inicialmente calculado com base em todas as relações dessa caixa de marchas.

A circular administrativa de 1977 esclarece que esta fórmula se destina a "obter uma potência administrativa que esteja em melhor correlação com a aptidão intrínseca do veículo para consumir combustível num percurso determinado e que incite a procurar uma diminuição desse consumo".

Entendeu o Tribunal de Justiça que a modalidade de cálculo da potência fiscal dos veículos automóveis era discriminatória. Ao limitar o fator K a um máximo de 21 para os veículos com uma potência real superior a $100 \mathrm{~kW}$, a regulamentação em causa teve como efeito atribuir, aos automóveis com caixa de velocidades manual e cilindrada superior a $3.109,7 \mathrm{~cm}^{3}$, potências fiscais superiores a $16 \mathrm{CV}$. Por outro lado, quando o fator $\mathrm{K}$ é limitado, apenas a cilindrada determina a potência fiscal. Sendo a cilindrada elevada a 1,48 , qualquer aumento de cilindrada faz com que esses automóveis se situem nos escalões de tributação mais elevados.

Depreendeu-se das informações fornecidas ao Tribunal pelo demandante no processo principal, que não foram contestadas pelo Governo francês, que nenhum automóvel de fabrico francês tinha uma cilindrada superior a 3.109,7 cm3. Nestas condições, a limitação do fator $\mathrm{K}$ a 21 faz com que apenas sejam incluídos nos escalões superiores de tributação automóveis importados, quando, sem essa limitação, seriam atribuídas a esses automóveis potências fiscais menores.

Uma tal limitação não se justifica, no entender do Tribunal, por considerações ligadas ao consumo de gasolina. Com efeito, não existe qualquer diferença importante, a este respeito, entre os automóveis abrangidos pela limitação do fator $\mathrm{K}$ e outros automóveis comparáveis não afetados por ela.

Declarou-se, pois, que esta modalidade de determinação da potência fiscal não 
apresenta um caráter objetivo e tem como resultado favorecer os automóveis de fabricação francesa.

Nestas condições, concluiu-se que as modalidades de cálculo do imposto diferencial são tais que os automóveis importados de outros Estados-membros são os únicos a serem abrangidos nas categorias fiscais mais fortemente tributadas, sem que isso se justifique por um critério objetivo. Como uma tal situação obriga os proprietários desses automóveis a suportar um custo suplementar, os consumidores são incitados a comprar, entre os veículos do topo de gama, automóveis de fabrico francês em vez de automóveis importados de outros Estados-membros.

Entendeu-se, portanto, que um sistema de imposto de circulação que, por um lado, ao estabelecer uma tabela de tributação que incluía maior número de potências fiscais que os outros, trava a progressão normal do imposto em benefício dos automóveis do topo de gama de fabricação nacional, e que, por outro, contém formas de determinação da potência fiscal que desfavorecem os automóveis importados de outros Estados-membros, tem um efeito discriminatório ou protetor na acepção do então artigo $95^{\circ}$ do Tratado.

Há outros casos semelhantes em que, não obstante, o acórdão não foi tão feliz em identificar a alteração, potencial ou efetiva, nas preferências e hábitos dos consumidores como fatores preponderantes na conclusão pela existência de efeito protetivo pela norma tributária. No entanto, já se pode considerar implícita tal consideração, diante da relativa consolidação jurisprudencial da formulação.

É o caso do processo 265/99, ação de incumprimento, da Comissão das Comunidades Europeias contra a República Francesa, tendo por objeto a declaração de que, ao manter e ao aplicar uma regulamentação que prevê a aplicação de uma fórmula de cálculo da potência administrativa desfavorável aos veículos equipados com caixa de marchas manual de 6 velocidades bem como com caixa automática de 5 velocidades, produzem-se efeitos discriminatórios e protecionistas quanto aos veículos fabricados noutros Estados-Membros relativamente aos veículos nacionais, franceses, similares ou concorrentes.

Segundo a Comissão, os veículos provenientes de outros Estados-Membros que integrem certas tecnologias inovadoras, e mais particularmente uma caixa de marchas automática de 5 velocidades e uma caixa manual de 6 velocidades, estavam sujeitos na França a um imposto anual de circulação muito mais elevado do que modelos similares nacionais em razão de uma diferença mínima de concepção da caixa. Esta sobretributação resulta da aplicação sistemática da fórmula de cálculo da potência administrativa prevista 
na circular administrativa, uma vez que não foram levados em conta tais avanços tecnológicos nas alterações da regulamentação, não obstante corresponderem a um aperfeiçoamento de técnicas já conhecidas e aplicadas industrialmente.

Inicialmente, para apreciar o caráter de similitude no qual se funda a proibição do artigo $95^{\circ}$, primeiro parágrafo, do Tratado, o Tribunal entendeu que há que examinar se os produtos apresentam propriedades análogas e satisfazem as mesmas necessidades dos consumidores (acórdão de 4 de Março de 1986, Comissão/Dinamarca, 106/84, Colect., p. $\left.833, \mathrm{n}^{\circ} 12\right)$.

Além disso, no n 28 do acórdão Tarantik (acórdão de 15 de Junho de 1999, C421/97, Colect., p. I-3633, n 8), o Tribunal de Justiça declarou, por um lado, que produtos como as viaturas são similares na acepção do artigo $95^{\circ}$, primeiro parágrafo, do Tratado quando as suas propriedades e as necessidades que satisfazem os coloquem numa relação de concorrência e, por outro, que o grau de concorrência entre dois modelos depende da medida em que estes satisfaçam diversas exigências, nomeadamente em matéria de preço, dimensões, conforto, resultados, consumo, longevidade e confiabilidade.

Uma vez que os critérios de similitude estabelecidos pela jurisprudência não respeitam exclusivamente ao equipamento técnico dos veículos, outras características podem igualmente entrar em linha de conta. Consequentemente, entendeu parecer que veículos de marcas diferentes, estejam ou não equipados com uma caixa manual de 6 velocidades ou de um caixa automática de 5 velocidades, podem constituir, aos olhos dos consumidores, veículos similares na acepção do artigo $95^{\circ}$, primeiro parágrafo, do Tratado, tal como foi interpretado no acórdão Tarantik, já referido.

Em um segundo passo, foi examinado se os veículos importados que integravam tecnologia inovadora eram tributados mais pesadamente do que os veículos nacionais similares. Nesse aspecto, afirmou que não foi contestado que os veículos importados representam a maioria dos veículos que integram tecnologia inovadora visados pela ação. Assim, resultou dos valores fornecidos pelo Governo francês em resposta às questões escritas do Tribunal de Justiça que, por um lado, a totalidade dos veículos equipados com caixas automáticas de 5 velocidades e, por outro, a grande maioria, se não a quase totalidade, dos veículos equipados com caixas manuais de 6 velocidades no merado francês eram veículos importados.

No terceiro passo, a aferição do efeito protetivo, o Tribunal de Justiça equivocou-se, aplicando o primeiro parágrafo, analisando então os efeitos da norma tributária sob a ótica da tributação superior, embora se trate de uma hipótese evidentemente 
de discriminação implícita. Como já se viu, pode-se aplicar a segunda frase ainda que os produtos sejam a priori entendidos como similares, dada a abrangência maior das hipóteses das relações de concorrência, no exclusivo aspecto das características intrínsecas do produto. Seria como se dizer que, havendo similaridade entre os produtos, nacional e importado, a relação de concorrência entre eles é presumida.

Por ter entendido aplicável à espécie a primeira frase, portanto, o Tribunal erradamente não analisou a existência de efeito protetivo na norma tributária. Embora partindo de premissas equivocadamente aplicáveis ao caso, ainda assim é interessante analisar como se houve o acórdão nesse aspecto.

O Tribunal declarou que já havia sido decidido, em diversas ocasiões, que há violação do artigo $95^{\circ}$, primeiro parágrafo, do Tratado, sempre que a imposição que incide sobre o produto importado e a que incide sobre o produto nacional similar sejam calculadas de forma diferente e segundo modalidades diferentes, que conduzam, ainda que apenas em certos casos, a uma tributação mais pesada do produto importado (v. acórdão de 23 de Outubro de 1997, Comissão/Grécia, C-375/95, Colect., p. I-5981, n² 20, e jurisprudência aí citada).

Por conseguinte, verificou que o sistema de tributação francês, na medida em que previa a aplicação da circular administrativa para calcular a potência administrativa dos veículos que integram tecnologia inovadora, maioritariamente importados, não é de natureza a excluir, em qualquer hipótese, que os veículos importados sejam tributados mais pesadamente do que os veículos de produção nacional susceptíveis de ser considerados similares.

Com isso, entendeu dever-se, portanto, concluir que, ao manter e ao aplicar uma regulamentação que prevê a aplicação de uma fórmula de cálculo da potência administrativa desfavorável aos veículos equipados com caixa manual de 6 velocidades bem como com caixa automática de 5 velocidades, produzindo efeitos discriminatórios e protecionistas quanto aos veículos fabricados noutros Estados-Membros relativamente aos veículos nacionais similares, a República Francesa não cumpriu as obrigações que lhe incumbem por força do artigo $95^{\circ}$, primeiro parágrafo, do Tratado de Roma.

Como também baseado no efeito concreto da norma tributária nas posições de mercado dos produtos em análise, temos o acórdão do Tribunal de Justiça, então das Comunidades Europeias, no processo John Walker \& Sons Ltd. v. Ministeriet for Skatter og Afgifter.

Após, em primeiro passo, como já examinamos acima, ter concluído que o 
uísque escocês e os vinhos de frutos do tipo vinho licoroso dinamarqueses não eram produtos similares, adentrou-se na segunda questão da jurisdição nacional, a qual visava a determinar se eles devem ser considerados como produtos concorrentes e se, caso positivo, uma evidente diferença de tributação dos dois produtos, tal como a resultante da legislação dinamarquesa já citada, deveria ser considerada como incompatível com o segundo parágrafo do artigo $95^{\circ}$, do Tratado CEE.

A requerente no processo principal, fabricante escocês de uísque, sustentou que, segundo a jurisprudência, é necessário focar, na análise da relação de concorrência, as possibilidades de evolução do mercado e as virtualidades de substituição entre os produtos. $\mathrm{O}$ uísque escocês representaria para o consumidor médio inglês ou escocês o que o vinho de frutos representa para o consumidor médio dinamarquês.

No que respeita ao nível da carga fiscal em relação à quantidade do produto, $\mathrm{o}$ seu teor em álcool e o seu preço, utilizados como critérios de comparação pelo Tribunal, o uísque escocês sofreria um acréscimo de tributação considerável em relação ao produto concorrente dinamarquês. Assim, estaria caracterizado o tratamento diferenciado.

O Governo dinamarquês e o Governo italiano, em suas observações escritas, observaram que, tendo em conta as suas características específicas, as suas qualidades organolépticas e, nomeadamente, os diferentes teores em álcool, o uísque escocês e os vinhos licorosos não constituiriam produtos concorrentes. Para os governos, os Estadosmembros teriam a faculdade de tributar as aguardentes mais fortemente que os vinhos e a legislação dinamarquesa nem teria por objeto, nem por efeito, proteger uma certa categoria de bebidas.

O Governo dinamarquês, chamou, aliás, a atenção para o fato de o regime fiscal dinamarquês não ter tido um efeito dissuasor sobre as importações. Resulta, com efeito, das estatísticas que, de 1980, ano da adoção do regime de tributação de então, na sequência do acórdão do Tribunal, de 27 de Fevereiro de 1980 (Comissão/Dinamarca, 171/78, Recueil 1980, p. 447), condenando a discriminação operada pela legislação anterior em favor da aquavit (aguardente escandinava), a 1985, as importações de uísque aumentaram mais de $30 \%$, mesmo se as vendas da requerente no processo principal acusaram uma baixa.

Por sua vez, segundo a Comissão, haveria que se examinar se o sistema fiscal dinamarquês tem um caráter protetor da produção nacional. Ela salienta, para este efeito, que as aguardentes fortemente tributadas são, na sua maior pane, constituídas por produtos de origem nacional. Um regime que se baseia para o uísque e as bebidas espirituosas 
nacionais, na graduação alcoométrica e nos preços e, para os vinhos licorosos nacionais e importados, só no volume, seria compatível com o segundo parágrafo do artigo $95^{\circ}$, se uma parte essencial da produção nacional se encontrasse em cada uma das categorias fiscais.

Na sua decisão, o Tribunal ponderou que o segundo parágrafo do artigo $95^{\circ}$, do Tratado CEE, ao proibir a um Estado-membro tributar os produtos dos outros Estadosmembros com impostos internos aptos a proteger indiretamente outros produtos nacionais, visa ao objetivo geral de assegurar a neutralidade fiscal e tende a assegurar que um Estadomembro não discrimine um produto originário de outro Estado-membro, favorecendo, por intermédio da sua legislação fiscal nacional, produtos de fabrico nacional, criando assim entraves à livre circulação das mercadorias entre os Estados-membros.

Do exame do processo enviado pelo órgão de jurisdição nacional e das observações apresentadas perante o Tribunal, asseverou o acórdão que concluiu que o produto que suportava a carga fiscal mais pesada era um produto quase exclusivamente de fabricação nacional e que o uísque, produto exclusivamente importado, não era tributado como tal, mas como bebida alcoólica que figura na categoria fiscal das aguardentes, bebidas de forte teor alcoólico, categoria na qual figuram outros produtos, cuja grande maioria é constituída por produtos nacionais.

A fim de colocar o órgão de jurisdição nacional em condições de determinar se, nestas condições, a diferença de tributação operada pelo regime físcal dinamarquês constitui uma violação do segundo parágrafo, do artigo $95^{\circ}$, lembrou, mais uma vez, que, de acordo com uma jurisprudência constante (ver, nomeadamente, o acórdão de 15 de Março de 1983, Comissão/Itália, 391/81, Recueil 1983, p. 601), o direito comunitário não restringe, no estado de então da sua evolução, a liberdade de cada Estado-membro estabelecer um sistema de tributação diferenciada para alguns produtos, em função de critérios objetivos, que podem ser a natureza das matérias-primas utilizadas ou os processos de produção aplicados. Tais diferenciações são compatíveis com o direito comunitário se perseguem objetivos de política econômica compatíveis, eles também, com as exigências do Tratado e do direito derivado, e se as suas modalidades são de forma a evitar toda a espécie de discriminação, direta ou indireta, em relação às importações provenientes dos outros Estados-membros, ou de protecionismo em favor de produtos nacionais concorrentes.

Assim, como não se verificou a obediência a requisito prejudicial, não foi necessário pronunciamento sobre a existência de uma eventual relação de concorrência entre o uísque escocês e os vinhos de frutos dinamarqueses do tipo vinho licoroso. 
Em conclusão, afirmou peremptoriamente o Tribunal que o segundo parágrafo do artigo $95^{\circ}$, do Tratado CEE, não constituía obstáculo à aplicação de um sistema de tributação diferenciada para certas bebidas, em função de critérios objetivos; e um tal sistema não tem efeito protetor a favor da produção nacional quando, em cada uma das categorias fiscais, figura uma parte essencial da produção nacional de bebidas alcoólicas.

Como se vê, embora o Tribunal afirme que a capitulação do uísque escocês, no sistema tributário dinamarquês, não como a bebida alcoólica mais onerada, nem tampouco sendo outra de proveniência importada, termine por caracterizar a inexistência de efeito protetor, tal conclusão é equivocada, pois o teste não contemplado foi o da obediência ao requisito do tratamento diferenciado.

Não obstante, a decisão do Tribunal no processo John Walker \& Sons Ltd. v. Ministeriet for Skatter og Afgifter, mesmo não sendo rigorosa tecnicamente, nos dá a certeza que o norte para a exegese do segundo parágrafo do artigo $95^{\circ}$, do Tratado CEE, atual artigo $110^{\circ}$ do Tratado EU, é a fotografia da divisão efetiva do mercado consumidor, atual ou potencial, com vistas a examinar ou antever os efeitos da norma tributária nas quantidades da produção nacional e do consumo de mercadorias importadas no mercado sob exame, para a verificação do efeito protetor, assim como nos respectivos preços de venda, para a caracterização do tratamento diferenciado.

No já mencionado caso Comissão das Comunidades Europeias contra República Italiana, processo 184/85, como visto, o Tribunal entendeu não haver relação de similaridade entre as duas categorias de frutas em causa, as bananas e as frutas de mesa de produção tipicamente italiana, por apresentarem características diferentes, especialmente as qualidades organolépticas e o teor em água das duas categorias de produtos. Não se verificando o requisito de similitude exigido pelo primeiro parágrafo do então artigo $95^{\circ}$, o Tribunal passou ao exme do segundo parágrafo do artigo, terminando por concluir que as bananas constituem uma alternativa para os consumidores de frutas, encontrando-se, assim, os dois produtos em relação de concorrência parcial.

Alcançada a conclusão pela relação de concorrência, passou-se a examinar se as bananas eram oneradas com imposições cujo efeito fosse o de proteger indiretamente as frutas de mesa de produção tipicamente italiana.

Quanto a esse aspecto, o Tribunal de Justiça entendeu que o regime fiscal italiano caracteriza-se pelo fato de o imposto sobre o consumo em causa não se aplicar às mais típicas frutas de mesa de produção nacional. A natureza protecionista desta imposição foi entendida como reforçada pelo fato de a sua alíquota ser de 525 LIT por kg, ou seja, 
praticamente metade do preço de importação em 1985. Ao final, o Tribunal de Justiça afirmou que esta tributação desigual influencia assim o mercado dos produtos em causa, diminuindo o consumo potencial dos produtos importados. Nestas condições, a natureza protecionista do regime fiscal visado pela Comissão tornou-se clara, no seu entender.

Portanto, no processo 184/85, mais uma vez o Tribunal, ao concluir pela existência de efeito protetivo em um regime tributário claramente diferenciado entre as bananas importadas dos departamentos ultramarinos franceses e as frutas frescas de mesa de procedência italiana, também corretamente atentou para as eventuais flutuações nas posições relativas de mercado entre os produtos nacionais e os importados sob análise.

$\mathrm{Na}$ mesma esteira, não se pode entender pela existência de efeito protetivo quando a norma, mesmo que, no caso extremo, seja explicitamente discriminatória, se não há concretamente nenhum produto nacional que possa vir a ser beneficiado por tal preferência.

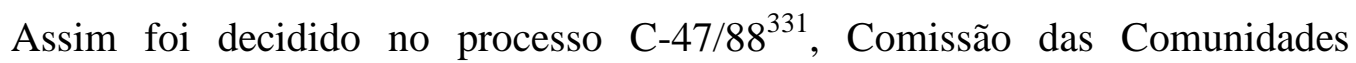
Europeias contra o Reino da Dinamarca.

Norma dinamarquesa, o Decreto-Lei $\mathrm{n}^{\circ} 13$ de 16 de Janeiro de 1985, criou um imposto de registro dos veículos, incidente quando do momento da primeira matrícula do veículo em território dinamarquês, sobre os automóveis particulares de tal forma que, no caso dos veículos automóveis novos importados é geralmente baseado num valor fixo superior ao valor real do veículo, e que os veículos automóveis usados importados são tributados de forma mais onerosa que os veículos usados vendidos na Dinamarca após aí terem sido previamente matriculados.

Os veículos automóveis matriculados em conformidade com as disposições do Código da Estrada estão sujeitos na Dinamarca a um imposto de registro. As alíquotas aplicáveis aos automóveis particulares, que são função do valor do veículo, incluindo o IVA, são as seguintes: $105 \%$ sobre as primeiras 19.750 DKR e $180 \%$ sobre o restante do preço.

No que respeita aos veículos usados importados, o valor tributável é igual a 100 $\%$ do preço do veículo novo se ele tiver menos de seis meses e $90 \%$ deste preço se tiver mais de seis meses. Em contrapartida, a venda de veículos já matriculados na Dinamarca não dava lugar à cobrança de um novo imposto de registro.

${ }^{331}$ ECR 1990, I -4530. 
Para a nossa análise, interessa examinar a questão relativa aos automóveis novos.

A Comissão, parte autora, alegava em primeiro lugar que o imposto de registo dinamarquês que incide sobre os veículos automóveis novos é incompatível com o artigo $95^{\circ}$ do Tratado porque, em virtude do seu nível muito elevado e na falta de produção nacional, comprometeria a livre circulação das mercadorias no mercado comum e não se enquadraria no sistema fiscal geral dinamarquês. A Comissão alegava em seguida que a circunstância de um Estado-membro não fabricar um produto determinado não constituiria obstáculo à aplicação dos princípios enunciados no então artigo $95^{\circ}$.

Primeiramente, o Tribunal ponderou, no que se refere ao registro de veículos novos, que convinha recordar, em primeiro lugar, que o então artigo $95^{\circ}$ proíbe, expressamente, que se façam incidir sobre os produtos de outros Estados-membros imposições internas superiores às que incidam sobre os produtos nacionais similares ou imposições internas de modo a proteger indiretamente outras produções.

Também recordou, ainda, tal como resulta da jurisprudência uniforme do TJCE (ver, como mais recente, o acórdão de 3 de Março de 1988, Bergandi, 252/86, Colect., p. 1343), que o artigo $95^{\circ}$, no seu conjunto, tem como objetivo garantir a livre circulação das mercadorias entre os Estados-membros em condições normais de concorrência, mediante a eliminação de quaisquer formas de proteção que possam resultar da aplicação de imposições internas discriminatórias em relação aos produtos originários de outros Estados-membros. Assim, este artigo deve garantir a perfeita neutralidade das imposições internas no que se refere à concorrência entre produtos nacionais e produtos importados.

O Tribunal entendeu que, em senso contrário, o artigo $95^{\circ}$ não poderia ser invocado contra imposições internas que incidam sobre os produtos importados, na falta de produção nacional similar ou concorrente. Em particular, este artigo não permitiria censurar o caráter excessivo do nível de tributação que os Estados-membros poderão adotar relativamente a determinados produtos na falta de qualquer efeito discriminatório ou protetor, dado que existia então na Dinamarca qualquer produção nacional de automóveis nem de produtos nacionais suscetíveis de concorrer com os automóveis. Nessas condições, portanto, o acórdão entendeu por concluir que o imposto de registro dinamarquês que incide sobre os veículos novos está fora do âmbito das proibições enunciadas no artigo $95^{\circ}$.

O Tribunal de Justiça lembrou que já havia decidido no seu acórdão de 4 de abril de 1968, Stier (31/67, Recueil, p. 348), que os Estados-membros não podem fazer incidir sobre os produtos que, na falta de produção interna comparável, estão fora do 
âmbito de aplicação das proibições do artigo $95^{\circ}$, impostos de um montante tal que a livre circulação de mercadorias no mercado comum fique comprometida no que se refere a esses produtos. Tal prejuízo para a livre circulação de mercadorias, todavia, só poderia ser apreciado eventualmente à luz das regras gerais contidas nos então artigos $30^{\circ}$ e seguintes do Tratado, referentes às restrições quantitativas, que não havia sido objeto da alegação presente na petição inicial.

Apenas para efeitos didáticos, já que se refere a aspecto já aqui abordado anteriormente, quando se tratou do conceito de carga fiscal, no que tange ao imposto de registro sobre os veículos usados, o Tribunal de Justiça, no processo C-47/88, recordou o que já havia decidido no seu acórdão de 22 de Março de 1977, Iannelli/Meroni (74/76, Recueil, p. 557), que, na aplicação do artigo $95^{\circ}$, há que tomar em consideração não apenas a alíquota da imposição interna que incide direta ou indiretamente sobre os produtos nacionais importados, mas também a base de cálculo e as modalidades do imposto em causa.

Assinalou o Tribunal que, mesmo que se verificasse que, em razão do montante muito elevado do imposto que incide sobre os automóveis novos, a parte do imposto ainda incorporada no valor do veículo fosse amortizada de forma mais lenta na Dinamarca do que noutros Estados-membros que exigissem um imposto de um valor menos elevado, estas circunstâncias não impedem que a cobrança de um imposto de registro, cuja base é de pelo menos $90 \%$ do valor do automóvel novo, constitui de forma geral uma sobretributação manifesta destes veículos em relação ao valor residual do imposto de registro dos automóveis usados previamente matriculados, comprados no mercado dinamarquês, seja qual for a sua antiguidade ou o estado de utilização. Em consequência, o Tribunal admitiu que a norma, que estabelece que a base de cálculo do imposto de registro dinamarquês incidente sobre os automóveis usados importados é pelo menos igual a $90 \%$ do preço do automóvel novo, implica uma tributação discriminatória aos automóveis usados importados.

Temos um típico e recente exemplo de discriminação implícita que é, ao mesmo tempo, exemplo modelar de que, mesmo em se tratando de um imposto especial de consumo harmonizado em nível comunitário, tendo em vista a arquitetura da harmonização desses tributos, mesmo em dias de evoluída fase do processo de integração econômica, a soberania fiscal dos Estados-membros ainda se presta a criar impostos discriminatórios, iniciativas com as quais o Tribunal de Justiça permanece sempre alerta. Trata-se do 
processo C-302/00, Comissão das Comunidades Europeias contra República Francesa ${ }^{332}$. Uma ação de incumprimento, portanto.

Tem por objeto obter, por parte do TJCE, a declaração de que, ao manter em vigor um sistema que: i) impõe um preço de referência mínimo para os cigarros e, ii) impõe uma tributação diferenciada dos cigarros de tabaco escuro e de tabaco claro, em detrimento dos cigarros de tabaco claro; a República Francesa não cumpriu as obrigações que the incumbem quer por força do artigo $9^{\circ}, \mathrm{n}^{\circ} 1$, do artigo $8^{\circ}, \mathrm{n}^{\circ} 2$, e do artigo $16^{\circ}, \mathrm{n}^{\circ}$ 5, da Directiva 95/59/CE do Conselho, de 27 de novembro de 1995, relativa aos impostos que incidem sobre o consumo de tabacos manufacturados (JO L 291, p. 40), na redação que lhe foi dada pela Directiva 1999/81/CE do Conselho, de 29 de julho de 1999 (JO L 211, p. 47), e do artigo $2^{\circ}$ da Directiva 92/79/CEE do Conselho, de 19 de Outubro de 1992, relativa à aproximação dos impostos sobre os cigarros (JO L 316, p. 8), quer por força do artigo $95^{\circ}$, primeiro parágrafo, do Tratado CEE (que passou, após alteração, a artigo $90^{\circ}$, primeiro parágrafo, TCE), e, a título subsidiário, do segundo parágrafo deste artigo $90^{\circ}$.

Para nossa análise, nesse momento, só nos interessa a segunda acusação, uma vez que a primeira das infrações consiste em colidência com a disciplina de norma comunitária derivada, já que a manutenção em vigor de um sistema que impõe um preço de referência mínimo para todos os cigarros vendidos sob a mesma marca consiste em descumprimento às obrigações que incumbem à República Francesa por força do artigo $9^{\circ}$, $\mathrm{n}^{\circ} 1$, da Directiva $95 / 59^{333}$.

Como já sabemos, os tabacos manufacturados estão sujeitos a impostos específicos sobre o consumo, harmonizados a nível comunitário. A Directiva 95/59 define as diferentes categorias de produtos sujeitos aos impostos específicos, bem como as suas regras de cálculo. A Directiva 92/79 fixa uma alíquota mínima de imposto para cada categoria de produtos.

O artigo $8^{\circ}, \mathrm{n}^{\circ \mathrm{s}} 1$ e $2^{334}$, da Directiva 95/59 dispõe acerca da forma de cálculo do imposto, sob alíquota mista (parte ad valorem, parte específica), desde que as mesmas para todos os cigarros sobre os quais o imposto seja incidente.

\footnotetext{
${ }^{332}$ ECR 2002, I - 2077.

${ }^{333}$ Segundo a tradução oficial portuguesa:

"Artigo $9^{\circ}$

1. É considerada fabricante a pessoa singular ou colectiva estabelecida na Comunidade que transforma o tabaco em produtos manufacturados preparados para venda ao público.

2. Os fabricantes ou, se for caso disso, os seus representantes ou mandatários na Comunidade bem como os importadores de países terceiros determinam livremente os preços máximos de venda ao público de cada um dos seus produtos em cada Estado-Membro em que se destinam a ser consumidos".

${ }^{334}$ Segundo a tradução oficial portuguesa:
} 
Quanto às normas tributárias internas francesas, o artigo $37^{\circ}$ da Lei $\mathrm{n}^{\circ} 97-1269$, de 30 de dezembro de 1997, Lei de Finanças de 1998 (JORF de 31 de dezembro de 1997, p. 19261, aplicável a partir de 1 de janeiro de $1998^{335}$, introduziu algumas alterações nos artigos $572^{\circ}$ e seguintes do Côde Géneral des Impôts. Em particular, o artigo $37^{\circ}, \mathrm{n}^{\circ} 3$, da lei de finanças de 1998 substituiu o artigo $575^{\circ}$-A, último parágrafo, do Côde Géneral des Impôts por três parágrafos ${ }^{336}$ que criavam uma tributação diferenciada, mais onerosa, para os cigarros de tabaco escuro, segundo sua definição.

Inicialmente, o TJCE declarou que que os cigarros de tabaco escuro e os cigarros de tabaco claro são fabricados a partir de diferentes tipos do mesmo produto de base, o tabaco, segundo processos comparáveis. Ponderou que, embora as características organolépticas dos cigarros escuros e dos cigarros claros, da mesma forma que o seu gosto e o seu cheiro, não sejam idênticos, são, no entanto, similares. Ademais, como resulta do próprio artigo $575^{\circ}$-A do Côde Géneral des Impôts alterado, a diferença entre os cigarros de tabaco escuro e os cigarros de tabaco claro foi entendida como muito relativa. Nos termos desta disposição, os cigarros que contêm pelo menos $60 \%$ de certos tipos de tabaco são considerados cigarros de tabaco escuro ao passo que todos os outros cigarros são considerados cigarros de tabaco claro. Para além disso, os dois tipos de produtos podem corresponder, dadas as suas propriedades similares, às mesmas necessidades dos consumidores, na medida em que se destinam ao consumo de tabaco sob a forma típica de cigarros, ou seja, rolos de tabaco prefabricados enrolados em folhas de papel. Esta conclusão não pode ser posta em dúvida pelo fato de a idade média dos consumidores de cigarros escuros ser claramente mais elevada do que a idade média dos consumidores de cigarros claros.

\footnotetext{
"Artigo $8^{\circ}$

1. Os cigarros fabricados na Comunidade e os importados de países terceiros serão sujeitos em cada EstadoMembro a um imposto proporcional calculado sobre o preço máximo de venda a retalho, incluindo os direitos aduaneiros, e a um imposto específico calculado por unidade de produto.

2. A taxa do imposto proporcional e o montante do imposto específico devem ser os mesmos para todos os cigarros."

${ }^{335}$ Como se vê, na França, também as leis veiculadoras de normas tributárias majoradoras de tributos costumam ser promulgadas e publicadas no último dia do ano, para vigerem a partir do dia seguinte. Não é provilégio, portanto, da república brasileira.

${ }^{336}$ Segundo a tradução oficial portuguesa:

"O imposto mínimo mencionado no artigo $575^{\circ}$ é fixado em $500 \mathrm{~F}$ para os cigarros. Todavia, para os cigarros de tabaco escuro, este imposto mínimo é fixado em $400 \mathrm{~F}$, e em $420 \mathrm{~F}$ a partir de 1 de Janeiro de 1999.

É fixado em $230 \mathrm{~F}$ para o tabaco de corte fino destinado a enrolar os cigarros.

São considerados cigarros de tabaco escuro os cigarros cuja composição em tabaco natural compreenda um mínimo de 60\% de tabacos pertencentes aos códigos NC 2401 10 41, 240110 70, 24012041 ou 24012070 da pauta aduaneira".
} 
O TJCE vislumbrou um argumento complementar no fato de que a semelhança dos cigarros de tabaco escuro e dos cigarros de tabaco claro é reconhecida pelo legislador comunitário que, nas Directivas 95/59 e 92/79, prevê um tratamento fiscal uniforme para todos os cigarros, e os cigarros de tabaco claro e os de tabaco escuro relevam também da mesma subposição da nomenclatura combinada que consta do Anexo I do Regulamento (CEE) $n^{\circ} 2658 / 87$ do Conselho, de 23 de Julho de 1987, relativo à nomenclatura pautal e estatística e à pauta aduaneira comum (JO L 256, p. 1).

Estando, assim, assente a semelhança dos dois produtos em questão na acepção do artigo $95^{\circ}$, primeiro parágrafo, do Tratado, o TJCE passou a averiguar se o artigo $575^{\circ}$ A do Côde Géneral des Impôts alterado apresenta caráter discriminatório, na medida em que fixa um mínimo de cobrança do imposto de consumo mais elevado para os cigarros de tabaco claro, que são essencialmente produtos importados, do que para os cigarros de tabaco escuro, que são quase exclusivamente fabricados na França.

O TJCE entendeu que, embora o artigo $575^{\circ}-\mathrm{A}$, na sua nova redação, não estabelecesse qualquer distinção formal segundo a origem dos produtos, organizou um sistema de tributação de tal maneira que os cigarros abrangidos pela categoria fiscal mais vantajosa provinham quase exclusivamente da produção nacional ao passo que a quase totalidade dos produtos importados era abrangida pela categoria menos favorável. Estas características do sistema não foram anuladas, no entender do Tribunal, pelo fato de uma fração mínima dos cigarros importados estar incluída na categoria mais beneficiada, ao passo que, pelo contrário, uma certa proporção da produção nacional está abrangida pela mesma categoria que os cigarros importados.

Segundo a conclusão do Tribunal, verificou-se, portanto, que o sistema de tributação estava concebido de tal forma que aproveitava a uma produção nacional típica e desfavorecia na mesma medida os cigarros importados (v., neste sentido, o acórdão de 27 de fevereiro de 1980, Comissão/Dinamarca, 171/88, Recueil, p. 447, n. ${ }^{\circ} 36$ ).

Ao final, para concluir a análise dos critérios relacionados à apreciação da existência do caráter discriminatório implícito de uma norma tributária, é relevante mencionar que uma importante diferença entre as disciplinas da primeira e da segunda frases do art. $110^{\circ}$ do TUE é o fato de que o Tribunal de Justiça tem sido remansoso em afirmar que, para a discriminação implícita, é possível a apreciação da defesa baseada no dano irrisório, o que a doutrina internacional, como Ortino (2004, p. 296) nomeia como “de minimis exception”. É um corolário, em verdade, da própria arquitetura do sistema, na medida em que o efeito protetivo, como algo efetivo, aferível no mercado consumidor do 
país importador, deve se revestir de relevância quantitativa a fim de ser economicamente consistente.

Como exemplo dessa aplicação, cujo acórdão é extremamente didático em esclarecer tal relação, lapidar é o processo 356/85, Comissão das Comunidades Europeias contra Reino da Bélgica ${ }^{337}$.

Nos termos do Decreto Real n. ${ }^{\circ} 20$, de 20 de Julho de 1970, que fixa a alíquota do imposto sobre o valor acrescentado e determina a repartição dos bens e serviços segundo essa alíquota (Moniteur belge de 31.7.1970), com as modificações que lhe foram introduzidas pelos decretos reais de 25 de Março de 1977 (Moniteur belge de 26.3.1977) e de 16 de Novembro de 1982 (Moniteur belge de 20 de Novembro de 1982), o Reino da Bélgica aplicava ao fornecimento de algumas bebidas destinadas ao consumo doméstico, e especialmente aos vinhos de uvas frescas, uma alíquota de IVA de $25 \%$. Em contrapartida, a alíquota de IVA aplicável à cerveja era de $19 \%$.

O Reino da Bélgica não era então produtor de vinho, mas dispunha de uma importante produção nacional de cerveja. Assim, afigurava-se evidente que a carga fiscal mais pesada era suportada pelo produto para o qual a procura interna é, na sua quase totalidade, satisfeita por importações, ao passo que o produto de que existia importante fabrico nacional suportava a carga mais leve.

O Tribunal, mais uma vez, ponderou que o artigo $95^{\circ}$ do Tratado CEE, no seu conjunto, tem por objetivo assegurar a livre circulação das mercadorias entre os Estadosmembros em condições normais de concorrência, através da eliminação de todas as formas de proteção que possam resultar da aplicação de imposições internas discriminatórias em relação a produtos dos outros Estados-membros e garantir a perfeita neutralidade das imposições internas relativamente à concorrência entre produtos nacionais e importados.

Nesta perspectiva, o segundo parágrafo do artigo citado tem mais precisamente por função abranger qualquer forma de protecionismo fiscal indireto no caso de produtos importados que, sem serem similares, na acepção do primeiro parágrafo, aos produtos nacionais, estão, apesar disso, numa relação de concorrência, ainda que parcial, indireta ou potencial, com alguns deles.

Repetiu a consideração que, enquanto o critério de apreciação referido no primeiro parágrafo consiste na comparação dos encargos fiscais, quer em função da alíquota, das condições da matéria tributável ou de outras modalidades de aplicação, o

${ }^{337}$ ECR 1987, 3299. 
segundo parágrafo, tendo em consideração a dificuldade de estabelecer comparações suficientemente precisas entre os produtos em causa, reporta-se a um critério mais global, ou seja, o caráter protetor de um sistema de imposições internas.

Concluiu-se daí que a apreciação da compatibilidade de um determinado encargo fiscal com o segundo parágrafo do artigo $95^{\circ}$ deve fazer-se em relação à incidência desse encargo fiscal nas relações de concorrência entre os produtos considerados. Assim, a questão essencial, como afirmado pelo Tribunal, é a de saber se esse encargo fiscal é ou não suscetível de influenciar o mercado em causa ao diminuir o consumo potencial dos produtos importados em proveito dos produtos nacionais concorrentes.

Tendo em consideração as grandes diferenças de qualidade e, portanto, de preços entre os vinhos, a relação de concorrência determinante, para efeitos da aplicação do segundo parágrafo do artigo $95^{\circ}$ do Tratado, entre a cerveja, bebida popular e largamente consumida, e o vinho deve ser estabelecida com os vinhos mais acessíveis ao grande público que são, em geral, os mais leves e os menos caros, e é, pois, nesta base que convém fazer as comparações fiscais. Por conseguinte, apenas os vinhos de consumo corrente que são, em geral, vinhos baratos, apresentam suficientes propriedades em comum com a cerveja para constituírem uma alternativa de escolha para o consumidor e podem, portanto, ser considerados numa relação de concorrência com a cerveja, na acepção da disposição atrás citada.

Para o Tribunal, um sistema fiscal nacional, que onere os vinhos de uvas frescas provenientes dos outros Estados-membros com uma alíquota do imposto sobre o valor acrescentado mais elevada do que aquela que onera a cerveja de produção nacional, não é incompatível com o segundo parágrafo do artigo $95^{\circ}$ do Tratado na medida em que, por um lado, a diferença entre os preços de venda respectivos do vinho e da cerveja de qualidade comparável é de tal modo importante que a diferença entre as alíquotas do imposto para os dois produtos não é suscetível de influenciar o comportamento do consumidor e, por outro, a realidade de um efeito protetor não resulta também dos dados estatísticos relativos à evolução comparada do consumo de vinho, por um lado, e de cerveja, por outro, no Estado-membro em questão.

Com efeito, o Tribunal reconheceu que a Comissão não demonstrou numericamente que a diferença entre os preços da cerveja e do vinho de qualidades comparáveis seja de tal modo importante que a diferença de $6 \%$ existente entre a alíquota de IVA para os dois produtos fosse apta susceptível de influenciar o comportamento do 
consumidor. Assim, em verdade, a Comissão não demonstrou a existência de um efeito protetor resultante desta diferença em favor da cerveja destinada ao consumo doméstico.

A existência de um efeito protetor não resultou igualmente de dados numéricos, apresentados pela Comissão, relativos à evolução comparativa do consumo da cerveja e do vinho. A este respeito, a Comissão indicou que o consumo de cerveja na Bélgica atingiu o seu máximo em 1973 tendo vindo a baixar desde então. Em contrapartida, o consumo de vinho triplicou no decorrer dos últimos vinte anos até 1987; todavia, desde mais ou menos 1980, o aumento do consumo abrandou para atingir uma estabilização em 1982 e 1983.

O Tribunal terminou por considerar que, se estes números salientam a tendência geral do consumo dos produtos considerados, não permitem estabelecer com segurança que exista um nexo de causalidade entre as evoluções descritas e a criação, em 1977, de uma alíquota de IVA mais elevada para o vinho. Por conseguinte, a Comissão não pode invocálos validamente para apoiar a tese de que o aumento progressivo do consumo do vinho foi travado e, finalmente, parou precisamente devido à introdução de uma alíquota de IVA mais elevada para o vinho. Aliás, esta tese não pareceu ao Tribunal condizer com o fato, salientado pelo Governo belga e não contestado pela Comissão, de que, entre 1978 e 1983, a alíquota de IVA aplicável à cerveja foi aumentada por três vezes, sem que essas modificações de alíquota tenham provocado, a médio prazo, um efeito restritivo no consumo da cerveja, em benefício do vinho.

Comentando esse julgado, Federico Ortino (2004, p. 296) afirma que essa didática consideração jurisprudencial demonstra que a dieferença entre os dois parágrafos é mais de grau do que de essência. Quanto mais fraca a relação de similitude entre os produtos analisados, maior o esforço que o autor - a Comissão Europeia, no caso das ações de incumprimento - deverá empreender para caracterizar o tratamento diferenciado entre os produtos nacional e importado e o efeito protetivo à produção nacional. Se os bens em questão são idênticos, qualquer diferença na determinação ou na exigência do respectivo crédito tributário será apto a caracterizar um tratamento discriminatório. Ao contrário, se as relações de concorrência entre eles é apenas parcial, a caracterização do efeito protetivo demandará relevante identificação do dano efetivo à importação do produto alienígena pela norma tributária discriminatória. 


\subsection{Das Exceções ao Princípio de Não-Discriminação}

\section{Tributária.}

Como se viu no item anterior, tem sido comum o Tribunal de Justiça considerar as políticas públicas que motivaram a exação fiscal diferenciada no exame de seu caráter protetivo ou não.

Porém, qual a base convencional comunitária para isso?

Contrariamente à obrigação do Tratamento Nacional presente no Art. III do GATT, para o qual há expresso rol de exceções, gerais e especiais, o sistema de vedação à discriminação tributária da União Europeia, representado pelo artigo $110^{\circ}$ do Tratado sobre o Funcionamento da União Europeia, não apresenta nenhuma expressa norma justificadora.

As razões de moralidade pública, ordem pública e segurança pública; de protecção da saúde e da vida das pessoas e animais ou de preservação das plantas; de proteção do patrimônio nacional de valor artístico, histórico ou arqueológico; ou de proteção da propriedade industrial e comercial, previstas no atual art. $36^{\circ}$ do Tratado sobre o Funcionamento da União Europeia ${ }^{338}$, ex-artigo $30^{\circ}$ do Tratado que institui a Comunidade Europeia, ainda antes artigo $36^{\circ}$ do Tratado que institui a Comunidade Econômica Europeia, são apenas excepcionadores dos direitos nacionais à imposição de restrições quantitativas à entrada de produtos estrangeiros.

No entanto, a doutrina, em especial Joseph Weiler (1999, p. 365), com suporte na jurisprudência do Tribunal de Justiça das Comunidades Europeias, admite que tem sido reconhecida uma cláusula de derrogação de fato das obrigações fiscais nãodiscriminatórias, tanto da primeira frase quanto da segunda, com base em políticas públicas justificadoras - o que denomina de "doctrine of mandatory requirements".

Como visto anteriormente, desde casos como o processo 140/79, Chemial Farmaceutice SpA. contra DAF SPA., segundo Joseph Weiler (1999, p. 365 - 366), o primeiro caso, juntamente com o seu análogo, Vinal $S p A$. contra Orbat $S p A .^{339}$, em que se admitiu essa possibilidade, o Tribunal tem constantemente reconhecido a liberdade de cada

\footnotetext{
338 “Artigo $36^{\circ}$

(ex-artigo $\left.30^{\circ} \mathrm{TCE}\right)$

As disposições dos artigos $34^{\circ}$ e $35^{\circ}$ são aplicáveis sem prejuízo das proibições ou restrições à importação, exportação ou trânsito justificadas por razões de moralidade pública, ordem pública e segurança pública; de protecção da saúde e da vida das pessoas e animais ou de preservação das plantas; de protecção do património nacional de valor artístico, histórico ou arqueológico; ou de protecção da propriedade industrial e comercial. Todavia, tais proibições ou restrições não devem constituir nem um meio de discriminação arbitrária nem qualquer restrição dissimulada ao comércio entre os Estados-Membros".

${ }^{339}$ ECR 1981, 77.
} 
Estado-membro estabelecer um sistema de tributação diferenciada para alguns produtos, em função de critérios objetivos, desde que tais diferenciações sejam compatíveis com o direito comunitário e persigam objetivos de política econômica compatíveis. No caso em concreto, o regime tributário diferenciado italiano tinha por fim um objetivo público legítimo, o de favorecer o uso de matérias-primas renováveis, com o fim de evitar a utilização de matérias-primas derivadas do petróleo.

Comentando o precedente italiano, Paul Craig e Gráinne de Búrca (2003, p. 596) afirmam que a intenção do Tribunal, ao criar esse entendimento, seria o de evitar que um artigo importante como o atual art. $110^{\circ}$, do TUE, fosse se tornar muito rigoroso ou draconiano com os Estados-membros, o que comprometeria em demasia as soberanias fiscais nacionais.

Porém, tais objetivos também devem ser compatíveis com as exigências do Tratado e do direito derivado, devendo ser implementados de forma a evitar toda a espécie de discriminação, direta ou indireta, em relação às importações provenientes dos outros Estados-membros, ou de protecionismo em favor de produtos nacionais concorrentes. Por isso, segundo Federico Ortino (2004, p. 298 - 299), haveria, no balanço entre o Princípio de Não-discriminação e a justificativa de interesse público, um claro viés tendencioso a conferir maior peso ao princípio.

Porém, há uma questão fulcral; qual seja, a de identificar quais seriam os limites entre uma situação e a outra. Quando um objetivo público, aparentemente legítimo, colide efetivamente com os princípios do direito comunitário, em particular o mais importante deles, o de não discriminação? Trata-se de mais uma pergunta com complexa resposta, quase sempre impossível de ser dada em tese, exigindo a análise da casuística aplicável.

Por vezes é fácil identificar os argumentos inválidos. Veja-se, por exemplo, o processo C-327/90, Comissão das Comunidades Europeias contra a República Helênica ${ }^{340}$. Trata-se de ação por incumprimento tendo por objeto a declaração de que, ao estabelecer regras diferentes para a apuração da base de cálculo do imposto especial de consumo incidente sobre os automóveis, sejam importados dos outros Estados-membros ou fabricados na Grécia, a República Helênica não cumpriu as obrigações que lhe incumbem por força do artigo $95^{\circ}$ do Tratado CEE.

A Lei $n^{\circ} 363$, de 22 de Junho de 1976, completada e alterada pelas Leis $\mathrm{n}^{\text {os }}$ 1.003/1979 e 1.591/1986, criou na Grécia um imposto especial de consumo sobre os

\footnotetext{
${ }^{340}$ ECR 1992, I - 3051.
} 
automóveis particulares, quer sejam importados quer sejam montados no interior do país. Nos termos do artigo $1^{\circ}, \mathrm{n}^{\circ} 3$, desta lei, a base de cálculo do imposto especial sobre os automóveis importados é determinada pela soma do preço líquido no atacado do automóvel à saída da fábrica, acrescido do preço de eventuais opcionais e somado a um acréscimo de $21 \%$ da soma dos elementos anteriores quando os automóveis são comprados diretamente ao construtor e o comprador seja concessionário exclusivo, distribuidor ou comerciante de automóveis. Relativamente às outras importações de automóveis, a percentagem do acréscimo é fixada em 23,2 \%. Em ambos os casos ainda há um acréscimo de $7 \%$ correspondente às despesas de seguro e importação do automóvel. Relativamente aos automóveis provenientes de países ultramarinos, esta percentagem total é fixada em $25 \%$.

Quanto aos automóveis montados na Grécia, o artigo $4^{\circ}, \mathrm{n}^{\circ} 2$, da Lei ${ }^{\circ} 1.573$, de 19 e 27 de Novembro de 1985, prevê, por um lado, que a base de cálculo do imposto é calculada a partir do preço ex factory (à saída da fábrica), indicado no catálogo apresentado pela indústria automóvel ao comité encarregado do controle dos preços, e esclarece, por outro lado, que os encargos fiscais de qualquer natureza incorporados no preço de compra não constituem fatores adicionais do preço do automóvel.

Inicialmente, recordou-se que, segundo a jurisprudência do Tribunal de Justiça, devem ser tomados em consideração, para aplicação do artigo $95^{\circ}$ do Tratado, não apenas a taxa do imposto interno que incide direta ou indiretamente sobre os produtos nacionais e importados, mas também a base de cálculo e as modalidades de cobrança do imposto em questão (v., quanto a este ponto, o acórdão de 27 de Fevereiro de 1980, Comissão/Irlanda, $\mathrm{n}^{\circ} 8,55 / 79$, Recueil, p. 481).

Além disso, o Tribunal também reforçou que foi decidido em diversas ocasiões que se verifica violação do artigo $95^{\circ}$, primeiro parágrafo, sempre que a imposição que incide sobre o produto importado e a que incide sobre o produto nacional similar sejam calculadas de forma diferente e segundo modalidades diferentes, que conduzam, ainda que apenas em certos casos, a uma imposição superior do produto importado (v., nomeadamente, acórdão de 17 de Fevereiro de 1976, Rewe-Zentrale, n 15, 45/75, Recueil, p. 181).

No caso do processo, tentou-se verificar se o sistema de cálculo da matéria tributável do imposto instituído pela legislação controvertida, evidentemente mais oneroso aos automóveis importados, podia ser excluído de alguma forma de qualquer risco de discriminação.

Analisando o argumento, trazido pelo Governo grego, que consiste em justificar 
o acréscimo de $21 \%$ ou $23,2 \%$ pela necessidade de restabelecer a igualdade com os construtores nacionais, que tomam a seu cargo as despesas de comercialização dos automóveis que produzem, asseverou-se que as despesas de comercialização estão frequentemente incluídas, pelo menos em parte, no preço à saída de fábrica dos automóveis importados.

Em seguida observou-se que, tal como resultou dos autos, o acréscimo fixo de $21 \%$ ou $23,2 \%$ foi determinado com base numa média, por sua vez estabelecida a partir de balanços de sociedades. Essa avaliação, em virtude do seu caráter fixo, segundo o Tribunal, não permite garantir que o produto importado não seja em caso algum sujeito a uma imposição fiscal superior à imposição do produto nacional correspondente.

Quanto ao acréscimo de $7 \%$ destinado a cobrir as despesas de transporte e seguro, observou-se que, embora as despesas de seguro sejam susceptíveis de variar em função do valor do produto, as despesas de transporte, pelo seu lado, variam mais em função do peso, das dimensões e do trajeto percorrido.

Finalmente, entendeu-se que, no caso de um sistema que, como a lei controvertida, contém regras diferentes para os produtos nacionais e para os produtos importados dos outros Estados-membros e que se caracteriza por uma falta de transparência e de precisão, compete ao Governo demandado produzir a prova de que o sistema impugnado pela Comissão não pode em caso algum ter efeitos discriminatórios (v. quanto a este ponto os acórdãos de 26 de Junho de 1991, Comissão/Luxemburgo, C152/89, Colect., p. 1-3141; e Comissão/Bélgica, C-153/89, Colect., p. 1-3171).

Ademais, a aplicação de artigo segundo o qual "a base de cálculo do imposto sobre os automóveis fabricados na Grécia não pode ser inferior ao valor mínimo admitido pelo comitê para os veículos importados de cilindrada correspondente ou similar" conduz, segundo o Tribunal, com efeito, a que, se vários modelos de marcas diferentes duma mesma cilindrada forem importados, os automóveis fabricados na Grécia sejam tributados não como os automóveis importados cuja base é a mais elevada, mas como os que são submetidos ao tratamento mais favorável.

Finalmente, o Tribunal de Justiça respondeu ao Governo grego, que argumentou que o sistema de tributação fixo pretende desencorajar os comportamentos fraudulentos a que as importações de automóveis particulares podem dar lugar, em virtude da alíquota elevada de imposto, que, de acordo com a jurisprudência do Tribunal de Justiça, a impossibilidade de proceder aos controles e verificações necessários dos automóveis importados não pode constituir uma justificação válida para a instituição dum 
sistema de tributação fixo apenas aplicável aos automóveis importados (v. o acórdão de 17 de Fevereiro de 1976, Rewe-Zentrale, já referido, ${ }^{\circ}$ 15).

O Advogado-Geral, Giuseppe Tesauro, nas suas conclusões ${ }^{341}$, entendeu que não vislumbrava claramente por que razão não é possível evitar os riscos de subfaturamento utilizando sistemas de cálculo da matéria tributável não discriminatórios, baseadas, por exemplo, no preço de catálogo, como fazem outros países que cobram imposições especiais sobre o consumo similares.

Comentando o caso, Federico Ortino (2004, p. 143 - 144) afirma que se trata de um teste de medida menos restritiva, ou necessária, em moldes análogos ao entendimento do OSC da OMC quanto ao Artigo XX do GATT. Mais do que isso, vislumbrou, nos argumentos do governo grego, uma tentativa de justificar o tratamento diferenciado como não discriminatório na medida em que tencionava assegurar uma igualdade substancial entre os agentes econômicos envolvidos no mercado distribuidor de automóveis na Grécia. Para ele, a recusa do Tribunal em acatar tais argumentos é precedente marcante na matéria.

Vale dizer, o que se pode concluir do exame minucioso do caso e da análise doutrinária a respeito é que a norma tributária não se presta a prover eventual correção de distorções concorrenciais, que sejam externas ao sistema tributário, sem que seja provado pelo interessado que, eventualmente, não imponha tratamento desfavorável ao produto importado.

Indo mais além, Ortino (p. 145) afirma que esse acórdão afastou definitivamente a possibilidade de manejo de argumentos baseados no que denominou de “justificações internas" - aquelas baseadas em considerações resultantes de falhas do próprio sistema tributário do país importador, como dificuldades na apuração da matéria de fato tributável no exterior ou necessidades de coibir a evasão fiscal.

No entanto, tal critério é gerador de discutível segurança jurídica. Diferentemente do sistema GATT/OMC, que possui listagem exaustiva dos motivos justificadores para que a norma proibidora seja excepcionada, o mesmo ocorrendo para a norma relacionada às restrições quantitativas do art. $36^{\circ}$ do TUE, como sabermos quais são essas justificações externas cabíveis?

A questão é complexa, uma vez que, mesmo as justificativas externas potencialmente legítimas, deverão, para consistirem motivo apto a descaracterizar o viés discriminatório, ser fundadas em procedimentos investigatórios e em fatos que confirmem

${ }^{341}$ ECR 1992, I - 3045. 
as suas premissas. Em especial, que comprovem a ausência de caráter discriminatório na sua efetiva aplicação.

Exemplo significativo dessa realidade é o processo C-375/95, Comissão das Comunidades Europeias contra República Helênica. Como já visto, a sua terceira acusação referia-se à previsão de benefícios fiscais (redução do imposto especial sobre o consumo) apenas a favor dos veículos novos com tecnologia antipoluição e não para os veículos usados importados com a mesma ou análoga tecnologia.

O Tribunal iniciou a análise desse ponto afirmando que um Estado-Membro não pode, sem infringir a regra da não discriminação constante do artigo $95^{\circ}$ do Tratado, conferir vantagens fiscais aos automóveis menos poluentes ao mesmo tempo que recusa conceder essas vantagens aos veículos provenientes de outros Estados-Membros que satisfazem, no entanto, às mesmas exigências que os veículos nacionais beneficiários.

Lembrou que o Governo helênico invocou, porém, uma declaração inscrita na ata de uma reunião do Conselho de Ministros do Ambiente, de 20 e 21 de Dezembro de 1990, pela qual a Comissão teria reconhecido os problemas particulares de poluição com que se defronta a República Helênica e teria admitido as medidas fiscais controvertidas destinadas a favorecer a aquisição de veículos novos e menos poluentes.

Ainda assim, sendo a preservação da saúde e da vida das pessoas claro objetivo legítimo até previsto tanto no art. XX do GATT/47 quanto no atual art. $36^{\circ}$ do TUE, o Tribunal assinalou que uma declaração desse tipo não é suscetível de afetar o alcance de uma disposição do Tratado e que a Comissão não pode dar a um Estado-Membro garantias sobre a compatibilidade com o Tratado de uma legislação fiscal nacional, competência do Tribunal de Justiça. De qualquer modo, o Tribunal ponderou que, na referida declaração, a Comissão fez expressamente depender a sua aprovação das medidas nacionais em causa da condição de observância das regras do Tratado, designadamente da proibição de qualquer discriminação entre veículos nacionais e veículos importados.

Em réplica, o Governo helênico alegou igualmente que a aplicação aos veículos usados importados das alíquotas reduzidas do imposto especial sobre o consumo exigiria que se procedesse a um controle técnico individual desses veículos quando da importação e que a instituição desse controle se defrontaria, então, com sérias dificuldades práticas.

Quanto a isso, o Tribunal sublinhou que, mesmo admitindo que a existência dessas dificuldades tivesse sido demonstrada, elas não poderiam justificar a aplicação de imposições fiscais internas discriminatórias em relação a produtos originários de outros Estados-Membros, em contradição com o disposto no artigo $95 .^{\circ}$ do Tratado (v., neste 
sentido, os acórdãos de 12 de Maio de 1992, Comissão/Grécia, n 24, e Nunes Tadeu, n. ${ }^{\circ}$ 19, já referidos).

Outros dois julgados referentes à amplitude que se pode conferir ao legítimo objetivo de proteção à vida e à saúde das pessoas são os processos apensos, julgados em conjunto $^{342}$, C-290/05, Ákos Nádasdi contra Vám- és Pénzügyőrség Észak-Alföldi Regionális Parancsnoksága (comando da guarda alfandegária e financeira da região de Észak-Alföld) e C-333/05, Ilona Németh contra Vám- és Pénzügyőrség Dél-Alföldi Regionális Parancsnoksága (comando da guarda alfandegária e financeira da região de Dél-Alföld), ambos pedidos de decisão prejudicial nos termos do artigo $234^{\circ} \mathrm{CE}$, ajuizados em cortes da República da Hungria e remetidos ao Tribunal de Justiça. Referem-se ao imposto automóvel a que os autores, cidadãos húngaros, foram sujeitos quando matricularam na Hungria veículos automóveis usados comprados na Alemanha, por conta da Lei n CX de 2003 (a regisztrációs adóról szóló 2003. évi CX. Törvény - "lei relativa ao imposto automóvel").

Tal norma previa que o imposto automóvel seria devido por todas as viaturas ligeiras de passageiros destinadas a ser postas em circulação no território da República da Hungria. A colocação em circulação implica uma primeira matrícula da viatura ligeira de passageiros em território nacional. Caso a colocação em circulação fosse consequência direta da importação da viatura ligeira de passageiros, o importador também estaria sujeito ao imposto. O montante do imposto era determinado no anexo da lei para as diferentes categorias de viaturas ligeiras de passageiros, em função da sua classificação ambiental.

Entre as diversas questões prejudiciais suscitadas, algumas referiam-se à caracterização do imposto automóvel magiar como encargo de efeito equivalente aos impostos de importação, a colidir com os pilares constitutivos da livre circulação de mercadorias e da união aduaneira, os atuais arts. $28^{\circ}$ e $30^{\circ}$, no TUE, ex-artigos $23^{\circ}$ e $25^{\circ}$ do TCE, sucessores dos arts. $9^{\circ}$ e $12^{\circ}$ do TCEE, esse último ainda meramente como cláusula de standstill. No entanto, a matéria não é nosso objeto de estudo. Não obstante, apenas com fins didáticos, deve-se apontar que o Tribunal entendeu que, como o imposto como o instituído pela lei relativa ao imposto automóvel não é cobrado devido à passagem da fronteira do Estado-Membro que aplica este imposto, mas quando do registro do veículo no território deste Estado com vista à sua colocação em circulação, faz parte do regime geral de imposições internas aplicadas às mercadorias e deve, por este motivo, ser apreciado à

\footnotetext{
${ }^{342}$ ECR 2005, I - 10155.
} 
luz do artigo $90^{\circ}$, TCE - não constitui, portanto, um direito aduaneiro de importação ou um encargo de efeito equivalente, na acepção dos artigos $23^{\circ}$, TCE e $25^{\circ}$, TCE.

No que nos toca examinar, o Tribunal de Justiça, então das Comunidades Europeias, foi instado a se pronunciar se: i) o artigo $90^{\circ}$, primeiro parágrafo, TCE, permite aos Estados-Membros manter em vigor um imposto sobre os veículos automóveis usados provenientes de outros Estados-Membros, que não tem absolutamente em conta o valor do veículo e cujo montante é determinado exclusivamente com base nas características técnicas dos automóveis (tipo de motor, cilindrada) e numa classificação em função de considerações ambientais? e ii) no estado atual do direito comunitário, um imposto de um Estado Membro, como o imposto automóvel húngaro, é compatível com as disposições do direito comunitário quando o montante do imposto automóvel tributado sobre os veículos ligeiros de passageiros novos e usados - sem ter em conta a classificação dos veículos em função de considerações ambientais - é idêntico, não reflete de nenhum modo a desvalorização dos veículos usados e não tem em consideração a data em que o automóvel foi colocado em circulação nem o período de tempo que esteve em circulação (legal)?

Respondendo às indagações, o Tribunal ponderou, inicialmente, que como já foi decidido anteriormente, o artigo $90^{\circ} \mathrm{CE}$ constitui, no sistema do Tratado da CE, um complemento das disposições relativas à supressão dos direitos aduaneiros e dos encargos de efeito equivalente. Essa disposição teria por objetivo assegurar a livre circulação de mercadorias entre os Estados-Membros em condições normais de concorrência, através da eliminação de qualquer forma de proteção que possa resultar da aplicação de imposições internas discriminatórias relativamente a produtos originários de outros Estados-Membros (acórdão de 15 de Junho de 2006, Air Liquide Industries Belgium, C-393/04 e C-41/05, Colect., p. I-5293, $n^{\circ} 55$ e a jurisprudência aí referida).

Continuando, afirma que, em matéria de tributação de veículos automóveis usados importados, o Tribunal de Justiça considerou igualmente que o artigo $90^{\circ} \mathrm{CE}$ visa a garantir a perfeita neutralidade das imposições internas no que se refere à concorrência entre os produtos que já se encontram no mercado nacional e os produtos importados (v. acórdão Weigel, C-387/01, Colect., p. I-4981, nº 66 e a jurisprudência aí referida).

Declara o acórdão que, nos termos de jurisprudência bem assente, haveria violação ao artigo $90^{\circ}$, primeiro parágrafo, TCE, sempre que a imposição que incide sobre o produto importado e a que incide sobre o produto nacional similar são calculadas de forma diferente e segundo modalidades diferentes que conduzam, ainda que apenas em certos casos, a uma tributação superior do produto importado (v. acórdão Weigel, já 
referido, $n^{\circ} 67$ e a jurisprudência aí referida). Contudo, mesmo que não estejam reunidas as condições de uma discriminação direta dessa natureza, uma imposição pode ser indiretamente discriminatória em razão dos seus efeitos.

Fundamentalmente, afirma o Tribunal de Justiça que, a fim de garantir a neutralidade das imposições internas relativamente à concorrência entre os veículos automóveis usados que já se encontram no mercado nacional e os veículos similares importados, há que comparar os efeitos do imposto automóvel que incide sobre os veículos usados recentemente importados a partir de um Estado-Membro diferente da República da Hungria com os do imposto automóvel residual que onera os veículos usados similares registados na Hungria e que, por esse fato, já foram sujeitos ao mesmo imposto.

Novamente o Tribunal de Justiça afirmou que o direito comunitário não limita a liberdade de cada Estado-Membro estabelecer um sistema de tributação diferenciado para certos produtos, ainda que similares, na acepção do artigo $90^{\circ}$, primeiro parágrafo, TCE, em função de critérios objetivos, como sejam a natureza das matérias-primas utilizadas ou os processos de produção aplicados.

Contudo, para o Tribunal, novamente, tais diferenciações só são compatíveis com o direito comunitário se perseguirem objetivos compatíveis, também eles, com as exigências do Tratado e do direito derivado e se as suas modalidades forem de molde a evitar qualquer forma de discriminação, direta ou indireta, das importações provenientes dos outros Estados-Membros, ou de proteção em favor de produções nacionais concorrentes (acórdão Outokumpu, de 2 de Abril de 1998, C-213/96, Colect., p. I - 1777, nº 20).

Entendeu o acórdão que, no âmbito de um regime relativo ao imposto automóvel, critérios como o tipo de motor, a cilindrada e uma classificação assente em considerações ambientais constituem critérios objetivos, que podem ser utilizados num regime desses. Não é exigível que o montante do imposto esteja relacionado com o preço do veículo, segundo o Tribunal de Justiça.

Contudo, é definitivo que um imposto automóvel não deve onerar mais os produtos provenientes de outros Estados-Membros do que os produtos nacionais similares. Como um veículo novo relativamente ao qual o imposto automóvel foi pago na Hungria perde, com o decorrer do tempo, uma parte do seu valor de mercado, diminui, na mesma medida, o montante do imposto automóvel compreendido no valor residual do veículo. Sendo um veículo usado, só pode ser vendido por uma percentagem do valor inicial, percentagem essa que engloba o montante residual do imposto automóvel. 
Porém, concluiu-se dos autos remetidos ao Tribunal de Justiça pelos órgãos jurisdicionais de reenvio que um veículo do mesmo modelo e de antiguidade, quilometragem e outras características idênticas, comprado em segunda mão noutro Estado-Membro e registado na Hungria, será, contudo, sujeito a $100 \%$ do imposto automóvel aplicável a um veículo dessa categoria. Por conseguinte, o referido imposto onera mais os veículos usados importados do que os veículos usados similares já registados na Hungria e sujeitos ao mesmo imposto.

Em conclusão, não obstante o caráter ambiental do objetivo e do fundamento do imposto automóvel e mesmo não tendo estes qualquer relação com o valor de mercado do veículo, o Tribunal de Justiça entendeu que o artigo $90^{\circ}$, primeiro parágrafo, TCE, exige que seja tida em conta a depreciação dos veículos usados que são objeto de tributação, visto que esse imposto se caracteriza por ser apenas cobrado uma vez quando do primeiro registro do veículo para efeitos da sua utilização no Estado-Membro em causa e por ser desta forma incorporado no referido valor.

A par da estranheza que tal julgado pode nos trazer, na medida em que admite que um legítimo objetivo de interesse público, como, no caso, a vida e a saúde das pessoas, com o fim de reduzir a poluição ambiental, pode vir até a preponderar sobre a capacidade contributiva, representada pelo valor venal do veículo, fato é que reiterou-se, mais uma vez, a proeminência da vedação à discriminação fiscal em relação a qualquer outro aspecto envolvido.

Outro caso extermamente assemelhado a esses, acerca do tratamento de automóveis usados adquiridos no exterior e a incidência de impostos especiais internos, é Fazenda Pública, Ministério Público contra Américo João Nunes Tadeu, processo C345/93 343 , acórdão de 9 de março de 1995.

Comentando esses casos, Peter Wattel (2008, p. 14) comenta que, ainda que a engenharia tributária possa potencialmente conceber, na espécie, tributos não discriminatórios aos produtos estrangeiros, a tributação dos automóveis usados consiste em uma distorção no mercado interno ainda não resolvida. Como os automóveis novos são tributados por imposto especial de consumo ou imposto de registro ou qualquer outra denominação empregada internamente, no seu país de origem, deveria haver alguma forma de reembolso parcial. Senão, na forma como o sistema existe hoje, mesmo que a base de cálculo do tributo considere com rigor factual a taxa de depreciação do veículo, sempre

${ }^{343}$ ECR 1995, I - 490. 
haverá um valor residual proporcional ao preço de venda no mercado secundário que será bitributado economicamente.

Outro exemplo de submissão do legítimo objetivo público ao Princípio de Nãodiscriminação se encontra no processo C-213/96, Outokumpu Oy contra Helsingin Piiritullikamari (Alfândega Regional de Helsinque) ${ }^{344}$, decisão em reenvio prejudicial, acórdão de 2 de abril de 1998. Caso raro, referente a imposto especial de consumo sobre energia elétrica e outras fontes de energia na Finlândia, antes da criação do análogo tributo comunitário, em 2003.

$\mathrm{O}$ artigo $1^{\circ}$ da Eräiden energialähteiden valmisteverosta annettu laki (Lei n. ${ }^{\circ}$ 1.473/94, de 29 de Dezembro de 1994, relativa à criação de um imposto especial sobre o consumo de determinadas fontes de energia) previa que a hulha, a turfa utilizada como combustível, o gás natural, a eletricidade e o tall-oil (resina líquida) estavam sujeitos a um imposto de base e a um adicional.

Ocorre que as alíquotas específicas do tributo base e do respectivo adicional diferenciavam-se consoante a modalidade de produção da eletricidade (a fonte primária da energia). Sobre a corrente elétrica de origem nuclear incidia um imposto especial sobre o consumo que abrange um imposto de base a uma alíquota de 0,015 FIM/kWh e um adicional a uma alíquota de 0,009 FIM/kWh. Sobre a corrente elétrica de origem hidráulica, incidia apenas o adicional, a uma alíquota de 0,004 FIM/kWh. Sobre a corrente elétrica produzida por outros meios, como por exemplo, a partir da hulha, incidia um imposto especial sobre o consumo calculado com base na quantidade de matéria-prima utilizada.

Ocorre que, sobre a corrente elétrica importada, independentemente da sua forma de produção, incidia o imposto especial sobre o consumo, que abrangia um imposto de base a uma alíquota de 0,013 FIM/kWh e um adicional a uma alíquota de 0,009 $\mathrm{FIM} / \mathrm{kWh}$. Vale dizer, o imposto especial sobre o consumo de corrente elétrica era calculado, no que diz respeito à corrente importada, a partir de uma base diferente da utilizada em relação à corrente produzida internamente.

Segundo o governo finlandês, o imposto especial sobre o consumo, calculado de acordo com o modo de produção da eletricidade, justificava-se por razões de política do ambiente. Porém, a taxa do imposto aplicável à corrente elétrica importada não era assim definida, mas sim de modo a corresponder à alíquota média do imposto que incidia sobre a

\footnotetext{
${ }^{344}$ ECR 1998, I - 1801.
} 
eletricidade produzida na Finlândia.

No entanto, como se viu no processo, em tal média não tinha sido levada em consideração a redução do imposto que incide sobre a turfa e o gás natural. Assim, a alíquota do imposto sobre a corrente elétrica importada era superior à alíquota de imposto mais baixa, mas inferior à alíquota mais elevada incidente sobre a corrente elétrica produzida no país.

A sociedade autora é a holding company de um grupo industrial metalúrgico finlandês que importava eletricidade proveniente da Suécia nos termos de um contrato que celebrou com a sociedade sueca Vattenfall $A B$.

Tratando da compatibilidade dessa disciplina com o então art. $95^{\circ}$ do TCEE, o então TJCE afirmou que a normativa primária comunitária não se opõe, dada a preservação da soberania dos Estados-membros em estabelecer um sistema de tributação diferenciado para certos produtos, a que a alíquota de um imposto interno que incida sobre a eletricidade varie consoante o seu modo de produção e as matérias-primas utilizadas para o efeito, na medida em que essa diferenciação assenta em considerações ambientais.

Tal como o TJCE já havia lembrado no acórdão de 20 de Setembro de 1988, Comissão/Dinamarca (302/86, Colect., p. 4607, n 8), a proteção do ambiente constitui um dos objetivos essenciais da Comunidade. Por outro lado, após a entrada em vigor do Tratado de Maastricht, a Comunidade passou a ter designadamente por missão promover um crescimento sustentável e não inflacionista que respeite o ambiente (artigo $2^{\circ}$ do Tratado CE) e a sua ação implica uma política no domínio do ambiente - artigo $3^{\circ}$, alínea $\mathrm{k}$, do Tratado CE.

Não obstante, o TJCE recordou que é de sua jurisprudência constante existir violação ao art. $95^{\circ}$ sempre que a imposição que incide sobre o produto importado e a que incide sobre o produto nacional similar sejam calculadas de forma diferente e segundo modalidades diferentes, que conduzam, ainda que apenas em certos casos, a uma tributação superior do produto importado (v., designadamente, acórdão de 26 de Junho de 1991, Comissão/Luxemburgo, C-152/89, Colect., p. 1 - 3141, n 20), como é o caso como o que, num sistema de tributação diferenciada, sobre a eletricidade importada, que é distribuída pela rede nacional, incida, independentemente do seu modo de produção, uma alíquota única superior à mais baixa que incide sobre a eletricidade de origem nacional distribuída por meio da rede nacional.

Quanto a isso, no caso, o TJCE afirmou que a circunstância de a eletricidade nacional ser, em determinados casos, mais pesadamente tributada do que a eletricidade 
importada não tinha qualquer relevância neste contexto, uma vez que, para verificar se o sistema em questão é compatível com o artigo $95 .^{\circ}$ do Tratado, importa comparar a carga fiscal que incide sobre a eletricidade importada com a carga fiscal mais reduzida que atinge a eletricidade de origem nacional (v., neste sentido, acórdão Comissão/Luxemburgo, já referido, $\mathrm{n}^{\text {os }} 21$ e 22 ).

Quanto à dificuldade em determinar com exatidão o modo de produção da eletricidade importada e, portanto, as fontes de energia primárias utilizadas para a sua produção, o TJCE salientou que a legislação finlandesa em causa no processo principal nem sequer previa a possibilidade de o importador provar que a eletricidade que importava foi produzida segundo um modo de produção determinado, para beneficiar da alíquota aplicável à eletricidade de origem nacional produzida de acordo com o mesmo modo de produção. Ademais, já havia o TJCE anteriormente sublinhado que dificuldades de ordem prática não podem justificar a aplicação de imposições fiscais internas discriminatórias em relação a produtos originários de outros Estados-Membros (v., designadamente, acórdão de 23 de Outubro de 1997, Comissão/Grécia, C-375/95, Colect., p. 1 - 5981, nº 47).

Em pelo menos um caso, esse já referido, de julgamento relativamente recente, o TJCE discordou do elastério exegético das exceções, oriundo da construção jurisprudencial, estendendo as previsões convencionais dos art. $28^{\circ}$ e $29^{\circ}$ ao art. $90^{\circ}$, todos do TCE (hoje, artigos $34^{\circ}, 35^{\circ}$ e $110^{\circ}$ do TUE). Isso se deu no processo C-302/00, Comissão das Comunidades Europeias contra República Francesa.

Apenas para recordar, a ação de incumprimento referida teve por objeto obter, por parte do TJCE, a declaração de que, ao manter em vigor um sistema que: i) impõe um preço de referência mínimo para os cigarros e, ii) impõe uma tributação diferenciada dos cigarros de tabaco escuro e de tabaco claro, em detrimento dos cigarros de tabaco claro; a República Francesa não teria cumprido as obrigações que lhe incumbem quer por força de norma do direito comunitário originário, o então artigo $90^{\circ}$ do Tratado CE, quanto do direito comunitário derivado, o artigo $9^{\circ}, \mathrm{n}^{\circ} 1$, e o artigo $8^{\circ}, \mathrm{n}^{\circ} 2$, da Directiva 95/59/CE do Conselho.

Sem invocar explicitamente o artigo $36^{\circ}$ do Tratado CEE (que passou, após alteração, a artigo $30^{\circ}$, TCE), o Governo francês alegou, em sua defesa, que o artigo $575^{\circ}$ A do Côde Géneral des Impôts alterado tenderia a proteger a saúde e a vida das pessoas.

No que toca a esse argumento, o TJCE ponderou que bastaria observar que o artigo $36^{\circ}$ do então Tratado CEE é de interpretação estrita para que se concluísse que não pode ser entendido no sentido de que autoriza medidas de natureza diferente das restrições 
quantitativas à importação e à exportação e as medidas de efeito equivalente previstas pelos artigos $30^{\circ}$ e $34^{\circ}$ do Tratado CEE (que passaram, após alteração, a artigos $28^{\circ} \mathrm{CE} \mathrm{e}$ $29^{\circ}$ CE) (v., neste sentido, acórdãos de 14 de Dezembro de 1972, Marimex, 29/72, Colect., p. $473, \mathrm{n}^{\text {os }} 4$ e 5 , e de 25 de Janeiro de 1977, Bauhuis, 46/76, Colect., p. 1, $\mathrm{n}^{\text {os }} 12$ a 14).

Malgrado todas essas considerações, e diante dessa controvérsia, pode-se concluir que ainda não existe uma resposta definitiva à pergunta sobre como sabermos quais são essas justificações externas cabíveis, mesmo passados tantos anos da criação da então Comunidade Econômica Europeia, sempre sendo objeto de adesão de novos Estadosmembros.

Porém, um aspecto é certo. Mesmo que o objetivo de política econômica aparentemente não seja revestido assim de tanta legitimidade, se a sua aplicação é estendida a produtos originários de outros Estados-membros, entende-se que há justificativa para a diferenciação.

Foi o que aconteceu, como já vimos anteriormente, no processo 196/85, Comissão das Comunidades Europeias contra República Francesa. O Tribunal de Justiça então das Comunidades Europeias admitiu a regularidade do regime privilegiado aplicado aos "vinhos doces naturais", denominação reservada aos "vinhos cuja produção é tradicional e usual", consoante descrição técnica de fabricação referida em lei, no artigo $416^{\circ}$ do Code Général des Impôts.

O Tribunal de Justiça, manejou o argumento, sempre empregado, de que o direito comunitário não limita a liberdade de cada Estado-membro em estabelecer um sistema de tributação diferenciado para certos produtos, ainda que similares no sentido do artigo $95^{\circ}$, primeiro parágrafo, do Tratado, em função de critérios objetivos, desde que não sejam discriminatórios aos produtos importados, admitindo-se que persigam objetivos de política econômica, eles próprios, compatíveis com as exigências do Tratado e do direito derivado.

O que foi fundamental no caso foi fato de que o Tribunal reconheceu que as vantagens fiscais concedidas, na persecução a objetivos econômicos ou sociais legítimos, sob a forma de isenções ou de reduções de direitos a certos tipos de álcool ou a certas categorias de produtores, são válidos consoante o Tratado e o direito derivado, desde que tais regimes mais favorecidos sejam alargados, sem discriminação, aos produtos importados que tenham as mesmas condições que as produções nacionais favorecidas.

O objetivo de interesse público legítimo foi, como já vimos, vislumbrado no fato de que os vinhos doces naturais são fabricados em regiões caracterizadas por uma 
fraca pluviometria e por terrenos relativamente áridos, nas quais, devido à dificuldade em cultivar outros produtos agrícolas, a economia local é fortemente dependente da sua produção.

Além disso, foi constatado pelo Tribunal que o caráter de "produção tradicional e usual" se referia indistintamente aos produtos nacionais e aos produtos importados. Nenhum elemento do processo indicou, segundo o acórdão, que da sua aplicação resultasse o favorecer dos vinhos de origem francesa em detrimento dos vinhos originários de outros Estados-membros e que apresentem as mesmas características. Assim, entendeu o Tribunal que a norma tributária não teria o caráter discriminatório que poderia parecer à primeira vista.

Em verdade, ao rigor técnico da abordagem dos requisitos à caracterização em concreto da existência de norma implicitamente discriminatória, na forma como aqui sistematizada, o mais correto seria que o Tribunal apontasse no caso a verificada inexistência de tratamento diferenciado e não pela ocorrência da justificativa de interesse público legítimo.

Não é por outro motivo que não se pode concordar com o argumento de Federico Ortino (2004, p. 301 - 303), quanto à pretensa incoerência do acórdão acima em relação ao anterior processo 277/83, Comissão das Comunidades Europeias contra República Italiana ${ }^{345}$, também conhecido como caso Marsala.

A legislação italiana tributava o álcool de vinho produção nacional de um imposto de fabricação em montante exatamente igual à sobretaxa de fronteira, incidente sobre o mesmo produto de fabricação importadada. O Decreto-lei ${ }^{\circ} 1200$, de 6 de outubro de 1948 (GURI n 233 de 6. 10. 1948, texto modificado pela Lei ${ }^{\circ} 891$ de 22. 12. 1980, GURI $n^{\circ} 355$, de 30. 12. 1980), estabelecia, em seu artigo 29 , uma redução de $60 \%$ do crédito tributário do imposto de fabricação desde que o álcool de vinho seja utilizado na fabricação dos vinhos licorosos que possuem a denominação de "Marsala". Trata-se de um vinho licoroso submetido a uma regulamentação especial concernente à delimitação geográfica dos vinhedos e à qualidade das uvas empregadas na sua fabricação, sob a supervisão dos poderes públicos no que se refere à sua produção e à sua comercialização.

Em julho de 1984, o parlamento italiano adotou a Lei ${ }^{\circ} 408$, de 28 de julho de 1984 (GURI n ${ }^{\circ} 212$ de 2. 8. 1984), cujo artigo 4 bis dispunha que a redução dos impostos de fabricação sobre os álcoois prevista no artigo 29 de Decreto-lei de 1948, no que

${ }^{345}$ ECR 1983, 2053 
concerne à fabricação do vinho de "Marsala" era estendida a todos os vinhos licorosos e aromáticos, incluindo tais produtos provenientes dos Estados-membros da Comunidade Europeia e importados pela Itália. A mesma lei determinava que entraria em vigor assim que os ministros competentes adotassem um decreto com esse fim, o que até o momento do julgamento ainda não havia ocorrido.

Novamente o Tribunal repisou a sua fórmula, afirmando que de seus acórdãos de 27 de Fevereiro de 1980 (Comissão/Itália, 169/78, Recueil 1980, p. 385; Essevi et Salengo, 142 e 143/80, Recueil 1980 p. 1413) depreender-se que o então artigo 95 , no seu conjunto, tem por fim assegurar a livre circulação das mercadorias entre os Estadosmembros em condições normais de concorrência, por meio da eliminação de todas as formas de protecionismo que possam resultar da aplicação de impostos internos discriminatórios ou protecionistas em relação aos produtos originários de outros Estadosmembros, e garantir a perfeita neutralidade dos impostos internos em face da concorrência entre produtos nacionais e produtos importados.

A regra de base foi considerada pelo Tribunal como sendo o parágrafo primeiro do então artigo 95, que é fundado, asseverou o acórdão, na comparação das cargas fiscais incidentes nos produtos nacionais em comparação com os produtos importados que possam ser qualificados como "similares". Tendo em vista o estado de evolução de então do direito comunitário, a outorga de certas exonerações ou de certos benefícios fiscais, como menciona o Tribunal, sob a forma de isenções ou de redução de alíquota em função de critérios objetivos é admitida, sob a condição de que o benefício dessas medidas seja estendido de maneira não discriminatória aos produtos importados que se encontrem nas mesmas condições.

O Tribunal preliminarmente entendeu que não se poderia colocar em dúvida que os vinhos licorosos formam uma gama de produtos homogêneos, de características semelhantes e que apresentam para os consumidores propriedades análogas ou atendem às suas mesmas necessidades.

Além disso, entendeu o Tribunal ser também certo que algum vinho licoroso importado não poderá jamais se beneficiar do tratamento preferencial deferido ao "Marsala" e que esses vinhos importados, portanto, serão objeto de discriminação.

Examinando as razões invocadas pelo governo italiano para justificar o tratamento diferenciado ao álcool de uva desde que seja destinado à fabricação do "Marsala", o Tribunal percebeu que os vinhos licorosos provenientes de outros Estadosmembros não poderão jamais preencher as condições estipuladas pela regulamentação 
italiana, por não poderem ter a denominação de origem, não podendo, portanto, em nenhuma hipótese, beneficiarem-se da vantagem fiscal concedida ao "Marsala".

Segundo o Tribunal de Justiça, o governo italiano não poderia empregar o argumento de estado quanto ao subdesenvolvimento da região de produção do "Marsala" uma vez que as práticas de discriminação fiscal não podem se desviar da aplicação do art. $95^{\circ}$ pelo fato de que elas podem ser substituídas por modos de financiamento por ajudas de estado (acórdão de 21 de maio de 1980, Comissão/Itália, 73/79, Rec. p. 1533).

Mesmo que se admitisse que a redução do imposto conferisse aos produtores de "Marsala" uma vantagem muito restrita, entendeu o Tribunal ser conveniente assinalar que o objetivo do artigo $95^{\circ}$, parágrafo primeiro, é o de abolir todas as formas de discriminação, direta ou indireta, não sendo necessário perquirir se as vantagens acordadas aos produtos nacionais podem ser eximidas da proibição do art. $95^{\circ}$ por conta de seu pretendido efeito limitado. Para o Tribunal, em conseqüência, mesmo um desgravame fiscal de efeito discriminatório fraco é submetido à restrição do art. $95^{\circ}$.

Em conclusão de todo esse raciocínio, o Tribunal entendeu que haveria de ser constatado que as disposições fiscais aplicadas na Itália, resultantes das normas legislativas citadas, são incompatíveis com as exigências do art. $95^{\circ}$ no que concerne, de uma parte, à tributação do vinho licoroso de denominação "Marsala" e, de outro lado, a sobretaxa de fronteira sobre o álcool de vinho utilizado na produção dos vinhos licorosos importados de outros Estados-membros.

Como se vê, não há colidência entre os julgados, uma vez que o ponto determinante do entendimento do Tribunal foi exatamente a existência, nesse caso, do tratamento diferenciado, pela impossibilidade do benéficio fiscal vir a ser aplicado a produtos oriundos de fora da Itália. Não obstante, a desconsideração do argumento de objetivo legítimo de políticas públicas é realmente radicalmente discordante do caso anterior. Porém, não é o de maior relevância, nem tampouco o fundamento da decisão da corte. A contradição é, portanto, apenas aparente. 


\section{DOS AJUSTES FISCAIS DE FRONTEIRA.}

\subsection{Do Conceito e Das Modalidades.}

Um dos problemas mais complexos e relevantes (JACKSON, 2000, p. 218), no que tange à disciplina do princípio de não-discriminação tributária e do sistema multilateral de regulação do comércio internacional como um todo, ao lado do correto entendimento do significado do conceito jurídico indeterminado representado pelo acrônimo SATAP, é o correto entendimento do alcance do conceito de ajuste fiscal de fronteira como admitido pelo sistema GATT/OMC, uma vez que o Acordo Geral não utiliza esses termos em sua redação.

Na definição de Harry Johnson e Mel Krauss (1970, p. 596), ajustes fiscais de fronteira são ajustes, por meio da tributação, direcionados ao produtor externo, quando os seus produtos cruzam uma fronteira internacional. Podem envolver adição ou subtração aos tributos já pagos por esse produtor, de modo a que tanto o produtor nacional quanto o estrangeiro enfrentem diante de si iguais cargas tributárias ou de subsídios, se o país importador preferir subsidiar aquele específico produto ao invés de tributá-lo.

Vale dizer, para Johnson e Krauss, o intento dos ajustes fiscais de fronteira é preservar as condições originais de competitividade entre as indústrias nacional e estrangeira, sejam importadoras ou exportadoras, por meio da equalização dos encargos tributários. Em outras palavras, manter as vantagens comparativas entre as indústrias dos respectivos países e permitir que os custos relativos de produção governem os padrões de comércio internacionais (1970, p. 596). Evitar, assim, que os países, no exercício de sua soberania impositiva, criem vantagens competitivas $^{346}$ artificiais em proveito dos produtores nacionais e em detrimento dos estrangeiros (MELLONI, 2005, p. 2). Nas palavras de Robert Floyd (1973, p. 489), os ajustes fiscais de fronteira são neutros ao comércio $^{347}$.

\footnotetext{
346 O conceito de "vantagem competitiva" foi criado por Michael Porter, estudioso da Teoria da Administração, em sua obra On Competition, Boston: Harvard Business School Publisher, 1998, p. 40 - 42, como sendo um atributo ou uma combinação de atributos adquiridos ou desenvolvidos por uma organização que lhe permite superar o desempenho dos seus concorrentes. Para ele, um dos três métodos de criar uma vantagem competitiva sustentável se dá por meio da liderança de custo, que consiste no oferecimento do mesmo serviço que o seu competidor por um custo menor.

347 "Trade-neutral", no original em inglês.
} 
Inserem-se, portanto, perfeitamente, nos objetivos do GATT relacionados por Won-Mog Choi (2003, p. 3 - 4), de controlar a intervenção governamental de modo a proteger as vantagens comparativas, levando assim à eficiência econômica e, em última análise, ao uso ótimo dos recursos mundiais.

Embora se manifestem por meio de incidências tributárias ou direitos de crédito de tributos, via ressarcimento ou utilização, os ajustes fiscais de fronteira não possuem caráter fiscal, apenas extra-fiscal (DEMARET; STEWARDSON, 1994, p. 7).

Diferem, no seu entender, substancialmente dos impostos na fronteira ${ }^{348}$, e com eles não podem ser confundidos, uma vez que esses são, por definição, como já afïrmamos aqui, discriminatórios e deletérios ao comércio internacional e à difusão internacional dos benefícios com a especialização internacional e com a divisão espacial do trabalho (JOHNSON; KRAUSS, 1970, p. 596). Com sua imposição, necessariamente se estão restringindo os volumes comercializados a montantes inferiores aos desejáveis pelo princípio das vantagens comparativas concebido por David Ricardo. Conclui Melvyn Krauss (1969, p. 554) afirmando que os ajustes fiscais de fronteira são compatíveis; os tributos na fronteira são incompatíveis com a eficiência no uso dos recursos globais.

Os ajustes fiscais de fronteira podem ser baseados em um de dois princípios: no princípio da origem ou no princípio do destino ou, na doutrina alemã, segundo Henry Tilbery (1971, p. 19), o "Prinzip der Besteuerung nach dem Bestimmungsland" ou o "Prinzip der Besteuerung nach dem Ursprungsland".

Sob o princípio da origem, um tributo é incidente na produção doméstica do bem, seja ele exportado ou não ou, como ensina Henry Tilbery (1971, p. 20), todas as mercadorias de mesma origem ficam gravadas com a mesma carga tributária, não importando seu destino.

Sob o princípio do destino, submete-se o produto importado à mesma carga tributária imposta ao similar produto nacional domesticamente produzido, ambos destinados ao consumo das famílias do país importador, ao mesmo passo que o produto domesticamente produzido destinado ao consumo no exterior é ressarcido - recebe um “export rebate", no dizer da OCDE (1988, p. 111) - do ônus tributário que a sua produção lhe impõe. Com isso, a lição de Henry Tilbery (1971, p. 20) é a de que, na vigência do princípio do país destinatário, todas as mercadorias consumidas no mesmo país ficam sujeitas à mesma carga tributária, sem distinção de sua origem.

348 "Border taxes", no original em inglês. 
Tais regras valem tanto para o imposto geral sobre o consumo ("general consumption tax”) quanto para as excises, no dizer da OCDE (1988, p. 111), ou tanto para a incidência sintética, geral e universal, quanto para a analítica, seletiva (BRITO FILHO, 2003b, p. $24-25)$.

Em teoria, se aplicado o princípio do destino, como bem esclarece John $\mathrm{H}$. Jackson (2000, p. 218), as mercadorias viajarão no comércio internacional livres de tributação e serão tributadas no local de consumo sob as mesmas regras que os produtos de fabricação local. Aplicado o princípio da origem, os tributos acompanharão as mercadorias para onde elas se destinarem (DEMARET; STEWARDSON, 1994, p. 6).

Na ótica de William Orzechowski (2001, p. 3), em se empregando o princípio do destino, os produtores que exportam suas mercadorias aplicariam aos seus produtos sempre a alíquota vigente no país de importação; os consumidores domésticos sempre verão os produtos importados sob a incidência do seu imposto indireto interno, da mesma forma que os produtos nacionais. Por outro lado, em se empregando o princípio da origem, os produtores aplicariam aos seus produtos sempre a alíquota vigente no seu país, independentemente se forem destinados à exportação ou não; os consumidores domésticos sempre verão os produtos à alíquota relativa ao país de fabricação - se importados, sob a incidência da alíquota vigente no país de exportação e se nacionais, sob a alíquota do imposto interno nacional.

Não há diferença, no longo prazo, se determinado país adota o princípio da origem ou do destino na tributação, no que tange aos seus efeitos no balanço de pagamentos e no preço dos fatores, se os mecanismos de internacionais de ajustes funcionam e se há a possibilidade de livre flutuação desses índices em uma economia aberta (KRAUSS, 1969, p. 555). Apenas a mudança de um regime para outro poderá afetálos, mas também tão somente no curto prazo, podendo criar ou vantagens ou desvantagens competitivas transitórias, dependendo da situação (KRAUSS, 1969, p. 555).

Como, em se tratando do princípio da origem, não há ressarcimento nem isenção de tributos quando a mercadoria é exportada nem tampouco incidência tributária quando mercadorias similares entram no país pela importação, autores como Hufbauer (1996, p. 23) afirmam que, adotando-se o princípio da origem, não haverá ajustes na fronteira. Johnson e Krauss (1970, p. 597), mais rigorosos, afirmam que nesse caso os ajustes fiscais não são visíveis, uma vez que não necessariamente devem ser impostos (ou ressarcidos) na transposição fronteiriça, mas sim de acordo com a sua respectiva destinação, conceito posteriormente corroborado no âmbito do GATT pré-OMC. Em 
verdade, tal preocupação é evidenciada no caso de fenômenos integracionistas nos quais é muito díspar a carga tributária indireta interna (TILBERY, 1971, p. 21).

Abstraída essa minúcia, o importante é perceber que o conceito de ajuste fiscal de fronteira é concebido em sua plenitude em se adotando o princípio do destino. Em verdade, o que se conhece mais vulgarmente como o conceito de ajuste fiscal de fronteira, e a forma como ele foi concebido originalmente por David Ricardo, remetem ao emprego do princípio do destino. Aplica-se, portanto, mediante o ressarcimento do tributo excessivo na exportação e pela incidência do equivalente encargo tributário na importação.

Por esse motivo, Henry Tilbery (1971, p. 20) afirma que, no caso da adoção do princípio do país de destino, continuará sendo necessário o controle físico nas fronteiras. Não mais como fronteiras alfandegárias, mas como fronteiras tributárias, visando a proceder corretamente a esses ajustes dos impostos internos, com o fim de não gerar distorções competitivas, seja a tributação protetiva ou discriminatória, seja a existência de prêmios ocultos à exportação, ou subsídios fiscais (1971, p. 21). Diferentemente, no caso da adoção do princípio de tributação na origem, afirma (1971, p. 21), a inexistência, $a$ priori, da necessidade de ajustes fiscais de fronteira faz com que haja realmente a abolição das fronteiras fiscais.

Não é por outro motivo que o Relatório do Grupo de Trabalho, instalado pelo GATT, sobre Ajustes Fiscais de Fronteira, adotado em 2 de dezembro de 1970, emprega a definição estabelecida pela OCDE, que restringe o conceito aos casos em que se adota o princípio do destino na tributação ${ }^{349}$. No entanto, outro Grupo de Trabalho, posterior, examinando a aplicabilidade dos ajustes fiscais de fronteira às medidas de cunho ambiental $^{350}$, menciona quatro possíveis formas de tratamento tributário:

i) um produto destinado à exportação pode ser isentado dos tributos domésticos ou receber um ressarcimento ou isenção pelo país de exportação, e então ser tributado pelo país de importação (princípio do destino);

ii) um produto destinado à exportação pode ser tributado no país de exportação e ser isentado de tributos no país de importação (princípio da origem);

\footnotetext{
349 "4. For the purpose of its examination, the Working Party used the definition of border tax adjustments applied in the OECD. Thus, border tax adjustments were regarded "as any fiscal measures which put into effect, in whole or in part, the destination principle (i.e. which enable exported products to be relieved of some or all of the tax charged in the exporting country in respect of similar domestic products sold to consumers on the home market and which enable imported products sold to consumers to be charged with some or all of the tax charged in the importing country in respect of similar domestic products)'"'.

${ }^{350}$ TRE/W/20, de 11 de janeiro de 1994, parágrafo 28.
} 
iii) um produto destinado à exportação pode ser tributado tanto pelo país de exportação quanto pelo país de importação (dupla tributação internacional);

iv) um produto destinado à exportação pode ser isentado dos tributos domésticos ou receber um ressarcimento ou isenção pelo país de exportação e não ser tributado pelo país de importação (isenção de tributos ou dupla não-tributação internacional).

Não se deve esquecer que a doutrina, como é o caso de Lagemann (1999, p. 185), também costuma mencionar que os ajustes fiscais de fronteira podem ser realizados por três meios: pela isenção ou não-incidência de impostos internos nas exportações; pelo ressarcimento ou manutenção e utilização dos impostos internos pagos pelo produtor ou exportador por suas compras de insumos ou matérias-primas ou de bens intermediários tributados; ou pela incidência de um imposto interno sobre as mercadorias importadas, de maneira tal que suportem a mesma carga tributária que os produtos similares de produção nacional. Por esse entendimento, comum a parcela da doutrina - no mesmo sentido, Harry Johnson (1965, p. 13 - 14), o segundo meio apontado corresponderia aos mecanismos de drawback dos tributos incidentes nos insumos, que fariam parte da remissão dos tributos na exportação, com o fim de que a mercadoria trafegue no comércio internacional de forma realmente completamente desonerada, ao menos em teoria. Deve-se ressaltar que aqui se está mencionando o drawback na forma como definido no Capítulo $3^{351}$ do Anexo Específico $\mathrm{F}$ da Convenção de Kioto da OMA, que abrange qualquer oneração tributária aduaneira vinculada fisicamente à mercadoria destinada à exportação, não apenas o imposto de importação incidente sobre as matérias-primas e produtos semi-elaborados e acabados, materiais de embalagem ou partes e peças de equipamentos, como está previsto nos arts. 383 a 403 do Regulamento Aduaneiro Brasileiro (Decreto $n^{\circ}$ 6.759/09) - a norma

351 "Chapter 3. Drawback. Definitions. For the purposes of this Chapter:

" drawback" means the amount of import duties and taxes repaid under the drawback procedure;

" drawback procedure" means the Customs procedure which, when goods are exported, provides for a repayment (total or partial) to be made in respect of the import duties and taxes charged on the goods, or on materials contained in them or consumed in their production;

" equivalent goods" means domestic or imported goods identical in description, quality and technical characteristics to those under the drawback procedure which they replace.

Principle. 1. Standard. The drawback procedure shall be governed by the provisions of this Chapter and, insofar as applicable, by the provisions of the General Annex.

Field of application. 2. Standard. National legislation shall enumerate the cases in which drawback may be claimed.

3. Recommended Practice. National legislation should include provision for the application of the drawback procedure in cases where the goods which have borne import duties and taxes have been replaced by equivalent goods used in the production of exported goods". 
convencional pretende que o produto efetivamente trafegue no comércio internacional completamente desonerado.

De se ressaltar que a opção pela adoção de ajustes fiscais de fronteira mediante o princípio de origem ou destino, no entender de Melvyn Krauss (1969, p. 555), deve se prender à natureza da imposição adotada pelo país importador: se é do tipo imposto sobre o consumo, essa opção de política fiscal implica o emprego do princípio do destino quando aos ajustes fiscais de fronteira; se o tributo indireto é concebido na modalidade tributo sobre a produção, necessária a utilização do princípio da origem. Embora conceitualmente correta, tal correlação nem sempre é verdadeira - veja-se, adiante, o caso do Brasil.

A propósito, Gary Hufbauer (1996, p. 23) esclarece que a opção pelo princípio de imposição tributária equivale a escolher onde as distorções decorrentes da incidência tributária irão preponderar. O princípio da origem minimizará distorções de preço ao nível do consumo, porque restará aos compradores adquirirem os produtos a preços internacionais. A propósito, William Orzechowski (2001, p. 5) defende que uma aparente vantagem do princípio da origem é o fato de que o seu emprego coloca os consumidores em posição de superioridade, uma vez que possibilita que eles tirem vantagens das diferenças nas cargas tributárias ao redor do mundo. Ao mesmo tempo, defende, cria uma pressão política nos países pela baixa de suas cargas tributárias indiretas.

Inversamente, a adoção do princípio do destino minimizará distorções de preço ao nível da produção, porque os produtores serão remunerados a preços internacionais, líquidos de impostos. Comenta Gary Hufbauer (1996, p. 23) que, exatamente por isso, com o fim de ganhar maior aceitabilidade de um novo sistema tributário, os países costumam optar politicamente pelo princípio do destino, uma vez que os consumidores possuem menor poder de barganha política e aos produtores sempre resta a possibilidade de realocar a sua produção. Também pode ser defendido que o princípio do destino força os produtores a abaixarem seus preços, diante do fato de que haveria maior evidenciação dos preços internacionais das mercadorias.

Com isso concorda William Orzechowski (2001, p. 6), mencionando que as vantagens políticas na adoção do princípio do destino podem se refletir tanto na maior flexibilidade que os exportadores terão ao se defrontar com aumentos de tributos - pois que implicarão aumentos também nos ressarcimentos - como também no fato de que os importadores também não se insurgirão contra tal realidade onerativa, lembrando que os produtos estrangeiros a ela também serão submetidos. 
No entanto, tal tipo de blindagem à competitividade internacional diante de aumentos de tributos oriunda do emprego dos ajustes fiscais de fronteira sob a sistemática do destino pode não ser necessariamente positiva tanto às firmas (produtores) quanto principalmente a famílias (consumidores), uma vez que tende a reduzir o bem-estar da sociedade como um todo.

Para Melvyn Krauss (1969, p. 554), a diferença na adoção da tributação no consumo ou na produção reside no fato de que um imposto sobre o consumo aumenta o nível dos preços das commodities na proporção do tributo, mas deixa o preço dos fatores de produção no mesmo nível de equilíbrio sem tributação; a adoção de um imposto sobre a produção reduz o preço dos fatores de produção na proporção do imposto, mas não tem qualquer efeito no preço final das commodities. Porém, no agregado, não haverá efeito diferenciado na ótica dos contribuintes.

Não obstante, do ponto de vista da eficiência econômica - tanto no que se refere aos preços relativos dos fatores quanto ao balanço de pagamentos - é irrelevante, no entender de Melvyn Krauss (1969, p. 554 - 555) - ou dele e Harry Johnson (1970, p. 598) se a opção de política fiscal do país importador se deu em proveito do princípio da origem ou do destino, da produção ou do consumo, desde que o ajuste fiscal de fronteira se aplique para a generalidade dos produtos importados e que o valor ressarcido ou exigido seja rigorosamente calculado de forma a ser realmente compensatório.

Gary Hufbauer (1996, p. 23) é mais rigoroso pois, além da generalidade, aponta outros dois requisitos para que o sistema de imposição não gere efeitos alocativos, à exceção da distorção de preços natural à incidência tributária: que todos os preços e salários sejam flexíveis ou que a taxa de câmbio seja de livre flutuação e que as ofertas dos fatores seja inelásticas e imóveis entre os países, de forma que o sistema tributário não afete o emprego de trabalho e capital da economia.

Reconhece (p. 24) que tais suposições não são realistas, na maior parte das vezes. Se é razoável supor-se a imobilidade do trabalho entre países, tal assunção no que tange ao capital é quimérica, hoje em dia. Da mesma forma, se ultimamente os regimes cambiais têm permitido seu livre ajuste, por outro lado os sistemas tributários muito raramente são uniformes em relação ao conjunto de bens produzidos na economia.

Por outro lado, a imposição de um tributo indireto analítico, ou seletivo, do tipo excise tax, diferentemente, possui evidente efeito distorcivo, no entender de Harry Johnson e Melvyn Krauss (1970, p. 601), tendo que ser examinado em conjunto com o imposto de importação e com o ajuste fiscal de fronteira para que a sua influência na eficiência 
alocativa e seus efeitos comerciais sejam corretamente aferidos (1970, p. 600). Assim, se o montante ressarcido na exportação for muito baixo ou o imposto incidente na importação muito alto, estar-se-á tributando o comércio internacional; se o montante ressarcido na exportação for muito alto ou o imposto incidente na importação muito baixo, teremos a situação de haver subsídio ao comércio internacional.

Nesse ponto é importante verificar que, se sem a miscelânea de incidências na importação, já seria difícil aferir qual o montante necessário a que o ajuste fiscal de fronteira cumpra o seu papel, tais dificuldades ficam multiplicadas no caso da existência de impostos seletivos específicos, já que aqueles cálculos anteriores deveriam ser refeitos (JOHNSON; KRAUSS, 1970, p. 601), o que pode até tornar inviável o mister, justificando o uso de aproximações, mesmo com o risco que isso eventualmente acarrete oneração ou proteção ao comércio internacional do país de tributação (KRAUSS, 1969, p. 558).

\subsection{Do Breve Histórico.}

A primeira referência na literatura econômica acerca da questão dos ajustes fiscais de fronteira vem de David Ricardo, em texto de 1822, denominado "On Protection to Agriculture", em sua Seção iii, que tem como título "On the Effects of Taxes imposed on a particular Commodity", traz pela primeira vez a ideia de que os tributos incidentes sobre os produtores locais de milho, que enumera, na medida em que acarretam o aumento do preço do milho, devem, para que o capital não seja desviado em prejuízo do país, nem tampouco deleteriamente atraído, ser compensados por meio da imposição de um encargo na importação e um ressarcimento (“drawback”) na exportação ${ }^{352}$. Em verdade, para Ricardo, os ajustes fiscais de fronteira se cristalizariam no caso da incidência por meio do princípio do destino, motivo pelo qual Hufbauer (1996, p. 23) o alça à categoria de pai do princípio.

\footnotetext{
352 "The growers of corn are subject to some of these peculiar taxes, such as tithes, a portion of the poors' rate, and, perhaps, one or two other taxes, all of which tend to raise the price of corn, and other raw produce, equal to these peculiar burthens. In the degree then in which these taxes raise the price of corn, a duty should be imposed on its importation. If from this cause it be raised ten shillings per quarter, a duty of ten shillings should be imposed on the importation of foreign corn, and a drawback of the same amount should be allowed on the exportation of corn. By means of this duty and this drawback, the trade would be placed on the same footing as if it had never been taxed, and we should be quite sure that capital would neither be injuriously for the interests of the country, attracted towards, nor repelled from it” (RICARDO, 2005, p. 217 - 218).
} 
Porém, Hufbauer (1996, p. 21 - 22 e 37) informa que desde o US Duty Drawback Statute, na sua primeira versão, que na verdade consistia no Second Act of the U. S. Congress, de 4 de julho de 1789, os Estados Unidos já possuíam normas legais que asseguravam mecanismos que podem ser modernamente considerados ajustes fiscais de fronteira - a incidência de encargos sobre o produto importado em equiparação ao nacional e o drawback na reexportação de produtos importados.

A remissão do excise tax incidente no tributo exportado foi incluída mediante alteração no mesmo diploma legal datada de dois anos após. Demaret e Stewarson (1994, p. 7, nota de rodapé 7), citam o Whiskey Act, de março de 1791, que determinava a incidência de um imposto federal sobre as bebidas destiladas e previa a remissão do tributo para as exportações de uísque americano. Em 1868, no caso da tributação do álcool, e em 1872, para o tabaco, foram previstos dispositivos determinando o ressarcimento de tributos incidentes sobre produtos a serem exportados. Hufbauer (1996, p. 21 - 22) também menciona o tratado celebrado em 1862 entre a França e o Zollverein, que previa a remissão dos impostos sobre o consumo incidentes, em relação aos produtos exportados entre os contratantes. Em 1882, tratado celebrado entre a Grã-Bretanha e a França exigia que os países assegurassem encargos tributários equivalentes entre produtos domésticos e importados do outro país contratante.

Robert Floyd (1973, p. 492 e nota de rodapé 10 e 493) enumera diversos tratados bilaterais de comércio celebrados pelos Estados Unidos com países da América Central e Caribe, durante a década de 30 do Século XX, prevendo imposições compensatórias às importações, sem falar em disposições iguais nos Tratados de Comércio e Navegação entre Alemanha e Grécia, de 1884; Egito e Rússia, de 1909; Grã-Bretanha e Portugal, de 1914 e Estados Unidos e Alemanha, de 1923.

A essa altura histórica, a possibilidade convencional de ajustamentos fiscais na fronteira era de emprego costumeiro nos tratados de comércio e navegação de então, especialmente a norma que autoriza os estados a tributarem as importações de forma a equiparar as incidências internas sobre a produção nacional. Hoje, Gary Hufbauer (1996, p. 21) afirma que tal cláusula se trata de uma prática consolidada e cada vez mais amplificada no Direito Internacional do Comércio.

Não obstante, a verdade é que a presença dessa cláusula nos esboços do que viria o ser o GATT, especialmente a "Suggested Charter for an International Trade Organization", de 1946, adveio de rigorosos estudos técnicos no Executive Committee on 
Economic Foreign Policy do Departamento de Estado dos Estados Unidos, apenas mediante consulta a órgão similar do Reino Unido.

A menção à imposição nas importações se vê presente desde debates de julho de 1943, ao passo que em outubro de 1943 começou-se a falar em ressarcimento nas exportações (FLOYD, 1973, p. 493) - ainda estando em curso a Segunda Guerra Mundial, portanto.

Tais disposições vieram, como veremos na seção seguinte, a se converter em normas do GATT, quase sem alteração em relação à redação gerada na burocracia norteamericana. A ideia original, informa Robert Floyd, era evitar a anulação dos benefícios decorrentes das concessões tarifárias oriundas das negociações internacionais por meio de tributos internos indiretos incidentes apenas ou mais onerosamente sobre o produto importado (1973, p. 494).

Mas logo após adveio outro propósito para a mesma norma, consistente na antevisão da possibilidade de os países contratantes se valerem de tributos internos para recomporem as perdas de receita decorrentes das reduções tarifárias decorrentes das concessões em negociação, sem que esse intuito fiscal viesse a obstar o comércio internacional, uma vez que necessariamente incidente também sobre o produto nacional.

Nessa oportunidade, Floyd (1973, p. 495 e nota de rodapé 18) noticia que um esboço logo descartado previa um requisito adicional de que esse imposto interno previsto no Artigo III fosse exigido apenas de mercadorias que tivessem uma substancial produção nacional anteriormente à sua instituição, comentando que semelhante dispositivo teria o efeito de desencorajar a instituição de tributos indiretos internos pelos estados, calando os críticos, especialmente nos Estados Unidos, que reclamam que o GATT estimularia a proliferação dessas incidências.

Disciplina semelhante a essa foi novamente sugerida pela Suécia em 16 de fevereiro de 1955, na Nona Sessão do GATT, em reunião de um grupo de trabalho ("Working Party II on Tariffs, Schedules and Customs Administration"), por meio de requerimento para inclusão de Nota Adicional ao parágrafo 1 do Artigo III, proposta que foi descartada nas discussões que se seguiram ${ }^{353}$. Tencionava reduzir a incidência da

\footnotetext{
353 “Article III - National Treatment on Internal Taxation and Regulation Paragraph 1

9. The delegate for Sweden proposed an interpretative note, on the lines of the statement adopted at the Havana Conference (Reports of Committees, page 64, paragraph 54), as follows:

"Under the provisions of Article III regulations and taxes would be permitted which, while perhaps having the effect of assisting the production of a particular domestic product (say, butter) are directed as much
} 
restrição convencional aos casos que eventual benefício a algumas indústrias fossem compensados por prejuízos a outras similares do mesmo país. Kenneth Dam (1970, p. 118 - 119) discorda da iniciativa, mencionando que semelhante dispositivo iria esvaziar por demais o escopo de aplicação do Artigo III:2.

Posteriormente às negociações do GATT e da OIC, o seguinte evento marcante na disciplina dos ajustes fiscais de fronteira foi, com o advento do Tratado de Roma, de 1957, que instituiu a Comunidade Econômica Europeia, o surgimento dos artigos $95^{\circ}$ (atualmente $90^{\circ}$, com o Tratado de Amsterdam ${ }^{354}$ ) e $96^{\circ}$ (atual $91^{\text {o355 }}$ ), adotando plenamente os ajustamentos fiscais de fronteira sob o princípio do destino no âmbito europeu. Tal disciplinamento será mais profundamente investigado em capítulo próprio.

O rápido e sólido desenvolvimento da tributação indireta, como se verá, no espaço econômico integrado europeu, acendeu as luzes vermelhas de alerta entre os estudiosos americanos no final da década de 60 do Século XX, a ponto de Melvyn Krauss, notório especialista na matéria, afirmar que se tratava de uma potencial disputa transatlântica, por meio de uma guerra comercial pela via dos ajustes fiscais de fronteira (1976, p. 154). A questão dos ajustes fiscais de fronteira, que antes soava como um corolário da equidade repleto de razoabilidade, passou a ser uma matéria debatida com aspereza pelos interlocutores dos dois lados do mundo desenvolvido (JOHNSON, 2000, p. 219).

Como informam Johnson e Krauss (1970, p. 595), a opinião pública americana, especialmente a comunidade empresarial e governamental (KRAUSS, 1969, p. 557), ficou muito preocupada com os efeitos do novo sistema do IVA europeu sobre o balanço de

against the domestic production of another product (say, domestic oleomargarine) of which there is a substantial domestic production as they are against imports (say, imported oleomargarine). "

After discussion the representative of Sweden expressed his willingness to withdraw his proposal but desired that the Working Party's report should records his statement that the system of levying internal fees on homeproduced and imported raw materials for oleomargarine manufacture, as well as on imports of oleomargarine, in order to help in the stabilization of the marketing of butter, which was mentioned in the report of Sub-Committee A of Committee III at Havana and found by that Sub-Committee to be consistent with the terms of the Charter Article 18 (Article III of GATT), was still in force. The Working Party took note of the Swedish statement" - W.9/200. Review Working Party II on Tariffs, Schedules and Customs Administration: Articles I, II, III and XXIV. Draft Report by Working Party II, de 16 de fevereiro de 1965.

354 "Artigo $90^{\circ}$.

Nenhum Estado-Membro pode fazer incidir, directa ou indirectamente, sobre os produtos dos outros EstadosMembros imposições internas, qualquer que seja a sua natureza, superiores às que incidam, directa ou indirectamente, sobre produtos nacionais similares.

Além disso, nenhum Estado-Membro pode fazer incidir sobre os produtos dos outros Estados-Membros imposições internas de modo a proteger indirectamente outras produções".

355 "Artigo 91\%.

Os produtos exportados para o território de um dos Estados-Membros não podem beneficiar de qualquer reembolso de imposições internas superior às imposições que sobre eles tenham incidido, directa ou indirectamente". 
pagamentos americano, diante do prejuízo à sua competitividade internacional. Tal situação foi ainda agravada com a decisão do governo alemão, em novembro de 1968, inicialmente destinada a viger até 31 de março de 1970, mas posteriormente estendida para após, de empregar os ajustes fiscais de fronteira como forma de evitar a desvalorização do marco alemão, reduzindo-os tanto na importação quanto na exportação.

Como - o que comprova Hufbauer (1996, p. 26) - os Estados Unidos se caracterizam por possuírem, entre os países da OCDE, a menor proporção de tributos federais sobre bens e serviços em relação ao produto interno bruto, chegando, em termos agregados, a 17\% do PIB, contra a média de 32\% da Europa Ocidental (ORZECHOWSKI, 2001, p. 8), o receio de muitos empresários americanos àquela altura foi o de que os países europeus não só pudessem se utilizar do mecanismo dos ajustes fiscais de fronteira de forma mais quantitativamente relevante como também, até, que tais ajustes, uma vez que pudessem compor percentuais de até $18 \%$ do PIB, em países como a Grécia em 1992, seriam instrumentos muito efetivos na formação de superavits comerciais, sempre à margem das limitações do sistema internacional de regulação do comércio exterior, pela sua não-aplicação aos tributos ditos diretos (FLOYD, 1973, p. 489), como veremos, e em função das dificuldades na apuração da correção quantitativa dos ajustes fronteiriços aplicados.

Como explicam Demaret e Stewardson (1994, p. 11, nota de rodapé no 24), o problema mais ressaltado pela comunidade empresarial americana de então era o de que, como os Estados Unidos aplicavam menores alíquotas de impostos indiretos, teriam que aplicar maiores de tributos diretos. Como os tributos diretos não seriam aptos aos ajustes de fronteira, pela disciplina do sistema GATT, um produto importado da então Comunidade Econômica Europeia teria todo o relevante montante do seu IVA comunitário ressarcido, passando a ser tributado nos Estados Unidos apenas pelo U. S. Sales Tax, como qualquer produto americano, mas sofrendo menor repercussão diante da suposta menor carga fiscal direta imposta aos fabricantes europeus.

Não é por outro motivo que diversos doutrinadores tanto do campo econômico quando do jurídico, como Hufbauer (1996, p. 26) e Demaret e Stewardson (1994, p. 14 15) criticam o sistema GATT/OMC por não incluírem na sua normativa autorizativa também os tributos diretos, reduzindo a margem de manobra de países como os Estados Unidos, cujos ajustes fiscais permitidos pelo sistema multilateral chegariam apenas a $5 \%$ do PIB. Melvyn Krauss (1976, p. 152) chega a se referir ao fato de que os ajustes fiscais de fronteira no sistema GATT sejam limitados aos tributos indiretos como "uma séria 
anomalia" nas normas do GATT. Para Gary Hufbauer (1996, p. 26), o regramento internacional contra o ajustamento na fronteira dos tributos diretos incidentes sobre as empresas faz pouco sentido. No mesmo sentido, John Howard Jackson (2000, p. 221).

Paul Demaret e Raoul Stewardson (1994, p. 14 - 15), com base em referências a trabalhos de John Jackson e Kenneth Dam (nota de rodapé no 39) atribuem o tratamento diferenciado, dentro de uma perspectiva histórica da evolução científica do sistema multilateral, à ideia consagrada e largamente difundida na década de 40 do Século XX de que haveria a possibilidade de existir a repercussão econômica do tributo indireto até que o ônus pelo seu pagamento fosse incorrido pelo consumidor final - o que a doutrina em língua inglesa denomina de "forward shifting" - translação para a frente. Seria uma consequência econômica que viria ao encontro do princípio da tributação no destino e em sentido contrário à tributação na origem.

Por outro lado, no que se refere aos tributos diretos, ensina John Howard Jackson (2000, p. 220) que o pensamento econômico tradicional os imaginou como sempre recaindo precipuamente sobre os detentores do capital, acionistas da pessoa jurídica. A isso denominariam "backward shifting" ou translação para trás. O fenômeno econômico, nessa hipótese, seria consentâneo com a adoção do princípio da tributação na origem e contraditório com o princípio de tributação no destino, aquele adotado pelo GATT e ao qual os ajustes fiscais de fronteira são adequados.

Assim, por esses motivos, os ajustes fiscais de fronteira previstos no GATT apenas precisariam se preocupar com os tributos indiretos, dentro de seu objetivo de preservar as vantagens comparativas e não criar vantagens competitivas artificiais.

No entanto, apontam Paul Demaret e Raoul Stewardson (1994, p. 14 - 15) que diversos economistas, desde mesmo a década de 40 do Século XX, incluindo os estudos realizados nos Relatórios Deringer e Neumark, ambos de 1963, no bojo dos esforços integracionistas europeus, já ensinavam que o fenômeno da repercussão ou translação econômica ${ }^{356}$ poderia estar presente tanto nos tributos diretos quanto nos indiretos, o que dependeria de fatores mais relevantes, como as estruturas de mercado, o ciclo de negócios e outras condições econômicas, todas dependentes do tempo e do setor econômico envolvidos, muito mais do que simplesmente a natureza da incidência tributária. Assim, concluem (1994, p. 15) que normas proibindo o ajuste de tributos diretos e permitindo para

\footnotetext{
${ }^{356}$ Cuja não aplicação aos impostos diretos Melvyn Krauss (1976, p. 153) denomina crença doente na origem ("ill-founded belief").
} 
os tributos indiretos são iníquas e constrangem irracionalmente o legislador nacional no desenho de sua estrutura tributária doméstica ${ }^{357}$.

Na mesma esteira, Robert Floyd (1973, p. 489) chega a dizer que só na hipótese em que apenas os impostos indiretos fossem integralmente transladados para os preços dos produtos e não houvesse qualquer reflexo semelhante nos impostos diretos, poder-se-ia dizer que as normas do GATT resultariam em neutralidade comercial. Até porque, como ensina John Howard Jackson (2000, p. 220), não há cálculo simples que possa definir a linha divisória entre os ônus do produtor e do consumidor em se tratando da incidência tributária por meio de qualquer das modalidades de impostos, o que provavelmente variará de acordo com o produto pesquisado.

Essa percepção, de que a autorização do GATT ser limitada aos tributos indiretos prejudicaria a competitividade internacional dos países cuja estrutura tributária fosse baseada nos impostos diretos, particularmente os Estados Unidos, ainda se agravou mais quando, no início da década de 70 do Século XX, os Estados Unidos, ainda presos ao sistema de taxa de câmbio fixo oriundo dos acordos de Bretton Woods, tiveram sérios problemas no seu balanço de pagamentos. Ademais, as reduções tarifárias decorrentes da Rodada Kennedy fizeram com que, no entender de John H. Jackson (2000, p. 220), os ajustes fiscais de fronteira adquirissem relevância quantitativa maior, aumentando a preocupação dos países no seio do GATT com o acerto do seu ajuste fino e as suas influências competitivas. Nesse ambiente, Robert Floyd (1973, p. 489), informa que foi intenso o debate, especialmente nos anos 60 do Século XX, acerca dos efeitos dos vários tributos, indiretos principalmente, mas também diretos, e dos ajustes fiscais de fronteira, sobre a competitividade internacional dos países.

A OCDE, em aprofundado estudo sobre o tema (1988, p. 112 -113), nos ensina que, entre 1962 e 1972, as normas do GATT relativas aos ajustes fiscais de fronteira foram objeto de pesadas críticas, especialmente nos Estados Unidos, fundamentalmente por quatro razões principais:

\footnotetext{
357 Por outro lado, Demaret e Stewardson (1994, p. 15 - 16) reconhecem que o cálculo do quantum transferido ao consumidor final do tributo direto e a sua atribuição a particulares produtos da fabricação da empresa tributada é problema de difícil resolução, chegando mesmo a, em alguns casos, ser de impossível apuração. Fatores tais como as diferenças nos sistemas de depreciação, a extensão da integração vertical do produtor e a disponibilidade para incentivos ao investimento e outros favores fiscais podem afetar a extensão dessa repercussão econômica. Assim, entendem que estender a todos os tributos diretos a possibilidade de ajuste fiscal de fronteira seria abrir inconvenientemente à possibilidade de que tais mecanismos fossem erroneamente empregados com fulcro protecionista, o que seria deixar a matéria por demais suscetível a disputas comerciais. Assim, detêm-se a relacionar quais seriam os tributos que seriam ajustáveis na fronteira, segundo seu entendimento (p. 16-20).
} 
i) o sistema cambial fixo, do tipo padrão ouro-dólar, decorrente dos Acordos de Bretton Woods, aliado ao pesado déficit externo americano, em muito agravado pelos custos da Guerra do Vietnã;

ii) o excessivo emprego de ressarcimentos, especialmente em países europeus ainda com a previsão legal de tributos indiretos em cascata, de forma abusiva em relação ao efetivamente devido, decorrentes da devolução de impostos ocultos, como os incidentes sobre bens e serviços empregados na produção, transporte e comercialização dos produtos finais (OCDE, 1988, p. 112);

iii) o escalonamento dos ajustes fiscais de fronteira decorrentes dos impostos ocultos, deteriorando a balança comercial de países que não empregavam impostos indiretos em cascata, como os Estados Unidos;

iv) o excesso de export rebates calculados por meios indiciários, com recurso a alíquotas médias, aproximadas, a forfait (XAVIER DE BASTO, 1991, p. 114 - 115), o que só veio a ser proibido, restrição ainda limitada à Europa dos Seis, pela "Primeira Directiva do Conselho de 11 de Abril de 1967 em matéria de harmonização das legislações dos EstadosMembros respeitantes aos impostos sobre o volume de negócios”, ainda assim com prazo de implantação até $1^{\circ}$ de Janeiro de 1970 - prazo que, por sinal, a República Italiana não cumpriu.

Nesse ambiente de pressão dos Estados Unidos contra uma realidade que se afigurava deletéria à sua competitividade internacional, três eventos dela decorrentes foram de extrema relevância no estudo dos ajustes fiscais de fronteira.

O primeiro foi a instauração, a 28 de março de $1968^{358}$, de um grupo de trabalho no seio do GATT, destinado a examinar o efeito dos ajustes fiscais de fronteira no comércio internacional - iniciativa que gerou o relatório ao qual já nos referimos no presente trabalho por diversas vezes, de 20 de novembro de 1970. As preocupações acima assinaladas, e que geraram a insatisfação motivadora do pedido de instalação do grupo de trabalho, não obstante, já haviam sido reiteradamente externadas pelos Estados Unidos aos membros do GATT desde poucos meses após as negociações no bojo da Rodada Kennedy ${ }^{359}$. A dicção detalhada desse relatório será examinada a seguir.

\footnotetext{
${ }^{358}$ Documento C/W/124.

${ }^{359}$ Ver o Documento TN.64/SR.16 - "Proceedings of the Sixteenth Meeting: Held at the Palais des Nations, Geneva, on 28 June 1967', de 2 de agosto de 1967, e, principalmente, o Documento W.24/40, de 24 de
} 
Depois, o segundo foi a adoção, por parte do governo americano, diante desse quadro de forte pressão dos industriais americanos em face da situação comunitária europeia, de uma legislação que admitia a isenção parcial de impostos diretos sobre receitas decorrentes da exportação de produtos ao exterior. Assim, em 1971, foi aprovada a norma denomidada U. S. Domestic International Sales Corporations (DISC), como parte do Revenue Act de 1971 - 85 Stat. 497 (1971), Sections 501 - 507, incorporados no U. S. Internal Revenue Code como Sections 991 - 997.

A norma permitia a criação de subsidiárias de empresas holding norteamericanas constituídas especificamente para permitir até que 50\% do imposto sobre a renda obtida por essas subsidiárias com as exportações de produtos para o exterior fosse diferida, sem a fluência de juros de mora, indefinidamente, apenas até que um desses eventos ocorresse (a) houvesse uma distribuição real dos dividendos decorrentes da parcela isenta, (b) a subsidiária DISC fosse liquidada, (c) um acionista vendesse suas ações da companhia DISC, ou (d) a companhia deixasse de se qualificar como DISC para o anobase corrente. A metade restante era considerada distribuída aos acionistas da subsidiária DISC e tributada como dividendo.

Essa norma foi objeto de um Grupo Especial ${ }^{360}$, no âmbito ainda do GATT, uma vez que as Comunidades Europeias entenderam que a legislação violaria o Artigo XVI:4 do Acordo Geral, que proíbe os subsídios às exportações. O Canadá posteriormente apoiou os argumentos europeus.

A defesa americana se baseou no fato de que aquelas normas estariam fora do escopo de atuação do GATT, uma vez que o Relatório do Grupo de Trabalho sobre Subsídios $^{361}$, na medida em que continha uma lista ilustrativa de práticas que seriam consideradas pelos países contratantes do GATT como subsídios, não menciona o diferimento de tributos, a isenção da renda de fonte estrangeira ou outras práticas relacionadas a tributos diretos. Demaret e Stewardson (1994, p. 12) mencionam que os Estados Unidos arguiram que o GATT não poderia ir tão a fundo na limitação aos poderes soberanos de imposição tributária das Partes Contratantes, pelo que deveriam ser examinadas outras normas semelhantes de outros estados, como da Bélgica, França e

novembro de 1967, denominado "Twenty-Fourth Session. Review of the Work of the CONTRACTING PARTIES and Future Programme. Statement by The Hon. Mr. William M. Roth, Special Trade Representative, Executive Office of the President of the United States, on 23 November 1967'.

${ }^{360}$ United States - Income Tax Legislation (DISC), de 2 de novembro de 1976, BISD 23S/98 (1977), L/4422. Estabelecido em 30 de julho de 1973 (C/M/89) e adotado pelo Conselho de Representantes em 7 e 8 de dezembro de 1981, BISD 28S/121.

${ }^{361}$ Report of the Working Party on Subsidies, L/1381, novembro de 1960. 
Países Baixos. Ao final, o Grupo Especial preferiu manter-se na posição tradicional e considerou a legislação DISC como contrária às obrigações do Acordo Geral. Vale dizer, foi reforçada a aplicabilidade exclusiva do GATT aos tributos indiretos.

O terceiro, o julgamento, pela Suprema Corte americana, do chamado caso “Zenith Radio Case", de 21 de junho de $1978^{362}$, com voto condutor do honorável Justice Marshall. Nele a corte constitucional americana considerou que os impostos ressarcidos ao exportador japonês de televisores pelo governo do Japão não poderia ser considerado um subsídio ("bounty or grant") justificador da imposição de direitos compensatórios pelo governo americano, como queria o autor, fabricante americano de televisores, desde que fossem não-excessivos ("non-excessive").

O artigo (Section) 303 do Tariff Act americano de 1930, emendado pelo 46 Stat. 687 e regulamentado pelo 19 U.S.C. $\$ 1303(\mathrm{a})^{363}$ previa que sempre que um país estrangeiro pagasse ao exportador nacional algum montante pelo produto que produzisse, $\mathrm{o}$ Secretário do Tesouro seria autorizado a impor um direito compensatório ("countervailing duty") igual ao montante líquido entregue ao produtor estrangeiro. Sob a Lei do Imposto sobre Commodities do Japão, Lei $\mathrm{n}^{\mathrm{o}} 48$ de 1962, diversos produtos de consumo, como os produtos eletrônicos sob exame, eram sujeitos a um imposto indireto tendo como base de cálculo o valor de venda do fabricante, aplicável tanto aos manufaturados no Japão (na ocasião da saída da fábrica) quanto aos importados (exigido na repartição aduaneira). No entanto, os impostos que seriam incidentes sobre os produtos destinados à exportação eram reeembolsados ao fabricante japonês.

A Suprema Corte norte-americana, nos casos Downs v. United States ${ }^{364}$, de 1903, e G. S. Nicholas \& Co. v. United States ${ }^{365}$, de 1919 , já havia se pronunciado no sentido de que quaisquer reembolsos de impostos no pais estrangeiro deveriam ser considerados subsídios justificadores de direitos compensatórios. Assim, a primeira

\footnotetext{
362 Zenith Radio Corp. v. United States, 437 U.S. 443 (1978).

363 “(1) Whenever any country, dependency, colony, province, or other political subdivision of government, person, partnership, association, cartel, or corporation, shall pay or bestow, directly or indirectly, any bounty or grant upon the manufacture or production or export of any article or merchandise manufactured or produced in such country, dependency, colony, province, or other political subdivision of government, then upon the importation of such article or merchandise into the United States, whether the same shall be imported directly from the country of production or otherwise, and whether such article or merchandise is imported in the same condition as when exported from the country of production or has been changed in condition by remanufacture or otherwise, there shall be levied and paid, in all such cases, in addition to any duties otherwise imposed, a duty equal to the net amount of such bounty or grant, however the same be paid or bestowed".

364 Downs v. United States, 187 U.S. 496 (1903).

365 G. S. Nicholas \& Co. v. U.S., 249 U.S. 34 (1919).
} 
instância do poder judiciário federal especializado americano, a Customs Court, com base nesses precedentes, julgou a favor do autor americano.

No entanto, desde a primeira lei americana sobre o assunto (" $U$. $S$. Countervailing Duty Statute"), de 1897, o Departamento do Tesouro havia consolidado um entendimento administrativo da lei de forma a admitir que só os ressarcimentos em excesso aos tributos indiretos incidentes seriam passíveis de serem objeto de direitos compensatórios. No caso Zenith Radio, a Suprema Corte americana, no que já havia sido antecedida pela segunda instância ("The Court of Customs and Patent Appeals"), entendeu que a interpretação legal empreendida pelo órgão administrativo seria razoável diante do objetivo da lei e da instituição de direitos compensatórios, o de contrabalançar as vantagens competitivas auferidas pelos produtos estrangeiros decorrentes de subsídios pagos pelos seus governos, sem que isso implicasse dupla incidência de encargos sobre os produtos.

Ademais, a interpretação do Departamento do Tesouro, no entender do julgado, seria permissível em 1898 assim como era em 1978, uma vez que os termos da lei nesse aspecto não haviam sido alterados nas cinco redações que a emendaram posteriormente, além do que a posição do Secretário do Tesouro havia sido incorporada em um acordo internacional que havia sido assinado pelas maiores nações do mundo, motivo pelo qual não seria o Poder Judiciário americano quem insistiria em impor a sua visão em detrimento da eficiência econômica oriunda da possibilidade de ressarcimento dos impostos indiretos na importação. Foi, portanto, um marco no respeito, pelo ordenamento interno americano, às determinações internacionais na matéria. Além disso, o caso pode ser visto como a reafirmação da distinção do GATT entre o tratamento dos tributos diretos e dos indiretos, sob a ótica americana (DEMARET; STEWARDSON, 1994, p. 13).

Do ponto de vista das importações, a disciplina multilateral de regulação do comércio internacional não sofreu alterações ao longo do tempo, sendo que Robert Floyd (1973, p. 492), em notável apanhado histórico, inclusive mediante entrevistas a componentes da delegação americana de então, informa que praticamente não sofreu alterações desde o primeiro esboço apresentado em Londres em outubro de 1946, passando por todas as redações, examinadas pelos grupos de trabalho que preparavam tanto a Carta de Havana, quanto o GATT, que nada mais era do que a sua seção de política comercial, tanto em Lake Success, Genebra, quanto finalmente em Havana, em março de 1948.

O mesmo não se pode dizer quanto aos aspectos relacionados às exportações. Embora primeiramente, no que tange à isenção dos produtos destinados à exportação, 
desde cedo houve consenso, não obstante ter havido alteração relevante de redação no GATT, a norma que previa o ressarcimento dos impostos incidentes sobre os produtos destinados à exportação só veio a ser inserida no texto do GATT em 1955, por meio de uma nota adicional, como veremos, provavelmente, segundo Floyd (1973, p. 492, nota de rodapé $\mathrm{n}^{\circ}$ 9), por ter sido conjuntamente debatida com o penoso tema dos subsídios fiscais à produção, prática muito em voga naquela época. Não obstante, Floyd afirma que esta possibilidade desde já estaria implícita na disciplina dos direitos compensatórios do Artigo VI.

Mas realmente o aspecto que mais se alterou ao longo do tempo na matéria se relaciona com o ressarcimento nas exportações. Tal se deve ao notável avanço que a disciplina dos subsídios, que é intrinsecamente relacionada aos "export rebates", embora não apenas concernente aos aspectos fiscais, sofreu com o passar do tempo.

Nessa perspectiva, foram três os seus grandes marcos históricos. Seus conteúdos serão mais bem conhecidos no item seguinte do presente trabalho, mas desde já merecem ser apontados.

O primeiro foi a instalação de um Grupo de Trabalho ("Working Party on Subsides"), ainda no seio do GATT, durante sua Décima-Sétima Sessão, que produziu um Relatório, L/1381, em novembro de 1960, trazendo uma lista de medidas consideradas proibidas diante do Artigo XVI:4 do GATT, fazendo expressa menção à possibilidade de ressarcimento de tributos na exportação em montante equivalente aos incidentes internamente.

A seguir, tem-se o advento, na Rodada Tóquio, do aqui chamado "Código de Subsídios e Medidas Compensatórias", o "Acordo Relativo à Interpretação e Aplicação dos Artigos VI, XVI e XXIII do Acordo Geral sobre Tarifas Aduaneiras e Comércio”, assinado em Genebra, a 12 de abril de 1979, aprovado pelo Decreto Legislativo $\mathrm{n}^{\mathrm{o}} 22$, de 5 de dezembro de 1986 e internalizado ao ordenamento jurídico brasileiro por meio do Decreto $\mathrm{n}^{\circ}$ 93.962, de 22 de janeiro de 1987.

O último, já como produto dos trabalhos da Rodada Uruguai, é o "Acordo Sobre Subsídios e Medidas Compensatórias", presente na Ata Final que Incorpora aos Resultados da Rodada Uruguai de Negociações Comerciais Multilaterais do GATT, assinada em Maraqueche, em 12 de abril de 1994, aprovada pelo Decreto Legislativo n ${ }^{\text {o } 30,}$ de 15 de dezembro de 1994 e promulgada pelo Decreto $\mathrm{n}^{\circ} 1.355$, de 30 de dezembro de 1994. Hoje tal disciplina é dada pela Lei nº 9.019, de 30 de março de 1995. 
Desde o início dos trabalhos acerca da matéria, estudiosos da área econômica, como Melvyn Krauss (1969, p. 557 - 558), afirmavam que os ajustes fiscais de fronteira não teriam assim tanta relevância tanto no ponto de vista da eficiência na alocação dos recursos dos fatores como no ajuste do balanço de pagamentos, sendo de muito menor eficácia nessas funções do que a taxa de câmbio, até por que só aplicáveis ao comércio de bens e não ao de serviços. Ocasionalmente na doutrina (FLOYD, 1973, p. 490), desde a década de 60 do Século XX já se criticava a importância dada ao tema, havendo quem dissesse (MUSGRAVE, 1969, p. 277 e 285) que a racionalidade dos ajustes fiscais de fronteira era um enigma.

Posteriormente, passaram a preponderar as visões como a de Orzechowski (2001, p. 1), no sentido de que a natural dinâmica dos preços, especialmente a taxa de câmbio, em regimes de plena liberdade cambial, mas também pela alteração dos custos dos fatores, capital e trabalho (2001, p. 6), teriam o condão de criar ambientes tributários neutros ao comércio internacional independentemente do emprego de ajustes fiscais de fronteira. Assim, o relativamente menor poder de ajustamento fiscal conferido a países como os Estados Unidos, dadas as restrições do sistema GATT e a sua estrutura tributária baseada nos impostos diretos, não acarretaria grande impacto na posição competitiva dos produtos norte-americanos nos mercados mundiais (ORZECHOWSKI, 2001, p. 1). Ademais, haveria relevantes custos associados à administração e ao cumprimento dos ajustes fiscais de fronteira, sem falar no fato de que o seu emprego tenderia a mascarar o real custo dos tributos corporativos, o que faria com que os acionistas e administradores societários, assim como os legisladores, se tornassem menos sensíveis aos aumentos de impostos internos (ORZECHOWSKI, 2001, p, 1).

Outro estudioso de peso, agora do Direito Internacional do Comércio, John Howard Jackson (2000, p. 221), após afirmar que qualquer distorção no comércio internacional eventualmente determinada por um ajuste fiscal de fronteira seria neutralizada pela flutuação na taxa de câmbio em poucos anos, afirmou entender absolutamente carente de qualquer sentido eventual iniciativa de se alterar uma política fiscal bem-sucedida, de basear sua incidência tributária mais fortemente em tributos diretos, o que seria mais desejável, por conta de sua progressividade, apenas em função de uma vantagem competitiva no comércio internacional de duvidosa relevância.

No mesmo sentido, Gary Hufbauer (1996, p. 35) revela que a razão fundamental para a existência dos ajustes fiscais de fronteira não é nem alterar a balança comercial ou o balanço de pagamento dos países nem achar um substituto para a taxa de 
câmbio como instrumento de ajuste internacional, mas sim o de contrabalançar eventuais ônus tributários que recaiam desigualmente em alguns setores da Economia em relação a outros. Seria, portanto, um exagero dos homens de negócio americanos da época em visualizar tanto impacto das alterações tributárias comunitárias da Europa no balanço de pagamentos dos Estados Unidos, o que seria muito mais reflexo dos eventuais superavits nas transações correntes em função dos fluxos de poupança e investimento entre os países (p. 27). Nesse contexto, o emprego de ajustes fiscais de fronteira teria apenas um modesto efeito macroeconômico (p. 27).

Nesse ambiente, embora houvessem sido diversas as propostas de discussão da racionalidade das normas do GATT referentes aos ajustes fiscais de fronteira tanto no seio de OCDE, de 1965 a 1968, quanto no próprio GATT, de 1969 a 1972, desde a abolição dos ajustes fiscais de fronteira em relação aos impostos ocultos até a extensão aos impostos diretos, tanto a OCDE quanto o GATT entenderam que a melhor solução não seria alterar o sistema, senão apenas possibilitar que, quando a situação fosse muito desigual, poder-se-ia instalar o procedimento de consulta (OCDE, 1988, p. 113). Com o fim do regime de paridade fixa do dólar e o desuso do emprego de ajustamentos fiscais para os impostos ocultos, nenhum governo, nem mesmo o americano, manteve a sua pressão para a alteração das regras do GATT referentes aos ajustes fiscais de fronteira no início dos anos 70 do século passado (OCDE, 1988, p. 113).

Some-se a essas constatações também o fim dos impostos indiretos em cascata decorrente da alteração do sistema fiscal comunitário europeu, com a adoção integral do denominado regime transitório, cujo mecanismo, como bem afirma Gary Hufbauer (1996, p. 42), é bem semelhante ao do "Retail Sales Tax" norte-americano: isenção do imposto indireto nas vendas fora do Estado, de forma a que não haja formalidades instrumentais nem incidência tributária na transição de fronteiras estaduais, sendo que competirá ao Estado onde o bem será consumido tributar os seus residentes consumidores.

Como veremos, com o regime transitório comunitário europeu, desapareceram os ajustamentos fiscais de fronteira, tanto nas importações quanto nas exportações, nas transações intracomunitárias. Haveria algo como uma suspensão do imposto nas importações, mas sem documentos aduaneiros e controles físicos das mercadorias importadas. Como consequência, tornou-se mais estratégica a eficiência na troca de informações entre as administrações tributárias dos diferentes países.

Por conta dessa realidade legislativa, verificou-se, durante as décadas de 80 e 90 do Século XX, relativamente pequena dedicação científica ao tema. Mesmo assim, John 
H. Jackson (2000, p. 219 e nota de rodapé 23, p. 398) aponta que ainda em 1988 os Estados Unidos afirmavam que o seu principal objetivo nas negociações da Rodada Uruguai, no que tange ao tratamento dos ajustes fiscais de fronteira, consistia na possibilidade de extensão dos efeitos das normas do GATT aos impostos diretos. Tal preocupação foi externada no Section 1101(b)(16) do "Omnibus Trade and Competitiveness Act ${ }^{\text {"366 }}$, de 1988, norma destinada a aprimorar a competitividade da indústria americana e outras providências, proposta pelo Deputado Republicano do Missouri Dick Gephardt e assinada pelo Presidente Ronald Reagan e que, entre outras, determinava ao Poder Executivo americano que examinasse com profundidade o comércio dos países com os quais os Estados Unidos tivessem déficit comercial, impondo metas para sua redução - uma autêntica recaída protecionista do governo republicano de então.

Não obstante, essa situação se reverteu no presente Século XXI, com as promulgações, no âmbito da Comunidade Europeia, da Directiva 2003/96/EC, do Conselho da Comunidade Europeia, com o fim de reestruturar "o quadro comunitário de tributação dos produtos energéticos e da electricidade”, como se verá adiante.

O surgimento da tributação "verde" na Comunidade Europeia, pela via da extensão da incidência do imposto comunitário especial de consumo sobre os óleos minerais a todos os produtos ditos, em português oficial, de Portugal, como energéticos, além da eletricidade, fez ressurgir o questionamento acerca das suas implicações no comércio internacional.

Pode ser entendido, dessa realidade atual, que tenha havido uma reversão na situação do século passado, porque, agora, diferentemente do final da década de 60 do Século XX, o mecanismo mais oneroso se verifica no âmbito europeu, uma vez que não há qualquer incidência, no sistema americano, que se pareça com tributos com fito extrafiscal em matéria ambiental.

Porém, antes mesmo disso, Demaret e Stewardson (1994, p. 5), já vislumbravam, com base em estudos da OCDE nos Países Baixos, Suécia e Finlândia, o cada vez mais comum emprego de instrumentos tributários com o fim de alcançar objetivos ambientais, saindo do tradicional uso de normas regulatórias como o mesmo intuito. A racionalidade, ensinavam, era a de modificar os padrões de comportamentos dos consumidores ou dos produtores, aumentando os custos de certos produtos ou atividades em relação a outros produtos ou atividades, muito embora ainda os tributos ambientais

${ }^{366}$ Public Law 100-148, 23 de agosto de 1988. 
àquela altura ainda não fossem exigidos a valores de maior grandeza. Mesmo assim, esse tipo de imposição tributária, na medida em que não exigida por todos os países, avaliam, poderiam afetar os custos dos produtos em relação aos de outros países e, em consequência, alterar as condições de competitividade internacional (DEMARET; STEWARDSON, 1994, p. 6).

Nessa mesma esteira, com esse mesmo tipo de preocupação, outros artigos foram publicados, sempre na perspectiva externa ao sistema americano ${ }^{367}$, refletindo um reavivamento da questão. Certamente ainda mais artigos virão a ser escritos sobre o assunto, especialmente com o enriquecimento das incidências ambientais no mundo, mormente se continuarmos a ver a omissão do governo americano em tomar semelhantes iniciativas.

\subsection{Do Tratamento no Sistema Multilateral de Regulação do Comércio Internacional.}

Quando discutíamos qual o âmbito de aplicação do artigo III do GATT, e afirmou-se que o mais correto é entender que o objeto do referido artigo são precipuamente os ajustes fiscais de fronteira, embora seja aplicável a qualquer incidência indireta e até a algumas modalidades de tributação direta, dado o seu potencial efeito protetivo, não se entrou em exame mais aprofundado de qual seria a disciplina jurídica dos ajustes fiscais de fronteira no sistema multilateral de regulação do comércio internacional.

Para efeito de facilidade didática, e também para que seja definido de forma mais clara o escopo de nossos estudos aqui empreendidos, já que, como já dito, o tema dos subsídios fiscais está fora do corte epistemológico empreendido pela presente pesquisa, há que se separar a disciplina regulamentar do ponto de vista das importações (situação em que é mais relevante, dada a opção pelo legislador do GATT pelos ajustes fiscais de fronteira sob o princípio do destino, a questão da tributação discriminatória e, principalmente, da protetiva) da disciplina na ótica das exportações (ocasião em que

367 Os exemplos mais evidentes dessa realidade são MAJOCCHI, Alberto; MISSAGLIA, Marco. Environmental taxes and border tax adjustments: an economic assessment. Rivista di Diritto Finanziario e Scienza delle Finanze. Milão. Vol. 61, nº 4, p. 584 - 610, dezembro de 2002 e GOH, Gavin. The World Trade Organization, Kyoto and energy tax adjustments at the border. Journal of World Trade. Genebra. Vol. 38, n'. 3, p. $395-423$. 
mencionar-se-á, embora de passagem, a disciplina do Acordo Geral em relação aos subsídios).

Quanto às importações, já conhecemos profundamente a disciplina do Artigo III $^{368}$ do GATT, cuja função, como já esclarecido, é reforçar o Princípio da Proteção Aduaneira Exclusiva, evitando que as Partes Contratantes empreguem tributos internos com fins protecionistas, em substituição aos impostos de importação ou direitos aduaneiros, cujas alíquotas foram objeto de concessões tarifárias. Como se viu, em verdade os dois princípios fundantes são mutuamente dependentes entre si - não haverá sentido em restringir a proteção às tarifas negociadas se fosse admitida a tributação interna discriminatória ou protetiva; não há sentido em se proibir a tributação interna discriminatória ou protetiva se não houver algum tipo de limitação aos encargos aduaneiros.

Exatamente em função desse caráter mutuamente dual que garante eficácia aos dois princípios fundantes do sistema, é necessária a presença, no Artigo II, que trata das concessões tarifárias, de previsão da possibilidade de algum mecanismo interno de tributação que garanta o direito às Partes Contratantes ao ajustamento fiscal de fronteira. Essa previsão está presente no Art. II:2(a) do $\mathrm{GATT}^{369}$. Importante dar o relevo devido ao fato de que a dicção convencional aponta para a necessidade que o imposto interno exigido

\footnotetext{
${ }^{368}$ Apenas para facilitar:

"ARTIGO III

TRATAMENTO NACIONAL NO TOCANTE A TRIBUTAÇÃO E REGULAMENTAÇÃO INTERNAS.

1. As Partes Contratantes reconhecem que os impostos e outros tributos internos, assim como leis, regulamentos e exigências relacionadas com a venda, oferta para venda, compra, transporte, distribuição ou utilização de produtos no mercado interno e as regulamentações sobre medidas quantitativas internas que exijam a mistura, a transformação ou utilização de produtos, em quantidade e proporções especificadas, não devem ser aplicados a produtos importados ou nacionais, de modo a proteger a produção nacional.

2. Os produtos do território de qualquer Parte Contratante, importados por outra Parte Contratante, não estão sujeitos, direta ou indiretamente, a impostos ou outros tributos internos de qualquer espécie superiores aos que incidem, direta ou indiretamente, sobre produtos nacionais. Além disso nenhuma Parte Contratante aplicará de outro modo, impostos ou outros encargos internos a produtos importados nacionais, contrariamente as principais estabelecidas no parágrafo 1".

${ }^{369}$ Segundo a Lei $n^{\circ} 313 / 48$ :

ARTIGO II
}

LISTAS DE CONCESSÕES

2. Nenhuma disposição do presente artigo impedirá que, uma Parte Contratante, a qualquer tempo, aplique no tocante à importação de qualquer produto:

(a) encargo equivalente a um imposto interno exigido, de conformidade como o disposto no parágrafo 2 do Artigo III, sobre um produto nacional similar ou uma mercadoria com a qual o produto importado tenha sido fabricado ou produzido no todo ou em parte;

(b) direitos destinados a contrabalançar ou a compensar o dumping quando, aplicados de conformidade com o disposto no Artigo IV (sic);

(c) taxas ou outros encargos que guardem proporção com os custos dos serviços prestados".

De se ressaltar que a a versão original da Lei no 313 de 30/07/1948 estabelece erroneamente “... no Artigo IV" no fim da alínea (b), quando deveria constar “... no Artigo VI", pois se refere aos direitos anti-dumping e compensatórios. 
do produto nacional corresponda a um "encargo equivalente" ao incidente sobre os produtos de fabricação nacional, o que corresponde justamente à exigência dos doutrinadores do campo econômico que o ajuste fiscal de fronteira corresponda quantitativamente justamente ao tributo incidente sobre o produto nacional, de forma a evitar o seu efeito protecionista.

Examinando a questão, no caso "United States - Taxes on Petroleum and certain Imported Substances", o Relatório do seu Grupo Especial, L/6175, de 5 de junho de 1987, afirma que o conceito de equivalência previsto no Artigo II:2(a) deve ser entendido de forma proporcional, inclusive considerando o percentual do produto tributado na composição química do produto final, usando o exemplo do tributo incidente sobre o álcool em relação ao perfume ${ }^{370}$.

Ressalve-se que tanto as disposições do Artigo II quanto as do Artigo III do GATT referem-se apenas a incidências sobre produtos (JACKSON, 2000, p. 219). Tal foi expressamente reconhecido no caso "United States - Restrictions on Imports of Tuna", no Relatório do seu Grupo Especial, de 3 de setembro de 1991, DS21/R ${ }^{371}$.

\footnotetext{
370 "5.2.7 The Panel, having concluded that the tax on certain chemicals was in principle eligible for border tax adjustment, then examined whether the tax on certain imported substances meets the national treatment requirement of Article III:2, first sentence. This provision permits the imposition of an internal tax on imported products provided the like domestic products are taxed, directly or indirectly, at the same or a higher rate. Such internal taxes may be levied on imported products at the time or point of importation (Note ad Article III). Paragraph 2(a) of Article II therefore clarifies that a tariff concession does not prevent the levying of

" a charge equivalent to an internal tax imposed consistently with the provisions of paragraph 2 of Article III in respect of the like domestic product or in respect of an article from which the imported product has been manufactured or produced in whole or in part."

The drafters of the General Agreement explained the word "equivalent" used in this provision with the following example:

"If a [charge] is imposed on perfume because it contains alcohol, the [charge] to be imposed must take into consideration the value of the alcohol and not the value of the perfume, that is to say the value of the content and not the value of the whole" (EPCT/TAC/PV/26, page 21).

5.2.8 The tax on certain imported substances equals in principle the amount of the tax which would have been imposed under the Superfund Act on the chemicals used as materials in the manufacture or production of the imported substance if these chemicals had been sold in the United States for use in the manufacture or production of the imported substance. In the words which the drafters of the General Agreement used in the above perfume-alcohol example: The tax is imposed on the imported substances because they are produced from chemicals subject to an excise tax in the United States and the tax rate is determined in principle in relation to the amount of these chemicals used and not in relation to the value of the imported substance. The Panel therefore concluded that, to the extent that the tax on certain imported substances was equivalent to the tax borne by like domestic substances as a result of the tax on certain chemicals, the tax met the national treatment requirement of Article III:2, first sentence".

371 "5.11. The text of Article III:1 refers to the application to imported or domestic products of "laws, regulations and requirements affecting the internal sale... of products" and "internal quantitative regulations requiring the mixture, processing or use of products'; it sets forth the principle that such regulations on products not be applied so as to afford protection to domestic production. Article III:4 refers solely to laws, regulations and requirements affecting the internal sale, etc. of products. This suggests that Article III covers only measures affecting products as such. Furthermore, the text of the Note Ad Article III refers to a measure "which applies to an imported product and the like domestic product and is collected or
} 
Do ponto de vista dos produtos exportados, verifica-se novamente que o princípio do destino é obedecido rigorosamente. Para ficar apenas na disciplina do Acordo Geral, já que o tema da normativa convencional aos subsídios (ou subvenções, como se dá a referência no Acordo Geral) não pertence ao nosso escopo de pesquisa, temos que o Artigo $\mathrm{XVI}^{372}$, especialmente o seu parágrafo 4, ao proibir às Partes Contratantes que concedam subsídios aos produtos, exceto aos primários (ou produto de base, na dicção convencional $^{373}$ ), menciona que tais subsídios não podem ter o resultado de reduzir o preço

enforced in the case of the imported product at the time or point of importation". This suggests that this Note covers only measures applied to imported products that are of the same nature as those applied to the domestic products, such as a prohibition on importation of a product which enforces at the border an internal sales prohibition applied to both imported and like domestic products" - os grifos estão presentes no original.

${ }^{372}$ Na redação da Lei ${ }^{\circ} 4.138$, de 17 de setembro de 1962:

"ARTIGO XVI

SUBVENÇÕES

SEÇÃO A

SUBVENÇÕES EM GERAL

1. Se uma Parte Contratante concede ou mantém uma subvenção qualquer, inclusive qualquer forma de proteção das rendas ou sustentação dos preços que tenha diretamente ou indiretamente por efeito elevar as exportações de um produto qualquer do território da referida Parte Contratante ou de reduzir as importações do mesmo no seu território, dará conhecimento, por escrito, às Partes Contratantes, não somente da importância e da natureza dessa subvenção, como dos resultados que possam ser esperados sobre as quantidades do ou dos produtos em questão por ele importados ou exportados e as circunstâncias que tornam a subvenção necessária. Em todos os casos em que fique estabelecido que uma tal subvenção causa ou ameaça causar um prejuízo sério aos interesses de outra Parte Contratante, a Parte Contratante que a concedeu examinará, quando solicitada, com a ou com as Partes Contratantes interessadas ou com as Partes Contratantes, a possibilidade de limitar a subvenção.

SEÇÃO B

DISPOSIÇÕES ADICIONAIS RELATIVAS ÀS SUBVENÇÕES E À EXPORTAÇÃO

2. As Partes Contratantes reconhecem que a outorga, por uma Parte Contratante, de uma subvenção à exportação de um produto pode ter conseqüências prejudiciais para outras Partes Contratantes, quer se trate de países importadores ou de países exportadores; que pode provocar perturbações injustificadas nos seus interesses comerciais normais e opor obstáculo à realização dos objetivos do presente Acordo.

3. Em consequiência, as Partes Contratantes deveriam se esforçar no sentido de enviar a concessão de subvenções à exportação de produtos base. Contudo, se uma Parte Contratante consegue diretamente ou indiretamente, sob uma forma qualquer, uma subvenção que tenha por efeito aumentar a exportação de um produto de base originária de seu território, esta subvenção não será concedida de tal maneira que a mencionada Parte Contratante detenha então uma parte mais do que razoável do comércio mundial de exportação do mesmo produto, tendo em vista a participação das Partes Contratantes no comércio deste produto durante um período de referência anterior, assim como todos os fatores especiais que possam ter afetado ou que possam afetar o comércio em questão.

4. Além disso, a partir de $1^{\circ}$ de janeiro de 1958 , ou o mais cedo possível depois desta data, as Partes Contratantes cessarão de conceder direta ou indiretamente qualquer subvenção, de qualquer natureza que ela seja, à exportação de todo produto que não seja produto de base, que tenha por resultado de reduzir o preço de venda na exportação deste produto abaixo do preço comparável cobrado aos consumidores do mercado interno para o produto similar. Até 31 de dezembro de 1957, nenhuma Parte Contratante estenderá o campo de aplicação de tais subvenções além do nível existente em $1^{\circ}$ de janeiro de 1955 , instituindo novas subvenções ou estendendo as subvenções existentes.

5. As Partes Contratantes procederão periodicamente a um exame de conjunto da aplicação das disposições do presente artigo a fim de determinar à luz da experiência, se elas contribuem eficazmente para a realização dos objetivos do presente acordo e se elas permitem efetivamente que as subvenções causem um prejuízo sério ao comércio ou aos interesses das Partes Contratantes".

${ }^{373}$ Segundo Nota Adicional à Seção B do Artigo XVI, trazida ao ordenamento jurídico brasileiro pela Lei $\mathrm{n}^{\circ}$ 4.138/62: "2. Para os fins de aplicação da seção B, a expressão "produtos de base" se entende como qualquer 
de venda na exportação do produto de tal forma que fique abaixo do preço comparável cobrado aos consumidores do mercado interno para o produto similar de origem nacional.

Para evitar que essa restrição se estenda ao ressarcimento dos tributos incidentes sobre os produtos destinados à exportação que caracterizam os ajustes fiscais de fronteira, a Lei $\mathrm{n}^{\mathrm{o}} 4.138 / 62$ internalizou no ordenamento jurídico brasileiro a Ad Note $e^{374}$ ao Artigo XVI ressalvando a hipótese. De se notar que, mais uma vez, a redação oficial traduzida para o português veio equivocada, na medida que emprega o vocábulo "emissão" quando queria se referir a "remissão", no sentido empregado no Direito Tributário brasileiro por meio do instituto jurídico da isenção ${ }^{375}$.

Comentando o teor dessa nota, documento do GATT de 12 de fevereiro de 1948 afirma que o conceito de remissão dos impostos referentes aos produtos destinados à exportação deveria ser amplo, abrangendo também os tributos incidentes sobre as matériasprimas e produtos intermediários empregados no processo produtivo ${ }^{376}$.

Um Grupo de Trabalho ("Working Party on Subsides") instalado durante a Décima-Sétima Sessão do GATT produziu um Relatório, L/1381, em novembro de 1960, em que se trouxe pela primeira vez uma lista, proposta pela França, de medidas consideradas proibidas diante do Artigo XVI:4 do GATT, fazendo expressa menção à possibilidade de isenção ou pagamento de tributos na exportação até o limite do montante equivalente aos incidentes internamente ${ }^{377}$, tomando o cuidado de declará-la

produto da agricultura, das florestas ou de pesca ou como qualquer maneira esteja este produto seja sob sua forma natural ou tenha sofrido a transformação que se exige comumente na venda em quantidades importantes no mercado internacional".

374 "AO ARTIGO XVI

A isenção em favor de um produto exportado, dos direitos ou taxas que atingem o produto similar quando este é destinado ao consumo interno, ou a emissão (sic), desses direitos ou taxas em quantidade que não excedam aqueles que eram devidos, não serão considerados como uma subvenção".

${ }^{375}$ No original em inglês, "remission".

376 "It is understood that the text - particularly the phrase "remission of such duties or taxes....... which have accrued" - cover the case of remission of duties or taxes imposed on raw materials and semi-manufactured products subsequently used in the production of exported manufactured goods" (E/CONF.2/C.3/51, p. 4).

377 "5. The following detailed List of measures which are considered as forms of export subsidies by a number of contracting parties was referred to in the proposal submitted by the Goverrment of France, and the question was raised whether it was clear that these measures could not be maintained if the provisions of the first sentence of paragraph 4 of Article XVI were to become fully operative.

(..)

(d) The exemption, in respect of exported goods, of charges or taxes, other than charges in connexion with importation or indirect taxes levied at one or several stages on the same goods if sold for internal consumption; or the payment, in respect of exported goods, or amounts exceeding those effectively levied at one or several stages on these goods in the form of indirect taxes or of charges in connexion with importation or in both forms.

(...)

The Working Party agreed that this list should not be considered exhaustive or to limit in any way the generality of the provisions of paragraph 4 of Article XVI. It noted that the government prepared to accept the Declaration contained in Annex A agreed that, for the purpose of that Declaration, these practices 
exemplificativa, de forma a não prejudicar uma aplicação mais generalizada da norma convencional.

Em conjunto com a norma referente aos subsídios, do Artigo XVI, o GATT prevê a posssibilidade, pelo país importador, nesse caso, da imposição de direitos compensatórios, ou de compensação, pelo Artigo VI:3 ${ }^{378}$, em montante igual ao subsídio concedido ao produto no seu país de origem. No entanto, e de acordo com a sistemática teórica que apresentamos atrás, o Artigo VI: $4^{379}$ retira do conceito de subsídio compensável o montante isentado ou ressarcido do tributo incidente internamente, quando o produto se verificou destinado à exportação pelo país de origem.

Deve ser novamente considerado que também tanto as disposições do Artigo VI quanto as do Artigo XVI do GATT referem-se apenas a incidências sobre produtos (JACKSON, 2000, p. 219).

Como bem apontam Paul Demaret e Raoul Stewardson (1994, p. 9 - 10), as disposições do GATT não explicam em detalhes a quais tributos tais artigos se aplicam nem como se procederá ao cálculo dos valores em excesso dos devidos de modo a proceder o correto ajuste fiscal de fronteira. Concretamente, nem mesmo os atuais Anexos II e III do “Acordo Sobre Subsídios e Medidas Compensatórias”, assinado na Rodada Uruguai - no Brasil, o Decreto n' 1.355/94 - como veremos, que se propõem a estabelecer "Diretrizes sobre os Insumos Consumidos no Processo Produtivo" e "Diretrizes para determinar se os Sistemas de Devolução constituem Subsídio à Exportação nos casos de Substituição" são minimamente conclusivos a respeito.

generally are to be considered as subsidies in the sense of article XVI:4 or are covered by the Articles of Agreement of the International Monetary Fund. The representatives of Governments which were not prepared to accept that Declaration were not able to subscribe at this juncture to a precise interpretation of the term "subsidies", but had no objection to the above interpretation being accepted by the future signatories of that Declaration for the purposes of its application".

${ }^{378} \mathrm{Na}$ redação do Decreto Legislativo no 43/50:

"ARTIGO VI

DIREITOS "ANTI-DUMPING" E DE COMPENSAÇÃO

(...)

3. Nenhum direito de compensação será cobrado de qualquer produto proveniente do território de uma Parte Contratante importado por outra Parte Contratante, que exceda a importância estimada do prêmio ou subsídio que, segundo se sabe foi concedido direta ou indiretamente à manufatura, produção ou exportação desse produto no país de origem ou de exportação, inclusive qualquer subsídio especial para o transporte de um produto determinado. A expressão "direito de compensação" significa um direito especial cobrado com o fim de neutralizar qualquer prêmio ou subvenção concedidos, direta ou indiretamente à manufatura, produção ou exportação de qualquer mercadoria".

${ }^{379} \mathrm{Na}$ redação do Decreto Legislativo no 43/50:

“4. Nenhum produto do território de qualquer Parte Contratante importado no de outra Parte Contratante, e (sic) será sujeito a direitos "anti-dumping" e a direitos de compensação, em virtude de ser esse produto isentado de direitos ou tributos que recaem sobre o produto similar, quando se destina ao consumo no país de origem ou exportação, ou em virtude de serem restituídos esses direitos ou tributos”. 
Diante do laconismo da disciplina multilateral e em função das preocupações dos Estados Unidos com as práticas que tais normas autorizavam os países europeus a empregar, como já mencionado anteriormente, foi instalado em 28 de março de 1968 um Grupo de Trabalho, no seio do antigo GATT, com mandato específico estabelecendo seus objetivos como os de examinar as disposições do Acordo Geral relevantes aos ajustes fiscais de fronteira, as práticas das Partes Contratantes em relação a esses ajustes e os possíveis efeitos desses ajustes no comércio internacional. Ao final do exame empreendido pelo grupo de trabalho, a proposta era a de considerar quaisquer proposições ou sugestões apresentadas e reportá-las ao Conselho do GATT e às Partes Contratantes ${ }^{380}$. O Grupo de Trabalho se reuniu por doze vezes entre abril de 1968 e outubro de 1970, produzindo ao final um Relatório, ao qual já houve referências por diversas vezes no presente trabalho, classificado como documento GATT L/3464, adotado em 2 de dezembro de 1970.

Quanto ao primeiro ponto, as disposições do GATT a respeito, o Relatório, após definir o conceito de ajuste fiscal de fronteira empregando a definição aplicada pela OCDE, comenta que o termo é por si equívoco, uma vez que o ajuste não é necessariamente realizado de fronteira, podendo ser feito após o cruzamento pelo produto da fronteira nacional, no momento de sua venda pelos importadores registrados a outros comerciantes ou consumidores. Em função dessa realidade, o Grupo de Trabalho entende que a melhor denominação seria a de "ajustes fiscais aplicados a bens entrantes vindos do comércio internacional" ${ }^{381}$, ou, por brevidade, como empregado em todo o Relatório, o termo "ajustes fiscais".

Referindo-se aos artigos do Acordo Geral acima mencionados, comenta que tais disposições refletem o estado dos estudos a respeito no momento em que o acordo foi desenhado. Ressalva a reclamação de alguns membros de que algumas suposições presentes nessas normas não seriam mais universalmente aceitas, especialmente a ideia de que os tributos indiretos implicariam plena repercussão ao consumidor final e não os

${ }^{380}$ Na redação do Relatório Final (L/3464):

"1. The Working Party was established by the Council on 28 March 1968 with the following terms of reference:

"Acting under paragraph 1 of Article XXV and with a view to furthering the objectives of the General Agreement, and taking into account the discussions in the Council:

"1. To examine:

(a) The provisions of the General Agreement relevant to border tax adjustments;

(b) The practices of contracting parties in relation to such adjustments;

(c) The possible effects of such adjustments on international trade.

"2. In the light of this examination, to consider any proposals and suggestions that may be put forward; and

"3. To report its findings and conclusions on these matters to the Council or to the CONTRACTING PARTIES."'”

381 "tax adjustments applied to goods entering into international trade", no original em inglês - parágrafo 5. 
diretos, o que, na dicção do Relatório, não seria um reflexo da realidade econômica. Haveria, portanto, discriminação aos países cujo sistema tributário fosse predominantemente baseado na tributação direta. Assim, o Relatório aponta que tais membros do Grupo de Trabalho entendem que as normas do GATT e as práticas fiscais das Partes Contratantes não seriam neutros ao comércio ${ }^{382}$. Essa questão foi retomada nas duas partes finais do Relatório, embora também de forma não conclusiva.

Quanto à primeira parte, no que tange, repita-se, às disposições do GATT quanto aos ajustes fiscais, o Relatório prefere restringir-se a obviedades técnicas, como o fato de que se adotou o princípio do destino ${ }^{383}$, que as normas apenas estabelecem limites máximos ao poder soberano de imposição tributária das Partes Contratantes ${ }^{384}$, não autorizando a que sejam empregados com intuito protecionista, mas sim de forma nãodiscriminatória ${ }^{385}$, desde que o montante compensado seja corretamente calculado, o que o Relatório reconhece que seja, em algumas vezes, de difícil consecução prática, especialmente em países cujas incidências se estruturem em cascata ${ }^{386}$, motivo pelo qual

\footnotetext{
382 "8. There was general agreement that the main provisions of the GATT represented the codification of practices which existed at the time these provisions were drafted, re-examined and completed. Some members of the Working Party considered, however, that the main provisions of the GATT relevant to tax adjustments represent an attempt at the codification of a wide range of past practices based on assumptions which are not now universally accepted. In particular, they felt the assumption of full shifting of direct taxes is not a reflection of economic reality. They considered that the present GATT rules favour countries which rely heavily on indirect taxes and discriminate against countries which rely predominantly on direct taxes. Further, in their view, the present rules are ambiguous and lead to differing tax adjustment practices for similar types of taxes. They concluded that the current GATT provisions and tax practices are not trade neutral".

383 "10. The Working Party also noted that there were differences in the terms used in these articles, in particular with respect to the provisions regarding importation and exportation: for instance, the terms "borne by" and "levied on". It was established that these differences in wording had not led to any differences in interpretation of the provisions. It was agreed that GATT provisions on tax adjustment applied the principle of destination identically to imports and exports".

384 "11. It was further agreed that these provisions set maxima limits for adjustment (compensation) which were not to be exceeded, but below which every contracting party was free to differentiate in the degree of compensation applied, provided that such action was in conformity with other provisions of the General Agreement".

385 "13. Some delegations did not share this view. GATT provisions on tax adjustments did not provide for any form of protection but rather for the possibility for governments to create equality in treatment between imported and domestically-produced goods. The various degrees of compensation practised in different countries were applied for fiscal revenue or budgetary reasons; there were no known cases of deliberate manipulation of compensation on selected products".

386 “16. The Working Party noted that there were some taxes which, while generally considered eligible for adjustment, presented a problem because of the difficulty in some cases of calculating exactly the amount of compensation. Examples of such difficulties were encountered in cascade taxes. For adjustment, countries operating cascade systems usually resorted to calculating average rates of rebate for categories of products rather than calculating the actual tax levied on a particular product. It was noted, however, that most cascade tax systems were to be replaced by TVA systems, and that therefore the area in which such problems occurred was diminishing. Other examples included composite goods which, on export, contained ingredients for which the Working Party agreed in principle it was administratively sensible and sufficiently accurate to rebate by average rates for a given class of goods".
} 
tais Partes Contratantes podem ser instadas, oportunamente, a provarem como chegaram aos valores exigidos a título de ajustes fiscais ${ }^{387}$.

Nessa primeira parte, apenas dois parágrafos apresentam alguma relevância. O parágrafo 14, que estabelece quais tributos são elegíveis à aplicação dessas normas, concluindo que teria havido convergência de pontos de vista de que seriam excises, impostos sobre vendas, em cascata e o imposto sobre o valor agregado, afirmando o critério geral é o de que os ajustes fiscais deveriam se aplicar apenas aos tributos diretamente incidentes sobre os produtos ${ }^{388}$. Não obstante, divergências surgiram quanto a alguns tipos de tributos, como os tributos indiretos incidentes sobre os bens de capital, bens auxiliares ou serviços, assim como tributos incidentes sobre alguma formalidade na importação, embora se tenha reconhecido a pouca importância dessas questões ${ }^{389}$.

Por fim, o parágrafo $18^{390}$, que se refere aos critérios para interpretação da questão da similaridade. Trata-se de questão que aparece, segundo o Relatório, dezesseis

387 "17. It was generally agreed that countries adjusting taxes should, at all times, be prepared, if requested, to account for the reasons for adjustment, for the methods used, for the amount of compensation and to furnish proof thereof'.

388 "14. On the question of eligibility of taxes for tax adjustment under the present rules, the discussion took into account the term "... directly or indirectly ..." (inter alia Article III:2). The Working Party concluded that there was convergence of views to the effect that taxes directly levied on products were eligible for tax adjustment. Examples of such taxes comprised specific excise duties, sales taxes and cascade taxes and the tax on value added. It was agreed that the TVA, regardless of its technical construction (fractioned collection), was equivalent in this respect to a tax levied directly - a retail or sales tax. Furthermore, the Working Party concluded that there was convergence of views to the effect that certain taxes that were not directly levied on products were not eligible for tax adjustment. Examples of such taxes comprised social security charges whether on employers or employees and payroll taxes".

389 "15. The Working Party noted that there was a divergence of views with regard to the eligibility for adjustment of certain categories of tax and that these could be sub-divided into

(a) "Taxes occultes" which the OECD defined as consumption taxes on capital equipment, auxiliary materials and services used in the transportation and production of other taxable goods. Taxes on advertising, energy, machinery and transport were among the more important taxes which might be involved. It appeared that adjustment was not normally made for taxes occultes except in countries having a cascade tax;

(b) Certain other taxes, such as property taxes, stamp duties and registration duties ... which are not generally considered eligible for tax adjustment. Most countries do not make adjustments for such taxes, but a few do as a few do for the payroll taxes and employers' social security charges referred to in the last sentence of paragraph 14.

It was generally felt that while this area of taxation was unclear, its importance - as indicated by the scarcity of complaints reported in connexion with adjustment of taxes occultes - was not such as to justify further examination".

390 "18. With regard to the interpretation of the term "... like or similar products ...", which occurs some sixteen times throughout the General Agreement, it was recalled that considerable discussion had taken place in the past, both in GATT and in other bodies, but that no further improvement of the term had been achieved. The Working Party concluded that problems arising from the interpretation of the term should be examined on a case-by-case basis. This would allow a fair assessment in each case of the different elements that constitute a "similar" product. Some criteria were suggested for determining, on a case-by-case basis, whether a product is "similar": the product's end-uses in a given market; consumers' tastes and habits, which change from country to country; the product's properties, nature and quality. It was observed, however, that the term "... like or similar products ..." caused some uncertainty and that it would be desirable to improve on it; however, no improved term was arrived at". 
vezes ao longo do Acordo Geral, o que já nos faz concluir que não se trata de aspecto especificamente relacionado com o tema principal do Relatório. Talvez por isso mesmo, trata-se do que há de mais importante do produto desse Grupo de Trabalho, ao menos do que se pode aferir do número de vezes que tal parágrafo veio mencionado em julgados do OSC, desde os tempos do GATT, mas ainda se estendendo aos tempos atuais, na era OMC.

Em resumo, como já afirmado anteriormente, o parágrafo 18 afirma que o conceito jurídico indeterminado representado pelos termos "like" e "similar" da versão original em inglês ${ }^{391}$ deve ser entendido em uma abordagem caso-a-caso, mas que considere aspectos microeconômicos, do ponto de vista do consumidor, mencionando exemplificativamente quais poderiam ser tais critérios. Não obstante, reconhece que tal recomendação pode gerar uma certa insegurança jurídica.

A propósito, deve-se notar que a redação brasileira do Artigo III:2 do GATT foge da questão, na medida em que não traz a referência à similaridade entre os $\operatorname{produtos}^{392}$, só havendo o emprego do termo "similar" na Nota Adicional ao Artigo III como um todo ${ }^{393}$, agora sim em plena consonância com o original em inglês ${ }^{394}$.

Pode-se concluir que foi exatamente pelo fato de que o parágrafo 18 tenha saído totalmente do escopo do mandato conferido ao Grupo de Trabalho que se pôde verificar que o que lá está dito alcançou tanta e tamanha relevância no Direito Internacional do Comércio, diferentemente do restante do Relatório.

Quanto ao aspecto das práticas das Partes Contratantes em relação aos ajustes fiscais, foi produzido um documento consolidado, L/3389, contendo o levantamento

391 “Article III

(...)

2. The products of the territory of any contracting party imported into the territory of any other contracting party shall not be subject, directly or indirectly, to internal taxes or other internal charges of any kind in excess of those applied, directly or indirectly, to like domestic products".

392 "Artigo III.

(...)

2. Os produtos do território de qualquer Parte Contratante, importados por outra Parte Contratante, não estão sujeitos, direta ou indiretamente, a impostos ou outros tributos internos de qualquer espécie superiores aos que incidem, direta ou indiretamente, sobre produtos nacionais".

393 “AO ARTIGO III

Qualquer imposto ou outros tributos internos, bem como qualquer lei, regulamento ou prescrição mencionados no $\S 1^{\circ}$ que se apliquem não só ao produto importado como também ao produto nacional similar e que sejam cobrados ou exigidos no caso do produto importado no momento e no local da importação, serão não obstante considerados como taxa interna ou um outro tributo interno ou como uma lei, regulamentação ou exigências regidas no $\S 1^{\circ}$ e estão conseqüentemente sujeitas às disposições do art. III".

394 "Ad Article III

Any internal tax or other internal charge, or any law, regulation or requirement of the kind referred to in paragraph 1 which applies to an imported product and to the like domestic product and is collected or enforced in the case of the imported product at the time or point of importation, is nevertheless to be regarded as an internal tax or other internal charge, or a law, regulation or requirement of the kind referred to in paragraph 1, and is accordingly subject to the provisions of Article III'. 
realizado em diversos países contendo informações e discussões sobre as práticas existentes no que tange à matéria, incluindo os locais nos quais os ajustes são realizados, se na fronteira, em zona primária, ou em estágio posterior, quais importações ou exportações são abrangidas, se na produção, no atacado ou no varejo, assim como outros aspectos. Tal documento não aborda o sistema e as práticas brasileiras.

Ao abordar o último ponto, os possíveis efeitos dos ajustes fiscais no comércio internacional, o Relatório alcança o tema que justificou a sua realização - a questão da translação do ônus tributário nos impostos indiretos e nos diretos e as implicações diferenciadas das normas do sistema GATT que se referem aos ajustes fiscais em se tratando de países com diferentes estruturas tributárias. No entanto, o Relatório expressamente reconhece que o Grupo de Trabalho não chegou a conclusões, tanto no que tange aos efeitos da repercussão dos tributos indiretos nos ônus financeiros ao consumidor final $^{395}$, quanto no que se refere ao desequilíbrio competitivo deles oriundos ${ }^{396}$.

O Relatório também se dedica, embora também seja aspecto alheio ao seu mandato, algumas implicações dos ajustes fiscais aos países em desenvolvimento. Novamente, o que aparece de mais relevante são aquelas considerações externas ao seu objeto principal. Embora não se fale especificamente nem em escalonamento de tarifas nem tampouco em proteção efetiva, algumas reclamações dos países em desenvolvimento trazidas ao Grupo de Trabalho, como veremos, prendem-se a esses artifícios tarifários que estudaremos a seguir ${ }^{397}$.

\footnotetext{
395 "22. The Working Party recognized that the problem of structural differences in taxation and the question as to what extent indirect taxes and direct taxes were shifted into commodity prices was full of difficulty and of a very complex nature. No conclusions were reached. Some members felt that this part of the Working Party's examination made it clear that present tax adjustment based on GATT provisions did not ensure trade neutrality and that it was important that solutions be found to this problem. Most other members of the Group, however, were of the opinion that the discussion rather tended to confirm that the current practices of tax adjustments were as consistent as possible with the objectives of trade neutrality. Still some others were of the opinion that the work done in the Working Party was not such as to permit definitive conclusions to be drawn regarding the objective truth in the two opposing contentions".

396 "24. The Working Party recognized that there were serious difficulties in the way of quantifying the possible effects of tax adjustments on international trade, it being difficult to determine what the trade figures would have been if tax adjustments had not been made".

397 "32. In referring to the proposal to suppress taxes on products not domestically produced in developed countries, some countries considered that it was of great importance not to introduce into fiscal policies considerations and preoccupations pertaining to trade policy. They stated that exemption of internal taxes on products of interest to developing countries would imply manipulation of the fiscal system for commercial purposes. This would create a dangerous precedent and would be contrary to the rules and basic principles of the GATT. They added that the provisions of Article III of the General Agreement could not be interpreted as forbidding the application of taxes to products not domestically produced but that they essentially aimed at preventing protection being given to national production by means of internal taxes. These provisions, therefore, did not oblige contracting parties to favour indirectly products not domestically produced by granting them tax exemption. As regards the Ministerial Conclusions of 1963, some countries recalled that
} 
À guisa de conclusão, o Relatório recomenda a adoção de um sistema de revisão de mudanças nos ajustes físcais no seio do GATT, implicando um procedimento para notificações e um para consultas, quando requeridas. Não obstante, no momento em que exarado, o Grupo de Trabalho não apresentou nenhuma proposta útil ao objetivo de aprimorar o sistema multilateral ${ }^{398}$.

Em suma, o Grupo de Trabalho não logrou alcançar, nem de perto, os objetivos aos quais se propôs. Apresentou um Relatório não conclusivo, mera petição de princípios

they had not subscribed to the obligations in those Conclusions, in particular those relating to taxes on products imported mainly from developing countries.

(...)

35. It was pointed out that some products were subject to unreasonable differential tax adjustment treatment. It was suggested that this form of differential tax treatment could be eliminated on a priority basis for developing countries by a downward adjustment of the tax rate on one product to the lower rate applied to another comparable product. However, the information so far available was not adequate for analysing this issue to the fullest extent. The representatives of some developed countries suggested that products which, according to developing countries, were subject to unreasonable differential tax adjustment, should be indicated and subsequently examined by the interested parties on a case-by-case basis.

36. It was pointed out that certain products of interest to developing countries were subject to very high and sometimes excessive rates of taxation. An example was tea, which in some developed countries was taxed at the same rate as wine. Such rates of taxation were excessive and should be reduced as these had adverse effects on consumption".

398 "V. Points 2 and 3: Proposals and Suggestions - Conclusions

39. The Working Party examined a proposal for the establishment of a regularized system of review of changes in tax adjustments within the GATT. The proposal comprises a notification procedure and a multilateral procedure for consultation on request.

40. The Working Party does not feel that any useful purpose would be served by pursuing the examination under its present terms of reference in the present circumstances. The Working Party recognizes the continuing interest of contracting parties in the subject and in particular in future changes in taxation systems. The Working Party recommends that a notification procedure be introduced, on a provisional basis whereby contracting parties will report changes in their tax adjustments. It is understood that such notifications need not be made prior to the changes. The contents of the notifications would aim generally at reporting any major changes in tax adjustment legislation and practices involving international trade, and in particular at bringing periodically up to date the information contained in the consolidated document on contracting parties' practices (L/3389) on tax adjustments drawn up in the course of the Working Party's work. While the notifications would cover changes in centrallycontrolled taxes, countries with large locallyor regionally controlled tax systems would be expected to make a special effort to report changes of a significance on a local or regional basis.

41. The Working Party took note of the particular interest of developing countries in the removal of tax adjustments on products not domestically produced by developed countries, and of the references which had been made in this context to Article XXXVII.

42. The Working Party agreed that the suggestions it makes concerning its own work should not affect the work under way in the Special Group on Tropical Products.

43. The Working Party recommends that a consultation procedure be established whereby, upon request by a contracting party, a multilateral consultation could take place on changes in tax adjustments, whether notified or not. Such consultations would be held within the scope of the relevant GATT provisions. Upon request, contracting parties should be prepared to justify the reasons for adjustment, the methods used, the amount of compensation and to furnish proof thereof.

44. It is suggested that this Working Party, because of its experience in the field of tax adjustments, is the appropriate forum for holding consultations.

45. The Working Party recommends that the Director-General should be asked to consider, at convenient intervals, on the basis of the notifications referred to above, and in consultation with interested parties, whether a review of notified changes is called for. He should also be asked to consider after an adequate period of operation, and in consultation with interested parties, whether the provisional notification procedure should be continued, modified or discontinued". 
programáticos, limitando-se a listar os argumentos utilizados pelos diferentes interesses representados no Grupo de Trabalho, sem considerar nenhum deles mais correto ou inconveniente.

Não é por outro motivo que Gary Clyde Hufbauer (1996, p. 54), afirma que o Relatório só teve três grandes méritos: de enunciar o que denomina "Princípio da Simetria”, no parágrafo 10, por meio do qual determinado país, se aplica os ajustes fiscais em uma determinada modalidade na importação, deverá aplicá-los também na importação, embora não necessariamente na mesma proporção; estabelecer que as normas do GATT determinam limites máximos, mas não obrigam as Partes Contratantes a exigirem os ajustes até tal limite (parágrafo 11); e enumerar quais tributos não são elegíveis aos ajustes fiscais (parágrafo 14).

Explicando melhor o que significa o "Princípio da Simetria", ao menos na forma como Gary Hufbauer (1996, p. 53 - 54) o viu enunciado pelo parágrafo $10^{399}$ do Relatório: o que o Grupo de Trabalho haveria determinado seria que todos os esquemas interpretativos aplicados ao lado das importações (vedação à tributação discriminatória ou protetiva) deveriam ser aplicados identicamente do lado das exportações (proibição aos subsídios fiscais).

Ocorre que o Artigo III:2 do GATT, ao afirmar que os "produtos do território de qualquer Parte Contratante, importados por outra Parte Contratante, não estão sujeitos, direta ou indiretamente, a impostos ou outros tributos internos de qualquer espécie superiores aos que incidem, direta ou indiretamente, sobre produtos nacionais" (grifado), permitiria que, na importação, se apurassem quantitativamente os ajustes fiscais de fronteira de forma ampla, abrangendo também todos os tributos indiretos incidentes sobre as matérias-primas e produtos intermediários presentes na mercadoria importada.

Tal intelecção ampla do Artigo III:2 do GATT, que empreendeu Hufbauer (1996, p. 53), veio a ser possibilitada, embora não propriamente confirmada, por um grupo de trabalho, o Working Party II on Tariffs, Schedules and Customs Administration, na Nona Sessão do GATT, de 16 de fevereiro de 1955, ao responder a um requerimento da então Alemanha Ocidental, para inclusão de Nota Adicional ao parágrafo 2 do Artigo III, explicitando que essa norma deveria ser aplicada a todos os estágios de produção, permitindo assim cálculo mais tecnicamente apurado do ônus tributário incidente. $\mathrm{O}$ grupo de trabalho, no entanto, recusou a inserção da nota adicional, ao argumento de que a

\footnotetext{
${ }^{399}$ Ver nota de rodapé ${ }^{\circ} 292$ acima.
} 
questão da aplicação do princípio da igualdade de tratamento nessa profundidade, dada a sua complexidade, deveria ser deixada ao exame caso-a-caso nos procedimentos de consulta ou de solução de controvérsias ${ }^{400}$.

Diferentemente, do lado da exportação, defende que a disciplina do regime de subsídios fiscais era inicialmente mais restritiva, não abrangendo, até a Rodada Tóquio, incidências indiretas sobre a energia, por exemplo e, mesmo após, os tributos diretos sobre as empresas exportadoras.

No que concerne à apuração financeira e não física do ajuste fiscal de fronteira, a situação é ilustrada pela presença, após a Rodada Tóquio, na "Lista Ilustrativa de Subsídios à Exportação" anexa ao Decreto n $n^{\circ}$ 93.962/87, texto internalizado ao ordenamento brasileiro do "Acordo Relativo à Interpretação e Aplicação dos Artigos VI, XVI e XXIII do Acordo Geral sobre Tarifas Aduaneiras e Comércio", dos termos "fisicamente incorporados" (alínea "h") e "materialmente incorporados" (alínea "i")

400 "10. The delegate for Germany proposed the insertion of an interpretative note as follows:

"The words 'internal taxes or other internal charges .. applied directly or indirectly' as employed in the first sentence of paragraph 2 shall be construed to denote the overall charge, including the charges borne by like domestic products through being subjected to internal taxes or other internal charges at various stages of their production (charges borne by the raw materials, semi-finished products, auxiliary materials, etc. incorporated in, and by the power consumed for the production of, the. finished products)."

The Working Party considered the significance of -the phrase "internal taxes or other internal charges" in relation to taxes which are levied at various stages of production, and in particular whether the rule of national

treatment would allow a government to tax imported products at a rate calculated to be the equivalent of the taxes levied at the various stages of production of the like domestic product or only at the rate of the tax levied at the last stage. Several representatives supported the former interpretation, while the representative of the United States, on the other hand, thought the reference to internal taxes covered only a tax levied on the final product competitive with the imported article. Against the latter view it was argued that that interpretation would establish a discrimination against countries which chose to levy taxes at various stages and in favour of those which levy a single turnover tax on finished products. Some other representatives were of the opinion that the equivalent of the taxes on the final product and on its components and ingredients would be permitted but not taxes on power consumed in manufacture, etc. In view of these differences of opinion, the Working Party does not recommend the insertion of an note, it being understood that the principle of equality of treatment would be upheld in the event of a tax on imported products being challenged under the consultation or complaint procedure of the Agreement" - W.9/200. Review Working Party II on Tariffs, Schedules and Customs Administration : Articles I, II, III and XXIV. Draft Report by Working Party II, de 16 de fevereiro de 1965.

401 “g) Isenção ou remissão de impostos indiretos ${ }^{(1)}$, sobre a produção e distribuição de produtos exportados, em montante superior àqueles cobrados sobre a produção e distribuição de produtos similares quando vendidos para consumo interno.

h) Isenção, remissão ou postergação de impostos indiretos em cascata incidentes em etapas anteriores ${ }^{(1)}$ sobre bens e serviços utilizados na produção de produtos exportados, quando superiores às isenções, remissões ou postergações dos impostos indiretos em cascata similares, que incidam em etapas anteriores, sobre os bens e serviços utilizados na produção de produtos similares quando vendidos para consumo interno, no entanto, a isenção, remissão ou postergação dos impostos indiretos em cascata incidentes em etapas anteriores poderá ser concedida à mercadorias exportadas, mesmo que não o seja para produtos similares quando vendidos para consumo interno, se tais impostos indiretos forem incidentes sobre produtos fisicamente incorporados (com o desconto normal pelo desperdício) no produto exportado ${ }^{(3)}$.

i) Remissão ou estorno ( $\underline{\text { drawback }}$ ) de gravames à importação ${ }^{(1)}$ de valor que exceda os cobrados sobre os produtos importados que estejam materialmente incorporados ao produto exportado (com o desconto normal 
redação em português, já que na redação em inglês em ambos se emprega a redação "physically incorporated" $" 402$

Tais termos foram alterados, quando da Rodada Uruguai, na "Lista Ilustrativa de Subsídios à Exportação", do Anexo I do Decreto no 1.355/94, o "Acordo Sobre Subsídios e Medidas Compensatórias", para serem empregados os termos "utilizados no fabrico de" (alínea "h") e "consumidos no fabrico de" (alínea "i") ${ }^{403}$, de forma a incluir também na possibilidade de ressarcimento (ou "devolução", na dicção convencional), dos impostos incidentes também sobre a energia, combustíveis, óleos e catalisadores

pelo desperdício); contudo, em casos particulares, uma empresa poderá utilizar produtos do mercado interno, em igual quantidade e da mesma qualidade e características que os produtos importados, em substituição a estes, com o objetivo de beneficiar-se da presente disposição, caso a operações de importação e de exportação correspondentes se realizem ambas dentro de um período razoável, que normalmente não deverá exceder dois anos".

402 " $(\mathrm{g})$ The exemption or remission in respect of the production and distribution of exported products, of indirect taxes ${ }^{l /}$ in excess of those levied in respect of the production and distribution of like products when sold for domestic consumption.

(h) The exemption, remission or deferral of prior stage cumulative indirect taxes ${ }^{l /}$ on goods or services used in the production of exported products in excess of the exemption, remission or deferral of like prior stage cumulative indirect taxes on goods or services used in the production of like products when sold for domestic consumption; provided, however, that prior stage cumulative indirect taxes may be exempted, remitted or deferred on exported products even when not exempted, remitted or deferred on like products when sold for domestic consumption, if the prior stage cumulative indirect taxes are levied on goods that are physically incorporated (making normal allowance for waste) in the exported product. ${ }^{3 /}$

(i) The remission or drawback of import charges ${ }^{1 /}$ in excess of those levied on imported goods that are physically incorporated (making normal allowance for waste) in the exported product; provided, however, that in particular cases a firm may use a quantity of home market goods equal to, and having the same quality and characteristics as, the imported goods as a substitute for them in order to benefit from this provision if the import and the corresponding export operations both occur within a reasonable time period, normally not to exceed two years".

403 “g) A isenção ou remissão de impostos indiretos ${ }^{(58)}$, sobre a produção e distribuição de produtos exportados, além daqueles aplicados sobre a produção e a distribuição de produto similar vendido para consumo interno.

h) A isenção, remissão ou diferimento de impostos indiretos sobre etapas anteriores ${ }^{(58)}$ de bens e serviços utilizados no fabrico de produtos exportados além da isenção, remissão ou diferimento de impostos indiretos equivalentes sobre etapas anteriores de bens e serviços utilizados no fabrico de produto similar destinado ao mercado interno; desde que, porém, impostos indiretos cumulativos sobre etapas anteriores possam ser objeto de isenção, remissão ou diferimento sobre produtos destinados à exportação mesmo quando tal não se aplique a produtos similares destinados ao para consumo interno, se os impostos indiretos cumulativos sobre atapas anteriores são aplicados aos insumos consumidos no fabrico de produto de exportação (levando-se em devida conta os desperdícios ${ }^{(60)}$. Este item será interpretado de acordo com as diretrizes sobre consumo de insumos no processo de produção contidas no Anexo II.

i) Remissão ou devolução de direitos de importação ${ }^{(58)}$ além daquelas praticadas sobre insumos importados que sejam consumidos no fabrico do produto exportado (levando em devida conta os desperdícios normais); desde que, porém, em casos especiais, uma empresa possa utilizar certa quantidade de insumos nacionais como substitutivo equivalente aos insumos importados, com as mesmas características e com a mesma qualidade, com vistas a beneficiar-se desta disposição, se tanto a importação quanto a exportação ocorrerem dentro de prazo razoável, não superior a 2 anos. Este item será interpretado de acordo com as diretrizes sobre consumo de insumos no processo de produção contidas no Anexo II e de acordo com as diretrizes para determinar se os sistemas de devolução de tributos sobre a importação em casos de substituição constituem subsídios à exportação, enunciadas no Anexo III". 
consumidos no processo produtivo, não apenas as matérias-primas que se incorporam fisicamente ao produto final, consoante a nota de rodapé $\mathrm{n}^{\circ} 61^{404}$.

Com isso, prossegue Gary Hufbauer (1996, p. 53 - 54), haveria uma assimetria entre os ajustes fiscais permitidos às importações em relação aos às exportações, configurada por essas disciplinas diferenciadas, muito embora o espírito do princípio do destino, como articulado por David Ricardo, implique o emprego equivalente de normas tanto às importações quanto às exportações (p. 50). No entanto, novamente segundo Hufbauer (p. 56), a jurisprudência do OSC do GATT privilegiaria não o espírito dos acordos convencionais, mas sim as suas literalidades. Assim, o Grupo de Trabalho sobre Ajustes Fiscais de Fronteira, no seu entender (p. 56), teria errado em uma das suas únicas determinações práticas de relevância, motivo pelo qual, ainda mais, como afirma textualmente, a ele não deve ser conferido muito peso.

A constatação da ocorrência de assimetria nas disciplinas não é correta, o que, não obstante, não contraria a crítica de Hufbauer à relevância do Relatório. Como vimos, o Documento E/CONF.2/C.3/51, de 12 de fevereiro de 1948, comentando o teor da Nota Adicional ao Artigo XVI, já ressalvava que o conceito de remissão dos impostos referentes aos produtos destinados à exportação deveria ser amplo, abrangendo também os tributos incidentes sobre as matérias-primas e produtos intermediários empregados no processo produtivo.

Em 11 de janeiro de 1994, agora na esteira da transferência da questão para a análise da tributação ambiental, o Secretariado da OMC, a pedido do Grupo especializado em Medidas Ambientais e Comércio Internacional ${ }^{405}$ para que fizesse uma nota técnica acerca do tema dos ajustes fiscais de fronteira.

Nele, o que se trouxe de relevante e concernente aos aspectos ambientais aplicáveis à tributação indireta foi apenas a confirmação da afirmação do Grupo Especial no caso "United States - Taxes on Petroleum and certain Imported Substances", de que o fato de um tributo ser elegível aos ajustes de fronteira, por ser diretamente incidente sobre produtos, como os mencionados pelo Relatório do Grupo de Trabalho, L/3464, não significa que eles não possam também ser exigidos por quaisquer outros motivos de

\footnotetext{
404 “61. Insumos consumidos no processo produtivo são insumos incorporados fisicamente, energia, combustíveis e óleos, utilizados no proceso produtivo, e catalisadores, que são consumidos ao longo do processo de obtenção do produto exportado".

405 "Group on Environmental Measures and International Trade",
} 
política fiscal, além da neutralidade fiscal ao comércio internacional, como, por exemplo, em função de uma extrafiscalidade ambiental ${ }^{406}$.

Assim, as Partes Contratantes podem usar o ajuste fiscal de fronteira como meio de alcançar o Princípio do Poluidor-pagador, de modo a tributar a produção local de um bem cuja industrialização interna se quer inibir, por ser ambientalmente onerosa, fomentando a sua aquisição no mercado externo, já que o seu consumo ou uso não apresentam os mesmos problemas ao meio-ambiente ${ }^{407}$. Tal se deve ao fato de que as normas do GATT conferem apenas limites aos direitos das Partes Contratantes, não obrigações de necessariamente compensarem as cargas tributárias de modo a viabilizarem a competitividade dos produtores internos.

Do lado da exportação, o único ponto relevante apresentado foi a ressalva quanto à alteração na disciplina do regime de subsídios fiscais, entre o "Acordo Relativo à Interpretação e Aplicação dos Artigos VI, XVI e XXIII do Acordo Geral sobre Tarifas Aduaneiras e Comércio”, da Rodada Tóquio, em relação à disciplina da Rodada Uruguai, no "Acordo Sobre Subsídios e Medidas Compensatórias", acima referida. O Relatório termina por concluir que essa previsão possui importantes implicações em aspectos de

406 "5.2.4 The report of the Working Party on Border Tax Adjustments, adopted by the CONTRACTING PARTIES in 1970, concluded the following on the rules of the General Agreement relating to tax adjustments applied to goods entering into international trade:

"There was convergence of views to the effect that taxes directly levied on products were eligible for tax adjustment. Examples of such taxes comprised specific excise duties, sales taxes and cascade taxes and the tax on value added ... Furthermore, the Working Party concluded that there was convergence of views to the effect that certain taxes that were not directly levied on products were not eligible for tax adjustment. Examples of such taxes comprised social security charges whether on employers or employees and payroll taxes" (BISD 18S/100-101).

As these conclusions of the CONTRACTING PARTIES clearly indicate, the tax adjustment rules of the General Agreement distinguish between taxes on products and taxes not directly levied on products; they do not distinguish between taxes with different policy purposes. Whether a sales tax is levied on a product for general revenue purposes or to encourage the rational use of environmental resources, is therefore not relevant for the determination of the eligibility of a tax for border tax adjustment. For these reasons the Panel concluded that the tax on certain chemicals, being a tax directly imposed on products, was eligible for border tax adjustment independent of the purpose it served. The Panel therefore did not examine whether the tax on chemicals served environmental purposes and, if so, whether a border tax adjustment would be consistent with these purposes" - L/6175, de 5 de junho de 1987.

407 "5.2.5 The Panel wishes to point out, however, that the Working Party on Border Tax Adjustment agreed that the provisions of the General Agreement on tax adjustment

"set maxima limits for adjustment (compensation) which were not to be exceeded, but below which every contracting party was free to differentiate in the degree of compensation applied, provided that such action was in conformity with other provisions of the General Agreement" (BISD 18S/100).

Consequently, if a contracting party wishes to tax the sale of certain domestic products (because their production pollutes the domestic environment) and to impose a lower tax or no tax at all on like imported products (because their consumption or use causes fewer or no environmental problems), it is in principle free to do so. The General Agreement's rules on tax adjustment thus give the contracting party in such a case the possibility to follow the Polluter-Pays Principle, but they do not oblige it to do so" - L/6175, de 5 de junho de 1987. 
competitividade que frequentemente surgem quando se trata de propostas de tributos sobre energia.

A preocupação dos fóruns destinados à matéria ambiental em abordar a questão se justifica. Não há dúvida de que há diminuição do rol dos chamados tributos ocultos (HUFBAUER; 1996, p. 49), aqueles que não podem ser considerados no cálculo do valor ajustável: antes da Rodada Uruguai abrangendo os impostos incidentes sobre a energia, combustíveis, óleos e catalisadores consumidos no processo produtivo, não apenas as matérias-primas e produtos intermediários que se incorporam fisicamente ao produto final, como mencionado na nota de rodapé $n^{\circ}$ 61; após a Rodada Uruguai, apenas incluindo, por exemplo, os tributos indiretos sobre os equipamentos empregados no processo produtivo, adquiridos para o Ativo Não Circulante Imobilizado, e os incidentes sobre os serviços prestados diretamente sobre o produto comercializado, se a legislação específica do tributo indireto não prever o diferimento dessa incidência - diferentemente do que ocorre no Brasil, no caso da legislação do IPI $^{408}$.

Não obstante, Gary Hufbauer (1996, p. 50) informa que os negociadores americanos, antes da redação da nota de rodapé $n^{\circ} 61$, defendiam que o teste do consumo na produção apenas fosse autorizado no caso de exportações de produtos intensivos em energia por parte de certos países em desenvolvimento. Mesmo após o seu advento, noticia que os americanos defendem, mencionando relatório oficial transcrito na publicação “Inside U. S. Trade" de 28 de janeiro de 1994, que esse texto aprovado na Rodada Uruguai não foi ali colocado para expandir significativamente o direito de os países desenvolvidos aplicarem ajustes fiscais de fronteira para um largo espectro de tributos sobre a energia, provavelmente por medo do uso indiscriminado do instrumento na nova realidade tributária comunitária.

Não obstante, de uma análise pormenorizada, pode-se concluir, como Gary Hufbauer (1996, p. 50), no sentido de que nada há no texto convencional que dê suporte a essa interpretação Mesmo assim, informa o autor que a questão dos ajustes fiscais de fronteira, em se tratando de tributos incidentes sobre a energia, foi deixada, por pressão dos Estados Unidos, nos dias finais da Rodada Uruguai, para ser discutida durante os trabalhos em tributação e meio ambiente da OCDE.

\footnotetext{
${ }^{408}$ No caso da legislação do Imposto sobre Produtos Industrializados, trata-se da previsão de suspensão do imposto no caso de prestação de serviços por encomenda, constante dos incisos VI e VII, "a" e "b", do art. 42 do Regulamento do IPI (Decreto ${ }^{\circ}$ 4.544, de 26 de dezembro de 2002).
} 


\subsection{Do Tratamento no Sistema da União Europeia.}

Como já vimos, até exaustivamente, o conceito de ajustes fiscais de fronteira é aplicável, simétricamente, tanto às importações quanto às exportações - mesmo em se aplicando o princípio da origem; mormente no caso dos sistemas estudados, nos quais se optou pelo o príncípio do destino.

Aqui nos utilizaremos do mesmo artifício didático referido no item anterior, o de separar as duas situações.

De um lado, com exame mais minucioso, a disciplina regulamentar do ponto de vista das importações, também uma situação em que avultam mais relevantes e complexas as questões da tributação discriminatória e, principalmente, da protetiva - dada, também, a opção, pelo legislador europeu, pelos ajustes fiscais de fronteira sob o princípio do destino. Tal análise foi feita no capítulo anterior.

De outro, a disciplina na ótica das exportações - em resumo, a vedação aos export rebates discriminatórios.

Nessa esteira, há que se proceder à análise jurisprudencial do artigo $96^{\circ}$ do TCEE, depois renumerado para artigo $91^{\circ}$ do TCE, hoje veiculado pelo artigo $111^{\circ}$ do TUE, como já visto, norma que permanece exatamente com a mesma redação desde a assinatura do Tratado de Roma, em 1957.

O primeiro processo referente a essa matéria é o $45 / 64^{409}$, Comissão da Comunidade Econômica Europeia contra República Italiana. Teve por objeto a declaração de que a República Italiana, ao fazer beneficiar determinados produtos da indústria mecânica exportados para outros Estados-membros de um reembolso de imposições internas contrário, tanto pela natureza das imposições reembolsadas como pelo método utilizado para esse fim, ao artigo $96^{\circ}$ do Tratado que institui a Comunidade Econômica Europeia, não cumpriu uma das obrigações que lhe incumbem por força do diploma comunitário originário.

A Lei italiana $\mathrm{n}^{\circ} 103$, de 10 de março de 1955, prorrogada até 31 de Dezembro de 1963 pela lei de 18 de Março de 1958, previa, quando da exportação dos produtos da indústria mecânica, o reembolso "do direito aduaneiro e das outras imposições indiretas" que incidem sobre os produtos siderúrgicos utilizados na sua transformação.

\footnotetext{
${ }^{409}$ ECR 1969, 169.
} 
Não obstante, o seu montante era, relativamente a cada operação, fixado a um nível único em liras por quilo. Portanto, o reembolso era fixado antecipadamente.

Além disso, o governo italiano admitiu, desde o início do litígio, que o reembolso incluía várias imposições, entre as quais figuravam principalmente os impostos de produção e os impostos sobre o consumo cobrados pelo Tesouro, que incidem sobre a produção da indústria mecânica. Mas não apenas, também o reembolso estendia-se à contribuição de registro, ao imposto de selo e de hipoteca e às taxas sobre as licenças e autorizações emitidas pelo Estado, sobre os veículos automóveis e sobre a publicidade. Relativamente a estes últimos impostos e taxas, a Comissão considerou que, onerando essencialmente a empresa e a produção no seu conjunto - e não o produto exportado - não podem ser tomados em consideração para efeitos do reembolso previsto no artigo $96^{\circ}$.

Assim, por não incidirem sobre os produtos enquanto tais nem sobre as matérias-primas ou os produtos semiacabados que entram na sua industrialização, sendo portanto impossível individualizar a respectiva incidência sobre o preço de custo dos produtos.

O Tribunal de Justiça entendeu que o artigo $96^{\circ}$ autoriza os Estados-membros a, relativamente aos produtos exportados para o território de um outro Estado-membro, concederem um reembolso de imposições internas que não seja superior às imposições que tenham incidido sobre esses produtos, direta ou indiretamente.

No seu entender, na acepção do artigo 96, a expressão "diretamente" deve ser entendida no sentido de que abrange as imposições que incidem sobre o produto acabado, enquanto que o termo "indiretamente" se refere às imposições que, nas diferentes fases da produção, incidem sobre as matérias-primas ou sobre os produtos semiacabados que entram no processo de industrialização do produto.

Assim, entendeu que resulta dos textos legais que os instituem que o objeto e a natureza da contribuição de registro, do imposto de selo e de hipoteca, bem como das taxas sobre as licenças e autorizações, sobre os veículos automóveis e sobre a publicidade, tem como efeito tributar a sociedade produtora, em realidades aliás muito diversificadas da sua atividade comercial ou financeira em geral, e não os produtos enquanto tais, nem nas diferentes fases do seu fabrico, nem no estágio final.

Vale dizer que, a contribuição de registro, o imposto de selo e de hipoteca, bem como as taxas sobre as licenças e autorizações, sobre os veículos automóveis e sobre a publicidade, não incidindo direta ou indiretamente sobre os produtos exportados; não são suscetíveis de ser objeto do reembolso previsto no artigo $96^{\circ}$. 
Quanto à acusação de a República Italiana ter violado o artigo $96^{\circ}$ do Tratado ao instituir um sistema fixo de reembolso, afirmou a defesa que o artigo $96^{\circ}$ não proíbe de escolher as modalidades de reembolso mais adequadas ao sistema jurídico, estando apenas o resultado final sujeito à fiscalização da Comissão.

Entendeu-se que resulta do artigo $96^{\circ}$ que a possibilidade de um Estado recorrer ao reembolso de imposições internas está sujeita à condição de, por um lado, essas imposições incidirem sobre o próprio produto e, por outro, de o reembolso ser inferior ou igual às referidas imposições.

Foi então necessário saber se a outra condição prevista no artigo $96^{\circ}$ está preenchida, isto é, se se trata verdadeiramente de um reembolso; noutros termos, saber se o seu montante é inferior ou igual ao montante das imposições. Tendo a República Italiana escolhido voluntariamente o método fixo, competiu-lhe demonstrar que, de qualquer modo, se mantém dentro nos limites impostos pelo artigo $96^{\circ}$, pelo que foi ordenado à República Italiana, no que tange aos reembolsos fixos, que fornecesse ao Tribunal, por escrito e acompanhados da respectiva justificação contabilística, esses esclarecimentos, relativamente aos diversos produtos na causa.

Assim, decidiu-se que: i) a República Italiana, ao incluir no reembolso de imposições internas de que beneficiam os produtos da indústria mecânica exportados para outros Estados-membros a contribuição de registro, o imposto de selo e o imposto sobre as hipotecas, bem como as taxas sobre as licenças e autorizações, sobre os veículos automóveis e sobre a publicidade, não cumpriu a obrigação que incumbe por força do artigo $96^{\circ}$ do Tratado; ii) a República Italiana, no prazo de três meses a contar da data em que foi proferido o acórdão, forneceria provas de que o montante fixo do reembolso de imposições internas que efetivamente incidem sobre os produtos da indústria mecânica exportados para outros Estados-membros não é superior ao montante dessas imposições.

Comentando o caso, Laurence Gormley (2005, p. 47 - 48) afirma que o reembolso previsto no art. $96^{\circ}$ do TCEE, depois artigo $91^{\circ}$ do TCE, hoje artigo $111^{\circ}$ do TUE, é limitado aos tributos sobre o volume de negócios, aos impostos especiais de consumo e a outras formas de tributos indiretos, a menos de aprovação, por período limitado, pelo Conselho, por maioria qualificada, mediante provocação da Comissão Europeia, embora, até a data da sua obra, nenhuma vez tal procedimento houvesse sido usado. 
Outro exemplo tem-se nos processos geminados C-152/89 $9^{410}$, Comissão das Comunidades Europeias contra Grão-Ducado do Luxemburgo, e C-153/89 ${ }^{411}$, Comissão das Comunidades Europeias contra Reino da Bélgica, tendo por objeto a obtenção da declaração de que, ao tomar em consideração, para efeitos da cobrança do imposto sobre o consumo de cerveja na importação e do seu reembolso na exportação, uma taxa de quebra entre o mosto e o produto acabado superior à que existe em média na indústria cervejeira belga e, em todo o caso, superior à de determinadas fábricas de cerveja belgas, o GrãoDucado do Luxemburgo e o Reino da Bélgica não cumpriram as obrigações que lhe incumbem por força dos artigos $95^{\circ}$ e $96^{\circ}$ do Tratado CEE.

Por força das normas comuns à União Econômica Belgo-Luxemburguesa, o imposto sobre o consumo da cerveja, em Luxemburgo e na Bélgica, não era cobrado sobre o produto acabado, mas sobre o mosto quente, sem ter em conta as quebras que as fases ulteriores de fabrico e de acondicionamento originavam. Em tal sistema, a carga fiscal que incidia sobre o produto acabado, a cerveja, dependia das quebras inerentes à passagem do mosto a cerveja. Seria tanto mais reduzida quanto menores sejam as próprias quebras.

Para determinar o montante do imposto específico, que o produto acabado deve pagar quando é exportado ou importado, é necessário remontar à base de cálculo, ou seja, ao mosto quente de que provém a cerveja, tendo em conta as quebras inerentes à sua passagem a cerveja. $\mathrm{Na}$ exportação, essa conversão do produto exportado em mosto quente fazia-se com base numa taxa de quebra de $10 \%$ do mosto. Na importação, as quantidades de cerveja efetivamente importadas eram aumentadas de $5 \%$ para ter em conta as quebras verificadas nas fábricas de cerveja do Estado-membro de origem, o que correspondia a uma taxa de quebra de $4,7619 \%$ de mosto quente.

Quanto às exportações, no que ora nos interessa, a Comissão alegou que uma fábrica de cerveja luxemburguesa ou belga que reduzisse as suas quebras a uma taxa situada abaixo da média de $10 \%$ aplicada como taxa fixa, receberia um reembolso do montante do imposto correspondente a frações de mosto não utilizadas no fabrico da cerveja exportada, e isto em violação do artigo $96^{\circ}$ do Tratado. A este respeito, a Comissão observou que os governos luxemburguês e belga, longe de provarem, como lhe incumbiam, que as suas unidades mais eficientes nunca atingem uma taxa de quebra igual ou inferior a $10 \%$, nem sequer foram capazes de provar que esse valor representa a taxa média das quebras verificadas.

\footnotetext{
${ }^{410}$ ECR 1991, I - 3160.

${ }^{411}$ ECR 1991, I - 3177.
} 
De acordo com o segundo relatório pericial, do professor Narziss, a taxa de quebra média para as cervejas destinadas à exportação é de 7,95 \%, com uma margem de variação de 1,5\%. Partindo da percentagem mais elevada, chega-se, portanto, a uma taxa de quebra de 9,45\%. Resulta, assim, desse relatório pericial, que a taxa de $10 \%$ não constitui um limite absoluto, abaixo do qual nenhuma fábrica de cerveja luxemburguesa ou belga jamais poderá reduzir as suas quebras no que se refere às cervejas de exportação.

Assim sendo, não tendo os governos demandados apresentado qualquer prova em contrário, foi considerado provado poder o reembolso na exportação ser, em certos casos, superior à carga fiscal efetivamente importada pela cerveja exportada.

Com efeito, o Tribunal de Justiça declarou, como já o havia feito no seu acórdão de $1^{\circ}$ de dezembro de 1965, Comissão/Itália (45/64, Recueil, p. 1057), que, quando um Estado-membro faça uso de um regime com base numa taxa fixa para determinar o montante das imposições internas que podem ser objeto de reembolso na exportação para outro Estado-membro, incumbe-lhe o ônus da prova de que tal regime não exorbita em caso algum dos limites imperativos do artigo $96^{\circ}$.

\subsection{Do caso Brasileiro.}

Como o documento consolidado, L/3389, produzido pelo Grupo de Trabalho Sobre Ajustes Fiscais de Fronteira, contendo o levantamento realizado em diversos países sobre as práticas das Partes Contratantes existentes no que tange à matéria dos ajustes fiscias de fronteira, não aborda o sistema e as práticas brasileiras, temos que procurar outros indícios e subsídios que nos permitam entender a aplicabilidade do conceito de ajustes fiscais de fronteira ao Sistema Tributário Nacional.

No julgamento do caso "Brazilian Internal Taxes", como já visto, com dois Relatórios adotados pelas Partes Contratantes (CP.3/42, de 30 de junho de 1949, e CP.5/37, de 13 de dezembro de 1950), examinou-se a adequação dos Decretos-leis $n^{\circ} 7.404$, de 22 de março de 1945 e n ${ }^{\circ}$ 8.538, de 8 de abril de 1946, da Lei no 494, de 26 de novembro de 1948 e do Projeto de Lei n ${ }^{\circ}$ 483/50 ao Artigo III, parágrafos 1 e 2 do GATT. Todos se referem ao então denominado Imposto de Consumo, sendo que o primeiro decreto-lei é a lei básica do imposto, denominada "Lei do Imposto de Consumo", revogado expressamente pela nova lei instituidora do tributo, a Lei $n^{\circ} 4.502$, de 30 de novembro de 
1964, em seu artigo $121^{412}$, norma ainda em vigor. A denominação do imposto foi alterada por meio do art. $1^{\circ}$ do Decreto-lei $\mathrm{n}^{\mathrm{o}} 34^{413}$, de 18 de novembro de 1966, para o novo nome vigente até hoje, Imposto sobre Produtos Industrializados (IPI).

Portanto, podemos implicitamente concluir, já que o Grupo Especial, instalado ainda pelo antigo GATT, considerou procedente a reclamação da França de então, que o atual IPI é considerado imposto indireto ajustável na fronteira, nos termos do que se entende como tributo interno previsto no Artigo III do GATT.

Daí poder-se concluir, então, que os tributos subsumidos ao artigo III são, em se tratando do Sistema Tributário Nacional, tipicamente os impostos brasileiros, como o Imposto sobre Produtos Industrializados (IPI) e o Imposto dos Estados e do Distrito Federal sobre operações relativas à circulação de mercadorias e sobre prestações de serviços de transporte interestadual e intermunicipal e de comunicação (ICMS), que incidem, igualmente, sobre as operações internas, assim entendidas as realizadas na zona secundária, quanto, em relação aos produtos importados do exterior, no desembaraço aduaneiro.

No caso do IPI, imposto da competência tributária federal, sua incidência tem sua base constitucional no art. 153 , IV e $\S 3^{\text {o414 }}$, sem qualquer referência minuciosa às materialidades de sua hipótese de incidência. Apenas na lei complementar tributária, o Código Tributário Nacional $(\mathrm{CTN})^{415}$, em seu art. $46^{416}$, estabelecem-se quais são as modalidades da incidência desse tributo, entre elas prevendo o ajuste fiscal na fronteira.

\footnotetext{
412 “Art. 121. Ficam revogados, no que não tenham sido mantidos expressamente por esta lei, o decreto-lei $\mathrm{n}^{\circ}$ 7.404, de 22 de março de 1945, e as leis posteriores que o modificaram, ressalvadas as disposições referentes ao processo fiscal e as que se apliquem também a outros tributos ou disciplinem matéria estranha ao impôsto de consumo".

413 “Art. $1^{\circ}$. O Impôsto de Consumo, de que trata a Lei $n^{\circ} 4.502$, de 30 de novembro de 1964, passa a denominar-se lmpôsto sôbre Produtos Industrializados".

414 “Art. 153. Compete à União instituir impostos sobre:

(...)

IV - produtos industrializados;

(...)

$\S 3^{\circ}$ - O imposto previsto no inciso IV:

I - será seletivo, em função da essencialidade do produto;

II - será não-cumulativo, compensando-se o que for devido em cada operação com o montante cobrado nas anteriores;

III - não incidirá sobre produtos industrializados destinados ao exterior.

IV - terá reduzido seu impacto sobre a aquisição de bens de capital pelo contribuinte do imposto, na forma da lei. (Incluído pela Emenda Constitucional no 42, de 19.12.2003)".

${ }^{415}$ Lei n ${ }^{\circ} 5.172$, de 25 de outubro de 1966, denominada Código Tributário Nacional por determinação do Art. $7^{\circ}$ "A Lei $n^{\circ} 5.172$, de 25 de outubro de 1966, e alterações posteriores passa a denominar-se "Código Tributário Nacional"”, do Ato Complementar n 36, de 13 de março de 1967, no uso das atribuições conferidas ao Presidente da República pelo art. 30 do Ato Institucional nº 2, de 27 de outubro de 1965.

416 “Art. 46. O imposto, de competência da União, sobre produtos industrializados tem como fato gerador:

I - o seu desembaraço aduaneiro, quando de procedência estrangeira;
} 
A doutrina brasileira, se, como afirma Adriana Stamato de Oliveira (2003, p. 30), pouco debate a natureza jurídica da incidência do IPI no desembaraço aduaneiro, o chamado IPI vinculado à importação, é absolutamente silente em entendê-la como corolário da neutralidade fiscal $^{417}$ não só em matéria de comércio exterior, já que estamos falando de tributos nacionais, mas também e principalmente no mercado interno, equiparando o ônus tributário a gravar o produto nacional e o importado.

Eduardo Domingos Bottallo (2002, p. 36 - 37), com suporte em afirmação de Paulo de Barros Carvalho, em obra específica sobre o tema ${ }^{418}$, defende que, sob a sigla IPI, o legislador complementar tencionou albergar três tributos distintos: o IPI em sentido estrito, aquele cujo aspecto material da regra-matriz de incidência é industrializar produto e celebrar operação jurídica que promova a transferência de sua propriedade ou posse, do inciso II; um adicional ao Imposto de Importação, a incidência que estamos querendo examinar, do inciso I; e um imposto da competência residual da União, no inciso III. Bottallo só discorda de Paulo de Barros Carvalho quanto à terceira incidência, afirmando que também é materialidade presa à circulação econômica, com o diferencial de se submeter à circunstância específica de ao produto industrializado ter sido dada pena de perdimento ou ter sido abandonado e, após, ter sido arrematado em leilão. Também Américo Lourenço Masset Lacombe (2000, p. 157 - 159), afirma tratar-se de três núcleos completamente distintos de incidência.

Tais abordagens são apenas parcialmente corretas. Não faz sentido entender que a incidência sobre a saída do produto industrializado do estabelecimento industrial ou a ele equiparado pela lei, como por exemplo, o comerciante atacadista, possa ser qualificada

II - a sua saída dos estabelecimentos a que se refere o parágrafo único do artigo 51;

III - a sua arrematação, quando apreendido ou abandonado e levado a leilão.

Parágrafo único. Para os efeitos deste imposto, considera-se industrializado o produto que tenha sido submetido a qualquer operação que lhe modifique a natureza ou a finalidade, ou o aperfeiçoe para o consumo.

(...)

Art. 51. Contribuinte do imposto é:

I - o importador ou quem a lei a ele equiparar;

II - o industrial ou quem a lei a ele equiparar;

III - o comerciante de produtos sujeitos ao imposto, que os forneça aos contribuintes definidos no inciso anterior;

IV - o arrematante de produtos apreendidos ou abandonados, levados a leilão.

Parágrafo único. Para os efeitos deste imposto, considera-se contribuinte autônomo qualquer estabelecimento de importador, industrial, comerciante ou arrematante".

${ }^{417}$ Segundo Paulo Antônio Caliendo Velloso da Silveira (2009, p. 113), a neutralidade fiscal tem por fim "diminuir legitimamente os efeitos da tributação sobre a decisão dos agentes econômicos, evitando distorções e consequentes ineficiências no sistema econômico".

418 "Imposto sobre Produtos Industrializados". In: Curso de Direito Empresarial. São Paulo: EDUC/ Resenha Tributária, 2 v., 1976, apud Bottallo (2002, p. 37). 
como o IPI em sentido estrito, uma vez que o diploma constitucional não traça contornos nítidos dos aspectos materiais da incidência, senão do objeto da manifestação signopresuntiva de capacidade contributiva, o "produto industrializado".

Melhor é entender que o constituinte quis definir a incidência sobre a industrialização da forma mais ampla possível, outorgando às normas gerais de Direito Tributário a possibilidade de restrição do campo de incidência. Porém, dentro dessa amplidão do espectro possível de incidência, o legislador constituinte, na esteira da incidência do seu antecessor, o Imposto sobre o Consumo, quis estabelecer a possibilidade de ajustamento fiscal na fronteira.

Alguns, baseados nessa pretensa diferença ontológica, defendem que a incidência do IPI vinculada à importação dos produtos industrializados é inconstitucional, já que o processo de industrialização não teria sido realizado em território nacional, o que infringiria o princípio da territorialidade da tributação. Edvaldo Brito (1998, p. 379), após defender que o índice de tributação alcançado pelo IPI não é o consumo, nem tampouco o ato industrial do qual resultou o produto industrializado, mas o próprio produto industrial decorrente de uma atividade industrial, conclui que a incidência sobre produto industrializado em país estrangeiro estaria fora do seu campo de incidência. No mesmo sentido, Antônio Maurício da Cruz (1984, p. 58) entende que apenas produtos industrializados brasileiros desnacionalizados ou reimportados poderiam sofrer a incidência do IPI na importação, sendo que os produtos realmente estrangeiros só se submeteriam ao Imposto de Importação.

Em outro lado da mesma discussão, quanto à materialidade do IPI se referir ao produto ou ao processo de industrialização, Adriana Stamato de Figueiredo (2003, p. 31), ao defender que o objeto material da incidência é o produto, conclui pela constitucionalidade da incidência na importação e pela inexistência de bitributação na espécie.

Não obstante, resta a indagação se, do ponto de vista da sua natureza jurídica, todas as incidências referem-se à circulação econômica e se podem ou não ser entendidas como diferenciadas nesse aspecto.

No caso do ICMS, exatamente por ser imposto de competência dos Estados e do Distrito Federal, as disposições legais são mais minuciosas desde o diploma constitucional, que faz expressa menção à incidência sobre a importação no Art. 155, § 2. ', IX, “a”, na redação conferida pela Emenda Constitucional n ${ }^{\circ} 33$, de 11 de dezembro de 
$2001^{419}$, como uma incidência apartada da natureza jurídica precípua dessa tributação, assim evidenciado pelo emprego dos termos "incidirá também".

Interessante é perceber que, ainda na época anterior à nova normativa constitucional, em que se discutia se a redação antiga ${ }^{420}$ tornava inconstitucional a exigência do ICMS na importação, especialmente se para pessoas físicas ou jurídicas unicamente prestadoras de serviços, nada se falou sobre a adequação da norma da lei complementar que a previa, os arts. $2^{\circ}, \S 1^{\circ}, I^{421}$ e $12, \mathrm{IX}^{422}$, da Lei Complementar $\mathrm{n}^{\mathrm{o}} 87$, de 13 de setembro de 1996, na redação da Lei Complementar $n^{\circ} 114$, de 16 de dezembro de 2002, aos acordos internacionais que regem o comércio internacional. Tampouco no julgado do Supremo Tribunal Federal que entendeu inconstitucional a incidência do ICMS na importação por não-contribuintes do imposto, ainda na vigência da disciplina

419 “Art. 155. Compete aos Estados e ao Distrito Federal instituir impostos sobre: (Redação dada pela Emenda Constitucional no 3, de 1993)

I - transmissão causa mortis e doação, de quaisquer bens ou direitos; (Redação dada pela Emenda Constitucional $\mathrm{n}^{\circ}$ 3, de 1993)

II - operações relativas à circulação de mercadorias e sobre prestações de serviços de transporte interestadual e intermunicipal e de comunicação, ainda que as operações e as prestações se iniciem no exterior; (Redação dada pela Emenda Constitucional no 3, de 1993)

III - propriedade de veículos automotores. (Redação dada pela Emenda Constitucional no 3, de 1993)

(...)

$\S 2 .^{\circ} \mathrm{O}$ imposto previsto no inciso II atenderá ao seguinte: (Redação dada pela Emenda Constitucional $\mathrm{n}^{\circ} 3$, de 1993)

(...)

IX - incidirá também:

a) sobre a entrada de bem ou mercadoria importados do exterior por pessoa física ou jurídica, ainda que não seja contribuinte habitual do imposto, qualquer que seja a sua finalidade, assim como sobre o serviço prestado no exterior, cabendo o imposto ao Estado onde estiver situado o domicílio ou o estabelecimento do destinatário da mercadoria, bem ou serviço;(Redação dada pela Emenda Constitucional n 33, de 2001)"

420 "IX - incidirá também:

a) sobre a entrada de mercadoria importada do exterior, ainda quando se tratar de bem destinado a consumo ou ativo fixo do estabelecimento, assim como sobre serviço prestado no exterior, cabendo o imposto ao Estado onde estiver situado o estabelecimento destinatário da mercadoria ou do serviço;"

421 “Art. $2^{\circ} \mathrm{O}$ imposto incide sobre:

I - operações relativas à circulação de mercadorias, inclusive o fornecimento de alimentação e bebidas em bares, restaurantes e estabelecimentos similares;

II - prestações de serviços de transporte interestadual e intermunicipal, por qualquer via, de pessoas, bens, mercadorias ou valores;

III - prestações onerosas de serviços de comunicação, por qualquer meio, inclusive a geração, a emissão, a recepção, a transmissão, a retransmissão, a repetição e a ampliação de comunicação de qualquer natureza;

IV - fornecimento de mercadorias com prestação de serviços não compreendidos na competência tributária dos Municípios;

V - fornecimento de mercadorias com prestação de serviços sujeitos ao imposto sobre serviços, de competência dos Municípios, quando a lei complementar aplicável expressamente o sujeitar à incidência do imposto estadual.

$\S 1^{\circ} \mathrm{O}$ imposto incide também:

I - sobre a entrada de mercadoria ou bem importados do exterior, por pessoa física ou jurídica, ainda que não seja contribuinte habitual do imposto, qualquer que seja a sua finalidade; (Redação dada pela Lcp 114, de 16.12.2002)"

422 “Art. 12. Considera-se ocorrido o fato gerador do imposto no momento:

IX - do desembaraço aduaneiro de mercadorias ou bens importados do exterior; (Redação dada pela Lcp 114, de 16.12.2002)" 
constitucional e de lei complementar anterior ${ }^{423}$, o Recurso Extraordinário $\mathrm{n}^{\mathrm{o}}$ 203.0759/DF, de 5 de agosto de 1998, nem nos votos do relator para acórdão, Min. Maurício Corrêa, nem tampouco nos restantes sete votos majoritários e nem mesmo, por incrível que pareça, nos dois votos vencidos, do relator, Min. Ilmar Galvão, e do Min. Nélson Jobim, que o acompanhou, houve qualquer menção à necessidade de neutralidade fiscal na incidência do ICMS como um todo, sendo que a discussão travada cingiu-se sempre ao conceito de circulação econômica e a sua ausência em se tratando de importação de bem destinado ao consumo (que se diferenciaria do conceito jurídico de mercadoria, como bem destinado à intermediação). É a demonstração mais do que cabal de que os aspectos de Direito Internacional são absolutamente ignorados quando do exame de quaisquer questões de Direito Tributário no Brasil, especialmente pelo Poder Judiciário nacional.

Mas não são só os juízes que ignoram considerações de Direito Internacional Tributário. Nossos doutrinadores também têm por hábito desprezar tanto o que toca às consequências internacionais das incidências tributárias internas como também os seus aspectos econômicos.

No campo do ICMS, encontra-se informação isolada de Ylves José de Miranda Guimarães (1975, p. 21), que, mencionando Gastão Luiz Lobo D’Eça (“O Novo Sistema Tributário Nacional", São Paulo: Editora do Departamento de Cultura da Associação dos Advogados de São Paulo, p. 27), aponta que esse autor, referindo-se às discussões referentes à Reforma Tributária, ressalvou o caráter de norma destinada a assegurar a neutralidade fiscal do novo imposto estadual, como instrumento de política fiscal, na então nova incidência, embora criticando-a veementemente.

Deve-se ressaltar que se está apreciando o regime jurídico do ICMS, imposto estadual, porque as normas dos acordos que estamos estudando possuem efeito vinculativo não apenas ao ente federal, mas também aos entes regionais, pelo que dispõe o parágrafo 13, referente ao artigo XXIV:12, do "Entendimento sobre a Interpretação do Artigo XXIV

\footnotetext{
423 "Art. $2^{\circ} \mathrm{O}$ imposto incide sobre:

(...)

$\S 1^{\circ} \mathrm{O}$ imposto incide também:

I - sobre a entrada de mercadoria importada do exterior, por pessoa física ou jurídica, ainda quando se tratar de bem destinado a consumo ou ativo permanente do estabelecimento;

(...)

Art. 12. Considera-se ocorrido o fato gerador do imposto no momento:

(...)

IX - do desembaraço aduaneiro das mercadorias importadas do exterior;”
} 
do Acordo Geral sobre Tarifas e Comércio 1994" ${ }^{\text {,424 }}$, celebrado como Resultado da Rodada Uruguai de negociações multilaterais ${ }^{425}$, em 15 de abril de 1994.

Da mesma forma, na apreciação do caso "United States - Measures Affecting Alcoholic and Malt Beverages”, de 19 de junho de 1992, entendeu-se que haver a extensão da norma menos favorável também a produtos de outras regiões do mesmo país não descaracterizaria a discriminação contra o estrangeiro, que deveria ser sempre aferida em relação a qualquer produto nacional, independentemente de sua origem, mas, mais particularmente, ao produto nacional mais favorecido em função de uma norma tributária regional $^{426}$.

A primeira previsão na lei complementar da incidência do então ICM na importação de produtos deu-se por meio da inclusão de um inciso II ao art. $52^{427}$ do CTN pelo art. $3^{\text {o }}$ do Ato Complementar $n^{\circ} 34$, de 30 de janeiro de 1967. No entanto, tal norma foi logo depois revogada pelo art. $8^{\circ}$ do Ato Complementar $n^{\circ} 36$, de 13 de março de 1967 e só voltou ao ordenamento por meio do Decreto-lei n ${ }^{\circ} 406$, de 31 de dezembro de 1968 , em seu art. $1^{\circ}, \mathrm{II}^{428}$. Como já se viu, hoje sua previsão está na Lei Complementar $n^{\circ}$ 87/96, na redação da Lei Complementar nº 114/02.

424 “13. Cada Membro é plenamente responsável sob o Gatt 1994 pela observância de todas as disposições do Gatt 1994, e tomarão todas as medidas razoáveis que estejam a sua disposição para assegurar tal observância por governos e autoridades regionais e locais dentro de seu território".

${ }^{425}$ Internalizado, no direito brasileiro, também pelo Decreto $\mathrm{n}^{\circ} 1.355$, de 30 de dezembro de 1994.

426 "The Panel did not consider relevant the fact that many of the state provisions at issue in this dispute provide the same treatment to products of other states of the United States as that provided to foreign products. The national treatment provisions require contracting parties to accord to imported products treatment no less favourable than that accorded to any like domestic product, whatever the domestic origin. Article III consequently requires treatment of imported products no less favourable than that accorded to the

most-favoured domestic products" - BISD/39S/206, parágrafo 5.17.

427 “SEÇÃO II

Imposto Estadual sobre Operações Relativas à Circulação de Mercadorias

Art. $52 \mathrm{O}$ impôsto, de competência dos Estados, sôbre operações relativas a circulação de mercadorias tem como fato gerador: (Redação dada pelo Ato Complementar no 34, de 30.1.1967).

I - a saída de mercadorias de estabelecimento comercial, industrial ou produtor; (Incluída pelo Ato Complementar $n^{\circ} 34$, de 30.1.1967)(Revogado pelo Decreto-lei nº 406, de 31.12.1968)

II - a entrada de mercadoria estrangeira em estabelecimento da emprêsa que houver realizado a importação, observado o disposto nos $\S \S 6^{\circ}$ e $7^{\circ}$, do art. 58; (Incluída pelo Ato Complementar $\mathrm{n}^{\circ} 34$, de 30.1.1967) (Revogado pelo Ato Complementar $\mathrm{n}^{\circ} 36$, de 1967)

III - o fornecimento de alimentação, bebidas e outras mercadorias, nos restautantes, bares, cafés e estabelecimentos similares. (Incluída pelo Ato Complementar n 34, de 30.1.1967)”.

428 "Art $1^{\circ} \mathrm{O}$ impôsto sôbre operações relativas à circulação de mercadorias tem como fato gerador:

I - a saída de mercadorias de estabelecimento comercial, industrial ou produtor;

II - a entrada, em estabelecimento comercial, industrial ou produtor, de mercadoria importada do exterior pelo titular do estabelecimento;

III - o fornecimento de alimentação, bebidas e outras mercadorias em restaurantes, bares, cafés e estabelecimentos similare". 
Foi constitucionalmente prevista em função do art. $1^{\circ}$ da Emenda Constitucional $\mathrm{n}^{\mathrm{o}} 23$, de $1^{\circ}$ de dezembro de 1983, que alterou o art. $23^{429}$ da Emenda Constitucional $\mathrm{n}^{\mathrm{o}} 1$, de 17 de outubro de 1969, outorgada pelo Poder Executivo Federal diante do recesso do Congresso Nacional, determinado pelo Ato Complementar $\mathrm{n}^{\mathbf{o}} 38$, de 13 de dezembro de 1968 , e diante da autorização para legislar conforme o disposto no $\S 1^{\circ}$ do artigo $2^{\circ}$ do Ato Institucional no 5, de 13 de dezembro de 1968.

Retomando a questão da apreciação doutrinária no Brasil a respeito dos ajustes fiscais na fronteira, o que prevalece são posições como a de José Eduardo Soares de Mello (1998, p. 37 - 42), que não faz nenhuma ressalva ontológica quanto à incidência sobre a importação de mercadorias em relação àquela sobre as operações decorrentes da saída da mercadoria do estabelecimento comercial. Outros, mais cuidadosos, como Ylves Guimarães (1975, p. 24), prefere equipará-las por completo, ao entender que ambas consubstanciariam-se em operações relativas à circulação de mercadorias, uma vez que, por meio dessas duas incidências, igualmente operar-se-iam transferências de titularidades, com a única diferença que a incidência sobre a entrada de mercadoria do exterior implicaria circulação econômica apenas parcialmente sob a territorialidade brasileira.

Diferentemente, Roque Antônio Carrazza (2009, p. 59) aponta que a incidência que estamos aqui estudando implica uma inversão da estrutura da incidência do ICMS, principalmente por conta da previsão do art. 155, § 2, IX, “a”, da Constituição da República, que prevê a capacidade tributária ativa ao estado destinatário.

Não há dúvida, com efeito, que estamos agora tratando de uma incidência integralmente obediente ao princípio do destino, contrariamente a toda a disciplina do IPI e do ICMS; no caso do primeiro tributo, sempre incidente na origem; no segundo, predominantemente na origem, mas parcialmente na origem e parcialmente no destino, apenas no caso das operações interestaduais. Não obstante, não há dúvida que se trata também de operação relativa à circulação de mercadorias, uma vez que a mercadoria, ao entrar no país, ingressa no seu ciclo comercial (CARRAZZA, 2009, p. 64 - 65). Isso não

\footnotetext{
429 “Art. 23. Compete aos Estados e ao Distrito Federal instituir impostos sôbre:

II - operações relativas à circulação de mercadorias realizadas por produtores, industriais e comerciantes, imposto que não será cumulativo e do qual se abaterá, nos termos do disposto em lei complementar, o montante cobrado nas anteriores pelo mesmo ou por outro Estado. A isenção ou não-incidência, salvo determinação em contrário da legislação, não implicará crédito de imposto para abatimento daquele incidente nas operações seguintes. (Redação dada pela Emenda Constitucional nº 23, de 1983)

(...)

$\S 11$ - O imposto a que se refere o item II incidirá, também, sobre a entrada, em estabelecimento comercial, industrial ou produtor, de mercadoria importada do exterior por seu titular, inclusive quando se tratar de bens destinados a consumo ou ativo fixo do estabelecimento". (Incluído pela Emenda Constitucional no 23 , de 1983)
} 
mascara, porém, a natureza eminentemente econômica, extrafiscal, da incidência, diferenciada da incidência principal, notadamente fiscal, o que define a sua ontologia autônoma. Empregando a classificação de Maurice Lauré (1960, p. 127 - 132), a incidência modal do ICMS possui a natureza de imposto sobre bens de produção, ao passo que o ajuste fiscal na fronteira, de imposto sobre produtos de consumo, o que atende à sua própria consideração de que os impostos sobre o volume de negócios podem guardar no seu bojo incidências das duas modalidades.

Partindo desse ponto de vista, são equivocadas as afirmações de que "o fato importação não despe o ICMS ora em estudo" (o ajuste) "de seu caráter mercantill" e que a “importação, no caso, há de ser relativa à circulação de mercadorias" (CARRAZZA, 2009, p. 64).

A incidência do ICMS, como já se viu, obedece ao princípio de destino, em contrariedade aos demais fatos geradores do imposto, e não apenas porque a outra parte da relação econômica mercantil que deu causa ao seu nascimento está fora do país, portanto fora do escopo territorial da tributação brasileira. Também e principalmente porque não há como ajustar a carga tributária na importação senão mediante o emprego desse princípio de atribuição da competência tributária, como já se examinou exaustivamente em oportunidade anterior.

Também não se pode concordar com a formulação acerca do necessário caráter mercantil da incidência do ICMS na importação de bens. Pela própria construção do conceito de ajuste fiscal na fronteira na importação - empregando o princípio do destino, portanto - o adquirente-importador é sempre considerado economicamente como mero consumidor, sendo assim tributado pela integralidade do tributo, ainda que com a possibilidade de creditamento posterior, como no caso brasileiro.

No caso brasileiro, essa integralidade do montante do elemento quantitativo do crédito tributário, referente tanto à base de cálculo quanto à alíquota, que caracteriza o tratamento diferenciado do consumidor final da mercadoria em relação àquele reservado ao operador mercantil, exatamente com o fim de não onerar por demais as fases intermediárias da cadeia de comercialização ou de produção, reservando às incidências tributárias intermediárias a oneração o tanto possível exclusiva do valor agregado parcial, é verificada pelo fato de que ao importador, mesmo sendo comerciante-revendedor da própria mercadoria ou, no caso do IPI, sendo industrial de produto que o empregue como matéria-prima ou produto intermediário, ainda assim não poderá usufruir dos benefícios, 
constitucionalmente previstos ${ }^{430}$, que a incidência modal, sobre operações relativas a mercadorias e serviços, reserva no caso de aquisição por contribuinte, para futura revenda ou industrialização - vale dizer, a base de cálculo computada sem compreender o crédito tributário referente ao IPI (art. 155, $\S 2^{\circ}, \mathrm{XI}$ ) e a minorada alíquota na entrada da mercadoria, decorrente do diferencial interestadual, a ser pago apenas quando da operação seguinte (art. 155, § 20, VII, “a”).

Quando do advento da lei paulista prevendo a incidência do então ICM sobre a mercadoria importada, foram publicados, em 1975, diversos pareceres de tributaristas nacionais, dentre eles os de Geraldo Ataliba, Aliomar Baleeiro, Alcides Jorge Costa e José Souto Maior Borges, todos tratando da constitucionalidade da referida incidência sobre bens de capital para uso do importador.

Como pontos de consenso, temos a concepção de que a saída da mercadoria do estabelecimento comercial não é a hipótese de incidência do ICM, mas sim o seu mero aspecto temporal, o momento que o legislador entendeu adequado para estabelecer a presunção de consumação do fato imponível (ATALIBA, 1975, p. 116). Embora nisso houvesse consenso, que, aliás, perdura até hoje, os pareceres mencionados discordam quanto à autoria primeira dessa formulação - Geraldo Ataliba a atribui a José Souto Maior Borges (1975, p. 116); Alcides Costa a José Nabantino Ramos (1975, p. 132). Outro ponto em comum é entender que a circulação à qual se refere o legislador constituinte é uma circulação que, se não se pode unissonamente denominar de econômica, também não pode ser tomada como apenas a física (ATALIBA, 1975, p. 117; BORGES, 1975, p. 123; COSTA, 1975, p. 133; BALEEIRO, 1975, p. 143).

430 "Seção IV

DOS IMPOSTOS DOS ESTADOS E DO DISTRITO FEDERAL

Art. 155. Compete aos Estados e ao Distrito Federal instituir impostos sobre: (Redação dada pela Emenda Constitucional $n^{\circ} 3$, de 1993)

II - operações relativas à circulação de mercadorias e sobre prestações de serviços de transporte interestadual e intermunicipal e de comunicação, ainda que as operações e as prestações se iniciem no exterior; (Redação dada pela Emenda Constitucional no 3 , de 1993)

$\S 2 .^{\circ} \mathrm{O}$ imposto previsto no inciso II atenderá ao seguinte: (Redação dada pela Emenda Constitucional $\mathrm{n}^{\circ} 3$, de 1993)

(...);

VII - em relação às operações e prestações que destinem bens e serviços a consumidor final localizado em outro Estado, adotar-se-á:

a) a alíquota interestadual, quando o destinatário for contribuinte do imposto;

b) a alíquota interna, quando o destinatário não for contribuinte dele;

(...);

XI - não compreenderá, em sua base de cálculo, o montante do imposto sobre produtos industrializados, quando a operação, realizada entre contribuintes e relativa a produto destinado à industrialização ou à comercialização, configure fato gerador dos dois impostos"; 
As unanimidades param por aí. O próprio conceito de circulação é diferenciado para os diversos autores. Para Geraldo Ataliba (p. 115), a partir das lições de José Nabantino Ramos, circular é mudar de titular, mediante negócios jurídicos, com o que concorda Souto Maior Borges (p. 122). Por outro lado, para Alcides Jorge Costa, “circulação é o curso da mercadoria dede a fonte de produção até o consumo; neste curso, o valor da mercadoria vai sendo adicionado pelas sucessivas transformações que ela sofre, pelo custo do transporte de um local para outro e por vários fatores" (p. 133 - 134). Aliomar Baleeiro, em raciocínio análogo, entende que a circulação "é uma etapa econômica sofrida apenas pelos bens que se produzem ou se adquirem para ulterior venda a consumidores ou compradores que não as vão utilizar em caráter permanente” (p. 143).

Como decorrência desse raciocínio, Aliomar Baleeiro defende que, na importação, à entrada no território nacional "não correspondeu uma operação de circulação, desde que a mercadoria era do importador a partir do minuto em que este, para seu uso, a adquiriu no estrangeiro, como bem instrumental, de produção ou de seu capital fixo", pelo que teria ocorrido no Brasil "simples operação de transporte", não operação de circulação de mercadorias (p. 148). A compra da mercadoria no país estrangeiro já teria sido o "elo final da circulação, que se encerrou definitivamente do ponto de vista fiscal quando sofreu ou podia sofrer" o imposto sobre o valor agregado no país de origem (p. 147). Portanto, termina por concluir pela inconstitucionalidade da incidência no caso da importação para uso próprio. No mesmo sentido, Geraldo Ataliba leciona que "no território nacional o bem já ingressa como bem de capital ou coisa civil de uso próprio" (p. 118), o que, diante de sua concepção de circulação como de mera transferência de titularidade, a "entrada, sendo mera exteriorização de operação realizada (fora do território do Estado), não é suficiente para configurar o fato imponível" (p. 119).

Em sentido contrário, José Souto Maior Borges (p. 124) afirma que no “processo de circulação é, em princípio, livre o legislador para eleger quer a saída, quer a entrada da mercadoria como o momento de aperfeiçoamento existencial da obrigação tributária, desde que observado o indeclinável pressuposto do relacionamento com operação de circulação da mercadoria”. Assim, a entrada da mercadoria no estabelecimento que a importa do exterior é um fato que, a teor do artigo $1^{\circ}$, II, do Decretolei $n^{\circ} 406 / 68$, exterioriza a circulação, não distoando em essência da incidência básica do imposto.

As formulações de Geraldo Ataliba e de Aliomar Baleeiro, embora não completamente corretas e distantes da percepção do caráter de ajustamento físcal na 
fronteira da incidência do inciso II do artigo $1^{\circ}$ do Decreto-lei $\mathrm{n}^{\circ} 406 / 68$, trazem em si a noção da diferenciação ontológica entre as duas modalidades de materialidades, não apenas como diferentes aspectos temporais do mesmo fato gerador, ou, mais bem explicado, como diversos meios de exteriorização da mesma hipótese de incidência, como entende Alcides Jorge Costa (1978, p. 79).

Não é por nela se verificar a tributação no destino, injunção necessária por conta da aplicação do princípio da territorialidade da lei fiscal, repita-se, nem tampouco pela concepção de que não mais pressupõe transferências de titularidades, algo que só seria aplicável no caso das importações de bens destinados ao ativo permanente ou ao consumo no processo produtivo.

Alcides Jorge Costa (1978, p. 81 - 83), bebendo da lição doutrinária de Carnelutti, em seu "Teoria Giuridica della Circolazione", de 1933, entende a distinção entre a circulação econômica da circulação física elaborada pelo autor italiano na medida em que aquela necessariamente pressupõe tanto os meios subjetivos (o comerciante, intermediário na circulação dos bens), quanto os objetivos, a moeda, "cuja função pode conceber-se como uma redução de bens ao mesmo denominador" (p. 82). Mesmo assim, ainda que pudesse concordar a priori com que "a ninguém ocorreria pretender que a saída de mercadoria por furto ou roubo constitui fato gerador do ICMS" (p. 83), a partir das formulações de Aliomar Baleeiro, a definição de Carnelutti também abrangeria essas situações, pois o furto, para o italiano, enseja circulação econômica, embora contra o direito.

Assim, a distinção merece maior consistência teórica. O que importa perceber é, para Alcides Jorge Costa (1978, p. 86 - 87), a existência de agregação de valor na operação que caracteriza a circulação econômica. Define então a circulação a que se refere a regra geral de incidência do ICMS como "a série de operações que levam as mercadorias da fonte de produção até o consumo final, de acordo com a sua natureza e finalidades, agregando-lhes valor em cada etapa desse percurso", sendo assim irrelevante que, em seu percurso, haja ou não transferência de posse ou de propriedade. Com isso, justifica a incidência do ICMS, então ICM, nas transferências de mercadorias entre estabelecimentos da mesma pessoa jurídica em diferentes unidades federativas, assim como o próprio princípio da autonomia dos estabelecimentos, básico no entendimento da sistemática desse imposto. Mas, por outro lado, diferencia a incidência da situação da frota de veículos de uma empresa, hipótese em que a circulação é meramente física (p. 88). Também é o caso 
do que Carnelutti denomina de escambo temporário ou crédito de uso, o que o Direito Civil pátrio menciona como sendo o comodato.

Em conclusão de seu raciocínio, ressalvado que escreveu em 1978, afirma que "nada" "impede que que a lei complementar venha a erigir o auto-consumo interno em fato gerador do ICN", dado que, nessa hipótese, não há transferência de propriedade na operação final (p. 87).

A partir de todas essas considerações, conclui por criticar as formulações de Aliomar Baleeiro e de Geraldo Ataliba (1978, p. 105 - 106), na medida em que propugna que "é incontestável a existência de circulação nas importações e exportações; não apenas a circulação física, mas a que nos interessa" (p. 106). Refuta o argumento da extraterritorialidade, afirmando que a "circulação pode iniciar-se num país e terminar noutro" (p. 106).

Não se discute a coerência dos argumentos de Alcides Jorge Costa. No entanto, mormente após o advento caso Emenda Constitucional $n^{\circ} 33 / 01$, ao estabelecer nova redação ao Art. 155, § 2., IX, “a”, em mais um episódio do abominável fenômeno da correção legislativa da jurisprudência $^{431}$, não há como se negar que, a par das ontologias diferentes, os regimes jurídicos claramente diferenciados, especialmente quanto à sujeição passiva e ao direito ao creditamento do imposto no caso de consumo próprio ou ativação, deixam entrever que os ajustes fiscais de fronteira revestem-se de autonomia conceitual em relação à incidência modal do ICMS.

É o reconhecimento que o imposto em tela, a par de sua natureza fiscal, visa a ser, o mais possível, neutro, de forma a "onerar, de maneira uniforme, o preço final das mercadorias" (COSTA, 1978, p. 85), embora não apenas no aspecto vertical, de não criar incentivos à integração vertical dos processos produtivos das empresas, como Alcides Jorge Costa reconhece, mas também no aspecto horizontal, especialmente em função da origem das mercadorias.

Retornando ao exame dogmático do direito positivo brasileiro, se, quanto aos mencionados impostos brasileiros, nenhuma dúvida há de restar quanto à aplicabilidade dos acima referidos impostos à sua disciplina, também se pode entender na mesma situação, com o advento da Lei $n^{\circ} 10.865$, de 30 de abril de 2004, que criou a Contribuição

\footnotetext{
${ }^{431}$ Sobre esse fenômeno, típico do Direito Tributário brasileiro, ver: TORRES, Ricardo Lobo. "A Integração entre a Lei e a Jurisprudência em Matéria Tributária". Cadernos de Direito Tributário e Finanças Públicas. São Paulo: Revista dos Tribunais, vol 3, p. 7 - 20, 1993. Deve-se ressaltar que, no caso específico da incidência do ICMS na importação em relação a não contribuintes (pessoas físicas e sociedades exclusivamente prestadoras de serviços), a jurisprudência do STF, equivocada, veio a ser corretamente corrigida, de forma a refletir plenamente a natureza jurídica diferenciada dessa incidência.
} 
para os Programas de Integração Social e de Formação do Patrimônio do Servidor Público e a Contribuição para o Financiamento da Seguridade Social, incidentes sobre a importação de bens e serviços, as respectivas contribuições, criadas pelas Leis Complementares $\mathrm{n}^{\mathrm{o}} 7$, de 7 de setembro de 1970, $\mathrm{n}^{\circ} 8$, de 3 de dezembro de 1970 e $\mathrm{n}^{\circ} 70$, de 30 de dezembro de 1991.

As contribuições para o PIS/PASEP e a COFINS nas importações estão na terceira modalidade mencionada por Lagemann (1999, p. 185) - na verdade em conjunto com as outras duas, que se supõe seja efetivadas pelo país de exportação. São também instrumentos para garantir a neutralidade econômica, por meio da incidência sobre o produto importado apenas para compensar ônus equivalente sobre produtos domésticos similares (ORTINO, 2004, p. 140), em modalidade típica de ajuste fiscal de fronteira, nos mesmos moldes, aqui defendidos, aplicáveis ao ICMS e ao IPI.

Como exemplo a confirmar a característica tanto das incidências do IPI quanto das Contribuições Sociais ao PIS/PASEP e a COFINS, nas operações de importação e de exportação, como de ajustes fiscais de fronteira, podemos ilustrar o direito ao crédito presumido de IPI, prevalente quando da vigência dos sistemas cumulativos das contribuições sociais mencionadas, como evidente exemplo de ajustes fiscais na exportação ("export rebates").

O crédito presumido de IPI foi criado com o fim de desonerar as exportações de produtos brasileiros das Contribuições Sociais do PIS/PASEP e COFINS, incidentes sobre as aquisições, no mercado interno, de matérias-primas, produtos intermediários e materiais de embalagem a serem utilizados no processo produtivo de bens destinados à exportação. Poderia ser beneficiada tanto a empresa diretamente exportadora quanto, no caso de exportação indireta, o fornecedor da empresa comercial exportadora.

Opera-se por meio da concessão de um crédito presumido de IPI, lançado à esquerda no Livro Registro de Apuração de IPI (modelo 9), como se fosse decorrente de uma aquisição tributada pelo IPI. Calculava-se a partir da multiplicação de um coeficiente $(5,37 \%)$ aplicado ao valor lançado das contribuições ao PIS/PASEP e da COFINS incidentes sobre os faturamentos correspondentes aos insumos adquiridos no mercado interno (excluindo-se os insumos importados) e consumidos na produção de bens efetivamente exportados, sendo que se presumia que o percentual de insumos consumidos nos bens exportados em relação ao total das aquisições era proporcional ao montante total da receita de exportação em relação ao total da receita bruta da empresa exportadora. 
O crédito presumido do IPI esteve em vigor desde a primeira edição da Medida Provisória n 674, de 25 de outubro de 1994, várias vezes renumerada, até se transformar na Medida Provisória n ${ }^{\circ}$ 1.484-27, de 22 de novembro de 1996 e se converter na Lei 9.363, de 13 de dezembro de $1996^{432}$.

Foi suspenso no período de 01/04/99 a 31/12/99, por intermédio do artigo 12 da segunda reedição da Medida Provisória no 1.807, de 28 de janeiro de 1999, a Medida Provisória $n^{\circ} 1.807-2$, de 25 de março de 1999, renumerada posteriormente para Medidas Provisórias $n^{\circ} 1.858,1.991,2.037$ e 2.113, sendo atualmente a Medida Provisória n ${ }^{\circ}$ 2.15835 , de 24 de agosto de $2001^{433}$, congelada após 35 reedições mensais e ainda não convertida em lei, pois foi anterior à alteração constitucional da Emenda Constitucional $\mathrm{n}^{\circ}$ 32, de 11 de setembro de 2001. Portanto, a partir de 01/01/00, os produtores exportadores voltaram temporariamente a ter direito ao benefício fiscal do crédito presumido em análise. Posteriormente, com o advento da Lei $\mathrm{n}^{\mathrm{o}} 10.276$, de 10 de setembro de $2001^{434}$, produto da conversão de duas reedições da Medida Provisória $\mathrm{n}^{\circ} 2.202$, de 26 de julho de

432 "Lei n” 9.363, de 13 de dezembro de 1996.

Dispõe sobre a instituição de crédito presumido do Imposto sobre Produtos Industrializados, para ressarcimento do valor do PIS/PASEP e COFINS nos casos que especifica, e dá outras providências.

Faço saber que o PRESIDENTE DA REPÚBLICA adotou a Medida Provisória nº 1.484-27, de 1996, que o Congresso Nacional aprovou, e eu, José Sarney, Presidente, para os efeitos do disposto no parágrafo único do art. 62 da Constituição Federal, promulgo a seguinte Lei:

Art. 1 A empresa produtora e exportadora de mercadorias nacionais fará jus a crédito presumido do Imposto sobre Produtos Industrializados, como ressarcimento das contribuições de que tratam as Leis Complementares $\mathrm{n}^{\circ} \mathrm{s} 7$, de 7 de setembro de 1970, 8, de 3 de dezembro de 1970, e 70, de 30 de dezembro de 1991, incidentes sobre as respectivas aquisições, no mercado interno, de matérias-primas, produtos intermediários e material de embalagem, para utilização no processo produtivo.

Art. $2^{\circ} \mathrm{A}$ base de cálculo do crédito presumido será determinada mediante a aplicação, sobre o valor total das aquisições de matérias-primas, produtos intermediários e material de embalagem referidos no artigo anterior, do percentual correspondente à relação entre a receita de exportação e a receita operacional bruta do produtor exportador.

$\S 1^{\circ} \mathrm{O}$ crédito fiscal será o resultado da aplicação do percentual de 5,37\% sobre a base de cálculo definida neste artigo.

$(\ldots)^{\prime}$

433 “Art. 12. Fica suspensa, a partir de $1^{\circ}$ de abril até 31 de dezembro de 1999 , a aplicação da Lei no 9.363 , de 13 de dezembro de 1996, que instituiu o crédito presumido do Imposto sobre Produtos Industrializados - IPI, como ressarcimento das contribuições para o Pis/Pasep e Cofins, incidentes sobre o valor das matériasprimas, dos produtos intermediários e dos materiais de embalagem utilizados na fabricação de produtos destinados à exportação"

434 “Lei n ${ }^{\circ} 10.276$, de 10 de setembro de 2001.

Dispõe sobre o ressarcimento das contribuições para os Programas de Integração Social e de Formação do Patrimônio do Servidor Público - PIS/PASEP e para a Seguridade Social - COFINS incidentes sobre insumos utilizados na fabricação de produtos destinados à exportação

Faço saber que o PRESIDENTE DA REPÚBLICA adotou a Medida Provisória n ${ }^{\circ} 2.202-2$, de 2001, que o Congresso Nacional aprovou, e eu, Efraim Morais, Primeiro Vice-Presidente da Mesa do Congresso Nacional, no exercício da Presidência, para os efeitos do disposto no parágrafo único do art. 62 da Constituição Federal, promulgo a seguinte Lei:

Art. $1^{\circ}$ Alternativamente ao disposto na Lei ${ }^{\circ} 9.363$, de 13 de dezembro de 1996, a pessoa jurídica produtora e exportadora de mercadorias nacionais para o exterior poderá determinar o valor do crédito presumido do Imposto sobre Produtos Industrializados (IPI), como ressarcimento relativo às contribuições para os 
2001, criou-se um método alternativo, opcional, para o cálculo do crédito presumido do IPI, agora considerando os custos correspondentes ao valor da prestação de serviços decorrentes de industrialização por encomenda.

A propósito, a diversidade, a relativa complexidade e a obscuridade quanto ao montante dos coeficientes determinados legalmente à quantificação da presunção no caso brasileiro das contribuições ao PIS/PASEP e da COFINS ilustram, em um caso prático, a propriedade da preocupação do Grupo de Trabalho sobre Ajustes Fiscais de Fronteira referente à dificuldade, no caso de impostos em cascata, cumulativos, em se conseguir apurar o exato montante do tributo a ser ajustado, dando azo a situações que podem vir a merecer, em tese, que a Parte Contratante que o empregue venha a provar às demais a regularidade dos valores autorizados legalmente, sob pena de a sua sistemática de ajustamento vir a ser considerada protecionista ${ }^{435}$.

Programas de Integração Social e de Formação do Patrimônio do Servidor Público (PIS/PASEP) e para a Seguridade Social (COFINS), de conformidade com o disposto em regulamento.

$\S 1^{\circ}$ A base de cálculo do crédito presumido será o somatório dos seguintes custos, sobre os quais incidiram as contribuições referidas no caput:

I - de aquisição de insumos, correspondentes a matérias-primas, a produtos intermediários e a materiais de embalagem, bem assim de energia elétrica e combustíveis, adquiridos no mercado interno e utilizados no processo produtivo;

II - correspondentes ao valor da prestação de serviços decorrente de industrialização por encomenda, na hipótese em que o encomendante seja o contribuinte do IPI, na forma da legislação deste imposto.

$\S 2^{\circ} \mathrm{O}$ crédito presumido será determinado mediante a aplicação, sobre a base de cálculo referida no $\S 1^{\circ}$, do fator calculado pela fórmula constante do Anexo.

$\S 3^{\circ} \mathrm{Na}$ determinação do fator $(\mathrm{F})$, indicado no Anexo, serão observadas as seguintes limitações:

I - o quociente será reduzido a cinco, quando resultar superior;

II - o valor dos custos previstos no $\S 1^{\circ}$ será apropriado até o limite de oitenta por cento da receita bruta operacional.

$\S 4^{\circ}$ A opção pela alternativa constante deste artigo será exercida de conformidade com normas estabelecidas pela Secretaria da Receita Federal e abrangerá, obrigatoriamente:

I - o último trimestre-calendário de 2001, quando exercida neste ano;

II - todo o ano-calendário, quando exercida nos anos subseqüentes.

$\S 5^{\circ}$ Aplicam-se ao crédito presumido determinado na forma deste artigo todas as demais normas estabelecidas na Lei ${ }^{\circ}$ 9.363, de 1996.

$\S 6^{\circ}$ Relativamente ao período de $1^{\circ}$ de janeiro de 2002 a 31 de dezembro de 2004 , a renúncia anual de receita, decorrente da modalidade de cálculo do ressarcimento instituída neste artigo, será apurada, pelo Poder Executivo, mediante projeção da renúncia efetiva verificada no primeiro semestre.

$\S 7^{\circ}$ Para os fins do disposto no art. 14 da Lei Complementar no 101, de 4 de maio de 2000, o montante anual da renúncia, apurado, na forma do $\S 6^{\circ}$, nos meses de setembro de cada ano, será custeado à conta de fontes financiadoras da reserva de contingência, salvo se verificado excesso de arrecadação, apurado também na forma do $\S 6^{\circ}$, em relação à previsão de receitas, para o mesmo período, deduzido o valor da renúncia.

(...)

ANEXO

$\mathrm{F}=0,0365 . \mathrm{Rx} /(\mathrm{Rt}-\mathrm{C})$, onde:

F é o fator; Rx é a receita de exportação; Rt é a receita operacional bruta; C é o custo de produção determinado na forma do $\S 1^{\circ}$ do art. $1^{\circ} ; \mathrm{Rx} /(\mathrm{Rt}-\mathrm{C})$ é o quociente de que trata o inciso I do $\S 3^{\circ}$ do art. $1^{\circ}$.

435 "16. The Working Party noted that there were some taxes which, while generally considered eligible for adjustment, presented a problem because of the difficulty in some cases of calculating exactly the amount of compensation. Examples of such difficulties were encountered in cascade taxes. For adjustment, countries operating cascade systems usually resorted to calculating average rates of rebate for categories of products rather than calculating the actual tax levied on a particular product. It was noted, however, that most 
No entanto, tais regimes de crédito presumido do IPI foram sendo derrogados à medida em que os sistemas cumulativos das Contribuições ao PIS/PASEP e da COFINS, de que tratam as Leis Complementares $n^{\circ} 7$, de 7 de setembro de 1970; $n^{\circ} 8$, de 3 de dezembro de 1970, e n $\mathrm{n}^{\mathrm{O}}$ 70, de 30 de dezembro de 1991 (às alíquotas de 0,65\% e de 3\%) foram se tornando exceções à regra geral de tributação das pessoas jurídicas.

Assim, as pessoas jurídicas enquadradas na modalidade de apuração nãocumulativa da Contribuição ao PIS/PASEP, desde a sua criação, pela Medida Provisória $\mathrm{n}^{\circ}$ 66, em 29 de agosto de 2002, posteriormente convertida na Lei $\mathrm{n}^{\mathbf{0}} 10.637$, de 30 de dezembro de $2002^{436}$, tiveram uma diminuição parcial do valor do crédito presumido de IPI, estabelecido pelas já mencionadas Leis $n^{\circ} 9.363 / 96$ e $\mathrm{n}^{\circ} 10.276 / 01$, por meio do seu art. $6^{0^{437}}$.

A diminuição parcial do benefício foi, portanto, justificada pela agora possibilidade de o contribuinte abater os créditos de PIS/PASEP incidentes nas suas aquisições de insumos dos valores dessas contribuições sociais devidos por conta das suas

cascade tax systems were to be replaced by TVA systems, and that therefore the area in which such problems occurred was diminishing. Other examples included composite goods which, on export, contained ingredients for which the Working Party agreed in principle it was administratively sensible and sufficiently accurate to rebate by average rates for a given class of goods.

17. It was generally agreed that countries adjusting taxes should, at all times, be prepared, if requested, toaccount for the reasons for adjustment, for the methods used, for the amount of compensation and to furnish proof thereof'.

436 "Lei n' 10.637, de 30 de dezembro de 2002.

Dispõe sobre a não-cumulatividade na cobrança da contribuição para os Programas de Integração Social (PIS) e de Formação do Patrimônio do Servidor Público (Pasep), nos casos que especifica; sobre o pagamento e o parcelamento de débitos tributários federais, a compensação de créditos fiscais, a declaração de inaptidão de inscrição de pessoas jurídicas, a legislação aduaneira, e dá outras providências.

O PRESIDENTE DA REPÚBLICA Faço saber que o Congresso Nacional decreta e eu sanciono a seguinte Lei:

CAPÍTULO I

DA COBRANÇA NÃO-CUMULATIVA DO PIS E DO PASEP

Art. $1^{\circ}$ A contribuição para o PIS/Pasep tem como fato gerador o faturamento mensal, assim entendido o total das receitas auferidas pela pessoa jurídica, independentemente de sua denominação ou classificação contábil. $\S 1^{\circ}$ Para efeito do disposto neste artigo, o total das receitas compreende a receita bruta da venda de bens e serviços nas operações em conta própria ou alheia e todas as demais receitas auferidas pela pessoa jurídica.

$\S 2^{\circ}$ A base de cálculo da contribuição para o PIS/Pasep é o valor do faturamento, conforme definido no caput.

(...)

Art. $2^{\circ}$ Para determinação do valor da contribuição para o PIS/Pasep aplicar-se-á, sobre a base de cálculo apurada conforme o disposto no art. $1^{\circ}$, a alíquota de $1,65 \%$ (um inteiro e sessenta e cinco centésimos por cento).

$(\ldots) "$

437 “Art. $6^{\circ} \mathrm{O}$ direito ao ressarcimento da contribuição para o PIS/Pasep de que tratam as Leis $\mathrm{n}^{\circ}$ 9.363, de 13 de dezembro de 1996 , e $\mathrm{n}^{\circ} 10.276$, de 10 de setembro de 2001, não se aplica à pessoa jurídica submetida à apuração do valor devido na forma dos arts. $2^{\circ}$ e $3^{\circ}$ desta Lei.

Parágrafo único. Relativamente à pessoa jurídica referida no caput:

I - o percentual referido no $\S 1^{\circ}$ do art. $2^{\circ}$ da Lei $n^{\circ} 9.363$, de 13 de dezembro de 1996, será de 4,04\% (quatro inteiros e quatro centésimos por cento);

II - o índice da fórmula de determinação do fator (F), constante do Anexo único da Lei $\mathrm{n}^{\circ} 10.276$, de 10 de setembro de 2001, será de 0,03 (três centésimos)". 
saídas de mercadorias, mesmo que não seja o produto final destinado à exportação, como determinado pelo extenso artigo $3^{\circ}$ da Medida Provisória $n^{\circ}$ 66/02 e da Lei $n^{\circ}$ 10.637/02.

Assim, a necessidade de desoneração das exportações (ou, mais tecnicamente, de ajuste fiscal de fronteira nas exportações) por meio de uma presunção de créditos passou a se resumir apenas à COFINS, já que a nova incidência das Contribuições para o PIS/PASEP no faturamento davam direito ao crédito efetivo referentes às entradas tributadas das mesmas contribuições.

Posteriormente, a Medida Provisória n ${ }^{\circ}$ 135, de 30 de outubro de 2003, também estendeu a sistemática da não-cumulatividade à COFINS, com vigência a partir de 01/02/2004, convertida que foi na Lei $n^{\circ} 10.833$, de 29 de dezembro de $2003^{438}$. Com isso, para as empresas sujeitas à apuração não-cumulativa da Contribuição para o PIS/PASEP e, desde então, da COFINS, por meio do seu art. $14^{439}$, houve a extinção do crédito presumido de IPI como forma de ressarcimento dessas contribuições incidentes nas aquisições de insumos relacionados a produtos destinados à exportação.

Assim, o regime de crédito presumido das Contribuições para o PIS/PASEP e COFINS apenas permanece vigente ainda hoje para as empresas exportadoras sujeitas ao regime cumulativo dessas duas contribuições. Para as demais, as pessoas jurídicas submetidas à apuração das Contribuições para o PIS/PASEP e COFINS de forma nãocumulativa (às alíquotas de 1,65\% e de 7,6\%), passou a não haver mais direito ao crédito presumido, já que tal direito passou a não mais fazer sentido, uma vez que tais empresas vieram a ter direito à apropriação do crédito efetivo dessas contribuições sociais nas suas entradas.

438 "Lei no 10.833 , de 29 de dezembro de 2003.

Altera a Legislação Tributária Federal e dá outras providências

O PRESIDENTE DA REPÚBLICA Faço saber que o Congresso Nacional decreta e eu sanciono a seguinte Lei:

CAPÍTULO I

DA COBRANÇA NÃO-CUMULATIVA DA COFINS

Art. $1^{\circ}$ A Contribuição para o Financiamento da Seguridade Social - COFINS, com a incidência nãocumulativa, tem como fato gerador o faturamento mensal, assim entendido o total das receitas auferidas pela pessoa jurídica, independentemente de sua denominação ou classificação contábil.

$\S 1^{\circ}$ Para efeito do disposto neste artigo, o total das receitas compreende a receita bruta da venda de bens e serviços nas operações em conta própria ou alheia e todas as demais receitas auferidas pela pessoa jurídica.

$\S 2^{\circ} \mathrm{A}$ base de cálculo da contribuição é o valor do faturamento, conforme definido no caput.

(...)

Art. $2^{\circ}$ Para determinação do valor da COFINS aplicar-se-á, sobre a base de cálculo apurada conforme o disposto no art. $1^{\circ}$, a alíquota de 7,6\% (sete inteiros e seis décimos por cento).

$(\ldots)^{\prime \prime}$

439 "Art. 14. O disposto nas Leis $\mathrm{n}^{\circ} \mathrm{s}$ 9.363, de 13 de dezembro de 1996, e 10.276, de 10 de setembro de 2001, não se aplica à pessoa jurídica submetida à apuração do valor devido na forma dos arts. $2^{\circ}$ e $3^{\circ}$ desta Lei e dos arts. $2^{\circ}$ e $3^{\circ}$ da Lei $n^{\circ} 10.637$, de 30 de dezembro de $2002^{\prime \prime}$. 
Outra incidência tributária brasileira que estaria abrangida pelo alcance do artigo III do Acordo Geral seria a Contribuição de Intervenção no Domínio Econômico incidente sobre a importação e a comercialização de petróleo e seus derivados, gás natural e seus derivados, e álcool etílico combustível (Cide), instituída pela Lei no 10.336, de 19 de dezembro de 2001, com as alterações da Lei n 10.866, de 4 de maio de 2004.

Como tal tributo também possui as características acima identificadas, já que o art. $3^{\circ}$ de sua lei instituidora menciona que a "Cide tem como fatos geradores as operações, realizadas pelos contribuintes referidos no art. $2^{\circ}$, de importação e de comercialização no mercado interno" dos combustíveis que relaciona, tem-se que se verifica a plena subsunção da incidência à disciplina convencional, pela definição da incidência não só às operações no mercado interno, como também pela extensão também às decorrentes das operações de importação. 


\section{DO PRINCÍPIO DE NÃO-DISCRIMINAÇÃO NA EXPERIÊNCIA DOS ESTADOS UNIDOS DA AMÉRICA.}

\subsection{Do Federalismo Constitucional norteamericano.}

\subsubsection{Do Histórico.}

Para que o leitor, precipuamente alguém familiarizado com o sistema de direito codificado, especialmente no que tange à estrutura fundamental do Estado, possa entender adequadamente como funciona o sistema de prevenção à discriminação em matéria tributária nos Estados Unidos da América, antes é necessária uma pequena incursão material e histórica tanto quanto às circunstâncias que cercaram o nascimento da questão quanto aos poderes centrais e regionais em matéria de comércio e, particularmente, do poder de tributar.

Como bem nos ensina Dan Coenen (2004, p. 1), no coração da identidade do cidadão norteamericano repousa a ideia de que "nós, o povo" ${ }^{440}$ logrou se organizar sob uma forma de governo, originalmente inspirada e unicamente efetiva, estabelecida pela Constituição dos Estados Unidos, assim por como suas emendas. Tal diploma constitucional, extremamente conciso na comparação com seus semelhantes de inspiração romanogermânica, se por um lado reflete inequivocamente preocupações com questões que fazem parte da história daquele povo, como a centralidade da dignidade da pessoa humana; a necessidade de igualdade de tratamento pela lei, sem discriminação por gênero, raça, origem nacional ou qualquer outra; os valores da liberdade individual e da autodeterminação coletiva; ou um sistema de separação de poderes por meio de um sistema de freios e contrapesos ("checks and balances") que visa a atenuar a concentração de poder nas suas estruturas fundamentais, com o fim de evitar o abuso no seu exercício; por outro lado, pode-se afirmar sem qualquer medo de errar que a adequada divisão de poderes

\footnotetext{
440 Como especial referência aos termos com que se inicia o preâmbulo do texto constitucional norteamericano: "We the People of the United States, in Order to form a more perfect Union, establish Justice, insure domestic Tranquility, provide for the common defence, promote the general Welfare, and secure the Blessings of Liberty to ourselves and our Posterity, do ordain and establish this Constitution for the United States of America".
} 
entre o governo federal e os dos estados foi o principal foco das pioneiras discussões constitucionais no país.

Já em novembro de 1777, pouco mais de um ano após Richard Henry Lee, representante do estado da Virginia, em junho de 1776, ter apresentado, durante o Segundo Congresso Continental ("Second Continental Congress"), a moção conclamando as demais doze colônias a declararem a independência em relação ao Império Britânico, documento aprovado em 2 de julho do mesmo ano, e que gerou a Declaração de Independência, breves dois dias após, já quando da ocasião da redação do primeiro diploma constitucional, o "Articles of Confederation", assim como da concepção do que viria a ser o Congresso da Confederação (“Congress of the Confederation”), primeiro órgão deliberativo governamental da União, unicameral e paritário, que existiu concretamente entre março de 1781 e março de 1789, os fundadores da nação depararamse com a relevante questão de como proceder-se-ia ao suprimento de fundos para o órgão, já que o nascente poder confederado não estava ainda investido do poder de tributar. Tratava-se de um desafio à própria confiança daqueles que estavam erigindo a nova nação, já que construir-se a vitória sobre um governo centralizador colonial por meio da instituição de algo a ele semelhante era hipótese que inicialmente teria que enfrentar uma plêiade de restrições.

Essa preocupação com um Estado centralizador, ensina R. B. Bernstein (2002, p. 10), ganhava relevo no aspecto fiscal, já que a guerra revolucionária havia sido em muito motivada por insurreições contra os abusos exacionais britânicos, como a "Boston Tea Party" de 1773. Por outro lado, a ideia de atribuir o poder de tributar unicamente aos estados-membros e repassar parte da arrecadação à União em repartição com base no valor das terras em cada estado não parecia a muitos ser conveniente.

Os primeiros anos de construção da nova república no Novo Mundo foram tomados por esse dilema entre viabilizar um novo estado confederado e preservar os poderes das treze colônias, àquela altura já convertidas em estados-membros, que se reuniram para o formar.

Assim decorreram os primeiros anos do novo país. Não obstante, os problemas decorrentes desse dilema foram se acentuando no curso da década de 1780. Em 1785, na Mount Vernon Conference, já havia ficado claro que o diploma que ainda regia a então Confederação, o "Articles of Confederation" não era suficiente para dirimir conflitos federativos relevantes que se acumulavam à época, especialmente em matéria de comércio, pesca e navegação ao longo dos rios Potomac e Pocomoke e na Baía Chesapeake, 
especialmente entre os estados da Virginia e de Maryland. É de se ressaltar também o desconforto dos estados com a instituição, pelo estado de Rhode Island, de um pedágio para os veículos e pessoas que trafegassem pela Boston Post Road, um feixe de estradas que ligava os maiores centros urbanos da época, New York, no estado de mesma denominação, e Boston, em Massachusets.

Comentando acerca do clima da época, o então presidente James Monroe, em 4 de maio de 1822, em seu magnífico discurso à Camara dos Representantes, que passou para a história como "Special Message to the House of Representatives Containing the Views of the President of the United States on the Subject of Internal Improvements" ${ }^{441}$, ao mencionar sua impressão de como se deveria tratar o Parágrafo 8 do Artigo $\mathrm{I}^{442}$ da Constituição norteamericana, abordou de forma lapidar a maneira como o poder de tributar, conferido aos estados, poderia ter o potencial até de destruir a federação, o que estaria acontecendo àquela altura dos acontecimentos ${ }^{443}$.

Nesse cenário, foi convocada a Philadelphia Convention, a convenção constitucional dos Estados Unidos da América, que veio a ser realizada de 25 de maio a 17

${ }^{441}$ Disponível em http://www.presidency.ucsb.edu/ws/index.php?pid=66323. Acesso em 30/12/2010.
${ }_{442}$ Article I. Section 8, no original em inglês. Doravante se adotará essa tradução, do termo em inglês
"Section" para a palavra em português "parágrafo".
443 "If we recur to the causes which produced the adoption of this Constitution, we shall find that injuries
resulting from the regulation of trade by the States respectively and the advantages anticipated from the
transfer of the power to Congress were among those which had the most weight. Instead of acting as a nation
in regard to foreign powers, the States individually had commenced a system of restraint on each other
whereby the interests of foreign powers were promoted at their expense. If one State imposed high duties on
the goods or vessels of a foreign power to countervail the regulations of such power, the next adjoining States
imposed lighter duties to invite those articles into their ports, that they might be transferred thence into the
other States, securing the duties to themselves. This contracted policy in some of the States was soon
counteracted by others. Restraints were immediately laid on such commerce by the suffering States, and thus
had grown up a state of affairs disorderly and unnatural, the tendency of which was to destroy the Union
itself and with it all hope of realizing those blessings which we had anticipated from the glorious Revolution
which had been so recently achieved. From this deplorable dilemma, or, rather, certain ruin, we were happily
rescued by the adoption of the Constitution. (...)

The last part of this grant, which provides that all duties, imposts, and excises shall be uniform throughout the United States, furnishes another strong proof that it was not intended that the second part should constitute a distinct grant in the sense above stated, or convey any other right than that of appropriation. This provision operates exclusively on the power granted in the first part of the clause. It recites three branches of that power--duties, imposts, and excises--those only on which it could operate, the rule by which the fourth-that is, taxes--should be laid being already provided for in another part of the Constitution. The object of this provision is to secure a just equality among the States in the exercise of that power by Congress. By placing it after both the grants--that is, after that to raise and that to appropriate the public money--and making it apply to the first only it shows that it was not intended that the power granted in the second should be paramount to and destroy that granted in the first. It shows also that no such formidable power as that suggested had been granted in the second, or any power against the abuse of which it was thought necessary specially to provide. Surely if it was deemed proper to guard a specific power of limited extent and wellknown import against injustice and abuse, it would have been much more so to have guarded against the abuse of a power of such vast extent and so indefinite as would have been granted by the second part of the clause if considered as a distinct and original grant (...)". 
de setembro de 1787, com o fim precípuo de resolver os problemas decorrentes da sensação então generalizada de que o governo central não tinha poderes para interferir nas políticas dos estados que se referissem ao poder de regular o comércio interestadual e o internacional.

Embora o pretexto para a sua convocação fosse a ideia de resolver os problemas do diploma instituidor da Confederação, por meio da revisão de seus artigos que tratassem principalmente do comércio interestadual, alguns dos líderes de então, especialmente James Madison e Alexander Hamilton, visavam realmente propor uma nova forma de governo para a nação que se formava. Por esse motivo, acabou por se constituir em um dos eventos mais relevantes da história política não só dos Estados Unidos da América, mas de toda a cultura ocidental republicana.

Quando de sua instalação, diversos planos foram apresentados ao seu presidente, George Washington, e aos demais presentes, como base da redação para o que seria o resultado da convenção, a promulgação da Constituição dos Estados Unidos da América. Entre esses planos, havia o elaborado por Alexander Hamilton, que propunha o fim do caráter autônomo dos estados-membros, afastado de plano pelos demais presentes, por erigir um estado demasiado semelhante ao britânico.

Em relação aos demais, as preferências se dividiram, como nos relata R. B. Bernstein (2002, p. 13 - 22). Entre os estados mais populosos, especialmente, prevalecia o apoio ao plano apresentado pela Virginia, liderada por James Madison, que propunha um Poder Legislativo bicameral inteiramente baseado na proporcionalidade populacional, atribuindo-se à Câmara Alta o poder de eleger indiretamente o chefe do Poder Executivo, investido do poder de tributar e de supremacia sobre o poder dos estados. Os estados menos populosos a ele se contrapunham, fechando fileira em torno da proposta de New Jersey, apresentada por William Patterson, que visava a preservar o Congress of the Confederation, com representação paritária entre os estados, apenas reforçando os poderes confederados, como o poder de tributar e o de regular o comércio entre os estados, prevendo a supremacia da legislação federal sobre a estadual.

Como solução de compromisso entre as propostas dos estados maiores e populosos e a dos menores e menos habitados, chegou-se ao The Connecticut Compromise, elaborado por Roger Sherman, representante do estado que nomeou o compromisso, que, misturando as duas propostas, sugeria a formação de um Poder Legislativo bicameral, no qual a Câmara Baixa teria seus representantes sufragados em proporção ao respectivo número de habitantes livres de cada estado, ao passo que, na Câmara Alta, a ser 
denominado Senado, cada estado teria, como no Congress of the Confederation, apenas um voto, jamais mais do que um, independentemente da contagem de sua população. Não é necessário nem ressaltar que essa proposta vencedora é a base hoje de diversos sistemas legislativos federais, mormente o brasileiro.

No que tange ao que interessa ao presente trabalho, quanto ao poder de tributar e de regular o comércio interestadual e internacional, atribuiu-se expressamente, na cabeça do Parágrafo 8 do Artigo I, ao Congresso Nacional, o poder de instituir e arrecadar impostos e encargos assemelhados, com o fim de fazer frente a despesas federais, como a defesa nacional e o bem-estar geral dos Estados Unidos, desde que sejam uniformes em todo o território nacional. Ao mesmo tempo, na Cláusula 3 do mesmo Parágrafo, também de forma literal, previu-se o poder outorgado ao legislativo federal de regular o comércio internacional, entre estados e em relação às tribos indígenas ${ }^{444}$.

Parece claro que as soluções da então nova carta constitucional não alcançaram absoluto consenso. Não apenas o estado de Rhode Island já não havia mandado representantes, com receio de perder sua fonte de renda acima mencionada, mas divergências quanto a assuntos de relevância, como a manutenção da escravidão, ponto considerado fora de discussão pelos estados do Sul, como Georgia e Carolina do Sul, fizeram com que estadistas comprometidos com os direitos humanos, como George Mason IV e Edmund Randolph da Virginia, e Elbridge Thomas Gerry, de Massachusets, viessem a se recusar a assinar o documento final.

Um dos mais importantes e influentes founding fathers, Thomas Jefferson, não participou da Philadelphia Convention, já que à época exercia o cargo de embaixador da nova nação na França. Possivelmente, se tivesse participado, a história hoje contada seria outra. O fato é que Thomas Jefferson sempre foi um dos mais combatentes defensores da manutenção e do fortalecimento dos poderes dos estados-membros. Assim, o que se viu, após a promulgação da Constituição dos Estados Unidos da América, no plano de sua interpretação, inclusive pela Suprema Corte, assunto que nos interessa em particular, dado o escopo da análise que aqui se pretende empreender, foi a recorrente controvérsia entre os

\footnotetext{
444 "Section 8 - Powers of Congress

The Congress shall have Power to lay and collect Taxes, Duties, Imposts and Excises, to pay the Debts and provide for the common Defence and general Welfare of the United States; but all Duties, Imposts and Excises shall be uniform throughout the United States;

To borrow money on the credit of the United States;

To regulate Commerce with foreign Nations, and among the several States, and with the Indian Tribes; $(\ldots)$ "
} 
Hamiltonianos, advogados de maiores poderes para a autoridade central, e os Jeffersonianos, tendentes a preservar os poderes descentralizados.

Ainda na fase de amadurecimento do novo sistema de governo, merece destaque a promulgação, em 1798, de quatro leis federais (conhecidas como "The Alien and Sedition Acts" ${ }^{\wedge 45}$ ) que, sob o pretexto de proteger o governo da União de uma iminente guerra naval contra a França, à época governada pelo "Directoire Exécutif” revolucionário, antes aliada nas batalhas pela independência, restringia bruscamente liberdades individuais.

Tal questão constituiu o principal mote eleitoral nas eleições presidenciais de 1800, entre o então Vice-presidente, Thomas Jefferson, da Virginia, à frente da oposição Republicana, e o presidente Federalista pleiteando a reeleição, John Adams, de Massachusets. Tal era o desacordo entre os dois detentores maiores do Poder Executivo, no mandato de 1796 a 1800, que Thomas Jefferson, diante dos atos de 1798 acima mencionados, liderou, em 1799, a prolação da "Virginia Resolution", declaração formal do governo desse estado de que não obedeceria às quatro leis por entendê-las inconstitucionais, motivo pelo qual não seriam eficazes no seu território. Com a vitória de Jefferson, recrudesceram os movimentos centrífugos, o que, durante o curso do Século XIX, especialmente diante dos movimentos abolicionistas no Nordeste do país, veio a ser o barril de pólvora sobre o qual eclodiu a Guerra Civil americana.

Portanto, o surgimento e as discussões em torno da The Commerce Clause merecem ser vistas à luz de todo esse pano de fundo institucional e histórico. Como explica Coenen (2004, p. 3), com o advento da Revolução Industrial, as economias das diferentes regiões necessitaram se integrar mais, ao mesmo tempo em que o governo central precisou se preocupar com a proteção dos trabalhadores, a regulação das transações comerciais e com o bem-estar da população. Assim, a conformação de todo o constitucionalismo norteamericano e até toda a história da nação americana propriamente dita e, dentro dessa

445 São elas: a "The Naturalization Act" (oficialmente, "An Act to Establish a Uniform Rule of Naturalization") que estendia o prazo de residência necessário aos estrangeiros para requerer a cidadania Americana, de 5 para 14 anos; a "The Alien Friends Act" (oficialmente, "An Act Concerning Aliens"), que autorizava o Presidente, por dois anos, a deportar qualquer residente estrangeiro considerado "perigoso à paz e à segurança dos Estados Unidos"; a "The Alien Enemies Act" (oficialmente, "An Act Respecting Alien Enemies"), que autorizava o Presidente a deter e a deportar residentes estrangeiros se os seus países de origem estivessem em guerra contra os Estados Unidos - norma, por sinal, em vigor até os dias de hoje e que foi muito utilizada contra japoneses e alemães na Segunda Guerra Mundial; e a "The Sedition Act" (oficialmente, "An Act for the Punishment of Certain Crimes against the United States"), que tipificava como crime, até 1801, publicar afirmações falsas, escandalosas ou maliciosas contra o governo da União ou seus agentes públicos. 
realidade, precipuamente e mais claramente, a história da The Commerce Clause, pode ser escrita à luz dos conflitos entre o poder federal e os poderes locais.

\subsubsection{Da doutrina dos poderes enumerados e da sua superação.}

Durante a Philadelphia Convention, de 1787, como já vimos, uma das decisões mais importantes lá tomadas foi a de que conferir-se-ia ao poder federal a autoridade para agir em torno dos interesses gerais da nação nas hipóteses em que ou os estados isoladamente mostravam-se incompetentes ou impotentes, ou que eventuais interesses discordantes poderiam comprometer a harmonia da federação. No entanto, no momento em que se delegou o poder a um comitê, o "Committee of Detail", para dar uma redação ao projeto de texto constitucional, como relata um dos seus componentes, James Wilson, da Pennsylvania, com vistas e remover dificuldades interpretativas, optou-se por substituir tais princípios genericamente enunciados por uma enumeração exaustiva dos poderes conferidos ao poder central, ainda que se admita alguma interpretação ampliativa dos seus comandos ${ }^{446}$. A isso, a que se soma a redação da Décima Emenda ${ }^{447}$ ("Powers of the States and People"), de 15 de dezembro de 1791, ao texto constitucional, que confere aos estados as competências não delegadas constitucionalmente, desde que não proibidas, denomina-se doutrina dos poderes enumerados ("The Doctrine of Enumerated Powers") (ENGDAHL, 1987, p. 7).

James Wilson, na verdade, não empregava o termo "poderes", mas sim expressava o princípio geral relacionado a "objetos de governo", muito mais corretamente

\footnotetext{
446 "They found themselves embarrassed with another, of peculiar delicacy and importance. I mean that of drawing a proper line between the national government and the governments of the several states. It was easy to discover a proper and satisfactory principle on the subject. Whatever object of government is confined, in its operation and effects, within the bounds of a particular state, should be considered as belonging to the government of that state; whatever object of government extends, in its operation or effects, beyond the bounds of a particular state, should be considered as belonging to the government of the United States. But though this principle be sound and satisfactory, its application to particular cases would be accompanied with much difficult, because, in its application, room must be allowed for great discretionary latitude of construction of the principle. In order to lessen or remove the difficulty arising from discretionary construction on this subject, an enumeration of particular instances, in which the application of the principle ought to take place, has been attempted with much industry and care. It is only a mathematical science that a line can be described with mathematical precision. But I flatter myself that, upon the strictest investigation, the enumeration will be found to be safe and unexceptionable, and accurate, too, in as great a degree as accuracy can be expected in a subject of this nature" (grifos não presentes no original) - em Works of The Honourable James Wilson, L. L. D., vol. 2. Disponível em http://www.constitution.org/jwilson/jwilson2.doc. Acesso em 23/12/2010.

447 "The powers not delegated to the United States by the Constitution, nor prohibited by it to the States, are reserved to the States respectively, or to the people".
} 
aplicável. Aliás, o que o enunciado da Décima Emenda quer corretamente dizer, nos explica Erwin Chemerinsky (2006, p. 234), segundo o entendimento atual, é que apenas os estados possuem o Poder de Polícia, considerado como tal a atribuição ao ente estatal de adotar qualquer lei não proibida pelo texto constitucional.

$\mathrm{Na}$ verdade, o mais correto entendimento é o de que a soberania declarada no texto constitucional, e na Décima Emenda em particular, é de titularidade do povo, não de qualquer ente governamental em particular.

Tal questão foi discutida com profundidade no caso Texas v. White ${ }^{448}$. Envolvia um pedido, do governo de reconstrução do estado do Texas, ao fim da Guerra Civil, de decretação de nulidade das vendas de títulos públicos federais (United States bonds) realizadas pelo governo confederado derrotado. A Suprema Corte entendeu que, mesmo que o Texas tenha aderido aos Confederate States of America, ainda assim não teria havido a sua secessão da União sob o poder militar, cujos atos, por conta dessa realidade, não deveriam ter efeito jurídico algum.

Porém, o importante da decisão deveu-se à explicitação do que a Suprema Corte entendeu como sendo o sentido constitucional que deve dar ao conceito de estadomembro, não como um ente político organizado, mas antes como um conjunto de pessoas ou uma comunidade, não necessariamente unidos sob um governo, mas de alguma forma relacionados politicamente ${ }^{449}$. Assim, todos os poderes do Estado, tanto o nacional quanto o regional, são delegados pelo povo, alguns necessariamente de forma expressa, outros facultativamente, de maneira implícita.

Mas nem sempre foi esse o entendimento predominante. Assim, como afirma David Engdahl (1987, p. 9 - 10), a doutrina dos poderes enumerados pode ser entendida como o ponto inicial da compreensão do federalismo norteamericano na medida em que o seu conteúdo mais apropriado é entender que o governo federal não possui nenhum poder

\footnotetext{
44874 U.S. 700 (1869).

449 "Some not unimportant aid, however, in ascertaining the true sense of the Constitution, may, be derived from considering what is the correct idea of a State, apart from any union or confederation with other States. The poverty of language often compels the employment of terms in quite different significations; and of this hardly any example more signal is to be found than in the use of the word we are now considering. It would serve no useful purpose to attempt an enumeration of all the various senses in which it is used. A few only need be noticed.

It describes sometimes a people or community of individuals united more or less closely in political relations, inhabiting temporarily or permanently the same country; often it denotes only the country or territorial region, inhabited by such a community; not unfrequently it is applied to the government under which the people live; at other times it represents the combined idea of people, territory, and government.

It is not difficult to see that in all these senses the primary conception is that of a people or community. The people, in whatever territory dwelling, either temporarily or permanently, and whether organized under a regular government, or united by looser and less definite relations, constitute the state". 74 U.S. 700,720 (1869).
} 
inerente ou intrínseco, uma vez que o repositório da competência geral em matéria legislativa são os estados. Pelo que majoritariamente entendem os constitucionalistas americanos, como Dan T. Coenen (2004, p. 11), a opção pela doutrina dos poderes enumerados foi a adotada pelos framers do texto constitucional originário, o que foi ainda reforçado posteriormente pelo advento da Décima Emenda.

Em verdade, o escopo do poder legislativo federal não veio a ficar realmente estabelecido senão com o julgamento, em 1819, do caso McCulloch v. Maryland ${ }^{450}$. Com o seu advento, o que aconteceu, na prática, foi que a doutrina dos poderes enumerados sofreu seu grande revés, panorama que perdurou até 1995, ocasião em que se deu a recente revirada conservadora, patrocinada por membros da Suprema Corte nomeados pelos presidentes republicanos, como William H. Rehnquist e Antonin Scalia (por Ronald Reagan) e Clarence Thomas (por George H. Bush) ${ }^{451}$.

O caso de 1819 trata da controvérsia sobre se o estado de Maryland poderia arrecadar um tributo incidente sobre transações realizadas por um banco federal, o The Second Bank of the United States, mediante uma cobrança de um valor fixo anual de US\$ 15.000,00 ou, alternativamente, uma alíquota de 2 por cento do valor de face de todos os papeis transacionados. James McCulloch, que exercia o cargo de tesoureiro da filial de Baltimore, Maryland, do banco federal, recusou-se a adimplir a obrigação tributária estadual, com o que se instaurou o litígio.

Em verdade, a própria criação de um banco estatal federal, ainda o The First Bank of the United States, já havia sido motivo, trinta anos antes, em 1790, durante ainda a fase inicial de consolidação do sistema constitucional a que nos referimos, de uma acesa controvérsia. Idealizada por Alexander Hamilton, na condição de então Secretário do Tesouro, a instituição do banco enfrentou ferrenha oposição tanto de Thomas Jefferson, então Secretário de Estado, quanto de Edmund Randolph, procurador-geral da União, que

${ }^{450} 17$ U.S. 316 (1819).

${ }^{451} \mathrm{O}$ caso mais evidente dessa fase, e o primeiro deles, foi United States v. Lopez (514 U.S. 549, de 1995). O caso trata do fato de que Alfonzo Lopez, um estudante do $12^{\circ}$ ano do ensino médio, foi acusado por agentes federais, de estar violando o "Gun-Free School Zones Act" de 1990, 18 U.S.C. 922, uma vez que foi pego carregando uma arma de fogo dentro da escola onde estudava, em San Antonio, Texas. Na medida em que a norma federal proibia o porte de armas em região sabidamente próxima a zonas escolares, o estudante foi condenado pela corte federal do Texas às penas cominadas ao crime que teria cometido, seis meses de prisão. A questão a ser resolvida pela Suprema Corte Americana repousava em saber se a norma federal, ao proibir indivíduos de portar armas em zonas escolares, seria inconstitucional, por extrapolar os poderes do Congresso Nacional em legislar sob a "The Commerce Clause"? A decisão, apertada, por 5 votos contra 4, determinou a inconstitucionalidade da lei federal, sob o argumento que o porte de armas não consiste em uma atividade econômica que, mesmo repetitivamente, não possuía o condão de produzir um efeito substancial no comércio interestadual. A lei então seria uma norma criminal de influência meramente local, sem relação com o comércio ou qualquer atividade econômica; de competência do legislativo estadual, portanto. 
arguiam a inconstitucionalidade da iniciativa, por falta de poderes expressos no texto constitucional. Embora os esforços de Hamilton tenham logrado convencer ao Presidente George Washington, ainda assim recebeu ferrenha oposição no Congresso, especialmente de James Madison, liderando a oposição republicana, como sempre em divergência em relação a Hamilton. Por conta de todos esses fatores, o fato é que a vida da instituição financeira durante esse período foi atribulada, só resistindo em função da maioria folgada que os federalistas desfrutavam no Congresso. Assim permaneceu até a expiração da carta patente do banco original, em 1811.

Com o advento de uma séria crise econômica, especialmente oriunda dos esforços financeiros necessários à sustentação da guerra de 1812 contra o Império Britânico, cuja motivação deu-se fundamentalmente por conta do embargo econômico imposto pelos britânicos aos americanos em relação ao seu comércio com a França, assim como pela posse dos territórios do noroeste (equivalentes à hoje conhecida como Região dos Grandes Lagos), o banco nacional estatal foi recriado em 1816, agora denominado de segundo e endossado pelo presidente de então, o mesmo James Madison que contra a criação de sua primeira versão havia sido ferrenho opositor.

Não obstante, sua criação não logrou resolver a crise econômica àquela altura instalada. Pelo contrário, atribuiu-se à política monetária por ele estabelecida a responsabilidade pelo agravamento da situação. Com isso, a sua instituição acabou sofrendo represálias de diversos estados, muitos deles limitando seus poderes. Entre eles, o de Maryland, um dos mais agressivos, preferiu a via da tributação de grande vulto.

Na oportunidade, o Chief Justice John Marshall proferiu voto antológico, seguido unanimemente pelos demais seis membros da Corte, dando ganho de causa ao recorrente, em detrimento do estado de Maryland. Nele, duas questões fundamentais foram respondidas: o Congresso possui a autoridade para criar o banco? E a lei estadual de Maryland pode interferir nos poderes do Congresso pela via, por exemplo, da cobrança de um tributo?

Comentando esse voto, Erwin Chemerinsky (2006, p. 237) nos ensina que é interessante perceber que Marshall poderia ter se atido a somente responder à primeira indagação, do ponto de vista estritamente técnico referente ao objeto do que havia sido deduzido em juízo; ou seja, a constitucionalidade ou não do tributo. No entanto, ao que se pode compreender do ocorrido, a atenção dada à questão preliminar pode ser vista como uma intenção do magistrado em aproveitar a oportunidade para articular de forma definitiva e histórica uma nova concepção do poder legislativo federal, rompendo o 
entendimento conservador da doutrina dos poderes enumerados, desfazendo o paradigma advindo da concepção originariamente formulada pelos framers da Constituição, assim como fez no caso Marbury v. Madison, muito estudado no Brasil, a respeito do controle judicial de constitucionalidade das leis (ou "power of judicial review").

Em resposta à primeira questão, sobre se o legislativo federal possuía a autoridade de criar um banco nacional, Marshall, na visão de Chemerinsky, erigiu seu voto em cima de quatro argumentos.

O primeiro se baseou na própria história do Bank of the United States para construir a ideia de que haveria um precedente importante repousando em todos os debates legislativos que foram travados quase trinta anos antes, e que teria sido aceito por sucessivas legislaturas sem maiores contestações ${ }^{452}$. Reconhecendo que a questão sofreu aguerrida oposição então, afirma que a necessidade da prolação da norma e, consequentemente, da sua aplicação, revelou-se proeminente ${ }^{453}$.

Há que se concordar, quanto a essa primeira ponderação, com a visão de Erwin Chemerinsky (2006, p. 238). Embora a Suprema Corte posteriormente tivesse empregado raciocínios baseados em experiências costumeiras históricas, como em United States $v$. Midwest Oil Co., de $1915^{454}$, ou em Youngstown Sheet \& Tube Co. v. Sawyer, de 1952 $2^{455}$, não há como se atribuir relevância normativa, especialmente em se tratando do exame de constitucionalidade de norma federal, a uma prática costumeira ou aos debates e circunstâncias históricas que cercaram sua criação e implementação, especialmente se em

452 "The first question made in the cause is - has Congress power to incorporate a bank? It has been truly said that this can scarcely be considered as an open question entirely unprejudiced by the former proceedings of the Nation respecting it. The principle now contested was introduced at a very early period of our history, has been recognised by many successive legislatures, and has been acted upon by the Judicial Department, in cases of peculiar delicacy, as a law of undoubted obligation" (17 US 401).

453 "It will not be denied that a bold and daring usurpation might be resisted after an acquiescence still longer and more complete than this. But it is conceived that a doubtful question, one on which human reason may pause and the human judgment be suspended, in the decision of which the great principles of liberty are not concerned, but the respective powers of those who are equally the representatives of the people, are to be adjusted, if not put at rest by the practice of the Government, ought to receive a considerable impression from that practice. An exposition of the Constitution, deliberately established by legislative acts, on the faith of which an immense property has been advanced, ought not to be lightly disregarded.

The power now contested was exercised by the first Congress elected under the present Constitution.

The bill for incorporating the Bank of the United States did not steal upon an unsuspecting legislature and pass unobserved. Its principle was completely understood, and was opposed with equal zeal and ability. After being resisted first in the fair and open field of debate, and afterwards in the executive cabinet, with as much persevering talent as any measure has ever experienced, and being supported by arguments which convinced minds as pure and as intelligent as this country can boast, it became a law. The original act was permitted to expire, but a short experience of the embarrassments to which the refusal to revive it exposed the Government convinced those who were most prejudiced against the measure of its necessity, and induced the passage of the present law" (17 U. S. $401-402)$.

454236 U.S. 459 (1915).

455343 U.S. 579 (1952). 
nenhum momento, nem nos debates legislativos, nem diante do Poder Judiciário, essa questão, acerca da constitucionalidade, havia sido aventada.

A segunda questão enfrentada por Marshall refere-se à titularidade da soberania que a Constituição de 17 de setembro de 1787 reconhecia, se conferida aos doze estados que a lavraram e ratificaram, ou ao povo, que o delegou aos representantes que a assinaram. Após enunciar o entendimento do estado de Maryland, no sentido de que a soberania pertencia aos estados, e que o poder do governo central seria meramente delegado e subordinado ${ }^{456}$, afirma que tal raciocínio restaria equivocado, pois o poder soberano emanaria do povo, sendo que os estados celebrantes da Constituição, em 1787, seriam apenas os veículos de reunião dos representantes populares em convenção, um mero modo de proceder, uma vez que a palavra final, pela adoção ou não do texto constitucional, coube e sempre caberá ao povo ${ }^{457}$, com o que termina por concluir que, em qualquer caso, o governo da União, verdadeira e enfáticamente, é um governo do povo, a ser exercido diretamente para ele e em seu benefício ${ }^{458}$.

Comentando a fundamentação, novamente Chemerinsky (2006, p. 239) questiona a fundamentação de Marshall. Ocorre que a Constituição, em função de seu

456 "In discussing this question, the counsel for the State of Maryland have deemed it of some importance, in the construction of the Constitution, to consider that instrument not as emanating from the people, but as the act of sovereign and independent States. The powers of the General Government, it has been said, are delegated by the States, who alone are truly sovereign, and must be exercised in subordination to the States, who alone possess supreme dominion" (17 U. S. 402).

457 "It would be difficult to sustain this proposition. The convention which framed the Constitution was indeed elected by the State legislatures. But the instrument, when it came from their hands, was a mere proposal, without obligation or pretensions to it. It was reported to the then existing Congress of the United States with a request that it might

"be submitted to a convention of delegates, chosen in each State by the people thereof, under the recommendation of its legislature, for their assent and ratification."

This mode of proceeding was adopted, and by the convention, by Congress, and by the State legislatures, the instrument was submitted to the people. They acted upon it in the only manner in which they can act safely, effectively and wisely, on such a subject -- by assembling in convention. It is true, they assembled in their several States -- and where else should they have assembled? No political dreamer was ever wild enough to think of breaking down the lines which separate the States, and of compounding the American people into one common mass. Of consequence, when they act, they act in their States. But the measures they adopt do not, on that account, cease to be the measures of the people themselves, or become the measures of the State governments.

From these conventions the Constitution derives its whole authority. The government proceeds directly from the people; is "ordained and established" in the name of the people, and is declared to be ordained,

"in order to form a more perfect union, establish justice, insure domestic tranquillity, and secure the blessings of liberty to themselves and to their posterity."

The assent of the States in their sovereign capacity is implied in calling a convention, and thus submitting that instrument to the people. But the people were at perfect liberty to accept or reject it, and their act was final. It required not the affirmance, and could not be negatived, by the State Governments. The Constitution, when thus adopted, was of complete obligation, and bound the State sovereignties" (17 U. S. 403 - 404).

458 "The Government of the Union then (whatever may be the influence of this fact on the case) is, emphatically and truly, a Government of the people. In form and in substance, it emanates from them. Its powers are granted by them, and are to be exercised directly on them, and for their benefit" (17 U. S. 404 405). 
artigo VII, que trata do processo de sua ratificação, apenas exige, para sua entrada em vigor, da anuência de nove estados, sem a exigência de qualquer procedimento plebiscitário do qual participasse o povo dos estados envolvidos ${ }^{459}$. Ao que nos parece, em realidade, pelo texto constitucional, os estados não seriam apenas veículos de transmissão do poder soberano popular, mas efetivos agentes do processo.

Foi apenas quando do emprego do seu terceiro fundamento argumentativo que Marshall tocou na questão dos poderes dos estados federados em relação aos da União. Inicialmente reconhecendo que a doutrina dos poderes enumerados era reconhecida pela grande maioria dos cidadãos, traz a questão a exame ao lembrar que faz parte do próprio sistema apreciar esse tipo de conflito federativo, que tenderia a se perpetuar, mas que seria inconsistente admitir a atuação do governo central na sua esfera própria, como o governo de todos, sem supremacia diante das normatizações regionais ${ }^{460}$. Entrando na questão pontual, acerca do poder de criar um banco estatal federal, Justice Marshall, reconhece que o texto constitucional efetivamente não confere expressamente tais poderes, assim como também não o proíbe, nem tampouco exige expresso e exaustivo rol estabelecido em alguma cláusula textual, nem mesmo na Décima Emenda ${ }^{461}$. Afirma que se a Constituição

459 "Article VII. Ratification. The Ratification of the Conventions of nine States, shall be sufficient for the Establishment of this Constitution between the States so ratifying the Same".

460 "This Government is acknowledged by all to be one of enumerated powers. The principle that it can exercise only the powers granted to it would seem too apparent to have required to be enforced by all those arguments which its enlightened friends, while it was depending before the people, found it necessary to urge; that principle is now universally admitted. But the question respecting the extent of the powers actually granted is perpetually arising, and will probably continue to arise so long as our system shall exist. In discussing these questions, the conflicting powers of the General and State Governments must be brought into view, and the supremacy of their respective laws, when they are in opposition, must be settled.

If any one proposition could command the universal assent of mankind, we might expect it would be this -that the Government of the Union, though limited in its powers, is supreme within its sphere of action. This would seem to result necessarily from its nature. It is the Government of all; its powers are delegated by all; it represents all, and acts for all. Though any one State may be willing to control its operations, no State is willing to allow others to control them. The nation, on those subjects on which it can act, must necessarily bind its component parts. But this question is not left to mere reason; the people have, in express terms, decided it by saying,

"this Constitution, and the laws of the United States, which shall be made in pursuance thereof," "shall be the supreme law of the land," and by requiring that the members of the State legislatures and the officers of the executive and judicial departments of the States shall take the oath of fidelity to it. The Government of the United States, then, though limited in its powers, is supreme, and its laws, when made in pursuance of the Constitution, form the supreme law of the land, "anything in the Constitution or laws of any State to the contrary notwithstanding." (17 U. S. 405 - 406)".

461 "Among the enumerated powers, we do not find that of establishing a bank or creating a corporation. But there is no phrase in the instrument which, like the Articles of Confederation, excludes incidental or implied powers and which requires that everything granted shall be expressly and minutely described. Even the 10th Amendment, which was framed for the purpose of quieting the excessive jealousies which had been excited, omits the word "expressly," and declares only that the powers "not delegated to the United States, nor prohibited to the States, are reserved to the States or to the people," thus leaving the question whether the particular power which may become the subject of contest has been delegated to the one Government, or prohibited to the other, to depend on a fair construction of the whole instrument. The men who drew and 
assim o fizesse ou exigisse, seu texto seria por demais prolixo e demandaria um poder legisferante tão minucioso que nenhuma inteligência humana poderia ter a habilidade de exercê-lo adequadamente. Afinal de contas, afirma, em frase que se tornou célebre, é da constituição que então estava se tratando, não de um texto legal ordinário ${ }^{462}$.

Comentando essa frase, retirada da fundamentação do voto de John Marshall no caso McCulloch v. Maryland, mas aplicável a todo o direito em geral e ao constitucional em particular, outro membro da Suprema Corte americana, o Justice Felix Frankfurter (1955, p. 219) a descreveu como o mais importante enunciado na literatura do direito constitucional, por ser a mais abrangente e a mais didática, fazendo um trocadilho na língua inglesa ${ }^{463}$.

Trata-se, na verdade, de uma frase, embora simplória, que inaugurou toda uma abordagem diferenciada na interpretação constitucional norteamericana. Em verdade, toda a conclusão de John Marshall revestiu-se de caráter revolucionário em relação à doutrina dos poderes enumerados, que então predominava. Como afirma com propriedade Erwin Chemerinsky (2006, p. 240), sem essa formulação de Marshall seria impossível poder viver-se no Século XXI sob a regência de um texto constitucional do Século XVIII, como efetivamente se faz nos Estados Unidos, com tantas alterações nos costumes e no modo de viver, sem uma infinidade de emendas ao texto constitucional.

Em verdade, a formulação magistral de John Marshall nesse ponto acima descrito serve como introdução ao seu último argumento, que tem sido entendido pelos estudiosos do direito constitucional norteamericano como a formulação primeira de um fundamento de argumentação posteriormente diversas vezes empregado pela Suprema Corte e que se convencionou chamar "The Necessary and Proper Clause".

adopted this amendment had experienced the embarrassments resulting from the insertion of this word in the Articles of Confederation, and probably omitted it to avoid those embarrassments. A Constitution, to contain an accurate detail of all the subdivisions of which its great powers will admit, and of all the means by which they may be carried into execution, would partake of the prolixity of a legal code, and could scarcely be embraced by the human mind. It would probably never be understood by the public. Its nature, therefore, requires that only its great outlines should be marked, its important objects designated, and the minor ingredients which compose those objects be deduced from the nature of the objects themselves. That this idea was entertained by the framers of the American Constitution is not only to be inferred from the nature of the instrument, but from the language. Why else were some of the limitations found in the 9th section of the 1st article introduced? It is also in some degree warranted by their having omitted to use any restrictive term which might prevent its receiving a fair and just interpretation" (17 U. S. 406 - 407).

462 "In considering this question, then, we must never forget that it is a Constitution we are expounding" (17 U. S. 407).

463 "the single most important utterance in the literature of constitutional law - most important because most comprehensive and most comprehending" In KURLAND, Philip B. (coord.). Felix Frankfurter on the Supreme Court: Extrajudicial Essays on the Court and the Constitution. Cambridge: Harvard University Press, 1970, p. 534. 
Tal cláusula vem prevista expressamente como norma de encerramento da descrição exaustiva dos poderes do congresso federal previstas na norma constitucional do Artigo I, Parágrafo 8 , já mencionada ${ }^{464}$.

Trata-se da concepção de que o legislativo federal pode se valer de todos os meios de execução, desde que não proibidos pela Constituição, para alcançar a máxima efetividade e eficácia dos poderes a ele atribuídos, o que foi por John Marshall exaustivamente esclarecido $^{465}$. Ao final, em parte conclusiva do seu voto no que tange a

464 "Section 8 - Powers of Congress

The Congress shall have Power To lay and collect Taxes, Duties, Imposts and Excises, to pay the Debts and provide for the common Defence and general Welfare of the United States; but all Duties, Imposts and Excises shall be uniform throughout the United States;

To borrow money on the credit of the United States;

To regulate Commerce with foreign Nations, and among the several States, and with the Indian Tribes;

To establish an uniform Rule of Naturalization, and uniform Laws on the subject of Bankruptcies throughout the United States;

To coin Money, regulate the Value thereof, and of foreign Coin, and fix the Standard of Weights and Measures;

To provide for the Punishment of counterfeiting the Securities and current Coin of the United States;

To establish Post Offices and Post Roads;

To promote the Progress of Science and useful Arts, by securing for limited Times to Authors and Inventors the exclusive Right to their respective Writings and Discoveries;

To constitute Tribunals inferior to the supreme Court;

To define and punish Piracies and Felonies committed on the high Seas, and Offenses against the Law of Nations;

To declare War, grant Letters of Marque and Reprisal, and make Rules concerning Captures on Land and Water;

To raise and support Armies, but no Appropriation of Money to that Use shall be for a longer Term than two Years;

To provide and maintain a Navy;

To make Rules for the Government and Regulation of the land and naval Forces;

To provide for calling forth the Militia to execute the Laws of the Union, suppress Insurrections and repel Invasions;

To provide for organizing, arming, and disciplining, the Militia, and for governing such Part of them as may be employed in the Service of the United States, reserving to the States respectively, the Appointment of the Officers, and the Authority of training the Militia according to the discipline prescribed by Congress;

To exercise exclusive Legislation in all Cases whatsoever, over such District (not exceeding ten Miles square) as may, by Cession of particular States, and the acceptance of Congress, become the Seat of the Government of the United States, and to exercise like Authority over all Places purchased by the Consent of the Legislature of the State in which the Same shall be, for the Erection of Forts, Magazines, Arsenals, dockYards, and other needful Buildings; And

To make all Laws which shall be necessary and proper for carrying into Execution the foregoing Powers, and all other Powers vested by this Constitution in the Government of the United States, or in any Department or Officer thereof" (original não grifado).

465 "Although, among the enumerated powers of Government, we do not find the word "bank" or "incorporation," we find the great powers, to lay and collect taxes; to borrow money; to regulate commerce; to declare and conduct a war; and to raise and support armies and navies. The sword and the purse, all the external relations, and no inconsiderable portion of the industry of the nation are intrusted to its Government. It can never be pretended that these vast powers draw after them others of inferior importance merely because they are inferior. Such an idea can never be advanced. But it may with great reason be contended that a Government intrusted with such ample powers, on the due execution of which the happiness and prosperity of the Nation so vitally depends, must also be intrusted with ample means for their execution. The power being given, it is the interest of the Nation to facilitate its execution. It can never be their interest, and cannot be presumed to have been their intention, to clog and embarrass its execution by withholding the most appropriate means. Throughout this vast republic, from the St. Croix to the Gulf of Mexico, from the 
essa questão preliminar, termina por nos ensinar que, sendo a finalidade legitimada, dentro dos objetivos da Constituição, então todos os meios que são apropriados, que são plenamente ajustados a esse fim, que não são vedados, mas que são consistentes com a letra e o espírito da Constituição, são portanto constitucionais ${ }^{466}$.

Embora em certos ordenamentos, e mesmo no constitucionalismo norteamericano, em outros horizontes, como o dos direitos humanos, o termo "necessário" consiste em uma limitação aos poderes congressuais, exigindo que se adote a norma menos onerosa àquele a ela obrigado - no sentido de essencial, indispensável - Marshall dedicouse a afastar esse entendimento quanto à exegese dos poderes congressuais, não só da The Commerce Clause como também dos poderes tributários previstos no Parágrafo 8. Para ele, necessário no contexto do Artigo I, Parágrafo 8 possui o significado de útil ou desejável, em função, novamente, do que entende ser o sentido e a natureza do texto constitucional ${ }^{467}$.

Atlantic to the Pacific, revenue is to be collected and expended, armies are to be marched and supported. The exigencies of the Nation may require that the treasure raised in the north should be transported to the south that raised in the east, conveyed to the west, or that this order should be reversed. Is that construction of the Constitution to be preferred which would render these operations difficult, hazardous and expensive? Can we adopt that construction (unless the words imperiously require it) which would impute to the framers of that instrument, when granting these powers for the public good, the intention of impeding their exercise, by withholding a choice of means? If, indeed, such be the mandate of the Constitution, we have only to obey; but that instrument does not profess to enumerate the means by which the powers it confers may be executed;

nor does it prohibit the creation of a corporation, if the existence of such a being be essential, to the beneficial exercise of those powers. It is, then, the subject of fair inquiry how far such means may be employed.

It is not denied that the powers given to the Government imply the ordinary means of execution. That, for example, of raising revenue and applying it to national purposes is admitted to imply the power of conveying money from place to place as the exigencies of the Nation may require, and of employing the usual means of conveyance. But it is denied that the Government has its choice of means, or that it may employ the most convenient means if, to employ them, it be necessary to erect a corporation. On what foundation does this argument rest? On this alone: the power of creating a corporation is one appertaining to sovereignty, and is not expressly conferred on Congress. This is true. But all legislative powers appertain to sovereignty. The original power of giving the law on any subject whatever is a sovereign power, and if the Government of the Union is restrained from creating a corporation as a means for performing its functions, on the single reason that the creation of a corporation is an act of sovereignty, if the sufficiency of this reason be acknowledged, there would be some difficulty in sustaining the authority of Congress to pass other laws for the accomplishment of the same objects. The Government which has a right to do an act and has imposed on it the duty of performing that act must, according to the dictates of reason, be allowed" (17 U. S. 407 - 409).

466 "We admit, as all must admit, that the powers of the Government are limited, and that its limits are not to be transcended. But we think the sound construction of the Constitution must allow to the national legislature that discretion with respect to the means by which the powers it confers are to be carried into execution which will enable that body to perform the high duties assigned to it in the manner most beneficial to the people. Let the end be legitimate, let it be within the scope of the Constitution, and all means which are appropriate, which are plainly adapted to that end, which are not prohibited, but consist with the letter and spirit of the Constitution, are Constitutional" (17 U. S. 421).

467 "The word "necessary" is considered as controlling the whole sentence, and as limiting the right to pass laws for the execution of the granted powers to such as are indispensable, and without which the power would be nugatory. That it excludes the choice of means, and leaves to Congress in each case that only which is most direct and simple.

Is it true that this is the sense in which the word "necessary" is always used? Does it always import an absolute physical necessity so strong that one thing to which another may be termed necessary cannot exist 
Afinal de contas, afirma, a "necessary and proper clause" veio trazida pelo legislador constitucional na disciplina dos poderes do Congresso, não no parágrafo seguinte (Section $\left.9^{468}\right)$, que corresponde aos respectivos limites, pelo que não pode ser cláusula a ser interpretada de forma restritiva ${ }^{469}$.

without that other? We think it does not. If reference be had to its use in the common affairs of the world or in approved authors, we find that it frequently imports no more than that one thing is convenient, or useful, or essential to another. To employ the means necessary to an end is generally understood as employing any means calculated to produce the end, and not as being confined to those single means without which the end would be entirely unattainable. Such is the character of human language that no word conveys to the mind in all situations one single definite idea, and nothing is more common than to use words in a figurative sense. Almost all compositions contain words which, taken in a their rigorous sense, would convey a meaning different from that which is obviously intended. It is essential to just construction that many words which import something excessive should be understood in a more mitigated sense -- in that sense which common usage justifies. The word "necessary" is of this description. It has not a fixed character peculiar to itself. It admits of all degrees of comparison, and is often connected with other words which increase or diminish the impression the mind receives of the urgency it imports. A thing may be necessary, very necessary, absolutely or indispensably necessary. To no mind would the same idea be conveyed by these several phrases. The comment on the word is well illustrated by the passage cited at the bar from the 10th section of the 1st article of the Constitution. It is, we think, impossible to compare the sentence which prohibits a State from laying "imposts, or duties on imports or exports, except what may be absolutely necessary for executing its inspection laws," with that which authorizes Congress "to make all laws which shall be necessary and proper for carrying into execution" the powers of the General Government without feeling a conviction that the convention understood itself to change materially the meaning of the word "necessary," by prefixing the word "absolutely." This word, then, like others, is used in various senses, and, in its construction, the subject, the context, the intention of the person using them are all to be taken into view" (17 U. S. $413-415)$.

468 "Section 9 - Limits on Congress.

The Migration or Importation of such Persons as any of the States now existing shall think proper to admit, shall not be prohibited by the Congress prior to the Year one thousand eight hundred and eight, but a tax or duty may be imposed on such Importation, not exceeding ten dollars for each Person.

The privilege of the Writ of Habeas Corpus shall not be suspended, unless when in Cases of Rebellion or Invasion the public Safety may require it.

No Bill of Attainder or ex post facto Law shall be passed.

(No capitation, or other direct, Tax shall be laid, unless in Proportion to the Census or Enumeration herein before directed to be taken.) (derrogado pela Décima Sexta Emenda)

No Tax or Duty shall be laid on Articles exported from any State.

No Preference shall be given by any Regulation of Commerce or Revenue to the Ports of one State over those of another: nor shall Vessels bound to, or from, one State, be obliged to enter, clear, or pay Duties in another.

No Money shall be drawn from the Treasury, but in Consequence of Appropriations made by Law; and a regular Statement and Account of the Receipts and Expenditures of all public Money shall be published from time to time.

No Title of Nobility shall be granted by the United States: And no Person holding any Office of Profit or Trust under them, shall, without the Consent of the Congress, accept of any present, Emolument, Office, or Title, of any kind whatever, from any King, Prince or foreign State".

469 "This clause, as construed by the State of Maryland, would abridge, and almost annihilate, this useful and necessary right of the legislature to select its means. That this could not be intended is, we should think, had it not been already controverted, too apparent for controversy.

We think so for the following reasons:

1st. The clause is placed among the powers of Congress, not among the limitations on those powers.

$2 d$. Its terms purport to enlarge, not to diminish, the powers vested in the Government. It purports to be an additional power, not a restriction on those already granted. No reason has been or can be assigned for thus concealing an intention to narrow the discretion of the National Legislature under words which purport to enlarge it. The framers of the Constitution wished its adoption, and well knew that it would be endangered by its strength, not by its weakness. Had they been capable of using language which would convey to the eye one idea and, after deep reflection, impress on the mind another, they would rather have disguised the grant of power than its limitation. If, then, their intention had been, by this clause, to restrain the free use of means 
Como se pode ver, a partir do voto do Chief Justice John Marshall no caso McCulloch v. Maryland, foi rejeitado todo o entendimento anterior que propugnava pela contenção dos poderes congressuais diante dos interesses das unidades regionais. A verdadeira revolução hermenêutica que partiu desse entendimento possui extraordinária relevância no tema fundamental do nosso estudo, como veremos adiante.

Suplantada, portanto, a questão prejudicial, o Chief Justice John Marshall posteriormente enfrentou o ponto principal da lide, a constitucionalidade da exação tributária. Novamente, em atenção a esse tema, foi proferida uma frase lapidar, sempre relembrada quando o assunto é a matéria fiscal: o poder de tributar envolve o poder de destruir $^{470}$, com o que restaria anulado o poder de criar a instituição financeira estatal, já que o poder de criar inclui o poder de preservar sua existência e de viabilizar sua atuação eficaz $^{471}$. Vale dizer, admitir a constitucionalidade do tributo seria permitir que o estado, por meio de seu aparentemente legítimo poder de tributar, inviabilizasse a atuação do ente federal ou até impedisse a existência de órgão por ele instituído.

which might otherwise have been implied, that intention would have been inserted in another place, and would have been expressed in terms resembling these. "In carrying into execution the foregoing powers, and all others," \&c., "no laws shall be passed but such as are necessary and proper." Had the intention been to make this clause restrictive, it would unquestionably have been so in form, as well as in effect.

The result of the most careful and attentive consideration bestowed upon this clause is that, if it does not enlarge, it cannot be construed to restrain, the powers of Congress, or to impair the right of the legislature to exercise its best judgment in the selection of measures to carry into execution the Constitutional powers of the Government. If no other motive for its insertion can be suggested, a sufficient one is found in the desire to remove all doubts respecting the right to legislate on that vast mass of incidental powers which must be involved in the Constitution if that instrument be not a splendid bauble" (17 U. S. 419-421).

470 "That the power to tax involves the power to destroy; that the power to destroy may defeat and render useless the power to create; that there is a plain repugnance in conferring on one Government a power to control the constitutional measures of another, which other, with respect to those very measures, is declared to be supreme over that which exerts the control, are propositions not to be denied" (17 U. S. 431).

471 "This great principle is that the Constitution and the laws made in pursuance thereof are supreme; that they control the Constitution and laws of the respective States, and cannot be controlled by them. From this, which may be almost termed an axiom, other propositions are deduced as corollaries, on the truth or error of which, and on their application to this case, the cause has been supposed to depend. These are, 1st. That a power to create implies a power to preserve; $2 d$. That a power to destroy, if wielded by a different hand, is hostile to, and incompatible with these powers to create and to preserve; $3 d$. That, where this repugnancy exists, that authority which is supreme must control, not yield to that over which it is supreme.

These propositions, as abstract truths, would perhaps never be controverted. Their application to this case, however, has been denied, and both in maintaining the affirmative and the negative, a splendor of eloquence, and strength of argument seldom if ever surpassed have been displayed.

The power of Congress to create and, of course, to continue the bank was the subject of the preceding part of this opinion, and is no longer to be considered as questionable.

That the power of taxing it by the States may be exercised so as to destroy it is too obvious to be denied. But taxation is said to be an absolute power which acknowledges no other limits than those expressly prescribed in the Constitution, and, like sovereign power of every other description, is intrusted to the discretion of those who use it. But the very terms of this argument admit that the sovereignty of the State, in the article of taxation itself, is subordinate to, and may be controlled by, the Constitution of the United States" (17 U. S. 426 - 427). 
Ademais, um tributo estadual sobre instituição federal pode ser entendido como a tributação por parte de um estado em relação a contribuintes de outros estados da federação - haveria, pois, uma deslegitimação da imposição, pois recairia contra sujeitos passivos que não teriam anuído com a sua instituição, pois não representados no poder legislativo local que a autorizou ${ }^{472}$. Essa visão de Marshall é importantíssima e é fundamento do principal aspecto limitador, no direito constitucional norteamericano, do poder estadual em regular o comércio interestadual de mercadorias, a "The Dormant Commerce Clause", nosso objeto de estudo central no que tange ao entendimento do que seja o Princípio de Não-Discriminação na experiência da Suprema Corte norteamericana, como se verá.

McCulloch v. Maryland constitui, portanto, um precedente fundamental no estudo do direito constitucional norteamericano, no que tange ao entendimento do federalismo fiscal nele estabelecido, em um modelo dual de divisão de competências, na classificação exposta por George Anderson (2008, p. 41 -42). Foi nas palavras do seu relator que se estabeleceram marcos divisórios até hoje respeitados no que tange aos limites dos poderes legislativos federais em relação aos estaduais e viceversa, especialmente, ao que nos interessa, quanto ao poder de tributar operações interestaduais. Como bem afirma Dan Coenen, ele próprio se respaldando nas lições de Charles L. Black $\mathrm{Jr}$, McCulloch v. Maryland é talvez o "maior dos precedentes constitucionais americanos" (2004, p. 23) e sem dúvida de fundamental importância para se entender a estrutura federal do poder de tributar naquele país, embora seja algo desprezado nos estudos dos tributaristas brasileiros.

\footnotetext{
472 "The people of all the States have created the General Government, and have conferred upon it the general power of taxation. The people of all the States, and the States themselves, are represented in Congress, and, by their representatives, exercise this power. When they tax the chartered institutions of the States, they tax their constituents, and these taxes must be uniform. But when a State taxes the operations of the Government of the United States, it acts upon institutions created not by their own constituents, but by people over whom they claim no control. It acts upon the measures of a Government created by others as well as themselves, for the benefit of others in common with themselves. The difference is that which always exists, and always must exist, between the action of the whole on a part, and the action of a part on the whole -- between the laws of a Government declared to be supreme, and those of a Government which, when in opposition to those laws, is not supreme.

But if the full application of this argument could be admitted, it might bring into question the right of Congress to tax the State banks, and could not prove the rights of the States to tax the Bank of the United States.

The Court has bestowed on this subject its most deliberate consideration. The result is a conviction that the States have no power, by taxation or otherwise, to retard, impede, burden, or in any manner control the operations of the constitutional laws enacted by Congress to carry into execution the powers vested in the General Government. This is, we think, the unavoidable consequence of that supremacy which the Constitution has declared.

We are unanimously of opinion that the law passed by the Legislature of Maryland, imposing a tax on the Bank of the United States is unconstitutional and void" (17 U. S. 435 - 436).
} 


\subsubsection{Da "The Supremacy Clause".}

Como vimos no item anterior, não há dúvidas hoje, no entendimento constitucional norteamericano, que aos estados resta o que se denomina poder de polícia, de natureza residual - aquele que pode ser exercido não sendo expressamente proibido pelo texto constitucional ou por sua interpretação consolidada. Não é o caso, no exemplo mais evidente, por estar expresso na norma maior, das hipóteses previstas no Parágrafo 10 do Artigo I, como são o poder de celebrar tratados e no plano internacional, de emitir moeda ou instituir tributos sobre a importação ou exportação de produtos (também conhecida como a "The Import-Export Clause"), a menos de taxas relacionadas à inspeção dos produtos, entre outras vedações ${ }^{473}$, sem falar nas restrições decorrentes dos direitos e garantias fundamentais, assuntos que aqui se evita mencionar, pois se verificam fora de escopo.

Ao contrário, o poder legislativo federal, como já vimos, mas é conveniente recordar, só poderá atuar quando houver autorização constitucional para tanto, mesmo que não expressa - o que nos dimensiona a relevância da "The Necessary and Proper Clause", especialmente diante do elastério de atribuições advindo da superação da doutrina dos poderes enumerados.

Não obstante, há limitações para os dois lados decorrentes da própria convivência dos poderes concorrentes entre as duas esferas de poder, federal e regional. Do ponto de vista da competência legislativa estadual, Erwin Chemerinsky (2006, p. 390) ensina que há duas possibilidades de invalidação de uma norma estadual decorrentes da convivência entre os dois âmbitos legislativos.

473 “Article I. Section 10. Powers prohibited of States.

No State shall enter into any Treaty, Alliance, or Confederation; grant Letters of Marque and Reprisal; coin Money; emit Bills of Credit; make any Thing but gold and silver Coin a Tender in Payment of Debts; pass any Bill of Attainder, ex post facto Law, or Law impairing the Obligation of Contracts, or grant any Title of Nobility.

No State shall, without the Consent of the Congress, lay any Imposts or Duties on Imports or Exports, except what may be absolutely necessary for executing it's Laws: and the net Produce of all Duties and Imposts, laid by any State on Imports or Exports, shall be for the Use of the Treasury of the United States; and all such Laws shall be subject to the Revision and Controul of the Congress.

No State shall, without the Consent of Congress, lay any duty of Tonnage, keep Troops, or Ships of War in time of Peace, enter into any Agreement or Compact with another State, or with a foreign Power, or engage in War, unless actually invaded, or in such imminent Danger as will not admit of delay". 
A primeira circunstância decorre das situações em que o poder legislativo federal efetivamente atuou ao mesmo tempo em que o estadual. A questão, então, colocase resumida no entendimento de como se dá o conflito entre as normas legais existentes. Como se diz na literatura do direito constitucional nortemericano, repousa em se verificar se a norma federal, escrita, expressa, positiva, prefere $^{474}$ à lei local ou estadual, seja essa de origem na common law (decorrente de precedentes judiciais) ou decorrente de norma positivada (statutory). É nessa situação que se insere o estudo dos pormenores teóricos referentes à aplicação da "The Supremacy Clause".

Quando, diferentemente, não há ação do legislativo federal, ou o Poder Judiciário entende que a norma federal não trata do mesmo tema que a estadual ou local, a norma regional ainda tem que passar em dois testes de validade.

O primeiro é o nosso objeto maior de estudo nesse capítulo, a verificação de sua violação ou não à "The Dormant Commerce Clause", ou seja, a aferição se a norma infranacional, tributária ou regulatória, acarreta um ônus indevido ao comércio interestadual $^{475}$. De se ressaltar que, adiante, examinar-se-ão os conceitos jurídicos indeterminados envolvidos nessa restrição.

A segunda possibilidade de violação decorre da previsão constitucional expressa no Artigo IV, Parágrafo 2 , in initio ${ }^{476}$, que prevê que cidadãos de outros estados não poderão sofrer discriminação por normas estaduais em benefício de cidadãos locais, a chamada "The Privileges and Immunities Clause".

Embora a Suprema Corte já tenha decidido, no julgamento do caso Hicklin v. Orbeck $^{477}$, em 1978, acerca da relação próxima e mutuamente imbricada entre a "The Privileges and Immunities Clause" e a "The Dormant Commerce Clause", motivo pelo qual diversos precedentes mencionados no voto condutor do Justice William J. Brennan,

\footnotetext{
474 A literatura jurídica norteamericana emprega o termo verbal, em inglês, "preempts", e o substantivo "preemption", que podem ser traduzidos como prevenção, excludência, antecipação, mas que ora se optou pelo uso dos termos em português "preferir" ou "preferência".

475 "Undue burden on interstate commerce", no original em inglês.

476 "Article IV. Section 2 - State citizens, Extradition.

The Citizens of each State shall be entitled to all Privileges and Immunities of Citizens in the several States. (...)

477437 U.S. 518 (1978). O caso refere-se à constitucionalidade da norma conhecida como "Alaska Hire Statute" (oficialmente, "Local Hire Under State Leases Act"), lei estadual expressamente promulgada com o fim de reduzir o desemprego no estado próximo ao Círculo Polar Ártico, que exigia que qualquer permissão ou concessão de lavra ou exploração de petróleo e gás emitida pelo governo do estado do Alaska deveria conter um requerimento de que residentes no estado há mais de um ano, se também qualificados, deveriam ser contratados em preferência a não residentes.
} 
Jr. referiam-se ao comércio interestadual ${ }^{478}$, prevalece no entendimento jurisprudencial supremo que a cláusula prevista no Artigo IV, Parágrafo 2, é dirigida aos cidadãos, pessoas físicas, não se applicando a pessoas jurídicas. Muito menos, por óbvio, à circulação de bens (CHEMERINSKY, 2006, p. 467). Por esse motivo, o estudo da "The Privileges and Immunities Clause" está fora do nosso objetivo de análise.

Christopher May e Allan Ides (2007, p. 267) também apresentam uma terceira possibilidade de limitação do poder legislativo estadual ou local. Trata-se do caso em que a lei regional tenta tributar ou regular serviços ou bens prestados ou fornecidos pelo governo federal. É, na visão desses constitucionalistas, uma classificação autônoma para a atuação da Suprema Corte no caso McCulloch v. Maryland, não como mera violação à "The Commerce Clause", mas com o fito de identificar em situações desse jaez uma violação à imunidade das ações federais às imposições, tributárias ou regulatórias, dos estados. A expressão imunidade federal à tributação estadual também é empregada por Dan Coenen (2004, p. 198). Equivale, no caso brasileiro, à previsão da, como conhecida por nossos doutrinadores em direito tribuário, imunidade recíproca. Não obstante, é uma visão aparentemente minoritária entre os constitucionalistas norteamericanos.

Também o estudo da "The Supremacy Clause" não está dentro do foco principal da abordagem a ser aqui empreendida. Sua importância aqui cinge-se realmente à contraposição que seu conceito deve fazer em relação à previsão da "The Dormant Commerce Clause", com o fim de compreender melhor a necessidade que a Suprema Corte entendeu haver para a sua criação.

Apenas para esclarecer melhor, a "The Supremacy Clause", em resumo, como trata de como se deve dar a disciplina do conflito de normas entre a Constituição e o direito estadual ou regional, de common law ou de direito positivo, divide tais conflitos em três categorias: i) express preemption; ii) conflict preemption e iii) field preemption (MAY; IDES, 2007, p. 268 - 269), sendo que para cada um dos casos estabeleceu-se um regime jurídico diferenciado (a denominada preemption doctrine). Algo que lembra a disciplina

\footnotetext{
478 "Although appellants raise no Commerce Clause challenge to the Act, the mutually reinforcing relationship between the Privileges and Immunities Clause of Art. IV, $\S 2$, and the Commerce Clause-a relationship that stems from their common origin in the Fourth Article of the Articles of Confederation and their shared vision of federalism, see Baldwin v. Montana Fish and Game Comm'n, 436 U.S. at 379-380, 98 S.Ct., at 1858, renders several Commerce Clause decisions appropriate support for our conclusion (...)" (437 U.S. 531).
} 
brasileira de revogação de normas prevista no Art. $2, \S 1$, da nossa Lei de Introdução ao Código Civil $^{479}$, o Decreto $n^{\circ} 4.657 / 42^{480}$.

\subsubsection{Do Poder de Tributar e de Despender ${ }^{481}$.}

A par das controvérsias que advêm da interpretação constitucional acerca da tênue linha divisória traçada pelo julgado no caso McCulloch v. Maryland, é indubitável que o voto do Justice Marshall, se por um lado, como já vimos, possuiu o condão de conferir um significativo elastério aos poderes legislativos federais quando se trata da implementação das competências a eles conferidas, de outro lado deixou bem claro que tais poderes não podem ser confundidos com uma permissão para a intervenção legislativa federal em todos os ramos da vida civil. Ao contrário, deixou-se bem claro que o emprego de tais meios mais estendidos não poderia ser tomado como um pretexto para se invadir áreas de competência do poder de polícia comum ${ }^{482}$ - como já vimos, conferido aos estados. Nesses casos, como afirma Marshall, irão ainda assim se submeter ao dever, algo dolorido, da Suprema Corte, como reconhece, em declarar a respectiva inconstitucionalidade - não ser a "law of the land".

Nessa perspectiva, a doutrina constitucionalista norteamericana identifica, de forma abrangente, quatro ordens de poderes que indubitavelmente são constitucionalmente atribuídos aos entes federais.

\footnotetext{
${ }^{479}$ Cuja denominação, que compunha a respectiva ementa, foi recentemente alterada, pela Lei $\mathrm{n}^{\circ} 12.376$, de 30 de dezembro de 2010, .para "Lei de Introdução às normas do Direito Brasileiro". No texto principal, escrito antes de tão significativa alteração legislativa, optou-se pela manutenção da dicção anterior, pois já consolidada no jargão jurídico.

480 “Art. $2^{\circ}$. Não se destinando à vigência temporária, a lei terá vigor até que outra a modifique ou revogue. $\S 1$. A lei posterior revoga a anterior quando expressamente o declare, quando seja com ela incompatível ou quando regule inteiramente a matéria de que tratava a lei anterior. (...)".

481 "The taxing and spending power", nos termos originais, em inglês, como a doutrina norteamericana se refere à questão.

482 "But were its necessity less apparent, none can deny its being an appropriate measure; and if it is, the decree of its necessity, as has been very justly observed, is to be discussed in another place. Should Congress, in the execution of its powers, adopt measures which are prohibited by the Constitution, or should Congress, under the pretext of executing its powers, pass laws for the accomplishment of objects not intrusted to the Government, it would become the painful duty of this tribunal, should a case requiring such a decision come before it, to say that such an act was not the law of the land. But where the law is not prohibited, and is really calculated to effect any of the objects intrusted to the Government, to undertake here to inquire into the decree of its necessity would be to pass the line which circumscribes the judicial department and to tread on legislative ground. This Court disclaims all pretensions to such a power" (17 U.S. 423).
} 
O primeiro e mais complexo é o poder expresso na "The Commerce Clause", objeto do próximo item de análise.

Deve-se ressaltar que, da mesma forma que, como comentado quando da menção ao conteúdo da "The Supremacy Clause", a análise aprofundada da "The Commerce Clause" não é de interesse maior para a linha de raciocínio que nos cabe desenvolver. Não obstante, sua importância para nosso estudo é de muito maior relevância do que uma simples contraposição conceitual, para fins didáticos, em relação à previsão da "The Dormant Commerce Clause", como foi a menção ainda há pouco da "The Supremacy Clause".

O estudo da "The Commerce Clause", ao qual se dedicará todo o item seguinte do presente capítulo, reveste-se de capital importância na compreensão da "The Dormant Commerce Clause", objeto principal de estudo desse capítulo como um todo, e não apenas por ser o seu "outro lado da moeda" 483 , como ensina Dan Coenen (2004, p. 197) - um o exercício, proativo, efetivo, sempre pela União, do poder de regular o comércio interestadual e exterior; outro, o poder federal de conter eventual iniciativa legislativa estadual, tributária ou regulatória, que seja contrária aos princípios da União (principalmente que seja discriminatória aos demais estados).

Há um motivo de muito maior relevância jurídica, que é o fato de que a compreensão jurisprudencial da disciplina da Cláusula 3 do Parágrafo 8 do Artigo I, que consiste no foco da "The Commerce Clause", ao nos fazer entender o alcance da expressão "The Congress shall have Power To regulate Commerce with foreign Nations, and among the several States, and with the Indian Tribes", traz uma reflexão sobre dois conceitos relevantes para também se entender a autoridade federal em impedir o exercício da competência tributária estadual deletéria aos interesses da manutenção da União: i) no que consiste o "comércio" cujo poder de regular é constitucionalmente deferido ao legislativo federal; ii) o que o legislador constituinte quis dizer com o termo "among the several States"; ou seja, o que caracteriza uma operação como interestadual a ponto de poder ser objeto de análise por ambas as cláusulas. Mas isso será abordado com profundidade posteriormente.

Adiante, há duas ordens de poderes de mais fácil compreensão, até porque presentes em qualquer texto constitucional, não apenas em normas constitucionais de elevado grau de simplicidade, acarretando altíssima complexidade na hermenêutica

\footnotetext{
483 "Flip side", no original em inglês.
} 
constitucional para operacionalizá-la, como é o caso do direito constitucional norteamericano. Também consistem em poderes cuja compreensão aprofundada não demanda maiores estudos nem tampouco que sejam objeto de nossa preocupação no momento.

A primeira ordem é denominada por Erwin Chemerinsky (2006, p. 281) como a disciplina da "Política Externa". Consiste nos poderes, quase todos previstos no Parágrafo 8 do Artigo I, de: ratificar tratados (esse poder é previsto, excepcionalmente, no Parágrafo 2 do Artigo II, quando da disciplina do poder executivo de celebrar tratados); de definir e punir crimes de pirataria cometidos no alto mar; de declarar guerra; de emitir represálias internacionais; de criar, manter e disciplinar as Forças Armadas; e de regular a imigração de maneira uniforme entre os estados.

Os poderes compreendidos na segunda ordem são aqueles que se subsumem ao que Erwin Chemerinsky (2006, p. 281) identifica como como "Questões Domésticas". Trata-se das atribuições, também quase todas previstas no Parágrafo 8 do Artigo I, de: estabelecer normas nacionalmente uniformes em relação às falências; de cunhar moedas, disciplinar a política monetária e de estabelecer os padrões de pesos e medidas, assim como de estabelecer punições administrativas às violações dessas normativas; de manter o serviço de correios e as respectivas estradas; de promover o progresso da ciência e das artes, assegurando os direitos de autor e de propriedade industrial em relação às obras de arte e às invenções; de constituir tribunais inferiores à Suprema Corte; de criar um distrito para ser a sede do governo dos Estados Unidos da América, assim como erigir edificações em qualquer lugar que seja do consenso congressual, para receber e poder prover os serviços necessários à manutenção de sua autoridade; e, finalmente, de aprovar convênios celebrados entre os estados ou entre um desses e poder estrangeiro (previsão no Parágrafo 10 do Artigo I).

O quarto e último poder, na classificação de Erwin Chemerinsky, é um dos que se relaciona diretamente com o objeto deste trabalho. Trata-se do poder de tributar e do seu complementar, na formulação da Suprema Corte, o poder de despender.

Em verdade, não há muito espaço para a construção jurisprudencial na concepção dos limites do poder de tributar. Como já vimos, a experiência dos "founding fathers" havia sido negativa por conta da ausência da previsão expressa de semelhante ordem de poderes na Articles of Confederation, o diploma legislativo rudimentar que antecedeu a Constituição atual, de 1787. Por conta disso, a presença de cláusula expressa verificava-se mandatória. 
Dada a redação da primeira cláusula do Parágrafo 8 do Artigo I, versada como "The Congress shall have Power To lay and collect Taxes, Duties, Imposts and Excises, to pay the Debts and provide for the common Defence and general Welfare of the United States; but all Duties, Imposts and Excises shall be uniform throughout the United States", como já visto, a primeira dúvida com a qual se defrontou a Suprema Corte foi o de entender o alcance do poder de tributar nela previsto. Será que o poder de tributar é limitado à provisão dos fundos necessários à viabilização dos poderes exaustivamente enumerados no texto constitucional, ou será que a referência ao bem-estar geral dos estados permite o exercício mais amplo de poder de tributar?

Tal questão foi definitivamente abordada no caso United States v. Butler ${ }^{484}$. Tratava-se da arguição quanto à constitucionalidade de uma lei de 1933, o "Agricultural Adjustment Act". Seguindo uma tradição protecionista do Congresso Americano, essa lei instituía um tributo, incidente sobre os processadores de produtos primários americanos, cuja receita seria dirigida diretamente aos respectivos fornecedores, desde que esses se comprometessem a reduzir suas áreas plantadas, e suas produções, por conseguinte. A lei, com esse subsídio direto, pretendia elevar o preço de algumas commodities específicas pela redução da respectiva oferta e com isso reduzir a crise econômica que à época se abatia sobre a agricultura americana, reflexo da situação econômica geral do país. William A. Butler era o responsável pela Hoosac Mills Corporation, uma indústria têxtil, processadora de algodão, situada em Boston.

O julgamento da Suprema Corte, conduzido pelo voto do Justice Owen J. Roberts, decidiu que a incidência tributária era inconstitucional, uma vez que, na medida em que não se tratava de uma norma puramente tributária, mas sim regulatória da produção, teria invadido a competência dos estados determinada pela Décima Emenda. O tributo, a apropriação de suas receitas e o seu direcionamento em proveito dos fazendeiros seriam meramente instrumentos para se chegar a um fim inconstitucional ${ }^{485}$. O voto de

\footnotetext{
${ }^{484} 297$ U.S. 1 (1936).

485 "Wholly apart from that question, another principle embedded in our Constitution prohibits the enforcement of the Agricultural Adjustment Act. The act invades the reserved rights of the states. It is a statutory plan to regulate and control agricultural production, a matter beyond the powers delegated to the federal government. The tax, the appropriation of the funds raised, and the direction for their disbursement are but parts of the plan. They are but means to an unconstitutional end.

From the accepted doctrine that the United States is a government of delegated powers, it follows that those not expressly granted, or reasonably to be implied from such as are conferred, are reserved to the states, or to the people. To forestall any suggestion to the contrary, the Tenth Amendment was adopted. The same proposition, otherwise stated, is that powers not granted are prohibited. None to regulate agricultural production is given, and therefore legislation by Congress for that purpose is forbidden" (297 U. S. 68).
} 
Roberts foi seguido por outros cinco Justices, recebendo opiniões discordantes dos Justices Louis Brandeis, Benjamin Cardozo e Harlan Stone.

O julgamento do caso United States v. Butler não se reveste de relevância como precedente hoje aplicável no seu mérito, até porque aplicava a doutrina dos poderes enumerados - como aqui já se viu, hoje superada. Na verdade, foi mais uma de uma série de derrotas que a Suprema Corte conservadora da época impôs ao governo de Franklin Delano Roosevelt e à sua política econômica intervencionista (o "New Deal"), o que perdurou até o ano seguinte - só superada a restrição jurisprudencial com o revolucionário voto do Justice Benjamin Cardozo no caso Carter v. Carter Coal Company ${ }^{486}$, acerca da constitucionalidade do "The Bituminous Coal Conservation Act", de 1935.

Não obstante, a análise empreendida em United States v. Butler acerca da compreensão do escopo do poder de tributar continua sendo até hoje empregada como precedente plenamente aplicável.

O foco da discussão em United States $v$. Butler cinge-se justamente aos limites da atuação do poder estatal por meio da criação de incidências tributárias, especialmente em função da previsão legal da atenção ao "bem-estar geral dos estados". A questão é fundamentalmente o entendimento escorreito quanto ao que consista o poder expresso de tributar no diploma constitucional diante da atenção que se deve dar à vedação, também expressa, na Cláusula 7 do Parágrafo 9 do Artigo I, à apropriação indébita do patrimônio dos particulares em proveito do tesouro nacional, senão mediante autorização legal, regularmente prevista em norma orçamentária periodicamente publicada ${ }^{487}$.

No voto do Justice Roberts, destaca-se especialmente, o que é de vital importância ao direito constitucional norteamericano até hoje, a discussão acerca da compatibilização entre esses dois princípios $^{488}$.

\footnotetext{
486298 U.S. 238 (1936).

487 "Section 9 - Limits on Congress.
}

(...)

No Money shall be drawn from the Treasury, but in Consequence of Appropriations made by Law; and a regular Statement and Account of the Receipts and Expenditures of all public Money shall be published from time to time".

488 "The Congress is expressly empowered to lay taxes to provide for the general welfare. Funds in the Treasury as a result of taxation may be expended only through appropriation. (Art. I, § 9, cl. 7.) They can never accomplish the objects for which they were collected unless the power to appropriate is as broad as the power to tax. The necessary implication from the terms of the grant is that the public funds may be appropriated "to provide for the general welfare of the United States." These words cannot be meaningless, else they would not have been used. The conclusion must be that they were intended to limit and define the granted power to raise and to expend money. How shall they be construed to effectuate the intent of the instrument?" (297 U. S. 65). 
Prossegue ilustrando que a questão, mais uma vez, remonta aos tempos da fundação da nação. Por um lado, James Madison defendendo que o poder de tributar, previsto em sua primeira cláusula, não seria mais do que uma referência aos demais poderes enumerados nas cláusulas subsequentes do Parágrafo 8 do Artigo I, pelo que o legislativo estadual estaria limitado em seu poder de tributar à viabilização dos demais poderes a seguir enumerados no mesmo parágrafo. Em contraposição, o Justice Roberts em seu voto esclarece-nos que a posição de Alexander Hamilton, de sua parte, mencionava que o poder de tributar é separado e distinto dos enumerados posteriormente e, portanto, não restringido a garanti-los - o poder de tributar seria, portanto, substantivo, cuja única limitação seria o seu exercício em proveito do bem-estar dos Estados Unidos ${ }^{489}$.

A Corte, após reconhecer a relevância da dúvida e mencionar que jamais anteriormente teria havido o seu pronunciamento a respeito, acompanhando o voto do relator, respaldado na lição doutrinária do Justice Joseph Story, em seus clássicos "Commentaries on the Constitution of the United States" de 1833, expressamente endossou a posição de Alexander Hamilton, reconhecendo-a como a correta ${ }^{490}$, pelo que o poder de tributar estaria conformado intrinsecamente à sua própria atribuição, de forma que não seria a enumeração dos poderes legislativos do Congresso que determinaria o seu confinamento ontológico $^{491}$.

Mas o que, então, seriam os limites constitucionais ao poder de tributar na visão da Suprema Corte norteamericana? Nesse ponto, o voto condutor do julgamento faz afirmação peremptória que é de capital relevância para o nosso estudo. Após novamente beber nas lições de Joseph Story, assim como nas de Alexander Hamilton, na sua obra

\footnotetext{
489 "Since the foundation of the Nation, sharp differences of opinion have persisted as to the true interpretation of the phrase. Madison asserted it amounted to no more than a reference to the other powers enumerated in the subsequent clauses of the same section; that, as the United States is a government of limited and enumerated powers, the grant of power to tax and spend for the general national welfare must be confined to the enumerated legislative fields committed to the Congress. In this view, the phrase is mere tautology, for taxation and appropriation are, or may be, necessary incidents of the exercise of any of the enumerated legislative powers. Hamilton, on the other hand, maintained the clause confers a power separate and distinct from those later enumerated, is not restricted in meaning by the grant of them, and Congress consequently has a substantive power to tax and to appropriate, limited only by the requirement that it shall be exercised to provide for the general welfare of the United States" (297 U. S. 65 - 66).

490 "Each contention has had the support of those whose views are entitled to weight. This court has noticed the question, but has never found it necessary to decide which is the true construction. Mr. Justice Story, in his Commentaries, espouses the Hamiltonian position. We shall not review the writings of public men and commentators or discuss the legislative practice. Study of all these leads us to conclude that the reading advocated by Mr. Justice Story is the correct one" (297 U. S. 66).

491 "While, therefore, the power to tax is not unlimited, its confines are set in the clause which confers it, and not in those of $\$ 8$ which bestow and define the legislative powers of the Congress. It results that the power of Congress to authorize expenditure of public moneys for public purposes is not limited by the direct grants of legislative power found in the Constitution" (297 U. S. 66).
} 
deslavadamente protecionista "Report on Manufactures", à qual anteriormente nos referimos, e nos discursos do founding father James Monroe ${ }^{492}$, termina por concluir, com fulcro específico em uma referência a Story, que o bem-estar que justifica o exercício do poder de tributar é o nacional, não o regional ou local ${ }^{493}$.

Ao final da análise dessa questão preliminar, talvez prevendo a relevância histórica do que então se estava decidindo naquela esfera jurisprudencial, reconhece que o texto constitucional não determina instruções e balizamentos rigorosamente estabelecidos, o que ainda tornaria mais difícil a espinhosa missão da Suprema Corte em declarar como inconstitucionais normas tributárias, para concluir com uma indagação sobre a ainda incerta extensão do conceito de bem-estar da nação ${ }^{494}$.

Essa discussão foi de tal forma consolidada como central na análise do escopo do poder federal legislativo de tributar, em função da apreciação e da abordagem empreendidas no julgamento do caso United States v. Butler, que a referida Cláusula 1 do Parágrafo 8 do Artigo I da constituição dos Estados Unidos da América tem sido conhecida não por meio de denominação popular que se refira ao poder de tributar, seu objetivo maior, mas sim como "The General Welfare Clause"495.

\footnotetext{
492 "But the adoption of the broader construction leaves the power to spend subject to limitations. As Story says:

"The Constitution was, from its very origin, contemplated to be the frame of a national government, of special and enumerated powers, and not of general and unlimited powers."

Again, he says:

"A power to lay taxes for the common defence and general welfare of the United States is not, in common sense, a general power. It is limited to those objects. It cannot constitutionally transcend them."

That the qualifying phrase must be given effect all advocates of broad construction admit. Hamilton, in his well known Report on Manufactures, states that the purpose must be "general, and not local." Monroe, an advocate of Hamilton's doctrine, wrote:

"Have Congress a right to raise and appropriate the money to any and to every purpose according to their will and pleasure? They certainly have not."

Story says that, if the tax be not proposed for the common defence or general welfare, but for other objects wholly extraneous, it would be wholly indefensible upon constitutional principles" (297 U. S. 66 - 67).

493 "And he makes it clear that the powers of taxation and appropriation extend only to matters of national, as distinguished from local, welfare" (297 U. S. 67).

494 "As elsewhere throughout the Constitution, the section in question lays down principles which control the use of the power, and does not attempt meticulous or detailed directions. Every presumption is to be indulged in favor of faithful compliance by Congress with the mandates of the fundamental law. Courts are reluctant to adjudge any statute in contravention of them. But, under our frame of government, no other place is provided where the citizen may be heard to urge that the law fails to conform to the limits set upon the use of a granted power. When such a contention comes here, we naturally require a showing that by no reasonable possibility can the challenged legislation fall within the wide range of discretion permitted to the Congress. How great is the extent of that range when the subject is the promotion of the general welfare of the United States we hardly need remark. But, despite the breadth of the legislative discretion, our duty to hear and to render judgment remains. If the statute plainly violates the stated principle of the Constitution, we must so declare" (297 U. S. 67).

${ }^{495}$ Para uma pesquisa quanto a todas as denominações populares das cláusulas do texto constitucional norteamericano, ver o sítio http://www.usconstitution.net/constpop.html.
} 
Com o passar da história, outros casos decididos pela Suprema Corte vieram a corroborar o entendimento primeiramente concebido pelo Justice Owen J. Roberts.

No caso Steward Machine Co. v. Collector of Internal Revenue ${ }^{496}, \operatorname{logo}$ no ano seguinte, discutiu-se a constitucionalidade de um tributo para a Seguridade Social, criado pelo Social Security Act de 1935, incidente sobre a folha de pagamentos dos empregados das sociedades empresárias e demais empregadores de mais de oito pessoas, compensável, em até $90 \%$ do tributo devido, com os tributos recolhidos aos fundos estaduais de compensação pelo desemprego, se houvesse lei estadual o criando e desde que a lei estadual seja certificada pelo Federal Social Security Board da Secretaria do Tesouro (federal) como sendo genuinamente uma lei de garantia contra o desemprego. Também era condicionado que os respectivos créditos tributários fossem integralmente destinados ao pagamento de modalidades estaduais de seguro-desemprego.

Entre outras discussões, como, por exemplo, se as isenções aos pequenos empregadores, assim como aos empregadores domésticos e rurais, violariam a cláusula de igualdade da Quinta Emenda (a "Equal protection clause", subentendida na "Due process of law clause" de forma substantiva), também se perquiriu a Suprema Corte quanto a se os termos em que desenhado o tributo não agiriam coercitivamente em relação aos estados, de forma a violar a Décima Emenda, na medida em que estar-se-ia coagindo os estados a criarem fundos do tipo "Unemployment Trust Funds" para suportar os encargos de benefícios assemelhados ao seguro-desemprego brasileiro.

A Suprema Corte, em voto do Justice Benjamin Cardozo, vencedor por cinco votos a quatro (o que ilustra a divisão da corte em matérias de fundo econômico naquela fase), esgrimindo estatísticas acerca da gravíssima situação econômica e de desemprego da época, afastou a hipótese de que a norma de incidência tributária fosse uma arma de coerção, destruição ou diminuição da autonomia dos estados, mas sim que os estados não possuem capacidade econômica e política de atenuar um problema que era então de abrangência nacional em área e em dimensões, o que se identifica plenamente com o conceito de bem-estar geral, previsto no texto constitucional, reportando-se quanto a isso diretamente ao caso United States v. Butler ${ }^{497}$.

\footnotetext{
496301 U.S. 548 (1937). Em algumas referências, o caso é denominado Steward Machine Co. v. Davis, por conta de Harwell G. Davis, que exercia então o cargo de Collector of Internal Revenue no Distrito do Alabama.

497 "But before the statute succumbs to an assault upon these lines, two propositions must be made out by the assailant. Cincinnati Soap Co. v. United States, supra. There must be a showing in the first place that separated from the credit the revenue provisions are incapable of standing by themselves. There must be a showing in the second place that the tax and the credit in combination are weapons of coercion, destroying
} 
Outro relevante caso acerca do entendimento da amplitude que se deve conferir ao poder de tributar atribuído pelo texto constitucional, é o caso Helvering v. Davis ${ }^{498}$, acerca da constitucionalidade da mesma norma, o Social Security Act de 1935, julgado logo depois do caso Steward Machine Co. v. Collector of Internal Revenue. Seu objeto era a constitucionalidade, agora não da contribuição para o financiamento do segurodesemprego, como no caso anterior, prevista no Título IX, mas de outra contribuição incidente sobre os empregadores, prevista no Título VIII, cuja base de cálculo é a folha de pagamentos de salários, independentemente de outra contribuição, essa cujos contribuintes seriam os empregados, a ser descontada dos respectivos salários. Trata-se de sistema, como se vê, semelhante ao posteriormente implantado no Brasil e até hoje vigente.

Ambas as contribuições, segundo os legisladores, relata o voto condutor do julgamento, lavrado pelo Justice Cardozo, destinariam-se ao financiamento dos benefícios criados pelo Título II da mesma norma estatutária, os Federal Old-Age Benefits: uma pensão mensal, paga aos cidadãos com mais de 65 anos de idade que houvessem trabalhado pelo menos um dia nos cinco anos posteriores a 31 de dezembro de 1936, que tivessem ganhado ao menos dois mil dólares desde então e que não estivessem mais recebendo salários, assim como um valor fixo a ser pago em uma única ocasião, pela forma de um benefício do tipo pecúlio ou lump-sum payment, de menor relevância. Ambos os tributos incidiriam a idênticas alíquotas, crescentes no tempo, a cada três anos, desde $1 \%$ no período compreendido entre os anos de 1937 e 1939, aumentando em meio por cento, até chegar ao patamar de 3\% a partir de janeiro de 1949.

Após entender que os dois tributos possuíam naturezas jurídicas diferenciadas o incidente sobre os empregados como uma modalidade de imposto sobre a renda, embora seu exame estivesse fora da lide; o outro, sobre os empregadores, como uma incidência

or impairing the autonomy of the states. The truth of each proposition being essential to the success of the assault, we pass for convenience to a consideration of the second, without pausing to inquire whether there has been a demonstration of the first.

To draw the line intelligently between duress and inducement there is need to remind ourselves of facts as to the problem of unemployment that are now matters of common knowledge. West Coast Hotel Co. v. Parrish, 300 U. S. 379. The relevant statistics are gathered in the brief of counsel for the Government. Of the many available figures a few only will be mentioned. During the years 1929 to 1936, when the country was passing through a cyclical depression, the number of the unemployed mounted to unprecedented heights. Often the average was more than 10 million; at times a peak was attained of 16 million or more. Disaster to the breadwinner meant disaster to dependents. Accordingly, the roll of the unemployed, itself formidable enough, was only a partial roll of the destitute or needy. The fact developed quickly that the states were unable to give the requisite relief. The problem had become national in area and dimensions. There was need of help from the nation if the people were not to starve. It is too late today for the argument to be heard with tolerance that, in a crisis so extreme, the use of the moneys of the nation to relieve the unemployed and their dependents is a use for any purpose narrower than the promotion of the general welfare. Cf. United States $v$. Butler, 297 U. S. 1, 297 U. S. 65, 297 U. S. 66" (301 U. S. $586-587$ ).

498301 U.S. 619 (1937). 
específica, do tipo excise tax ${ }^{499}$-, Justice Cardozo passou a examinar a legitimidade ativa do autor.

Ocorre que a demanda foi oferecida orginariamente às instâncias inferiores por George P. Davis, um acionista da Edison Electric Illuminating Company de Boston, sociedade que havia decidido obedecer à nova disposição legal de incidência tributária, malgrado a manifestação em contrário do demandante em assembleia interna corporis, após estar-se procedendo à retenção dos tributos incidentes sobre os salários dos empregados.

Em sede recursal à Suprema Corte, o recorrente foi Guy T. Helvering, à época exercendo o cargo de Commissioner of the U.S. Internal Revenue Service (IRS), contra a decisão da corte federal de apelações do primeiro circuito (U.S. First Circuit Court of Appeals), que entendeu que as incidências do Título II consistiriam em invasões às competências reservadas aos estados, já que o financiamento de benefícios como os Federal Old-Age Benefits não seria um objetivo autorizado pelo texto constitucional.

A decisão quanto a essa condição da ação não nos interessa aqui, mas é importante ressaltar que o voto condutor do julgamento, ao enfrentar as alegações aduzidas, novamente tocou na questão da competência federal para instituir contribuições para o sistema de seguridade social. Houve dois votos discordantes.

Após uma extensa justificativa, toda mais econômica e social do que jurídica, quanto à necessidade da instituição do benefício diante da situação calamitosa da população de então, por conta da crise econômica, assim como da impossibilidade e do desinteresse de os estados proverem isoladamente um benefício daquela magnitude, pelo que caracterizado no caso o bem-estar da nação previsto no texto constitucional ${ }^{500}$, a

\footnotetext{
499 "In this case, Titles VIII and II are the subject of attack. Title VIII lays another excise upon employers in addition to the one imposed by Title IX (though with different exemptions). It lays a special income tax upon employees to be deducted from their wages and paid by the employers. Title II provides for the payment of Old Age Benefits, and supplies the motive and occasion, in the view of the assailants of the statute, for the levy of the taxes imposed by Title VIII. The plan of the two titles will now be summarized more fully.

Title VIII, as we have said, lays two different types of tax, an "income tax on employees" and "an excise tax on employers." The income tax on employees is measured by wages paid during the calendar year. $\$ 801$. The excise tax on the employer is to be paid "with respect to having individuals in his employ," and, like the tax on employees, is measured by wages. $\$ 804$ " (301 U. S. $634-635)$.

500 "Nor is the concept of the general welfare static. Needs that were narrow or parochial a century ago may be interwoven in our day with the wellbeing of the Nation. What is critical or urgent changes with the times. The purge of nationwide calamity that began in 1929 has taught us many lessons. Not the least is the solidarity of interests that may once have seemed to be divided. Unemployment spreads from State to State, the hinterland now settled that, in pioneer days gave an avenue of escape. Home Building \& Loan Assn. v. Blaisdell, 290 U. S. 398, 290 U. S. 442. Spreading from State to State, unemployment is an ill not particular, but general, which may be checked, if Congress so determines, by the resources of the Nation. If this can have been doubtful until now, our ruling today in the case of the Steward Machine Co., supra, has set the doubt at rest. But the ill is all one, or at least not greatly different, whether men are thrown out of work
} 
Suprema Corte logicamente concluiu seu raciocínio com a constatação de que a função do

Poder Judiciário deveria se limitar à apreciação dos limites do exercício do poder de tributar, não podendo se imiscuir na inteligência do seu exercício, atribuição exclusiva do Congresso nacional ${ }^{501}$. Também não caberia ao poder regional ou local, até para evitar divergências ideológicas entre os estados ou até mesmo guerras fiscais. Em resumo, afirma

because there is no longer work to do or because the disabilities of age make them incapable of doing it. Rescue becomes necessary irrespective of the cause. The hope behind this statute is to save men and women from the rigors of the poor house, as well as from the haunting fear that such a lot awaits them when journey's end is near.

Congress did not improvise a judgment when it found that the award of old age benefits would be conducive to the general welfare. The President's Committee on Economic Security made an investigation and report, aided by a research staff of Government officers and employees, and by an Advisory Council and seven other advisory Groups. Extensive hearings followed before the House Committee on Ways and Means, and the Senate Committee on Finance. A great mass of evidence was brought together supporting the policy which finds expression in the act. Among the relevant facts are these: the number of persons in the United States 65 years of age or over is increasing proportionately as well as absolutely. What is even more important, the number of such persons unable to take care of themselves is growing at a threatening pace. More and more, our population is becoming urban and industrial, instead of rural and agricultural. The evidence is impressive that, among industrial workers, the younger men and women are preferred over the older. In times of retrenchment, the older are commonly the first to go, and even if retained, their wages are likely to be lowered. The plight of men and women at so low an age as 40 is hard, almost hopeless, when they are driven to seek for reemployment. Statistics are in the brief. A few illustrations will be chosen from many there collected. In 1930, out of 224 American factories investigated, 71, or almost one third, had fixed maximum hiring age limits; in 4 plants, the limit was under 40; in 41, it was under 46. In the other 153 plants, there were no fixed limits, but in practice few were hired if they were over 50 years of age. With the loss of savings inevitable in periods of idleness, the fate of workers over 65, when thrown out of work, is little less than desperate. A recent study of the Social Security Board informs us that

"one-fifth of the aged in the United States were receiving old-age assistance, emergency relief, institutional care, employment under the works program, or some other form of aid from public or private funds; twofifths to one-half were dependent on friends and relatives, one-eighth had some income from earnings, and possibly one-sixth had some savings or property. Approximately three out of four persons 65 or over were probably dependent wholly or partially on others for support. "

We summarize in the margin the results of other studies by state and national commissions. They point the same way.

The problem is plainly national in area and dimensions. Moreover, laws of the separate states cannot deal with it effectively. Congress, at least, had a basis for that belief. States and local governments are often lacking in the resources that are necessary to finance an adequate program of security for the aged. This is brought out with a wealth of illustration in recent studies of the problem. Apart from the failure of resources, states and local governments are at times reluctant to increase so heavily the burden of taxation to be borne by their residents for fear of placing themselves in a position of economic disadvantage as compared with neighbors or competitors. We have seen this in our study of the problem of unemployment compensation. Steward Machine Co. v. Davis, supra. A system of old age pensions has special dangers of its own if put in force in one state and rejected in another. The existence of such a system is a bait to the needy and dependent elsewhere, encouraging them to migrate and seek a haven of repose. Only a power that is national can serve the interests of all" (301 U. S. $641-644)$.

501 "Whether wisdom or unwisdom resides in the scheme of benefits set forth in Title II it is not for us to say. The answer to such inquiries must come from Congress, not the courts. Our concern here, as often, is with power, not with wisdom. Counsel for respondent has recalled to us the virtues of self-reliance and frugality. There is a possibility, he says, that aid from a paternal government may sap those sturdy virtues and breed a race of weaklings. If Massachusetts so believes and shapes her laws in that conviction, must her breed of sons be changed, he asks, because some other philosophy of government finds favor in the halls of Congress? But the answer is not doubtful. One might ask with equal reason whether the system of protective tariffs is to be set aside at will in one state or another whenever local policy prefers the rule of laissez faire. The issue is a closed one. It was fought out long ago. When money is spent to promote the general welfare, the concept of welfare or the opposite is shaped by Congress, not the states. So the concept be not arbitrary, the locality must yield. Constitution, Art. VI, Par. 2" (Page 301 U. S. $644-645)$. 
Benjamin Cardozo, a menos de uma escolha claramente equivocada, no caso do exercício arbitrário de poder, a discricionariedade em avaliar a correção da política e das incidências tributárias, no que tange ao atendimento ao interesse público inserido na cláusula do bemestar dos estados, deverá estar unicamente jungida às competências do poder legislativo federal $^{502}$.

A importância de desses casos por meio dos quais a Suprema Corte norteamericana optou por uma visão mais ampla do poder federal de tributar é tal que eles são até hoje objeto de acesas críticas por parte dos estudiosos de linha conservadora, na esteira das posições originárias de James Madison e Thomas Jefferson. Especialmente os casos United States v. Butler e Helvering v. Davis frequentemente são listados como entre os casos sujos da Suprema Corte, aqueles em que o direito do cidadão comum teria sido mais vilipendiado no curso da história da nação ${ }^{503}$.

Verificada a amplitude do poder de tributar, que não se limita a apenas financiar despesas e serviços federais especificamente listados constitucionalmente, outras questões de menor importância foram, ao longo da história constitucional norteamericana, sendo discutidas.

Já se ressaltou que, além da "The Import-Export Clause", da Cláusula 2 do Parágrafo 10 do Artigo I, dirigida aos estados e referente tanto à exportação quanto à importação, também a Cláusula 4 do Parágrafo 9 do Artigo I da Constituição dos Estados Unidos da América, ao estabelecer os limites ao poder legislativo federal, prevê ("No Tax or Duty shall be laid on Articles exported from any State") a proibição à instituição de

\footnotetext{
502 "Second. The scheme of benefits created by the provisions of Title II is not in contravention of the limitations of the Tenth Amendment.

Congress may spend money in aid of the "general welfare." Constitution, Art. I, section 8; United States v. Butler,297 U.S. 1, 297 U.S.65; Steward Machine Co. v. Davis, supra. There have been great statesmen in our history who have stood for other views. We will not resurrect the contest. It is now settled by decision. United States $v$. Butler, supra. The conception of the spending power advocated by Hamilton and strongly reinforced by Story has prevailed over that of Madison, which has not been lacking in adherents. Yet difficulties are left when the power is conceded. The line must still be drawn between one welfare and another, between particular and general. Where this shall be placed cannot be known through a formula in advance of the event. There is a middle ground, or certainly a penumbra, in which discretion is at large. The discretion, however, is not confided to the courts. The discretion belongs to Congress, unless the choice is clearly wrong, a display of arbitrary power, not an exercise of judgment. This is now familiar law" (301 U. S. 640).

${ }^{503}$ Nesse sentido, veja-se LEVY, Robert; MELLOR, William. The Dirty Dozen: How Twelve Supreme Court Cases Radically Expanded Government and Eroded Freedom, With a New Preface. Washington: Cato Institute, 2010 e EASTMAN, John C. Restoring the "General" to the General Welfare Clause. Chapman Law Review. Orange: Chapman University Press, vol. 4, p. 63 - 95, 2001. Nesse segundo texto, o autor examina detidamente os debates travados entre James Madison e Alexander Hamilton para ao final concluir que o entendimento iniciado pelo Justice Cardozo não encontraria respaldo em nenhuma das suas posições.
} 
qualquer encargo tributário sobre bens a serem exportados, exclusivamente - a "The Export Clause".

O termo "exported from any State" deve ser entendido como uma exportação para o exterior, jamais a exportação entre Estados, assim como decidiu a Suprema Corte no caso Dooley v. United States ${ }^{504}$. Tratava-se do exame da constitucionalidade da incidência, criada pelo Foraker Act de 1900, de um imposto sobre as vendas de mercadorias destinadas a Porto Rico de origem no território dos Estados Unidos da América, à alíquota de $15 \%$ sobre o valor do imposto de importação que seria incidente em importação de mercadoria assemelhada se de origem em país estrangeiro ${ }^{505}$. Portanto, ao final, a incidência foi declarada inconstitucional, não por violar a "The Export Clause", já que de exportação não tratava, mas sim por infringir o requisito de uniformidade na tributação entre os estados, expressa na cláusula que atribui ao legislativo federal o poder de tributar 506 .

A questão da uniformidade tributária entre os estados, que é um dos fundamentos da "The Dormant Commerce Clause", como se verá adiante com rigor, assim como toda a disciplina do comércio, na forma como tratada na Constituição norteamericana e interpretada pela sua Suprema Corte, foi muito bem resumida pelo relator, Justice Henry Billings Brown, referindo a uma passagem dos casos License Tax Cases $^{507}$, especialmente as regras de repartição de receitas para os tributos diretos e de uniformidade para os tributos indiretos, como se examinará adiante, assim como a relação

\footnotetext{
504183 U.S. 151 (1901).

505 "It being, then, beyond doubt that this Court has, in a line of well considered cases, determined that the words "export" and "import," when employed in the Constitution, relate to the bringing in of goods from a country foreign to the United States and to the carrying out of goods from the United States to such a country, the only question remaining is is Porto Rico a country foreign to the United States? In answering this question, it is manifest, from the entire reasoning of the Court in the cases in which it was decided that the terms "export" and "import" relate to a foreign country alone, that the words "foreign country," as used in those opinions, signified a country outside of the sovereignty of the United States and beyond its legislative authority, and that such meaning of those words was absolutely essential to the process of reasoning by which the conclusion in the cases referred to was reached" (183 U. S. 162 - 163).

506 "It having been thus affirmatively repeatedly determined that the export and import clauses of the Constitution refer only to commerce with foreign countries -- that is, to a country or countries without the sovereignty and entirely beyond the legislative authority of the United States -- and it having been conclusively settled that Porto Rico is not such a country, it seems to me the claim here made that the tax imposed by Congress in Porto Rico is an export or an import within the meaning of the Constitution is untenable. But, it is said, if Porto Rico is not foreign, and therefore the tax laid on goods in that island on their arrival from the United States is not within the purview of the import and the inhibition of the export clauses of the Constitution, then Porto Rico is domestic, and the tax is void because repugnant to the first clause of Section 8 of Article I of the Constitution, conferring upon Congress "the power to lay and collect taxes, duties, imposts, and excises, . . . but all duties, imposts, and excises shall be uniform throughout the United States."'” (183 U. S. 164 - 165).
}

50772 U.S. 462 (1866). 
que deve haver entre o poder de tributar e a liberdade de comerciar ${ }^{508}$. Nesse julgamento, de 1866, a propósito, definiu-se, no ponto indicado trinta e cinco anos depois, a extensão do poder de tributar, como sendo possível ao Congresso tributar qualquer artigo, ato, transação, atividade, evento, ocorrência, empresa ou outro bem tangível ou intangível que seja eleito para sofrer a incidência (ENGDAHL, 1987, p. 144).

Resolvendo indagação acerca do alcance da limitação da "The Export Clause", especificamente se era extensível aos bens destinados à exportação, mesmo em fases anteriores da cadeia produtiva, a Suprema Corte, no recente julgamento do caso United States v. International Business Machines Corp. ${ }^{509}$ tratou da questão.

A demandante, empresa exportadora de equipamentos de informática desde os Estados Unidos, insurgiu-se contra o tributo incidente sobre os prêmios de seguro por ela pagos a seguradoras não norteamericanas (não contribuintes do imposto de renda nacional) por conta de embarques de mercadorias por ela produzidas a serem destinadas às suas subsidiárias estrangeiras.

O julgamento desse caso torna-se importante porque um dos argumentos dos advogados governamentais era o de que a mudança no entendimento da "The Commerce Clause" e da "The Dormant Commerce Clause", que estudaremos a seguir, implicaria também uma alteração na formulação acerca do alcance dessa nomeada "The Export Clause $^{, 510}$, embora em casos isolados e antigos, Pace v. Burgess ${ }^{511}$ e Turpin v. Burgess ${ }^{512}$,

\footnotetext{
508 "Because the grant of power as to imposts contained in the first clause of Section 8 of Article I of the Constitution relates to foreign commerce, there arises no limitation on the general authority to tax as to all other subjects, which flows from the other provisions of the same clause. Referring to such power -- the authority to levy and collect taxes, duties, imposts, and excises -- the Court, in the @ 72 U.S. 471, said:

"The power of Congress to tax is a very extensive power. It is given in the Constitution with only one exception and only two qualifications. Congress cannot tax exports, and it must impose direct taxes by the rule of apportionment, and indirect taxes by the rule of uniformity. Thus limited, and thus only, it reaches every subject, and may be exercised at discretion."

Of course the Constitution contemplates freedom of commerce between the states, but it also confers upon Congress the powers of taxation to which I have referred, and safeguarded the freedom of commerce and equality of taxation between the states by conferring upon Congress the power to regulate such commerce, by providing for the apportionment of direct taxes, by exacting uniformity throughout the United States in the laying of duties, imposts, and excises, and by prohibiting preferences between ports of different states. Indeed, when the argument which I am considering is properly analyzed, it amounts to a denial, as I have said, of the substantial powers of Congress with regard to domestic taxation, and, as I understand it, overthrows the settled interpretation of the Constitution, long since announced and consistently adhered to" (183 U. S. 165 - 166). 509517 U.S. 843 (1996).

510 "The Government asserts that the Export Clause permits the imposition of generally applicable, nondiscriminatory taxes, even on goods in export transit. The Government urges that we have historically interpreted the Commerce, Import- Export, and Export Clauses in harmony and that we have rejected the theory underlying Thames \& Mersey in the context of the Commerce and Import-Export Clauses. Accordingly, the Government contends that our Export Clause jurisprudence, symbolized by Thames \& Mersey, has become an anachronism in need of modernization. The Government asks us to reinterpret the
} 
ambos referentes à exportação de tabaco ou de cigarros, a Suprema Corte tenha optado por dar um efeito restritivo ao termo "articles exported", não o estendendo aos seus produtos intermediários. Em apoio à tese da constitucionalidade da exação, os defensores governamentais aduziram também argumentos históricos, que informavam que a motivação inicial da "The Export Clause" não foi econômica, mas política, o que justificaria uma interpretação atual mais restritiva ${ }^{513}$.

O voto condutor do julgamento foi proferido pelo Justice conservador, nomeado por George Herbert Walker Bush, o pai, em 1991, Clarence Thomas, já mencionado, no que foi acompanhado por cinco magistrados, havendo o voto dissidente do Justice Anthony Kennedy, acompanhado por um colega, e uma abstenção.

Nele, a Suprema Corte expressamente afastou qualquer relacionamento entre a exegese da "The Export Clause" em relação aos entendimentos acerca tanto da "The Commerce Clause" quanto da "The Dormant Commerce Clause" 514.

A situação seria diversa, no entanto, no que se refere ao entendimento acerca da relação com a "The Import-Export Clause", sendo esse o mais importante caso que trata das diferenças entre ambas - especialmente a conseqüência advinda do uso dos termos, quanto ao objeto da restrição, como "Imposts or Duties" na "The Import-Export Clause",

Export Clause to permit the imposition of generally applicable, nondiscriminatory taxes as we have under the Commerce Clause and, it argues, under the Import-Export Clause.

The Government contends that our dormant Commerce Clause jurisprudence has shifted dramatically and that our traditional understanding of the Export Clause, which is based partly on an outmoded view of the Commerce Clause, can no longer be justified" (517 U.S. 850).

51192 U. S. 372 (1876).

512117 U. S. 504 (1886).

513 "As a purely historical matter, the Export Clause was originally proposed by delegates to the Federal Convention from the Southern States, who feared that the Northern States would control Congress and would use taxes and duties on exports to raise a disproportionate share of federal revenues from the South. See 2 M. Farrand, The Records of the Federal Convention of 1787, pp. 95, 305-308, 359-363 (rev. ed. 1966). The Government argues that this "narrow historical purpose" justifies a narrow interpretation of the text and that application of $\$ 4371$ to policies insuring exports does not conflict with the policies embodied in the Clause" (517 U.S. 859).

514 "Our rejection in Complete Auto of much of our early dormant Commerce Clause jurisprudence did not, however, signal a similar rejection of our Export Clause cases. Our decades-long struggle over the meaning of the nontextual negative command of the dormant Commerce Clause does not lead to the conclusion that our interpretation of the textual command of the Export Clause is equally fluid. At one time, the Court may have thought that the dormant Commerce Clause required a strict ban on state taxation of interstate commerce, but the text did not require that view.

The Commerce Clause is an express grant of power to Congress to "regulate Commerce ... among the several States." U. S. Const., Art. I, $\S 8$, cl. 3. It does not expressly prohibit the States from doing anything. The text of the Export Clause, on the other hand, expressly prohibits Congress from laying any tax or duty on exports. These textual disparities strongly suggest that shifts in the Court's view of the scope of the dormant Commerce Clause should not, and indeed cannot, govern our interpretation of the Export Clause. Cf. Richfield Oil Corp. v. State Bd. of Equalization, 329 U. S. 69, 75-76 (1946) (distinguishing accommodations made under the Commerce Clause from the express textual prohibition of the Import-Export Clause)" (517 U.S. 851 - 852). 
ao passo que os empregados na "The Export Clause", "Tax or Duty", por terem alcance mais amplo, aberto, especialmente o termo "Tax", acarretariam uma restrição maior. Tal ponto, embora de grande relevância jurisprudencial, não é de maior interesse dentro do desenvolvimento do raciocínio jurídico que aqui se quer alcançar.

Importante mesmo é apontar que o caso United States v. International Business Machines Corp. terminou por concluir que a "The Export Clause" não permite a instituição de incidências tributárias, mesmo que sejam não-discriminatórias, que se apliquem a mercadorias que se encontrem em trânsito para a exportação ${ }^{515}$.

Outro importante ponto referente aos condicionamentos constitucionais ao poder de tributar federal, embora hoje seja apenas uma reminiscência histórica, decorre da redação originária da Cláusula 3 do Parágrafo 2 do Artigo $I^{516}$. Nela se determinava que a instituição de tributos diretos dependeria de determinação da repartição ${ }^{517}$ das respectivas receitas em rigorosa proporcionalidade com a população livre do país, excluindo escravos e incluindo os indígenas não tributados e os conscritos. Corroborando essa determinação, a Cláusula 4 do Parágrafo 9 também do Artigo ${ }^{518}$ reforçava o fato de que tal condição era condicionante prévia para a regularidade da incidência tributária.

Em função dessas normas legais, hoje ambas derrogadas, percebe-se na atividade inicial da Suprema Corte uma preocupação em estabelecer o que seriam os impostos diretos a serem abrangidos por essa condição constitucionalmente imposta.

Nos primeiros casos a Suprema Corte sinalizou para um entendimento de que impostos diretos seriam aqueles incidentes sobre a propriedade imóvel. Assim, qualquer outro tributo que não tivesse essa característica estaria dispensado de obedecer a essa condição de pré-determinação da repartição tributária. Por exemplo, pode-se mencionar o importantíssimo caso Hylton v. United States ${ }^{519}$, de 1796.

Daniel Lawrence Hylton era um milionário que possuía 125 carruagens para o seu uso próprio em 1794 (alegava não empregá-las para locação), quando, em 6 de junho,

\footnotetext{
515 "Thus, contrary to the Government's contention, this Court's Import-Export Clause cases have not upheld the validity of generally applicable, nondiscriminatory taxes that fall on imports or exports in transit. We think those cases leave us free to follow the express textual command of the Export Clause to prohibit the application of any tax "laid on Articles exported from any State." We conclude that the Export Clause does not permit assessment of nondiscriminatory federal taxes on goods in export transit" (517 U.S. 862 - 863).

516 "Representatives and direct Taxes shall be apportioned among the several States which may be included within this Union, according to their respective Numbers, which shall be determined by adding to the whole Number of free Persons, including those bound to Service for a Term of Years, and excluding Indians not taxed, three fifths of all other Persons".

${ }^{517}$ Apportionment, no original em inglês.

518 "No capitation, or other direct, Tax shall be laid, unless in Proportion to the Census or Enumeration herein before directed to be taken".

5193 U.S. 171 (1796).
} 
uma lei do Congresso nacional tributou a propriedade de carruagens particulares para o transporte de pessoas, a um valor fixo de US\$ 16,00 por carruagem. Alegou que o tributo seria direto e não preveria a sua repartição entre os estados, motivo de sua inconstitucionalidade.

O cerne da questão trazida a juízo, no entender do Justice William Patterson, no que foi acompanhado pelos demais cinco membros da Suprema Corte, era saber qual a natureza jurídica do imposto em questão: se um imposto direto, dependente de prévia regra de repartição de receitas, ou indireto, tendo que obedecer à regra da uniformidade entre os estados $?^{520} \mathrm{O}$ julgamento faz uma interessante consideração acerca da turbulenta (até hoje) conceituação do que seja um imposto direto, inclusive mediante o emprego da então recente lição de Adam Smith a respeito ${ }^{521}$. Não obstante, não vale distrair o nosso foco para esse exame. Importante é asseverar que a decisão final da Suprema Corte foi a manifestação jurisprudencial pioneira em se referir a condições de competitividade entre os estados, terminando por concluir que um tributo incidente sobre carruagens, da natureza do analisado, não poderia ser um tributo direto ${ }^{522}$.

\footnotetext{
520 "By the second section of the first article of the Constitution of the United States it is ordained that representatives and direct taxes shall be apportioned among the states according to their respective numbers, which shall be determined by adding to the whole number of free persons, including those bound to service for a term of years, and including Indians not taxed, three fifths of all other persons.

The eighth section of the said article declares that Congress shall have power to lay and collect taxes, duties, imposts, and excises, but all duties, imposts and excises, shall be uniform throughout the United States.

The ninth section of the same article provides that no capitation or other direct tax shall be laid unless in proportion to the census or enumeration before directed to be taken.

Congress passed a law on 5 June, 1794, entitled, "An act laying duties upon carriages for the conveyance of persons."

Daniel Lawrence Hilton, on 5 June, 1794, and therefrom to the last day of September next following, owned, possessed, and kept one hundred and twenty-five chariots for the conveyance of persons, but exclusively for his own separate use, and not to let out to hire, or for the conveyance of persons for hire.

The question is whether a tax upon carriages be a direct tax? If it be a direct tax, it is unconstitutional, because it has been laid pursuant to the rule of uniformity, and not to the rule of apportionment. In behalf of the plaintiff in error, it has been urged that a tax on carriages does not come within the description of a duty, impost, or excise, and therefore is a direct tax. It has, on the other hand, been contended that as a tax on carriages is not a direct tax, it must fall within one of the classifications just enumerated, and particularly must be a duty or excise. The argument on both sides turns in a circle; it is not a duty, impost, or excise, and therefore must be a direct tax; it is not tax, and therefore must be a duty or excise. What is the natural and common, or technical and appropriate, meaning of the words "duty" and "excise" it is not easy to ascertain. They present no clear and precise idea to the mind. Different persons will annex different significations to the terms" (3 U. S. 175 - 176).

${ }^{521}$ Como se sabe, a primeira edição do "An Inquiry into the Nature and Causes of the Wealth of Nations" data de 1776.

522 "The truth is that the articles taxed in one state should be taxed in another; in this way the spirit of jealousy is appeased and tranquility preserved; in this way the pressure on industry will be equal in the several states, and the relation between the different subjects of taxation duly preserved. Apportionment is an operation on states, and involves valuations and assessments which are arbitrary and should not be resorted to but in case of necessity. Uniformity is an instant operation on individuals, without the intervention of assessments or any regard to states, and is at once easy, certain, and efficacious. All taxes on expenses or consumption are indirect taxes. A tax on carriages is of this kind, and of course is not a direct tax. Indirect
} 
Outro Justice que se manifestou, em votação que, diferentemente do comum, apresentou diversas proclamações de voto ${ }^{523}$, foi James Iredell, que, usando exemplos numéricos, afirmou que o tributo em análise não poderia ser distribuído em proporção à população, pelo que logicamente não poderia ser considerado um imposto direto ${ }^{524}$.

Logo após a abolição da escravatura, com a promulgação, em 6 de dezembro de 1865, da Décima-Terceira Emenda, percebeu-se a necessidade de alterar a redação da Cláusula 3 do Parágrafo 2 do Artigo I, o que só veio a se realizar com a Décima-Quarta Emenda, de 9 de julho de 1868, por meio da qual se retirou a referência à matéria tributária na sua disciplina, que passou a tratar apenas do aspecto eleitoral. No entanto, permanecia a restrição da Cláusula 4 do Parágrafo 9 do Artigo I. Assim, manteve-se a necessidade de tratar da classificação dos tributos em sede jurisprudencial.

taxes are circuitous modes of reaching the revenue of individuals, who generally live according to their income" (3 U. S. 180).

523 O caso Hylton v. United States possui diversas particularidades interessantes. Uma é o fato de haver diversas proclamações de voto, no sistema chamado de seriatim opinions. Também porque se trata do primeiro caso julgado pela Suprema Corte americana em que se aplicou o que se convencionou chamar de "Judicial Review Power" - o poder das cortes federais em analisar a constitucionalidade das leis federais e estaduais ou os atos administrativos dos respectivos poderes executivos (CHEMERINSKY, 2006, p. 37). Embora seja comum, especialmente aqui na doutrina constitucional do Brasil, atribuir esse ineditismo ao caso Marbury v. Madison, 5 U.S. 137 (1803), tal afirmação não é verdadeira. O que ocorre é que o caso de 1803 foi o primeiro em que se declarou a inconstitucionalidade de uma lei federal. Portanto, para empregar pela primeira vez o poder efetivamente, houve a necessidade de se entender o seu alcance. A esse respeito, consultar FRANKEL JR., Robert P. Before Marbury: Hylton v. United States and the Origins of Judicial Review. Journal of Supreme Court History. Washington: Wiley, Vol. 28, Issue 1, mar 2003, p. 1 - 13. O caso também se notabilizou porque a sustentação oral em nome do governo federal foi realizada por Alexandre Hamilton, para uma das maiores plateias em uma sessão de julgamento da história da corte.

524 "As all direct taxes must be apportioned, it is evident that the Constitution contemplated none as direct but such as could be apportioned.

If this cannot be apportioned, it is therefore not a direct tax in the sense of the Constitution.

That this tax cannot be apportioned is evident. Suppose $\$ 10$ contemplated as a tax on each chariot, or post chaise, in the United States, and the number of both in all the United States be computed at 105, the number of Representatives in Congress.

This would produce in the whole \$1,050.

The share of Virginia being 19/105 parts, would be $\$ 190$.

The share of Connecticut being 7/105 parts, would be $\$ 70$.

Then suppose Virginia had 50 carriages, Connecticut 2.

The share of Virginia being \$190, this must of course be collected from the owners of carriages, and there would therefore be collected from each carriage $\$ 3.80$.

The share of Connecticut being \$70, each carriage would pay $\$ 35$.

If any state had no carriages, there could be no apportionment at all. This mode is too manifestly absurd to be supported, and has not even been attempted in debate.

But two expedients have been proposed of a very extraordinary nature, to evade the difficulty.

1. To raise the money a tax on carriages would produce not by laying a tax on each carriage uniformly, but by selecting different articles in different states, so that the amount paid in each state may be equal to the sum due upon a principle of apportionment. One state might pay by a tax on carriages, another by a tax on slaves, etc.

I should have thought this merely an exercise of ingenuity if it had not been pressed with some earnestness, and as this was done by gentlemen of high respectability in their possession, it deserves a serious answer, though it is very difficult to give such a one.

1. This is not an apportionment of a tax on Carriages, but of the money a tax on carriages might be supposed to produce, which is quite a different thing" (3 U. S. 181 -182). 
A tendência dos primeiros julgamentos da Suprema Corte foi a de garantir a constitucionalidade das incidências tributárias. Por exemplo, em Veazie Bank v. Fenno ${ }^{525}$, um tributo federal, criado em 1866, exigido aos bancos nacionais ou estaduais, sobre o montante dos títulos colocados em circulação e pagos após $1^{\circ}$ de agosto de 1866, à alíquota de $10 \%$ do valor de face, não foi considerado um imposto direto nos termos da Constituição. Nesse julgamento, apreciado por maioria de votos, o relator, o Chief Justice Salmon Chase, esclareceu que impostos diretos só poderiam ser considerados os incidentes sobre a propriedade e outros direitos reais sobre a terra e impostos sobre a pessoa física ${ }^{526}$. Essa visão foi confirmada no caso Springer v. United States ${ }^{527}$, em que, por incrível que isso possa parecer a nós, o recémcriado imposto de renda federal, pelo Revenue Act de 5 de agosto de $1861^{528}$, a primeira versão de imposto dessa natureza nos Estados Unidos da América, instituído para fazer frente ao esforço financeiro com a guerra civil e que só vigeu durante os anos de 1866 a 1872 (por isso mais conhecido como Civil War Income Tax), foi entendido, pelo Justice Noah Swayne, como não sendo um tributo direto $^{529}$.

Revogado (pelo legislativo) em 1871, o imposto de renda federal só veio a ser novamente instituído pelo Wilson-Gorman Tariff Act de 1894, como forma de compensar a

\footnotetext{
52575 U.S. 533 (1869).

526 "The fact, then, that slaves were valued, under the acts referred to, far from showing, as some have supposed, that Congress regarded personal property as a proper object of direct taxation under the Constitution, shows only that Congress, after 1798, regarded slaves, for the purposes of taxation, as realty. It may be rightly affirmed, therefore, that in the practical construction of the Constitution by Congress, direct taxes have been limited to taxes on land and appurtenances and taxes on polls or capitation taxes.

And this construction is entitled to great consideration, especially in the absence of anything adverse to it in the discussions of the Convention which framed and of the conventions which ratified the Constitution (75 U. S. $543-544)$.

527102 U.S. 586 (1880).

${ }^{528}$ Inicialmente em valor fixo, passando a ser progressivo com o valor da renda, sua base de cálculo, a partir do Revenue Act de $1^{\circ}$ de julho de 1862 , com alíquotas de $3 \%$ ou $5 \%$ e retenção na fonte sobre os salários dos empregados, pela primeira vez na história, com vigência temporária até 1866.

529 "The question, what is a direct tax, is one exclusively in American jurisprudence. The text writers of the country are in entire accord upon the subject.

Mr. Justice Story says all taxes are usually divided into two classes -- those which are direct and those which are indirect -- and that "under the former denomination are included taxes on land or real property, and, under the latter, taxes on consumption." 1 Const., sec. 950.

Chancellor Kent, speaking of the case of Hylton v. United States, says: "The better opinion seemed to be that the direct taxes contemplated by the Constitution were only two, viz., a capitation or poll tax and a tax on land." 1 Com. 257. See also Cooley, Taxation, p. 5, note 2; Pomeroy, Const.Law 157; Sharswood's Blackstone 308, note; Rawle, Const. 30; Sergenat, Const. 305.

We are not aware that any writer, since Hylton v. United States was decided, has expressed a view of the subject different from that of these authors.

Our conclusions are, that direct taxes, within the meaning of the Constitution, are only capitation taxes, as expressed in that instrument, and taxes on real estate; and that the tax of which the plaintiff in error complains is within the category of an excise or duty. Pomeroy, Const.Law, 177; Pacific Insurance Co. v. Soule, and Scholey v. Rew, supra" (102 U.S. 602).
} 
redução de receita tributária com o imposto de importação decorrente da redução das suas alíquotas aos patamares do McKinley Tariff Act de 1890. Previa a alíquota de $2 \%$ para receitas anuais maiores do que US\$ 4.000. No entanto, foi declarado inconstitucional, por maioria de cinco votos contra quatro, no julgamento do caso Pollock v. Farmers' Loan \& Trust $C_{0}{ }^{530}$, já referido, que, embora tenha chegado a resultado diferenciado, usou a mesma linha de raciocínio de Hylton $v$. United States e Springer v. United States.

Charles Pollock, cidadão do estado de Massachusetts, assim como outros acionistas, ajuizaram a ação contra Farmers' Loan and Trust Company e seus diretores, uma companhia, situada em New York, voltada à administração de bens de terceiros, cujos ativos montavam a mais de cinco milhões de dólares, dos quais pelo menos um milhão deles em propriedades imóveis. Sua fundamentação, no que mais nos interessa, tinha por supedâneo o fato de que um imposto sobre renda, incluindo receitas oriundas da propriedade de bens imóveis, como a de alugueis, equivale a um tributo incidente sobre a propriedade real ela própria - portanto, um imposto direto que necessita ser repartido com os estados para ser constitucional.

$\mathrm{O}$ voto condutor, do Chief Justice Melville Fuller, inclusive com remissão à Common Law inglesa, acatou plenamente os argumentos da parte autora originária ${ }^{531}$.

\footnotetext{
${ }^{530} 157$ U.S. 429 (1895).

531 "The Constitution accordingly, when completed, divided the taxes which might be levied under the authority of Congress into those which were direct and those which were indirect. Direct taxes, in a general and large sense, may be described as taxes derived immediately from the person, or from real or personal property, without any recourse therefrom to other sources for reimbursement. In a more restricted sense, they have sometimes been confined to taxes on real property, including the rents and income derived therefrom. Such taxes are conceded to be direct taxes, however taxes on other property are designated, and they are to be apportioned among the States of the Union according to their respective numbers. The second section of article I of the Constitution declares that representatives and direct taxes shall be thus apportioned. It had been a favorite doctrine in England and in the colonies, before the adoption of the Constitution, that taxation and representation should go together. The Constitution prescribes such apportionment among the several States according to their respective numbers, to be determined by adding to the whole number of free persons, including those bound to service for a term of years, and excluding Indians not taxed, three-fifths of all other persons.

Some decisions of this court have qualified or thrown doubts upon the exact meaning of the words "direct taxes." Thus, in Springer v. United States, 102 U. S. 586, it was held that a tax upon gains, profits, and income was an excise or duty, and not a direct tax within the meaning of the Constitution, and that its imposition was not therefore unconstitutional. And in Pacific Insurance Co. v. Soule, 7 Wall. 433, it was held that an income tax or duty upon the amounts insured, renewed or continued by insurance companies, upon the gross amounts of premiums received by them and upon assessments made by them, and upon dividends and undistributed sums, was not a direct tax, but a duty or excise.

In the discussions on the subject of direct taxes in the British Parliament, an income tax has been generally designated as a direct tax, differing in that respect from the decision of this court in Springer v. United States. But whether the latter can be accepted as correct or otherwise, it does not affect the tax upon real property and its rents and income as a direct tax. Such a tax is by universal consent recognized to be a direct tax.

As stated, the rents and income of real property are included in the designation of direct taxes as part of the real property. Such has been the law in England for centuries, and in this country from the early settlement of the colonies, and it is strange that any member of the legal profession should, at this day, question a
} 
Declarado inconstitucional, em 1895, o Imposto de Renda federal americano apenas pode ser reinstituído com o advento, em 3 de fevereiro de 1913, da Décima-Sexta Emenda à Constituição, que eliminou a exigência de distribuição das receitas com os estados para a instituição de tributos, pela União, que incidam sobre a renda ${ }^{532}$.

A questão da distinção entre tributos diretos e indiretos, com isso, perdeu sua importância, até porque jamais houve a intenção, por parte do poder legislativo federal, em instituir impostos incidentes sobre a propriedade. No entanto, a riqueza dos argumentos empregados nas contendas jurisprudenciais anteriores a 1895 é demonstrativa de um dos aspectos mais relevantes da disciplina do poder de tributar pela Constituição norteamericana.

Há duas questões acerca do poder de tributar que decorrem unicamente de construções jurisprudenciais.

A primeira é a restrição ao emprego do poder de tributar como penalidade pela ilicitude do ato. No caso Bailey v. Drexel Furniture Co. ${ }^{533}$, também conhecido como Child Labor Tax Case, decidiu-se que o tributo incidente a $10 \%$ sobre as rendas empresariais obtidas por meio do emprego de mão-de-obra de adolescentes de menos de quatorze anos ou, se entre quatorze e dezesseis anos, por mais de oito horas por dia ou no horário noturno, o Tax on Employment of Child Labor, previsto no Revenue Act de 1919, foi declarado inconstitucional pela diferenciação empreendida pelo Chief Justice William Taft entre o tributo - nos quais o efeito regulatório apenador pode ser meramente incidental - e

doctrine which has always been thus accepted by common law lawyers. It is so declared in approved treatises upon real property and in accepted authorities on particular branches of real estate law, and has been so announced in decisions in the English courts and our own courts without number" (157 U. S. 588 589).

532 "The Congress shall have power to lay and collect taxes on incomes, from whatever source derived, without apportionment among the several States, and without regard to any census or enumeration".

533259 U.S. 20 (1922). 
a penalidade ${ }^{534}$. Semelhantes considerações foram desenvolvidas nos casos Hill $v$. Wallace $^{535}$ e United States v. Constantine ${ }^{536}$.

Situação radicalmente diferente, embora as fundamentações jurisprudenciais sejam de certo modo assemelhadas aos casos de tributos como penalidade, refere-se à verificação de algum caráter extrafiscal (dito pela doutrina norteamericana CHEMERINSKY, 2006, p. 276 - 278 como regulatório) na incidência tributária - a intenção de induzir os particulares a algum tipo de atitude desejada pelo legislador, ou a dissuadi-los, sendo o comportamento entendido como deletério.

No caso McCray v. United States ${ }^{537}$, um fabricante de margarinas de Ohio insurgiu-se contra o Oleomargarine Act de 1886, na redação alterada em 1902, que impunha um tributo, do tipo excise tax, tributo indireto específico, de US\$ 0,10 por libra sobre as margarinas artificialmente coloridas de amarelo, com o fim de terem a aparência de manteiga. No seu voto, o então Associate Justice Edward Douglass White Jr., posteriormente Chief Justice, expressa seu entendimento de que os efeitos da norma não podem ser considerados, como seria a restrição ou a inviabilização da manufatura de margarinas artificialmente coloridas, uma vez que não há qualquer restrição no texto constitucional a essa produção secundária de efeitos, que não o mero auferimento de receitas fiscais ${ }^{538}$.

\footnotetext{
534 "The difference between a tax and a penalty is sometimes difficult to define, and yet the consequences of the distinction in the required method of their collection often are important. Where the sovereign enacting the law has power to impose both tax and penalty, the difference between revenue production and mere regulation may be immaterial, but not so when one sovereign can impose a tax only, and the power of regulation rests in another. Taxes are occasionally imposed in the discretion of the legislature on proper subjects with the primary motive of obtaining revenue from them and with the incidental motive of discouraging them by making their continuance onerous. They do not lose their character as taxes because of the incidental motive. But there comes a time in the extension of the penalizing features of the so-called tax when it loses its character as such and becomes a mere penalty with the characteristics of regulation and punishment. Such is the case in the law before us. Although Congress does not invalidate the contract of employment or expressly declare that the employment within the mentioned ages is illegal, it does exhibit its intent practically to achieve the latter result by adopting the criteria of wrongdoing and imposing its principal consequence on those who transgress its standard" (259 U.S. 38).

${ }_{535} 259$ U.S. 44 (1922).

536296 U.S. 287 (1935).

537 195 U.S. 27 (1904).

538 "Undoubtedly, in determining whether a particular act is within a granted power, its scope and effect are to be considered. Applying this rule to the acts assailed, it is self-evident that, on their face, they levy an excise tax. That being their necessary scope and operation, it follows that the acts are within the grant of power. The argument to the contrary rests on the proposition that, although the tax be within the power, as enforcing it will destroy or restrict the manufacture of artificially colored oleomargarine, therefore the power to levy the tax did not obtain. This, however, is but to say that the question of power depends not upon the authority conferred by the Constitution, but upon what may be the consequence arising from the exercise of the lawful authority.

Since, as pointed out in all the decisions referred to, the taxing power conferred by the Constitution knows no limits except those expressly stated in that instrument, it must follow, if a tax be within the lawful power, the
} 
Tal entendimento foi seguido nos casos United States v. Doremus ${ }^{539}$, acerca do tributo, instituído pelo Narcotic Drug Act de 1914, sobre a produção, importação ou industrialização de ópio e de coca ou de seus derivados ou componentes; Sonzinsky v. United States $^{540}$, sobre a taxa anual, criada pelo National Firearms Act de 1934, exigida dos comerciantes de armas; e United States v. Kahriger ${ }^{541}$, sobre a incidência, prevista no Revenue Act de 1951 (informalmente conhecido como Gamblers' Occupational Tax Act), de uma tributação, também anualmente exigida, sobre as pessoas que prestassem o serviço de aceitar apostas. Todas essas incidências foram consideradas constitucionais.

Semelhantes às discussões jurisprudenciais, aqui resumidas, acerca do poder de tributar, também foram desenvolvidas, ao longo da história, considerações sobre o outro lado do exercício do poder de tributar previsto na Cláusula 1 do Parágrafo 8 do Artigo I, que consiste no poder de despender. Vale dizer, a faculdade de a União fazer frente a despesas sem depender de requisições aos estados, como no tempo do Articles of Confederation, que gerou a necessidade de definir a competência tributária federal, como ensina David Engdahl (1987, p. 162 - 163), também fez suscitar em Alexander Hamilton a preocupação com a imprevisibilidade da antecipação com precisão do montante das despesas necessárias às obrigações conferidas ao poder federal, com o que também não poderia haver o confinamento orçamentário do poder executivo.

As normas que o condicionam, ensina Engdahl, são fundamentalmente a já mencionada Cláusula 1 do Parágrafo 8 do Artigo I, especialmente pelo uso do termo "pay the Debts"; a também já referida Cláusula 7 do Parágrafo 9 do Artigo I ("No Money shall be drawn from the Treasury, but in Consequence of Appropriations made by Law; and a regular Statement and Account of the Receipts and Expenditures of all public Money shall be published from time to time") e a Cláusula 2 do Parágrafo 3 do Artigo $\mathrm{IV}^{542}$, especialmente no que tange ao poder de dispor da propriedade pertencente aos Estados

exertion of that power may not be judicially restrained because of the results to arise from its exercise" (195 U.S. 59).

${ }_{539} 249$ U.S. 86 (1919).

540300 U.S. 506 (1937).

541345 U.S. 22 (1953).

542 "Section 3 - New States

New States may be admitted by the Congress into this Union; but no new States shall be formed or erected within the Jurisdiction of any other State; nor any State be formed by the Junction of two or more States, or parts of States, without the Consent of the Legislatures of the States concerned as well as of the Congress.

The Congress shall have Power to dispose of and make all needful Rules and Regulations respecting the Territory or other Property belonging to the United States; and nothing in this Constitution shall be so construed as to Prejudice any Claims of the United States, or of any particular State". 
Unidos ("The Congress shall have Power to dispose of (...) other Property belonging to the United States").

A adequação desses termos normativos a diversas modalidades de incentivos fiscais e subsídios proporcionados pelo governo federal e a conformação de ambos ao objetivo de bem-estar geral da Cláusula 1 do Parágrafo 8 do Artigo I tem sido objeto de caudalosa produção jurisprudencial pela Suprema Corte ao longo dos anos, em quantidade até maior do que a desenvolvida sobre o poder de tributar. Não obstante, por não ser nosso foco de estudo, a sua existência será apenas ora mencionada, e não estudada com alguma profundidade, como feito anteriormente em relação ao aspecto da incidência tributária.

\subsection{Da "The Commerce Clause".}

Agora devemos nos ater a entender qual tem sido, ao longo da história, a compreensão jurisprudencial da disciplina da Cláusula 3 do Parágrafo 8 do Artigo I, a chamada "The Commerce Clause", a partir da compreensão do alcance da expressão "The Congress shall have Power To regulate Commerce with foreign Nations, and among the several States, and with the Indian Tribes". Trata-se, no escólio de Erwin Chemerinsky (2006, p. 242), não só da mais importante cláusula entre as dezoito referentes aos poderes do legislativo federal, como também a que implica a mais rica gama de concepções teóricas, a partir de um conjunto de julgados da Suprema Corte que supera em muito, em termos de número, complexidade e variedade, qualquer outro tema que se refira aos poderes legislativos nas diferentes esferas e ao federalismo.

Por conta dos seus três planos de aplicação, a "The Commerce Clause" também tem sido usualmente referida simultaneamente como "The Foreign Commerce Clause", "The Interstate Commerce Clause", e "The Indian Commerce Clause", sendo a questão interestadual a que, também por sua dificuldade e multiplicidade, mais tem comportado discussões doutrinárias e jurisprudenciais ao longo dos anos.

Já foi aqui ressaltado que, ao menos no que interessa ao estudo do que consista o Princípio de Não-Discriminação na ótica do direito norteamericano, o estudo da "The Commerce Clause" é de suma relevância para se compreender dois conceitos fundamentais para se rastrear o caminho histórico pelo qual foi sendo construída jurisprudencialmente a autoridade federal em impedir o exercício da competência tributária 
estadual nociva aos interesses na manutenção da União: i) no que consiste o "comércio" cujo poder de regular é constitucionalmente deferido ao legislativo federal; ii) o que o legislador constituinte quis dizer com o termo "among the several States"; ou seja, o que caracteriza uma operação como interestadual a ponto de poder ser objeto de análise pela cláusula.

Resumindo as questões, Erwin Chemerinsky (2006, p. 243), aponta didaticamente três questões que, ao longo de sua história, foram objeto de análise pela Suprema Corte, no exame da "The Commerce Clause".

Primeiramente, o conceito de comércio consiste apenas na compra e venda de mercadorias ou se inclui diferentes aspectos da vida negocial privada? Em segundo lugar, quando se pode considerar que a transação comercial é interestadual, se apenas no caso em que há ultrapassagem de fronteiras físicas, ou se há de alguma maneira influência na atividade econômica de estados vizinhos? Por último, se, a partir da inteleção da Décima Emenda, com o poder de polícia genericamente considerado delegados aos estados, há algum limite para o poder do Congresso em matéria de comércio interestadual e qual o alcance possível da normatização federal?

Tais questões, assim como uma quarta, vieram a exame, apenas cinco anos após McCulloch v. Maryland, quando da apreciação do caso Gibbons v. Ogden ${ }^{543}$, também em um voto do Chief Justice John Marshall, acompanhado por quatro dos seus pares, com um voto contrário e uma abstenção.

No início do Século XIX, Aaron Ogden adquiriu o direito de operar os serviços de transporte por navio a vapor entre as cidades de Nova York e Elizabethtown (atualmente Elizabeth), assim como de outros portos em New Jersey, a partir da licença concedida por Robert R. Livingston e Robert Fulton, a quem havia sido garantido o monopólio para a exploração exclusiva do serviço pelas leis do estado de New York, em todas as águas territoriais daquele estado. Thomas Gibbons já mantinha, por meio de dois barcos a vapor, o serviço de transporte entre Nova York e Elizabethtown. Portanto, aparentemente em violação ao privilégio exclusivo conferido pelo estado.

A defesa de Gibbons se baseava em uma lei federal, de 18 de fevereiro de 1793, cuja rubrica ${ }^{544}$ mencionava o licenciamento de embarcações para a navegação costeira (de cabotagem), e que, segundo ele, regularizava a sua atividade econômica nas águas do

\footnotetext{
54322 U.S. 1 (1824).

544 "An act for enrolling and licensing ships and vessels to be employed in the coasting trade and fisheries, and for regulating the same."
} 
estado de New York, uma vez que as barcas de sua propriedade estavam legalizadas segundo o que determinava a norma federal.

Como estabelecido no julgamento ${ }^{545}$, o que estava em questão era, na esteira dos três pontos já mencionados, fundamentalmente, se o poder de regular o comércio se estendia para a regulação da navegação; se o poder de regular o comércio poderia alcançar todas as espécies de intercursos entre os Estados Unidos e as nações estrangeiras e entre os diversos estados; se o poder de regular o comércio é geral, sem limitações em relação ao que é prescrito pela Constituição; e se o poder de regular o comércio é exclusivo da União, nada restando a ser exercido pelos estados.

Entre essas, como já vimos, nos interessam por enquanto as duas primeiras indagações e, como veremos no item seguinte, a quarta. As diferentes respostas à terceira pergunta consistem exatamente no sentido da "The Commerce Clause". A discussão quanto à quarta é o fundamento conceitual do entendimento quanto à "The Dormant Commerce Clause", nosso objeto principal de estudo, a ser desenvolvido adiante.

Quanto à primeira, que consiste no significado do termo "commerce", diante da alegação da parte autora da demanda originária, então apelada, Aaron Ogden, de que deveria se restringir ao tráfego, à compra e à venda, ou ao intercâmbio de commodities, jamais à navegação, Justice Marshall retrucou afirmando que essa visão seria demasiado restritiva a um termo geral, limitando-o a apenas uma das suas possibilidades de significação. Para o relator, comércio é também, decerto, tráfego, mas é mais, é o intercâmbio. É a circulação econômica entre nações e partes delas, que deve ser regulada

\footnotetext{
545 "The laws of New York granting to Robert R. Livingston and Robert Fulton the exclusive right of navigating the waters of that State with steamboats are in collision with the acts of Congress regulating the coasting trade, which, being made in pursuance of the Constitution, are supreme, and the State laws must yield to that supremacy, even though enacted in pursuance of powers acknowledged to remain in the States.

The power of regulating commerce extends to the regulation of navigation.

The power to regulate commerce extends to every species of commercial intercourse between the United States and foreign nations, and among the several States. It does not stop at the external boundary of a State. But it does not extend to a commerce which is completely internal.

The power to regulate commerce is general, and has no limitations but such as are prescribed in the Constitution itself.

The power to regulate commerce, so far as it extends, is exclusively bested in Congress, and no part of it can be exercised by a State.

A license under the acts of Congress for regulating the coasting trade gives a permission to carry on that trade.

State inspection laws, health laws, and laws for regulating the internal commerce of a State, and those which respect turnpike roads, ferries, \&c. are not within the power granted to Congress.

The license is not merely intended to confer the national character.

The power of regulating commerce extends to navigation carried on by vessels exclusively employed in transporting passengers.

The power of regulating commerce extends to vessels propelled by steam or fire as well as to those navigated by the instrumentality of wind and sails" (22 U.S. 1).
} 
por normas que visem à manutenção desse intercâmbio. Nessa perspectiva, jamais poderia excluir as normas concernentes à navegação, especialmente no que tange às eventuais proibições de uma embarcação adentrar águas de uma determinada jurisdição, já que isso implicaria negar a ingerência da legislação federal nessa esfera de atuação legislativa ${ }^{546}$. Em outras palavras, para Chemerinsky (2006, p. 244), o termo "commerce" deve incluir todas as etapas de negócio, incluindo o transporte e a navegação, o objeto do exame no caso concreto.

Em seguida, há que ser indagado qual o significado do termo "among the states", Justice Marshall afirmou que retrucou que o termo deve significar entremeado entre, de forma que não deva ficar restrito às linhas fronteiriças exteriores de cada estado, mas sim que deve ser estendido até seu interior se em direção a ele se dirija. Isso não quer dizer que deva ser exageradamente elastecido até o comércio que seja completamente interno. O que importa é o fato de que a operação comercial interesse a mais de um estado, ou que tenha o potencial de afetar ou não outros estados, ou sua população ${ }^{547}$.

\footnotetext{
546 "The words are, "Congress shall have power to regulate commerce with foreign nations, and among the several States, and with the Indian tribes."

The subject to be regulated is commerce, and our Constitution being, as was aptly said at the bar, one of enumeration, and not of definition, to ascertain the extent of the power, it becomes necessary to settle the meaning of the word. The counsel for the appellee would limit it to traffic, to buying and selling, or the interchange of commodities, and do not admit that it comprehends navigation. This would restrict a general term, applicable to many objects, to one of its significations. Commerce, undoubtedly, is traffic, but it is something more: it is intercourse. It describes the commercial intercourse between nations, and parts of nations, in all its branches, and is regulated by prescribing rules for carrying on that intercourse. The mind can scarcely conceive a system for regulating commerce between nations which shall exclude all laws concerning navigation, which shall be silent on the admission of the vessels of the one nation into the ports of the other, and be confined to prescribing rules for the conduct of individuals in the actual employment of buying and selling or of barter.

If commerce does not include navigation, the government of the Union has no direct power over that subject, and can make no law prescribing what shall constitute American vessels or requiring that they shall be navigated by American seamen. Yet this power has been exercised from the commencement of the government, has been exercised with the consent of all, and has been understood by all to be a commercial regulation. All America understands, and has uniformly understood, the word "commerce" to comprehend navigation. It was so understood, and must have been so understood, when the Constitution was framed. The power over commerce, including navigation, was one of the primary objects for which the people of America adopted their government, and must have been contemplated in forming it. The convention must have used the word in that sense, because all have understood it in that sense, and the attempt to restrict it comes too late" (22 U. S. 189 - 190).

547 "To what commerce does this power extend? The Constitution informs us, to commerce "with foreign nations, and among the several States, and with the Indian tribes."

It has, we believe, been universally admitted that these words comprehend every species of commercial intercourse between the United States and foreign nations. No sort of trade can be carried on between this country and any other to which this power does not extend. It has been truly said that "commerce," as the word is used in the Constitution, is a unit every part of which is indicated by the term.

If this be the admitted meaning of the word in its application to foreign nations, it must carry the same meaning throughout the sentence, and remain a unit, unless there be some plain intelligible cause which alters it.

The subject to which the power is next applied is to commerce "among the several States." The word "among" means intermingled with. A thing which is among others is intermingled with them. Commerce
} 
Daí se pode concluir que o próprio exame dessa questão preliminar, quanto ao fato de a operação comercial em análise ser ou não interestadual demanda uma avaliação caso a caso, até para que a Suprema Corte, como ensina Chemerinsky (2006, p. 245), avalie o quão diretos e substanciais tais efeitos, na esfera jurídica de outro estado ou da população de outros estados, deverão ser, para poderem ser submetidos ao escrutínio constitucional.

Essa questão, assim como a resposta à pergunta se o poder federal de regular o comércio é geral, sem limitações em relação ao que é prescrito pela Constituição, diante da intelecção da Décima Emenda, essa última que é o núcleo da análise da "The Commerce Clause", são pontos que têm sido enfrentados de forma diferenciada ao longo da história constitucional norteamericana, representando diferentes posições jurídicas e ideológicas em relação às questões colocadas pelo voto pioneiro de John Marshall, no exame do caso Gibbons v. Ogden, de 1824. Nesse próprio voto, quando teve que enfrentar a questão do

among the States cannot stop at the external boundary line of each State, but may be introduced into the interior.

It is not intended to say that these words comprehend that commerce which is completely internal, which is carried on between man and man in a State, or between different parts of the same State, and which does not extend to or affect other States. Such a power would be inconvenient, and is certainly unnecessary.

Comprehensive as the word "among" is, it may very properly be restricted to that commerce which concerns more States than one. The phrase is not one which would probably have been selected to indicate the completely interior traffic of a State, because it is not an apt phrase for that purpose, and the enumeration of the particular classes of commerce to which the power was to be extended would not have been made had the intention been to extend the power to every description. The enumeration presupposes something not enumerated, and that something, if we regard the language or the subject of the sentence, must be the exclusively internal commerce of a State. The genius and character of the whole government seem to be that its action is to be applied to all the external concerns of the nation, and to those internal concerns which affect the States generally, but not to those which are completely within a particular State, which do not affect other States, and with which it is not necessary to interfere for the purpose of executing some of the general powers of the government. The completely internal commerce of a State, then, may be considered as reserved for the State itself. But, in regulating commerce with foreign nations, the power of Congress does not stop at the jurisdictional lines of the several States. It would be a very useless power if it could not pass those lines. The commerce of the United States with foreign nations is that of the whole United States. Every district has a right to participate in it. The deep streams which penetrate our country in every direction pass through the interior of almost every State in the Union, and furnish the means of exercising this right. If Congress has the power to regulate it, that power must be exercised whenever the subject exists. If it exists within the States, if a foreign voyage may commence or terminate at a port within a State, then the power of Congress may be exercised within a State.

This principle is, if possible, still more clear, when applied to commerce "among the several States." They either join each other, in which case they are separated by a mathematical line, or they are remote from each other, in which case other States lie between them. What is commerce "among" them, and how is it to be conducted? Can a trading expedition between two adjoining States, commence and terminate outside of each? And if the trading intercourse be between two States remote from each other, must it not commence in one, terminate in the other, and probably pass through a third? Commerce among the States must, of necessity, be commerce with the States. In the regulation of trade with the Indian tribes, the action of the law, especially when the Constitution was made, was chiefly within a State. The power of Congress, then, whatever it may be, must be exercised within the territorial jurisdiction of the several States. The sense of the nation on this subject is unequivocally manifested by the provisions made in the laws for transporting goods by land between Baltimore and Providence, between New York and Philadelphia, and between Philadelphia and Baltimore" (U. S. 193 - 196). 
que seria esse poder, logo após ter abordado o conceito de "among the states", John Marshall visionariamente identifica a complexidade e a relevância da questão ${ }^{548}$.

O objeto da "The Commerce Clause" é, assim, o poder federal de regular o comércio, que, como vimos, em uma interpretação ampla, como a originária, do Justice Marshall, refere-se à própria regulação da vida negocial e da liberdade de contratar como um todo - vale dizer, da vida econômica em geral da sociedade. Diante do fato de ser uma cláusula constitucional de tanta imbricação, de insuperável penetração nas relações econômicas da nação, tem sido submetida a crivos ideológicos de aprofundada relevância ao longo da história.

Segundo as lições de especialistas no assunto, como Dan Coenen (2004, p. 32 142) e Erwin Chemerinsky (2006, p. 242 - 273), dada a sua relevância, a "The Commerce Clause" passou, em uma classificação de cunho didático, por três grandes períodos na sua interpretação.

A primeira fase, de 1824 a 1937, e, principalmente, depois do fim da Guerra Civil, a partir de 1887, corresponde ao período de densificação das discussões iniciadas pelo voto de John Marshall em Gibbons v. Ogden. O resultado desse aprofundamento foi o agressivo emprego do poder judicial de revisão da legislação para invalidar normas, principalmente federais, mas também estaduais, que consistissem, na visão dos juízes conservadores de então, em excessiva intervenção estatal nas relações econômicas privadas, com vistas a preservar a liberdade contratual. Pela maior parte do tempo, esse período de interpretação restritiva do texto constitucional norteamericano, e da "The Commerce Clause" em particular, corresponde à fase conhecida pelos estudiosos como "Lochner era"; a era Lochner. O seu início tem sido usualmente entendido como sendo o

\footnotetext{
548 "We are now arrived at the inquiry -- What is this power?

It is the power to regulate, that is, to prescribe the rule by which commerce is to be governed. This power, like all others vested in Congress, is complete in itself, may be exercised to its utmost extent, and acknowledges no limitations other than are prescribed in the Constitution. These are expressed in plain terms, and do not affect the questions which arise in this case, or which have been discussed at the bar. If, as has always been understood, the sovereignty of Congress, though limited to specified objects, is plenary as to those objects, the power over commerce with foreign nations, and among the several States, is vested in Congress as absolutely as it would be in a single government, having in its Constitution the same restrictions on the exercise of the power as are found in the Constitution of the United States. The wisdom and the discretion of Congress, their identity with the people, and the influence which their constituents possess at elections are, in this, as in many other instances, as that, for example, of declaring war, the sole restraints on which they have relied, to secure them from its abuse. They are the restraints on which the people must often they solely, in all representative governments" (22 U. S. 196 - 197).
} 
julgamento do caso Allgeyer v. Louisiana ${ }^{549}$, de 1897, e sua denominação mais comum se deve ao caso Lochner v. New York ${ }^{550}$, de 1905.

Embora os casos paradigmáticos dessa fase tenham dado amplo e ilimitado alcance à liberdade de contratar com base na "The Due Process Clause" da Cláusula 1 da Décima-Quarta Emenda ${ }^{551}$, de 1868, corresponde a esse período o entendimento do escopo da regulação do comércio como fundamentalmente dentro da competência dos estados que comércio compreendia apenas um estágio, de comercialização, distribuição e varejo, de mercadorias, e que a operação comercial só poderia ser entendida como interestadual se acarretasse um substancial efeito no comércio entre estados (CHEMERINSKY, 2006, p. 248).

Com a crise econômica de 1929 e os esforços do Congresso, na consecução da política intervencionista do Presidente Franklin Delano Roosevelt conhecida como "New Deal', em intervir nas relações econômicas no esforço de soerguimento dos fundamentos econômicos da nação, tal posicionamento da Suprema Corte revelou-se deveras incômodo. Tal situação chegou ao ápice como o julgamento, por unanimidade, do caso A.L.A. Schechter Poultry Corp. v. United States ${ }^{552}$, de 1935, que declarou inconstitucional um dos mais importantes diplomas legislativos destinados a atenuar os efeitos da recessão que abalava o país, o "National Industrial Recovery Act", de 1933. Também significativa a decisão, essa por maioria, no caso Carter v. Carter Coal Company ${ }^{553}$, não só por ter declarado a inconstitucionalidade do "The Bituminous Coal Conservation Act", de 1935, também importante instrumento de política pública dentro do "New Deal", como também por já nele se ver sinalizada a futura alteração de posicionamento jurisprudencial com o voto dissidente do Justice Benjamin Cardozo, referindo-se ao efeito direto no comércio interestadual - no que foi acompanhado pelos Justices Louis Brandeis e Harlan Stone (esse último, posteriormente Chief Justice).

Nesse momento histórico, era grande a pressão sobre a Suprema Corte para que tal entendimento majoritário fosse alterado, a tal ponto de o Presidente Roosevelt ter

\footnotetext{
549165 U.S. 578 (1897).

550198 U.S. 45 (1905).

551 "Amendment 14 - Citizenship Rights.

1. All persons born or naturalized in the United States, and subject to the jurisdiction thereof, are citizens of the United States and of the State wherein they reside. No State shall make or enforce any law which shall abridge the privileges or immunities of citizens of the United States; nor shall any State deprive any person of life, liberty, or property, without due process of law; nor deny to any person within its jurisdiction the equal protection of the laws (...)".

552295 U.S. 495 (1935).

553298 U.S. 238 (1936).
} 
proposto, em março de 1937, a reformulação da composição do tribunal maior do país. Tal iniciativa foi extremamente mal recebida, mas o fato é que o Justice Owen Roberts acabou mudando de opinião no julgamento do caso West Coast Hotel Co. v. Parrish ${ }^{554}$, de 1937, sobre a constitucionalidade das leis federais definidoras de salários mínimos. Tal julgamento foi considerado o fim da era Lochner, por conta do fato de a matéria anteriormente ter sido apreciada em sentido contrário no caso Adkins v. Children's Hospital $^{555}$, de 1923. No que tange especificamente à "The Commerce Clause", o ponto de inflexão se deu no julgamento do caso National Labor Relations Board v. Jones \& Laughlin Steel Corporation ${ }^{556}$, de 1937, que declarou a constitucionalidade do "National Labor Relations Act”, de 1935, acerca da demissão imotivada de empregados que haviam se filiado ao sindicato respectivo.

Com esse julgamento, retomaram-se as visões do Justice Marshall em Gibbons v. Ogden. De 1937 até a recente data de 26 de abril de 1995, a Suprema Corte não declarou inconstitucional nem sequer uma lei federal por infringência à "The Commerce Clause".

Essa é a data de julgamento do caso United States v. Lopez ${ }^{557}$ que, ao declarar inconstitucional o "Gun-Free School Zones Act" "558, de 1990, inaugurou uma fase conservadora conhecida como era Rehnquist, em função do nome do Chief Justice William H. Rehnquist, situação que perdura até hoje.

Não está no escopo do presente trabalho examinar a fundo as minúcias do entendimento jurisprudencial acerca da "The Commerce Clause" em cada um desses períodos, até porque o exame do poder regulatório do comércio por parte do legislativo federal não é o presente objeto de estudo. Porém devemos ter em mente a existência de tais reviravoltas jurisprudenciais, assim como o período histórico aos quais correspondem, porque tais posturas ideológicas também lograram repercutir bastante no exame jurisprudencial da face posterior desse poder, a qual será agora abordada com vagar.

\subsection{Da "The Dormant Commerce Clause".}

\subsubsection{Da evolução conceitual.}

\footnotetext{
554300 U.S. 379 (1937).

555261 U.S. 525 (1923).

556301 U.S. 1 (1937).

557514 U. S. 549 (1995).

558 18 U.S.C. 922.
} 
Como já vimos, no julgamento do caso Gibbons v. Ogden, examinou-se o alcance do poder federal de regular o comércio, não só quanto ao seu objeto regulatório, como também quanto à eventual existência de limitações constitucionalmente estabelecidas ao seu exercício.

Nesse mesmo voto, também foi abordado um fundamental aspecto de análise, no que tange à compreensão do federalismo norteamericano, que consiste em verificar se o poder de regular o comércio é exclusivo da União, ou se há algo restante a ser exercido pelos estados. Esse é, originalmente, o sentido da "The Dormant Commerce Clause", embora, como veremos, o seu fundamento conceitual tenha daí evoluído no decorrer da história.

Ainda antes de tocar nos pontos mencionados no item anterior, necessários ao deslinde da controvérsia concreta apreciada no caso, sobre a navegação em New Jersey, John Marshall analisa uma questão preliminar, posta pela parte que defendia a manutenção da regulação determinada pela norma estadual, que é a própria existência da doutrina dos poderes enumerados, já referida. Ao retrucar argumentações da parte interessada que defendiam a leitura estrita dos poderes congressuais, com base no próprio processo de formação do estado norteamericano, Justice Marshall alegou que a transformação dos embaixadores em deputados tem que ser visto como também uma mudança política que deve ser considerada na interpretação do instrumento constitucional ${ }^{559}$. Nessa perpectiva, a cláusula que atribui ao Congresso o poder de elaborar quaisquer leis que julgue necessárias e próprias ("The Necessary and Proper Clause"), no seu entender, se examinada tecnicamente, a largo de seu sentido leigo, e a partir dessa leitura política, não recomendaria a construção restritiva do alcance do poder legislativo federal ${ }^{560}$. Assim,

\footnotetext{
559 "As preliminary to the very able discussions of the Constitution which we have heard from the bar, and as having some influence on its construction, reference has been made to the political situation of these States anterior to its formation. It has been said that they were sovereign, were completely independent, and were connected with each other only by a league. This is true. But, when these allied sovereigns converted their league into a government, when they converted their Congress of Ambassadors, deputed to deliberate on their common concerns and to recommend measures of general utility, into a Legislature, empowered to enact laws on the most interesting subjects, the whole character in which the States appear underwent a change, the extent of which must be determined by a fair consideration of the instrument by which that change was effected" (22 U. S. 187).

560 "This instrument contains an enumeration of powers expressly granted by the people to their government. It has been said that these powers ought to be construed strictly. But why ought they to be so construed? Is there one sentence in the Constitution which gives countenance to this rule? In the last of the enumerated powers, that which grants expressly the means for carrying all others into execution, Congress is authorized "to make all laws which shall be necessary and proper" for the purpose. But this limitation on the means which may be used is not extended to the powers which are conferred, nor is there one sentence in the Constitution which has been pointed out by the gentlemen of the bar or which we have been able to discern
} 
concluindo seu raciocínio, em que pela primeira vez emprega o termo (“dormant”) que, segundo a maior parte da doutrina constitucional norteamericana, denomina o princípio inserto na construção jurisprudencial, afirma que tal interpretação extensiva deve ser tomada por especialistas, que a empreguem no sentido de aumentar o bem-estar geral, que é o motivo de sua delegação ao Estado, senão seria melhor que restasse inerte, dormente, adormecido, inativo, hibernante ${ }^{561}$.

No mesmo julgamento, em seu solitário voto em contrário à posição de John Marshall, quanto à matéria de mérito, Justice William Johnson apoia o voto majoritário nesse aspecto, concluindo pelo poder exclusivo do Congresso sobre a matéria comercial $^{562}$.

Embora sem que fosse empregado o termo "dormant", a discussão do poder estadual em matéria comercial na ausência de regulação federal já havia sido objeto de apreciação desde a Philadelphia Convention. Em 15 de setembro de 1787, diante da alegação dos representantes do estado de Maryland, James McHenry e Daniel Carroll, posteriormente signatários da Constituição, de que aos estados deveria restar a possibilidade de controlar a tonelagem das embarcações, incluindo impondo tributos e penalidades, sem a interferência federal, como o fim de prover recursos ao

that prescribes this rule. We do not, therefore, think ourselves justified in adopting it. What do gentlemen mean by a "strict construction?" If they contend only against that enlarged construction, which would extend words beyond their natural and obvious import, we might question the application of the term, but should not controvert the principle. If they contend for that narrow construction which, in support or some theory not to be found in the Constitution, would deny to the government those powers which the words of the grant, as usually understood, import, and which are consistent with the general views and objects of the instrument; for that narrow construction which would cripple the government and render it unequal to the object for which it is declared to be instituted, and to which the powers given, as fairly understood, render it competent; then we cannot perceive the propriety of this strict construction, nor adopt it as the rule by which the Constitution is to be expounded. As men whose intentions require no concealment generally employ the words which most directly and aptly express the ideas they intend to convey, the enlightened patriots who framed our Constitution, and the people who adopted it, must be understood to have employed words in their natural sense, and to have intended what they have said. If, from the imperfection of human language, there should be serious doubts respecting the extent of any given power, it is a well settled rule that the objects for which it was given, especially when those objects are expressed in the instrument itself, should have great influence in the construction" (22 U. S. 187 - 189).

561 "We know of no reason for excluding this rule from the present case. The grant does not convey power which might be beneficial to the grantor if retained by himself, or which can enure solely to the benefit of the grantee, but is an investment of power for the general advantage, in the hands of agents selected for that purpose, which power can never be exercised by the people themselves, but must be placed in the hands of agents or lie dormant. We know of no rule for construing the extent of such powers other than is given by the language of the instrument which confers them, taken in connexion with the purposes for which they were conferred" (22 U. S. 189).

562 "But so far from sustaining an inference in favour of the power of the States over commerce, I cannot but think that the guarded provisions of the 10th section on this subject furnish a strong argument against that inference. It was obvious that inspection laws must combine municipal with commercial regulations, and, while the power over the subject is yielded to the States, for obvious reasons, an absolute control is given over State legislation on the subject, as far as that legislation may be exercised, so as to affect the commerce of the country. The inferences to be correctly drawn from this whole article appear to me to be altogether in favour of the exclusive grants to Congress of power over commerce, and the reverse of that which the appellee contends for" (22 U. S. 236). 
desassoreamento dos portos e à construção de faróis, James Madison então discordou ao afirmar que estava convencido que a regulação do comércio, como é o caso da navegação, seria, por natureza, indivisível e deveria ser submetida a apenas uma autoridade ${ }^{563}$.

A ideia da permanência da esfera de atuação federal mesmo quando de sua inércia em exercer a sua competência, como algo diferenciado da questão de avaliar o conflito de disciplinas entre a normativa federal e a estadual, foi também originariamente trazida pelo Justice John Marshall no julgamento do caso Willson v. Black-Bird Creek Marsh Co., de $1829^{564}$. Nesse caso, o estado de Delaware havia autorizado uma sociedade, a Black-Bird Creek Marsh Co., a construir uma barragem sobre o Rio Blackbird, com o fim de conter as suas águas e evitar alagamentos às margens do Rio Delaware. Willson era o proprietário de uma embarcação a vela, regularmente licenciada à navegação no Rio Blackbird, que, navegando no local, causou prejuízos à construção. A demanda, vencida nas instâncias inferiores, consistia no pedido de indenização pelos danos causados. O recurso à Suprema Corte baseou-se no fato de que a "The Commerce Clause", atribuição exclusiva do Congresso, aplicável à navegação, teria sido infringida pelo ato do poder legislativo estadual que teria inconstitucionalmente autorizado a limitação ao direito de navegar pelo local.

$\mathrm{O}$ voto do Justice Marshall, acompanhado à unanimidade, entendeu que o ato legislativo estadual é concernente apenas aos cidadãos do estado de Delaware, na medida em que seja um ato reservado à competência estadual, já que não entra em colisão com os poderes consignados ao ente federal ${ }^{565}$. Continuando seu raciocínio, Marshall então estabelece a diferenciação entre a infração ao poder de regular o comércio quando exercido concretamente pelo ente federal em constraste com a situação em que esse exercício não se perfaz - quando o poder resta inerte ${ }^{566}$. Para isso, novamente emprega o uso "dormant".

\footnotetext{
563 "Mr. Madison. Whether the States are now restrained from laying tonnage duties depends on the extent of the power "to regulate commerce". These terms are vague but seem to exclude this power of the States-- They may certainly be restrained by Treaty. He observed that there were other objects for tonnage Duties as the support of Seamen \&c. He was more \& more convinced that the regulation of Commerce was in its nature indivisible and ought to be wholly under one authority." Records of the Federal Convention of 1787. Disponível em http://press-pubs.uchicago.edu/founders/documents/a1_10_3s2.html. Consulta em 03/01/2011.

56427 U.S. 245 (1829).

565 "Measures calculated to produce these objects, provided they do not come into collision with the powers of the General Government, are undoubtedly within those which are reserved to the States. But the measure authorised by this act stops a navigable creek, and must be supposed to abridge the rights of those who have been accustomed to use it. But this abridgement, unless it comes in conflict with the Constitution or a law of the United States, is an affair between the government of Delaware and its citizens of which this Court can take no cognizance" (27 U. S. 251).

566 "The counsel for the plaintiffs in error insist that it comes in conflict with the power of the United States "to regulate commerce with foreign nations and among the several States." If Congress had passed any act
} 
Logo após, a própria existência do poder federal mesmo no seu não exercício foi reconhecido em voto de outro reconhecido magistrado, Justice Joseph Story, no julgamento do caso Mayor of the City of New York v. Miln ${ }^{567}$. A demanda é oriunda da norma local de New York, de fevereiro de 1824, que exigia que o capitão de toda embarcação de passageiros chegando ao porto de Nova York, vinda de destino no exterior ou de porto fora do estado, deveria, em vinte e quatro horas após a atracação, preencher um formulário reportando nomes, idades e ocupação legal de todos os passageiros, identificando também os respectivos portos de origem. Miln era o capitão do navio Emily, que, tendo chegado ao porto de Nova York em agosto de 1829, vindo do exterior, com cem passageiros, recusou-se a fornecer tais informações à municipalidade local, tendo sido pecuniariamente apenado em função disso.

Embora o julgamento final tenha afirmado a constitucionalidade da lei estadual, em fase ainda de solidificação da "The Commerce Clause", Justice Story, em voto dissidente, apoia o voto de outro dissidente, Justice Smith Thompson, que recordou os termos do voto de John Marshall ${ }^{568}$, para, de forma mais enfática e veemente, recordando o julgamento do caso Brown v. State of Maryland ${ }^{569}$, reiterar o seu pleno consentimento com a formulação de John Marshall, então recentemente falecido, em ambos os casos, tanto nesse quanto em Gibbons v. Ogden ${ }^{570}$. Tal julgamento é deveras criticado, havendo sido expressamente contrariado no caso Edwards v. People of State of California ${ }^{571}$, em 1941.

which bore upon the case, any act in execution of the power to regulate commerce the object of which was to control State legislation over those small navigable creeks into which the tide flows, and which abound throughout the lower country of the middle and southern States, we should feel not much difficulty in saying that a State law coming in conflict with such act would be void. But Congress has passed no such act. The repugnancy of the law of Delaware to the Constitution is placed entirely on its repugnancy to the power to regulate commerce with foreign nations and among the several States -- a power which has not been so exercised as to affect the question. We do not think that the Act empowering the Black Bird Creek Marsh Company to place a dam across the creek can, under all the circumstances of the case, be considered as repugnant to the power to regulate commerce in its dormant State, or as being in conflict with any law passed on the subject. There is no error, and the judgment is affirmed" (27 U. S. 251 - 252).

56736 U.S. 102 (1837).

568 "The state law here operated upon the navigation of waters over which the power to regulate commerce confessedly extends, and yet the state law, not coming in conflict with any act of Congress, was held not to be unconstitutional, and was not affected by the dormant power to regulate commerce. By the same rule of construction, the law of New York, not coming in conflict with any act of Congress, is not void by reason of the dormant power to regulate commerce, even if it should be admitted that the subject embraced in that law fell within such power. This principle is fully recognized by the whole Court in the case of Houston v. Moore, 5 Wheat. l" (36 U. S. 150).

56925 U.S. 419 (1827). Tratava da arguição da constitucionalidade de norma estadual de Maryland, de 1821, que exigia de todo importador de artigos ou commodities estrangeiras, mercadorias secas ou bebidas, para ser autorizado a vender a varejo tais itens, deveria pagar uma taxa de licenciamento de cinqüenta dólares. $\mathrm{O}$ voto condutor também foi elaborado pelo Justice John Marshall.

570 "This whole reasoning is directly applicable to the present case if, instead of the language respecting the introduction and importation of goods, we merely substitute the words, respecting the introduction and importation of passengers, we shall instantly perceive its full purpose and effect. The result of the whole 
Porém, a existência da "The Dormant Commerce Clause" só veio a se solidificar realmente quando do julgamento dos chamados "Passenger Cases" ${ }^{\text {"572, }}$, por sinal referentes à matéria tributária. Consistem em dois casos similares, na verdade, Smith $v$. Turner e Norris v. City of Boston.

Smith era o capitão de uma embarcação britânica, Henry Bliss, que atracou no porto de Nova York em junho de 1841, com duzentos e noventa e cinco passageiros, que se insurgiu contra a exigência do Comissário de Saúde do estado de New York, Turner, com base em lei estadual que criava um tributo, cujo contribuinte era o responsável pelo navio, à razão de um dólar por cada passageiro ou tripulante que chegasse às docas, ou de um dólar e meio, no caso do capitão e dos ocupantes de cabines de luxo. Tais valores referiamse aos passageiros vindos do exterior. Se a origem da embarcação fosse os estados de Connecticut, New Jersey ou Rhode Island, o valor seria de vinte e cinco cents, apenas para o primeiro desembarque no mês; e, se oriunda dos outros estados, de vinte e cinco cents por cabeça.

Norris, também britânico, residente na Província de New Brunswick (atual Canadá, então pertencente ao Império Britânico), no comando de uma embarcação, Union Jack, desembarcou, no porto de Boston, em junho de 1837, dezenove passageiros de fora da cidade, tendo sido obrigado a pagar a soma de dois dólares por passageiro não residente na cidade, por norma local contra a qual se insurgiu, a título de taxa por uma inspeção de saúde. Se a verificação médica concluísse pela existência de alguma enfermidade, ou mesmo se constatada sua pobreza, o tributo cobrado do capitão subiria a mil dólares por pessoa assim considerada.

Os dois casos foram reunidos em função da semelhança nos pedidos e da identidade nas causas de pedir. Tais casos são notáveis na história dos julgamentos da Suprema Corte pela quantidade de votos discordantes em diversos aspectos da lide, o que os prejudicam como precedente jurisprudencial, na verdade. Por sinal, o resultado da votação apontou a maioria mínima de cinco votos a quatro pela inconstitucionalidade dos

reasoning is that whatever restrains or prevents the introduction or importation of passengers or goods into the country, authorized and allowed by Congress, whether in the shape of a tax or other charge or whether before or after their arrival in port, interferes with the exclusive right of Congress to regulate commerce. Such is a brief view of the grounds upon which my judgment is that the act of New York is unconstitutional and void. In this opinion I have the consolation to know that I had the entire concurrence, upon the same grounds, of that great constitutional jurist, the late Mr. Chief Justice Marshall. Having heard the former arguments, his deliberate opinion was that the act of New York was unconstitutional and that the present case fell directly within the principles established in the case of Gibbons v. Ogden, 9 Wheat. 1, and Brown v. State of Maryland, 12 Wheat. 419"' (36 U. S. 160 - 161).

571314 U.S. 160 (1941).

57248 U.S. 283 (1849). 
tributos, tanto o de New York quanto o de Massachusetts. Não obstante, o fato de que tanto votos majoritários, como o do Justice Robert Grier ${ }^{573}$, quanto dissidentes, como o do Justice Levi Woodbury ${ }^{574}$, fizeram menção ao poder federal em tratar da matéria tributária de forma a limitar o poder dos estados a respeito.

Mas, se coube a John Marshall tanto a atribuição da denominação da cláusula, quanto a identificação primeira quanto à importância da diferenciação entre eventuais conflitos entre normas federais, no exercício dos poderes da "The Commerce Clause", em matéria regulatória ou fiscal, em relação a normas estaduais e a infringência ao que é insitamente federal, mesmo que não exercido, o fato é que a "The Dormant Commerce Clause" evoluiu drásticamente ao longo da história a partir dessas considerações iniciais.

O ponto fulcral na compreensão do correto sentido da "The Dormant Commerce Clause" é entender o que é exatamente esse poder insitamente federal, ou quais são os princípios inerentes ao federalismo que decorrem da só existência da "The Commerce Clause", mesmo que eles não venham expressos em nenhum ato proveniente do legislativo federal - ou seja, que o poder federal remanesça adormecido.

É de mais fácil compreensão, primeiramente, identificar que a construção histórica da jurisprudência quanto à "The Commerce Clause" revela a todos suas duas

\footnotetext{
573 "The question whether this power is exclusive is one on which the majority of this Court have intimated different opinions at different times, but it is one of little practical importance in the present case, for this power has not lain dormant, like those for enacting a uniform bankrupt law and for organizing the militia. The United States has made treaties and has regulated our intercourse with foreign nations by prescribing its conditions. No single state has, therefore, a right to change them. To what purpose commit to Congress the power of regulating our intercourse with foreign nations and among the states if these regulations may be changed at the discretion of each state? And to what weight is that argument entitled which assumes that, because it is the policy of Congress to leave this intercourse free, therefore it has not been regulated, and each state may put as many restrictions upon it as she pleases?" (48 U. S. 462).

574 "To show further that these grants of power are not always and necessarily exclusive and that legislation on them by Congress to any extent is not as prohibitory on the states where it is silent as where it enacts, the states have not only continued to punish crimes which Congress could punish, but they have in numerous instances regulated matters connected, locally at least, with commerce abroad, and between the states, and with the Indians.

In so large a territory as the jurisdiction of the general government embraces, in so many and so diversified topics as come before it, and in the nature of its supervisory powers on certain subjects, requiring action only on what is general and foreign, and to produce uniformity merely as to that, it becomes almost inevitable that many local matters and details must be left to be regulated by some local authorities. Yet, as explained in the License Cases, like the by-laws of corporations, made by them and not the legislature, they must not conflict with the general regulations or laws prescribed by the paramount power. But so far from being exclusive, even while it is exercised, and much less while it is dormant or unexercised, the paramount power summons to its aid, in order to be effective, the contemporaneous and continued action of others. Thus not only moneyed corporations but towns and cities must make numerous by-laws in order to enforce the general provisions laid down by the legislation of the state. Thus too this Court must make numerous rules to carry into effect the legislation of Congress in respect to it, and the War and the Navy Departments must compile and enforce volumes of regulations of a like kind and for a like purpose, taking care, as all subordinate power in such cases must, not to violate any general law prescribed on the subject. See 1 Woodb. \& Min. 423" (48 U. S. 564).
} 
funções: uma primeira, como abordamos resumidamente no item anterior, consiste no poder atribuído ao Congresso para atuar legislativamente com vistas a regular determinadas atividades econômicas; a segunda, é a de limitar os poderes legislativos estaduais quando exercem suas funções em contradição com o exercício do poder federal, mesmo que esse não esteja sendo exercido em concreto. Como nos ensina Donald Regan (1986, p. 1092), a "The Dormant Commerce Clause" nada mais é do que a face negativa, restritiva, limitadora, da "The Commerce Clause", agindo de forma implícita.

Portanto, a questão de fundo é podermos identificar que princípios seriam esses. Dan Coenen (2004, p. 210), um dos principais estudiosos da matéria, afirma que a experiência histórica da atuação da Suprema Corte é a de invalidar leis estaduais que: ou discriminem contra produtos oriundos do comércio com outros estados ${ }^{575}$, como afirmado no julgamento do caso City of Philadelphia v. New Jersey ${ }^{576}$, de 1978; ou imponham ônus indevidos ao comércio interestadual ${ }^{577}$, como expressamente manifestado no julgamento do caso Dean Milk Co. v. City of Madison ${ }^{578}$, de 1951. O problema é que, novamente, como no caso do Artigo III do GATT, seja identificada claramente a presença de conceitos jurídicos indeterminados envolvidos no entendimento, a serem semanticamente densificados mediante unicamente exame jurisprudencial.

Tais princípios foram didaticamente sintetizados no julgamento do caso $H$. $P$. Hood \& Sons, Inc. v. Du Mond ${ }^{579}$, de 1949. Trata-se de demanda ajuizada por distribuidora de leite do estado de Massachusetts, já operando três centros de distribuição no estado de New York, todos regularmente licenciados segundo a norma estadual, a Agriculture \& Markets Law of New York, ao ter seu pedido de abertura de estabelecimento adicional recusado pelo Comissário estadual, ao fundamento que a expansão das instalações da distribuidora de leite, como proposta, iria reduzir a oferta de leite por produtores locais, resultando em competição deletéria a mercado já adequadamente servido.

\footnotetext{
575 “(c) Since the evil of protectionism can reside in legislative means as well as legislative ends, it is immaterial whether the legislative purpose of ch. 363 is to protect New Jersey's environment or its economy, for, whatever the purpose, it may not be accomplished by discriminating against articles of commerce coming from outside the State unless there is some reason, apart from their origin, to treat them differently. Both on its face and in its plain effect, ch. 363 violates this principle of nondiscrimination. A State may not attempt to isolate itself from a problem common to many by erecting a barrier against the movement of interstate trade, as ch. 363 seeks to do by imposing on out-of-state commercial interests the full burden of conserving New Jersey's remaining landfill space. Pp. 437 U. S. 625-628" (437 U.S. 617).

576437 U.S. 617.

577 "Upon these facts, we find it necessary to determine only the issue raised under the Commerce Clause, for we agree with appellant that the ordinance imposes an undue burden on interstate commerce" (340 U.S. 353).

578340 U.S. 349.

579336 U.S. 525.
} 
Como resumido na própria ementa do voto condutor, mantido pela margem mínima de votação, cinco votos a quatro, a questão que suscitou a procedência do pedido formulado pela sociedade é a de que um estado não pode promover as suas próprias vantagens econômicas locais por meio da restrição ao comércio interestadual. Nele, Justice Robert Jackson recorda precedente anterior sobre o comércio interestadual de leite, o caso Baldwin v. G. A. F. Seelig Inc. ${ }^{580}$, de 1935 , em que o seu relator, Justice Cardozo, ao mesmo tempo em que reconheceu o poder dos estados em proteger seus cidadãos contra perigos à saúde e à segurança, assim como contra o comércio fraudulento ou os riscos do transporte nas rodovias, mesmo por meios que eventualmente onerem o comércio interestadual, ponderou que essa faculdade não poderia ser usada para proporcionar vantagens econômicas pela restrição ou inviabilização econômica da oferta por produtores de outros estados.

Em voto que trouxe marcante abordagem econômica justificadora da motivação para esse tipo de regulação do comércio interestadual, Justice Jackson, interpretando as palavras do Justice Benjamin Cardozo, afirmava que o objetivo econômico, caso indevido, poderia anular outro qualquer que fosse justo, como a saúde ou a segurança, na medida em que poderia neutralizar o desejado livre comércio entre os estados, funcionando como um encargo de efeito equivalente às imposições aduaneiras. Nas palavras de 1935, a prosperidade e a salvação estão na união entre os estados, não na divisão, e que os estados, se não nadarem juntos, acabarão afundando todos ao mesmo tempo. Em suma, Cardozo estabelecia então que nem o poder de tributar nem o poder de polícia poderiam ser empregados como barreiras contra a competição entre produtos de outros estados ou o trabalho de seus residentes, de forma a invalidar as vantagens econômicas do local de origem $^{581}$.

580294 U. S. 511.

581 "The Constitution, said Mr. Justice Cardozo for the unanimous Court,

"was framed upon the theory that the peoples of the several states must sink or swim together, and that, in the long run, prosperity and salvation are in union, and not division."

He reiterated that the economic objective, as distinguished from any health, safety and fair-dealing purpose of the regulation, was the root of its invalidity. The action of the State would "neutralize the economic consequences of free trade among the states."

"Such a power, if exerted, will set a barrier to traffic between one state and another as effective as if customs duties, equal to the price differential, had been laid upon the thing transported."

"If New York, in order to promote the economic welfare of her farmers, may guard them against competition with the cheaper prices of Vermont, the door has been opened to rivalries and reprisals that were meant to be averted by subjecting commerce between the states to the power of the nation."

And again,

"Neither the power to tax nor the police power may be used by the state of destination with the aim and effect of establishing an economic barrier against competition with the products of another state or the labor of its residents. Restrictions so contrived are an unreasonable clog upon the mobility of commerce. They set up 
Segundo Justice Jackson, com base em documentação histórica que menciona, a manutenção das vantagens econômicas sem a criação artificial, normativa, de diferenciais competitivos entre os estados, é preocupação que remonta à própria construção da nação americana, estando presente na formulação federativa dos Forefathers, especificamente Thomas Jefferson ${ }^{582}$. Após reconhecer que a "The Commerce Clause" é a mais fértil fonte de poder federal e de conflitos entre as unidades federativas e entre estas e a nacional, traz a importante afirmação que, embora não escritos no texto constitucional, tanto no que concerne à limitação ao poder legislativo estadual na ausência da ação congressual quanto mesmo ao que seja o comércio interestadual, tais construções jurisprudenciais nos silêncios constitucionais foram os responsáveis pelo fato de a Suprema Corte ter propiciado a solidariedade e a prosperidade da nação ${ }^{583}$.

what is equivalent to a rampart of customs duties designed to neutralize advantages belonging to the place of origin. They are thus hostile in conception as well as burdensome in result."” (336 U. S. 532 - 533).

582 "This distinction between the power of the State to shelter its people from menaces to their health or safety and from fraud, even when those dangers emanate from interstate commerce, and its lack of power to retard, burden or constrict the flow of such commerce for their economic advantage is one deeply rooted in both our history and our law.

When victory relieved the Colonies from the pressure for solidarity that war had exerted, a drift toward anarchy and commercial warfare between states began.

". . . each State would legislate according to its estimate of its own interests, the importance of its own products, and the local advantages or disadvantages of its position in a political or commercial view."

This came "to threaten at once the peace and safety of the Union." Story, The Constitution, \$\$ 259, 260. See Fiske, The Critical Period of American History, 144; Warren, The Making of the Constitution, 567. The sole purpose for which Virginia initiated the movement which ultimately produced the Constitution was

"to take into consideration the trade of the United States; to examine the relative situations and trade of the said States; to consider how far a uniform system in their commercial regulations may be necessary to their common interest and their permanent harmony," and, for that purpose, the General Assembly of Virginia, in January of 1786, named commissioners and proposed their meeting with those from other states. Documents, Formation of the Union, H.R.Doc. No. 398, 12 H. Docs., 69th Cong., 1st Sess., p. 38.

The desire of the Forefathers to federalize regulation of foreign and interstate commerce stands in sharp contrast to their jealous preservation of the state's power over its internal affairs. No other federal power was so universally assumed to be necessary, no other state power was so readily relinquished. There was no desire to authorize federal interference with social conditions or legal institutions of the states. Even the Bill of Rights amendments were framed only as a limitation upon the powers of Congress. The states were quite content with their several and diverse controls over most matters, but, as Madison has indicated,

"want of a general power over Commerce led to an exercise of this power separately, by the States, wch [sic] not only proved abortive, but engendered rival, conflicting and angry regulations." 3 Farrand, Records of the Federal Convention, 547.

The necessity of centralized regulation of commerce among the states was so obvious and so fully recognized that the few words of the Commerce Clause were little illuminated by debate. But the significance of the clause was not lost, and its effect was immediate and salutary. We are told by so responsible an authority as Mr. Jefferson's first appointee to this Court that

"there was not a State in the Union, in which there did not, at that time, exist a variety of commercial regulations; concerning which it is too much to suppose that the whole ground covered by those regulations was immediately assumed by actual legislation under the authority of the Union. But where was the existing statute on this subject that a State attempted to execute? or by what State was it ever thought necessary to repeal those statutes? By common consent, those laws dropped lifeless from their statute books for want of the sustaining power that had been relinquished to Congress." @ 22 U. S. 226." (336 U. S. 533 -534).

583 "The Commerce Clause is one of the most prolific sources of national power, and an equally prolific source of conflict with legislation of the state. While the Constitution vests in Congress the power to regulate 
Assim, o princípio por trás da "The Commerce Clause" e, por consequência, da "The Dormant Commerce Clause", no entender do relator, é o de que a unidade econômica que se pretende preservar jurisprudencialmente é a União, não os estados isoladamente considerados, sendo esse o motivo pelo qual compete apenas à União erigir barreiras alfandegárias contra a concorrência internacional ${ }^{584}$.

O relator termina por concluir que esse entendimento é o responsável pelo sucesso da economia norteamericana, o mais impressionante na história, ao seu ver, e que a interdependência entre os estados enfatiza a necessidade de se proteger a circulação de bens contra onerações e barreiras locais. Para ele, o sucesso da nação repousa no fato de que, com base no entendimento jurisprudencial formulado sob a denominação de "The Commerce Clause", cada fazendeiro e cada industrial no território americano deve se sentir encorajado a produzir com a certeza de ter à sua disposição o livre acesso a todos os mercados nacionais, sem temer quaisquer embargos locais, em um ambiente de livre concorrência $^{585}$.

Com o passar dos anos, o sentido da "The Dormant Commerce Clause" foi se tornando mais claro e seus contornos mais nítidos. Se tomarmos à análise alguns casos mais recentes, podemos verificar que a formulação jurisprudencial norteamericana evoluiu de forma a se identificar plenamente com a construção no seio da OMC, já profundamente

commerce among the states, it does not say what the states may or may not do in the absence of congressional action, nor how to draw the line between what is and what is not commerce among the states. Perhaps even more than by interpretation of its written word, this Court has advanced the solidarity and prosperity of this Nation by the meaning it has given to these great silences of the Constitution" (336 U. S. $534-535)$.

584 "This principle that our economic unit is the Nation, which alone has the gamut of powers necessary to control of the economy, including the vital power of erecting customs barriers against foreign competition, has as its corollary that the states are not separable economic units" (336 U. S. 537 - 538).

585 "The material success that has come to inhabitants of the states which make up this federal free trade unit has been the most impressive in the history of commerce, but the established interdependence of the states only emphasizes the necessity of protecting interstate movement of goods against local burdens and repressions. We need only consider the consequences if each of the few states that produce copper, lead, high-grade iron ore, timber, cotton, oil or gas should decree that industries located in that state shall have priority. What fantastic rivalries and dislocations and reprisals would ensue if such practices were begun. Or suppose that the field of discrimination and retaliation be industry. May Michigan provide that automobiles cannot be taken out of that State until local dealers' demands are fully met? Would she not have every argument in the favor of such a statute that can be offered in support of New York's limiting sales of milk for out-of-state shipment to protect the economic interests of her competing dealers and local consumers? Could Ohio then pounce upon the rubber tire industry, on which she has a substantial grip, to retaliate for Michigan's auto monopoly?

Our system, fostered by the Commerce Clause, is that every farmer and every craftsman shall be encouraged to produce by the certainty that he will have free access to every market in the Nation, that no home embargoes will withhold his exports, and no foreign state will by customs duties or regulations exclude them. Likewise, every consumer may look to the free competition from every producing area in the Nation to protect him from exploitation by any. Such was the vision of the Founders; such has been the doctrine of this Court which has given it reality" (336 U. S. 538 - 539). 
examinada. Por exemplo, veja-se o caso New Energy Company of Indiana v. Limbach ${ }^{586}$, de 1988, hipótese típica de discriminação fiscal explícita. Trata-se da contestação, sob a "The Dormant Commerce Clause", quanto à constitucionalidade de uma lei do estado de Ohio que garantia um crédito do imposto sobre vendas a varejo estadual (Sales Tax) incidente sobre combustíveis, para cada galão de etanol vendido, desde que o combustível comercializado houvesse sido fabricado no estado de Ohio ou viesse de estado que provesse semelhante subsídio aos produtos combustíveis renováveis vindos de Ohio. A apelante era uma produtora de etanol situada no estado de Indiana, que não oferecia qualquer benefício fiscal às vendas de etanol, onde quer que fosse o produto comercializado houvesse sido produzido.

Nesse julgamento, cuja votação pela evidente inconstitucionalidade da norma foi unânime, seu relator, Justice Antonin Scalia, traz um interessante apanhado resumido do entendimento da Suprema Corte na matéria, nos ensinando que a "The Commerce Clause" não só possui um efeito positivo, de autorizar a regulação do comércio entre os estados, como também possui um lado negativo, pelo qual impõe limitações aos estados no que tange à possibilidade de discriminar o comércio interestadual, o que visa a evitar o protecionismo econômico $^{587}$, seja por meio da inviabilização da comercialização no estado alienígena, seja, como no caso em exame, pela imposição de uma "substancial desvantagem comercial", que se constituiria em uma "barreira econômica à concorrência", equivalente a um "obstáculo formado de encargos aduaneiros" 588.

\footnotetext{
${ }^{586} 486$ U.S. 269 (1988).

587 "It has long been accepted that the Commerce Clause not only grants Congress the authority to regulate commerce among the States, but also directly limits the power of the States to discriminate against interstate commerce. See, e.g., Hughes v. Oklahoma, 441 U. S. 322, 441 U. S. 326 (1979); H. P. Hood \& Sons, Inc. v. Du Mond, 336 U. S. 525, 336 U. S. 534-535 (1949); Welton v. Missouri, 91 U. S. 275 (1876). This "negative" aspect of the Commerce Clause prohibits economic protectionism -- that is, regulatory measures designed to benefit in-state economic interests by burdening out-of-state competitors. See, e.g., Bacchus Imports, Ltd. v. Dias, 468 U. S. 263, 468 U. S. 270-273 (1984); H. P. Hood \& Sons, supra, at 336 U. S. 532-533; Guy v. Baltimore, 100 U. S. 434, 100 U.S. 443 (1880). Thus, state statutes that clearly discriminate against interstate commerce are routinely struck down, see, e.g., Sporhase v. Nebraska ex rel. Douglas, 458 U. S. 941 (1982); Lewis v. BT Investment Managers, Inc., 447 U. S. 27 (1980); Dean Milk Co. v. Madison, 340 U. S. 349 (1951), unless the discrimination is demonstrably justified by a valid factor unrelated to economic protectionism, see, e.g., Maine v. Taylor, 477 U. S. 131 (1986)" (486 U. S. 273 - 274).

588 "It is true that, in Cottrell and Sporhase, the effect of a State's refusal to accept the offered reciprocity was total elimination of all transport of the subject product into or out of the offering State, whereas in the present case the only effect of refusal is that the out-of-state product is placed at a substantial commercial disadvantage through discriminatory tax treatment. That makes no difference for purposes of Commerce Clause analysis. In the leading case of Baldwin v. G.A.F. Seelig, Inc., 294 U. S. 511 (1935), the New York law excluding out-of-state milk did not impose an absolute ban, but rather allowed importation and sale so long as the initial purchase from the dairy farmer was made at or above the New York State-mandated price. In other words, just as the appellant here, in order to sell its product in Ohio, only has to cut its profits by reducing its sales price below the market price sufficiently to compensate the Ohio purchaser-retailer for the forgone tax credit, so also the milk wholesaler-distributor in Baldwin, in order to sell its product in New
} 
Em outro caso também recente, C\&A Carbone, Inc., et al. v. Town of Clarkstown, New York $^{589}$, de 1994, referente a uma norma que impunha que os resíduos sólidos produzidos no município fossem comercializados com uma concessionária do poder local, o voto da Justice Sandra O’Connor fornece uma aula acerca do que consista a "The Dormant Commerce Clause", no mesmo sentido aqui já relatado ${ }^{590}$, inclusive mencionando as modalidades de discriminação, o que será abordado adiante, ao passo que o voto do relator, Justice Anthony Kennedy, explica que a razão central para a regra antidiscriminatória é a proibição de que normas estaduais ou municipais imponham objetivos protecionistas, o que compete à Constituição prevenir $^{591}$.

York, only had to cut its profits by increasing its purchase price above the market price sufficiently to meet the New York-prescribed minimum. We viewed the New York law as "an economic barrier against competition" that was "equivalent to a rampart of customs duties." Id. at 294 U. S. 527. Similarly, in Hunt v. Washington Apple Advertising Comm'n, 432 U. S. 333, 432 U. S. 349-351 (1977), we found invalid under the Commerce Clause a North Carolina statute that did not exclude apples from other States, but merely imposed additional costs upon Washington sellers and deprived them of the commercial advantage of their distinctive grading system. The present law likewise imposes an economic disadvantage upon out-of-state sellers, and the promise to remove that if reciprocity is accepted no more justifies disparity of treatment than it would justify categorical exclusion" (486 U. S. 275).

589511 U.S. 383.

590 "The scope of the dormant Commerce Clause is a judicial creation. On its face, the Clause provides only that "[t]he Congress shall have Power ... To regulate Commerce ... among the several States ... " u. S. Const., Art. I, $\$ 8$, cl. 3. This Court long ago concluded, however, that the Clause not only empowers Congress to regulate interstate commerce, but also imposes limitations on the States in the absence of congressional action:

"This principle that our economic unit is the Nation, which alone has the gamut of powers necessary to control of the economy, including the vital power of erecting customs barriers against foreign competition, has as its corollary that the states are not separable economic units .... [W] hat is ultimate is the principle that one state in its dealings with another may not place itself in a position of economic isolation." $H$. P. Hood \& Sons, Inc. v. Du Mond, 336 U. S. 525, 537-538 (1949) (internal quotation marks and citations omitted).

Our decisions therefore hold that the dormant Commerce Clause forbids States and their subdivisions to regulate interstate commerce. We have generally distinguished between two types of impermissible regulations. A facially nondiscriminatory regulation supported by a legitimate state interest which incidentally burdens interstate commerce is constitutional unless the burden on interstate trade is clearly excessive in relation to the local benefits. See Brown-Forman Distillers Corp. v. New York State Liquor Authority, 476 U.S. 573, 579 (1986); Pike v. Bruce Church, Inc., 397 U.S. 137, 142 (1970). Where, however, a regulation "affirmatively" or "clearly" discriminates against interstate commerce on its face or in practical effect, it violates the Constitution unless the discrimination is demonstrably justified by a valid factor unrelated to protectionism. See Wyoming v. Oklahoma, 502 U. S. 437, 454 (1992); Maine v. Taylor, 477 U. S. 131, 138 (1986). Of course, there is no clear line separating these categories. "In either situation the critical consideration is the overall effect of the statute on both local and interstate activity." Brown-Forman Distillers, supra, at 579" (511 U.S. 401 - 402).

591 "The central rationale for the rule against discrimination is to prohibit state or municipal laws whose object is local economic protectionism, laws that would excite those jealousies and retaliatory measures the Constitution was designed to prevent. See The Federalist No. 22, pp. 143-145 (C. Rossiter ed. 1961) (A. Hamilton); Madison, Vices of the Political System of the United States, in 2 Writings of James Madison 362363 (G. Hunt ed. 1901). We have interpreted the Commerce Clause to invalidate local laws that impose commercial barriers or discriminate against an article of commerce by reason of its origin or destination out of State. See, e. g., Philadelphia, supra (striking down New Jersey statute that prohibited the import of solid waste); Hughes v. Oklahoma, 441 U.S. 322 (1979) (striking down Oklahoma law that prohibited the export of natural minnows)" (511 U.S. 390). 
Em outro julgado também esclarecedor, Hughes v. Oklahoma ${ }^{592}$, de 1979, Justice William Brennan, Jr. afirma que as palavras simples da "The Commerce Clause" refletem uma preocupação dos fundadores da nação de que o sucesso da união entre os estados dependeria de se neutralizar as tendências de balcanização econômica, o que só poderia ser efetivado por meio de uma interpretação constitucional que permitisse a restrição ao poder regulatório estadual, mesmo na ausência de norma federal com ela conflitante ${ }^{593}$.

Tais palavras foram reforçadas pelo voto do recémaposentado Justice David Souter, no voto condutor do importante caso tributário Oklahoma Tax Comission v. Jefferson Lines, Inc. ${ }^{594}$, de 1995. Jefferson Lines, Inc. era uma empresa transportadora de passageiros em ônibus, sediada no estado de Minnesota, que era obrigada, pela lei do estado de Oklahoma, a tributar tais vendas pelo Sales Tax, desde que a operação comercial houvesse sido realizada no estado de Oklahoma, sejam as viagens comercializadas lá interestaduais ou locais. Ocorre que a empresa apenas recolhia tal tributo das vendas de bilhetes para viagens locais. Quando requereu a proteção contra a falência, a administração fiscal do estado de Oklahoma requereu a habilitação dos créditos tributários referentes às prestações de serviço de transporte interestadual que houvessem se iniciado no estado, com o que a empresa insurgiu-se.

No seu voto, Justice Souter afirma que tem sido o entendimento da Suprema Corte o de que a restrição ao poder legistativo estadual seria uma forma de se precaver contra as iniciativas estaduais que visariam a se isolar economicamente em detrimento do bem-estar geral da população de todo o território nacional, pela restrição ao comércio de mercadorias para além de suas fronteiras, ao final mencionando a formulação econômica do Justice Brennan referida acima, em Hughes v. Oklahoma ${ }^{595}$.

\footnotetext{
592441 U.S. 322 (1979).

593 "The few simple words of the Commerce Clause -- "The Congress shall have Power. . . To regulate Commerce . . . among the several States ..."-- reflected a central concern of the Framers that was an immediate reason for calling the Constitutional Convention: the conviction that, in order to succeed, the new Union would have to avoid the tendencies toward economic Balkanization that had plagued relations among the Colonies and later among the States under the Articles of Confederation. See H. P. Hood \& Sons, Inc. v. Du Mond, 336 U. S. 525, 336 U. S. 533-534 (1949). The Commerce Clause has accordingly been interpreted by this Court not only as an authorization for congressional action, but also, even in the absence of a conflicting federal statute, as a restriction on permissible state regulation. The cases defining the cope of permissible state regulation in areas of congressional silence reflect an often controversial evolution of rules to accommodate federal and state interests" (441 U. S. 325 - 326).

594514 U.S. 175 (1995).

595 "Despite the express grant to Congress of the power to "regulate Commerce . . among the several States," U. S. Const., Art. I, $\S 8$, cl. 3, we have consistently held this language to contain a further, negative command, known as the dormant Commerce Clause, prohibiting certain state taxation even when Congress has failed to legislate on the subject. Quill Corp v. North Dakota, 504 U.S. 298, 309 (1992); Northwestern
} 
Em outro caso recente, West Lynn Creamery, Inc. v. Healy, Commissioner of Massachusetts Department of Food and Agriculture ${ }^{596}$, de 1994, a justificativa para o emprego da "The Dormant Commerce Clause" também foi tratada de forma muito interessante. $\mathrm{O}$ caso refere-se à constitucionalidade de norma emitida pelo Departamento de Alimentos e Agricultura do estado de Massachusetts, que exigia de cada atacadista de leite (no estado líquido) que comercializasse essa mercadoria para que varejistas localizados no estado a revendessem, deveria pagar um adicional de quinze dólares por cada cem libras de lei in natura vendido, visando a prover de recursos um fundo (Dairy Equalization Fund) que subsidiaria os produtores de leite localizados no estado. West Lynn Creamery, Inc. era uma sociedade distribuidora atacadista de leite, localizada em Massachusetts, cujos fornecedores eram todos de fora do estado. $\mathrm{Na}$ verdade, de todo o leite vendido no estado, menos de um terço era produzido internamente, pelos pecuaristas que seriam beneficiados pela norma estadual.

No seu voto, Justice John Paul Stevens, no que foi apoiado por mais quatro magistrados, recebendo votos contrários da ala conservadora, Justices Rehnquist e Blackmun e votos discordantes na fundamentação, embora coincidentes no dispositivo ${ }^{597}$, dos Justices Scalia, e Thomas, também conservadores, entendeu pela inconstitucionalidade da norma, na medida em que esse adicional ao preço discriminaria o comércio interestadual, já que se constituiria, na verdade, em um tributo que neutralizaria as vantagens competitivas dos produtores que tivessem mais baixos custos de produção ${ }^{598}$.

States Portland Cement Co. v. Minnesota, 358 U.S. 450, 458 (1959); H. P. Hood \& Sons, Inc. v. Du Mond, 336 U.S. 525, 534-535 (1949); cf. Gibbons v. Ogden, 9 Wheat. 1, 209 (1824) (Marshall, C. J.) (dictum). We have understood this construction to serve the Commerce Clause's purpose of preventing a State from retreating into economic isolation or jeopardizing the welfare of the Nation as a whole, as it would do if it were free to place burdens on the flow of commerce across its borders that commerce wholly within those borders would not bear. The provision thus "'reflect[s] a central concern of the Framers that was an immediate reason for calling the Constitutional Convention: the conviction that in order to succeed, the new Union would have to avoid the tendencies toward economic Balkanization that had plagued relations among the Colonies and later among the States under the Articles of Confederation.' " Wardair Canada Inc. v. Florida Dept. of Revenue, 477 U.S. 1, 7 (1986), quoting Hughes v. Oklahoma, 441 U.S. 322, 325-326 (1979); see also The Federalist No. 42 (J. Madison), 7 (A. Hamilton), 11 (A. Hamilton) (J. Cooke ed. 1961)" (514 U.S. $179-180)$.

${ }^{596} 512$ U.S. 186 (1994).

${ }^{597}$ O que se denomina "concurring opinion", na tradição da Common Law.

598 "Held: The pricing order unconstitutionally discriminates against interstate commerce. Pp. 192-207.

(a) The order is clearly unconstitutional under this Court's decisions invalidating state laws designed to benefit local producers of goods by creating tariff-like barriers that neutralized the competitive and economic advantages possessed by lower cost out-of-state producers. See, e. g., Bacchus Imports, Ltd. v. Dias, 468 U. S. 263. The "premium payments" are effectively a tax making milk produced out of State more expensive. Although that tax also applies to milk produced in Massachusetts, its effect on Massachusetts producers is entirely (indeed more than) offset by the subsidy provided exclusively to Massachusetts dairy farmers, who are thereby empowered to sell at or below the price charged by lower cost out-of-state producers. Pp. 192-197' (512 U.S. 186). 
Ao enfrentar o argumento de que a norma não era protecionista porque o adicional seria pago unicamente por varejistas estabelecidos em Massachusetts e, em consequência, por consumidores lá residentes, Justice Stevens afirma categoricamente que a nação deve ser entendida como um mercado interestadual integrado, da qual os produtores de leite do estado devem participar em igualdade de condições com os demais agentes econômicos ${ }^{599}$.

Adiante em sua fundamentação, afirma didaticamente o conteúdo da "The Commerce Clause", assim como reafirma o seu aspecto negativo, como fim de coibir o protecionismo econômico, relembrando a introdução da possibilidade de que haja uma motivação não baseada em questões econômicas para justificar a discriminação ${ }^{600}$. Caso contrário, como ocorre na demanda sob análise, pontua tratar-se de situação assemelhada à hipótese de instituição de um encargo aduaneiro estadual, ou de exigência com efeitos assemelhados, na medida em que incidente apenas sobre os produtos que atravessaram alguma fronteira estadual para ser vendido ao consumidor final, o que consiste em clara violação do princípio do mercado unitário nacional, causando distorções alocativas na geografia da produção nacional ${ }^{601}$. Ao final, menciona discurso de James Madison, que afirma a maior relevância do aspecto negativo da "The Commerce Clause"602.

599 “(d) If accepted, respondent's third argument-that the order is not protectionist because the program's costs are borne only by Massachusetts dealers and consumers and its benefits are distributed exclusively to Massachusetts farmers-would undermine almost every discriminatory tax case. State taxes are ordinarily paid by in-state businesses and consumers, yet if they discriminate against out-of-state products they are unconstitutional. More fundamentally, the argument ignores the fact that Massachusetts dairy farmers are part of an integrated interstate market. The obvious impact of the order on out-of-state production demonstrates that it is simply wrong to assume that it burdens only in-state consumers and dealers. Pp. 203204" (512 U.S. 187).

600 "The Commerce Clause vests Congress with ample power to enact legislation providing for the regulation of prices paid to farmers for their products. United States v. Darby,312 U.S. 100 (1941); Wickard v. Filburn, 317 U. S. 111 (1942); Mandeville Island Farms, Inc. v. American Crystal Sugar Co., 334 U. S. 219 (1948). An affirmative exercise of that power led to the promulgation of the federal order setting minimum milk prices. The Commerce Clause also limits the power of the Commonwealth of Massachusetts to adopt regulations that discriminate against interstate commerce. "This 'negative' aspect of the Commerce Clause prohibits economic protectionism-that is, regulatory measures designed to benefit in-state economic interests by burdening out-of-state competitors .... Thus, state statutes that clearly discriminate against interstate commerce are routinely struck down ... unless the discrimination is demonstrably justified by a valid factor unrelated to economic protectionism...". New Energy Co. of Indiana v. Limbach, 486 U.S. 269, 273-274 (1988)." (512 U.S. 192).

601 "The paradigmatic example of a law discriminating against interstate commerce is the protective tariff or customs duty, which taxes goods imported from other States, but does not tax similar products produced in State. A tariff is an attractive measure because it simultaneously raises revenue and benefits local producers by burdening their out of state competitors. Nevertheless, it violates the principle of the unitary national market by handicapping out of state competitors, thus artificially encouraging in state production even when the same goods could be produced at lower cost in other States.

Because of their distorting effects on the geography of production, tariffs have long been recognized as violative of the Commerce Clause. In fact, tariffs against the products of other States are so patently unconstitutional that our cases reveal not a single attempt by any State to enact one. Instead, the cases are filled with state laws that aspire to reap some of the benefits of tariffs by other means. In Baldwin v. G. A. F. 
A partir de considerações jurisprudenciais como essas, Dan Coenen (2004, p. 212) relaciona pelo menos cinco razões, fundadas na teoria econômica, que explicam porque o mercado comum nacional, na dicção dos magistrados, em função da proteção empreendida pela "The Dormant Commerce Clause", realmente poderia alcançar o objetivo, constitucionalmente expresso, de maximização do bem estar dos indivíduos. Segundo ele, porque, em primeiro lugar, a expansão dos mercados facilita a especialização do trabalho, do que resultam eficiências decorrentes da canalização das atividades produtivas àquelas firmas que possuem melhores atributos para explorá-las. Em segundo lugar, porque mercados comuns tendem a fazer os preços diminuírem, por conta do incremento do número de ofertantes competidores dispostos a distribuírem seu produto a qualquer local do território. Além disso, mercados comuns aumentam o bem estar agregado dentro da unidade territorial por conta da redução das externalidades impostas pelos produtores locais aos seus vizinhos, como poluição, acidentes e assemelhados. Em quarto lugar, porque há a tendência ao fim das guerras comerciais regionais, que progressivamente diminuem o bem estar de todos os envolvidos. Por último, o emprego de mercados comuns reduz os custos de transação relacionados à administração das autoridades regionais, uma vez que seu poder se desloca unicamente para uma autoridade central.

Seelig, Inc., 294 U.S. 511 (1935), the State of New York attempted to protect its dairy farmers from the adverse effects of Vermont competition by establishing a single minimum price for all milk, whether produced in New York or elsewhere. This Court did not hesitate, however, to strike it down. Writing for a unanimous Court, Justice Cardozo reasoned:

"Neither the power to tax nor the police power may be used by the state of destination with the aim and effect of establishing an economic barrier against competition with the products of another state or the labor of its residents. Restrictions so contrived are an unreasonable clog upon the mobility of commerce. They set up what is equivalent to a rampart of customs duties designed to neutralize advantages belonging to the place of origin." Id., at 527.

Thus, because the minimum price regulation had the same effect as a tariff or customs duty--neutralizing the advantage possessed by lower cost out of state producers--it was held unconstitutional. Similarly, in Bacchus Imports, Ltd. v. Dias, 468 U.S. 263 (1984), this Court invalidated a law which advantaged local production by granting a tax exemption to certain liquors produced in Hawaii. Other cases of this kind are legion. Welton v. Missouri, 91 U.S. 275 (1876); Guy v. Baltimore, 100 U.S. 434 (1880); Toomer v. Witsell, 334 U.S. 385 (1948); Polar Ice Cream \& Creamery Co. v. Andrews, 375 U.S. 361 (1964); Chemical Waste Management, Inc. v. Hunt, 504 U. S. __ (1992); see also, Hunt v. Washington State Apple Advertising Comm'n, 432 U.S. 333, 351(1977) (invalidating statute, because it "has the effectof stripping away from the Washington apple industry the competitive and economic advantages it has earned . . .")" (512 U.S. 193 194).

602 "The "negative" aspect of the Commerce Clause was considered the more important by the "father of the Constitution," James Madison. In one of his letters, Madison wrote that the Commerce Clause "grew out of the abuse of the power by the importing States in taxing the non importing, and was intended as a negative and preventive provision against injustice among the States themselves, rather than as a power to be used for the positive purposes of the General Government." 3 M. Farrand, Records of the Federal Convention of 1787, p. 478 (1911)" (512 U.S. 193). 
O mesmo autor, logo após tais considerações, faz, com apoio em Donald Regan (1986, p. 1126), uma ressalva muito importante, especialmente direcionada aos críticos de visões analíticas do direito com fulcro econômico. Para Coenen (2004, p. 212, nota de rodapé $\mathrm{n}^{\circ}$ 12), dizer que a "The Dormant Commerce Clause" é uma claúsula oriunda de uma construção jurisprudencial visando a objetivos econômicos não significa dizer que o requisito de validade das normas, a serem submetidas a essa espécie de crivo, repouse primacialmente na eficiência econômica da disciplina normativa. Em verdade, a partir da constatação efetivada por Donald Regan no mesmo ponto, quanto a que o entendimento da "The Dormant Commerce Clause" implica a necessidade de densificação de conceitos jurídicos indeterminados, como os de bem estar e de mercado comum nacional, entre outros, por meio de construções econômicas, na exata maneira como o OSC da OMC pacificou o entendimento do que sejam produtos similares ou complementares e substitutos, denota que a análise econômica de tais conceitos jurídicos deva ser empreendida muito mais no seu aspecto jurídico-normativo do que no positivo-alocativo.

Embora preponderantes, os aspectos econômicos não são os únicos a justificarem a construção da "The Dormant Commerce Clause" pela Suprema Corte. Há um evidente aspecto político, consistente na vedação a que procedimentos legislativos estaduais venham a gerar consequências diretas, por meio de normas que venham a gerar danos ao comércio interestadual, a populações de fora do estado que a produziu - cuja vontade soberana não foi levada em conta, portanto. Tal formulação remonta originariamente ao Justice John Marshall, em Gibbons v. Ogden ${ }^{603}$, de 1824.

Não se pode esquecer que toda a contextualização histórica que cerca as normas constitucionais aplicáveis à intelecção das cláusulas relacionadas à matéria, acima descritas, aponta para o que Dan Coenen (2004, p. 214) chama de um caráter político de "solidariedade nacional” que está por trás de toda a formulação dos Founding Fathers quanto à necessidade de sustentação da união recéminstituída.

Argumentos irrefutáveis como esses não tornam a própria existência da "The Dormant Commerce Clause" imune a oposições ferrenhas. Se, quando do exame, embora superficial, acima empreendido, acerca da "The Commerce Clause", já se mencionou a guinada conservadora empreendida pela Corte Rehnquist, a qual, com a morte do Chief

\footnotetext{
603 "The great and paramount purpose was to unite this mass of wealth and power, for the protection of the humblest individual, his rights, civil and political, his interests and prosperity, are the sole end; the rest are nothing but the means. But the principal of those means, one so essential as to approach nearer the characteristics of an end, was the independence and harmony of the States that they may the better subserve the purposes of cherishing and protecting the respective families of this great republic" (22 U. S. 223).
} 
Justice, em 2005, tem sido ultimamente ainda mais restritiva aos poderes do legislativo federal sob Chief Justice John Roberts, o que dirá da visão que atualmente podemos esperar presenciar quanto à doutrina da "The Dormant Commerce Clause", por ser ainda mais fluido o seu suporte no direito positivo? Temos presenciado ultimamente diversas críticas, não só da doutrina, mas também dos Justices Scalia e Thomas, baseadas, como resumido por Dan Coenen (2004, p. 214 - 215, nota de rodapé $n^{\circ}$ 19) nos seguintes fundamentos: i) ausência de base constitucional expressa; ii) controvérsia quanto à comprovação histórica da intenção de sua inclusão, tanto na convenção constitucional quanto na sua ratificação; iii) aparente antinomia com a "The Import Export Clause", que pressuporia o poder dos estados em regular matéria comercial; iv) desnecessidade da sua existência, dada a possibilidade de a ação legislativa efetiva federal poder revogar a norma estadual eventualmente deletéria ao comércio interestadual; v) possibilidade de conferir poder excessivamente relevante às funções judiciais, estimulando um certo ativismo judicial $^{604}$.

Sem querer entrar nesse mérito, o fato inconteste é que a doutrina acerca da "The Dormant Commerce Clause", especialmente em matéria regulatória, é de extrema complexidade, certamente a mais complexa do direito constitucional norteamericano e, para além disso, ainda está atualmente em aberto, especialmente após os últimos anos da Corte Rehnquist e com o que se avista dos primeiros cinco anos da Corte Roberts. Diante disso, e sempre tendo em vista que o objetivo do presente trabalho é examinar a aplicação dos critérios de verificação do caráter discriminatório às normas de incidência ou de estrutura em matéria tributária, não se dedicará maior atenção ao complicado trajeto pelo qual a Suprema Corte norteamericana evoluiu, com o correr do processo histórico, na intelecção desses critérios no que tange à matéria regulatória.

Apenas, a título de breve ilustração, menciona-se que, em Cooley v. Board of Wardens $^{605}$, de 1852, o critério distintivo referia-se ao caráter nacional (então inconstitucional) ou local (hipótese em que se decide pela constitucionalidade) da matéria sendo regulada pela lei estadual; em Di Santo v. Pennsylvania ${ }^{606}$, de 1927, o traço diferenciador passou a ser a produção direta (situação de declaração de

\footnotetext{
${ }^{604}$ Para uma maior compreensão desse gênero de críticas, ver TUSHNET, Mark V. Scalia and the Dormant Commerce Clause: A Foolish Formalism? Cardozo Law Review. New York: Yeshiva University Press, 1991, p. 1717 - 1744. No mesmo sentido, sob diferentes argumentos, ver FRIEDMAN, Richard D. Putting the Dormancy Doctrine out of its Misery. Cardozo Law Review. New York: Yeshiva University Press, 1991, p. $1745-1764$.

60553 U.S. 299 (1852).

606273 U.S. 34 (1927).
} 
inconstitucionalidade) ou apenas indireta (constitucional) de efeitos no comércio interestadual pela norma local; e que, a partir de Pike v. Bruce Church, Inc. ${ }^{607}$, de 1970, a Suprema Corte passou a aplicar um teste comparativo entre o ônus que o estado prolator da norma impôs ao comércio interestadual e os benefícios que a nova disciplina poderia gerar em termos de bem estar no estado de origem, seja de que natureza for - o que veio a ser chamado, posteriormente, no julgamento do caso Oregon Waste Systems, Inc. v. Department of Environmental Quality of Oregon ${ }^{608}$, de 1994, como teste Pike de balanceamento $^{609}$.

\subsubsection{Da Discriminação Tributária.}

Inicialmente, deve-se assinalar que a evolução histórica da construção jurisprudencial do aspecto negativo da "The Commerce Clause" em matéria tributária implica muito menos dificuldade de entendimento do que a sua aplicação à matéria regulatória.

A melhor síntese de tal transformação vem dada pelo Justice David Souter, no voto condutor do já mencionado e importante caso tributário Oklahoma Tax Comission v. Jefferson Lines, Inc. ${ }^{610}$, de 1995.

No seu voto, Justice Souter afirma que se podem identificar dois grandes períodos de exame da questão pela Suprema Corte.

Em um primeiro, a Suprema Corte recusava qualquer incidência, tributada pelos estados, que se referissem a operações que fossem caracterizadas como comércio interestadual ${ }^{611}$. Assim, a doutrina tem classificado a abordagem jurisprudencial adotada

\footnotetext{
607397 U.S. 137 (1970).

608 511 U.S. 93 (1994).

609 "Pike balancing test", no original em inglês.

610514 U.S. 175 (1995).

611 "The command has been stated more easily than its object has been attained, however, and the Court's understanding of the dormant Commerce Clause has taken some turns. In its early stages, see $1 \mathrm{~J}$. Hellerstein \& W. Hellerstein, State Taxation "4.05-4.08 (2d ed. 1993) (hereinafter Hellerstein \& Hellerstein); Hartman, supra $n .3$, $\$ 2: 9-2: 16$, the Court held the view that interstate commerce was wholly immune from state taxation "in any form," "even though the same amount of tax should be laid on [intrastate] commerce," Robbins v. Shelby County Taxing Dist., 120 U. S. 489, 497 (1887); see also Cooley v. Board of Wardens of Port of Philadelphia ex rel. Soc. for Relief of Distressed Pilots, 12 How. 299 (1852); Brown v. Maryland, 12 Wheat. 419 (1827). This position gave way in time to a less uncompromising but formal approach, according to which, for example, the Court would invalidate a state tax levied on gross receipts from interstate commerce, New Jersey Bell Telephone Co. v. State Bd. of Taxes and Assessments of N. J., 280 U. S. 338 (1930); Meyer v. Wells, Fargo \& Co., 223 U. S. 298 (1912), or upon the "freight carried" in interstate commerce, Case of the State Freight Tax, 15 Wall. 232, 278 (1873), but would allow a tax merely measured
} 
então como formal, pelo que também tem sido conhecido como "período formalista", ou da regra formal, como por William Lockhart $\left(1981\right.$, p. 1026) ${ }^{612}$. Outros, como Jenkins e Hribenick (1982, p. 953) denominam como "commerce per se rule", ou de período de prevalência da "tax immunity doctrine", como David Shores (1982, p. 133), ou de período de imunidade do comércio interestadual, como Michel de Wolf (2005, p. 76).

Tal entendimento iniciou-se no julgamento do caso Leloup v. Port of Mobile ${ }^{613}$, de 1888, Uma importante companhia prestadora de serviços de comunicações telegráficas, a The Western Union Telegraph Company, abriu uma filial no condado de Mobile, Alabama, pelo que foi instada a pagar uma taxa, por norma local, a título de licenciamento anual, a qual não foi paga pelo agente local da empresa, Edward Leloup, por conta de sua inconstitucionalidade.

A Corte decidiu que, como a comunicação por telégrafo é comércio e, pela sua própria natureza, a ser prestada entre diferentes municípios e entre diferentes estados, está diretamente inserida no exclusivo poder de legislar do Congresso, pelo que impossível a criação de hipótese de incidência por norma local sobre esse tipo de operação, que não possa ser considerada intraestatal ou intramunicipal ${ }^{614}$.

by gross receipts from interstate commerce as long as the tax was formally imposed upon franchises, Maine v. Grand Trunk R. Co., 142 U. S. 217 (1891), or "'in lieu of all taxes upon [the taxpayer's] property,'" United States Express Co. v. Minnesota, 223 U. S. 335, 346 (1912).4 See generally Lockhart, Gross Receipts Taxes on Interstate Transportation and Communication, 57 Harv. L. Rev. 40, 43-66 (1943) (hereinafter Lockhart). Dissenting from this formal approach in 1927, Justice Stone remarked that it was "too mechanical, too uncertain in its application, and too remote from actualities, to be of value." Di Santo v. Pennsylvania, 273 U.S. 34, 44 (1927) (dissenting opinion)" (514 U.S. 180 - 181).

612 "Formal rule", no original em inglês.

613127 U. S. 640 (1888).

614 "Now we have decided that communication by telegraph is commerce, as well as in the nature of postal service, and, if carried on between different states, it is commerce among the several states, and directly within the power of regulation conferred upon Congress, and free from the control of state regulations except such as are strictly of a police character. In the case of Pensacola Telegraph Company v. Western Union Telegraph Company, 96 U. S. 1, we held that it was not only the right but the duty of Congress to take care that intercourse among the states and the transmission of intelligence between them be not obstructed or unnecessarily encumbered by state legislation, and that the Act of Congress passed July 24, 1866, above referred to, so far as it declares that the erection of telegraph lines shall, as against state interference, be free to all who accept its terms and conditions, and that a telegraph company of one state shall not, after accepting them, be excluded by another state from prosecuting its business within her jurisdiction, is a legitimate regulation of commercial intercourse among the states, and is also appropriate legislation to execute the powers of Congress over the postal service. In Western Union Telegraph Co. v. Texas, 105 U. S. 460, we decided that a state cannot lay a tax on the interstate business of a telegraph company, as it is interstate commerce, and that, if the company accepts the provisions of the act of 1866, it becomes an agent of the United States so far as the business of the government is concerned, and state laws are unconstitutional which impose a tax on messages sent in the service of the government or sent by any persons from one state to another. In the present case it is true, the tax is not laid upon individual messages, but it is laid on the occupation, or the business of sending such messages.

It comes plainly within the principle of the decisions lately made by this Court in Robbins v. Taxing District of Shelby County, 120 U. S. 489, and Philadelphia \& Southern Steamship Co. v. Pennsylvania, 122 U. S. $326 "$ "(127 U. S. $645-646)$. 
Resumindo a opinião da corte, Justice Joseph Bradley afirma, ao final, que os estados não possuem o direito de imporem tributos sobre o comércio interestadual sob qualquer forma, tanto se incidentes sobre a operação de transporte, quanto sobre as receitas derivadas da prestação do serviço ou da realização da atividade empresarial, uma vez que todas essas modalidades implicariam encargos ao comércio interestadual, cuja regulação é reservada ao Congresso ${ }^{615}$.

$\mathrm{Na}$ verdade, assim também havia entendido anteriormente a corte em Robbins v. Shelby County Taxing District ${ }^{616}$, um caso análogo, embora de forma menos esclarecedora $^{617}$.

A melhor definição encontrada na doutrina internacional quanto ao significado desse entendimento dito formalista da primeira fase jurisprudencial quanto ao aspecto negativo da "The Commerce Clause" em matéria tributária, não por acaso proveniente de um estudioso estrangeiro, foi empreendida por Michel de Wolf (2005, p. 87), nos ensinando que o que se determina é que o legislador fiscal estadual é limitado em sua soberania não apenas por questões de fundo, como a não-discriminação e a proporcionalidade, mas também por aspectos formais, na medida em que as incidências por ele instituídas não podem absolutamente onerar diretamente operações interestaduais.

Julgado considerado o mais fundamentado dentro desse raciocínio, embora já prolatado quando de uma fase de transição, é o caso Freeman v. Hewitt ${ }^{618}$, de 1946. Um trustee $^{619}$, Freeman, residente no estado de Indiana, pretendeu oferecer à venda títulos e valores mobiliários do trust na bolsa de Nova York. O estado de sua residência, com base no The Indiana Gross Income Tax Act, 1933, pretendeu tributar a renda bruta decorrente

\footnotetext{
615 "In our opinion, such a construction of the Constitution leads to the conclusion that no state has the right to lay a tax on interstate commerce in any form, whether by way of duties laid on the transportation of the subjects of that commerce or on the receipts derived from that transportation or on the occupation or business of carrying it on, and the reason is that such taxation is a burden on that commerce, and amounts to a regulation of it, which belongs solely to Congress. This is the result of so many recent cases that citation is hardly necessary. As a matter of convenient reference, we give the following list: @ 82 U.S. 411.

We may here repeat what we have so often said before that this exemption of interstate and foreign commerce from state regulation does not prevent the state from taxing the property of those engaged in such commerce located within the state as the property of other citizens is taxed, nor from regulating matters of local concern which may incidentally affect commerce, such as wharfage, pilotage, and the like. We have recently had before us the question of taxing the property of a telegraph company in the case of Western Union Telegraph Co. v. Massachusetts, 125 U. S. 530" (127 U. S. 648 - 649).

616120 U.S. 489 (1887).

617 "Interstate commerce cannot be taxed at all by a state even though the same amount of tax should be laid on domestic commerce or that which is carried on solely within the state" (120 U.S. 489).

618329 U. S. 249 (1946).

${ }^{619}$ Trustee é o administrador de um trust, que consiste em uma universalidade de bens, de propriedade anterior de um instituidor, o settler, constituída em benefício de um terceiro, o beneficiary. A propriedade dos bens que constituem o trust é transferida ao trustee, que, porém, só poderá dela dispor se em benefício do terceiro. Trata-se de um instituto típico dos sistemas de Common Law.
} 
dessa operação, o que foi combatido ao argumento de que constituiria uma violação à "The Commerce Clause", por se tratar de encargo direito ao comércio interestadual.

No seu voto, Justice Felix Frankfurter tratou de forma bem abrangente e didática do tema, em decisão por maioria, após introduzir o tema referindo-se ao longo e contínuo processo de maturação e ajustamento do entendimento quanto à "The Commerce Clause ${ }^{\text {}, 620}$, afirma que a cláusula não apenas é uma autorização ao legislativo federal para que prolate normas que tenham por escopo proteger e estimular o comércio entre os diversos estados da união, mas gera também, pela sua própria eficácia, uma área de livre comércio, infensa ao poder exacional dos estados, dentro do território federal. É uma limitação, portanto, ao poder dos estados, mesmo na ausência de legislação federal, não apenas contra ações hostis aos demais estados da nação, mas a qualquer ato que venha a gerar o efeito de impedir o livre fluxo de mercadorias entre os estados ${ }^{621}$.

Assim deve-se entender, no entender de Justice Frankfurter, independentemente de considerações sobre se transações intraestaduais sejam semelhantemente tributadas. Para o julgador, o que importa não é o caráter de justiça na incidência, não é puramente o aspecto não-discriminatório, mas o fato de que o estado não pode de maneira nenhuma exercer o controle sobre operações interestaduais, muito menos impedi-las, como corolário do sistema federativo adotado ${ }^{622}$.

620 "The power of the States to tax and the limitations upon that power imposed by the Commerce Clause have necessitated a long, continuous process of judicial adjustment. The need for such adjustment is inherent in a federal government like ours, where the same transaction has aspects that may concern the interests and involve the authority of both the central government and of the constituent States.

The history of this problem is spread over hundreds of volumes of our Reports. To attempt to harmonize all that has been said in the past would neither clarify what has gone before not guide the future. Suffice it to say that, especially in this field, opinions must be read in the setting of the particular cases, and as the product of preoccupation with their special facts" (329 U. S. 251 - 252).

621 "Our starting point is clear. In two recent cases, we applied the principle that the Commerce Clause was not merely an authorization to Congress to enact laws for the protection and encouragement of commerce among the States, but, by its own force, created an area of trade free from interference by the States. In short, the Commerce Clause, even without implementing legislation by Congress, is a limitation upon the power of the States. Southern Pacific Co. v. Arizona, 325 U. S. 761; Morgan v. Virginia, 328 U. S. 373. In so deciding, we reaffirmed, upon fullest consideration, the course of adjudication unbroken through the Nation's history. This limitation on State power, as the Morgan case so well illustrates, does not merely forbid a State to single out interstate commerce for hostile action. A State is also precluded from taking any action which may fairly be deemed to have the effect of impeding the free flow of trade between States. It is immaterial that local commerce is subjected to a similar encumbrance. It may commend itself to a State to encourage a pastoral, instead of an industrial, society. That is its concern, and its privilege. But to compare a State's treatment of its local trade with the exertion of its authority against commerce in the national domain is to compare incomparables" (329 U. S. 252).

622 "It has been suggested that such a tax is valid when a similar tax is placed on local trade, and a specious appearance of fairness is sought to be imparted by the argument that interstate commerce should not be favored at the expense of local trade. So to argue is to disregard the life of the Commerce Clause. Of course, a State is not required to give active advantage to interstate trade. But it cannot aim to control that trade, even though it desires to control its own. It cannot justify what amounts to a levy upon the very process of commerce across State lines by pointing to a similar hobble on its local trade. It is true that the existence of a 
Comentando o voto do Justice Frankfurter, Michel de Wolf (2005, p. 81), de forma deveras exagerada, afirma que se trata da primeira vez, no caso Freeman v. Hewitt, que a teoria da imunidade das operações interestaduais ganhou apoio em uma exposição doutrinária que justificasse consistentemente os fundamentos de seu desenvolvimento, a partir do conceito teórico de zona de livre comércio, malgrado eventualmente suas regras formais até poderem produzir efeitos pontuais desfavoráveis ao comércio interestadual.

Essa visão, dita formalista, já vinha sendo combatida desde quase uma década antes, ainda como posições minoritárias. Célebre, nesse aspecto de pioneirismo, é o voto do Justice Harlan Stone (ainda como Associate Justice), condutor do julgamento do caso Western Live Stock v. Bureau of Revenue ${ }^{623}$, de 1938.

Subdivision I, Chapter 7, Section 201 das New Mexico Special Session Laws, de 1934, criou um tributo incidente à alíquota de $2 \%$ sobre as receitas brutas da prestação de certo tipo de serviços, incluindo a venda de espaço de propaganda pelas editoras de jornais e revistas. A questão discutida no caso era saber se o tributo incidente sobre os espaços alienados a empresas de propaganda sediadas fora do estado do Novo México, em periódicos elaborados, editados e impressos no estado, embora circulantes nele e fora, imporia um ônus inconstitucional ao comércio interestadual.

O voto condutor do julgamento revolucionou esse conceito de encargo inconstitucional ao comércio interestadual, trazendo-o à análise do efetivo prejuízo, ainda que presumido. Defendeu que o mero fato de que as partes de uma contratação sejam residentes de estados diferentes, ou que sua execução transborde as fronteiras estaduais, não implica necessariamente afronta à "The Commerce Clause". Para o relator, a cláusula não tem por objetivo aliviar os que realizam transações interestaduais de arcarem com os custos da máquina estatal local ${ }^{624}$. Assim é que não podem ser consideradas

tax on its local commerce detracts from the deterrent effect of a tax on interstate commerce to the extent that it removes the temptation to sell the goods locally. But the fact of such a tax, in any event, puts impediments upon the currents of commerce across the State line, while the aim of the Commerce Clause was precisely to prevent States from exacting toll from those engaged in national commerce. The Commerce Clause does not involve an exercise in the logic of empty categories. It operates within the framework of our federal scheme, and with due regard to the national experience reflected by the decisions of this Court, even though the terms in which these decisions have been cast may have varied. Language alters, and there is a fashion in judicial writing, as in other things" (329 U. S. 254).

623303 U. S. 250 (1938).

624 "Here, the tax which is laid on the compensation received under the contract is not forbidden either because the contract, apart from its performance, is within the protection of the commerce clause or because, as an incident preliminary to printing and publishing the advertisements, the advertisers send cuts, copy, and the like to appellants.

We turn to the other and more vexed question whether the tax is invalid because the performance of the contract for which the compensation is paid involves to some extent the distribution, interstate, of some copies of the magazine containing the advertisements. We lay to one side the fact that appellants do not 
inconstitucionais, por esse motivo apenas, tributos sobre a propriedade de instrumentos empregados no comércio internacional ou sobre as rendas líquidas decorrentes dessas operações, tributos que, se, de uma forma ou de outra, oneram o comércio interestadual, não devem ser só por essa razão proibidos ${ }^{625}$.

Por outro lado, tributos locais que incidirem sobre as operações comerciais interestaduais, afirma, geralmente têm sido declarados inconstitucionais em função do receio de que a proliferação dessas exações poderia destruir o comércio interestadual e renovar a criação de barreiras estaduais ao comércio nacional, motivação principal da criação da "The Commerce Clause"626. Assim, o fato de a publicação circular por entre mais de um estado não pressupõe o prejuízo ao comércio interestadual ${ }^{627}$.

allege specifically that the contract stipulates that the advertisements shall be sent to subscribers out of the state, or is so framed that the compensation would not be earned if subscribers outside the state should cancel their subscriptions. We assume the point in appellants' favor, and address ourselves to their argument that the present tax infringes the commerce clause because it is measured by gross receipts which are to some extent augmented by appellants' maintenance of an interstate circulation of their magazine.

It was not the purpose of the commerce clause to relieve those engaged in interstate commerce from their just share of state tax burden even though it increases the cost of doing the business. "Even interstate business must pay its way," Postal Telegraph-Cable Co. v. Richmond, 249 U. S. 252, 249 U. S. 259; Ficklen v. Shelby County Taxing District, 145 U. S. 1, 145 U. S. 24; Postal Telegraph Cable Co. v. Adams, 155 U. S. 688, 155 U. S. 696; Galveston, H. \& S.A. R. Co. v. Texas, 210 U. S. 217, 210 U. S. 225-227, and the bare fact that one is carrying on interstate commerce does not relieve him from many forms of state taxation which add to the cost of his business" (303 U.S. 254).

625 "He is subject to a property tax on the instruments employed in the commerce, Western Union Telegraph Co. v. Massachusetts, 125 U. S. 530; Cleveland, C., C. \& St.L. R. Co. v. Backus, 154 U. S. 439; Adams Express Co. v. Ohio State Auditor, 165 U. S. 194; Adams Express Co. v. Kentucky, 166 U. S. 171; Western Union Tel. Co. v. Missouri ex rel. Gottlieb, 190 U. S. 412; Old Dominion S.S. Co. v. Virginia, 198 U. S. 299, and, if the property devoted to interstate transportation is used both within and without the state, a tax fairly apportioned to its use within the state will be sustained, Pullman's Palace-Car Co. v. Pennsylvania, 141 U. S. 18; Cudahy Packing Co. v. Minnesota, 246 U. S. 450. Net earnings from interstate commerce are subject to income tax, United States Glue Co. v. Oak Creek, 247 U. S. 321, and, if the commerce is carried on by a corporation, a franchise tax may be imposed measured by the net income from business done within the state, including such portion of the income derived from interstate commerce as may be justly attributable to business done within the state by a fair method of apportionment, Underwood Typewriter Co. $v$. Chamberlain, 254 U. S. 113. Cf. Bass, Ratcliff \& Gretton, Ltd. v. State Tax Commission, 266 U. S. 271.

All of these taxes in one way or another add to the expense of carrying on interstate commerce, and in that sense burden it; but they are not for that reason prohibited" (303 U.S. 254 - 255).

626 "On the other hand, local taxes measured by gross receipts from interstate commerce have often been pronounced unconstitutional. The vice characteristic of those which have been held invalid is that they have placed on the commerce burdens of such a nature as to be capable, in point of substance, of being imposed (Fargo v. Stevens, Michigan, 121 U. S. 230; Philadelphia \& Sou.S.S. Co. v. Pennsylvania, 122 U. S. 326; Galveston, H. \& S.A. R. Co. v. Texas, supra; Meyer v. Wells, Fargo \& Co., 223 U. S. 298) or added to (Crew Levick Co. v. Pennsylvania, 245 U. S. 292; 297 U. S. 346; 82 U. S. 280; Bradley, J., dissenting in Maine v. Grand Trunk Ry. Co., 142 U. S. 217, 142 U. S. 235. Cf. Pullman's Palace-Car Co. v. Pennsylvania, supra, 141 U. S. 26. The multiplication of state taxes measured by the gross receipts from interstate transactions would spell the destruction of interstate commerce and renew the barriers to interstate trade which it was the object of the commerce clause to remove. Baldwin v. G.A.F. Seelig, 294 U. S. 511, 294 U. S. 523" (303 U.S. 255).

627 "As we have said, the carrying on of a local business may be made the condition of state taxation if it is distinct from interstate commerce and the business of preparing, printing and publishing magazine advertising is peculiarly local and distinct from its circulation, whether or not that circulation be interstate commerce" (303 U.S. 258). 
A importância do voto do Justice Harlan Stone no caso Western Live Stock v. Bureau of Revenue foi devidamente reverenciada pelo Justice David Souter, no voto condutor do relevante caso Oklahoma Tax Comission v. Jefferson Lines, Inc, quando da análise da evolução da "The Dormant Commerce Clause" em matéria tributária, nos aproximados termos com que descritos acima ${ }^{628}$.

Em verdade, a partir das décadas de 20 e 40 do Século XX e até o fim da década de 70, a Suprema Corte norteamericana experimentou uma evidente indecisão em identificar qual fosse a semântica da "The Dormant Commerce Clause". Diversos julgados decidiam pela possibilidade de tributar o comércio interestadual, sem que se pudesse divisar, como comenta De Wolf (2005, p. 82), qualquer plano lógico de justificação. Por diversas vezes, usando a técnica do distinguishing ${ }^{629}$, a Suprema Corte admitiu a constitucionalidade de incidências interestaduais de, apenas a título ilustrativo, impostos

628 "In 1938, the old formalism began to give way with Justice Stone's opinion in Western Live Stock $v$. Bureau of Revenue, 303 U. S. 250, which examined New Mexico's franchise tax, measured by gross receipts, as applied to receipts from out of-state advertisers in a journal produced by taxpayers in New Mexico but circulated both inside and outside the State. Although the assessment could have been sustained solely on prior precedent, see id., at 258; Lockhart 66, and n. 122, Justice Stone added a dash of the pragmatism that, with a brief interlude, has since become our aspiration in this quarter of the law. The Court had no trouble rejecting the claim that the "mere formation of the contract between persons in different states" insulated the receipts from taxation, Western Live Stock, 303 U. S., at 253, and it saw the business of "preparing, printing and publishing magazine advertising [as] peculiarly local" and therefore subject to taxation by the State within which the business operated. Id., at 258. The more "vexed question," however, was one that today we would call a question of apportionment: whether the interstate circulation of the journal barred taxation of receipts from advertisements enhanced in value by the journal's wide dissemination. Id., at 254. After rebuffing any such challenge on the ground that the burden on interstate commerce was "too remote and too attenuated" in the light of analogous taxation of railroad property, id., at 259, Justice Stone provided an "added reason" for sustaining the tax:

"So far as the value contributed to appellants' New Mexico business by circulation of the magazine interstate is taxed, it cannot again be taxed elsewhere any more than the value of railroad property taxed locally. The tax is not one which in form or substance can be repeated by other states in such manner as to lay an added burden on the interstate distribution of the magazine." Id., at 260.

The Court explained that "[i]t was not the purpose of the commerce clause to relieve those engaged in interstate commerce from their just share of state tax burden even though it increases the cost of doing the business." Id., at 254. Soon after Western Live Stock, the Court expressly rested the invalidation of an unapportioned gross receipts tax on the ground that it violated the prohibition against multiple taxation:

"The vice of the statute as applied to receipts from interstate sales is that the tax includes in its measure, without apportionment, receipts derived from activities in interstate commerce; and that the exaction is of such a character that if lawful it may in substance be laid to the fullest extent by States in which the goods are sold as well as those in which they are manufactured." J. D. Adams Mfg. Co. v. Storen, 304 U. S. 307, 311 (1938). See also Gwin, White \& Prince, Inc. v. Henneford, 305 U. S. 434, 438-439 (1939).

After a brief resurgence of the old absolutism that proscribed all taxation formally levied upon interstate commerce, see Freeman v. Hewit, 329 U. S. 249 (1946); Spector Motor Service, Inc. v. O'Connor, 340 U. S. 602 (1951), the Court returned to Western Live Stock's multiple taxation rule in Northwestern States Portland Cement Co. v. Minnesota, 358 U. S. 450 (1959), and we categorically abandoned the latter-day formalism when Complete Auto Transit, Inc. v. Brady, 430 U. S. 274 (1977), overruled Spector and Freeman" (514 U.S. 181 - 183).

${ }^{629}$ Técnica empregada em sistemas de Common Law, por meio da qual o julgador ressalta os contrastes entre as situações de fato ou de direito do caso em exame, em relação a determinado precedente aparentemente similar, tornando-os relevantes para que se adote uma solução jurisprudencial parcial ou totalmente diversa. 
sobre receitas brutas, como no caso Underwood Typewriter Co. v. Chamberlain $^{630}$, de 1920, sobre o valor de minerais extraídos, caso Oliver Iron Co. v. Lord ${ }^{631}$, de 1923 e sobre aquisições de carvão mineral da Pennsylvania para New York, caso McGoldrick v Berwind-White Coal Mining Co. ${ }^{632}$, de 1940.

Como afirmado pelo Justice David Souter, no voto condutor em Oklahoma Tax Comission v. Jefferson Lines, Inc, em excerto destacado acima, o tardio caso Spector Motor Service, Inc. v. O'Connor ${ }^{633}$, de 1951, é dos últimos exemplos de aplicação da visão formalista pela Suprema Corte.

O estado de Connecticut exigia, das filiais de companhias não locais, pelo privilégio de realizar atividade econômica no território do estado, um tributo calculado sobre o percentual das receitas líquidas da companhia imputáveis aos negócios no estado. Tratava-se, portanto, de um tratamento sem nenhum viés discriminatório. No entanto, entendeu-se tal tributo como violador da "The Dormant Commerce Clause", na medida em que incidente sobre as atividades econômicas de Spector Motor Service, Inc., uma companhia que atuava apenas e exclusivamente no mercado de transporte interestadual rodoviário, cuja matriz estava localizada em Missouri.

Comentando acerca desse (des)entendimento da Suprema Corte, um dos dois mais férteis e profundos doutrinadores americanos acerca da tributação estadual e dos seus limites impostos pela estrutura federalista, ao lado de Walter Hellerstein, Paul Hartman, em 1960, comentando os casos Northwestern States Portland Cement Co. v. Minnesota e Williams, State Revenue Commissioner, v. Stockham Valves \& Fittings, Inc. ${ }^{634}$, casos geminados ambos acerca da constitucionalidade de incidências sobre receitas societárias advindas de operações interestaduais, especialmente examinando tais julgados tributários em confrontação com a então já mais razoável, embora mais complexa, formulação acerca da "The Dormant Commerce Clause" em matéria regulatória, a qual abordou-se aqui apenas tangencialmente, perguntava-se de onde no texto constitucional a Suprema Corte havia retirado a formulação quanto à ausência do poder concorrente dos estados em matéria fiscal, quanto às operações interestaduais, já que a reconhecia plenamente no plano regulatório, desde que não discriminatória (1960, p. 1071 - 1072).

\footnotetext{
${ }^{630} 254$ U. S. 113 (1920).

631262 U.S. 172 (1923).

632309 U.S. 33 (1940).

633340 U. S. 602 (1951).

634358 U.S. 450 (1959).
} 
Porém, os entendimentos ditos formalistas, assim como os julgamentos em contrário por motivos diversos, foram expressamente objeto do emprego da técnica do overruling $^{635}$ somente no distante ano de 1977, na apreciação do relevantíssimo caso Complete Auto Transit, Inc. v. Brady ${ }^{636}$, que será objeto de exame aprofundado adiante. A partir desse momento, a Suprema Corte passou a adotar um teste para a norma tributária de forma similar ao adotado para a norma regulatória, ambas incidentes sobre operações interestaduais, o que, no aspecto regulatório, já estava consolidado desde o caso Pike v. Bruce Church, Inc. ${ }^{637}$, de $1970^{638}$.

A partir de então, prevalece o entendimento doutrinário, como, por exemplo, o de Robert A. Sedler (1985, p. 1027), em conclusão de seu raciocínio, de que o conteúdo, hoje, da "The Dormant Commerce Clause", em matéria tributária ou regulatória, limita-se ao princípio de não-discriminação. Ou, como prefere Dan Coenen (2004, p. 224), o núcleo da moderna "The Dormant Commerce Clause" repousa na proibição, que impõe às leis estaduais, à determinação de discriminações às operações interestaduais.

\subsubsection{Da Discriminação Tributária Explícita.}

As hipóteses mais evidentes de normas tributárias discriminatórias ocorrem nas situações em que, costuma-se dizer, há normas facialmente, evidentemente, explicitamente discriminatórias - "facially discriminatory". Nesses casos, a Suprema Corte emprega a mesma técnica de exame mais rigoroso de controle judicial (judicial review), o mais exigente dos três níveis ${ }^{639}$, utilizada nos casos de violação às Cláusulas de "Due Process of Law" e "Equal Protection of Law", atinentes às disposições das Quinta e Décima-Quarta Emendas - o "strict scrutiny".

"Strict scrutiny" consiste em uma fortíssima presunção de inconstitucionalidade da norma e que, no caso da "Equal Protection of Law", é aplicada quando a norma traz

\footnotetext{
635 "Accordingly, we now reject the rule of Spector Motor Service, Inc. v. O'Connor that a state tax on the "privilege of doing business" is per se unconstitutional when it is applied to interstate commerce, and that case is overruled" (430 U. S. 288 - 289).

${ }^{636} 430$ U.S. 274 (1977).

${ }^{637} 397$ U.S. 137 (1970).

${ }^{638}$ Para maiores digressões, inclusive acerca da origem histórica, do chamado "Pike Balancing Test", consistente na verificação do caráter discriminatório ou não de norma de cunho regulatório, mediante balanceamento dos seus custos em relação a seus beneficios, ver DAY, David S. "Revisiting Pike: The Origins of The Nondiscrimination Tier of the Dormant Commerce Clause Doctrine”. Hamline Law Review. Saint Paul: Hamline University Press. Vol. 27, 2004, p. 45 - 62.

639 "Levels of Scrutiny", termo originário, em inglês.
} 
uma discriminação baseada na raça ou na origem nacional da pessoa física. A norma só é aprovada no teste de constitucionalidade se o legislativo ou executivo prolator demonstra que o caráter discriminatório da norma é estritamente necessário para o atingimento de um objetivo ou interesse governamental impositivo ${ }^{640}$, como esclarecido na decisão no caso Palmore v. Sidoti ${ }^{641}$, de 1984, um contencioso de direito de família entre dois ex-cônjuges divorciados, ambos brancos, a respeito da custódia da filha de ambos, cuja guarda, ora atribuída à mãe, era contestada pelo pai em função de relacionamento estável da mãe com padrasto afroamericano.

Em outras palavras, a instituição pública responsável pela norma, geral ou individual, deverá, com o fim de salvar a validade constitucional da norma, arcar com o ônus de provar a existência de um fim de interesse público realmente relevante para justificar o caráter discriminatório da disposição, assim como, e isso é muito importante, comprovar que tal finalidade não poderia ser alcançada por uma alternativa jurídica menos discriminatória.

Em se tratando do aspecto negativo da "The Commerce Clause", já foi dito, por Justice Antonin Scalia, no exame do caso New Energy Co. v. Limbach ${ }^{642}$, de 1988, que o fator de interesse público, para esse tipo de análise de constitucionalidade, dada a natureza da vedação que se impõe ao poder legislativo estadual, para ser considerado válido, deve ser algo que seja diferente do protecionismo econômico ${ }^{643}$.

Como comenta Erwin Chemerinsky (2006, p. 671), o "strict scrutiny" implica, muitíssimo provavelmente, uma análise fatal à constitucionalidade da norma examinada,

\footnotetext{
640 "A core purpose of the Fourteenth Amendment was to do away with all governmentally imposed discrimination based on race. See Strauder v. West Virginia, 100 U. S. 303, 100 U. S. 307-308, 310 (1880). Classifying persons according to their race is more likely to reflect racial prejudice than legitimate public concerns; the race, not the person, dictates the category. See Personnel Administrator of Mass. v. Feeney, 442 U. S. 256, 442 U. S. 272 (1979). Such classifications are subject to the most exacting scrutiny; to pass constitutional muster, they must be justified by a compelling governmental interest and must be "necessary. . . to the accomplishment" of their legitimate purpose, McLaughlin v. Florida, 379 U. S. 184, 379 U. S. 196 (1964). See Loving v. Virginia, 388 U. S. 1, 388 U. S. 11 (1967)" (466 U. S. 432 - 433).

641466 U.S. 429 (1984).

642486 U.S. 269 (1988).

643 "It has long been accepted that the Commerce Clause not only grants Congress the authority to regulate commerce among the States, but also directly limits the power of the States to discriminate against interstate commerce. See, e.g., Hughes v. Oklahoma, 441 U. S. 322, 441 U. S. 326 (1979); H. P. Hood \& Sons, Inc. v. Du Mond, 336 U. S. 525, 336 U. S. 534-535 (1949); Welton v. Missouri, 91 U. S. 275 (1876). This "negative" aspect of the Commerce Clause prohibits economic protectionism -- that is, regulatory measures designed to benefit in-state economic interests by burdening out-of-state competitors. See, e.g., Bacchus Imports, Ltd. $v$. Dias, 468 U. S. 263, 468 U. S. 270-273 (1984); H. P. Hood \& Sons, supra, at 336 U. S. 532-533; Guy v. Baltimore, 100 U. S. 434, 100 U. S. 443 (1880). Thus, state statutes that clearly discriminate against interstate commerce are routinely struck down, see, e.g., Sporhase v. Nebraska ex rel. Douglas, 458 U. S. 941 (1982); Lewis v. BT Investment Managers, Inc., 447 U. S. 27 (1980); Dean Milk Co. v. Madison, 340 U. S. 349 (1951), unless the discrimination is demonstrably justified by a valid factor unrelated to economic protectionism, see, e.g., Maine v. Taylor, 477 U. S. 131 (1986)" (486 U. S. 273 - 274).
} 
embora, no caso da "The Dormant Commerce Clause", a lógica dos julgamentos da Suprema Corte seja algo diversa dos relativos à "Equal Protection Clause", já que exige a pesquisa tanto dos seus fins quanto dos meios empregados para alcançá-los (p. 444)

Apenas a título ilustrativo, cabe ressaltar que a hieraquização dos três "levels of scrutiny", separando-os de acordo com a natureza da discriminação identificada, foi estabelecida em nota de rodapé ${ }^{644}$ ao voto condutor do caso United States v. Carolene Products Co. ${ }^{645}$, de 1938, da lavra do Justice Harlan Stone, atribuindo o exame mais minucioso a qualquer violação a uma proibição específica do texto constitucional, como, no caso em exame, de caráter regulatório do comércio, já que se referia à proibição da comercialização interestadual de leite, sob qualquer modalidade ou apresentação, adicionado de gorduras ou óleos.

São diversos os exemplos de casos jurisprudenciais, apreciados pela Suprema Corte, referentes à discriminação explícita em matéria tributária.

Apenas para citar alguns mais recentes e importantes, podemos apontar o caso New Energy Co. v. Limbach, de 1988, de que já tratamos em item precedente, acerca do imposto sobre vendas a varejo estadual (Sales Tax) do estado de Ohio, que garantia um crédito incidente sobre combustíveis, para cada galão de etanol vendido, desde que o combustível comercializado houvesse sido fabricado no estado de Ohio ou viesse de estado que provesse semelhante subsídio aos produtos combustíveis renováveis vindos de Ohio.

644 "[Footnote 4]

There may be narrower scope for operation of the presumption of constitutionality when legislation appears on its face to be within a specific prohibition of the Constitution, such as those of the first ten amendments, which are deemed equally specific when held to be embraced within the Fourteenth. See Stromberg v. California, 283 U. S. 359, 283 U. S. 369-370; Lovell v. Griffin, 303 U. S. 444, 303 U. S. 452.

It is unnecessary to consider now whether legislation which restricts those political processes which can ordinarily be expected to bring about repeal of undesirable legislation is to be subjected to more exacting judicial scrutiny under the general prohibitions of the Fourteenth Amendment than are most other types of legislation. On restrictions upon the right to vote, see Nixon v. Herndon, 273 U. S. 536; Nixon v. Condon, 286 U. S. 73; on restraints upon the dissemination of information, see Near v. Minnesota ex rel. Olson, 283 U. S. 697, 283 U. S. 713-714, 283 U. S. 718-720, 283 U. S. 722; Grosjean v. American Press Co., 297 U. S. 233; Lovell v. Griffin, supra; on interferences with political organizations, see Stromberg v. California, supra, 283 U. S. 369; Fiske v. Kansas, 274 U. S. 380; Whitney v. California, 274 U. S. 357, 274 U. S. $373-$ 378; Herndon v. Lowry, 301 U. S. 242, and see Holmes, J., in Gitlow v. New York, 268 U. S. 652, 268 U. S. 673; as to prohibition of peaceable assembly, see De Jonge v. Oregon, 299 U. S. 353, 299 U. S. 365.

Nor need we enquire whether similar considerations enter into the review of statutes directed at particular religious, Pierce v. Society of Sisters, 268 U. S. 510, or national, Meyer v. Nebraska, 262 U. S. 390; Bartels v. Iowa, 262 U. S. 404; Farrington v. Tokushige, 273 U. S. 284, or racial minorities, Nixon v. Herndon, supra; Nixon v. Condon, supra: whether prejudice against discrete and insular minorities may be a special condition, which tends seriously to curtail the operation of those political processes ordinarily to be relied upon to protect minorities, and which may call for a correspondingly more searching judicial inquiry. Compare 17 U. S. 428; South Carolina v. Barnwell Bros., @ 303 U. S. 177, 303 U. S. 184, n 2, and cases cited" (304 U. S. 155).

645304 U.S. 144 (1938). 
Outro exemplo é o caso Fulton Corp. v. Faulkner, Secretary of Revenue of North Carolina ${ }^{646}$, de 1996. Trata do exame da constitucionalidade do "Intangibles Tax", tributo criado pelo estado da Carolina do Norte, um imposto anual sobre a propriedade de ativos incidente sobre o valor de mercado das ações detidas por residentes no estado da Carolina do Norte, ou os que tivessem estabelecimentos permanentes no estado, à alíquota de $0,25 \%$. Ocorre que, do tributo devido, seria dedutível um percentual correspondente à fração do faturamento, folha de pagamento e imóveis da sociedade oriundos de atividades na Carolina do Norte, prestados no estado ou nele situados - portanto, sujeito à repartição de receitas tributárias com o estado. Assim, se a sociedade tivesse a totalidade de seus negócios, empregados e patrimônio localizados no estado, estaria completamente isenta do "Intangibles Tax", e assim proporcionalmente.

Fulton Corporation era uma companhia situada no estado, mas que havia, durante o ano de 1990, adquirido participações acionárias em seis corporações, das quais cinco não auferiam receitas no estado da Carolina do Norte - cujas propriedades, portanto, seriam tributadas a $100 \%$ da alíquota. A restante, Food Lion, Inc., que realizava $46 \%$ de suas atividades no estado, seria, então, tributada pelo "Intangibles Tax" no percentual de $54 \%$ da alíquota anual cheia, de $0,25 \%$ sobre o seu valor de mercado.

O voto condutor do Justice David Souter, acompanhado à unanimidade, primeiramente ponderou o que deve ser inicialmente verificado - a avaliação do quão deletérios são os efeitos da norma no comércio interestadual, se há discriminação direta ou apenas incidental. Para ele, o que importa é saber se a carga tributária será mais onerosa com o transbordar de fronteiras do que seria se todas as transações fossem intraestaduais. Assim, acaso verificada a infração explícita, a norma deveria ser de per si declarada inválida ${ }^{647}$.

\footnotetext{
${ }^{646} 516$ U.S. 325 (1996).

647 "In evaluating state regulatory measures under the dormant Commerce Clause, we have held that "the first step ... is to determine whether it 'regulates evenhandedly with only "incidental" effects on interstate commerce, or discriminates against interstate commerce." Oregon Waste Systems, Inc. v. Department of Environmental Quality of Ore., 511 U. S. 93, 99 (1994) (quoting Hughes v. Oklahoma, 441 U. S. 322, 336 (1979)). With respect to state taxation, one element of the protocol summarized in Complete Auto Transit, Inc. v. Brady, 430 U. S. 274 (1977), treats a law as discriminatory if it "tax[es] a transaction or incident more heavily when it crosses state lines than when it occurs entirely within the State."' Chemical Waste Management, Inc. v. Hunt, 504 U. S. 334, 342 (1992) (quoting Armco Inc. v. Hardesty, 467 U. S. 638, 642 (1984)); see also Boston Stock Exchange v. State Tax Comm'n, 429 U. S. 318, 332, n. 12 (1977) (noting that a State "may not discriminate between transactions on the basis of some interstate element"). State laws discriminating against interstate commerce on their face are "virtually per se invalid." Oregon Waste, supra, at 99; see also Philadelphia v. New Jersey, 437 U. S. 617, 624 (1978)" (516 U.S. 331).
} 
No caso, entendeu não haver dúvidas que o tributo tinha por finalidade favorecer companhias localizadas no estado, de forma a concentrar investimentos apenas mas fronteiras regionais ${ }^{648}$.

Porém, tal julgado é importante, não só porque, até por ser dos mais recentes, é um dos casos mais evidentes ainda referentes à discriminação explícita nos dias de hoje, como também porque toca em dois pontos realmente relevantes no que tange ao exame do caráter discriminatório da tributação.

Em primeiro lugar, porque a Administração Fiscal da Carolina do Norte usou, em sua contestação, o argumento do dano irrisório, ou “'de minimis' defense”, como também denominado no âmbito da OMC. Entendiam que o tributo exigido é de pequena monta, não acarretando, portanto, impacto relevante no comércio interestadual.

A alegação foi de pronto afastada, com base em precedentes mencionados, já que qualquer discriminação, no entender histórico da Corte, deveria ser entendida como não permitida, independentente do seu grau de iniquidade ${ }^{649}$. Também foi rejeitada a consideração de que haveria apenas efeitos positivos na Carolina do Norte, mas não negativos nos demais estados, mencionando novamente a balcanização do sistema federativo que uma guerra fiscal entre estados poderia proporcionar, preocupação fundamental da "The Commerce Clause" $" 650$.

O segundo ponto abordado nesse julgado refere-se ao fato, também alegado por Faulkner, Secretário da Receita da Carolina do Norte, de que o tributo teria um caráter

648 "There is no doubt that the intangibles tax facially discriminates against interstate commerce. A regime that taxes stock only to the degree that its issuing corporation participates in interstate commerce favors domestic corporations over their foreign competitors in raising capital among North Carolina residents and tends, at least, to discourage domestic corporations from playing their trades in interstate commerce" (516 U.S. 333).

649 "Although the Secretary does suggest that the tax is so small in amount as to have no practical impact at all, we have never recognized a "de minimis" defense to a charge of discriminatory taxation under the Commerce Clause. See, e. g., Associated Industries of Mo. v. Lohman, 511 U. S. 641, 650 (1994) ("[A]ctual discrimination, wherever it is found, is impermissible, and the magnitude and scope of the discrimination have no bearing on the determinative question whether discrimination has occurred"); Maryland $v$. Louisiana, 451 U. S. 725, 760 (1981) ("We need not know how unequal the Tax is before concluding that it unconstitutionally discriminates")" (idem).

650 "We likewise reject the Secretary's speculation that the most likely effect, if any, of the taxable percentage deduction is to encourage out-of-state firms to compete in the North Carolina market so that their North Carolina shareholders may take advantage of the deduction. As we explain further, supra, at 330-331, such promotion of in-state markets at the expense of out-of-state ones furthers the "economic Balkanization" that our dormant Commerce Clause jurisprudence has long sought to prevent. Hughes v. Oklahoma, 441 U. S. 322, 325-326 (1979); see also Halliburton Oil Well Cementing Co. v. Reily, 373 U. S. 64, 72 (1963) (a State may not impose "a tax which is discriminatory in favor of the local merchant" so as to "encourag[e] an outof-state operator to become a resident in order to compete on equal terms") (internal quotation marks and citation omitted)" (idem). 
compensatório, nos exatos moldes operativos de um ajuste fiscal de fronteira (embora a Suprema Corte não empregue tal termo).

O termo "compensatório" ou, alternativamente, "complementar", para qualificar essa característica de determinados tributos, costumam ser empregados, pela Suprema Corte, com o fim de identificar os tributos incidentes sobre transações interestaduais que visam a compensar a carga tributária incidente sobre análogas operações intraestatuais, como comenta o relator em nota de pé de página ${ }^{651}$.

Em outra nota de pé de página, mencionando um caso de 1869, Hinson v. Lott $^{652}$, acerca de tributo sobre bebidas alcoólicas no estado do Alabama, o relator comenta que a racionalidade por detrás desse entendimento jurisprudencial era a necessidade de preservação da igualdade competitiva entre residentes no estado ou não ${ }^{653}$.

Assim, o tributo, ao ter o seu caráter compensatório assim reconhecido, teria justificado o seu caráter facialmente discriminatório ${ }^{654}$. É como haveria sido firmado jurisprudencialmente, desde os casos Oregon Waste Systems, Inc. v. Department of Environmental Quality of Oregon ${ }^{655}$ e Associated Industries of Missouri et al. v. Lohman, Director of Revenue of Missouri, et al. ${ }^{656}$, ambos de 1994.

Segundo Justice David Souter, desde um precedente de 1937, Henneford v. Silas Mason Co. ${ }^{657}$, a Suprema Corte teria estabelecido três condições necessárias para que se entendesse um tributo como validamente compensatório: o estado deve identificar claramente qual o encargo tributário intraestadual que se quer compensar; o tributo sobre o

651 "[Footnote 2]

We use the terms "compensatory" tax and "complementary" tax as two ways of describing the same phenomenon: a tax on interstate commerce "complements" a tax on intrastate commerce to the extent that it "compensates" for the burdens imposed on intrastate commerce by imposing a similar burden on interstate commerce. We have also described taxes on interstate commerce as being imposed "in lieu" of taxes on intrastate commerce. See, e. g., Railway Express Agency, Inc. v. Virginia, 358 U. S. 434, 436 (1959); Postal Telegraph Cable Co. v. Adams, 155 U. S. 688, 700 (1895). This last class of cases, however, has involved taxes which were at least arguably not facially discriminatory, and we have evaluated these cases under a somewhat different standard" (516 U.S. 332).

65275 U.S. 148 (1869).

653 "[Footnote 8]

The only exception of which we are aware is Hinson v. Lott, 8 Wall. 148 (1869). In that case, we upheld an Alabama tax on each gallon of liquor imported into the State on the ground that it complemented a tax of equal magnitude on each gallon of liquor distilled in the State. We noted that this tax scheme was "necessary to make the tax equal on all liquors sold in the State," id., at 153, a rationale consistent with our conclusion that the compensatory tax doctrine is fundamentally concerned with equalizing competition between in staters and out of staters" (516 U.S. 342).

654 "We have also recognized, however, that a facially discriminatory tax may still survive Commerce Clause scrutiny if it is a truly "'compensatory tax' designed simply to make interstate commerce bear a burden already borne by intrastate commerce." Associated Industries, supra, at 647" (516 U.S. 331).

655 511 U.S. 93 (1994).

${ }^{656} 511$ U.S. 641 (1994).

657300 U. S. 577 (1937). 
comércio interestadual pode ser aproximado, mas jamais ser maior do que o ônus sobre o comércio intraestatal que ser quer ver anulado em seus efeitos e; os fatos geradores das duas incidências devem ser subtancialmente equivalentes ${ }^{658}$.

No caso concreto, a defesa do Fisco da Carolina do Norte de que o que estaria compensando o "Intangibles Tax" seria o imposto de renda sobre as empresas, exigido das sociedades que auferissem receitas no estado, não foi aprovado em nenhum dos três critérios.

Nos mencionados casos de 1994, Oregon Waste Systems, Inc. v. Department of Environmental Quality of Oregon e Associated Industries of Missouri et al. v. Lohman, Director of Revenue of Missouri, et al., em que aplicou recentemente a chamada "Compensatory Tax Doctrine", ambos foram decididos pela inconstitucionalidade das incidências estaduais por conta de o respectivo encargo tributário exceder aquele que se queria compensar, em ambos os casos especificamente identificados, caracterizando o seu viés discriminatório.

No primeiro caso, o estado do Oregon exigia um tributo adicional de US\$ 2,25 por tonelada a cada descarga, no território do estado, de resíduos sólidos vindos de outros estados, e de US\$ 0,80 por tonelada, no caso de haverem sido gerados no interior do estado.

No segundo caso, o estado do Missouri impunha um tributo estadual, o "Additional Use Tax" de 1,5\%, sobre todas as mercadorias adquiridas em outros estados, porém estocadas, usadas ou consumidas no estado, além do "Use Tax", de $4 \%$, exigido quando das aquisições internas.

Como afirma Dan Coenen (2004, p. 319), a chamada "Compensatory Tax Doctrine" tem sido, na experiência histórica da Suprema Corte, a única exceção admitida no caso de discriminação tributária, mesmo a implícita, já que a aplicação das exceções fundadas no legítimo propósito de interesse público, baseadas na doutrina aplicada ao "strict scrutiny" em matéria de "Equal Protection of Law", jamais foram aplicadas na disciplina fiscal, embora, em tese, seja possível admitir um propósito extrafiscal na norma tributária discriminatória. Sua aplicação, sempre mencionando que o propósito identificado

\footnotetext{
658 "Since Silas Mason, our cases have distilled three conditions necessary for a valid compensatory tax. First, "a State must, as a threshold matter, 'identif[y] ... the [intrastate tax] burden for which the State is attempting to compensate." Oregon Waste, supra, at 103 (quoting Maryland v. Louisiana, 451 U. S. 725 , 758 (1981)). Second, "the tax on interstate commerce must be shown roughly to approximate-but not exceedthe amount of the tax on intrastate commerce." Oregon Waste, 511 U. S., at 103. "Finally, the events on which the interstate and intrastate taxes are imposed must be 'substantially equivalent'; that is, they must be sufficiently similar in substance to serve as mutually exclusive 'prox[ies]' for each other." Ibid. (quoting Armco Inc. v. Hardesty, supra, at 643)" (511 U.S. 332 - 333).
} 
deve sempre ser diverso do protecionismo econômico, tem se verificado, portanto, apenas em matéria regulatória - do que o exemplo mais típico, com manutenção da constitucionalidade da norma discriminatória, é Maine v. Taylor ${ }^{659}$, de 1986.

Em verdade, há uma exceção, além da qualificação do tributo como compensatório, que tem sido admitida pela jurisprudência, embora não possa ser propriamente entendido como excepcionalidade à "The Dormant Commerce Clause". Trata-se do caso em que há expressa permissão legislativa prolatada pelo Congresso.

Como exemplo típico dessa hipótese, temos o caso Western \& Southern Life Insurance Co. v. Board of Equalization of California ${ }^{660}$, de 1981. O estado da California impôs um tributo sobre os prêmios de seguro pagos tanto por operações de seguro firmadas com seguradoras do estado quanto estrangeiras. Ocorre que um "Retaliatory Tax" passou a ser também exigido das seguradoras de fora do estado, quando o estado de origem da instituição financeira impusesse alíquotas diferenciadas em situações assemelhadas. Western \& Southern, uma companhia de seguros sediada no estado de Ohio, alegou violação tanto à "The Commerce Clause" quanto à "The Equal Protection Clause", da Décima Quarta Emenda.

Entendeu a corte, por sete votos a dois, que uma lei federal, o McCarranFerguson Act, que delega a regulação e a tributação das companhias seguradoras aos estados, teria removido qualquer obstáculo eventualmente imposto tanto pela "The Commerce Clause" quanto à "The Equal Protection Clause" ao poder de tributar do estado da California e que o propósito da incidência retaliatória, de fomentar operações intraestaduais de coberturas de seguros, evitando retaliações semelhantes de outros estados, é um legítimo objetivo estatal, na medida em que teria o potencial de induzir os outros estados a revogar suas legislações analogamente discriminatórias ${ }^{661}$.

\footnotetext{
${ }^{659} 477$ U. S. 131 (1986).

660451 U.S. 648 (1981).

661 "Syllabus
}

California, in addition to imposing a premiums tax on both foreign and domestic insurance companies doing business in the State, imposes a "retaliatory" tax on such a foreign insurer when the insurer's State of incorporation imposes higher taxes on California insurers doing business in that State than California would otherwise impose on that State's insurers doing business in California. Appellant, an Ohio insurer doing business in California, after unsuccessfully filing administrative refund claims for California retaliatory taxes paid, brought a refund suit in California Superior Court, alleging that the retaliatory tax violates the Commerce Clause and the Equal Protection Clause of the Fourteenth Amendment. The Superior Court ruled the tax unconstitutional, but the California Court of Appeal reversed.

Held:

1. The retaliatory tax does not violate the Commerce Clause. The McCarran-Ferguson Act, which leaves the regulation and taxation of insurance companies to the States, removes entirely any Commerce Clause restriction upon California's power to tax the insurance business. Neither the language nor the history of that 
Curioso é perceber que, em caso assemelhado, Metropolitan Life Insurance Co. v. $\operatorname{Ward}^{662}$, com base na "The Equal Protection Clause", o acórdão decidiu de forma radicalmente contrária.

Cabe ressaltar que, à semelhança dos julgados do OSC da OMC, embora a questão não costume aparecer de forma tão frequente quanto no plano internacional, a Suprema Corte norteamericana também se preocupa com a comparabilidade entre as mercadorias objeto de análise dos efeitos e objetivos da norma tributária quanto ao seu caráter discriminatório. Aponta-se o exame do caso General Motors Corporation v. Tracy, Tax Commissioner of Ohio ${ }^{663}$, de 1997, que tratava do "General Sales and Use Tax" do estado de Ohio, incidente sobre aquisições de gás natural de todos os revendedores, sejam do estado ou não, desde que sejam entendidos na definição de "natural gas company", à luz da legislação local. Por outro lado, as plantas de gás natural estatais, conhecidas como "local distribution companies", sociedades constituídas fundamentalmente para prover o mercado de consumidores pessoas físicas, eram isentas desse mesmo tributo nas suas operações de venda de gás natural. A apelante, empresa industrial de veículos automotores, que adquiria essa mercadoria de produtores independentes, alegou que o tratamento isentivo dado às empresas de propriedade do estado violaria a "The Commerce Clause" e a "The Equal Protection Clause".

Nessa oportunidade, então, Justice Souter manteve a constitucionalidade da incidência, afirmando que qualquer conceito de discriminação sob a "The Commerce Clause" pressupõe a comparação entre entidades substancialmente similares. No caso, como os produtos comercializados por cada tipo de sociedade destinavam-se a diferentes mercados, sendo diferenciados, portanto, não seria aplicável a cláusula constitucional, uma vez esvaziado o seu propósito, de preservar o mercado nacional de distúrbios

Act suggests that it does not permit, as appellant argues, "anticompetitive state taxation that discriminates against out-of-state insurers." Pp. 451 U. S. 652-655.

2. Nor does the retaliatory tax violate the Equal Protection Clause. Pp. 451 U. S. 655-674.

(a) Whatever the extent of a State's authority to exclude foreign corporations from doing business within the State, that authority does not justify imposition of more onerous taxes or other burdens on foreign corporations than those imposed on domestic corporations, unless the discrimination between foreign and domestic corporations bears a rational relation to a legitimate state purpose. Pp. 451 U. S. 655-668.

(b) The purpose of the retaliatory tax, to promote the interstate business of California insurers by deterring other States from imposing discriminatory or excessive taxes on California insurers, is a legitimate state purpose. And the California Legislature rationally could have believed that the retaliatory tax would promote that purpose, it being immaterial whether, in fact, the tax will accomplish its objectives. Assuming that the lawmakers of each State are motivated in part by a desire to promote the interests of their domestic insurance industry, it is reasonable to suppose that California's retaliatory tax will induce other States to lower the burdens on California insurers in order to spare their domestic insurers the cost of the retaliatory tax in California. Pp. 451 U. S. 668-674" (451 U. S. $648-649)$.

662470 U.S. 869 (1985).

663519 U.S. 278 (1997). 
concorrenciais oriundos de vantagens preferenciais conferidas por um estado em detrimento do outro ${ }^{664}$.

\subsubsection{Da Discriminação Tributária Implícita.}

Como já examinamos, temos um caso de discriminação tributária implícita quando não se pode identificar, no texto da norma, tratamento diferenciado em relação a produtos de origem interestadual. Trata-se das "normas facialmente neutras" ${ }^{" 665}$, para as quais a Suprema Corte admite a verificação do seu caráter discriminatório tanto em relação aos seus propósitos como quando aos seus efeitos (CHEMERINSKY, 2006, p. 433; COENEN, 2004, p. 224).

Nesse caso, a complexidade do exame do caráter discriminatório é deveras mais evidente, especialmente em matéria regulatória. Não é o nosso escopo presentemente, mas a análise do conteúdo da "The Dormant Commerce Clause", no que tange à disciplina regulatória em matéria de normas facialmente neutras, é certamente o estudo mais difícil do Direito Constitucional norteamericano. Quanto às matérias fiscais, a complexidade não é assim tão evidente, por dois motivos principais: em primeiro lugar, porque, como já explicado, durante muito tempo a Suprema Corte proibiu qualquer norma estadual que instituísse incidências sobre operações interestaduais, no exercício de um entendimento dito formalista da construção jurisprudencial; em segundo lugar, como já visto, porque se deu, em 1977, a expressa revogação (overruling) do entendimento anterior, representado pelo caso Spector Motor Service v. O'Connor, na apreciação do relevantíssimo caso Complete Auto Transit, Inc. v. Brady, de forma muito didática e desde então mantida remansosamente pelos demais julgados supervenientes.

Portanto, perceber como a Suprema Corte tem identificado o caráter implicitamente discriminatório de norma tributária resume-se a compreender o conteúdo

\footnotetext{
664 “(b) Any notion of discrimination under the Commerce Clause assumes a comparison of substantially similar entities. When the allegedly competing entities provide different products, there is a threshold question whether the companies are indeed similarly situated for constitutional purposes. If the difference in products means that the entities serve different markets, and would continue to do so even if the supposedly discriminatory burden were removed, eliminating the burden would not serve the dormant Commerce Clause's fundamental objective of preserving a national market for competition undisturbed by preferential advantages conferred by a State upon its residents or resident competitors" 519 U. S. 278 (1997).

665 "Facially Neutral Laws", no original em inglês de, por exemplo, Chemerinsky (2006, p. 433) e Coenen (2004, p. 231).
} 
do voto relator do Justice William J. Brennan, Jr., acompanhado unanimente pelos demais oito membros da Corte. Segundo a sua formulação, um tributo exigido de atividades interestaduais pode ser considerado constitucional se houver: i) nexo substancial com o estado tributante; ii) é isonomicamente distribuído; iii) não discrimina o comércio interestadual e iv) é razoavelmente relacionado com os serviços prestados pelo estado exator $^{666}$.

Interessante é perceber que o relator, ao introduzir o caso, refere-se à matéria, citando precedentes anteriores, especialmente Memphis Gas Co. v. Stone $e^{667}$, de 1948, como o interminável problema de validar tributos estaduais discriminatórios ${ }^{668}$ - tão interminável que, podemos dizer, suscita tantas e tão complexas dúvidas em diversas jurisdições ao redor do mundo até o dia de hoje e é o motivo para a presente pesquisa.

Embora o relator refira-se ao tributo em questão como um tributo sobre vendas ("Sales Tax"), trata-se, na verdade, de uma incidência sobre o faturamento bruto de sociedades, à alíquota de $5 \%$, exigido das atividades empresariais realizadas no estado do Mississippi, consoante normas tributárias do estado ${ }^{669}$. Trata-se de um "Privilege Tax",

666 "U.S. Supreme Court

Complete Auto Transit, Inc. v. Brady, 430 U.S. 274 (1977)

Complete Auto Transit, Inc. v. Brady

No. 76-29

Argued January 19, 1977

Decided March 7, 1977

430 U.S. 274

APPEAL FROM THE SUPREME COURT OF MISSISSIPPI

Syllabus

A Mississippi tax on the privilege of doing business in the State held not to violate the Commerce Clause when it is applied to an interstate activity (here, the transportation by motor carrier in Mississippi to Mississippi dealers of cars manufactured outside the State) with a substantial nexus with the taxing State, is fairly apportioned, does not discriminate against interstate commerce, and is fairly related to the services provided by the State. Spector Motor Service v. O'Connor, 340 U. S. 602, overruled. Pp. 430 U. S. 279-289. 330 So.2d 268, affirmed.

BLACKMUN, J., delivered the opinion for a unanimous Court" (430 U.S. 274).

667335 U. S. 80 (1948).

668 "Once again we are presented with

"'the perennial problem of the validity of a state tax for the privilege of carrying on, within a state, certain activities' related to a corporation's operation of an interstate business" Colonial Pipeline Co. v. Traigle, 421 U. S. 100, 421 U. S. 101 (1975), quoting Memphis Gas Co. v. Stone, 335 U. S. 80, 335 U. S. 85 (1948).” (430 U.S. 274).

669 ""There is hereby levied and assessed and shall be collected, privilege taxes for the privilege of engaging or continuing in business or doing business within this state to be determined by the application of rates against gross proceeds of sales or gross income or values, as the case may be, as provided in the following sections." Miss. Code Ann., 1942, § 10105 (1972 Supp.).

"Upon every person operating a pipeline, railroad, airplane, bus, truck, or any other transportation business for the transportation of persons or property for compensation or hire between points within this State, there is hereby levied, assessed, and shall be collected, a tax equal to five per cent of the gross income of such business. . . " Miss. Code Ann., 1942, § 10109(2)" (430 U. S. 275). 
tributo exigido pelo estado pelo privilégio de realizar e manter em operação atividades econômicas no estado.

A sociedade apelante é uma companhia, sediada no estado de Michigan, cujo objeto social é o transporte de veículos automotores fabricados pela General Motors Corporation, desde Detroit, Michigan, por meio ferroviário até Jackson, Mississippi, e de lá, por meio rodoviário, para cada um dos revendedores da marca no estado de Mississippi, mediante remuneração, frete proporcional à carga transportada. Sua fundamentação, à luz da "The Dormant Commerce Clause", baseava-se na inconstitucionalidade da incidência diretamente onerosa à operação interestadual, com base em precedentes formalistas, como Spector Motor Service v. O'Connor, de 1951, e Freeman v. Hewitt, de 1946.

Diferentemente, Justice Brennan, como base no voto divergente de Justice Wiley Rutledge no caso sobre o tributo do estado de Indiana, concorda com a visão dissidente, de que um tributo deve ser julgado pelos seus efeitos econômicos, e não pelos termos formais com que exigido, e que também a mera incidência direta sobre transações interestaduais poderia ser motivo para a invalidade da incidência, mas só ou se a atividade não possuísse suficiente nexo com o estado tributante, de forma a que lhe faltasse competência tributária ("jurisdiction to tax"), ou se o tributo possuísse caráter discriminatório interestadual, ou se a incidência suscitasse problemas de dupla tributação interestadual $^{670}$. Com base no voto de Justice Rutledge, assim como em artigos doutrinários, afirmou que a visão anterior consistia no triunfo do formalismo sobre a substância, e que a visão baseada nos efeitos reais era um movimento que estava sendo percebido nos julgados da Suprema Corte ${ }^{671}$.

Cumpridos os requisitos definidos no julgamento, o tributo exigido pelo estado do Mississippi foi unanimemente entendido como constitucional.

\footnotetext{
670 "Mr. Justice Rutledge, in a lengthy concurring opinion, argued that the tax should be judged by its economic effects, rather than by its formal phrasing. After reviewing the Court's prior decisions, he concluded:

"The fact is that 'direct incidence' of a state tax or regulation . . . has long since been discarded as being in itself sufficient to outlaw state legislation." Id. at 329 U. S. 265-266.

In his view, a state tax is unconstitutional only if the activity lacks the necessary connection with the taxing state to give "jurisdiction to tax," id. at 329 U. S. 271, or if the tax discriminates against interstate commerce, or if the activity is subject to multiple taxation. Id. at 329 U. S. 276-277" (430 U. S. 280 - 281).

671 "The rule announced in Freeman was viewed in the commentary as a triumph of formalism over substance, providing little guidance even as to formal requirements. See P. Hartman, State Taxation of Interstate Commerce 200-204 (1953); Dunham, Gross Receipts Taxes on Interstate Transactions, 47 Colum.L.Rev. 211 (1947). Although the rule might have been utilized as the keystone of a movement toward absolute immunity of interstate commerce from state taxation, the Court consistently has indicated that "interstate commerce may be made to pay its way," and has moved toward a standard of permissibility of state taxation based upon its actual effect, rather than its legal terminology" (430 U. S. 281).
} 
O primeiro requisito definido em Complete Auto Transit, Inc. v. Brady refere-se à significante conexão entre a atividade tributada e o estado tributante. Haveria duas fontes constitucionais distintas fundantes de tal requisito: a "The Commerce Clause" e a "The Due Process of Law Clause".

Nos casos F. W. Woolworth Co. v. Taxation and Revenue Department of New Mexico $^{672}$ e Asarco Inc. v. Idaho State Tax Commission ${ }^{673}$, ambos de 1982, tal requisito foi utilizado para tributos diretos, de forma a negar a constitucionalidade de incidências sobre dividendos pagos por holding companies, sediadas em outros estados, oriundas de atividades econômicas realizadas no estado, assim tributadas pelos estados de New Mexico e Idaho com base no "unitary-business principle" - um princípio que considerava a unidade produtiva do grupo econômico como um todo e desconsiderava a personalidade jurídica da empresa controladora.

O segundo requisito consiste na correta e justa repartição de receitas entre os estados envolvidos na atividade econômica tributada. Esse requisito, acima de tudo, visa a evitar a dupla tributação interestadual, e está intimamente ligado ao anterior.

O caso mais típico de aplicação desse requisito foi o caso Container Corporation of America v. Franchise Tax Board ${ }^{674}$, de 1983. Nele, a Suprema Corte declarou a constitucionalidade de um tributo exigido das companhias como autorização para a realização de atividades no estado da Califórnia ("Franchise Tax"), mesmo empregando o "unitary-business principle", uma vez que o tributo, quando exigido de companhias que exercessem operações mercantis em diversos estados, era cobrado proporcionalmente a uma fórmula de três fatores: a folha de pagamentos, as propriedades imóveis e móveis tangíveis e o faturamento bruto das vendas de bens e serviços, sempre considerando o percentual localizado no estado. Assim se entendeu a incidência obediente tanto à "The Commerce Clause" e quanto à "The Due Process of Law Clause", passando a ser exemplo para incidências a serem posteriormente examinadas ${ }^{675}$.

\footnotetext{
672458 U.S. 354 (1982).

673458 U.S. 307 (1982).

674463 U.S. 159 (1983).

675 "Having determined that a certain set of activities constitute a "unitary business," a State must then apply a formula apportioning the income of that business within and without the State. Such an apportionment formula must, under both the Due Process and Commerce Clauses, be fair. See Exxon Corp., supra, at 447 U. S. 219, 447 U. S. 227-228; Moorman Mfg. Co., 437 U.S. at 437 U. S. 272-273; Hans Rees' Sons, Inc., 283 U.S. at 283 U.S. 134. The first, and again obvious, component of fairness in an apportionment formula is what might be called internal consistency -- that is, the formula must be such that, if applied by every jurisdiction, it would result in no more than all of the unitary business' income's being taxed. The second and more difficult requirement is what might be called external consistency -- the factor or factors used in the
} 
Anteriormente, em Moorman Manufacturing Co. v. Bair ${ }^{676}$, em 1978, um tributo instituído pelo estado de Iowa apenas diretamente proporcional às receitas brutas havia sido declarado inconstitucional, por empregar uma fórmula de um fator apenas.

$\mathrm{O}$ quarto requisito exige que o estado tributante proporcione algum tipo de serviço ao contribuinte. Se a incidência transbordar para contribuintes de outro estado, a Suprema Corte deve então ser capaz de identificar algum benefício a eles assegurado pela atuação do estado tributante. Na verdade, trata-se de mais um requisito que está muito ligado aos dois primeiros, pois o retorno que o estado tributante espera alcançar é, em última análise, proporcional à capacidade contributiva oriunda do auferimento de receitas das atividades nele localizadas.

Caso típico de aplicação desse requisito é Commonwealth Edison Co. v. Montana $^{677}$, de 1981, em que se manteve a validade de um tributo, exigido pelo estado de Montana, de até $30 \%$ do valor de venda de carvão mineral extraído das minas no estado, por entendê-lo oriundo de benefício da companhia mineradora advindo das oportunidades e da proteção empreendidas pelo estado tributante ${ }^{678}$.

O terceiro critério, na ordem estabelecida por Justice Brenann em Complete Auto Transit, Inc. v. Brady, é aquele que, como já vimos, por exemplo, por Sedler (1985, p. 1027), consiste no núcleo semântico do princípio da "The Dormant Commerce Clause" como entendida atualmente.

apportionment formula must actually reflect a reasonable sense of how income is generated. The Constitution does not

"invalidat[e] an apportionment formula whenever it may result in taxation of some income that did not have its source in the taxing State. ..."

Moorman Mfg. Co., supra, at 437 U. S. 272 (emphasis added). See Underwood Typewriter Co., 254 U.S. at 254 U. S. 120-121. Nevertheless, we will strike down the application of an apportionment formula if the taxpayer can prove

"by 'clear and cogent evidence' that the income attributed to the State is, in fact, 'out of all appropriate proportions to the business transacted. . in that State,' [Hans Rees' Sons, Inc.,] 283 U.S. at 283 U. S. 135, or has 'led to a grossly distorted result,' [Norfolk \& Western R. Co. v. State Tax Comm'n, 390 U. S. 317,390 U. S. 326 (1968)]."

Moorman Mfg. Co., supra, at 437 U. S. 274.

California and the other States that have adopted the Uniform Act use a formula -- commonly called the "three-factor" formula -- which is based, in equal parts, on the proportion of a unitary business' total payroll, property, and sales which are located in the taxing State. See Cal.Tax \& Rev.Code Ann. \$\$ 2512825136 (West 1979). We approved the three-factor formula in Butler Bros. v. McColgan, 315 U. S. 501 (1942). Indeed, not only has the three-factor formula met our approval, but it has become, for reasons we discuss in more detail infra, at 463 U. S. 183, something of a benchmark against which other apportionment formulas are judged"' (463 U. S. 169 - 170).

676437 U.S. 267 (1978).

677453 U.S. 609 (1981).

678 "Because it is measured as a percentage of the value of the coal taken, the Montana tax, a general revenue tax, is in proper proportion to appellants' activities within the State, and, therefore, to their enjoyment of the opportunities and protection which the State has afforded in connection with those activities, such as police and fire protection, the benefit of a trained workforce, and the advantages of a civilized society" (453 U.S. 610). 
Agora, remansosamente após 1977, não há mais vedação à tributação do comércio interestadual, mas a incidência não pode ser concebida a tal ponto de tributá-lo de forma mais onerosa do que o comércio intraestadual. Ao estado tributante resta demonstrar que não haveria maneira menos discriminatória de alcançar o mesmo legítimo interesse estatal.

Não obstante, a Suprema Corte, ao longo desses trinta e cinco anos, aproximadamente, jamais delineou com precisão os contornos da doutrina quanto a o que seja um tributo que discrimine o comércio interestadual, já que não se trata de conceito autodefinível. Resta, então, tentar sistematizar a jurisprudência a respeito, como nos alerta Walter Hellerstein (2005, p. 376).

Um exemplo esclarecedor desse entendimento, acerca da discriminação implícita, tratando, não por coincidência, também de incidências sobre bebidas alcoólicas, é o caso Bacchus Imports, Ltd. et al. v . Herbert H. Dias, Director of Taxation of the State of Hawaii, et al. ${ }^{679}$, de 1984.

O estado do Hawaii instituiu, em 1939, um tributo indireto analítico, ou seletivo ou específico, do tipo excise tax, o "Liquor Tax", com vistas a fazer frente às despesas do estado com os custos de segurança pública e de outros serviços governamentais decorrentes do consumo de bebidas alcoólicas no seu território. Inicialmente, o tributo era exigido na incidência sobre as vendas no atacado à aliquota de $20 \%$ sobre o preço praticado na operação.

Posteriormente, como se verá, para fomentar o desenvolvimento da indústria de bebidas no afastado estado federal, criou-se uma isenção para as vendas de okolehao, a partir de maio de 1971, e de vinho de fruta, após maio de 1976 - Haw. Rev. Stat. $§ \S 244-$ 4(6), (7) (Supp.1983).

Okolehao é uma bebida destilada, do tipo brandy, obtida das raízes de um arbusto indígena epidêmico do Hawaii, chamado ti (Cordyline fruticosa). O único vinho de fruta fabricado no Hawaii à época era o vinho de abacaxi. Também havia produção local de saquê e licores de fruta, mas que, não obstante, não se beneficiavam de isenção tributária do "Liquor Tax".

Os apelantes, Bacchus Imports, Ltd., e Eagle Distributors, Inc., eram atacadistas de bebidas, que as comercializavam com varejistas autorizados, mediante a tributação do "Liquor Tax". Consoante uma norma estadual do Avaí, Haw. Rev. Stat. § 40 -

${ }^{679} 468$ U.S. 263 (1984). 
35 (Supp. 1983), que autoriza um contribuinte a pagar tributos sobre protesto, assim procederam, ao mesmo tempo em que ajuizaram suas ações no foro adequado, como vistas à repetição do respectivo indébito, diante da violação tanto à "The Import-Export Clause" quanto à "The Commerce Clause", ambas da Constituição dos Estados Unidos da América.

$\mathrm{O}$ voto do Justice Byron White, vencedor por pequena maioria, inicialmente tocou em aspecto bem interessante, embora não relacionado ao caráter discriminatório da norma. O estado alegou, em preliminar, a ausência de interesse das sociedades comerciais, já que não teria ficado comprovado seu prejuízo econômico com a incidência, uma vez que teriam a possibilidade de repassar tais custos para os consumidores e que, certamente, tentariam fazê-lo. Justice White retrucou tal argumento por duas vias: primeiramente, porque os contribuintes deveriam arcar com o tributo mesmo que os seus clientes eventualmente não pagassem suas dívidas com eles; e também porque, mesmo que haja integral repasse aos seguintes na cadeia de comercialização, ainda assim o tributo aumentaria o preço da mercadoria, o que imporia um impacto competitivo adverso em sua atividade comercial $^{680}$.

A fundamentação do estado do Avaí baseou-se na consideração de que o okolehao e o vinho de abacaxi não competiriam com outros produtos vendidos pelos atacadistas de bebidas em seu território. Com base em estatísticas, comprovou-se, à época, que as vendas de okolehao e de vinho de abacaxi constituíam menos de um por cento das vendas totais de bebidas alcoólicas no estado. Não constituiriam, portanto, ameaça competitiva às demais bebidas alcóolicas produzidas em outros estados e consumidas no Avaí.

Justice Byron White afastou a possibilidade de que o pequeno volume de vendas da bebida isenta ou a pretensa ausência de ameaça competitiva aos demais preparados alcoólicos fossem asepctos relevantes, uma vez que ainda persistia competição com as bebidas produzidas localmente ou alienígenas, uma vez que não há grau para a discriminação tributária, na jurisprudência da Suprema Corte. Ademais, afirma, o fomento à produção local poderia acarretar que consumidores de outras bebidas alcoólicas viriam a

\footnotetext{
680 "The State presents a claim, not made below, that the wholesalers have no standing to challenge the tax, because they have shown no economic injury from the claimed discriminatory tax. The wholesalers are, however, liable for the tax. Although they may pass it on to their customers, and attempt to do so, they must return the tax to the State whether or not their customers pay their bills. Furthermore, even if the tax is completely and successfully passed on, it increases the price of their products as compared to the exempted beverages, and the wholesalers are surely entitled to litigate whether the discriminatory tax has had an adverse competitive impact on their business. The wholesalers plainly have standing to challenge the tax in this Court" (468 U.S. 267).
} 
migrar para o consumo das isentas, o que também poderia se dar com os jovens ainda em fase de formação de seus gostos e preferências ${ }^{681}$.

No que concerne ao núcleo da controvérsia, o estado do Avaí alegava que, além do pequeno efeito prático da norma e ao seu relativo irrisório prejuízo ao comércio, a visão da Corte deveria ser mais flexível uma vez que: legítimos objetivos estatais haviam sido alcançados; não haveria discriminação patente contra o comércio interestadual e o efeito sobre o comércio interestadual seria meramente incidental.

Justice Byron White afastou tais argumentos, nos dando uma aula de como a Suprema Corte passaria a tratar a matéria. Para ele, a conclusão de que uma norma estadual constitui protecionismo econômico pode ser alcançada com base tanto nos seus efeitos quando nos seus objetivos, nos casos em que a discriminação não é claramente detectada à primeira vista ${ }^{682}$.

Mediante pesquisa à exposição de motivos da respectiva legislação do estado do Avaí, pode o relator perceber que a sua inspiração realmente foi a de fomentar o nascimento de uma nova indústria local ${ }^{683}$. Assim, não teria se tornado nem ao menos

681 "However, neither the small volume of sales of exempted liquor nor the fact that the exempted liquors do not constitute a present "competitive threat" to other liquors is dispositive of the question whether competition exists between the locally produced beverages and foreign beverages; instead, they go only to the extent of such competition. It is well settled that "[w]e need not know how unequal the Tax is before concluding that it unconstitutionally discriminates." Maryland v. Louisiana, 451 U. S. 725, 451 U. S. 760 (1981).

The State's position that there is no competition is belied by its purported justification of the exemption in the first place. The legislature originally exempted the locally produced beverages in order to foster the local industries by encouraging increased consumption of their product. Surely one way that the tax exemption might produce that result is that drinkers of other alcoholic beverages might give up or consume less of their customary drinks in favor of the exempted products because of the price differential that the exemption will permit. Similarly, nondrinkers, such as the maturing young, might be attracted by the low prices of okolehao and pineapple wine. On the stipulated facts in this case, we are unwilling to conclude that no competition exists between the exempted and the nonexempted liquors" (468 U.S. 269).

682 "The State contends that a more flexible approach, taking into account the practical effect and relative burden on commerce, must be employed in this case because (1) legitimate state objectives are credibly advanced, (2) there is no patent discrimination against interstate trade, and (3) the effect on interstate commerce is incidental. See Philadelphia v. New Jersey, 437 U. S. 617, 437 U. S. 624 (1978). On the other hand, it acknowledges that, where simple economic protectionism is effected by state legislation, a stricter rule of invalidity has been erected. Ibid. See also Minnesota v. Clover Leaf Creamery Co., 449 U. S. 456, 449 U. S. 471 (1981); Lewis v. BT Investment Managers, Inc., 447 U. S. 27, 447 U. S. 36-37 (1980).

A finding that state legislation constitutes "economic protectionism" may be made on the basis of either discriminatory purpose, see Hunt v. Washington Apple Advertising Comm'n, 432 U. S. 333, 432 U. S. 352353 (1977), or discriminatory effect, see Philadelphia v. New Jersey, supra. See also Minnesota v. Clover Leaf Creamery Co., supra, at 449 U.S. 471, n. 15. Examination of the State's purpose in this case is sufficient to demonstrate the State's lack of entitlement to a more flexible approach permitting inquiry into the balance between local benefits and the burden on interstate commerce. See Pike v. Bruce Church, Inc., 397 U. S. 137, 397 U. S. 142 (1970)" (468 U. S. 270).

683 "The Hawaii Supreme Court described the legislature's motivation in enacting the exemptions as follows: "The legislature's reason for exempting 'ti root okolehao' from the 'alcohol tax' was to 'encourage and promote the establishment of a new industry,' S.L.H.1960, c. 26; Sen.Stand.Comm. Rep. No. 87, in 1960 Senate Journal at 224, and the exemption of 'fruit wine manufactured in the State from products grown in the 
necessária a suposição da motivação legislativa estadual, que, dessa forma, pode-se verificar de plano como claramente discriminatória.

Semelhantemente, seu efeito também é evidentemente discriminatório, uma vez que, como ficou comprovado nos autos, tanto o okolehao quanto o vinho de abacaxi não seriam produzidos em outras partes do país ou do mundo, o que torna a isenção aplicável apenas a produtos produzidos localmente.

Com isso, segundo o relator, com base em copiosos precedentes, como a norma se destina a proteger produtores locais, trata-se de uma restrição ao comércio violadora da "The Commerce Clause", que possui, em seu núcleo, a restrição às imposições competitivas de um estado em detrimento das mercadorias produzidas por outro estado da união $^{684}$.

Justice White também afastou a consideração de que o ônus pela incidência do tributo recairia nos consumidores havaianos, sem haver prejuízo para companhias de outros estados, com o que tencionaria afastar os precedentes mencionados. Segundo o fisco do Havaí, o objetivo legislativo seria não o de prejudicar os concorrentes de origem em outros estados, senão o de recuperar a combalida indústria do okolehao e erguer a nascente produção do vinho de abacaxi, o que lhe recusaria a caracterização como discriminatória.

State' was intended 'to help' in stimulating 'the local fruit wine industry.' S.L.H.1976, c. 39; Sen.Stand.Comm. Rep. No. 408-76, in 1976 Senate Journal at Page 1056. In re Bacchus Imports, Ltd., supra, at 573-574, 656 P.2d at 730." (468 U. S. 270 - 271)"

684 "Thus, we need not guess at the legislature's motivation, for it is undisputed that the purpose of the exemption was to aid Hawaiian industry. Likewise, the effect of the exemption is clearly discriminatory, in that it applies only to locally produced beverages, even though it does not apply to all such products. Consequently, as long as there is some competition between the locally produced exempt products and nonexempt products from outside the State, there is a discriminatory effect.

No one disputes that a State may enact laws pursuant to its police powers that have the purpose and effect of encouraging domestic industry. However, the Commerce Clause stands as a limitation on the means by which a State can constitutionally seek to achieve that goal. One of the fundamental purposes of the Clause "was to insure . . against discriminating State legislation." Welton v. Missouri, 91 U. S. 275, 91 U. S. 280 (1876). In Welton, the Court struck down a Missouri statute that

"discriminat[ed] in favor of goods, wares, and merchandise which are the growth, product, or manufacture of the State, and against those which are the growth, product, or manufacture of other states or countries. . ." Id. at 91 U. S. 277. Similarly, in Walling v. Michigan, 116 U. S. 446, 116 U. S. 455 (1886), the Court struck down a law imposing a tax on the sale of alcoholic beverages produced outside the State, declaring: "A discriminating tax imposed by a State operating to the disadvantage of the products of other States when introduced into the first mentioned State is, in effect, a regulation in restraint of commerce among the States, and as such is a usurpation of the power conferred by the Constitution upon the Congress of the United States." See also I. M. Darnell \& Son Co. v. Memphis, 208 U. S. 113 (1908).

More recently, in Boston Stock Exchange v. State Tax Comm'n, 429 U. S. 318 (1977), the Court struck down a New York law that imposed a higher tax on transfers of stock occurring outside the State than on transfers involving a sale within the State. We observed that competition among the States for a share of interstate commerce is a central element of our free-trade policy, but held that a State may not tax interstate transactions in order to favor local businesses over out-of-state businesses. Thus, the Commerce Clause limits the manner in which States may legitimately compete for interstate trade, for,

"in the process of competition, no State may discriminatorily tax the products manufactured or the business operations performed in any other State." Id. at 3429 U. S. 37" (468 U. S. 271 - 272). 
No seu voto, o relator é peremptório em reforçar que tal distinção não encontraria previsão na "The Commerce Clause", em ambos os casos constituindo-se "protecionismo econômico" punido pela declaração de inconstitucionalidade da norma ${ }^{685}$.

Tal voto veio acompanhado da votação de apenas cinco outros Justices, o que demonstra a complexidade de julgamentos que tratam da discriminação tributária implícita, não só na $\mathrm{OMC}$, mesmo não havendo tantos interesses internacionais envolvidos. Justice Brennan, o mesmo relator do paradigmático caso Complete Auto Transit, Inc. v. Brady absteve-se de votar, e os Justices John Paul Stevens e Sandra Day O’Connor foram votos dissidentes, no que foram acompanhados pelo então Associate Justice William Rehnquist. Embora discordante quanto à aplicabilidade no caso da Vigésima-Primeira Emenda, os argumentos do relator majoritário quanto ao impacto competitivo da isenção do tributo sobre bebidas alcoólicas foram refutados pelo condutor da dissidência, Justice Stevens, ao

685 "It is therefore apparent that the Hawaii Supreme Court erred in concluding that there was no improper discrimination against interstate commerce merely because the burden of the tax was borne by consumers in Hawaii. The State attempts to put aside this Court's cases that have invalidated discriminatory state statutes enacted for protectionist purposes. See Minnesota v. Clover Leaf Creamery Co., supra, at 449 U. S. 471; Lewis v. BT Investment Managers, Inc., supra, at 447 U. S. 36-37. The State would distinguish these cases because they all involved attempts "to enhance thriving and substantial business enterprises at the expense of any foreign competitors." Brief for Appellee Dias 30. Hawaii's attempt, on the other hand, was "to subsidize nonexistent (pineapple wine) and financially troubled (okolehao) liquor industries peculiar to Hawaii." Id. at 33. However, we perceive no principle of Commerce Clause jurisprudence supporting a distinction between thriving and struggling enterprises under these circumstances, and the State cites no authority for its proposed distinction. In either event, the legislation constitutes "economic protectionism" in every sense of the phrase. It has long been the law that States may not "build up [their] domestic commerce by means of unequal and oppressive burdens upon the industry and business of other States." Guy v. Baltimore, 100 U. S. 434, 100 U. S. 443 (1880). Were it otherwise,

"the trade and business of the country [would be] at the mercy of local regulations, having for their object to secure exclusive benefits to the citizens and products of particular States."

Id. at 100 U. S. 442. It was to prohibit such a "multiplication of preferential trade areas" that the Commerce Clause was adopted. Dean Milk Co. v. Madison, 340 U. S. 349, 340 U. S. 356 (1951). Consequently, the propriety of economic protectionism may not be allowed to hinge upon the State's -- or this Court's -characterization of the industry as either "thriving" or "struggling."

We also find unpersuasive the State's contention that there was no discriminatory intent on the part of the legislature because "the exemptions in question were not enacted to discriminate against foreign products, but rather, to promote a local industry." Brieffor Appellee Dias 40. If we were to accept that justification, we would have little occasion ever to find a statute unconstitutionally discriminatory. Virtually every discriminatory statute allocates benefits or burdens unequally; each can be viewed as conferring a benefit on one party and a detriment on the other, in either an absolute or relative sense. The determination of constitutionality does not depend upon whether one focuses upon the benefited or the burdened party. A discrimination claim, by its nature, requires a comparison of the two classifications, and it could always be said that there was no intent to impose a burden on one party, but rather the intent was to confer a benefit on the other. Consequently, it is irrelevant to the Commerce Clause inquiry that the motivation of the legislature was the desire to aid the makers of the locally produced beverage, rather than to harm out-of-state producers.

We therefore conclude that the Hawaii liquor tax exemption for okolehao and pineapple wine violated the Commerce Clause because it had both the purpose and effect of discriminating in favor of local products" (468 U. S. 272 - 274). 
asseverar que não vislumbrava na espécie qualquer prejuízo aos comerciantes $\operatorname{atacadistas}^{686}$.

A caracterização do viés discriminatório das normas tributárias estaduais, em relação ao comércio interestadual, ainda é um campo que, em particular na construção jurisprudencial norteamericana, está por se solidificar. Como bem conclui Dan Coenen (2004, p. 325) a respeito, estaremos por ver, certamente, novas estruturas tributárias que desafiarão os nossos conceitos atinentes à matéria.

De qualquer forma, no seu entender, uma mensagem sempre se sobressairá dos julgados da Suprema Corte norteamericana, mensagem essa que foi expressa quando da apreciação do caso Boston Stock Exchange v. State Tax Commission ${ }^{687}$, um caso acerca de não-discriminação em incidência de um imposto sobre transações financeiras em operações sobre valores mobiliários: a decisão da Suprema Corte não visa a prevenir que os estados estruturem seus sistemas tributários de maneira a estimular e a desenvolver o comércio e a indústria intraestaduais, nem tampouco se defende que um estado não possa competir com outros estados por fatias maiores no comércio interestaduais, uma vez que esse tipo de competição repousa no coração da política de livre comércio que caracteriza o sistema norteamericano. O que se quer evitar é que, nesse processo de competição, algum estado venha a tributar de forma discriminatória produtos manufaturados ou operações mercantis realizadas por outros estados ${ }^{688}$.

\footnotetext{
686 "Today the Court holds that these wholesalers are "entitled to litigate whether the discriminatory tax has had an adverse competitive impact on their business." Ante at 468 U. S. 267. I am skeptical about the ability of the wholesalers to prove that the exemption for okolehao and pineapple wine has harmed their businesses at all, partly because their customers have reimbursed them for the excise tax and partly because they are free to take advantage of the benefit of the exemption by selling the exempted products themselves. Even if some minimal harm can be proved, I am even more skeptical about the possibility that it will result in the multimillion-dollar refund that the wholesalers are claiming. My skepticism concerning the economics of the wholesalers' position is not, however, the basis for my dissent. I would affirm the judgment of the Supreme Court of Hawaii because the wholesalers' Commerce Clause claim is squarely foreclosed by the Twenty-first Amendment to the United States Constitution" (468 U. S. 278 - 279).

687429 U.S. 318 (1977).

688 "Our decision today does not prevent the States from structuring their tax systems to encourage the growth and development of intrastate commerce and industry. Nor do we hold that a State may not compete with other States for a share of interstate commerce; such competition lies at the heart of a free trade policy. We hold only that in the process of competition no State may discriminatorily tax the products manufactured or the business operations performed in any other State" (429 U. S. 336 - 337).
} 


\section{DO PRINCÍPIO DE NÃO-DISCRIMINAÇÃO TRIBUTÁRIA NA EXPERIÊNCIA DO MERCOSUL E DO BRASIL.}

\subsection{Do Princípio de Não-discriminação Tributária na experiência do MERCOSUL.}

O MERCOSUL, alcunha popular para o Mercado Comum do Sul (em castelhano: Mercado Común del Sur, Mercosur; em guarani: Ñemby Ñemuha ${ }^{689}$ ) é a união aduaneira imperfeita (SANTA-BÁRBARA RUPÉREZ, 2001, p. 203), dada a extensa lista de exceções à sua Tarifa Externa Comum, atualmente entre cinco países da América do Sul.

Em sua formação original o fenômeno de integração econômica era composto por quatro países: República Argentina, República Federativa do Brasil, República do Paraguai e República Oriental do Uruguai.

Suas origens remontam à Declaração de Iguaçu, de 30 de novembro de 1985, assinada pelo presidente brasileiro José Sarney e pelo presidente argentino Raúl Alfonsín. Ambas as repúblicas acabavam de sair de períodos ditatoriais e enfrentavam a necessidade de reorientar suas economias para o mundo exterior e globalizado, assim como se defrontavam com o reconhecimento da insuficiência da ALALC (Associação LatinoAmericana de Livre Comércio), criada em $1^{\circ}$ de junho de 1960, pelo (Primeiro) Tratado de Montevidéu, em impedir o protecionismo europeu e estadunidense (FERNANDES, 2006, p. $58-59)$.

Os dois países haviam contraído uma grande dívida externa no período dos governos militares e não gozavam de crédito e confiabilidade no exterior. Havia uma grande necessidade de investimentos nos países, mas não o interesse dos investidores internacionais, dados os episódios de seguidos planos econômicos que foram experimentados em ambos os países com o fim de combater as respectivas escaladas inflacionárias. Esta situação comum fez com que ambos percebessem a necessidade e a urgência de um intercâmbio econômico mais próximo e facilitado.

\footnotetext{
${ }^{689}$ O guarani foi incorporado como um dos idiomas do MERCOSUL, sem, não obstante, ser seu idioma de trabalho, pela Decisão $\mathrm{n}^{\circ}$ 31, de 13 de dezembro de 2006, do Conselho do Mercado Comum. Atualmente está em cogitação proposta de transformá-lo em idioma oficial.
} 
Não se pode esquecer que o (Segundo) Tratado de Montevidéu, de 18 de março de 1980, que constituiu a Associação Latino-Americana de Integração (ALADI), firmado pelo Brasil em 12 de agosto de 1980 e aprovado pelo Congresso Nacional, por meio do Decreto Legislativo $\mathrm{n}^{\circ}$ 66, de 16 de novembro de 1981, havia autorizado a possibilidade da lavratura de acordos sub-regionais, dentro do território latinoamericano, por meio da modalidade de Acordo de Complementação Econômica, com o fim de facilitar o cumprimento dos seus objetivos.

Logo após a assinatura da declaração de Iguaçu, em fevereiro de 1986, a Argentina declara a intenção de uma "associação preferencial" com o Brasil. Em 29 de julho de 1986, em Buenos Aires, foi firmada a "Ata de Integração Brasileiro-Argentina" que instituiu o Programa de Integração e Cooperação Econômica (PICE), estabelecendo seus princípios fundamentais. O objetivo do Programa era o de propiciar um espaço econômico comum, com a abertura seletiva dos respectivos mercados e o estímulo à complementação de setores específicos da economia dos dois países.

Por meio da Decisão Tripartite ${ }^{\circ}$ 01, de 06/04/86, o Uruguai passa a participar efetivamente do processo de integração. Em 10/12/86 foi assinada a "Ata da Amizade Brasileiro-Argentina, Democracia, Paz e Desenvolvimento".

Em 29 de novembro de 1988, com vistas a consolidar o processo de integração, foi assinado o "Tratado de Integração, Cooperação e Desenvolvimento entre o Governo da República Federativa do Brasil e o Governo da República da Argentina”, pelo qual ambos os governos demonstraram o desejo de constituir um espaço econômico comum no prazo máximo de 10 anos, por meio da liberalização integral do comércio recíproco. O tratado previa, entre outras medidas, a eliminação de todos os obstáculos tributários e regulatórios ao comércio de bens e serviços e a harmonização de políticas macroeconômicas. O tratado foi sancionado pelos congressos brasileiro e argentino em agosto de 1989.

Durante esse período, foram assinados 24 protocolos sobre temas diversos: Protocolo no 1 - Bens de capital (Buenos Aires, 29/07/1986); Protocolo n ${ }^{\circ} 2$ - Trigo (Rio de Janeiro, 17/09/1986); Protocolo n ${ }^{\circ} 3$ - Complementação do Abastecimento alimentar (Buenos Aires, 29/07/1986); Protocolo n ${ }^{o} 4$ - Expansão do Comércio (Buenos Aires, 29/07/1986); Protocolo n 5 - Empresas Binacionais (Buenos Aires, 29/07/1986); Protocolo $n^{\circ} 6$ - Assuntos Financeiros (Buenos Aires, 29/07/1986); Protocolo $n^{\text {o }} 7$ - Fundo de Investimentos (Buenos Aires, 29/07/1986); Protocolo $n^{\circ} 8$ - Energia (Buenos Aires, 29/07/1986); Protocolo no 9 - Biotecnologia (Buenos Aires, 29/07/1986); Protocolo $n^{\circ} 10$ Estudos Econômicos (Buenos Aires, 29/07/1986); Protocolo nº 11 - Informação imediata e 
Assistência Recíproca em caso de Acidentes Nucleares e Emergências Radiológicas (Buenos Aires, 29/07/1986); Protocolo no 12 - Cooperação Aeronáutica (Buenos Aires, 29/07/1986); Protocolo $n^{\circ} 13$ - Siderurgia (Brasília, 10/12/1986); Protocolo $n^{\circ} 14$ Transporte Terrestre (Brasília, 10/12/1986); Protocolo no 15 - Transporte Marítimo (Brasília, 10/12/1986); Protocolo no 16 - Comunicações (Brasília, 10/12/1986); Protocolo no 17 - Cooperação Nuclear (Brasília, 10/12/1986); Protocolo no 18 - Cultura (Buenos Aires, 15/07/1987); Protocolo N. ${ }^{\circ} 19$ - Administração Pública (Viedma, 17/07/1987); Protocolo no 20 - Moeda (Viedma, 17/07/1987); Protocolo nº 21 - Indústria Automotriz (Brasília, 07/04/1988); Protocolo no 22 - Indústria de Alimentação (Brasília, 07/04/1988); Protocolo no 23 - Regional Fronteiriço (Buenos Aires, 29/11/1988); Protocolo no 24 Planejamento Econômico e Social (Brasília, 23/08/1989).

Esses acordos foram todos absorvidos no denominado Acordo de Complementação Econômica n ${ }^{\circ}$ 14, assinado em dezembro de 1990, no âmbito da ALADI, que constituiu a base para a implementação dos acordos consistentes no MERCOSUL. Não só englobava os Protocolos já assinados anteriormente como também previa reduções gradativas nas alíquotas de importação dos produtos relacionados produzidos nos dois países.

Em 6 de julho de 1990, o presidente do Brasil, Fernando Collor de Mello, e o da Argentina, Carlos Menem, assinaram a "Ata de Buenos Aires", de integração econômica entre os dois países, por meio da qual decidiu-se estabelecer um mercado comum entre ambos, cujo prazo para sua instalação definitiva foi fixado em 31 de dezembro de 1994. Para cumprir as metas previstas foi criado o Grupo Mercado Comum, com a função de elaborar e propor, pelos dois Governos, todas as medidas para dar cumprimento aos objetivos e prazos adotados. Foram criados, ainda, 10 Subgrupos Técnicos de Trabalho, para analisarem as políticas dos mais variados setores e áreas.

Em setembro de 1990 foi apresentado às delegações do Uruguai e Paraguai o andamento do processo de integração Argentina-Brasil, ocasião em que expressaram a vontade de seus Governos em participar da integração.

Como resultado de todas essas iniciativas, foi assinado, em 26 de março de 1991, o Tratado de Assunção, entre Brasil, Argentina, Uruguai e Paraguai. Previa a formação do Mercosul - Mercado Comum do Sul ("Tratado para a Constituição de um Mercado Comum entre a República Argentina, a República Federativa do Brasil, a República do Paraguai e a República Oriental do Uruguai”), a partir de janeiro de 1995. Em seus anexos, especifica prazos para a formação deste Mercado Comum, para a livre 
circulação de bens e serviços entre os países; estabelece uma política comercial comum em relação aos terceiros países, além de resguardar, em listas de exceções, os produtos que não teriam imediatamente suas tarifas reduzidas, a pedido dos próprios países participantes.

O Congresso Nacional aprovou o referido tratado por meio do Decreto Legislativo $\mathrm{n}^{\circ}$ 197, de 25 de setembro de 1991. A Carta de Ratificação do Tratado foi depositada pelo Brasil em 30 de outubro de 1991. Publicado no Diário Oficial da União de 22/11/91, promulgado que foi pelo Decreto $n^{\circ} 350$, do dia anterior..

O Tratado de Assunção foi internalizado, no âmbito da ALADI, por meio do Acordo de Complementação Econômica no 18, assinado em 29 de novembro de 1991.

Inicialmente foi estabelecida uma zona de livre comércio, em que os países signatários não tributariam ou restringiriam as importações um do outro. A partir de $1^{\circ}$ de janeiro de 1995, como resultado das Reuniões de 12 a 17 de dezembro de 1994, do Conselho do Mercado Comum e do Grupo Mercado Comum, a zona converteu-se em união aduaneira, com a adoção da tarifa externa comum. Na mesma oportunidadem, em 17 de dezembro de 1994, foi firmado o Protocolo de Ouro Preto, definindo a estrutura institucional do Mercosul, que contaria com o Conselho do Mercado Comum; o Grupo Mercado Comum; a Comissão de Comércio; a Comissão Parlamentar Conjunta; o Foro Consultivo Econômico- Social e a Secretaria Administrativa do MERCOSUL. Com o Protocolo de Ouro Preto, o MERCOSUL passa a ser dotado de personalidade jurídica internacional.

Antes disso, em 17 de dezembro de 1991, havia sido firmado em Brasília o "Protocolo para a Solução de Controvérsias" no âmbito do Mercado Comum do Sul (MERCOSUL), internalizado no direito brasileiro pelo Decreto $\mathrm{n}^{\circ}$ 922, de 10 de setembro de 1993. Foi derrogado, assim como o respectivo regulamento, aprovado pela Decisão CMC 17/98, pelo "Protocolo de Olivos para a Solução de Controvérsias no MERCOSUL", de 18 de fevereiro de 2002; aprovado pelo Congresso Nacional, por meio do Decreto Legislativo $\mathrm{n}^{\circ}$ 712, de 14 de outubro de 2003; cujo instrumento de ratificação foi depositado pelo Governo brasileiro em 2 de dezembro de 2003; e que entrou em vigor no plano internacional em $1^{\circ}$ de janeiro de 2004, sendo promulgado pelo Decreto $\mathrm{n}^{\circ} 4.982$, de 9 de fevereiro de 2004.

Por meio do Protocolo de Olivos foi criado o Tribunal Permanente de Revisão (TPR), com o fim de controlar a legalidade das decisões arbitrais de primeira instância nos moldes do sistema criado pelo Protocolo de Brasília, como uma instância recursal. O TPR é formado por cinco árbitros, designados um por Estado, por um período de dois anos, 
renovável por até duas vezes consecutivas. A escolha do quinto árbitro será feita por unanimidade, para um período de três anos, não renovável, salvo acordo em contrário.

No caso de dois Estados se envolverem em uma controvérsia, ela será resolvida em primeira instância por arbitragem ad hoc, por árbitros escolhidos dentre uma lista de nomes previamente fornecida pelos Estados. Poderá existir recurso do laudo arbitral ao TPR, caso em que será integrado por três árbitros. Dois deles serão nacionais dos dois Estados-parte litigantes e o terceiro, que será o presidente, será sorteado entre os demais árbitros que não sejam nacionais dos referidos Estados. Caso a controvérsia envolva mais que dois Estados, o Tribunal contará com a totalidade de seus árbitros. As votações e deliberações seguirão o princípio majoritário e serão confidenciais. Os laudos do TPR possuirão força de coisa julgada. O TPR será sediado em Assunção mas poderá se reunir, em caso de necessidade devidamente justificada, em outras cidades dentro do território dos Estados Partes do MERCOSUL.

Está previsto no Protocolo de Olivos que os árbitros supracitados deverão ser juristas de reconhecida competência e ter conhecimento do conjunto normativo do MERCOSUL. Deverão ser imparciais em relação à administração pública e sem interesse de qualquer natureza na controvérsia.

Hoje, o MERCOSUL possui, como Estados Associados, Bolívia (admitida em 1996), Chile (em 1996), Peru (em 2003), Colômbia (em 2004) e Equador (em 2004).

O status de Estado Associado é atribuído por Decisão do Conselho do Mercado Comum. Para aceder a esse status, a Decisão CMC N ${ }^{\circ} 18 / 04$, que dispõe sobre a admissão de novos Estados Associados no MERCOSUL, exige, no seu artigo $1^{\circ}$, a assinatura prévia de Acordos de Complementação Econômica, nos quais se estabelece um cronograma para a criação de uma zona de livre comércio com os Estados Partes do Mercosul e uma gradual redução de tarifas entre o MERCOSUL e os Estados signatários. Além de poder participar na qualidade de convidado nas reuniões dos organismos do Mercosul, os Estados Associados também podem ser signatários de Acordos sobre matérias comuns.

Mediante a assinatura, em Caracas, em 4 de julho de 2006, do Protocolo de Adesão da República Bolivariana da Venezuela ao MERCOSUL, a união aduaneira passou a ter um quinto membro, embora sua adesão ainda dependa de ratificação por parte do Poder Legislativo da República do Paraguai. 
No Preâmbulo do Tratado de Assunção ${ }^{690}$ é reiterada a formulação da necessidade da integração econômica como condição fundamental para acelerar seus processos de desenvolvimento econômico com justiça social, por meio do aproveitamento mais eficaz dos recursos disponíveis, a preservação do meio ambiente, o melhoramento das interconexões físicas, a coordenação de políticas macroeconômicas e a complementação dos diferentes setores da economia.

Seu Artigo $1^{0691}$, embora não se refira a questões discriminatórias no plano tributário, afirma que o esforço integracionista que representa implica "a livre circulação de bens, serviços e fatores produtivos entre os países, através, entre outros, da eliminação dos direitos alfandegários e restrições não tarifárias à circulação de mercadorias e de qualquer outra medida de efeito equivalente".

\section{0 “TRATADO PARA A CONSTITUIÇÃO DE UM MERCADO COMUM ENTRE A REPÚBLICA ARGENTINA, A REPÚBLICA FEDERTIVA DO BRASIL, A REPÚBLICA DO PARAGUAI E A REPÚBLICA ORIENTAL DO URUGUAI}

A República Argentina, a República Federativa do Brasil, a República do Paraguai e a República Oriental do Uruguai, doravante denominados "Estados Partes";

Considerando que a ampliação das atuais dimensões de seus mercados nacionais, através da integração, constitui condição fundamental para acelerar seus processos de desenvolvimento econômico com justiça social;

Entendendo que esse objetivo deve ser alcançado mediante o aproveitamento mais eficaz dos recursos disponíveis, a preservação do meio ambiente, o melhoramento das interconexões físicas, a coordenação de políticas macroeconômicas e a complementação dos diferentes setores da economia, com base nos princípios de gradualidade, flexibilidade e equilíbrio;

Tendo em conta a evolução dos acontecimentos internacionais, em especial a consolidação de grandes espaços econômicos, e a importância de lograr uma adequada inserção internacional para seus países;

Expressando que este processo de integração constitui uma resposta adequada a tais acontecimentos;

Conscientes de que o presente Tratado deve ser considerado como um novo avanço no esforço tendente ao desenvolvimento progressivo da integração da América Latina, conforme o objetivo do Tratado de Montevidéu de 1980.

Convencidos da necessidade de promover o desenvolvimento cientifico e tecnológico dos Estados Partes e de modernizar suas economias para ampliar a oferta e a qualidade dos bens de serviço disponíveis, a fim de melhorar as condições de vida de seus habitantes;

Reafirmando sua vontade política de deixar estabelecidas as bases para uma união cada vez mais estreita entre seus povos, com a finalidade de alcançar os objetivos supramencionados".

691 "CAPÍTULO I

Propósitos, Princípios e Instrumentos

ARTIGO 1

Os Estados Partes decidem constituir um Mercado Comum, que deverá estar estabelecido a 31 de dezembro de 1994, e que se denominará "Mercado Comum do Sul" (MERCOSUL).

Este Mercado comum implica:

A livre circulação de bens, serviços e fatores produtivos entre os países, através, entre outros, da eliminação dos direitos alfandegários e restrições não tarifárias à circulação de mercadorias e de qualquer outra medida de efeito equivalente;

O estabelecimento de uma tarifa externa comum e a adoção de uma política comercial comum e relação a terceiros Estados ou agrupamentos de Estados e a coordenação de posições em foros econômico-comerciais regionais e internacionais;

A coordenação de políticas macroeconômicas e setoriais entre os Estados Partes - de comércio exterior, agrícola, industrial, fiscal, monetária, cambial e de capitais, de outras que se acordem -, a fim de assegurar condições adequadas de concorrência entre os Estados Partes, e

O compromisso dos Estados Partes de harmonizar suas legislações, nas áreas pertinentes, para lograr o fortalecimento do processo de integração". 
No Artigo $5^{0692}$, sim, aparece uma norma tributária concernente à eliminação dos impostos de importação, dentro de um Programa de Libertação Comercial, que consistiria "em reduções tarifárias progressivas, lineares e automáticas, acompanhadas da eliminação de restrições não tarifárias ou medidas de efeito equivalente, assim como de outras restrições ao comércio entre os Estados Partes, para chegar a 31 de dezembro de 1994 com tarifa zero, sem barreiras não tarifárias sobre a totalidade do universo tarifário". Não é preciso nem se dizer que tais compromissos não foram cumpridos até hoje.

O Princípio da Não-Discriminação em matéria tributária é apenas enunciado no seu Artigo $7^{6693}$, de uma forma muito pobre e que, por isso mesmo, não mereceu da doutrina regional, como expõe Edison Carlos Fernandes (2006, p. 116 - 123), maiores aprofundamentos quanto ao seu conteúdo, senão considerações comparativas mais superficiais do que as então empreendidas no presente trabalho. Por exemplo, na coletânea de textos relacionadas na obra, em nenhuma delas abordou-se a questão se a disciplina regional do Cone Sul, em matéria de discriminação tributária, abrange apenas a discriminação de jure, ou se também teria o condão de coibir a de facto.

$\mathrm{O}$ art. $7^{\circ}$ é uma norma unicamente voltada para o comércio de bens e serviços, de escasso desenvolvimento na sua redação, baseado em uma igualdade formal e que, por isso, ainda deve percorrer um longo caminho, tanto legislativo quanto jurisprudencial (SANTA-BÁRBARA RUPÉREZ, 2001, p. 203), para conseguir, com segurança jurídica e justiça fiscal, resolver os conflitos em matéria tributária que potencialmente se vislumbram a partir de sua aplicação cada vez maior em decorrência do sempre constante incremento das trocas entre os países do bloco, como se viu.

A partir da dicção do Artigo $7^{\circ}$ do Tratado de Assunção, até pode-se entender possível a abrangência à repressão à discriminação implícita, se o órgão julgador eventualmente conferir um elastério interpretativo maior à expressão "mesmo tratamento".

692 "ARTIGO 5

Durante o período de transição, os principais instrumentos pra a constituição do Mercado Comum são:

a. Um Programa de Libertação Comercial, que consistirá em reduções tarifárias progressivas, lineares e automáticas, acompanhadas da eliminação de restrições não tarifárias ou medidas de efeito equivalente, assim como de outras restrições ao comércio entre os Estados Partes, para chegar a 31 de dezembro de 1994 com tarifa zero, sem barreiras não tarifárias sobre a totalidade do universo tarifário (Anexo I);

b. A coordenação de políticas macroeconômicas que se realizará gradualmente e de forma convergente com os programas de desgravação tarifária e eliminação de restrições não tarifárias, indicados na letra anterior;

c. Uma tarifa externa comum, que incentive a competitividade externa dos Estados Partes;

d. A adoção de acordo setoriais, com o fim de otimizar a utilização e mobilidade dos fatores de produção e alcançar escalas operativas eficientes".

693 "ARTIGO 7

Em matéria de impostos, taxas e outros gravames internos, os produtos originários do território de um Estado Parte gozarão, nos outros Estados Partes, do mesmo tratamento que se aplique ao produto nacional”. 
Por outro lado, não parece ser viável qualquer expansão do escopo de abrangência do artigo a produtos que não sejam idênticos - nem sequer os similares restariam dentro da eficácia da norma, muito menos os em mera relação de concorrência - dado o emprego do termo "produto nacional". Nessa perspectiva, com o fim de resgatar a coerência na norma, uma vez que parece artificial vislumbrar a possibilidade de discriminação implícita em relação a produtos idênticos, melhor entender a norma regional sulamericana como repressiva apenas à discriminação explícita ou de jure. A conclusão nesse sentido é mesmo a melhor, porque o artigo todo, em leitura abrangente, passa uma ideia de irrelevância de aspectos concernentes ao mercado consumidor, deixando transparecer unicamente uma preocupação de preservação formal das condições de igualdade. Jesús Santa-Bárbara Rupérez (2001, p. 205) comunga da mesma opinião quanto à inaplicabilidade do art. $7^{\circ}$ à discriminação de facto.

Por último, o seu Anexo I, que trata do Programa de Liberação Comercial, em seu Artigo Segundo, traz o conceito de gravames como sendo "os direitos aduaneiros e quaisquer outras medidas de efeito equivalente, sejam de caráter fiscal, monetário, cambial ou de qualquer natureza, que incidam sobre o comércio exterior" - não estão compreendidas neste conceito taxas e medidas análogas quando respondam ao custo aproximado dos serviços prestados; e de restrições como "qualquer medida de caráter administrativo, financeiro, cambial ou de qualquer natureza, mediante a qual um Estado Parte impeça ou dificulte, por decisão unilateral, o comércio recíproco".

Para compreender realmente o alcance do Princípio de Não-Discriminação no MERCOSUL, restaria-nos, então, partir para o exame da jurisprudência arbitral a respeito.

Só há dois laudos arbitrais no MERCOSUL que tratam de matéria tributária, ambos referentes à discriminação explícita e que não foram muito profundos em examinar os pressupostos da norma, ainda que meramente com vistas a, para julgados futuros, fixar os respectivos balizamentos exegéticos.

O primeiro caso é o Laudo Arbitral $n^{\circ}$ 08, cujas partes são a República do Paraguai, como Reclamante; e a República Oriental do Uruguai, como Reclamada, acerca da aplicação do "IMESI" à comercialização de cigarros. Foi emitido em São Paulo, em função da saúde do Presidente do Tribunal Ad-hoc Prof. Luiz Olavo Baptista, em 21 de maio de 2002, ainda quando vigente o Protocolo de Brasília.

Juntamente com o Impuesto al Valor Agregado (IVA), pela Ley $\mathrm{n}^{\circ} 14.100$, de 29 de dezembro de 1972, foi originalmente instituído no Uruguai o Imposto Específico Interno (Impuesto Específico Interno, abreviadamente IMESI), como tributo monofásico 
de competência do estado nacional uruguaio. Hoje, a incidência é definida a partir das alterações empreendidas por diversas normas posteriores, das quais a última relevante é a Ley $\mathrm{n}^{\circ} 18.083$, de $27 / 12 / 006$, arts. $33^{\circ}$ a $36^{\circ}$ e $38^{\circ}$.

Seu fato gerador define-se materialmente, no art. $1^{0694}$ do Título 11 do Texto Ordenado em 1996 pela Dirección General Impositiva (DGI) ${ }^{695}$ da República Oriental do Uruguai, Decreto 338/996 $6^{696}$, como ocorrido na primeira alienação, a qualquer título, dos bens que se enumeram, com a alíquota fixada pelo Poder Executivo, obedecido o valor máximo indicado em tabela estipulada na lei. Tais bens, sobre os quais o IMESI incide, são, entre outros, bebidas alcoólicas; cosméticos, perfumaria e artigos de toucador em geral; tabacos, cigarros e charutos; energia elétrica; veículos automotores; combustíveis líquidos e gasosos e lubrificantes.

Segundo o Paraguai, o objeto da controvérsia é a incompatibilidade das normas uruguaias referentes à aplicação do "IMESI", uma vez que alega que a forma de calcular a incidência de tal imposto é discriminatória e contradiz os artigos $1^{\circ}$ e $7^{\circ}$ do Tratado de Assunção e seu Anexo I.

Embora a alíquota do IMESI, tanto para os produtos nacionais como para os oriundos de países fronteiriços ou não fronteiriços, seja a mesma, a base de cálculo era obtida de forma que seria discriminatória, já que era determinada, para o produto importado, a partir de um preço ficto correspondente ao preço aplicado ao cigarro nacional de maior categoria. Após, essa base de cálculo ficta é multiplicada por um coeficiente prefixado também diferenciado para o produto similar nacional com relação ao produto tanto de país limítrofe $(1,3)$ quanto, mais ainda, de não limítrofe (2). O cigarro paraguaio resultava, portanto, duplamente discriminado, por não provir de um país limítrofe ao Uruguai.

O Paraguai sustentou que a apuração do IMESI rompe o princípio de igualdade de tratamento e restringe o acesso de seus produtos ao mercado uruguaio, o que causa incompatibilidade com o princípio do art. $7^{\circ}$ do Tratado de Assunção. Dito imposto inibiria, ainda, a livre circulação de bens, segundo o que se estabelece no art. $1^{\circ}$ do tratado,

\footnotetext{
694 "Artículo 1". - Estructura.- Créase el Impuesto Específico Interno que gravará la primera enajenación, a cualquier título, de los bienes que se enumeran, con la tasa que fije el Poder Ejecutivo, cuyo valor máximo en cada caso se indica":

695 Consolidação das normas legais por meio de ato infra-legal exarado pela administração tributária uruguaia.

696 Disponível em http://www.dgi.gub.uy/wdgi/hgxpp001?6,4,207,O,S,0,MNU;E;178;2;MNU; acesso em 26/03/2011.
} 
assim como a reciprocidade de direitos e obrigações entre os Estados partes já que o acesso ao Paraguai dos cigarros uruguaios é irrestrito.

O tribunal iniciou seu julgamento estabelecendo que a demanda que se lhe apresentava possuía dupla natureza: a igualdade de tratamento e a harmonização das normas do MERCOSUL como restrições da livre circulação de bens. Estipulou que a norma que estabelece o dever de harmonização e eliminação de obstáculos à livre circulação de bens nasce da própria natureza do tratado e é deduzida de alguns de seus pontos, tendo sido também, recordada em decisões de tribunais anteriores.

O tribunal reconheceu que a regra de igualdade no MERCOSUL, apesar de ser essencialmente a mesma que se deduz do Tratado de Montevidéu e que aparece no GATT 1947, persistindo ainda hoje na OMC, tratados de que ambas as partes fazem parte, adquire especificidade no bloco, cujo sentido parte do que se entende em nível multilateral e regional, mas deve servir preponderantemente a integrar lacunas.

A igualdade de tratamento no MERCOSUL será concretizada, em primeiro lugar, pela existência de fato e de direito da não discriminação ente os Estados membros na prática. Quer dizer, uma norma que aparentemente não seja discriminatória, se não o é de fato e, com mais razão, se a norma em si mesma é discriminatória, será incompatível com a igualdade de tratamento estabelecida no tratado do MERCOSUL ${ }^{697}$.

Para o tribunal arbitral, a livre circulação deve ocorrer tanto no campo da imposição tarifária quanto no campo das práticas administrativas. Dessa forma, os Estados membros não podem criar obstáculos de qualquer natureza que impeçam a livre circulação dos produtos. As exceções, embora não previstas diretamente pelos tratados do MERCOSUL, serão apenas aquelas do art. 50 do Tratado de Montevidéu de 1980 e dos arts. XX e XXI do GATT 1994.

O tribunal decidiu que o Uruguai tem o direito de tributar os bens dentro de seu próprio território, mas não pode fazê-lo de forma que um produto oriundo de outro país seja tratado com discriminação relativamente a produtos similares nacionais, sendo esta a

697 “(...) La regla de igualdad en Mercosur, en su esencia, es la misma que se deduce de los Tratados de Montevideo y que aparece en el Gatt de 1947 y que persiste aun hoy en la OMC, de los cuales hacen partes todos los Estados Miembros, que se han sometido también a las reglas del tratado de Montevideo, del cual también hacen parte. De esta forma, la definición de lo que es igualdad parte de ai pero adquiere especificidad en el Mercosur. La referencia que se haga a las demás normas de derecho internacional, como los Tratados de Montevideo y la OMC solo serviría para integrar lagunas.

La igualdad de trato en Mercosur ha de concretarse, en primer lugar en la existencia de hecho y de derecho de la no discriminación entre los estados miembros en la practica. Es decir, que una norma que aparentemente no fuera discriminatoria, se lo es de hecho y com mas razón si la norma en si misma tiene discriminación, son incompatibles con la igualdad de trato establecida en el tratado del Mercosur. (...)". Disponível em http://www.tprmercosur.org/pt/sol_contr_laudos.htm, acesso em 23/03/2011. 
regra do MERCOSUL, pelo art. $7^{\circ}$ do Tratado, da ALADI e da OMC, organizações das quais ambos os países são signatários. Assim sendo, a aplicação do IMESI discrimina duplamente o cigarro paraguaio, ao impor sobre ele maior pressão fiscal com relação a produtos similares uruguaios e originários de países fronteiriços, o que vai de encontro à normativa MERCOSUL - os produtos paraguaios são tratados como se fossem extra-zona. Este tratamento não se fundamenta na lista de exceções prevista no âmbito do MERCOSUL, tampouco naquelas previstas no GATT 1994, e, portanto, não é admissível e não pode ser permitido. A anterioridade do IMESI em relação ao surgimento do MERCOSUL não o coloca em conformidade com a normativa convencional. Ao assinar o tratado constitutivo do MERCOSUL o Uruguai se comprometeu, pela boa-fé, a adequar sua legislação interna aos propósitos da integração. Portanto, quando da adoção do Tratado de Assunção, instaurou-se uma antinomia entre a forma de aplicação do IMESI e o tratado.

O segundo caso é o Laudo Arbitral no 10, de 5 de agosto de 2005, também anterior ao Protocolo de Olivos, cujas partes são a República Oriental do Uruguai, como Reclamante; e a República Federativa do Brasil, como Reclamada, sobre medidas discriminatórias e restritivas ao comércio de tabaco e produtos derivados do tabaco.

A controvérsia se iniciou com a reclamação de uma empresa, com domicílio no Uruguai, perante a Sessão Nacional do GMC do Uruguai, alegando a existência de prejuízos atuais e futuros em conseqüência da implementação dos Decretos $n^{\circ} 3.646$ e $n^{\circ}$ 3.647, de 30 de outubro de 2000, da República Federativa do Brasil. Segundo a empresa, tais decretos tinham efeito restritivo e discriminatório ao comércio em matéria de exportação de tabaco, produtos derivados do tabaco, filtros de cigarros, papel para cigarros e embalagens para filtros. 
O Decreto $\mathrm{n}^{\mathrm{o}} 3.646 / 00^{698}$ determinava a incidência do Imposto de Exportação, à alíquota de cento e cinqüenta por cento, sobre o fumo e o tabaco, manufaturados ou in natura, quando exportados para o Paraguai e o Uruguai. O Decreto $\mathrm{n}^{\mathbf{0}} 3.647 / 00^{699}$ determinava também a incidência do Imposto de Exportação, à alíquota de cento e cinqüenta por cento, sobre o papel para cigarros e cilindros para filtros de cigarros, quando exportados para a América do Sul e América Central, inclusive Caribe, exceto para Argentina, Chile e Equador. Provavelmente, tais normas visavam a combater, na produção, o contrabando de cigarros vindos de países limítrofes ao Brasil.

Em 20 de julho de 2005, o tribunal foi informado, por meio da Secretaria do MERCOSUL, do conteúdo de uma nota emanada da coordenação brasileira no GMC, do dia 19 de julho, e dirigida ao coordenador nacional do GMC do Uruguai, pela qual

698 “DECRETO n 3.646, DE 30 DE OUTUBRO DE 2000. Dispõe sobre o Imposto de Exportação incidente sobre os produtos que menciona.

O PRESIDENTE DA REPÚBLICA, no uso da atribuição que lhe confere o art. 84, inciso IV, da Constituição, e tendo em vista o disposto nos arts. $1^{\circ}$ a $4^{\circ}$ do Decreto-Lei no 1.578 , de 11 de outubro de 1977 , DE C R E T A :

Art. 1 Os produtos classificados nas posições 2401 e 2403 da Tabela de Incidência do Imposto sobre Produtos Industrializados - TIPI, aprovada pelo Decreto no 2.092, de 10 de dezembro de 1996, quando exportados para o Paraguai e o Uruguai, ficam sujeitos à incidência do Imposto de Exportação à alíquota de cento e cinqüenta por cento.

Parágrafo único. O disposto no caput aplica-se também na exportação dos produtos objeto de registro de exportação que já esteja aprovado pelo órgão competente na data da publicação deste Decreto, no Sistema Integrado de Comércio Exterior - Siscomex, e que venham a sofrer alteração, inclusive no que se refere ao prazo de validade para o embarque.

Art. 2 A Secretaria da Receita Federal expedirá as normas necessárias à aplicação do disposto neste Decreto.

Art. $3^{\circ}$ Este Decreto entra em vigor na data de sua publicação.

Brasília, 30 de outubro de $2000 ; 179^{\circ}$ da Independência e $112^{\circ}$ da República.

FERNANDO HENRIQUE CARDOSO

Pedro Malan"

699 "DECRETO n' 3.647, DE 30 DE OUTUBRO DE 2000. Dispõe sobre o Imposto de Exportação incidente sobre os produtos que menciona.

O PRESIDENTE DA REPÚBLICA, no uso da atribuição que lhe confere o art. 84, inciso IV, da Constituição, e tendo em vista o disposto nos arts. $1^{\circ}$ a $4^{\circ}$ do Decreto-Lei n ${ }^{\circ} 1.578$, de 11 de outubro de 1977,

DE C R E T A :

Art. 1 Os produtos classificados na posição 4813 e no código 5601.22 .91 da Tabela de Incidência do Imposto sobre Produtos Industrializados - TIPI, aprovada pelo Decreto no 2.092, de 10 de dezembro de 1996, quando exportados para a América do Sul e América Central, inclusive Caribe, ficam sujeitos à incidência do Imposto de Exportação à alíquota de cento e cinqüenta por cento.

$\S 1^{\circ} \mathrm{O}$ disposto no caput aplica-se também na exportação dos produtos objeto de registro de exportação que já esteja aprovado pelo órgão competente na data da publicação deste Decreto, no Sistema Integrado de Comércio Exterior - Siscomex, e que venham a sofrer alteração, inclusive no que se refere ao prazo de validade para o embarque.

$\S 2^{\circ}$ Excetuam-se das disposições contidas neste artigo os produtos exportados para a Argentina, Chile e Equador.

Art. 2 A Secretaria da Receita Federal expedirá as normas necessárias à aplicação do disposto neste Decreto.

Art. $3^{\circ}$ Este Decreto entra em vigor na data de sua publicação.

Art. 4 Fica revogado o Decreto ${ }^{\circ} 3.586$, de 5 de setembro de 2000.

Brasília, 30 de outubro de $2000 ; 179^{\circ}$ da Independência e $112^{\circ}$ da República.

FERNANDO HENRIQUE CARDOSO

Pedro Malan" 
notificava a publicação, no Diário Oficial da União, do Decreto ${ }^{\circ} 5.492$, de 18 de julho de 2005, que revogava o Decreto $\mathrm{n}^{\mathrm{o}} 3.646 / 00$. Notificou, também, que a Resolução CAMEX $n^{\circ} 26 / 2003$, que tratava das exportações brasileiras de tabaco e insumos para a fabricação de derivados de tabaco, havia sido revogada com a publicação, no dia 13 de julho, no Diário Oficial da União, da Resolução CAMEX nº 20/05 de 05 de julho de 2005.

A coordenação nacional brasileira, assim, entendeu que a revogação de ambas as normas tornava sem objeto a controvérsia, em razão do fato de que não estava mais em vigor o imposto à exportação discriminatório.

De se notar que o Decreto no 3.647/00 já havia sido, antes mesmo da instalação do tribunal arbitral, sido revogado pelo Decreto ${ }^{\circ} 4.831$, de 5 de setembro de 2003.

O Uruguai então considerou que também constituía objeto da controvérsia toda medida similar do Brasil de efeito restritivo e/ ou discriminatório relativa a exportações ao Uruguai de tais produtos. Pediu, ainda, que o tribunal determinasse ao Brasil que se abstivesse de adotar no futuro outras medidas que produzam efeitos similares aos que se questionavam na reclamação.

O tribunal entendeu que o Uruguai, apesar de ter se referido, em reiteradas oportunidades, a "outras medidas de efeitos similares", não identificou ditas medidas nem tampouco alegou particularmente sua incompatibilidade com o sistema do MERCOSUL. Assim sendo, o tribunal decide que a referência generalizada a "outras medidas de efeitos similares" não integrava o conteúdo do objeto da controvérsia, como parte autônoma. Entretanto, sem dúvida, aquelas medidas internas diretamente relacionadas com a medida questionada conformam o objeto da controvérsia.

Quanto a saber se dentro do objeto da controvérsia deve incluir-se o solicitado pelo Uruguai com relação à obrigação do Brasil de abster-se de adotar, no futuro, outras medidas que produzam efeitos restritivos e/ ou discriminatórios similares aos que se questionava em sua reclamação, o tribunal considerou que, em princípio, toda controvérsia submetida a um procedimento arbitral deve se referir a diferenças existentes e não a possíveis ou eventuais futuras diferenças.

Da avaliação das comunicações trocadas entre os países, o tribunal concluiu pelo término da controvérsia, fundamentando-se no fato de que a reclamação do Uruguai foi satisfeita pelo Brasil por meio da revogação daquelas normas internas que violavam regras e princípios do MERCOSUL.

Como se pode facilmente concluir, o estudo da casuística do MERCOSUL em nada contribui para o enriquecimento científico do entendimento do Princípio de Não- 
Discriminação. Pelo contrário, no primeiro caso estudado, chegou-se a dizer, inexplicavelmente, que o seu escopo é diverso do das disposições similares no GATT e na ALADI.

\subsection{Do Princípio de Não-discriminação Tributária na experiência brasileira.}

Já que concluímos que os julgados arbitrais referentes ao Princípio de NãoDiscriminação no âmbito do MERCOSUL não tocam em nenhum momento em qualquer das formulações fundadas na análise do mercado de consumo no país importador em que se baseia a jurisprudência do Sistema GATT/OMC, acordos internacionais dos quais o Brasil e os demais Estados Partes são signatários. Vejamos agora como é a realidade nacional brasileira a respeito, lembrando-se que, especificamente, o Brasil é uma das vinte e três Partes Contratantes do GATT, em 1947.

Inicialmente, examinemos os entendimentos jurisprudenciais externados pelos acórdãos do Superior Tribunal de Justiça (STJ) e do Supremo Tribunal Federal (STF) que, de alguma maneira, tocam no tema da interpretação das regras internacionais sobre a matéria.

No Direito Tributário brasileiro, há a particularidade de existir o artigo 98 do $\mathrm{CTN}^{700}$, que determina a necessária observância dos tratados pela legislação tributária interna, em função do qual poder-se-ia a priori presumir que as regras do GATT fossem aqui consideradas em sua plenitude de eficácia e alcance hermenêutico.

De início já se pode apontar que a aplicabilidade genericamente considerada do art. 98 não é pacífica, na medida em que se identificam precedentes jurisprudenciais que limitam sua eficácia aos tratados de natureza contratual, não incluindo os de caráter geral. É o caso dos precedentes acerca da isenção do Adicional ao Frete para Renovação da Marinha Mercante (AFRMM), como os RREEsp no 31.849-3/SP; 34.025-5/PR e 50.0583/SP, que negavam a isenção da referida contribuição de intervenção no domínio econômico com base na aplicação direta de acordos internacionais, uma vez que entendeuse que a "expressão "atos internacionais firmados pelo Brasil (Decreto-Lei no 2.404/87, art.

\footnotetext{
700 “Art. 98. Os tratados e as convenções internacionais revogam ou modificam a legislação tributária interna, e serão observados pela que lhes sobrevenha”.
} 
$5^{\circ}$, inciso $\mathrm{V}$, "c")" refere-se aos tratados de natureza contratual e não a tratados de caráter geral, como o acordo do GATT".

Essa distinção entre tratados de natureza contratual e tratados de caráter geral é discutida, havendo mesmo entre autores clássicos quem a refute, como Alberto Xavier (1997), e a reproduza, como Jacob Dolinger (1995). Assim, como esses próprios precedentes expressamente refletem, mesmo sendo o GATT um tratado de caráter geral, e não contratual, o que é hoje respaldado pela doutrina, como Leandro Paulsen (2003, p. 734 - 735), pode-se dizer que há precedentes jurisprudenciais fortes no sentido de que a disciplina do GATT não tenha efeito direto no Direito Tributário brasileiro.

Mas essa posição não é pacífica; ao menos não para outras questões que envolvam conflito entre norma tributária brasileira discriminatória e o GATT. A propósito, Heleno Tôrres (2004, p. 424), aponta o julgamento do RE nº 90.824/SP, relator Ministro Moreira Alves, como um exemplo de entendimento do GATT como tratado de caráter geral. Com efeito direto sobre a norma tributária nacional portanto, a teor do art. 98 do CTN.

Não é por outro motivo que o STF, por meio do verbete $\mathrm{n}^{\circ} 575^{701}$ da sua Súmula de Jurisprudência, e o STJ, por meio dos seus verbetes sumulares $n^{\circ} 20^{702}$ e $n^{\circ}$ $71^{703}$, considerou aplicáveis as regras do GATT a questões internas referentes ao então ICM, hoje sucedido pelo ICMS. Como o GATT e o (Primeiro) Tratado de Montevidéu, referente à ALALC, são anteriores à Emenda Constitucional no 18/65, que criou o ICM, e possibilitou a sua instituição, ou mesmo à Emenda Constitucional no $23 / 83$, que permitiu a sua incidência na importação, deve-se concluir que em todos os casos as regras do GATT foram consideradas eficazes mesmo em face de legislação interna posterior, em respeito à determinação do art. 98 do CTN e de forma contrária a uma pretensa equiparação do tratado internacional à lei interna, como é a visão ainda prevalente dos tribunais superiores em matéria de tratados de natureza não tributária ${ }^{704}$.

Examinar-se-á primeiramente o verbete proferido pelo STF, por ser omais antigo, ainda de antes do texto constitucional de 5 de outubro de 1988 e, ainda mais importante, por ser referenciado pela jurisprudência posterior do STJ.

\footnotetext{
701 “À mercadoria importada de país signatário do (GATT), ou membro da (ALALC), estende-se a isenção do imposto de circulação de mercadorias concedida a similar nacional”.

702 "A mercadoria importada de país signatário do GATT e isenta do ICM, quando contemplado com esse favor o similar nacional".

703 "O bacalhau importado de país signatário do GATT é isento do ICM".

${ }^{704}$ A esse respeito, vide a posição do STF no RE no 80.004/SE, em RTJ 83/809.
} 
O verbete sumular do STF teve origem nos RREE $n^{\circ}$ 83.428/SP, $n^{\circ} 76.099 / \mathrm{SP}$, $n^{\circ} 82.509 / \mathrm{SP}, \mathrm{n}^{\circ} 83.531 / \mathrm{SP}, \mathrm{n}^{\circ} 83.806 / \mathrm{SP}, \mathrm{n}^{\circ} 83.430 / \mathrm{SP}, \mathrm{n}^{\circ} 84.400 / \mathrm{SP}, \mathrm{n}^{\circ} 84.010 / \mathrm{SP}$ e ${ }^{\circ}$ 84.892/SP, na mesma ordem com a qual são tais arestos listados na página eletrônica do $\mathrm{STF}^{705}$.

Todos são recursos manejados em autos de mandado de segurança. Tratavam de importações de fungicidas ou fertilizantes para a agricultura (RREE $\mathrm{n}^{\mathrm{o}}$ 83.428/SP, $\mathrm{n}^{\circ}$ 76.099/SP, $n^{\text {o } 84.010 / S P ~ e ~} n^{\circ} 83.531 / \mathrm{SP}$ ), alho (RREE $n^{\circ} 82.509 / \mathrm{SP}$ e $\mathrm{n}^{\circ} 83.806 / \mathrm{SP}$ ) ou produtos não indicados nos acórdãos, nos demais casos. Em todos os processos, o pedido é a ordem mandamental de sustação do ato da autoridade aduaneira que exigia a apresentação da comprovação do pagamento do ICM para o desembaraço aduaneiro das mercadorias descritas, sob a alegação de que a mercadoria idêntica nacional seria beneficiária de isenção desse tributo.

Os fundamentos das decisões divergem um pouco. No RE $\mathrm{n}^{\circ} 76.099 / \mathrm{SP}$, sobre a importação de ácido ortofosfórico, o voto trata da inaplicabilidade ao caso do disposto nos arts. $3^{\circ}$ e $4^{0706}$ do Tratado de Montevidéu de 1960, instituidor da ALALC, referentes às negociações para o desgravamento, obviamente matéria concernente ao imposto de importação e não ao ICM, objeto, na qualidade de imposição interna, como exaustivamente visto, do art. $21^{707}$ do mesmo tratado. No RE $n^{\circ} 82.509 / \mathrm{SP}$, acerca da importação de fungicida, a procuradoria fiscal paulista alegou que a isenção conferida pela Lei (estadual)

705 Trata-se da página eletrônica, no sítio do Supremo Tribunal Federal, disponível em http://www.stf.jus.br/portal/jurisprudencia/listarJurisprudencia.asp?s1=575.NUME. NAO S.FLSV.\&base=baseSumulas. Acesso em 26/03/2011.

706 “Artigo 3". - Durante o período indicado no Artigo 2, as Partes Contratantes eliminarão, gradualmente, para o essencial de seu comércio recíproco, os gravames e as restrições de toda ordem que incidam sobre a importação de produtos originários do território de qualquer Parte Contratante.

Para fins do presente Tratado, entende-se por gravames os direitos aduaneiros e quaisquer outros encargos de efeitos equivalentes - sejam de caráter fiscal, monetário ou cambial - que incidam sobre as importações.

O disposto neste artigo não é aplicável às taxas ou encargos análogos, quando correspondam ao custo dos serviços prestados.

Artigo $4^{\circ}$. - O objetivo previsto no Artigo 3 será alcançado por meio de negociações periódicas que se realizarão entre as Partes Contratantes e das quais deverão resultar:

a) listas nacionais, com as reduções anuais de gravames e demais restrições que cada Parte Contratante conceda às demais Partes Contratantes, de acordo com o disposto no Artigo 5; e

b) uma lista comum, com a relação dos produtos cujos gravames e demais restrições as Partes Contratantes se comprometem, por decisão coletiva, a eliminar integralmente para o comércio intrazonal, no período referido no Artigo 2, obedecidas as percentagens mínimas fixadas no Artigo 7 e o processo de redução gradual estabelecido no Artigo 5".

Disponível em http://www2.uol.com.br/actasoft/actamercosul/novo/tratmonte_1960.htm. Acesso em 26/03/2011.

707 “CAPÍTULO V

Tratamento em matéria de tributos internos

Artigo 21 - Em matéria de impostos, taxas e outra gravames internos, os produtos originários do território de uma Parte Contratante gozarão, no território de outra Parte Contratante, de tratamento não menos favorável que o aplicado a produtos similares nacionais". 
$n^{\circ}$ 91/72, refere-se a uma isenção na saída da mercadoria, não na sua importação, que corresponderia a uma entrada no estabelecimento. No RE $n^{\circ} 83.806 / \mathrm{SP}$, foram aduzidas ambas as alegações. No RE $n^{\circ} 83.531 / \mathrm{SP}$, também sobre fungicidas, empregou-se o argumento de que a lide implicaria reexame de matéria de fato, algo incabível em sede suprema. Nos acórdãos RREE n 83.430/SP, no 84.400/SP, nº 84.010/SP e no 84.892/SP, como razão de decidir, o STF limita-se a mencionar os precedentes anteriores.

Em todas as fundamentações, não houve que se indagar a questão concernente à similaridade dos produtos, pois os benefícios fiscais eram aplicáveis a produto nacional de características idênticas. Tampouco a existência de tratamento tributário diferenciado era questionável, já que evidentemente mais oneroso ao importado, havendo para o nacional a isenção e para o alienígena a exigência fiscal concreta, como condição ao desembaraço aduaneiro.

Assim, o foco da fundamentação dos ministros do STF sempre foi o do conflito de normas entre a lei (ou o convênio ICM ou a Emenda Constitucional no 23/83) e o tratado internacional, à luz do direito brasileiro e os critérios cronológico, de especialidade ou hierárquico. Nada se falou em nenhum deles sobre o mercado de consumo dos produtos no país de importação - até porque, na verdade, tal consideração, dada a simplicidade das questões, não era necessária. A referência à condição de similaridade, presente no enunciado do verbete, não encontra correspondência nos objetos dos acórdãos que lhe deram base.

O verbete $\mathrm{n}^{\circ} 20$ da súmula do STJ teve origem nos acórdãos dos Recursos Especiais $\mathrm{n}^{\circ} 3.143 / \mathrm{SP}, \mathrm{n}^{\circ} 1.845 / \mathrm{SP}, \mathrm{n}^{\circ} 1.309 / \mathrm{SP}$ e $\mathrm{n}^{\circ} 1.532 / \mathrm{SP}$, na ordem trazida pela página eletrônica daquela corte ${ }^{708}$. Trata-se, todos, de recursos interpostos em autos de mandado de segurança. O primeiro deles tratava da importação de ácido fosfórico, o segundo de "máquina bobinadora, recobridora de fios elásticos Arnold, de 80 posições, com fusos de 9.000 rpm., produto com isenção parcial do referido tributo no mercado interno" pelos Convênios ICM n ${ }^{\circ}$ 20/84 e nº 63/86. O terceiro caso tratava da importação de 1.000 toneladas de fosfato monoamônico, uma espécie de fertilizante. O último tratava da importação de um bem de capital.

Até por serem acórdãos todos de 1990, o mais novo de agosto desse ano, logo após a sua criação e à sua assunção de competência para a matéria, tais julgados

708 A página do sítio do Superior Tribunal de Justiça referida no texto é http://www.stj.jus.br/SCON/sumulas/doc.jsp?livre=\%40docn \&\&b=SUMU\&p=true \&t=\&l=10\&i=451.

Acesso em 26/03/2011. 
reproduzem as formulações já expostas pelo STF, quanto era de sua competência tratar de matéria recursal estadual não constitucional. Todas são discussões relacionadas a conflitos de norma interna versus tratado internacional, já que os produtos em questão eram idênticos, e evidente a discrepância no ônus tributário entre o produto nacional e o importado.

A questão é diferenciada quanto ao verbete $\mathrm{n}^{\circ} 71$, da Súmula de Jurisprudência do STJ. Seus precedentes, novamente na ordem trazida pelo sítio do próprio tribunal, são os RREEsp $n^{\circ} 21577 / \mathrm{SP}, \mathrm{n}^{\circ}$ 20052/SP, $\mathrm{n}^{\circ}$ 13866/SP, $\mathrm{n}^{\circ} 12059 / \mathrm{RJ}, \mathrm{n}^{\circ} 10872 / \mathrm{SP}, \mathrm{n}^{\circ}$ 10635/SP, no 5142/SP e n ${ }^{\circ} 715 / \mathrm{RJ}$.

Trata-se, nesses casos, de lide que versa a diferença consistente no fato de que a norma isentiva interna refere-se ao "peixe salgado e seco" nacional, e a sua condição se similaridade em relação ao bacalhau importado.

A questão remonta à assinatura do Convênio de Porto Alegre, em 16 de fevereiro de 1968, norma que dispõe sobre a concessão de isenção para a primeira saída de produtos agropecuários in natura e para as saídas de produtos hortifrutigranjeiros, revogação das disposições atinentes a crédito fiscal presumido, redução da base de cálculo nas saídas, para o exterior, de carne, milho, arroz e soja, aproveitamento de crédito do ICM pela entrada de equipamentos industriais, e estabelece outras providências. Em sua sua Cláusula $2^{\mathrm{a} 709}$, previu a possibilidade de os estados signatários concederem isenção para o pescado.

Posteriormente, a cláusula $2^{\text {a }}$ do III Convênio do Rio de Janeiro, de 19/03/68, estendeu a autorização para isenção da cláusula $2^{\mathrm{a}}$ às operações interestaduais e de exportação para o exterior, conforme especifica, bem como estendeu, em sua cláusula 9a às frutas frescas, provenientes da ALALC, tratamento fiscal idêntico ao que os Estados dispensam aos mesmos produtos nacionais. Os Convênios ICM nº 07/80 e n 13/80 excluíram da isenção, prevista na cláusula $2^{\text {a }}$ do Convênio de Porto Alegre, as saídas de crustáceos, moluscos, hadoque, bacalhau, merluza e salmão. O Convênio ICM nº 18/83 excluiu da isenção, prevista na cláusula $2^{a}$ do Convênio de Porto Alegre, as saídas de pescados destinados a emprego como matéria-prima em processo de industrialização (e

\footnotetext{
709 “Cláusula 2 2a Permitir às entidades signatárias conceder isenção do imposto de circulação de mercadorias para as saídas dos produtos hortifrutigranjeiros, relacionados na cláusula $1^{\mathrm{a}}$ do Convênio de Cuiabá e na cláusula $5^{\mathrm{a}}$ do II Convênio do Rio de Janeiro, celebrados em junho de 1967, bem como para as saídas de pescados, aves e ovos, em estado natural ou congelados, efetuadas por quaisquer estabelecimentos para o território da unidade federada em que foram produzidos.

Parágrafo único. Fica revogado, em relação às saídas dos produtos referidos nesta cláusula, efetuadas pelos próprios produtores, o sistema de crédito fiscal previsto nos citados Convênios".
} 
concedeu diferimento). O Convênio ICM nº 29/85 excluiu da isenção, prevista na cláusula $2^{\mathrm{a}}$ do Convênio de Porto Alegre, somente para o Estado do Rio de Janeiro, as saídas de peixes secos e/ou salgados e defumados. Porém, como o Convênio ICM n $29 / 87$, tal isenção foi revogada.

Pelo Convênio ICM n ${ }^{\circ} 08 / 88$, em sua Cláusula $1^{\text {a710 }}$, a autorização para prever a isenção nas operações internas foi reinstituída, com o seu prazo tendo sido prorrogado até 28/02/89 pelo Convênio ICM nº 60/88.

No mais antigo dos julgados tomados como precedente sumular, o REsp $\mathrm{n}^{\circ}$ 715/RJ discutiram-se precisamente as disposições revogatórias do Convênio ICM nº 07/80 às "saídas de hadoque, bacalhau, merluza e salmão" do potencial direito à isenção, mantidas para o pescado nacional congelado, conforme originariamente previsto no Convênio de Porto Alegre.

O Recurso Especial foi provido com base no voto condutor do Ministro Carlos Mário da Silva Velloso, relator para acórdão, apoiando-se em um outro julgado proferido no Recurso Especial $n^{\circ}$ 1.149/RJ, sendo seguido dos Ministros Américo Luz e Ilmar Galvão, baseado unicamente no fato de que o bacalhau é comercializado na forma desidratada, sendo pertencente, portanto, ao gênero de peixe seco e salgado ${ }^{711}$. O voto condutor da votação por maioria também mencionou julgado do STF em que foi proferido voto pelo Ministro Aldir Passarinho, RE $n^{\circ} 110.437 / R J$, no qual também se tratou basicamente do conflito normativo entre o tratado internacional e a lei interna ${ }^{712}$.

No entanto, merecem ser apontados os termos em que lavrado o voto minoritário do relator original do REsp no 715/RJ, o Ministro Vicente Cernichiaro, o único ministro que ousou sobrepujar a avaliação meramente baseada nas características físicas dos produtos considerados. Segundo ele, o argumento central do voto majoritário, o fato de

\footnotetext{
710 "Cláusula primeira. Ficam os Estados e o Distrito Federal autorizados a conceder, até 31 de dezembro de 1988, isenção do ICM nas operações internas de pescado em estado natural, resfriado, congelado, salgado, seco, eviscerado, filetado, postejado ou defumado para conservação, desde que não enlatado ou cozido.

Parágrafo único. O disposto nesta cláusula não se aplica:

I - às remessas para industrialização;

II - ao crustáceo, ao molusco, ao adoque, ao bacalhau, à merluza e ao salmão".

711 "No RE 105.606-RJ (RTJ 116/794) a Corte Suprema, pelo voto do eminente Relator, Ministro Rafael Mayer, deixou claro que o bacalhau não é de origem nacional. Mas o que o acordo do GATT deseja é que sejam evitadas discriminações entre o produto estrangeiro e o nacional, quando nele se verifique similaridade. Na verdade, não há bacalhau brasileiro, repete-se. O acordo internacional, entretanto, não fala em produto idêntico, mas em produto similar. Ora, se o peixe seco nacional possui as conotações do gênero, então não é possível afastá-lo, como similar, do bacalhau norueguês."

712 "Se é certo que, segundo o art. III do GATT, e na conformidade da Súmula 575, o produto importado de país participante do Acordo deve receber o mesmo tratamento concedido ao produto similar nacional (Súmula 575), não há como prevalecer a exclusão do bacalhau, da isenção concedida ao peixe seco e salgado nacional, sob pena de, mediante forma artificiosa, fazer-se preponderar o convênio interestadual sobre aquele Tratado".
} 
o bacalhar ser similar ao peixe seco e salgado, levava em consideração apenas o plano material. No entanto, no plano jurídico, segundo o Ministro Cernichiaro, a isenção de tributo, decorrente do GATT, ou mesmo da ALALC, não se preocupa com a analogia física, sendo o seu sentido "eminentemente econômico", buscando "estabelecer equilíbrio, na lei da oferta e da procura, entre os produtores nacionais e estrangeiros". Para ele, a "finalidade é que ônus fiscais incidentes em mercadorias importadas, havendo similar nacional, não dificulte (sic), desistimulando (sic), (sic) as importações”. Entendeu que, concorrentemente à semelhança física, cumpre atender à lei econômica.

Mencionando o Decreto $\mathrm{n}^{\circ} 72.573$, de 2 de agosto de 1973, o Protocolo relativo às Negociações entre Países em Desenvolvimento - GATT - noticiava que a norma referida busca contribuir para o desenvolvimento das economias dos países singnatários, "reconhecendo a necessidadade de reforçar suas economias graças às possibilidades de aumento da produção, de economias de escala e de especialização que poderiam resultar do crescimento se suas trocas comerciais mútuas".

O Ministro Vicente Cernichiaro acaba por concluir com um raciocínio de encerramento de seu ponto de vista, indagando se "o peixe seco e salgado nacional, economicamente, concorre com o bacalhau norueguês?" e, respondendo que não, evidentemente, já que os consumidores seriam distintos, aduz uma prosaica consideração: "ninguém admitirá o bacalhau ser substituído pelo pirarucu seco. Sabores inconfundíveis. Não marcam presença nos mesmos cardápios." Haveria, pois, fazendo referência aos votos de desembargadores da corte a quo, o Tribunal de Justiça do Rio de Janeiro, que se constatar que o elemento teleológico da isenção não se aplicaria ao produto importado, destinado a uma faixa de consumidores com maior capacidade contributiva. Com isso, o benefício fiscal não seria extensível, no caso concreto.

Fora esse voto minoritário, não acompanhado por ninguém, embora o verbete $\mathrm{n}^{\circ}$ 71 implique alguma evolução no que tange a tocar no assunto da similaridade, sempre os julgados, na forma dos votos dos respectivos relatores, fazem menção unicamente a aspectos físicos dos produtos. Assim foi, por exemplo, com os Ministros José de Jesus 
Filho, no REsp n ${ }^{\circ}$ 10635/SP ${ }^{713}$; Ilmar Galvão, no REsp n ${ }^{\circ}$ 10872/SP ${ }^{714}$; e Garcia Vieira, no REsp n ${ }^{\mathrm{o}} 21577 / \mathrm{SP}^{715}$.

Em todos esses acórdãos, a isenção ao produto nacional foi estendida ao bacalhau estrangeiro, por votação unânime, em votos concisos, com mera remissão aos precedentes. Como se vê, o correto e isolado entendimento primeiro do Ministro Vicente Cernichiaro foi varrido do horizonte jurídico brasileiro pelo rolo compressor da jurisprudência pacificada.

Posteriormente, quando os contribuintes passaram a tentar trasladar o mesmo raciocínio aplicado ao bacalhau para a merluza, já que o Convênio ICMS nº 60/91 não contemplava as suas vendas internas com isenção, o STJ passou a se dedicar a considerações ictiológicas, indagando-se acerca da existência dessa espécie de peixe em águas brasileiras. É o caso dos Embargos de Divergência no Recurso Especial (EResp) $n^{\circ}$ 515.292/SP ou o Agravo de Instrumento (AG) $n^{\circ} 415.764 / \mathrm{SP}$, relator Ministro José Delgado $^{716}$. Pelo raciocínio dos ministros do STJ, não sendo o pescado em questão tipicamente alienígena, como o bacalhau, a jurisprudência consolidada em relação ao peixe do Mar do Norte não se aplicaria ao epidêmico no Atlântico Sul.

Essa formulação, quanto à exclusividade da produção estrangeira do bem, aparentemente, colide frontalmente com os julgamentos nos RREEsp $n^{\circ} 480563 / R S, n^{\circ}$ 642.663/RS e no 685.410/RS.

Tais julgados encontram seu fundamento jurídico na Lei $\mathrm{n}^{\circ}$ 8.820/89, do Estado do Rio Grande do Sul, com a redação conferida pela Lei n. ${ }^{\circ} 10.908 / 96$, que isenta do ICMS

\footnotetext{
713 “A questão dos autos cinge-se ao problema da isenção do ICM na importação de bacalhau da Noruega, tendo em conta idêntico benefício conferido a similar nacional (peixe seco e salgado), por força do GATT”. 714 “A importação de mercadoria de países signatários do GATT, de acordo com a jurisprudência unânime desta Egrégia Turma, quando contemplado com isenção o similar nacional, está a salvo de tributação, pelo ICM."

715 "Não existe o bacalhau brasileiro. Ele é pescado nas águas frias e temperadas do Hemisfério Norte, das Costas da Terra Nova, Noruega, Inglaterra e Islândia, e deve ser enquadrado na categoria de peixes salgados e secos, isentos do Imposto de Circulação de Mercadorias, nos termos da cláusula primeira do Convênio ICM $n^{\circ}$ 089/88, prorrogado pelo Convênio ICM no 60/88. A exclusão do bacalhau feita pelo parágrafo único da cláusula primeira do Convênio ICM n ${ }^{\circ}$ 08/88 contraria o artigo III do GATT que garante a isenção ao produto importado de país signatário do acordo, com similar nacional, e prevalece sobre a legislação tributária interna (CTN, artigo 98), e esta isenção não foi revogada pela Emenda Constitucional no $23 / 83$."

716 “A Merluza Merluccius Hubbei Marini é uma espécie bentônica que habita águas temperadas e temperado-frias, ocorrendo no Uruguai, Argentina e, mais esporadicamente, na região Sul do Brasil, nos Estados de Santa Catarina e Rio Grande do Sul, tendo sua ocorrência entre os paralelos $23^{\circ} 4^{\prime} \mathrm{S}$ e $60^{\circ} \mathrm{S}$. Sua afluência em águas brasileiras é determinada pela entrada de águas frias, através da corrente das Malvinas, pelo Sul, o que explica a ocorrência de capturas esporádicas, registradas nas estatísticas de pesca nacionais. Com efeito, os desembarques controlados de pescado nos Estados de Santa Catarina e Rio Grande do Sul, efetuados pelos Centros de Pesquisa do IBAMA nesses Estados - respectivamente CEPSUL (Itajaí/SC) e CEPERG (Rio Grande/RS) apontam capturas não superiores a 454 toneladas, enquanto o volume de pescado importado do Uruguai e Argentina é da ordem de 12 mil toneladas, evidenciando o caráter eventual das capturas em águas nacionais”.
} 
o leite fluido, pasteurizado ou não, esterilizado ou reidratado, sem que estenda o benefício ao leite importado do Uruguai ou vindo de outra unidade da federação. Por conta do verbete $\mathrm{n}^{\mathrm{o}} 71$ da Súmula de Jurisprudência do STJ, combinada com o art. $7^{\circ}$, do Decreto $\mathrm{n}^{\circ}$ 350/91, o Tratado de Assunção, os acórdão estenderam o mesmo benefício fiscal ao leite importado do Uruguai e comercializado naquela unidade da federação.

Comentando o caso, Maurício Barros (2006, p. 679) entende que tais decisões criam uma distorção no tratamento entre os produtos gaúchos e os oriundos de outros estados, embora assegure a não-discriminação com os produtos uruguaios ou outros estrangeiros, o que infringiria o princípio constitucional da livre concorrência. Não é por outro motivo que, quanto à mesma questão, o REsp n696.713/RS entendeu de forma radicalmente diversa, afirmando que não "se pode interpretar o GATT de maneira a conferir ao produto importado tratamento mais vantajoso do que o dispensado ao nacional", já que os "produtos que compõem a cesta básica do Rio Grande do Sul só gozam de redução da base de cálculo nos limites do Estado". Assim, não "havendo previsão do benefício para as operações interestaduais, não cabe estendê-lo às importações".

Como se vê, o direito brasileiro ainda tem que evoluir muito para realmente alcançar a maturidade científica das formulações jurídicas apresentadas na experiência internacional. Mas assim não deveria ser, já que, de há muito, desde 1951, quando da primeira edição das suas "Limitações Constitucionais ao Poder de Tributar", Aliomar Baleeiro já havia reunido $(1997$, p. 372 - 373) as regras referentes: i) "à uniformidade dos tributos federais em todo o território nacional, excluídas distinções ou preferências em relação a qualquer Estado em detrimento de outro" (art. 20, I da Constituição da República de 1967; atualmente art. 151, I $\mathrm{I}^{717}$ da Constituição de 1988); ii) à "vedação de discriminações tributárias de Estado, Distrito Federal e Municípios em razão de procedência ou destino, entre bens de qualquer natureza" (art. 20, III do diploma constitucional anterior; atual atualmente art. $152^{718}$ ); iii) à "uniformidade do Imposto sobre Operações de Circulação de Mercadorias quanto à espécie, procedência ou destino" (art. 20, III) e "quanto à alíquota" (art. 22, § 50); iv) à "vedação de tributos interestaduais ou

\footnotetext{
717 “Art. 151. É vedado à União:

I - instituir tributo que não seja uniforme em todo o território nacional ou que implique distinção ou preferência em relação a Estado, ao Distrito Federal ou a Município, em detrimento de outro, admitida a concessão de incentivos fiscais destinados a promover o equilíbrio do desenvolvimento sócio-econômico entre as diferentes regiões do País";

718 “Art. 152. É vedado aos Estados, ao Distrito Federal e aos Municípios estabelecer diferença tributária entre bens e serviços, de qualquer natureza, em razão de sua procedência ou destino".
} 
intermunicipais sobre o tráfego de pessoas ou mercadorias" (art. 19, II, revogado; atual art. $150, \mathrm{~V}^{719}$ ); em um só contexto jurídico, de índole econômica, como Princípios vinculados à Unidade Econômica do País. Atualizando a obra, após a morte do autor, Misabel Abreu Machado Derzi adaptou a terceira regra, por se tratar de norma que assegura a integração do mercado interno e a adoção do princípio da origem, com suas atenuantes, nas operações interestaduais sujeitas ao ICMS, para considerá-la como sendo a norma constitucional do art. $155, \S 2^{\mathrm{o}}, \mathrm{I}^{720}$.

Para Baleeiro, o território, mais do que o local onde se projeta a unidade política do país, deve representar um todo econômico. A necessidade de que todo o país constitua um único mercado interno comum, no seu entender, é mais importante do que a homogeneidade cultural, lingüística, religiosa ou de costumes, como imposição para a manutenção da unidade nacional. Baleeiro defende que essa consciência é requisito para o desenvolvimento do país. Essa necessidade, de segurança na unidade econômica nacional, tem como um dos meios mais eficientes para miná-la, no seu entender, a existência de exações ao comércio interestadual que ignorem esse sentido de unidade. Assim, as discriminações dos tributos deverão se limitar a critérios pessoais, reais ou de valor, mas jamais de local.

Quanto à uniformidade geográfica dos tributos federais, menciona que a "regra é velha, de 1891, e tem ascendência americana" (p. 373). È inovador em prever a inconstitucionalidade das normas discriminatórias não só diretas como também indiretas, tanto ostensivas quanto dissimuladas. Ilustra seu entendimento com as "tarifas especiais", experimentadas durante o regime imperial, nas então Províncias do Rio Grande do Sul e Mato Grosso, sob o pretexto de funcionarem como antídotos do contrabando nas fronteiras. Aliomar Baleeiro defende a atitude de Rui Barbosa, no governo provisório, em 1890, que

\footnotetext{
719 “Art. 150. Sem prejuízo de outras garantias asseguradas ao contribuinte, é vedado à União, aos Estados, ao Distrito Federal e aos Municípios:

(...)

V - estabelecer limitações ao tráfego de pessoas ou bens, por meio de tributos interestaduais ou intermunicipais, ressalvada a cobrança de pedágio pela utilização de vias conservadas pelo Poder Público;"

720 "Art. 155. Compete aos Estados e ao Distrito Federal instituir impostos sobre: (Redação dada pela Emenda Constitucional n 3, de 1993)

(...);

II - operações relativas à circulação de mercadorias e sobre prestações de serviços de transporte interestadual e intermunicipal e de comunicação, ainda que as operações e as prestações se iniciem no exterior;(Redação dada pela Emenda Constitucional n ${ }^{\circ}$, de 1993)

$(\ldots)$;

$\S 2 .^{\circ} \mathrm{O}$ imposto previsto no inciso II atenderá ao seguinte: (Redação dada pela Emenda Constitucional no 3 , de 1993)

I - será não-cumulativo, compensando-se o que for devido em cada operação relativa à circulação de mercadorias ou prestação de serviços com o montante cobrado nas anteriores pelo mesmo ou outro Estado ou pelo Distrito Federal;"
} 
as extinguiu, entendendo-as não eficazes e ilegais. Ressalva, no entanto, a possibilidade de isenções ou reduções tributárias em casos de calamidade pública.

Comentando a obra, Misabel Derzi insere no tema a disciplina da Lei $n^{\circ}$ 8.393/91, que trouxe alíquotas máximas do ICMS para as saídas tributadas de açúcar e a cana de açúcar (18\%), porém diferenciando nas ressalvas para os produtores na área de atuação da Sudene, Sudam (isenção), e os estados do Rio de Janeiro e Espírito Santo (9\%). A partir daí, elabora um aprofundado estudo sobre os limites constitucionais da extrafiscalidade e dos incentivos fiscais regionais.

Infelizmente, em um panorama atual em que há tantos problemas na tributação indireta brasileira, e aqui não se está abordando apenas as incidências dos ajustes fiscais de fronteira na importação, mas dos conflitos em geral que diuturnamente afloram, no que se refere às operações interestaduais, fruto da particularidade brasileira de possuir um tributo do tipo IVA em nível regional, essa visão ligada à eficiência econômica deveria ser mais considerada na jurisprudência brasileira. É o caso de conflitos relacionados à "guerra fiscal", como, por exemplo, o caso da ADI no 2548-1/PR; da ADI no 2021-8/SP e da ADI $\mathrm{n}^{\circ}$ 2352-7/ES, entre outras; ou à glosa de créditos beneficiados de outro estado, como as AADDII $n^{\circ}$ 2377-2/MG e $n^{\circ} 3389-1 / R J$, entre outras, muitas vezes julgados mais em função da irregularidade formal na instituição desses benefícios e penalidades unilaterais do que nos seus efeitos materiais - basicamente em função das disposições da Lei Complementar $n^{\circ} 24$, de 7 de janeiro de 1975.

Curioso é que Jesús Santa-Bárbara Rupérez (2001, p. 57 - 73) faz um extenso estudo de Direito Comparado acerca do nível de proteção, nos respectivos direitos internos, do comércio de bens contra eventuais normas tributárias discriminatórias em diversos países do mundo. Exibe um espectro de tratamentos próprios ao tema, desde países que seguem por sistema condutas sistematicamente fiscalmente discriminatórias, como Kuwait, Arábia Saudita, Emiratos Árabes Unidos e Omã; passando por países cujos ordenamentos jurídicos não fazem menção alguma à matéria, como Dinamarca, Reino Unido - entre eles os que têm se negado a celebrar tratados com semelhantes cláusulas, especialmente na tributação direta, como Austrália, Canadá e Nova Zelândia; os que possuem a disciplina apenas em normas ordinárias, como o Peru; os que possuem apenas a disciplina constitucional genérica de igualdade, mesmo assim limitada aos nacionais, como França, Finlândia, Bélgica e Luxemburgo; aqueles na mesma situação, mas que estendem a garantia aos não nacionais, como Coreia, Espanha e Itália; e os mais avançados, em que o teto constitucional expressa a vedação à não discriminação tributária e a manifestamente 
estende aos nacionais. Nesse último e evoluído grupo de países estão os Estados Unidos de México, a República Argentina e, em posição de destaque, a República Federativa do Brasil. 


\section{PARA UMA DENSIFICAÇÃO SEMÂNTICA DO PRINCÍPIO DE NÃO-DISCRIMINAÇÃO TRIBUTÁRIA.}

\subsection{Dos Conceitos Jurídicos Indeterminados e a Jurisprudência.}

Em resumo, como se viu nos itens anteriores, o OSC da OMC, em 1996, quando do julgamento do caso “Japão - Bebidas Alcoólicas II”, traçou as linhas definitivas de interpretação do Artigo III do GATT.

Se o caso com que se está deparando trata de discriminação explícita (ou "de jure" ou de tributação discriminatória), há que se aplicar a subsunção do fato à norma da primeira frase do segundo parágrafo do artigo III do GATT, situação em que se requer apenas o exame de dois aspectos: i) se o produto importado e o produto nacional seriam similares e ii) se os impostos ou outros tributos internos aplicados ao produto importado seriam "superiores" aos incidentes sobre o nacional.

No caso em que estamos tratando da discriminação implícita (ou "de facto" ou de tributação protetiva), haveria três questões a serem enfrentadas no exame da adequação de um tributo à segunda frase do parágrafo segundo do artigo III: i) se os produtos importados e os produtos nacionais são diretamente competidores ou possam ser substitutos diretos; ii) se o produto importado diretamente competidor ou substituível pelo nacional não é tributado igualmente ao local e iii) se a tributação desigual não está sendo aplicada a produtos importados ou nacionais diretamente competidores ou substituíveis "de modo a proteger a produção nacional".

Examinando essa formulação do OSC, ora já pacificada, Mattia Melloni (2005, p. 10) expressa o seu ponto de vista de que o tratamento nacional previsto no GATT possui duas grandes estruturas ${ }^{721}$ em seu bojo, representadas pelas questões ${ }^{722}$ da similaridade ${ }^{723}$ e da proteção ${ }^{724}$.

Porém, como vimos logo acima, como o conceito de produtos similares é apenas relevante para a primeira frase do parágrafo 2, na existência de discriminação explícita, sendo que, para a segunda frase, na avaliação da discriminação implícita, o que

\footnotetext{
721 "Features", no original em inglês.

722 "Assessments", no original em inglês.

723 "Likeliness", no original em inglês.

724 "Protection", no original em inglês.
} 
se deve perquirir é a existência de produtos diretamente substitutos ou competidores (segundo a nota interpretativa ao parágrafo 2), melhor é mencionar, como o faz Won-Mog Choi (2003, p. xix), que a primeira questão refere-se à similaridade/substitutabilidade ${ }^{725}$.

Quanto à outra estrutura, referente à proteção, vem determinada pela locução, em português, “de modo a proteger a produção nacional" do parágrafo 1 do Artigo III do GATT, correspondente ao SATAP em inglês.

Como já visto, o Órgão de Apelação da OMC, no caso "Japão - Bebidas Alcoólicas II", declarou que apenas ter havido remissão ao parágrafo 1, que contém tais termos, por meio da Nota Adicional ao Parágrafo 2, não significa que a aplicação protetiva (no dizer do Órgão de Apelação, e que se quer aqui entender como sendo o efeito protetivo enunciado inicialmente por Bela Balassa, como se verá) não se aplica à primeira sentença. Ao contrário, deve ser entendido que sim, a omissão da referência expressa deve encerrar um sentido, mas não esse.

O entendimento do Órgão de Apelação deu-se no sentido de que a primeira sentença do parágrafo segundo Artigo III é corolário direto dos princípios gerais do parágrafo primeiro. Assim, verificado que os bens são similares, que a tributação incidente sobre o bem estrangeiro é superior à do bem estrangeiro, estabeleceu o Órgão de Apelação que se entende haver nos casos de tributação discriminatória prima facie uma violação ao Acordo Geral que, nos termos do Artigo 3.8 do Entendimento sobre XXX (DSU), possui presumidamente o efeito de anular ou prejudicar os benefícios, nos termos do Artigo XXIII do GATT.

Vale dizer, em resumo, tanto para a experiência europeia quanto para a multilateral, alcançada a verificação da existência de discriminação explícita ou "de jure", opera-se uma presunção juris et de jure, absoluta, sem possibilidade de demonstração em contrário, de efeito protetivo da norma. Por isso a desnecessidade de sua verificação concretamente. Não se trata, portanto, de sua inaplicabilidade aos casos colidentes com a primeira sentença, mas sim a desnecessidade de sua verificação nos casos em exame quando do momento de sua aferição pelo órgão julgado, o OSC ou o TJCE.

$\mathrm{Na}$ experiência europeia, a disciplina relativa à não-discriminação tributária explícita, no âmbito comunitário, vem trazida pela primeira frase do art. $90^{\circ}$ do Tratado que institui a Comunidade Europeia (Tratado de Maastricht, na numeração conferida pelo Tratado de Amsterdam), que corresponde, atualmente, a partir de $1^{\circ}$ de dezembro de 2009 ,

725 “Likeliness/Substitutability”, no original em inglês. 
com o advento do Tratado de Lisboa, ao art. $110^{\circ}$ do Tratado sobre o Funcionamento da União Europeia. No campo da discriminação aberta, dois seriam os nortes hermenêuticos a serem perseguidos em relação aos conceitos jurídicos indeterminados presentes no texto legal.

Primeiramente, em relação ao conceito de imposições internas "superiores", deveria se empreender a comparação entre as cargas fiscais incidentes sobre cada um dos produtos sendo comparados. Dentro do conceito de carga tributária, não é apenas relevante o valor da alíquota, como também a forma com que se processa a exigência e se aplica a norma tributária.

O segundo é o conceito jurídico de produtos "similares", para o qual o entendimento jurisprudencial remansoso determina que não se poderia ficar preso às características físicas, mas sim aos produtos que, aos olhos dos consumidores, possuíssem propriedades análogas ou que satisfizessem às suas mesmas necessidades, de acordo com sua utilização no mercado.

A disciplina relativa à não-discriminação tributária explícita, aquela que é vazada em normas aparentemente neutras consoante a origem, no âmbito comunitário, vem trazida pela segunda frase do art. $90^{\circ}$ do Tratado que institui a Comunidade Europeia atualmente, art. $110^{\circ}$ do Tratado sobre o Funcionamento da União Europeia.

Nesse exame, há três passos a serem percorridos pelo julgador: a determinação da "relação de concorrência" entre os produtos sob exame (ORTINO, 2004, p. 278); verificarmos a existência de um "tratamento diferenciado" determinado pela norma tributária submetida à análise de seu caráter discriminatório e a identificação do "efeito protetivo" da norma tributária (ORTINO, 2004, p. 284); esses dois últimos conceitos podendo ser definidos em conjunto como os efeitos concretos da medida em si na produção doméstica e no consumo dos produtos importados.

Vimos então que extensa foi a atuação jurisprudencial, especialmente nos anos oitenta, com vistas a aclarar o significado de conceitos jurídicos indeterminados como "imposição interna", "imposição discriminatória", "imposição protetiva", "imposições superiores", "produtos similares", "produtos em relação de concorrência", "tratamento diferenciado" e "efeito protetivo", com vistas a, em última análise, realizar concretamente a harmonização tributária europeia, no seu sentido negativo.

No sistema americano, a análise do escopo do poder federal legislativo de tributar, em função da apreciação e da abordagem empreendidas no julgamento do caso United States v. Butler, concluiu que Cláusula 1 do Parágrafo 8 do Artigo I da constituição 
dos Estados Unidos da América, que confere o poder de tributar e de despender, possui o objetivo maior de assegurar o "bem-estar da nação" e desde que sejam as incidências uniformes em todo o território nacional.

Mas qual a natureza jurídica dessas questões subjacentes ao emprego de semelhantes termos? Quais ferramentas possui o Direito para solvê-las?

Karl Engisch, em obra clássica do Direito (2008), escrita em sua primeira versão em 1956, nos ensina que o operador do Direito, em seu mister diuturno de realizar a subsunção, a aplicação do fato concreto à norma abstrata, defronta-se com ambivalências, basicamente decorrentes da diversidade dos métodos de interpretação e da pluralidade de sentido dos conceitos objeto de interpretação (p. 205).

Comenta que, na época do Iluminismo, assentou-se a ideia de que deveria ser possível estabelecer clareza e segurança jurídicas absolutas por meio de normas rigorosamente elaboradas, com o fim de garantir uma absoluta univocidade a todas as decisões judiciais e a todos os atos administrativos. A origem dessa formulação teórica era a desconfiança com que os teóricos da época viam os juízes, por conta da justiça de arbítrio e de gabinete, presa aos interesses dos detentores do poder e da terra, sem se preocupar com a fundamentação de suas decisões, que havia predominado no período logo anterior (“Ancien Régime”), aliada ao espírito racionalista, que entendia que ao homem era possível criar leis perfeitas e infalíveis. Mencionando Bockelmann, entendia-se então que o juiz deveria ser o "escravo da lei" (p. 206), ao qual se impôs a insustentável proibição de interpretar a lei, nem sequer para a permitir a apreciação da individualização da pena privativa de liberdade no Direito Penal (sistema das "peines fixes" do Code Pénal francês de 1791).

Porém, no curso do Século XIX, à medida em que os tribunais foram se libertando do poder dos senhores da terra e passaram a autonomizar-se como verdadeiras autoridades jurisdicionais independentes, com objetividade e sentido de justiça próprios, a eles conferiu-se a liberdade necessária a que pudessem decidir da maneira que fosse a mais conveniente para dominar a vida na pluralidade de suas formas e na sua imprevisibilidade típicas.

Chegou-se a um ponto, dentro dessa evolução histórica, em que as leis, em todos os campos do Direito, são elaboradas de tal forma a que os juízes e funcionários da administração não precisem alcançar e fundamentar as suas decisões apenas por meio da subsunção a conceitos jurídicos fixos, cujo conteúdo seja explicitado com segurança por meios objetivos de interpretação. Pelo contrário, são frequentemente chamados a valorar 
autonomamente as normas postas e, por vezes, a agir e a decidir de um modo semelhante ao do legislador (p. 207).

Nessa perspectiva, a própria técnica legislativa tem adotado a sistemática de afrouxar o vínculo que prende os tribunais e os órgãos administrativos às leis, conferindolhes maior autonomia. Um desses modos de expressão legislativa são os conceitos jurídicos indeterminados (unbestimmte Rechtsbegriffe), modalidade à qual os conceitos de similaridade ou substitutabilidade e de efeito protetivo estão perfeitamente adequados.

Para Engisch (2008, p. 208), por conceito indeterminado deve se entender um conceito cujo conteúdo e extensão são em larga escala incertos. Nessas hipóteses, segundo Garcia de Enterría e Fernández (1990, p. 393), a lei se refere a uma esfera de realidade cujos limites não aparecem bem precisados no seu enunciado, uma vez que não admitem uma quantificação ou determinação rigorosas.

Diferenciam-se dos conceitos jurídicos determinados, que se caracterizam por delimitar o seu âmbito de realidade de uma maneira precisa e inequívoca (ENTERRÍA; FERNÁNDEZ, 1990, p. 393). É o caso da determinação da maioridade cível aos dezoito anos (e não, hipoteticamente, quando o jovem puder ter consciência das consequências dos seus atos da vida civil, como poderia o legislador ter optado por estabelecer) ou da imposição compulsória da aposentadoria ao servidor público aos setenta anos de idade (e não apenas quando o servidor não puder mais exercer convenientemente as suas atividades profissionais por senilidade, por exemplo).

Como aborda José Carlos Barbosa Moreira (1988, p. 64), o legislador, sem querer se preocupar em definir todas as noções de que se serve, nem tampouco se esforçando em empregar apenas palavras e expressões de cunho tecnico-juridico, tem a expectativa de ser entendido na medida em que confia na existência de um acervo de conhecimentos comum à generalidade das pessoas que terão que lidar com as normas.

António Menezes Cordeiro (2007, p. 1176 - 1177), referindo a Gomes Canotilho, entende que a indeterminação conceitual ocorre sempre que não haja comunicação clara quanto ao conteúdo do conceito, por polissemia (existência de vários sentidos possíveis), vaguidade (largueza de extensão e escassez de compreensão da informação), ambiguidade (possibilidade de referência a mais de elemento integrante da proposição na qual o conceito se insere), porosidade (necessidade de evolução semântica do sentido do termo) ou esvaziamento (ausência de sentido útil).

No momento de aplicação, tais lacunas do conceito são preenchidas pelo jurista (BARBOSA MOREIRA, 1988, p. 64), mediante valorações, de modo a que ele obtenha a 
regra do caso concreto (CORDEIRO, 2007, p. 1178). Referem-se a hipóteses da realidade que necessitam da determinação do conceito no momento de sua aplicação (ENTERRÍA; FERNÁNDEZ, 1990, p. 393), pelo que não há que se falar em indeterminação das aplicações do conceito. Por esses motivos, Cordeiro (2007, p. 1178) afirma que os conceitos indeterminados dizem-se carecidos de preenchimento ou de valoração. Ou, nas palavras de Barbosa Moreira (1988, p. 66), a liberdade de aplicador se exaure no momento da fixação da premissa, no momento em que afere a coincidência ou a não-coincidência entre o acontecimento real e o modelo normativo, após o qual a solução estará predeterminada pela lei.

Esse processo de determinação do conceito no momento de sua aplicação pode ser empreendido por meio do emprego de regras de experiência (no caso do cuidado não negligente com o animal ou da força irresistível a justificar a auto-tutela da posse) ou de valor (situações como a da boa-fé, na interpretação das cláusulas contratuais, ou o justo título a conferir o direito ao usucapião ordinário) (ENTERRÍA; FERNÁNDEZ, 1990, p. 393). Nada impede, não obstante, que tais regras de experiência sejam enriquecidas por informações hauridas de conhecimentos técnicos específicos (como no caso da incapacidade absoluta para o exercício das funções, no Direito Previdenciário, que demanda prova pericial em Medicina do Trabalho, ou na manifesta necessidade de reparos na obra que entrou em ruína, no Direito Civil, que, via de regra, implica a realização de laudo técnico de Engenharia Civil). Ou, talvez, de conceitos vindos da Teoria do Comércio Internacional.

O conceito jurídico indeterminado pode vir previsto na norma jurídica tanto na sua hipótese de incidência (no antecedente, previsão abstrata de fato ou ato jurídico), o que é a situação mais comum, quanto na determinação ou estatuição legal, nas palavras de Karl Engisch, ou o consequente da norma. É o caso do §231 do Código de Processo Penal alemão, que prevê que o juiz pode impor ao acusado "medidas apropriadas" para evitar que ele se evada da jurisdição (2008, p. 210).

$\mathrm{O}$ conceito jurídico indeterminado pode reportar-se a realidades fáticas (ou descritivas) ou normativas (CORDEIRO, 2007, p. 1179 e ENGISCH, 2008, p. 210 - 211). Comentando o tema, Karl Engisch vislumbra que não há propriamente valoração no caso da aplicação dos conceitos jurídicos descritivos, aqueles que designam objetos reais ou que de certa forma participam de realidade, como os conceitos de nascimento ou de morte, o que os diferenciaria, para ele, dos conceitos normativos (como os de mulher honesta ou de 
atos libidinosos), uma vez que ambos são elementos constitutivos de normas jurídicas - por isso ambos são jurídicos -, mas apenas referência a valores (2008, p. 211 - 212).

Cordeiro (2207, p. 1179) discorda dessa afirmação e defende que qualquer conceito jurídico indeterminado não prescinde da mediação constituinte do intérpreteaplicador - portanto, necessariamente com a relevância da subjetividade humana. Para o civilista português, a diferença repousa na natureza da linguagem empregada: comum no caso dos conceitos indeterminados descritivos; técnico-juridica no caso dos conceitos indeterminados normativos.

Em verdade, o que os diferencia é aspecto meramente tangenciado por António Cordeiro (p. 1179): a amplitude do labor valorativo exigido do intérprete-aplicador da norma, necessariamente maior no caso dos conceitos jurídicos indeterminados de cunho normativo. A diferença, portanto, não é de natureza, mas de grau.

Os conceitos jurídicos indeterminados de natureza valorativa são, dado o alto grau de valoração que exigem do seu aplicador, muito permeáveis a mudanças nas tradições morais e juízos de valor ao longo dos tempos. Como afirma Karl Engisch (2008, p. 239), o órgão aplicador do Direito, Poder Judiciário ou Administração Pública, tem de averiguar quais são as concepções éticas efetivamente vigentes no meio social, e não apenas a sua, particular. Por isso, fala em valorações objetivas (p. 236). Com isso, os conceitos normativos, objetivos, possuem uma característica que foge aos normativos: por meio das valorações a que remetem, podem adaptar-se elasticamente à configuração particular ás circunstâncias do caso concreto e a qualquer mudança das concepções valorativas da época ou do lugar onde será aplicado (p. 240).

Aprofundando o exame do grau necessário à valoração desse tipo de conceitos jurídicos, tem-se que na estrutura do conceito indeterminado se pode identificar um núcleo fixo (Begriffkern), ou zona de certeza, configurada por contornos prévios e seguros; uma zona intermédia ou de incerteza, o halo do conceito (Begriffhof), parcialmente imprecisa; e uma zona de certeza negativa, clara quanto à exclusão do conceito (ENTERRÍA; FERNÁNDEZ, 1990, p. 396). Corresponde à situação do halo conceitual a atribuição de uma margem de apreciação (Beurteilungsspielraum) à Administração e ao Judiciário, mas dentro de um âmbito puramente cognoscitivo e interpretativo da lei, diante do reconhecimento da dificuldade na aproximação à forma totalmente exata da solução justa (ENTERRÍA; FERNÁNDEZ, 1990, p. 396 - 397).

Tais formulações teóricas, produto da nossa tradição jurídica romanogermânica, possuem plena consonância com a imagem, produzida pelo OSC da OMC, 
mais especificamente seu Órgão de Apelação, no caso “Japão - Bebidas Alcoólicas II”, na sua principiologia baseada na Common Law (CHOI, 2003, p. xxi), de que o conceito de similaridade, ao longo de todo o Acordo Geral, é relativo e evoca a imagem de um acordeão ${ }^{726}$. Possui como que um fole, que deve ser estendido ou estreitado de acordo com a melhor interpretação consentânea com o caso concreto e com a norma do GATT em exame. Assim é que Órgão de Apelação, como já mencionado, entendeu que o fole do acordeão chamado similaridade deve estar apertado quando do exame da adequação à primeira sentença do Artigo III:2 (verificação da similaridade propriamente dita) e bem mais distendido no caso da segunda sentença (identificação da ocorrência da substitutabilidade).

O GATT, desde a sua fase anterior à OMC, com a edição do Relatório do Grupo de Trabalho sobre Ajustes Fiscais de Fronteira, o que foi corroborado pelos julgamentos posteriores a $1^{\circ}$ de janeiro de 1995, dadas as seguidas referências a esse trabalho nas fundamentações de diversos casos, tanto nos Grupos Especiais quanto pelo Órgão de Apelação, apontou que o critério para permitir se estender ou contrair o acordeão se baseia em conceitos microeconômicos, com base na preferência dos consumidores.

No caso absolutamente paradigmático, já na fase da OMC, “Japão - Bebidas Alcoólicas II", como já se mencionou, determinou-se que o julgador arbitral tem que olhar não para características físicas ou a classificação fiscal das mercadorias, mas para o mercado, pois, afinal de contas, o GATT 1994 é um acordo comercial e a OMC está preocupada com os mercados, já que busca, como já mencionado, assegurar pleno acesso a mercados em condições de igualdade de competitividade a todas as Partes Contratantes.

Por outro lado, quanto ao outro conceito jurídico indeterminado presente na Cláusula do Tratamento Nacional do GATT, a questão da proteção, SATAP, o “de modo a proteger" ou melhor, do efeito protetivo da tributação interna, ainda é objeto de muitas discussões doutrinárias diante da obscuridade dos critérios adotados historicamente pelo OSC da OMC.

\footnotetext{
726 "No one approach to exercising judgement will be appropriate for all cases. The criteria in Border Tax Adjustments should be examined, but there can be no one precise and absolute definition of what is "like". The concept of "likeness" is a relative one that evokes the image of an accordion. The accordion of "likeness" stretches and squeezes in different places as different provisions of the WTO Agreement are applied. The width of the accordion in any one of those places must be determined by the particular provision in which the term "like" is encountered as well as by the context and the circumstances that prevail in any given case to which that provision may apply. We believe that, in Article III:2, first sentence of the GATT 1994, the accordion of "likeness" is meant to be narrowly squeezed" - WT/DS8/AB/R, WT/DS10/AB/R, WT/DS11/AB/R, item H.1.(a).
} 
Conceito semelhante, na experiência comunitária europeia, também é objeto de indefinição doutrinária e incerteza jurisprudencial, quanto ao exame do segundo parágrafo do anterior art. $90^{\circ}$, atual art. $110^{\circ}$.

$\mathrm{Na}$ Economia Internacional, por outro lado, tal conceito já foi bastante investigado. Tal se deve pioneiramente à obra de Bela Balassa, economista nascido na Hungria, então professor na Universidade Yale. Dedicou pelo menos oito artigos ou livros de sua autoria tratando do tema da proteção tarifária ${ }^{727}$, desde meados da década de 60 até o início da seguinte, inicialmente na perspectiva dos países industrializados. A sua primeira obra a respeito $^{728}$, publicada em dezembro de 1965, é ampla no exame dos pressupostos da análise quantitativa do que ele denomina efeitos restritivos dos ônus ${ }^{729}$ nos fluxos comerciais, embora tenha se proposto, nesse primeiro artigo, a empreender efetivamente cálculos apenas no que se refere às tarifas (incidências do imposto sobre importação, como já visto).

Para Balassa, em um ambiente de equilíbrio geral, o efeito restritivo de uma tarifa nacional pode ser aferido pela diferença entre o fluxo comercial efetivo, com a presença de sua incidência, e o que chama de fluxo comercial potencial, aquele que seria o real se o país em questão eliminasse a incidência tarifária, ceteris paribus fundamentalmente, dada uma taxa de câmbio fixada, independentemente dos efeitos na balança comercial, e supondo imodificadas as tarifas dos outros países com quem aquele em questão comercializa.

Embora qualquer majoração tarifária implique alteração nos padrões de produção e consumo a ponto tanto de reduzir não só as importações, pelo aumento dos preços ao consumidor com o consequente deslocamento na curva de demanda da quantidade demandada, como também as exportações, pela substituição da quantidade

\footnotetext{
727 "Tariff Protection in Industrial Countries: An Evaluation" (The Journal of Political Economy, vol. 73, $\mathrm{n}^{\circ}$ 6, dez. 1965); "The Impact of the Industrial Countries' Tariff Structure on Their Imports of Manufactures from Less-Developed Areas" (Economica, New Series, vol. 34, $\mathrm{n}^{\circ}$ 136, nov. 1967); "Tariff Protection in Industrial Nations and Its Effects on the Exports of Processed Goods from Developing Countries" (The Canadian Journal of Economics / Revue canadienne d'Economique, vol. 1, no 3, ago. 1968); "Growth Strategies in Semi-Industrial Countries" (The Quarterly Journal of Economics, vol. 84, issue 1, fev. 1970); "The Impact of the Industrial Countries' Tariff Structure on Their Imports of Manufactures from Less Developed Areas: A Reply" (Economica, New Series, vol. 37, $\mathrm{n}^{\circ}$ 147, ago. 1970); "Industrial Policies in Taiwan and Korea" (Weltwirtschaftliches Archiv. Berlin/Heidelberg: Springer. Vol. 106, $\mathrm{n}^{\circ}$ 1, março 1971, p. 55 - 77); "Trade Policies in Developing Countries" (The American Economic Review, vol. 61, no 2, mai. 1971); The Structure of Protection in Developing Countries, Baltimore: Johns Hopkins Press, 1971; "Effective Protection in Developing Countries", in J. BHAGWATI; R. W. JONES; R. A. MUNDELL; e J. VANEK (eds.): Trade, Balance of Payments, and Growth: Essays in Honor of Charles P. Kindleberger, Amsterdam: North-Holland Publishing Co., 1971, p. 300 - 323.

728 "Tariff Protection in Industrial Countries: An Evaluation". The Journal of Political Economy, vol. 73, no 6, dez. 1965 , p. $573-594$.

${ }^{729}$ Duties, no original em inglês.
} 
ofertada pelo produto estrangeiro pelo produzido pela indústria nacional dele competidora em detrimento da quantidade exportada (supondo-se economia em pleno emprego e sem capacidade ociosa), para o emprego analitico-quantitativo do conceito, deve-se, no seu entender, tomar-se apenas a diferença entre o efetivo e o potencial nível de importações.

Feita essa ressalva, Balassa (1965, p. 574) enuncia então o conceito basilar aplicável ao Direito Tributário, o de "efeito protetivo da tarifa",730, como sendo o aumento da produção doméstica das mercadorias protegidas por um aumento da imposição tributária na importação ${ }^{731}$. Com isso, apresenta conceito alternativo ao cálculo da tarifa média ponderada ou não-ponderada, critério usual de então, que já havia criticado em sua obra clássica sobre a teoria da integração econômica (1962, p. 45 - 46), inclusive mencionando casos em que tais cômputos logravam resultados flagrantemente enganosos, como é o caso da França.

Por que não entender possível a densificação semântica do conceito jurídico indeterminado, como o de "efeito protetivo" da norma tributária, a partir de considerações econômicas como a formulada por Bela Balassa?

Já vimos que a "Regra Geral de Interpretação" dos tratados, presente no Art. 31, parágrafo 1, da Convenção de Viena, dispõe que, além da boa fé, o tratado deve ser interpretado segundo o sentido comum atribuível aos seus termos, em seu contexto e à luz de seu objetivo e finalidade.

Como já foi reiteradamente afirmado pelo OSC da OMC e pelo TJUE, o objetivo e a finalidade tanto do GATT quanto dos tratados institutivos comunitários europeus são de naturezas predominantemente econômicas.

Exatamente por isso, os conceitos de produtos similares ou diretamente competidores ou substitutos diretos têm sido cada vez mais empregados no caso da OMC, até alcançar hoje uma posição já consolidada, em sua acepção econômica, de mercado, dentro de uma perspectiva do consumidor, o que a doutrina denomina "Market Based Approach" (BRONCKERS; McNELIS, 2000, p. 345 - 348), que corresponde à formulação, na jurisrpudência comunitária, da identificação da "relação de concorrência". A priori, portanto, nada haveria a impedir que semelhante abordagem fosse também aplicada ao SATAP ou ao efeito protetivo concebido pelo TJCE; antes o contrário.

\footnotetext{
${ }^{730}$ Protective effect of the tariff, no original em inglês.

731 "The decline in imports following the imposition of duties will generally be associated with a fall in the consumption and an increase in the domestic production of the porotected commodities; the latter is customarily referred to as the protective effect of the tariff'.
} 
Deve-se também reconhecer que a aplicação da análise econômica a abordagens jurídicas recebe no campo do Direito Internacional do Comércio um reconhecimento já tradicional e consagrado. Não é por outro motivo que Avery Wiener Katz (1996, p. 2229) distingue os campos da International Trade Law e da Tax Law do moderno objeto do estudo de Law and Economics, ao lado da regulação empresarial, matéria que abrangeria a proteção da concorrência, querendo reconhecer que tais campos seriam mais naturalmente aptos a admitir semelhantes considerações, diferentemente do Direito de Família ou do Direito Penal, por exemplo.

Não é de desconhecimento de ninguém a relevância, até no campo normativo, do emprego de formulações de modelos econômicos na área do Direito Antitruste, uma vez que conceitos jurídicos indeterminados desse ramo do Direito, como "mercado relevante" e "posição dominante", entre outros, são interpretados mediante pesquisa a estudos interdisciplinares com fulcro na Teoria Microeconômica. Em adendo, Robert Cooter e Thomas Ulen (2008, p. 1 - 2), listam entre as disciplinas tradicionais na análise econômica do Direito também o Direito Tributário, especificamente quanto a questões sobre a repercussão econômica dos tributos, matéria já referida anteriormente.

Não é por outro motivo que economistas especializados na Economia Internacional, como Jagdish Bhagwati (2002, p. V), reconhecem que os grandes luminares do Direito Internacional do Comércio, como Robert Hudec, John Howard Jackson e Kenneth Dam, eram conhecedores profundos da Teoria Econômica por detrás da disciplina convencional da área, notabilizando-se todos pelo manejo de forma criativa da interação entre a Economia e a disciplina legal.

$\mathrm{O}$ que poderia comprometer a validade de uma análise baseada em avaliações oriundas da Teoria Econômica é o fato de que existem, como bem salienta Avery Wiener Katz (1996, p. 2230), diferenças metodológicas e culturais. Trata-se de campos que usam diferentes retóricas, estilos de discurso diversos e articulam suas visões de mundo de maneiras assaz contraditórias. Assim, ocorre que nem os juristas nem tampouco os economistas abrem mão de suas idiossincrasias em proveito das do outro.

Se isso é verdade no campo do Direito como um todo, trata-se de realidade ainda mais agravada no campo do Direito Internacional Público em geral, não só do Direito Internacional do Comércio ou do Direito Comunitário, no qual a necessidade de atingimento do consenso entre os países celebrantes acarreta que as normas convencionais sejam vazadas em linguagem ampla, aberta, politicamente aceitável (CHOI, 2003, p. 2). 
Para confirmar tal afirmação, basta examinarmos os termos com que lavrado o GATT. Claramente, volta-se muito mais à composição momentânea de interesses do que ao compromisso de clareza com o fim de evitar potenciais conflitos futuros.

Assim, nesse particular campo do Direito, dadas as exigências diplomáticas típicas do seu ambiente legislativo, por assim dizer, ainda mais distante ficará a precisão terminológica e a busca da inequivocidade das expressões econômicas. Como bem menciona Won-Mog Choi (2003, p. 2), trata-se do necessário reconhecimento, por parte do intérprete, da dimensão política das normas internacionais, oriundas da luta do Direito Internacional Público em sobreviver em um meio-ambiente orientado para as relações de poder.

Assim, na correta interpretação do alcance de expressões como "imposição discriminatória", "imposição protetiva", "imposições superiores", "produtos similares", "produtos em relação de concorrência", "tratamento diferenciado", SATAP, "bem-estar da nação" e "efeito protetivo", todos típicos institutos do Direito Tributário Internacional, é plenamente válido o emprego de conceitos econômicos como os apresentados ou mesmo os utilizados na experiência jurisprudencial exaustivamente relacionada, contrariando a visão de Heleno Tôrres (2003, p. 213) de que não seria "metodologicamente correto interpretar textos jurídicos com critérios que só poderiam ser aplicados em domínios alheios ao sistema jurídico, o econômico". Não se trata do que modernamente se entende por Análise Econômica do Direito, estudo basicamente de cunho positivo ${ }^{732}$; tampouco e muito menos, de interpretação econômica do Direito.

\footnotetext{
732 Os economistas empregam o termo "positiva" para as análises econômicas que são descritivas e não normativas. Vale dizer, a análise econômica positiva se preocupa em levantar relações de causa e efeito, como "se a indústria doméstica não é competitiva, quotas de importação de produtos estrangeiros resultarão em preços ao consumidor interno maiores”. Em contraste, a análise econômica normativa envolve escolhas políticas entre alternativas. Na mesma situação, uma proposição normativa enunciaria "quotas de importação não são boas políticas comerciais, particularmente se a indústria doméstica não é competitiva" (HOVENKAMP, 1990, p. 816). O método positivista, na visão de Milton Friedman (1953, p. 3 - 4) é empiricista, de linha Popperiana: sua teoria é uma metodologia por meio da qual descreve-se um procedimento que se inicia com a formulação de uma hipótese a qual pode ser testada na sua confiabilidade por meio de tentativas de comprovar a falsidade de suas premissas pela observação empírica. Não se alcançando o falseamento da hipótese, ela é considerada robusta o suficiente para ser considerada verdadeira, até que um outro cientista a contradiga e o comprove. A particularidade da análise econômica positiva é que, mais do que a sua plausibilidade ou verossimilhança, o mais relevante é o seu poder preditivo a partir de um conjunto de generalizações. Na definição de Avery Wiener Katz (1996, p. 2238 - 2239), a Economia positiva procura explicar porque os atores econômicos se comportam da forma como o fazem e a predizer como agirão no futuro; a Economia positiva, por seu lado, denota o aspecto da disciplina que avalia os comportamentos e recomenda reformas de políticas. Ou, como resumido por John Neville Keynes (apud Friedman, 1953, p. 3), em seu "The Scope and Method of Political Economy", a ciência positiva é um corpo de conhecimento sistematizado referente ao que é ("what is"); a ciência normativa ou regulativa é um corpo de conhecimento sistematizado discutindo critérios do que deveria ser ("ought to be").
} 
Trata-se, na verdade, de mais um exemplo do "fluxo semântico" (TÔRRES, 2003, p. 77) de conceitos, agora vindos não do Direito Privado, mas de outro ramo do conhecimento, na elaboração de formulações de Direito Tributário, mediante transformação, incorporação ou recepção, na medida em que se vislumbra a sua funcionalidade da interpretação de matéria tributária nos tratados internacionais que versam a matéria, especialmente dada a característica, acima mencionada, que é a tônica das negociações convencionais na esfera alienígena. Plenamente válido o seu emprego e justificável, portanto, à luz da melhor doutrina.

\subsection{Da Não-discriminação Tributária como Neutralidade Fiscal.}

\subsubsection{Da (impossível) Neutralidade Fiscal Absoluta.}

Verificada a importância de estudos com base econômica no entendimento da ontologia do Princípio de Não-discriminação, nosso objetivo, no presente momento, dada a abordagem que a experiência internacional, tanto doutrinária, quanto jurisprudencial, quanto positiva, em que se faz reiterada menção a conceitos da ciência econômica, dedica ao assunto, necessário se faz pesquisarmos as lições principais do modelo microeconômico de equilíbrio de mercados.

Trata-se de uma abstração matemática do comportamento de mercados, e dos meios e modos com que neles se dá a produção e a alocação de recursos econômicos portanto, escassos. Faz parte da Teoria Microeconômica ou Teoria dos Preços, que se preocupa em estudar o comportamento econômico das unidades econômicas individuais, tais como consumidores, empresas e proprietários de recursos e do fluxo de bens e serviços entre esses agentes, inclusive a sua formação de preços.

Para sua compreensão, portanto, o primeiro passo consiste em alcançar a conceituação de mercado. Fundamentalmente, pode ser compreendido como o local onde se encontram os vendedores e compradores de determinados bens e serviços. Mas não é simplesmente um locus físico; mais do que isso, é um ambiente que se sujeita a uma série de regras, cujo modelo matemático aqui relatado a tenta descrever. 
Se houvesse a possibilidade de funcionamento do mercado em regime de concorrência absolutamente perfeita - aquele em que existem inúmeros compradores e vendedores, de tal forma que nenhum deles, agindo individualmente, consegue exercer influência significativa sobre os preços e quantidades praticados no mercado -, o grande e quase único determinante dos preços seria a interação entre a oferta e a demanda, o que geraria o preço de equilíbrio, comprovando a "mão invisível” descrita por Adam Smith.

A ideia da mão invisível repousa na certeza de que os agentes econômicos, ao procurarem o mercado para encontrar com quem negociar, agem egoisticamente nas suas tomadas de decisão: os produtores procurando elevar ao máximo os seus preços, para maximizarem seus lucros; os consumidores tentando adquirir os bens de que necessitam mediante o menor preço possível, para reduzir sua despesa com insumos.

No entanto, não impera a vontade dos produtores, à primeira vista com mais instrumentos de manipulação dos mercados.

Ao contrário, em situação de concorrência perfeita - e aqui não se abordará o comportamento dos mercados em regime de monopólio -, o preço de equilíbrio é determinado tanto pelos produtores quanto pelos consumidores, sendo aquele que ambos estariam dispostos a receber e aptos a pagar, respectivamente, nas aquisições de produtos. A forma como se chega a esse equilíbrio é o pilar central do modelo matemático microeconômico.

Não obstante o mercado de concorrência perfeita ser uma abstração, um "ideal" a ser perseguido, o estudo de uma modelagem o supondo é importante mesmo para que se entendam suas várias imperfeições, nas quais determinam-se relações de preços que não seguem o auto-equilíbrio, como os mercados da realidade fática à nossa volta.

A primeira função do modelo, observada do ponto de vista dos consumidores, é a Curva de Demanda. A demanda por determinado bem é dada pela quantidade de bens que os compradores desejam adquirir num determinado período de tempo em relação a um seu dado preço.

Importante ressaltar que a demanda, individualmente considerada, é uma aspiração, não a realização de um desejo. Expressa a vontade de adquirir um determinado bem, ainda que essa intenção não venha a se concretizar. Para isso, é necessário que o indivíduo tenha potencial para se transformar em consumidor - vale dizer, esteja capacitado a consumir. Ou melhor, tenha renda suficiente para concretizar seu desejo, ainda que a concreção efetiva não venha a se realizar. 
A demanda, representada pelo símbolo D na Curva de Demanda, não é a demanda individual de um consumidor específico, mas a soma ponderada das demandas individuais de todos os agentes que estejam atuando no mercado em questão. Também deve ficar claro que os valores que compõem a curva são os valores máximos - as quantidades máximas de um bem que se deseja adquirir para determinado preço.

A função matemática que a descreve deve, como se sabe, possuir o mesmo comportamento que os consumidores que demandam um determinado bem. Ora, o comprador, dado a sua limitada renda, vai adquirir maior quantidade de bens se o seu preço for menor. À medida em que o preço do bem for crescendo, os compradores vão deixar de consumir o bem e passar a adquirir bens substitutos. Esse comportamento reflete os dois principais efeitos que regem a curva de demanda: o efeito-substituição - o recurso dos consumidores em comprarem bens, cujos preços relativos tenham baixado em relação àqueles mais caros, que possam substituir sua necessidade de consumo; e o efeito-renda com o aumento de preço de um bem regularmente adquirido, o poder de compra total do consumidor é diminuído, pelo que sobrará menos renda para a aquisição de outros bens, tão ou mais importantes do que aquele.

Com isso, pode-se enunciar uma Lei Geral da Demanda nos seguintes termos: "a quantidade demandada de um bem ou serviço, em qualquer período de tempo, varia inversamente ao seu preço, pressupondo-se que tudo o mais que possa afetar a demanda especialmente a renda, o gosto e preferência do consumidor, o preço dos bens relacionados e as expectativas quanto à renda, preços e disponibilidades - permaneça o mesmo" (PASSOS e NOGAMI, 2003, p. 81).

Portanto, a Curva de Demanda possuirá um aspecto em que as grandezas preço (P) e quantidade $(\mathrm{Q})$ do bem são inversamente proporcionais, em função decrescente.

Para efeito simplificador, toma-se a situação conhecida como cœteris paribus supõe-se que todas as demais variáveis que influenciam a demanda (o preço dos bens relacionados; a renda do consumidor; os hábitos e gostos dos consumidores; a população do local; as condições de crédito; efeitos sazonais, entre outros) permaneçam com o mesmo valor, de modo que a variação da quantidade demandada seja atribuível exclusivamente à alteração no preço.

Passando para a modelagem do comportamento dos produtores, temos a Curva de Oferta. Representada por $\mathrm{S}$, denota a quantidade do bem $\mathrm{x}$, por unidade de tempo, que os vendedores desejam oferecer no mercado, para cada preço praticado. Para a sua construção valem as mesmas observações levantadas quanto à Curva de Demanda. 
Agora, quanto maior o preço, maior será a quantidade que os produtores desejarão oferecer no mercado, uma vez que vislumbram a possibilidade de maximizarem seu potencial de lucros. Dessa forma, a oferta do bem x é uma curva ascendente da esquerda para a direita, em que o preço e a quantidade ofertados são diretamente proporcionais entre si, em função direta.

Analogamente, a Lei Geral da Oferta pode ser versada nos seguintes termos: “a oferta de um produto ou serviço, em determinado período de tempo, varia na razão direta da variação de preços desse produto ou serviço, a partir de um nível de preços tal que seja suficiente para fazer face ao custo de produção do mesmo até o limite superior de pleno emprego dos fatores (de produção), quando se tornará constante, ainda que os preços em referência possam continuar oscilando, mantidas constantes as demais condições" (PASSOS e NOGAMI, 2003, p. 92).

Da mesma forma como se fez para a demanda, simplifica-se o modelo supondose que todas as demais variáveis que influenciam a oferta (o preço dos bens relacionados; o preço dos insumos utilizados na produção; a capacidade instalada da indústria no local; e a tecnologia necessária) permaneçam com o mesmo valor, de modo que a variação da quantidade ofertada seja atribuível exclusivamente à alteração no preço.

Levantando-se todas as curvas de oferta relativas a todos os produtores de um determinado local e todas as curvas de demanda concernentes a todos os consumidores propensos a consumir nas mesmas condições de tempo e espaço, teremos as Curvas de Oferta e de Demanda de um determinado mercado tomado como um todo.

Combinando-se essas duas curvas, pode-se verificar como as regras de mercado de Adam Smith são matematicamente modeladas e, em conseqüência, representadas por gráfico. Chama-se o ponto de intersecção entre as duas curvas de Ponto de Equilíbrio de mercado.

Maria Isabel Clímaco (1994, p. 73 - 74) esclarece que se define a grandeza "excedente do consumidor" como sendo "o montante de rendimento monetário que o consumidor estaria disposto a pagar para além do que realmente paga, e que garantisse o consumo do bem em causa", cujo montante é dado, na situação de equilíbrio, pela área entre a Curva de Demanda $\mathrm{D}$ e a linha horizontal $\mathrm{P}_{0}$, correspondente ao Preço de Equilíbrio.

Analogamente, o "excedente do produtor" é definido "como a receita obtida acima do nível considerado mínimo para continuar a produzir uma dada quantidade do bem" e é geometricamente medido pela área abaixo de $\mathrm{P}_{0}$ e acima da curva $\mathrm{S}$. 
Esses conceitos de excedente do produtor e do consumidor são importantes para se quantificar o custo de bem-estar que advém das imperfeições de mercado, notadamente a criação de um imposto indireto sobre a venda do bem, o que se examinará adiante, que não só distorce a informação dada pelo preço de mercado, como também provoca uma redução desses excedentes, que será parcialmente suportada por cada um dos agentes econômicos no mercado.

Em muitas situações a alteração do equilíbrio dos mercados ocorre tanto em função de uma flutuação na curva de oferta quanto na de demanda. Nesses casos, é necessário maior conhecimento das funções demanda e oferta para se avaliar o correto impacto no Ponto de Equilíbrio. O motivo é que, sem saber a inclinação das curvas, assim como o montante em que se deu sua translação, torna-se imprevisível antecipar se haverá aumento ou diminuição da quantidade e do preço no novo ponto de equilíbrio. Daí a necessidade de se aprofundar no estudo do comportamento dessas curvas, introduzindo os conceitos de elasticidade-preço da oferta e da demanda.

Visto como os mercados operam, a partir da compreensão de como funcionam a oferta e a demanda, deve-se agora indagar de que forma as respostas de mercado variam em função das características particulares dos diversos bens. Sim, porque, embora se conheça o comportamento genérico das curvas, se ascendentes ou descendentes, a avaliação mais precisa de suas inclinações ainda não foi estudada.

Para tanto, introduzem-se os conceitos de Elasticidade-preço da Demanda e da Oferta. Porém, por ser o segundo irrelevante ao estudo do impacto da tributação - pois, como se verá, a introdução de um imposto indireto sobre o bem acarreta alteração apenas na Curva de Oferta, pelo que é necessário apenas entendermos a resposta dessa alteração no mercado pelo estudo do comportamento da Curva de Demanda - aqui só veremos o conceito de Elasticidade-preço da Demanda.

A Elasticidade-preço da Demanda indica a sensibilidade da quantidade demandada de um bem em relação ao aumento de seu preço. Representa o que os consumidores estão dispostos a acatar nas mudanças no preço de um produto.

Para determinados produtos, uma pequena alteração no preço pode provocar alterações bastante acentuadas nas quantidades procuradas. Para outros, pode ocorrer exatamente o inverso: mesmo alterações muito acentuadas nos preços não são capazes de provocar grandes modificações nas quantidades procuradas. E há casos em que as variações preço-quantidade são rigorosamente proporcionais. 
Apura-se pelo quociente entre a variação proporcional na quantidade demandada e a variação proporcional no preço.

Entre os fatores que influenciam a Elasticidade-preço da Demanda podemos mencionar: a disponibilidade de bens substitutos para o produto considerado - muitos substitutos, maior elasticidade; a essencialidade do produto - maior essencialidade tende a produzir coeficientes de elasticidade baixos; o preço do produto em relação à renda dos consumidores - alta relevância no orçamento, alta elasticidade, baixa importância, por ter preços unitários irrisórios, baixa elasticidade; a periodicidade de aquisição - longo tempo de aquisição, baixa elasticidade; os hábitos dos consumidores - a rigidez de hábitos determina baixa elasticidade, como é o caso dos bens consumidos por vícios dos demandantes, como os cigarros.

Apresentado o modelo econômico de equilíbrio de mercados, cabe investigar agora de que forma a introdução de um imposto sobre o bem examinado alterará a situação de equilíbrio microeconômico. No entanto, antes de entrar no equilíbrio propriamente dito, é necessário examinar-se em que a introdução de impostos altera as Curvas de Demanda ou Oferta.

Já foi visto que a Curva de Demanda representa a aptidão dos consumidores de um determinado bem em consumirem-no. É intuitivo, portanto, de sua definição conceitual, que a incidência tributária sobre o bem não vai alterar a forma como o consumidor o encara dentro de suas escalas de preferência, ao menos não de forma direta.

Por outro lado, vimos que a Curva de Oferta tem como fator a variar sua posição o custo dos fatores de produção. Assim, a introdução de um imposto, do tipo indireto, sobre o bem, afetará a Curva de Oferta de modo a aumentar o preço de venda à disposição do público consumidor para cada quantidade ofertada.

O gráfico ilustra a situação. 


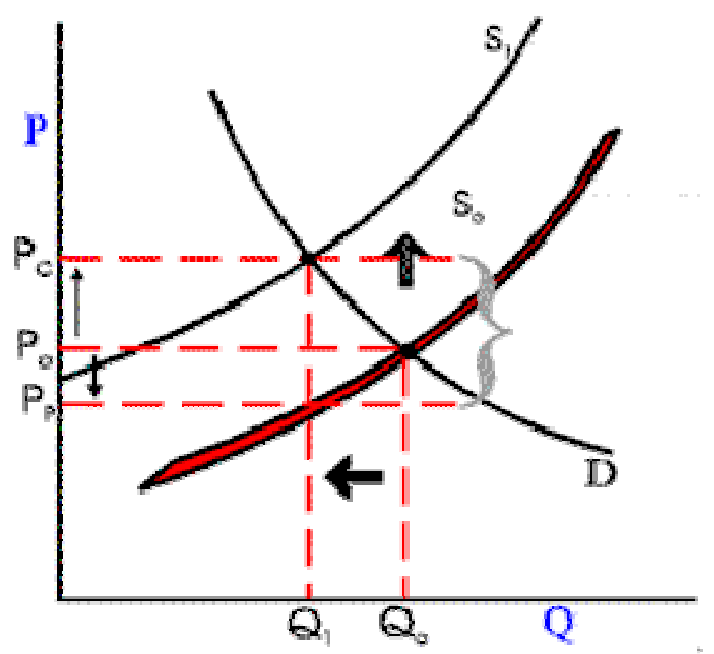

Antes da introdução da incidência tributária, tínhamos as curvas $\mathrm{D}$ e $\mathrm{S}_{0}$, representativas da oferta e da demanda iniciais. Após a tributação, passamos a ter a Curva de Oferta $\mathrm{S}_{1}$.

O montante de tributo incidente verifica-se pela diferença apontada pela chave, o segmento vertical correspondente à translação da curva para cima - preços maiores para quantidades idênticas. Importante ressaltar que o imposto indireto representado possui alíquota específica, já que não varia em função do preço de venda. Se a alíquota fosse ad valorem, a curva $S_{0}$ sofreria uma deflexão para cima ainda maior à medida em que se percorresse o eixo das quantidades.

Examinando-se o efeito do imposto no equilíbrio do mercado, vê-se que no novo ponto de equilíbrio $\left(\mathrm{P}_{\mathrm{c}}, \mathrm{Q}_{1}\right)$ a quantidade transacionada é menor do que a anterior $\mathrm{Q}_{0}$. Portanto, os produtores terão uma diminuição da quantidade vendida dos bens de sua produção, pelo que o valor que deverão recolher de imposto aos cofres públicos, $\left(\mathrm{P}_{\mathrm{c}}\right.$ $\left.\mathrm{P}_{\mathrm{p}}\right) \mathrm{Q}_{1}$, deverá sê-lo com parcela de ônus seu.

O motivo é justamente a redução da quantidade demandada após a introdução do imposto. Ocorre o chamado efeito-substituição - diante de um aumento de imposto seletivamente para determinado bem, o consumidor passa a adquirir bens similares para si. Exatamente porque a influência da tributação no equilíbrio de mercados atrela-se ao efeitosubstituição, tal análise só faz sentido em se tratando de incidências seletivas ou especiais, não em relação às gerais, como ensina Hyman (1999, p. 408).

Isso não quer dizer que a incidência indireta geral não comporte diminuição da quantidade demandada - e, por conseguinte, ônus parcial aos consumidores. É possível, 
simplesmente, a abstenção ao consumo, mesmo que não totalmente, ainda que sejam bens de primeira necessidade.

Daí se comprova, mais uma vez, que a definição de imposto indireto pelo critério da repercussão econômica é incorreto. Primeiro porque parcela do montante de tributo pago recai mesmo sobre os produtores. Ademais, como se verá, a distribuição quantitativa da repartição desse ônus depende da Elasticidade-preço da Demanda daquele bem. E, por fim, porque a existência e o montante da repercussão econômica do tributo indireto dependem de características de mercado que estão fora da consideração da presente análise, como, por exemplo, o grau de oligopolização e cartelização dos fabricantes.

Assim, havendo tantos fatores intrínsecos à natureza do bem e à organização dos mercados a influir na repercussão econômica sobre o consumidor final, esse não pode ser o critério para uma classificação jurídica de tributos em diretos ou indiretos, como já mencionado anteriormente e agora ratificado pela análise do modelo.

A distribuição do ônus econômico do tributo pelos agentes pode ser calculado também graficamente. Retomando os conceitos apresentados de excedentes do produtor e do consumidor, vê-se que passam agora a ser figurativamente representados, respectivamente, pela área acima da curva $S_{0}$ e abaixo da reta $P_{p}$ e a área acima da reta $P_{c}$ e abaixo da curva $S_{1}$.

Comparando-se os excedentes no equilíbrio anterior com os do equilíbrio posterior ao imposto, e excluindo-se o retângulo que denota a receita tributária, $\left(\mathrm{P}_{\mathrm{c}}-\mathrm{P}_{\mathrm{p}}\right) \mathrm{Q}_{1}$, correspondente à soma do tributo pago pelos produtores, $\left(\mathrm{P}_{0}-\mathrm{P}_{\mathrm{p}}\right) \mathrm{Q}_{1}$, e do pago pelos consumidores, $\left(\mathrm{P}_{\mathrm{c}}-\mathrm{P}_{0}\right) \mathrm{Q}_{1}$, verifica-se que há um triângulo a menor na nova situação de equilíbrio, de área equivalente a $(1 / 2)\left(\mathrm{P}_{\mathrm{c}}-\mathrm{P}_{\mathrm{p}}\right)\left(\mathrm{Q}_{0}-\mathrm{Q}_{1}\right)$.

Essa área triangular, denominada na Economia de Triângulo de Harberger (FRANCESCO FORTE, 1990, p. 35), equivale ao montante total de perda de eficiência econômica pela introdução do imposto indireto e é designada por excess burden, ou “encargo excedente” (CLÍMACO, 1994, p. 75).

Francesco Forte (2002, p. 243 - 247) ensina que a "taxação ótima", como aquela que minimiza os efeitos distorcivos alocativos inevitavelmente causados pela tributação, tanto no plano geral quanto no individual, implica, em se tratando de impostos sobre o consumo de bens incidentes sobre a produção, ou "indiretos", a redução máxima da área do Triângulo de Harberger. 
Dentro do encargo excedente há como, também, aquilatarem-se as parcelas de perda de bem-estar econômico a onerar cada um dos agentes econômicos. O subtriângulo abaixo de $\mathrm{P}_{0}$, cuja área é obtenível por $(1 / 2)\left(\mathrm{P}_{0}-\mathrm{P}_{\mathrm{p}}\right)\left(\mathrm{Q}_{0}-\mathrm{Q}_{1}\right)$, corresponde ao encargo dos produtores; aquele superior a $\mathrm{P}_{0}$, cuja área monta a $(1 / 2)\left(\mathrm{P}_{\mathrm{c}}-\mathrm{P}_{0}\right)\left(\mathrm{Q}_{0}-\mathrm{Q}_{1}\right)$, corresponde ao encargo dos consumidores (FRANCESCO FORTE, 1990, p. 37).

O comportamento do encargo excedente para bens com diferentes Elasticidades-preço da demanda, assim como a sua distribuição entre os produtores e os consumidores, é a chave para a compreensão do efeito da tributação sobre o mercado.

Tome-se a incidência de tributo indireto sobre um bem de alta Elasticidadepreço da demanda.

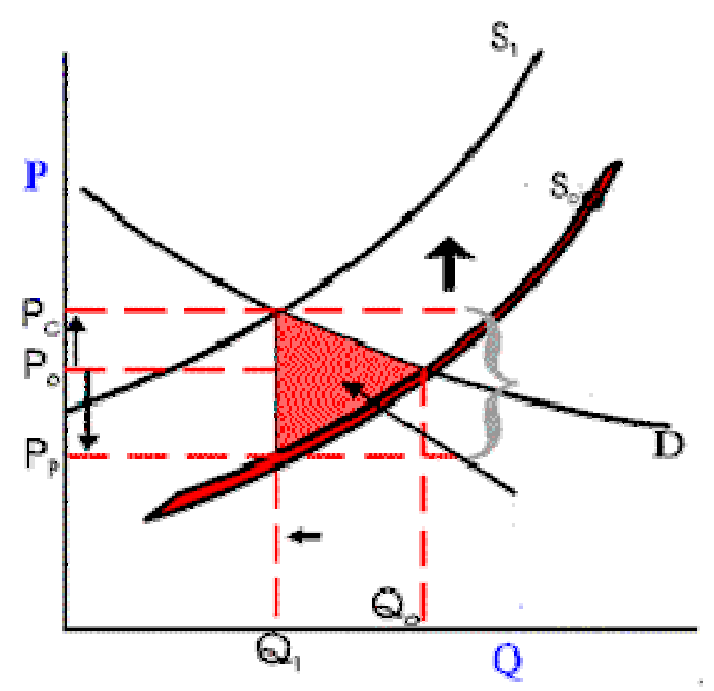

Observa-se que a quantidade demandada sofre redução considerável, de $\mathrm{Q}_{0}$ para $\mathrm{Q}_{1}$, com a introdução do tributo indireto, uma vez que, sendo um bem de alta Elasticidadepreço da demanda, a inclinação da curva $\mathrm{D}$ é pequena, pelo que os diferentes pontos de equilíbrio, de antes e de depois do tributo, ficam muitos distantes de si horizontalmente, embora não verticalmente. Vale dizer, como as quantidades demandadas diminuem muito, já que os consumidores seguramente procurarão bens substitutos (efeito-substituição) ou simplesmente deixarão de consumir o bem tributado, os produtores não poderão aumentar muito seus preços, sob pena de não conseguirem vender seus produtos.

Como se depreende do exame do gráfico, o encargo excedente é considerável e, como consequiência do afirmado no parágrafo anterior, substancial parcela dele recai sobre os produtores - como visto, a área de Triângulo de Harberger, preenchida, que está abaixo da linha correspondente ao preço $\mathrm{P}_{0}$. Apenas pequena parte dele incide sobre os consumidores. É, portanto, a situação em que mais se está distante da tributação ótima. 
Francesco Forte (2002, p. 302), entre outros teóricos das Finanças Públicas - ou Ciência das Finanças, como denominam os italianos -, defende que a tributação geral sobre as vendas a varejo, nos termos do "Retail Sales Tax" a que se refere a OCDE (1988, p. 68), é a modalidade ideal de tributação indireta, na medida em que mais se aproxima de uma autêntica tributação sobre o consumo - à exceção da sofisticada imposição imaginada por Nicholas Kaldor, sobre a renda consumida (Expenditure Tax), concebida em 1955 e mencionada, entre outros, por Musgrave (1969, p. 267) e Hyman (1999, p. 572 - 573). A própria OCDE a qualifica como superior, ponderando que adoção da incidência em estágios anteriores, especialmente em países menos desenvolvidos, só se justificaria pelos menores custos de administração e pela dificuldade da evasão, dado o menor universo contributivo subjetivo.

Nessa perspectiva, verificado que a repercussão econômica do ônus tributário ao consumidor, como contribuinte de fato, não é a regra - ao contrário, só se produz integralmente em se tratando de bens de Elasticidade-preço da Demanda nula - conclui-se que vai se estar cada vez mais distante da situação ótima de tributação quanto maior for o ônus imposto aos consumidores. Ou seja, quanto maior a Elasticidade-preço da Demanda do bem tributado.

A situação se inverte em sendo incidente o imposto indireto sobre bem de baixa Elasticidade-preço da Demanda:

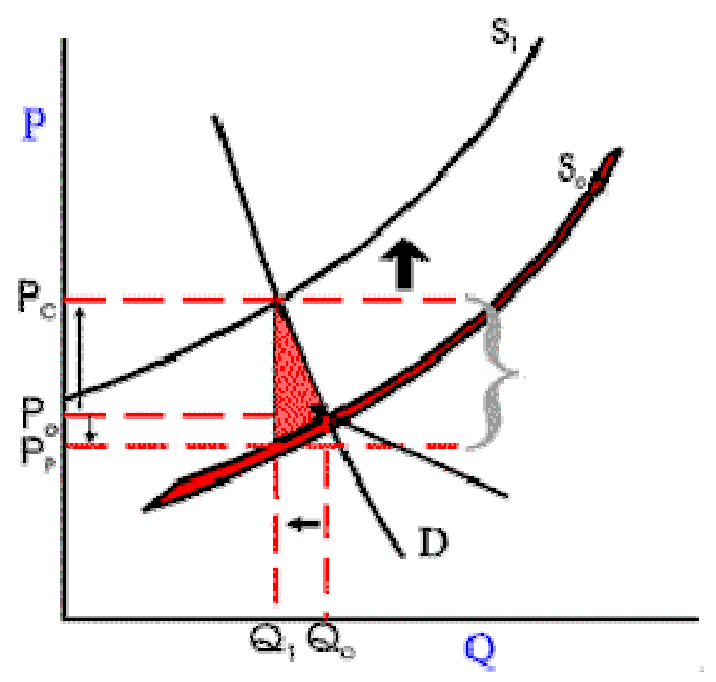

Agora, o que se pode observar é que a quantidade demandada sofre apenas ligeira redução, de $\mathrm{Q}_{0}$ para $\mathrm{Q}_{1}$. Tratando-se de um bem de baixa Elasticidade-preço da demanda, D será curva de grande inclinação. O efeito disso é sentido nos diferentes pontos de equilíbrio, de antes e de depois do tributo, que ficam muitos distantes de si agora apenas 
verticalmente, e não mais horizontalmente. Ou seja, as quantidades demandadas não diminuirão tanto como no caso anteriormente estudado, já que o efeito-substituição não se operará. Como os produtores poderão aumentar substancialmente seus preços, tem-se a situação em que há relevante transferência do ônus econômico para o consumidor, melhorando a eficiência econômica do sistema.

Do ponto de vista do exame do encargo excedente, a conclusão alcançada será a mesma. A área de Triângulo de Harberger, preenchida, será muito menor, no total, do que a anteriormente verificada, e de menor monta ainda no que tange à sua parcela que está abaixo da linha correspondente ao preço $\mathrm{P}_{0}$. Sua quase totalidade recai sobre os consumidores.

Como a receita tributária total, após a introdução do novo imposto, corresponde a $(\mathrm{Pc}-\mathrm{Pp})\left(\mathrm{Q}_{1}\right)$, ou seja, compõe-se de uma parcela fixa, que é a própria alíquota, específica ou ad valorem, e de uma variável, $\mathrm{Q}_{1}$, o que se pode concluir é que, quanto menos a quantidade demandada diminuir em relação à de equilíbrio anterior, $\mathrm{Q}_{0}$, maior receita tributária o ente instituidor angariará. É o que justamente acontece com os bens de baixa Elasticidade-preço da Demanda.

Exatamente por isso que, ao longo da História, assim como nos tempos atuais, como no exemplo da União Europeia, os impostos seletivos têm selecionado bens de demanda inelástica. Assim foi com aquele que Sérgio Vasques (2001, p. 53) entende ter sido o primeiro dos impostos especiais de consumo dos Estados-Modernos, o imposto sobre o sal, produto de que não se podia prescindir na conservação dos alimentos à época. E da mesma forma, no decorrer da História, com as accises europeias sobre as aguardentes, os cereais, o pescado, o tabaco, os panos e as especiarias, em função do que as necessidades tecnológicas ou os modismos de cada época impunham.

Vasques informa também que o "isolar de consumos de base larga e procura rígida, com potencial financeiro elevado, foi o critério orientador do programa de harmonização comunitária dos impostos especiais de consumo", já que combustíveis, tabaco e bebidas alcoólicas possuem perfis de consumo "marcados por uma rigidez importante, sendo elevada a pressão fiscal que os contribuintes se mostram dispostos a suportar antes de prescindir do respectivo consumo".

Outra e melhor maneira que a teoria econômica concebeu de avaliação do desequilíbrio de um sistema em relação ao ponto de máxima eficiência econômica é a formulada por Vilfredo Pareto. De acordo com o critério de eficiência de Pareto, considera-se que uma dada alocação de recursos é eficiente de acordo com o quando é 
impossível modificá-la, com vistas a melhorar o nível de bem-estar de um indivíduo, sem piorar a situação de um outro qualquer (REZENDE, 2001, p. 159). Avalia, portanto, o efeito do emprego dos recursos por meio de um sistema econômico no bem-estar dos indivíduos (HYMAN, 1999, p. 53).

Resumidamente, Pareto desenvolveu a Teoria da Utilidade Marginal, com vistas a mensurar a percepção, psicológica e subjetiva, de bem-estar dos consumidores com o consumo de um conjunto de bens nas suas respectivas quantidades. A utilidade marginal, calculada como a utilidade adicional no consumo de uma unidade de um bem, avalia a escolha do consumidor como um problema de maximização da função utilidade, sujeita à restrição de renda da família (PARETO, 1996, p. 8 - 9 e 199 - 212).

Paralelamente, confrontou, do lado dos produtores, com a Curva de Possibilidades de Produção, que representa os limites de produção de bens e serviços que uma determinada sociedade pode alcançar (PASSOS e NOGAMI, p. 52 - 54).

A eficiência seria alcançada no ponto em que o bem-estar de qualquer dos consumidores, crescente com o aumento de bens e serviços que ele pode consumir, se encontrasse otimamente com o que denomina obstáculos, basicamente os montantes de recursos produtivos e o existente estado de tecnologia em que se encontrassem os produtores desses mesmos bens e serviços (HYMAN, 1999, p. 53).

Para proceder à comprovação desse conceito de equilíbrio sem recorrer a formulações matemáticas, algo fora do escopo do presente trabalho, deve-se saber que o chamado "Ótimo de Pareto" é dado pelo ponto em que a taxa marginal de substituição no consumo iguala as possibilidades de produção.

O critério de eficiência econômica de Pareto pode ser utilizado para se aferir a influência que a tributação indireta acarreta nas decisões dos agentes econômicos, o que compromete a sua neutralidade, levando a um subemprego dos fatores de produção.

O gráfico a seguir representa a influência da tributação indireta na eficiência econômica isoladamente considerada, a partir do critério de eficiência concebido por Pareto (REZENDE, 2001, p. 160). 


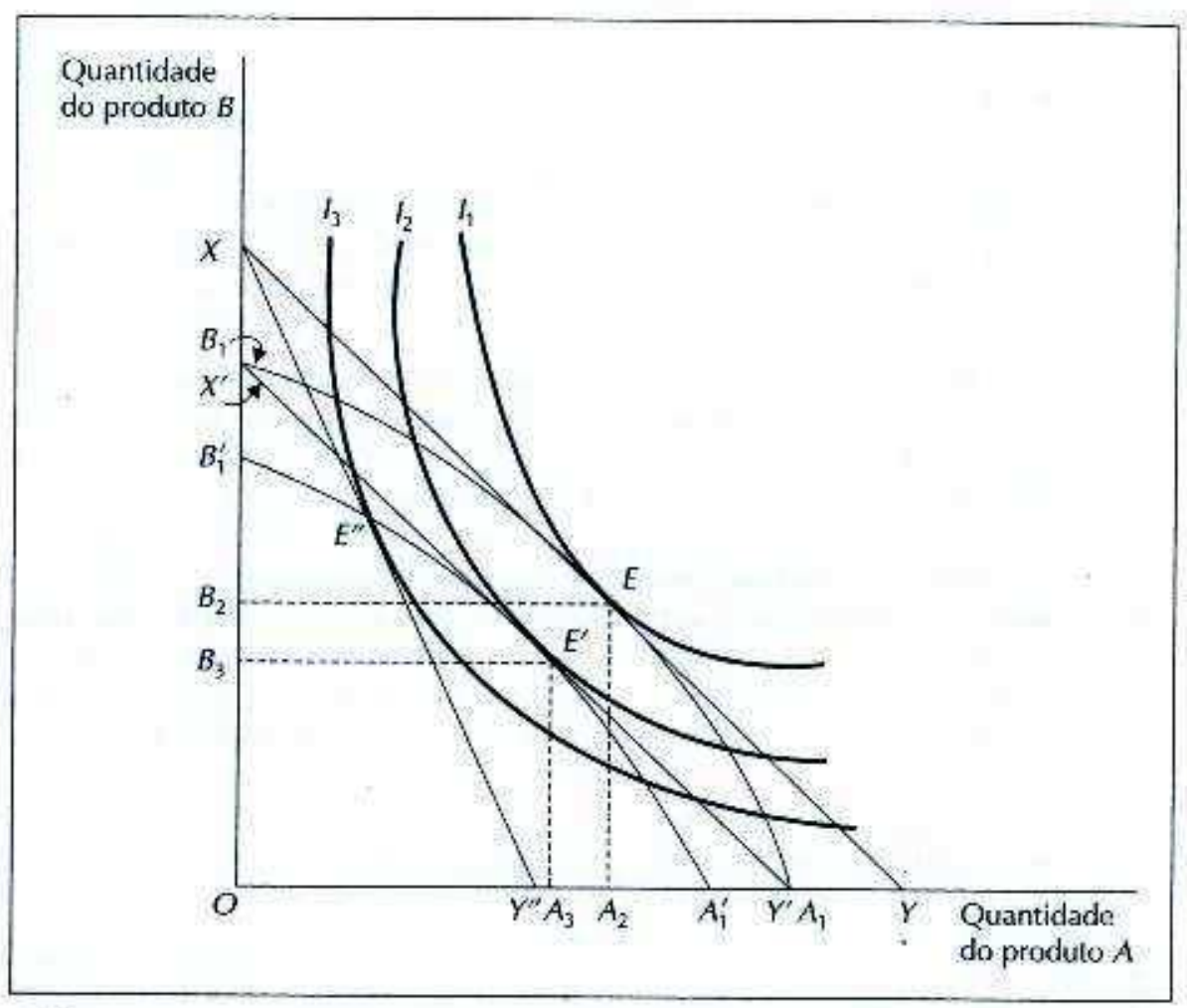

Gráfico 8.1 Efeitos da tributaçâo sobre as decisōes de produçâo.

Nele, $\mathrm{A}_{1} \mathrm{~B}_{1}$ representa a curva de possibilidades de produção dos produtos $\mathrm{A}$ e $\mathrm{B}$, dados os recursos disponíveis, e $\mathrm{I}_{1}, \mathrm{I}_{2}$ e $\mathrm{I}_{3}$ representam as preferências individuais em termos de consumo para diferentes níveis de bem-estar. A solução eficiente é representada pelo ponto $\mathrm{E}$, em que prevalece a igualdade entre as taxas marginais de substituição no consumo e na produção. As quantidades produzidas (e consumidas) de A seriam iguais a $\mathrm{OA}_{2}$, e as de $\mathrm{B}, \mathrm{OB}_{2}$. A reta $\mathrm{XY}$ determina, nesse caso, a relação de preços entre os dois pontos.

Cumpre, agora, considerar a imposição alternada de várias espécies de tributos. Primeiramente, um imposto geral e universal sobre o consumo, com exatamente as mesmas alíquotas, do tipo flat tax - aquele em que o ônus da tributação fosse repartido igualmente pelo número de consumidores, independentemente de quaisquer de suas características socioeconômicas.

Do ponto de vista individual, um imposto desse tipo representa um deslocamento para dentro da reta XY, já que ela é também a linha de orçamento para o consumidor. Reflete, assim, o menor poder de consumo individual com a imposição tributária idêntica para ambos os bens. Pelo lado da produção, a transferência de recursos financeiros do setor privado para o setor público via tributação implica reduzir a 
quantidade de recursos (reais e financeiros) para produzir os produtos em questão. Tal fato implica apenas a redução do máximo do produto que pode ser obtido, sem afetar as taxas marginais de substituição na produção de A e B. No entanto, também implica interferência da tributação na eficiência econômica, embora em menor grau.

A hipótese, na análise gráfica, corresponde a um deslocamento, também para dentro da fronteira de possibilidades de produção, que passa a ser a curva $\mathrm{A}^{\prime}{ }_{1} \mathrm{~B}^{\prime}{ }_{1}$. O montante do imposto passa a ser o equivalente a $\mathrm{A}^{\prime}{ }_{1} \mathrm{~A}_{1}$ em termos do produto $\mathrm{A}$ e $\mathrm{B}{ }_{1} \mathrm{~B}_{1}$ em termos do produto B. O “Ótimo de Pareto" encontra-se ora no ponto E'. A nova relação de preços, representada por $X^{\prime} Y^{\prime}$, permanece imutável em sua inclinação, apenas trasladada proporcionalmente à incidência do tributo sobre os bens A e B. O consumo de B é agora igual a $\mathrm{OB}_{3}$. $\mathrm{O}$ de $\mathrm{A}, \mathrm{OA}_{3}$.

Um resultado idêntico seria obtido com um imposto geral, universal e proporcional sobre a renda. Nesse caso, a redução na renda disponível do consumidor reduziria igualmente suas potencialidades de consumo, sem afetar a escala de preferências. A nova posição de equilíbrio estaria também no ponto E', sendo o efeito do imposto representado pelo deslocamento para dentro da linha de preço XY, até a nova posição X'Y', mesma distância horizontal igual ao montante da contribuição para o governo em termos dos produtos A e B.

Pode-se concluir, portanto, que a eficiência nas decisões sobre alocação de recursos para produção e consumo de mercadorias e serviços não seria, assim, afetada por impostos gerais e universais, sobre o consumo ou sobre a renda. Não obstante, haveria influência no mercado decorrente do deslocamento da curva de possibilidades de produção, o que denota subemprego dos fatores de produção, dada a redução das possibilidades do consumidor quanto ao consumo de $\mathrm{A}$ e de $\mathrm{B}$, em função das suas restrições de receita.

Confira-se agora o que ocorre no caso de impostos seletivos sobre o consumo ou no caso de impostos gerais incidentes a alíquotas diferenciadas, como é a comum das situações em se tratando de impostos indiretos.

Na suposição de que o governo institua um imposto apenas sobre o produto A, ou que incida mais sobre $A$ do que sobre $B$, esse imposto seria representado por uma rotação para a esquerda da linha de preços XY até a posição XY', indicando uma mudança nos preços relativos dos produtos (o preço de A em relação ao de B aumenta). Então, a relação relevante de preços para os consumidores é a posterior ao imposto e representada pela reta $\mathrm{XY}$ ", muito embora a relevante para os produtores permanecer sendo a representada pela reta $X^{\prime} Y^{\prime}$. 
A nova posição de equilíbrio para o consumidor seria agora representada pelo ponto E', em que a igualdade entre as taxas marginais de substituição no consumo e na produção é obtida após levar-se em conta o efeito provocado pela instituição do tributo, mantendo-se inalteradas as preferências dos consumidores. Ocorrerá, portanto, a uma curva de indiferença $I_{3}$, inferior ao equilíbrio anterior $I_{2}$. O ponto $E$ '” será interno à fronteira de possibilidades de produção.

Esses dois fatores representam perda de bem-estar, caracterizadora da inconveniência dessa opção de tributação, aquilatada pelo algumas vezes chamado peso morto da tributação, medido pela diferença entre $I_{2}$ e $I_{3}$.

Fernando Rezende (2001, p. 161 - 162) conclui que, a partir dessa análise, é possível inferir, com algumas aproximações, que impostos gerais (sobre a renda ou sobre o consumo) são mais eficientes economicamente que impostos parciais ou seletivos, mas que ambos, de qualquer forma, impõem alguma forma de deslocamento na posição ótima da economia. Tal raciocínio decorre da presunção de que a situação anterior à introdução do imposto pressupõe o funcionamento de um mercado em concorrência perfeita, o que nem sempre é verdadeiro.

Ressalva, não obstante, que sua abordagem parte apenas da consideração quanto às decisões a respeito da produção e consumo de mercadorias, desprezando outras, como as entre consumo presente e consumo futuro, ou entra trabalho e lazer, por exemplo.

Em casos como tais, essas diferentes escolhas seriam os eixos de figuras análogas à exibida anteriormente. Por exemplo, um imposto sobre o consumo poderia suscitar a postergação da decisão de consumir por motivação tributária. Assim, por meio de análises gráficas assemelhadas, chega-se à conclusão que sempre a incidência tributária indicará uma redução no nível de bem estar.

Assim, como ensinam Richard Musgrave e Peggy Musgrave (1973, p. 448 449), apenas no caso da um imposto uniforme per capita, do tipo lump sum, a eficiência econômica seria mantida sob qualquer forma de análise. Também o seria na situação em que a incidência dependesse de alguma característica que independesse das escolhas do contribuinte, como a sua altura, o tamanho do seu pé, ou algo assemelhado.

No entanto, por evidente, tais tributos falhariam no que tange ao seu caráter de justiça, ou de equidade, em termos econômicos. Portanto, o que se pode concluir é que não existe neutralidade fiscal absoluta em sistemas fiscais que se baseiam na capacidade contributiva, como é o desejado modernamente, pelo que só se pode falar no conceito de neutralidade de uma forma relativa, temperada como tem que ser pela equidade. 


\subsubsection{Do (inexistente) Princípio Geral de Neutralidade Fiscal.}

Antes de tocarmos com maior profundidade no conceito de equidade, há que pensarmos em que neutralidade fiscal se pode pensar, já que concluímos, no item anterior, que tal característica não se verifica se tomada de uma forma absoluta. Não obstante, ainda que estejamos resignados com essa constatação, mesmo assim não há dúvida que a tributação deve perseguir o mais possível ser eficiente economicamente, na busca do desenvolvimento econômico e de redução das desigualdades sociais. Nessa perspectiva de raciocínio, avulta a importância de se estudarem os princípios econômicos da tributação.

Já de muito tempo ocupam-se os economistas com essa questão. Referência clássica à matéria remete ao fim do Século XVIII, especificamente aos estudos de Adam Smith. Embora, como teria dito Proudhon, mencionado por Stourm (1912, p. 25), seriam os primeiros passos de uma ciência das Finanças Públicas, ditadas mais pelo bom senso. Talvez por isso mesmo sejam tão atuais.

Consistem em quatro máximas a serem obedecidas por todas as nações na construção dos seus sistemas tributários. Por isso que Stourm (1912, p. 25) as classifica como a "Declaração dos Direitos do Contribuinte". São regras que, entende Adam Smith (1996, p. 283 - 285), procuram tornar os impostos "tão eqüitativos quanto possível, tão fixos e tão convenientes para o contribuinte, quer no tocante ao tempo, quer no tocante à forma de pagamento, quer em proporção à receita que carreavam para o príncipe, como também pouco incômodo às pessoas" e que correspondem, para Stourm (1912, p. 31), às palavras-chave justiça, certeza, comodidade e economia.

A primeira delas refere-se à proporcionalidade. Os súditos de cada Estado devem contribuir o máximo possível para a manutenção do Governo, em proporção às suas respectivas capacidades. Portanto, em proporção ao rendimento de que cada um desfruta, sob a proteção do Estado. Adam Smith afirma que "as despesas de governo, em relação aos indivíduos de uma grande nação, são como despesas de administração em relação aos rendeiros associados de uma grande propriedade, os quais são obrigados a contribuir em proporção aos respectivos interesses que têm na propriedade". É princípio que corresponde ao "que se denomina de eqüidade ou falta de eqüidade da tributação".

A segunda máxima corresponde à regra de certeza. O imposto que cada individuo é obrigado a pagar deve ser fixo e não arbitrário. Para Adam Smith, a data do 
recolhimento, a forma de recolhimento, a soma a pagar, devem ser claras e evidentes para o contribuinte e para qualquer outra pessoa. Se assim não for, toda pessoa sujeita ao imposto está mais ou menos exposta ao arbítrio do coletor, o qual pode aumentar o imposto para qualquer contribuinte que lhe é odioso ou então extorquir, mediante a ameaça de aumento do imposto, algum presente ou gorjeta para si mesmo. A indefinição da taxação para Adam Smith estimula a insolência e favorece a corrupção de uma categoria de pessoas que são por natureza impopulares mesmo quando não são insolentes nem corruptas. A certeza sobre aquilo que cada indivíduo deve pagar é, em matéria de tributação, de tal relevância que, segundo entende economista inglês e com base na experiência de todas as nações, um grau muito elevado de falta de eqüidade de impostos nem de longe representa um mal tão grande quanto um grau muito pequeno de incerteza ou indefinição.

A terceira qualidade do imposto, na visão clássica de Adam Smith, é a comodidade para o sujeito passivo. Todo imposto deve ser recolhido no momento e da maneira que, com maior probabilidade, forem mais convenientes para o contribuinte. Ilustra que "um imposto sobre o arrendamento da terra ou sobre o aluguel de casas, se cobrado no mesmo período em que se costuma pagar tais arrendamentos ou alugueis, é recolhido no momento em que, com maior probabilidade, o contribuinte terá facilidade em pagar, ou seja, quando é mais provável que ele tenha com que pagar o imposto". No caso de impostos indiretos, ou, como denomina, sobre "bens de consumo, tais como artigos de luxo", defende que "são todos, em última análise, pagos pelo consumidor, e geralmente de uma forma que é muito conveniente para ele. Ele os paga pouco a pouco, na medida em que compra as mercadorias".

Por fim, a máxima da eficiência econômica. Todo imposto deve ser planejado de tal modo que retire e conserve fora do bolso das pessoas o mínimo possível, além da soma que ele carreia para os cofres do Estado. Adam Smith aponta quatro maneiras de fazer com que um imposto retire ou então conserve fora do bolso das pessoas muito mais do que aquilo que arrecada. Devido a um ou outro desses quatro modos inadequados de impor ou recolher tributos, considera que muitas vezes criam-se muito mais incômodos para as pessoas do que benefícios para o soberano.

Primeiramente, o recolhimento do imposto pode exigir um grande número de funcionários, cujos salários podem devorar a maior parte do montante do imposto, e cujas gorjetas podem impor ao povo uma nova taxa adicional. Em segundo lugar, o imposto pode dificultar a iniciativa das pessoas e desestimulá-las de aplicar em certos setores de negócios que poderiam dar sustento e empregos a grandes multidões. Ao mesmo tempo em 
que o imposto obriga as pessoas a pagar, ele pode assim diminuir, ou talvez até destruir, na visão de Smith, alguns dos fundos que lhes poderiam possibilitar fazer isto com mais facilidade. Em terceiro lugar, devido aos confiscos e outras penalidades em que incorrem os indivíduos que tentam, sem êxito, sonegar o imposto, este pode muitas vezes arruiná-los e com isto por fim ao beneficio que a comunidade poderia ter auferido do emprego de seus capitais. Em quarto lugar, o imposto, por sujeitar as pessoas "às visitas freqüentes e à odiosa inspeção dos coletores", pode expô-las a "muitos incômodos, vexames e opressões desnecessários". Reflete Adam Smith que, "embora o vexame não seja, no sentido estrito da palavra, uma despesa", pode ser considerado "equivalente à despesa pela qual cada um gostaria de livrar-se dele".

Após as lições clássicas de Adam Smith, numerosos economistas aventuraramse a formular suas regras aplicáveis ao sistema tributário ideal. Embora não seja o objetivo momentâneo entrar a fundo nessa discussão, cuja referência presta-se tão-somente a introduzir a visão mais moderna a respeito, pode ser mencionada a lição de Sismondi, mencionada por Stourm (1912, p. 31), para quem se deveria recomendar aos sistemas fiscais a moderação, a humanidade, a prudência e a habilidade. O próprio René Stourm defendeu como as três qualidades necessárias ao imposto: os contatos muito freqüentes e diretos entre os empregados do Fisco e os contribuintes devem ser evitados, uma vez que a comodidade aos contribuintes os faz pagar seus impostos mais serenamente; o imposto ganha em ser antigo, já que a instituição de um novo imposto tende a gerar imperfeições técnicas só corrigíveis com o tempo, a despeito dos progressos da arte fiscal; e o imposto não deve ser nem estimulante, nem moralizador nem protetor, mas sim exclusivamente provedor de recursos para o Estado.

Na doutrina jurídica brasileira, a título de exemplo, Antônio Carlos Rodrigues do Amaral (1994b, p. 91) aponta três objetivos elementares à imposição tributária: o tributo deve ser justo, economicamente eficiente e administrável.

Entende que a justiça tributária se alcança quando se aproxima a tributação daquele que se aproveitou das despesas efetuadas pelo Estado, ou quando se identifica a capacidade contributiva do sujeito passivo. Implica a expectativa de que o mais rico sofra uma incidência proporcionalmente maior, "moderadamente progressiva", na subvenção dos gastos públicos.

Por eficiência diz traduzir-se a busca da neutralidade econômica da imposição tributária. Vale dizer, o tributo não pode ser fator a influir nas escolhas dos agentes econômicos, seja entre consumo e poupança, entre trabalho e lazer, ou na aquisição de um 
bem ou serviço ou outro, com vista a que os recursos econômicos sejam empregados da maneira a dispendê-los o menos possível.

Também os tributos devem, por fim, impor encargos burocráticos aos contribuintes de forma a atender, com maior razoabilidade, à necessidade de informação pela Administração Tributária, sem onerar em demasia os custos administrativos do particular.

A OCDE, por sua vez, costuma relacionar, em seus documentos (como, por exemplo, o de 1998, elaborado pelo Comitê de Assuntos Fiscais, acerca do comércio eletrônico, denominado "Electronic Commerce: a discussion paper on taxation issues"), entre os princípios tributários básicos geralmente aceitos os da neutralidade - a tributação não pode influir nas decisões empresariais; da eficiência - os custos para a autoridade tributária e para os contribuintes, no que diz respeito à arrecadação e ao atendimento das normas tributárias, deve ser o menor possível e eqüitativo em relação a contribuintes em situações similares; da certeza e simplicidade - as normas tributárias devem ser claras e de simples interpretação, com vistas a assegurar a segurança jurídica aos agentes econômicos; da efetividade e justiça - a tributação deve produzir o montante apropriado de tributo no momento adequado e o potencial de evasão ou elisão fiscal deve ser eliminado; e da flexibilidade - os sistemas tributários devem ser flexíveis e dinâmicos, de modo a assegurar que acompanhem o desenvolvimento tecnológico e comercial (p. 7).

Há outras formulações semelhantes, tanto entre os juristas especializados na matéria tributária, quanto entre os financistas. Não é necessário enunciarem-se mais teorias a respeito, senão apenas a clássica, da qual todos partiram, uma de um jurista ligado aos estudos de integração econômica e a formulação de Organização Internacional, especializada em matéria econômica, para se concluir que as dissonâncias entre os aspectos a serem considerados repousam apenas na classificação e escolha dos termos adotados. Assim é que alguns dos princípios relacionados pela OCDE já foram mencionados quanto da abordagem dos fatores fiscais a nortear qualquer modalidade tributária e a tributação indireta em particular.

O que se deve considerar como base de análise é o que, no estudo das Finanças Públicas, no campo da Economia, tem sido pacífico denominar "princípios teóricos da tributação", esclarece Fernando Rezende (2001, p. 158). São os fatores que se devem ponderar na instituição e avaliação de sistemas fiscais ou de impostos isoladamente considerados, e assim será tal concepção adotada. Para ele, a teoria da tributação, portanto, repousa nos Princípios da Neutralidade e da Equidade. 
Em verdade, Rezende ainda arrola um outro critério, que seria a "produtividade" do tributo do ponto de vista de sua contribuição para a receita fiscal, avaliada "com base na identificação de coeficientes de elasticidade da receita em relação à renda para diferentes alternativas de tributação". Visaria a apreciar a conveniência de um tributo em face de sua compatibilidade com os requisitos de financiamento dos crescentes encargos governamentais e à própria expansão econômica.

Sérgio Vasques (2001, p. 56) ensina que tal critério deve refletir a preocupação do ente tributante com o que Fritz Neumark designava de Princípio da Suficiência da receita fiscal ("Grundsatz der Ausreichendheit der Steuererträge”). Esclarece que, nos termos desse princípio, o sistema fiscal "deve ser configurado em termos tais que permita cobrir as despesas públicas de modo duradouro". O sistema pode, assim, para ele, dizer-se suficiente quando "compreenda impostos que, pela sua estrutura, estejam em relação próxima com o desenvolvimento econômico, mostrando-se capazes de o acompanhar em tempo e proporção".

O Princípio da Neutralidade, como o define Rezende (2001, p. 158 - 159), consiste na inexistência de influência nos mecanismos de mercado das questões relacionadas à incidência tributária. A neutralidade, portanto, traz em seu bojo uma relação direta entre a não interferência governamental nas decisões de alocação de recursos na produção e no consumo e a manutenção da eficiência econômica ínsita à determinação de preços pelo mercado.

Não resta dúvida que a neutralidade tributária consiste, portanto, em um princípio econômico da tributação, corolário da preocupação, fundamental nesse ramo científico, com a eficiência das instituições e dos mercados. Princípio econômico sim, com evidentes influências no fenômeno da tributação. Afinal de contas, como afirma Klaus Vogel (1990, p. 137) a discussão de aspectos econômicos e de justiça deverá sempre estar presente em consideração a questões sobre ambos os ramos do conhecimento. Ou, como prefere Eros Grau, a Economia condiciona o Direito, mas o Direito condiciona a Economia (2008, p. 59) - tese do vai-e-vem..

Porém, existe um Princípio (jurídico) de Neutralidade Fiscal?

A respeito, Paulo Caliendo (2006), com propriedade, afirma que, embora os sistemas da economia e o tributário possuam "coerência intersistemática" (p. 506), cada um dos sistemas irá ler as mensagens a seu modo, filtrando as informações ao estilo de seu código próprio, mantendo, contudo, a abertura necessária para as significações advindas do outro subsistema (p. 511). Nessa perpectiva, a tributação é um "fenômeno intersistêmico" 
que envolve ambos os saberes (p. 512). No entanto, as trocas entre ambos os subsistemas devem ser realizadas de modo equilibrado, de tal forma que não ocorra a "corrupção" do sistema, ou seja, a imposição do código binário de um subsistema em outro - vale dizer, a justiça cedendo espaço para as exigências de eficiência econômica (p. 512).

Até esse ponto, nada a reparar na formulação. Após, defende que o "princípio da neutralidade fiscal poderia ser lido, neste sentido, como o modo do sistema jurídico proceder o correto filtro para as informações advindas do subsistema da economia sobre a tributação e, assim, indicar como devem ser programadas as expectativas dos agentes" (p. 513). Funcionaria, portanto, como um acoplamento estrutural (LUHMANN, 2009, p. 128 151) entre os dois subsistemas.

Em obra posterior, de 2009, defende que tal princípio "estabelece um valor ou fim, qual seja, diminuir legitimamente os efeitos da tributação sobre a decisão dos agentes econômicos, evitando distorções e conseqüente ( $\mathrm{sic}$ ) ineficiências no sistema econômico" (2009, p. 113). Defende que se trata de princípio que se encontra em igualdade de condições com a justiça fiscal, como os dois princípios "que irão nortear todo o sistema jurídico tributário", já que tendentes a alcançar "os dois objetivos máximos da sociedade", invocando as lições de Immanuel Kant acerca da relevância da busca da paz e da prosperidade (p. 116).

Com o advento da Emenda Constitucional no 42, de 19 de dezembro de 2003 e a consequente inclusão no texto constitucional de um dispositivo ${ }^{733}$ que fala na possibilidade de a lei tributária perseguir desequilíbrios da concorrência, o tema, de uma hora para a outra, passou a estar na ordem do dia da doutrina tributária. Grande parte dos que se debruçaram sobre o tema defendem, em resumo, que o artigo 146-A da Constituição Federal veiculou não só uma uma regra, de autorização para estabelecimento de critérios especiais de tributação, como um princípio (SCHOUERI, 2009, p. 18) pretensamente destinado a legitimar a produção de normas tributárias tendentes a realizar o aspecto positivo da neutralidade tributária. Em especial, proliferaram desde então trabalhos acadêmicos a respeito $^{734}$.

\footnotetext{
733 “Art. 146-A. Lei complementar poderá estabelecer critérios especiais de tributação, com o objetivo de prevenir desequilíbrios da concorrência, sem prejuízo da competência de a União, por lei, estabelecer normas de igual objetivo".

734 Após uma breve pesquisa, LIMA, Ricardo Seibel de Freitas. Livre concorrência e o dever de neutralidade tributária. 2006. Dissertação (Mestrado em Direito) - Universidade Federal do Rio Grande do Sul; PASIN, João Bosco Coelho. Considerações sobre a Imposição Tributária em Face dos Princípios Constitucionais de Direito Econômico. 2002. Dissertação (Mestrado em Direito Político e Econômico) Universidade Presbiteriana Mackenzie;; JORDÃO, Eduardo Ferreira Jordão. O impacto anticompetitivo da regulação estatal. 2007. Dissertação (Mestrado em Direito) - Universidade de São Paulo; SILVEIRA,
} 
José Luis Brazuna (2009, p. 144 - 145), com fulcro na lição de Misabel Derzi que menciona, defende ser a neutralidade tributária um "princípio limitador ao poder de tributar, não se admitindo que a ação arrecadadora" (cobrança e arrecadação) do Estado "provoque, ela própria, desequilíbrios na concorrência", tanto na imposição principal quanto nas acessórias. Haveria, implícita, uma autorização para o legislador infraconstitucional utilizasse normas tributárias indutoras, com o objetivo de prevenir desequilíbrios concorrenciais (p. 256).

Em outro trabalho acadêmico do gênero, Ricardo Lima defende que a neutralidade tributária (2005, p. 135) é, de um lado, um dever negativo, de omissão ao Estado, de não interferir na concorrência por meio da tributação e, de outro, como um dever positivo, ou de ação, de prevenir ou restaurar, quando for o caso, a igualdade de condições na concorrência, sempre preservando a igualdade de condições competitivas no mercado.

De outro lado, com mais correção, Diego Bomfim (2010, p. 206) afirma que o art. 146-A da Constituição não trouxe ao ordenamento jurídico pátrio o princípio da neutralidade tributária. No entanto, o considera existente e, como corolário do princípio da livre concorrência (p. 186), já estava presente no texto constitucional, como norma que permite a interpretação de uma "regra que impossibilitava a utilização da tributação como instrumento de fomento de desequilíbrios concorrenciais por parte do ente estatal".

Com efeito, é parcialmente correta uma das formulações por detrás do pensamento esposado por Ricardo Lima, no sentido de que a neutralidade possui seu viés positivo. A propósito, Fritz Neumark (1974, p. 316 - 318), após ressaltar a equivocidade da expressão neutralidade fiscal, relegando-a a um postulado da época liberal, e negar a possibilidade da neutralidade fiscal absoluta, o que aqui já se comprovou, afirmava que, ao seu caráter negativo, de não intervenção no mecanismo concorrencial, contrapunha-se um outro, de natureza positiva, que viabiliza a realização de políticas fiscais que estimulem a concorrência nos casos em que seja imperfeita por motivos não fiscais, evitando a produção de efeitos econômicos ou eticossociais deletérios. Assim entendida, para ele não existe a neutralidade fiscal liberal e utópica, nem tampouco ela se constitui em um

Rodrigo Maito da Silveira. Tributação e concorrência. 2009. Tese (Doutorado em Direito) - Universidade de São Paulo; GOUVÊA, Clóvis Ernesto Gouvêa. Justiça fiscal e tributação indireta. 1999. Tese (Doutorado em Direito) - Universidade de São Paulo; FARO, Maurício Pereira. Tributação, Igualdade e Livre Concorrência. 2009. Dissertação (Mestrado em Direito) - Universidade Gama Filho. Além dessas, duas delas foram publicadas: BRAZUNA, José Luis Ribeiro. Defesa da Concorrência e Tributação - à luz do Artigo 146-A da Constituição. Série Doutrina Tributária, vol. II. São Paulo: IBDT/Quartier Latin, 2009; BOMFIM, Diego. Tributação e Livre Concorrência. São Paulo: Saraiva, 2011. 
desiderato geral e absoluto, senão um postulado condicionado - dependente do grau de concorrência existente e da plausibilidade dos resultados originados.

Eros Grau, tratando do tema dos princípios do Direito Comercial (2005, p. 136), afirma-os como vetores, ou linhas diretrizes de uma determinada ordem jurídica - no caso, a ordem mercantil. Ricardo Lobo Torres (2005, p. 275), com base na visão de Karl Larenz, exibe a definição de princípios como pensamentos diretivos de um ordenamento jurídico, possível ou constituído, mencionando, agora com base em Miguel Reale, a sua função de condicionar e orientar a compreensão de ordenamento jurídico, quer para a a plicação, quer para a elaboração de novas normas.

Não se pode entender a neutralidade como um principio tributário portanto. Não é, necessariamente, um norte a ser seguido pelo operador do Direito, na sua atividade de interpretação ou de aplicação do Direito. Não se pode usar a neutralidade como diretriz da ordem tributária, sob pena de subverter seus pressupostos.

Na verdade, a neutralidade tributária, como bem aponta James Buchanan (1968, p. 162), nada mais é do que a base de um sistema tributário ideal, a proporcionar com mais eficiência bens e serviços. É um conceito de trabalho ideal, como a concorrência perfeita ou o pleno emprego para a Economia, o vácuo absoluto ou a força de atrito desprezível para a Mecânica, a entropia zero para a Termodinâmica ou o condutor perfeito e a fonte de energia infinita para o Eletromagnetismo.

A neutralidade não pode se tomada nem como princípio, enunciado diretor de um sistema, nem tampouco como regra geral da tributação. Como bem afirma Klaus Vogel (1990, p. 137), aceita-se e até se incentiva que a norma tributária possa buscar o quanto mais possível a neutralidade, mas os critérios substantivos, que ele denomina de justiça, devem preponderar. Como já dissemos, a modalidade de tributos intrínsecamente neutra é a das lump-sum taxes, de resto completamente apartadas dos cânones tributários mais básicos.

Nem se pode dizer que a neutralidade tributária, tomada de forma superior, seja a opção que mais convenientemente venha ao encontro da eficiência econômica, no plano jurídico. Tanto é que Paula Forgioni (2009, p. 230), quando menciona as características necessárias à ordem jurídica para ordenar convenientemente o mercado, com o perdão da deliberada redundância, usando a lição de Natalino Irti, lista-as como a normalidade, a presença de regras; a uniformidade, a adequação a um esquema; e regularidade, o atingimento de um tipo normativo, que perde o seu caráter de fortuito e arbitrário, alcançando a função de produzir comportamentos previsíveis e calculáveis. 
Como, portanto, esquecer a segurança jurídica, na visão de Alberto Xavier (1978, p. 50), a eliminação, no maior grau possível, de "todos os fatores que possam traduzir-se em incertezas econômicas suscetíveis de prejudicar a expansão livre da empresa"? Seria, na verdade, presumir que o princípio da livre iniciativa, como a oportunidade de oferecer oportunidades de troca, garantindo que os agentes econômicos tenham acesso ao mercado e nele possam permanecer (FORGIONI, 2009, p. 205), já que desfrutando de um ambiente ordenado e estável, não seja assim tão relevante. Qual o motivo de se privilegiar a livre concorrência em detrimento da livre iniciativa, já que são princípios de absoluta equiparação constitucional?

Ademais, a se tomar o conceito do princípio de neutralidade fiscal como o de ser a tentativa ótima de diminuir legitimamente, o quanto possível, os efeitos da tributação sobre a decisão dos agentes econômicos, se visto como um princípio geral e mandatório, levaria à própria negação da possibilidade de realização de negócios jurídicos sem causa outra que não a mera economia de impostos.

O que existe não é um Princípio Geral de Neutralidade Tributária, mas hipóteses em que a neutralidade das operações tributadas vem ao encontro dos princípios basilares do Direito Tributário, como o da equidade e, por conseguinte, da capacidade contributiva, sendo assim de conveniente perseguição pelo legislador.

\subsubsection{Das (possíveis) Neutralidades Fiscais (Relativas e Parciais).}

O segundo princípio teórico (econômico) da tributação, e que complementa o princípio da neutralidade, na visão de Fernando Rezende (2001, p. 162), é o da equidade, que se pode identificar com a justiça fiscal a que se refere Klaus Tipke (TIPKE; YAMASHITA, 2002, p. 15 - 18). Diz com a necessidade da distribuição justa e equitativa da carga tributária entre indivíduos, constituindo um dos critérios básicos para a formulação de uma estrutura tributária adequada.

Em um primeiro momento, o princípio da equidade implica dar-se um tratamento uniforme aos iguais. Os contribuintes com igual capacidade contributiva deverão, portanto, pagar o mesmo tributo ao Estado. É a equidade horizontal.

No segundo momento, aplica-se a equidade vertical, que recomenda tratamento tributário diferente aos contribuintes com capacidade econômica desigual, remetendo-nos à questão da progressividade e regressividade do imposto. 
É pacífico, na doutrina, o entendimento quanto à aspiração, ao menos ideal, de equidade no sistema tributário. Contudo, há divergência acerca de como se aferir o quantum da parcela justa de contribuição para o financiamento do setor público.

Daí surgiram dois critérios para a classificação do que seriam contribuintes iguais e quais as normas adequadas de diferenciação, na lição de Rezende (2001, p. 162 163): o critério do benefício e o da capacidade contributiva.

O critério do benefício atribui a cada indivíduo um ônus equivalente aos benefícios governamentais por ele usufruídos. Tem fulcro nas preferências individuais pelo consumo de bens e serviços produzidos pelo governo. Visa a igualar o preço unitário do serviço ou bem públicos ao benefício marginal auferido pelo contribuinte com a sua prestação ou aquisição. Não merece maior atenção por que se refere a tributos contraprestacionais, como taxas e contribuições de melhoria, que estão fora do nosso escopo presente.

Já o critério da capacidade contributiva defende a repartição do ônus tributário em função das respectivas capacidades contributivas individuais. Baseia-se nas possibilidades de pagamento pelos particulares.

Do ponto de vista da equidade horizontal, não é difícil mensurar-se a capacidade contributiva, ensina José Maurício Conti (1997, p. 73 - 74), pois se pode aplicar a teoria do bem-estar, uma vez que, como o sacrifício de pessoas com a mesma renda ao pagarem seus impostos é o mesmo, abrindo mão da mesma utilidade marginal da renda, é suficiente que se instituam impostos proporcionais à capacidade econômica de cada indivíduo para que se alcance uma tributação justa e equitativa.

Por outro lado, Conti defende (1997, p. 74) que a implementação da equidade vertical apresenta problemas de muito mais alto relevo, exatamente porque visa a estabelecer a melhor distribuição do ônus tributário entre contribuintes com capacidades econômicas distintas.

A partir dessa constatação surge a grande questão acerca do princípio da eqüidade: qual a correta forma de se diferenciar os desiguais? Fundamentalmente, o ônus tributário deve onerar o contribuinte de maneira proporcional, mais que proporcional ou menos que proporcional à variação da capacidade contributiva?

Os tributos podem ser classificados sob o aspecto da distribuição da carga tributária em face da renda. Caso o aumento na contribuição individual seja proporcionalmente menor que ao de sua renda, vale dizer, a relação entre imposto a pagar e a renda do contribuinte decresce com o aumento desse segundo fator, configura-se a 
distribuição regressiva da carga tributária. Se o aumento na contribuição for proporcional ao aumento da renda do sujeito passivo, a distribuição será dita proporcional, e a relação entre imposto a pagar e a renda do contribuinte permanecerá constante. Entretanto, se o aumento na contribuição for proporcionalmente maior que o aumento da renda, diz-se que a distribuição da carga tributária será progressiva.

Importante ressaltar que essa conceituação de progressividade é típica da Ciência Econômica, relacionando intrinsecamente o imposto a pagar e a renda do contribuinte que arca com o seu pagamento. Distingue-se da classificação puramente jurídica de progressividade, a que se refere Rubens Gomes de Sousa (1952, p. 142), baseada no critério formal de apuração do imposto e, por conseguinte, da alíquota, a partir da confrontação entre o imposto a pagar e a sua respectiva base de cálculo. Para a conceituação jurídica, então, cunhada por Rubens Gomes de Sousa, progressividade é a característica dos impostos "cuja alíquota é fixada na lei em porcentagem variável conforme o valor da matéria tributável".

Não é difícil concluir que coincidem as definições de progressividade econômica e jurídica apenas no Imposto de Renda - o imposto progressivo por natureza, cuja base de cálculo é justamente a renda da pessoa física ou jurídica.

Ponderando que a política de gastos públicos não pode anular o efeito redistributivo obtido na arrecadação, Fernando Rezende (2001, p. 308) introduz o conceito de progressividade fiscal, entendendo que essa é a principal característica a ser buscada por um sistema tributário. Sua visão visa a evitar que se onerem os contribuintes com maior capacidade contributiva ao mesmo tempo em que se canalizem essas receitas a projetos que os privilegiem, o que neutraliza a ação desconcentradora do ideal de justiça fiscal perseguido.

Portanto, a progressividade fiscal pode ser resumida pela seguinte máxima: há que se avaliar o impacto conjunto no sistema econômico das variáveis receita e despesa públicas. Para Rezende, a experiência internacional tem mostrado que um sistema fiscal justo e equilibrado não só é fruto de uma boa arrecadação, a despeito da questão da regressividade da tributação, desde que realizadas, em contrapartida, despesas públicas voltadas para as camadas mais pobres.

Abstraindo-se a análise quanto aos gastos públicos, e retornando ao exame da progressividade econômica, resta a dúvida quanto a perquirir sobre o critério que melhor atende precipuamente ao princípio da justiça tributária vertical. 
Paul Hugon (1945, p. 74) afirma literalmente que apenas pela progressividade econômica se pode obter maior exatidão no cálculo verdadeiro da capacidade contributiva: "é pela progressividade que tenderemos a satisfazer a justiça fiscal no imposto". Antes, já havia afirmado que o "imposto proporcional não é, pois, um cálculo verdadeiro da capacidade contributiva, uma vez que não permite assegurar a igualdade de sacrifício”.

Outros, mencionados por Conti (1997, p. 78 - 79), discordam, propugnando que a progressividade apenas pune os mais eficientes e inibe os investimentos. Rezende (2001, p. 166 - 170), por sua vez, relata os estudos, formulados inicialmente por Richard Musgrave, que relacionam a progressividade econômica com a utilidade marginal da renda, a partir dos quais construíram-se teorias, contrárias ou favoráveis à progressividade, a partir de diferentes acepções para o conceito de "igual sacrifício" - igualdade absoluta, proporcional ou marginal.

A par de todas essas considerações, e sem entrar no mérito da própria conceituação de capacidade contributiva, questão basilar do Direito Tributário, certo é que a equidade tributária definitivamente não se alcança pela regressividade econômica.

Ocorre que os impostos indiretos, ou melhor, aqueles que incidem sobre bens e serviços, caracterizam-se justamente por serem regressivos, na medida em que oneram mais as pessoas que menor rendimento, que têm que comprometer maior parcela de sua renda com a aquisição de bens e serviços para consumo (GIAMBIAGI; ALÉM, 2000, p. 259). Como explica Fernando Rezende (2001, p. 219), pelo fato de o consumo ser decrescente com o acréscimo da renda, a tributação uniforme de um imposto geral e universal sobre vendas de mercadorias e serviços torna a relação imposto/renda também decrescente, o que se agrava quanto maior for a transferência do ônus tributário para o consumidor, a partir das características do bem tributado e do mercado em que é comercializado. É o que Adilson Pires (1999, p. 122) denomina "o caráter injusto do imposto indireto não seletivo", circunstância em que a neutralidade "conflita com o princípio da justiça" (1999, p. 124).

A maneira de atenuar esse problema, ensinam Rezende (2001, p. 219) e Pires (1999, p. 125), seria impor alguma seletividade, por exemplo, em função da essencialidade do produto tributado, aqueles consumidos pelas camadas de menor renda da população.

Porém, adverte Fernando Rezende (2001, p. 217) que é solução que traz inconvenientes sob outros aspectos. Além de romper com a neutralidade ínsita a essa modalidade tributária, há um comprometimento da simplicidade na administração do 
imposto. Acaba por concluir que, para impostos do tipo do IVA, "a universalidade do escopo e a uniformidade de alíquotas são fatores essenciais ao seu bom funcionamento".

Nesse ponto há que se ponderar se realmente existe, no desenho de um sistema fiscal indireto, uma questão de ponderação entre os princípios da neutralidade e da equidade - o dilema “Equity versus Efficiency” referido por Hyman (1999, p. 383 - 384).

O sistema tributário de um Estado não pode ser considerado apenas como um conjunto de imposições previstas no ordenamento jurídico, como o examina Ricardo Lobo Torres (1986, p. 2), negando "unidade interna, coerência lógica, ordem, ausência de contradições e independência ao todo em relação às partes". Mais do que isso, um sistema tributário, ou o subsistema tributário indireto ora especificamente em estudo, tem que ser tomado como um "objeto unitário de conhecimento", na lição de Fernando Sainz de Bujanda (1962, p. $252-258)$.

Sem se negar a forte dose de historicidade na construção dos sistemas tributários no direito comparado, ensina o catedrático de Fazenda Pública da Universidade de Madri que o estudo científico dos sistemas tributários não pode furtar-se a, pelo menos, reconhecer a possibilidade racional da existência de uma estrutura conjunta, em que os efeitos de uma incidência anulam-se ou se complementam, corrigindo e equilibrando-se umas às outras. Assim, certos gravames só poderiam ser estudados como partes ou elementos de um todo, sem esquecer de uma certa idealização dessa abordagem, notadamente em vista das circunstâncias em que por regra são estabelecidas as normas jurídicas. É realidade ainda mais evidente no que tange às tributárias, sempre pressionadas por exigências fiscais dos entes tributantes decorrentes de necessidades conjunturais de alguma política pública considerada como primordial à época.

A par dessas considerações, uma visão científica dos sistemas tributários deve buscar harmonias no que foi determinado pelo legislador, com vistas ao atendimento de princípios maiores das ciências do Direito e da Economia (SAINZ DE BUJANDA, 1986, p. 256).

Assim, na tentativa consciente de modelagem de um sistema tributário próximo do ideal, em que não fossem ignoradas as variáveis de mercado e a influência dos aspectos tributários nas decisões dos agentes econômicos, a equidade e a neutralidade seriam como que dois pratos de uma mesma balança, na busca do equilíbrio econômico do sistema financeiro do Estado, dentro dos objetivos políticos de conjugação dos interesses entre governo, empresário e consumidor. 
Deve-se assinalar que a equidade, ou igualdade, que aqui se quer ressaltar é aquela projetada na capacidade contributiva, baseada, como ensina Andrei Velloso (2010, p. 167) em um fundamento jurídico-positivo claro, que é a posição dos produtos nacionais e dos importados no mercado consumidor (TERRA; WATTEL, 2008, p. 44), evitando a criação normativa e artificial de vantagens competitivas. Importante ressaltar que a capacidade contributiva que se toma aqui não é aquela considerada como pressuposto da tributação, em que a sua relevância se descola da igualdade, mas sim como graduação da carga tributária (VELLOSO, 2010, p. 318 - 319), como régua de medição dos efeitos sobre os destinatários da norma tributária - nas palavras de Enrico de Mita (2005, p. 223), como limite da atividade impositiva.

Comentando as diferenças entre igualdade e não-discriminação, Jesús de SantaBárbara Rupérez (2001, p. 46) afirma que a primeira é uma formulação positiva, ao passo que o segundo é um enunciado negativo, restrito - a não-discriminação é a face negativa da igualdade, para ele.

A diferença não é essa. A não-discriminação, e aqui se está referindo apenas àquela aplicável ao comércio internacional ou interestadual de bens, atual objeto de estudo, é a projeção concreta, no mercado, da igualdade. Assim foi concebida tanto no sistema do GATT quanto no da Comunidade Econômica Europeia. Assim permanece até hoje, na OMC e na União Europeia. Não obstante, possui também um caráter positivo, consoante as lições de Fritz Neumark (1974, p. 318). E o instrumento para a sua consecução são os ajustes fiscais de fronteira.

Em verdade, como afirma Fabrizio Amatucci (2003, p. 12 - 13), os princípios se equivalem, sendo que apenas a não-discriminação se diferencia na medida em que deve ser aferida de um ponto de vista interdisciplinar (DORDI, 2002, p. 44).

As fronteiras fiscais, que devem existir sempre que vigore o princípio do destino, como são os sistemas desenhados na prática internacional, não constituem, em si mesmas, um obstáculo ao comércio internacional (a não ser num mero sentido burocrático ou administrativo) (XAVIER DE BASTO, 1991, p. 80). Ao contrário, entende o catedrático de Coimbra que as fronteiras fiscais existem para proporcionar ajustamentos corretos e neutralidade fiscal, tanto na exportação como na importação. Para garantir, em suma, que os impostos internos de consumo não possam ser usados para desviar o comércio internacional do padrão estabelecido pelo funcionamento livre dos mercados, quebrando a continuidade da aplicação dos impostos e isolando os sistemas fiscais dos vários países. 
Embora se admita que o princípio da origem contém uma solução superior para os objetivos da integração econômica, já que, em ele sendo utilizado, as mercadorias circulam na área integrada como se circulassem no interior do mesmo país - livres dos obstáculos burocráticos e administrativos que as fronteiras fiscais sempre constituem - o economista português aponta a necessidade de que o princípio da origem, para funcionar eficazmente, isto é, para não originar distorções ao comércio internacional, seja unicamente utilizado em sendo verificadas condições que são de difícil preenchimento. Referem-se ao requisito de vigorar em um espaço econômico realmente integrado em sua plenitude, vigente um único sistema fiscal, no qual não só a alíquota que grava qualquer das operações nesse espaço é a mesma, como também são idênticas as obrigações acessórias incidentes - ou, como afirma Sacha C. N. Coêlho (1993, p. 90), o emprego do critério de origem nos impostos indiretos requer absoluta igualdade nos países em relação aos quais se pretende haja a harmonização tributária.

Para piorar, como já mencionado, o princípio da origem só poderá ser efetivo em um ambiente economicamente integrado e apenas em teoria poderia ser concebido como solução universal. Na prática, sendo as relações desse espaço com o resto do mundo reguladas pelo princípio do destino, o que se adota é o princípio da origem restrito (restrained origin principle) - em que a tributação na origem vigora no espaço integrado e a tributação no destino é a regra de tratamento das transações com o resto do mundo.

Havendo o emprego do princípio do destino, em compensação, embora opção pior para a consecução de um mercado comum neutro, pois exige a manutenção de “fronteiras fiscais", é solução que viabiliza de forma mais eficiente a meta do atingimento da neutralidade fiscal positiva, pela possibilidade de proceder a ajustes fiscais de fronteira por parte do país exportador, como já visto.

Portanto, a neutralidade fiscal na importação e na exportação de bens, objeto de perseguição exaustiva por parte da caudalosa jurisprudência aqui examinada, em diferentes sistemas normativos, em diferentes planos, nacionais, regionais ou multilateral, é e sempre será apenas isso, um ideal a ser buscado, jamais plenamente alcançado.

Como se vê, a neutralidade fiscal só pode ser alcançada de forma relativa e parcial, jamais absoluta e geral.

Assim também é a realidade em se tratando de outras neutralidades fiscais parciais, fora do nosso atual objeto de estudo, como, por exemplo, a neutralidade concorrencial da norma tributária, a que se refere Tércio Sampaio Ferraz Jr. (2005, p. 731 - 732) - aquela mesma que o referido autor também entende presente no novel art. 146-A 
da Constituição, embora defenda, diferentemente dos demais autores aqui mencionados anteriormente, que tal princípio decorra diretamente do Princípio da Livre Iniciativa e não do da Livre Concorrência.

Também é o caso da neutralidade à exportação de capital, só alcançada no caso do emprego do método do crédito de imposto, em acordos internacionais para prevenir a bitributação (MUSGRAVE, P., 2005, p. 45); da neutralidade à importação de capital, apenas atingida quando se aplica o método da isenção (MUSGRAVE, P., 2005, p. 45); e da neutralidade nacional, que exige a dedução, do imposto pago no país da fonte, da base tributável do imposto pago no país da residência (MUSGRAVE, P., 2005, p. 267). 


\section{DAS CONCLUSÕES.}

Embora esteja sendo comum, ultimamente, um certo tipo de discurso entusiasmado acerca da importância do sistema multilateral de regulação do comércio internacional, institucionalizado hoje pela OMC, em proporcionar um novo patamar nas relações internacionais, pudemos perceber, de um estudo mais aprofundado da jurisprudência do OSC em uma matéria que se pode dizer fundamental, que ainda há muitas dúvidas quanto à juridicidade e acerto dos seus julgamentos. No caso do Brasil, especialmente diante do relativo sucesso dos nossos representantes na casuística do OSC, assim como em função de uma certa falta de maturidade do pensamento acadêmico brasileiro no tratamento da matéria jurídica internacional, tal realidade torna-se ainda mais evidente.

Ocorre que tais visões repousam muito mais em considerações econômicas e políticas do que propriamente jurídicas, muito embora, paradoxalmente, o que se glorifique seja justamente uma pretensa juridificação do sistema.

Vimos que uma breve contextualização historico-factual descritora das circunstâncias e motivações que erigiram as iniciativas de política comercial ao longo da História, na qual se procedeu ao cotejo dos fatos históricos, com ênfase na normatização jurídica que os provocou, em contraste com a exposição resumida do pensamento jurídico e econômico que banhava o conhecimento científico naqueles momentos, fez o leitor concluir que a principiologia econômica rende-se largamente ao jogo de interesses nacionais, na rotina do curso do processo histórico.

A jurisprudência arbitral tem sido reiterada em afirmar que o objetivo do sistema GATT/OMC é o de, mediante um contínuo processo de reforma e liberalização das políticas comerciais nacionais, proporcionar melhores condições de competitividade entre os países, especialmente por meio da proibição da edição de normas nacionais discriminatórias, tanto no que se refira à matéria tributária quanto à regulatória.

Para isso, toma-se como base uma certa formulação no inconsciente coletivo das partes envolvidas, baseada fundamentalmente nas contribuições de Adam Smith, por meio da concepção das vantagens absolutas, e de David Ricardo, acerca da Teoria das Vantagens Comparativas, tendente a que se chegue a uma conclusão, quase natural, de que a liberdade no comércio internacional é mais benéfica do que a proteção.

Tal sentimento inclui a percepção de que os ganhos para a sociedade decorrentes do comércio ultrapassam as perdas impostas àqueles que são solapados pela concorrência 
internacional e que há criação de valor por meio da especialização e das trocas em mercados abertos.

Sem ter a pretensão de penetrar na discussão de políticas públicas, muito menos no debate econômico liberalismo $\mathrm{X}$ intervencionismo ou livrecambismo X protecionismo, o que se percebe é que uma proposição da teoria econômica acaba valendo como verdade quase absoluta, ao menos no discurso dos formuladores de políticas dos entes responsáveis pelo comércio internacional, tanto nacionais quanto regionais e multilaterais.

No entanto, examinando-se a evolução legislativa a que as políticas comerciais nos principais países do mundo têm se submetido no curso da história, chega-se à conclusão que o pensamento econômico cientificamente fundamentado tem reiteradamente capitulado diante dos jogos de interesses de parcelas ínfimas de população ocasionalmente afetadas pela liberalização comercial.

Trata-se de fenômeno natural, já que o acréscimo de bem-estar oriundo da liberalização é, a menos na teoria, necessariamente repartido por todos os agentes econômicos, enquanto os prejuízos costumam recair sobre quantidades concentradas deles.

À mesma conclusão pode-se chegar a partir do estudo das circunstâncias históricas que cercaram a criação do GATT e, posteriormente, da OMC. O que diferencia as situações é o fato de que, no que tange à história do sistema multilateral, os interesses que orientaram as negociações são predominante aqueles dos Estados detentores do poder de barganha tradicional.

Se segmentos da população ou parcelas da comunidade internacional, o fato é que as ideias abstratas com fulcro científico têm sido sempre ultrapassadas por interesses e, mais do que isso, interesses de minorias.

Sem partir desse pressuposto, não se vai conseguir entender o motivo pelo qual os Estados, no exercício de sua soberania, ora algo mitigada, para conceberem o que se costuma mencionar como a sua política comercial, ainda lancem mão de um conjunto de diversos instrumentos de intervenção pública sobre o comércio exterior unicamente com o objetivo de favorecer o produtor nacional frente aos concorrentes estrangeiros.

Ocorre que o sistema multilateral, sob os auspícios do GATT e aprimorado pela Rodada Uruguai, retirou indubitavelmente graus de liberdade da política comercial das partes contratantes, mas deixou de fora do seu campo de atuação um número bastante significativo desses mecanismos.

Interessante observar que os obstáculos ao livre comércio imunes às restrições do sistema multilateral, em regra, são justamente aqueles que podem ser empregados pelos 
seus Estados-Membros mais poderosos, contra outros Estados-Membros ou não, dado o seu assimétrico poder de negociação. Com isso, os Estados-Membros hipossuficientes se veem duplamente prejudicados, já que reduzida está a sua soberania quanto à imposição de medidas unilaterais e impossibilitados estarão de fazerem valer seus interesses no plano bi ou plurilateral.

Diante disso, nem seria necessário aos países centrais retomar as práticas protecionistas tradicionais. Mesmo assim, ainda se percebe o ressurgimento do protecionismo pelas vias unilaterais. Como exemplos dessa realidade, apenas para mencionar dois subterfúgios unilaterais lícitos comumente empregados, temos os picos tarifários e os escalonamentos tarifários. Isso sem falar no protecionismo proscrito, porém não evidente, dissimulado, cujos contornos de caracterização costumam ser por vezes irreconhecíveis, e cuja repressão não alcança eficácia dados os parcos meios de cumprimento que o sistema internacional possui.

Mais uma vez as nações menos desenvolvidas e menos preparadas para a corrida para o desenvolvimento se prejudicam, na medida em que não conseguirão talvez nem perceber que tais mecanismos foram implementados. Assim, por tudo isso, o livre comércio torna-se mais uma figura de retórica do que realmente uma preocupação dos Estados ou mesmo das organizações internacionais responsáveis por regular o comércio internacional.

Um dos mais importantes constrangimentos ao poder soberano nacional em impor normas discriminatórias é a obrigação do Tratamento Nacional, uma das projeções do Princípio de Não-discriminação, aplicado ao produto nacional em relação ao produto estrangeiro.

A doutrina tem sistematizado essa obrigação, presente no Artigo III do GATT, no que tange especificamente à matéria tributária, como as vedações à tributação discriminatória (ou explícita ou "de jure") e à tributação protetiva (ou implícita ou "de facto"), dependendo das frases tomadas do seu parágrafo 2 - a primeira ou a segunda.

Após um período de certa insegurança jurídica, o OSC da OMC, em 1996, quando do julgamento do caso "Japão - Bebidas Alcoólicas II", traçou as linhas definitivas de interpretação do Artigo III do GATT.

Se o caso com que se está deparando trata de discriminação explícita, há que se aplicar a subsunção do fato à norma da primeira frase do segundo parágrafo do artigo III do GATT, situação em que se requer apenas o exame de dois aspectos: i) se o produto importado e o produto nacional seriam similares e ii) se os impostos ou outros tributos 
internos aplicados ao produto importado seriam "superiores" aos incidentes sobre o nacional.

No caso em que estivermos tratando da discriminação implícita, haveria três questões a serem enfrentadas no exame da adequação de um tributo à segunda frase do parágrafo segundo do artigo III: i) se os produtos importados e os produtos nacionais são diretamente competidores ou possam ser substitutos diretos; ii) se o produto importado diretamente competidor ou substituível pelo nacional não é tributado igualmente ao local e iii) se a tributação desigual não está sendo aplicada a produtos importados ou nacionais diretamente competidores ou substituíveis “de modo a proteger a produção nacional”.

Examinando essa formulação do OSC, ora já pacificada, o que podemos concluir é que a obrigação convencional do Tratamento Nacional encerra dentro de si dois conceitos jurídicos indeterminados, a similaridade/substitutabilidade e a proteção (ou aplicação protetiva).

Quanto ao conceito jurídico indeterminado referente ao aspecto da similaridade/substitutabilidade, desde a época do GATT, na sua fase anterior à OMC, com a edição do Relatório do Grupo de Trabalho sobre Ajustes Fiscais de Fronteira, o que foi corroborado pelos julgamentos arbitrais posteriores a $1^{\circ}$ de janeiro de 1995 , dadas as seguidas referências a esse trabalho nas fundamentações de diversos casos, tanto nos Grupos Especiais quanto pelo Órgão de Apelação, tem sido remansosamente apontado que o critério para se determinar o conceito jurídico funda-se em considerações microeconômicas, com base na preferência dos consumidores pelos produtos em comparação - o que se convencionou denominar "market based approach".

Embora também relevantes, são meramente subsidiárias análises quanto às características físicas ou a classificação fiscal das mercadorias, uma vez que, ao menos na retórica, o GATT visa a assegurar pleno acesso a mercados em condições de igualdade de competitividade a todas as Partes Contratantes.

Por outro lado, quanto ao outro conceito jurídico indeterminado presente na Cláusula do Tratamento Nacional do GATT, a questão da proteção, o "de modo a proteger", do Artigo III:1, in fine, ainda é objeto de muitas discussões doutrinárias diante da obscuridade dos critérios adotados historicamente pelo OSC da OMC. A doutrina especializada no Direito Internacional do Comércio é corretamente unânime no sentido de criticar a forma como a sensível questão da aplicação protetiva da norma tributária tem sido abordada e julgada nos laudos arbitrais. 
Há duas grandes vertentes de entendimento sobre a questão. De um lado, a visão tradicional, de base econômica, mas também capitaneada pelos especialistas em Relações Internacionais e Ciência Política, além dos economistas, mormente os de linha liberal, que vê no sistema multilateral de regulação do comércio internacional um meio de abolir o mais possível os obstáculos às livres trocas de mercadorias, talvez na concretização da quimera visualizada por Adam Smith. Com isso, como já vimos, se consagraria a visão econômica prevalente, ao menos na retórica, de que a melhor forma de auferir ganhos com o comércio internacional, para todos os países, se daria com a plena liberalização dos fluxos de bens e serviços.

Por outro lado, colocam-se os doutrinadores de viés jurídico, que percebem no sistema multilateral de regulação do comércio internacional uma forma de restrição ao poder soberano dos Estados-Membros, limitação da competência tributária ou regulatória, a competência que deve se operar para atingir os interesses próprios do Estado-Membro.

Para a primeira visão, em resumo, na análise do Artigo III deve prevalecer apenas a verificação dos efeitos concretos das normas tributárias na proteção da indústria doméstica. É uma visão objetiva. Para a segunda visão, o que importa é perceber o seu objetivo regulatório. É subjetiva, portanto.

A mera consideração de caráter literal que se pode empreender à primeira vista, uma vez que a dicção em português do Artigo III:1 reporta-se aos termos "de modo a proteger a produção nacional", claramente referentes à mera pesquisa aos efeitos da norma, independentemente de qualquer indagação sobre a intenção protecionista do legislador, já nos dá a resposta quanto à mais apropriada opção, que favorece a visão objetiva.

Ocorre que a verificação profunda do caráter protetivo da norma tributária exige uma análise objetiva e de maior rigor conceitual e científico.

De toda a análise do problema da proteção na jurisprudência do OSC, o que sobressalta é a constatação de que, muito embora se percebam esforços da doutrina especializada em divisar critérios empregados pelos julgadores arbitrais, assim como alguma lógica neles, o que se conclui da fluidez no emprego em concreto de cada uma das formas de examinar tais questões é que, na verdade, tais critérios são muito mais apenas tipologias de argumentos a serem esgrimidos conforme sejam mais úteis e convincentes a embasarem a decisão do OSC na situação específica, resolvendo seu problema pontual, do que propriamente vetores a definirem uma metodologia de análise. 
Falta ao OSC, claramente, definir uma sistemática de análise que confira a segurança e a previsibilidade que o sistema multilateral de regulação do comércio internacional tanto almeja construir, como já mencionado.

$\mathrm{Na}$ experiência europeia, a formulação do conteúdo jurídico da liberdade de circulação de mercadorias a divide em um princípio de acesso ao mercado, que diz com o direito de atravessar as fronteiras físicas, e um princípio de igualdade no mercado, que consiste justamente na vedação à discriminação por nacionalidade ou origem.

Por sua vez, o princípio de acesso ao mercado se divide em duas disciplinas: de um lado, o art. $12^{\circ}$ do TCEE; após, art. 25 $5^{\circ}$ TCE; atual art. $30^{\circ}$ do TUE, que pode ser resumido na proibição de "medidas de efeito equivalente" aos direitos aduaneiros; de outro, a eliminação das restrições quantitativas, do art. $30^{\circ}$ originário, após art. $28^{\circ}$, atual art. $34^{\circ}$.

O princípio de igualdade no mercado, o Princípio de Não-Discriminação, está vazado no art. $95^{\circ}$ do TCEE; após, art. 90 do TCE; atual art. $110^{\circ}$ do TUE. Foi larga a atuação jurisprudencial, especialmente nos anos oitenta, com vistas a dar efetividade a essa disposição comunitária, aclarando o significado de termos como "imposição interna", "imposição discriminatória", "produtos similares", "produtos em relação de concorrência", "tratamento diferenciado" e "efeito protetivo", o que alcançou, em última análise, a realização concreta da harmonização tributária europeia, no seu aspecto negativo. A partir da construção jurisprudencial europeia, por meio da exaustiva pesquisa aos seus julgados, verificou-se objetivamente a relevância da definição, tendo em vista os fundamentos integracionistas subjacentes à iniciativa comunitária, do chamado Princípio de NãoDiscriminação.

A disciplina relativa à não-discriminação tributária explícita, no âmbito comunitário, vem trazida pelo primeiro parágrafo do art. $90^{\circ}$ do TCE, hoje art. $110^{\circ}$ do TUE. No campo da discriminação aberta, dois seriam os nortes hermenêuticos a serem perseguidos em relação aos conceitos jurídicos indeterminados presentes no texto legal.

Primeiramente, em relação ao conceito de imposições internas "superiores", deveria se empreender a comparação entre as cargas fiscais incidentes sobre cada um dos produtos sendo comparados. Dentro do conceito de carga tributária, não é apenas relevante o valor da alíquota, como também a forma com que se processa a exigência e se aplica a norma tributária.

O segundo é o conceito jurídico de produtos "similares", para o qual o entendimento jurisprudencial remansoso determina que não se poderia ficar preso às 
características físicas, mas sim aos produtos que, aos olhos dos consumidores, possuíssem propriedades análogas ou que satisfizessem às suas mesmas necessidades, de acordo com sua utilização no mercado.

A disciplina relativa à não-discriminação tributária explícita, aquela que é vazada em normas aparentemente neutras consoante a origem, no âmbito comunitário, vem trazida pelo segundo parágrafo do art. $90^{\circ}$ do TCE, atualmente, art. $110^{\circ}$ do TUE.

Nesse exame, há três passos a serem percorridos pelo julgador: a determinação da "relação de concorrência" entre os produtos sob exame; verificarmos a existência de um "tratamento diferenciado" determinado pela norma tributária submetida à análise de seu caráter discriminatório; e a identificação do "efeito protetivo" da norma tributária; esses dois últimos conceitos podendo ser definidos em conjunto como os efeitos concretos da medida em si na produção doméstica e no consumo dos produtos importados.

No sistema americano, a análise do escopo do poder federal legislativo de tributar, em função da apreciação e da abordagem empreendidas no julgamento do caso United States v. Butler, de 1936, concluiu que a Cláusula 1 do Parágrafo 8 do Artigo I da constituição dos Estados Unidos da América, que confere o poder de tributar e de despender, possui o objetivo maior de assegurar o "bem-estar da nação" e desde que sejam as incidências uniformes em todo o território nacional.

A partir desse requisito, a Suprema Corte dos Estados Unidos formulou a doutrina da "The Dormant Commerce Clause". Trata-se exatamente da limitação ao poder dos estados-membros da federação americana em legislarem quanto a relações comerciais interestaduais, retirada da interpretação pretoriana dessa mesma norma, que autoriza o Congresso Nacional a regular o comércio entre estados. Construída ao longo de quase duzentos anos, desde 1824, no caso Gibbons v. Ogden, possui essa identificação porque se entende utilizável mesmo que o Congresso Nacional permaneça dormente; vale dizer, ainda que não haja lei federal acerca da matéria, mesmo com a autorização constitucional para o potencial exercício de tal poder. É baseada em um princípio de liberdade de iniciativa econômica e permite que a Suprema Corte aprecie a constitucionalidade de lei estadual ou local diante de eventual restrição à liberdade de comércio interestadual.

Na verdade, a sua aplicação prática exige que a Suprema Corte avalie os efeitos discriminatórios da lei. Caso não seja neutra em relação à origem, muito provavelmente será declarada inconstitucional, dentro do que se chama de "strict scrutiny" - escrutínio estrito, que consiste em uma fortíssima presunção de inconstitucionalidade da norma, que só será aprovada no teste de constitucionalidade se o legislativo ou executivo prolator 
demonstrar que o caráter discriminatório da norma é estritamente necessário para o atingimento de um objetivo ou interesse governamental impositivo - que há um "legítimo interesse ou objetivo local" perseguido por ela, desde que o fator de interesse público seja diferente do protecionismo econômico. Caso contrário, é submetida a um teste de balanceamento, o "Complete Auto Transit (v. Brady) Test", em referência ao caso em que foi enunciado, em 1977. Entende-se, por meio dele, não haver o caráter implicitamente discriminatório da norma tributária incidente sobre atividades interestaduais - ou seja, a incidência pode ser considerada constitucional - se houver: i) nexo substancial com o estado tributante; ii) isonomicamente distribuição; iii) não discriminação do comércio interestadual e iv) razoável relação com os serviços prestados pelo estado exator. Assim, se o resultado não é a neutralidade econômica da lei, ela é declarada inconstitucional.

No sistema multilateral de regulação do comércio internacional disciplinado pela OMC, encontra-se o sistema de direito positivo que mais bem aborda e trata o importante conceito jurídico-tributário de ajuste fiscal de fronteira, de capital importância para o entendimento de um conceito mais amplo, menos meramente formalista e negativo, de não-discriminação.

Por outro lado, no que tange à experiência europeia na matéria, a disciplina normativa da União Europeia nesse ponto difere muito da multilateral, quanto às exportações, embora se assemelhe nas importações, sendo que ambas, União Europeia e OMC, aplicam o princípio da tributação no destino. Quanto às exportações, há pouca casuística europeia, como de resto também no sistema da $\mathrm{OMC}$, até porque seu tratamento é menos rico e, portanto, menos sujeito à conflituosidade.

No Brasil, o Sistema Tributário Nacional é prenhe de incidências que se caracterizam dentro da definição de ajuste fiscal de fronteira, embora não seja termo empregado no nosso direito interno e a doutrina relute em vislumbrar a sua presença nas incidências vinculadas à importação do IPI e do ICMS, ou mesmo da Contribuição para o PIS/COFINS incidente sobre a importação.

Quanto ao MERCOSUL, o Princípio de Não-Discriminação no comércio de bens é previsto no art. $1^{\circ}$ e, principalmente, no art. $7^{\circ}$ do Tratado de Assunção. Embora ainda de forma muito menos elaborada do que na experiência internacional, já se podem verificar controvérsias trazidas ao exame ainda do "Tribunal Arbitral Ad Hoc" do Mercosul - consoante os ditames do Protocolo de Brasília para a Solução de Controvérsias, antes do advento no Protocolo de Olivos para a Solução de Controvérsias no Mercosul - referentes à não-discriminação, especialmente em matéria tributária. Como exemplos, há a 
controvérsia, entre a República do Paraguai e a República Oriental do Uruguai, sobre a aplicação do Impuesto Especifico Interno (IMESI) à comercialização de cigarros (Laudo VIII, de 21 dias de maio de 2002) e a entre a República Oriental do Uruguai e a República Federativa do Brasil, sobre medidas discriminatórias e restritivas ao comércio de tabaco e produtos derivados do tabaco (Laudo X, de 5 de agosto de 2005).

No direito interno brasileiro, ainda há controvérsia a respeito do efeito das normas do GATT sobre as leis tributárias brasileiras, mesmo considerando a determinação do art. 98 do CTN, que derrogaria, em se tratando de matéria tributária, uma pretensa equiparação do tratado internacional à lei interna. Mesmo assim, o STF, por meio do verbete $n^{\circ} 575$ da sua Súmula de Jurisprudência, e o STJ, por meio dos seus verbetes sumulares $n^{\circ} 20$ e $n^{\circ} 71$, considerou aplicáveis as regras do GATT a questões internas referentes ao então ICM, hoje sucedido pelo ICMS. Não obstante, as razões de decidir cingem-se sempre apenas aos aspectos relacionados ao conflito de leis, jamais considerando os argumentos de igualdade diante do mercado, como deveria ser a tônica do exame do Princípio de Não-Discriminação no comércio de bens. Nesse sentido, apenas se identificou um voto minoritário no STJ.

Para alcançar o intento de solver em definitivo a intrincada questão do sentido do Princípio de Não-Discriminação no comércio de bens, sugere-se adensar os conceitos jurídicos indeterminados presentes nas diversas experiências internacionais mediante o emprego, com fulcro na obra de Bela Balassa, do conceito de "efeito protetivo", como sendo o aumento da produção doméstica das mercadorias protegidas por um aumento da imposição tributária na importação, que deveria ser o empregado no exame da casuística apresentada ao OSC da OMC. Avaliar-se-iam, portanto, os efeitos da norma tributária no mercado consumidor do país importador, no caso de ajuste fiscal de fronteira na importação, caso mais comum e complexo.

A adoção do conceito de efeito protetivo com base na lição econômica permite que a compreensão na inteireza da obrigação do Tratamento Nacional seja vista de forma perfeitamente simétrica: do ponto de vista dos consumidores, o conceito jurídico indeterminado de similaridade/substitutabilidade, como já o faz o OSC da OMC na chamada "market based approach"; do ponto de vista dos produtores, o conceito de efeito protetivo da tributação interna.

Por outro lado, alguns julgados do TJCE, como o processo John Walker \& Sons Ltd. v. Ministeriet for Skatter og Afgifter, têm empregado esse conceito, vindo da lição econômica, embora sem mencionar sua origem. 
No entanto, para que essa solução seja possível no sistema OMC, será necessário alterar o entendimento, externado no caso "Argentina-Measures Affecting the Export of Bovine Hides and the Import of Finished Leather", de que não é necessário que se demonstre a existência de prejuízo real com a medida, senão meramente o prejuízo potencial. Os resultados decorrentes da aplicação do conceito de efeito protetivo devem poder ser elididos mediante comprovação fática da inexistência de acréscimos de posição de mercado por parte dos produtores nacionais. Faz parte da racionalidade do emprego de instrumentos de Economia ao Direito a possibilidade de apresentação de contraprovas empíricas.

A existência, sem utilização, desde o início da década de 70 do Século XX, de um ferramental teórico da Economia Internacional que possui o grande potencial de resolver um grande enigma da hermenêutica do GATT, nos faz retomar novamente a questão dos interesses que estão por trás de todas as formulações do sistema multilateral de regulação do comércio internacional. Não interessa aos países desenvolvidos dar relevo a uma teoria que evidenciaria claramente o emprego de práticas protecionistas. Pode-se ver nas simulações quantitativas empreendidas por Bela Balassa para se aferir o quantum de concentração de renda é atribuível às políticas comerciais dos países centrais, especialmente no que se refere a indústrias como a têxtil, a de alimentos e a de calçados.

De todo o exposto e diante de tudo que não se tem empregado no sistema multilateral de solução de controvérsias, mas que sem dúvida alguma viria de pleno encontro aos anseios do livre comércio, há que se concordar mesmo que a intenção dos países detentores do poder na instituição do GATT parece ter sido muito mais construir um conjunto normativo que garanta segurança jurídica aos seus agentes econômicos internos e a paz para os seus signatários estatais pela via da redução dos conflitos econômicos, do que prover o aumento de bem-estar da população mundial por meio do livre comércio.

Em toda a caudalosa jurisprudência, examinada de forma exaustiva no presente trabalho, pôde-se verificar que o caráter não-discriminatório costuma ser entendido como um pressuposto de neutralidade da norma tributária.

Examinando do que se trata, verificou-se que a Teoria Microeconômica prova, com base tanto no modelo de equilíbrio de mercados quando no de possibilidades de produção, que não existe neutralidade tributária absoluta, já que, diferentemente da norma regulatória, que se pode pretender neutra, a tributária sempre irá acarretar perda de eficiência, até porque implica a destinação de parte do bem-estar para o Estado, ente que não participa da ordenação dos fatores de produção. 
Por outro lado, não se pode entender existir um Princípio de Neutralidade Fiscal, mesmo se tomado de forma relativa. Não se pode usar a neutralidade como diretriz genérica da ordem tributária, sob pena de subverter seus pressupostos. Em verdade, a neutralidade tributária é apenas um ideal normativo, ao encalço, nem sempre bem sucedido, até porque nem sempre possível, da eficiência econômica.

O que existe não é um Princípio Geral de Neutralidade Tributária, mas hipóteses em que a neutralidade das operações tributadas vem ao encontro dos princípios basilares do Direito Tributário, como o da equidade e, por conseguinte, da capacidade contributiva, sendo assim de conveniente busca pelo legislador.

Portanto, a neutralidade fiscal na importação e na exportação de bens, objeto de perseguição exaustiva por parte da caudalosa jurisprudência aqui examinada e exibida de forma deliberadamente exaustiva, proveniente de diferentes sistemas normativos, em diferentes planos, nacionais, regionais ou multilateral, é e sempre será apenas isso, um ideal a ser buscado, que só pode ser alcançado de forma relativa e parcial, jamais absoluta e geral.

Não obstante, não se pode admitir que se veja o Princípio de NãoDiscriminação tributária no comércio de bens como meramente um conceito negativo. É possível e, mais do que isso, desejável, que se tenha como norte o caráter positivo da neutralidade tributária, por meio do emprego do instrumento dos ajustes físcais de fronteira, para que a política fiscal possa tentar ser ainda mais eficaz no respeito, no máximo possível, ao ordenamento econômico, tanto na produção de riquezas quanto na preservação da esfera privada dos indivíduos - em suma, na produção de bem-estar.

Ao final, tentando sistematizar o conceito do Princípio de Não-Discriminação tributária no comércio de bens, podemos defini-lo como o ideal de perseguir a neutralidade fiscal na importação e na exportação de bens, no comércio internacional ou interestatal, evitando o efeito protetivo da norma tributária ou corrigindo-o pelo emprego de ajustes fiscais de fronteira, com o fim de que a incidência tributária não proporcione o surgimento de vantagens competitivas no mercado de consumo daquele bem. 


\section{DA BIBLIOGRAFIA.}

ABREU. Marcelo de Paiva. Falar e fazer. São Paulo: O Estado de São Paulo, de 20 de outubro de 2008. Disponível em http://www.econ.pucrio.br/Mpabreu/pdf/oesp08.10.20.pdf. Acesso em 20/08/09.

ADONNINO, Pietro. Il principio di non discriminazione nei rapporti tributari fra paesi membri secondo le norme della CEE e la giurisprudenza della Corte di Giustizia delle Comunità. Rivista di Diritto Finanziario e Scienza delle Finanze, Milão, v. LII, n. 1, mar. 1993, p. 63-87.

ALMEIDA, José Carlos Moitinho de. Direito Comunitário. A Ordem Jurídica Comunitária - As Liberdades Fundamentais na C.E.E. Lisboa: Centro de Publicações do Ministério da Justiça, 1985.

AMARAL, Antônio C. Rodrigues do. A experiência brasileira com o Imposto sobre o Valor Agregado - IVA e Mercosul. Cadernos de Direito Tributário e Finanças Públicas, São Paulo: RT, vol. 13, out./dez. 1995, p. 179-185.

Imposto sobre Valor Agregado - IVA. MERCOSUL e União Européia. São Paulo: Ed. Rumo/ABDT, 1995.

. O Mercosul e o Imposto sobre o Valor Agregado; uma proposta para ajustes na tributação do consumo no Brasil. Cadernos de Direito Tributário e Finanças Públicas, São Paulo: RT, vol. 8, jul./set. 1994, p. 175 - 182.

Por uma tributação justa, moderna e eficiente. Cadernos de Direito Tributário e Finanças Públicas, São Paulo: RT, vol. 9, out./dez. 1994, p. 90 - 97.

. Visão Global da Fiscalidade no MERCOSUL: Tributação do Consumo e da Renda. In: MARTINS, Ives Gandra da S. (coord.). O Direito Tributário no Mercosul. Rio de Janeiro: Forense, 2000. 
AMARAL, Gustavo. A lei do biodiesel e o princípio internacional de não-discriminação: meio ambiente, tributação e regras internacionais. In: TÔRRES, Heleno T.; CATÃO, Marcos André V. Tributação no setor de petróleo. São Paulo: Quartier Latin, 2005, p. $207-229$.

Consequencialismo e Ordem Econômica na Interpretação e Aplicação do ICMS. Tese de Doutorado. Rio de Janeiro: Universidade do Estado do Rio de Janeiro, Faculdade de Direito, 2009.

AMARO, Luciano. Direito Tributário Brasileiro. São Paulo: Saraiva, 7ª ed., 2001.

AMATUCCI, Fabrizio. Il Principio di non discriminazione fiscale (Ristampa con appendice di aggiornamento). Pádua: CEDAM, 2003.

ANDERSON, George. Una introducción al federalismo. Madri: Marcial Pons, 2008.

ANNAN, Kofi. Laying the foundations of a fair and free world trade system. In: SAMPSON, Gary P. (coord.). The Role of the World Trade Organization in Global Governance. Tóquio: United Nations University Press, 2001, p. 19 - 27.

ASCANI, Ottorino e RIZZARDI, Raffaele. IVA comunitaria. Commercio estero. Accise. Milão: Il Sole 24 Ore, $7^{\mathrm{a}}$ ed., 2002.

La Fiscalitá del commercio communitario ed internazionale. Milão: Il Sole 24 Ore, 2005.

ATALIBA, Geraldo. ICM sobre a importação de Bens de Capital para uso do Importador. Revista Forense. Rio de Janeiro: Forense, vol. 250, ano 71, abril - maio - junho de 1975, p. $114-120$.

AVELÃS NUNES, António José. Uma Introdução à Economia Política. São Paulo: Quartier Latin, 2007. 
AVI-YONAH, Reuven S. International Tax as International Law: An Analysis of the International Tax Regime. Cambridge Tax Law Series. Cambridge: Cambridge University Press, 2007.

- Treating Tax Issues through Trade Regimes. Brooklyn

Journal of International Law, Nova York, v. 26, nº 4, 2001, p. 1683 - 1692.

BAIRD, Douglas G.; GERTNER, Robert H. E PICKER, Randal C. Game Theory and the Law. Cambridge: Harvard University Press, 2003.

BAKER, Philip. A Tributação Internacional no Século XXI. Direito Tributário Atual. São Paulo: IBDT/Dialética, 2005, vol. 19, p. 41 - 51.

BALASSA, Bela. The Theory of Economic Integration. Londres: George Allen and Unwin, 1962.

. Tariff Protection in Industrial Countries: An Evaluation. Journal of Political Economy. Chicago: The University of Chicago Press, Vol. 73, $\mathrm{n}^{\circ}$ 6, dezembro de 1965 , p. $573-594$.

. Effective Protection: A Summary Appraisal. In: GRUBEL, Herbert G.;

JOHNSON, Harry G. Effective Tariff Protection. Genebra: Graduate Institute of International Studies, 1971, p. 247 - 263.

BALEEIRO, Aliomar. Limitações Constitucionais ao Poder de Tributar. Rio de Janeiro: Forense, ed. revista e complementada por Misabel Abreu Machado Derzi, 1997.

. Uma Introdução à Ciência das Finanças. Rio de Janeiro: Forense, $14^{\mathrm{a}}$ ed., ver. atualizada por Flávio Bauer Novelli, 1987.

Direito Tributário Brasileiro. Rio de Janeiro: Forense, 9a ed., 1977. 
. ICM sobre a importação de Bens de Capital para uso do Importador.

Revista Forense. Rio de Janeiro: Forense, vol. 250, ano 71, abril - maio - junho de 1975, p. $138-139$.

BALTHAZAR, Ubaldo. Notas sobre o IVA e sua instituição no sistema tributário brasileiro. Revista dos Tribunais, São Paulo, vol. 707, 1994, p. 254-260.

BARNARD, Catherine. The Substantive Law of the EU. The Four Freedoms. Oxford: Oxford University Press, $2^{\mathrm{a}}$ ed., 2007.

BARRAL, Welber. Protecionismo e Neoprotecionismo no Comércio Internacional. In: BARRAL, Welber (Org.). O Brasil e o Protecionismo. São Paulo: Aduaneiras, 2002, p. $13-38$.

Desenvolvimento na Rodada Doha da OMC. In: CHEREM, Mônica Teresa Costa Sousa; DI SENA JUNIOR, Roberto (Org.). Comércio Internacional e Desenvolvimento: uma perspectiva brasileira. São Paulo: Saraiva, 2004.

. Direito e Desenvolvimento: um Modelo de Análise. In: BARRAL, Welber (Org.). Direito e Desenvolvimento. Análise da ordem jurídica brasileira sob a ótica do Desenvolvimento. São Paulo: Singular, 2005, p. 31 - 60.

A Influência do Comércio Internacional no Processo de Desenvolvimento. In: BARRAL, Welber; PIMENTEL, Luiz Otávio (Org.). Comércio Internacional e Desenvolvimento. Florianópolis: Fundação Boiteux, 2006, p. 11 - 35.

BARRAL, Welber; CORREA, Carlos. Prologo. In: BARRAL, Welber; CORREA, Carlos (Org.). Derecho, Desarollo y Sistema Multilateral del Comercio. Florianópolis: Fundação Boiteux, 2007, p. 7 - 9.

BARROS, Maurício. State ICMS (VAT Tax) benefits in Brazil and the GATT national treatment clause. Diritto e Pratica Tributaria Internazionale. Pádua: CEDAM, v. 2, p. 676 - 682, 2006. 
BAUMANN, Renato; CANUTO, Otaviano; GONÇALVES, Reinaldo. Economia Internacional. Teoria e Experiência Brasileira. Rio de Janeiro: Elsevier, 2004.

BECKER, Alfredo Augusto. Teoria Geral do Direito Tributário. São Paulo: Lejus, $3^{\mathrm{a}}$ ed., 1998.

BELTRAME, Pierre. Os sistemas fiscais. Coimbra: Almedina, 1976.

BERLIN, Dominique. Droit Fiscal Communautaire. Paris: PUF, 1988.

BERLIRI, Antonio. Principios de Derecho Tributario. Madrid: Ediciones de Derecho Financiero, 1964.

BERNSTEIN, R. B. Introduction. In: BERNSTEIN, R. B. The Constitution of the United States with the Declaration of Independence and the Articles of Confederation. Nova York: Barnes and Noble, 2002.

BERNSTEIN, William J. A Splendid Exchange. How Trade Shaped the World. Nova York: Atlantic Monthly Press, 2008.

BETHELL, Leslie. The Abolition of the Brazilian Slave Trade. Cambridge: Cambridge University Press, 1970.

BHAGWATI, Jagdish. Fair Trade, Reciprocity, and Harmonization: the novel challenge to the Theory and Policy of Free Trade. In: SALVATORE, Dominick. (coord.). Protectionism and world welfare. Cambridge: Cambridge University Press, 1993, p. 17 53.

Protectionism. Cambridge: MIT Press, $8^{\mathrm{a}}$ ed., 2000.

Foreword. In: MATHIS, James M. Regional Trade Agreements in the GATT/WTO. Article XXIV and the Internal Trade Requirement. Haia: T-M-CAsser Press, 2002, p. V - VII. 
BHALA, Raj. International Trade Law: Theory and Practice. Nova York: LexisNexis, $2^{\mathrm{a}}$ ed., 2001.

BIANCHI, Andrea. Globalization of Human Rights: The Role of Non-state Actors. In: TEUBNER, Gunther (coord.). Global Law Without a State. Burlington: Ashgate, 2006, $1^{\mathrm{a}}$ ed., $2^{\mathrm{a}}$ reimpressão, p. $179-212$.

BIRK, Dieter. The Limited Impact of the Principle of Equality in Tax Law. In: GRIBNAU, Hans (coord.). Legal Protection against Discriminatory Tax Legislation. The Struggle for Equality in European Tax Law. Haia: Kluwer Law International, 2003, p. 45-53.

BlaACHERIEne, Ana Carla. Defesa Comercial. Dumping. Antidumping. Subsídio. Medidas compensatórias. Medidas de salvaguarda. São Paulo: Quartier Latin, 2007.

BOMFIM, Diego. Tributação e Livre Concorrência. São Paulo: Saraiva, 2011.

BONILHA, Paulo Celso B. IPI e ICM. Fundamentos da técnica não-cumulativa. São Paulo: IBDT/Resenha Tributária, 1979.

BORDIN, Luiz Carlos Vitali e LAGEMANN, Eugênio. Os Sistemas Tributários vigentes nos países-membros do MERCOSUL: Argentina, Brasil, Paraguai e Uruguai. In: Tributação na Economia Globalizada (debate sobre princípios e uma proposta de Reforma Tributária). São Paulo: SINAFRESP/FGV, 1999.

BORGES, Antônio de Moura. O Princípio da Igualdade na tributação. Direito Tributário Atual, São Paulo: Resenha Tributária, v. 6, 1986, p. 1621-1637.

BORGES, José Souto Maior. ICM sobre a importação de Bens de Capital para uso do Importador. Revista Forense. Rio de Janeiro: Forense, vol. 250, ano 71, abril - maio junho de 1975, p. $120-131$.

BORREGO, Félix Alberto V. La interdicción de la discriminación impositiva en la Organización Mundial del Comercio: a proposito del asunto Japon-Impuestos Especiales 
sobre Bebidas Alcoolicas. Revista de Derecho Financiero y de Hacienda Pública, Madri, v. XLVIII, n. 250, out./dez. 1998, p. 789-816.

BOTtAllo, Eduardo Domingos. Fundamentos do IPI (Imposto sobre Produtos Industrializados). São Paulo: Revista dos Tribunais, 2002.

BOURGEOIS, Jacques. Direct Taxation and the WTO: In or Out? In BOURGEOIS, Jacques: Trade Law Experienced - Pottering about in the GATT and WTO. Londres: Cameron May, 2005, p. 125 - 143.

Comments on Papers Presented by Paul Demaret and Piet Eeckhout. In: COTTIER, Thomas; MAVROIDIS, Petros C. (coord.). Regulatory Barriers and the Principle of Non-Discrimination in World Trade Law. Ann Arbor: The University of Michigan Press, 2000, p. 207-210.

BRADFORD, David F. Fundamental Issues in Consumption Taxation. Washington: The AEI Press, 1996.

BRASIL, Francisco de Souza. O ICM e os impostos sobre vendas no Brasil. Rio de Janeiro: Forense, 1987.

BRASIL. Resultados da Rodada Uruguai do GATT. Decreto $n^{0}$ 1.355 - de 30/12/94. São Paulo: Aduaneiras, 1995.

BRAZUNA, José Luis Ribeiro. Defesa da Concorrência e Tributação - à luz do Artigo 146-A da Constituição. Série Doutrina Tributária, vol. II. São Paulo: IBDT/Quartier Latin, 2009.

BRITO, Edvaldo Pereira de. Comentários ao CTN. São Paulo: Saraiva, 1998, vol. 1.

BRITO FILHO, Washington Juarez de. Tributação Indireta Analítica na União Européia e nos países do Mercosul - Harmonização Positiva e Negativa. Dissertação de Mestrado. Rio de Janeiro: UERJ, Faculdade de Direito, 2003. 
BRONCKERS, Marco; McNELIS, Natalie. Rethinking the "Like Product" Definition in GATT 1994: Anti-Dumping and Environmental Protection. In: COTTIER, Thomas; MAVROIDIS, Petros C. (coord.). Regulatory Barriers and the Principle of NonDiscrimination in World Trade Law. Ann Arbor: The University of Michigan Press, 2000, p. $345-385$.

BuCHAnAn, James. Hacienda Publica. Tradução de Alfonso Rodríguez Sáinz. Madri: Editorial de Derecho Financiero, 1968.

CALIENDO, Paulo. Princípio da Igualdade de Tratamento entre Nacionais e Estrangeiros em Direito Tributário. In: TÔRRES, Heleno Taveira. Direito Tributário Internacional Aplicado. São Paulo: Quartier Latin, vol. III, 2005, p. 25 - 60.

Princípio da Neutralidade Fiscal. Conceito e Aplicação. In: PIRES, Adílson R.; TÔRRES, Heleno T. (org.). Estudos em homenagem ao Professor Ricardo Lobo Torres. Rio de Janeiro: Renovar, 2006, p. 503 - 540.

Direito Tributário e Análise Econômica do Direito: uma visão crítica. Rio de Janeiro: Elsevier, 2009.

CALKINS, Robert. Foreword. In: JOHNSON, Harry G. Economic Policies Toward Less Developed Countries. Washington: The Brookings Institution, 1967.

CAMPANALE, Stelio. Diritto del commercio internazionale e normativa comunitaria. Milão: Giuffrè, 2005.

CAMPANHOle, Hilton L; CAMPANHOlE, Adriano. Constituições do Brasil. São Paulo: Atlas, $13^{\text {a }}$ ed., 1999.

CAMPOS, Dejalma de. O Imposto sobre o Valor Agregado. Cadernos de Direito Tributário e Finanças Públicas. São Paulo: RT, vol. 1, out./dez. 1992, p. 334-336.

CAMPOS, Diogo Leite de. A Harmonização Fiscal na C. E. E. In: O Direito Comunitário e a Construção Européia. Stvdia Ivridica, Coimbra, n. 38, Colloquia 1, 1999, p. 135-141. 
CAMPOS, João Mota de. Direito Comunitário. Lisboa: Fundação Calouste Gulbenkian, v. II, $5^{\text {a }}$ ed., 1997.

CARRAZZA, Roque Antônio. ICMS. São Paulo: Malheiros, 14ª ed. revista e ampliada, 2009.

CARTOU, Louis. Droit Fiscal International et Européen. Paris: Dalloz, 2a ed., 1986.

CARVALHO, Maria Auxiliadora de; SILVA, César Roberto Leite da. Economia Internacional. São Paulo: Saraiva, $3^{\mathrm{a}}$ ed., 2004.

CASAIS, José Manuel Iglesias. No Discriminación Fiscal y Derecho de Establecimiento en la Unión Europea. Pamplona: Aranzadi, 2007.

CASALTA NABAIS, José. A Soberania Fiscal no Actual Quadro de Internacionalização, Integração e Globalização Econômicas. Temas de Integração, Coimbra, n. 15 e 16, $1^{\circ}$ e $2^{\circ}$ sem. 2003, p. 63-93.

CASÁS, José Osvaldo. Globalización y Justicia Tributaria. Revista de Direito Tributário. São Paulo: Malheiros, $\mathrm{n}^{\circ}$ 86, 2003, p. 65-102.

CASELLA, Paulo B. Comunidade Européia e seu ordenamento jurídico. São Paulo: LTr, 1994.

CATTAUI, Maria Livanos. Trade Rules after Seattle: A Business Perspective. In: SAMPSON, Gary P. (coord.). The Role of the World Trade Organization in Global Governance. Tóquio: United Nations University Press, 2001, p. 259 - 270.

CHANG, Ha-Joon. Chutando a Escada. A Estratégia do Desenvolvimento em Perspectiva Histórica. São Paulo: Editora Unesp, 2003.

CHEMERINSKY, Erwin. Constitutional Law: Principles and Policies. Introduction to Law Series. Nova York: Aspen Publishers, 2006. 
CHOI, Won-Mog. 'Like Products' in International Trade Law. Towards a Consistent GATT/WTO Jurisprudence. Oxford: The Oxford University Press, 2003.

CHRISTIAANSE, Jan H. Recentes Progressos no Direito Tributário Internacional. In: TAVOLARO, Agostinho T.; MACHADO, Brandão; MARTINS, Ives Gandra da S. (coord.). Princípios tributários no Direito Brasileiro e Comparado - estudos em homenagem a Gilberto de Ulhôa Canto. Rio de Janeiro: Forense, 1988.

CLÍMACO, Maria Isabel Namorado. Os Impostos Especiais de Consumo. Efeitos Econômicos e Objectivos Fiscais. Ciência e Técnica Fiscal. Lisboa: Centro de Estudos Fiscais, vol. 376, out./dez. 1994, p. 61 - 153.

CNOSSEN, Sijbren; SMART, Michael. Tobacco Taxation. In: CNOSSEN, Sijbren (org.). Excise Tax Policy and Administration Conference. Roterdã: Erasmus University, 2002.

COCKFIELD, Arthur J. NAFTA Tax Law and Policy. Resolving the Clash between Economic and Sovereignty Interests. Toronto: University of Toronto Press, 2005.

COELHO, Sacha C. N. Os impostos sobre o consumo no Mercosul. Cadernos de Direito Tributário e Finanças Públicas. São Paulo: RT, vol. 5, out./dez. 1993, p. 88 - 92.

COENEN, Dan T. Constitutional Law: The Commerce Clause. Turning Point Series. Nova York: Foundation Press, 2004.

COLANINO, Antonio Ziino; AICHINO, Juan O. Zanotti e BILLARDI, Cristian J. MERCOSUR: Aspectos Institucionales y Tributarios. In: UCKMAR, Victor (coord.). Corso di Diritto Tributario Internazionale. Pádua: CEDAM, II ed., 2002, p. 873-929.

COLISTETE, Renato Perim. A força das idéias: a CEPAL e os industriais paulistas na primeira metade da década de 1950. História Econômica \& História de Empresas. Campinas, vol. X, 2006, p. 123 - 153. 
CONTI, José Maurício. Princípios Tributários da Capacidade Contributiva e da Progressividade. São Paulo: Dialética, 1997.

COOPER, Richard N. Trade Policy as Foreign Policy. In: STERN, Robert M. U. S. Trade Policies in a Changing World Economy. Cambridge: The MIT Press, 1988, p. 291 - 322.

COOTER, Robert; ULEN, Thomas. Law \& Economics. Boston: Pearson Education, $5^{\text {a }}$ ed., 2008 .

CORDEIRO, António Menezes. Da Boa-Fé no Direito Civil. Coimbra: Almedina, 2007.

CORDEN, William M. The Structure of a Tariff System and the Effective Protective Rate. Journal of Political Economy. Chicago: The University of Chicago Press, junho de 1966, p. $135-141$.

CORDES, Joseph J.; EBEL, Robert D.; GRAVELLE, Jane G. The Encyclopedia of Taxation \& Tax Policy. Washington: The Urban Institute Press, 2a ed., 2005.

CORREIA, Arlindo. O IVA na União Européia - as dificuldades do processo de harmonização. In: BALTHAZAR, Ubaldo (coord.). Reforma Tributária e Mercosul. Belo Horizonte: Del Rey, 1999, p. 219 - 236.

COSCIANI, Cesare. EI Impuesto al Valor Agregado. Buenos Aires: Depalma, 1969.

COSTA, Alcides Jorge. ICM sobre a importação de Bens de Capital para uso do Importador. Revista Forense. Rio de Janeiro: Forense, vol. 250, ano 71, abril - maio junho de 1975, p. 131 - 138.

- ICM na Constituição e na Lei Complementar. São Paulo: Resenha Tributária, 1978.

Os acordos para evitar a bitributação e a cláusula de não-discriminação.

Revista Dialética de Direito Tributário. São Paulo: Dialética, vol. 6, mar. 1996, p. 7 - 10. 
COSTA, Gustavo de F. C. Federalismo \& ICMS - reflexos tributários. Curitiba: Juruá, 1999.

COSTA, Ramón Valdés. Naturaleza jurídica de los sujetos pasivos del IVA: comunicación sobre el tema - sujeción y responsables tributários. Cadernos de Direito Tributário e Finanças Públicas. São Paulo: RT, vol. 11, out./dez. 1995, p. 205 - 220.

COTTIER, Thomas; OESCH, Matthias. International Trade Regulation - Law and Policy in the WTO, the European Union and Switzerland. Cases, Materials and Comments. Londres: Cameron May, 2005.

COTTIER, Thomas; MAVROIDIS, Petros C. Regulatory Barriers and the Principle of Non-Discrimination in WTO Law: An Overview. In: COTTIER, Thomas; MAVROIDIS, Petros C. (coord.). Regulatory Barriers and the Principle of Non-Discrimination in World Trade Law. Ann Arbor: The University of Michigan Press, 2000, p. 3 - 10.

Conclusions. In: COTTIER, Thomas; MAVROIDIS, Petros C. (coord.). Regulatory Barriers and the Principle of Non-Discrimination in World Trade Law. Ann Arbor: The University of Michigan Press, 2000, p. 389 - 394.

CRAIG, Paul; DE BÚRCA, Gráinne. EU Law. Text, Cases and Materials. Oxford: Oxford University Press, $3^{\mathrm{a}}$ ed., 2003.

CREMONA, Marise. Neutrality or Discrimination? The WTO, the EU and External Trade. In: DE BÚRCA, Gráinne; SCOTT, Joanne (coord.). The EU and the WTO. Legal and Constitutional Issues. Oxford: Hart Publishing, 2002, p. 151-184.

CRETTON, Ricardo A. Um IVA à brasileira para a integração econômica? Juris Poiesis .Rio de Janeiro: Universidade Estácio de Sá, ano I, nº. 2, out./dez. 1999, p. 171-182.

CUNHA, Patrícia Noiret e VASQUES, Sérgio. Jurisprudência Fiscal Comunitária Anotada. Vol. I. Coimbra: Almedina, 2002. 
CRUZ, Antônio Maurício da. IPI - Limites Constitucionais. Coleção Textos de Direito Tributário, vol. 5. São Paulo: Revista dos Tribunais, 1984.

CURZON, Gerard. Multilateral Commercial Diplomacy. An Examination of the Impact of the General Agreement on Tariffs and Trade on National Commercial Policies and Techniques. Londres: Michael Joseph, 1965.

DALLARI, Pedro B. de Abreu. O MERCOSUL perante o Sistema Constitucional Brasileiro. In: BASSO, Maristela (coord.). MERCOSUL. Seus Efeitos Jurídicos, Econômicos e Políticos nos Estados-Membros. Porto Alegre: Livraria do Advogado, 1997, p. 102-116.

DAM, Kenneth W. The GATT. Law and International Economic Organization. Chicago: The University of Chicago Press, 1977.

DAUVERGNE, Catherine. New Directions for Jurisprudence. In: DAUVERGNE, Catherine (coord.). Jurisprudence for an Interconnected Globe. Burlington: Ashgate, 2006, $1^{\text {a }}$ ed., $1^{\text {a }}$ reimpressão, p. 1 - 9.

DAVEY, William J. The WTO dispute settlement system. Journal of International Economic Law. Oxford: Oxford University Press, Vol. 3, nº 1, março 2000, p. 15 - 18.

DAVEY, William J.; PAUWELYN, Joost. MFN Unconditionality: A Legal Analysis of the Concept in View of its Evolution in the GATT/WTO Jurisprudence with Particular Reference to the Issue of "Like Product". In: COTTIER, Thomas; MAVROIDIS, Petros C. (coord.). Regulatory Barriers and the Principle of Non-Discrimination in World Trade Law. Ann Arbor: The University of Michigan Press, 2000, p. 13 - 50.

DE MITA, Enrico. Principi di Diritto Tributario. Milão: Giuffrè, $3^{\mathrm{a}}$ ed., 2002.

O Princípio da Capacidade Contributiva. In: FERRAZ, Roberto (coord.). Princípios e Limites da Tributação. São Paulo: Quatier Latin, 2005, p. 221 256. 
DE WOLF, Michel. Principe de Non Discrimination et Souveraineté Fiscale dans la Union Européene et dans l'ordre juridique fédéral américain. Annales de Droit de Louvain, Bruxelas, v. 3, 1994, p. 287 - 308.

Souveraineté Fiscale et Principe de Non Discrimination dans la jurisprudence de la Cour de Justice des Communautés Européenes et de la Cour Suprême des États-Unis. Bruxelas: Emile Bruylant, 2005.

DELBEZ, Louis. Éléments de Finances Publiques. Paris: A. Pedone, 1955.

DELL'ANESE, Luca. Il Principio di non-discriminazione nel Diritto Internazionale Tributario. Diritto e Pratica Tributaria Internazionale. Pádua: CEDAM, v. 1, 2002, p. 48-74.

DEMARET, Paul; STEWARDSON, Raoul. Border Tax Adjustments under GATT and EC Law and General Implications for Environmental Taxes. Journal of World Trade. Genebra, v. 28, no 4, ago. 1994, p. 5 - 65.

DEODATO, Alberto. Manual de Ciência das Finanças. São Paulo: Saraiva, 1969.

DEVERS, M.; VANHOERNBEECK, W. Pas de problèmes avec la TVA. Paris: Vander, 1990.

DEROUIN, Philippe; MARTIN, Philippe. Droit communautaire et fiscalité. Sélection d' arrêts et de décisions. Paris: LexisNexis - Litec, $2^{\mathrm{a}}$ ed., 2008.

DERZI, Misabel A. M. A necessidade da instituição do IVA no sistema constitucional tributário brasileiro. In: BALTHAZAR, Ubaldo (coord.). Reforma Tributária e Mercosul. Belo Horizonte: Del Rey, 1999, p. 17-30.

Posfácio. In: BALTHAZAR, Ubaldo (coord.). Reforma Tributária e Mercosul. Belo Horizonte: Del Rey, 1999, p. 237-255. 
Distorções no princípio da não-cumulatividade no ICMS - comparação com o IVA europeu. In: COELHO, Sacha Calmon N. et alii (org.). Temas de Direito Tributário. Belo Horizonte: Del Rey, 1998.

DIALLO, Alfa Oumar. Tributação do Comércio Brasileiro e Internacional. São Paulo: Método, 2001.

DI MALTA, Pierre. Droit Fiscal Européen Comparé. Paris: PUF, 1995.

DI PIETRO, Adriano. El principio de igualdad: la influencia en el sistema fiscal italiano del articulo 14 de la Convención Europea de Derechos del Hombre y del articulo 26 de la Convención Internacional de Derechos Civiles y Politicos. Revista de Derecho Financiero y de Hacienda Pública, Madri, v. XLVIII, n. 250, out./dez. 1998, p. 775-787.

El futuro tributario de Unión Europea: del mercado al ordenamiento juridico, de las libertades económicas a los principios de la imposición. Civitas - Revista española de Derecho Financiero, Madri, n. 116, out./dez. 2002, p. 573-580.

DOLINGER, J. . As Soluções da Suprema Corte Brasileira Para Os Conflitos Entre O Direito Interno e O Direito Internacional; Um Exercicio de Ecletismo. Rio de Janeiro: Revista Forense, v. 334, p. 71 - 107, 1995.

DORDI, Claudio. La discriminazione commerciale nel Diritto Internazionale. Milão: Giuffrè, 2002.

DOURADO, Ana Paula. Do caso "Saint-Gobain" ao caso "Metallgesellshaft": o âmbito do Princípio da Não-Discriminação do Estabelecimento Estável no Tratado da Comunidade Européia e a Cláusula da Nação Mais Favorecida. Revista de Direito Tributário. São Paulo: Malheiros, $\mathrm{n}^{\circ}$ 86, 2003, p. 7-26.

DRIESEN, David. What is Free Trade? The Real Issue Lurking Behind the Trade and Environment Debate. Virginia Journal of International Law. Charlottesville, v. 41, $\mathrm{n}^{\mathrm{o}} 2$, 2001, p. 279 - 294. 
EGRET, Georges. La TVA. Coleção “Que sais-je?”. Paris: PUF, vol. 1748, $3^{\text {a }}$ ed., 1978.

EHRING, Lothar. De Facto Discrimination in World Trade Law - National and MostFavored-Nation Treatment - or Equal Treatment? Journal of World Trade, Genebra, v. 36, n. 5, out. 2002, p. 921 - 977.

ENGDAHL, David E. Constitutional Federalism in a nut shell. Saint Paul: West Publishing, $2^{\text {a }}$ ed., 1987.

ENGISCH, Karl. Introdução ao Pensamento Jurídico. Tradução de J. Baptista Machado. Lisboa: Fundação Calouste Gulbenkian, 10ª Ed., 2008.

ENTERRÍA, Eduardo Garcia de; FERNÁNDEZ, Tomás-Ramón. Curso de Direito Administrativo. Tradução de Arnaldo Setti. São Paulo: Revista dos Tribunais, 1990.

EUROPA. Textos legais disponíveis em http://europa.eu/. Bruxelas: Comissão das Comunidades Europeias.

EUROPA. Acórdãos e Pareceres do Advogado-Geral disponíveis em http://curia.eu/. Bruxelas: Tribunal de Justiça das Comunidades Europeias.

FANTOZZI, Augusto. Diritto Tributario. Turim: UTET, vol. I, 1998.

Il Principio Comunitário di Non Discriminazione nell'imposizione sull Reddito. Revista de Direito Tributário. São Paulo: Malheiros, n º 86, 2003, p. 27-39.

FARIA, Werter R. Métodos de harmonização aplicáveis no MERCOSUL e incorporação das normas correspondentes nas Ordens Jurídicas Internas. In: BASSO, Maristela (coord.). MERCOSUL. Seus Efeitos Jurídicos, Econômicos e Políticos nos Estados-Membros. Porto Alegre: Livraria do Advogado, 1997, p. 143-153.

FAUCHALD, Ole K. Flexibility and Predictability Under the WTO's Non-Discrimination Clauses. Journal of World Trade, Genebra, v. 37, n. 3, jun. 2003, p. 443 - 482. 
FERNANDES, Edison C. O Mercosul na Reforma Constitucional Tributária. Cadernos de Direito Tributário e Finanças Públicas. São Paulo: RT, vol. 13, out./dez. 1995, p. 186189.

. Sistema Tributário do Mercosul. São Paulo: Revista dos Tribunais, $2^{a}$ ed., 1999.

Normas tributárias do MERCOSUL. In: MARTINS, Ives Gandra da S. (coord.). O Direito Tributário no Mercosul. Rio de Janeiro: Forense, 2000.

\section{A Não-Discriminação Tributária nos Acordos Multilaterais do} Comércio. São Paulo: Quartier Latin, 2006.

FERRAZ JR., Tércio Sampaio. Obrigação tributária acessória e limites de imposição: razoabilidade e neutralidade concorrencial do Estado. In: FERRAZ, Roberto (coord.). Princípios e Limites da Tributação. São Paulo: Quatier Latin, 2005, p. 715 - 735.

FIGUEIREDO, Adriana Stamato de. IPI nas Operações de Importação. In: PEIXOTO, Marcelo Magalhães (coord.). IPI - Aspectos Jurídicos Relevantes. São Paulo: Quartier Latin, 2003.

FONSECA, José Roberto Franco da. A função jurisdicional na União Européia na sua Primeira Fase: Estudo de Casos. São Paulo: Instituto de Direito Internacional e Relações Internacionais/Departamento de Direito Internacional da Universidade de São Paulo, 1997.

FLOYD, Robert H. GATT Provisions on Border Tax Adjustments. Journal of World Trade Law. Genebra, v. 7, n. 5, set. out. 1973, p. 489 - 499.

FMI. Tax Harmonization in the European Community. Policy Issues and Analysis. Washington: IMF, 1992.

FONTOURA, Jorge. A Construção Jurisprudencial do Direito Comunitário Europeu. In: BASSO, Maristela (coord.). MERCOSUL. Seus Efeitos Jurídicos, Econômicos e Políticos nos Estados-Membros. Porto Alegre: Livraria do Advogado, 1997, p. 89 - 101. 
FORGIONI, Paula A. A Evolução do Direito Comercial Brasileiro: Da mercancia ao mercado. São Paulo: Revista dos Tribunais, 2009.

FORTE, Francesco. IVA, Accise e Grande Mercato Europeo. Milão: Giuffrè, 1990.

Scienza delle Finanze. Milão: Giuffrè, 2002.

FORTE, Umberto. União Européia - Comunidade Econômica Européia (Direito das comunidades européias e harmonização fiscal). São Paulo: Malheiros, 1994.

FRIEDMAN, Milton. The Methodology of Positive Economics. In: FRIEDMAN, Milton. Essays in Positive Economics. Chicago: University of Chicago Press, 1953, p. 3 - 46.

GALGANO, Francesco; MARELLA, Fabrizio. Diritto del Commercio Internazionale. Pádua: CEDAM, 2004.

GANDOLFO, Giancarlo. International Trade Theory and Policy. Heidelberg: Springer Verlag, 1998.

GARCÍA PRATS, Francisco Alfredo. Asscher, o la expansión del principio comunitario de no discriminación en materia tributaria. Civitas - Revista española de Derecho Financiero, Madri, n. 94, abr./jun. 1997, p. 215-236.

GATT. The Tokyo Round of Multilateral Trade Negotiations. Report by DirectorGeneral. Genebra: GATT, 1979.

GEFFROY, Jean-Baptiste. Grands Problèmes Fiscaux Contemporains. Paris: PUF, 1993.

GENTILI, Alberico. De Jure Belli Libri Tres. In: Rolfe, John C. The Three Books on the Law of War. Oxford: Clarendon Press, 1933.

GEST, Guy e TIXIER, Gilbert. Droit fiscal international. Paris: PUF, 2ª ed., 1990. 
Giambiagi, Fábio e AlÉM, Ana Cláudia. Finanças Públicas. Teoria e Prática no Brasil. Rio de Janeiro: Campus, $2^{\mathrm{a}}$ ed., revista e atualizada, 2000.

GIANNINI, Achille Donato. Istituzioni di Diritto Tributario. Milão: Giuffrè, $9^{a}$ ed., 1974.

GOLDMAN, David B. Historical Aspects of Globalization and Law. In: DAUVERGNE, Catherine (coord.). Jurisprudence for an Interconnected Globe. Burlington: Ashgate, 2006, $1^{\text {a }}$ ed., $1^{\text {a }}$ reimpressão, p. 43 - 68.

GONÇALVES, Reinaldo. O Nó Econômico. Rio de Janeiro: Record, 2003.

GORJÃO-HENRIQUES, Miguel. Direito Comunitário. Coimbra: Almedina, $3^{\mathrm{a}}$ ed., 2005.

GORMLEY, Laurence W. EU Taxation Law. Richmond: Richmond Law \& Tax, 2005.

GRAU, Eros Roberto. O Direito Posto e o Direito Pressuposto. São Paulo: Malheiros, $7^{\text {a }}$ ed., 2008.

Ensaio e Discurso sobre a Interpretação/Aplicação do Direito.

São Paulo: Malheiros, $3^{\text {a }}$ ed., 2005.

A Ordem Econômica na Constituição de 1988. São Paulo: Malheiros, $4^{\mathrm{a}}$ ed., 1998.

GRIBNAU, J. L. M. Equality, Consistency and Impartiality in Tax Legislation. In: GRIBNAU, Hans (coord.). Legal Protection against Discriminatory Tax Legislation. The Struggle for Equality in European Tax Law. Haia: Kluwer Law International, 2003, p. 7-32.

GRIBNAU, J. L. M.; PETERS, Cees. Introduction. In: GRIBNAU, Hans (coord.). Legal Protection against Discriminatory Tax Legislation. The Struggle for Equality in European Tax Law. Haia: Kluwer Law International, 2003, p. 1-5. 
GRIBNAU, J. L. M.; SADDIKI, Jaouad. Protection of European Taxpayers by the Principle of Equality. In: GRIBNAU, Hans (coord.). Legal Protection against Discriminatory Tax Legislation. The Struggle for Equality in European Tax Law. Haia: Kluwer Law International, 2003, p. 65-99.

GROTIUS, Hugo. De Jure Belli Ac Pacis Libri Tres. The Law of War and Peace. Oxford: Clarendon Press, 1925.

De Jure Praedae. Commentaries on the Law of War. Oxford: Clarendon Press, 1950.

GUIMARÃeS, Ylves José de Miranda. ICMS - Análise e Princípios Estruturais. São Paulo: LTr, 1975.

GUTMANN, Daniel. Globalisation et Justice Fiscale. Revista Internacional de Direito Tributário. Belo Horizonte: Del Rey, vol. 1, jan./jun. 2004, p. 27 - 45.

HAUFLER, Andreas. Commodity Tax Harmonization in the European Community. Heidelberg: Physica-Verlag, 1993.

HARTMAN, Paul J. State Taxation of Interstate Commerce: A Survey and an Appraisal. Virginia Law Review. Charlottesville: University of Virginia Press, vol 46, nº 6, outubro 1960, p. $1051-1088$.

HELLERSTEIN, Walter. The US Supreme Court's State Tax Jurisprudence: A Template for Comparison. In: AVI-YONAH, Reuven; HINES JR., James R.; LANG, Michael. Comparative Fiscal Federalism. Comparing the European Court of Justice and the US Supreme Court's Tax Jurisprudence. A Haia: Kluwer Law International, 2007, p. 67 $-118$.

Subnational State Tax Incentives in the United States: Constitutional Restrainsts and Congressional Oversight. In: TÔRRES, Heleno Taveira. 
Direito Tributário Internacional Aplicado. São Paulo: Quartier Latin, vol. III, 2005, p. $375-394$.

HELLERSTEIN, Walter; SHACKELFORD, Francis. Subnational State Tax Incentives in the United States: Constitutional Restraints and Congressional Oversight. Cornell Law Review, Ithaca, v. 81, 1996, p. 789 - 807.

HENRIQUES, Guilherme de Almeida. A Tributação do Comércio Interestadual sob a Égide do Princípio da Unidade Federativa: uma análise crítica da evolução jurisprudencial da Suprema Corte norte-americana e do Supremo Tribunal Federal. Dissertação de mestrado. Porto Alegre: Universidade Federal de Minas Gerais, Faculdade de Direito, 2006.

HERRERÍAS, Armando. Fundamentos para la Historia del Pensamiento Económico.

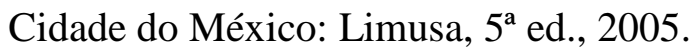

HOEKMAN, Bernard M.; KOSTECKI, Michael M. The Political Economy of the World Trading System. Oxford: Oxford University Press, 2a ed., 2001.

HOEKMAN, Bernard M.; MATOO, Aaditya; ENGLISH, Philip. Development, Trade and the WTO. Washington: The World Bank, 2002.

HOLMES, Peter. The WTO and the EU: Some Constitutional Comparisons. In: DE BÚRCA, Gráinne; SCOTT, Joanne (coord.). The EU and the WTO. Legal and Constitutional Issues. Oxford: Hart Publishing, 2002, p. 59-80.

HORLICK, Gary N. Comment on "Managing the Interface between International Trade Law and the Regulatory State: What Lessons Should (and Should Not) Be Drawn from the Jurisprudence of the United States Dormant Commerce Clause”. In: COTTIER, Thomas; MAVROIDIS, Petros C. (coord.). Regulatory Barriers and the Principle of NonDiscrimination in World Trade Law. Ann Arbor: The University of Michigan Press, 2000, p. 167-170. 
HORN, Henrik; WEILER, Joseph H. H. European Communities - Measures Affecting Asbestos and Asbestos-Containing Products. Filadélfia: The American Law Institute, 2003. Disponível em http://www.ali.org/doc/wto/wto2001/Asbestos.pdf. Acesso em 25/05/09.

HORN, Henrik; MAVROIDIS, Petros C. Still Hazy after All These Years: The Interpretation of National Treatment in the GATT/WTO Case-law on Tax Discrimination. European Journal of International Law, Florença, vol. 15, nº 1, 2004, p. 39 - 69.

HOVENKAMP. Herbert. Positivism in Law \& Economics. California Law Review. Berkeley: University of California Press, v. 78, nº 4, jul 1990, p. 815 - 852.

HOWSE, Robert. Managing the Interface between International Trade Law and the Regulatory State: What Lessons Should (and Should Not) Be Drawn from the Jurisprudence of the United States Dormant Commerce Clause. In: COTTIER, Thomas; MAVROIDIS, Petros C. (coord.). Regulatory Barriers and the Principle of NonDiscrimination in World Trade Law. Ann Arbor: The University of Michigan Press, 2000, p. 139-166.

From Politics to Technocracy - and back again: The Fate of the Multilateral Trade Regime. American Journal of International Law, Washington, v. 96, 2002, p. 94-117.

HOWSE, Robert; REGAN, Donald. The Product/Process Distinction - An Illusory Basis for Disciplining 'Unilateralism' in Trade Policy. European Journal of International Law, Florença, vol. 11, n 2, 2000, p. 249 - 289.

HOWSE, Robert; TUERK, Elisabeth. The WTO Impact on Internal Regulations - A Case Study of the Canada - EC Asbestos Dispute. In: DE BÚRCA, Gráinne; SCOTT, Joanne. The EU and the WTO. Legal and Constitutional Issues. Oxford: Hart Publishing, 2003, p. $283-328$.

HUDEC, Robert E. The GATT Legal System and World Trade Diplomacy. Praeger Special Studies in International Politics and Government. Nova York: Praeger, 1975. 
Developing Countries in the GATT Legal System. Londres: Gower, 1987.

. GATT/WTO Constraints on National Regulation: Requiem for an “Aims and Effects” Test. International Lawyer, Dallas, v. 32, no 3, 1998, p. 619 - 649.

. Essay on the Nature of International Trade Law. Londres: Cameron May, 1999.

."Like Product": The Differences in Meaning in GATT Articles I and III. In: COTTIER, Thomas; MAVROIDIS, Petros C. (coord.). Regulatory Barriers and the Principle of Non-Discrimination in World Trade Law. Ann Arbor: The University of Michigan Press, 2000, p. 101-123.

HUFBAUER, Gary Clyde. Fundamental Tax Reform and Border Tax Adjustments. Washington: Institute for International Economics, 1996.

HUGON, Paul. O Imposto. São Paulo: Renascença, 1945.

HYMAN, David N. Public Finance. A Contemporary Application of Theory to Policy. The Dryden Press Series. FortWorth: Harcourt Brace College Publishers, 6 ${ }^{\text {a }}$ ed., 1999.

IRWIN, Douglas A. The GATT in historical perspective. American Economic Association Papers and Proceedings, 1995, p. 323 - 328.

Against the Tide. An Intellectual History of Free Trade. Princeton: Princeton University Press, $1^{\text {a }}$ ed., $5^{\text {a }}$ reimpressão, 1998.

IRWIN, Douglas A.; MAVROIDIS, Petros C.; SYKES, Alan O. The Genesis of the GATT. Nova York: The American Law Institute/ Cambridge University Press, 2008.

JACKSON, John H. World Trade and the Law of GATT. Albany: Lexis Law, 1969. 
National Treatment Obligations and Non-Tariff Barriers. Michigan

Journal of International Law. Ann Arbor: The University of Michigan Press, v. 10, $\mathrm{n}^{\mathrm{o}} 3$, Inverno de 1989, p. $207-224$.

The World Trading System: Law and Policy of International

Economic Relations. Cambridge: The MIT Press, 2ª ed., 4ª reimpressão, 2000.

The Jurisprudence of the GATT and the WTO: insights on treaty

Law and Economic Relations. $2^{a}$ reimpressão. Cambridge: Cambridge University Press, 2002.

JACKSON, John H.; DAVEY, William J. Legal Problems of International Economic Relations. Cases, Materials and Text. Saint Paul: West Publishing, $2^{\mathrm{a}}$ edição, 1986.

JEFFERY, Ramon. The Impact of State Sovereignty on Global Trade and International Taxation. Londres: Kluwer Law International, 2001.

JENKINS, Michael; HRIBERNICK, Paul. State taxation of interstate commerce: is it a question of power? Louisiana Law Review. Baton Rouge: Louisiana State University Press, vol. 42, 1981 - 1982, p. $951-977$.

JOHNSON, Harry G. The Theory of Tariff Structure with Special Reference to World Trade and Development. In: JOHNSON, Harry G.; KENEN, Peter. Trade and Development. Genebra: Institut Universitaire de Hautes Études Internationales, 1965, p. 5 -30 .

. Economic Policies Toward Less Developed Countries.

Washington: The Brookings Institution, 1967.

. The Theory of Effective Protection and Preferences. Economica. Londres: London School of Economics and Political Science Press, maio 1969, p. 119 138. 
Aspects of the Theory of Tariffs. Cambridge: Harvard University

Press, 1971.

JOHNSON, Harry G ; KRAUSS, Mel. Border Taxes, Border Tax Adjustments, Comparative Advantage, and the Balance of Payments. The Canadian Journal of Economics / Revue Canadienne d'Economique. Montreal: Université de Montréal, Vol. III, $n^{\circ} 4$, novembro 1970, p. 595 - 602.

JORDAN, Bill. Building a WTO that can contribute effectively to economic and social development worldwide. In: SAMPSON, Gary P. (coord.). The Role of the World Trade Organization in Global Governance. Tóquio: United Nations University Press, 2001, p. 243-257.

KAPSTEIN, Ethan B. Distributive Justice and International Trade. Ethics and International Affairs. Nova York, vol. 13, 1999, p. 175 - 183.

KATZ. Avery Wiener. Positivism and the Separation of Law and Economics. Michigan Law Review. Ann Arbor: The University of Michigan Press, v. 94, nº 7, jun 1996, p. 2229 -2269 .

KAYE, Tracy A. Tax Discrimination: A Comparative Analysis of US and EU Approaches. In: AVI-YONAH, Reuven; HINES JR., James R.; LANG, Michael. Comparative Fiscal Federalism. Comparing the European Court of Justice and the US Supreme Court's Tax Jurisprudence. A Haia: Kluwer Law International, 2007, p. 191 - 261.

KRASNER, Stephen. Abiding Sovereignity. International Political Science Review. Berkeley: International Political Science Association, vol. 22, n 3, 2001, p. 230 - 255.

KRAUSS, Mel. The Issue of Border Tax Adjustments. Journal of World Trade Law. Genebra, v. 3, n. 5, set. out. 1969, p. 553 - 561.

Border Tax Adjustments: A Potential Trans-Atlantic Trade Dispute.

Journal of World Trade Law. Genebra, v. 10, n. 2, mar. abr. 1976, p. 145 - 156. 
KRUGMAN, Paul R.; OBSTFELD, Maurice. Economia Internacional. Teoria e Política. São Paulo: Pearson Education do Brasil, 5ª ed., 2004.

KUYPER, Pieter Jan. Booze and Fast Cars: Tax Discrimination under GATT and the EC. Legal Issues of Economic Integration. Haia: Kluwer Law International. Vol. 23, Issue 1, 1996, p. $129-144$.

LACOMBE, Américo L. Masset. Princípios Constitucionais Tributários. São Paulo: Malheiros, $2^{\mathrm{a}}$ ed., 2000.

LADEUR, Karl-Heinz. Globalisation and the Conversion of Democracy to Polycentric Networks: Can Democracy Survive the End of the Nation State? EUI Working Paper Law. Florença, 2003, $n^{\circ} 4$.

Post-Modern Constitutional Theory: A Prospect for the SelfOrganizing Society. The Modern Law Review. Malden/Oxford, vol. 60, $\mathrm{n}^{\circ}$ 5, setembro 1997 , p. $617-629$

LAFER, Celso. Comércio e Relações Internacionais. São Paulo: Perspectiva, 1977.

A OMC e a Regulamentação do Comércio Internacional. Uma visão brasileira. Porto Alegre: Livraria do Advogado, 1998.

LAGEMANN, Eugênio. Há necessidade de um imposto único sobre o consumo no âmbito do Mercosul? In: BALTHAZAR, Ubaldo (coord.). Reforma Tributária e Mercosul. Belo Horizonte: Del Rey, 1999.

LAURÉ, Maurice. Tratado de Politica Fiscal. Tradução para o espanhol de Manuel Garcia-Morgallo Riaza. Madri: Editorial de Derecho Financiero, 1960.

LAUREANO, Abel. Discriminação Inversa na Comunidade Européia. O desfavorecimento dos próprios nacionais na tributação indirecta. Lisboa: Quid Juris, 1997. 
LEHNER, Moris. The national power of taxation and the fundamental freedoms and nondiscrimination clauses of the EC Treaty. Revista de Direito Tributário. São Paulo: Malheiros, $\mathrm{n}^{\circ} 83,2002$, p. 87 - 101.

LIMA, Ricardo Seibel de Freitas. Livre Concorrência e o Dever de Neutralidade Tributária. Dissertação de mestrado. Porto Alegre: Universidade Federal do Rio Grande do Sul, Faculdade de Direito, 2005.

LOCKHART, William B. A revolution in state taxation of commerce? Minnesota Law Review. Minneapolis: University of Minnesota Law School Press. Vol. 65, 1981, p. 1025 1061.

LOWENFELD, Andreas F. International Economic Law. 2a edição, Oxford: Oxford University Press, 2008.

LUHMANN, Niklas. Law as a Social System. Oxford: Oxford University Press, 2004.

Introdução à Teoria dos Sistemas. Tradução de Ana Cristina Arantes Nasser. Petrópolis: Vozes, Coleção Sociologia, 2009.

MADURO, Miguel Poiares. Is there any Such Thing as Free or Fair Trade? A Constitutional Analysis on the Impact of International Trade on the European Social Model. In: DE BÚRCA, Gráinne; SCOTT, Joanne (coord.). The EU and the WTO. Legal and Constitutional Issues. Oxford: Hart Publishing, 2002, p. 257 - 281.

We, the Court. The European Court of Justice \& the European Economic Constitution. A critical reading of Article 30 of the EC Treaty. Oxford: Hart Publishing, $1^{\mathrm{a}}$ ed., $2^{\mathrm{a}}$ reimp., 2002.

MAGALHÃES FILHO, Francisco de B B. de. História Econômica. São Paulo: Sugestões Literárias, 1970.

MANOILESCO, Mihail. Theoria do proteccionismo e da permuta internacional. São Paulo: Centro das Indústrias do Estado de São Paulo, 1931. 
MARCEAU, Gabrielle; TRACHTMAN, Joel P. GATT, TBT and SPS: A Map of WTO Law of Domestic Regulation of Goods. In: ORTINO, Federico; PETERSMANN, ErnstUlrich (coord.). The WTO Dispute Settlement System 1995-2003. Studies in Transnational Economic Law. Haia: Kluwer Law International, 2004, p. 275 - 340.

MARTINEZ, Jean-Claude e DI MALTA, Pierre. Droit Fiscal Contemporain. Tome 1 L’impôt, le fisc, le contribuable. Paris: Litec, 1986.

MATSUSHITA, Mitsuo; SCHOENBAUM, Thomas J.; MAVROIDIS, Petros C. The World Trade Organization Law, Practice and Policy. Oxford: Oxford University Press, 2005.

MATTOO, Aaditya; SUBRAMANIAN, Arvind. Regulatory Autonomy and Multilateral Disciplines: the Dilemma and a Possible Resolution. Journal of International Economic Law. Oxford: Oxford University Press, Vol. 1, nº 2, junho 1998, p. 303 - 322.

MAY, Christopher N.; IDES, Allan. Constitucional Law. National Power and Federalism. Nova York: Aspen Publishers, 2007, $4^{\mathrm{a}}$ ed.

MAZZ, Addy. El impuesto al valor agregado. Cadernos de Direito Tributário e Finanças Públicas. São Paulo: Revista dos Tribunais, n ${ }^{\circ}$ 29, 1999, p. 14-49.

McDANIEL, Paul. Trade and Taxation. Brooklyn Journal of International Law, Nova York, v. 26, nº 4, 2001, p. 1621 - 1640.

. NAFTA and Formulary Apportionment: An Exploration of the Issues.

In: UCKMAR, Victor (coord.). Corso di Diritto Tributario Internazionale. Pádua: CEDAM, II ed., 2002, p. 965-986.

The Impact of Trade Agreements on Tax Systems. In: KIRCHHOF, Paul; LEHNER, Moris; VAN RAAD, Kees; RAUPACH, Arndt e RODI, Michael (coord.). International and Comparative Taxation. Essays in honor of Klaus Vogel. Londres: Kluwer Law International, 2002, p. 151 - 162. 
McFARLAND, Charles K.; NEAL, Nevin E. The Nascence of Protectionism: American Tariff Policies, 1816 - 1824. Land Economics. Madison: University of Wisconsin Press, vol. $45, \mathrm{n}^{\circ} 1$, fevereiro 1969 , p. 22 - 30.

McGINNIS, John O.; MOVSESIAN, Mark L. The World Trade Constitution. Harvard Law Review. Cambridge, vol. 114, julho 2001, p. 511 - 605.

McGOVERN, Edmond. International Trade Regulation. Londres: Globefield Press, 2001.

MÉGRET, Jean. Précis de Droit Fiscal (tous les impôts). Paris: Les Éditions du Prétoire, 1949.

MEHL, Lucien. Elementos de Ciencia Fiscal. Barcelona: Bosch, 1964.

MEIRELLES, José Ricardo. Impostos indiretos no Mercosul e integração. São Paulo: LTr, 2000.

MELlO, Celso Antônio Bandeira de. O Conteúdo Jurídico do Princípio da Igualdade. São Paulo: Malheiros, $3^{\mathrm{a}}$ ed, 19a tiragem, 2010.

MELlO, José Eduardo Soares de. ICMS. Teoria e Prática. São Paulo: Dialética, $3^{\text {a }}$ ed., 1998.

MELLONI, Mattia. The Principle of National Treatment in the GATT: A survey of the Jurisprudence, Practice and Policy. Bruxelas: Bruylant, 2005.

MENÉNDEZ MORENO, Alejandro. El principio de no discriminación fiscal: alcance y excepciones a su aplicación en el Derecho español. Civitas - Revista española de Derecho Financiero, Madri, n. 116, out./dez. 2002, p. 581 - 609. 
Aspectos jurídicos de la armonización fiscal de la Unión Europea. In: MERCOSUR y la Unión Europea: Dos modelos de integración económica. Valladolid: Lex Nova, 1998.

MERCOSUL. Laudos Arbitrais disponíveis em http://www.mercosur.org.uy/. Montevidéu: Secretaria do MERCOSUL.

MICK, Marcus. Steuerharmonisierungs der Umsatzsteuer. In: BIRK, Dieter (coord.). Handbuch des Europäischen Steuer- und Abgabenrechts. Berlim: Neue Wirtschaftsbriefe, 1995 , p. 679-708.

MONIZ, Ana Raquel Gonçalves. A Liberdade de Circulação de Mercadorias. Temas de Integração - A união Europeia - os caminhos depois de Nice, Coimbra: Almedina, $\mathrm{n}^{\text {os }}$ 12 e $13,2^{\circ}$ sem. 2001 e $1^{\text {o }}$ sem. 2002, p. 237 - 309.

MORAES, Bernardo R. de. Compêndio de Direito Tributário. São Paulo: Saraiva, $5^{\text {a }}$ ed., vol. $1,1996$.

MOREIRA, José Carlos Barbosa. Regras de Experiência e Conceitos Juridicamente Indeterminados. In: MOREIRA, José Carlos Barbosa. Temas de Direito Processual (Segunda Série). São Paulo: Saraiva, 2ª ed., 1988, p. 61 - 72.

MORO, Maitê C. Aspectos Tributários do Mercosul. Cadernos de Direito Tributário e Finanças Públicas. São Paulo: RT, vol. 13, out./dez. 1995, p. 186-189.

MOTA, Pedro Infante. O Sistema GATT/OMC. Introdução Histórica e Princípios Fundamentais. Coimbra: Almedina, 2005.

MOTA, Pedro Infante; BORGES, Ricardo H. Da Palma. National Report - Portugal. In: LANG, Michael; HERDIN, Judith; HOFBAUER, Ines (coord.). WTO and Direct Taxation. Haia: Kluwer Law International, 2005, p. 561 - 609. 
MUSGRAVE, Peggy B. Capital Export Neutrality. In: CORDES, Joseph J.; EBEL, Robert D.; GRAVELlE, Jane G. The Encyclopedia of Taxation \& Tax Policy. Washington: The Urban Institute Press, 2005, p. 45 - 46.

Capital Import Neutrality. In: CORDES, Joseph J.; EBEL, Robert D.; GRAVELLE, Jane G. The Encyclopedia of Taxation \& Tax Policy. Washington: The Urban Institute Press, 2005, p. 50 - 51.

National Neutrality. In: CORDES, Joseph J.; EBEL, Robert D.;

GRAVELle, Jane G. The Encyclopedia of Taxation \& Tax Policy. Washington: The Urban Institute Press, 2005, p. 267.

MUSGRAVE, Richard A. Fiscal Systems. New Haven: Yale University Press, 1969.

MUSGRAVE, Richard A.; MUSGRAVE, Peggy. Public finance in theory and practice. New York: McGraw-Hill, 1973.

NEUMARK, Fritz. Principios de la Imposición. Madri: Instituto de Estudios Fiscales, $2^{\text {a }}$ ed., 1994.

NEVEN, Damien J. The Economic Evaluation of Protection under Art. III: Some Principles and Suggestions for the Definition of a Trade Relevant Market. In: COTTIER, Thomas; MAVROIDIS, Petros C. (coord.). Regulatory Barriers and the Principle of Non-Discrimination in World Trade Law. Ann Arbor: The University of Michigan Press, 2000, p. $331-342$.

How Should "Protection" be evaluated in Art. III GATT Disputes? European Journal of Political Economy. Amsterdam: Elsevier, vol. 17, 2001, p. 421 444.

NICHOLSON, Walter. Microeconomic Theory. Basic Principles and Extensions. Mason: South Western Thomson Learning, $8^{\mathrm{a}}$ ed., 2002. 
NUSDEO, Fábio. Curso de Economia. Introdução ao Direito Econômico. São Paulo: Revista dos Tribunais, $6^{\mathrm{a}}$ ed., 2010.

OCDE. Consumption Tax Trends. VAT/GST, Excise and Environmental Taxes. Paris: OECD, 2001.

OCDE. Electronic Commerce: A Discussion Paper on Taxation Issues. Paris: OECD Committee on Fiscal Affairs, 1998.

OCDE. Tax and the Economy. A Comparative Assessment of OECD Countries. OECD Tax Policy Studies, nº 6. Paris: OECD, 2001.

OCDE. Taxing Consumption. Paris: OECD, 1988.

OMC. Decisões disponíveis em http://gatt.stanford.edu. Genebra: Organização Mundial do Comércio.

OMC. Textos convencionais disponíveis em http://www.wto.org/. Genebra: Organização Mundial do Comércio.

OMC. Relatórios dos Grupos Especiais disponíveis em http://www.wto.org/. Genebra: Organização Mundial do Comércio.

OMC. Relatórios do Órgão de Apelação disponíveis em http://www.wto.org/. Genebra: Organização Mundial do Comércio.

ONU. Carta das Nações Unidas disponível em http://www.onu-brasil.org.br/doc2.php. Nova York: Organização das Nações Unidas. Acesso em 02/04/2009.

OKUMA, Alessandra. Princípio da Não-Discriminação e Tributação da Renda de NãoResidentes no Brasil. In: TORRES, Heleno T. (coord.). Direito Tributário Internacional Aplicado. São Paulo: Quartier Latin, 2003, p. 255 - 285. 
ORTINO, Federico. WTO Jurisprudence on De Jure and De Facto Discrimination. In: ORTINO, Federico; PETERSMANN, Ernst-Ulrich (coord.). The WTO Dispute Settlement System 1995-2003. Studies in Transnational Economic Law. Haia: Kluwer Law International, 2004, p. 217 - 262.

Basic Legal Instruments for the Liberalisation of Trade: a Comparative Analysis of EC and WTO Law. Studies in International Trade Law. Oxford: Hart Publishing, 2004.

ORZECHOWSKI, William P. Border Tax Adjustments and Fundamental Tax Reform. Background Paper $n^{\circ}$ 39. Washington: The Tax Foundation, 2001. Disponível em http://www.taxfoundation.org/files/38c5b3cd4944d0774ca268dce2999a66.pdf. Acesso em 30/04/09.

O’SHEA, Tom. Direito Tributário Europeu. Direito Tributário Atual. São Paulo: IBDT/Dialética, 2005, vol. 19, p. 103 - 118.

PAHUJA, Sundhya. Globalization and International Economic Law. In: DAUVERGNE, Catherine (coord.). Jurisprudence for an Interconnected Globe. Burlington: Ashgate, 2006, $1^{\text {a }}$ ed., $1^{\text {a }}$ reimpressão, p. 71 - 91.

PANITCHPAKDI, Supachai. Balancing Competing Interests: The Future Role of the WTO. In: SAMPSON, Gary P. (coord.). The Role of the World Trade Organization in Global Governance. Tóquio: United Nations University Press, 2001, p. 29 - 35.

PARETO, Vilfredo. Manual de Economia Política. Coleção "Os Economistas", apresentação de Fernando GARCIA, São Paulo: Nova Cultural, 1996.

PASSOS, Carlos Roberto M. e NOGAMI, Otto. Princípios de Economia. São Paulo: Pioneira Thomson Learning, $4^{\mathrm{a}}$ ed., 2003.

PAULSEN, Leandro. Direito Tributário. Porto Alegre: Livraria do Advogado, 2003. 
PETERS, Cees. Non-discrimination: The Freedom of Establishment and European Tax Law. In: GRIBNAU, Hans (coord.). Legal Protection against Discriminatory Tax Legislation. The Struggle for Equality in European Tax Law. Haia: Kluwer Law International, 2003, p. 101-122.

PETERS, Martin; BONGARTZ, Matthias e SCHRÖER-SCHALLENBERG, Sabine. Verbrauchsteuerrecht. Munique: C. H. Beck, 2000.

PETERSMANN, Ernst-Ulrich. From the Hobbesian International Law of Coexistence to Modern Integration Law: The WTO Dispute Settlement System. Journal of International Economic Law. Oxford: Oxford University Press, Vol. 1, nº 2, junho 1998, p. 175 - 198.

PETERSMANN, Ernst-Ulrich; POLLACK, Mark A. Transatlantic Trade Disputes: the EU, the US and the WTO. Oxford: Oxford University Press, 2004.

PHILIPPE, Jean-Jacques. La Taxe sur la Valeur Ajoutée - technique et économie. Coleção L'Administration Nouvelle. Paris: Berger-Levrault, 1973.

PICONE, Paolo; LIGUSTRO, Aldo. Diritto Dell Organizzacione Mondiale Del Commercio. Pádua: CEDAM, 2002.

PIRES, Adílson Rodrigues. Práticas Abusivas no Comércio Internacional. Rio de Janeiro: Forense, 2001.

Harmonização tributária em processos de integração econômica. In: CARVALHO, Maria Augusta M. de (coord.). Estudos de Direito Tributário em Homenagem à Memória de Gilberto de Ulhôa Canto. Rio de Janeiro: Forense, 1998.

PITTA E CUNHA, Paulo de. A Harmonização Fiscal Européia e o Sistema Fiscal Português. In: PITTA E CUNHA, Paulo de. A Fiscalidade dos anos 90. Estudos e Pareceres. Coimbra: Almedina, 1996. 
Tax Harmonization. In: PITTA E CUNHA, Paulo de. A Integração Européia no Dobrar do Século. Coimbra: Almedina, 2003.

. O Sistema Fiscal no Limiar do Século XXI. In: PITTA E CUNHA, Paulo de. A Integração Européia no Dobrar do Século. Coimbra: Almedina, 2003.

\section{Aspectos Fiscais da Integração Económica Internacional.}

Lisboa: Centro de Estudos Fiscais, 1964.

PORTER, Michael. A Vantagem Competitiva das Nações. Rio de Janeiro: Campus, 1993.

PORTO, Manuel Carlos Lopes. Teoria da Integração e Políticas Comunitárias. Coimbra: Almedina, $3^{\mathrm{a}}$ ed., 2001.

RÄDLER, Albert J. Most Favored Nation Concept in Tax Treaties. In: LANG, Michael (coord.). Multilateral Tax Treaties. New Developments in International Tax Law. Viena: Linde, 1997, p. 1-14.

REGAN, Donald H. Regulatory Purpose and "Like Products" in Article III:4 of the GATT (With Additional Remarks on Article III:2). Journal of World Trade, Genebra, v. 36, n. 3, jun. 2002, p. $443-478$.

. The Supreme Court and State Protectionism: Making Sense of the Dormant Commerce Clause. Michigan Law Review. Ann Arbor: The University of Michigan Press, vol. 84, 1986, p. 1091 - 1287.

REIMER, Ekkehart. Die Auswirkungen der europarechtlichen Grundfreiheiten auf das Ertragsteuerrecht der Bundesrepublik Deutschland. In: LEHNER, Moris (coord.). Die Bedeutung der Grundfreiheiten für das Steuerrecht der EU-Mitgliedstaaten. Munique: C. H. Beck, 2002, p. 540 - 567. 
RICARDO, David. On the Principles of Political Economy and Taxation. Londres: John Murray, $\quad 3^{\mathrm{a}}$ ed., 1821. Disponível no inteiro teor em http://www.econlib.org/library/Ricardo/ricP.html. Acesso em 01/09/2009.

The Works and Correspondence of David Ricardo. Vol. 4 Pamphlets and Papers 1815-1823. Indianápolis: Liberty Fund, 2005.

RICUPERO, Rubens. Rebuilding confidence in the multilateral trading system: Closing the "legitimacy gap". In: SAMPSON, Gary P. (coord.). The Role of the World Trade Organization in Global Governance. Tóquio: United Nations University Press, 2001, p. 37 - 58 .

ROBÉ, Jean-Philippe. Multinational Entreprises: The Constitution of a Pluralistic Legal Order. In: TEUBNER, Gunther (coord.). Global Law Without a State. Burlington: Ashgate, 2006, $1^{\text {a }}$ ed., $2^{\text {a }}$ reimpressão, p. 45 - 77.

ROCCATAGLIATA, Franco. Diritto Tributario Comunitario. In: UCKMAR, Victor (coord.). Corso di Diritto Tributario Internazionale. Pádua: CEDAM, II ed., 2002, p. 781-844.

RODRIGUES, Carlos Henrique Lopes. A Questão do Protecionismo no Debate entre Roberto Simonsen e Eugênio Gudin. Dissertação de Mestrado. Campinas: Unicamp, Instituto de Economia, 2005.

SAINZ DE BUJANDA, Fernando. Hacienda y Derecho - estudios de Derecho Financiero. Madri: Instituto de Estudios Politicos, vol. II, 1962.

SALVATORE, Dominick. Protectionism and world welfare: introduction. In: SALVATORE, Dominick. (coord.). Protectionism and world welfare. Cambridge: Cambridge University Press, 1993, p. 1 - 13.

Economia Internacional. Tradução de Edith Zonenschain. Rio de Janeiro: Livros Técnicos e Científicos, 6ª Ed., 1998. 
SAMPAIO, Carlos de Almeida. A Harmonização Fiscal nas Comunidades Européias. O IVA e o Modelo Económico Português. Lisboa: Centro de Estudos Fiscais, 1991.

SAMPSON, Gary P. Overview. In: SAMPSON, Gary P. (coord.). The Role of the World Trade Organization in Global Governance. Tóquio: United Nations University Press, 2001, p. 1 - 18.

SÁNCHEZ-POBRE, Pilar Cubiles. Repercusiones fiscales de la libertad de circulación en Derecho Comunitario. Civitas - Revista española de Derecho Financiero, Madri, n. 92, out./dez. 1996, p. 775 - 788.

SANTA-BÁRBARA RUPÉREZ, Jesus. La no discriminación fiscal. Madri: Edersa, 2001.

SANTOS, Ruth Maria P.; VARELLA, Marcelo Dias. Solução de Controvérsias na Organização Mundial do Comércio e o seu caráter jurisdicional. In: MENEZES, Wagner. Estudos de Direito Internacional. Anais do $7^{\circ}$ Congresso Brasileiro de Direito Internacional. Curitiba: Juruá, 2009, p. 184 - 192.

SCHMÖLDERS, Günter. Teoria general del impuesto. Madrid: Ediciones de Derecho Financiero, 1962.

SCHOEURI, Luís Eduardo. Prefácio. In: BRAZUNA, José Luis Ribeiro. Defesa da Concorrência e Tributação - à luz do Artigo 146-A da Constituição. Série Doutrina Tributária, vol. II. São Paulo: IBDT/Quartier Latin, 2009.

SCHRÖER-SCHALLENBERG, Sabine. Harmonisierung der sonstigen Verbrauchssteuern. In: BIRK, Dieter (coord.). Handbuch des Europäischen Steuer- und Abgabenrechts. Berlim: Neue Wirtschafts-briefe, 1995, p. 709-731.

SCHUMPETER, Joseph A. History of Economic Analysis. Nova York: Oxford University Press, 1954. 
SEDLER, Robert A. The Negative Commerce Clause as a Restriction on State Regulation and Taxation: An Analysis in Terms of Constitutional Structure. Wayne Law Review. Detroit: Wayne State University Press. Vol. 31, 1985, p. 885 - 1027.

SELIGMAN, Edwin R. A. Essais sûr l’impôt. Paris: M. Giard \& E. Bière, vol. 2, 1914.

SHORES, David F. State Taxation of Interstate Commerce - Quiet Revolution or Much Ado about Nothing? Tax Law Review. Nova York: New York University Press. Vol. 38, 1982 -1983, p 127 - 169.

SHORT, Clare. Making the development round a reality. In: SAMPSON, Gary P. (coord.). The Role of the World Trade Organization in Global Governance. Tóquio: United Nations University Press, 2001, p. 59 - 80.

SKINNER, Andrew S. The Shaping of Political Economy in the Enlightment. Scottish Journal of Political Economy. Glasgow: Scottish Economic Society. Vol. 37, maio 1990, p. $145-165$.

SMITH, Adam. An Inquiry into the Nature and Causes of the Wealth of Nations. Londres: Methuen \& Co., $5^{\mathrm{a}}$ ed., 1904. Disponível no inteiro teor em http://www.econlib.org/library/Smith/smWN.html. Acesso em 01/09/2009.

SILVA, Luciara Lima Simeão da. O Tribunal de Justiça das Comunidades Européias e o princípio da aplicabilidade direta. Prim@ Facie: Revista da Pós-Gradução em Ciências Jurídicas. João Pessoa: PPGCJ/CCJP/UFPB, Ano 2, n 2, jan./jun. 2003. Disponível em http://www.estig.ipbeja.pt/ ac_direito/artigo_7.pdf. Acesso em 14 de março de 2011.

SMITH, Adam. A Riqueza das Nações. Investigação sobre sua Natureza e suas Causas. Coleção “Os Economistas”, vol. II, São Paulo: Nova Cultural, 1996.

SMITH, Stephen. Alcohol Taxation. In: CNOSSEN, Sijbren (org.). Excise Tax Policy and Administration Conference. Roterdã: Erasmus University, 2002. 
SOARES, Cláudio César. Introdução ao Comércio Exterior. Fundamentos Teóricos do Comércio Internacional. São Paulo: Saraiva, 2004.

SOUSA, Mônica Teresa Costa. A Vinculação entre Comércio Internacional e Desenvolvimento: Possibilidades Reais ou Quimera do Mercado? In: BARRAL, Welber; PIMENTEL, Luiz Otávio (Org.). Comércio Internacional e Desenvolvimento. Florianópolis: Fundação Boiteux, 2006, p. 53 - 85.

SOUSA, Rubens Gomes de. Compêndio de legislação tributária. Rio de Janeiro: Financeiras, 1952.

STIGLITZ, Joseph E. Making Globalization Work. Nova York: W. W. Norton \& Company, 2007.

Globalization and its Discontents. Nova York: W. W. Norton \& Company, 2003.

STIGLITZ, Joseph E; CHARLTON, Andrew. Fair Trade for all. How Trade can promote Development. Oxford: Oxford University Press, 2005.

STEGER, Debra. Peace Through Trade: Building the World Trade Organization. Londres: Cameron May, 2004.

STOURM, René. Systèmes Généraux d'Impots. Paris: Librairie Félix Alcan, 1912.

STRENGER, Irineu. Direito do Comércio Internacional e Lex Mercatoria. São Paulo: LTr, 1996.

SUÁREZ, Francisco. Selections from Three Works of Francisco Suárez, S.J. Vol. 2. Oxford: Clarendon Press, 1934.

SUTHERLAND, Peter; SEWELL, John; WEINER, David. Challenges facing the WTO and policies to address global governance. In: SAMPSON, Gary P. (coord.). The Role of 
the World Trade Organization in Global Governance. Tóquio: United Nations University Press, 2001, p. 81 - 111.

TAKACS, Peter. Das Steuerrecht der Europäische Union. Korneuburg: Ueberreuter, 2001.

TANZI, Vito. Globalization, Tax Competition by the Future of Tax Systems. In: UCKMAR, Victor (coord.). Corso di Diritto Tributario Internazionale. Pádua: CEDAM, II ed., 2002, p. 21 - 41.

TEUBNER, Gunther. Foreword: Legal Regimes of Global Non-state Actors. In: TEUBNER, Gunther (coord.). Global Law Without a State. Burlington: Ashgate, 2006, $1^{\mathrm{a}}$ ed., $2^{\mathrm{a}}$ reimpressão, p. xiii - xvii.

'Global Bukowina': Legal Pluralism in the World Society. In:

TEUBNER, Gunther (coord.). Global Law Without a State. Burlington: Ashgate, 2006, $1^{\mathrm{a}}$ ed., $2^{\mathrm{a}}$ reimpressão, p. $3-28$.

THOMAS, Parakunnel Joseph. Mercantilism and the East India Trade. Londres: Frank Cass \& Co., 1963.

TERRA, Ben. A eliminação das fronteiras fiscais - nova Diretiva adicional à $6^{\mathrm{a}}$ Diretiva na qual introduz algumas alterações. Cadernos de Direito Tributário e Finanças Públicas. São Paulo: RT, vol. 5, out./dez. 1993, p. 93-153.

Excises. In: THURONYI, Victor et alii. Tax Law design and drafting. Washington: IMF, v. 2, 1998.

TERRA, Ben; WATTEL, Peter. European Tax Law. Haia: Kluwer Law International, $5^{\text {a }}$ ed., 2008 .

TILBERY, Henry. Tributação e integração da América Latina. São Paulo: José Bushatsky, 1971. 
TIPKE, Klaus. Princípio de Igualdade e idéia de sistema no Direito Tributário. In: MACHADO, Brandão (coord.). Direito Tributário - estudos em homenagem ao prof. Ruy Barbosa Nogueira. São Paulo: Saraiva, 1984, p. 517 - 527.

TIPKE, Klaus; YAMASHITA, Douglas. Justiça Fiscal e Princípio da Capacidade Contributiva. São Paulo: Malheiros, 2002.

TÔRRES, Heleno T. Princípio da não-discriminação tributária na aplicação do capital estrangeiro - algumas reflexões. Revista de Direito Internacional e Econômico. Porto Alegre, vol. 1, n. 1, out./nov./dez. 2002, p. 103 - 124.

. Direito Tributário e Direito Privado. São Paulo: Revista dos

Tribunais, 2003.

Princípio de não-discriminação tributária na Constituição e no GATT e a prevalência dos tratados internacionais em matéria tributária. In: DERZI, Misabel Abreu Machado (coord.). Construindo o Direito Tributário na Constituição. Uma análise da obra do Ministro Carlos Mário Velloso. Belo Horizonte: Del Rey, 2004, p. $423-442$.

TORRES, Ricardo L. Tratado de Direito Constitucional Financeiro e Tributário. Volume II. Valores e Princípios Constitucionais Tributários. Rio de Janeiro: Renovar, 2005.

Curso de Direito Financeiro e Tributário. Rio de Janeiro:

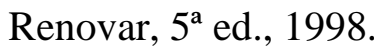

- Sistemas Constitucionais Tributários. Tratado de Direito Tributário Brasileiro. Rio de Janeiro: Forense, tomo II, 1986.

TREBILCOCK, Michael J.; GIRI, Shiva K. The National Treatment Principle in International Trade Law. American Law \& Economics Association Annual Meetings. Texto 8, 2004. Berkeley: The Berkeley Electronic Press. Disponível em 
http://law.bepress.com/cgi/viewcontent.cgi?article=1007\&context=alea. Acesso em $30 / 06 / 2009$.

TREBILCOCK, Michael J.; HOWSE, Robert. The Regulation of International Trade. Londres: Routledge, $3^{\mathrm{a}}$ ed., 2005.

TREVISAN, Marília Lopes. A Arbitragem dentro do Sistema de Solução de Controvérsias do Mercado Comum do Sul (MERCOSUL): perspectivas para a atuação dos Tribunais Arbitrais Ad Hoc do Mercosul através de uma análise comparativa do conteúdo dos laudos arbitrais já proferidos. Tese de Láurea. São Paulo: Universidade de São Paulo, Faculdade de Direito, 2007.

TWINING, William. The Province of Jurisprudence Re-examined. In: DAUVERGNE, Catherine (coord.). Jurisprudence for an Interconnected Globe. Burlington: Ashgate, 2006, $1^{\text {a }}$ ed., $1^{\text {a }}$ reimpressão, p. 13 - 42.

UCKMAR, Antonio. Aspetti Fiscali nelle Regole della Organizzazione Mondiale Del Comercio (OMC/WTO). In: UCKMAR, Victor (coord.). Corso di Diritto Tributario Internazionale. Pádua: CEDAM, II ed., 2002, p. 1097 - 1122.

Tributos aduaneros y subsídios em la OMC. In: UCKMAR, Victor; ALTAMIRANO, Alejandro C.; TORRES, Heleno T. (coord.). Impuestos sobre el comercio internacional. Buenos Aires: Ábaco de Rodolfo Depalma, 2003, p. 325-349.

UCKMAR, Victor. Introduzione. In: UCKMAR, Victor (coord.). Corso di Diritto Tributario Internazionale. Pádua: CEDAM, II ed., 2002, p. 1-19.

Sobre a Harmonização Tributária nos Países da Comunidade Econômica Européia. In: SCHOUERI, Luís Eduardo; ZILVETI, Fernando Aurélio (coord.). Direito Tributário - estudos em homenagem a Brandão Machado. São Paulo: Dialética, 1998, p. 286-303. 
URRESTI, Esteban Juan e CARDOZO, Horacio Félix. Comentarios sobre la instauración del Impuesto al Valor Agregado em um Estado Federal. In: BALTHAZAR, Ubaldo (coord.). Reforma Tributária e Mercosul. Belo Horizonte: Del Rey, 1999, p. 145-163.

VAN DEN BOSSCHE, Peter. The Law and Policy of the World Trade Organization. Cambridge: Cambridge University Press, 2005.

VAN GINKEL, Hans. Preface. In: SAMPSON, Gary P. (coord.). The Role of the World Trade Organization in Global Governance. Tóquio: United Nations University Press, 2001, p. vii - viii.

VAN HOORN Jr., J. O Papel dos Tratados de Impostos no Comércio Internacional. In: TAVOLARO, Agostinho T.; MACHADO, Brandão; MARTINS, Ives Gandra da S. (coord.). Princípios tributários no Direito Brasileiro e Comparado - estudos em homenagem a Gilberto de Ulhôa Canto. Rio de Janeiro: Forense, 1984.

VAN RAAD, Kees. Nondiscrimination in International Tax Law. Deventer: Kluwer Law and Taxation, 1986.

VAN VliET, D. G.; HEERING, A. D. G. e ZEVENBOOM, G. H. Tax and Legal Aspects of EC Harmonization. Deventer: Kluwer, 1993.

VARELLA, Marcelo Dias; SILVA, Alice Rocha da. A mudança de orientação da lógica de solução das controvérsias econômicas internacionais. Revista Brasileira de Política Internacional. Brasília, dez. 2006, vol. 49, nº 2, p. 24 - 40.

VARIAN, Hal R. Microeconomia. Princípios Básicos. Uma abordagem moderna. Tradução de Maria José Cyhlar Monteiro e Ricardo Doninelli. Rio de Janeiro: Elsevier, 2006, $7^{\mathrm{a}}$ ed., $2^{\mathrm{a}}$ reimpressão.

VASQUES, Sérgio. Os impostos especiais de consumo. Coimbra: Almedina, 2001. 
VEHORN, Charles. Border Tax Adjustments. In: CORDES, Joseph J.; EBEL, Robert D.; GRAVELle, Jane G. The Encyclopedia of Taxation \& Tax Policy. Washington: The Urban Institute Press, 2005, p. 24 - 27.

VERHOOSEL, Gaëtan. National Treatment and WTO Dispute Settlement. Oxford Portland: Hart, 2002.

VICTORIA, Francisco de. De Indis et de Jure Belli. Nova York/ Londres: Oceana Publications/ Wildy and Sons, 1964.

VILLEGAS, Hector. Curso de Finanzas, Derecho Financiero y Tributario. Buenos Aires: Depalma, 1972.

VILLEMOT, Dominique. L'Harmonisation Fiscale Européene. Coleção “Que sais-je?”. Paris: PUF, vol. 2618, 2a ed., 1995.

VINER, Jacob. Studies in the Theory of International Trade. Nova York: Harper Bros., 1937.

The Customs Union Issue. Nova York: Carnegie Endowment for International Peace, 1950.

. The Role of Providence in the Social Order. Princeton: Princeton University Press, 1976.

. Religious Thought and Economic Society. Durham: Duke University Press, 1978.

Essays on the Intellectual History of Economics. Princeton: Princeton University Press, 1991.

VOGEL, Klaus. Harmonia Decisória e Problemática da Qualificação nos Acordos de Bitributação. In: SCHOUERI, Luís Eduardo; ZILVETI, Fernando Aurélio (coord.). Direito 
Tributário - estudos em homenagem a Brandão Machado. São Paulo: Dialética, 1998, p. $71-81$.

Worldwide versus Source Taxation on Income. A Review and Reevaluation of Arguments. In: VOGEL, Klaus (Ed.). Influence of Tax Differentials on International Competitiveness. Proceedings of the VIIIth Munich Symposium on International Taxation (1989). Deventer: Kluwer Law and Taxation Publishers, 1990, p. $117-166$.

WEBER, Max. Economia e Sociedade: fundamentos da Sociologia compreensiva. Brasília/ São Paulo: Editora UnB/ Imprensa Oficial do Estado de São Paulo, vol. 2, 1999.

História Geral da Economia. Tradução de Klaus Von Puschen. São Paulo: Centauro, 2006.

WEILER, Joseph H. H. The Rule of Lawyers and the Ethos of Diplomats: Reflections on the Internal and External Legitimacy of WTO Dispute Settlement. Disponível em http://www.jeanmonnetprogram.org/papers/00/000901.html. Nova York: NYU School of Law - Jean Monnet Centre. 2000. Acesso em 06/04/2009.

The EU, the WTO, and the NAFTA: Towards a Common Law of International Trade? Florença/Oxford: European University Institute/ Oxford University Press. 2000.

The Constitution of the Common Market Place: Text and Context in the Evolution of the Free Movement of Goods. In: CRAIG, Paul; DE BÚRCA, Gráinne. The Evolution of EU Law. Oxford: Oxford University Press, 1999, p. 349 - 376.

The European Court and National Courts: Doctrine and Jurisprudence. Oxford: Hart Publishing, 1998.

WILLIAMS, David. Value-added Tax. In: THURONYI, Victor et alii. Tax Law design and drafting. Washington: IMF, v. 2, 1998. 
WILLIAMSON, John. Economia aberta e a Economia mundial. Rio de Janeiro: Campus. 1996.

WOLF, Martin. What the world needs from the multilateral trade system. In: SAMPSON, Gary P. (coord.). The Role of the World Trade Organization in Global Governance. Tóquio: United Nations University Press, 2001, p. 183 - 208.

WONNACOTT, Paul; WONNACOTT, Ronald. Economia. São Paulo: Pearson Education, $2^{\mathrm{a}}$ ed., 2004.

XAVIER, Alberto. Direito Tributário Internacional do Brasil: tributação das operações internacionais. Rio de Janeiro: Forense, $4^{\text {a }}$ ed., 1997.

Os Princípios da Legalidade e da Tipicidade da Tributação. São Paulo: Revista dos Tribunais, 1978.

Manual de Direito Fiscal. Lisboa: Faculdade de Direito de Lisboa, vol. I, 1974.

XAVIER DE BASTO, José Guilherme. A tributação do consumo e a sua coordenação internacional. Lições sobre Harmonização Fiscal na Comunidade Econômica Européia. Lisboa: Centro de Estudos Fiscais, 1991.

. Os Desenvolvimentos Recentes da Harmonização Fiscal Européia em Matéria de Tributação Indirecta. In: PITTA E CUNHA, Paulo de et alii (coord.). A União Européia na Encruzilhada. Coimbra: Almedina, 1996.

ZARRILLI, Simonetta. Domestic Taxation of Energy Products and Multilateral Trade Rules - Is this a Case of Unlawful Discrimination? Journal of World Trade, Genebra, v. 37, n. 2, abr. 2003, p. 359 - 394.

ZDOUC, Werner. WTO Dispute Settlement Practice relating to the General Agreement on Trade in Services. In: ORTINO, Federico; PETERSMANN, Ernst-Ulrich (coord.). The 
WTO Dispute Settlement System 1995-2003. Studies in Transnational Economic Law. Haia: Kluwer Law International, 2004, p. 381-419.

ZILVETI, Fernando Aurélio. Variações sobre o Princípio da Neutralidade no Direito Tributário Internacional. Direito Tributário Atual. São Paulo: IBDT/Dialética, 2005, vol. 19 , p. $24-40$. 